Göttingen Studies in

Criminal Law and Criminal Justice

Marcelo F. Aebi et al.

European Sourcebook of Crime and Criminal Justice Statistics - 2021

Sixth Edition 

Marcelo F. Aebi et al.

European Sourcebook of Crime and Criminal Justice Statistics - 2021

This work is licensed under a Creative Commons Attribution-ShareAlike 4.0 International License.

(c) (1) () 
Published als Volume 41 of the Series „Göttingen Studies in Criminal Law and Criminal Justice“ by Göttingen University Press 2021 
Marcelo F. Aebi, Stefano Caneppele, Stefan Harrendorf, Yuji Z. Hashimoto, Jörg-Martin Jehle, Tara S. Khan, Olivia Kühn, Chris Lewis, Lorena Molnar, Paul Smit, Rannveig Dórisdóttir and the ESB Network of National Correspondents

European Sourcebook of Crime and Criminal Justice Statistics - 2021 Sixth Edition

Göttingen Studies in Criminal Law and Criminal Justice

Volume 41

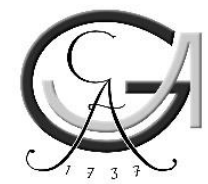

Göttingen University Press 2021 


\section{Bibliographic information}

The German National Library lists this publication in the Deutsche

Nationalbibliografie; detailed bibliographic data are available in the Internet at http://dnb.dnb.de.

\section{Editors of the Series}

Institute of Criminal Law and Criminal Justice

Faculty of Law, Georg-August-Universität Göttingen

Profs. Drs. Kai Ambos, Gunnar Duttge, Katrin Höffler, Jörg-Martin Jehle, Uwe Murmann

Recommended citation (APA 7th Edition):

Aebi, M.F, Caneppele, S., Hashimoto, Y. Z., Jehle, J.-M., Khan, T.S., Kühn, O., Lewis, C., Molnar, L., Smit, P., Pórisdóttir, R. and the ESB network of national correspondents (2021). European Sourcebook of Crime and Criminal Justice Statistics 2021 (6th ed.). Göttingen University Press.

This work is protected by German Intellectual Property Right Law.

It is also available as an Open Access version through the publisher's homepage and the Göttingen University Catalogue (GUK) at the Göttingen State and University Library (http://www.sub.uni-goettingen.de). The license terms of the online version apply.

Setting and layout: Yuji Z. Hashimoto, Lorena Molnar, Stefan Harrendorf

(C) 2021 Göttingen University Press https://univerlag.uni-goettingen.de ISBN: 978-3-86395-519-9

DOI: https://doi.org/10.17875/gup2021-1787

ISSN: $1864-2136$

eISSN: 2512-7047 


\section{National Correspondents}

This report has been built upon the knowledge, commitment, and active contribution of many experts from all European countries. The questionnaire devised by the European Sourcebook group has been discussed with and answered by the following national correspondents:

\footnotetext{
* Albania: Evisa Kambellari, University of Tirana

* Armenia: Anna Margaryan, Yerevan State University

* Austria: Monika Stempkowski and Christian Grafl, University of Vienna

* Azerbaijan: Khayyam Bayramov, Azerbaijan Republic Ministry of Justice

* Belgium : Charlotte Vanneste, Université de Liège

* Bulgaria: Dinko Kanchev, Sofia, Bulgaria

* Croatia: Anna-Maria Getos-Kalac and Reana Bezic, University of Zagreb

* Cyprus: Maria Konstantinou, University of Cyprus

* Crech Republic: Simona Diblikova, Institute of Criminology and Social Prevention, Prague

* Denmark: Britta Kyvsgaard, Ministry of Justice, Copenhagen

* Estonia: Andri Ahven, Ministry of Justice, Tallinn

* Finland: Tappio Lappi-Seppala, University of Helsinki and Anniina Jokinen, Heuni
} 
* France: Annie Kensey and Nolwenn Piquet, Ministry of Justice, Paris

* Georgia: Georgi Glonti, Grigol Robakidze University

* Germany: Stefan Harrendorf, Greifswald University (ESB group member)

* Greece: Calliope Spinellis, University of Athens and Georgios Papanicolaou, Teesside University

* Hungary: Gábor Szászvai-Papp, Office of the Prosecutor General

* Iceland: Rannveig Thorisdottir and Tara Sif Khan, Metropolitan Police, Reykjavik (ESB group members)

* Ireland: Sam Scriven, Central Statistics Office, Cork

* Italy: Uberto Gatti and Gabrielle Rocca, University of Genoa

* Latvia: Kalvis Okmanis, Central Statistical Bureau of Latvia

* Lithuania: Aleksandras Dobryninas, Algimantas Čepas, Rimantè Gaičevskytė-Savickė and Evaldas Visockas, Vilnius University

* Luxembourg: Clarissa Dahmen, Statistical National Institute

* Malta: Saviour Formosa, University of Malta

* Moldova: Mihaela Vidaicu, Moldova State University

* Montenegro: Velimir Rakocevic, University of Montenegro

* Netherlands: Paul Smit, Ministry of Justice, WODC (ESB group member)

* North Macedonia: Gordana Lazetic University of Ss. Cyril and Methodius

* Poland: Beata Gruszczynska, University of Warsaw

* Portugal: Maria Joao Morgado Costa, Direção-Geral da Política de Justiça, Lisbon

* Romania: Andra-Roxana Trandafir, University of Bucharest

* Russian Federation: Artem Kulintsov, Federal Penitentiary Service

* Serbia: Sanja Copic, Institute of Criminological and Sociological Research, Belgrade

* Slovenia: Gorazd Mesko, University of Maribor

* Spain: Antonia Linde Garcia, Open University of Catalonia (UOC), Barcelona

* Sweden: Louise Ekström, Division of Criminal Statistics, Stockholm

* Switzerland: Anne-Corinne Vollenweider Wyss, Federal Statistical Office, Neuchâtel

* Turkey: Galma Akdeniz, İstanbul Bilgi University

* Ukraine: Olha Podilchak, National Prosecution Academy of Ukraine, and Olena Shostko, Yaroslav Mudryi National Law University.

* United Kingdom: Chris Lewis, University of Portsmouth (ESB group member) 


\section{Acknowledgments}

The following experts were involved in the discussions related to the project and gave helpful advice:

* Claudia Campistol, University of Lausanne

* Anna-Maria Getos-Kalac, University of Zagreb

* Matti Näsi, University of Helsinki, Finland

* Lieven Pauwels, University of Ghent, Belgium

* Mélanie M. Tiago, University of Lausanne

* Johan Van Wilsem, Netherlands Court of Audit

* Nina Palmowski, Georg-August University of Göttingen

A major contribution to the data collection wave of the sixth edition was made within the framework of the LINCS project, implemented by the Council of Europe and co-founded by the Council of Europe and the European Commission. We are especially grateful to

* Ilina Taneva, Council of Europe, Strasbourg 



\section{Dedication}

The 6th edition of the European Sourcebook is dedicated to the memory of our colleague and friend Professor Kauko Aromaa (1943-2019) of Helsinki University. Professor Aromaa was a part of the European Sourcebook group for many years and promoted its publication.

We have lost a good friend. 



\section{Preface}

This is the sixth edition of a data collection initiative that started in 1993 under the umbrella of the Council of Europe and has been continued since 2000 by an international group of experts that created the European Sourcebook of Criminal Justice e.V. ${ }^{1}$ and is also a Working Group of the European Society of Criminology. These experts act as regional coordinators of a network of national correspondents whose contribution has been decisive in collecting and validating data on a variety of subjects from 42 countries. $^{2}$

This edition of the Sourcebook is composed of six chapters. The first five cover the current main types of national crime and criminal justice statistics - police, prosecution, conviction, prison, and probation statistics - for the years 2011 to 2016, providing detailed analysis for 2015 . The sixth chapter covers national victimization surveys, providing rates for the main indicators every five years from 1990 to 2015.

As with every new edition of the Sourcebook, the group has tried to improve data quality as well as comparability and, where appropriate, increase the scope of data collection. For example, offence definitions were updated to reflect the lessons learned from previous editions.

\footnotetext{
1 A legal entity and registered association according to German law (eingetragener Verein).

${ }^{2}$ Including the constituent countries of the United Kingdom that have separate criminal justice systems, namely England and Wales, Northern Ireland, and Scotland.
} 
Basically, all data included were originally collected by the national correspondents. The present document also includes, in chapter 4 and 5 , data provided by the SPACE project of the Council of Europe. ${ }^{3}$

The European Sourcebook is also freely available for download on the website www.unil.ch/europeansourcebook. The original data used to create the European Sourcebook can also be found in a separate publication on that website. This includes the absolute crime figures and comments provided by the national correspondents when answering the European Sourcebook questionnaire.

The Sourcebook group wishes to thank all those who, in whatever capacity, have worked on the present edition. First of all, our thanks go to the national correspondents. Without them, such an endeavour as this would never possible. We acknowledged their significant contributions by making the network of national correspondents co-author. We are also grateful to Claudia Campistol and Nina Palmowski, who, while working at the Universities of Lausanne and Göttingen, respectively, supported the project, especially by assisting the revision of the questionnaire and the data collection. Special thanks are due to the Council of Europe, particularly to Ilina Taneva, for their support in the framework of the project LINCS (Linking International Criminal Statistics). The project was co-funded by the Council of Europe and the European Commission and provided the framework for two conferences with the national correspondents and LINCS country experts on 16 to 17 April 2018 and then again on 3 and 4 June 2019. The Council of Europe also organised a virtual conference on "Three Decades of Crime and Criminal Justice Statistics in Europe: Methods, Trends and the Impact on Policy Making" on 22 and 23 March 2021, at which the results of the LINCS project and of the Sourcebook data collection were presented and discussed. Special thanks are also due to the University of Lausanne and its School of Criminal Justice, who have been supporting this project since the beginning.

While all members of the Sourcebook group in principle contributed equally to the preparation and writing of this book, a special mention is due to Lorena Molnar and Yuji Zocatelli Hashimoto (both University of Lausanne) and Olivia Kühn (University of Greifswald) for their invaluable additional support. Lorena and Yuji were especially in charge of the creation, management and update of the ESB database and the copyediting of the final publication, while Olivia furthered and improved data validation significantly.

We hope that this new edition will continue to promote comparative research throughout Europe and make European experiences and data available worldwide.

Lausanne, October 2021

Marcelo Aebi, Chair

\footnotetext{
${ }^{3}$ See https://wp.unil.ch/space.
} 


\section{Contents}

National Correspondents..................................................................................... V

Acknowledgments ................................................................................................ VII

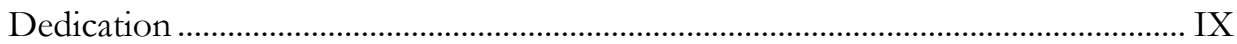

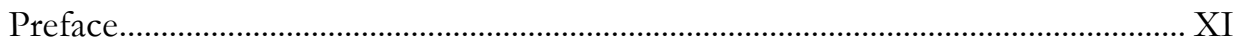

General Introduction: The European Sourcebook Project ………………………..... 1

1 Background: Past and present of the European Sourcebook Group ............... 1

2 Definitions of offences and sanctions .............................................................. 5

3 The structure of the European Sourcebook....................................................... 5

4 Methodological issues ....................................................................................

4.1 Data recording methods ........................................................................

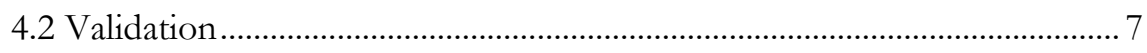

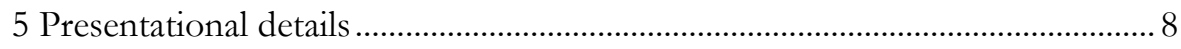

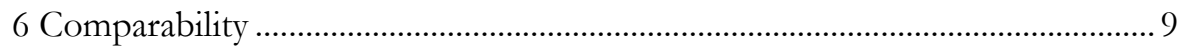


7 Basic rules on how to use the statistical information contained in the Sourcebook

1 Police Statistics

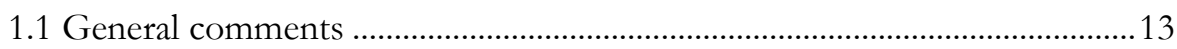

1.1.1 Police statistics as a measure of crime..................................................... 13

1.1.2 Police in the criminal justice system ....................................................... 14

1.1.3 Counting offences and offenders.......................................................... 15

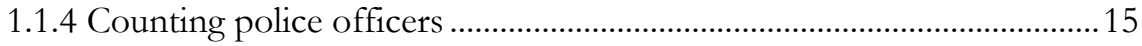

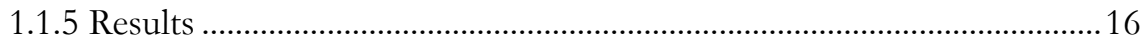

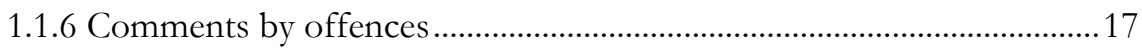

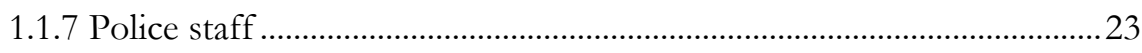

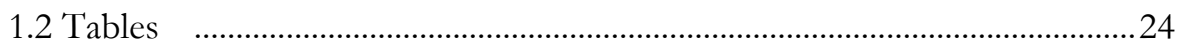

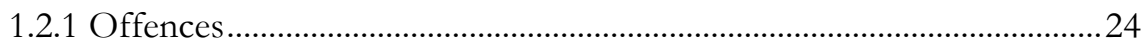

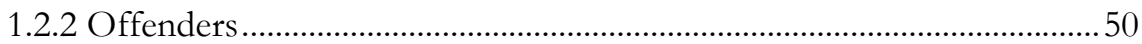

1.2.3 Percentage of women, minors, and foreigners among offenders in

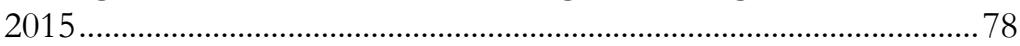

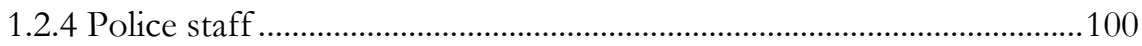

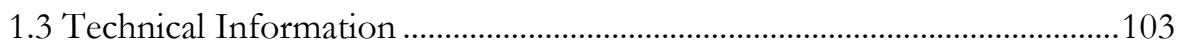

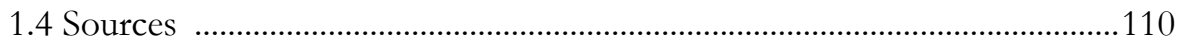

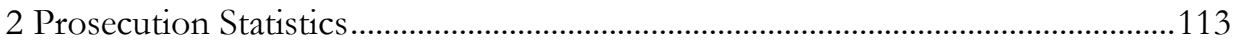

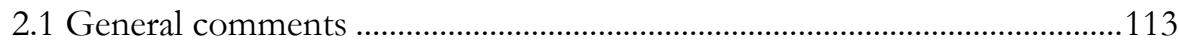

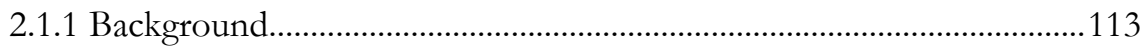

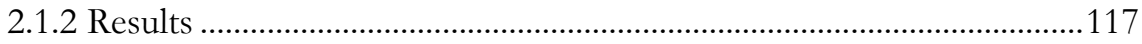

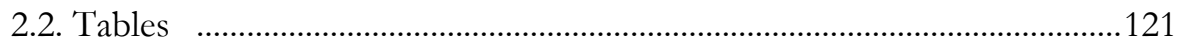

2.2.1 Criminal cases handled by the prosecuting authorities 2011-2016.....121

2.2.2 Criminal cases handled by the prosecuting authorities in 2015 ...........124

2.2.3 Criminal cases handled by the prosecuting authorities in 2015 by

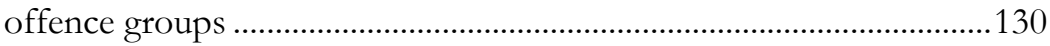

2.2.4 Police custody and pre-trial detention.................................................137

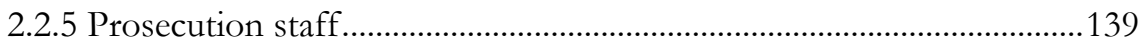

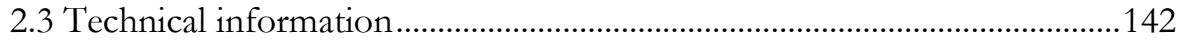

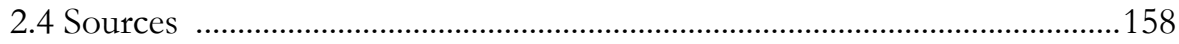




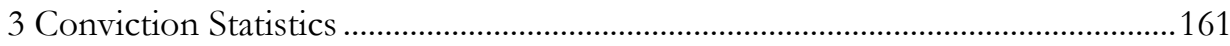

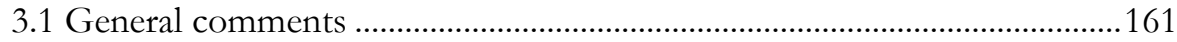

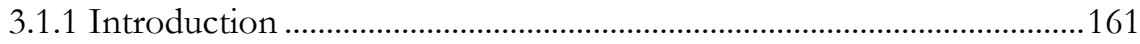

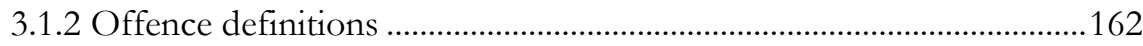

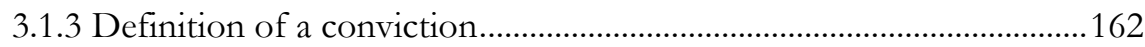

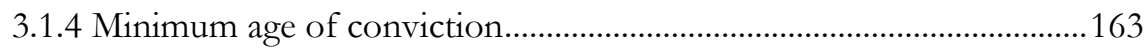

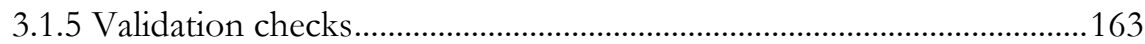

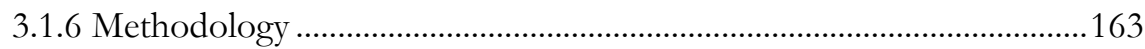

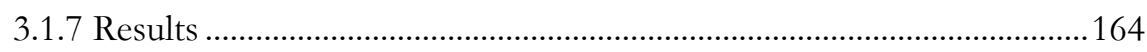

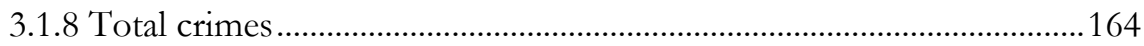

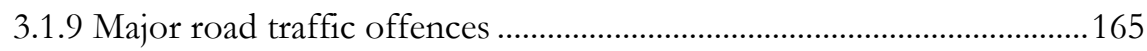

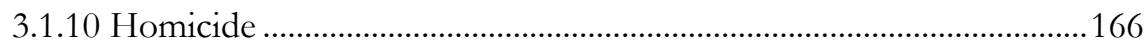

3.1.11 Bodily inujries .................................................................................166

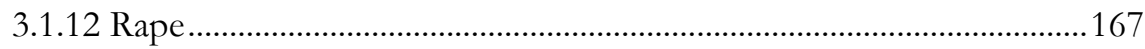

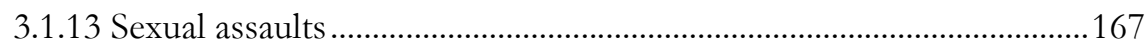

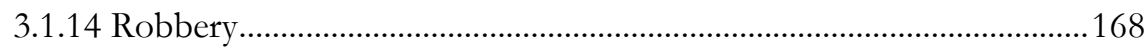

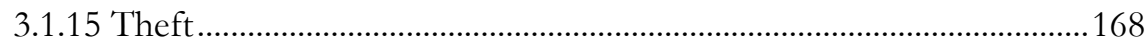

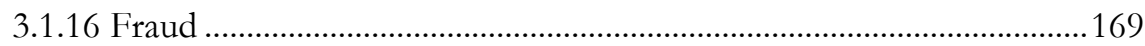

3.1.17 Money laundering...............................................................................169

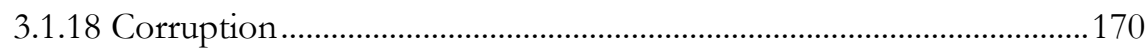

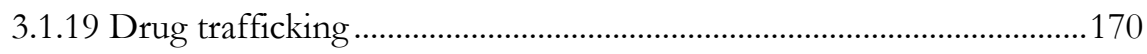

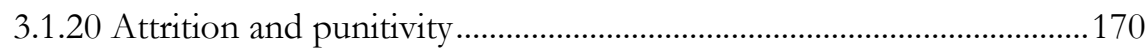

3.1.21 Crime types, relative number of convicted persons .............................172

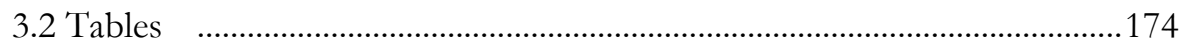

3.2.1 Total number of convictions per 100000 population............................174

3.2.2 Percentage of women, minors, and foreigners among convicted

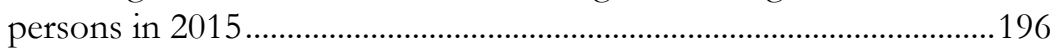

3.2.3 Total persons receiving sanctions/measures in 2015 …........................217

3.2.4 Minors receiving sanctions/measures in 2015 ........................................236

3.2.5 Persons convicted by length of unsuspended custodial sanctions and measures imposed in 2015 ..............................................................254

3.2.6 Persons held in pre-trial detention (at least temporarily) among persons convicted in 2015 ...................................................................2 271

3.2.7 Judges in criminal courts per 100000 population - 2015 .....................272

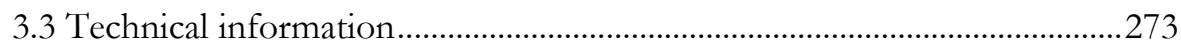




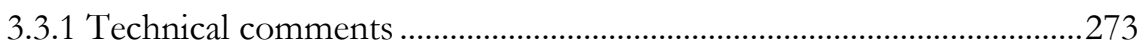

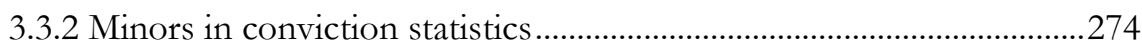

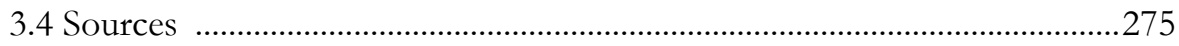

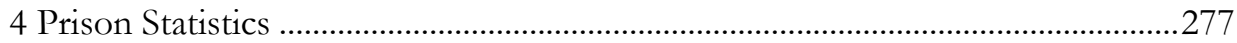

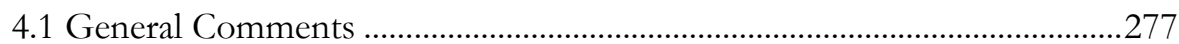

4.1.1 Introduction .......................................................................................2. 277

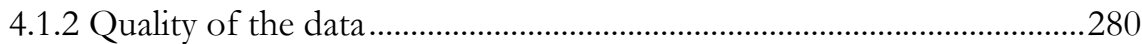

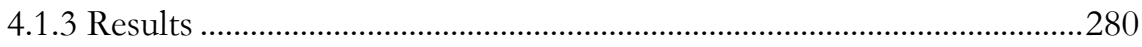

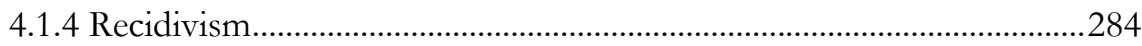

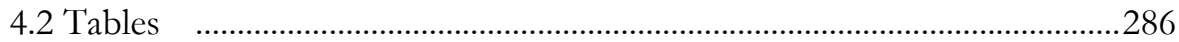

4.2.1 Prison population: Stock of inmates on 1 September ..........................286

4.2.2 Convicted prison population by type of offence on 1 September

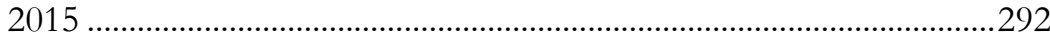

4.2.3. Prison population: Flow of entries into penal institutions ..................300

4.2.4. Prison population: Flow of exits from penal institutions .....................304

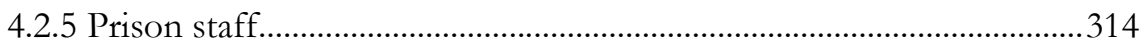

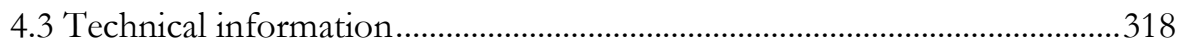

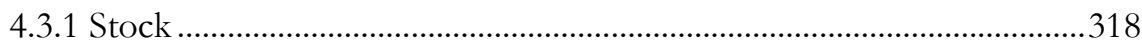

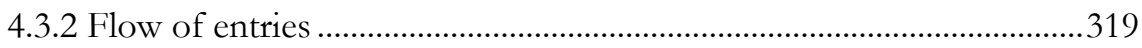

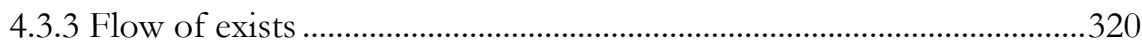

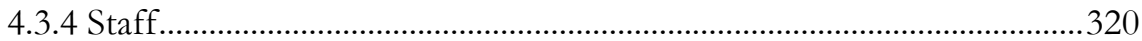

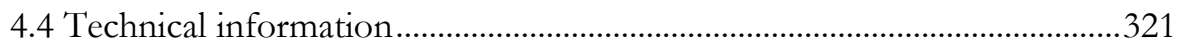

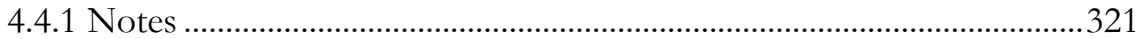

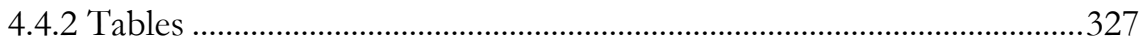

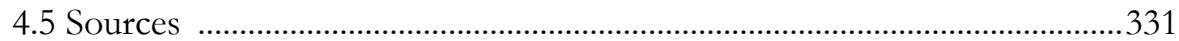

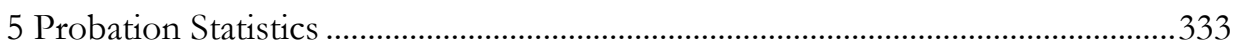

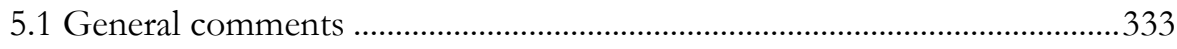

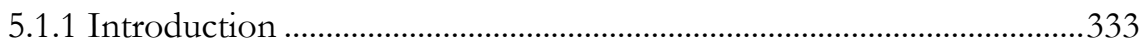

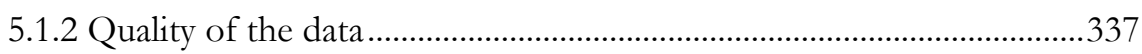

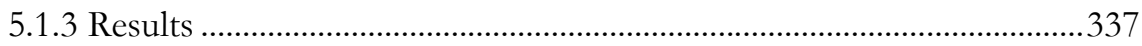

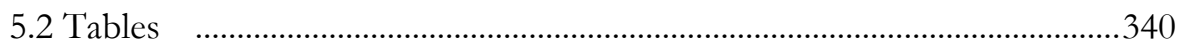

5.2.1 Probation population: Stock of probationers ........................................340

5.2.2 Probation population: Flow of entries in probation..............................344 
5.2.3 Probation population: Flow of exits from probation............................348

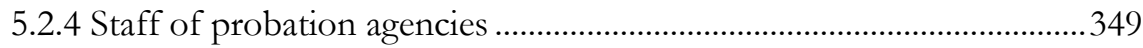

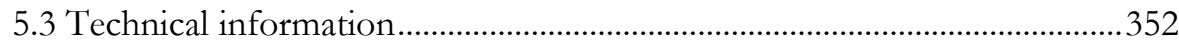

5.3.1 The structure and organisation of Probation Agencies.........................352

5.3.2 Description of data recording methods for Tables on probation.......356

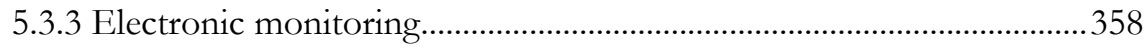

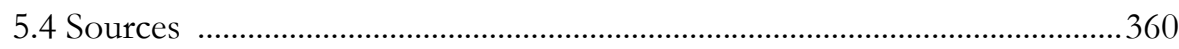

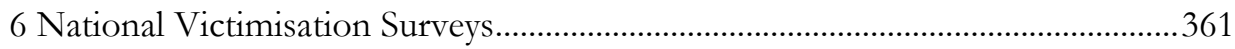

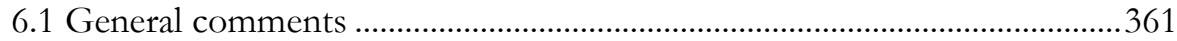

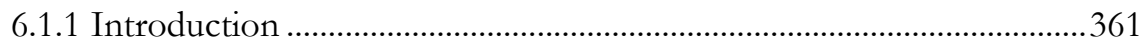

6.1.2 Data collected on Victimisation Surveys for the European

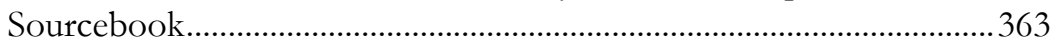

6.1.3 Standard wording of the questions included in national

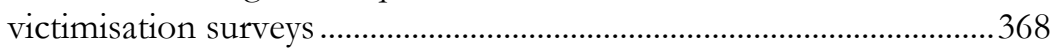

6.1.4 Completeness and quality of the data ..................................................371

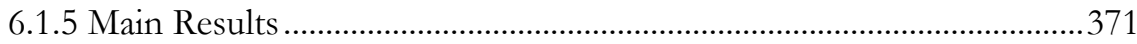

6.1.6. Other victimisation surveys carried out by European countries. .......371

6.2 Tables from household victimisation surveys .............................................374

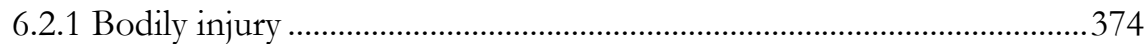

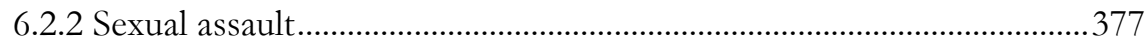

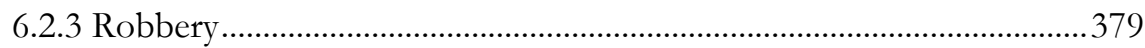

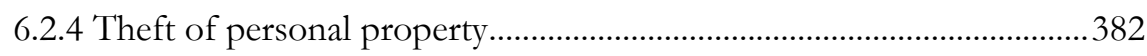

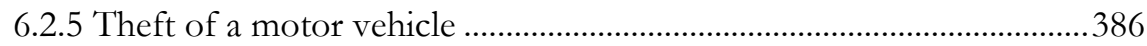

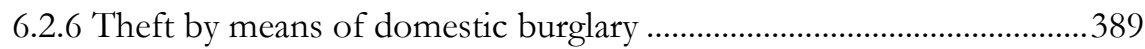

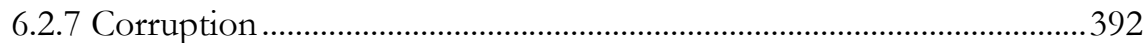

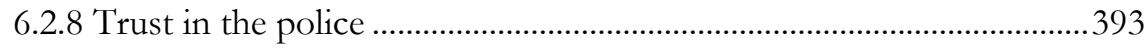

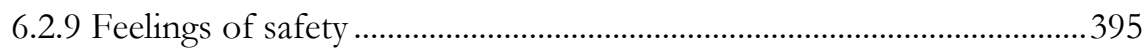

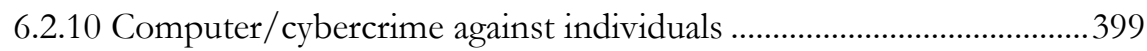

6.2.11 Computer/cybercrime against companies and charities ....................402

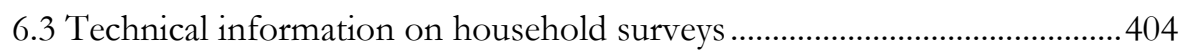

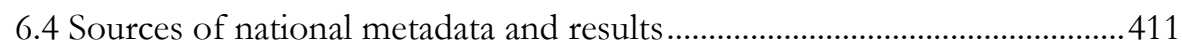

6.5 Other topics covered by National Victimisation Surveys in Europe .........413 
Appendix I: Definitions ………………………………………………………....417

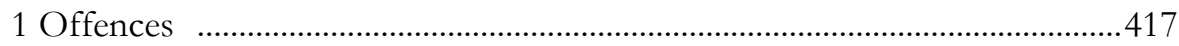

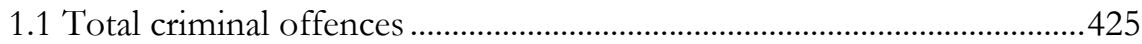

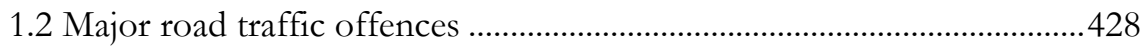

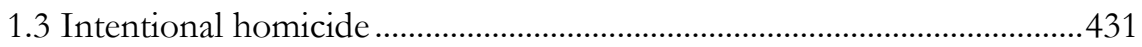

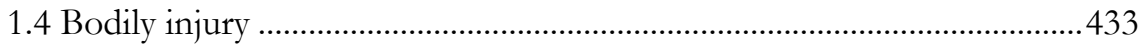

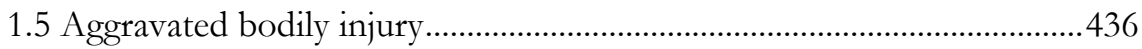

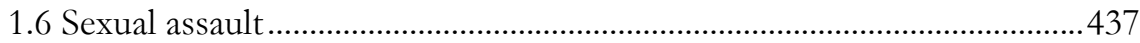

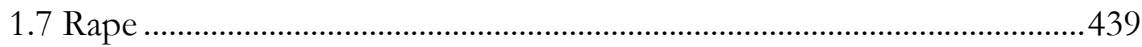

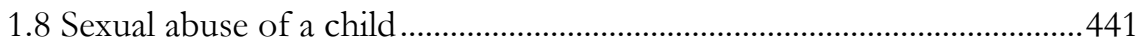

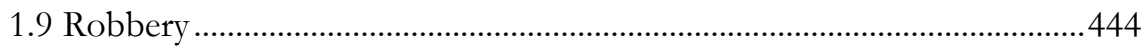

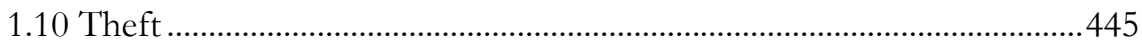

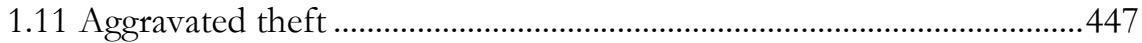

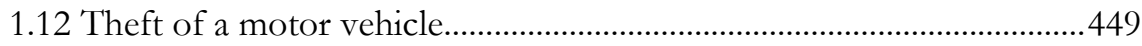

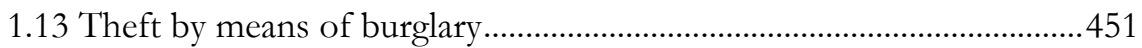

1.14 Theft by means of domestic burglary...................................................... 453

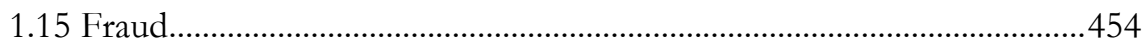

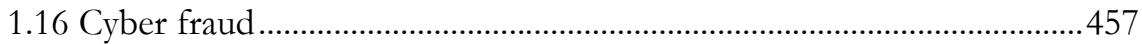

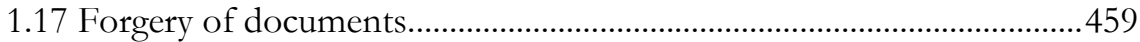

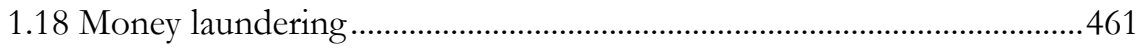

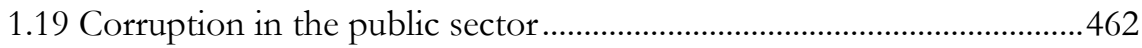

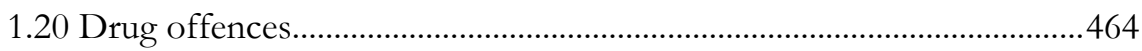

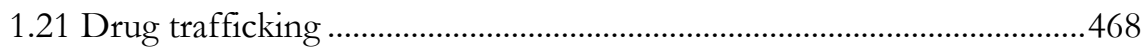

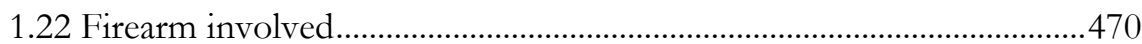

2 Young offenders and state reactions to their offending....................................474

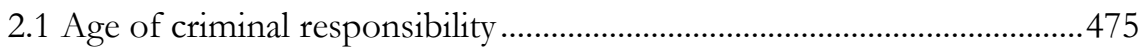

2.2 Age of adulthood in penal law................................................................476

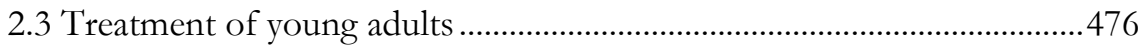

2.4 State reactions to criminal acts of minors.................................................477

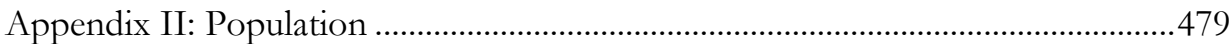




\section{General Introduction: The European Sourcebook Project}

\section{Background: Past and present of the European Sourcebook Group}

The assessment of trends in crime and criminal justice has been a permanent concern of international organisations and a major source of interest and debate for researchers and policy makers. Following the reunification of the European continent that started in 1989, the necessity of a reliable data source became evident. Against this background, the European Committee on Crime Problems (CDPC) created in 1993 a group on "Trends in crime and criminal justice: statistics and other quantitative data on crime and criminal justice systems" (PC-S-ST), composed of experts from France, Germany, Hungary, the Netherlands, Sweden, Switzerland and the United Kingdom. ${ }^{4}$

In 1995, the group presented the European Sourcebook of Crime and Criminal Justice Statistics. Draft model (Strasbourg: Council of Europe, 1995, 194 pp) to the CDPC.

\footnotetext{
${ }^{4}$ The members of the group were: Martin Killias (Switzerland; chair), Gordon Barclay (United Kingdom), Hanns von Hofer (Sweden), Imre Kertesz (Hungary), Max Kommer (Netherlands), Jörg-Martin Jehle (Germany), Chris Lewis (United Kingdom) and Pierre Tournier (France). HEUNI was represented by an observer (Kristiina Kangaspunta). The secretary to the Group was Wolfgang Rau, Directorate of Legal Affairs, Council of Europe.
} 
General Introduction

The draft model collated crime and criminal justice data for the year 1990 on ten European countries. ${ }^{5}$ At its 45th plenary session in June 1996, the CDPC entrusted the expert group with the preparation of a compendium of crime and criminal justice data for the whole of Europe. This required the enlargement of the Group through the incorporation of specialists in comparative criminology and in the collection and analysis of statistical data. ${ }^{6}$

In its work, the group took account of the periodic surveys on crime and criminal justice statistics carried out by INTERPOL -that was eventually abandoned in 2006- and the UNODC. These surveys relied on the provision of data by official authorities of each country, which usually would transmit the figures as published in their national statistics. The group decided to follow a different approach by creating a co-ordinated network of national correspondents that would access the main statistical sources within each country, collect data and metadata (i.e., information on the legal definitions of offences and the statistical counting rules applied when compiling the data), and adapt as much as possible the available figures to a standard definition of each offence developed by the group.

The development of a sustainable network of national correspondents requires the identification in each country of an expert in crime and criminal justice statistics who becomes responsible for the collection and initial checking of the data. In a quarter of a century, many colleagues assumed that role, some during several sweeps of the Sourcebook and some for one or two editions. The list of the current national correspondents is provided at the beginning of this publication. The national correspondents are responsible for the accuracy of the data provided for their respective countries as well as for identifying legal and statistical changes, or factual incidents that can explain variations in the trends observed. The members of the European Sourcebook Group -whose composition has also changed throughout the years, as can be seen in the list of authors of each edition- act as regional co-ordinators for groups of several countries.

The methodology developed by the European Sourcebook Group proved successful, and the first edition of the Sourcebook was published in 1999. Later, that methodology inspired the collection of data started at the beginning of the 2000s by Eurostat. In the same perspective, the United Nations Survey on Crime Trends and the Operations of Criminal Justice Systems (CTS) conducted by the UNODC has also incorporated, since the mid-2000s, the questions on metadata developed by the Group.

\footnotetext{
${ }^{5}$ France, Germany, Hungary, Ireland, Italy, the Netherlands, Norway, Sweden, Switzerland, United Kingdom.

${ }^{6}$ The new members of the enlarged group of Specialists were: Marcelo Aebi (Switzerland), Andri Ahven (Estonia), Uberto Gatti (Italy), Zdenek Karabec (Czech Republic), Vlado Kambovski (The Former Yugoslav Republic of Macedonia), Alberto Laguia Arrazola (Spain) and Calliope Spinellis (Greece). Paul Smit (Netherlands) and Bruno Aubusson de Cavarlay (France) joined the Group in December 1997 and April 1998 replacing Max Kommer and Pierre Tournier, respectively.
} 
After the publication of the first edition in $1999,{ }^{7}$ the Council of Europe was, unfortunately, no longer able to support the project financially. To maintain continuity in the data collection effort and especially to avoid dismantling the network of national correspondents from the whole of Europe, the second (2003) ${ }^{8}$ and the third edition (2006) ${ }^{9}$ were funded and supported by different institutions: the British Home Office, the Swiss Foreign Ministry (through the Federal Office of Statistics and the School of Criminal Sciences of the University of Lausanne), the Dutch Ministry of Justice, the Centre d'Etudes Sociologiques sur le Droit et les Institutions Pénales (CESDIP), the European Commission and the German Federal Ministry of Justice. A small group of experts was responsible for updating data and improving data quality of the European Sourcebook of Crime and Criminal Justice Statistics. ${ }^{10}$

The fourth edition of the European Sourcebook ${ }^{11}$ was made possible with support from the European Commission under the AGIS programme. ${ }^{12}$ The results of the project funded by the Commission were published independently ${ }^{13}$ and, although the Sourcebook itself was not a result of that project, the data collection instrument developed for it was used for collecting the data included in the fourth edition of the Sourcebook. In that context, efforts were made to extend the

\footnotetext{
${ }^{7}$ Council of Europe (Ed.) (1999). European sourcebook of crime and criminal justice statistics. Strasbourg: Council of Europe. Analysis of the results of the first edition is presented in a special issue of the European Journal of Criminal Policy and Research (8/1, 2000).

8 Aebi, M., Aromaa, K., Aubusson de Cavarlay, B., Barclay, G., Gruszcryńska, B., Hofer, H. v., Hysi, V., Jeble, J.-M., Killias, M., Smit, P. \& Tavares, C. (2003). European Sourcebook of Crime and Criminal Justice Statistics - 2003. 2nd edition. Den Haag: Boom. Analysis of the results of the second edition is presented in a special issue of the European Journal of Criminal Policy and Research (10/2-3, 2004).

9 Aebi, M., Aromaa, K., Aubusson de Cavarlay, B., Barclay, G., Gruszcryńska, B., Hofer, H. v., Hysi, V., Jeble, J.-M., Killias, M., Smit, P. \& Tavares, C. (2006). European Sourcebook of Crime and Criminal Justice Statistics - 2006. 3rd edition. Den Haag: Boom.

${ }^{10}$ The members of the new group of experts were: Martin Killias (Switzerland, chair), Marcelo F. Aebi (Switzerland/Spain, database administrator), Kauko Aromaa (Finland), Bruno Aubusson de Cavarlay (France), Gordon Barclay (United Kingdom), Hanns von Hofer (Sweden), Beata Gruszczynska (Poland), Vasilika Hysi (Albania), Jörg-Martin Jehle (Germany), Paul Smit (Netherlands, website administrator), and Cynthia Tavares (United Kingdom, Secretariat). Chris Lewis (United Kingdom) also assisted with the editing of the final publication.

${ }_{11}$ Aebi, M., Aubusson de Cavarlay, B., Barclay, G., Gruszcrynskea, B., Harrendorf, S., Heiskanen, M., Hysi, V., Jaquier, V., Jehle, J-M., Killias, M., Shostko, O., Smit, P. \& Dorisdottir, R. (2010). European Sourcebook of Crime and Criminal Justice Statistics - 2010. 4th edition. Den Haag: Boom. Analysis of the results of the first edition is presented in a special issue of the European Journal of Criminal Policy and Research (18/1, 2012).

${ }^{12} \mathrm{JLS} / 2006 /$ AGIS/134. The members of the expert group for the fourth edition were Martin Killias (Switzerland, chair); Marcelo Aebi (Switzerland, database administrator), Bruno Aubusson de Cavarlay (France), Gordon Barclay (United Kingdom), Beata Gruszczyńska (Poland), Stefan Harrendorf (Germany), Markku Heiskanen (Finland), Vasilika Hysi (Albania), Véronique Jaquier (Switzerland), JörgMartin Jehle (Germany), Olena Shostko (Ukraine), Paul Smit (The Netherlands), Rannveig Porisdottir (Iceland).

${ }^{13}$ Detailed results of the project can be found in: Jeble/Harrendorf (Eds.): Defining and Registering Criminal Offences and Measures. Standards for a European Comparison. Göttingen: Universitätsverlag Göttingen 2010.
} 
General Introduction

Sourcebook's coverage beyond ordinary ("street level") crimes and to include offences such as fraud, offences against computer data and systems, money laundering and corruption. Other offence definitions were completed or differentiated, such as bodily injury, drug trafficking, sexual assault and sexual abuse of minors.

The fifth edition ${ }^{14}$ took advantage of a project funded by the European Commission under the ISEC 2010 programme ${ }^{15}$ and aiming at improving data collection on the tasks and work of probation agencies and on community sanctions and measures, as well as developing indicators for the attrition process within the criminal justice system. ${ }^{16}$ Experts from the CEP (Confederation of European Probation) were involved in order to improve the questionnaire and the data validation procedure in respect of probation statistics. Based on these efforts a broader range of data and information on community sanctions and measures connected with prosecutorial decisions and orders by the court and implemented by probation agencies - both for adults and for minors - could be presented in the fifth edition. Building on this experience, the current sixth edition also presents probation data in a separate chapter.

This sixth edition signs a return to the sources of the Sourcebook project, as it was developed in collaboration with the Council of Europe. An international network of experts was needed to collect the data required for the LINCS-project (Linking International Criminal Statistics), implemented by the Council of Europe and co-funded by the European Commission, and the network of national correspondents developed by the European Sourcebook Group assumed that role. In that context two conferences with the national correspondents, who also became the LINCS experts, took place (April 2018 and June 2019), where the data collection procedures were discussed, and preliminary data were evaluated. Finally, in an online conference in March 2021 the results of the sixth survey wave were presented

\footnotetext{
14 Aebi, M., F., Akdeniz, G., Barclay, G., Campistol, C., Caneppele, S., Gruszcryńska, B., Harrendorf, S., Heiskanen, M., Hysi, V., Jeble, J-M., Jokinen, A., Kensey, A., Killias, M., Lewis, C. G., Savona, E., Smit, P. \& Dórisdottir, R. (2014). European Sourcebook of Crime and Criminal Justice Statistics - 2014, $5^{\text {th }}$ edition. HEUNI Publication Series No. 80.

${ }_{15}$ DECODEUR (HOME/2010/ISEC/FP/C1/4000001420). The project was managed by the European Institute for Crime Prevention and Control, affiliated with the United Nations (HEUNI). The members of the expert group for the fifth edition were Jörg-Martin Jehle (Germany, chair); Marcelo Aebi (Switzerland, database administrator), Galma Akdeniz (Turkey), Gordon Barclay (United Kingdom), Claudia Campistol (Switzerland), Stefano Caneppele (Italy), Beata Gruszczyńska (Poland), Stefan Harrendorf (Germany), Markku Heiskanen (Finland), Vasilika Hysi (Albania), Annina Jokinen (Finland), Annie Kensey (France), Martin Killias (Switzerland), Chris Lewis (UK), Ennesto Savona (Italy), Paul Smit (The Netherlands), Rannveig Porisdottir (Iceland).

16 Detailed results of this project are publicized parallel to this book in: Heiskanen/Aebi/van der Brugge/Jehle (Eds.): Recording Community Sanctions and Measures and Assessing Attrition. A Methodological Study on Comparative Data in Europe. Helsinki: HEUNI 2014.
} 
and reflected in an expanded context, also taking into account other data collection initiatives, victimisation studies and the needs of and impact on criminal policy. ${ }^{17}$

From 2001 to 2012, the Dutch Ministry of Justice provided the necessary resources to set up and maintain a website containing all the data of the 1999, 2003, 2006 and 2010 editions of the European Sourcebook under the supervision of Paul Smit (WODC, Ministry of Justice of the Netherlands). Since 2012, the University of Lausanne has taken over this function for the European Sourcebook, under the supervision of Marcelo Aebi. Results for all ESB editions, including the respective original data, are available on this ESB website (www.unil.ch/europeansourcebook).

\section{Definitions of offences and sanctions}

Comparative criminology has to face the problem of national offence definitions that are often incompatible. The group adopted the following procedure: For all offences included in the European Sourcebook, a standard definition was developed, and countries were invited to follow it whenever possible. Offence definitions and related commentaries are given in an appendix of this book, providing for each of the selected offences detailed information on which countries (among those providing numerical data) were able to fully conform to the definition and which countries deviated from it. For the latter, there is also an indication of the elements of the definition that they were unable to meet. Data on definitions are presented separately for police and convictions levels.

\section{The structure of the European Sourcebook}

This edition of the European Sourcebook is divided into six chapters, each of which is, in general, subdivided into four sections:

1. General comments

2. Tables

3. Technical information

4. Sources

The six chapters are:

A. Police data. Chapter 1 provides information on offences and suspected offenders known to the police in each country, as well as on police staff. Most of the data are available as time-series covering the years 2011 to 2016. Detailed information on the sex, age group, and nationality of suspects is provided for 2015. This sixth edition includes three additional offences: aggravated theft, cyberfraud, and forgery of documents. It also brings

17 Aebi, M. F. et al (2021): Three Decades of Crime and Criminal Justice Statistics in Europe: Methods, Trends and the Impact on Policy Making. Council of Europe, Strasbourg. 
significant improvements to the definitions or major road traffic offences, rape, and sexual abuse of a child, which are based on an analysis of the data and metadata collected in previous editions. These modifications are aiming to improve comparability across countries in this edition of the European Sourcebook, although they imply that the figures collected are not fully comparable with those included in earlier editions of it. For most of the other offences, only minor improvements and clarifications were introduced.

B. Prosecution statistics. Chapter 2 covers all steps of decision-making at the prosecution level, such as initiating and ending proceedings, bringing cases to court and sanctioning offenders by summary decisions. Data on the output of the prosecution level both for all cases and cases brought before a court refer to 2011 to 2016, which is also the period covered by data on the staff of prosecution authorities. Separate data for groups of offenders and offences and the breakdown by various case-ending decisions are provided for 2015. The chapter also included data on compulsory measures during criminal proceedings, such as police custody and pre-trial detention.

C. Conviction statistics. The tables in chapter 3 deal with persons who have been convicted, i.e., found guilty according to the law, of having committed a criminal offence. Information on convictions is presented by offence for the years 2011 to 2016. Detailed information on the type of sanction imposed (including community sanctions and measures), on sentence lengths of custodial sanctions and on sex, age group, nationality, and prior pre-trial detention of sentenced persons are provided for the year 2015. This edition also includes an overview of the number of judges by country in that year.

D. Prison statistics. Chapter 4 includes data on 'stock', 'flow of entries' and 'flow of exits' of prison populations for the years 2011 to 2016, including percentages of pre-trial detainees, women, minors and foreigners. Data on exits is also breakdown by releases and deaths. The chapter also includes data on the convicted prison population by offence group in 2015, as well as on prison staff on 1 September 2016.

E. Probation statistics. Chapter 5 provides information on the number of persons placed annually under the supervision of probation agencies from 2011 to 2016 (flow of entries), as well as on the number of persons under such supervision (stock) on 31st December of each of these years. The detailed information provided for the year 2015 includes the type of supervision under which probationers were placed, the percentage of women, minors and foreigners among the stock of probationers, the number of persons leaving probation (flow of exits) -including the reasons for ending supervision- as well as the staff of probation agencies, and the number of reports written by them.

F. National victimisation surveys. Chapter 6 presents data on national victimisation surveys carried out by the responding countries every five years from 
1990 to 2015. The chapter provides information about the methodology used in these surveys and the labelling of the questions include and presents some selected results.

\section{Methodological issues}

\subsection{Data recording methods}

Since the timing and method of recording can have a considerable impact on a statistical measure, the Group paid much attention to the way in which national data were collected and recorded, and what operational definitions were applied at the several stages of the criminal justice process. Detailed information provided on this has been summarised in the form of tables, short comments, as well as in the definitions appendix.

\subsection{Validation}

Validation is often the most important and, in many cases, the most forgotten stage of the data collection process. As a first step, the group identified and discussed obvious problems relating to this process. Data validation involved:

A. Trend checks: Evaluation of the consistency of the trends for the years covered in this edition and also in comparison with the data provided for the previous edition of the European Sourcebook. This was mainly a check for 'outliers', i.e., extreme values which are difficult, if not impossible, to explain.

B. Internal validity checks: Evaluation of the coherence of the results provided for different, logically connected variables was checked (for example, differences in the total provided for one item and the addition of its subcategories, or the acceptable range of certain ratios (for example, suspects by offences or convictions by suspects).

C. Other sources checks: Whenever possible, results were compared to the results published in the surveys of Eurostat, UNODC and the Council of Europe (SPACE).

This procedure resulted in the need to go back to many national correspondents for clarifications and additional cross-checking. It allowed correcting some mistakes, but also revealed many differences in the national statistical systems, which are extensively documented in the metadata.

As an additional validity check, the year 2011 is covered by both the 5 th and the 6th edition of the European Sourcebook. In some cases, both figures are not identical. In principle, data included in the present edition should be considered as more accurate. Usually, the reason for these differences was that the data for the year 
2011 of the fifth edition were provisional as the questionnaire had been sent a few months after the end of that year.

\section{Presentational details}

In order to increase the readability of the present report, the group took the following practical decisions:

A. To make all raw data and all comments available in a separate publication (Original Data of the European Sourcebook of Crime and Criminal Justice Statistics 2021-Sixth edition) freely available for download on the website www.unil.ch/europeansourcebook. Consequently, the present document contains only a selection of all the data and comments received.

B. To shorten, in general, tables where the number of reporting countries was small. ${ }^{18}$

C. To use decimals sparingly so as to avoid giving a false impression of precision.

D. To use the English notation for figures. The decimal marker is represented by a dot (i.e., 1.5 means one and a half). The thousand marker is represented by a space (i.e., 1500 means one thousand five hundred).

E. To translate comments, where necessary (although left in the original language in the database that can be accessed through the European Sourcebook website).

F. To use the following symbols throughout the tables:

a) ' 0 ' to indicate a number between 0 and 0.4 ;

b) '...' to indicate that data is not (yet) available or that the question / concept as used in the European Sourcebook questionnaire does not exist in the country;

c) '> 1000 ' to indicate that the percentage change between 2011 and 2016 is above one thousand per cent.

G. To condense the vast amount of technical information on definitions, data collection methods, processing rules, and other metadata in summary tables, listings and footnotes.

H. Whenever possible and reasonable, figures were transformed into rates per 100000 population or indicated as percentages. In the case of minors, rates are given per 100000 total population because information on the number of minors in the total population of each country was not available.

I. The total population figures used are contained in Appendix II at the end of the publication.

\footnotetext{
18 Only very few tables have been totally eliminated from the publication. In such cases, the original data are available in the publication mentioned above.
} 
J. To use the following measures throughout the tables to provide information on the data dispersion:

a. Mean: The (unweighted) arithmetic average; the sum of scores divided by the number of countries that provided data. The value of the mean is sensitive to the presence of very high or very low scores. For this reason, the median was also included as an indicator of the central tendency of the data.

b. Median: The (unweighted) median is the score that divides the distribution of scores into two exact halves.

c. Minimum: The lowest score in the table.

d. Maximum: The highest score in the table.

e. Percentage change 2011 to 2016 (exact calculation based on the original data with all the decimals not shown here).

\section{Comparability}

The basic aim of the European Sourcebook data collection is to present comparable information on crime and criminal justice statistics in Europe. ${ }^{19}$ However, the issue of whether or not it is feasible or appropriate to use official criminal justice statistics for decision-making in crime policy or for conducting scientific studies is one of the classic debates of criminology. The problems involved are even more serious when it comes to international comparisons, because nations differ widely in the way they organise their police and court systems, the way they define their legal concepts, and the way they collect and present their statistics. In fact, the lack of uniform definitions of offences and sanctions, of common measuring instruments and of a common methodology makes comparisons between countries extremely hazardous. ${ }^{20}$ This is the reason why criminologists over the last decades have developed alternatives to complement the existing official statistics: international comparative victimisation studies, on the one hand, and international comparative self-report studies on the other. Due to a lack of recent international victimisation studies, Chapter 6 includes data from national victimisation surveys, which can be compared only with extreme caution.

Comparative analyses generally fall into one of three categories: (A) distributive comparisons, (B) level comparisons and, (C) trend comparisons.

\footnotetext{
${ }^{19}$ See further Jehle, J.-M. (2013). Crime and Criminal Justice in Europe. The Approach of the European Sourcebook. In Kuhn, A., Schwarzenegger, C., Margot, P., Donatsch, A., Aebi, M.F. \& Jositsch, D. (eds.), Criminology, Criminal Policy and Criminal Law in an International Perspective, Essays in Honour of Martin Killias on the Occasion of his 65th Birthday (pp. 191-205). Zürich: Stämpfli 2013.

${ }^{20}$ Detailed: Harrendorf, S. (2018). Prospects, Problems, and Pitfalls in Comparative Analyses of Criminal Justice Data. Crime and Justice: A Review of Research 47, 159-207.
} 
A. Distributive comparisons are aimed at answering questions such as: Do theft offences dominate the crime picture in most countries? What is the age profile of sentenced offenders in the various countries?

B. Level comparisons are aimed at answering questions of the following type: Which country reports the highest robbery rate? Which countries show low rates of incarcerated offenders? Which criminal justice systems have a high level of attrition, e.g., measured by the relation of convicted to suspected persons?

C. In contrast, interpretations of trends deal with such questions as: Did crime increase or decrease during the period under study? Did the decrease in theft of a motor vehicle offences differ over time in various countries?

Before these and other questions can be answered, it should be noted that official crime and criminal justice statistics are fundamentally dependent upon four sets of circumstances: (a) substantive factors such as the propensity of individuals to commit crimes, the opportunity structure, the risk of detection, the willingness of the public to report crimes, or the efficiency of criminal justice authorities; (b) legal factors such as the design of the Criminal Code, the Code of Criminal Procedure and other relevant legislation; the formal organisation of criminal justice agencies and the informal application of the law in everyday life; (c) statistical factors such as the formal data collection and processing rules and their practical implementation and (d) criminal policy factors, which relate to the crime and crime prevention policies applied in each country that may focus the available resources on some offences (for example, drug offences or domestic violence offences). ${ }^{21}$

To ensure comparability when making distribution and level comparisons, one must carefully control the legal and statistical circumstances before concluding that similarities or dissimilarities can be taken as real. The demands are somewhat different when it comes to ascertaining crime trends. For such analyses, the 'real' crime level does not need to be known; it is sufficient to control for possible changes to the legal and statistical systems, or in the criminal policies applied. This is, of course, a difficult task and identifying informal changes in criminal justice procedures and in statistical routines is especially difficult. In order to assist the reader in making

\footnotetext{
${ }^{21}$ For details, see von Hofer, H. (2000). Crime statistics as constructs: The case of Swedish rape statistics. European Journal on Criminal Policy and Research, 8(1), 77-89; Aebi, M.F. (2010). Methodological Issues in the Comparison of Police-Recorded Crime Rates. In Shoham S.G., Knepper P. \& Kett M. (Eds.). International Handbook of Criminology (pp. 211-227). CRC Press; Harrendorf, S. (2012). Offence Definitions in the European Sourcebook of Crime and Criminal Justice Statistics and Their Influence on Data Quality and Comparability, European Journal on Criminal Policy and Research 18(1), 23-53.
} 
informed decisions on the validity of trend data, possible changes in the data recording methods are indicated in the technical information contained in each chapter. $^{22}$

To facilitate the use of the data contained in this European Sourcebook, comprehensive additional information concerning the definition of offences and sanctions, the data collection and processing rules were collected. This information is contained in section 3 of each chapter. However, it is not possible to easily quantify the extent to which over- or under-reporting occurs.

\section{Basic rules on how to use the statistical information contained in the Sourcebook ${ }^{23}$}

1. Do not use any figures from the Sourcebook without referring to the footnotes and the technical information provided in each chapter.

2. Do not over-interpret relatively 'small' differences in the tables, especially between countries.

3. Do not over-interpret relatively 'large' differences in the tables, especially between countries.

4. Do not stress differences between individual countries too much. It is better to compare an individual country with a larger group of countries or with the average for all countries.

5. Whenever possible, avoid using the tables on police-recorded offences for 'level' comparisons between countries. Rather, they should be used for 'trend' comparisons. Victimisation surveys are a more valid source for cross-national comparisons, namely when they are conducted using the same questionnaire.

6. Avoid interpreting 'large' variations from one year to another as evidence for changes in the measured phenomenon. Sudden increases or decreases are often merely indicative of modifications in the law, the criminal policy, or in the underlying statistical routines/counting rules.

\footnotetext{
${ }^{22}$ Examples of how European Sourcebook data can be analysed can especially be found in the following special issues of the European Journal of Criminal Policy and Research: 8/1 (2000), 10/2-3 (2004), 18/1 (2012). For a more detailed list of publications referring to European Sourcebook data, see http://www3.unil.ch/wpmu/europeansourcebook/publications/.

23 Also see the detailed list of 16 "dos and don'ts" of comparison of international crime and criminal justice data in Harrendorf, S. (2018). Prospects, Problems, and Pitfalls in Comparative Analyses of Criminal Justice Data. Crime and Justice: A Review of Research 47, 159-207, at 200-202.
} 



\section{Police Statistics}

\subsection{General comments}

\subsubsection{Police statistics as a measure of crime}

This chapter provides information on offences recorded by the police, the number of offences per 100000 population, the characteristics of suspected offenders, and the number of police staff.

Police statistics are collected in every country but for several reasons they do not offer a comprehensive measure of crime. Victims may choose not to report the crime to the police (e.g., depending on how serious they view the offence, their previous experiences or trust in the police) or they may not be aware that they have been a victim of crime. In addition, reporting may be self-incriminating (e.g., when a victim is also an offender) or humiliating or the victim may think that nothing will be gained by reporting (e.g., the victim thinks that the police will not be able to solve the crime).

If the victim does not report a crime, and the police do not learn about the offence from another source, the offence will not be recorded and therefore not counted in police statistics. Research suggests that victims of bodily injury or rape, 
for example, tend to be less likely to report the offence than victims of property crimes. ${ }^{24}$

Not all crimes are reported by a victim or a witness. The police themselves may report violent crimes, for example homicide and 'victimless' offences (such as illegal possession of arms, drink-driving and drug offences). Even when a crime is reported to the police, it may not be recorded in the official statistics. This may occur if the police believe that the event reported did not actually constitute a crime. Petty offences are not always recorded in police statistics. Also, countries differ in the way they consider certain offences as petty (e.g., theft of low-value items). In assessing national differences, comparisons with other data sources, such as victimization surveys (e.g., the International Crime Victims Survey, ICVS), are helpful. The last sweep of the ICVS was carried out in 2005. More information about victimization surveys is given in Chapter 6.

\subsubsection{Police in the criminal justice system}

In most countries the police are the first stage of the criminal justice process. However, this does not mean that the figures on recorded crime, such as those in this chapter, give an accurate account of the total input to the criminal justice system. In several countries, the prosecuting authorities may initiate criminal proceedings without receiving a police report. Also, other agencies (military police, customs, border police, and fiscal fraud squads) and individuals (foresters, judges, or even citizens) may have the power to initiate criminal proceedings by filing a complaint with the prosecution authorities or the court. Nevertheless, most of the offences covered by the Sourcebook will be reported to or detected by the police.

The position of the police in the criminal justice system may also directly influence the number of offences recorded and how they are classified. In some countries the police are quite independent in their activities, whilst in others they may work under the close supervision of the prosecutor or the court.

Substantial differences exist between countries in the tasks that the police carry out. For example, in most countries the police deal with traffic offences such as drink-driving, causing bodily harm or petty traffic offences (such as speeding and illegal parking). Also, in most countries, the police have the additional task of maintaining public order and of assisting the public in various situations (from providing information to rendering first aid). This may not apply, however, to all types of police or related agencies that have been included in the tables on police staff. Therefore, care should be taken when relating police resources to the volume of recorded crime or the number of suspected offenders.

${ }^{24}$ Van Dijk, J., van Kesteren, J. \& Smit, P. (2007). Criminal Victimisation in International Perspective. Key Findings from the 2004-2005 ICVS and EU ICS. 257 Onderzoek en beleid. Den Haag: WODC. 


\subsubsection{Counting offences and offenders}

Certain classification issues need to be considered when examining police statistics: 25

- The point in time when the offence is recorded in the statistics: did the recording follow the initial report ('input' statistic) or the initial investigation ('output' statistic)?

- Multiple offences: One offence can consist of several offences (e.g., rape, followed by a homicide and the use of an illegal weapon). Therefore, awareness of whether the offences committed are counted separately or whether a principal offence rule is applied (i.e., only counting the most serious offence) is essential.

- In addition, in relation to serial or continuous offending, issues such as whether a report of domestic violence experienced over a period of time is counted as one or several incidents are important.

Similar issues arise in connection with the counting of offenders. Differences between countries exist and practices range from recording a person as a 'suspected offender' as soon as the police are reasonably convinced that this is the case, to recording a person as a 'suspect' only after the prosecutor has started criminal proceedings.

\subsubsection{Counting police officers}

European countries organise their police systems in different ways. Most of them have more than one police force, e.g., state police, communal police, municipal police, gendarmerie, or judicial police. They perform tasks in connection with the offences under consideration in this Sourcebook although some also undertake military duties (e.g., gendarmerie).

A standard definition for police officer was used. This included criminal police, traffic police, border police, gendarmerie and uniformed police but excluded customs police, tax police, military police, secret service police, part-time officers, police reservists, cadet police officers and court police (see Tables 1.3.1 - 1.3.2).

Many European countries have seen considerable increases in the private security industry over recent years and such increases can influence the counting of crime. For example, the increase of private security guards and doormen can lead to a fall in the counts of crime in retail shops and clubs as some guards may deal with crime themselves by banning offenders from their premises.

\footnotetext{
25 Aebi, M. F. (2008). Measuring the Influence of Statistical Counting Rules on Cross-National Differences in Recorded Crime. In K. Aromaa \& M. Heiskanen (Eds.), Crime and Criminal Justice Systems in Europe and North America 1995-2004, 196-214. HEUNI Publication Series No. 55. Helsinki: European Institute for Crime Prevention and Control.
} 


\subsubsection{Results}

All participating countries, except from Croatia, were able to provide information on some offences reported to the police. Croatia was not able to provide any data since they only collect information regarding the offenders but not offences. Turkey was not able to provide any data for the year 2016 and Luxembourg only for homicide. Information from Russia was limited to bodily injury, robbery, and theft (total, theft of motor vehicle and burglary).

The moment at which the data is recorded varies between countries; Seventeen countries reported that offences were recorded as soon as an offence is first reported to the police and in some cases also later in the procedure. Thirteen countries reported that recording is done subsequently, and nine reported that recording occurs only after investigation. It is difficult to interpret the impact of these findings on the statistics, but it seems that 'as soon as' and 'subsequently' imply that the legal labelling of the offence is the task of the police, whilst 'after investigation' seems to indicate that the labelling is done by the prosecuting authorities (output statistics) once the police inquiry has been completed. This might explain some of the differences in levels between countries, especially for offences such as homicide and bodily injury.

The rules for recording both multiple and serial offences vary between countries. For example, 16 countries stated that they apply a principal offence rule and 20 stated they do not. In addition, multiple offences are counted as two or more offences in 20 countries but as one offence in 15 countries. Most countries, 31, count an offence committed by more than one person as one offence.

In total 38 countries answered one or more questions regarding offenders, whilst eight countries were not able to provide any data. Not all countries providing data were able to answer questions regarding definitions of persons suspected. In general, most countries include all persons under suspicion, persons who are interrogated as suspects, persons arrested, cautioned and persons who are accused, charged, or later indicted. Sixteen of the countries also reported that they include minors in statistics regarding suspected persons. Twelve countries provided data that is collected at the same time as the data on offences is collected, indicating that the labelling of the offender is done by the police. Five countries reported that the data was collected at a later stage and one country reported mixed methods.

Whilst many countries answered the question on the number of police officers and civilians working within the police, few were able to meet the standard definition.

Trends in both recorded crime and suspected offenders over the years 20112016 vary from one type of offence to another. But in general, the majority of countries are reporting a decrease in number of offences per 100000 population. This applies mostly to homicide and bodily injury and financial offences excluding fraud. Fraud and cyber fraud are the only offences that the majority of countries are reporting an increase in numbers per 100000 population. 


\subsubsection{Comments by offences}

Police statistics contain tables on offences and perpetrators, both on the total number of offences and offenders and information regarding 24 crime categories, including information regarding the number of homicides and robberies committed with firearms. Additionally, information on police staff is included.

\section{Total offences}

Of participating countries $80 \%$ were able to provide data on total offences. Most of the countries were able to follow the guidelines of which offences they should include or exclude. Still there are large differences between countries in the number of total criminal offences, even when traffic offences are excluded. This indicates large variations in how police data is defined e.g., in how large-scale traffic offences are included in police statistics. It also indicates variations in definitions that many of the countries with the highest number of total offences per 100000 population do not report the highest number of suspected offenders. This for example applies to Sweden. Still there is some correlation between the number of offences per 100 000 and number of suspected offenders.

Around $54 \%$ of the countries providing data, show a decrease in the number of total offences between 2011 and 2016 and 22\% show an increase in the same period. About $24 \%$ of countries show stability when the number of total offences in 2016 is compared with the number of total offences in 2011 per 100000 population. The largest reductions are reported in countries in the Eastern part of Europe e.g., Poland, Hungary, Czech Republic, Estonia, and Slovenia.

The same pattern emerges when looking at changes in the number of suspected offenders since $59 \%$ of countries that could provide data are reporting a decrease between 2011 and 2016 per 100000 population.

\section{Major road traffic offences}

More than half of the countries report a decrease in the number of major road traffic offences per 100000 population between the years 2011 and 2016. In 2010 changes were made to a series of traffic offences in Greece downgrading them from misdemeanour to minor offences. This can possibly explain the steep decline in number of reported major road traffic offences there.

Wide variations were found in a number of reported major road traffic offences with a number of Nordic countries reporting highest values (over 700 offences per 100000 population) as well as Belgium.

\section{Intentional homicide (attempts and completed)}

Roughly $83 \%$ of the countries asked provided data for this category in 2016 . The majority of the countries reported a decrease in the number of cases per 100000 population, both in the regard of completed cases and including attempts. About 
$18 \%$ of the countries show an increase in number of intentional homicides both completed and including attempts compared to 2011. The largest increase is in Ukraine but in the same period there is a decrease in the number of suspected offenders there. This increase in number of intentional homicide is due to a new Criminal Procedural Code of Ukraine that came into force in 2012.

The large decrease shown for Norway is due to the terrorist attacks of Anders Breivik in 2011 which are included in the figures for intentional homicide that year.

\section{Bodily injury}

The majority of countries report a decrease in the number of bodily injury cases and aggravated bodily injury cases registered by the police in 2016 compared to 2011 . There are large differences in the number of cases per 100000 population reported but many of the countries reporting the highest number of cases report that they cannot exclude assaults only causing pain from the number of bodily injury cases. This applies for example to Belgium, Finland, Romania, and Sweden (who report the highest number of cases per 100000 population for bodily injury).

\section{Sexual Assault}

Most countries can provide information regarding sexual assault, the majority showing an increase in the number of reported cases to the police between 2011 and 2016. The variation in the number of cases per 100000 population is large, ranging from less than five cases in many countries in the Eastern part of Europe such as Ukraine, Montenegro, Armenia, Albania, and Serbia to over 100 cases per 100000 population in UK: England \& Wales, UK: Scotland, Sweden, UK: Northern Ireland and in Iceland. Results for reported rape are similar, showing 44\% of the countries reporting an increase in the number of registered cases but large differences in numbers per 100000 population from less than one case in countries in Eastern Europe to more than 20 and to the maximum of 68 cases per 100000 population in Northern parts of Europe.

\section{Sexual abuse of a child}

Thirty countries provided data on sexual abuse of a child. Most of them were not able to follow the standard definitions, for example many were not able to exclude verbal abuse i.e., via the internet and/ or include attempts. Of the countries providing data 12 reported an increase in the number of cases per 100000 population between 2011 and 2016 and the same number of countries reported a decrease. A large increase is reported in UK: England \& Wales due to changes in the legislation and new offences being added. 


\section{Robbery}

Close to $96 \%$ of the countries provided data regarding reported robbery, more than 79\% reporting a decrease between 2011 and 2016. As with most other types of offences the variation of the number of offences per 100000 population is large, from under 10 cases per 100000 in Albania, Azerbaijan, Malta, and Russia (reporting a large decrease between 2012 and 2013) to more than 100 per 100000 population in Portugal, Spain, France, and Belgium. The mean rate is 41 robberies per 100 000 population.

Half of the countries provided data regarding robbery with firearm, most of them (89\%) reporting more than 10 percent decrease between 2011 and 2016 per 100000 population.

\section{Theft}

Here the standard definition of theft is "depriving a person or organization of property with the intent to keep it". Included are minor thefts, thefts committed by means of burglary, theft of motor vehicles and thefts by employees. Attempts are also included here. Excluded are robberies, fraud, and handling with stolen goods.

A large majority of the countries were able to follow the definitions, with the exception of those countries that exclude either minor thefts and/or attempts. This can partly explain large variations in the number of thefts per 100000 population, ranging from five cases per 100000 population in Albania to 5.025 cases in Sweden. But definitions cannot fully explain these large differences since for example those both countries report that they were able to follow the definitions.

In total close to $70 \%$ of countries showed a decrease in number of cases between 2011 and 2016. Five countries report an increase in the number of thefts during the period, Armenia showing the greatest increase (45\%), followed by Azerbaijan (35\%) and Belgium (27\%), Ukraine (20\% and Greece (17\%).

Only $37 \%$ of countries were able to provide data on aggravated theft, most of them reporting a decrease (59\%) in the number of cases between 2011 and 2016 per 100000 population. Only three countries reported an increase in the period, Albania, Armenia, and Greece but in all instances the figures are very low, or the growth is not linear during the period.

When asking specifically on theft of a motor vehicle, it is obvious that number of cases is going down in most countries in Europe since $84 \%$ of those countries that could provide data reported so ( $87 \%$ of countries provided data). Only two countries reported an increase in the number of cases between 2011 and 2016 and four showed a stable situation. Despite clear development it is obvious that there are large deviations in how motor vehicle theft is defined, for example "joy ride" is not included in many instances as is theft of motor vehicle parts included in many countries. 


\section{Burglary and domestic burglary}

Approximately $70 \%$ of the countries provided data for cases of theft by means of burglary with $77 \%$ of them reporting a decrease and only three countries reporting an increase between the years 2011 and 2016. There are large variations in the number of cases ranging from less than 100 cases per 100000 population in Albania, Armenia, Bosnia-Herzegovina, Georgia, and Moldova to more than 600 cases per 100000 in Austria, Belgium, Denmark, Netherlands, Sweden, and UK: England \& Wales. Variations in definitions can explain these differences but only partly.

The majority of countries also report a decline in the number of thefts by means of domestic burglary between 2011 and 2016, or more than 59\% of countries that were able to provide data. Nine countries reported an increase and five a stable situation during this period.

\section{Frand}

At the same time as many countries report a decline in reported theft and burglary, reported incidents of fraud are increasing. Little more than $55 \%$ of countries reported an increase in the number of frauds reported to the police between 2011 and 2016 per 100000 population but only 24\% reported a decrease. The increase might indicate a growth in cyber fraud but $79 \%$ of those countries that were able to provide data report an increase (more than 10\% increase between 2011 and 2016 per 100000 population. There are huge variations in the number of reported cases, with the lowest numbers in the Eastern part of Europe and the highest numbers in the Northern part (Sweden, Denmark, Germany, and Belgium reporting the highest numbers).

\section{Forgery of documents}

Of the countries asked, $61 \%$ provided data, the majority of them (59\%) reporting a decrease in the number of cases per 100000 population between 2011 and 2016 and seven countries reporting an increase. Fourteen countries gave information regarding suspected offenders of forgery of documents. Six of these countries reported that foreign nationals were more than $50 \%$ of those suspected of forgery of documents in 2016.

\section{Money Laundering}

Money laundering is defined as "specific financial transactions to conceal the identity, source, and/or destination of money or non-monetary property deriving from criminal activities". Even though there has been an emphasis on harmonising criminal penalties for money laundering within the EU only little more than half of the countries were able to provide data on money laundering, $58 \%$ of them reported an increase between 2011 and 2016. 


\section{Corruption in the public sector}

Of the 28 countries that provided data roughly 44\% reported an increase in the number of cases per 100000 population between 2011 and 2016. Eight countries reported a decrease of cases in the period and seven a stable situation.

\section{Drug offences}

Most countries were able to provide data on drug offences. It is very interesting to see the large differences between countries regarding trends in the number of drug offences between 2011 and 2016 per 100000 population with 15 countries reporting an increase, 12 a decrease and 12 reporting a stable situation. There are also large differences in the number of cases per capita. Ranging from 22 cases per 100000 population in Romania to 1000 cases in Switzerland with the mean of 230 cases in 2016.

The same picture emerges when looking at the number of drug trafficking offences. From 2011 to 2016, 42\% of countries report an increase, 32\% a decrease and a quarter report a stable situation.

\section{Trends}

Table 1.a summarises trends (i.e., percentage changes between 2011 and 2016 per 100000 population) in police data by types of offences. The table shows a general trend towards a decline in the number of offences that are reported by the countries here since more than half of countries reported a decline in 15 of the offences reported here. 
Table 1.a: Trends in police data (percentage change of the rates between 2011 and 2016 per 100000 population)

\begin{tabular}{|c|c|c|c|c|c|c|c|c|c|c|c|c|c|c|c|c|c|c|c|c|c|c|c|c|}
\hline & 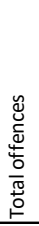 & 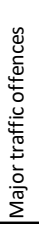 & 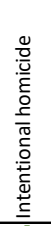 & 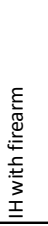 & 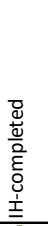 & 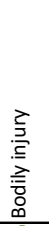 & 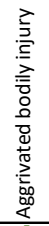 & 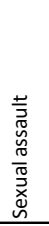 & 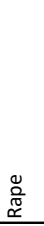 & 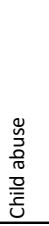 & $\begin{array}{l}\text { ते } \\
\text { o } \\
\text { o } \\
0\end{array}$ & 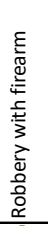 & $\begin{array}{l}\frac{\vec{U}}{d} \\
\vec{F}\end{array}$ & 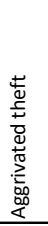 & 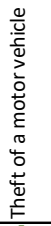 & $\begin{array}{l}\frac{2}{0} \\
\frac{\pi}{00} \\
\overline{0} \\
0\end{array}$ & 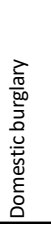 & 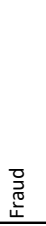 & 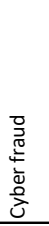 & 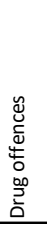 & 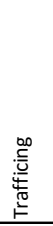 & 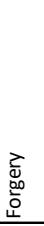 & 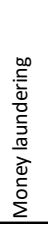 & 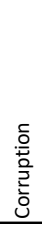 \\
\hline Albania & $\uparrow$ & $\Rightarrow$ & $\downarrow$ & $\ldots$ & $\Downarrow$ & $\downarrow$ & $\downarrow$ & $\uparrow$ & $\uparrow$ & $\uparrow$ & $\downarrow$ & $\Downarrow$ & $\downarrow$ & $\uparrow$ & $\downarrow$ & $\downarrow$ & $\uparrow$ & $\uparrow$ & $\uparrow$ & 个 & $\uparrow$ & $\uparrow$ & $\uparrow$ & $\uparrow$ \\
\hline Armenia & $\uparrow$ & $\downarrow$ & $\uparrow$ & $\ldots$ & $\uparrow$ & $\Rightarrow$ & $\uparrow$ & $\uparrow$ & $\uparrow$ & & $\Rightarrow$ & & $\uparrow$ & $\uparrow$ & $\Rightarrow$ & $\uparrow$ & $\uparrow$ & $\uparrow$ & $\ldots$ & $\downarrow$ & $\downarrow$ & $\ldots$ & $\ldots$ & $\uparrow$ \\
\hline Austria & $\Rightarrow$ & $\downarrow$ & $\downarrow$ & $\Rightarrow$ & $\downarrow$ & $\Rightarrow$ & $\Rightarrow$ & $\Rightarrow$ & $\Rightarrow$ & $\downarrow$ & $\downarrow$ & $\Downarrow$ & $\Rightarrow$ & $\Rightarrow$ & $\downarrow$ & $\Rightarrow$ & $\uparrow$ & $\Rightarrow$ & $\ldots$ & $\uparrow$ & $\ldots$ & $\Rightarrow$ & $\Rightarrow$ & $\downarrow$ \\
\hline Azerbaijan & $\Rightarrow$ & $\downarrow$ & $\downarrow$ & $\ldots$ & $\downarrow$ & $\ldots$ & $\Rightarrow$ & $\ldots$ & $\uparrow$ & $\ldots$ & $\Rightarrow$ & & $\uparrow$ & $\ldots$ & & & & $\uparrow$ & $\ldots$ & $\Rightarrow$ & & $\cdots$ & $\ldots$ & \\
\hline Belgium & $\downarrow$ & $\downarrow$ & $\Rightarrow$ & $\downarrow$ & $\downarrow$ & $\Downarrow$ & $\ldots$ & $\Rightarrow$ & $\Rightarrow$ & $\Rightarrow$ & $\downarrow$ & $\Downarrow$ & $\uparrow$ & $\ldots$ & $\Downarrow$ & $\Downarrow$ & $\Downarrow$ & $\uparrow$ & $\uparrow$ & $\uparrow$ & $\downarrow$ & $\Downarrow$ & $\Rightarrow$ & $\Downarrow$ \\
\hline Bosnia-Herzegovina & $\ldots$ & $\ldots$ & $\ldots$ & $\ldots$ & $\Rightarrow$ & 个 & $\ldots$ & $\ldots$ & $\downarrow$ & $\ldots$ & $\uparrow$ & $\uparrow$ & $\downarrow$ & $\ldots$ & $\Rightarrow$ & $\downarrow$ & $\ldots$ & $\ldots$ & $\ldots$ & $\ldots$ & 个 & $\ldots$ & $\ldots$ & $\ldots$ \\
\hline Bulgaria & $\downarrow$ & $\Rightarrow$ & $\downarrow$ & $\ldots$ & $\downarrow$ & $v$ & $\Rightarrow$ & $\downarrow$ & $\downarrow$ & $\downarrow$ & $\downarrow$ & $\downarrow$ & $\downarrow$ & $\downarrow$ & $\Rightarrow$ & $\downarrow$ & $\Downarrow$ & $\uparrow$ & $\uparrow$ & $\uparrow$ & $\ldots$ & $\ldots$ & $\uparrow$ & $\Rightarrow$ \\
\hline Croatia & $\ldots$ & $\ldots$ & $\ldots$ & $\ldots$ & $\ldots$ & $\ldots$ & $\ldots$ & $\ldots$ & $\ldots$ & $\ldots$ & $\ldots$ & $\ldots$ & $\ldots$ & $\ldots$ & $\ldots$ & $\ldots$ & $\ldots$ & $\ldots$ & $\ldots$ & $\ldots$ & $\ldots$ & $\ldots$ & $\ldots$ & $\ldots$ \\
\hline Cyprus & $\ldots$ & $\downarrow$ & $\downarrow$ & $\ldots$ & 个 & $\downarrow$ & $\rightarrow$ & $\downarrow$ & $\downarrow$ & $\ldots$ & $\downarrow$ & $\ldots$ & $\downarrow$ & $\ldots$ & $\ldots$ & $\downarrow$ & $\downarrow$ & $\downarrow$ & $\ldots$ & $\Rightarrow$ & $\Rightarrow$ & $\downarrow$ & $\uparrow$ & $\uparrow$ \\
\hline Czech Republic & $\downarrow$ & $\Rightarrow$ & $\downarrow$ & $\ldots$ & $\ldots$ & $\Rightarrow$ & $\ldots$ & $\ldots$ & $\Rightarrow$ & $\Rightarrow$ & $\downarrow$ & $\ldots$ & $\downarrow$ & & $\downarrow$ & $\downarrow$ & $\downarrow$ & $\Rightarrow$ & $\uparrow$ & $\uparrow$ & $\uparrow$ & $\uparrow$ & $\uparrow$ & $\downarrow$ \\
\hline Denmark & $\downarrow$ & $\ldots$ & $\uparrow$ & $\ldots$ & $\Rightarrow$ & $\uparrow$ & $\Rightarrow$ & $\uparrow$ & $\uparrow$ & $\uparrow$ & $\downarrow$ & $\ldots$ & $\downarrow$ & $\downarrow$ & $\downarrow$ & $\downarrow$ & $\downarrow$ & $\uparrow$ & $\uparrow$ & $\Rightarrow$ & $\uparrow$ & $\downarrow$ & $\ldots$ & $\uparrow$ \\
\hline Estoni & $\downarrow$ & $\Rightarrow$ & $\downarrow$ & $\ldots$ & $\downarrow$ & $\uparrow$ & $\Rightarrow$ & $\uparrow$ & $\uparrow$ & $\uparrow$ & $\downarrow$ & $\ldots$ & $\downarrow$ & $\ldots$ & $\downarrow$ & $\ldots$ & $\downarrow$ & $\Rightarrow$ & $\ldots$ & $\uparrow$ & $\uparrow$ & $\Rightarrow$ & 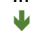 & $\uparrow$ \\
\hline Finland & $\downarrow$ & $\downarrow$ & $\Rightarrow$ & $\ldots$ & $\downarrow$ & $\downarrow$ & $\downarrow$ & $\Rightarrow$ & $\Rightarrow$ & $\downarrow$ & $\Rightarrow$ & $\ldots$ & $\downarrow$ & $\Rightarrow$ & $\downarrow$ & $\rightarrow$ & $\downarrow$ & $\uparrow$ & $\ldots$ & $\uparrow$ & $\uparrow$ & $\downarrow$ & $\uparrow$ & $\Rightarrow$ \\
\hline France & $\Rightarrow$ & $\ldots$ & $\uparrow$ & $\ldots$ & $\Rightarrow$ & $\uparrow$ & $\ldots$ & $\uparrow$ & $\uparrow$ & $\uparrow$ & $\downarrow$ & $\downarrow$ & $\rightarrow$ & $\ldots$ & $\downarrow$ & $\rightarrow$ & $\Rightarrow$ & $\Rightarrow$ & $\ldots$ & $\uparrow$ & $\uparrow$ & $\ldots$ & $\ldots$ & $\ldots$ \\
\hline Georgía & $\uparrow$ & $\uparrow$ & $\downarrow$ & $\ldots$ & $\uparrow$ & $\uparrow$ & $\uparrow$ & $\Rightarrow$ & $\downarrow$ & $\ldots$ & $\Rightarrow$ & $\uparrow$ & $\Rightarrow$ & $\ldots$ & $\downarrow$ & $\uparrow$ & $\uparrow$ & $\Rightarrow$ & $\ldots$ & $\uparrow$ & $\uparrow$ & $\uparrow$ & $\ldots$ & $\uparrow$ \\
\hline Germany & $\Rightarrow$ & $\ldots$ & $\Rightarrow$ & $\uparrow$ & $\Rightarrow$ & $\Rightarrow$ & $\Rightarrow$ & $\Rightarrow$ & $\Rightarrow$ & $\downarrow$ & $\downarrow$ & $\downarrow$ & $\Rightarrow$ & $\Rightarrow$ & $\downarrow$ & $\Rightarrow$ & $\uparrow$ & $\downarrow$ & $\Rightarrow$ & $\uparrow$ & $\Rightarrow$ & $\Rightarrow$ & $\uparrow$ & $\Rightarrow$ \\
\hline Greece & $\Rightarrow$ & $\downarrow$ & $\Rightarrow$ & $\ldots$ & $\downarrow$ & $\downarrow$ & $\ldots$ & $\uparrow$ & $\uparrow$ & $\ldots$ & $\uparrow$ & $\ldots$ & $\uparrow$ & $\uparrow$ & $\ldots$ & $\downarrow$ & $\ldots$ & $\uparrow$ & $\ldots$ & $\uparrow$ & $\ldots$ & $\uparrow$ & $\ldots$ & $\Rightarrow$ \\
\hline Hungary & $\downarrow$ & $\uparrow$ & $\downarrow$ & $\downarrow$ & $\downarrow$ & $\downarrow$ & $\downarrow$ & $\uparrow$ & $\uparrow$ & $\uparrow$ & $\downarrow$ & $\downarrow$ & $\downarrow$ & $\ldots$ & $\downarrow$ & $\ldots$ & $\ldots$ & $\uparrow$ & $\ldots$ & $\Rightarrow$ & $\downarrow$ & $\downarrow$ & $\uparrow$ & $\uparrow$ \\
\hline Icelanc & $\uparrow$ & $\uparrow$ & $\uparrow$ & $\ldots$ & $\downarrow$ & $\Rightarrow$ & $\uparrow$ & $\uparrow$ & $\uparrow$ & $\downarrow$ & $\uparrow$ & $\ldots$ & $\downarrow$ & $\ldots$ & $\Rightarrow$ & $\downarrow$ & $\ldots$ & $\Rightarrow$ & $\ldots$ & $\Rightarrow$ & $\uparrow$ & $\downarrow$ & $\ldots$ & $\ldots$ \\
\hline Irelan & $\ldots$ & $\downarrow$ & $\downarrow$ & $\ldots$ & $\ldots$ & $\ldots$ & $\ldots$ & $\uparrow$ & $\uparrow$ & $\Rightarrow$ & $\downarrow$ & $\ldots$ & $\downarrow$ & $\ldots$ & $\downarrow$ & $\ldots$ & $\ldots$ & $\downarrow$ & $\ldots$ & $\downarrow$ & $\Rightarrow$ & $\ldots$ & $\ldots$ & $\ldots$ \\
\hline Italy & $\downarrow$ & $\Downarrow$ & $\downarrow$ & $\ldots$ & $\downarrow$ & $\Rightarrow$ & $\ldots$ & $\downarrow$ & $\ldots$ & $\Rightarrow$ & $\downarrow$ & $\ldots$ & $\Rightarrow$ & $\ldots$ & $\downarrow$ & $\ldots$ & $\Rightarrow$ & $\uparrow$ & $\ldots$ & $\Rightarrow$ & $\ldots$ & $\ldots$ & $\uparrow$ & $\ldots$ \\
\hline Kosovo & $\ldots$ & $\ldots$ & $\ldots$ & $\ldots$ & $\downarrow$ & $\downarrow$ & $\ldots$ & $\ldots$ & $\uparrow$ & $\ldots$ & $\downarrow$ & $\uparrow$ & $\downarrow$ & $\ldots$ & $\downarrow$ & $\downarrow$ & $\uparrow$ & $\ldots$ & $\ldots$ & $\ldots$ & $\uparrow$ & $\ldots$ & $\ldots$ & $\ldots$ \\
\hline Latvia & $\Rightarrow$ & $\downarrow$ & $\downarrow$ & $\ldots$ & $\ldots$ & $\Rightarrow$ & $\Rightarrow$ & $\ldots$ & $\uparrow$ & $\ldots$ & $\downarrow$ & $\ldots$ & $\downarrow$ & & $\ldots$ & $\ldots$ & $\ldots$ & $\ldots$ & $\ldots$ & $\Downarrow$ & $\ldots$ & $\ldots$ & $\ldots$ & $\ldots$ \\
\hline Lithuani & $\downarrow$ & $\downarrow$ & $\downarrow$ & $\downarrow$ & $\downarrow$ & $\uparrow$ & $\uparrow$ & $\Downarrow$ & $\downarrow$ & $\downarrow$ & $\Downarrow$ & $\uparrow$ & $\downarrow$ & & $\ldots$ & $\ldots$ & $\downarrow$ & $\downarrow$ & $\ldots$ & $\Rightarrow$ & $\downarrow$ & $\Downarrow$ & $\Rightarrow$ & $\uparrow$ \\
\hline Luxembour & $\ldots$ & $\ldots$ & $\ldots$ & $\ldots$ & $\uparrow$ & $\ldots$ & $\ldots$ & $\ldots$ & $\ldots$ & $\ldots$ & $\ldots$ & $\ldots$ & $\ldots$ & $\ldots$ & $\ldots$ & $\ldots$ & $\ldots$ & $\ldots$ & $\ldots$ & $\ldots$ & $\ldots$ & $\ldots$ & $\ldots$ & $\ldots$ \\
\hline Malt & $\uparrow$ & $\ldots$ & $\Downarrow$ & $\downarrow$ & $\uparrow$ & $\downarrow$ & $\Rightarrow$ & $\Rightarrow$ & $\uparrow$ & $\Downarrow$ & $\Downarrow$ & $\ldots$ & $\Rightarrow$ & $\ldots$ & $\Downarrow$ & $\Downarrow$ & $\Downarrow$ & $\uparrow$ & $\ldots$ & $\uparrow$ & $\Rightarrow$ & $\Downarrow$ & $\ldots$ & $\ldots$ \\
\hline Moldova & $\uparrow$ & $\downarrow$ & $\downarrow$ & $\downarrow$ & $\downarrow$ & $\downarrow$ & $\downarrow$ & $\uparrow$ & $\uparrow$ & $\uparrow$ & $\downarrow$ & $\downarrow$ & $\Rightarrow$ & $\Rightarrow$ & $\uparrow$ & $\uparrow$ & $\uparrow$ & $\uparrow$ & $\Rightarrow$ & $\downarrow$ & $\downarrow$ & $\downarrow$ & $\uparrow$ & $\uparrow$ \\
\hline Mon & $\downarrow$ & $\Rightarrow$ & $\uparrow$ & $\uparrow$ & $\ldots$ & $\downarrow$ & $\downarrow$ & $\downarrow$ & $\downarrow$ & $\downarrow$ & $\Rightarrow$ & $\ldots$ & $\downarrow$ & $\downarrow$ & & & $\ldots$ & $\downarrow$ & 个 & $\downarrow$ & $\downarrow$ & $\downarrow$ & $\downarrow$ & $\downarrow$ \\
\hline Netherlands & $\downarrow$ & $\downarrow$ & $\downarrow$ & $\ldots$ & $\downarrow$ & $\downarrow$ & $\ldots$ & $\Rightarrow$ & $\Rightarrow$ & $\ldots$ & $\downarrow$ & $\ldots$ & $\downarrow$ & $\ldots$ & $\downarrow$ & $\downarrow$ & $\downarrow$ & $\uparrow$ & $\ldots$ & $\downarrow$ & $\ldots$ & $\ldots$ & $\ldots$ & $\ldots$ \\
\hline North & $\downarrow$ & $\Rightarrow$ & $\downarrow$ & $\ldots$ & $\downarrow$ & $\downarrow$ & $\downarrow$ & $\downarrow$ & $\downarrow$ & $\downarrow$ & $\downarrow$ & $\ldots$ & $\downarrow$ & $\downarrow$ & $\downarrow$ & $\ldots$ & $\Rightarrow$ & $\downarrow$ & 个 & $\Rightarrow$ & $\downarrow$ & $\Downarrow$ & $\Downarrow$ & $\ldots$ \\
\hline Norway & $\downarrow$ & $\downarrow$ & $\downarrow$ & $\downarrow$ & $\downarrow$ & $\downarrow$ & $\downarrow$ & $\uparrow$ & $\uparrow$ & $\uparrow$ & $\Downarrow$ & $\uparrow$ & $\downarrow$ & $\downarrow$ & $\downarrow$ & $\uparrow$ & $\ldots$ & $\uparrow$ & $\ldots$ & $\downarrow$ & $\ldots$ & $\uparrow$ & $\uparrow$ & $\Downarrow$ \\
\hline Polan & $\downarrow$ & $\downarrow$ & $\downarrow$ & & $\downarrow$ & $\downarrow$ & $\downarrow$ & $\downarrow$ & $\downarrow$ & $\downarrow$ & $\downarrow$ & $\downarrow$ & $\downarrow$ & $\downarrow$ & $\downarrow$ & $\downarrow$ & $\downarrow$ & $\Rightarrow$ & $\ldots$ & $\downarrow$ & $\downarrow$ & $\uparrow$ & $\Rightarrow$ & $\downarrow$ \\
\hline Portugal & $\downarrow$ & $\Rightarrow$ & $\ldots$ & $\downarrow$ & $\downarrow$ & $\uparrow$ & $\downarrow$ & $\uparrow$ & $\Rightarrow$ & $\ldots$ & $\downarrow$ & $\downarrow$ & $\downarrow$ & $\downarrow$ & $\downarrow$ & $\downarrow$ & $\downarrow$ & $\uparrow$ & $\uparrow$ & $\uparrow$ & $\uparrow$ & $\downarrow$ & $\uparrow$ & $\Rightarrow$ \\
\hline Roma & $\ldots$ & $\ldots$ & $\downarrow$ & $\ldots$ & $\downarrow$ & $\downarrow$ & $\Rightarrow$ & $\Rightarrow$ & $\Rightarrow$ & $\uparrow$ & $\downarrow$ & $\downarrow$ & $\downarrow$ & $\ldots$ & $\downarrow$ & $\ldots$ & $\downarrow$ & $\downarrow$ & $\ldots$ & $\Rightarrow$ & $\ldots$ & $\ldots$ & $\Rightarrow$ & $\Rightarrow$ \\
\hline Russia & $\Rightarrow$ & $\Rightarrow$ & $\ldots$ & $\dddot{v}$ & $\ldots$ & $\downarrow$ & $\cdots$ & $\ldots$ & $\cdots$ & $\ldots$ & $\downarrow$ & $\ldots$ & $\downarrow$ & $\ldots$ & $\downarrow$ & $\dddot{\Downarrow}$ & $\ldots$ & $\ldots$ & $\cdots$ & $\ldots$ & $\cdots$ & 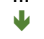 & & 2 \\
\hline Serbia & $\ldots$ & $\ldots$ & $\downarrow$ & $\ldots$ & $\Rightarrow$ & $\downarrow$ & $\downarrow$ & $\Rightarrow$ & $\Downarrow$ & $\Rightarrow$ & $\downarrow$ & $\Downarrow$ & $\Rightarrow$ & $\downarrow$ & $\downarrow$ & $\downarrow$ & $\Rightarrow$ & $\uparrow$ & $\uparrow$ & $\uparrow$ & $\Rightarrow$ & $\ldots$ & $\Downarrow$ & $\Downarrow$ \\
\hline Slovaki & $\downarrow$ & $\cdots$ & $\ldots$ & $\downarrow$ & $\downarrow$ & $\downarrow$ & $\cdots$ & $\ldots$ & $\downarrow$ & & $\downarrow$ & & $\downarrow$ & & $\downarrow$ & $\downarrow$ & $\downarrow$ & & $\ldots$ & $\ldots$ & $\uparrow$ & $\Downarrow$ & $\ldots$ & $\ldots$ \\
\hline Slovenia & $\downarrow$ & $\ddot{v}$ & 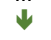 & $\uparrow$ & $\downarrow$ & $\Rightarrow$ & $\Downarrow$ & $\Downarrow$ & $\downarrow$ & $\Downarrow$ & $\downarrow$ & $\Downarrow$ & $\downarrow$ & 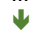 & $\downarrow$ & $\downarrow$ & $\uparrow$ & 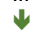 & $\uparrow$ & $\Rightarrow$ & $\Rightarrow$ & $\downarrow$ & $\Rightarrow$ & $\uparrow$ \\
\hline Spain & $\Rightarrow$ & $\Rightarrow$ & $\Rightarrow$ & $\ldots$ & $\downarrow$ & $\Rightarrow$ & $\ldots$ & $\uparrow$ & $\downarrow$ & $\uparrow$ & $\downarrow$ & $\downarrow$ & $\downarrow$ & $\ldots$ & $\downarrow$ & $\Rightarrow$ & $\uparrow$ & $\uparrow$ & $\uparrow$ & $\Downarrow$ & $\ldots$ & $\Rightarrow$ & $\uparrow$ & $\uparrow$ \\
\hline Sweden & $\downarrow$ & $\ldots$ & $\Rightarrow$ & $\Rightarrow$ & $\uparrow$ & $\downarrow$ & $\ldots$ & $\uparrow$ & $\Rightarrow$ & $\uparrow$ & $\Downarrow$ & $\Rightarrow$ & $\downarrow$ & $\downarrow$ & $\downarrow$ & $\Rightarrow$ & $\Rightarrow$ & $\uparrow$ & $\uparrow$ & $\Rightarrow$ & $\Rightarrow$ & $\uparrow$ & $\uparrow$ & $\uparrow$ \\
\hline Switzerlan & $\downarrow$ & $\downarrow$ & $\Rightarrow$ & $\downarrow$ & $\Rightarrow$ & $\Rightarrow$ & $\Rightarrow$ & $\Rightarrow$ & $\Rightarrow$ & $\downarrow$ & $\downarrow$ & $\ldots$ & $\downarrow$ & $\ldots$ & $\downarrow$ & $\downarrow$ & $\downarrow$ & $\Rightarrow$ & $\downarrow$ & $\downarrow$ & $\uparrow$ & $\downarrow$ & $\uparrow$ & $\Rightarrow$ \\
\hline Turkey & $\ldots$ & $\ldots$ & $\ldots$ & $\ldots$ & $\ldots$ & $\ldots$ & $\ldots$ & $\ldots$ & $\ldots$ & $\ldots$ & $\ldots$ & $\ldots$ & $\ldots$ & $\ldots$ & $\ldots$ & $\ldots$ & $\ldots$ & $\ldots$ & $\ldots$ & $\ldots$ & $\ldots$ & $\ldots$ & $\ldots$ & $\cdots$ \\
\hline Ukraine & $\uparrow$ & $\uparrow$ & $\uparrow$ & $\downarrow$ & $\cdots$ & $\uparrow$ & $\downarrow$ & $\cdots$ & $\downarrow$ & $\cdots$ & $\uparrow$ & & $\uparrow$ & $\ldots$ & $\uparrow$ & $\ldots$ & $\uparrow$ & $\uparrow$ & $\ldots$ & $\downarrow$ & $\downarrow$ & $\ldots$ & $\downarrow$ & $\downarrow$ \\
\hline UK:Englar & $\uparrow$ & $\uparrow$ & $\uparrow$ & $\ldots$ & 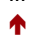 & $\uparrow$ & $\downarrow$ & 个 & $\uparrow$ & 个 & $\checkmark$ & $\ddot{\Downarrow}$ & $\downarrow$ & & $\downarrow$ & $\ddot{\Downarrow}$ & $\downarrow$ & $\uparrow$ & $\ldots$ & $\downarrow$ & $\downarrow$ & $\cdots$ & $\ldots$ & $\ldots$ \\
\hline UK:Northern I & $\Rightarrow$ & $\Rightarrow$ & $\downarrow$ & & $\downarrow$ & $\uparrow$ & $\cdots$ & $\uparrow$ & $\uparrow$ & $\uparrow$ & $\downarrow$ & $\downarrow$ & $\downarrow$ & $\cdots$ & $\downarrow$ & $\downarrow$ & $\downarrow$ & $\uparrow$ & $\cdots$ & $\uparrow$ & $\Rightarrow$ & $\cdots$ & $\ldots$ & $\cdots$ \\
\hline UK:Scotland & $\downarrow$ & $\ldots$ & $\Rightarrow$ & $\ldots$ & $\downarrow$ & $\downarrow$ & $\Downarrow$ & $\uparrow$ & $\uparrow$ & & $\Downarrow$ & & $\downarrow$ & & $\Downarrow$ & $\downarrow$ & $\Downarrow$ & $\downarrow$ & & $\Rightarrow$ & & & & \\
\hline
\end{tabular}

... No data available

个 More than $10 \%$ increase

$\downarrow \quad$ More than $10 \%$ decrease

$\Rightarrow$ Betw een $-10 \%$ and $10 \%$ change 


\subsubsection{Police staff}

The ratio of police officers (excluding civilians) per 100000 population is here referred to as police density. Table 1.b shows the distribution of police density in 2016. As shown most countries report between 300 and 399 police officers per 100000 population but the rate was from 58 police officers in Romania per 100000 population to 573 officers in Cyprus.

In total the mean police density was 337 police officers per 100000 population. Eleven countries reported police density below 300 and eight above 399 .

Table 1.b. Number of police officers excluding civilians per 100000 population (police density) in 2016

\begin{tabular}{|c|c|c|c|c|}
\hline Under 200 & $200-299$ & $300-399$ & $400-499$ & 500 and over \\
\hline Denmark & Estonia & Albania & Croatia & Cyprus \\
\hline Finland & Lithuania & Belgium & Italy & Georgia \\
\hline Iceland & Netherlands & Czech Republic & Latvia & Malta \\
\hline \multirow[t]{8}{*}{ Romania } & Poland & France & North Macedonia & \\
\hline & Sweden & Germany & Portugal & \\
\hline & Switzerland & Hungary & & \\
\hline & Ukraine & Slovenia & & \\
\hline & UK: England \& Wales & Spain & & \\
\hline & & Turkey & & \\
\hline & & UK: Northern Ireland & & \\
\hline & & UK: Scotland & & \\
\hline
\end{tabular}

In 201620 countries were able to provide information on the number of civilian employees in the police force. The share of civilians was the highest in Sweden and England \& Wales but lowest in Malta and Portugal. From the countries providing data, it is most common that the percentage of civilians is between 20 and $39 \%$.

Table 1.c. Percentage of civilian police staff (officers and civilians) in 2016

\begin{tabular}{lllll}
\hline Under $10 \%$ & $10 \%-19 \%$ & $20 \%-29 \%$ & $30 \%-39 \%$ & $40 \%$ or more \\
\hline Malta & France & Belgium & Denmark & Sweden \\
Portugal & Germany & Croatia & Estonia & UK: England \& \\
& Netherlands & Czech Republic & Finland & \\
& Slovenia & Lithuania & Hungary & \\
& Ukraine & Poland & Iceland & \\
& & & UK: Northern & \\
& & & Ireland & \\
\end{tabular}




\subsection{Tables}

\subsubsection{Offences}

Table 1.2.1.1 Offences per 100000 population - Criminal offences: Total

\begin{tabular}{|c|c|c|c|c|c|c|c|}
\hline & 2011 & 2012 & 2013 & 2014 & 2015 & 2016 & $\begin{array}{r}\% \text { change } \\
2011-2016\end{array}$ \\
\hline Albania & 606.9 & 712.6 & 787.4 & 1079.6 & 1242.8 & 1175.7 & 93.7 \\
\hline Armenia & 507.9 & 481.8 & 633.5 & 603.8 & 566.1 & 625.8 & 23.2 \\
\hline Austria & 6447.7 & 6517.8 & 6464.8 & 6202.5 & 6032.3 & 6181.2 & -4.1 \\
\hline Azerbaijan & 266.3 & 237.1 & 239.2 & 259.6 & 280.6 & 274.2 & 3.0 \\
\hline Belgium & 9665.5 & 9391.9 & 8958.6 & 8742.8 & 8191.4 & 7857.2 & -18.7 \\
\hline Bosnia-Herzegovina & & & & $\ldots$ & & 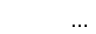 & 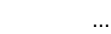 \\
\hline Bulgaria & 1745.1 & 1645.3 & 1675.9 & 1573.4 & 1555.6 & 1450.6 & -16.9 \\
\hline Croatia & & & $\ldots$ & $\ldots$ & $\ldots$ & $\ldots$ & $\ldots$ \\
\hline Cyprus & 1005.3 & 926.6 & 819.9 & 796.4 & 698.3 & $\ldots$ & $\ldots$ \\
\hline Czech Republic & 3024.6 & 2898.8 & 3094.0 & 2745.9 & 2349.8 & 2067.1 & -31.7 \\
\hline Denmark & 8394.2 & 7898.5 & 7662.4 & 7217.8 & 6865.1 & 7033.3 & -16.2 \\
\hline Estonia & 3201.3 & 3079.9 & 3002.0 & 2871.7 & 2477.4 & 2202.7 & -31.2 \\
\hline Finland & 8525.2 & 7876.3 & 7827.7 & 7666.1 & 7552.1 & 7503.2 & -12.0 \\
\hline France & 5549.6 & 5479.0 & 5509.2 & 5548.9 & 5540.2 & 5504.0 & -0.8 \\
\hline Georgia & 721.8 & 861.3 & 1063.5 & 813.4 & 941.0 & 967.6 & 34.0 \\
\hline Germany & 7467.6 & 7465.7 & 7403.6 & 7530.3 & 7796.6 & 7754.8 & 3.8 \\
\hline Greece & 1744.4 & 1752.1 & 1815.8 & 1740.8 & 1815.0 & 1903.0 & 9.1 \\
\hline Hungary & 4520.2 & 4754.7 & 3813.1 & 3336.7 & 2842.2 & 2957.9 & -34.6 \\
\hline Iceland & 17905.7 & 19349.8 & 16546.2 & 20277.8 & 21385.3 & 25794.1 & 44.1 \\
\hline Ireland & & & $\ldots$ & $\ldots$ & $\ldots$ & $\ldots$ & $\ldots$ \\
\hline Italy & 4654.3 & 4746.0 & 4845.7 & 4627.9 & 4420.1 & 4100.2 & -11.9 \\
\hline Kosovo (UN R/1244/99) & & & & $\ldots$ & & & \\
\hline Latvia & 2486.4 & 2440.6 & 2350.1 & 2422.1 & 2386.9 & 2317.9 & -6.8 \\
\hline Lithuania & 2605.1 & 2746.4 & 2850.5 & 2815.5 & 2476.4 & 2045.1 & -21.5 \\
\hline Luxembourg & & & & $\ldots$ & $\ldots$ & $\ldots$ & $\ldots$ \\
\hline Malta & 3443.2 & 3741.4 & 4165.1 & 3878.0 & 3897.7 & 3840.5 & 11.5 \\
\hline Moldova & 986.5 & 1028.6 & 1072.0 & 1174.5 & 1119.0 & 1124.5 & 14.0 \\
\hline Montenegro & 991.7 & 939.4 & 950.1 & 917.3 & 843.4 & 774.8 & -21.9 \\
\hline Netherlands & 7244.1 & 6903.3 & 6588.7 & 6094.3 & 5792.4 & 5479.1 & -24.4 \\
\hline North Macedonia & 1435.3 & 1453.5 & 1472.4 & 1343.5 & 1193.6 & 1195.2 & -16.7 \\
\hline Norway & 7725.0 & 7895.8 & 7691.2 & 7284.8 & 6802.7 & 6456.2 & -16.4 \\
\hline Poland & 3045.7 & 2941.9 & 2788.1 & 2282.8 & 2104.4 & 1971.3 & -35.3 \\
\hline Portugal & 3939.6 & 3861.0 & 3609.8 & 3386.2 & 3442.8 & 3209.4 & $-18.5 \%$ \\
\hline Romania & 3630.6 & 3442.7 & 3295.9 & 3225.8 & 3156.4 & 2933.5 & -19.2 \\
\hline Russian Federation & & & & $\ldots$ & $\ldots$ & $\ldots$ & $\ldots$ \\
\hline Serbia & 1397.3 & 1346.7 & 1584.3 & 1443.0 & 1389.4 & 1326.8 & -5.0 \\
\hline Slovak Republic & & & $\ldots$ & $\ldots$ & & $\ldots$ & $\ldots$ \\
\hline Slovenia & 4327.5 & 4448.1 & 4557.6 & 4244.1 & 3335.6 & 2983.0 & -31.1 \\
\hline Spain & 2394.2 & 2374.5 & 2260.8 & 2155.5 & 2358.9 & 2118.9 & -11.5 \\
\hline Sweden & 15041.9 & 14790.8 & 14671.4 & 14969.1 & 15423.7 & 15330.4 & 1.9 \\
\hline Switzerland & 8804.9 & 9433.1 & 9027.0 & 8097.6 & 7649.0 & 7119.9 & -19.1 \\
\hline Turkey & $\ldots$ & 2083.3 & 2168.6 & $\ldots$ & $\ldots$ & $\ldots$ & $\ldots$ \\
\hline Ukraine & 1131.3 & 976.1 & 1242.1 & 1169.5 & 1321.8 & 1391.4 & 23.0 \\
\hline UK: England \& Wales & 7198.0 & 6698.6 & 6517.3 & 6565.5 & 7633.2 & 8232.4 & 14.4 \\
\hline UK: Northern Ireland & 5622.4 & 5404.5 & 5515.4 & 5605.9 & 5666.7 & 5263.5 & -6.4 \\
\hline UK: Scotland & 6099.1 & 5912.9 & 5125.2 & 5056.4 & 4771.1 & 4556.1 & -25.3 \\
\hline Mean & 4618 & 4536 & 4401 & 4414 & 4350 & 4460 & \\
\hline Median & 3537 & 3443 & 3296 & 3281 & 2999 & 2958 & \\
\hline Minimum & 266 & 237 & 239 & 260 & 281 & 274 & \\
\hline Maximum & 17906 & 19350 & 16546 & 20278 & 21385 & 25794 & \\
\hline
\end{tabular}


Table 1.2.1.2 Offences per 100000 population - Major road traffic offences

\begin{tabular}{|c|c|c|c|c|c|c|c|}
\hline & 2011 & 2012 & 2013 & 2014 & 2015 & 2016 & $\begin{array}{c}\% \text { change } \\
2011-2016\end{array}$ \\
\hline Albania & 26.5 & 28.1 & 17.4 & 21.6 & 23.3 & 25.0 & -5.6 \\
\hline Armenia & 29.2 & 29.3 & 36.3 & 29.1 & 28.1 & 23.3 & -20.1 \\
\hline Austria & 424.8 & 399.7 & 376.9 & 354.0 & 361.1 & 362.2 & -14.8 \\
\hline Azerbaijan & 31.7 & 31.3 & 30.4 & 27.8 & 23.1 & 20.7 & -34.8 \\
\hline Belgium & 1228.4 & 1036.4 & 1131.6 & 1166.6 & 1034.0 & 1049.3 & -14.6 \\
\hline Bosnia-Herzegovina & & & & & $\ldots$ & & \\
\hline Bulgaria & 204.6 & 187.9 & 177.9 & 175.1 & 154.6 & 203.3 & -0.7 \\
\hline Croatia & & & & & $\ldots$ & & \\
\hline Cyprus & 63.6 & 61.3 & 45.7 & 51.2 & 44.9 & 47.2 & -25.9 \\
\hline Czech Republic & 63.8 & 64.6 & 60.0 & 61.8 & 62.9 & 61.6 & -3.4 \\
\hline Denmark & & & & & & & \\
\hline Estonia & 286.8 & 280.2 & 279.1 & 252.8 & 305.2 & 283.9 & -1.0 \\
\hline Finland & 996.7 & 879.9 & 825.6 & 828.0 & 815.2 & 809.1 & -18.8 \\
\hline France & & & & & & & \\
\hline Georgia & 61.6 & 68.4 & 87.5 & 76.9 & 85.3 & 83.8 & 36.1 \\
\hline Germany & $\ldots$ & $\ldots$ & $\ldots$ & $\ldots$ & $\ldots$ & $\ldots$ & \\
\hline Greece & 39.5 & 64.6 & 1.1 & 1.4 & 1.5 & 1.5 & -96.2 \\
\hline Hungary & 140.2 & 131.7 & 149.4 & 178.6 & 179.5 & 201.7 & 43.9 \\
\hline Iceland & 684.6 & 656.8 & 676.7 & 545.9 & 562.1 & 776.8 & 13.5 \\
\hline Ireland & 206.0 & 186.7 & 156.9 & 149.9 & 147.3 & 155.8 & -24.3 \\
\hline Italy & 2.2 & 2.0 & 1.8 & 1.8 & 1.8 & 1.9 & -12.7 \\
\hline Kosovo (UN R/1244/99) & $\ldots$ & & $\ldots$ & $\ldots$ & $\ldots$ & $\ldots$ & \\
\hline Latvia & 34.8 & 34.9 & 32.9 & 33.5 & 34.7 & 29.1 & -16.4 \\
\hline Lithuania & 46.1 & 45.1 & 43.0 & 44.4 & 40.6 & 36.4 & -21.1 \\
\hline Luxembourg & $\ldots$ & $\ldots$ & $\ldots$ & $\ldots$ & $\ldots$ & $\ldots$ & ... \\
\hline Malta & $\ldots$ & $\ldots$ & 374.4 & 418.2 & 389.1 & 411.2 & ... \\
\hline Moldova & 28.9 & 27.6 & 25.1 & 23.9 & 24.8 & 23.8 & -17.8 \\
\hline Montenegro & 106.6 & 78.5 & 102.6 & 94.9 & 96.0 & 106.1 & -0.5 \\
\hline Netherlands & 880.8 & 818.5 & 782.7 & 725.8 & 678.9 & 676.4 & -23.2 \\
\hline North Macedonia & 163.8 & 137.4 & 138.7 & 124.2 & 124.7 & 127.7 & -22.0 \\
\hline Norway & 991.1 & 1029.9 & 985.6 & 988.6 & 933.9 & 927.7 & -6.4 \\
\hline Poland & 432.4 & 386.8 & 370.9 & 229.0 & 201.4 & 194.0 & -55.1 \\
\hline Portugal & 402.7 & 409.5 & 367.4 & 308.4 & 335.7 & 304.8 & $-24.3 \%$ \\
\hline Romania & 206.7 & 171.4 & 210.6 & 185.6 & 206.4 & 197.1 & -4.6 \\
\hline Russian Federation & & & & & & & \\
\hline Serbia & 123.6 & 116.0 & 120.5 & 114.1 & 116.6 & 121.0 & -2.1 \\
\hline Slovak Republic & $\ldots$ & $\ldots$ & $\ldots$ & $\ldots$ & $\ldots$ & $\ldots$ & $\ldots$ \\
\hline Slovenia & $\ldots$ & & $\ldots$ & $\ldots$ & $\ldots$ & $\ldots$ & \\
\hline Spain & 144.4 & 127.4 & 118.2 & 110.5 & 99.0 & 94.6 & -34.5 \\
\hline Sweden & 822.4 & 757.8 & 764.8 & 858.8 & 820.8 & 805.0 & -2.1 \\
\hline Switzerland & $\ldots$ & $\ldots$ & $\ldots$ & $\ldots$ & $\ldots$ & $\ldots$ & ... \\
\hline Turkey & $\ldots$ & $\ldots$ & $\ldots$ & $\ldots$ & $\ldots$ & $\ldots$ & ... \\
\hline Ukraine & 30.3 & 30.6 & 43.5 & 54.6 & 56.2 & 61.4 & 102.6 \\
\hline UK: England \& Wales & 6.7 & 6.1 & 6.4 & 6.7 & 7.6 & 8.9 & 33.5 \\
\hline $\begin{array}{l}\text { UK: Northern Ireland } \\
\text { UK: Scotland }\end{array}$ & 44.1 & 42.9 & 43.7 & 43.7 & 49.3 & 44.0 & -0.4 \\
\hline Mean & 280 & 260 & 260 & 251 & 244 & 251 & \\
\hline Median & 132 & 122 & 121 & 114 & 117 & 121 & \\
\hline Minimum & 2 & 2 & 1 & 1 & 2 & 2 & \\
\hline Maximum & 1228 & 1036 & 1132 & 1167 & 1034 & 1049 & \\
\hline
\end{tabular}


Table 1.2.1.3 Offences per 100000 population - Intentional homicide

\begin{tabular}{|c|c|c|c|c|c|c|c|}
\hline & 2011 & 2012 & 2013 & 2014 & 2015 & 2016 & $\begin{array}{c}\% \text { change } \\
2011-2016\end{array}$ \\
\hline Albania & 11.5 & 11.8 & 11.3 & 8.8 & 6.7 & 7.1 & -38.4 \\
\hline Armenia & 2.7 & 2.3 & 2.5 & 2.8 & 2.9 & 3.4 & 24.7 \\
\hline Austria & 2.2 & 2.3 & 2.0 & 1.3 & 1.6 & 1.7 & -23.0 \\
\hline Azerbaijan & 11.9 & 11.9 & 12.2 & 11.2 & 9.1 & 7.9 & -33.5 \\
\hline Belgium & 9.7 & 9.4 & 9.1 & 9.5 & 9.9 & 9.3 & -4.7 \\
\hline Bosnia-Herzegovina & & $\ldots$ & $\ldots$ & $\ldots$ & $\ldots$ & $\ldots$ & \\
\hline Bulgaria & 2.6 & 2.5 & 2.4 & 2.2 & 2.2 & 2.2 & -14.4 \\
\hline Croatia & & & & & $\ldots$ & $\ldots$ & \\
\hline Cyprus & 2.5 & 3.6 & 2.2 & 2.3 & 2.7 & 2.1 & -15.2 \\
\hline Czech Republic & 1.6 & 1.8 & 1.7 & 1.5 & 1.5 & 1.3 & -22.0 \\
\hline Denmark & 3.7 & 3.4 & 3.7 & 3.7 & 3.4 & 4.4 & 20.0 \\
\hline Estonia & 7.5 & 6.0 & 4.7 & 4.2 & 3.8 & 3.3 & -55.5 \\
\hline Finland & 8.2 & 8.5 & 6.9 & 8.1 & 7.6 & 7.4 & -9.2 \\
\hline France & 3.6 & 3.8 & 3.7 & 3.9 & 4.8 & 5.2 & 43.9 \\
\hline Georgia & 8.9 & 10.2 & 7.2 & 4.5 & 6.3 & 5.4 & -39.5 \\
\hline Germany & 2.8 & 2.7 & 2.7 & 2.8 & 2.7 & 3.0 & 8.7 \\
\hline Greece & 2.0 & 2.1 & 3.3 & 2.7 & 2.6 & 2.1 & 7.4 \\
\hline Hungary & 2.8 & 2.2 & 2.5 & 2.4 & 1.9 & 2.0 & -26.5 \\
\hline Iceland & 1.9 & 2.2 & 1.9 & 2.1 & 1.2 & 2.1 & 11.7 \\
\hline Ireland & 0.9 & 1.1 & 1.1 & 1.1 & 0.7 & 0.8 & -14.8 \\
\hline Italy & 3.3 & 3.1 & 2.9 & 2.8 & 2.8 & 2.4 & -25.7 \\
\hline Kosovo (UN R/1244/99) & $\ldots$ & $\ldots$ & 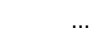 & $\ldots$ & $\ldots$ & $\ldots$ & \\
\hline Latvia & 4.4 & 5.6 & 3.7 & 4.2 & 4.4 & 3.4 & -22.4 \\
\hline Lithuania & 6.9 & 6.6 & 6.3 & 5.9 & 6.5 & 5.6 & $\begin{array}{l}219.4 \\
-19.4\end{array}$ \\
\hline Luxembourg & & & 15.8 & 16.0 & 12.3 & 13.4 & \\
\hline Malta & 2.2 & 3.8 & 1.7 & 2.6 & 1.1 & 1.3 & -38.6 \\
\hline Moldova & 6.1 & 6.3 & 6.0 & 4.8 & 5.0 & 5.1 & -16.4 \\
\hline Montenegro & 3.4 & 2.6 & 1.4 & 3.1 & 2.7 & 3.9 & 13.9 \\
\hline Netherlands & 25.4 & 23.3 & 21.0 & 20.0 & 19.2 & 18.4 & -27.6 \\
\hline North Macedonia & 3.4 & 2.3 & 3.5 & 3.6 & 2.9 & 2.2 & -35.2 \\
\hline Norway & 2.3 & 0.5 & 0.9 & 0.6 & 0.5 & 0.5 & -77.0 \\
\hline Poland & 2.2 & 2.0 & 1.9 & 1.7 & 1.5 & 1.4 & -34.0 \\
\hline Portugal & & $\ldots$ & $\ldots$ & $\ldots$ & $\ldots$ & $\ldots$ & \\
\hline Romania & 1.8 & 2.1 & 1.7 & 1.7 & 1.6 & 1.3 & -28.3 \\
\hline Russian Federation & & & & & & & \\
\hline Serbia & 4.2 & 4.3 & 4.9 & 4.0 & 3.3 & 3.6 & -12.7 \\
\hline Slovak Republic & & & & & & $\ldots$ & \\
\hline Slovenia & 0.9 & 0.9 & 0.7 & 0.7 & 1.2 & 0.6 & -28.3 \\
\hline Spain & 2.6 & 2.4 & 2.1 & 2.3 & 2.1 & 2.4 & -8.1 \\
\hline Sweden & 9.8 & 9.2 & 8.5 & 9.1 & 9.8 & 10.0 & 2.0 \\
\hline Switzerland & 2.9 & 2.9 & 2.6 & 2.1 & 2.4 & 2.8 & -4.7 \\
\hline Turkey & 4.2 & 4.2 & $\ldots$ & $\ldots$ & $\ldots$ & $\ldots$ & \\
\hline Ukraine & 5.5 & 4.6 & 13.1 & 25.5 & 19.4 & 14.2 & 158.5 \\
\hline UK: England \& Wales & 1.9 & 1.8 & 1.8 & 1.9 & 2.2 & 2.5 & 32.6 \\
\hline $\begin{array}{l}\text { UK: Northern Ireland } \\
\text { UK: Scotland }\end{array}$ & 7.6 & 6.8 & 7.4 & 7.7 & 6.5 & 5.4 & -29.4 \\
\hline Mean & 4.9 & 4.8 & 5.0 & 5.1 & 4.7 & 4.5 & \\
\hline Median & 3.3 & 3.3 & 3.1 & 2.9 & 2.8 & 3.2 & \\
\hline Minimum & 0.9 & 0.5 & 0.7 & 0.6 & 0.5 & 0.5 & \\
\hline Maximum & 25.4 & 23.3 & 21.0 & 25.5 & 19.4 & 18.4 & \\
\hline
\end{tabular}


Table 1.2.1.4 Offences per 100000 population - Intentional homicide: Firearm involved

\begin{tabular}{|c|c|c|c|c|c|c|c|}
\hline & 2011 & 2012 & 2013 & 2014 & 2015 & 2016 & $\begin{array}{c}\% \text { change } \\
2011-2016\end{array}$ \\
\hline Albania & $\ldots$ & $\ldots$ & $\ldots$ & $\ldots$ & $\ldots$ & $\ldots$ & $\ldots$ \\
\hline Armenia & & & & & & & \\
\hline Austria & 0.3 & 0.1 & 0.2 & 0.2 & 0.2 & 0.2 & -8.3 \\
\hline Azerbaijan & $\ldots$ & $\ldots$ & & $\ldots$ & & $\ldots$ & \\
\hline Belgium & 1.0 & 0.9 & 0.9 & 1.0 & 0.9 & 0.7 & -27.7 \\
\hline Bosnia-Herzegovina & $\ldots$ & $\ldots$ & & $\ldots$ & & $\ldots$ & $\ldots$ \\
\hline Bulgaria & $\ldots$ & 0.2 & 0.3 & 0.2 & 0.4 & 0.2 & $\ldots$ \\
\hline Croatia & $\ldots$ & $\ldots$ & $\ldots$ & $\ldots$ & $\ldots$ & $\ldots$ & $\ldots$ \\
\hline Cyprus & $\ldots$ & $\ldots$ & $\ldots$ & $\ldots$ & $\ldots$ & $\ldots$ & $\ldots$ \\
\hline Czech Republic & $\ldots$ & $\ldots$ & $\ldots$ & $\ldots$ & $\ldots$ & $\ldots$ & $\ldots$ \\
\hline Denmark & $\ldots$ & $\ldots$ & $\ldots$ & $\ldots$ & $\ldots$ & $\ldots$ & $\ldots$ \\
\hline Estonia & $\ldots$ & $\ldots$ & $\ldots$ & $\ldots$ & $\ldots$ & $\ldots$ & $\ldots$ \\
\hline Finland & $\ldots$ & $\ldots$ & $\ldots$ & $\ldots$ & $\ldots$ & $\ldots$ & $\ldots$ \\
\hline France & $\ldots$ & $\ldots$ & $\ldots$ & $\ldots$ & $\ldots$ & $\ldots$ & $\ldots$ \\
\hline Georgia & $\ldots$ & $\ldots$ & $\ldots$ & $\ldots$ & $\ldots$ & $\ldots$ & \\
\hline Germany & 0.2 & 0.2 & 0.2 & 0.1 & 0.2 & 0.2 & 16.1 \\
\hline Greece & $\ldots$ & $\ldots$ & $\ldots$ & $\ldots$ & $\ldots$ & $\ldots$ & \\
\hline Hungary & 0.2 & 0.1 & 0.1 & 0.1 & 0.1 & 0.1 & -46.5 \\
\hline Iceland & 0.0 & 0.0 & 0.0 & 0.0 & 0.0 & 0.0 & $\ldots$ \\
\hline Ireland & $\ldots$ & $\ldots$ & $\ldots$ & $\ldots$ & $\ldots$ & $\ldots$ & $\ldots$ \\
\hline Italy & $\ldots$ & $\ldots$ & $\ldots$ & $\ldots$ & $\ldots$ & $\ldots$ & $\ldots$ \\
\hline Kosovo (UN R/1244/99) & $\ldots$ & $\ldots$ & $\ldots$ & $\ldots$ & $\ldots$ & $\ldots$ & $\ldots$ \\
\hline Latvia & $\ldots$ & $\ldots$ & $\ldots$ & $\ldots$ & $\ldots$ & $\ldots$ & $\ldots$ \\
\hline Lithuania & 0.0 & 0.1 & 0.0 & 0.1 & 0.0 & 0.0 & -100.0 \\
\hline Luxembourg & $\ldots$ & $\ldots$ & $\ldots$ & 0.2 & & $\ldots$ & \\
\hline Malta & 0.2 & 1.7 & 0.9 & 1.2 & 0.7 & 0.0 & -100.0 \\
\hline Moldova & 0.3 & 0.3 & 0.2 & 0.2 & 0.1 & 0.2 & -15.1 \\
\hline Montenegro & 2.3 & 1.5 & 0.8 & 1.9 & 1.6 & 2.6 & 13.9 \\
\hline Netherlands & $\ldots$ & $\ldots$ & & $\ldots$ & & $\ldots$ & \\
\hline North Macedonia & 0.8 & 0.6 & 0.6 & 0.7 & 0.7 & 0.2 & -70.8 \\
\hline Norway & $\ldots$ & $\ldots$ & $\ldots$ & $\ldots$ & $\ldots$ & $\ldots$ & \\
\hline Poland & 0.1 & 0.1 & 0.1 & 0.1 & 0.0 & 0.0 & -24.8 \\
\hline Portugal & $\ldots$ & $\ldots$ & & $\ldots$ & $\ldots$ & $\ldots$ & \\
\hline Romania & 0.0 & 0.0 & 0.0 & 0.0 & 0.0 & 0.0 & -77.3 \\
\hline Russian Federation & $\ldots$ & $\ldots$ & & 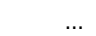 & & $\ldots$ & \\
\hline Serbia & 0.9 & 0.6 & 0.8 & 0.7 & 0.4 & 0.3 & -61.0 \\
\hline Slovak Republic & $\ldots$ & $\ldots$ & & & & $\ldots$ & \\
\hline Slovenia & 0.4 & 0.4 & 0.2 & 0.2 & 0.2 & 0.1 & -75.2 \\
\hline Spain & 0.4 & 0.4 & 0.4 & 0.4 & 0.3 & 0.4 & 14.4 \\
\hline Sweden & & & & & & $\ldots$ & \\
\hline Switzerland & 0.6 & 0.6 & 0.6 & 0.2 & 0.4 & 0.6 & -1.3 \\
\hline Turkey & & & & & & & \\
\hline Ukraine & 0.3 & 0.2 & 0.1 & 0.7 & 0.5 & 0.2 & -13.1 \\
\hline UK: England \& Wales & $\ldots$ & $\ldots$ & $\ldots$ & $\ldots$ & $\ldots$ & $\ldots$ & $\ldots$ \\
\hline UK: Northern Ireland & $\ldots$ & $\ldots$ & $\ldots$ & $\ldots$ & $\ldots$ & $\ldots$ & $\ldots$ \\
\hline UK: Scotland & $\ldots$ & $\ldots$ & $\ldots$ & $\ldots$ & & $\ldots$ & $\ldots$ \\
\hline Mean & 0.5 & 0.4 & 0.3 & 0.4 & 0.4 & 0.3 & \\
\hline Median & 0.3 & 0.3 & 0.2 & 0.2 & 0.3 & 0.2 & \\
\hline Minimum & 0.0 & 0.0 & 0.0 & 0.0 & 0.0 & 0.0 & \\
\hline Maximum & 2.3 & 1.7 & 0.9 & 1.9 & 1.6 & 2.6 & \\
\hline
\end{tabular}


Table 1.2.1.5 Offences per 100000 population - Intentional homicide completed

\begin{tabular}{|c|c|c|c|c|c|c|c|}
\hline & 2011 & 2012 & 2013 & 2014 & 2015 & 2016 & $\begin{array}{c}\% \text { change } \\
2011-2016\end{array}$ \\
\hline Albania & 4.2 & 4.3 & 3.7 & 3.4 & 1.9 & 2.5 & -41.2 \\
\hline Armenia & 1.8 & 1.5 & 1.7 & 1.8 & 1.7 & 2.2 & 19.7 \\
\hline Austria & 1.0 & 1.0 & 0.7 & 0.5 & 0.5 & 0.6 & -41.0 \\
\hline Azerbaijan & 11.0 & 11.0 & 11.5 & 10.4 & 8.3 & 7.2 & -34.6 \\
\hline Belgium & 1.9 & 1.9 & 1.8 & 1.9 & 2.0 & 1.5 & -21.4 \\
\hline Bosnia-Herzegovina & 1.3 & 1.6 & 1.3 & 1.4 & 1.6 & 1.2 & -2.7 \\
\hline Bulgaria & 1.7 & 1.9 & 1.5 & 1.6 & 1.8 & 1.1 & -34.8 \\
\hline Croatia & & & & & $\ldots$ & $\ldots$ & \\
\hline Cyprus & 1.0 & 2.2 & 1.3 & 1.2 & 1.4 & 1.3 & 36.1 \\
\hline Czech Republic & $\ldots$ & $\ldots$ & $\ldots$ & $\ldots$ & $\ldots$ & $\ldots$ & \\
\hline Denmark & 1.0 & 0.9 & 0.8 & 1.1 & 1.0 & 1.0 & -0.8 \\
\hline Estonia & 4.9 & 4.8 & 3.9 & 3.2 & 3.4 & 2.5 & -48.7 \\
\hline Finland & 2.5 & 2.0 & 2.0 & 2.1 & 2.1 & 1.8 & -29.1 \\
\hline France & 1.5 & 1.5 & 1.4 & 1.4 & 1.5 & 1.6 & 1.4 \\
\hline Georgia & 2.3 & 2.4 & 3.0 & 2.4 & 3.0 & 3.1 & 34.3 \\
\hline Germany & 0.9 & 0.8 & 0.8 & 0.8 & 0.8 & 0.9 & 5.8 \\
\hline Greece & 0.9 & 1.0 & 1.3 & 1.0 & 0.9 & 0.8 & -16.5 \\
\hline Hungary & 1.4 & 1.1 & 1.4 & 1.3 & 1.0 & 1.0 & -27.8 \\
\hline Iceland & 0.9 & 0.3 & 0.3 & 0.6 & 0.9 & 0.3 & -68.1 \\
\hline Ireland & $\ldots$ & $\ldots$ & $\ldots$ & $\ldots$ & $\ldots$ & $\ldots$ & \\
\hline Italy & 0.9 & 0.9 & 0.8 & 0.8 & 0.8 & 0.7 & -28.8 \\
\hline Kosovo (UN R/1244/99) & 3.5 & 5.0 & 2.2 & 2.1 & 1.5 & 1.6 & -52.6 \\
\hline Latvia & $\ldots$ & $\ldots$ & $\ldots$ & $\ldots$ & $\ldots$ & $\ldots$ & \\
\hline Lithuania & 6.2 & 6.0 & 5.8 & 5.3 & 5.2 & 4.9 & -20.6 \\
\hline Luxembourg & 0.8 & 0.0 & 0.4 & 0.7 & 0.7 & 0.9 & 11.0 \\
\hline Malta & 0.7 & 2.4 & 1.4 & 1.4 & 0.9 & 1.1 & 53.6 \\
\hline Moldova & 4.7 & 4.7 & 4.4 & 3.6 & 3.6 & 3.8 & -17.7 \\
\hline Montenegro & $\ldots$ & & & $\ldots$ & & $\ldots$ & \\
\hline Netherlands & 1.0 & 0.9 & 0.9 & 0.9 & 0.7 & 0.6 & -34.6 \\
\hline North Macedonia & 1.4 & 1.4 & 1.0 & 1.2 & 1.1 & 0.8 & -42 \\
\hline Norway & 2.3 & 0.5 & 0.9 & 0.6 & 0.5 & 0.5 & -77.0 \\
\hline Poland & 1.6 & 1.4 & 1.2 & 1.1 & 1.0 & 0.9 & -42.8 \\
\hline Portugal & 1.1 & 1.4 & 1.2 & 1.0 & 1.0 & 0.7 & -33.6 \\
\hline Romania & 1.6 & 1.9 & 1.6 & 1.5 & 1.5 & 1.2 & -24.1 \\
\hline Russian Federation & & & & & & & \\
\hline Serbia & 1.7 & 1.5 & 1.8 & 1.6 & 1.3 & 1.5 & -9 \\
\hline Slovak Republic & 1.8 & 1.4 & 1.4 & 1.3 & 0.9 & 1.1 & -38 \\
\hline Slovenia & 0.6 & 0.5 & 0.3 & 0.5 & 0.7 & 0.4 & -34 \\
\hline Spain & 0.8 & 0.8 & 0.6 & 0.7 & 0.7 & 0.6 & -23 \\
\hline Sweden & 0.9 & 0.7 & 0.9 & 0.9 & 1.1 & 1.1 & 25 \\
\hline Switzerland & 0.6 & 0.6 & 0.7 & 0.5 & 0.7 & 0.5 & -8 \\
\hline Turkey & 1.5 & 1.7 & $\ldots$ & $\ldots$ & & $\ldots$ & $\ldots$ \\
\hline Ukraine & $\ldots$ & & $\ldots$ & 10.9 & 7.5 & 4.3 & . \\
\hline UK: England \& Wales & 0.9 & 1.0 & 1.0 & 0.9 & 1.0 & 1.2 & 30 \\
\hline UK: Northern Ireland & 1.3 & 1.1 & 1.1 & 1.4 & 1.1 & 0.9 & -31 \\
\hline UK: Scotland & 2.3 & 2.3 & 1.7 & 2.0 & 2.0 & 1.5 & -35 \\
\hline Mean & 2.0 & 2.0 & 1.8 & 2.0 & 1.8 & 1.6 & \\
\hline Median & 1.4 & 1.4 & 1.3 & 1.3 & 1.1 & 1.1 & \\
\hline Minimum & 0.6 & 0.0 & 0.3 & 0.5 & 0.5 & 0.3 & \\
\hline Maximum & 11.0 & 11.0 & 11.5 & 10.9 & 8.3 & 7.2 & \\
\hline
\end{tabular}


Table 1.2.1.6 Offences per 100000 population - Intentional homicide completed: Firearm involved

\begin{tabular}{|c|c|c|c|c|c|c|c|}
\hline & 2011 & 2012 & 2013 & 2014 & 2015 & 2016 & $\begin{array}{c}\% \text { change } \\
2011-2016\end{array}$ \\
\hline Albania & $\ldots$ & $\ldots$ & $\ldots$ & $\ldots$ & $\ldots$ & $\ldots$ & $\ldots$ \\
\hline Armenia & & & & & & & \\
\hline Austria & 0.1 & 0.0 & 0.0 & 0.1 & 0.1 & 0.1 & -23.0 \\
\hline Azerbaijan & & & & & & & \\
\hline Belgium & 0.2 & 0.2 & 0.2 & 0.2 & 0.2 & 0.1 & -38.1 \\
\hline Bosnia-Herzegovina & & $\ldots$ & $\ldots$ & $\ldots$ & $\ldots$ & $\ldots$ & $\ldots$ \\
\hline Bulgaria & 0.0 & $\ldots$ & $\ldots$ & $\ldots$ & $\ldots$ & $\ldots$ & $\ldots$ \\
\hline Croatia & & & & & & & \\
\hline Cyprus & 0.4 & 1.4 & 0.7 & 0.3 & 0.7 & 0.7 & 98.0 \\
\hline Czech Republic & $\ldots$ & $\ldots$ & $\ldots$ & $\ldots$ & $\ldots$ & $\ldots$ & $\ldots$ \\
\hline Denmark & $\cdots$ & $\cdots$ & $\cdots$ & $\cdots$ & $\cdots$ & $\begin{array}{l}\cdots \\
\ldots\end{array}$ & $\cdots$ \\
\hline Estonia & 0.7 & 0.2 & 0.2 & 0.2 & 0.0 & 0.3 & -55.1 \\
\hline Finland & $\ldots$ & $\ldots$ & $\ldots$ & $\ldots$ & $\ldots$ & $\ldots$ & $\ldots$ \\
\hline France & $\ldots$ & $\ldots$ & $\ldots$ & $\ldots$ & $\ldots$ & $\ldots$ & $\ldots$ \\
\hline Georgia & $\ldots$ & $\ldots$ & $\ldots$ & $\ldots$ & $\ldots$ & $\ldots$ & $\ldots$ \\
\hline Germany & $\ldots$ & $\ldots$ & $\ldots$ & $\ldots$ & $\ldots$ & $\ldots$ & $\ldots$ \\
\hline Greece & & $\ldots$ & $\ldots$ & $\ldots$ & $\ldots$ & $\ldots$ & $\ldots$ \\
\hline Hungary & 0.1 & 0.1 & 0.1 & 0.0 & 0.1 & 0.1 & -49.2 \\
\hline Iceland & 0.0 & 0.0 & 0.0 & 0.0 & 0.0 & 0.0 & $\ldots$ \\
\hline Ireland & $\ldots$ & $\ldots$ & $\ldots$ & $\ldots$ & $\ldots$ & $\ldots$ & $\ldots$ \\
\hline Italy & $\ldots$ & $\ldots$ & $\ldots$ & $\ldots$ & $\ldots$ & $\ldots$ & $\ldots$ \\
\hline Kosovo (UN R/1244/99) & $\ldots$ & $\ldots$ & $\ldots$ & $\ldots$ & $\ldots$ & $\ldots$ & $\ldots$ \\
\hline Latvia & $\ldots$ & $\ldots$ & $\ldots$ & $\ldots$ & $\ldots$ & $\ldots$ & $\ldots$ \\
\hline Lithuania & 0.0 & 0.1 & 0.0 & 0.1 & 0.0 & 0.0 & -100.0 \\
\hline Luxembourg & & & & & $\ldots$ & $\ldots$ & $\ldots$ \\
\hline Malta & 0.0 & 1.0 & 0.9 & 0.7 & 0.5 & 0.0 & $\ldots$ \\
\hline Moldova & $\ldots$ & $\ldots$ & $\ldots$ & $\ldots$ & $\ldots$ & $\ldots$ & $\ldots$ \\
\hline Montenegro & $\ldots$ & $\ldots$ & $\ldots$ & $\ldots$ & $\ldots$ & $\ldots$ & $\ldots$ \\
\hline Netherlands & $\ldots$ & $\ldots$ & $\ldots$ & $\ldots$ & $\ldots$ & $\ldots$ & $\ldots$ \\
\hline North Macedonia & & & & & $\ldots$ & $\ldots$ & $\ldots$ \\
\hline Norway & 0.0 & 0.0 & 0.0 & 0.0 & 0.0 & 0.0 & $\ldots$ \\
\hline Poland & & $\ldots$ & $\ldots$ & $\ldots$ & $\ldots$ & $\ldots$ & $\ldots$ \\
\hline Portugal & 0.2 & 0.4 & 0.3 & 0.2 & 0.3 & 0.2 & -11.1 \\
\hline Romania & $\ldots$ & $\ldots$ & $\ldots$ & $\ldots$ & $\ldots$ & $\ldots$ & $\ldots$ \\
\hline Russian Federation & $\ldots$ & $\ldots$ & $\ldots$ & $\ldots$ & $\ldots$ & $\ldots$ & \\
\hline Serbia & 0.3 & 0.2 & 0.4 & 0.2 & 0.2 & 0.2 & -46.7 \\
\hline Slovak Republic & & & & & $\ldots$ & $\ldots$ & \\
\hline Slovenia & 0.4 & 0.4 & 0.2 & 0.2 & 0.2 & 0.1 & -75.2 \\
\hline Spain & 0.1 & 0.1 & 0.1 & 0.1 & 0.1 & 0.1 & -24.6 \\
\hline Sweden & $\ldots$ & $\ldots$ & $\ldots$ & $\ldots$ & $\ldots$ & $\ldots$ & $\ldots$ \\
\hline Switzerland & $\ldots$ & $\ldots$ & $\ldots$ & $\ldots$ & $\ldots$ & $\ldots$ & $\ldots$ \\
\hline Turkey & $\ldots$ & $\ldots$ & $\ldots$ & $\ldots$ & $\ldots$ & $\ldots$ & $\ldots$ \\
\hline Ukraine & $\ldots$ & $\ldots$ & $\ldots$ & & $\ldots$ & $\ldots$ & \\
\hline UK: England \& Wales & 0.1 & 0.1 & 0.0 & 0.0 & 0.0 & 0.1 & -30.0 \\
\hline $\begin{array}{l}\text { UK: Northern Ireland } \\
\text { UK: Scotland }\end{array}$ & 0.2 & 0.3 & 0.1 & $\ldots$ & $\begin{array}{l}\ldots \\
\ldots\end{array}$ & $\begin{array}{l}\ldots \\
\ldots\end{array}$ & $\ldots$ \\
\hline Mean & 0.2 & 0.3 & 0.2 & 0.2 & 0.2 & 0.1 & \\
\hline Median & 0.1 & 0.2 & 0.1 & 0.1 & 0.1 & 0.1 & \\
\hline Minimum & 0.0 & 0.0 & 0.0 & 0.0 & 0.0 & 0.0 & \\
\hline Maximum & 0.7 & 1.4 & 0.9 & 0.7 & 0.7 & 0.7 & \\
\hline
\end{tabular}


1 Police Statistics

Table 1.2.1.7 Offences per 100000 population - Bodily injury

\begin{tabular}{|c|c|c|c|c|c|c|c|}
\hline & 2011 & 2012 & 2013 & 2014 & 2015 & 2016 & $\begin{array}{c}\% \text { change } \\
2011-2016\end{array}$ \\
\hline Albania & 50.1 & 52.8 & 51.9 & 41.0 & 51.9 & 43.2 & -13.8 \\
\hline Armenia & 41.7 & 50.1 & 48.8 & 45.5 & 36.4 & 38.3 & -8.0 \\
\hline Austria & 482.2 & 491.5 & 467.5 & 442.6 & 440.5 & 462.3 & -4.1 \\
\hline Azerbaijan & & & & $\ldots$ & & & \\
\hline Belgium & 777.1 & 713.1 & 681.6 & 684.0 & 663.3 & 657.8 & -15.4 \\
\hline Bosnia-Herzegovina & 17.0 & 16.1 & 16.3 & 17.0 & 28.9 & 29.8 & 75.6 \\
\hline Bulgaria & 19.9 & 19.2 & 19.3 & 19.5 & 18.6 & 16.4 & -17.4 \\
\hline Croatia & & & & & & & \\
\hline Cyprus & 19.5 & 17.2 & 15.2 & 15.6 & 16.6 & 17.1 & -12.5 \\
\hline Czech Republic & 50.2 & 49.9 & 51.1 & 49.5 & 49.6 & 47.8 & -4.7 \\
\hline Denmark & 223.8 & 210.6 & 208.5 & 210.5 & 215.7 & 270.9 & 21.0 \\
\hline Estonia & 413.6 & 444.7 & 456.5 & 439.0 & 470.5 & 461.0 & 11.5 \\
\hline Finland & 747.3 & 707.8 & 654.5 & 604.0 & 619.1 & 615.4 & -17.7 \\
\hline France & 390.9 & 399.2 & 399.8 & 417.5 & 449.0 & 454.5 & 16.3 \\
\hline Georgia & 9.1 & 89.1 & 96.0 & 86.8 & 122.5 & 123.6 & 1257.7 \\
\hline Germany & 646.0 & 653.0 & 634.9 & 625.3 & 624.9 & 670.2 & 3.7 \\
\hline Greece & 45.2 & 41.4 & 52.7 & 53.6 & 54.5 & 56.9 & 26.1 \\
\hline Hungary & 142.6 & 140.9 & 135.2 & 136.7 & 127.9 & 118.1 & -17.2 \\
\hline Iceland & 89.2 & 95.8 & 91.3 & 100.1 & 100.0 & 89.6 & 0.5 \\
\hline Ireland & or. & & on & $\ldots$ & & & $\ldots$ \\
\hline Italy & 115.4 & 117.1 & 111.1 & 108.9 & 105.3 & 104.1 & -9.8 \\
\hline Kosovo (UN R/1244/99) & 208.6 & 210.8 & 35.8 & 44.9 & 21.8 & 20.5 & -90.2 \\
\hline Latvia & 58.7 & 59.6 & 58.2 & 60.7 & 45.4 & 60.7 & 3.4 \\
\hline Lithuania & 134.5 & 345.7 & 412.8 & 395.3 & 385.2 & 371.1 & 175.8 \\
\hline Luxembourg & $\ldots$ & & & & & & \\
\hline Malta & 267.0 & 247.2 & 226.7 & 230.5 & 210.6 & 200.0 & -25.1 \\
\hline Moldova & 43.1 & 41.1 & 37.4 & 36.2 & 31.9 & 32.5 & -24.7 \\
\hline Montenegro & 64.9 & 76.9 & 73.3 & 57.0 & 52.6 & 52.2 & -19.5 \\
\hline Netherlands & 362.9 & 344.2 & 318.5 & 302.5 & 285.7 & 276.8 & -23.7 \\
\hline North Macedonia & 31.3 & 32.2 & 31.0 & 38.0 & 38.0 & 33.2 & 6.1 \\
\hline Norway & 296.4 & 298.0 & 283.6 & 268.7 & 270.6 & 236.2 & -20.3 \\
\hline Poland & 137.9 & 131.5 & 121.5 & 105.4 & 88.9 & 92.6 & -32.9 \\
\hline Portugal & 565.0 & 529.7 & 521.9 & 517.7 & 505.2 & 507.5 & $-10.2 \%$ \\
\hline Romania & 496.3 & 505.3 & 455.0 & 603.3 & 608.5 & 635.7 & 28.1 \\
\hline Russian Federation & 20.8 & 20.3 & 21.2 & 20.4 & 18.9 & 17.4 & -16.0 \\
\hline Serbia & 42.3 & 41.6 & 40.1 & 37.7 & 37.2 & 35.5 & -16.2 \\
\hline Slovak Republic & 41.3 & 40.4 & 37.3 & 36.7 & 35.7 & 30.7 & -25.7 \\
\hline Slovenia & 96.3 & 98.9 & 89.8 & 80.4 & 74.7 & 72.2 & -25.0 \\
\hline Spain & 39.3 & 37.1 & 35.7 & 36.1 & 41.0 & 37.3 & -5.0 \\
\hline Sweden & 1006.3 & 972.7 & 889.3 & 910.1 & 918.2 & 944.9 & -6.1 \\
\hline Switzerland & 121.0 & 117.2 & 113.1 & 103.1 & 97.1 & 100.4 & -17.0 \\
\hline Turkey & 323.4 & 351.1 & & & & & \\
\hline Ukraine & 28.7 & 25.1 & 128.8 & 99.7 & 95.2 & 83.4 & 190.7 \\
\hline UK: England \& Wales & 616.4 & 559.0 & 553.4 & 632.1 & 721.0 & 782.8 & 27.0 \\
\hline UK: Northern Ireland & 55.0 & 61.9 & 57.1 & 63.8 & 69.9 & 62.9 & 14.3 \\
\hline UK: Scotland & 103.6 & 88.3 & 68.4 & 61.1 & 58.9 & 74.1 & -28.5 \\
\hline Mean & 225 & 227 & 215 & 216 & 217 & 220 & \\
\hline Median & 110 & 108 & 96 & 100 & 95 & 90 & \\
\hline Minimum & 9 & 16 & 15 & 16 & 17 & 16 & \\
\hline Maximum & 1006 & 973 & 889 & 910 & 918 & 945 & \\
\hline
\end{tabular}


Table 1.2.1.8 Offences per 100000 population - Aggravated bodily injury

\begin{tabular}{|c|c|c|c|c|c|c|c|}
\hline & 2011 & 2012 & 2013 & 2014 & 2015 & 2016 & $\begin{array}{c}\% \text { change } \\
2011-2016\end{array}$ \\
\hline Albania & 5.8 & 5.4 & 5.6 & 4.6 & 5.9 & 4.1 & -29.4 \\
\hline Armenia & 5.2 & 5.2 & 6.4 & 7.4 & 5.7 & 6.7 & 28.0 \\
\hline Austria & 46.5 & 47.9 & 44.2 & 42.8 & 40.3 & 43.6 & -6.3 \\
\hline Azerbaijan & 3.5 & 4.0 & 4.1 & 4.1 & 3.8 & 3.6 & 2.6 \\
\hline Belgium & $\ldots$ & $\ldots$ & $\ldots$ & $\ldots$ & $\ldots$ & $\ldots$ & $\ldots$ \\
\hline Bosnia-Herzegovina & $\ldots$ & & & $\ldots$ & $\ldots$ & & \\
\hline Bulgaria & 0.5 & 0.5 & 0.6 & 0.3 & 0.3 & 0.5 & -4.9 \\
\hline Croatia & $\ldots$ & & & & $\ldots$ & $\ldots$ & \\
\hline Cyprus & 15.1 & 14.8 & 12.8 & 12.9 & 13.9 & 14.4 & -4.9 \\
\hline Czech Republic & $\ldots$ & & & & $\ldots$ & 0.0 & \\
\hline Denmark & 30.5 & 29.7 & 26.8 & 27.2 & 25.8 & 30.4 & -0.4 \\
\hline Estonia & 7.8 & 7.5 & 7.5 & 5.9 & 7.5 & 7.1 & -9.6 \\
\hline Finland & 38.2 & 34.7 & 33.0 & 30.2 & 28.6 & 29.0 & -24.0 \\
\hline France & & & & & $\ldots$ & & \\
\hline Georgia & 3.0 & 2.7 & 4.2 & 5.1 & 4.7 & 6.7 & 127.5 \\
\hline Germany & 173.4 & 169.4 & 158.8 & 155.7 & 156.9 & 170.4 & -1.7 \\
\hline Greece & $\ldots$ & $\ldots$ & & $\ldots$ & $\ldots$ & $\ldots$ & $\ldots$ \\
\hline Hungary & 68.0 & 66.3 & 70.3 & 64.1 & 60.2 & 54.5 & -19.9 \\
\hline Iceland & 18.8 & 23.2 & 28.6 & 31.0 & 25.8 & 22.3 & 18.1 \\
\hline Ireland & $\ldots$ & $\ldots$ & $\ldots$ & $\ldots$ & $\ldots$ & $\ldots$ & $\ldots$ \\
\hline Italy & $\ldots$ & $\ldots$ & $\ldots$ & $\ldots$ & $\ldots$ & $\ldots$ & $\ldots$ \\
\hline Kosovo (UN R/1244/99) & $\ldots$ & $\ldots$ & $\ldots$ & $\ldots$ & $\ldots$ & $\ldots$ & $\ldots$ \\
\hline Latvia & 9.7 & 10.0 & 10.7 & 11.3 & 9.0 & 9.9 & 2.2 \\
\hline Lithuania & 5.9 & 5.2 & 6.3 & 6.4 & 6.5 & 7.0 & 19.2 \\
\hline Luxembourg & $\ldots$ & & 132.8 & 132.4 & 108.0 & 97.0 & $\ldots$ \\
\hline Malta & 38.8 & 35.2 & 41.4 & 31.7 & 36.6 & 36.4 & -6.1 \\
\hline Moldova & 36.9 & 34.6 & 29.9 & 28.2 & 25.1 & 24.5 & -33.4 \\
\hline Montenegro & 26.0 & 27.1 & 27.9 & 20.8 & 22.5 & 20.6 & -20.8 \\
\hline Netherlands & & & & & & & \\
\hline North Macedonia & 11.6 & 10.2 & 10.5 & 10.3 & 7.4 & 8.4 & -28.1 \\
\hline Norway & 15.2 & 14.3 & 13.1 & 10.4 & 10.6 & 9.6 & -36.8 \\
\hline Poland & 2.5 & 2.7 & 2.0 & 2.0 & 1.8 & 1.8 & -28.7 \\
\hline Portugal & 7.7 & 6.7 & 5.6 & 5.2 & 4.5 & 5.0 & -34.4 \\
\hline Romania & 144.9 & 140.8 & 127.6 & 125.7 & 140.2 & 153.7 & 6.1 \\
\hline Russian Federation & & & & & & & \\
\hline Serbia & 18.2 & 18.2 & 18.1 & 16.1 & 16.1 & 14.9 & -18.0 \\
\hline Slovak Republic & & & & & & $\ldots$ & \\
\hline Slovenia & 9.1 & 10.5 & 8.4 & 8.8 & 8.0 & 7.4 & -18.7 \\
\hline Spain & $\ldots$ & & & & $\ldots$ & $\ldots$ & $\ldots$ \\
\hline Sweden & $\ldots$ & 56.3 & 48.8 & 47.4 & 47.5 & 50.1 & \\
\hline Switzerland & 7.9 & 8.5 & 7.5 & 8.4 & 8.3 & 7.5 & -5.0 \\
\hline Turkey & & & & & & & \\
\hline Ukraine & 7.5 & 6.7 & 6.7 & 6.9 & 5.9 & 5.3 & -29.8 \\
\hline UK: England \& Wales & 60.2 & 41.0 & 36.8 & 42.4 & 45.8 & 50.8 & -15.7 \\
\hline UK: Northern Ireland & & & & & & & \\
\hline UK: Scotland & 88.5 & 68.6 & 61.3 & 59.2 & 74.6 & 77.5 & -12.5 \\
\hline Mean & 31 & 30 & 32 & 31 & 31 & 31 & \\
\hline Median & 15 & 15 & 13 & 13 & 14 & 12 & \\
\hline Minimum & 1 & 0 & 1 & 0 & 0 & 0 & \\
\hline Maximum & 173 & 169 & 159 & 156 & 157 & 170 & \\
\hline
\end{tabular}


Table 1.2.1.9 Offences per 100000 population - Sexual assault

\begin{tabular}{|c|c|c|c|c|c|c|c|}
\hline & 2011 & 2012 & 2013 & 2014 & 2015 & 2016 & $\begin{array}{c}\% \text { change } \\
2011-2016\end{array}$ \\
\hline Albania & 1.5 & 1.5 & 3.0 & 3.4 & 5.2 & 4.2 & 175.7 \\
\hline Armenia & 2.2 & 3.2 & 4.0 & 3.3 & 4.0 & 3.9 & 80.8 \\
\hline Austria & 44.8 & 45.1 & 42.2 & 39.7 & 38.0 & 48.3 & 7.8 \\
\hline Azerbaijan & & & & & & & \\
\hline Belgium & 65.7 & 64.0 & 64.6 & 61.7 & 59.6 & 63.7 & -3.2 \\
\hline Bosnia-Herzegovina & & & & & & & \\
\hline Bulgaria & 7.5 & 8.0 & 7.6 & 7.6 & 7.0 & 6.1 & -18.6 \\
\hline Croatia & & & & & & & \\
\hline Cyprus & 7.9 & 5.6 & 4.0 & 4.7 & 4.6 & 0.0 & -100.0 \\
\hline Czech Republic & 13.9 & 13.5 & 13.6 & 13.7 & 13.9 & 13.2 & -5.1 \\
\hline Denmark & 25.3 & 25.4 & 23.6 & 24.6 & 28.5 & 43.7 & 72.4 \\
\hline Estonia & 13.5 & 18.7 & 18.2 & 15.1 & 21.6 & 20.6 & 52.1 \\
\hline Finland & 58.8 & 59.9 & 55.1 & 51.8 & 51.0 & 58.1 & -1.1 \\
\hline France & 64.3 & 65.4 & 65.6 & 69.4 & 73.0 & 75.8 & 17.9 \\
\hline Georgia & 9.0 & 8.6 & 9.6 & 7.6 & 7.3 & 9.1 & 1.6 \\
\hline Germany & 31.1 & 30.7 & 31.1 & 28.3 & 27.5 & 30.1 & -3.3 \\
\hline Greece & 5.2 & 6.6 & 13.3 & 10.7 & 10.4 & 11.1 & 113.8 \\
\hline Hungary & 10.3 & 12.2 & 12.4 & 12.7 & 13.8 & 14.5 & 40.6 \\
\hline Iceland & 89.5 & 85.4 & 140.4 & 98.3 & 108.8 & 102.5 & 14.6 \\
\hline Ireland & 39.6 & 40.0 & 38.6 & 40.1 & 44.4 & 47.2 & 19.3 \\
\hline Italy & 7.8 & 7.9 & 7.5 & 7.0 & 6.6 & 6.7 & -14.2 \\
\hline Kosovo (UN R/1244/99) & $\ldots$ & $\ldots$ & $\ldots$ & $\ldots$ & $\ldots$ & $\ldots$ & $\ldots$ \\
\hline Latvia & & & $\ldots$ & $\ldots$ & $\ldots$ & $\ldots$ & $\ldots$ \\
\hline Lithuania & 17.7 & 14.8 & 11.8 & 13.7 & 12.7 & 10.5 & -40.5 \\
\hline Luxembourg & $\ldots$ & & 66.5 & 65.3 & 58.3 & 72.7 & $\ldots$ \\
\hline Malta & 23.4 & 26.6 & 27.0 & 23.1 & 28.2 & 24.9 & 6.4 \\
\hline Moldova & 12.9 & 17.4 & 17.1 & 18.2 & 18.0 & 17.2 & 33.0 \\
\hline Montenegro & 4.0 & 3.9 & 4.0 & 5.0 & 4.2 & 3.5 & -12.3 \\
\hline Netherlands & 39.7 & 39.1 & 36.1 & 35.1 & 33.3 & 37.7 & -5.2 \\
\hline North Macedonia & 6.1 & 5.8 & 7.3 & 6.5 & 5.8 & 5.5 & -10.1 \\
\hline Norway & 56.1 & 55.2 & 51.5 & 53.7 & 62.5 & 75.2 & 33.9 \\
\hline Poland & 8.3 & 7.4 & 7.3 & 6.0 & 5.6 & 6.4 & -23.4 \\
\hline Portugal & 19.8 & 19.3 & 20.5 & 22.5 & 23.6 & 24 & 20.9 \\
\hline Romania & 22.0 & 23.7 & 23.7 & 21.7 & 22.4 & 23.7 & 7.7 \\
\hline Russian Federation & & & & & & & \\
\hline Serbia & 4.8 & 4.9 & 3.9 & 4.3 & 3.7 & 4.3 & -8.8 \\
\hline Slovak Republic & & & & & & & \\
\hline Slovenia & 16.7 & 14.7 & 15.5 & 10.7 & 8.9 & 11.9 & -28.6 \\
\hline Spain & 21.2 & 19.2 & 19.1 & 20.4 & 21.2 & 23.4 & 10.2 \\
\hline Sweden & 161.4 & 159.2 & 166.1 & 193.5 & 169.3 & 189.1 & 17.1 \\
\hline Switzerland & 49.9 & 46.7 & 47.1 & 46.4 & 46.0 & 47.7 & -4.4 \\
\hline Turkey & 16.1 & 18.1 & & $\ldots$ & & & $\ldots$ \\
\hline Ukraine & & 2.7 & 2.5 & 2.0 & 1.8 & 2.1 & \\
\hline UK: England \& Wales & 81.2 & 92.3 & 106.9 & 139.8 & 178.4 & 198.7 & 144.6 \\
\hline UK: Northern Ireland & 87.2 & 106.0 & 122.0 & 148.3 & 163.6 & 169.2 & 94.0 \\
\hline UK: Scotland & 126.3 & 138.5 & 144.4 & 160.9 & 177.9 & 190.1 & 50.4 \\
\hline Mean & 34 & 35 & 38 & 39 & 41 & 45 & \\
\hline Median & 20 & 19 & 20 & 21 & 22 & 24 & \\
\hline Minimum & 2 & 2 & 2 & 2 & 2 & 0 & \\
\hline Maximum & 161 & 159 & 166 & 194 & 178 & 199 & \\
\hline
\end{tabular}


Table 1.2.1.10 Offences per 100000 population - Rape

\begin{tabular}{|c|c|c|c|c|c|c|c|}
\hline & 2011 & 2012 & 2013 & 2014 & 2015 & 2016 & $\begin{array}{c}\% \text { change } \\
2011-2016\end{array}$ \\
\hline Albania & 0.0 & 0.5 & 0.5 & 0.4 & 0.6 & 0.6 & 1517.7 \\
\hline Armenia & 0.5 & 0.6 & 0.7 & 0.8 & 1.3 & 0.8 & 81.3 \\
\hline Austria & 17.8 & 16.5 & 15.9 & 15.0 & 14.5 & 16.8 & -5.2 \\
\hline Azerbaijan & 0.3 & 0.2 & 0.3 & 0.3 & 0.3 & 0.4 & 14.0 \\
\hline Belgium & 31.2 & 31.3 & 30.8 & 28.5 & 28.4 & 29.1 & -6.7 \\
\hline Bosnia-Herzegovina & 0.9 & 1.1 & 1.0 & 0.8 & 1.0 & 0.8 & -12.4 \\
\hline Bulgaria & 2.5 & 3.1 & 2.7 & 2.6 & 2.1 & 2.2 & -14.6 \\
\hline \multicolumn{8}{|l|}{ Croatia } \\
\hline Cyprus & 4.5 & 2.9 & 2.1 & 1.6 & 2.4 & 2.6 & -42.7 \\
\hline Czech Republic & 6.4 & 6.4 & 5.6 & 6.4 & 5.7 & 6.1 & -4.5 \\
\hline Denmark & 11.1 & 10.6 & 10.7 & 10.7 & 14.0 & 23.0 & 107.7 \\
\hline Estonia & 6.8 & 10.8 & 10.2 & 11.2 & 12.2 & 11.6 & 68.8 \\
\hline Finland & 19.3 & 18.7 & 18.0 & 18.5 & 19.2 & 21.1 & 9.4 \\
\hline France & 17.3 & 17.9 & 18.4 & 19.7 & 20.7 & 22.9 & 32.1 \\
\hline Georgia & 1.7 & 1.8 & 1.8 & 1.4 & 1.1 & 1.5 & -12.2 \\
\hline Germany & 10.2 & 10.7 & 9.6 & 9.8 & 9.2 & 9.7 & -4.3 \\
\hline Greece & 1.6 & 1.7 & 2.4 & 2.2 & 1.9 & 2.4 & 47.4 \\
\hline Hungary & 2.0 & 1.9 & 5.1 & 4.0 & 4.2 & 4.1 & 109.4 \\
\hline Iceland & 40.2 & 38.2 & 55.9 & 39.6 & 54.1 & 55.6 & 38.4 \\
\hline Ireland & 9.8 & 10.0 & 8.5 & 10.3 & 11.1 & 10.9 & 11.7 \\
\hline \multicolumn{8}{|l|}{ Italy } \\
\hline Kosovo (UN R/1244/99) & 1.3 & 1.8 & 1.8 & 1.6 & 1.7 & 1.6 & 18.2 \\
\hline Latvia & 2.4 & 3.4 & 3.6 & 3.7 & 3.0 & 3.0 & 24.3 \\
\hline Lithuania & 12.4 & 10.6 & 8.2 & 10.4 & 8.8 & 7.1 & -43.0 \\
\hline Luxembourg & $\ldots$ & & 16.6 & 13.3 & 12.1 & 18.4 & \\
\hline Malta & 4.3 & 3.1 & 3.6 & 2.6 & 5.2 & 6.0 & 38.2 \\
\hline Moldova & 8.2 & 10.1 & 9.8 & 9.9 & 8.5 & 9.1 & 11.9 \\
\hline Montenegro & 0.5 & 0.5 & 0.6 & 0.8 & 0.8 & 0.3 & -33.6 \\
\hline Netherlands & 9.4 & 8.7 & 7.4 & 7.2 & 7.5 & 9.0 & -4.4 \\
\hline North Macedonia & 2.0 & 2.1 & 1.8 & 2.2 & 2.0 & 1.7 & -12.8 \\
\hline Norway & 35.7 & 35.1 & 33.5 & 33.6 & 38.4 & 45.1 & 26.0 \\
\hline Poland & 4.3 & 3.9 & 3.7 & 3.4 & 3.1 & 3.8 & -11.9 \\
\hline Portugal & 3.5 & 3.6 & 3.3 & 3.6 & 3.6 & 3.2 & -8.4 \\
\hline Romania & 12.1 & 11.9 & 11.5 & 10.6 & 11.0 & 11.0 & -9.0 \\
\hline \multicolumn{8}{|l|}{ Russian Federation } \\
\hline Serbia & 1.1 & 1.2 & 1.1 & 0.9 & 0.9 & 0.7 & -37.0 \\
\hline Slovak Republic & 2.8 & 1.6 & 1.7 & 1.6 & 1.6 & 1.5 & -45.7 \\
\hline Slovenia & 2.7 & 2.8 & 2.6 & 2.1 & 2.0 & 1.6 & -40.4 \\
\hline Spain & 3.2 & 2.7 & 2.8 & 2.7 & 2.6 & 2.7 & -17.0 \\
\hline Sweden & 69.4 & 66.7 & 63.0 & 69.4 & 60.7 & 68.2 & -1.7 \\
\hline Switzerland & 7.0 & 7.2 & 7.1 & 6.8 & 6.5 & 7.1 & 0.7 \\
\hline \multicolumn{8}{|l|}{ Turkey } \\
\hline Ukraine & 1.4 & 1.1 & 1.1 & 0.9 & 0.8 & 0.8 & -40.7 \\
\hline UK: England \& Wales & 29.1 & 28.2 & 33.6 & 46.5 & 59.9 & 67.4 & 131.5 \\
\hline UK: Northern Ireland & 30.5 & 29.3 & 30.1 & 40.0 & 42.0 & 44.1 & 44.7 \\
\hline UK: Scotland & 21.3 & 24.0 & 27.4 & 33.8 & 35.4 & 33.5 & 56.8 \\
\hline Mean & 11.0 & 10.8 & 11.3 & 11.7 & 12.4 & 13.5 & \\
\hline Median & 4.5 & 3.9 & 5.3 & 5.2 & 5.5 & 6.1 & \\
\hline Minimum & 0.0 & 0.2 & 0.3 & 0.3 & 0.3 & 0.3 & \\
\hline Maximum & 69.4 & 66.7 & 63.0 & 69.4 & 60.7 & 68.2 & \\
\hline
\end{tabular}


Table 1.2.1.11 Offences per 100000 population - Sexual abuse of a child

\begin{tabular}{|c|c|c|c|c|c|c|c|}
\hline & 2011 & 2012 & 2013 & 2014 & 2015 & 2016 & $\begin{array}{l}\% \text { change } \\
2011-2016\end{array}$ \\
\hline Albania & 0.3 & 0.3 & 0.6 & 0.4 & 0.8 & 0.5 & 51.7 \\
\hline Armenia & & & & & & 0.0 & \\
\hline Austria & 8.3 & 8.7 & 8.4 & 7.2 & 7.2 & 6.8 & -17.6 \\
\hline Azerbaijan & & $\ldots$ & & $\ldots$ & & $\ldots$ & \\
\hline Belgium & 22.3 & 20.6 & 21.6 & 21.5 & 20.5 & 21.4 & -4.2 \\
\hline Bosnia-Herzegovina & & $\ldots$ & & $\ldots$ & & $\ldots$ & \\
\hline $\begin{array}{l}\text { Bulgaria } \\
\text { Pan }\end{array}$ & 1.4 & 1.5 & 1.6 & 1.6 & 1.5 & 1.1 & -24.2 \\
\hline Croatia & $\ldots$ & $\ldots$ & & & & $\ldots$ & $\ldots$ \\
\hline Cyprus & $\ldots$ & 1.2 & 0.6 & 0.8 & 1.3 & 0.0 & $\ldots$ \\
\hline Czech Republic & 7.2 & 6.7 & 7.6 & 6.9 & 7.2 & 6.7 & -7.1 \\
\hline Denmark & 2.5 & 3.5 & 2.5 & 2.5 & 3.3 & 3.6 & 42.0 \\
\hline Estonia & 3.4 & 4.4 & 3.9 & 1.9 & 2.4 & 4.3 & 25.7 \\
\hline Finland & 31.3 & 29.0 & 30.5 & 26.0 & 22.4 & 22.6 & -27.7 \\
\hline France & 13.1 & 16.1 & 17.0 & 18.3 & 19.5 & 20.4 & 56.2 \\
\hline Georgia & & & & & & & \\
\hline Germany & 9.2 & 9.3 & 8.5 & 8.3 & 8.1 & 8.2 & -11.5 \\
\hline Greece & $\ldots$ & $\ldots$ & 0.0 & $\ldots$ & $\ldots$ & $\ldots$ & \\
\hline Hungary & 0.7 & 0.8 & 0.7 & 0.8 & 0.7 & 1.1 & 51.7 \\
\hline Iceland & 35.8 & 37.9 & 64.9 & 43.9 & 39.8 & 31.9 & -11.0 \\
\hline Ireland & 3.2 & 2.8 & 1.9 & 2.7 & 2.7 & 3.4 & 6.0 \\
\hline Italy & 0.8 & 0.9 & 0.9 & 0.8 & 0.8 & 0.8 & -8.3 \\
\hline Kosovo (UN R/1244/99) & $\ldots$ & $\ldots$ & $\ldots$ & $\ldots$ & $\ldots$ & $\ldots$ & $\ldots$ \\
\hline Latvia & . & $\ldots$ & $\ldots$ & $\ldots$ & $\ldots$ & $\ldots$ & \\
\hline Lithuania & 4.3 & 3.8 & 3.3 & 2.8 & 3.7 & 3.3 & -22.8 \\
\hline Luxembourg & & & & $\ldots$ & & $\ldots$ & \\
\hline Malta & 6.7 & 5.7 & 6.4 & 6.8 & 7.3 & 4.4 & -34.2 \\
\hline Moldova & 5.2 & 7.6 & 7.3 & 8.7 & 9.8 & 8.4 & 60.2 \\
\hline Montenegro & 0.3 & 0.2 & 0.8 & 0.5 & 0.2 & 0.2 & -50.2 \\
\hline Netherlands & & & & $\ldots$ & & $\ldots$ & \\
\hline North Macedonia & 1.7 & 1.7 & 2.3 & 2.1 & 1.8 & 1.4 & -14.9 \\
\hline Norway & 16.0 & 14.9 & 13.8 & 15.9 & 21.3 & 35.5 & 121.3 \\
\hline Poland & 4.0 & 3.5 & 3.6 & 2.6 & 2.5 & 2.6 & -35.7 \\
\hline Portugal & 7.4 & 7.4 & 8.2 & 9.7 & 10.1 & 9.5 & 27.7 \\
\hline Romania & 7.0 & 8.7 & 8.8 & 9.7 & 9.9 & 10.8 & 55.4 \\
\hline Russian Federation & & & & & & & \\
\hline Serbia & 2.2 & 2.4 & 1.9 & 2.1. & 1.8 & 2.3 & 6.3 \\
\hline Slovak Republic & & & & & & & \\
\hline Slovenia & 10.6 & 7.8 & 8.2 & 5.3 & 3.9 & 6.5 & -38.9 \\
\hline Spain & 2.1 & 1.8 & 2.0 & 2.4 & 3.1 & 2.9 & 40.6 \\
\hline Sweden & 52.4 & 49.2 & 51.5 & 70.4 & 54.1 & 59.7 & 13.9 \\
\hline Switzerland & 17.8 & 15.1 & 16.5 & 16.0 & 14.9 & 14.8 & -17.1 \\
\hline Turkey & 9.7 & 10.8 & $\ldots$ & $\ldots$ & $\ldots$ & $\ldots$ & $\ldots$ \\
\hline Ukraine & 0.1 & 0.2 & & $\ldots$ & & $\ldots$ & \\
\hline UK: England \& Wales & 30.0 & 31.5 & 37.1 & 58.1 & 62.2 & 73.5 & 145.0 \\
\hline $\begin{array}{l}\text { UK: Northern Ireland } \\
\text { UK: Scotland }\end{array}$ & 54.7 & 58.1 & 73.5 & 82.4 & 97.6 & 100.7 & 84.2 \\
\hline Mean & 11.6 & 11.3 & 13.4 & 14.2 & 14.3 & 15.1 & \\
\hline Median & 6.8 & 6.7 & 7.3 & 6.8 & 7.2 & 6.5 & \\
\hline Minimum & 0.1 & 0.2 & 0.6 & 0.4 & 0.2 & 0.0 & \\
\hline Maximum & 54.7 & 58.1 & 73.5 & 82.4 & 97.6 & 100.7 & \\
\hline
\end{tabular}


Table 1.2.1.12 Offences per 100000 population - Robbery

\begin{tabular}{|c|c|c|c|c|c|c|c|}
\hline & 2011 & 2012 & 2013 & 2014 & 2015 & 2016 & $\begin{array}{c}\% \text { change } \\
2011-2016\end{array}$ \\
\hline Albania & 6.0 & 7.7 & 9.3 & 8.7 & 6.3 & 4.8 & -19.3 \\
\hline Armenia & 10.5 & 9.5 & 8.9 & 9.9 & 9.7 & 10.3 & -2.6 \\
\hline Austria & 48.5 & 48.7 & 44.2 & 40.9 & 39.8 & 35.7 & -26.5 \\
\hline Azerbaijan & 5.0 & 4.2 & 3.8 & 4.2 & 5.7 & 5.0 & 0.2 \\
\hline Belgium & 248.6 & 231.2 & 205.6 & 196.1 & 199.3 & 181.1 & -27.1 \\
\hline Bosnia-Herzegovina & 25.4 & 26.3 & 31.1 & 29.4 & 0.0 & 30.0 & 18.1 \\
\hline Bulgaria & 42.2 & 40.6 & 41.0 & 32.3 & 27.2 & 23.5 & -44.3 \\
\hline Croatia & & & & $\ldots$ & & & \\
\hline Cyprus & 16.3 & 20.1 & 17.2 & 12.1 & 11.0 & 12.4 & -24.1 \\
\hline Czech Republic & 37.0 & 32.5 & 29.0 & 24.2 & 19.2 & 15.6 & -57.9 \\
\hline Denmark & 40.4 & 38.4 & 40.4 & 27.8 & 25.6 & 28.7 & -28.8 \\
\hline Estonia & 39.5 & 34.5 & 36.1 & 27.4 & 25.6 & 18.8 & -52.3 \\
\hline Finland & 30.2 & 29.9 & 28.1 & 31.0 & 28.3 & 30.5 & 1.0 \\
\hline France & 193.8 & 198.4 & 200.0 & 182.9 & 168.2 & 160.6 & -17.1 \\
\hline Georgia & 16.7 & 18.4 & 26.2 & 16.9 & 21.3 & 15.3 & -8.5 \\
\hline Germany & 59.9 & 60.6 & 58.7 & 56.3 & 55.0 & 52.3 & -12.6 \\
\hline Greece & 40.9 & 35.2 & 50.1 & 39.5 & 44.0 & 47.6 & 16.5 \\
\hline Hungary & 31.9 & 30.4 & 23.0 & 19.7 & 14.5 & 11.5 & -63.9 \\
\hline Iceland & 13.2 & 15.6 & 15.2 & 15.7 & 16.1 & 15.0 & 14.0 \\
\hline Ireland & 61.9 & 58.3 & 58.7 & 54.6 & 51.8 & 41.4 & -33.1 \\
\hline Italy & 68.3 & 71.8 & 73.3 & 64.6 & 57.7 & 54.3 & -20.6 \\
\hline Kosovo (UN R/1244/99) & 35.1 & 29.2 & 28.0 & 24.5 & 15.8 & 16.3 & -53.6 \\
\hline Latvia & 51.1 & 47.1 & 45.3 & 40.4 & 39.2 & 33.1 & -35.4 \\
\hline Lithuania & 82.0 & 64.0 & 62.8 & 57.3 & 54.4 & 46.5 & -43.3 \\
\hline Luxembourg & & & 108.4 & 111.9 & 98.4 & 79.7 & \\
\hline Malta & 9.4 & 6.9 & 6.2 & 4.7 & 8.6 & 5.6 & -40.9 \\
\hline Moldova & 32.3 & 33.0 & 32.1 & 31.7 & 28.0 & 29.0 & -10.2 \\
\hline Montenegro & 21.0 & 17.7 & 24.6 & 29.0 & 22.7 & 19.3 & -8.0 \\
\hline Netherlands & 93.6 & 89.3 & 79.6 & 62.1 & 57.6 & 52.9 & -43.4 \\
\hline North Macedonia & 24.9 & 22.8 & 22.7 & 14.8 & 13.4 & 12.0 & -52.0 \\
\hline Norway & 33.0 & 29.8 & 33.0 & 20.8 & 18.0 & 15.5 & -52.9 \\
\hline Poland & 40.3 & 37.5 & 35.6 & 22.8 & 18.7 & 17.9 & -55.6 \\
\hline Portugal & 193.2 & 176.5 & 159.1 & 150.3 & 149.6 & 129.1 & $-33.2 \%$ \\
\hline Romania & 30.3 & 32.6 & 24.9 & 22.5 & 21.1 & 19.6 & -35.4 \\
\hline Russian Federation & 89.4 & 76.9 & 11.4 & 10.0 & 9.5 & 7.9 & -91.2 \\
\hline Serbia & 48.3 & 52.9 & 53.6 & 45.2 & 42.6 & 34.2 & -29.1 \\
\hline Slovak Republic & 15.8 & 18.0 & 15.4 & 12.6 & 9.9 & 9.7 & -38.6 \\
\hline Slovenia & 23.6 & 23.0 & 22.0 & 17.7 & 14.1 & 13.6 & -42.3 \\
\hline Spain & 188.0 & 206.3 & 184.1 & 152.3 & 139.0 & 135.6 & -27.9 \\
\hline Sweden & 103.2 & 97.2 & 87.5 & 86.7 & 86.8 & 86.9 & -15.8 \\
\hline Switzerland & 66.5 & 76.4 & 67.5 & 49.2 & 39.8 & 36.9 & -44.5 \\
\hline Turkey & 13.1 & 13.8 & & & & & \\
\hline Ukraine & 50.4 & 43.4 & 50.0 & 45.4 & 51.7 & 63.9 & 26.8 \\
\hline UK: England \& Wales & 137.6 & 119.2 & 104.4 & 89.9 & 87.6 & 95.6 & -30.5 \\
\hline UK: Northern Ireland & 67.3 & 55.6 & 52.4 & 47.8 & 39.5 & 35.1 & -47.9 \\
\hline UK: Scotland & 48.2 & 42.2 & 34.4 & 28.0 & 27.9 & 24.6 & -49.1 \\
\hline Mean & 58 & 55 & 53 & 47 & 44 & 41 & \\
\hline Median & 40 & 36 & 36 & 30 & 28 & 29 & \\
\hline Minimum & 5 & 4 & 4 & 4 & 0 & 5 & \\
\hline Maximum & 249 & 231 & 206 & 196 & 199 & 181 & \\
\hline
\end{tabular}


Table 1.2.1.13 Offences per 100000 population - Robbery: Firearm involved

\begin{tabular}{|c|c|c|c|c|c|c|c|}
\hline & 2011 & 2012 & 2013 & 2014 & 2015 & 2016 & $\begin{array}{c}\% \text { change } \\
2011-2016\end{array}$ \\
\hline Albania & 3.2 & 3.4 & 3.3 & 1.5 & 1.7 & 0.5 & -84 \\
\hline Armenia & & $\ldots$ & & & $\ldots$ & $\ldots$ & \\
\hline Austria & 2.5 & 2.6 & 2.5 & 2.2 & 2.5 & 1.9 & -24 \\
\hline Azerbaijan & & & $\ldots$ & & $\ldots$ & $\ldots$ & \\
\hline Belgium & 16.3 & 14.7 & 12.0 & 11.8 & 11.7 & 10.3 & -37 \\
\hline Bosnia-Herzegovina & 0.0 & 0.0 & 0.0 & 0.0 & 0.0 & 0.0 & \\
\hline Bulgaria & 1.4 & 1.4 & 1.2 & 0.9 & 0.6 & 0.6 & -58 \\
\hline Croatia & $\ldots$ & $\ldots$ & $\ldots$ & $\ldots$ & $\ldots$ & $\ldots$ & $\ldots$ \\
\hline Cyprus & $\ldots$ & $\ldots$ & $\ldots$ & $\ldots$ & $\ldots$ & $\ldots$ & $\ldots$ \\
\hline Czech Republic & $\ldots$ & $\ldots$ & $\ldots$ & $\ldots$ & $\ldots$ & $\ldots$ & $\ldots$ \\
\hline Denmark & $\ldots$ & $\ldots$ & $\ldots$ & $\ldots$ & $\ldots$ & $\ldots$ & $\ldots$ \\
\hline Estonia & $\ldots$ & $\ldots$ & $\ldots$ & $\ldots$ & $\ldots$ & $\ldots$ & $\ldots$ \\
\hline Finland & $\ldots$ & $\ldots$ & $\ldots$ & $\ldots$ & $\ldots$ & $\ldots$ & $\ldots$ \\
\hline France & 10.0 & 9.5 & 9.4 & 8.3 & 7.9 & 6.3 & -37 \\
\hline Georgia & 0.0 & 0.0 & 0.0 & 0.0 & 0.0 & 0.0 & \\
\hline Germany & 4.3 & 3.9 & 3.1 & 2.7 & 2.7 & 2.3 & -47 \\
\hline Greece & $\ldots$ & $\ldots$ & $\ldots$ & $\ldots$ & $\ldots$ & 0.0 & $\ldots$ \\
\hline Hungary & 1.5 & 1.0 & 0.6 & 0.4 & 0.8 & 0.3 & -78 \\
\hline Iceland & $\ldots$ & $\ldots$ & $\ldots$ & $\ldots$ & $\ldots$ & $\ldots$ & $\ldots$ \\
\hline Ireland & $\ldots$ & $\ldots$ & $\ldots$ & $\ldots$ & $\ldots$ & $\ldots$ & $\ldots$ \\
\hline Italy & & $\ldots$ & & & & & $\ldots$ \\
\hline Kosovo (UN R/1244/99) & 0.0 & 0.0 & 0.0 & 0.0 & 0.0 & 0.0 & $\ldots$ \\
\hline Latvia & & $\ldots$ & $\ldots$ & & $\ldots$ & $\ldots$ & \\
\hline Lithuania & 0.0 & 0.1 & 0.0 & 0.0 & 0.1 & 0.1 & 217 \\
\hline Luxembourg & $\ldots$ & $\ldots$ & $\ldots$ & $\ldots$ & $\ldots$ & $\ldots$ & $\ldots$ \\
\hline Malta & $\ldots$ & $\ldots$ & $\ldots$ & $\ldots$ & $\ldots$ & $\ldots$ & $\ldots$ \\
\hline Moldova & 0.0 & 0.0 & 0.0 & 0.1 & 0.0 & 0.0 & -100 \\
\hline Montenegro & $\ldots$ & $\ldots$ & $\ldots$ & $\ldots$ & $\ldots$ & $\ldots$ & $\ldots$ \\
\hline Netherlands & $\ldots$ & $\ldots$ & $\ldots$ & $\ldots$ & $\ldots$ & $\ldots$ & $\ldots$ \\
\hline North Macedonia & & $\ldots$ & $\ldots$ & $\ldots$ & $\ldots$ & $\ldots$ & $\ldots$ \\
\hline Norway & 0.0 & 0.0 & 0.0 & 0.0 & 0.0 & 0.0 & $\ldots$ \\
\hline Poland & 0.6 & 0.4 & 0.4 & 0.2 & 0.2 & 0.3 & -49 \\
\hline Portugal & 16.5 & 16.9 & 14.4 & 8.8 & 8.8 & 6.8 & -59 \\
\hline Romania & 0.1 & 0.1 & 0.1 & 0.1 & 0.1 & 0.1 & -57 \\
\hline Russian Federation & & & & & & & \\
\hline Serbia & 13.5 & 12.1 & 9.7 & 7.2 & 6.7 & 4.4 & -67 \\
\hline Slovak Republic & & & & & & $\ldots$ & \\
\hline Slovenia & 1.3 & 1.2 & 1.8 & 1.5 & 0.9 & 0.7 & -43 \\
\hline Spain & 4.3 & 3.6 & 3.5 & 2.7 & 2.7 & 2.9 & -33 \\
\hline Sweden & 10.8 & 9.1 & 9.0 & 9.0 & 10.2 & 10.0 & -8 \\
\hline Switzerland & $\ldots$ & $\ldots$ & $\ldots$ & $\ldots$ & $\ldots$ & $\ldots$ & $\ldots$ \\
\hline Turkey & $\ldots$ & $\ldots$ & $\ldots$ & $\ldots$ & $\ldots$ & $\ldots$ & $\ldots$ \\
\hline Ukraine & & $\ldots$ & $\ldots$ & & $\ldots$ & $\ldots$ & \\
\hline UK: England \& Wales & 4.5 & 3.8 & 3.3 & 2.9 & 2.6 & 2.8 & -37 \\
\hline $\begin{array}{l}\text { UK: Northern Ireland } \\
\text { UK: Scotland }\end{array}$ & 30.5 & 22.3 & 20.5 & 19.7 & 15.0 & 14.0 & -54 \\
\hline Mean & 5.5 & 4.8 & 4.3 & 3.6 & 3.4 & 2.8 & \\
\hline Median & 2.0 & 2.0 & 2.2 & 1.5 & 1.3 & 0.6 & \\
\hline Minimum & 0.0 & 0.0 & 0.0 & 0.0 & 0.0 & 0.0 & \\
\hline Maximum & 30.5 & 22.3 & 20.5 & 19.7 & 15.0 & 14.0 & \\
\hline
\end{tabular}


Table 1.2.1.14 Offences per 100000 population - Theft

\begin{tabular}{|c|c|c|c|c|c|c|c|}
\hline & 2011 & 2012 & 2013 & 2014 & 2015 & 2016 & $\begin{array}{l}\% \text { change } \\
2011-2016\end{array}$ \\
\hline Albania & 9.1 & 11.1 & 12.6 & 10.2 & 8.0 & 5.3 & -41.6 \\
\hline Armenia & 130.6 & 122.7 & 161.0 & 159.0 & 176.1 & 189.3 & 45.0 \\
\hline Austria & 2833.5 & 2852.1 & 2913.0 & 2785.0 & 2589.1 & 2603.4 & -8.1 \\
\hline Azerbaijan & 55.1 & 45.9 & 55.0 & 61.8 & 66.1 & 74.1 & 34.5 \\
\hline \multicolumn{8}{|l|}{ Belgium } \\
\hline Bosnia-Herzegovina & 175.3 & 173.9 & 182.8 & 170.3 & 142.1 & 132.6 & -24.3 \\
\hline Bulgaria & 961.1 & 877.3 & 905.8 & 831.9 & 754.7 & 644.1 & -33.0 \\
\hline \multicolumn{8}{|l|}{ Croatia } \\
\hline Cyprus & 603.3 & 522.4 & 452.8 & 384.5 & 338.4 & 284.0 & -52.9 \\
\hline Czech Republic & 1754.1 & 1665.1 & 1787.3 & 1455.5 & 1131.8 & 942.3 & -46.3 \\
\hline Denmark & 5395.8 & 5087.4 & 4939.2 & 4396.9 & 3895.9 & 3815.2 & -29.3 \\
\hline Estonia & 1517.3 & 1405.7 & 1247.2 & 1196.1 & 863.5 & 682.6 & -55.0 \\
\hline Finland & 2813.7 & 2568.8 & 2605.6 & 2625.8 & 2532.5 & 2395.2 & -14.9 \\
\hline France & 2681.1 & 2700.3 & 2794.6 & 2824.5 & 2773.8 & 2745.5 & 2.4 \\
\hline Georgia & 254.7 & 305.5 & 299.5 & 213.5 & 247.4 & 259.3 & 1.8 \\
\hline Germany & 2991.6 & 2957.6 & 2906.3 & 3015.7 & 3053.3 & 2883.6 & -3.6 \\
\hline Greece & 885.7 & 820.6 & 1025.9 & 940.9 & 1008.4 & 1032.0 & 16.5 \\
\hline Hungary & 1839.4 & 1875.0 & 1702.7 & 1445.2 & 1140.8 & 947.1 & -48.5 \\
\hline Iceland & 1916.5 & 1727.6 & 1613.8 & 1477.9 & 1612.0 & 1356.3 & -29.2 \\
\hline Ireland & 1677.3 & 1658.5 & 1701.3 & 1673.6 & 1618.9 & 1370.8 & -18.3 \\
\hline Italy & 2459.7 & 2560.2 & 2605.0 & 2588.3 & 2407.3 & 2219.8 & -9.8 \\
\hline Kosovo (UN R/1244/99) & 955.4 & 902.6 & 929.9 & 856.6 & 682.3 & 710.8 & -25.6 \\
\hline Latvia & 1258.0 & 1194.6 & 1123.9 & 1129.8 & 1097.8 & 1057.3 & -16.0 \\
\hline Lithuania & 1211.1 & 1076.8 & 1050.4 & 1061.2 & 882.6 & 783.1 & -35.3 \\
\hline Luxembourg & & $\ldots$ & 2350.3 & 2469.4 & 2129.6 & 2111.2 & 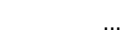 \\
\hline Malta & 2053.5 & 2081.2 & 2004.5 & 1909.1 & 1968.2 & 1958.4 & -4.6 \\
\hline Moldova & 422.9 & 401.6 & 432.0 & 470.2 & 432.1 & 435.6 & 3.0 \\
\hline Montenegro & 307.7 & 361.1 & 305.2 & 296.5 & 283.9 & 217.4 & -29.3 \\
\hline Netherlands & 3976.9 & 3834.4 & 3798.1 & 3459.1 & 3191.4 & 2881.9 & -27.5 \\
\hline North Macedonia & 949.3 & 1002.4 & 1000.8 & 875.8 & 742.5 & 751.9 & -20.8 \\
\hline Norway & 3025.1 & 3132.5 & 2906.8 & 2603.6 & 2238.3 & 2017.8 & -33.3 \\
\hline Poland & 972.8 & 952.5 & 901.2 & 729.2 & 638.7 & 558.9 & -42.6 \\
\hline Portugal & 1612.4 & 1544.9 & 1420.2 & 1343.4 & 1236.0 & 1120.3 & -30.5 \\
\hline Romania & 1120.1 & 1214.6 & 1118.1 & 1042.7 & 964.4 & 833.5 & -25.6 \\
\hline Russian Federation & 727.0 & 693.6 & 558.8 & 558.3 & 771.6 & 510.1 & -29.8 \\
\hline Serbia & 657.9 & 643.2 & 871.3 & 749.2 & 660.4 & 595.1 & -9.5 \\
\hline Slovak Republic & 417.3 & 385.6 & 382.7 & 342.8 & 444.4 & 292.5 & -29.9 \\
\hline Slovenia & 2190.1 & 2362.0 & 2473.9 & 2149.4 & 1639.7 & 1555.1 & -29.0 \\
\hline Spain & 2775.7 & 2694.9 & 2678.1 & 2582.0 & 2402.3 & 2328.5 & -16.1 \\
\hline Sweden & 5700.6 & 5537.0 & 5490.6 & 5514.5 & 5346.1 & 5024.7 & -11.9 \\
\hline Switzerland & 3338.0 & 3551.3 & 3232.1 & 2860.4 & 2490.3 & 2254.2 & -32.5 \\
\hline Turkey & 247.4 & 279.6 & & & & & \\
\hline Ukraine & 608.8 & 530.3 & 535.1 & 501.3 & 640.2 & 733.0 & 20.4 \\
\hline UK: England \& Wales & 3639.9 & 3423.0 & 3286.6 & 3814.3 & 3026.3 & 3117.6 & -14.3 \\
\hline UK: Northern Ireland & 2054.2 & 1952.7 & 1968.8 & 1925.8 & 1843.2 & 1664.8 & -19.0 \\
\hline UK: Scotland & 2941.0 & 2904.6 & 2286.1 & 2306.5 & 2152.0 & 1931.4 & -34.3 \\
\hline Mean & 1724 & 1688 & 1698 & 1623 & 1494 & 1396 & \\
\hline Median & 1517 & 1406 & 1412 & 1337 & 1132 & 1032 & \\
\hline Minimum & 9 & 11 & 13 & 10 & 8 & 5 & \\
\hline Maximum & 5701 & 5537 & 5491 & 5514 & 5346 & 5025 & \\
\hline
\end{tabular}


Table 1.2.1.15 Offences per 100000 population - Aggravated theft

\begin{tabular}{|c|c|c|c|c|c|c|c|}
\hline & 2011 & 2012 & 2013 & 2014 & 2015 & 2016 & $\begin{array}{l}\% \text { change } \\
2011-2016\end{array}$ \\
\hline Albania & 0.1 & 0.1 & 0.2 & 0.1 & 0.1 & 0.2 & 102.2 \\
\hline Armenia & 29 & 34 & 47 & 51 & 47 & 43 & 48.2 \\
\hline Austria & 1097 & 1110 & 1151 & 1095 & 1005 & 988 & -10.0 \\
\hline Azerbaijan & $\ldots$ & $\ldots$ & $\ldots$ & $\ldots$ & $\ldots$ & ... & $\ldots$ \\
\hline Belgium & $\begin{array}{l}\cdots \\
\ldots\end{array}$ & $\cdots$ & $\cdots$ & $\begin{array}{l}\cdots \\
\ldots\end{array}$ & $\cdots$ & $\begin{array}{l}\cdots \\
\ldots\end{array}$ & $\cdots$ \\
\hline Bosnia-Herzegovina & & $\ldots$ & $\ldots$ & & $\ldots$ & $\ldots$ & \\
\hline Bulgaria & 495 & 426 & 435 & 389 & 339 & 267 & -46.0 \\
\hline Croatia & $\ldots$ & $\ldots$ & $\ldots$ & $\ldots$ & $\ldots$ & $\ldots$ & $\ldots$ \\
\hline Cyprus & $\ldots$ & $\ldots$ & $\ldots$ & $\ldots$ & $\ldots$ & $\ldots$ & $\ldots$ \\
\hline Czech Republic & $\ldots$ & $\ldots$ & $\ldots$ & $\ldots$ & $\ldots$ & $\ldots$ & \\
\hline Denmark & 1921 & 1656 & 1599 & 1406 & 1277 & 1216 & -36.7 \\
\hline Estonia & & $\ldots$ & & & $\ldots$ & ... & \\
\hline Finland & 58 & 60 & 56 & 68 & 65 & 61 & 6.3 \\
\hline France & $\ldots$ & $\ldots$ & $\ldots$ & $\ldots$ & $\ldots$ & $\ldots$ & $\ldots$ \\
\hline Georgia & $\ldots$ & $\ldots$ & $\ldots$ & $\ldots$ & $\ldots$ & $\ldots$ & $\ldots$ \\
\hline Germany & 1388 & 1367 & 1346 & 1384 & 1398 & 1318 & -5.0 \\
\hline Greece & 12 & 14 & 26 & 21 & 21 & 23 & 101.1 \\
\hline Hungary & $\ldots$ & $\ldots$ & $\ldots$ & $\ldots$ & $\ldots$ & $\ldots$ & $\ldots$ \\
\hline Iceland & $\ldots$ & $\ldots$ & $\ldots$ & $\ldots$ & $\ldots$ & $\ldots$ & $\ldots$ \\
\hline Ireland & $\ldots$ & $\ldots$ & $\ldots$ & $\ldots$ & $\ldots$ & $\ldots$ & $\ldots$ \\
\hline Italy & $\ldots$ & $\ldots$ & $\ldots$ & $\ldots$ & $\ldots$ & $\ldots$ & $\ldots$ \\
\hline Kosovo (UN R/1244/99) & $\ldots$ & $\ldots$ & $\ldots$ & $\ldots$ & $\ldots$ & $\ldots$ & $\ldots$ \\
\hline Latvia & $\ldots$ & $\ldots$ & $\ldots$ & $\ldots$ & $\ldots$ & $\ldots$ & $\ldots$ \\
\hline Lithuania & $\begin{array}{l}\cdots \\
\ldots\end{array}$ & $\begin{array}{l}\cdots \\
\ldots\end{array}$ & $\begin{array}{l}\cdots \\
\cdots\end{array}$ & $\begin{array}{l}\cdots \\
\ldots\end{array}$ & $\begin{array}{l}\cdots \\
\ldots\end{array}$ & $\begin{array}{l}\cdots \\
\ldots\end{array}$ & $\begin{array}{l}\cdots \\
\ldots\end{array}$ \\
\hline Luxembourg & $\ldots$ & $\ldots$ & $\ldots$ & $\ldots$ & $\ldots$ & $\ldots$ & $\ldots$ \\
\hline Malta & & $\ldots$ & $\ldots$ & $\ldots$ & $\ldots$ & $\ldots$ & \\
\hline Moldova & 407 & 386 & 417 & 418 & 420 & 423 & 4.0 \\
\hline Montenegro & 199 & 223 & 190 & 153 & 151 & 136 & -31.6 \\
\hline Netherlands & & & & & $\ldots$ & $\ldots$ & \\
\hline North Macedonia & 703 & 727 & 733 & 635 & 504 & 524 & -25.4 \\
\hline Norway & 985 & 1020 & 890 & 709 & 556 & 331 & -66.4 \\
\hline Poland & 411 & 389 & 359 & 314 & 279 & 240 & -41.6 \\
\hline Portugal & 681 & 571 & 512 & 467 & 401 & 367 & -46.1 \\
\hline Romania & $\ldots$ & $\ldots$ & $\ldots$ & $\ldots$ & $\ldots$ & $\ldots$ & $\ldots$ \\
\hline Russian Federation & & & & & & & \\
\hline Serbia & 364 & 357 & 441 & 375 & 316 & 278 & -23.6 \\
\hline Slovak Republic & & & & & $\ldots$ & & \\
\hline Slovenia & 735 & 760 & 821 & 719 & 539 & 560 & -23.7 \\
\hline Spain & & ... & & & $\ldots$ & ... & \\
\hline Sweden & 1399 & 1323 & 1273 & 1301 & 1287 & 1238 & -11.5 \\
\hline Switzerland & $\ldots$ & $\ldots$ & $\ldots$ & $\ldots$ & $\ldots$ & $\ldots$ & $\ldots$ \\
\hline Turkey & $\ldots$ & $\ldots$ & $\ldots$ & $\ldots$ & $\ldots$ & $\ldots$ & $\ldots$ \\
\hline Ukraine & $\begin{array}{l}\cdots \\
\ldots\end{array}$ & $\cdots$ & $\begin{array}{l}\cdots \\
\ldots\end{array}$ & $\ldots$ & $\ldots$ & $\ldots$ & $\ldots$ \\
\hline UK: England \& Wales & $\ldots$ & $\ldots$ & $\begin{array}{l}\cdots \\
\cdots\end{array}$ & $\ldots$ & $\ldots$ & $\ldots$ & $\ldots$ \\
\hline $\begin{array}{l}\text { UK: Northern Ireland } \\
\text { UK: Scotland }\end{array}$ & $\ldots$ & $\ldots$ & $\ldots$ & $\ldots$ & $\cdots$ & $\ldots$ & $\ldots$ \\
\hline Mean & 640 & $\frac{\ldots}{613}$ & 606 & 559 & ... & 471 & \\
\hline Median & 495 & 426 & 441 & 418 & 400 & 331 & \\
\hline Minimum & 0.1 & 0.1 & 0.2 & 0.1 & 0.1 & 0.2 & \\
\hline Maximum & 1921 & 1656 & 1599 & 1406 & 1398 & 1318 & \\
\hline
\end{tabular}


Table 1.2.1.16 Offences per 100000 population - Theft of a motor vehicle

\begin{tabular}{|c|c|c|c|c|c|c|c|}
\hline & 2011 & 2012 & 2013 & 2014 & 2015 & 2016 & $\begin{array}{c}\% \text { change } \\
2011-2016\end{array}$ \\
\hline Albania & 21.0 & 23.3 & 19.7 & 13.9 & 9.6 & 10.4 & -50.6 \\
\hline Armenia & 1.6 & 1.9 & 1.8 & 1.8 & 1.9 & 1.6 & 0.6 \\
\hline Austria & 78.1 & 66.7 & 74.5 & 61.0 & 59.0 & 55.0 & -29.5 \\
\hline Azerbaijan & & & & & . & & \\
\hline Belgium & 176.2 & 155.4 & 141.9 & 141.2 & 133.0 & 117.3 & -33.4 \\
\hline Bosnia-Herzegovina & 28.4 & 34.6 & 38.8 & 39.1 & 37.3 & 30.4 & 7.0 \\
\hline Bulgaria & 43.9 & 41.8 & 49.0 & 51.1 & 55.7 & 44.6 & 1.7 \\
\hline Croatia & $\ldots$ & & & & & & $\ldots$ \\
\hline Cyprus & $\ldots$ & 34.7 & 24.5 & 20.0 & 17.6 & 29.2 & \\
\hline Czech Republic & 118.2 & 105.9 & 110.7 & 90.0 & 65.3 & 50.7 & -57.1 \\
\hline Denmark & 271.0 & 205.5 & 189.1 & 168.0 & 157.7 & 162.0 & -40.2 \\
\hline Estonia & 56.6 & 46.8 & 41.4 & 45.4 & 38.4 & 28.3 & -49.9 \\
\hline Finland & 222.9 & 163.2 & 146.7 & 142.6 & 135.9 & 122.1 & -45.2 \\
\hline France & 296.1 & 281.9 & 273.7 & 265.2 & 263.1 & 252.9 & -14.6 \\
\hline Georgia & 1.9 & 2.0 & 1.3 & 1.1 & 1.1 & 1.0 & -45.5 \\
\hline Germany & 97.9 & 87.8 & 108.9 & 79.6 & 76.5 & 72.6 & -25.9 \\
\hline Greece & & & & & $\ldots$ & & \\
\hline Hungary & 88.4 & 92.8 & 73.6 & 60.2 & 41.9 & 30.4 & -65.6 \\
\hline Iceland & 121.8 & 90.7 & 64.6 & 102.6 & 123.4 & 114.9 & -5.7 \\
\hline Ireland & 229.3 & 184.7 & 159.6 & 167.4 & 138.0 & 102.5 & -55.3 \\
\hline Italy & 334.8 & 331.0 & 307.4 & 290.3 & 272.5 & 258.7 & -22.7 \\
\hline Kosovo (UN R/1244/99) & 24.2 & 17.5 & 21.2 & 12.2 & 15.5 & 16.7 & -31.2 \\
\hline Latvia & $\ldots$ & $\ldots$ & - & $\ldots$ & $\ldots$ & $\ldots$ & $\ldots$ \\
\hline Lithuania & 64.3 & 62.5 & 55.4 & 47.8 & 43.5 & & $\ldots$ \\
\hline Luxembourg & & & 425.5 & 407.5 & 359.9 & 295.7 & \\
\hline Malta & 87.7 & 73.5 & 76.9 & 56.4 & 52.1 & 56.8 & -35.2 \\
\hline Moldova & 2.8 & 3.3 & 5.5 & 5.0 & 4.1 & 5.2 & 89.1 \\
\hline Montenegro & & & & & & 10.4 & \\
\hline Netherlands & 128.2 & 120.7 & 126.9 & 116.8 & 108.1 & 95.1 & -25.9 \\
\hline North Macedonia & 23.7 & 18.0 & 24.6 & 26.2 & 19.3 & 20.6 & -13.1 \\
\hline Norway & 189.4 & 159.5 & 131.3 & 128.9 & 103.8 & 85.7 & -54.7 \\
\hline Poland & 55.2 & 53.5 & 47.3 & 43.9 & 38.6 & 37.1 & -32.7 \\
\hline Portugal & 185.0 & 151.6 & 141.9 & 132.3 & 116.2 & 111.8 & -39.5 \\
\hline Romania & 17.3 & 14.7 & 10.9 & 10.4 & 9.9 & 10.3 & -40.7 \\
\hline Russian Federation & 35.2 & 37.0 & 36.0 & 34.9 & 30.9 & 24.1 & -31.4 \\
\hline Serbia & 41.2 & 33.4 & 33.4 & 29.0 & 26.0 & 23.1 & -43.9 \\
\hline Slovak Republic & 50.0 & 47.1 & 44.9 & 42.4 & 35.6 & 30.8 & -38.4 \\
\hline Slovenia & 44.4 & 47.5 & 54.9 & 48.7 & 38.6 & 35.2 & -20.8 \\
\hline Spain & 111.0 & 117.9 & 104.6 & 92.9 & 92.9 & 93.3 & -15.9 \\
\hline Sweden & 366.1 & 305.0 & 290.1 & 290.3 & 272.0 & 255.6 & -30.2 \\
\hline Switzerland & 100.3 & 101.0 & 76.5 & 79.2 & 75.2 & 71.3 & -28.9 \\
\hline Turkey & 37.3 & 41.5 & & & & & \\
\hline Ukraine & 10.3 & 11.4 & 15.0 & 27.9 & 26.8 & 28.7 & 179.1 \\
\hline UK: England \& Wales & 172.8 & 144.9 & 133.8 & 130.6 & 128.8 & 149.2 & -13.6 \\
\hline UK: Northern Ireland & 113.9 & 104.2 & 106.2 & 91.5 & 77.1 & 70.3 & -38.3 \\
\hline UK: Scotland & 343.6 & 302.0 & 223.2 & 227.5 & 209.2 & 179.7 & -47.7 \\
\hline Mean & 113 & 98 & 100 & 96 & 88 & 80 & \\
\hline Median & 88 & 70 & 74 & 61 & 57 & 53 & \\
\hline Minimum & 2 & 2 & 1 & 1 & 1 & 1 & \\
\hline Maximum & 366 & 331 & 425 & 408 & 360 & 296 & \\
\hline
\end{tabular}


Table 1.2.1.17 Offences per 100000 population - Theft by means of burglary

\begin{tabular}{|c|c|c|c|c|c|c|c|}
\hline & 2011 & 2012 & 2013 & 2014 & 2015 & 2016 & $\begin{array}{c}\% \text { change } \\
2011-2016\end{array}$ \\
\hline Albania & 35.6 & 44.6 & 38.0 & 32.9 & 27.4 & 21.0 & -41.1 \\
\hline Armenia & 74.2 & 59.0 & 72.6 & 80.4 & 83.6 & 83.8 & 13.0 \\
\hline Austria & 1006.3 & 1013.8 & 1049.5 & 1004.8 & 922.0 & 925.3 & -8.0 \\
\hline \multicolumn{8}{|l|}{ Azerbaijan } \\
\hline Belgium & 887.5 & 925.1 & 897.2 & 862.8 & 789.2 & 670.7 & -24.4 \\
\hline Bosnia-Herzegovina & 380.4 & 340.7 & 336.1 & 296.5 & 82.5 & 77.9 & -79.5 \\
\hline Bulgaria & 275.1 & 229.0 & 235.6 & 211.5 & 167.1 & 142.0 & -48.4 \\
\hline \multicolumn{8}{|l|}{ Croatia } \\
\hline Cyprus & 402.4 & 342.6 & 309.1 & 271.9 & 230.0 & 198.9 & -50.6 \\
\hline Czech Republic & 569.0 & 528.8 & 593.2 & 469.0 & 327.2 & 267.4 & -53.0 \\
\hline Denmark & 1649.7 & 1450.2 & 1409.2 & 1237.5 & 1119.2 & 1053.7 & -36.1 \\
\hline Estonia & & & & & & & \\
\hline Finland & 480.9 & 450.0 & 422.3 & 453.5 & 450.8 & 448.3 & -6.8 \\
\hline France & 550.2 & 577.1 & 607.5 & 592.7 & 596.4 & 599.0 & 8.9 \\
\hline Georgia & 30.9 & 35.0 & 38.1 & 32.2 & 36.1 & 41.0 & 32.7 \\
\hline Germany & 525.1 & 535.6 & 543.3 & 552.3 & 571.4 & 526.6 & 0.3 \\
\hline Greece & 500.3 & 453.0 & 211.4 & 229.2 & 231.0 & 230.3 & -54.0 \\
\hline \multicolumn{8}{|l|}{ Hungary } \\
\hline Iceland & 596.6 & 429.9 & 339.3 & 351.0 & 386.8 & 312.2 & -47.7 \\
\hline Ireland & $\ldots$ & $\ldots$ & $\ldots$ & $\ldots$ & $\ldots$ & $\ldots$ & $\ldots$ \\
\hline Italy & & & & & & & \\
\hline Kosovo (UN R/1244/99) & 423.8 & 387.2 & 419.7 & 402.6 & 315.3 & 336.1 & -20.7 \\
\hline Latvia & $\ldots$ & $\ldots$ & $\ldots$ & $\ldots$ & $\ldots$ & $\ldots$ & $\ldots$ \\
\hline Lithuania & $\begin{array}{l}\cdots \\
\cdots\end{array}$ & $\begin{array}{l}\cdots \\
\ldots\end{array}$ & $\begin{array}{l}\ldots \\
\ldots\end{array}$ & $\begin{array}{l}\ldots \\
\ldots\end{array}$ & $\cdots$ & $\begin{array}{l}\cdots \\
\ldots\end{array}$ & $\begin{array}{l}\cdots \\
\ldots\end{array}$ \\
\hline Luxembourg & $\ldots$ & $\ldots$ & 414.9 & 603.1 & 478.9 & 368.4 & \\
\hline Malta & 410.6 & 333.4 & 316.7 & 291.3 & 313.9 & 252.4 & -38.5 \\
\hline Moldova & 26.5 & 25.2 & 31.1 & 35.0 & 26.4 & 35.3 & 33.5 \\
\hline \multicolumn{8}{|l|}{ Montenegro } \\
\hline Netherlands & 1224.7 & 1205.1 & 1191.0 & 1042.2 & 967.5 & 864.8 & -29.4 \\
\hline North Macedonia & & $\ldots$ & & & $\ldots$ & $\ldots$ & $\ldots$ \\
\hline Norway & 365.5 & 348.8 & 311.6 & 291.5 & & & \\
\hline Poland & 356.3 & 335.5 & 311.4 & 270.4 & 240.3 & 203.3 & -42.9 \\
\hline \multirow{2}{*}{\multicolumn{8}{|c|}{ Romania }} \\
\hline & & & & & & & \\
\hline Russian Federation & 220.0 & 193.3 & 174.3 & 166.5 & 181.4 & 165.2 & -24.9 \\
\hline Serbia & 320.7 & 302.1 & 386.5 & 334.6 & 283.2 & 245.6 & -23.4 \\
\hline Slovak Republic & 238.9 & 219.4 & 206.4 & 174.1 & 126.6 & 115.4 & -51.7 \\
\hline Slovenia & 668.0 & 686.3 & 746.5 & 660.0 & 496.9 & 518.7 & -22.4 \\
\hline Spain & 632.8 & 656.7 & 622.2 & 569.6 & 541.0 & 549.5 & -13.2 \\
\hline Sweden & 998.7 & 925.8 & 892.0 & 918.2 & 921.6 & 901.5 & -9.7 \\
\hline Switzerland & 665.5 & 768.5 & 708.2 & 643.0 & 514.9 & 444.0 & -33.3 \\
\hline Turkey & 136.5 & 160.0 & $\ldots$ & $\ldots$ & $\ldots$ & $\ldots$ & $\ldots$ \\
\hline \multicolumn{8}{|l|}{ Ukraine } \\
\hline UK: England \& Wales & 912.0 & 827.7 & 785.3 & 730.5 & 691.7 & 692.5 & -24.1 \\
\hline UK: Northern Ireland & 583.1 & 525.4 & 495.5 & 485.6 & 473.8 & 382.6 & -34.4 \\
\hline UK: Scotland & 548.6 & 522.3 & 464.4 & 476.7 & 437.1 & 366.9 & -33.1 \\
\hline Mean & 521 & 493 & 483 & 458 & 416 & 384 & \\
\hline Median & 493 & 430 & 415 & 403 & 357 & 324 & \\
\hline Minimum & 26 & 25 & 31 & 32 & 26 & 21 & \\
\hline Maximum & 1650 & 1450 & 1409 & 1237 & 1119 & 1054 & \\
\hline
\end{tabular}


Table 1.2.1.18 Offences per 100000 population - Theft by means of domestic burglary

\begin{tabular}{|c|c|c|c|c|c|c|c|}
\hline & 2011 & 2012 & 2013 & 2014 & 2015 & 2016 & $\begin{array}{c}\% \text { change } \\
2011-2016\end{array}$ \\
\hline Albania & 33.7 & 42.6 & 44.0 & 57.3 & 48.1 & 42.3 & 25.6 \\
\hline Armenia & 27.6 & 32.2 & 45.7 & 49.6 & 45.5 & 41.7 & 51.0 \\
\hline Austria & 252.7 & 256.7 & 330.9 & 318.8 & 287.4 & 282.4 & 11.8 \\
\hline \multicolumn{8}{|l|}{ Azerbaijan } \\
\hline Belgium & 636.7 & 683.0 & 677.7 & 650.4 & 597.4 & 499.7 & -21.5 \\
\hline Bosnia-Herzegovina & & & 4.1 & & 34.4 & & \\
\hline Bulgaria & 216.1 & 202.6 & 198.0 & 166.3 & 147.6 & 123.5 & -42.8 \\
\hline \multicolumn{8}{|l|}{ Croatia } \\
\hline Cyprus & 233.5 & 233.2 & 206.1 & 189.4 & 160.8 & 128.3 & -45.1 \\
\hline Czech Republic & 91.2 & 92.5 & 105.7 & 84.4 & 65.4 & 57.8 & -36.7 \\
\hline Denmark & 1047.9 & 953.8 & 924.2 & 819.0 & 731.9 & 698.8 & -33.3 \\
\hline Estonia & 210.0 & 205.1 & 161.5 & 157.5 & 126.4 & 100.9 & -51.9 \\
\hline Finland & 124.1 & 116.3 & 105.9 & 116.7 & 109.4 & 96.6 & -22.2 \\
\hline France & 349.6 & 376.2 & 393.3 & 367.7 & 365.6 & 378.6 & 8.3 \\
\hline Georgia & 0.0 & 57.1 & 60.1 & 59.1 & 62.8 & 53.4 & \\
\hline Germany & 268.9 & 285.3 & 230.3 & 313.6 & 334.8 & 308.9 & 14.9 \\
\hline Greece & $\ldots$ & $\ldots$ & $\ldots$ & $\ldots$ & $\ldots$ & $\ldots$ & $\ldots$ \\
\hline Hungary & $\ldots$ & $\ldots$ & $\ldots$ & $\ldots$ & $\ldots$ & $\ldots$ & ... \\
\hline Iceland & $\ldots$ & $\ldots$ & $\ldots$ & $\ldots$ & $\ldots$ & $\ldots$ & ... \\
\hline Ireland & & $\ldots$ & $\ldots$ & & & & \\
\hline Italy & 345.1 & 399.6 & 421.2 & 421.0 & 386.1 & 352.8 & 2.2 \\
\hline Kosovo (UN R/1244/99) & 185.5 & 180.4 & 360.0 & 293.5 & 233.5 & 252.1 & 35.9 \\
\hline Latvia & & $\ldots$ & 108.5 & 116.6 & 106.3 & 108.0 & \\
\hline Lithuania & 133.7 & 117.4 & 109.9 & 113.5 & 102.7 & 92.0 & -31.2 \\
\hline \multicolumn{8}{|l|}{ Luxembourg } \\
\hline Malta & 229.4 & 240.5 & 183.9 & 217.0 & 161.9 & 171.4 & -25.3 \\
\hline Moldova & 59.3 & 54.8 & 74.2 & 78.5 & 88.0 & 114.9 & 93.9 \\
\hline \multicolumn{8}{|l|}{ Montenegro } \\
\hline Netherlands & 652.4 & 670.6 & 662.1 & 554.8 & 509.7 & 437.3 & -33.0 \\
\hline North Macedonia & 2.1 & 2.0 & 1.9 & 2.4 & 1.6 & 1.9 & -9.9 \\
\hline Norway & 117.7 & 120.1 & 108.1 & 98.6 & & & \\
\hline Poland & 136.3 & & 63.7 & 58.1 & 52.8 & 68.0 & -50.1 \\
\hline Portugal & 268.5 & 239.8 & 213.0 & 186.1 & 156.5 & 139.4 & -48.1 \\
\hline Romania & 68.6 & 77.2 & 69.6 & 69.8 & 60.4 & 54.2 & -21.0 \\
\hline \multicolumn{8}{|l|}{ Russian Federation } \\
\hline Serbia & 184.0 & 191.5 & 283.2 & 239.0 & 213.4 & 191.3 & 3.9 \\
\hline Slovak Republic & 56.1 & 58.5 & 59.6 & 50.0 & 35.5 & 32.5 & -42.0 \\
\hline Slovenia & 141.0 & 157.3 & 218.3 & 197.9 & 168.6 & 171.6 & 21.7 \\
\hline Spain & 216.0 & 270.0 & 272.7 & 259.7 & 248.2 & 244.0 & 13.0 \\
\hline Sweden & 455.1 & 417.1 & 425.4 & 439.0 & 435.9 & 428.6 & -5.8 \\
\hline Switzerland & 158.0 & 158.2 & 146.8 & 139.7 & 123.3 & 114.9 & -27.3 \\
\hline Turkey & 64.5 & 72.5 & & & & & \\
\hline Ukraine & 54.7 & 47.2 & 38.5 & 42.0 & 50.0 & 63.9 & 16.8 \\
\hline UK: England \& Wales & 446.4 & 407.2 & 381.9 & 349.7 & 333.4 & 343.7 & -23.0 \\
\hline UK: Northern Ireland & 366.5 & 326.0 & 314.4 & 319.1 & 316.3 & 253.2 & -30.9 \\
\hline UK: Scotland & 472.0 & 455.8 & 403.8 & 416.5 & 383.5 & 326.3 & -30.9 \\
\hline Mean & 237 & 241 & 234 & 229 & 208 & 199 & \\
\hline Median & 186 & 197 & 191 & 185 & 156 & 134 & \\
\hline Minimum & 0 & 2 & 2 & 2 & 2 & 2 & \\
\hline Maximum & 1048 & 954 & 924 & 819 & 732 & 699 & \\
\hline
\end{tabular}


Table 1.2.1.19 Offences per 100000 population - Fraud

\begin{tabular}{|c|c|c|c|c|c|c|c|}
\hline & 2011 & 2012 & 2013 & 2014 & 2015 & 2016 & $\begin{array}{c}\% \text { change } \\
2011-2016\end{array}$ \\
\hline Albania & 11.6 & 16.0 & 19.4 & 18.9 & 13.6 & 19.8 & 70.7 \\
\hline Armenia & 22.6 & 27.2 & 30.9 & 33.7 & 30.2 & 32.1 & 42.3 \\
\hline Austria & 347.8 & 431.9 & 415.5 & 353.4 & 346.4 & 348.7 & 0.3 \\
\hline Azerbaijan & 17.4 & 18.6 & 25.3 & 28.2 & 38.2 & 45.1 & 158.5 \\
\hline Belgium & 134.9 & 200.4 & 193.4 & 199.6 & 211.7 & 210.4 & 56.0 \\
\hline Bosnia-Herzegovina & 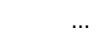 & & & & & & \\
\hline Bulgaria & 34.2 & 31.2 & 40.0 & 44.7 & 56.5 & 50.4 & 47.5 \\
\hline Croatia & & & & & & & \\
\hline Cyprus & 23.3 & 27.1 & 23.9 & 17.4 & 15.9 & 18.7 & -19.7 \\
\hline Czech Republic & 86.4 & 93.0 & 104.0 & 102.3 & 101.0 & 93.2 & 7.8 \\
\hline Denmark & 179.7 & 168.2 & 214.3 & 282.3 & 534.5 & 665.8 & 270.6 \\
\hline Estonia & 125.4 & 121.0 & 181.3 & 150.4 & 104.9 & 117.4 & -6.4 \\
\hline Finland & 331.0 & 387.8 & 420.8 & 431.4 & 466.5 & 456.8 & 38.0 \\
\hline France & 315.5 & 254.4 & 281.3 & 284.0 & 303.8 & 319.0 & 1.1 \\
\hline Georgia & 39.9 & 41.7 & 38.5 & 36.8 & 40.8 & 37.0 & -7.3 \\
\hline Germany & 795.3 & 817.4 & 812.7 & 800.4 & 790.8 & 701.3 & -11.8 \\
\hline Greece & 17.3 & 19.8 & 27.8 & 29.3 & 31.7 & 41.7 & 141.9 \\
\hline Hungary & 279.5 & 371.6 & 376.9 & 337.8 & 324.4 & 441.3 & 57.9 \\
\hline Iceland & 133.5 & 124.5 & 125.5 & 105.9 & 117.0 & 123.9 & -7.2 \\
\hline Ireland & 120.2 & 124.2 & 103.9 & 111.2 & 123.6 & 104.5 & -13.1 \\
\hline Italy & 178.0 & 196.6 & 235.6 & 219.2 & 238.5 & 249.7 & 40.2 \\
\hline Kosovo (UN R/1244/99) & $\ldots$ & $\ldots$ & $\ldots$ & $\ldots$ & $\ldots$ & $\ldots$ & $\ldots$ \\
\hline Latvia & $\ldots$ & & $\ldots$ & $\ldots$ & & $\ldots$ & ... \\
\hline Lithuania & 179.5 & 165.8 & 186.4 & 201.6 & 153.6 & 107.7 & -40.0 \\
\hline Luxembourg & & & & $\ldots$ & & & \\
\hline Malta & 64.8 & 86.0 & 148.2 & 100.1 & 106.9 & 111.0 & 71.3 \\
\hline Moldova & 44.2 & 46.4 & 58.0 & 58.1 & 58.4 & 64.1 & 45.0 \\
\hline Montenegro & 14.2 & 12.6 & 15.6 & 11.4 & 6.1 & 7.7 & -45.7 \\
\hline Netherlands & 153.6 & 165.1 & 130.9 & 117.2 & 221.4 & 266.0 & 73.1 \\
\hline North Macedonia & 21.2 & 26.2 & 32.1 & 17.9 & 14.9 & 14.7 & -30.5 \\
\hline Norway & 269.0 & 285.2 & 287.0 & 279.3 & 339.1 & 409.9 & 52.4 \\
\hline Poland & 261.7 & 242.1 & 264.3 & 288.7 & 316.6 & 269.3 & 2.9 \\
\hline Portugal & 87.7 & 104.7 & 113.1 & 116.7 & 162.8 & 176.7 & 101.5 \\
\hline Romania & 179.3 & 160.3 & 183.2 & 156.5 & 151.3 & 132.2 & -26.3 \\
\hline Russian Federation & & & & & & & \\
\hline Serbia & 26.0 & 21.3 & 34.5 & 31.9 & 33.6 & 30.6 & 17.7 \\
\hline Slovak Republic & & & & & & & \\
\hline Slovenia & 161.6 & 202.4 & 214.6 & 186.3 & 141.8 & 136.4 & -15.6 \\
\hline Spain & 227.7 & 266.2 & 262.1 & 301.9 & 355.8 & 387.0 & 70.0 \\
\hline Sweden & 1114.9 & 1243.1 & 1414.0 & 1495.1 & 1788.9 & 1976.6 & 77.3 \\
\hline Switzerland & 138.7 & 159.2 & 162.2 & 122.1 & 131.2 & 128.4 & -7.4 \\
\hline Turkey & 4.6 & & & & & & \\
\hline Ukraine & 52.8 & 51.3 & 103.9 & 92.7 & 107.4 & 108.0 & 104.8 \\
\hline UK: England \& Wales & 254.1 & 292.1 & 363.9 & 391.8 & 1066.1 & 1098.9 & 332.5 \\
\hline UK: Northern Ireland & 152.1 & 200.8 & 199.9 & 206.0 & 120.4 & 170.2 & 11.9 \\
\hline UK: Scotland & 169.5 & 167.3 & 167.0 & 151.2 & 128.7 & 136.9 & -19.2 \\
\hline Mean & 174 & 194 & 211 & 208 & 245 & 258 & \\
\hline Median & 135 & 160 & 165 & 136 & 130 & 130 & \\
\hline Minimum & 5 & 13 & 16 & 11 & 6 & 8 & \\
\hline Maximum & 1115 & 1243 & 1414 & 1495 & 1789 & 1977 & \\
\hline
\end{tabular}


Table 1.2.1.20 Offences per 100000 population - Cyber fraud

\begin{tabular}{|c|c|c|c|c|c|c|c|}
\hline & 2011 & 2012 & 2013 & 2014 & 2015 & 2016 & $\begin{array}{c}\% \text { change } \\
2011-2016\end{array}$ \\
\hline Albania & 2.9 & 2.8 & 3.7 & 6.1 & 4.2 & 6.1 & 110.6 \\
\hline Armenia & $\ldots$ & $\ldots$ & $\ldots$ & $\ldots$ & $\ldots$ & $\ldots$ & $\ldots$ \\
\hline Austria & $\ldots$ & $\ldots$ & $\ldots$ & $\ldots$ & $\ldots$ & $\ldots$ & $\ldots$ \\
\hline Azerbaijan & $\ldots$ & $\ldots$ & $\ldots$ & & & & $\ldots$ \\
\hline Belgium & 39.2 & 105.7 & 87.1 & 99.0 & 113.6 & 114.7 & 192.7 \\
\hline Bosnia-Herzegovina & & & & & & & \\
\hline Bulgaria & 0.3 & 0.3 & 0.6 & 0.7 & 1.5 & 1.6 & 507.2 \\
\hline Croatia & $\ldots$ & $\ldots$ & $\ldots$ & $\ldots$ & $\ldots$ & $\ldots$ & $\ldots$ \\
\hline Cyprus & $\ldots$ & $\ldots$ & $\ldots$ & & & & $\ldots$ \\
\hline Czech Republic & 1.3 & 1.7 & 2.9 & 6.4 & 6.7 & 6.0 & 370.9 \\
\hline Denmark & 11.6 & 25.6 & 44.8 & 110.7 & 287.8 & 391.4 & 3264.0 \\
\hline Estonia & $\ldots$ & $\ldots$ & $\ldots$ & $\ldots$ & $\ldots$ & $\ldots$ & $\ldots$ \\
\hline Finland & $\ldots$ & $\ldots$ & $\ldots$ & $\ldots$ & $\ldots$ & $\ldots$ & $\ldots$ \\
\hline France & $\ldots$ & $\ldots$ & $\ldots$ & $\ldots$ & $\ldots$ & $\ldots$ & $\ldots$ \\
\hline Georgia & $\ldots$ & $\ldots$ & $\ldots$ & $\ldots$ & $\ldots$ & $\ldots$ & $\ldots$ \\
\hline Germany & 182.7 & 178.6 & 202.1 & 206.3 & 202.4 & 194.1 & 6.2 \\
\hline Greece & $\ldots$ & $\ldots$ & & & & & $\ldots$ \\
\hline Hungary & $\ldots$ & $\ldots$ & 2.5 & 14.2 & 22.1 & 34.7 & $\ldots$ \\
\hline Iceland & $\ldots$ & $\ldots$ & $\ldots$ & $\ldots$ & $\ldots$ & $\ldots$ & $\ldots$ \\
\hline Ireland & $\ldots$ & $\ldots$ & $\ldots$ & $\ldots$ & $\ldots$ & $\ldots$ & $\ldots$ \\
\hline Italy & $\ldots$ & $\ldots$ & $\ldots$ & $\ldots$ & $\ldots$ & $\ldots$ & $\ldots$ \\
\hline Kosovo (UN R/1244/99) & $\ldots$ & $\ldots$ & $\ldots$ & $\ldots$ & $\ldots$ & $\ldots$ & $\ldots$ \\
\hline Latvia & $\ldots$ & $\ldots$ & $\ldots$ & $\ldots$ & $\ldots$ & $\ldots$ & $\ldots$ \\
\hline Lithuania & $\ldots$ & $\ldots$ & $\ldots$ & $\ldots$ & $\ldots$ & $\ldots$ & $\ldots$ \\
\hline Luxembourg & $\ldots$ & $\ldots$ & $\ldots$ & $\ldots$ & $\ldots$ & $\ldots$ & $\ldots$ \\
\hline Malta & $\ldots$ & $\ldots$ & $\ldots$ & & & & $\ldots$ \\
\hline Moldova & 0.1 & 0.1 & 0.1 & 0.3 & 0.3 & 0.1 & -4.5 \\
\hline Montenegro & 0.0 & 0.0 & 0.0 & 0.0 & 0.0 & 0.0 & 0.0 \\
\hline Netherlands & & & & & & & \\
\hline North Macedonia & 0.0 & 0.3 & 0.2 & 0.2 & 0.4 & 0.6 & 1091.9 \\
\hline Norway & $\ldots$ & $\ldots$ & $\ldots$ & $\ldots$ & $\ldots$ & $\ldots$ & $\ldots$ \\
\hline Poland & . & $\ldots$ & $\ldots$ & - & & & $\ldots$ \\
\hline Portugal & 25.6 & 34.5 & 33.2 & 43.5 & 75.7 & 81.9 & 220.5 \\
\hline Romania & $\ldots$ & $\ldots$ & $\ldots$ & 1.1 & 1.4 & 1.4 & $\ldots$ \\
\hline Russian Federation & & $\ldots$ & & & & & \\
\hline Serbia & 0.0 & 0.0 & 0.2 & 0.0 & 0.1 & 0.2 & 275.7 \\
\hline Slovak Republic & & $\ldots$ & & & & & \\
\hline Slovenia & 4.1 & 4.3 & 5.6 & 7.9 & 6.1 & 5.8 & 40.7 \\
\hline Spain & 80.2 & 91.4 & 90.7 & 107.4 & 178.8 & 199.6 & 149.0 \\
\hline Sweden & 370.5 & 461.0 & 612.3 & 688.6 & 935.7 & 1162.7 & 213.8 \\
\hline Switzerland & 70.1 & 79.5 & 69.1 & 51.8 & 53.0 & 57.5 & -18.0 \\
\hline Turkey & $\ldots$ & $\ldots$ & $\ldots$ & $\ldots$ & $\ldots$ & $\ldots$ & $\ldots$ \\
\hline Ukraine & $\ldots$ & $\ldots$ & $\ldots$ & $\ldots$ & $\ldots$ & $\ldots$ & $\ldots$ \\
\hline UK: England \& Wales & $\ldots$ & $\ldots$ & $\ldots$ & $\ldots$ & $\ldots$ & $\ldots$ & $\ldots$ \\
\hline UK: Northern Ireland & $\ldots$ & $\ldots$ & $\ldots$ & $\ldots$ & $\ldots$ & $\ldots$ & $\ldots$ \\
\hline UK: Scotland & $\ldots$ & $\ldots$ & & & & & \\
\hline Mean & 52.6 & 65.7 & 72.2 & 79.1 & 111.1 & 132.8 & \\
\hline Median & 4.1 & 4.3 & 4.7 & 7.9 & 6.7 & 6.1 & \\
\hline Minimum & 0.0 & 0.0 & 0.0 & 0.0 & 0.0 & 0.0 & \\
\hline Maximum & 370.5 & 461.0 & 612.3 & 688.6 & 935.7 & 1162.7 & \\
\hline
\end{tabular}


1 Police Statistics

Table 1.2.1.21 Offences per 100000 population - Forgery of documents

\begin{tabular}{|c|c|c|c|c|c|c|c|}
\hline & 2011 & 2012 & 2013 & 2014 & 2015 & 2016 & $\begin{array}{l}\% \text { change } \\
2011-2016\end{array}$ \\
\hline Albania & 24.2 & 23.5 & 18.4 & 19.1 & 22.3 & 28.1 & 15.9 \\
\hline Armenia & & & & & & & \\
\hline Austria & 50.4 & 55.7 & 50.5 & 55.9 & 51.9 & 55.2 & 9.6 \\
\hline Azerbaijan & & & & & & & \\
\hline Belgium & 10.2 & 15.4 & 13.1 & 12.2 & 10.6 & 8.4 & -16.9 \\
\hline Bosnia-Herzegovina & $\ldots$ & $\ldots$ & $\ldots$ & $\ldots$ & $\ldots$ & $\ldots$ & $\ldots$ \\
\hline Bulgaria & $\ldots$ & $\ldots$ & $\ldots$ & $\ldots$ & $\ldots$ & $\ldots$ & $\ldots$ \\
\hline Croatia & . & & & & $\ldots$ & & \\
\hline Cyprus & 81.1 & 68.0 & 43.2 & 32.8 & 41.4 & 27.9 & -65.5 \\
\hline Czech Republic & 6.7 & 7.0 & 6.1 & 7.6 & 7.2 & 9.3 & 39.3 \\
\hline Denmark & 57.7 & 42.8 & 41.7 & 40.1 & 42.3 & 51.0 & -11.6 \\
\hline Estonia & 53.1 & 45.7 & 65.0 & 80.8 & 79.5 & 53.0 & -0.2 \\
\hline \multirow{2}{*}{\multicolumn{8}{|c|}{ France }} \\
\hline & & & & & & & \\
\hline Georgia & 27.6 & 24.5 & 41.4 & 29.5 & 39.0 & 36.7 & 33.1 \\
\hline Germany & 58.5 & 56.5 & 56.1 & 56.4 & 56.0 & 60.7 & 3.6 \\
\hline Greece & 8.4 & 8.8 & 12.0 & 13.4 & 11.9 & 10.8 & 29.1 \\
\hline Hungary & 234.8 & 250.0 & 258.6 & 290.0 & 230.0 & 189.1 & -19.5 \\
\hline Iceland & 80.1 & 77.6 & 62.5 & 84.1 & 63.5 & 65.6 & -18.1 \\
\hline Ireland & $\ldots$ & $\ldots$ & $\ldots$ & $\ldots$ & $\ldots$ & $\ldots$ & $\ldots$ \\
\hline Italy & $\ldots$ & $\ldots$ & $\ldots$ & $\ldots$ & $\ldots$ & $\ldots$ & $\ldots$ \\
\hline Kosovo (UN R/1244/99) & $\ldots$ & $\ldots$ & $\ldots$ & $\ldots$ & $\ldots$ & $\ldots$ & $\ldots$ \\
\hline Latvia & $\ldots$ & $\ldots$ & $\ldots$ & $\ldots$ & $\ldots$ & $\ldots$ & $\ldots$ \\
\hline Lithuania & 86.1 & 94.0 & 97.2 & 81.4 & 80.1 & 48.2 & -44.0 \\
\hline \multicolumn{8}{|l|}{ Luxembourg } \\
\hline Malta & 12.8 & 20.6 & 18.7 & 11.2 & 12.3 & 11.1 & -13.1 \\
\hline Moldova & 32.8 & 27.8 & 33.3 & 28.6 & 25.7 & 25.6 & -21.8 \\
\hline Montenegro & 26.6 & 27.6 & 23.8 & 21.7 & 20.1 & 19.6 & -26.3 \\
\hline Netherlands & 59.6 & 62.0 & 45.0 & 42.8 & 85.8 & & \\
\hline North Macedonia & 22.8 & 10.9 & 1.5 & 16.7 & 17.7 & 19.3 & -15.5 \\
\hline Norway & 78.3 & 62.8 & 57.1 & 52.4 & 45.8 & 41.2 & -47.3 \\
\hline Poland & 57.6 & 60.3 & 79.7 & 79.8 & 71.0 & 74.6 & 29.6 \\
\hline Portugal & 18.0 & 22.0 & 21.0 & 22.1 & 24.3 & 21.9 & 22.1 \\
\hline Romania & 73.4 & 35.3 & 36.2 & 32.0 & 30.7 & 28.8 & -60.8 \\
\hline \multicolumn{8}{|l|}{ Russian Federation } \\
\hline Serbia & 72.0 & 59.6 & 46.0 & 50.4 & 51.6 & 48.9 & -32.0 \\
\hline \multicolumn{8}{|l|}{ Slovak Republic } \\
\hline Slovenia & 106.0 & 119.4 & 119.9 & 152.6 & 82.5 & 71.6 & -32.5 \\
\hline Spain & 19.2 & 19.1 & 18.4 & 19.3 & 18.7 & 17.0 & -11.6 \\
\hline Sweden & 62.2 & 57.3 & 59.8 & 63.2 & 72.2 & 63.3 & 1.9 \\
\hline Switzerland & 54.3 & 65.3 & 86.3 & 66.2 & 79.8 & 114.2 & 110.2 \\
\hline Turkey & 5.4 & 3.8 & 4.3 & & & & 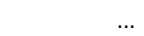 \\
\hline Ukraine & $\ldots$ & $\ldots$ & 39.3 & 32.8 & 33.3 & 32.8 & $\ldots$ \\
\hline UK: England \& Wales & $\ldots$ & $\ldots$ & $\ldots$ & $\ldots$ & $\ldots$ & $\ldots$ & $\ldots$ \\
\hline UK: Northern Ireland & $\ldots$ & $\ldots$ & $\ldots$ & $\ldots$ & $\ldots$ & $\ldots$ & $\ldots$ \\
\hline UK: Scotland & $\ldots$ & & & $\ldots$ & $\ldots$ & & \\
\hline Mean & 54 & 52 & 51 & 54 & 50 & 46 & \\
\hline Median & 54 & 46 & 42 & 40 & 42 & 39 & \\
\hline Minimum & 5 & 4 & 1 & 8 & 7 & 8 & \\
\hline Maximum & 235 & 250 & 259 & 290 & 230 & 189 & \\
\hline
\end{tabular}


Table 1.2.1.22 Offences per 100000 population - Money laundering

\begin{tabular}{|c|c|c|c|c|c|c|c|}
\hline & 2011 & 2012 & 2013 & 2014 & 2015 & 2016 & $\begin{array}{l}\% \text { change } \\
2011-2016\end{array}$ \\
\hline Albania & 3.0 & 4.0 & 4.3 & 11.3 & 12.3 & 13.2 & 345.6 \\
\hline Armenia & $\ldots$ & & $\ldots$ & $\ldots$ & & $\ldots$ & \\
\hline Austria & 6.4 & 4.9 & 4.0 & 5.0 & 5.3 & 6.5 & 0.7 \\
\hline Azerbaijan & $\ldots$ & & & $\ldots$ & & & \\
\hline Belgium & 7.5 & 8.0 & 8.3 & 7.6 & 7.5 & 7.4 & -1.1 \\
\hline Bosnia-Herzegovina & & & $\ldots$ & $\ldots$ & & $\ldots$ & \\
\hline Bulgaria & 0.2 & 0.2 & 0.3 & 0.1 & 0.3 & 0.4 & 145.6 \\
\hline Croatia & & & & & & & \\
\hline Cyprus & 0.6 & 0.7 & 0.7 & 13.3 & 0.7 & 0.7 & 18.8 \\
\hline Czech Republic & 2.4 & 3.8 & 4.1 & 5.5 & 4.5 & 5.4 & 124.2 \\
\hline Denmark & & & & & & & \\
\hline Estonia & 6.0 & 3.9 & 2.6 & 3.5 & 2.0 & 5.2 & -14.1 \\
\hline Finland & 2.0 & 4.2 & 3.3 & 3.8 & 3.2 & 6.7 & 241.0 \\
\hline France & $\ldots$ & $\ldots$ & $\ldots$ & $\ldots$ & $\ldots$ & $\ldots$ & $\ldots$ \\
\hline Georgia & $\ldots$ & $\ldots$ & $\ldots$ & $\ldots$ & $\ldots$ & $\ldots$ & $\ldots$ \\
\hline Germany & 10.7 & 9.6 & 10.1 & 10.1 & 11.9 & 14.0 & 31.5 \\
\hline Greece & $\ldots$ & & & $\ldots$ & & & \\
\hline Hungary & 0.1 & 0.2 & 0.2 & 0.2 & 0.3 & 0.7 & 423.5 \\
\hline Iceland & $\cdots$ & $\cdots$ & $\cdots$ & $\cdots$ & $\ldots$ & $\cdots$ & $\ldots$ \\
\hline $\begin{array}{l}\text { Ireland } \\
\text { Italy }\end{array}$ & 2.3 & 2.8 & $\begin{array}{l}3.2 \\
3.2\end{array}$ & $\begin{array}{l}\ldots \\
2.6\end{array}$ & 3.0 & $\begin{array}{r}\cdots \\
2.9\end{array}$ & 26.5 \\
\hline Kosovo (UN R/1244/99) & $\ldots$ & $\ldots$ & $\ldots$ & $\ldots$ & $\ldots$ & $\ldots$ & $\ldots$ \\
\hline Latvia & $\ldots$ & $\ldots$ & $\ldots$ & $\ldots$ & $\ldots$ & $\ldots$ & $\ldots$ \\
\hline Lithuania & 1.1 & 0.9 & 1.9 & 2.0 & 3.4 & 1.1 & -0.5 \\
\hline Luxembourg & $\ldots$ & $\ldots$ & $\ldots$ & $\ldots$ & $\ldots$ & $\ldots$ & $\ldots$ \\
\hline Malta & $\ldots$ & & $\ldots$ & $\ldots$ & $\ldots$ & $\ldots$ & $\ldots$ \\
\hline Moldova & 0.8 & 0.9 & 1.5 & 1.7 & 1.4 & 1.5 & 98.1 \\
\hline Montenegro & 0.6 & 0.0 & 0.6 & 0.0 & 0.0 & 0.0 & -100.0 \\
\hline Netherlands & 2.6 & 2.9 & 3.6 & 3.7 & 3.2 & $\ldots$ & \\
\hline North Macedonia & 0.3 & 0.5 & 0.6 & 0.3 & 0.3 & 0.2 & -43.2 \\
\hline Norway & 1.8 & 1.0 & 1.4 & 2.0 & 1.4 & 2.2 & 21.0 \\
\hline Poland & 0.7 & 1.0 & 0.7 & 0.5 & 1.1 & 0.8 & 9.7 \\
\hline Portugal & 0.1 & 0.1 & 0.3 & 0.2 & 0.2 & 0.2 & 104.5 \\
\hline Romania & 2.1 & 1.9 & 2.5 & 2.4 & 2.3 & 2.0 & -5.8 \\
\hline Russian Federation & & & & $\ldots$ & & & \\
\hline Serbia & 2.5 & 1.7 & 0.4 & 0.4 & 0.1 & 0.2 & -93.2 \\
\hline Slovak Republic & & & & & & & \\
\hline Slovenia & 2.3 & 6.9 & 4.7 & 3.7 & 3.0 & 2.5 & 5.5 \\
\hline Spain & 0.4 & 0.4 & 0.5 & 0.5 & 0.6 & 0.6 & 54.0 \\
\hline Sweden & 5.4 & 5.7 & 7.4 & 4.5 & 20.2 & 20.0 & 271.6 \\
\hline Switzerland & 3.7 & 4.4 & 4.4 & 4.7 & 4.5 & 8.0 & 116.1 \\
\hline Turkey & & & & & & & \\
\hline Ukraine & 0.8 & 0.6 & 0.6 & 0.7 & 0.5 & 0.4 & -50.5 \\
\hline UK: England \& Wales & $\ldots$ & $\ldots$ & $\ldots$ & $\ldots$ & $\ldots$ & $\ldots$ & $\ldots$ \\
\hline UK: Northern Ireland & $\ldots$ & $\ldots$ & $\ldots$ & $\ldots$ & $\ldots$ & $\ldots$ & $\ldots$ \\
\hline UK: Scotland & $\ldots$ & & & $\ldots$ & & $\ldots$ & \\
\hline Mean & 2.6 & 2.7 & 2.8 & 3.5 & 3.6 & 4.1 & \\
\hline Median & 2.1 & 1.8 & 2.2 & 2.5 & 2.2 & 2.0 & \\
\hline Minimum & 0.1 & 0.0 & 0.2 & 0.0 & 0.0 & 0.0 & \\
\hline Maximum & 10.7 & 9.6 & 10.1 & 13.3 & 20.2 & 20.0 & \\
\hline
\end{tabular}


Table 1.2.1.23 Offences per 100000 population - Corruption in the public sector

\begin{tabular}{|c|c|c|c|c|c|c|c|}
\hline & 2011 & 2012 & 2013 & 2014 & 2015 & 2016 & $\begin{array}{l}\% \text { change } \\
2011-2016\end{array}$ \\
\hline Albania & 9.9 & 11.3 & 11.7 & 18.6 & 21.9 & 22.3 & 124.2 \\
\hline Armenia & 3.9 & 4.9 & 6.3 & 7.5 & 8.8 & 6.9 & 78.8 \\
\hline Austria & 8.0 & 6.3 & 6.4 & 4.9 & 4.1 & 4.3 & -45.8 \\
\hline Azerbaijan & & & & & & & \\
\hline Belgium & 0.9 & 0.8 & 0.7 & 0.6 & 0.5 & 0.6 & -30.1 \\
\hline Bosnia-Herzegovina & & $\ldots$ & & $\ldots$ & & & \\
\hline Bulgaria & 2.1 & 1.9 & 1.3 & 1.4 & 1.2 & 2.0 & -4.3 \\
\hline Croatia & & $\ldots$ & & $\ldots$ & & & \\
\hline Cyprus & 1.2 & 0.6 & 1.4 & 1.5 & 3.2 & 4.8 & 305.9 \\
\hline Czech Republic & 2.5 & 2.8 & 2.7 & 1.8 & 1.8 & 0.9 & -63.5 \\
\hline Denmark & 0.1 & 0.1 & 0.1 & 0.2 & 0.4 & 0.9 & 637.7 \\
\hline Estonia & 8.1 & 8.5 & 19.5 & 19.8 & 24.6 & 27.1 & 234.0 \\
\hline Finland & 0.1 & 0.1 & 0.2 & 0.1 & 0.2 & 0.1 & -2.0 \\
\hline \multicolumn{8}{|l|}{ France } \\
\hline Georgia & 11.4 & 8.8 & 15.9 & 8.5 & 13.9 & 13.5 & 18.2 \\
\hline Germany & 1.4 & 1.6 & 1.4 & 2.6 & 1.3 & 1.4 & -1.0 \\
\hline Greece & 1.0 & 1.3 & 1.2 & 1.3 & 1.0 & 1.1 & 3.1 \\
\hline Hungary & 7.4 & 8.3 & 11.2 & 33.1 & 7.7 & 10.0 & 35.4 \\
\hline Iceland & $\ldots$ & $\ldots$ & $\ldots$ & $\ldots$ & $\ldots$ & $\ldots$ & $\ldots$ \\
\hline Ireland & $\ldots$ & $\ldots$ & $\ldots$ & $\ldots$ & $\ldots$ & $\ldots$ & ... \\
\hline Italy & $\ldots$ & $\ldots$ & $\ldots$ & $\ldots$ & $\ldots$ & $\ldots$ & $\ldots$ \\
\hline Kosovo (UN R/1244/99) & $\ldots$ & $\ldots$ & $\ldots$ & $\ldots$ & $\ldots$ & $\ldots$ & $\ldots$ \\
\hline Latvia & $\ldots$ & $\ldots$ & $\ldots$ & $\ldots$ & $\ldots$ & $\ldots$ & $\ldots$ \\
\hline Lithuania & 17.5 & 30.2 & 37.0 & 44.2 & 36.3 & 22.4 & 28.3 \\
\hline Luxembourg & $\ldots$ & $\ldots$ & 0.4 & 0.5 & 0.4 & 0.0 & $\ldots$ \\
\hline Malta & & $\ldots$ & & & & $\ldots$ & \\
\hline Moldova & 25.4 & 31.6 & 28.3 & 27.9 & 26.9 & 30.1 & 18.5 \\
\hline Montenegro & 19.5 & 15.5 & 15.0 & 13.5 & 11.1 & 12.9 & -34.1 \\
\hline Netherlands & $\ldots$ & $\ldots$ & $\ldots$ & $\ldots$ & $\ldots$ & $\ldots$ & $\ldots$ \\
\hline North Macedonia & & $\ldots$ & & $\ldots$ & & & \\
\hline Norway & 2.5 & 1.2 & 0.9 & 0.5 & 0.9 & 0.9 & -65.3 \\
\hline Poland & 23.4 & 17.5 & 18.0 & 16.0 & 11.2 & 17.3 & -26.0 \\
\hline Portugal & 0.6 & 0.5 & 0.6 & 0.8 & 0.7 & 0.7 & 8.5 \\
\hline Romania & 76.6 & 66.1 & 63.6 & 70.7 & 80.2 & 74.0 & -3.4 \\
\hline \multicolumn{8}{|l|}{ Russian Federation } \\
\hline Serbia & 3.0 & 3.6 & 2.9 & 2.1 & 6.5 & 2.1 & -31.2 \\
\hline \multicolumn{8}{|l|}{ Slovak Republic } \\
\hline Slovenia & 3.4 & 3.2 & 1.4 & 0.9 & 3.4 & 7.1 & 110.2 \\
\hline Spain & 1.0 & 1.0 & 1.1 & 1.3 & 1.3 & 1.4 & 40.2 \\
\hline Sweden & 1.3 & 1.5 & 1.3 & 1.2 & 1.7 & 2.5 & 90.4 \\
\hline Switzerland & 0.3 & 0.2 & 0.2 & 0.9 & 0.6 & 0.2 & -5.5 \\
\hline \multicolumn{8}{|l|}{ Turkey } \\
\hline Ukraine & 6.3 & 3.2 & 3.7 & 3.4 & 3.7 & 3.7 & -41.2 \\
\hline UK: England \& Wales & $\ldots$ & $\ldots$ & $\ldots$ & $\ldots$ & $\ldots$ & $\ldots$ & $\ldots$ \\
\hline UK: Northern Ireland & $\ldots$ & $\ldots$ & $\ldots$ & $\ldots$ & $\ldots$ & $\ldots$ & $\ldots$ \\
\hline UK: Scotland & & $\ldots$ & & $\ldots$ & & $\ldots$ & \\
\hline Mean & 8.8 & 8.6 & 9.1 & 10.2 & 9.8 & 9.7 & \\
\hline Median & 3.0 & 3.2 & 2.0 & 1.9 & 3.3 & 3.1 & \\
\hline Minimum & 0.1 & 0.1 & 0.1 & 0.1 & 0.2 & 0.0 & \\
\hline Maximum & 76.6 & 66.1 & 63.6 & 70.7 & 80.2 & 74.0 & \\
\hline
\end{tabular}


Table 1.2.1.24 Offences per 100000 population - Drug offences: Total

\begin{tabular}{|c|c|c|c|c|c|c|c|}
\hline & 2011 & 2012 & 2013 & 2014 & 2015 & 2016 & $\begin{array}{c}\% \text { change } \\
2011-2016\end{array}$ \\
\hline Albania & 25.5 & 38.1 & 46.0 & 61.4 & 80.9 & 113.9 & 347.3 \\
\hline Armenia & 46.7 & 34.8 & 42.2 & 36.0 & 31.0 & 33.6 & -28.1 \\
\hline Austria & 309.2 & 283.0 & 334.0 & 355.6 & 383.3 & 416.5 & 34.7 \\
\hline Azerbaijan & 29.1 & 26.1 & 26.9 & 31.8 & 30.7 & 31.8 & 9.4 \\
\hline Belgium & 437.6 & 399.7 & 435.0 & 493.1 & 466.7 & 484.8 & 10.8 \\
\hline Bosnia-Herzegovina & & & & & & & \\
\hline Bulgaria & 38.7 & 40.4 & 41.9 & 44.7 & 55.7 & 66.2 & 70.9 \\
\hline Croatia & & & & & & & \\
\hline Cyprus & 111.9 & 119.5 & 115.0 & 125.9 & 111.5 & 105.3 & -6.0 \\
\hline Czech Republic & 36.6 & 38.4 & 48.7 & 53.2 & 52.7 & 52.7 & 44.3 \\
\hline Denmark & 385.2 & 389.7 & 434.5 & 475.8 & 415.0 & 394.6 & 2.4 \\
\hline Estonia & 68.7 & 65.3 & 77.2 & 90.4 & 102.6 & 98.9 & 44.0 \\
\hline Finland & 379.4 & 372.2 & 417.5 & 399.6 & 427.7 & 457.1 & 20.5 \\
\hline France & 298.0 & 302.4 & 317.6 & 326.6 & 327.1 & 328.4 & 10.2 \\
\hline Georgia & 84.5 & 70.4 & 262.9 & 162.8 & 137.4 & 128.0 & 51.5 \\
\hline Germany & 294.8 & 295.2 & 314.8 & 342.6 & 348.0 & 368.2 & 24.9 \\
\hline Greece & 71.6 & 68.8 & 103.8 & 108.3 & 111.2 & 113.7 & 58.9 \\
\hline Hungary & 60.0 & 52.5 & 56.0 & 65.9 & 67.2 & 65.8 & 9.8 \\
\hline Iceland & 571.2 & 641.2 & 678.3 & 729.3 & 580.7 & 563.3 & -1.4 \\
\hline Ireland & 384.4 & 356.9 & 332.4 & 342.0 & 321.8 & 339.4 & -11.7 \\
\hline Italy & 57.3 & 57.0 & 56.3 & 54.7 & 53.6 & 59.6 & 3.9 \\
\hline Kosovo (UN R/1244/99) & & & & & & & \\
\hline Latvia & 94.8 & 134.5 & 80.9 & 138.1 & 177.7 & 60.7 & -36.0 \\
\hline Lithuania & 72.8 & 98.4 & 75.8 & 85.2 & 84.2 & 78.6 & 8.1 \\
\hline Luxembourg & & & 600.0 & 762.3 & 830.4 & 690.8 & \\
\hline Malta & 42.9 & 48.6 & 49.2 & 44.7 & 35.7 & 48.2 & 12.3 \\
\hline Moldova & 46.6 & 44.3 & 32.8 & 36.2 & 33.5 & 30.9 & -33.6 \\
\hline Montenegro & 49.5 & 30.1 & 27.7 & 28.8 & 29.6 & 33.1 & -33.2 \\
\hline Netherlands & 102.8 & 105.1 & 101.5 & 96.9 & 87.4 & 78.3 & -23.8 \\
\hline North Macedonia & 29.0 & 29.3 & 26.1 & 34.7 & 29.5 & 29.4 & 1.5 \\
\hline Norway & 406.2 & 433.3 & 457.7 & 432.9 & 384.6 & 316.6 & -22.0 \\
\hline Poland & 195.8 & 200.6 & 189.0 & 130.4 & 121.9 & 135.0 & -31.1 \\
\hline Portugal & 53.2 & 56.1 & 53.8 & 56.2 & 64.2 & 70.4 & 32.4 \\
\hline Romania & 21.5 & 27.7 & 15.2 & 16.3 & 23.1 & 22.3 & 3.6 \\
\hline Russian Federation & & & & & & & \\
\hline Serbia & 68.1 & 66.2 & 78.6 & 87.0 & 80.2 & 99.2 & 45.6 \\
\hline Slovak Republic & & & & & & & \\
\hline Slovenia & 82.3 & 94.4 & 91.5 & 90.1 & 90.7 & 76.6 & -7.0 \\
\hline Spain & 32.6 & 31.0 & 30.6 & 28.8 & 26.0 & 26.8 & -17.8 \\
\hline Sweden & 977.1 & 1026.9 & 1037.8 & 1018.4 & 990.6 & 949.6 & -2.8 \\
\hline Switzerland & 1159.0 & 1167.4 & 1210.2 & 995.0 & 1045.5 & 1000.0 & -13.7 \\
\hline Turkey & & & & & & & \\
\hline Ukraine & 116.7 & 99.7 & 74.9 & 67.4 & 60.6 & 54.1 & -53.7 \\
\hline UK: England \& Wales & 416.1 & 375.1 & 352.6 & 311.3 & 262.1 & 238.6 & -42.7 \\
\hline UK: Northern Ireland & 208.3 & 240.1 & 258.6 & 274.3 & 299.7 & 290.8 & 39.6 \\
\hline UK: Scotland & 648.1 & 661.6 & 651.1 & 666.0 & 685.6 & 656.4 & 1.3 \\
\hline Mean & 218 & 221 & 241 & 243 & 239 & 230 & \\
\hline Median & 84 & 98 & 96 & 103 & 107 & 102 & \\
\hline Minimum & 21 & 26 & 15 & 16 & 23 & 22 & \\
\hline Maximum & 1159 & 1167 & 1210 & 1018 & 1046 & 1000 & \\
\hline
\end{tabular}


1 Police Statistics

Table 1.2.1.25 Offences per 100000 population - Drug trafficking

\begin{tabular}{|c|c|c|c|c|c|c|c|}
\hline & 2011 & 2012 & 2013 & 2014 & 2015 & 2016 & $\begin{array}{l}\% \text { change } \\
2011-2016\end{array}$ \\
\hline Albania & 2.2 & 3.7 & 5.3 & 4.1 & 2.4 & 4.3 & 92.9 \\
\hline Armenia & 23.1 & 15.7 & 18.2 & 19.6 & 15.9 & 17.6 & -24.0 \\
\hline Austria & $\ldots$ & $\ldots$ & $\ldots$ & $\ldots$ & $\ldots$ & $\ldots$ & $\ldots$ \\
\hline Azerbaijan & $\ldots$ & & $\ldots$ & $\ldots$ & & $\ldots$ & \\
\hline Belgium & 139.2 & 116.0 & 116.4 & 126.9 & 122.2 & 122.8 & -11.8 \\
\hline Bosnia-Herzegovina & 1.4 & 1.1 & 0.6 & 2.0 & 2.4 & 22.1 & 1470.0 \\
\hline Bulgaria & $\ldots$ & $\ldots$ & $\ldots$ & $\ldots$ & $\ldots$ & $\ldots$ & $\ldots$ \\
\hline Croatia & & & $\ldots$ & $\ldots$ & & $\ldots$ & \\
\hline Cyprus & 15.4 & 19.0 & 18.6 & 16.1 & 15.6 & 16.6 & 8.2 \\
\hline Czech Republic & 29.5 & 31.0 & 37.5 & 42.0 & 42.8 & 42.8 & 44.8 \\
\hline Denmark & 64.3 & 65.5 & 73.9 & 89.5 & 77.6 & 74.8 & 16.3 \\
\hline Estonia & 68.7 & 65.3 & 77.2 & 90.4 & 102.6 & 98.9 & 44.0 \\
\hline Finland & 154.4 & 163.1 & 182.0 & 148.6 & 150.4 & 170.8 & 10.6 \\
\hline France & 9.9 & 9.8 & 10.6 & 11.0 & 12.1 & 14.1 & 42.8 \\
\hline Georgia & 24.6 & 27.1 & 87.4 & 61.0 & 56.6 & 66.5 & 170.3 \\
\hline Germany & 77.7 & 74.1 & 73.1 & 76.3 & 77.8 & 80.2 & 3.2 \\
\hline Greece & $\ldots$ & & $\ldots$ & $\ldots$ & & $\ldots$ & \\
\hline Hungary & 7.1 & 5.6 & 4.9 & 4.4 & 4.6 & 4.8 & -32.9 \\
\hline Iceland & 26.1 & 28.8 & 54.7 & 71.5 & 57.7 & 67.4 & 158.5 \\
\hline $\begin{array}{l}\text { Ireland } \\
\text { Italy }\end{array}$ & 83.5 & 75.4 & 70.3 & 76.8 & 72.0 & 76.8 & -8.1 \\
\hline Kosovo (UN R/1244/99) & 29.8 & 30.7 & 29.2 & 35.6 & 22.3 & 33.1 & 10.9 \\
\hline Latvia & $\ldots$ & $\ldots$ & $\ldots$ & $\ldots$ & 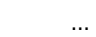 & $\ldots$ & $\ldots$ \\
\hline Lithuania & 32.0 & 56.4 & 28.2 & 32.6 & 26.5 & 23.4 & -26.7 \\
\hline Luxembourg & $\ldots$ & & 29.8 & 38.0 & 36.1 & 47.5 & \\
\hline Malta & 2.7 & 4.8 & 3.1 & 2.6 & 1.6 & 2.9 & 8.9 \\
\hline Moldova & 1.2 & 1.9 & 1.0 & 0.9 & 1.0 & 0.9 & -18.5 \\
\hline Montenegro & 41.0 & 23.7 & 24.0 & 24.1 & 25.1 & 28.8 & -29.8 \\
\hline Netherlands & & & & & & & \\
\hline North Macedonia & 28.6 & 22.7 & 19.6 & 27.9 & 24.9 & 23.6 & -17.6 \\
\hline Norway & $\ldots$ & & $\ldots$ & $\ldots$ & & $\ldots$ & \\
\hline Poland & 11.4 & 11.4 & 11.2 & 11.1 & 7.4 & 7.0 & -39.2 \\
\hline Portugal & 40.0 & 44.2 & 42.0 & 43.5 & 49.1 & 54.2 & 35.7 \\
\hline Romania & $\ldots$ & $\ldots$ & $\ldots$ & $\ldots$ & $\ldots$ & $\ldots$ & $\ldots$ \\
\hline Russian Federation & & & $\ldots$ & & & & \\
\hline Serbia & 19.9 & 19.2 & 21.1 & 17.7 & 16.9 & 19.3 & -2.6 \\
\hline Slovak Republic & 14.1 & 14.0 & 35.7 & 29.7 & 32.3 & 27.5 & 94.7 \\
\hline Slovenia & 73.4 & 85.6 & 83.2 & 80.6 & 84.2 & 69.6 & -5.2 \\
\hline Spain & & & $\ldots$ & & & $\ldots$ & $\ldots$ \\
\hline Sweden & 117.7 & 154.1 & 151.9 & 132.2 & 123.8 & 107.6 & -8.5 \\
\hline Switzerland & 80.0 & 91.7 & 96.0 & 106.0 & 100.0 & 101.4 & 26.8 \\
\hline Turkey & & & & & & & \\
\hline Ukraine & 35.8 & 31.6 & 20.8 & 18.6 & 15.5 & 5.4 & -85.0 \\
\hline UK: England \& Wales & 57.5 & 52.6 & 51.7 & 48.8 & 45.4 & 42.2 & -26.6 \\
\hline UK: Northern Ireland & 46.6 & 48.8 & 52.9 & 47.3 & 47.1 & 44.5 & -4.6 \\
\hline UK: Scotland & & & 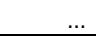 & & & $\ldots$ & \\
\hline Mean & 44 & 45 & 48 & 48 & 46 & 47 & \\
\hline Median & 30 & 31 & 33 & 37 & 34 & 38 & \\
\hline Minimum & 1 & 1 & 1 & 1 & 1 & 1 & \\
\hline Maximum & 154 & 163 & 182 & 149 & 150 & 171 & \\
\hline
\end{tabular}


Notes on tables 1.2.1.1-1.2.25

\begin{tabular}{|c|c|}
\hline Albania & $\begin{array}{l}\text { Forced intra-marital intercourse was introduced in the Criminal Code in May } 2013 . \\
\text { Under such a provision constitutes a criminal act to engage in sexual activity by use of force } \\
\text { spouses or cohabitants. }\end{array}$ \\
\hline Denmark & $\begin{array}{l}\text { Drug offences include both some according to the penal code and some according to a } \\
\text { special law on (less severe) drug offences. } \\
\text { Part of the increase in both fraud and cyber fraud is caused by changes in the police regis- } \\
\text { tration practice in these types of cases. Cyber fraud includes violations of } \S 279 \text { a in the } \\
\text { Penal Code exclusively, as this is currently the best approximation available of cyber fraud } \\
\text { in a Danish context. As a result, some types of cyber fraud are not encompassed by the } \\
\text { definition, and the definition may encompass offences, which are not 'cyber' fraud per se. }\end{array}$ \\
\hline Finland & $\begin{array}{l}\text { There is no clear crime category for sexual assault in Finland. If it includes violence it can } \\
\text { be classified as an assault. }\end{array}$ \\
\hline Germany & Police statistics do not include traffic offences. \\
\hline Greece & The police data system was redesigned in 2013 causing possible breaks in the data series. \\
\hline Hungary & $\begin{array}{l}\text { Changes were made to the Criminal code in } 2013 \text { causing e.g., changes in number of rapes. } \\
\text { The so-called "foreign language examination scandal" contributed to the figure for corruption } \\
\text { to be remarkably higher in } 2014 \text {. }\end{array}$ \\
\hline Iceland & $\begin{array}{l}\text { Changes were made to the working procedure in cases of domestic violence in } 2014 \text { caus- } \\
\text { ing increase in registered violence. }\end{array}$ \\
\hline Lithuania & $\begin{array}{l}\text { The statistics for the year of } 2016 \text { cover only thefts of automobiles, because thefts of motor } \\
\text { vehicles are not criminalized separately in the Criminal Code of Lithuania, while had been } \\
\text { counted separately by the police till } 2015 \text {. }\end{array}$ \\
\hline Norway & The figures for homicide in 2011 include the terrorist attacks of Andrew Breivik. \\
\hline Poland & $\begin{array}{l}\text { From November } 2013 \text { - driving under the influence of alcohol other than motor vehicle (e.g., } \\
\text { bicycle) is not a crime but misdemeanour (wykroczenie) and it is not included in the crime } \\
\text { statistics. }\end{array}$ \\
\hline Romania & $\begin{array}{l}\text { Data reported by the police only refer to offences perpetrated until February 1, } 2014 \text { (under } \\
\text { the Criminal Code of 1969). }\end{array}$ \\
\hline Spain & In 2015 a modification of the penal code, raised the age of sexual consent from 13 to 16 . \\
\hline Slovenia & $\begin{array}{l}\text { In the revision of police statistical data, it appears that intentional murders prior to } 2011 \text { also } \\
\text { contains manslaughters, which are unintentional murders. The data from } 2011 \text { contains only } \\
\text { murders that were intentional, for mentioned reason data prior of } 2011 \text { is incomparable. }\end{array}$ \\
\hline Turkey & In cases where UNODC data was used there are no information regarding definitions. \\
\hline Ukraine & $\begin{array}{l}\text { At the end of } 2012 \text { the new Criminal Procedural Code of Ukraine came into force and as a } \\
\text { consequence, new methods of data collection were adopted. The substantive increase of } \\
\text { the intentional homicide rate in } 2014-2015 \text { is due to these changes. }\end{array}$ \\
\hline UK: England and Wales & $\begin{array}{l}\text { From } 2014 \text { onwards, following inspections of the accuracy of crime recording, police forces } \\
\text { improved the recording of all offence types leading to increased numbers being recorded. } \\
\text { There were also many definitional changes in the types of offences which comprise aggra- } \\
\text { vated bodily injury and sexual offences between } 2011 \text { and } 2012 \text {, leading to a break in the } \\
\text { series. } \\
\text { The recording of fraud offences gradually became a centralized one between } 2012 \text { and } \\
2014 \text {. Police forces no longer record such data. Much of the recorded increase since } 2012 \\
\text { in this table is due to better procedures for recording. }\end{array}$ \\
\hline UK: Northern Ireland & $\begin{array}{l}\text { In April } 2008 \text { the Home Office issued clarification to police forces on how to record offences } \\
\text { of wounding with intent/Grievous bodily harm (GBH) with intent for those assaults resulting } \\
\text { in minor or no injury to a victim, but where the intent was to cause serious injury. The effect } \\
\text { of this clarification was that some offences that would previously have been recorded as } \\
\text { other types of assault are now recorded as GBH with intent. } \\
\text { The number of robberies with firearms for } 2011-2016 \text { is the sum of 'armed robberies busi- } \\
\text { ness' and 'armed robberies personal' in the published statistics. This causes a break in the } \\
\text { series. The reason is unknown as the source of the pre-2011 figures for robberies with fire- } \\
\text { arms was not recorded. }\end{array}$ \\
\hline
\end{tabular}




\subsubsection{Offenders}

Table 1.2.2.0 Definitions of persons suspected (1/2)

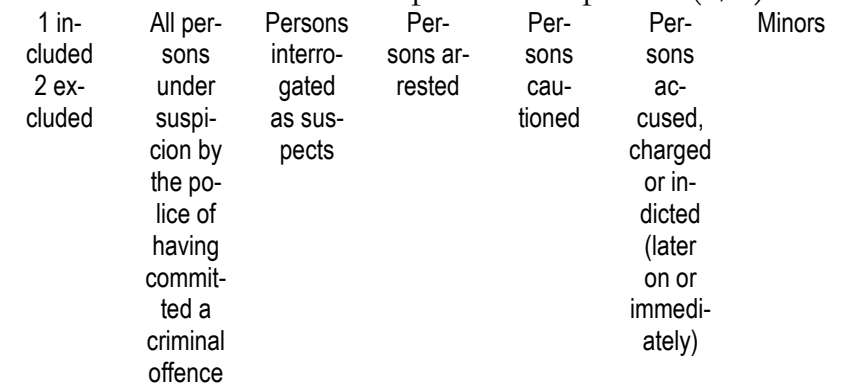

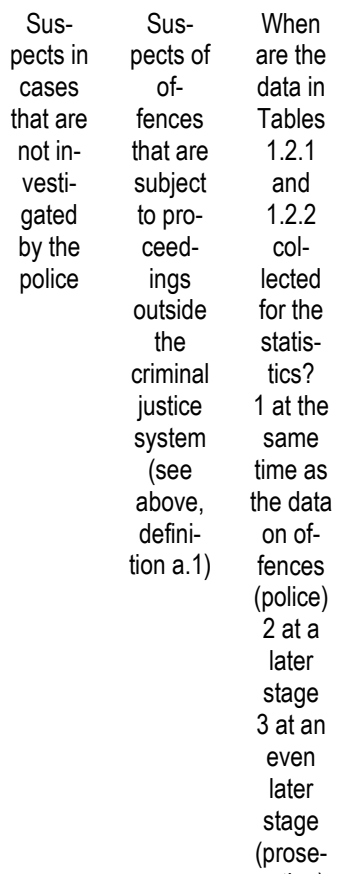

\begin{tabular}{|c|c|c|c|c|c|c|c|c|c|}
\hline & & & & & & & & & tion) \\
\hline Albania & 1 & 1 & 1 & 1 & 1 & 1 & 2 & 2 & $\ldots$ \\
\hline Armenia & $\ldots$ & $\ldots$ & $\ldots$ & $\ldots$ & $\ldots$ & $\ldots$ & $\ldots$ & $\ldots$ & $\ldots$ \\
\hline Austria & 1 & 1 & 1 & 2 & 1 & 1 & 2 & 2 & 1 \\
\hline $\begin{array}{l}\text { Azerbai- } \\
\text { jan }\end{array}$ & $\ldots$ & $\ldots$ & $\ldots$ & $\ldots$ & $\ldots$ & $\ldots$ & $\ldots$ & $\ldots$ & $\ldots$ \\
\hline Belgium & 1 & 1 & 1 & 1 & 1 & 1 & 2 & 2 & 1,2 \\
\hline Bulgaria & 1 & 1 & 1 & 1 & 1 & 1 & 2 & 2 & 1 \\
\hline Croatia & $\ldots$ & $\ldots$ & $\ldots$ & $\ldots$ & $\ldots$ & $\ldots$ & $\ldots$ & $\ldots$ & $\ldots$ \\
\hline Cyprus & 2 & 2 & 1 & 2 & 2 & 1 & 2 & 2 & 2 \\
\hline $\begin{array}{l}\text { Czech } \\
\text { Republic }\end{array}$ & 2 & 1 & 2 & 2 & 1 & 1 & 2 & 2 & 1 \\
\hline Denmark & $\ldots$ & $\ldots$ & $\ldots$ & $\ldots$ & $\ldots$ & $\ldots$ & $\ldots$ & $\ldots$ & $\ldots$ \\
\hline Estonia & $\ldots$ & $\ldots$ & $\ldots$ & $\ldots$ & $\ldots$ & $\ldots$ & $\ldots$ & $\ldots$ & $\ldots$ \\
\hline Finland & 1 & 1 & 1 & 1 & 1 & 1 & 2 & 1 & 1 \\
\hline France & $\ldots$ & $\ldots$ & $\ldots$ & $\ldots$ & $\ldots$ & $\ldots$ & $\ldots$ & $\ldots$ & $\ldots$ \\
\hline Georgia & 1 & 1 & 1 & 1 & 1 & 1 & 2 & 2 & 1 \\
\hline $\begin{array}{l}\text { Germany } \\
\text { Greece }\end{array}$ & 1 & 1 & 1 & $\ldots$ & 1 & 1 & 2 & 2 & 1 \\
\hline Hungary & 1 & 1 & 1 & 1 & 1 & 1 & 1 & 2 & 1 \\
\hline $\begin{array}{l}\text { Iceland } \\
\text { Italy }\end{array}$ & 1 & 1 & 1 & 1 & 1 & 1 & 1 & & 1 \\
\hline Latvia & 1 & 1 & 1 & 1 & 1 & 1 & 2 & 2 & 2 \\
\hline Lithuania & 1 & 1 & 1 & 1 & 1 & 1 & 1 & 2 & 1 \\
\hline $\begin{array}{l}\text { Moldova } \\
\text { Monte- } \\
\text { negro }\end{array}$ & $\ldots$ & $\ldots$ & $\ldots$ & $\ldots$ & $\ldots$ & $\ldots$ & $\ldots$ & $\ldots$ & $\ldots$ \\
\hline
\end{tabular}


Table 1.2.2.0 Definitions of persons suspected (2/2)

\begin{tabular}{|c|c|c|c|c|c|c|c|c|c|}
\hline $\begin{array}{c}1 \text { in- } \\
\text { cluded } \\
2 \text { ex- } \\
\text { cluded }\end{array}$ & $\begin{array}{l}\text { All per- } \\
\text { sons } \\
\text { under } \\
\text { suspi- } \\
\text { cion by } \\
\text { the po- } \\
\text { lice of } \\
\text { having } \\
\text { commit- } \\
\text { ted a } \\
\text { criminal } \\
\text { offence }\end{array}$ & $\begin{array}{c}\text { Persons } \\
\text { interro- } \\
\text { gated } \\
\text { as sus- } \\
\text { pects }\end{array}$ & $\begin{array}{l}\text { Persons } \\
\text { arrested }\end{array}$ & $\begin{array}{l}\text { Persons } \\
\text { cau- } \\
\text { tioned }\end{array}$ & $\begin{array}{l}\text { Persons } \\
\text { ac- } \\
\text { cused, } \\
\text { charged } \\
\text { or in- } \\
\text { dicted } \\
\text { (later on } \\
\text { or im- } \\
\text { medi- } \\
\text { ately) }\end{array}$ & Minors & $\begin{array}{l}\text { Sus- } \\
\text { pects in } \\
\text { cases } \\
\text { that are } \\
\text { not in- } \\
\text { vesti- } \\
\text { gated } \\
\text { by the } \\
\text { police }\end{array}$ & $\begin{array}{l}\text { Sus- } \\
\text { pects of } \\
\text { of- } \\
\text { fences } \\
\text { that are } \\
\text { subject } \\
\text { to pro- } \\
\text { ceed- } \\
\text { ings } \\
\text { outside } \\
\text { the } \\
\text { criminal } \\
\text { justice } \\
\text { system } \\
\text { (see } \\
\text { above, } \\
\text { defini- } \\
\text { tion a.1) }\end{array}$ & $\begin{array}{c}\text { When } \\
\text { are the } \\
\text { data in } \\
\text { Tables } \\
1.2 .1 \\
\text { and } \\
1.2 .2 \\
\text { col- } \\
\text { lected } \\
\text { for the } \\
\text { statis- } \\
\text { tics? } \\
1 \text { at the } \\
\text { same } \\
\text { time as } \\
\text { the data } \\
\text { on of- } \\
\text { fences } \\
\text { (police) } \\
2 \text { at a } \\
\text { later } \\
\text { stage } \\
3 \text { at an } \\
\text { even } \\
\text { later } \\
\text { stage } \\
\text { (prose- } \\
\text { cution) }\end{array}$ \\
\hline $\begin{array}{l}\text { Nether- } \\
\text { lands }\end{array}$ & 1 & 1 & 1 & $\ldots$ & 1 & 1 & 2 & 2 & 2 \\
\hline $\begin{array}{l}\text { North } \\
\text { Macedo- } \\
\text { nia }\end{array}$ & 2 & 2 & 2 & 2 & 1 & 2 & 2 & 2 & 2 \\
\hline Poland & 1 & 1 & 1 & 1 & 1 & 2 & 2 & 2 & 1 \\
\hline Portugal & 2 & 1 & 1 & 2 & 1 & 1 & 2 & 2 & 2 \\
\hline $\begin{array}{l}\text { Roma- } \\
\text { nia }\end{array}$ & $\ldots$ & $\ldots$ & $\ldots$ & $\ldots$ & $\ldots$ & $\ldots$ & $\ldots$ & $\ldots$ & $\ldots$ \\
\hline Serbia & 2 & 2 & 2 & 2 & 1 & 2 & 1 & 1 & 2 \\
\hline Slovenia & 1 & 1 & 1 & 1 & 1 & 1 & 2 & 2 & 2 \\
\hline Spain & 1 & 1 & 1 & 1 & 1 & 2 & 2 & 2 & 2 \\
\hline Sweden & 1 & 1 & 1 & 1 & 1 & 2 & 1 & 2 & 1 \\
\hline $\begin{array}{l}\text { Switzer- } \\
\text { land }\end{array}$ & 1 & 1 & 1 & 1 & 1 & 1 & 2 & 2 & 1 \\
\hline Turkey & 1 & 1 & 1 & 1 & 1 & 1 & 2 & 2 & $\ldots$ \\
\hline Ukraine & 1 & 1 & 1 & 1 & 1 & 1 & 1 & 2 & 1 \\
\hline $\begin{array}{l}\text { UK: } \\
\text { England } \\
\& \text { Wales }\end{array}$ & $\ldots$ & $\ldots$ & $\ldots$ & $\ldots$ & $\ldots$ & $\ldots$ & $\ldots$ & $\ldots$ & $\ldots$ \\
\hline $\begin{array}{l}\text { UK: } \\
\text { Northern } \\
\text { Ireland }\end{array}$ & $\ldots$ & $\ldots$ & $\ldots$ & $\ldots$ & $\ldots$ & $\ldots$ & $\ldots$ & $\ldots$ & $\ldots$ \\
\hline $\begin{array}{l}\text { UK: } \\
\text { Scotland }\end{array}$ & $\ldots$ & $\ldots$ & $\ldots$ & $\ldots$ & $\ldots$ & $\ldots$ & $\ldots$ & $\ldots$ & $\ldots$ \\
\hline
\end{tabular}


Table 1.2.2.1 Offenders per 100000 population - Total

\begin{tabular}{|c|c|c|c|c|c|c|c|}
\hline & 2011 & 2012 & 2013 & 2014 & 2015 & 2016 & $\begin{array}{l}\% \text { change } \\
2011-2016\end{array}$ \\
\hline Albania & 463.2 & 542.4 & 999.0 & 1023.1 & 1178.6 & 1086.1 & 134.5 \\
\hline Armenia & 364.5 & 357.9 & 395.5 & 376.6 & 364.4 & 373.3 & 2.4 \\
\hline Austria & 3092.8 & 3091.3 & 3105.1 & 3006.8 & 2918.8 & 3105.1 & 0.4 \\
\hline Azerbaijan & 204.3 & 184.4 & 158.6 & 164.2 & 170.1 & 171.8 & -15.9 \\
\hline Belgium & 2507.5 & 2265.8 & 2278.4 & 2351.4 & 2382.4 & 2618.4 & 4.4 \\
\hline Bosnia-Herzegovina & 757.5 & 761.9 & 776.4 & 742.5 & 646.9 & 637.5 & -15.8 \\
\hline Bulgaria & 695.8 & 628.8 & 612.1 & 570.0 & 566.8 & 620.4 & -10.8 \\
\hline Croatia & 1672.7 & 1569.7 & 1390.3 & 1267.0 & 1425.7 & 1497.5 & -10.5 \\
\hline Cyprus & & 558.1 & 512.8 & 508.0 & 573.7 & 593.3 & \\
\hline Czech Republic & 1096.4 & 1075.9 & 1118.9 & 1090.2 & 966.1 & 884.8 & -19.3 \\
\hline Denmark & $\ldots$ & $\ldots$ & $\ldots$ & $\ldots$ & $\ldots$ & $\ldots$ & $\ldots$ \\
\hline Estonia & $\ldots$ & & $\ldots$ & & $\ldots$ & & \\
\hline Finland & 5632.5 & 5240.5 & 5092.6 & 4830.1 & 4788.1 & 4708.4 & -16.4 \\
\hline France & 1955.9 & 1909.9 & 1794.6 & 1786.8 & 1748.4 & 1697.9 & -13.2 \\
\hline Georgia & 391.3 & 331.8 & 591.7 & 493.7 & 567.8 & 570.9 & 45.9 \\
\hline Germany & 2633.7 & 2607.0 & 2801.3 & 2661.3 & 2917.6 & 2872.9 & 9.1 \\
\hline Greece & 1214.4 & 1138.9 & 1086.5 & 1004.2 & 1022.5 & 1138.1 & -6.3 \\
\hline Hungary & 1130.6 & 1009.3 & 1046.3 & 1069.0 & 1004.4 & 998.3 & -11.7 \\
\hline $\begin{array}{l}\text { Iceland } \\
\text { Ireland }\end{array}$ & 1223.1 & 1161.2 & $\ldots$ & 1131.2 & 1176.8 & 1155.7 & -5.5 \\
\hline Italy & 1518.1 & 1572.8 & 1639.9 & 1616.1 & 1586.3 & 1474.5 & -2.9 \\
\hline Kosovo (UN R/1244/99) & & & & & & & \\
\hline Latvia & 1182.3 & 1202.5 & 1093.6 & 1097.2 & 1169.9 & 761.7 & -35.6 \\
\hline Lithuania & 797.1 & 968.4 & 1035.9 & 1042.5 & 919.5 & 731.3 & -8.3 \\
\hline Luxembourg & $\ldots$ & $\ldots$ & 5087.0 & 5357.7 & 5051.2 & 4820.3 & $\ldots$ \\
\hline Malta & $\ldots$ & & & & & & \\
\hline Moldova & 535.1 & 582.7 & 448.7 & 496.3 & 482.7 & 471.5 & -11.9 \\
\hline Montenegro & 817.5 & 703.0 & 772.8 & 833.6 & 619.2 & 579.5 & -29.1 \\
\hline Netherlands & 2388.3 & 2232.4 & 2088.3 & 1944.9 & 1784.3 & 1641.4 & -31.3 \\
\hline North Macedonia & 993.0 & 853.3 & 887.9 & 831.7 & 769.4 & 768.3 & -22.6 \\
\hline Norway & 753.0 & 724.6 & 1629.5 & 1589.6 & 1555.0 & 1535.3 & 103.9 \\
\hline Poland & 1370.9 & 1315.0 & 1152.1 & 908.9 & 804.7 & 788.5 & -42.5 \\
\hline Portugal & 2037.0 & 2015.1 & 1906.5 & 1774.8 & 1803.1 & 1704.4 & -16.3 \\
\hline Romania & & & & & & & \\
\hline Russian Federation & 728.9 & 706.7 & 705.6 & 700.2 & 746.2 & 704.0 & -3.4 \\
\hline Serbia & 719.5 & 693.4 & 723.0 & 680.2 & 694.5 & 696.6 & -3.2 \\
\hline Slovak Republic & 983.3 & 990.1 & 995.3 & 942.6 & 856.4 & 800.3 & -18.6 \\
\hline Slovenia & 2626.1 & 2621.4 & 2722.2 & 2960.4 & 2191.9 & 1973.7 & -24.8 \\
\hline Spain & 835.1 & 808.9 & 802.1 & 748.8 & 684.9 & 645.0 & -22.8 \\
\hline Sweden & 2034.5 & 1970.5 & 1842.9 & 1811.5 & 1796.5 & 1763.2 & -13.3 \\
\hline Switzerland & 1708.5 & 1795.8 & 1813.0 & 1663.3 & 1670.5 & 1660.3 & -2.8 \\
\hline Turkey & & & & & & & \\
\hline Ukraine & 494.6 & 429.0 & 359.7 & 315.4 & 313.1 & 262.5 & -46.9 \\
\hline UK: England \& Wales & $\ldots$ & $\ldots$ & $\ldots$ & $\ldots$ & $\ldots$ & $\ldots$ & $\ldots$ \\
\hline $\begin{array}{l}\text { UK: Northern Ireland } \\
\text { UK: Scotland }\end{array}$ & $\ldots$ & $\ldots$ & $\cdots$ & $\ldots$ & $\cdots$ & $\ldots$ & $\ldots$ \\
\hline Mean & 1399 & 1332 & 1470 & 1427 & 1386 & 1347 & \\
\hline Median & 1113 & 1009 & 1087 & 1056 & 1013 & 942 & \\
\hline Minimum & 204 & 184 & 159 & 164 & 170 & 172 & \\
\hline Maximum & 5632 & 5240 & 5093 & 5358 & 5051 & 4820 & \\
\hline
\end{tabular}


Table 1.2.2.2 Offenders per 100000 population - Major road traffic offences

\begin{tabular}{|c|c|c|c|c|c|c|c|}
\hline & 2011 & 2012 & 2013 & 2014 & 2015 & 2016 & $\begin{array}{l}\% \text { change } \\
2011-2016\end{array}$ \\
\hline Albania & 75.9 & 82.5 & 82.2 & 147.9 & 177.0 & 177.2 & 133.3 \\
\hline Armenia & & & & & & & \\
\hline Austria & 461.0 & 439.6 & 418.8 & 397.9 & 405.3 & 411.9 & -10.7 \\
\hline Azerbaijan & 17.3 & 19.8 & 22.3 & 20.9 & 18.2 & 16.5 & -4.6 \\
\hline Belgium & 0.5 & 0.7 & 0.6 & 0.8 & 1.9 & 4.5 & 716.9 \\
\hline Bosnia-Herzegovina & & & & 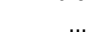 & $\ldots$ & & \\
\hline Bulgaria & 167.8 & 141.0 & 134.2 & 131.5 & 142.6 & 170.9 & 1.9 \\
\hline Croatia & 38.7 & 36.5 & 30.9 & 29.4 & 31.3 & 35.0 & -9.6 \\
\hline Cyprus & & & & & . & & \\
\hline Czech Republic & 58.6 & 59.5 & 54.3 & 57.7 & 56.4 & 57.2 & -2.3 \\
\hline Denmark & $\ldots$ & $\ldots$ & $\ldots$ & $\ldots$ & $\ldots$ & $\ldots$ & $\ldots$ \\
\hline Estonia & & $\ldots$ & & $\ldots$ & $\ldots$ & & \\
\hline Finland & 984.6 & 882.9 & 811.7 & 806.7 & 799.3 & 785.2 & -20.3 \\
\hline France & & & & & & & \\
\hline Georgia & 18.1 & 14.1 & 14.5 & 16.6 & 19.9 & 21.6 & 19.7 \\
\hline Germany & & $\ldots$ & & (1.0 & $\ldots$ & & \\
\hline Greece & 37.4 & 51.8 & 1.3 & 1.7 & 2.2 & 1.9 & -94.9 \\
\hline Hungary & 111.5 & 102.6 & 121.1 & 160.1 & 163.6 & 186.3 & 67.2 \\
\hline Iceland & & 1796 & & 1453 & 1420 & 1494 & -268 \\
\hline $\begin{array}{l}\text { Ireland } \\
\text { Italy }\end{array}$ & $\begin{array}{r}204.1 \\
2.1\end{array}$ & $\begin{array}{r}179.6 \\
1.9\end{array}$ & $\begin{array}{r}151.1 \\
1.8\end{array}$ & $\begin{array}{r}14.3 \\
1.8\end{array}$ & $\begin{array}{r}142.0 \\
1.9\end{array}$ & $\begin{array}{r}149.4 \\
1.9\end{array}$ & $\begin{array}{l}-26.8 \\
-10.8\end{array}$ \\
\hline Kosovo (UN R/1244/99) & $\ldots$ & $\ldots$ & $\ldots$ & $\ldots$ & $\ldots$ & $\ldots$ & $\ldots$ \\
\hline Latvia & & $\ldots$ & & $\ldots$ & $\ldots$ & $\ldots$ & $\ldots$ \\
\hline Lithuania & 32.1 & 34.8 & 33.1 & 32.8 & 34.1 & 21.7 & -32.3 \\
\hline Luxembourg & $\ldots$ & $\ldots$ & $\ldots$ & $\ldots$ & $\ldots$ & $\ldots$ & $\ldots$ \\
\hline Malta & $\ldots$ & $\ldots$ & $\ldots$ & $\ldots$ & $\ldots$ & $\ldots$ & $\ldots$ \\
\hline Moldova & 20.3 & 20.4 & 12.3 & 11.8 & 10.6 & 12.6 & -38.0 \\
\hline Montenegro & 100.3 & 71.9 & 95.7 & 84.0 & 88.2 & 99.3 & -1.0 \\
\hline Netherlands & 382.4 & 346.9 & 310.0 & 293.4 & 254.4 & 248.8 & -34.9 \\
\hline North Macedonia & 155.2 & 133.0 & 136.1 & 119.6 & 121.0 & 125.0 & -19.5 \\
\hline Norway & & & & & & & \\
\hline Poland & 415.8 & 372.1 & 353.5 & 216.7 & 190.0 & 181.8 & -56.3 \\
\hline Portugal & 401.9 & 407.7 & 366.7 & 306.2 & 333.7 & 302.9 & -24.6 \\
\hline Romania & $\ldots$ & $\ldots$ & $\ldots$ & $\ldots$ & $\ldots$ & $\ldots$ & $\ldots$ \\
\hline Russian Federation & & & & & & & \\
\hline Serbia & 120.6 & 113.2 & 117.0 & 109.2 & 111.2 & 115.5 & -4.2 \\
\hline Slovak Republic & $\ldots$ & $\ldots$ & $\ldots$ & $\ldots$ & $\ldots$ & $\ldots$ & $\ldots$ \\
\hline Slovenia & & & & & & & \\
\hline Spain & 112.4 & 102.8 & 95.5 & 88.5 & 76.1 & 69.8 & -37.9 \\
\hline Sweden & 389.0 & 365.2 & 335.5 & 337.2 & 335.9 & 333.6 & -14.3 \\
\hline Switzerland & $\ldots$ & $\ldots$ & $\ldots$ & $\ldots$ & $\ldots$ & $\ldots$ & $\ldots$ \\
\hline Turkey & & $\ldots$ & & $\ldots$ & $\ldots$ & $\ldots$ & $\ldots$ \\
\hline Ukraine & 21.4 & 21.8 & 17.2 & 16.4 & 15.3 & 14.9 & -30.6 \\
\hline UK: England \& Wales & $\ldots$ & $\ldots$ & $\ldots$ & $\ldots$ & $\ldots$ & $\ldots$ & $\ldots$ \\
\hline $\begin{array}{l}\text { UK: Northern Ireland } \\
\text { UK: Scotland }\end{array}$ & $\ldots$ & $\ldots$ & $\ldots$ & $\ldots$ & $\ldots$ & $\ldots$ & $\ldots$ \\
\hline Mean & 180 & 167 & 155 & 147 & 147 & 148 & \\
\hline Median & 106 & 93 & 96 & 99 & 100 & 107 & \\
\hline Minimum & 1 & 1 & 1 & 1 & 2 & 2 & \\
\hline Maximum & 985 & 883 & 812 & 807 & 799 & 785 & \\
\hline
\end{tabular}


Table 1.2.2.3 Offenders per 100000 population - Intentional homicide

\begin{tabular}{|c|c|c|c|c|c|c|c|}
\hline & 2011 & 2012 & 2013 & 2014 & 2015 & 2016 & $\begin{array}{l}\% \text { change } \\
2011-2016\end{array}$ \\
\hline Albania & 12.7 & 13.5 & 7.9 & 10.6 & 9.4 & 8.5 & -33.1 \\
\hline Armenia & & 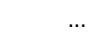 & $\ldots$ & & & & \\
\hline Austria & 2.2 & 2.3 & 2.1 & 1.3 & 1.9 & 2.0 & -9.4 \\
\hline Azerbaijan & 10.2 & 10.9 & 11.0 & 10.0 & 9.4 & 7.6 & -25.5 \\
\hline Belgium & 6.7 & 6.1 & 6.0 & 5.8 & 5.7 & 5.5 & -17.4 \\
\hline Bosnia-Herzegovina & & $\ldots$ & & & & & \\
\hline Bulgaria & 1.6 & 1.5 & 1.2 & 1.6 & 1.7 & 1.7 & 12.0 \\
\hline Croatia & 4.5 & 3.6 & 3.1 & 3.9 & 2.9 & 3.5 & -21.9 \\
\hline Cyprus & & $\ldots$ & $\ldots$ & & & $\ldots$ & \\
\hline Czech Republic & 1.6 & 1.9 & 1.8 & 1.4 & 1.5 & 1.4 & -9.1 \\
\hline Denmark & $\ldots$ & $\ldots$ & $\ldots$ & $\ldots$ & $\ldots$ & $\ldots$ & $\ldots$ \\
\hline Estonia & $\ldots$ & $\ldots$ & $\ldots$ & $\ldots$ & $\ldots$ & $\ldots$ & \\
\hline Finland & 8.6 & 8.8 & 7.1 & 8.4 & 7.2 & 7.7 & -10.9 \\
\hline France & 3.6 & 3.5 & 3.5 & 3.7 & 3.8 & 4.0 & 9.9 \\
\hline Georgia & 7.1 & 6.8 & 6.6 & 5.2 & 6.0 & 5.7 & -19.8 \\
\hline Germany & 3.5 & 3.3 & 3.4 & 3.5 & 3.2 & 3.5 & 1.8 \\
\hline Greece & 2.2 & 2.6 & 4.5 & 2.9 & 3.6 & 2.4 & 11.6 \\
\hline $\begin{array}{l}\text { Hungary } \\
\text { Iceland }\end{array}$ & 2.9 & 2.5 & 2.9 & 2.4 & 2.0 & 2.1 & -28.5 \\
\hline Ireland & 1.2 & 1.3 & 1.3 & 1.4 & 0.7 & 0.7 & -39.6 \\
\hline Italy & 3.5 & 3.8 & 3.7 & 3.6 & 3.7 & 3.3 & -6.6 \\
\hline Kosovo (UN R/1244/99) & $\ldots$ & $\ldots$ & & & & & $\ldots$ \\
\hline Latvia & $\ldots$ & $\ldots$ & 8.3 & 8.1 & 8.2 & 7.2 & \\
\hline Lithuania & 8.6 & 7.1 & 6.9 & 7.3 & 5.3 & 5.6 & -35.3 \\
\hline Luxembourg & $\ldots$ & $\ldots$ & $\ldots$ & $\ldots$ & $\ldots$ & $\ldots$ & $\ldots$ \\
\hline Malta & & $\ldots$ & $\ldots$ & $\ldots$ & $\ldots$ & $\ldots$ & \\
\hline Moldova & 5.8 & 5.6 & 5.3 & 3.8 & 4.1 & 4.2 & -28.0 \\
\hline Montenegro & 3.1 & 3.2 & 1.6 & 2.4 & 2.7 & 3.5 & 15.3 \\
\hline Netherlands & 25.9 & 23.8 & 21.2 & 19.7 & 19.2 & 18.0 & -30.6 \\
\hline North Macedonia & 1.6 & 1.2 & 0.9 & 1.2 & 1.1 & 1.0 & -39.8 \\
\hline Norway & $\ldots$ & $\ldots$ & $\ldots$ & $\ldots$ & $\ldots$ & $\ldots$ & \\
\hline Poland & 2.3 & 2.2 & 1.8 & 1.6 & 1.4 & 1.3 & -42.7 \\
\hline Portugal & $\ldots$ & $\ldots$ & $\ldots$ & $\ldots$ & $\ldots$ & $\ldots$ & $\ldots$ \\
\hline Romania & $\ldots$ & $\ldots$ & $\ldots$ & $\ldots$ & $\ldots$ & $\ldots$ & $\ldots$ \\
\hline Russian Federation & & 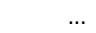 & & & & & \\
\hline Serbia & 4.9 & 4.5 & 5.2 & 4.3 & 3.9 & 4.2 & -13.0 \\
\hline Slovak Republic & & & & & & & \\
\hline Slovenia & 1.1 & 1.2 & 1.0 & 0.8 & 1.2 & 0.8 & -23.3 \\
\hline Spain & 3.0 & 2.8 & 2.3 & 2.4 & 2.3 & 2.7 & -10.9 \\
\hline Sweden & 8.3 & 8.3 & 8.3 & 9.2 & 9.1 & 10.4 & 24.4 \\
\hline Switzerland & 3.2 & 3.3 & 2.6 & 2.5 & 2.4 & 2.6 & -19.3 \\
\hline Turkey & & & & & & & \\
\hline Ukraine & 5.7 & 4.8 & 3.9 & 4.0 & 3.7 & 3.4 & -39.7 \\
\hline UK: England \& Wales & $\ldots$ & $\ldots$ & $\ldots$ & $\ldots$ & $\ldots$ & $\ldots$ & $\ldots$ \\
\hline UK: Northern Ireland & $\ldots$ & $\ldots$ & $\ldots$ & $\ldots$ & $\ldots$ & $\ldots$ & $\ldots$ \\
\hline UK: Scotland & $\ldots$ & $\ldots$ & $\ldots$ & & & 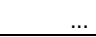 & \\
\hline Mean & 5 & 5 & 5 & 5 & 5 & 4 & \\
\hline Median & 4 & 4 & 4 & 4 & 4 & 4 & \\
\hline Minimum & 1 & 1 & 1 & 1 & 1 & 1 & \\
\hline Maximum & 26 & 24 & 21 & 20 & 19 & 18 & \\
\hline
\end{tabular}


Table 1.2.2.4 Offenders per 100000 population - Intentional homicide: Firearm involved

\begin{tabular}{|c|c|c|c|c|c|c|c|}
\hline & 2011 & 2012 & 2013 & 2014 & 2015 & 2016 & $\begin{array}{l}\% \text { change } \\
2011-2016\end{array}$ \\
\hline Albania & $\ldots$ & $\ldots$ & $\ldots$ & $\ldots$ & $\ldots$ & $\ldots$ & $\ldots$ \\
\hline Armenia & $\ldots$ & $\ldots$ & $\ldots$ & $\ldots$ & $\ldots$ & $\ldots$ & $\ldots$ \\
\hline Austria & $\ldots$ & $\ldots$ & $\ldots$ & $\ldots$ & $\ldots$ & $\ldots$ & $\ldots$ \\
\hline Azerbaijan & $\ldots$ & $\ldots$ & & $\ldots$ & & $\ldots$ & $\ldots$ \\
\hline Belgium & 2.8 & 1.6 & 1.9 & 1.5 & 1.5 & 0.9 & -67 \\
\hline Bosnia-Herzegovina & $\ldots$ & $\ldots$ & & $\ldots$ & & $\ldots$ & $\ldots$ \\
\hline Bulgaria & $\ldots$ & 0.2 & 0.2 & 0.2 & 0.3 & 0.2 & $\ldots$ \\
\hline Croatia & $\ldots$ & $\ldots$ & $\ldots$ & $\ldots$ & $\ldots$ & $\ldots$ & $\ldots$ \\
\hline Cyprus & $\ldots$ & $\ldots$ & $\ldots$ & $\ldots$ & $\ldots$ & $\ldots$ & $\ldots$ \\
\hline Czech Republic & $\ldots$ & $\ldots$ & $\ldots$ & $\ldots$ & $\ldots$ & $\ldots$ & $\ldots$ \\
\hline Denmark & $\ldots$ & $\ldots$ & $\ldots$ & $\ldots$ & $\ldots$ & $\ldots$ & $\ldots$ \\
\hline Estonia & $\ldots$ & $\ldots$ & $\ldots$ & $\ldots$ & $\ldots$ & $\ldots$ & $\ldots$ \\
\hline Finland & $\ldots$ & $\ldots$ & $\ldots$ & $\ldots$ & $\ldots$ & $\ldots$ & $\ldots$ \\
\hline France & $\ldots$ & $\ldots$ & $\ldots$ & $\ldots$ & $\ldots$ & $\ldots$ & $\ldots$ \\
\hline Georgia & $\ldots$ & $\ldots$ & $\ldots$ & $\ldots$ & $\ldots$ & $\ldots$ & $\ldots$ \\
\hline Germany & 0.2 & 0.2 & 0.2 & 0.2 & 0.2 & 0.2 & -1 \\
\hline Greece & $\ldots$ & $\ldots$ & 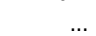 & $\ldots$ & $\ldots$ & $\ldots$ & $\ldots$ \\
\hline Hungary & 0.2 & 0.2 & 0.2 & 0.1 & 0.1 & 0.1 & -52 \\
\hline Iceland & $\ldots$ & $\ldots$ & $\ldots$ & $\ldots$ & $\ldots$ & $\ldots$ & $\ldots$ \\
\hline Ireland & $\ldots$ & $\ldots$ & $\ldots$ & $\ldots$ & $\ldots$ & $\ldots$ & $\ldots$ \\
\hline Italy & $\ldots$ & $\ldots$ & $\ldots$ & $\ldots$ & $\ldots$ & $\ldots$ & $\ldots$ \\
\hline Kosovo (UN R/1244/99) & $\ldots$ & $\ldots$ & $\ldots$ & $\ldots$ & $\ldots$ & $\ldots$ & $\ldots$ \\
\hline Latvia & $\ldots$ & $\ldots$ & $\ldots$ & $\ldots$ & $\ldots$ & $\ldots$ & $\ldots$ \\
\hline Lithuania & $\ldots$ & $\ldots$ & $\ldots$ & $\ldots$ & $\ldots$ & $\ldots$ & $\ldots$ \\
\hline Luxembourg & $\ldots$ & $\ldots$ & $\ldots$ & $\ldots$ & $\ldots$ & $\ldots$ & $\ldots$ \\
\hline Malta & $\ldots$ & & $\ldots$ & $\ldots$ & & $\ldots$ & $\ldots$ \\
\hline Moldova & 0.3 & 0.3 & 0.1 & 0.3 & 0.1 & 0.2 & -43 \\
\hline Montenegro & 1.9 & $\ldots$ & $\ldots$ & $\ldots$ & $\ldots$ & 2.1 & 8 \\
\hline Netherlands & $\ldots$ & $\ldots$ & $\ldots$ & $\ldots$ & $\ldots$ & $\ldots$ & $\ldots$ \\
\hline North Macedonia & 1.1 & 0.8 & 0.4 & 0.5 & 0.8 & 0.3 & $\begin{array}{l}\cdots \\
-73\end{array}$ \\
\hline Norway & 0.0 & 0.0 & 0.0 & 0.0 & 0.0 & 0.0 & $\ldots$ \\
\hline Poland & $\ldots$ & $\ldots$ & $\ldots$ & $\ldots$ & $\ldots$ & $\ldots$ & $\ldots$ \\
\hline Portugal & $\ldots$ & $\ldots$ & $\ldots$ & $\ldots$ & $\ldots$ & $\ldots$ & $\ldots$ \\
\hline Romania & $\ldots$ & & & & & $\ldots$ & $\ldots$ \\
\hline Russian Federation & 0.0 & 0.0 & 0.0 & 0.0 & 0.0 & 0.0 & 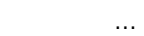 \\
\hline Serbia & 1.1 & 0.5 & 0.9 & 0.7 & 0.5 & 0.6 & -50 \\
\hline Slovak Republic & $\ldots$ & & & & & $\ldots$ & $\ldots$ \\
\hline Slovenia & 0.5 & 0.4 & 0.2 & 0.2 & 0.2 & 0.3 & -40 \\
\hline Spain & 0.5 & 0.4 & 0.4 & 0.3 & 0.3 & 0.5 & 6 \\
\hline Sweden & 2.4 & 2.5 & 2.6 & 2.9 & 2.9 & 3.1 & 32 \\
\hline Switzerland & $\ldots$ & $\ldots$ & $\ldots$ & $\ldots$ & $\ldots$ & $\ldots$ & $\ldots$ \\
\hline Turkey & 5.1 & 5.4 & $\ldots$ & $\ldots$ & $\ldots$ & $\ldots$ & $\ldots$ \\
\hline Ukraine & $\ldots$ & $\ldots$ & $\ldots$ & $\ldots$ & $\ldots$ & $\ldots$ & $\ldots$ \\
\hline UK: England \& Wales & $\ldots$ & $\ldots$ & $\ldots$ & $\ldots$ & $\ldots$ & $\ldots$ & $\ldots$ \\
\hline UK: Northern Ireland & $\ldots$ & $\ldots$ & $\ldots$ & $\ldots$ & $\ldots$ & $\ldots$ & $\ldots$ \\
\hline UK: Scotland & $\ldots$ & $\ldots$ & $\ldots$ & $\ldots$ & P & $\ldots$ & $\ldots$ \\
\hline Mean & 1 & 1 & 1 & 1 & 1 & 1 & \\
\hline Median & 0 & 0 & 0 & 0 & 0 & 0 & \\
\hline Minimum & 0 & 0 & 0 & 0 & 0 & 0 & \\
\hline Maximum & 5 & 5 & 3 & 3 & 3 & 3 & \\
\hline
\end{tabular}


1 Police Statistics

Table 1.2.2.5 Offenders per 100000 population - Intentional homicide completed

\begin{tabular}{|c|c|c|c|c|c|c|c|}
\hline & 2011 & 2012 & 2013 & 2014 & 2015 & 2016 & $\begin{array}{l}\% \text { change } \\
2011-2016\end{array}$ \\
\hline Albania & 4.8 & 5.4 & 4.2 & 3.8 & 2.8 & 2.8 & -42.2 \\
\hline Armenia & $\ldots$ & $\ldots$ & $\ldots$ & $\ldots$ & $\ldots$ & $\ldots$ & $\ldots$ \\
\hline Austria & $\ldots$ & $\ldots$ & $\ldots$ & $\ldots$ & & & $\ldots$ \\
\hline Azerbaijan & 7.1 & 7.5 & 7.8 & 7.2 & 5.8 & 4.6 & -35.1 \\
\hline Belgium & 1.4 & 1.1 & 1.2 & 1.1 & 1.1 & 1.0 & -24.8 \\
\hline Bosnia-Herzegovina & $\ldots$ & $\ldots$ & $\ldots$ & $\ldots$ & $\ldots$ & $\ldots$ & $\ldots$ \\
\hline Bulgaria & $\ldots$ & $\ldots$ & $\ldots$ & $\ldots$ & $\ldots$ & $\ldots$ & $\ldots$ \\
\hline Croatia & $\ldots$ & $\ldots$ & $\ldots$ & $\ldots$ & $\ldots$ & $\ldots$ & $\ldots$ \\
\hline Cyprus & $\ldots$ & $\ldots$ & $\ldots$ & $\ldots$ & $\ldots$ & $\ldots$ & $\ldots$ \\
\hline Czech Republic & $\ldots$ & $\ldots$ & $\ldots$ & $\ldots$ & $\ldots$ & $\ldots$ & $\ldots$ \\
\hline Denmark & $\ldots$ & $\ldots$ & $\ldots$ & $\ldots$ & $\ldots$ & $\ldots$ & $\ldots$ \\
\hline Estonia & $\ldots$ & $\ldots$ & $\ldots$ & $\ldots$ & $\ldots$ & $\ldots$ & $\ldots$ \\
\hline Finland & 2.4 & 1.9 & 2.2 & 2.0 & 1.9 & 1.8 & -25.0 \\
\hline France & & $\ldots$ & $\ldots$ & & & & \\
\hline Georgia & 5.2 & 4.6 & 3.9 & 2.7 & 3.2 & 3.0 & -43.0 \\
\hline Germany & $\ldots$ & $\ldots$ & 0.9 & 1.0 & 0.9 & 1.0 & $\ldots$ \\
\hline Greece & $\ldots$ & $\ldots$ & $\ldots$ & $\ldots$ & $\ldots$ & & $\ldots$ \\
\hline Hungary & 1.6 & 1.3 & 1.7 & 1.3 & 1.1 & 1.1 & -32.1 \\
\hline Iceland & $\ldots$ & $\ldots$ & $\ldots$ & $\ldots$ & $\ldots$ & $\ldots$ & $\ldots$ \\
\hline Ireland & $\ldots$ & $\ldots$ & $\ldots$ & $\ldots$ & $\ldots$ & & $\ldots$ \\
\hline Italy & 1.6 & 1.8 & 1.9 & 1.8 & 1.8 & 1.7 & 6.7 \\
\hline Kosovo (UN R/1244/99) & $\ldots$ & $\ldots$ & $\ldots$ & $\ldots$ & $\ldots$ & $\ldots$ & $\ldots$ \\
\hline Latvia & $\ldots$ & $\ldots$ & $\ldots$ & $\ldots$ & $\ldots$ & $\ldots$ & $\ldots$ \\
\hline Lithuania & $\ldots$ & $\ldots$ & $\ldots$ & $\ldots$ & $\ldots$ & & $\ldots$ \\
\hline Luxembourg & $\ldots$ & $\ldots$ & $\ldots$ & $\ldots$ & 0.5 & 0.5 & $\ldots$ \\
\hline Malta & $\ldots$ & $\ldots$ & $\ldots$ & $\ldots$ & $\ldots$ & $\ldots$ & $\ldots$ \\
\hline Moldova & 4.4 & 4.5 & 4.1 & 2.8 & 3.1 & 3.2 & -27.5 \\
\hline Montenegro & $\ldots$ & $\ldots$ & $\ldots$ & $\ldots$ & $\ldots$ & $\ldots$ & $\ldots$ \\
\hline Netherlands & $\ldots$ & $\ldots$ & $\ldots$ & $\ldots$ & $\ldots$ & $\ldots$ & $\ldots$ \\
\hline North Macedonia & $\ldots$ & $\ldots$ & $\ldots$ & $\ldots$ & $\ldots$ & $\ldots$ & $\ldots$ \\
\hline Norway & $\ldots$ & $\ldots$ & $\ldots$ & $\ldots$ & $\ldots$ & $\ldots$ & $\ldots$ \\
\hline Poland & . & $\ldots$ & $\ldots$ & $\ldots$ & $\ldots$ & & $\ldots$ \\
\hline Portugal & 0.6 & 0.9 & 0.7 & 0.5 & 0.5 & 0.5 & -9.5 \\
\hline Romania & $\ldots$ & $\ldots$ & $\ldots$ & $\ldots$ & $\ldots$ & & $\ldots$ \\
\hline Russian Federation & 0.0 & 0.0 & 0.0 & 0.0 & 0.0 & 0.0 & 0.0 \\
\hline Serbia & 1.9 & 1.6 & 2.2 & 1.8 & 1.5 & 1.8 & -7.0 \\
\hline Slovak Republic & & $\ldots$ & $\ldots$ & $\ldots$ & $\ldots$ & $\ldots$ & \\
\hline Slovenia & 0.7 & 0.8 & 0.5 & 0.6 & 0.7 & 0.5 & -33.8 \\
\hline Spain & 1.2 & 1.1 & 0.8 & 0.8 & 0.9 & 0.9 & -24.2 \\
\hline Sweden & 2.6 & 2.3 & 2.3 & 2.7 & 2.8 & 3.3 & 27.8 \\
\hline Switzerland & $\ldots$ & $\ldots$ & $\ldots$ & $\ldots$ & $\ldots$ & $\ldots$ & $\ldots$ \\
\hline Turkey & $\ldots$ & $\ldots$ & $\ldots$ & $\ldots$ & $\ldots$ & $\ldots$ & $\ldots$ \\
\hline Ukraine & $\ldots$ & $\ldots$ & $\ldots$ & $\ldots$ & $\ldots$ & $\ldots$ & $\ldots$ \\
\hline UK: England \& Wales & $\ldots$ & $\ldots$ & $\ldots$ & $\ldots$ & $\ldots$ & $\ldots$ & $\ldots$ \\
\hline UK: Northern Ireland & $\ldots$ & $\ldots$ & $\ldots$ & $\ldots$ & $\ldots$ & $\ldots$ & $\ldots$ \\
\hline UK: Scotland & & . & $\ldots$ & $\ldots$ & $\ldots$ & $\ldots$ & \\
\hline Mean & 3 & 2 & 2 & 2 & 2 & 2 & \\
\hline Median & 2 & 2 & 2 & 2 & 1 & 1 & \\
\hline Minimum & 0 & 0 & 0 & 0 & 0 & 0 & \\
\hline Maximum & 7 & 8 & 8 & 7 & 6 & 5 & \\
\hline
\end{tabular}


Table 1.2.2.6 Offenders per 100000 population - Intentional homicide completed: Firearm involved

\begin{tabular}{|c|c|c|c|c|c|c|c|}
\hline & 2011 & 2012 & 2013 & 2014 & 2015 & 2016 & $\begin{array}{c}\% \text { change } \\
2011-2016\end{array}$ \\
\hline Albania & & & & & & & \\
\hline Armenia & 0.2 & 0.2 & 0.4 & 0.3 & 0.9 & 0.5 & 172.0 \\
\hline Austria & $\ldots$ & $\ldots$ & $\ldots$ & $\ldots$ & $\ldots$ & $\ldots$ & $\ldots$ \\
\hline Azerbaijan & & & & $\ldots$ & $\ldots$ & & \\
\hline Belgium & 1.2 & 0.2 & 1.0 & 0.3 & 0.3 & 0.1 & -90.9 \\
\hline Bosnia-Herzegovina & $\ldots$ & 1.0 & 0.6 & 0.7 & 0.9 & 0.6 & $\ldots$ \\
\hline Bulgaria & $\ldots$ & $\ldots$ & $\ldots$ & $\ldots$ & $\ldots$ & $\ldots$ & $\ldots$ \\
\hline Croatia & $\ldots$ & $\ldots$ & $\ldots$ & $\ldots$ & $\ldots$ & $\ldots$ & $\ldots$ \\
\hline Cyprus & $\ldots$ & $\ldots$ & $\ldots$ & $\ldots$ & $\ldots$ & $\ldots$ & $\ldots$ \\
\hline Czech Republic & $\ldots$ & $\ldots$ & $\ldots$ & $\ldots$ & $\ldots$ & $\ldots$ & $\ldots$ \\
\hline Denmark & $\ldots$ & $\ldots$ & $\ldots$ & $\ldots$ & $\ldots$ & $\ldots$ & $\ldots$ \\
\hline Estonia & $\ldots$ & $\ldots$ & $\ldots$ & $\ldots$ & $\ldots$ & $\ldots$ & $\ldots$ \\
\hline Finland & $\ldots$ & $\ldots$ & $\ldots$ & $\ldots$ & $\ldots$ & $\ldots$ & $\ldots$ \\
\hline France & $\ldots$ & & $\ldots$ & $\ldots$ & $\ldots$ & $\ldots$ & $\ldots$ \\
\hline Georgia & 0.9 & 1.0 & 0.6 & 0.7 & 0.8 & $\ldots$ & $\ldots$ \\
\hline Germany & $\ldots$ & $\ldots$ & $\ldots$ & $\ldots$ & $\ldots$ & $\ldots$ & $\ldots$ \\
\hline Greece & $\ldots$ & & $\ldots$ & $\ldots$ & $\ldots$ & $\ldots$ & $\ldots$ \\
\hline Hungary & 0.1 & 0.2 & 0.1 & 0.0 & 0.1 & 0.1 & -60.9 \\
\hline Iceland & $\ldots$ & $\ldots$ & $\ldots$ & $\ldots$ & $\ldots$ & $\ldots$ & $\ldots$ \\
\hline Ireland & $\ldots$ & $\ldots$ & $\ldots$ & $\ldots$ & $\ldots$ & $\ldots$ & $\ldots$ \\
\hline Italy & $\ldots$ & $\ldots$ & $\ldots$ & $\ldots$ & $\ldots$ & $\ldots$ & $\ldots$ \\
\hline Kosovo (UN R/1244/99) & $\ldots$ & $\ldots$ & $\ldots$ & $\ldots$ & $\ldots$ & $\ldots$ & $\ldots$ \\
\hline Latvia & $\ldots$ & $\ldots$ & $\ldots$ & $\ldots$ & $\ldots$ & $\ldots$ & $\ldots$ \\
\hline Lithuania & $\ldots$ & $\ldots$ & $\ldots$ & $\ldots$ & $\ldots$ & $\ldots$ & $\ldots$ \\
\hline Luxembourg & $\ldots$ & $\ldots$ & $\ldots$ & $\ldots$ & $\ldots$ & $\ldots$ & $\ldots$ \\
\hline Malta & & & & $\ldots$ & $\ldots$ & $\ldots$ & $\ldots$ \\
\hline Moldova & 0.2 & 0.2 & 0.1 & 0.2 & 0.0 & 0.1 & -64.2 \\
\hline Montenegro & $\ldots$ & $\ldots$ & $\ldots$ & $\ldots$ & $\ldots$ & $\ldots$ & $\ldots$ \\
\hline Netherlands & $\ldots$ & $\ldots$ & $\ldots$ & $\ldots$ & $\ldots$ & $\ldots$ & $\ldots$ \\
\hline North Macedonia & $\ldots$ & & $\ldots$ & $\ldots$ & $\ldots$ & $\ldots$ & $\ldots$ \\
\hline Norway & 1.4 & 0.1 & 0.1 & 0.1 & $\ldots$ & $\ldots$ & $\ldots$ \\
\hline Poland & $\ldots$ & $\ldots$ & $\ldots$ & $\ldots$ & $\ldots$ & $\ldots$ & $\ldots$ \\
\hline Portugal & $\ldots$ & $\ldots$ & $\ldots$ & $\ldots$ & $\ldots$ & $\ldots$ & $\ldots$ \\
\hline Romania & $\ldots$ & $\ldots$ & $\ldots$ & $\ldots$ & $\ldots$ & $\ldots$ & $\ldots$ \\
\hline Russian Federation & $\ldots$ & & $\ldots$ & $\ldots$ & $\ldots$ & $\ldots$ & $\ldots$ \\
\hline Serbia & 0.5 & 0.2 & 0.5 & 0.2 & 0.2 & 0.4 & -16.2 \\
\hline Slovak Republic & & 0.2 & 0.3 & 0.3 & $\ldots$ & & \\
\hline Slovenia & 0.5 & 0.4 & 0.2 & 0.2 & 0.2 & 0.3 & -40.4 \\
\hline Spain & 0.2 & 0.2 & 0.1 & 0.1 & 0.1 & 0.1 & -25.0 \\
\hline Sweden & 0.8 & 0.8 & 0.7 & 1.1 & 1.1 & 1.0 & 20.7 \\
\hline Switzerland & $\ldots$ & $\ldots$ & $\ldots$ & $\ldots$ & $\ldots$ & $\ldots$ & $\ldots$ \\
\hline Turkey & $\ldots$ & $\ldots$ & $\ldots$ & $\ldots$ & $\ldots$ & $\ldots$ & $\ldots$ \\
\hline Ukraine & $\ldots$ & $\ldots$ & $\ldots$ & $\ldots$ & $\ldots$ & $\ldots$ & $\ldots$ \\
\hline UK: England \& Wales & $\ldots$ & $\ldots$ & $\ldots$ & $\ldots$ & $\ldots$ & $\ldots$ & $\ldots$ \\
\hline UK: Northern Ireland & $\ldots$ & $\ldots$ & $\ldots$ & $\ldots$ & $\ldots$ & $\ldots$ & $\ldots$ \\
\hline UK: Scotland & & & & $\ldots$ & $\ldots$ & & \\
\hline Mean & 0.6 & 0.4 & 0.4 & 0.4 & 0.5 & 0.3 & \\
\hline Median & 0.5 & 0.2 & 0.3 & 0.3 & 0.3 & 0.3 & \\
\hline Minimum & 0.1 & 0.1 & 0.1 & 0.0 & 0.0 & 0.1 & \\
\hline Maximum & 1.4 & 1.0 & 1.0 & 1.1 & 1.1 & 1.0 & \\
\hline
\end{tabular}


1 Police Statistics

Table 1.2.2.7 Offenders per 100000 population - Bodily injury

\begin{tabular}{|c|c|c|c|c|c|c|c|}
\hline & 2011 & 2012 & 2013 & 2014 & 2015 & 2016 & $\begin{array}{c}\% \text { change } \\
2011-2016\end{array}$ \\
\hline Albania & 50.1 & 55.1 & 55.2 & 68.1 & 67.5 & 57.5 & 14.6 \\
\hline Armenia & & & & & & & \\
\hline Austria & 452.0 & 464.2 & 444.6 & 441.7 & 446.7 & 464.2 & 2.7 \\
\hline Azerbaijan & & & & & & (1) & \\
\hline Belgium & 349.9 & 281.2 & 268.2 & 265.6 & 269.2 & 271.1 & -22.5 \\
\hline Bosnia-Herzegovina & & & & $\ldots$ & & . & \\
\hline Bulgaria & 9.3 & 8.3 & 7.9 & 7.9 & 6.9 & 9.1 & -2.3 \\
\hline Croatia & 41.4 & 39.8 & 42.6 & 38.0 & 39.7 & 41.6 & 0.5 \\
\hline Cyprus & $\ldots$ & $\ldots$ & & $\ldots$ & & $\ldots$ & \\
\hline Czech Republic & 41.2 & 44.4 & 43.0 & 42.1 & 41.1 & 44.4 & 7.7 \\
\hline Denmark & $\ldots$ & $\ldots$ & $\ldots$ & $\ldots$ & $\ldots$ & $\ldots$ & $\ldots$ \\
\hline Estonia & $\ldots$ & & & $\ldots$ & & $\ldots$ & $\ldots$ \\
\hline Finland & 617.2 & 596.8 & 553.8 & 499.6 & 472.9 & 451.6 & -26.8 \\
\hline France & 299.3 & 300.9 & 303.1 & 307.2 & 314.3 & 316.3 & 5.7 \\
\hline Georgia & $\ldots$ & 111.4 & 121.0 & 109.1 & 142.7 & 146.6 & $\ldots$ \\
\hline Germany & 552.9 & 552.2 & 537.7 & 529.1 & 526.7 & 564.8 & 2.2 \\
\hline Greece & 50.5 & 47.0 & 56.4 & 56.7 & 57.4 & 56.7 & -12.3 \\
\hline Hungary & 56.7 & 52.4 & 55.2 & 52.7 & 50.1 & 46.9 & -17.2 \\
\hline Iceland & 302.1 & 304.5 & $\ldots$ & 327.9 & 408.4 & 436.4 & 44.4 \\
\hline Ireland & & & & & & & \\
\hline Italy & 105.3 & 108.8 & 107.2 & 105.7 & 103.4 & 102.5 & -2.6 \\
\hline Kosovo (UN R/1244/99) & $\ldots$ & $\ldots$ & $\ldots$ & $\ldots$ & $\ldots$ & $\ldots$ & $\ldots$ \\
\hline Latvia & $\ldots$ & $\ldots$ & $\ldots$ & $\ldots$ & & $\ldots$ & $\ldots$ \\
\hline Lithuania & 79.7 & 256.9 & 318.0 & 316.4 & 310.7 & 233.8 & 193.4 \\
\hline Luxembourg & $\ldots$ & $\ldots$ & $\ldots$ & $\ldots$ & $\ldots$ & $\ldots$ & $\ldots$ \\
\hline Malta & $\ldots$ & & $\ldots$ & $\ldots$ & & $\ldots$ & $\ldots$ \\
\hline Moldova & 31.1 & 32.0 & 19.9 & 20.8 & 17.4 & 18.1 & -41.8 \\
\hline Montenegro & 80.0 & 90.9 & 82.8 & 61.9 & 57.1 & 54.0 & -32.5 \\
\hline Netherlands & 307.5 & 289.4 & 262.8 & 242.2 & 227.5 & 211.4 & -31.2 \\
\hline North Macedonia & 34.9 & 34.9 & 33.2 & 40.6 & 40.9 & 36.4 & 4.2 \\
\hline Norway & & & & & & & \\
\hline Poland & 131.8 & 123.9 & 105.6 & 92.7 & 77.2 & 81.3 & -38.3 \\
\hline Portugal & 605.4 & 576.9 & 565.2 & 560.2 & 543.9 & 543.7 & -10.2 \\
\hline Romania & $\ldots$ & $\ldots$ & $\ldots$ & $\ldots$ & $\ldots$ & $\ldots$ & $\ldots$ \\
\hline Russian Federation & & & & $\ldots$ & & & \\
\hline Serbia & 46.7 & 45.7 & 43.9 & 40.1 & 41.2 & 38.4 & -17.7 \\
\hline Slovak Republic & & & & & & & \\
\hline Slovenia & 95.2 & 98.6 & 88.4 & 79.0 & 73.4 & 70.7 & -25.7 \\
\hline Spain & 34.9 & 32.2 & 31.1 & 31.5 & 35.5 & 27.1 & -22.5 \\
\hline Sweden & 512.1 & 475.0 & 435.0 & 420.2 & 426.1 & 417.8 & -18.4 \\
\hline Switzerland & 109.8 & 108.4 & 102.5 & 95.3 & 88.7 & 92.7 & -15.6 \\
\hline Turkey & & & $\ldots$ & $\ldots$ & $\ldots$ & $\ldots$ & $\ldots$ \\
\hline Ukraine & 20.0 & 18.3 & $\ldots$ & $\ldots$ & $\ldots$ & $\ldots$ & $\ldots$ \\
\hline UK: England \& Wales & $\ldots$ & $\ldots$ & $\ldots$ & $\ldots$ & $\ldots$ & $\ldots$ & $\ldots$ \\
\hline UK: Northern Ireland & $\ldots$ & $\ldots$ & $\ldots$ & $\ldots$ & $\ldots$ & $\ldots$ & $\ldots$ \\
\hline UK: Scotland & $\ldots$ & $\ldots$ & & $\ldots$ & & $\ldots$ & $\ldots$ \\
\hline Mean & 193 & 191 & 187 & 187 & 188 & 186 & \\
\hline Median & 88 & 108 & 103 & 94 & 83 & 87 & \\
\hline Minimum & 9 & 8 & 8 & 8 & 7 & 9 & \\
\hline Maximum & 617 & 597 & 562 & 557 & 542 & 565 & \\
\hline
\end{tabular}


Table 1.2.2.8 Offenders per 100000 population - Aggravated bodily injury

\begin{tabular}{|c|c|c|c|c|c|c|c|}
\hline & 2011 & 2012 & 2013 & 2014 & 2015 & 2016 & $\begin{array}{c}\% \text { change } \\
2011-2016\end{array}$ \\
\hline Albania & $\ldots$ & $\ldots$ & $\ldots$ & $\ldots$ & $\ldots$ & $\ldots$ & $\ldots$ \\
\hline Armenia & $\ldots$ & $\ldots$ & $\ldots$ & $\ldots$ & $\ldots$ & & $\ldots$ \\
\hline Austria & 44.2 & 45.8 & 42.6 & 45.0 & 42.8 & 45.9 & 3.8 \\
\hline Azerbaijan & 2.5 & 3.6 & 3.6 & 3.8 & 3.2 & 3.0 & 19.9 \\
\hline Belgium & $\ldots$ & $\ldots$ & $\ldots$ & $\ldots$ & $\ldots$ & $\ldots$ & $\ldots$ \\
\hline Bosnia-Herzegovina & $\ldots$ & $\ldots$ & $\ldots$ & $\ldots$ & $\ldots$ & $\ldots$ & $\ldots$ \\
\hline Bulgaria & 0.3 & 0.2 & 0.3 & 0.2 & 0.1 & 0.3 & -22.7 \\
\hline Croatia & 23.4 & 23.3 & 21.6 & 18.6 & 21.9 & 25.1 & 7.4 \\
\hline Cyprus & $\ldots$ & $\ldots$ & $\ldots$ & $\ldots$ & $\ldots$ & $\ldots$ & $\ldots$ \\
\hline Czech Republic & $\ldots$ & $\ldots$ & $\ldots$ & $\ldots$ & $\ldots$ & $\ldots$ & $\ldots$ \\
\hline Denmark & $\begin{array}{l}\cdots \\
\ldots\end{array}$ & $\begin{array}{l}\cdots \\
\ldots\end{array}$ & $\begin{array}{l}\cdots \\
\ldots\end{array}$ & $\begin{array}{l}\cdots \\
\ldots\end{array}$ & $\begin{array}{l}\cdots \\
\ldots\end{array}$ & $\begin{array}{l}\cdots \\
\ldots\end{array}$ & $\begin{array}{l}\cdots \\
\cdots\end{array}$ \\
\hline Estonia & $\ldots$ & $\ldots$ & $\ldots$ & $\ldots$ & $\ldots$ & $\ldots$ & $\ldots$ \\
\hline Finland & 41.2 & 35.8 & 36.5 & 31.2 & 29.6 & 29.3 & -28.8 \\
\hline France & & & $\ldots$ & $\ldots$ & & & \\
\hline Georgia & 2.3 & 2.7 & 4.2 & 5.1 & 5.3 & 5.0 & 112.8 \\
\hline Germany & 191.1 & 183.2 & 171.6 & 166.0 & 165.7 & 182.0 & -4.8 \\
\hline Greece & $\ldots$ & $\ldots$ & $\ldots$ & $\ldots$ & & & \\
\hline Hungary & 45.9 & 42.9 & 45.7 & 42.8 & 40.2 & 36.7 & -20.2 \\
\hline Iceland & $\ldots$ & $\ldots$ & $\ldots$ & $\ldots$ & $\ldots$ & $\ldots$ & $\ldots$ \\
\hline Ireland & $\ldots$ & $\ldots$ & $\ldots$ & $\ldots$ & $\ldots$ & & $\ldots$ \\
\hline Italy & 88.6 & 91.2 & 89.8 & 88.4 & 86.2 & 86.5 & -2.4 \\
\hline Kosovo (UN R/1244/99) & $\ldots$ & $\ldots$ & $\ldots$ & $\ldots$ & $\ldots$ & $\ldots$ & $\ldots$ \\
\hline Latvia & $\ldots$ & $\ldots$ & $\ldots$ & $\ldots$ & $\ldots$ & $\ldots$ & $\ldots$ \\
\hline Lithuania & 8.5 & 7.7 & 8.4 & 8.0 & 5.7 & 6.1 & -27.9 \\
\hline Luxembourg & $\ldots$ & $\ldots$ & $\ldots$ & $\ldots$ & $\ldots$ & $\ldots$ & $\ldots$ \\
\hline Malta & $\ldots$ & $\ldots$ & $\ldots$ & $\ldots$ & & $\ldots$ & $\ldots$ \\
\hline Moldova & 27.3 & 27.4 & 16.2 & 16.2 & 13.7 & 13.9 & -49.0 \\
\hline Montenegro & 33.1 & 34.0 & 31.7 & 22.0 & 24.4 & 21.5 & -34.9 \\
\hline Netherlands & $\ldots$ & & & & & & \\
\hline North Macedonia & 14.2 & 12.2 & 11.7 & 11.8 & 9.2 & 10.1 & -29.2 \\
\hline Norway & $\ldots$ & $\ldots$ & $\ldots$ & .1. & 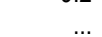 & . & ... \\
\hline Poland & 2.8 & 3.1 & 2.2 & 2.2 & 1.9 & 1.9 & -34.1 \\
\hline Portugal & 7.0 & 6.8 & 5.1 & 4.4 & 4.7 & 4.6 & -34.3 \\
\hline Romania & $\ldots$ & $\ldots$ & $\ldots$ & $\ldots$ & $\ldots$ & $\ldots$ & $\ldots$ \\
\hline Russian Federation & $\ldots$ & & $\ldots$ & $\ldots$ & & & \\
\hline Serbia & 21.2 & 20.8 & 20.3 & 17.8 & 18.3 & 16.7 & -21.2 \\
\hline Slovak Republic & & & & & & & \\
\hline Slovenia & 10.0 & 9.3 & 8.2 & 8.5 & 7.6 & 6.8 & -31.7 \\
\hline Spain & $\ldots$ & $\ldots$ & $\ldots$ & $\ldots$ & $\ldots$ & $\ldots$ & $\ldots$ \\
\hline Sweden & $\ldots$ & $\ldots$ & $\ldots$ & $\ldots$ & $\ldots$ & & \\
\hline Switzerland & 12.4 & 13.0 & 11.3 & 12.8 & 12.2 & 11.8 & -4.2 \\
\hline Turkey & & & & & & & \\
\hline Ukraine & 7.6 & 7.0 & 5.8 & 5.3 & 4.8 & 4.5 & -41.4 \\
\hline UK: England \& Wales & $\ldots$ & $\ldots$ & $\ldots$ & $\ldots$ & $\ldots$ & $\ldots$ & $\ldots$ \\
\hline UK: Northern Ireland & $\ldots$ & $\ldots$ & $\ldots$ & $\ldots$ & $\ldots$ & $\ldots$ & $\ldots$ \\
\hline UK: Scotland & $\ldots$ & $\ldots$ & $\ldots$ & $\ldots$ & & & $\ldots$ \\
\hline Mean & 30.7 & 30.0 & 28.2 & 26.8 & 26.2 & 26.9 & \\
\hline Median & 14.2 & 13.0 & 11.7 & 12.8 & 12.2 & 11.8 & \\
\hline Minimum & 0.3 & 0.2 & 0.3 & 0.2 & 0.1 & 0.3 & \\
\hline Maximum & 191.1 & 183.2 & 171.6 & 166.0 & 165.7 & 182.0 & \\
\hline
\end{tabular}


1 Police Statistics

Table 1.2.2.9 Offenders per 100000 population - Sexual assault

\begin{tabular}{|c|c|c|c|c|c|c|c|}
\hline & 2011 & 2012 & 2013 & 2014 & 2015 & 2016 & $\begin{array}{c}\% \text { change } \\
2011-2016\end{array}$ \\
\hline Albania & 1.4 & 1.6 & 3.0 & 3.5 & 5.5 & 4.1 & 186.5 \\
\hline Armenia & & & & & $\ldots$ & & \\
\hline Austria & 34.7 & 35.1 & 33.1 & 32.8 & 31.1 & 40.6 & 16.8 \\
\hline Azerbaijan & & & $\ldots$ & $\ldots$ & $\ldots$ & $\ldots$ & \\
\hline Belgium & 13.3 & 11.7 & 11.4 & 11.2 & 10.3 & 10.0 & -25.0 \\
\hline Bosnia-Herzegovina & & $\ldots$ & $\ldots$ & $\ldots$ & $\ldots$ & 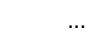 & \\
\hline Bulgaria & 4.8 & 4.9 & 4.5 & 4.6 & 4.0 & 3.9 & -19.6 \\
\hline Croatia & 8.9 & 8.2 & 8.3 & 9.0 & 9.0 & 9.9 & 11.5 \\
\hline Cyprus & & $\ldots$ & $\ldots$ & $\ldots$ & $\ldots$ & $\ldots$ & \\
\hline Czech Republic & 8.7 & 9.1 & 9.1 & 8.9 & 8.9 & 10.1 & 15.3 \\
\hline Denmark & $\ldots$ & $\ldots$ & $\ldots$ & $\ldots$ & $\ldots$ & $\ldots$ & $\ldots$ \\
\hline Estonia & $\ldots$ & $\ldots$ & $\ldots$ & $\ldots$ & $\ldots$ & $\ldots$ & $\ldots$ \\
\hline Finland & 39.3 & 53.5 & 45.1 & 41.3 & 41.2 & 40.1 & 1.9 \\
\hline France & 43.6 & 44.9 & 43.9 & 45.0 & 45.9 & 45.8 & 5.1 \\
\hline Georgia & 2.8 & 9.4 & 9.0 & 7.1 & 8.3 & 8.0 & 182.8 \\
\hline Germany & 25.7 & 24.9 & 24.0 & 23.2 & 22.3 & 24.2 & -5.9 \\
\hline Greece & 6.0 & 9.8 & 16.0 & 12.7 & 11.4 & 11.9 & 97.2 \\
\hline Hungary & 5.2 & 5.6 & 5.9 & 6.2 & 6.8 & 7.1 & 37.1 \\
\hline Iceland & & & & & & & \\
\hline Ireland & 25.9 & 23.9 & 21.5 & 20.1 & 20.2 & 19.0 & -26.5 \\
\hline Italy & 9.0 & 8.5 & 8.4 & 7.8 & 7.6 & 7.4 & -17.3 \\
\hline Kosovo (UN R/1244/99) & $\ldots$ & $\ldots$ & $\ldots$ & $\ldots$ & $\ldots$ & $\ldots$ & $\ldots$ \\
\hline Latvia & $\ldots$ & $\ldots$ & 9.9 & 11.0 & 10.7 & 9.4 & $\ldots$ \\
\hline Lithuania & 12.3 & 8.5 & 7.4 & 8.7 & 8.0 & 7.1 & -42.7 \\
\hline Luxembourg & $\ldots$ & $\ldots$ & $\ldots$ & $\ldots$ & $\ldots$ & $\ldots$ & $\ldots$ \\
\hline Malta & $\ldots$ & $\ldots$ & $\ldots$ & $\ldots$ & $\ldots$ & $\ldots$ & $\ldots$ \\
\hline Moldova & 9.8 & 11.3 & 7.8 & 8.7 & 9.6 & 7.7 & -21.4 \\
\hline Montenegro & 5.0 & 4.2 & 4.0 & 4.3 & 4.5 & 3.9 & -22.9 \\
\hline Netherlands & 22.2 & 19.8 & 18.1 & 16.2 & 15.7 & 14.4 & -35.0 \\
\hline North Macedonia & 6.7 & 5.3 & 7.1 & 7.2 & 5.5 & 4.9 & -26.8 \\
\hline Norway & & $\ldots$ & & $\ldots$ & $\ldots$ & & \\
\hline Poland & 4.7 & 4.4 & 3.9 & 3.4 & 3.1 & 3.3 & -30.3 \\
\hline Portugal & 10.5 & 10.1 & 10.9 & 10.7 & 11.0 & 11.5 & 9.7 \\
\hline Romania & $\ldots$ & $\ldots$ & $\ldots$ & $\ldots$ & $\ldots$ & $\ldots$ & $\ldots$ \\
\hline Russian Federation & & 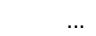 & $\ldots$ & $\ldots$ & $\ldots$ & $\ldots$ & $\ldots$ \\
\hline Serbia & 4.7 & 4.4 & 4.0 & 3.8 & 3.6 & 4.1 & -13.0 \\
\hline Slovak Republic & & & & & $\ldots$ & & \\
\hline Slovenia & 15.6 & 14.2 & 14.6 & 9.8 & 8.0 & 10.6 & -32.3 \\
\hline Spain & 14.4 & 13.3 & 12.5 & 13.3 & 13.0 & 13.7 & -4.5 \\
\hline Sweden & 57.2 & 55.3 & 52.9 & 53.0 & 55.6 & 60.0 & 4.9 \\
\hline Switzerland & 30.9 & 30.6 & 30.5 & 32.5 & 30.3 & 32.3 & 4.7 \\
\hline Turkey & $\ldots$ & & & $\ldots$ & $\ldots$ & $\ldots$ & $\ldots$ \\
\hline Ukraine & $\ldots$ & 1.8 & 1.2 & 0.9 & 0.7 & 0.8 & $\ldots$ \\
\hline UK: England \& Wales & $\ldots$ & $\ldots$ & $\ldots$ & $\ldots$ & $\ldots$ & $\ldots$ & $\ldots$ \\
\hline $\begin{array}{l}\text { UK: Northern Ireland } \\
\text { UK: Scotland }\end{array}$ & $\ldots$ & $\cdots$ & $\cdots$ & $\cdots$ & $\ldots$ & $\ldots$ & $\ldots$ \\
\hline Mean & 16 & 16 & 15 & 15 & 15 & 15 & \\
\hline Median & 10 & 10 & 10 & 9 & 9 & 10 & \\
\hline Minimum & 1 & 2 & 1 & 1 & 1 & 1 & \\
\hline Maximum & 57 & 55 & 53 & 53 & 56 & 60 & \\
\hline
\end{tabular}


Table 1.2.2.10 Offenders per 100000 population - Rape

\begin{tabular}{|c|c|c|c|c|c|c|c|}
\hline & 2011 & 2012 & 2013 & 2014 & 2015 & 2016 & $\begin{array}{c}\% \text { change } \\
2011-2016\end{array}$ \\
\hline Albania & $\ldots$ & $\ldots$ & $\ldots$ & $\ldots$ & $\ldots$ & $\ldots$ & $\ldots$ \\
\hline Armenia & & $\ldots$ & $\ldots$ & $\ldots$ & $\ldots$ & $\ldots$ & $\ldots$ \\
\hline Austria & 14.3 & 13.6 & 12.8 & 13.0 & 12.4 & 14.9 & 3.7 \\
\hline Azerbaijan & 0.2 & 0.1 & 0.1 & 0.3 & 0.3 & 0.2 & 25.2 \\
\hline Belgium & 5.7 & 5.2 & 4.8 & 4.3 & 4.2 & 3.7 & -34.9 \\
\hline Bosnia-Herzegovina & & $\ldots$ & $\ldots$ & $\ldots$ & $\ldots$ & $\ldots$ & \\
\hline Bulgaria & 1.3 & 1.8 & 1.5 & 1.5 & 1.0 & 1.3 & -1.4 \\
\hline Croatia & 4.8 & 4.3 & 4.7 & 5.8 & 5.8 & 5.5 & 15.8 \\
\hline Cyprus & & & $\ldots$ & $\ldots$ & $\ldots$ & $\ldots$ & \\
\hline Czech Republic & 3.9 & 3.8 & 3.5 & 3.7 & 3.7 & 4.4 & 13.6 \\
\hline Denmark & $\ldots$ & $\ldots$ & $\ldots$ & $\ldots$ & $\ldots$ & $\ldots$ & ... \\
\hline Estonia & $\ldots$ & $\ldots$ & $\ldots$ & $\ldots$ & $\ldots$ & $\ldots$ & ... \\
\hline Finland & 12.0 & 14.3 & 14.7 & 13.2 & 14.8 & 15.1 & 25.6 \\
\hline France & 12.1 & 12.4 & 13.0 & 13.5 & 14.2 & 14.8 & 22.3 \\
\hline Georgia & 0.8 & 0.8 & 0.5 & 0.3 & 0.3 & 0.3 & -57.8 \\
\hline Germany & 8.6 & 8.9 & 8.4 & 7.2 & 7.7 & 8.2 & -4.3 \\
\hline Greece & 1.5 & 1.4 & 1.9 & 1.8 & 1.7 & 2.2 & 42.0 \\
\hline Hungary & 2.3 & 2.6 & 2.2 & 2.3 & 2.6 & 2.6 & 13.2 \\
\hline Iceland & & & & & & & \\
\hline Ireland & 6.5 & 5.8 & 4.9 & 5.8 & 5.3 & 4.5 & -31.4 \\
\hline Italy & 7.8 & 7.5 & 7.4 & 6.8 & 6.6 & 6.5 & -17.3 \\
\hline Kosovo (UN R/1244/99) & $\ldots$ & $\ldots$ & $\ldots$ & $\ldots$ & $\ldots$ & $\ldots$ & ... \\
\hline Latvia & $\ldots$ & $\ldots$ & 4.2 & 4.8 & 3.9 & 6.1 & ... \\
\hline Lithuania & 10.1 & 6.7 & 6.0 & 7.0 & 5.7 & 5.2 & -48.2 \\
\hline Luxembourg & $\ldots$ & $\ldots$ & $\ldots$ & $\ldots$ & $\ldots$ & $\ldots$ & $\ldots$ \\
\hline Malta & & $\ldots$ & $\ldots$ & $\ldots$ & $\ldots$ & $\ldots$ & ... \\
\hline Moldova & 5.9 & 7.1 & 4.8 & 4.8 & 4.6 & 4.3 & -26.8 \\
\hline Montenegro & 0.5 & 0.5 & 0.5 & 0.6 & 0.8 & 0.3 & -33.6 \\
\hline Netherlands & 5.7 & 4.9 & 4.2 & 3.8 & 3.7 & 3.4 & -40.8 \\
\hline North Macedonia & 1.9 & 1.7 & 1.7 & 2.3 & 1.6 & 1.6 & -16.0 \\
\hline Norway & & $\ldots$ & $\ldots$ & $\ldots$ & $\ldots$ & $\ldots$ & \\
\hline Poland & 2.5 & 2.1 & 1.8 & 1.7 & 1.5 & 1.8 & -27.9 \\
\hline Portugal & 1.4 & 1.4 & 1.6 & 1.4 & 1.4 & 1.4 & 2.2 \\
\hline Romania & $\ldots$ & $\ldots$ & $\ldots$ & $\ldots$ & $\ldots$ & $\ldots$ & ... \\
\hline Russian Federation & & & $\ldots$ & $\ldots$ & $\ldots$ & $\ldots$ & \\
\hline Serbia & 1.2 & 1.3 & 1.2 & 0.8 & 0.9 & 0.7 & -39.7 \\
\hline Slovak Republic & & & & & & & \\
\hline Slovenia & 2.5 & 2.9 & 2.3 & 2.1 & 2.0 & 1.5 & -41.6 \\
\hline Spain & 2.4 & 2.0 & 2.0 & 2.0 & 1.8 & 1.9 & -20.5 \\
\hline Sweden & 30.6 & 30.2 & 29.1 & 29.2 & 29.2 & 29.8 & -2.8 \\
\hline Switzerland & 5.8 & 5.8 & 5.4 & 5.7 & 5.1 & 5.9 & 3.0 \\
\hline Turkey & & & & & $\ldots$ & & \\
\hline Ukraine & 1.2 & 1.0 & 0.7 & 0.6 & 0.4 & 0.5 & -56.8 \\
\hline UK: England \& Wales & $\ldots$ & $\ldots$ & $\ldots$ & $\ldots$ & $\ldots$ & $\ldots$ & ... \\
\hline UK: Northern Ireland & $\ldots$ & $\ldots$ & $\ldots$ & $\ldots$ & $\ldots$ & $\ldots$ & $\ldots$ \\
\hline UK: Scotland & & & $\ldots$ & $\ldots$ & $\ldots$ & $\ldots$ & \\
\hline Mean & 5.7 & 5.6 & 5.2 & 5.2 & 5.1 & 5.3 & \\
\hline Median & 3.9 & 3.8 & 3.8 & 3.8 & 3.7 & 3.5 & \\
\hline Minimum & 0.2 & 0.1 & 0.1 & 0.3 & 0.3 & 0.2 & \\
\hline Maximum & 30.6 & 30.2 & 29.1 & 29.2 & 29.2 & 29.8 & \\
\hline
\end{tabular}


Table 1.2.2.11 Offenders per 100000 population - Sexual abuse of a child

\begin{tabular}{|c|c|c|c|c|c|c|c|}
\hline & 2011 & 2012 & 2013 & 2014 & 2015 & 2016 & $\begin{array}{c}\% \text { change } \\
2011-2016\end{array}$ \\
\hline Albania & $\ldots$ & $\ldots$ & $\ldots$ & $\ldots$ & $\ldots$ & $\ldots$ & $\ldots$ \\
\hline Armenia & & & & $\ldots$ & & $\ldots$ & \\
\hline Austria & 8.2 & 8.8 & 8.5 & 8.2 & 7.7 & 7.3 & -10.5 \\
\hline Azerbaijan & & $\ldots$ & $\ldots$ & $\ldots$ & $\ldots$ & $\ldots$ & \\
\hline Belgium & 5.0 & 4.3 & 4.1 & 4.5 & 4.3 & 4.0 & -19.2 \\
\hline Bosnia-Herzegovina & & & $\ldots$ & $\ldots$ & $\ldots$ & $\ldots$ & \\
\hline Bulgaria & 0.9 & 0.9 & 1.0 & 1.0 & 1.0 & 0.8 & -13.9 \\
\hline Croatia & 2.4 & 2.2 & 0.8 & 1.1 & 1.5 & 1.0 & -55.4 \\
\hline Cyprus & $\ldots$ & $\ldots$ & & $\ldots$ & $\ldots$ & $\ldots$ & \\
\hline Czech Republic & 4.7 & 5.2 & 5.5 & 5.0 & 5.1 & 5.4 & 15.5 \\
\hline Denmark & $\ldots$ & $\ldots$ & $\ldots$ & $\ldots$ & $\ldots$ & $\ldots$ & $\ldots$ \\
\hline Estonia & $\ldots$ & $\ldots$ & $\ldots$ & $\ldots$ & $\ldots$ & $\ldots$ & \\
\hline Finland & 20.1 & 26.3 & 19.8 & 21.3 & 18.8 & 16.3 & -19.1 \\
\hline France & 8.3 & 10.7 & 11.0 & 11.8 & 12.5 & 12.7 & 51.8 \\
\hline Georgia & & & & & & & \\
\hline Germany & 8.2 & 7.9 & 7.9 & 7.3 & 7.2 & 7.2 & -11.6 \\
\hline Greece & $\ldots$ & $\ldots$ & $\ldots$ & $\ldots$ & $\ldots$ & $\ldots$ & \\
\hline Hungary & 0.2 & 0.2 & 0.2 & 0.3 & 0.3 & 0.4 & 89.3 \\
\hline Iceland & & & & & & & \\
\hline Ireland & 2.3 & 1.9 & 1.0 & 1.7 & 1.3 & 1.5 & -34.9 \\
\hline Italy & 1.1 & 1.1 & 1.0 & 1.0 & 1.0 & 0.9 & -16.9 \\
\hline Kosovo (UN R/1244/99) & $\ldots$ & $\ldots$ & $\ldots$ & $\ldots$ & $\ldots$ & $\ldots$ & $\ldots$ \\
\hline Latvia & $\ldots$ & $\ldots$ & $\ldots$ & $\ldots$ & $\ldots$ & $\ldots$ & \\
\hline Lithuania & 1.9 & 1.7 & 1.2 & 1.3 & 2.1 & 1.8 & -3.6 \\
\hline Luxembourg & $\ldots$ & $\ldots$ & $\ldots$ & $\ldots$ & $\ldots$ & $\ldots$ & $\ldots$ \\
\hline Malta & $\ldots$ & $\ldots$ & $\ldots$ & $\ldots$ & $\ldots$ & $\ldots$ & $\ldots$ \\
\hline Moldova & 3.8 & 4.0 & 3.0 & 3.5 & 5.0 & 3.4 & -10.8 \\
\hline Montenegro & 0.3 & 0.2 & 0.8 & 0.5 & 0.2 & 0.2 & -50.2 \\
\hline Netherlands & & & & ... & & ... & \\
\hline North Macedonia & 1.8 & 1.7 & 2.5 & 2.6 & 1.8 & 1.4 & -24.8 \\
\hline Norway & & & & & & & \\
\hline Poland & 2.3 & 2.3 & 2.1 & 1.7 & 1.5 & 1.5 & -32.9 \\
\hline Portugal & 3.1 & 3.0 & 3.3 & 3.9 & 3.5 & 3.3 & 4.1 \\
\hline Romania & $\ldots$ & $\ldots$ & $\ldots$ & $\ldots$ & $\ldots$ & $\ldots$ & $\ldots$ \\
\hline Russian Federation & & $\ldots$ & & $\ldots$ & & $\ldots$ & \\
\hline Serbia & 2.2 & 2.1 & 1.9 & 1.9 & 1.7 & 2.1 & -2.0 \\
\hline Slovak Republic & & & & & & & \\
\hline Slovenia & 10.4 & 7.3 & 7.7 & 4.9 & 3.6 & 5.7 & -45.0 \\
\hline Spain & 1.5 & 1.5 & 1.4 & 1.6 & 1.7 & 1.6 & 13.4 \\
\hline Sweden & 19.1 & 17.4 & 18.2 & 19.4 & 19.0 & 19.2 & 0.4 \\
\hline Switzerland & 9.3 & 9.0 & 9.8 & 10.2 & 9.3 & 8.9 & -4.2 \\
\hline Turkey & $\ldots$ & $\ldots$ & $\ldots$ & $\ldots$ & $\ldots$ & $\ldots$ & $\ldots$ \\
\hline Ukraine & $\ldots$ & $\ldots$ & $\ldots$ & $\ldots$ & $\ldots$ & $\ldots$ & $\ldots$ \\
\hline UK: England \& Wales & $\ldots$ & $\ldots$ & $\ldots$ & $\ldots$ & $\ldots$ & $\ldots$ & $\ldots$ \\
\hline UK: Northern Ireland & $\ldots$ & $\ldots$ & $\ldots$ & $\ldots$ & $\ldots$ & $\ldots$ & $\ldots$ \\
\hline UK: Scotland & & & & & & & \\
\hline Mean & 5.3 & 5.4 & 5.1 & 5.2 & 5.0 & 4.9 & \\
\hline Median & 2.7 & 2.7 & 2.7 & 3.1 & 2.8 & 2.7 & \\
\hline Minimum & 0.2 & 0.2 & 0.2 & 0.3 & 0.2 & 0.2 & \\
\hline Maximum & 20.1 & 26.3 & 19.8 & 21.3 & 19.0 & 19.2 & \\
\hline
\end{tabular}


Table 1.2.2.12 Offenders per 100000 population - Robbery

\begin{tabular}{|c|c|c|c|c|c|c|c|}
\hline & 2011 & 2012 & 2013 & 2014 & 2015 & 2016 & $\begin{array}{c}\% \text { change } \\
2011-2016\end{array}$ \\
\hline Albania & 9 & 12 & 13 & 9 & 8 & 7 & -28.3 \\
\hline Armenia & $\ldots$ & $\ldots$ & $\ldots$ & $\ldots$ & $\ldots$ & $\ldots$ & 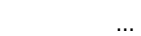 \\
\hline Austria & 25 & 27 & 24 & 26 & 28 & 24 & -4.9 \\
\hline Azerbaijan & 4 & 3 & 3 & 3 & 4 & 5 & 27.2 \\
\hline Belgium & 68 & 60 & 55 & 52 & 51 & 49 & -28.5 \\
\hline Bosnia-Herzegovina & $\ldots$ & $\ldots$ & $\ldots$ & $\ldots$ & $\ldots$ & $\ldots$ & \\
\hline Bulgaria & 17 & 15 & 15 & 13 & 11 & 12 & -29.0 \\
\hline Croatia & 26 & 31 & 30 & 31 & 37 & 30 & 15.1 \\
\hline Cyprus & $\ldots$ & $\ldots$ & $\ldots$ & $\ldots$ & $\ldots$ & $\ldots$ & \\
\hline Czech Republic & 21 & 18 & 19 & 16 & 14 & 14 & -31.8 \\
\hline Denmark & $\ldots$ & $\ldots$ & $\ldots$ & $\ldots$ & $\ldots$ & $\ldots$ & $\ldots$ \\
\hline Estonia & $\ldots$ & $\ldots$ & $\ldots$ & $\ldots$ & $\ldots$ & $\ldots$ & $\ldots$ \\
\hline Finland & 26 & 27 & 25 & 29 & 29 & 27 & 3.0 \\
\hline France & 35 & 34 & 34 & 31 & 28 & 27 & -22.9 \\
\hline Georgia & 12 & 12 & 18 & 19 & 22 & 21 & 72.1 \\
\hline Germany & 40 & 39 & 38 & 36 & 35 & 34 & -14.8 \\
\hline Greece & 12 & 12 & 27 & 13 & 22 & 33 & 175.5 \\
\hline Hungary & 16 & 14 & 16 & 14 & 11 & 10 & -37.1 \\
\hline Iceland & & $\ldots$ & $\ldots$ & $\ldots$ & $\ldots$ & $\ldots$ & $\ldots$ \\
\hline Ireland & 44 & 38 & 34 & 31 & 29 & 23 & -46.4 \\
\hline Italy & 34 & 35 & 39 & 37 & 36 & 35 & 4.5 \\
\hline Kosovo (UN R/1244/99) & $\ldots$ & $\ldots$ & $\ldots$ & $\ldots$ & $\ldots$ & $\ldots$ & $\ldots$ \\
\hline Latvia & $\ldots$ & $\ldots$ & $\ldots$ & $\ldots$ & $\ldots$ & $\ldots$ & $\ldots$ \\
\hline Lithuania & 49 & 41 & 34 & 35 & 31 & 25 & -48.6 \\
\hline Luxembourg & $\ldots$ & $\ldots$ & $\ldots$ & $\ldots$ & $\ldots$ & $\ldots$ & $\ldots$ \\
\hline Malta & $\ldots$ & $\ldots$ & $\ldots$ & $\ldots$ & $\ldots$ & $\ldots$ & $\ldots$ \\
\hline Moldova & 24 & 24 & 19 & 19 & 17 & 17 & -29.8 \\
\hline Montenegro & 13 & 8 & 11 & 10 & 7 & 8 & -42.9 \\
\hline Netherlands & 54 & 51 & 45 & 35 & 32 & 30 & -45.1 \\
\hline North Macedonia & 17 & 17 & 17 & 12 & 14 & 8 & -54.6 \\
\hline Norway & $\ldots$ & $\ldots$ & $\ldots$ & $\ldots$ & $\ldots$ & $\ldots$ & $\ldots$ \\
\hline Poland & 28 & 26 & 20 & 16 & 13 & 14 & -50.8 \\
\hline Portugal & 120 & 103 & 91 & 82 & 78 & 62 & -48.8 \\
\hline Romania & $\ldots$ & $\ldots$ & $\ldots$ & $\ldots$ & $\ldots$ & $\ldots$ & $\ldots$ \\
\hline Russian Federation & & $\ldots$ & $\ldots$ & $\ldots$ & $\ldots$ & $\ldots$ & $\ldots$ \\
\hline Serbia & 22 & 23 & 23 & 20 & 21 & 17 & -22.6 \\
\hline Slovak Republic & & $\ldots$ & $\ldots$ & $\ldots$ & $\ldots$ & $\ldots$ & \\
\hline Slovenia & 18 & 15 & 16 & 11 & 8 & 9 & -46.9 \\
\hline Spain & 49 & 50 & 47 & 39 & 33 & 33 & -32.9 \\
\hline Sweden & 31 & 29 & 26 & 26 & 25 & 26 & -15.3 \\
\hline Switzerland & 21 & 24 & 21 & 18 & 14 & 14 & -31.5 \\
\hline Turkey & & 21 & $\ldots$ & $\ldots$ & $\ldots$ & $\ldots$ & \\
\hline Ukraine & 28 & 24 & 17 & 15 & 16 & 5 & -80.2 \\
\hline UK: England \& Wales & $\ldots$ & $\ldots$ & $\ldots$ & $\ldots$ & $\ldots$ & $\ldots$ & $\ldots$ \\
\hline UK: Northern Ireland & $\ldots$ & $\ldots$ & $\ldots$ & $\ldots$ & $\ldots$ & $\ldots$ & $\ldots$ \\
\hline UK: Scotland & & $\ldots$ & $\ldots$ & $\ldots$ & $\ldots$ & $\ldots$ & $\ldots$ \\
\hline Mean & 31 & 29 & 28 & 25 & 24 & 22 & \\
\hline Median & 25 & 25 & 24 & 20 & 22 & 22 & \\
\hline Minimum & 4 & 3 & 3 & 3 & 4 & 5 & \\
\hline Maximum & 120 & 102 & 91 & 82 & 78 & 62 & \\
\hline
\end{tabular}


1 Police Statistics

Table 1.2.2.13 Offenders per 100000 population - Robbery: Firearm involved

\begin{tabular}{|c|c|c|c|c|c|c|c|}
\hline & 2011 & 2012 & 2013 & 2014 & 2015 & 2016 & $\begin{array}{l}\% \text { change } \\
2011-2016\end{array}$ \\
\hline Albania & 3.2 & 3.9 & 3.8 & 1.9 & 2.4 & 0.7 & -78.3 \\
\hline Armenia & $\ldots$ & $\ldots$ & $\ldots$ & $\ldots$ & $\ldots$ & $\ldots$ & $\ldots$ \\
\hline Austria & $\ldots$ & $\ldots$ & $\cdots$ & $\ldots$ & $\ldots$ & $\cdots$ & $\ldots$ \\
\hline Azerbaijan & $\ldots$ & $\ldots$ & $\ldots$ & $\ldots$ & $\ldots$ & $\ldots$ & $\ldots$ \\
\hline Belgium & 8.6 & 8.9 & 7.1 & 8.9 & 7.8 & 6.1 & -28.7 \\
\hline Bosnia-Herzegovina & $\ldots$ & $\ldots$ & $\ldots$ & $\ldots$ & $\ldots$ & $\ldots$ & $\ldots$ \\
\hline Bulgaria & $\ldots$ & $\ldots$ & ... & $\ldots$ & $\ldots$ & $\ldots$ & $\ldots$ \\
\hline Croatia & $\ldots$ & $\ldots$ & $\ldots$ & $\ldots$ & $\ldots$ & $\ldots$ & $\ldots$ \\
\hline Cyprus & $\ldots$ & $\ldots$ & $\ldots$ & $\ldots$ & $\ldots$ & $\ldots$ & $\ldots$ \\
\hline Czech Republic & $\ldots$ & $\ldots$ & $\ldots$ & $\ldots$ & $\ldots$ & $\ldots$ & $\ldots$ \\
\hline Denmark & $\ldots$ & $\ldots$ & ... & $\ldots$ & $\ldots$ & $\ldots$ & $\ldots$ \\
\hline Estonia & $\ldots$ & $\ldots$ & $\ldots$ & $\ldots$ & $\ldots$ & $\ldots$ & $\ldots$ \\
\hline Finland & $\ldots$ & $\ldots$ & $\ldots$ & $\ldots$ & $\ldots$ & $\ldots$ & $\ldots$ \\
\hline France & 5.1 & 5.0 & 4.8 & 4.7 & 4.4 & 3.4 & -34.1 \\
\hline Georgia & 7.1 & 7.2 & 10.0 & 6.4 & 9.8 & 10.7 & 49.9 \\
\hline Germany & 2.4 & 2.4 & 2.1 & 1.7 & 1.7 & 1.6 & -32.8 \\
\hline Greece & $\ldots$ & $\ldots$ & $\ldots$ & $\ldots$ & $\ldots$ & $\ldots$ & $\ldots$ \\
\hline Hungary & 0.3 & 0.1 & 0.3 & 0.2 & 0.2 & 0.3 & -25.3 \\
\hline Iceland & $\ldots$ & $\ldots$ & $\ldots$ & $\ldots$ & $\ldots$ & $\ldots$ & $\ldots$ \\
\hline Ireland & $\ldots$ & $\ldots$ & $\ldots$ & $\ldots$ & $\ldots$ & $\ldots$ & $\ldots$ \\
\hline Italy & $\ldots$ & $\ldots$ & $\ldots$ & $\ldots$ & $\ldots$ & $\ldots$ & $\ldots$ \\
\hline Kosovo (UN R/1244/99) & $\ldots$ & $\ldots$ & $\ldots$ & $\ldots$ & $\ldots$ & $\ldots$ & $\ldots$ \\
\hline Latvia & $\ldots$ & $\ldots$ & ... & $\ldots$ & $\ldots$ & $\ldots$ & $\ldots$ \\
\hline Lithuania & $\ldots$ & $\ldots$ & $\ldots$ & $\ldots$ & $\ldots$ & $\ldots$ & $\ldots$ \\
\hline Luxembourg & $\ldots$ & $\ldots$ & $\ldots$ & $\ldots$ & $\ldots$ & $\ldots$ & $\ldots$ \\
\hline Malta & $\ldots$ & $\ldots$ & $\ldots$ & $\ldots$ & $\ldots$ & $\ldots$ & $\ldots$ \\
\hline Moldova & 0.0 & 0.0 & 0.0 & 0.0 & 0.0 & 0.0 & 0.0 \\
\hline Montenegro & $\ldots$ & $\ldots$ & $\ldots$ & $\ldots$ & $\ldots$ & $\ldots$ & $\ldots$ \\
\hline Netherlands & $\ldots$ & $\ldots$ & $\ldots$ & $\ldots$ & $\ldots$ & $\ldots$ & $\ldots$ \\
\hline North Macedonia & $\ldots$ & $\ldots$ & $\ldots$ & $\ldots$ & $\ldots$ & $\ldots$ & $\ldots$ \\
\hline Norway & $\ldots$ & $\ldots$ & $\ldots$ & $\ldots$ & $\ldots$ & $\ldots$ & $\ldots$ \\
\hline Poland & $\ldots$ & $\ldots$ & $\ldots$ & $\ldots$ & $\ldots$ & $\ldots$ & $\ldots$ \\
\hline Portugal & $\ldots$ & $\ldots$ & $\ldots$ & $\ldots$ & $\ldots$ & $\ldots$ & ... \\
\hline Romania & $\ldots$ & $\ldots$ & ... & $\ldots$ & $\ldots$ & $\ldots$ & $\ldots$ \\
\hline Russian Federation & . & & $\ldots$ & . & $\ldots$ & & $\ldots$ \\
\hline Serbia & 4.9 & 3.6 & 3.0 & 2.2 & 2.1 & 1.7 & -65.1 \\
\hline Slovak Republic & & & & & $\ldots$ & $\ldots$ & $\ldots$ \\
\hline Slovenia & 2.0 & 0.6 & 0.9 & 0.9 & 0.7 & 0.4 & -81.1 \\
\hline Spain & 2.3 & 1.8 & 1.9 & 1.5 & 1.0 & 1.0 & -56.9 \\
\hline Sweden & 7.1 & 6.6 & 5.9 & 5.5 & 5.8 & 6.2 & -12.9 \\
\hline Switzerland & $\ldots$ & $\ldots$ & $\ldots$ & $\ldots$ & $\ldots$ & $\ldots$ & $\ldots$ \\
\hline Turkey & $\ldots$ & $\ldots$ & $\ldots$ & $\ldots$ & $\ldots$ & $\ldots$ & $\ldots$ \\
\hline Ukraine & $\ldots$ & $\ldots$ & $\ldots$ & $\ldots$ & $\ldots$ & $\ldots$ & $\ldots$ \\
\hline UK: England \& Wales & $\ldots$ & $\ldots$ & $\ldots$ & $\ldots$ & $\ldots$ & $\ldots$ & $\ldots$ \\
\hline $\begin{array}{l}\text { UK: Northern Ireland } \\
\text { UK: Scotland }\end{array}$ & $\begin{array}{l}\ldots \\
\ldots\end{array}$ & $\ldots$ & $\begin{array}{l}\ldots \\
\ldots\end{array}$ & $\ldots$ & $\begin{array}{l}\ldots \\
\ldots\end{array}$ & $\begin{array}{l}\ldots \\
\ldots\end{array}$ & $\begin{array}{l}\ldots \\
\ldots\end{array}$ \\
\hline Mean & 3.9 & 3.6 & 3.6 & 3.1 & 3.3 & 2.9 & \\
\hline Median & 3.2 & 3.6 & 3.0 & 1.9 & 2.1 & 1.6 & \\
\hline Minimum & 0.0 & 0.0 & 0.0 & 0.0 & 0.0 & 0.0 & \\
\hline Maximum & 8.6 & 8.9 & 10.0 & 8.9 & 9.8 & 10.7 & \\
\hline
\end{tabular}


Table 1.2.2.14 Offenders per 100000 population - Theft

\begin{tabular}{|c|c|c|c|c|c|c|c|}
\hline & 2011 & 2012 & 2013 & 2014 & 2015 & 2016 & $\begin{array}{l}\% \text { change } \\
2011-2016\end{array}$ \\
\hline Albania & $\ldots$ & $\ldots$ & $\ldots$ & $\ldots$ & $\ldots$ & $\ldots$ & $\ldots$ \\
\hline Armenia & & $\ldots$ & $\ldots$ & $\ldots$ & $\ldots$ & $\ldots$ & $\ldots$ \\
\hline Austria & 614.3 & 608.3 & 644.6 & 607.9 & 572.9 & 734.0 & 19.5 \\
\hline Azerbaijan & 19.7 & 17.1 & 17.7 & 19.7 & 22.8 & 27.7 & 40.3 \\
\hline Belgium & 485.6 & 429.3 & 410.2 & 407.9 & 379.0 & 360.6 & -25.7 \\
\hline \multicolumn{8}{|l|}{ Bosnia-Herzegovina } \\
\hline Bulgaria & 316.1 & 271.3 & 253.5 & 219.9 & 198.1 & 191.8 & -39.3 \\
\hline Croatia & 693.2 & 771.7 & 778.4 & 668.0 & 698.3 & 691.5 & -0.2 \\
\hline \multicolumn{8}{|l|}{ Cyprus } \\
\hline Czech Republic & 283.6 & 287.6 & 293.3 & 276.4 & 210.1 & 202.2 & -28.7 \\
\hline Denmark & & $\ldots$ & $\ldots$ & $\ldots$ & $\ldots$ & $\ldots$ & $\ldots$ \\
\hline Estonia & & & & & 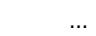 & & \\
\hline Finland & 1253.6 & 1112.9 & 1114.1 & 1074.8 & 1014.1 & 967.3 & -22.8 \\
\hline France & 351.1 & 346.2 & 346.0 & 333.7 & 322.4 & 309.2 & -11.9 \\
\hline Georgia & 90.7 & 56.6 & 76.9 & 73.6 & 80.8 & 78.6 & -13.4 \\
\hline Germany & 628.5 & 598.8 & 576.0 & 565.9 & 565.3 & 538.5 & -14.3 \\
\hline Greece & 117.0 & 117.9 & 245.1 & 173.8 & 186.6 & 244.0 & 108.5 \\
\hline Hungary & 283.3 & 252.1 & 261.7 & 234.7 & 198.9 & 180.5 & -36.3 \\
\hline \multicolumn{8}{|l|}{ Iceland } \\
\hline Ireland & 720.4 & 679.1 & 673.2 & 641.7 & 636.0 & 604.0 & -16.2 \\
\hline Italy & 169.1 & 191.5 & 207.2 & 205.7 & 201.1 & 191.2 & 13.1 \\
\hline Kosovo (UN R/1244/99) & $\cdots$ & $\ldots$ & $\ldots$ & $\ldots$ & $\ldots$ & $\ldots$ & $\ldots$ \\
\hline Latvia & & $\ldots$ & $\ldots$ & $\ldots$ & $\ldots$ & & $\ldots$ \\
\hline Lithuania & 272.5 & 251.1 & 239.9 & 242.7 & 169.1 & 120.0 & -56.0 \\
\hline Luxembourg & $\ldots$ & $\ldots$ & $\ldots$ & $\ldots$ & $\ldots$ & $\ldots$ & $\ldots$ \\
\hline Malta & & & $\ldots$ & $\ldots$ & $\ldots$ & & $\ldots$ \\
\hline Moldova & 181.2 & 194.5 & 152.1 & 155.4 & 151.6 & 144.7 & -20.1 \\
\hline Montenegro & 172.1 & 155.2 & 162.5 & 136.8 & 111.4 & 97.1 & -43.6 \\
\hline Netherlands & 639.3 & 613.3 & 619.9 & 567.9 & 527.1 & 473.0 & -26.0 \\
\hline North Macedonia & 103.4 & 91.1 & 91.1 & 95.6 & 103.5 & 103.4 & 0.0 \\
\hline \multicolumn{8}{|l|}{ Norway } \\
\hline Poland & 213.8 & 219.6 & 189.7 & 140.8 & 120.9 & 110.0 & -48.6 \\
\hline Portugal & 229.3 & 234.5 & 221.2 & 205.1 & 196.8 & 180.8 & -21.1 \\
\hline Romania & $\ldots$ & $\ldots$ & $\ldots$ & $\ldots$ & $\ldots$ & $\ldots$ & $\ldots$ \\
\hline Russian Federation & & & & & & & \\
\hline Serbia & 214.9 & 214.8 & 243.8 & 206.6 & 189.6 & 170.9 & -20.5 \\
\hline \multicolumn{8}{|l|}{ Slovak Republic } \\
\hline Slovenia & 481.0 & 524.7 & 605.4 & 693.4 & 425.7 & 402.2 & -16.4 \\
\hline Spain & 122.1 & 118.5 & 120.3 & 97.3 & 78.4 & 71.2 & -41.6 \\
\hline Sweden & 442.2 & 433.0 & 387.5 & 386.1 & 389.1 & 359.0 & -18.8 \\
\hline Switzerland & 359.4 & 389.8 & 361.3 & 335.1 & 292.5 & 286.5 & -20.3 \\
\hline Turkey & 42.1 & & & & & & \\
\hline Ukraine & 191.1 & 168.0 & 116.3 & 106.7 & 122.8 & 106.8 & -44.1 \\
\hline UK: England \& Wales & $\ldots$ & $\ldots$ & $\ldots$ & $\ldots$ & $\ldots$ & $\ldots$ & $\ldots$ \\
\hline $\begin{array}{l}\text { UK: Northern Ireland } \\
\text { UK: Scotland }\end{array}$ & $\ldots$ & $\ldots$ & $\ldots$ & $\ldots$ & $\ldots$ & $\ldots$ & $\ldots$ \\
\hline Mean & 346 & 346 & 348 & 329 & 302 & 291 & \\
\hline Median & 278 & 252 & 253 & 235 & 199 & 191 & \\
\hline Minimum & 20 & 17 & 18 & 20 & 23 & 28 & \\
\hline Maximum & 1254 & 1113 & 1114 & 1075 & 1014 & 967 & \\
\hline
\end{tabular}


1 Police Statistics

Table 1.2.2.15 Offenders per 100000 population - Aggravated theft

\begin{tabular}{|c|c|c|c|c|c|c|c|}
\hline & 2011 & 2012 & 2013 & 2014 & 2015 & 2016 & $\begin{array}{l}\% \text { change } \\
2011-2016\end{array}$ \\
\hline Albania & 0.1 & 0.2 & 0.1 & 0.3 & 0.8 & 0.3 & 237.0 \\
\hline Armenia & & & & $\ldots$ & & & \\
\hline Austria & 236.5 & 213.0 & 232.9 & 211.9 & 192.0 & 282.5 & 19.4 \\
\hline Azerbaijan & $\ldots$ & $\ldots$ & $\ldots$ & $\ldots$ & $\ldots$ & $\ldots$ & $\ldots$ \\
\hline Belgium & $\ldots$ & $\ldots$ & $\ldots$ & $\ldots$ & $\ldots$ & $\ldots$ & $\ldots$ \\
\hline Bosnia-Herzegovina & $\ldots$ & $\ldots$ & $\ldots$ & $\ldots$ & $\ldots$ & $\ldots$ & $\ldots$ \\
\hline Bulgaria & $\ldots$ & $\ldots$ & $\ldots$ & $\ldots$ & $\ldots$ & $\ldots$ & $\ldots$ \\
\hline Croatia & 410.0 & 433.7 & 436.5 & 380.4 & 339.4 & 312.1 & -23.9 \\
\hline Cyprus & $\ldots$ & $\ldots$ & $\ldots$ & $\ldots$ & $\ldots$ & $\ldots$ & $\ldots$ \\
\hline Czech Republic & $\ldots$ & $\ldots$ & $\ldots$ & $\ldots$ & $\ldots$ & $\ldots$ & $\ldots$ \\
\hline Denmark & $\ldots$ & $\ldots$ & $\ldots$ & $\ldots$ & $\ldots$ & $\ldots$ & $\ldots$ \\
\hline Estonia & $\ldots$ & $\ldots$ & $\ldots$ & $\ldots$ & $\ldots$ & $\ldots$ & $\ldots$ \\
\hline Finland & 36.3 & 42.0 & 46.5 & 36.4 & 35.6 & 34.7 & -4.3 \\
\hline France & $\ldots$ & $\ldots$ & $\ldots$ & $\ldots$ & $\ldots$ & $\ldots$ & $\ldots$ \\
\hline Georgia & $\ldots$ & & & $\ldots$ & & & $\ldots$ \\
\hline Germany & 133.0 & 129.8 & 125.3 & 124.4 & 122.2 & 117.8 & -11.4 \\
\hline Greece & 5.8 & 7.3 & 56.5 & 39.0 & 36.9 & 39.2 & 580.5 \\
\hline Hungary & $\ldots$ & $\ldots$ & $\ldots$ & $\ldots$ & $\ldots$ & $\ldots$ & $\ldots$ \\
\hline Iceland & $\ldots$ & $\ldots$ & $\ldots$ & $\ldots$ & $\ldots$ & $\ldots$ & $\ldots$ \\
\hline Ireland & $\ldots$ & $\ldots$ & $\ldots$ & $\ldots$ & $\ldots$ & $\ldots$ & $\ldots$ \\
\hline Italy & $\ldots$ & $\ldots$ & $\ldots$ & $\ldots$ & $\ldots$ & $\ldots$ & $\ldots$ \\
\hline Kosovo (UN R/1244/99) & $\ldots$ & $\ldots$ & $\ldots$ & $\ldots$ & $\ldots$ & $\ldots$ & $\ldots$ \\
\hline Latvia & $\ldots$ & $\ldots$ & $\ldots$ & $\ldots$ & ... & $\ldots$ & $\ldots$ \\
\hline Lithuania & $\ldots$ & $\ldots$ & $\ldots$ & $\ldots$ & $\ldots$ & $\ldots$ & $\ldots$ \\
\hline Luxembourg & $\ldots$ & $\ldots$ & $\ldots$ & $\ldots$ & $\ldots$ & $\ldots$ & $\ldots$ \\
\hline Malta & $\ldots$ & $\ldots$ & $\ldots$ & $\ldots$ & $\ldots$ & $\ldots$ & $\ldots$ \\
\hline Moldova & 406.9 & 385.6 & 416.6 & 455.6 & 419.7 & 423.2 & 4.0 \\
\hline Montenegro & 102.1 & 77.1 & 81.3 & 62.1 & 50.6 & 48.4 & -52.6 \\
\hline Netherlands & & & & & & & \\
\hline North Macedonia & 337.8 & 264.4 & 266.4 & 217.4 & 172.4 & 198.5 & -41.2 \\
\hline Norway & & & & & & & \\
\hline Poland & 73.5 & 71.4 & 52.7 & 43.7 & 37.1 & 31.5 & -57.2 \\
\hline Portugal & 92.8 & 69.9 & 63.4 & 55.9 & 47.0 & 43.4 & -53.2 \\
\hline Romania & $\ldots$ & $\ldots$ & $\ldots$ & $\ldots$ & $\ldots$ & $\ldots$ & $\ldots$ \\
\hline Russian Federation & & & & $\ldots$ & & & \\
\hline Serbia & 103.0 & 101.8 & 107.6 & 86.0 & 75.8 & 67.3 & -34.7 \\
\hline Slovak Republic & & & & & & & \\
\hline Slovenia & 174.9 & 189.2 & 227.3 & 355.1 & 141.1 & 116.4 & -33.4 \\
\hline Spain & & & & & & & \\
\hline Sweden & 71.5 & 70.5 & 62.8 & 62.6 & 63.1 & 56.1 & -21.6 \\
\hline Switzerland & $\ldots$ & $\ldots$ & $\ldots$ & $\ldots$ & $\ldots$ & $\ldots$ & $\ldots$ \\
\hline Turkey & $\ldots$ & $\ldots$ & $\ldots$ & $\ldots$ & $\ldots$ & $\ldots$ & $\ldots$ \\
\hline Ukraine & $\ldots$ & $\ldots$ & $\ldots$ & $\ldots$ & $\ldots$ & $\ldots$ & ... \\
\hline UK: England \& Wales & $\ldots$ & $\ldots$ & $\ldots$ & $\ldots$ & $\ldots$ & $\ldots$ & $\ldots$ \\
\hline UK: Northern Ireland & $\ldots$ & $\ldots$ & $\ldots$ & $\ldots$ & $\cdots$ & $\ldots$ & $\ldots$ \\
\hline UK: Scotland & & & & & & & $\ldots$ \\
\hline Mean & 156.0 & 146.8 & 155.4 & 152.2 & 123.8 & 126.5 & \\
\hline Median & 102.5 & 89.4 & 94.5 & 74.3 & 69.5 & 61.7 & \\
\hline Minimum & 0.1 & 0.2 & 0.1 & 0.3 & 0.8 & 0.3 & \\
\hline Maximum & 410.0 & 433.7 & 436.5 & 455.6 & 419.7 & 423.2 & \\
\hline
\end{tabular}


Table 1.2.2.16 Offenders per 100000 population - Theft of a motor vehicle

\begin{tabular}{|c|c|c|c|c|c|c|c|}
\hline & 2011 & 2012 & 2013 & 2014 & 2015 & 2016 & $\begin{array}{l}\% \text { change } \\
2011-2016\end{array}$ \\
\hline Albania & 21.0 & 19.7 & 23.4 & 3.8 & 4.5 & 4.3 & -79.6 \\
\hline Armenia & & & $\ldots$ & & & & \\
\hline Austria & 27.8 & 21.2 & 28.0 & 23.2 & 22.3 & 23.3 & -16.1 \\
\hline Azerbaijan & & & & & & & \\
\hline $\begin{array}{l}\text { Belgium } \\
\text { Bosnia-Herzegovina }\end{array}$ & 30.1 & 22.6 & $\begin{array}{r}21.6 \\
\ldots\end{array}$ & 20.7 & 21.4 & 18.9 & -37.4 \\
\hline Bulgaria & 5.0 & 4.2 & 5.0 & 3.9 & 4.8 & 5.7 & 15.1 \\
\hline $\begin{array}{l}\text { Croatia } \\
\text { Cyprus }\end{array}$ & $\cdots$ & $\cdots$ & $\cdots$ & $\cdots$ & $\cdots$ & $\cdots$ & $\cdots$ \\
\hline Czech Republic & 16.7 & 15.3 & 15.1 & 13.6 & 11.2 & 13.5 & $\begin{array}{r}\ldots \\
-19.5\end{array}$ \\
\hline Denmark & $\ldots$ & $\ldots$ & $\ldots$ & $\ldots$ & $\ldots$ & $\ldots$ & $\ldots$ \\
\hline Estonia & $\ldots$ & $\ldots$ & $\ldots$ & & $\ldots$ & & \\
\hline Finland & 92.8 & 79.9 & 61.8 & 61.2 & 61.9 & 53.5 & -42.3 \\
\hline France & 27.4 & 27.1 & 23.7 & 21.9 & 21.1 & 20.7 & -24.6 \\
\hline Georgia & & & $\ldots$ & & & & \\
\hline Germany & 24.8 & 22.2 & 19.8 & 19.0 & 18.0 & 17.1 & -30.8 \\
\hline Greece & & & & & & & \\
\hline Hungary & 10.6 & 8.2 & 8.3 & 8.2 & 7.1 & 6.0 & -43.0 \\
\hline Iceland & $\cdots$ & $\ldots$ & $\ldots$ & $\ldots$ & $\ldots$ & $\ldots$ & $\ldots$ \\
\hline $\begin{array}{l}\text { Ireland } \\
\text { Italy }\end{array}$ & 8.4 & 7.9 & 7.2 & 8.1 & 7.7 & 7.9 & -6.3 \\
\hline Kosovo (UN R/1244/99) & $\ldots$ & $\ldots$ & $\ldots$ & $\ldots$ & $\ldots$ & $\ldots$ & $\ldots$ \\
\hline Latvia & $\ldots$ & $\ldots$ & $\ldots$ & $\ldots$ & $\ldots$ & $\ldots$ & $\ldots$ \\
\hline Lithuania & 5.3 & 6.1 & 6.1 & 5.2 & 5.1 & $\ldots$ & $\ldots$ \\
\hline Luxembourg & $\ldots$ & $\ldots$ & $\ldots$ & $\ldots$ & $\ldots$ & $\ldots$ & $\ldots$ \\
\hline Malta & $\ldots$ & $\ldots$ & $\ldots$ & $\ldots$ & $\ldots$ & $\ldots$ & $\ldots$ \\
\hline Moldova & 1.6 & 1.9 & 2.6 & 2.7 & 2.1 & 2.5 & 53.1 \\
\hline Montenegro & & & $\ldots$ & & & $\ldots$ & $\ldots$ \\
\hline Netherlands & 16.6 & 14.7 & 15.1 & 13.6 & 9.8 & $\ldots$ & $\ldots$ \\
\hline North Macedonia & 18.9 & 16.2 & 16.6 & 12.7 & 10.0 & 10.0 & -47.1 \\
\hline Norway & $\ldots$ & $\ldots$ & $\ldots$ & $\ldots$ & $\ldots$ & $\ldots$ & $\ldots$ \\
\hline Poland & 8.2 & 8.3 & $\ldots$ & $\ldots$ & $\ldots$ & . & \\
\hline Portugal & 16.6 & 12.1 & 11.4 & 11.4 & 8.7 & 8.9 & -46.0 \\
\hline Romania & $\ldots$ & $\ldots$ & $\ldots$ & $\ldots$ & $\ldots$ & $\ldots$ & $\ldots$ \\
\hline Russian Federation & & & & & & & \\
\hline Serbia & 11.0 & 10.5 & 10.8 & 8.6 & 8.7 & 7.0 & -36.5 \\
\hline Slovak Republic & $\ldots$ & $\ldots$ & $\ldots$ & $\ldots$ & $\ldots$ & $\ldots$ & $\ldots$ \\
\hline Slovenia & & & $\ldots$ & $\ldots$ & $\ldots$ & $\ldots$ & \\
\hline Spain & 16.3 & 14.5 & 13.3 & 11.6 & 10.6 & 10.4 & -36.2 \\
\hline Sweden & 38.5 & 33.3 & 30.8 & 30.5 & 29.8 & 27.2 & -29.5 \\
\hline Switzerland & 19.0 & 19.2 & 17.1 & 18.1 & 18.6 & 15.1 & -20.5 \\
\hline Turkey & 1.7 & $\ldots$ & $\ldots$ & & $\ldots$ & & \\
\hline Ukraine & 6.5 & 7.3 & 6.9 & 7.2 & 7.2 & 6.7 & 3.3 \\
\hline UK: England \& Wales & $\ldots$ & $\ldots$ & $\ldots$ & $\ldots$ & $\ldots$ & $\ldots$ & $\ldots$ \\
\hline $\begin{array}{l}\text { UK: Northern Ireland } \\
\text { UK: Scotland }\end{array}$ & $\cdots$ & $\ldots$ & $\ldots$ & $\ldots$ & $\ldots$ & $\ldots$ & $\cdots$ \\
\hline Mean & 19 & 18 & 17 & 15 & 15 & 14 & \\
\hline Median & 17 & 15 & 15 & 12 & 10 & 10 & \\
\hline Minimum & 2 & 2 & 3 & 3 & 2 & 2 & \\
\hline Maximum & 93 & 80 & 62 & 61 & 62 & 54 & \\
\hline
\end{tabular}


Table 1.2.2.17 Offenders per 100000 population - Theft by means of burglary

\begin{tabular}{|c|c|c|c|c|c|c|c|}
\hline & 2011 & 2012 & 2013 & 2014 & 2015 & 2016 & $\begin{array}{c}\% \text { change } \\
2011-2016\end{array}$ \\
\hline Albania & 34.1 & 38.0 & 45.2 & 17.5 & 18.2 & 12.2 & -64.1 \\
\hline Armenia & & & & & & & \\
\hline Austria & 163.4 & 134.8 & 150.8 & 140.2 & 125.6 & 226.0 & 38.3 \\
\hline $\begin{array}{l}\text { Azerbaijan } \\
\text { Belgium }\end{array}$ & 93.3 & 87.9 & $\begin{array}{r}\ldots \\
77.8\end{array}$ & 82.3 & $\begin{array}{r}\ldots \\
71.2\end{array}$ & $\begin{array}{r}\ldots \\
61.9\end{array}$ & -33.6 \\
\hline Bosnia-Herzegovina & $\ldots$ & $\ldots$ & $\ldots$ & $\ldots$ & $\ldots$ & $\ldots$ & $\ldots$ \\
\hline Bulgaria & & $\ldots$ & $\ldots$ & & $\ldots$ & $\ldots$ & \\
\hline Croatia & 381.9 & 403.0 & 402.7 & 360.0 & 326.5 & 294.4 & -22.9 \\
\hline Cyprus & & 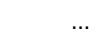 & $\ldots$ & & & $\ldots$ & \\
\hline Czech Republic & 95.9 & 91.5 & 97.0 & 86.0 & 58.8 & 53.6 & -44.2 \\
\hline Denmark & $\ldots$ & $\ldots$ & $\ldots$ & $\ldots$ & $\ldots$ & $\ldots$ & $\ldots$ \\
\hline Estonia & $\ldots$ & $\ldots$ & $\ldots$ & $\ldots$ & $\ldots$ & $\ldots$ & \\
\hline Finland & 172.3 & 169.8 & 163.8 & 154.3 & 134.0 & 128.3 & -25.5 \\
\hline France & 69.9 & 69.8 & 72.0 & 71.0 & 70.9 & 65.9 & -5.8 \\
\hline Georgia & & & & & & & \\
\hline Germany & 88.1 & 85.8 & 84.0 & 82.4 & 82.5 & 79.4 & -9.8 \\
\hline Greece & 56.0 & 58.8 & 57.4 & 43.5 & 48.2 & 71.2 & 27.2 \\
\hline Hungary & $\ldots$ & $\ldots$ & $\ldots$ & $\ldots$ & $\ldots$ & $\ldots$ & $\ldots$ \\
\hline Iceland & $\ldots$ & $\ldots$ & $\ldots$ & $\ldots$ & $\ldots$ & $\ldots$ & $\ldots$ \\
\hline Ireland & $\ldots$ & $\ldots$ & $\ldots$ & $\ldots$ & $\ldots$ & $\ldots$ & $\ldots$ \\
\hline Italy & $\ldots$ & $\ldots$ & $\ldots$ & $\ldots$ & $\ldots$ & $\ldots$ & $\ldots$ \\
\hline Kosovo (UN R/1244/99) & $\ldots$ & $\ldots$ & $\ldots$ & $\ldots$ & $\ldots$ & $\ldots$ & $\ldots$ \\
\hline Latvia & & $\ldots$ & $\ldots$ & $\ldots$ & $\ldots$ & $\ldots$ & $\ldots$ \\
\hline Lithuania & 17.5 & 14.5 & 14.0 & 11.5 & 11.4 & $\ldots$ & $\ldots$ \\
\hline Luxembourg & $\ldots$ & $\ldots$ & $\ldots$ & $\ldots$ & $\ldots$ & $\ldots$ & $\ldots$ \\
\hline Malta & & $\ldots$ & $\ldots$ & $\ldots$ & $\ldots$ & $\ldots$ & $\ldots$ \\
\hline Moldova & 8.6 & 10.3 & 8.7 & 10.2 & 7.4 & 11.1 & 29.0 \\
\hline Montenegro & & $\ldots$ & & & & $\ldots$ & $\ldots$ \\
\hline Netherlands & 387.3 & 381.1 & 388.2 & 352.5 & 328.7 & $\ldots$ & $\ldots$ \\
\hline North Macedonia & $\ldots$ & $\ldots$ & $\ldots$ & $\ldots$ & $\ldots$ & $\ldots$ & $\ldots$ \\
\hline Norway & & $\ldots$ & & & $\ldots$ & & \\
\hline Poland & 65.3 & 63.1 & 50.5 & 41.8 & 35.4 & 29.8 & -54.3 \\
\hline Portugal & 76.0 & 57.6 & 51.8 & 44.4 & 38.2 & 34.3 & -54.8 \\
\hline Romania & $\ldots$ & $\ldots$ & $\ldots$ & $\ldots$ & $\ldots$ & $\ldots$ & $\ldots$ \\
\hline Russian Federation & & & & & & & \\
\hline Serbia & 90.9 & 87.5 & 95.9 & 76.2 & 67.5 & 59.6 & -34.4 \\
\hline Slovak Republic & & & & & & & \\
\hline Slovenia & 136.1 & 140.2 & 182.6 & 303.0 & 111.3 & 91.2 & -33.0 \\
\hline Spain & 52.1 & 58.2 & 62.8 & 52.2 & 43.4 & 41.7 & -20.0 \\
\hline Sweden & 69.4 & 64.8 & 57.8 & 57.2 & 57.7 & 51.5 & -25.8 \\
\hline Switzerland & 47.9 & 55.0 & 56.5 & 52.5 & 42.0 & 40.8 & -14.7 \\
\hline Turkey & $\ldots$ & $\ldots$ & $\ldots$ & $\ldots$ & $\ldots$ & $\ldots$ & $\ldots$ \\
\hline Ukraine & $\ldots$ & $\ldots$ & $\ldots$ & $\ldots$ & $\ldots$ & $\ldots$ & $\ldots$ \\
\hline UK: England \& Wales & $\ldots$ & $\ldots$ & $\ldots$ & $\ldots$ & $\ldots$ & $\ldots$ & $\ldots$ \\
\hline $\begin{array}{l}\text { UK: Northern Ireland } \\
\text { UK: Scotland }\end{array}$ & $\ldots$ & $\ldots$ & $\ldots$ & $\ldots$ & $\ldots$ & $\ldots$ & $\ldots$ \\
\hline Mean & 111 & 109 & 112 & 107 & 88 & 80 & \\
\hline Median & 76 & 70 & 72 & 71 & 59 & 60 & \\
\hline Minimum & 9 & 10 & 9 & 10 & 7 & 11 & \\
\hline Maximum & 387 & 403 & 403 & 360 & 329 & 294 & \\
\hline
\end{tabular}


Table 1.2.2.18 Offenders per 100000 population - Theft by means of domestic burglary

\begin{tabular}{|c|c|c|c|c|c|c|c|}
\hline & 2011 & 2012 & 2013 & 2014 & 2015 & 2016 & $\begin{array}{c}\% \text { change } \\
2011-2016\end{array}$ \\
\hline Albania & 33.7 & 44.1 & 43.0 & 20.5 & 27.9 & 28.7 & -14.9 \\
\hline Armenia & & & & & & & \\
\hline Austria & 28.2 & 26.7 & 33.2 & 35.6 & 31.1 & 53.1 & 88.0 \\
\hline Azerbaijan & & & & & $\ldots$ & & \\
\hline Belgium & 50.7 & 48.7 & 44.9 & 46.9 & 38.4 & 33.7 & -33.5 \\
\hline Bosnia-Herzegovina & $\ldots$ & $\ldots$ & $\ldots$ & $\ldots$ & $\ldots$ & $\ldots$ & $\ldots$ \\
\hline Bulgaria & $\ldots$ & $\ldots$ & $\ldots$ & $\ldots$ & $\ldots$ & $\ldots$ & $\ldots$ \\
\hline Croatia & $\ldots$ & $\ldots$ & $\ldots$ & $\ldots$ & $\ldots$ & $\ldots$ & $\ldots$ \\
\hline Cyprus & $\ldots$ & $\ldots$ & & & $\ldots$ & $\ldots$ & 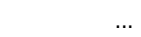 \\
\hline Czech Republic & 16.6 & 17.0 & 17.7 & 17.4 & 13.7 & 14.9 & -10.1 \\
\hline Denmark & $\ldots$ & $\ldots$ & $\ldots$ & $\ldots$ & $\ldots$ & $\ldots$ & $\ldots$ \\
\hline Estonia & $\ldots$ & $\ldots$ & $\ldots$ & & $\ldots$ & $\ldots$ & \\
\hline Finland & 47.9 & 60.2 & 61.1 & 48.2 & 42.9 & 40.3 & -16.0 \\
\hline France & 35.6 & 36.6 & 38.0 & 36.8 & 35.9 & 34.0 & -4.7 \\
\hline Georgia & & $\ldots$ & & & & & \\
\hline Germany & 28.5 & 28.4 & 28.1 & 26.9 & 27.7 & 26.6 & -6.8 \\
\hline Greece & $\ldots$ & $\ldots$ & $\ldots$ & $\ldots$ & $\ldots$ & $\ldots$ & $\ldots$ \\
\hline Hungary & $\ldots$ & $\ldots$ & $\ldots$ & $\ldots$ & $\ldots$ & $\ldots$ & $\ldots$ \\
\hline Iceland & $\ldots$ & $\ldots$ & $\ldots$ & $\ldots$ & $\ldots$ & $\ldots$ & $\ldots$ \\
\hline Ireland & $\ldots$ & $\ldots$ & & & $\ldots$ & $\ldots$ & $\ldots$ \\
\hline Italy & 18.5 & 24.0 & 25.7 & 25.8 & 24.6 & 24.2 & 31.0 \\
\hline Kosovo (UN R/1244/99) & $\ldots$ & $\ldots$ & $\ldots$ & $\ldots$ & $\ldots$ & $\ldots$ & $\ldots$ \\
\hline Latvia & $\ldots$ & $\ldots$ & $\ldots$ & $\ldots$ & $\ldots$ & $\ldots$ & $\ldots$ \\
\hline Lithuania & 12.8 & 10.8 & 8.8 & 8.5 & 7.7 & $\ldots$ & $\ldots$ \\
\hline Luxembourg & $\ldots$ & $\ldots$ & $\ldots$ & $\ldots$ & $\ldots$ & $\ldots$ & $\ldots$ \\
\hline Malta & & . & & & $\ldots$ & & \\
\hline Moldova & 59.5 & 55.0 & 31.0 & 33.2 & 32.5 & 41.8 & -29.8 \\
\hline Montenegro & & & & & & $\ldots$ & $\ldots$ \\
\hline Netherlands & 79.8 & 81.8 & 82.5 & 63.0 & 53.6 & $\ldots$ & $\ldots$ \\
\hline North Macedonia & $\ldots$ & $\ldots$ & $\ldots$ & $\ldots$ & $\ldots$ & $\ldots$ & $\ldots$ \\
\hline Norway & $\ldots$ & $\ldots$ & $\ldots$ & $\ldots$ & $\ldots$ & $\ldots$ & $\ldots$ \\
\hline Poland & $\ldots$ & $\ldots$ & & & $\ldots$ & $\ldots$ & $\ldots$ \\
\hline Portugal & 38.7 & 29.8 & 28.4 & 23.6 & 20.6 & 17.6 & -54.6 \\
\hline Romania & $\ldots$ & $\ldots$ & $\ldots$ & $\ldots$ & $\ldots$ & $\ldots$ & $\ldots$ \\
\hline Russian Federation & $\ldots$ & $\ldots$ & $\ldots$ & $\ldots$ & $\ldots$ & $\ldots$ & $\ldots$ \\
\hline Serbia & 79.4 & 85.7 & 104.3 & 83.0 & 74.6 & 68.3 & -14.0 \\
\hline Slovak Republic & & & & & & & \\
\hline Slovenia & 23.3 & 21.0 & 41.1 & 27.1 & 23.5 & 15.8 & -32.1 \\
\hline Spain & 23.7 & 31.0 & 35.2 & 29.1 & 23.2 & 22.1 & -7.0 \\
\hline Sweden & 27.3 & 25.9 & 25.3 & 25.3 & 25.2 & 22.2 & -18.7 \\
\hline Switzerland & 18.6 & 20.1 & 19.3 & 19.1 & 16.9 & 16.5 & -11.3 \\
\hline Turkey & & & & & & & \\
\hline Ukraine & 11.9 & 11.6 & 5.6 & 5.4 & 5.3 & 6.0 & -49.6 \\
\hline UK: England \& Wales & $\ldots$ & $\ldots$ & $\ldots$ & $\ldots$ & $\ldots$ & $\ldots$ & $\ldots$ \\
\hline UK: Northern Ireland & $\ldots$ & $\ldots$ & $\ldots$ & $\ldots$ & $\ldots$ & $\ldots$ & $\cdots$ \\
\hline UK: Scotland & & & & & & & \\
\hline Mean & 35 & 37 & 37 & 32 & 29 & 29 & \\
\hline Median & 28 & 29 & 32 & 27 & 26 & 25 & \\
\hline Minimum & 12 & 11 & 6 & 5 & 5 & 6 & \\
\hline Maximum & 80 & 86 & 104 & 83 & 75 & 68 & \\
\hline
\end{tabular}


1 Police Statistics

Table 1.2.2.19 Offenders per 100000 population - Fraud

\begin{tabular}{|c|c|c|c|c|c|c|c|}
\hline & 2011 & 2012 & 2013 & 2014 & 2015 & 2016 & $\begin{array}{l}\% \text { change } \\
2011-2016\end{array}$ \\
\hline Albania & 13.0 & 15.4 & 19.2 & 20.4 & 15.8 & 22.6 & 73.9 \\
\hline Armenia & & & & & & & \\
\hline Austria & 240.3 & 237.4 & 267.0 & 239.8 & 221.8 & 263.3 & 9.6 \\
\hline Azerbaijan & 4.8 & 6.4 & 8.3 & 9.7 & 11.4 & 14.2 & 195.7 \\
\hline $\begin{array}{l}\text { Belgium } \\
\text { Bosnia-Herzegovina }\end{array}$ & 43.4 & 37.8 & 41.7 & 36.2 & 35.2 & 33.8 & -22.3 \\
\hline $\begin{array}{l}\text { Bosnia-Herzegovina } \\
\text { Bulgaria }\end{array}$ & 7.2 & 5.7 & $\begin{array}{l}\ldots .4 \\
5.4\end{array}$ & 6.0 & 5.5 & 6.7 & $\begin{array}{r}\ldots .5 \\
-6.5\end{array}$ \\
\hline Croatia & 131.8 & 92.2 & 76.7 & 71.2 & 109.2 & 141.2 & 7.1 \\
\hline Cyprus & & & & & & & \\
\hline Czech Republic & 44.9 & 46.9 & 51.9 & 50.1 & 45.5 & 49.6 & 10.5 \\
\hline Denmark & $\ldots$ & $\ldots$ & $\ldots$ & $\ldots$ & $\ldots$ & $\ldots$ & $\ldots$ \\
\hline Estonia & & $\ldots$ & $\ldots$ & & $\ldots$ & & $\ldots$ \\
\hline Finland & 312.9 & 316.6 & 363.7 & 331.4 & 404.6 & 419.6 & 34.1 \\
\hline France & 82.9 & 83.5 & 80.2 & 81.9 & 87.0 & 89.2 & 7.6 \\
\hline Georgia & & 29.4 & 38.2 & 39.8 & 41.7 & 48.0 & $\ldots$ \\
\hline Germany & 330.2 & 326.1 & 332.2 & 327.3 & 321.8 & 290.4 & -12.1 \\
\hline Greece & 6.9 & 7.0 & 20.7 & 21.3 & 14.7 & 20.1 & 191.5 \\
\hline Hungary & 60.7 & 48.8 & 50.3 & 42.3 & 42.0 & 36.6 & -39.7 \\
\hline Iceland & & & & & & & \\
\hline Ireland & 61.8 & 58.4 & 48.6 & 48.4 & 56.9 & 45.6 & -26.1 \\
\hline Italy & 87.3 & 94.9 & 109.7 & 111.0 & 110.3 & 111.2 & 27.3 \\
\hline Kosovo (UN R/1244/99) & $\ldots$ & $\ldots$ & $\ldots$ & $\ldots$ & $\ldots$ & $\ldots$ & $\ldots$ \\
\hline Latvia & & $\ldots$ & $\ldots$ & & $\ldots$ & & $\ldots$ \\
\hline Lithuania & 58.1 & 48.6 & 62.9 & 68.9 & 55.1 & 40.4 & -30.5 \\
\hline Luxembourg & $\ldots$ & $\ldots$ & $\ldots$ & $\ldots$ & $\ldots$ & $\ldots$ & $\ldots$ \\
\hline Malta & $\ldots$ & $\ldots$ & $\ldots$ & $\ldots$ & $\ldots$ & & $\ldots$ \\
\hline Moldova & 17.8 & 15.4 & 11.9 & 13.7 & 13.1 & 16.1 & -9.5 \\
\hline Montenegro & 12.1 & 11.0 & 14.3 & 10.8 & 2.7 & 7.6 & -37.6 \\
\hline Netherlands & 56.1 & 56.8 & 51.7 & 43.0 & 25.1 & 15.7 & -72.1 \\
\hline North Macedonia & 24.0 & 25.1 & 8.6 & 18.3 & 14.0 & 13.3 & -44.5 \\
\hline Norway & & & & & & & \\
\hline Poland & 89.3 & 85.5 & 76.0 & 80.1 & 68.6 & 66.2 & -25.9 \\
\hline Portugal & 32.5 & 36.8 & 38.6 & 35.3 & 41.4 & 39.9 & 22.9 \\
\hline Romania & $\ldots$ & $\ldots$ & $\ldots$ & $\ldots$ & $\ldots$ & $\ldots$ & $\ldots$ \\
\hline Russian Federation & & & & & & & \\
\hline Serbia & 11.7 & 9.8 & 14.4 & 13.7 & 12.2 & 13.6 & 16.3 \\
\hline Slovak Republic & & & & & $\ldots$ & & \\
\hline Slovenia & 156.0 & 207.7 & 238.8 & 188.4 & 145.1 & 143.6 & -7.9 \\
\hline Spain & 19.6 & 20.3 & 20.2 & 21.4 & 18.4 & 17.0 & -13.4 \\
\hline Sweden & 100.7 & 98.5 & 88.9 & 88.6 & 88.5 & 76.5 & -24.1 \\
\hline Switzerland & 93.1 & 97.5 & 105.1 & 101.2 & 106.3 & 109.2 & 17.3 \\
\hline Turkey & 3.9 & $\ldots$ & $\ldots$ & & $\ldots$ & & ... \\
\hline Ukraine & 17.5 & 16.9 & 12.6 & 10.8 & 9.4 & 8.0 & -54.1 \\
\hline UK: England \& Wales & $\ldots$ & $\ldots$ & $\ldots$ & $\ldots$ & $\ldots$ & $\ldots$ & $\ldots$ \\
\hline UK: Northern Ireland & $\ldots$ & $\ldots$ & $\ldots$ & $\ldots$ & $\ldots$ & $\ldots$ & $\ldots$ \\
\hline Mean & 76 & 76 & 81 & 76 & 76 & 77 & \\
\hline Median & 51 & 48 & 49 & 43 & 42 & 40 & \\
\hline Minimum & 4 & 6 & 5 & 6 & 3 & 7 & \\
\hline Maximum & 330 & 326 & 364 & 331 & 405 & 420 & \\
\hline
\end{tabular}


Table 1.2.2.20 Offenders per 100000 population - Cyber fraud

\begin{tabular}{|c|c|c|c|c|c|c|c|}
\hline & 2011 & 2012 & 2013 & 2014 & 2015 & 2016 & $\begin{array}{c}\% \text { change } \\
2011-2016\end{array}$ \\
\hline Albania & $\ldots$ & $\ldots$ & $\ldots$ & $\ldots$ & $\ldots$ & $\ldots$ & $\ldots$ \\
\hline Armenia & $\begin{array}{l}\cdots \\
\ldots\end{array}$ & $\begin{array}{l}\cdots \\
\ldots\end{array}$ & $\begin{array}{l}\cdots \\
\ldots\end{array}$ & $\cdots$ & $\begin{array}{l}\cdots \\
\ldots\end{array}$ & $\ldots$ & $\ldots$ \\
\hline Austria & $\ldots$ & $\ldots$ & $\ldots$ & $\ldots$ & $\ldots$ & $\ldots$ & $\ldots$ \\
\hline Azerbaijan & $\ldots$ & $\ldots$ & $\ldots$ & $\ldots$ & $\ldots$ & $\ldots$ & $\ldots$ \\
\hline Belgium & 4.8 & 6.5 & 7.8 & 6.0 & 7.5 & 8.0 & 67.7 \\
\hline Bosnia-Herzegovina & $\ldots$ & $\ldots$ & $\ldots$ & $\ldots$ & & & $\ldots$ \\
\hline Bulgaria & 0.0 & 0.0 & 0.0 & 0.0 & 0.0 & 0.1 & 415.1 \\
\hline Croatia & $\ldots$ & $\ldots$ & $\ldots$ & $\ldots$ & $\ldots$ & $\ldots$ & $\ldots$ \\
\hline Cyprus & $\ldots$ & $\ldots$ & $\ldots$ & $\ldots$ & $\ldots$ & $\ldots$ & $\ldots$ \\
\hline Czech Republic & 0.5 & 0.4 & 0.5 & 0.8 & 1.2 & 1.8 & 303.7 \\
\hline Denmark & $\ldots$ & $\ldots$ & $\ldots$ & $\ldots$ & $\ldots$ & $\ldots$ & $\ldots$ \\
\hline Estonia & $\ldots$ & $\ldots$ & $\ldots$ & $\ldots$ & $\ldots$ & $\ldots$ & $\ldots$ \\
\hline Finland & $\ldots$ & $\ldots$ & $\ldots$ & $\ldots$ & $\ldots$ & $\ldots$ & $\ldots$ \\
\hline France & $\ldots$ & $\ldots$ & $\ldots$ & $\ldots$ & ... & $\ldots$ & $\ldots$ \\
\hline Georgia & $\ldots$ & $\ldots$ & $\ldots$ & $\ldots$ & $\ldots$ & $\ldots$ & $\ldots$ \\
\hline Germany & $\ldots$ & $\ldots$ & $\ldots$ & $\ldots$ & $\ldots$ & $\ldots$ & $\ldots$ \\
\hline Greece & $\ldots$ & $\ldots$ & $\ldots$ & $\ldots$ & $\ldots$ & $\ldots$ & $\ldots$ \\
\hline Hungary & $\ldots$ & $\ldots$ & 0.3 & 2.1 & 3.3 & 5.3 & $\ldots$ \\
\hline Iceland & $\ldots$ & $\ldots$ & $\ldots$ & $\ldots$ & $\ldots$ & $\ldots$ & $\ldots$ \\
\hline Ireland & $\ldots$ & $\ldots$ & $\ldots$ & $\ldots$ & $\ldots$ & $\ldots$ & $\ldots$ \\
\hline Italy & $\ldots$ & $\ldots$ & $\ldots$ & $\ldots$ & $\ldots$ & $\ldots$ & $\ldots$ \\
\hline Kosovo (UN R/1244/99) & $\ldots$ & $\ldots$ & $\ldots$ & $\ldots$ & $\ldots$ & $\ldots$ & $\ldots$ \\
\hline Latvia & $\ldots$ & $\ldots$ & $\ldots$ & $\ldots$ & $\ldots$ & $\ldots$ & $\ldots$ \\
\hline Lithuania & $\ldots$ & $\ldots$ & $\ldots$ & $\ldots$ & $\ldots$ & $\ldots$ & $\ldots$ \\
\hline Luxembourg & $\ldots$ & $\ldots$ & $\ldots$ & $\ldots$ & $\ldots$ & $\ldots$ & $\ldots$ \\
\hline Malta & $\ldots$ & $\ldots$ & $\ldots$ & $\ldots$ & $\ldots$ & $\ldots$ & $\ldots$ \\
\hline Moldova & 0.0 & 0.0 & 0.0 & 0.1 & 0.1 & 0.0 & $\ldots$ \\
\hline Montenegro & 0.0 & 0.0 & 0.0 & 0.0 & 0.0 & 0.0 & $\ldots$ \\
\hline Netherlands & $\ldots$ & $\ldots$ & $\ldots$ & $\ldots$ & $\ldots$ & $\ldots$ & $\ldots$ \\
\hline North Macedonia & 0.1 & 0.2 & 0.2 & 0.2 & 0.1 & 0.1 & 49.0 \\
\hline Norway & $\ldots$ & $\ldots$ & $\ldots$ & $\ldots$ & $\ldots$ & $\ldots$ & $\ldots$ \\
\hline Poland & $\ldots$ & $\ldots$ & $\ldots$ & $\ldots$ & $\ldots$ & $\ldots$ & $\ldots$ \\
\hline Portugal & 2.1 & 2.7 & 3.2 & 3.4 & 3.7 & 3.2 & 51.1 \\
\hline Romania & $\ldots$ & $\ldots$ & $\ldots$ & $\ldots$ & $\ldots$ & $\ldots$ & $\ldots$ \\
\hline Russian Federation & $\ldots$ & $\ldots$ & $\ldots$ & $\ldots$ & $\ldots$ & $\ldots$ & $\ldots$ \\
\hline Serbia & 0.1 & 0.2 & 0.1 & 0.1 & 0.1 & 0.3 & 309.9 \\
\hline Slovak Republic & & $\ldots$ & & & & $\ldots$ & \\
\hline Slovenia & 2.2 & 1.9 & 3.6 & 5.5 & 5.5 & 1.6 & -27.2 \\
\hline Spain & 3.1 & 3.2 & 3.1 & 3.4 & 3.6 & 3.9 & 27.5 \\
\hline Sweden & 33.8 & 31.9 & 31.5 & 33.3 & 31.9 & 28.2 & -16.7 \\
\hline Switzerland & 14.3 & 13.8 & 13.7 & 12.9 & 13.1 & 13.0 & -8.6 \\
\hline Turkey & $\ldots$ & $\ldots$ & $\ldots$ & $\ldots$ & $\ldots$ & 3.3 & $\ldots$ \\
\hline Ukraine & $\ldots$ & $\ldots$ & $\ldots$ & $\ldots$ & $\ldots$ & $\ldots$ & $\ldots$ \\
\hline UK: England \& Wales & $\ldots$ & $\ldots$ & $\ldots$ & $\ldots$ & $\ldots$ & $\ldots$ & $\ldots$ \\
\hline UK: Northern Ireland & $\ldots$ & $\ldots$ & $\ldots$ & $\ldots$ & $\ldots$ & $\ldots$ & $\ldots$ \\
\hline UK: Scotland & $\ldots$ & $\ldots$ & $\ldots$ & $\ldots$ & $\ldots$ & $\ldots$ & $\ldots$ \\
\hline Mean & 5 & 5 & 5 & 5 & 5 & 5 & \\
\hline Median & 1 & 1 & 1 & 2 & 3 & 3 & \\
\hline Minimum & 0 & 0 & 0 & 0 & 0 & 0 & \\
\hline Maximum & 34 & 32 & 31 & 33 & 32 & 28 & \\
\hline
\end{tabular}


Table 1.2.2.21 Offenders per 100000 population - Forgery of documents

\begin{tabular}{|c|c|c|c|c|c|c|c|}
\hline & 2011 & 2012 & 2013 & 2014 & 2015 & 2016 & $\begin{array}{l}\% \text { change } \\
2011-2016\end{array}$ \\
\hline Albania & 25.0 & 24.2 & 19.4 & 19.8 & 24.2 & 32.9 & 31.7 \\
\hline Armenia & & & $\ldots$ & & & & \\
\hline Austria & 46.5 & 51.5 & 47.1 & 51.7 & 49.9 & 54.8 & 18.0 \\
\hline Azerbaijan & $\ldots$ & & $\ldots$ & $\ldots$ & & $\ldots$ & \\
\hline Belgium & 5.3 & 5.7 & 4.7 & 3.8 & 3.8 & 4.0 & -25.0 \\
\hline Bosnia-Herzegovina & $\ldots$ & $\ldots$ & $\ldots$ & $\ldots$ & $\ldots$ & $\ldots$ & $\ldots$ \\
\hline Bulgaria & $\ldots$ & $\ldots$ & $\ldots$ & $\ldots$ & $\ldots$ & $\ldots$ & \\
\hline Croatia & 42.9 & 32.4 & 28.2 & 28.5 & 34.8 & 40.4 & -5.9 \\
\hline Cyprus & $\ldots$ & $\ldots$ & $\ldots$ & $\ldots$ & & $\ldots$ & \\
\hline Czech Republic & 4.2 & 4.1 & 2.9 & 4.1 & 5.2 & 8.0 & 92.4 \\
\hline Denmark & $\ldots$ & $\ldots$ & $\ldots$ & $\ldots$ & $\ldots$ & $\ldots$ & $\ldots$ \\
\hline Estonia & $\ldots$ & $\ldots$ & $\ldots$ & $\ldots$ & $\ldots$ & $\ldots$ & $\ldots$ \\
\hline Finland & 96.7 & 74.1 & 71.6 & 55.7 & 56.8 & 51.8 & -46.4 \\
\hline France & $\ldots$ & $\ldots$ & $\ldots$ & $\ldots$ & $\ldots$ & $\ldots$ & $\ldots$ \\
\hline Georgia & $\ldots$ & 27.4 & 35.4 & 29.9 & 41.4 & 33.1 & \\
\hline Germany & 48.3 & 47.5 & 46.3 & 44.3 & 44.7 & 48.2 & -0.1 \\
\hline Greece & 9.8 & 11.3 & 15.1 & 17.2 & 14.9 & 14.4 & 46.7 \\
\hline Hungary & 88.6 & 77.6 & 74.0 & 76.1 & 70.9 & 68.5 & -22.7 \\
\hline Iceland & $\ldots$ & $\ldots$ & $\ldots$ & $\ldots$ & $\ldots$ & $\ldots$ & $\ldots$ \\
\hline Ireland & $\ldots$ & $\ldots$ & $\ldots$ & $\ldots$ & $\ldots$ & $\ldots$ & $\ldots$ \\
\hline Italy & $\ldots$ & $\ldots$ & $\ldots$ & $\ldots$ & $\ldots$ & $\ldots$ & $\ldots$ \\
\hline Kosovo (UN R/1244/99) & $\ldots$ & $\ldots$ & $\ldots$ & $\ldots$ & $\ldots$ & $\ldots$ & $\ldots$ \\
\hline Latvia & $\ldots$ & $\ldots$ & $\ldots$ & $\ldots$ & $\ldots$ & $\ldots$ & \\
\hline Lithuania & 40.8 & 38.8 & 38.7 & 36.9 & 33.2 & 29.0 & -28.7 \\
\hline Luxembourg & $\ldots$ & $\ldots$ & $\ldots$ & $\ldots$ & $\ldots$ & $\ldots$ & $\ldots$ \\
\hline Malta & $\ldots$ & $\ldots$ & $\ldots$ & $\ldots$ & $\ldots$ & $\ldots$ & \\
\hline Moldova & 17.3 & 13.5 & 7.4 & 6.8 & 6.8 & 5.4 & -68.8 \\
\hline Montenegro & 23.7 & 24.0 & 22.2 & 20.3 & 20.1 & 19.0 & -20.0 \\
\hline Netherlands & 20.4 & 18.7 & 15.7 & 16.6 & 27.2 & $\ldots$ & \\
\hline North Macedonia & 28.8 & 13.2 & 14.9 & 22.8 & 19.4 & 21.2 & -26.3 \\
\hline Norway & & $\ldots$ & $\ldots$ & $\ldots$ & & & \\
\hline Poland & 19.9 & 20.0 & 21.9 & 20.3 & 16.7 & 16.6 & -16.7 \\
\hline Portugal & 9.1 & 10.6 & 11.2 & 14.4 & 11.3 & 9.8 & 7.3 \\
\hline Romania & $\ldots$ & $\ldots$ & $\ldots$ & $\ldots$ & $\ldots$ & $\ldots$ & $\ldots$ \\
\hline Russian Federation & & $\ldots$ & & & & & \\
\hline Serbia & 59.2 & 47.4 & 37.7 & 37.7 & 36.3 & 36.4 & -38.5 \\
\hline Slovak Republic & & & $\ldots$ & $\ldots$ & & & \\
\hline Slovenia & 120.2 & 141.5 & 129.1 & 160.4 & 85.9 & 77.9 & -35.2 \\
\hline Spain & 18.2 & 19.3 & 25.2 & 20.4 & 20.5 & 17.1 & -6.3 \\
\hline Sweden & 27.4 & 26.1 & 25.6 & 26.0 & 27.5 & 26.3 & -3.8 \\
\hline Switzerland & 47.2 & 51.4 & 60.3 & 57.1 & 59.3 & 58.7 & 24.6 \\
\hline Turkey & $\ldots$ & $\ldots$ & $\ldots$ & $\ldots$ & & $\ldots$ & $\ldots$ \\
\hline Ukraine & $\ldots$ & 9.1 & 6.5 & 6.4 & 3.9 & 3.3 & $\ldots$ \\
\hline UK: England \& Wales & $\ldots$ & $\ldots$ & $\ldots$ & $\ldots$ & $\ldots$ & $\ldots$ & $\ldots$ \\
\hline $\begin{array}{l}\text { UK: Northern Ireland } \\
\text { UK: Scotland }\end{array}$ & $\ldots$ & $\ldots$ & $\ldots$ & $\ldots$ & $\ldots$ & $\ldots$ & $\ldots$ \\
\hline Mean & 38 & 34 & 33 & 34 & 31 & 31 & \\
\hline Median & 27 & 24 & 25 & 23 & 27 & 28 & \\
\hline Minimum & 4 & 4 & 3 & 4 & 4 & 3 & \\
\hline Maximum & 120 & 141 & 129 & 160 & 86 & 78 & \\
\hline
\end{tabular}


Table 1.2.2.22 Offenders per 100000 population - Money laundering

\begin{tabular}{|c|c|c|c|c|c|c|c|}
\hline & 2011 & 2012 & 2013 & 2014 & 2015 & 2016 & $\begin{array}{l}\% \text { change } \\
2011-2016\end{array}$ \\
\hline Albania & 4.5 & 4.2 & 3.7 & 9.1 & 12.8 & 13.9 & 208.7 \\
\hline Armenia & $\ldots$ & $\ldots$ & $\ldots$ & $\ldots$ & & & \\
\hline Austria & 7.2 & 5.6 & 5.1 & 6.1 & 6.2 & 8.1 & 13.1 \\
\hline Azerbaijan & $\ldots$ & $\ldots$ & & $\ldots$ & & & \\
\hline Belgium & 4.5 & 5.3 & 6.2 & 6.3 & 6.4 & 5.6 & 23.6 \\
\hline Bosnia-Herzegovina & $\ldots$ & $\ldots$ & $\ldots$ & $\ldots$ & & $\ldots$ & \\
\hline Bulgaria & 0.0 & 0.0 & 0.0 & 0.0 & 0.0 & 0.1 & 0.0 \\
\hline Croatia & 0.3 & 0.4 & 0.0 & 0.2 & 0.4 & 1.0 & 230.7 \\
\hline Cyprus & $\ldots$ & $\ldots$ & & $\ldots$ & & $\ldots$ & \\
\hline Czech Republic & 1.0 & 1.2 & 1.7 & 2.0 & 2.2 & 2.1 & 114.5 \\
\hline Denmark & $\ldots$ & $\ldots$ & $\ldots$ & $\ldots$ & $\ldots$ & $\ldots$ & $\ldots$ \\
\hline Estonia & $\ldots$ & $\ldots$ & $\ldots$ & $\ldots$ & $\ldots$ & $\ldots$ & $\ldots$ \\
\hline Finland & $\ldots$ & $\ldots$ & $\ldots$ & $\ldots$ & $\ldots$ & $\ldots$ & $\ldots$ \\
\hline France & $\ldots$ & $\ldots$ & $\ldots$ & $\ldots$ & $\ldots$ & $\ldots$ & $\ldots$ \\
\hline Georgia & $\ldots$ & $\ldots$ & $\ldots$ & $\ldots$ & $\ldots$ & $\ldots$ & $\ldots$ \\
\hline Germany & 8.8 & 8.1 & 9.2 & 9.8 & 11.6 & 13.0 & 47.5 \\
\hline Greece & $\ldots$ & $\ldots$ & $\ldots$ & $\ldots$ & $\ldots$ & & \\
\hline Hungary & 0.1 & 0.1 & 0.2 & 0.1 & 0.1 & 0.5 & 547.6 \\
\hline Iceland & $\ldots$ & $\ldots$ & $\ldots$ & $\ldots$ & $\ldots$ & $\ldots$ & $\ldots$ \\
\hline Ireland & $\ldots$ & $\ldots$ & $\cdots$ & $\ldots$ & $\ldots$ & & $\ldots$ \\
\hline $\begin{array}{l}\text { Italy } \\
\text { Kosovo (UN R/1244/99) }\end{array}$ & 5.5 & 5.7 & 6.4 & 6.5 & 7.0 & 6.7 & 22.8 \\
\hline $\begin{array}{l}\text { Kosovo (UN R/1244/99) } \\
\text { Latvia }\end{array}$ & $\ldots$ & $\ldots$ & $\ldots$ & $\ldots$ & $\cdots$ & $\cdots$ & $\cdots$ \\
\hline $\begin{array}{l}\text { Latvia } \\
\text { Lithuania }\end{array}$ & $\begin{array}{r}\ldots \\
0.9\end{array}$ & 0.6 & 0.6 & 0.8 & 0.8 & 0.8 & -17.0 \\
\hline Luxembourg & $\ldots$ & $\ldots$ & $\ldots$ & $\ldots$ & $\ldots$ & $\ldots$ & $\ldots$ \\
\hline Malta & $\ldots$ & $\ldots$ & $\ldots$ & $\ldots$ & $\ldots$ & $\ldots$ & $\ldots$ \\
\hline Moldova & 0.2 & 0.0 & 0.1 & 0.1 & 0.1 & 0.0 & -100.0 \\
\hline Montenegro & 0.6 & 0.0 & 0.6 & 0.0 & 0.0 & 0.0 & -100.0 \\
\hline Netherlands & 3.8 & 4.3 & 5.2 & 5.4 & 4.5 & & \\
\hline North Macedonia & 0.7 & 2.3 & 2.2 & 1.5 & 1.2 & 1.5 & 127.0 \\
\hline Norway & $\ldots$ & $\ldots$ & $\ldots$ & $\ldots$ & $\ldots$ & $\ldots$ & $\ldots$ \\
\hline Poland & 0.3 & 0.4 & 0.4 & 0.2 & 0.5 & 0.4 & 9.1 \\
\hline Portugal & 0.0 & 0.0 & 0.1 & 0.0 & 0.0 & 0.0 & 206.7 \\
\hline Romania & $\ldots$ & $\ldots$ & $\ldots$ & $\ldots$ & $\ldots$ & $\ldots$ & $\ldots$ \\
\hline Russian Federation & $\ldots$ & $\ldots$ & $\ldots$ & $\ldots$ & & & $\ldots$ \\
\hline Serbia & 2.9 & 2.0 & 0.6 & 0.6 & 0.2 & 0.2 & -93.1 \\
\hline Slovak Republic & & $\ldots$ & & & & & \\
\hline Slovenia & 4.5 & 11.9 & 10.4 & 8.1 & 5.4 & 5.4 & 18.5 \\
\hline Spain & 0.9 & 1.2 & 1.3 & 1.7 & 1.4 & 1.1 & 26.4 \\
\hline Sweden & 2.6 & 2.9 & 5.6 & 1.2 & 8.0 & 9.8 & 278.0 \\
\hline Switzerland & 4.2 & 4.5 & 4.4 & 5.0 & 4.2 & 7.0 & 69.7 \\
\hline Turkey & $\ldots$ & $\ldots$ & & $\ldots$ & & & \\
\hline Ukraine & 0.6 & 0.6 & 0.1 & 0.1 & 0.1 & 0.1 & -81.8 \\
\hline UK: England \& Wales & $\ldots$ & $\ldots$ & $\ldots$ & $\ldots$ & $\ldots$ & $\ldots$ & $\ldots$ \\
\hline UK: Northern Ireland & $\ldots$ & $\ldots$ & $\ldots$ & $\ldots$ & $\ldots$ & $\ldots$ & $\ldots$ \\
\hline UK: Scotland & $\ldots$ & $\ldots$ & $\ldots$ & $\ldots$ & & & \\
\hline Mean & 2.5 & 2.8 & 2.9 & 2.9 & 3.3 & 3.7 & \\
\hline Median & 0.9 & 1.6 & 1.5 & 1.3 & 1.3 & 1.1 & \\
\hline Minimum & 0.0 & 0.0 & 0.0 & 0.0 & 0.0 & 0.0 & \\
\hline Maximum & 8.8 & 11.9 & 10.4 & 9.8 & 12.8 & 13.9 & \\
\hline
\end{tabular}


1 Police Statistics

Table 1.2.2.23 Offenders per 100000 population - Corruption in the public sector

\begin{tabular}{|c|c|c|c|c|c|c|c|}
\hline & 2011 & 2012 & 2013 & 2014 & 2015 & 2016 & $\begin{array}{l}\% \text { change } \\
2011-2016\end{array}$ \\
\hline Albania & 13.5 & 16.2 & 17.1 & 8.3 & 11.4 & 15.6 & 16.1 \\
\hline Armenia & & & & & & $\ldots$ & \\
\hline Austria & 7.9 & 6.0 & 6.3 & 4.3 & 4.7 & 5.0 & -35.9 \\
\hline Azerbaijan & 0.3 & 0.4 & 0.4 & 0.1 & 0.3 & 0.4 & 19.8 \\
\hline Belgium & 0.5 & 0.5 & 0.4 & 0.2 & 0.2 & 0.3 & -43.4 \\
\hline Bosnia-Herzegovina & & & $\ldots$ & & & $\ldots$ & \\
\hline Bulgaria & 1.5 & 1.2 & 1.1 & 1.0 & 1.0 & 1.9 & 26.9 \\
\hline Croatia & 38.8 & 31.1 & 32.7 & 23.4 & 33.4 & 33.1 & -14.8 \\
\hline Cyprus & $\ldots$ & $\ldots$ & $\ldots$ & $\ldots$ & 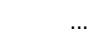 & $\ldots$ & $\ldots$ \\
\hline Czech Republic & 1.9 & 2.0 & 1.5 & 1.2 & 1.6 & 0.9 & -49.6 \\
\hline Denmark & $\ldots$ & $\ldots$ & $\ldots$ & $\ldots$ & $\ldots$ & $\ldots$ & $\ldots$ \\
\hline Estonia & $\ldots$ & $\ldots$ & $\ldots$ & $\ldots$ & $\ldots$ & $\ldots$ & $\ldots$ \\
\hline Finland & $\ldots$ & $\ldots$ & $\ldots$ & $\ldots$ & $\ldots$ & $\ldots$ & $\ldots$ \\
\hline France & $\ldots$ & $\ldots$ & $\ldots$ & $\ldots$ & $\ldots$ & $\ldots$ & $\ldots$ \\
\hline Georgia & $\ldots$ & 6.4 & 8.5 & 6.7 & 8.6 & 9.3 & $\ldots$ \\
\hline Germany & 1.4 & 1.7 & 1.5 & 2.0 & 1.4 & 1.1 & -20.9 \\
\hline Greece & 1.4 & 1.9 & 1.2 & 1.9 & 1.3 & 1.2 & -13.2 \\
\hline Hungary & 2.5 & 2.9 & 4.4 & 17.5 & 3.3 & 2.5 & -0.4 \\
\hline Iceland & $\ldots$ & $\ldots$ & $\ldots$ & $\ldots$ & $\ldots$ & $\ldots$ & $\ldots$ \\
\hline Ireland & $\ldots$ & $\ldots$ & $\ldots$ & $\ldots$ & $\ldots$ & $\ldots$ & $\ldots$ \\
\hline Italy & $\ldots$ & $\ldots$ & $\ldots$ & $\ldots$ & $\ldots$ & $\ldots$ & $\ldots$ \\
\hline Kosovo (UN R/1244/99) & $\ldots$ & $\ldots$ & $\ldots$ & $\ldots$ & $\ldots$ & $\ldots$ & $\ldots$ \\
\hline Latvia & $\ldots$ & $\ldots$ & $\ldots$ & $\ldots$ & $\ldots$ & $\ldots$ & $\ldots$ \\
\hline Lithuania & 14.5 & 22.8 & 30.2 & 36.3 & 33.0 & 17.8 & 22.1 \\
\hline Luxembourg & $\ldots$ & $\ldots$ & $\ldots$ & $\ldots$ & $\ldots$ & $\ldots$ & $\ldots$ \\
\hline Malta & $\ldots$ & $\ldots$ & $\ldots$ & $\ldots$ & $\ldots$ & $\ldots$ & $\ldots$ \\
\hline Moldova & 9.5 & 11.5 & 5.8 & 6.0 & 6.4 & 4.7 & -49.8 \\
\hline Montenegro & 19.2 & 14.8 & 14.7 & 11.1 & 15.1 & 13.7 & -28.8 \\
\hline Netherlands & $\ldots$ & $\ldots$ & $\ldots$ & $\ldots$ & $\ldots$ & $\ldots$ & $\ldots$ \\
\hline North Macedonia & $\ldots$ & $\ldots$ & $\ldots$ & $\ldots$ & $\ldots$ & $\ldots$ & $\ldots$ \\
\hline Norway & & & & . & & $\ldots$ & \\
\hline Poland & 7.4 & 6.1 & 4.8 & 4.5 & 3.9 & 3.2 & -56.0 \\
\hline Portugal & 0.1 & 0.1 & 0.1 & 0.1 & 0.1 & 0.2 & 31.4 \\
\hline Romania & $\ldots$ & $\ldots$ & $\ldots$ & $\ldots$ & $\ldots$ & $\ldots$ & $\ldots$ \\
\hline Russian Federation & & & & & & $\ldots$ & \\
\hline Serbia & 2.5 & 2.4 & 1.9 & 1.4 & 4.0 & 2.1 & -16.3 \\
\hline Slovak Republic & & & & $\ldots$ & & $\ldots$ & \\
\hline Slovenia & 4.2 & 3.8 & 1.7 & 1.1 & 3.4 & 7.1 & 67.8 \\
\hline Spain & 1.3 & 1.0 & 1.2 & 1.5 & 2.2 & 2.0 & 48.7 \\
\hline Sweden & 1.7 & 1.0 & 0.8 & 0.7 & 0.8 & 1.8 & 4.9 \\
\hline Switzerland & 0.2 & 0.1 & 0.2 & 0.9 & 0.6 & 0.2 & -5.5 \\
\hline Turkey & & & $\ldots$ & & & $\ldots$ & \\
\hline Ukraine & 4.1 & 2.7 & 2.2 & 1.6 & 2.1 & 2.0 & -52.2 \\
\hline UK: England \& Wales & $\ldots$ & $\ldots$ & $\ldots$ & $\ldots$ & $\ldots$ & $\ldots$ & $\ldots$ \\
\hline $\begin{array}{l}\text { UK: Northern Ireland } \\
\text { UK: Scotland }\end{array}$ & $\cdots$ & $\cdots$ & $\cdots$ & $\ldots$ & $\ldots$ & $\ldots$ & $\ldots$ \\
\hline Mean & 6.4 & 6.2 & 6.3 & 6.0 & 6.3 & 5.7 & \\
\hline Median & 2.5 & 2.6 & 1.8 & 1.8 & 2.7 & 2.0 & \\
\hline Minimum & 0.1 & 0.1 & 0.1 & 0.1 & 0.1 & 0.2 & \\
\hline Maximum & 38.8 & 31.1 & 32.7 & 36.3 & 33.4 & 33.1 & \\
\hline
\end{tabular}


Table 1.2.2.24 Offenders per 100000 population - Drug offences: Total

\begin{tabular}{|c|c|c|c|c|c|c|c|}
\hline & 2011 & 2012 & 2013 & 2014 & 2015 & 2016 & $\begin{array}{c}\% \text { change } \\
2011-2016\end{array}$ \\
\hline Albania & 32.5 & 43.4 & 45.7 & 53.0 & 49.0 & 47.4 & 45.8 \\
\hline Armenia & $\ldots$ & & & & & & \\
\hline Austria & 299.4 & 271.0 & 315.5 & 333.1 & 358.8 & 384.5 & 28.4 \\
\hline Azerbaijan & 25.7 & 23.6 & 24.0 & 26.4 & 26.3 & 26.5 & 3.2 \\
\hline Belgium & 398.7 & 361.8 & 398.1 & 457.0 & 431.6 & 457.9 & 14.9 \\
\hline Bosnia-Herzegovina & & & & & & & \\
\hline Bulgaria & 27.1 & 27.7 & 31.5 & 34.2 & 40.1 & 53.0 & 95.5 \\
\hline Croatia & 33.8 & 25.7 & 25.8 & 27.5 & 27.1 & 33.2 & -1.8 \\
\hline Cyprus & & & & & & & \\
\hline Czech Republic & 26.5 & 26.9 & 33.9 & 37.9 & 36.2 & 40.2 & 51.7 \\
\hline Denmark & $\ldots$ & $\ldots$ & $\ldots$ & $\ldots$ & $\ldots$ & $\ldots$ & $\ldots$ \\
\hline Estonia & $\ldots$ & $\ldots$ & $\ldots$ & $\ldots$ & & $\ldots$ & \\
\hline Finland & 358.9 & 354.0 & 381.5 & 378.1 & 402.4 & 420.6 & 17.2 \\
\hline France & 304.1 & 302.7 & 316.0 & 323.4 & 304.0 & 288.4 & -5.1 \\
\hline Georgia & 41.4 & 27.1 & 88.0 & 61.3 & 53.9 & 47.3 & 14.3 \\
\hline Germany & 244.7 & 246.6 & 261.8 & 282.4 & 285.4 & 299.0 & 22.2 \\
\hline Greece & 88.8 & 88.4 & 130.4 & 141.6 & 143.4 & 149.6 & 68.4 \\
\hline Hungary & 55.3 & 47.9 & 51.4 & 60.7 & 60.5 & 62.1 & 12.3 \\
\hline Iceland & 429.9 & 440.9 & & 490.7 & 470.4 & 366.9 & -14.7 \\
\hline Ireland & 401.0 & 373.9 & 347.8 & 356.4 & 335.9 & 352.9 & -12.0 \\
\hline Italy & 110.5 & 111.7 & 112.8 & 105.6 & 101.3 & 106.7 & -3.4 \\
\hline Kosovo (UN R/1244/99) & $\ldots$ & $\ldots$ & $\ldots$ & $\ldots$ & $\ldots$ & & $\ldots$ \\
\hline Latvia & $\ldots$ & $\ldots$ & $\ldots$ & $\ldots$ & $\ldots$ & 110.3 & $\ldots$ \\
\hline Lithuania & 50.2 & 52.6 & 51.8 & 63.4 & 61.4 & 52.8 & 5.1 \\
\hline Luxembourg & $\ldots$ & $\ldots$ & $\ldots$ & $\ldots$ & $\ldots$ & 923.6 & $\ldots$ \\
\hline Malta & $\ldots$ & & $\ldots$ & $\ldots$ & & & \\
\hline Moldova & 35.0 & 31.7 & 19.0 & 22.7 & 21.0 & 19.7 & -43.8 \\
\hline Montenegro & 50.5 & 32.4 & 28.3 & 31.9 & 29.6 & 34.1 & -32.5 \\
\hline Netherlands & 144.6 & 144.6 & 142.4 & 134.2 & 122.2 & 109.0 & -24.6 \\
\hline North Macedonia & 34.9 & 35.7 & 30.1 & 42.2 & 34.7 & 34.3 & -1.8 \\
\hline Norway & & & & & & & \\
\hline Poland & 76.6 & 77.1 & 74.2 & 67.2 & 64.9 & 71.8 & -6.2 \\
\hline Portugal & 59.6 & 63.6 & 60.4 & 60.2 & 68.8 & 75.1 & 25.9 \\
\hline Romania & $\ldots$ & $\ldots$ & $\ldots$ & $\ldots$ & $\ldots$ & $\ldots$ & $\ldots$ \\
\hline Russian Federation & & & & & & & \\
\hline Serbia & 71.4 & 67.3 & 79.8 & 87.5 & 80.5 & 98.1 & 37.4 \\
\hline Slovak Republic & & & & & & & \\
\hline Slovenia & 94.8 & 109.7 & 98.3 & 101.4 & 103.1 & 89.0 & -6.1 \\
\hline Spain & 50.6 & 48.2 & 47.7 & 44.5 & 39.3 & 40.0 & -21.0 \\
\hline Sweden & 423.0 & 436.5 & 422.8 & 434.1 & 427.0 & 420.7 & -0.5 \\
\hline Switzerland & 481.8 & 501.8 & 518.5 & 416.3 & 432.3 & 417.3 & -13.4 \\
\hline Turkey & & & & & & & \\
\hline Ukraine & 81.1 & 69.1 & 45.4 & 39.6 & 32.4 & 27.9 & -65.6 \\
\hline UK: England \& Wales & $\ldots$ & $\ldots$ & $\ldots$ & $\ldots$ & $\ldots$ & $\ldots$ & $\ldots$ \\
\hline UK: Northern Ireland & $\ldots$ & $\ldots$ & $\ldots$ & $\ldots$ & $\ldots$ & $\ldots$ & $\ldots$ \\
\hline UK: Scotland & $\ldots$ & & & $\ldots$ & & & \\
\hline Mean & 156 & 153 & 149 & 163 & 160 & 183 & \\
\hline Median & 77 & 69 & 77 & 67 & 69 & 89 & \\
\hline Minimum & 26 & 24 & 19 & 23 & 21 & 20 & \\
\hline Maximum & 482 & 502 & 518 & 491 & 470 & 924 & \\
\hline
\end{tabular}


Table 1.2.2.25 Offenders per 100000 population - Drug trafficking

\begin{tabular}{|c|c|c|c|c|c|c|c|}
\hline & 2011 & 2012 & 2013 & 2014 & 2015 & 2016 & $\begin{array}{c}\% \text { change } \\
2011-2016\end{array}$ \\
\hline Albania & 2.9 & 5.3 & 6.6 & 6.9 & 4.0 & 5.4 & 86.6 \\
\hline Armenia & $\ldots$ & $\ldots$ & $\ldots$ & $\ldots$ & $\ldots$ & $\ldots$ & $\ldots$ \\
\hline Austria & $\ldots$ & $\ldots$ & $\ldots$ & $\ldots$ & $\ldots$ & $\ldots$ & $\ldots$ \\
\hline Azerbaijan & $\ldots$ & $\ldots$ & $\ldots$ & $\ldots$ & $\ldots$ & $\ldots$ & $\ldots$ \\
\hline Belgium & 112.8 & 93.3 & 96.6 & 107.7 & 104.5 & 108.1 & -4.2 \\
\hline Bosnia-Herzegovina & $\ldots$ & $\ldots$ & $\ldots$ & $\ldots$ & $\ldots$ & $\ldots$ & $\ldots$ \\
\hline Bulgaria & $\ldots$ & $\ldots$ & & $\ldots$ & $\ldots$ & & $\ldots$ \\
\hline Croatia & 33.8 & 25.7 & 25.8 & 27.5 & 27.1 & 33.2 & -1.8 \\
\hline Cyprus & 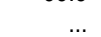 & & & & & & \\
\hline Czech Republic & 21.2 & 21.7 & 25.6 & 29.8 & 28.7 & 31.2 & 47.0 \\
\hline Denmark & $\ldots$ & $\ldots$ & $\ldots$ & $\ldots$ & $\ldots$ & $\ldots$ & $\ldots$ \\
\hline Estonia & $\ldots$ & $\ldots$ & $\ldots$ & $\ldots$ & $\ldots$ & $\ldots$ & $\ldots$ \\
\hline Finland & 139.2 & 143.6 & 155.3 & 140.5 & 136.9 & 151.6 & 8.9 \\
\hline France & 19.0 & 18.1 & 19.5 & 19.3 & 18.9 & 20.3 & 6.9 \\
\hline Georgia & & 2.5 & 4.1 & 4.2 & 5.3 & 5.7 & $\ldots$ \\
\hline Germany & 75.8 & 72.4 & 71.6 & 74.5 & 75.0 & 77.1 & 1.7 \\
\hline Greece & $\ldots$ & $\ldots$ & $\ldots$ & $\ldots$ & $\ldots$ & $\ldots$ & $\ldots$ \\
\hline Hungary & 5.0 & 4.2 & 3.1 & 3.5 & 3.9 & 4.5 & -9.9 \\
\hline Iceland & & & & & & & \\
\hline Ireland & 93.3 & 85.2 & 78.8 & 84.7 & 79.7 & 84.2 & -9.8 \\
\hline Italy & $\ldots$ & $\ldots$ & $\ldots$ & $\ldots$ & $\ldots$ & $\ldots$ & $\ldots$ \\
\hline Kosovo (UN R/1244/99) & $\ldots$ & $\ldots$ & $\ldots$ & $\ldots$ & $\ldots$ & $\ldots$ & $\ldots$ \\
\hline Latvia & $\ldots$ & $\ldots$ & $\ldots$ & $\ldots$ & $\ldots$ & 35.2 & $\ldots$ \\
\hline Lithuania & 16.2 & 19.4 & 17.3 & 20.4 & 15.3 & 16.1 & -1.1 \\
\hline Luxembourg & $\ldots$ & $\ldots$ & $\ldots$ & $\ldots$ & $\ldots$ & 96.3 & $\ldots$ \\
\hline Malta & $\ldots$ & $\ldots$ & $\ldots$ & $\ldots$ & $\ldots$ & & $\ldots$ \\
\hline Moldova & 0.5 & 0.5 & 0.3 & 0.3 & 0.5 & 0.3 & -36.3 \\
\hline Montenegro & 41.0 & 23.7 & 24.0 & 27.4 & 25.1 & 28.8 & -29.8 \\
\hline Netherlands & & & & & & & \\
\hline North Macedonia & 28.6 & 28.4 & 22.6 & 34.6 & 29.7 & 27.6 & -3.4 \\
\hline Norway & & & & $\ldots$ & & & \\
\hline Poland & 5.3 & 5.1 & 4.2 & 4.4 & 3.9 & 3.9 & -27.4 \\
\hline Portugal & 44.2 & 49.3 & 46.3 & 46.7 & 52.6 & 58.1 & 31.4 \\
\hline Romania & $\ldots$ & $\ldots$ & $\ldots$ & $\ldots$ & $\ldots$ & $\ldots$ & $\ldots$ \\
\hline Russian Federation & 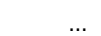 & $\ldots$ & $\ldots$ & $\ldots$ & $\ldots$ & $\ldots$ & $\ldots$ \\
\hline Serbia & 24.4 & 21.4 & 24.4 & 20.6 & 19.4 & 22.0 & -9.5 \\
\hline Slovak Republic & & & & & & & \\
\hline Slovenia & 85.9 & 101.5 & 90.6 & 92.3 & 96.8 & 82.3 & -4.2 \\
\hline Spain & & & & & & & \\
\hline Sweden & 68.1 & 65.9 & 68.5 & 67.6 & 61.3 & 57.2 & -16.0 \\
\hline Switzerland & 69.2 & 79.0 & 82.9 & 91.1 & 84.9 & 86.4 & 25.0 \\
\hline Turkey & & & & & & & \\
\hline Ukraine & 16.3 & 14.3 & 7.1 & 6.3 & 5.0 & 1.3 & -92.1 \\
\hline UK: England \& Wales & $\ldots$ & $\ldots$ & $\ldots$ & $\ldots$ & $\ldots$ & $\ldots$ & $\ldots$ \\
\hline UK: Northern Ireland & $\ldots$ & $\ldots$ & $\ldots$ & $\ldots$ & $\ldots$ & $\ldots$ & $\ldots$ \\
\hline UK: Scotland & & & & & & & \\
\hline Mean & 45.1 & 41.9 & 41.7 & 43.3 & 41.8 & 45.1 & \\
\hline Median & 31.2 & 23.7 & 24.4 & 27.5 & 27.1 & 31.2 & \\
\hline Minimum & 0.5 & 0.5 & 0.3 & 0.3 & 0.5 & 0.3 & \\
\hline Maximum & 139.2 & 143.6 & 155.3 & 140.5 & 136.9 & 151.6 & \\
\hline
\end{tabular}


Notes on tables 1.2.2.1 - 1.2.2.25

Germany Data on suspects for completed intentional homicide only available since 2013

Greece There might be breaks in the data series due to changes made to the police data system in 2013

Sweden Changes were made to the registration of offenders in 2017, now all suspects are counted. The data here has been updated based on these changes and is therefore not comparable with the previous statistics. 
1.2.3 Percentage of women, minors, and foreigners among offenders in 2015

Table 1.2.3.1 Percentage of women, minors, and foreigners among offenders in 2015 - Criminal offences: Total

\begin{tabular}{|c|c|c|c|c|c|}
\hline & $\begin{array}{c}\text { Total offenders per } \\
100000 \text { pop. }\end{array}$ & $\begin{array}{l}\text { of which \% } \\
\text { of women }\end{array}$ & $\begin{array}{l}\text { of which } \% \\
\text { of minors }\end{array}$ & $\begin{array}{l}\text { of which \% } \\
\text { of foreigners }\end{array}$ & $\begin{array}{c}\% \text { of EU citizens } \\
\text { amongst foreigners }\end{array}$ \\
\hline Albania & 1178.6 & 7.9 & 6.9 & 1.0 & $\ldots$ \\
\hline Armenia & 364.4 & 12.2 & 3.0 & 1.3 & $\ldots$ \\
\hline Austria & 2918.8 & 20.8 & 12.0 & 37.0 & $\ldots$ \\
\hline Azerbaijan & 170.1 & 6.9 & 2.9 & $\ldots$ & $\ldots$ \\
\hline Belgium & 0.0 & $\ldots$ & $\ldots$ & $\ldots$ & 44.4 \\
\hline Bosnia-Herzegovina & 646.9 & $\ldots$ & 3.8 & 0.4 & $\ldots$ \\
\hline Bulgaria & 566.8 & 13.4 & 8.1 & 7.0 & $\cdots$ \\
\hline Croatia & 1425.7 & 7.9 & 2.9 & $\ldots$ & $\ldots$ \\
\hline Cyprus & 698.3 & 8.7 & 2.3 & 18.3 & 44.3 \\
\hline Czech Republic & 966.1 & 15.6 & 3.4 & 7.1 & 62.4 \\
\hline Denmark & $\ldots$ & $\ldots$ & $\ldots$ & $\ldots$ & $\ldots$ \\
\hline Estonia & $\ldots$ & $\ldots$ & $\ldots$ & $\ldots$ & $\ldots$ \\
\hline Finland & 4788.1 & 18.6 & 8.7 & 12.1 & 42.3 \\
\hline France & 1748.4 & 17.9 & 17.2 & 16.2 & $\ldots$ \\
\hline Georgia & 567.8 & 4.5 & 1.4 & 4.5 & 2.7 \\
\hline Germany & 2917.6 & 24.8 & 12.6 & 38.5 & 23.9 \\
\hline Greece & 1022.5 & 26.2 & 4.1 & 24.1 & $\ldots$ \\
\hline Hungary & 1004.4 & 16.3 & 7.9 & 5.1 & 41.0 \\
\hline Iceland & 1176.8 & 23.0 & $\ldots$ & $\ldots$ & $\ldots$ \\
\hline Ireland & & & $\ldots$ & $\ldots$ & $\ldots$ \\
\hline Italy & 1586.3 & 18.5 & 3.7 & 32.1 & $\ldots$ \\
\hline Kosovo (UN R/1244/99) & $\ldots$ & $\ldots$ & $\ldots$ & $\ldots$ & $\ldots$ \\
\hline Latvia & 1169.9 & 12.5 & 5.8 & 4.1 & $\ldots$ \\
\hline Lithuania & 919.5 & 10.5 & 7.5 & 2.0 & $\ldots$ \\
\hline Luxembourg & 5051.2 & 23.7 & 8.4 & 59.2 & $\ldots$ \\
\hline Malta & $\ldots$ & $\ldots$ & $\ldots$ & $\ldots$ & $\ldots$ \\
\hline Moldova & 482.7 & 7.7 & 7.7 & 1.2 & 20.4 \\
\hline Montenegro & 579.7 & 7.1 & 8.1 & 13.1 & $\ldots$ \\
\hline Netherlands & 1784.3 & 16.3 & 12.4 & $\ldots$ & $\ldots$ \\
\hline North Macedonia & 1193.6 & $\ldots$ & 5.9 & 1.2 & $\ldots$ \\
\hline Norway & 1555.0 & $\ldots$ & 7.4 & 22.5 & $\cdots$ \\
\hline Poland & 840.4 & 11.3 & 8.1 & 1.1 & 37.8 \\
\hline Portugal & 1803.1 & 20.2 & $\ldots$ & $\ldots$ & $\ldots$ \\
\hline Romania & $\ldots$ & $\ldots$ & $\cdots$ & $\cdots$ & $\begin{array}{l}\cdots \\
\cdots\end{array}$ \\
\hline Russian Federation & 746.2 & $\ldots$ & 5.2 & 3.9 & $\ldots$ \\
\hline Serbia & 694.5 & 10.9 & 7.5 & 3.0 & $\ldots$ \\
\hline Slovak Republic & 856.4 & $\ldots$ & 6.0 & 0.7 & $\ldots$ \\
\hline Slovenia & 2191.9 & 18.6 & 3.5 & 11.1 & 42.1 \\
\hline Spain & 684.9 & 13.9 & 5.1 & 33.4 & 30.6 \\
\hline Sweden & 1796.5 & 20.9 & 9.2 & $\ldots$ & $\ldots$ \\
\hline Switzerland & 1670.5 & 20.2 & 9.9 & 57.3 & $\ldots$ \\
\hline Turkey & $\ldots$ & $\ldots$ & $\ldots$ & $\ldots$ & $\ldots$ \\
\hline Ukraine & 313.1 & 11.7 & 4.4 & 0.8 & $\ldots$ \\
\hline UK: England \& Wales & $\ldots$ & $\ldots$ & $\ldots$ & $\ldots$ & $\ldots$ \\
\hline UK: Northern Ireland & $\ldots$ & $\ldots$ & $\ldots$ & $\ldots$ & $\ldots$ \\
\hline UK: Scotland & $\ldots$ & $\ldots$ & $\ldots$ & $\ldots$ & $\ldots$ \\
\hline Mean & 1335 & 15.0 & 6.8 & 14.5 & 35.6 \\
\hline Median & 1013 & 14.8 & 6.9 & 7.0 & 41.0 \\
\hline Minimum & 0 & 4.5 & 1.4 & 0.4 & 2.7 \\
\hline Maximum & 5051 & 26 & 17.2 & 59 & 62.4 \\
\hline
\end{tabular}


Table 1.2.3.2 Percentage of women, minors, and foreigners among offenders in 2015 - Major road traffic offences

\begin{tabular}{|c|c|c|c|c|c|}
\hline & $\begin{array}{l}\text { Total offenders per } \\
100000 \text { pop. }\end{array}$ & $\begin{array}{l}\text { of which \% } \\
\text { of women }\end{array}$ & $\begin{array}{l}\text { of which } \% \\
\text { of minors }\end{array}$ & $\begin{array}{c}\text { of which } \% \\
\text { of foreigners }\end{array}$ & $\begin{array}{c}\% \text { of EU citizens } \\
\text { amongst foreigners }\end{array}$ \\
\hline Albania & 177 & 0.1 & $\ldots$ & $\ldots$ & $\ldots$ \\
\hline Armenia & & & & & \\
\hline Austria & 405 & 29 & 3.6 & 19.7 & 59.7 \\
\hline Azerbaijan & 18 & 1.7 & 0.7 & $\ldots$ & $\ldots$ \\
\hline Belgium & $\ldots$ & $\ldots$ & $\ldots$ & $\ldots$ & $\ldots$ \\
\hline Bosnia-Herzegovina & $\ldots$ & $\ldots$ & $\ldots$ & $\ldots$ & $\ldots$ \\
\hline Bulgaria & $\ldots$ & $\ldots$ & $\ldots$ & $\ldots$ & $\ldots$ \\
\hline Croatia & $\ldots$ & $\ldots$ & $\ldots$ & $\ldots$ & $\ldots$ \\
\hline Cyprus & 106 & & $\ldots$ & $\ldots$ & $\ldots$ \\
\hline Czech Republic & 56 & 19.4 & 0.4 & 7.1 & 62.8 \\
\hline Denmark & $\ldots$ & $\ldots$ & $\ldots$ & $\ldots$ & $\ldots$ \\
\hline Estonia & $\ldots$ & $\ldots$ & $\ldots$ & $\ldots$ & $\ldots$ \\
\hline Finland & $\ldots$ & $\ldots$ & $\ldots$ & $\ldots$ & 65.5 \\
\hline France & $\ldots$ & $\ldots$ & $\ldots$ & $\ldots$ & $\ldots$ \\
\hline Georgia & $\ldots$ & $\ldots$ & $\ldots$ & $\ldots$ & $\ldots$ \\
\hline Germany & $\ldots$ & $\ldots$ & $\ldots$ & $\ldots$ & $\ldots$ \\
\hline Greece & $\ldots$ & $\ldots$ & $\ldots$ & $\ldots$ & $\ldots$ \\
\hline Hungary & 164 & 8.3 & 0.9 & 3.5 & 79.3 \\
\hline Iceland & 170 & $\ldots$ & $\ldots$ & $\ldots$ & $\ldots$ \\
\hline Ireland & $\ldots$ & & $\ldots$ & $\ldots$ & $\ldots$ \\
\hline Italy & 2 & 13.4 & 0.9 & 18.0 & $\ldots$ \\
\hline Kosovo (UN R/1244/99) & $\ldots$ & $\ldots$ & $\ldots$ & $\ldots$ & $\ldots$ \\
\hline Latvia & $\ldots$ & $\ldots$ & $\ldots$ & $\ldots$ & $\ldots$ \\
\hline Lithuania & $\ldots$ & $\ldots$ & $\ldots$ & $\ldots$ & $\ldots$ \\
\hline Luxembourg & $\ldots$ & $\ldots$ & $\ldots$ & $\ldots$ & $\ldots$ \\
\hline Malta & $\ldots$ & & $\ldots$ & $\ldots$ & $\ldots$ \\
\hline Moldova & 11 & 5.1 & 1.3 & 0.5 & 100.0 \\
\hline Montenegro & $\ldots$ & $\ldots$ & $\ldots$ & $\ldots$ & 0.0 \\
\hline Netherlands & $\ldots$ & $\ldots$ & $\ldots$ & $\ldots$ & $\ldots$ \\
\hline North Macedonia & 125 & $\ldots$ & 1.6 & 1.0 & $\ldots$ \\
\hline Norway & $\ldots$ & & $\ldots$ & $\ldots$ & $\ldots$ \\
\hline Poland & 191 & 7.6 & 0.8 & 1.6 & 39.4 \\
\hline Portugal & 334 & 8.2 & $\ldots$ & $\ldots$ & $\ldots$ \\
\hline Romania & $\ldots$ & $\ldots$ & $\ldots$ & $\ldots$ & $\ldots$ \\
\hline Russian Federation & $\ldots$ & & $\ldots$ & $\ldots$ & $\ldots$ \\
\hline Serbia & 111 & 12.9 & 0.7 & 3.5 & $\ldots$ \\
\hline Slovak Republic & $\ldots$ & $\ldots$ & $\ldots$ & $\ldots$ & $\ldots$ \\
\hline Slovenia & $\ldots$ & $\ldots$ & $\ldots$ & $\ldots$ & $\ldots$ \\
\hline Spain & 76 & 8.6 & 1.9 & 21.6 & 42.2 \\
\hline Sweden & 413 & 10.5 & 6.0 & $\ldots$ & $\ldots$ \\
\hline Switzerland & $\ldots$ & $\ldots$ & $\ldots$ & $\ldots$ & $\ldots$ \\
\hline Turkey & $\ldots$ & & $\ldots$ & $\ldots$ & $\ldots$ \\
\hline Ukraine & 15 & 3.4 & 8.0 & 1.0 & $\ldots$ \\
\hline UK: England \& Wales & $\ldots$ & $\ldots$ & $\ldots$ & $\ldots$ & $\ldots$ \\
\hline $\begin{array}{l}\text { UK: Northern Ireland } \\
\text { UK: Scotland }\end{array}$ & $\cdots$ & $\ldots$ & $\cdots$ & $\cdots$ & $\cdots$ \\
\hline Mean & 148 & 9.9 & 2.2 & 7.8 & 56.1 \\
\hline Median & 118 & 8.3 & 1.1 & 3.5 & 61.2 \\
\hline Minimum & 2 & 0.1 & 0.4 & 0.5 & 0.0 \\
\hline Maximum & 413 & 28.9 & 8.0 & 21.6 & 100.0 \\
\hline
\end{tabular}


Table 1.2.3.3 Percentage of women, minors, and foreigners among offenders in 2015 - Intentional homicide

\begin{tabular}{|c|c|c|c|c|c|}
\hline & $\begin{array}{l}\text { Total offenders per } \\
100000 \text { pop. }\end{array}$ & $\begin{array}{l}\text { of which } \% \\
\text { of women }\end{array}$ & $\begin{array}{l}\text { of which } \% \\
\text { of minors }\end{array}$ & $\begin{array}{l}\text { of which } \% \\
\text { of foreigners }\end{array}$ & $\begin{array}{l}\% \text { of EU citizens } \\
\text { amongst foreigners }\end{array}$ \\
\hline Albania & 9 & 1.5 & 1.8 & 0.0 & $\ldots$ \\
\hline Armenia & $\ldots$ & $\ldots$ & $\ldots$ & $\ldots$ & $\ldots$ \\
\hline Austria & 2 & 15.4 & 6.2 & 48.8 & 32.9 \\
\hline Azerbaijan & 9 & 1.9 & 1.7 & $\ldots$ & \\
\hline Belgium & 0 & $\ldots$ & $\ldots$ & $\ldots$ & 40.2 \\
\hline Bosnia-Herzegovina & $\ldots$ & $\ldots$ & $\ldots$ & $\ldots$ & $\ldots$ \\
\hline Bulgaria & 2 & 11.9 & 4.8 & 4.8 & $\ldots$ \\
\hline Croatia & 3 & 9.8 & 1.6 & $\ldots$ & $\ldots$ \\
\hline Cyprus & 1 & 14.3 & 0.0 & $\ldots$ & $\ldots$ \\
\hline Czech Republic & 1 & 3.8 & 3.2 & 10.3 & 43.8 \\
\hline Denmark & $\ldots$ & $\ldots$ & $\ldots$ & $\ldots$ & $\ldots$ \\
\hline Estonia & $\ldots$ & $\ldots$ & $\ldots$ & $\ldots$ & $\ldots$ \\
\hline Finland & 7 & 12.9 & 2.8 & 7.9 & 29.0 \\
\hline France & 4 & 11.0 & 7.2 & 17.2 & $\ldots$ \\
\hline Georgia & 2 & 3.3 & 7.7 & 1.1 & $\ldots$ \\
\hline Germany & 3 & 12.1 & 5.3 & 35.3 & 27.8 \\
\hline Greece & 4 & 27.6 & 0.0 & 29.8 & $\ldots$ \\
\hline Hungary & 2 & 15.0 & 4.1 & 7.3 & 92.9 \\
\hline Iceland & $\ldots$ & $\ldots$ & $\ldots$ & $\ldots$ & $\ldots$ \\
\hline Ireland & $\ldots$ & $\ldots$ & $\ldots$ & $\ldots$ & $\ldots$ \\
\hline Italy & 4 & 9.0 & 4.1 & 45.5 & $\ldots$ \\
\hline Kosovo (UN R/1244/99) & $\ldots$ & $\ldots$ & $\ldots$ & $\ldots$ & $\ldots$ \\
\hline Latvia & $\ldots$ & $\ldots$ & $\ldots$ & $\ldots$ & $\ldots$ \\
\hline Lithuania & 5 & 9.7 & 8.4 & $\ldots$ & $\ldots$ \\
\hline Luxembourg & $\ldots$ & $\ldots$ & $\ldots$ & $\ldots$ & $\ldots$ \\
\hline Malta & $\ldots$ & $\ldots$ & $\ldots$ & $\ldots$ & $\ldots$ \\
\hline Moldova & 4 & 10.4 & 4.2 & 0.7 & 0.0 \\
\hline Montenegro & 4 & 4.5 & 0.0 & 0.0 & $\ldots$ \\
\hline Netherlands & 19 & $\ldots$ & 6.2 & $\ldots$ & $\ldots$ \\
\hline North Macedonia & 1 & 0.0 & 0.0 & 0.0 & $\ldots$ \\
\hline Norway & $\ldots$ & $\ldots$ & $\ldots$ & $\ldots$ & $\ldots$ \\
\hline Poland & 1 & 15.5 & 2.4 & 0.9 & 40.0 \\
\hline Portugal & $\ldots$ & $\ldots$ & $\ldots$ & $\ldots$ & $\ldots$ \\
\hline Romania & $\ldots$ & $\ldots$ & $\ldots$ & $\ldots$ & $\ldots$ \\
\hline Russian Federation & $\ldots$ & $\ldots$ & $\ldots$ & $\ldots$ & $\ldots$ \\
\hline Serbia & 4 & 8.4 & 8.0 & 2.9 & 0.0 \\
\hline Slovak Republic & $\ldots$ & $\ldots$ & $\ldots$ & $\ldots$ & $\ldots$ \\
\hline Slovenia & 1 & 4.0 & 4.0 & 4.0 & 0.0 \\
\hline Spain & 2 & 12.5 & 3.3 & 36.4 & 21.4 \\
\hline Sweden & 9 & 8.8 & 8.9 & $\ldots$ & $\ldots$ \\
\hline Switzerland & 2 & 13.3 & 1.0 & 55.1 & $\ldots$ \\
\hline Turkey & $\ldots$ & & $\ldots$ & & $\ldots$ \\
\hline Ukraine & 4 & 8.9 & 2.4 & 1.7 & $\ldots$ \\
\hline UK: England \& Wales & $\ldots$ & $\ldots$ & $\ldots$ & $\ldots$ & $\ldots$ \\
\hline $\begin{array}{l}\text { UK: Northern Ireland } \\
\text { UK: Scotland }\end{array}$ & $\begin{array}{l}\ldots \\
\ldots\end{array}$ & $\ldots$ & $\ldots$ & $\ldots$ & $\ldots$ \\
\hline Mean & 4 & 9.8 & 3.8 & 15.5 & 29.8 \\
\hline Median & 3 & 9.8 & 3.7 & 6.0 & 29.0 \\
\hline Minimum & 0 & 0.0 & 0.0 & 0.0 & 0.0 \\
\hline Maximum & 19 & 27.6 & 8.9 & 55.1 & 92.9 \\
\hline
\end{tabular}


Table 1.2.3.4 Percentage of women, minors, and foreigners among offenders in 2015 - Intentional homicide: Completed

\begin{tabular}{|c|c|c|c|c|c|}
\hline & $\begin{array}{l}\text { Total offenders per } \\
100000 \text { pop. }\end{array}$ & $\begin{array}{l}\text { of which } \% \\
\text { of women }\end{array}$ & $\begin{array}{l}\text { of which } \% \\
\text { of minors }\end{array}$ & $\begin{array}{l}\text { of which \% } \\
\text { of foreigners }\end{array}$ & $\begin{array}{c}\% \text { of EU citizens } \\
\text { amongst foreigners }\end{array}$ \\
\hline Albania & 2.8 & $\ldots$ & $\ldots$ & 0.0 & $\ldots$ \\
\hline Armenia & 0.0 & $\ldots$ & $\ldots$ & $\ldots$ & $\ldots$ \\
\hline Austria & & $\ldots$ & $\ldots$ & $\ldots$ & $\ldots$ \\
\hline Azerbaijan & & $\ldots$ & $\ldots$ & $\ldots$ & $\ldots$ \\
\hline Belgium & 0.0 & $\ldots$ & $\ldots$ & $\ldots$ & 50.0 \\
\hline Bosnia-Herzegovina & $\ldots$ & $\ldots$ & $\ldots$ & $\ldots$ & $\ldots$ \\
\hline Bulgaria & $\ldots$ & $\ldots$ & $\ldots$ & $\ldots$ & $\ldots$ \\
\hline Croatia & & & & & $\ldots$ \\
\hline Cyprus & 0.9 & 0.0 & 0.0 & 0.0 & $\ldots$ \\
\hline Czech Republic & $\ldots$ & $\ldots$ & $\ldots$ & $\ldots$ & $\ldots$ \\
\hline Denmark & $\ldots$ & $\ldots$ & $\ldots$ & $\ldots$ & $\ldots$ \\
\hline Estonia & & & $\ldots$ & & $\ldots$ \\
\hline Finland & 1.9 & 15.5 & 4.9 & 7.8 & 12.5 \\
\hline France & 1.3 & 13.9 & 5.7 & 16.6 & $\ldots$ \\
\hline Georgia & 2.7 & 3.0 & 6.9 & 1.0 & $\ldots$ \\
\hline Germany & 0.9 & 16.5 & 3.8 & $\ldots$ & $\ldots$ \\
\hline Greece & & & $\ldots$ & & $\ldots$ \\
\hline Hungary & 1.1 & 12.6 & 4.5 & 8.1 & 100.0 \\
\hline Iceland & $\ldots$ & $\ldots$ & $\cdots$ & $\ldots$ & $\ldots$ \\
\hline Ireland & & & $\ldots$ & & $\cdots$ \\
\hline Italy & 1.8 & 6.8 & 3.1 & 25.0 & $\ldots$ \\
\hline Kosovo (UN R/1244/99) & $\ldots$ & $\ldots$ & $\ldots$ & $\ldots$ & $\ldots$ \\
\hline Latvia & $\ldots$ & $\ldots$ & $\ldots$ & $\ldots$ & $\ldots$ \\
\hline Lithuania & & & $\ldots$ & $\ldots$ & $\ldots$ \\
\hline Luxembourg & 0.5 & 0.0 & $\ldots$ & $\ldots$ & $\ldots$ \\
\hline Malta & & & & & $\ldots$ \\
\hline Moldova & 3.1 & 12.6 & 6.3 & 1.8 & 0.0 \\
\hline Montenegro & 2.1 & 0.0 & 0.0 & 0.0 & $\ldots$ \\
\hline Netherlands & $\ldots$ & $\ldots$ & $\ldots$ & $\ldots$ & $\ldots$ \\
\hline North Macedonia & $\ldots$ & $\ldots$ & $\ldots$ & $\ldots$ & $\ldots$ \\
\hline Norway & $\ldots$ & $\ldots$ & $\ldots$ & $\ldots$ & $\ldots$ \\
\hline Poland & & & $\ldots$ & $\ldots$ & $\ldots$ \\
\hline Portugal & 0.5 & 5.6 & $\ldots$ & $\ldots$ & $\ldots$ \\
\hline Romania & $\ldots$ & $\ldots$ & $\ldots$ & $\ldots$ & $\ldots$ \\
\hline Russian Federation & & & $\ldots$ & & $\ldots$ \\
\hline Serbia & 1.5 & 9.1 & 3.6 & 5.5 & $\ldots$ \\
\hline Slovak Republic & & & & & $\ldots$ \\
\hline Slovenia & 0.7 & 0.0 & 6.7 & 0.0 & $\ldots$ \\
\hline Spain & 0.9 & 14.2 & 3.5 & 25.2 & 35.6 \\
\hline Sweden & 2.8 & 7.6 & 7.6 & $\ldots$ & $\ldots$ \\
\hline Switzerland & 0.7 & $\ldots$ & $\ldots$ & $\ldots$ & $\ldots$ \\
\hline Turkey & $\ldots$ & $\ldots$ & $\ldots$ & $\ldots$ & $\ldots$ \\
\hline Ukraine & $\ldots$ & $\ldots$ & $\ldots$ & $\ldots$ & $\ldots$ \\
\hline UK: England \& Wales & $\ldots$ & $\ldots$ & $\ldots$ & $\ldots$ & $\ldots$ \\
\hline UK: Northern Ireland & $\ldots$ & $\ldots$ & $\ldots$ & $\ldots$ & $\ldots$ \\
\hline UK: Scotland & & & & & \\
\hline Mean & 1 & 7.8 & 4.3 & 7.6 & 39.6 \\
\hline Median & 1 & 7.6 & 4.5 & 3.6 & 35.6 \\
\hline Minimum & 0 & 0.0 & 0.0 & 0.0 & 0.0 \\
\hline Maximum & 3 & 16.5 & 7.6 & 25.2 & 100.0 \\
\hline
\end{tabular}


Table 1.2.3.5 Percentage of women, minors, and foreigners among offenders in 2015 - Bodily injury

\begin{tabular}{ccccc}
$\begin{array}{c}\text { Total offenders per } \\
100000 \text { pop. }\end{array}$ & $\begin{array}{c}\text { of which } \% \\
\text { of women }\end{array}$ & $\begin{array}{c}\text { of which } \% \\
\text { of minors }\end{array}$ & $\begin{array}{c}\text { of which } \% \\
\text { of foreigners }\end{array}$ & $\begin{array}{c}\% \text { of EU citizens } \\
\text { amongst foreigners }\end{array}$ \\
\hline
\end{tabular}

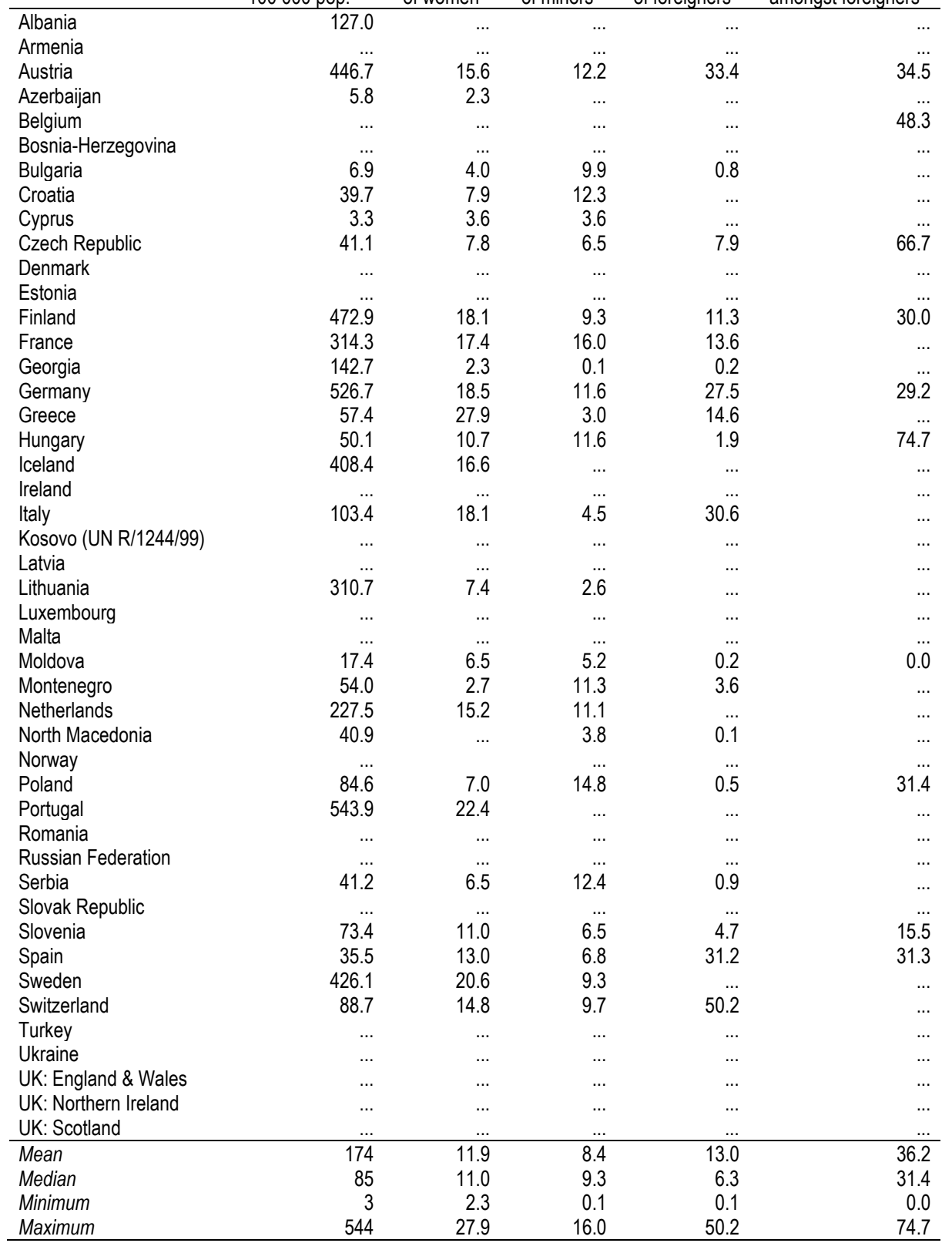


Table 1.2.3.6 Percentage of women, minors, and foreigners among offenders in 2015 - Aggravated bodily injury Total offenders per 100000 pop.

\begin{tabular}{|c|c|c|c|c|c|}
\hline & 100000 pop. & of women & of minors & of foreigners & amongst foreigners \\
\hline Albania & $\ldots$ & $\ldots$ & $\ldots$ & & $\ldots$ \\
\hline Armenia & & & & & \\
\hline Austria & 42.8 & 10.0 & 12.8 & 39.8 & 34.0 \\
\hline Azerbaijan & $\ldots$ & $\ldots$ & $\ldots$ & $\ldots$ & $\ldots$ \\
\hline Belgium & $\ldots$ & $\ldots$ & $\ldots$ & $\ldots$ & $\ldots$ \\
\hline Bosnia-Herzegovina & $\ldots$ & $\ldots$ & $\ldots$ & $\ldots$ & $\ldots$ \\
\hline Bulgaria & 0.1 & 25.0 & 0.0 & 0.0 & $\ldots$ \\
\hline Croatia & 21.9 & 5.1 & 5.7 & $\ldots$ & $\ldots$ \\
\hline Cyprus & $\ldots$ & $\ldots$ & $\ldots$ & $\ldots$ & $\ldots$ \\
\hline Czech Republic & $\ldots$ & $\ldots$ & $\ldots$ & $\ldots$ & $\ldots$ \\
\hline Denmark & $\cdots$ & $\ldots$ & $\ldots$ & $\ldots$ & $\ldots$ \\
\hline Estonia & & $\ldots$ & & & \\
\hline Finland & 29.6 & 17.7 & 5.5 & 8.3 & 29.9 \\
\hline France & $\ldots$ & $\ldots$ & $\ldots$ & $\ldots$ & $\ldots$ \\
\hline Georgia & 5.3 & 1.0 & 0.5 & & $\ldots$ \\
\hline Germany & 165.7 & 15.6 & 15.8 & 27.4 & 31.3 \\
\hline Greece & & $\ldots$ & & & $\ldots$ \\
\hline Hungary & 40.2 & 7.4 & 8.7 & 1.7 & 79.1 \\
\hline Iceland & $\ldots$ & $\ldots$ & $\ldots$ & $\ldots$ & $\ldots$ \\
\hline Ireland & & $\ldots$ & & & $\ldots$ \\
\hline Italy & 86.2 & 16.8 & 4.5 & 31.8 & $\ldots$ \\
\hline Kosovo (UN R/1244/99) & $\ldots$ & $\ldots$ & $\ldots$ & $\ldots$ & $\ldots$ \\
\hline Latvia & & $\ldots$ & $\ldots$ & $\ldots$ & $\ldots$ \\
\hline Lithuania & 5.7 & 12.0 & 9.0 & $\ldots$ & $\ldots$ \\
\hline Luxembourg & $\ldots$ & $\ldots$ & $\ldots$ & $\ldots$ & $\ldots$ \\
\hline Malta & & $\ldots$ & & & \\
\hline Moldova & 13.7 & 8.0 & 7.0 & 0.2 & 0.0 \\
\hline Montenegro & 21.5 & 0.7 & 11.2 & 0.0 & $\ldots$ \\
\hline Netherlands & & $\ldots$ & & & $\ldots$ \\
\hline North Macedonia & 9.2 & $\ldots$ & 13.6 & 0.5 & $\ldots$ \\
\hline Norway & 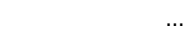 & $\ldots$ & & & \\
\hline Poland & 2.0 & 9.3 & 3.0 & 1.5 & 9.1 \\
\hline Portugal & 4.7 & 12.2 & $\ldots$ & $\ldots$ & $\ldots$ \\
\hline Romania & $\ldots$ & $\ldots$ & $\ldots$ & $\ldots$ & $\ldots$ \\
\hline Russian Federation & $\ldots$ & $\ldots$ & $\ldots$ & $\ldots$ & $\ldots$ \\
\hline Serbia & 18.3 & 2.7 & 13.3 & 0.8 & $\ldots$ \\
\hline Slovak Republic & & $\ldots$ & & & \\
\hline Slovenia & 7.6 & 6.4 & 8.3 & 3.2 & 0.0 \\
\hline Spain & $\ldots$ & $\ldots$ & $\ldots$ & $\ldots$ & $\ldots$ \\
\hline Sweden & & $\ldots$ & & & $\ldots$ \\
\hline Switzerland & 6.6 & 8.6 & 13.0 & 53.2 & $\ldots$ \\
\hline Turkey & & & & & $\ldots$ \\
\hline Ukraine & 4.8 & 11.6 & 2.2 & 0.9 & $\ldots$ \\
\hline UK: England \& Wales & $\ldots$ & $\ldots$ & $\ldots$ & $\ldots$ & $\ldots$ \\
\hline UK: Northern Ireland & $\ldots$ & $\cdots$ & $\ldots$ & $\ldots$ & $\ldots$ \\
\hline UK: Scotland & & & & & \\
\hline $\begin{array}{l}\text { Mean } \\
\text { Median }\end{array}$ & $\begin{array}{l}27 \\
11\end{array}$ & $\begin{array}{r}10.0 \\
9.3\end{array}$ & $\begin{array}{l}7.9 \\
8.3\end{array}$ & $\begin{array}{r}12.1 \\
1.6\end{array}$ & $\begin{array}{l}26.2 \\
29.9\end{array}$ \\
\hline Minimum & 0 & 0.7 & 0.0 & 0.0 & 0.0 \\
\hline Maximum & 166 & 25.0 & 15.8 & 53.2 & 79.1 \\
\hline
\end{tabular}


Table 1.2.3.7 Percentage of women, minors, and foreigners among offenders in 2015 - Sexual assault

\begin{tabular}{|c|c|c|c|c|c|}
\hline & $\begin{array}{l}\text { Total offenders per } \\
100000 \text { pop. }\end{array}$ & $\begin{array}{l}\text { of which } \% \\
\text { of women }\end{array}$ & $\begin{array}{l}\text { of which } \% \\
\text { of minors }\end{array}$ & $\begin{array}{l}\text { of which } \% \\
\text { of foreigners }\end{array}$ & $\begin{array}{l}\% \text { of EU citizens } \\
\text { amongst foreigners }\end{array}$ \\
\hline Albania & 5.6 & $\ldots$ & $\ldots$ & $\ldots$ & $\ldots$ \\
\hline Armenia & & $\ldots$ & & & \\
\hline Austria & 31.1 & 3.1 & 15.0 & 29.2 & 35.0 \\
\hline Azerbaijan & $\ldots$ & $\ldots$ & $\ldots$ & $\ldots$ & \\
\hline Belgium & $\ldots$ & $\ldots$ & $\ldots$ & $\ldots$ & 39.3 \\
\hline Bosnia-Herzegovina & & & & & $\ldots$ \\
\hline Bulgaria & 4.0 & 2.8 & 21.3 & 1.7 & $\ldots$ \\
\hline Croatia & 9.0 & 0.5 & 5.8 & $\ldots$ & $\ldots$ \\
\hline Cyprus & & & $\ldots$ & & \\
\hline Czech Republic & 9.0 & 6.5 & 26.1 & 9.2 & 67.8 \\
\hline Denmark & $\ldots$ & $\ldots$ & $\ldots$ & $\ldots$ & $\ldots$ \\
\hline Estonia & & $\ldots$ & & $\ldots$ & \\
\hline Finland & 41.2 & 1.9 & 9.3 & 18.3 & 14.5 \\
\hline France & 45.9 & 6.6 & 24.2 & 14.0 & $\ldots$ \\
\hline Georgia & 8.3 & $\ldots$ & & $\ldots$ & $\ldots$ \\
\hline Germany & 22.3 & 2.6 & 16.7 & 24.0 & 29.2 \\
\hline Greece & 11.4 & 26.4 & 3.8 & 36.9 & $\ldots$ \\
\hline Hungary & 6.8 & 6.8 & 10.5 & 3.0 & 85.0 \\
\hline Iceland & 96.0 & 3.5 & $\ldots$ & $\ldots$ & $\ldots$ \\
\hline Ireland & & & & $\ldots$ & $\ldots$ \\
\hline Italy & 7.6 & 2.8 & 5.8 & 38.9 & $\ldots$ \\
\hline Kosovo (UN R/1244/99) & $\ldots$ & $\ldots$ & $\ldots$ & $\ldots$ & $\ldots$ \\
\hline Latvia & & $\ldots$ & $\ldots$ & $\ldots$ & $\ldots$ \\
\hline Lithuania & 8.0 & 1.7 & 12.9 & $\ldots$ & $\ldots$ \\
\hline Luxembourg & 61.1 & 32.8 & $\ldots$ & $\ldots$ & $\ldots$ \\
\hline Malta & & & & $\ldots$ & $\ldots$ \\
\hline Moldova & 9.6 & 0.3 & 9.1 & $(0.3)$ & $\ldots$ \\
\hline Montenegro & 3.9 & 4.2 & 8.3 & 8.3 & 0.0 \\
\hline Netherlands & 15.7 & 1.9 & 12.1 & $\ldots$ & $\ldots$ \\
\hline North Macedonia & 5.5 & $\ldots$ & 12.4 & 0.9 & $\ldots$ \\
\hline Norway & & $\ldots$ & & $\ldots$ & \\
\hline Poland & 3.5 & 1.0 & 15.6 & 0.7 & 55.6 \\
\hline Portugal & 11.0 & 5.0 & $\ldots$ & $\ldots$ & $\ldots$ \\
\hline Romania & $\ldots$ & $\ldots$ & $\ldots$ & $\ldots$ & $\ldots$ \\
\hline Russian Federation & & $\ldots$ & & $\ldots$ & $\ldots$ \\
\hline Serbia & 3.6 & 0.4 & 15.2 & 1.9 & $\ldots$ \\
\hline Slovak Republic & & $\ldots$ & & $\ldots$ & $\ldots$ \\
\hline Slovenia & 8.0 & 0.6 & 10.4 & 9.1 & 26.7 \\
\hline Spain & 13.0 & 4.5 & 6.9 & 37.1 & 22.6 \\
\hline Sweden & 55.6 & 2.3 & 12.5 & $\ldots$ & $\ldots$ \\
\hline Switzerland & 30.3 & 2.8 & 16.4 & 46.8 & $\ldots$ \\
\hline Turkey & & & & & $\ldots$ \\
\hline Ukraine & 0.7 & 0.6 & 4.5 & 2.5 & $\ldots$ \\
\hline UK: England \& Wales & $\ldots$ & $\ldots$ & $\ldots$ & $\ldots$ & $\ldots$ \\
\hline $\begin{array}{l}\text { UK: Northern Ireland } \\
\text { UK: Scotland }\end{array}$ & $\cdots$ & $\cdots$ & $\ldots$ & $\cdots$ & $\ldots$ \\
\hline Mean & 20 & 5.1 & 12.5 & 16.6 & 37.6 \\
\hline Median & 9 & 2.8 & 12.2 & 9.2 & 32.1 \\
\hline Minimum & 1 & 0.3 & 3.8 & 0.7 & 0.0 \\
\hline Maximum & 96 & 32.8 & 26.1 & 46.8 & 85.0 \\
\hline
\end{tabular}


Table 1.2.3.8 Percentage of women, minors, and foreigners among offenders in 2015 - Rape

\begin{tabular}{|c|c|c|c|c|c|}
\hline & $\begin{array}{c}\text { Total offenders per } \\
100000 \text { pop. }\end{array}$ & $\begin{array}{l}\text { of which \% } \\
\text { of women }\end{array}$ & $\begin{array}{l}\text { of which } \% \\
\text { of minors }\end{array}$ & $\begin{array}{l}\text { of which } \% \\
\text { of foreigners }\end{array}$ & $\begin{array}{c}\% \text { of EU citizens } \\
\text { amongst foreigners }\end{array}$ \\
\hline Albania & $\ldots$ & $\ldots$ & $\ldots$ & $\ldots$ & $\ldots$ \\
\hline $\begin{array}{l}\text { Armenia } \\
\text { Austria }\end{array}$ & 12... & $\ldots$ & 13 & & \\
\hline $\begin{array}{l}\text { Austria } \\
\text { Azerbaijan }\end{array}$ & $\begin{array}{r}12.4 \\
0.3\end{array}$ & 3.7 & $\begin{array}{r}13.3 \\
0.0\end{array}$ & 44.8 & 20.7 \\
\hline $\begin{array}{l}\text { Azerbaijan } \\
\text { Belgium }\end{array}$ & 0.3 & $\ldots$ & 0.0 & $\ldots$ & \\
\hline $\begin{array}{l}\text { Belgium } \\
\text { Bosnia-Herzegovina }\end{array}$ & $\cdots$ & $\ldots$ & $\cdots$ & $\ldots$ & 31.6 \\
\hline $\begin{array}{l}\text { Bosnia-Herzegovina } \\
\text { Bulgaria }\end{array}$ & & & $\ldots$ & & .. \\
\hline Bulgaria & 1.0 & 2.7 & 16.0 & 1.3 & $\ldots$ \\
\hline Croatia & 5.8 & 0.4 & 4.0 & $\ldots$ & $\ldots$ \\
\hline Cyprus & & & $\ldots$ & & \\
\hline Czech Republic & 3.7 & 0.5 & 11.1 & 16.3 & 61.9 \\
\hline Denmark & $\ldots$ & $\ldots$ & $\ldots$ & $\ldots$ & $\ldots$ \\
\hline Estonia & & $\ldots$ & $\ldots$ & & \\
\hline Finland & 14.8 & 0.4 & 6.7 & 24.2 & 17.9 \\
\hline France & 14.2 & 1.6 & 28.5 & 13.9 & $\ldots$ \\
\hline Georgia & 0.3 & $\ldots$ & 9.1 & & \\
\hline Germany & 7.7 & 1.5 & 8.8 & 29.9 & 24.7 \\
\hline Greece & 1.7 & 22.7 & 5.0 & 37.0 & \\
\hline Hungary & 2.6 & 2.0 & 19.0 & 2.0 & 80.0 \\
\hline Iceland & & $\ldots$ & $\ldots$ & $\ldots$ & $\ldots$ \\
\hline Ireland & 0.0 & $\ldots$ & $\ldots$ & & ... \\
\hline Italy & 6.6 & 2.5 & 5.6 & 41.6 & ... \\
\hline Kosovo (UN R/1244/99) & $\ldots$ & $\ldots$ & $\ldots$ & $\ldots$ & $\ldots$ \\
\hline Latvia & & $\ldots$ & $\ldots$ & $\ldots$ & $\ldots$ \\
\hline Lithuania & 5.7 & 0.0 & 15.7 & $\ldots$ & $\ldots$ \\
\hline Luxembourg & 9.1 & 5.9 & $\ldots$ & $\ldots$ & $\ldots$ \\
\hline Malta & & & $\ldots$ & & \\
\hline Moldova & 4.6 & 0.0 & 9.9 & 0.6 & 0.0 \\
\hline Montenegro & 0.3 & 0.0 & 0.0 & 0.0 & $\ldots$ \\
\hline Netherlands & 3.7 & $\ldots$ & 12.8 & & $\ldots$ \\
\hline North Macedonia & 1.6 & $\ldots$ & 42.4 & 0.0 & $\ldots$ \\
\hline Norway & $\ldots$ & $\ldots$ & $\ldots$ & & \\
\hline Poland & 1.6 & 0.3 & 10.6 & 1.0 & 33.3 \\
\hline Portugal & 1.4 & 4.7 & $\ldots$ & $\ldots$ & $\ldots$ \\
\hline Romania & $\ldots$ & $\ldots$ & $\ldots$ & $\ldots$ & $\ldots$ \\
\hline Russian Federation & . & $\ldots$ & $\ldots$ & & $\ldots$ \\
\hline Serbia & 0.9 & 0.0 & 21.0 & 4.8 & $\ldots$ \\
\hline Slovak Republic & & & & & \\
\hline Slovenia & 2.0 & 0.0 & 9.8 & 14.6 & 16.7 \\
\hline Spain & 1.8 & 2.0 & 10.2 & 55.5 & 20.2 \\
\hline Sweden & 29.2 & 1.4 & 12.9 & $\ldots$ & $\ldots$ \\
\hline Switzerland & 5.1 & 0.2 & 6.7 & 59.1 & $\ldots$ \\
\hline Turkey & & & & & $\ldots$ \\
\hline Ukraine & 0.4 & 0.5 & 5.9 & 3.2 & $\ldots$ \\
\hline UK: England \& Wales & $\ldots$ & $\ldots$ & $\ldots$ & $\ldots$ & $\ldots$ \\
\hline UK: Northern Ireland & $\ldots$ & $\ldots$ & $\ldots$ & $\ldots$ & ... \\
\hline UK: Scotland & . & $\ldots$ & $\ldots$ & & \\
\hline Mean & 5 & 2.4 & 11.9 & 19.4 & 30.7 \\
\hline Median & 3 & 1.0 & 10.0 & 14.3 & 22.7 \\
\hline Minimum & 0 & 0.0 & 0.0 & 0.0 & 0.0 \\
\hline Maximum & 29 & 22.7 & 42.4 & 59.1 & 80.0 \\
\hline
\end{tabular}


Table 1.2.3.9 Percentage of women, minors, and foreigners among offenders in 2015 - Sexual abuse of a child

\begin{tabular}{ccccc}
$\begin{array}{c}\text { Total offenders per } \\
100000 \text { pop. }\end{array}$ & $\begin{array}{c}\text { of which } \% \\
\text { of women }\end{array}$ & $\begin{array}{c}\text { of which } \% \\
\text { of minors }\end{array}$ & $\begin{array}{c}\text { of which } \% \\
\text { of foreigners }\end{array}$ & $\begin{array}{c}\% \text { of EU citizens } \\
\text { amongst foreigners }\end{array}$ \\
\hline
\end{tabular}

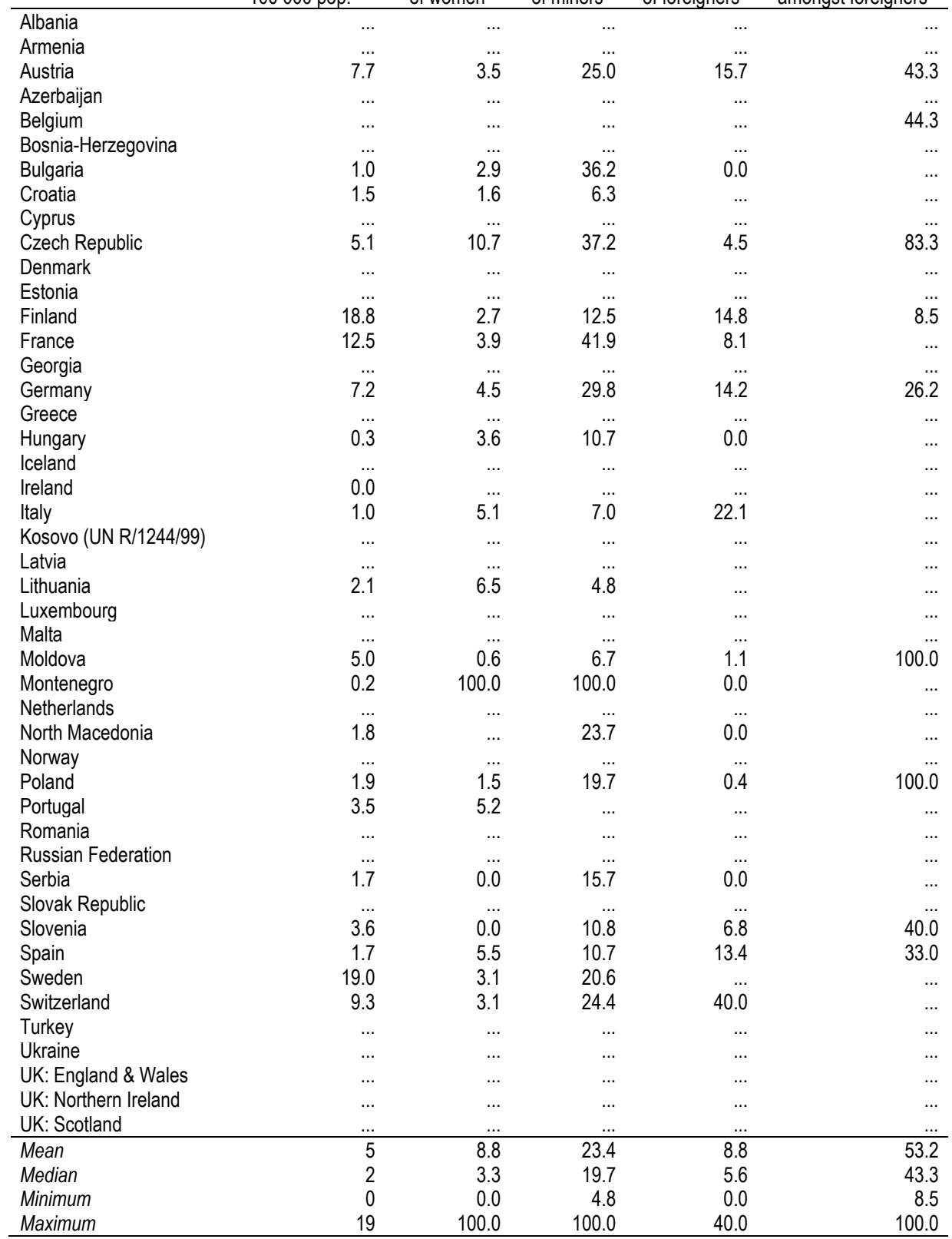


Table 1.2.3.10 Percentage of women, minors, and foreigners among offenders in 2015 - Robbery

\begin{tabular}{|c|c|c|c|c|c|}
\hline & $\begin{array}{l}\text { Total offenders per } \\
100000 \text { pop. }\end{array}$ & $\begin{array}{l}\text { of which } \% \\
\text { of women }\end{array}$ & $\begin{array}{l}\text { of which } \% \\
\text { of minors }\end{array}$ & $\begin{array}{l}\text { of which \% } \\
\text { of foreigners }\end{array}$ & $\begin{array}{l}\% \text { of EU citizens } \\
\text { amongst foreigners }\end{array}$ \\
\hline Albania & 21.0 & 0.8 & $\ldots$ & $\ldots$ & $\ldots$ \\
\hline Armenia & & & & & \\
\hline Austria & 27.9 & 8.9 & 31.3 & 58.6 & 32.1 \\
\hline Azerbaijan & 3.9 & 2.7 & 5.9 & $\ldots$ & \\
\hline Belgium & $\ldots$ & $\ldots$ & $\ldots$ & $\ldots$ & 45.1 \\
\hline Bosnia-Herzegovina & & & & & $\ldots$ \\
\hline Bulgaria & 11.2 & 3.6 & 17.9 & 1.2 & $\ldots$ \\
\hline Croatia & 36.8 & 2.2 & 2.8 & $\ldots$ & $\ldots$ \\
\hline Cyprus & 7.0 & 0.0 & 15.3 & & - \\
\hline Czech Republic & 14.1 & 8.2 & 16.2 & 9.4 & 72.9 \\
\hline Denmark & $\ldots$ & $\ldots$ & $\ldots$ & $\ldots$ & $\ldots$ \\
\hline Estonia & & & & & \\
\hline Finland & 28.5 & 13.1 & 15.9 & 12.2 & 37.9 \\
\hline France & 28.0 & 8.1 & 40.9 & 17.6 & $\ldots$ \\
\hline Georgia & 22.8 & 1.1 & 0.2 & 0.5 & $\ldots$ \\
\hline Germany & 35.3 & 9.9 & 21.4 & 38.4 & 29.2 \\
\hline Greece & 22.1 & 36.4 & 14.9 & 29.2 & \\
\hline Hungary & 10.9 & 10.3 & 22.9 & 3.0 & 75.0 \\
\hline Iceland & $\ldots$ & $\ldots$ & $\ldots$ & $\ldots$ & $\cdots$ \\
\hline Ireland & & & & & $\cdots$ \\
\hline Italy & 35.8 & 7.6 & 9.3 & 41.1 & $\ldots$ \\
\hline Kosovo (UN R/1244/99) & $\ldots$ & $\ldots$ & $\ldots$ & $\ldots$ & $\ldots$ \\
\hline Latvia & $\ldots$ & $\ldots$ & $\ldots$ & $\ldots$ & $\ldots$ \\
\hline Lithuania & 31.2 & 6.4 & 36.0 & $\ldots$ & $\ldots$ \\
\hline Luxembourg & $\ldots$ & $\ldots$ & $\ldots$ & $\ldots$ & $\ldots$ \\
\hline Malta & & & & & \\
\hline Moldova & 16.8 & 3.5 & 17.5 & 0.7 & 0.0 \\
\hline Montenegro & 7.6 & 0.0 & 12.8 & 10.6 & $\ldots$ \\
\hline Netherlands & 31.8 & $\ldots$ & 27.3 & & $\ldots$ \\
\hline North Macedonia & 14.0 & $\ldots$ & 21.0 & 1.0 & $\ldots$ \\
\hline Norway & & & & & $\ldots$ \\
\hline Poland & 14.5 & 5.6 & 19.2 & 0.7 & 52.8 \\
\hline Portugal & 78.1 & 6.7 & $\ldots$ & $\ldots$ & $\ldots$ \\
\hline Romania & $\ldots$ & $\ldots$ & $\ldots$ & $\ldots$ & $\ldots$ \\
\hline Russian Federation & & & $\ldots$ & $\ldots$ & $\ldots$ \\
\hline Serbia & 20.5 & 5.4 & 23.2 & 2.1 & $\ldots$ \\
\hline Slovak Republic & & & & & \\
\hline Slovenia & 8.0 & 9.0 & 27.1 & 17.5 & 34.5 \\
\hline Spain & 33.2 & 11.3 & 16.7 & 45.9 & 19.3 \\
\hline Sweden & 24.6 & 7.4 & 21.6 & & $\ldots$ \\
\hline Switzerland & 13.7 & 9.3 & 23.3 & 60.5 & $\ldots$ \\
\hline Turkey & & & & & $\ldots$ \\
\hline Ukraine & 15.8 & 4.3 & 8.1 & 1.3 & $\ldots$ \\
\hline UK: England \& Wales & $\ldots$ & $\ldots$ & $\ldots$ & $\ldots$ & $\ldots$ \\
\hline $\begin{array}{l}\text { UK: Northern Ireland } \\
\text { UK: Scotland }\end{array}$ & $\ldots$ & $\ldots$ & $\begin{array}{l}\ldots \\
\ldots\end{array}$ & $\ldots$ & $\ldots$ \\
\hline Mean & 23 & 7.3 & 18.8 & 18.5 & 39.9 \\
\hline Median & 21 & 6.7 & 17.9 & 10.6 & 36.2 \\
\hline Minimum & 4 & 0.0 & 0.2 & 0.5 & 0.0 \\
\hline Maximum & 78 & 36.4 & 40.9 & 60.5 & 75.0 \\
\hline
\end{tabular}


Table 1.2.3.11 Percentage of women, minors, and foreigners among offenders in 2015 - Theft: Total

\begin{tabular}{|c|c|c|c|c|c|}
\hline & $\begin{array}{l}\text { Total offenders per } \\
100000 \text { pop. }\end{array}$ & $\begin{array}{l}\text { of which } \% \\
\text { of women }\end{array}$ & $\begin{array}{l}\text { of which \% } \\
\text { of minors }\end{array}$ & $\begin{array}{l}\text { of which } \% \\
\text { of foreigners }\end{array}$ & $\begin{array}{l}\% \text { of EU citizens } \\
\text { amongst foreigners }\end{array}$ \\
\hline Albania & $\ldots$ & $\ldots$ & $\ldots$ & $\ldots$ & $\ldots$ \\
\hline Armenia & & & $\ldots$ & $\ldots$ & \\
\hline Austria & 572.9 & 27.2 & 18.9 & 57.1 & 54.0 \\
\hline Azerbaijan & 22.8 & 6.3 & 10.6 & $\ldots$ & \\
\hline Belgium & $\ldots$ & $\ldots$ & $\ldots$ & $\ldots$ & 53.5 \\
\hline Bosnia-Herzegovina & & & & & $\ldots$ \\
\hline Bulgaria & 198.1 & 19.5 & 14.4 & 0.9 & $\ldots$ \\
\hline Croatia & 698.3 & 2.5 & 3.2 & $\ldots$ & $\ldots$ \\
\hline Cyprus & 69.7 & 28.6 & 2.5 & & $\ldots$ \\
\hline Czech Republic & 210.1 & 14.6 & 5.4 & 5.9 & 81.2 \\
\hline Denmark & $\ldots$ & $\ldots$ & $\ldots$ & $\ldots$ & $\ldots$ \\
\hline Estonia & $\ldots$ & & $\ldots$ & $\ldots$ & \\
\hline Finland & 1014.1 & 25.5 & 12.3 & 13.4 & 53.7 \\
\hline France & 322.4 & 20.8 & 27.5 & 19.9 & $\ldots$ \\
\hline Georgia & 80.8 & 2.6 & 4.7 & 2.2 & $\ldots$ \\
\hline Germany & 565.3 & 29.0 & 18.8 & 38.5 & 43.1 \\
\hline Greece & 186.6 & 28.1 & 10.9 & 25.2 & $\ldots$ \\
\hline Hungary & 198.9 & 17.4 & 15.8 & 1.6 & 78.0 \\
\hline Iceland & & $\ldots$ & $\ldots$ & $\ldots$ & $\ldots$ \\
\hline Ireland & 0.0 & $\ldots$ & $\ldots$ & $\ldots$ & $\ldots$ \\
\hline Italy & 201.1 & 20.8 & 8.3 & 48.3 & $\ldots$ \\
\hline Kosovo (UN R/1244/99) & $\ldots$ & $\ldots$ & $\ldots$ & $\ldots$ & $\ldots$ \\
\hline Latvia & $\ldots$ & $\ldots$ & $\ldots$ & $\ldots$ & $\ldots$ \\
\hline Lithuania & 169.1 & 8.4 & 1.1 & 0.8 & $\ldots$ \\
\hline Luxembourg & $\ldots$ & $\ldots$ & $\ldots$ & $\ldots$ & $\ldots$ \\
\hline Malta & & $\ldots$ & $\ldots$ & $\ldots$ & $\ldots$ \\
\hline Moldova & 151.6 & 9.9 & 16.1 & 0.6 & 18.2 \\
\hline Montenegro & 97.1 & 5.5 & 35.3 & 22.2 & $\ldots$ \\
\hline Netherlands & 527.1 & 22.9 & 16.1 & $\ldots$ & $\ldots$ \\
\hline North Macedonia & 103.5 & $\ldots$ & 6.9 & 1.2 & $\ldots$ \\
\hline Norway & & & $\ldots$ & $\ldots$ & $\ldots$ \\
\hline Poland & 130.5 & 12.2 & 14.3 & 0.9 & 48.0 \\
\hline Portugal & 196.8 & 31.7 & $\ldots$ & $\ldots$ & $\ldots$ \\
\hline Romania & $\ldots$ & $\ldots$ & $\ldots$ & $\ldots$ & $\ldots$ \\
\hline Russian Federation & & . & $\ldots$ & $\ldots$ & $\ldots$ \\
\hline Serbia & 189.6 & 10.6 & 17.8 & 2.0 & $\ldots$ \\
\hline Slovak Republic & $\ldots$ & $\ldots$ & $\ldots$ & $\ldots$ & $\ldots$ \\
\hline Slovenia & 425.7 & 22.4 & 9.9 & 14.4 & 52.3 \\
\hline Spain & 78.4 & 7.0 & 10.6 & 34.5 & 32.4 \\
\hline Sweden & 389.1 & 28.1 & 13.3 & $\ldots$ & $\ldots$ \\
\hline Switzerland & 292.6 & 25.1 & 16.9 & 63.2 & $\ldots$ \\
\hline Turkey & & & & & $\ldots$ \\
\hline Ukraine & 122.8 & 11.4 & 6.6 & 0.7 & $\ldots$ \\
\hline UK: England \& Wales & $\ldots$ & $\ldots$ & $\ldots$ & $\ldots$ & $\ldots$ \\
\hline $\begin{array}{l}\text { UK: Northern Ireland } \\
\text { UK: Scotland }\end{array}$ & $\cdots$ & $\cdots$ & $\cdots$ & $\cdots$ & $\cdots$ \\
\hline Mean & 267 & 17.5 & 12.7 & 17.7 & 51.4 \\
\hline Median & 197 & 19.5 & 12.3 & 9.6 & 52.9 \\
\hline Minimum & 0 & 2.5 & 1.1 & 0.6 & 18.2 \\
\hline Maximum & 1014 & 31.7 & 35.3 & 63.2 & 81.2 \\
\hline
\end{tabular}


Table 1.2.3.12 Percentage of women, minors, and foreigners among offenders in 2015 - Aggravated theft

\begin{tabular}{|c|c|c|c|c|c|}
\hline & $\begin{array}{l}\text { Total offenders per } \\
100000 \text { pop. }\end{array}$ & $\begin{array}{l}\text { of which } \% \\
\text { of women }\end{array}$ & $\begin{array}{l}\text { of which } \% \\
\text { of minors }\end{array}$ & $\begin{array}{c}\text { of which } \% \\
\text { of foreigners }\end{array}$ & $\begin{array}{l}\% \text { of EU citizens } \\
\text { amongst foreigners }\end{array}$ \\
\hline Albania & $\ldots$ & $\ldots$ & $\ldots$ & $\ldots$ & $\ldots$ \\
\hline Armenia & & & & & \\
\hline Austria & 192.0 & 14.0 & 18.4 & 64.1 & 56.4 \\
\hline Azerbaijan & $\ldots$ & $\ldots$ & $\ldots$ & $\ldots$ & $\ldots$ \\
\hline Belgium & $\ldots$ & $\ldots$ & $\ldots$ & $\ldots$ & $\ldots$ \\
\hline Bosnia-Herzegovina & $\ldots$ & $\ldots$ & $\ldots$ & $\ldots$ & $\ldots$ \\
\hline Bulgaria & & & $\ldots$ & $\ldots$ & $\ldots$ \\
\hline Croatia & 339.4 & 1.3 & 3.8 & $\ldots$ & $\ldots$ \\
\hline Cyprus & $\ldots$ & $\ldots$ & $\ldots$ & $\ldots$ & $\ldots$ \\
\hline Czech Republic & $\ldots$ & $\ldots$ & $\ldots$ & $\ldots$ & $\ldots$ \\
\hline Denmark & $\ldots$ & $\ldots$ & $\ldots$ & $\ldots$ & $\ldots$ \\
\hline Estonia & & & $\ldots$ & $\ldots$ & \\
\hline Finland & 35.6 & 11.1 & 5.8 & 32.9 & 62.0 \\
\hline France & $\ldots$ & $\ldots$ & $\ldots$ & $\ldots$ & $\ldots$ \\
\hline Georgia & 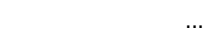 & & $\ldots$ & & \\
\hline Germany & 122.2 & 12.7 & 16.1 & 43.3 & 45.8 \\
\hline Greece & 36.9 & 28.5 & 8.0 & 34.4 & $\ldots$ \\
\hline Hungary & $\ldots$ & $\ldots$ & $\ldots$ & $\ldots$ & $\ldots$ \\
\hline Iceland & $\ldots$ & $\ldots$ & $\ldots$ & $\ldots$ & $\ldots$ \\
\hline Ireland & $\ldots$ & $\ldots$ & $\ldots$ & $\ldots$ & $\ldots$ \\
\hline Italy & $\ldots$ & $\ldots$ & $\ldots$ & $\ldots$ & $\ldots$ \\
\hline Kosovo (UN R/1244/99) & $\ldots$ & $\ldots$ & $\ldots$ & $\ldots$ & $\ldots$ \\
\hline Latvia & $\ldots$ & $\ldots$ & $\ldots$ & $\ldots$ & $\ldots$ \\
\hline Lithuania & $\ldots$ & $\ldots$ & $\ldots$ & $\ldots$ & $\ldots$ \\
\hline Luxembourg & $\ldots$ & $\ldots$ & $\ldots$ & $\ldots$ & $\ldots$ \\
\hline Malta & & & & & \\
\hline Moldova & 419.7 & 3.3 & 5.4 & 0.2 & 18.8 \\
\hline Montenegro & 48.4 & 1.0 & 41.2 & 22.3 & 0.0 \\
\hline Netherlands & & $\ldots$ & & & $\ldots$ \\
\hline North Macedonia & 172.4 & $\ldots$ & 25.3 & 0.5 & $\ldots$ \\
\hline Norway & & & & & \\
\hline Poland & 40.4 & 4.2 & 16.2 & 0.6 & 60.0 \\
\hline Portugal & 47.0 & 12.5 & $\ldots$ & $\ldots$ & $\ldots$ \\
\hline Romania & $\ldots$ & $\ldots$ & $\ldots$ & $\ldots$ & $\ldots$ \\
\hline Russian Federation & & & $\ldots$ & $\ldots$ & $\ldots$ \\
\hline Serbia & 75.8 & 5.0 & 19.4 & 1.7 & 0.0 \\
\hline Slovak Republic & & & $\ldots$ & & \\
\hline Slovenia & 141.1 & 16.7 & 14.4 & 22.0 & 61.7 \\
\hline Spain & & & $\ldots$ & $\ldots$ & $\ldots$ \\
\hline Sweden & 63.1 & 16.9 & 18.1 & $\ldots$ & $\ldots$ \\
\hline Switzerland & $\ldots$ & $\ldots$ & $\ldots$ & $\ldots$ & $\ldots$ \\
\hline Turkey & $\ldots$ & $\ldots$ & $\ldots$ & $\ldots$ & $\ldots$ \\
\hline Ukraine & $\ldots$ & $\ldots$ & $\ldots$ & $\ldots$ & $\ldots$ \\
\hline UK: England \& Wales & $\ldots$ & $\ldots$ & $\ldots$ & $\ldots$ & $\ldots$ \\
\hline $\begin{array}{l}\text { UK: Northern Ireland } \\
\text { UK: Scotland }\end{array}$ & $\ldots$ & $\ldots$ & $\begin{array}{l}\ldots \\
\ldots\end{array}$ & $\ldots$ & $\ldots$ \\
\hline Mean & 133 & 10.6 & 16.0 & 22.2 & 38.1 \\
\hline Median & 76 & 11.8 & 16.2 & 22.1 & 51.1 \\
\hline Minimum & 36 & 1.0 & 3.8 & 0.2 & 0.0 \\
\hline Maximum & 420 & 28.5 & 41.2 & 64.1 & 62.0 \\
\hline
\end{tabular}


Table 1.2.3.13 Percentage of women, minors, and foreigners among offenders in 2015 - Theft of a motor vehicle

\begin{tabular}{ccccc}
$\begin{array}{c}\text { Total offenders per } \\
100000 \text { pop. }\end{array}$ & $\begin{array}{c}\text { of which } \% \\
\text { of women }\end{array}$ & $\begin{array}{c}\text { of which } \% \\
\text { of minors }\end{array}$ & $\begin{array}{c}\text { of which } \% \\
\text { of foreigners }\end{array}$ & $\begin{array}{c}\% \text { of EU citizens } \\
\text { amongst foreigners }\end{array}$ \\
\hline
\end{tabular}

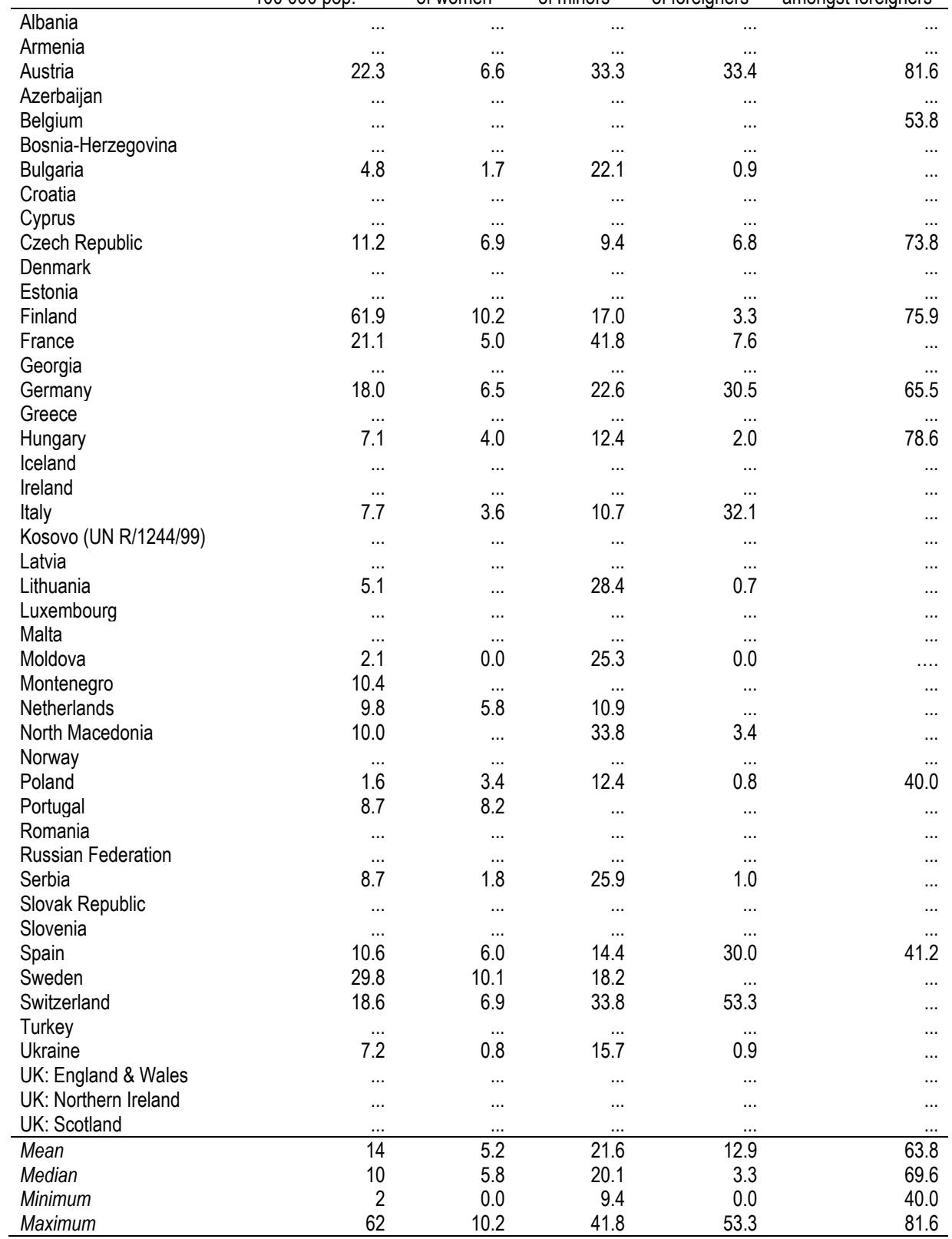


Table 1.2.3.14 Percentage of women, minors, and foreigners among offenders in 2015 - Theft by means of burglary

\begin{tabular}{|c|c|c|c|c|c|}
\hline & $\begin{array}{l}\text { Total offenders per } \\
100000 \text { pop. }\end{array}$ & $\begin{array}{l}\text { of which \% } \\
\text { of women }\end{array}$ & $\begin{array}{c}\text { of which } \% \\
\text { of minors }\end{array}$ & $\begin{array}{c}\text { of which } \% \\
\text { of foreigners }\end{array}$ & $\begin{array}{c}\% \text { of EU citizens } \\
\text { amongst foreigners }\end{array}$ \\
\hline Albania & $\ldots$ & $\ldots$ & $\ldots$ & $\ldots$ & $\ldots$ \\
\hline Armenia & & & & $\ldots$ & \\
\hline Austria & 125.6 & 7.3 & 21.5 & 59.3 & 52.4 \\
\hline Azerbaijan & $\ldots$ & $\ldots$ & $\ldots$ & $\ldots$ & $\ldots$ \\
\hline Belgium & $\ldots$ & $\ldots$ & $\ldots$ & $\ldots$ & $\ldots$ \\
\hline Bosnia-Herzegovina & $\ldots$ & $\ldots$ & $\ldots$ & $\ldots$ & $\ldots$ \\
\hline Bulgaria & $\ldots$ & $\ldots$ & $\ldots$ & $\ldots$ & $\ldots$ \\
\hline Croatia & 326.5 & 1.1 & 3.8 & $\ldots$ & $\ldots$ \\
\hline Cyprus & 134.8 & 2.8 & 6.6 & 0.0 & \\
\hline Czech Republic & 58.8 & 7.4 & 8.6 & 7.9 & 51.2 \\
\hline Denmark & $\ldots$ & $\ldots$ & $\ldots$ & $\ldots$ & $\ldots$ \\
\hline Estonia & $\ldots$ & $\ldots$ & $\ldots$ & $\ldots$ & $\ldots$ \\
\hline Finland & 134.0 & 11.2 & 11.8 & $\ldots$ & $\ldots$ \\
\hline France & 70.9 & 6.2 & 30.7 & 17.0 & $\ldots$ \\
\hline Georgia & $\ldots$ & $\ldots$ & $\ldots$ & $\ldots$ & $\ldots$ \\
\hline Germany & 82.5 & 12.9 & 13.9 & 44.0 & 41.9 \\
\hline Greece & 48.2 & 22.5 & 8.5 & 28.0 & $\ldots$ \\
\hline Hungary & $\ldots$ & $\ldots$ & $\ldots$ & $\ldots$ & $\ldots$ \\
\hline Iceland & $\ldots$ & $\ldots$ & $\ldots$ & $\ldots$ & $\ldots$ \\
\hline Ireland & $\ldots$ & $\ldots$ & $\ldots$ & $\ldots$ & $\ldots$ \\
\hline Italy & $\ldots$ & $\ldots$ & $\ldots$ & $\ldots$ & $\ldots$ \\
\hline Kosovo (UN R/1244/99) & $\ldots$ & $\ldots$ & $\ldots$ & $\ldots$ & $\ldots$ \\
\hline Latvia & $\ldots$ & $\ldots$ & $\ldots$ & $\ldots$ & $\ldots$ \\
\hline Lithuania & 11.4 & $\ldots$ & $\ldots$ & $\ldots$ & $\ldots$ \\
\hline Luxembourg & $\ldots$ & $\ldots$ & $\ldots$ & $\ldots$ & $\ldots$ \\
\hline Malta & $\ldots$ & $\ldots$ & $\ldots$ & $\ldots$ & $\ldots$ \\
\hline Moldova & 7.4 & 4.2 & 31.3 & 0.4 & 0.0 \\
\hline Montenegro & $\ldots$ & $\ldots$ & $\ldots$ & $\ldots$ & $\ldots$ \\
\hline Netherlands & 328.7 & 32.0 & 16.3 & $\ldots$ & $\ldots$ \\
\hline North Macedonia & $\ldots$ & $\ldots$ & $\ldots$ & $\ldots$ & $\ldots$ \\
\hline Norway & $\ldots$ & $\ldots$ & $\ldots$ & $\ldots$ & $\ldots$ \\
\hline Poland & 38.8 & 4.2 & 16.4 & 0.5 & 61.3 \\
\hline Portugal & 38.2 & 13.5 & $\ldots$ & $\ldots$ & $\ldots$ \\
\hline Romania & $\ldots$ & $\ldots$ & $\ldots$ & $\ldots$ & $\ldots$ \\
\hline Russian Federation & $\ldots$ & $\ldots$ & $\ldots$ & $\ldots$ & $\ldots$ \\
\hline Serbia & 67.5 & 4.1 & 19.7 & 1.6 & $\ldots$ \\
\hline Slovak Republic & $\ldots$ & $\ldots$ & $\ldots$ & $\ldots$ & $\ldots$ \\
\hline Slovenia & 111.3 & 14.0 & 15.9 & 21.0 & 62.7 \\
\hline Spain & 43.4 & 3.0 & 4.6 & 12.5 & 45.2 \\
\hline Sweden & 57.7 & 9.8 & 9.9 & $\ldots$ & $\ldots$ \\
\hline Switzerland & 42.0 & 8.7 & 18.5 & 71.1 & $\ldots$ \\
\hline Turkey & $\ldots$ & $\ldots$ & $\ldots$ & $\ldots$ & $\ldots$ \\
\hline Ukraine & $\ldots$ & $\ldots$ & $\ldots$ & $\ldots$ & $\ldots$ \\
\hline UK: England \& Wales & $\ldots$ & $\ldots$ & $\ldots$ & $\ldots$ & $\ldots$ \\
\hline UK: Northern Ireland & $\ldots$ & $\ldots$ & $\ldots$ & $\ldots$ & $\ldots$ \\
\hline UK: Scotland & & & & & \\
\hline Mean & 96 & 9.7 & 14.9 & 21.9 & 45.0 \\
\hline Median & 63 & 7.4 & 14.9 & 14.7 & 51.2 \\
\hline Minimum & 7 & 1.1 & 3.8 & 0.0 & 0.0 \\
\hline Maximum & 329 & 32.0 & 31.3 & 71.1 & 62.7 \\
\hline
\end{tabular}


Table 1.2.3.15 Percentage of women, minors, and foreigners among offenders in 2015 - Theft by means of domestic burglary

\begin{tabular}{ccccc}
$\begin{array}{c}\text { Total offenders per } \\
100000 \text { pop. }\end{array}$ & $\begin{array}{c}\text { of which } \% \\
\text { of women }\end{array}$ & $\begin{array}{c}\text { of which } \% \\
\text { of minors }\end{array}$ & $\begin{array}{c}\text { of which } \% \\
\text { of foreigners }\end{array}$ & $\begin{array}{c}\% \text { of EU citizens } \\
\text { amongst foreigners }\end{array}$ \\
\hline
\end{tabular}

\begin{tabular}{|c|c|c|c|c|c|}
\hline & & & & & \\
\hline Albania & $\ldots$ & $\ldots$ & $\ldots$ & $\ldots$ & $\ldots$ \\
\hline Armenia & & & $\ldots$ & $\ldots$ & $\ldots$ \\
\hline Austria & 31.1 & 10.8 & 12.4 & 75.1 & 53.1 \\
\hline Azerbaijan & & $\ldots$ & $\ldots$ & $\ldots$ & \\
\hline Belgium & 0.0 & $\ldots$ & $\ldots$ & $\ldots$ & 32.2 \\
\hline Bosnia-Herzegovina & $\ldots$ & $\ldots$ & $\ldots$ & $\ldots$ & $\ldots$ \\
\hline Bulgaria & $\ldots$ & $\ldots$ & $\ldots$ & $\ldots$ & $\ldots$ \\
\hline Croatia & $\ldots$ & $\ldots$ & $\ldots$ & $\ldots$ & $\ldots$ \\
\hline Cyprus & & & $\ldots$ & $\ldots$ & $\ldots$ \\
\hline Czech Republic & 13.7 & 12.0 & 8.2 & 4.0 & 77.6 \\
\hline Denmark & $\ldots$ & $\ldots$ & $\ldots$ & $\ldots$ & $\ldots$ \\
\hline Estonia & $\ldots$ & $\ldots$ & $\ldots$ & $\ldots$ & $\ldots$ \\
\hline Finland & 42.9 & 13.7 & 10.1 & $\ldots$ & $\ldots$ \\
\hline France & 35.9 & 7.0 & 31.1 & 18.4 & $\ldots$ \\
\hline Georgia & & & $\ldots$ & & \\
\hline Germany & 27.7 & 14.1 & 12.2 & 35.6 & 37.2 \\
\hline Greece & $\ldots$ & $\ldots$ & $\ldots$ & $\ldots$ & $\ldots$ \\
\hline Hungary & $\ldots$ & $\ldots$ & $\ldots$ & $\ldots$ & $\ldots$ \\
\hline Iceland & $\ldots$ & $\ldots$ & $\ldots$ & $\ldots$ & $\ldots$ \\
\hline Ireland & & & & $\ldots$ & $\ldots$ \\
\hline Italy & 24.6 & 15.9 & 7.5 & 54.6 & $\ldots$ \\
\hline Kosovo (UN R/1244/99) & $\ldots$ & $\ldots$ & $\ldots$ & $\ldots$ & $\ldots$ \\
\hline Latvia & & $\ldots$ & $\ldots$ & $\ldots$ & $\ldots$ \\
\hline Lithuania & 7.7 & $\ldots$ & $\ldots$ & $\ldots$ & $\ldots$ \\
\hline Luxembourg & $\ldots$ & $\ldots$ & $\ldots$ & $\ldots$ & $\ldots$ \\
\hline Malta & & & $\ldots$ & $\ldots$ & \\
\hline Moldova & 32.5 & 13.4 & 16.1 & 1.0 & 18.2 \\
\hline Montenegro & & & $\ldots$ & $\ldots$ & $\ldots$ \\
\hline Netherlands & 53.6 & 10.8 & 17.3 & $\ldots$ & $\ldots$ \\
\hline North Macedonia & $\ldots$ & $\ldots$ & $\ldots$ & $\begin{array}{l}\cdots \\
\cdots\end{array}$ & $\begin{array}{l}\cdots \\
\cdots\end{array}$ \\
\hline Norway & $\ldots$ & $\ldots$ & $\ldots$ & $\ldots$ & $\ldots$ \\
\hline Poland & & $\ldots$ & $\ldots$ & $\ldots$ & $\ldots$ \\
\hline Portugal & 20.6 & 17.5 & $\begin{array}{l}\cdots \\
\ldots\end{array}$ & $\begin{array}{l}\cdots \\
\cdots\end{array}$ & $\begin{array}{l}\cdots \\
\ldots\end{array}$ \\
\hline Romania & $\ldots$ & $\ldots$ & $\ldots$ & $\ldots$ & $\ldots$ \\
\hline Russian Federation & & $\ldots$ & $\ldots$ & $\ldots$ & $\ldots$ \\
\hline Serbia & 74.6 & 8.1 & 16.1 & 1.4 & $\begin{array}{l}\cdots \\
\cdots\end{array}$ \\
\hline Slovak Republic & & & $\ldots$ & & $\ldots$ \\
\hline Slovenia & 23.5 & 11.6 & 14.0 & 16.3 & 65.8 \\
\hline Spain & 23.2 & 11.8 & 13.6 & 33.4 & 35.6 \\
\hline Sweden & 25.2 & 10.3 & 8.5 & $\ldots$ & $\ldots$ \\
\hline Switzerland & 16.9 & 12.6 & 23.2 & 56.4 & $\ldots$ \\
\hline Turkey & & & & & $\ldots$ \\
\hline Ukraine & 5.3 & 16.6 & 5.7 & 1.6 & $\ldots$ \\
\hline UK: England \& Wales & $\ldots$ & $\ldots$ & $\ldots$ & $\ldots$ & $\ldots$ \\
\hline UK: Northern Ireland & $\begin{array}{l}\cdots \\
\ldots\end{array}$ & $\begin{array}{l}\cdots \\
\cdots\end{array}$ & $\cdots$ & $\begin{array}{l}\cdots \\
\cdots\end{array}$ & $\cdots$ \\
\hline Mean & 27 & 12.4 & $\begin{array}{ll}\ldots \\
14.0\end{array}$ & 27.1 & 45.7 \\
\hline Median & 25 & 12.0 & 13.0 & 18.4 & 37.2 \\
\hline Minimum & 0 & 7.0 & 5.7 & 1.0 & 18.2 \\
\hline Maximum & 75 & 17.5 & 31.1 & 75.1 & 77.6 \\
\hline
\end{tabular}


Table 1.2.3.16 Percentage of women, minors, and foreigners among offenders in 2015 - Fraud

\begin{tabular}{|c|c|c|c|c|c|}
\hline & $\begin{array}{l}\text { Total offenders per } \\
100000 \text { pop. }\end{array}$ & $\begin{array}{l}\text { of which } \% \\
\text { of women }\end{array}$ & $\begin{array}{l}\text { of which } \% \\
\text { of minors }\end{array}$ & $\begin{array}{c}\text { of which } \% \\
\text { of foreigners }\end{array}$ & $\begin{array}{l}\% \text { of EU citizens } \\
\text { amongst foreigners }\end{array}$ \\
\hline Albania & 29.6 & $\ldots$ & $\ldots$ & $\ldots$ & $\ldots$ \\
\hline Armenia & & & & & \\
\hline Austria & 221.8 & 25.0 & 2.7 & 38.5 & 61.7 \\
\hline Azerbaijan & 11.4 & 11.5 & 0.5 & $\ldots$ & \\
\hline Belgium & $\ldots$ & $\ldots$ & $\ldots$ & $\begin{array}{l}\cdots \\
\ldots\end{array}$ & 69.5 \\
\hline Bosnia-Herzegovina & & & & $\ldots$ & $\ldots$ \\
\hline Bulgaria & 5.5 & 15.3 & 3.5 & 1.3 & $\ldots$ \\
\hline Croatia & 109.2 & 14.4 & 0.6 & $\ldots$ & $\ldots$ \\
\hline Cyprus & 25.9 & 10.0 & 3.2 & $\ldots$ & $\ldots$ \\
\hline Czech Republic & 45.5 & 28.2 & 0.6 & 5.3 & 82.0 \\
\hline Denmark & $\ldots$ & $\ldots$ & $\ldots$ & $\ldots$ & $\ldots$ \\
\hline Estonia & $\ldots$ & & $\ldots$ & & \\
\hline Finland & 404.6 & 27.0 & 3.2 & 5.2 & 43.6 \\
\hline France & 87.0 & 32.0 & 3.9 & 13.7 & $\ldots$ \\
\hline Georgia & 41.7 & 0.8 & $\ldots$ & 0.1 & $\ldots$ \\
\hline Germany & 321.8 & 34.3 & 3.6 & 25.9 & 44.3 \\
\hline Greece & 14.7 & 23.0 & 1.5 & 19.0 & \\
\hline Hungary & 42.0 & 24.9 & 1.4 & 1.7 & 72.5 \\
\hline Iceland & $\ldots$ & $\ldots$ & $\ldots$ & $\ldots$ & $\ldots$ \\
\hline Ireland & & $\ldots$ & $\ldots$ & & $\ldots$ \\
\hline Italy & 110.3 & 24.0 & 0.5 & 14.7 & $\ldots$ \\
\hline Kosovo (UN R/1244/99) & $\ldots$ & $\ldots$ & $\ldots$ & $\ldots$ & $\ldots$ \\
\hline Latvia & & $\ldots$ & $\ldots$ & $\ldots$ & $\ldots$ \\
\hline Lithuania & 55.1 & 20.0 & 3.9 & 0.9 & $\ldots$ \\
\hline Luxembourg & $\ldots$ & $\ldots$ & $\ldots$ & $\ldots$ & $\ldots$ \\
\hline Malta & & & & & \\
\hline Moldova & 13.1 & 16.3 & 2.8 & 0.9 & 75.0 \\
\hline Montenegro & 7.6 & 12.8 & 0.0 & 36.2 & 0.0 \\
\hline Netherlands & 25.1 & $\ldots$ & 6.4 & & $\ldots$ \\
\hline North Macedonia & 14.0 & $\ldots$ & 0.3 & 1.0 & $\ldots$ \\
\hline Norway & & & $\ldots$ & & \\
\hline Poland & 69.2 & 27.6 & 1.0 & 0.5 & 66.2 \\
\hline Portugal & 41.3 & 30.9 & $\ldots$ & $\ldots$ & $\ldots$ \\
\hline Romania & $\ldots$ & $\ldots$ & $\ldots$ & $\ldots$ & $\ldots$ \\
\hline Russian Federation & & & $\ldots$ & $\ldots$ & $\ldots$ \\
\hline Serbia & 12.2 & 15.9 & 1.8 & 2.6 & $\ldots$ \\
\hline Slovak Republic & & & & & \\
\hline Slovenia & 145.0 & 24.7 & 0.6 & 17.3 & 49.2 \\
\hline Spain & 18.4 & 25.4 & 1.0 & 28.3 & 36.0 \\
\hline Sweden & 88.5 & 29.3 & 18.0 & & $\ldots$ \\
\hline Switzerland & 108.1 & 26.7 & 4.5 & 55.1 & $\ldots$ \\
\hline Turkey & & & & & $\ldots$ \\
\hline Ukraine & 9.4 & 20.7 & 3.3 & 0.3 & $\ldots$ \\
\hline UK: England \& Wales & $\ldots$ & $\ldots$ & $\ldots$ & $\ldots$ & $\ldots$ \\
\hline $\begin{array}{l}\text { UK: Northern Ireland } \\
\text { UK: Scotland }\end{array}$ & $\ldots$ & $\ldots$ & $\ldots$ & $\ldots$ & $\ldots$ \\
\hline Mean & 77 & 21.7 & 2.9 & 13.4 & 54.5 \\
\hline Median & 42 & 24.4 & 2.3 & 5.3 & 61.7 \\
\hline Minimum & 6 & 0.8 & 0.0 & 0.1 & 0.0 \\
\hline Maximum & 405 & 34.3 & 18.0 & 55.1 & 82.0 \\
\hline
\end{tabular}


Table 1.2.3.17 Percentage of women, minors, and foreigners among offenders in 2015 - Cyber fraud

\begin{tabular}{|c|c|c|c|c|c|}
\hline & $\begin{array}{l}\text { Total offenders per } \\
100000 \text { pop. }\end{array}$ & $\begin{array}{l}\text { of which } \% \\
\text { of women }\end{array}$ & $\begin{array}{l}\text { of which } \% \\
\text { of minors }\end{array}$ & $\begin{array}{l}\text { of which } \% \\
\text { of foreigners }\end{array}$ & $\begin{array}{l}\% \text { of EU citizens } \\
\text { amongst foreigners }\end{array}$ \\
\hline Albania & $\ldots$ & $\ldots$ & $\ldots$ & $\ldots$ & $\ldots$ \\
\hline Armenia & $\ldots$ & $\ldots$ & $\ldots$ & $\ldots$ & $\ldots$ \\
\hline Austria & $\ldots$ & $\ldots$ & $\ldots$ & $\ldots$ & $\ldots$ \\
\hline Azerbaijan & $\ldots$ & $\ldots$ & $\ldots$ & $\ldots$ & $\ldots$ \\
\hline Belgium & $\ldots$ & $\ldots$ & $\ldots$ & $\ldots$ & 66.5 \\
\hline Bosnia-Herzegovina & & & & & $\cdots$ \\
\hline Bulgaria & 0.0 & 33.3 & 0.0 & 0.0 & $\ldots$ \\
\hline Croatia & $\ldots$ & $\ldots$ & $\ldots$ & $\ldots$ & $\ldots$ \\
\hline Cyprus & $\ldots$ & $\ldots$ & $\ldots$ & $\ldots$ & \\
\hline Czech Republic & 1.2 & 28.3 & 22.0 & 1.6 & 0.0 \\
\hline Denmark & $\ldots$ & $\ldots$ & $\ldots$ & $\ldots$ & $\ldots$ \\
\hline Estonia & $\ldots$ & $\ldots$ & $\ldots$ & $\ldots$ & $\ldots$ \\
\hline Finland & $\ldots$ & $\ldots$ & $\ldots$ & $\ldots$ & $\ldots$ \\
\hline France & $\ldots$ & $\ldots$ & $\ldots$ & $\ldots$ & $\ldots$ \\
\hline Georgia & $\ldots$ & $\ldots$ & $\ldots$ & $\ldots$ & $\ldots$ \\
\hline Germany & $\ldots$ & $\ldots$ & $\ldots$ & $\ldots$ & $\ldots$ \\
\hline Greece & $\ldots$ & $\ldots$ & $\ldots$ & $\ldots$ & $\ldots$ \\
\hline Hungary & 3.3 & 29.6 & 6.8 & 3.1 & 100.0 \\
\hline Iceland & $\ldots$ & $\ldots$ & $\ldots$ & $\ldots$ & $\ldots$ \\
\hline Ireland & $\ldots$ & $\ldots$ & $\ldots$ & $\ldots$ & $\ldots$ \\
\hline Italy & $\ldots$ & $\ldots$ & $\ldots$ & $\ldots$ & $\cdots$ \\
\hline Kosovo (UN R/1244/99) & $\ldots$ & $\ldots$ & $\ldots$ & $\ldots$ & $\ldots$ \\
\hline Latvia & $\ldots$ & $\ldots$ & $\ldots$ & $\ldots$ & $\ldots$ \\
\hline Lithuania & $\ldots$ & $\ldots$ & $\ldots$ & $\ldots$ & $\ldots$ \\
\hline Luxembourg & $\ldots$ & $\ldots$ & $\ldots$ & $\ldots$ & $\ldots$ \\
\hline Malta & $\ldots$ & $\ldots$ & $\ldots$ & $\ldots$ & $\ldots$ \\
\hline Moldova & 0.1 & 50.0 & 0.0 & 0.0 & $\ldots$ \\
\hline Montenegro & 0.0 & $\ldots$ & $\ldots$ & $\ldots$ & $\ldots$ \\
\hline Netherlands & $\ldots$ & $\ldots$ & $\ldots$ & $\ldots$ & $\ldots$ \\
\hline North Macedonia & 0.1 & $\ldots$ & 0.0 & 0.0 & $\ldots$ \\
\hline Norway & $\ldots$ & $\ldots$ & $\ldots$ & $\ldots$ & $\ldots$ \\
\hline Poland & 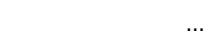 & $\ldots$ & $\ldots$ & $\ldots$ & $\ldots$ \\
\hline Portugal & 3.7 & 37.3 & $\ldots$ & $\ldots$ & $\ldots$ \\
\hline Romania & $\ldots$ & $\ldots$ & $\ldots$ & $\ldots$ & $\ldots$ \\
\hline Russian Federation & & . & $\ldots$ & $\ldots$ & $\ldots$ \\
\hline Serbia & 0.1 & 14.3 & 0.0 & 71.4 & $\ldots$ \\
\hline Slovak Republic & $\ldots$ & $\ldots$ & $\ldots$ & $\ldots$ & \\
\hline Slovenia & 5.5 & 41.2 & 2.6 & 67.5 & 98.7 \\
\hline Spain & 3.6 & 27.7 & 0.9 & 24.2 & 41.9 \\
\hline Sweden & 31.9 & 32.2 & 3.2 & & $\ldots$ \\
\hline Switzerland & 13.2 & 28.6 & 8.1 & 62.5 & $\ldots$ \\
\hline Turkey & $\ldots$ & $\ldots$ & $\ldots$ & $\ldots$ & $\ldots$ \\
\hline Ukraine & $\ldots$ & $\ldots$ & $\ldots$ & $\ldots$ & $\ldots$ \\
\hline UK: England \& Wales & $\ldots$ & $\ldots$ & $\ldots$ & $\ldots$ & $\ldots$ \\
\hline $\begin{array}{l}\text { UK: Northern Ireland } \\
\text { UK: Scotland }\end{array}$ & $\begin{array}{l}\cdots \\
\ldots\end{array}$ & $\ldots$ & $\begin{array}{l}\ldots \\
\ldots\end{array}$ & $\ldots$ & $\ldots$ \\
\hline Mean & 5 & 32.3 & 4.4 & 25.6 & 61.4 \\
\hline Median & 2 & 30.9 & 1.8 & 3.1 & 66.5 \\
\hline Minimum & 0 & 14.3 & 0.0 & 0.0 & 0.0 \\
\hline Maximum & 32 & 50.0 & 22.0 & 71.4 & 100.0 \\
\hline
\end{tabular}


Table 1.2.3.18 Percentage of women, minors, and foreigners among offenders in 2015 - Forgery of documents

\begin{tabular}{|c|c|c|c|c|c|}
\hline & $\begin{array}{l}\text { Total offenders } \\
\text { per } 100000 \text { pop. }\end{array}$ & $\begin{array}{l}\text { of which \% } \\
\text { of women }\end{array}$ & $\begin{array}{l}\text { of which \% } \\
\text { of minors }\end{array}$ & $\begin{array}{l}\text { of which \% } \\
\text { of foreigners }\end{array}$ & $\begin{array}{c}\% \text { of EU citizens } \\
\text { amongst foreigners }\end{array}$ \\
\hline Albania & 24.2 & 8.5 & $\ldots$ & 0.1 & $\ldots$ \\
\hline Armenia & & & & & \\
\hline Austria & 49.9 & 17.3 & 6.6 & 64.5 & 21.9 \\
\hline Azerbaijan & $\ldots$ & $\ldots$ & $\ldots$ & $\ldots$ & \\
\hline Belgium & $\ldots$ & $\ldots$ & $\ldots$ & $\ldots$ & 42.7 \\
\hline Bosnia-Herzegovina & $\ldots$ & $\ldots$ & $\ldots$ & $\ldots$ & $\ldots$ \\
\hline Bulgaria & $\ldots$ & $\ldots$ & $\ldots$ & $\ldots$ & $\ldots$ \\
\hline Croatia & 34.8 & 14.2 & 0.7 & $\ldots$ & $\ldots$ \\
\hline Cyprus & 30.2 & 9.0 & 1.6 & $\ldots$ & $\ldots$ \\
\hline Czech Republic & 5.2 & 20.6 & 0.9 & 51.7 & 9.2 \\
\hline Denmark & $\ldots$ & $\ldots$ & $\ldots$ & $\ldots$ & $\ldots$ \\
\hline Estonia & The & $\ldots$ & $\ldots$ & $\ldots$ & $\ldots$ \\
\hline Finland & 56.8 & 22.2 & 5.3 & 19.5 & 26.6 \\
\hline France & $\ldots$ & $\ldots$ & $\ldots$ & $\ldots$ & $\ldots$ \\
\hline Georgia & 41.4 & $\ldots$ & $\ldots$ & $\ldots$ & $\ldots$ \\
\hline Germany & 44.7 & 18.5 & 4.6 & 41.7 & 35.5 \\
\hline Greece & 14.9 & 21.1 & 1.2 & 64.9 & \\
\hline Hungary & 70.9 & 32.6 & 2.6 & 14.4 & 18.2 \\
\hline Iceland & $\ldots$ & $\ldots$ & $\ldots$ & $\ldots$ & $\ldots$ \\
\hline Ireland & $\ldots$ & $\ldots$ & $\ldots$ & $\ldots$ & $\ldots$ \\
\hline Italy & $\ldots$ & $\ldots$ & $\ldots$ & $\ldots$ & $\ldots$ \\
\hline Kosovo (UN R/1244/99) & $\ldots$ & $\ldots$ & $\ldots$ & $\ldots$ & $\ldots$ \\
\hline Latvia & $\cdots$ & $\ldots$ & $\ldots$ & $\ldots$ & $\ldots$ \\
\hline Lithuania & 33.2 & 17.7 & 2.7 & $\begin{array}{l}\cdots \\
\ldots\end{array}$ & $\begin{array}{l}\cdots \\
\ldots\end{array}$ \\
\hline Luxembourg & $\ldots$ & $\ldots$ & $\ldots$ & $\ldots$ & $\ldots$ \\
\hline Malta & & & $\ldots$ & $\ldots$ & $\ldots$ \\
\hline Moldova & 6.8 & 32.6 & 0.0 & 9.9 & 8.3 \\
\hline Montenegro & 19.0 & 5.1 & 0.0 & 51.7 & $\ldots$ \\
\hline Netherlands & 27.2 & $\ldots$ & 11.1 & $\ldots$ & $\ldots$ \\
\hline North Macedonia & 17.7 & $\begin{array}{l}\cdots \\
\cdots\end{array}$ & 0.0 & 23.8 & $\begin{array}{l}\cdots \\
\cdots\end{array}$ \\
\hline Norway & $\ldots$ & $\ldots$ & $\ldots$ & $\ldots$ & $\ldots$ \\
\hline Poland & 17.3 & 35.0 & 4.6 & 6.1 & 12.1 \\
\hline Portugal & 11.3 & 23.5 & $\ldots$ & $\ldots$ & $\ldots$ \\
\hline Romania & $\ldots$ & $\ldots$ & $\begin{array}{l}\cdots \\
\ldots\end{array}$ & $\ldots$ & $\cdots$ \\
\hline Russian Federation & $\ldots$ & $\ldots$ & $\ldots$ & $\ldots$ & $\ldots$ \\
\hline Serbia & 36.3 & 12.5 & 2.0 & 6.4 & $\ldots$ \\
\hline Slovak Republic & & & & $\ldots$ & $\ldots$ \\
\hline Slovenia & 85.9 & 19.9 & 0.3 & 45.1 & 28.4 \\
\hline Spain & 20.5 & 20.5 & 1.0 & 62.6 & 11.7 \\
\hline Sweden & 27.5 & 20.8 & 3.2 & $\ldots$ & $\ldots$ \\
\hline Switzerland & 59.6 & 25.0 & 8.4 & 67.9 & $\ldots$ \\
\hline Turkey & & & $\ldots$ & & $\ldots$ \\
\hline Ukraine & 3.9 & 36.0 & 0.4 & 6.7 & $\ldots$ \\
\hline UK: England \& Wales & $\ldots$ & $\ldots$ & $\ldots$ & $\ldots$ & $\ldots$ \\
\hline UK: Northern Ireland & $\ldots$ & $\ldots$ & $\ldots$ & $\ldots$ & $\ldots$ \\
\hline UK: Scotland & & $\ldots$ & $\ldots$ & $\ldots$ & \\
\hline Mean & 32 & 20.6 & 2.9 & 33.6 & 21.5 \\
\hline Median & 27 & 20.5 & 1.8 & 32.7 & 20.1 \\
\hline Minimum & 4 & 5.1 & 0.0 & 0.1 & 8.3 \\
\hline Maximum & 86 & 36.0 & 11.1 & 67.9 & 42.7 \\
\hline
\end{tabular}


Table 1.2.3.19 Percentage of women, minors, and foreigners among offenders in 2015 - Money laundering

\begin{tabular}{|c|c|c|c|c|c|}
\hline & $\begin{array}{l}\text { Total offenders per } \\
100000 \text { pop. }\end{array}$ & $\begin{array}{l}\text { of which \% } \\
\text { of women }\end{array}$ & $\begin{array}{l}\text { of which \% } \\
\text { of minors }\end{array}$ & $\begin{array}{l}\text { of which \% } \\
\text { of foreigners }\end{array}$ & $\begin{array}{l}\% \text { of EU citizens } \\
\text { amongst foreigners }\end{array}$ \\
\hline Albania & 12.8 & 11.9 & 0.3 & 1.6 & $\ldots$ \\
\hline Armenia & & & & & $\ldots$ \\
\hline Austria & 6.2 & 24.9 & 0.0 & 52.5 & $\ldots$ \\
\hline Azerbaijan & $\ldots$ & $\ldots$ & $\ldots$ & $\ldots$ & $\ldots$ \\
\hline Belgium & $\ldots$ & $\ldots$ & $\ldots$ & $\ldots$ & 45.1 \\
\hline Bosnia-Herzegovina & $\ldots$ & $\ldots$ & $\ldots$ & $\ldots$ & $\ldots$ \\
\hline Bulgaria & 0.0 & $\ldots$ & & $\ldots$ & ... \\
\hline Croatia & 0.4 & 20.0 & 0.0 & 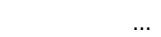 & $\ldots$ \\
\hline Cyprus & 2.1 & 0.0 & 0.0 & & $\ldots$ \\
\hline Czech Republic & 2.2 & 27.7 & 0.4 & 15.6 & 69.4 \\
\hline Denmark & $\ldots$ & $\ldots$ & $\ldots$ & $\ldots$ & $\ldots$ \\
\hline Estonia & $\ldots$ & $\ldots$ & $\ldots$ & $\ldots$ & $\ldots$ \\
\hline Finland & $\ldots$ & $\ldots$ & $\ldots$ & $\ldots$ & $\ldots$ \\
\hline France & $\ldots$ & $\ldots$ & $\ldots$ & $\ldots$ & $\ldots$ \\
\hline Georgia & $\ldots$ & & & & $\ldots$ \\
\hline Germany & 11.6 & 29.7 & 1.0 & 39.0 & 39.5 \\
\hline Greece & $\ldots$ & & $\ldots$ & & $\ldots$ \\
\hline Hungary & 0.1 & 30.0 & 0.0 & 10.0 & 100.0 \\
\hline Iceland & $\ldots$ & $\ldots$ & $\ldots$ & & $\ldots$ \\
\hline Ireland & $\ldots$ & $\ldots$ & $\ldots$ & & $\ldots$ \\
\hline Italy & 7.0 & 16.4 & 1.0 & 27.3 & $\ldots$ \\
\hline Kosovo (UN R/1244/99) & $\ldots$ & $\ldots$ & $\ldots$ & $\ldots$ & ... \\
\hline Latvia & $\ldots$ & $\ldots$ & & $\ldots$ & $\ldots$ \\
\hline Lithuania & 0.8 & 29.2 & 0.0 & $\ldots$ & $\ldots$ \\
\hline Luxembourg & $\ldots$ & $\ldots$ & $\ldots$ & $\ldots$ & $\ldots$ \\
\hline Malta & $\ldots$ & $\ldots$ & 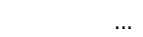 & & $\ldots$ \\
\hline Moldova & 0.1 & 0.0 & 0.0 & 0.0 & $\ldots$ \\
\hline Montenegro & 0.0 & $\ldots$ & & $\ldots$ & $\ldots$ \\
\hline Netherlands & 4.5 & $\ldots$ & 0.7 & $\ldots$ & $\ldots$ \\
\hline North Macedonia & 1.2 & 0.0 & 0.0 & 0.0 & ... \\
\hline Norway & & & & & $\ldots$ \\
\hline Poland & 0.6 & 15.0 & 0.0 & 1.3 & 33.3 \\
\hline Portugal & 0.0 & 50.0 & $\ldots$ & $\ldots$ & $\ldots$ \\
\hline Romania & $\ldots$ & $\ldots$ & $\ldots$ & $\ldots$ & $\ldots$ \\
\hline Russian Federation & $\ldots$ & & & & $\ldots$ \\
\hline Serbia & 0.2 & 0.0 & 0.0 & 18.2 & $\ldots$ \\
\hline Slovak Republic & $\ldots$ & $\ldots$ & $\ldots$ & & $\ldots$ \\
\hline Slovenia & 5.4 & 16.1 & 0.0 & 11.6 & 15.4 \\
\hline Spain & 1.4 & 27.8 & 0.2 & 35.2 & 20.5 \\
\hline Sweden & 8.0 & 22.0 & 1.9 & & $\ldots$ \\
\hline Switzerland & 4.3 & 25.4 & 0.6 & 61.5 & $\ldots$ \\
\hline Turkey & & & & & $\ldots$ \\
\hline Ukraine & 0.1 & 12.0 & 0.0 & 0.0 & $\ldots$ \\
\hline UK: England \& Wales & $\ldots$ & $\ldots$ & $\ldots$ & $\ldots$ & $\ldots$ \\
\hline $\begin{array}{l}\text { UK: Northern Ireland } \\
\text { UK: Scotland }\end{array}$ & $\ldots$ & $\ldots$ & $\ldots$ & $\ldots$ & $\ldots$ \\
\hline Mean & 3 & 18.8 & 0.3 & 19.6 & 46.2 \\
\hline Median & 1 & 20.0 & 0.0 & 13.6 & 39.5 \\
\hline Minimum & 0 & 0.0 & 0.0 & 0.0 & 15.4 \\
\hline Maximum & 13 & 50.0 & 1.9 & 61.5 & 100.0 \\
\hline
\end{tabular}


Table 1.2.3.20 Percentage of women, minors, and foreigners among offenders in 2015 - Corruption in the public sector

\begin{tabular}{|c|c|c|c|c|c|}
\hline & $\begin{array}{l}\text { Total offenders per } \\
100000 \text { pop. }\end{array}$ & $\begin{array}{l}\text { of which } \% \\
\text { of women }\end{array}$ & $\begin{array}{l}\text { of which } \% \\
\text { of minors }\end{array}$ & $\begin{array}{l}\text { of which } \% \\
\text { of foreigners }\end{array}$ & $\begin{array}{l}\% \text { of EU citizens } \\
\text { amongst foreigners }\end{array}$ \\
\hline Albania & 11.4 & 1.2 & $\ldots$ & 0.3 & $\ldots$ \\
\hline Armenia & & & & & \\
\hline Austria & 4.7 & 20.4 & 0.0 & 2.7 & 54.5 \\
\hline Azerbaijan & 0.3 & 20.8 & $\ldots$ & $\ldots$ & $\ldots$ \\
\hline Belgium & 0.0 & $\ldots$ & $\begin{array}{l}\cdots \\
\ldots\end{array}$ & $\begin{array}{l}\cdots \\
\ldots\end{array}$ & 50.0 \\
\hline Bosnia-Herzegovina & & & $\ldots$ & $\ldots$ & $\ldots$ \\
\hline Bulgaria & 1.0 & 5.7 & 2.9 & 14.3 & $\ldots$ \\
\hline Croatia & 33.4 & 29.6 & 0.0 & $\ldots$ & $\ldots$ \\
\hline Cyprus & 10.5 & 4.5 & 5.6 & $\ldots$ & $\ldots$ \\
\hline Czech Republic & 1.6 & 16.9 & 0.0 & 13.4 & 30.4 \\
\hline Denmark & $\ldots$ & $\ldots$ & $\ldots$ & $\ldots$ & $\ldots$ \\
\hline Estonia & $\ldots$ & $\ldots$ & $\ldots$ & $\ldots$ & $\ldots$ \\
\hline Finland & $\ldots$ & $\ldots$ & $\ldots$ & $\ldots$ & $\ldots$ \\
\hline France & $\ldots$ & $\ldots$ & $\ldots$ & $\ldots$ & $\ldots$ \\
\hline Georgia & 8.6 & 1.3 & $\ldots$ & $\ldots$ & $\ldots$ \\
\hline Germany & 1.4 & 21.5 & 0.2 & 18.4 & 30.4 \\
\hline Greece & 1.3 & 31.5 & 4.2 & 5.6 & $\ldots$ \\
\hline Hungary & 3.3 & 14.9 & 0.0 & 5.2 & 70.6 \\
\hline Iceland & $\ldots$ & $\ldots$ & $\ldots$ & $\ldots$ & $\ldots$ \\
\hline Ireland & $\ldots$ & $\ldots$ & $\ldots$ & $\ldots$ & $\ldots$ \\
\hline Italy & $\ldots$ & $\ldots$ & $\ldots$ & $\ldots$ & $\ldots$ \\
\hline Kosovo (UN R/1244/99) & $\ldots$ & $\ldots$ & $\ldots$ & $\ldots$ & $\ldots$ \\
\hline Latvia & & & $\ldots$ & $\ldots$ & $\ldots$ \\
\hline Lithuania & 33.0 & 7.1 & $\ldots$ & $\ldots$ & $\ldots$ \\
\hline Luxembourg & $\ldots$ & $\ldots$ & $\ldots$ & $\ldots$ & $\ldots$ \\
\hline Malta & & & $\ldots$ & $\ldots$ & $\ldots$ \\
\hline Moldova & 6.4 & 40.7 & 0.0 & 4.9 & 18.2 \\
\hline Montenegro & 13.7 & 20.0 & 0.0 & 7.1 & 0.0 \\
\hline Netherlands & $\ldots$ & $\ldots$ & $\ldots$ & $\ldots$ & $\ldots$ \\
\hline North Macedonia & $\ldots$ & $\ldots$ & $\ldots$ & $\ldots$ & $\ldots$ \\
\hline Norway & $\cdots$ & $\cdots$ & $\ldots$ & $\ldots$ & $\ldots$ \\
\hline Poland & 3.9 & 16.8 & 0.1 & 4.3 & 28.1 \\
\hline Portugal & 0.2 & 11.1 & $\ldots$ & $\ldots$ & $\ldots$ \\
\hline Romania & $\ldots$ & $\ldots$ & $\ldots$ & $\ldots$ & $\ldots$ \\
\hline Russian Federation & & $\ldots$ & $\ldots$ & $\ldots$ & $\ldots$ \\
\hline Serbia & 4.0 & 17.8 & 1.4 & 0.0 & $\ldots$ \\
\hline Slovak Republic & & & $\ldots$ & $\ldots$ & $\ldots$ \\
\hline Slovenia & 3.4 & 14.1 & 0.0 & 9.9 & 0.0 \\
\hline Spain & 2.2 & 17.3 & 0.0 & 4.8 & 50.0 \\
\hline Sweden & 0.8 & 19.5 & 0.0 & $\ldots$ & $\ldots$ \\
\hline Switzerland & 0.6 & 23.5 & 0.0 & 47.1 & $\ldots$ \\
\hline Turkey & & & & & $\ldots$ \\
\hline Ukraine & 2.1 & 12.3 & 0.0 & 0.3 & $\ldots$ \\
\hline UK: England \& Wales & $\ldots$ & $\ldots$ & $\ldots$ & $\ldots$ & $\ldots$ \\
\hline $\begin{array}{l}\text { UK: Northern Ireland } \\
\text { UK: Scotland }\end{array}$ & $\ldots$ & $\ldots$ & $\ldots$ & $\ldots$ & $\ldots$ \\
\hline Mean & 6 & 16.7 & 0.8 & 9.2 & 33.2 \\
\hline Median & 3 & 17.1 & 0.0 & 5.2 & 30.4 \\
\hline Minimum & 0 & 1.2 & 0.0 & 0.0 & 0.0 \\
\hline Maximum & 33 & 40.7 & 5.6 & 47.1 & 70.6 \\
\hline
\end{tabular}


Table 1.2.3.21 Percentage of women, minors, and foreigners among offenders in 2015 - Drug offences: Total

\begin{tabular}{|c|c|c|c|c|c|}
\hline & $\begin{array}{l}\text { Total offenders per } \\
100000 \text { pop. }\end{array}$ & $\begin{array}{l}\text { of which } \% \\
\text { of women }\end{array}$ & $\begin{array}{l}\text { of which } \% \\
\text { of minors }\end{array}$ & $\begin{array}{l}\text { of which \% } \\
\text { of foreigners }\end{array}$ & $\begin{array}{l}\% \text { of EU citizens } \\
\text { amongst foreigners }\end{array}$ \\
\hline Albania & 49.0 & 0.1 & 0.0 & 0.8 & $\ldots$ \\
\hline Armenia & $\ldots$ & $\ldots$ & $\ldots$ & $\ldots$ & \\
\hline Austria & & $\ldots$ & & $\ldots$ & 25.9 \\
\hline Azerbaijan & 26.3 & 2.1 & 0.3 & $\ldots$ & \\
\hline Belgium & $\ldots$ & $\ldots$ & $\ldots$ & $\ldots$ & 56.9 \\
\hline Bosnia-Herzegovina & & & . & $\ldots$ & $\ldots$ \\
\hline Bulgaria & 40.1 & 8.2 & 15.2 & 1.5 & $\ldots$ \\
\hline Croatia & 27.1 & 7.0 & 6.9 & $\ldots$ & $\ldots$ \\
\hline Cyprus & 120.3 & 8.1 & 11.9 & $\ldots$ & $\ldots$ \\
\hline Czech Republic & 36.2 & 15.9 & 4.4 & 9.4 & 34.7 \\
\hline Denmark & $\ldots$ & $\ldots$ & $\ldots$ & $\ldots$ & $\ldots$ \\
\hline Estonia & $\ldots$ & $\ldots$ & $\ldots$ & $\ldots$ & $\ldots$ \\
\hline Finland & 402.4 & 14.0 & 5.0 & 9.0 & 44.3 \\
\hline France & 304.0 & 9.3 & 17.1 & 8.8 & $\ldots$ \\
\hline Georgia & 53.9 & 3.8 & 0.5 & 4.6 & $\ldots$ \\
\hline Germany & 285.4 & 12.9 & 8.9 & 22.3 & 38.7 \\
\hline Greece & 143.4 & 22.4 & 1.8 & 17.8 & $\ldots$ \\
\hline Hungary & 60.5 & 9.8 & 5.8 & 5.4 & 72.0 \\
\hline Iceland & 470.4 & 13.7 & $\ldots$ & $\ldots$ & $\ldots$ \\
\hline Ireland & & $\ldots$ & $\ldots$ & $\ldots$ & $\ldots$ \\
\hline Italy & 101.3 & 7.4 & 5.1 & 39.0 & $\ldots$ \\
\hline Kosovo (UN R/1244/99) & $\ldots$ & $\ldots$ & $\ldots$ & $\ldots$ & $\ldots$ \\
\hline Latvia & $\ldots$ & $\ldots$ & $\ldots$ & $\ldots$ & $\ldots$ \\
\hline Lithuania & 61.4 & 9.5 & 5.0 & $\ldots$ & $\ldots$ \\
\hline Luxembourg & $\ldots$ & $\ldots$ & $\ldots$ & $\ldots$ & $\ldots$ \\
\hline Malta & & $\ldots$ & & $\ldots$ & $\ldots$ \\
\hline Moldova & 21.0 & 11.1 & 3.2 & 0.5 & 50.0 \\
\hline Montenegro & 34.1 & 7.5 & 3.8 & 18.9 & $\ldots$ \\
\hline Netherlands & 122.2 & 11.6 & 5.4 & $\ldots$ & $\ldots$ \\
\hline North Macedonia & 34.7 & $\ldots$ & 2.6 & 1.0 & $\ldots$ \\
\hline Norway & & $\ldots$ & & $\ldots$ & $\ldots$ \\
\hline Poland & 70.4 & 5.8 & 13.6 & 0.9 & 44.9 \\
\hline Portugal & 68.8 & 8.5 & $\ldots$ & $\ldots$ & $\ldots$ \\
\hline Romania & $\ldots$ & $\ldots$ & $\ldots$ & $\ldots$ & $\ldots$ \\
\hline Russian Federation & & $\ldots$ & $\ldots$ & $\ldots$ & $\ldots$ \\
\hline Serbia & 80.5 & 6.4 & 6.1 & 5.8 & $\ldots$ \\
\hline Slovak Republic & $\ldots$ & $\ldots$ & $\ldots$ & $\ldots$ & $\ldots$ \\
\hline Slovenia & 103.1 & 11.5 & 5.0 & 5.8 & 70.2 \\
\hline Spain & 39.3 & 15.4 & 1.8 & 37.0 & 21.3 \\
\hline Sweden & 427.0 & 14.1 & 9.3 & $\ldots$ & $\ldots$ \\
\hline Switzerland & 432.3 & 12.5 & 15.7 & 42.6 & $\ldots$ \\
\hline Turkey & & & & & $\ldots$ \\
\hline Ukraine & 32.4 & 12.2 & 1.4 & 0.7 & $\ldots$ \\
\hline UK: England \& Wales & $\ldots$ & $\ldots$ & $\ldots$ & $\ldots$ & $\ldots$ \\
\hline $\begin{array}{l}\text { UK: Northern Ireland } \\
\text { UK: Scotland }\end{array}$ & $\ldots$ & $\ldots$ & $\ldots$ & $\ldots$ & $\ldots$ \\
\hline Mean & 135 & 10.0 & 6.2 & 12.2 & 45.9 \\
\hline Median & 69 & 9.7 & 5.0 & 5.8 & 44.6 \\
\hline Minimum & 21 & 0.1 & 0.0 & 0.5 & 21.3 \\
\hline Maximum & 470 & 22.4 & 17.1 & 42.6 & 72.0 \\
\hline
\end{tabular}


Table 1.2.3.22 Percentage of women, minors, and foreigners among offenders in 2015 - Drug trafficking

\begin{tabular}{|c|c|c|c|c|c|}
\hline & $\begin{array}{l}\text { Total offenders per } \\
100000 \text { pop. }\end{array}$ & $\begin{array}{l}\text { of which \% } \\
\text { of women }\end{array}$ & $\begin{array}{l}\text { of which } \% \\
\text { of minors }\end{array}$ & $\begin{array}{c}\text { of which } \% \\
\text { of foreigners }\end{array}$ & $\begin{array}{c}\% \text { of EU citizens } \\
\text { amongst foreigners }\end{array}$ \\
\hline Albania & $\ldots$ & $\ldots$ & $\ldots$ & $\ldots$ & $\ldots$ \\
\hline Armenia & $\ldots$ & $\ldots$ & $\ldots$ & $\ldots$ & $\ldots$ \\
\hline Austria & $\ldots$ & $\ldots$ & $\ldots$ & $\ldots$ & $\ldots$ \\
\hline Azerbaijan & $\ldots$ & $\ldots$ & $\ldots$ & $\ldots$ & ... \\
\hline Belgium & $\ldots$ & $\ldots$ & $\ldots$ & $\ldots$ & $\ldots$ \\
\hline Bosnia-Herzegovina & $\ldots$ & $\ldots$ & $\ldots$ & $\ldots$ & $\ldots$ \\
\hline Bulgaria & & $\ldots$ & $\ldots$ & $\ldots$ & $\ldots$ \\
\hline Croatia & 27.1 & 7.0 & 6.9 & $\ldots$ & $\ldots$ \\
\hline Cyprus & & $\ldots$ & $\ldots$ & $\ldots$ & $\ldots$ \\
\hline Czech Republic & 28.7 & 16.9 & 5.1 & 10.0 & 30.8 \\
\hline Denmark & $\ldots$ & $\ldots$ & $\ldots$ & $\ldots$ & $\ldots$ \\
\hline Estonia & & $\ldots$ & $\ldots$ & $\ldots$ & $\ldots$ \\
\hline Finland & 136.9 & 13.5 & 3.1 & 11.1 & 42.0 \\
\hline France & 18.9 & 9.7 & 13.2 & 19.2 & $\ldots$ \\
\hline Georgia & 5.3 & 3.0 & $\ldots$ & 41.2 & $\ldots$ \\
\hline Germany & 75.0 & 10.6 & 0.9 & 28.4 & 34.1 \\
\hline Greece & & $\ldots$ & $\ldots$ & $\ldots$ & $\ldots$ \\
\hline Hungary & 3.9 & 10.6 & 1.3 & 6.7 & 34.6 \\
\hline Iceland & $\ldots$ & $\ldots$ & $\ldots$ & $\ldots$ & $\ldots$ \\
\hline Ireland & $\ldots$ & $\ldots$ & $\ldots$ & $\ldots$ & $\ldots$ \\
\hline Italy & $\ldots$ & $\ldots$ & $\ldots$ & $\ldots$ & $\ldots$ \\
\hline Kosovo (UN R/1244/99) & $\ldots$ & $\ldots$ & $\ldots$ & $\ldots$ & $\ldots$ \\
\hline Latvia & & $\ldots$ & $\ldots$ & $\ldots$ & $\ldots$ \\
\hline Lithuania & 15.3 & 16.1 & 4.7 & $\ldots$ & $\ldots$ \\
\hline Luxembourg & $\ldots$ & $\ldots$ & $\ldots$ & $\ldots$ & $\ldots$ \\
\hline Malta & & $\ldots$ & $\ldots$ & $\ldots$ & $\ldots$ \\
\hline Moldova & 0.5 & 6.3 & 0.0 & 0.0 & $\ldots$ \\
\hline Montenegro & 28.8 & $\ldots$ & 3.4 & 20.7 & $\ldots$ \\
\hline Netherlands & & $\ldots$ & $\ldots$ & $\ldots$ & $\ldots$ \\
\hline North Macedonia & 29.7 & $\ldots$ & 2.3 & 1.1 & $\ldots$ \\
\hline Norway & & $\ldots$ & . & $\ldots$ & $\ldots$ \\
\hline Poland & 3.9 & 6.5 & 19.5 & 0.1 & 100.0 \\
\hline Portugal & 52.6 & 8.9 & $\ldots$ & $\ldots$ & $\ldots$ \\
\hline Romania & $\ldots$ & $\ldots$ & $\ldots$ & $\ldots$ & $\ldots$ \\
\hline Russian Federation & & $\ldots$ & $\ldots$ & $\ldots$ & $\ldots$ \\
\hline Serbia & 19.4 & 6.8 & 3.1 & 3.0 & $\ldots$ \\
\hline Slovak Republic & & $\ldots$ & $\ldots$ & $\ldots$ & $\ldots$ \\
\hline Slovenia & 96.8 & 11.4 & 4.0 & 6.2 & 70.2 \\
\hline Spain & & $\ldots$ & $\ldots$ & $\ldots$ & $\ldots$ \\
\hline Sweden & 61.3 & 13.4 & 4.9 & $\ldots$ & $\ldots$ \\
\hline Switzerland & 88.0 & 8.0 & 7.8 & 61.2 & $\ldots$ \\
\hline Turkey & & & & & $\ldots$ \\
\hline Ukraine & 5.0 & 12.0 & 1.7 & 0.7 & $\ldots$ \\
\hline UK: England \& Wales & $\ldots$ & $\ldots$ & $\ldots$ & $\ldots$ & $\ldots$ \\
\hline UK: Northern Ireland & $\ldots$ & $\ldots$ & $\ldots$ & $\ldots$ & $\ldots$ \\
\hline UK: Scotland & & & & & \\
\hline Mean & 39 & 10.0 & 5.1 & 15.0 & 51.9 \\
\hline Median & 28 & 10.1 & 3.7 & 8.4 & 38.3 \\
\hline Minimum & 0 & 3.0 & 0.0 & 0.0 & 30.8 \\
\hline Maximum & 137 & 16.9 & 19.5 & 61.2 & 100.0 \\
\hline
\end{tabular}




\subsubsection{Police staff}

Table 1.2.4.1 Police staff: Number of police officers per 100000 population

\begin{tabular}{|c|c|c|c|c|c|c|c|}
\hline & 2011 & 2012 & 2013 & 2014 & 2015 & 2016 & $\begin{array}{l}\% \text { change } \\
2011-2016\end{array}$ \\
\hline Albania & 309.5 & 306.9 & 307.8 & 308.4 & 345.2 & 346.0 & 11.8 \\
\hline Armenia & $\ldots$ & $\ldots$ & $\ldots$ & $\ldots$ & $\ldots$ & $\ldots$ & $\ldots$ \\
\hline Austria & $\ldots$ & $\ldots$ & $\ldots$ & $\ldots$ & $\ldots$ & $\ldots$ & $\ldots$ \\
\hline Azerbaijan & & & & & $\ldots$ & & \\
\hline Belgium & 344.7 & 339.8 & 339.1 & 338.7 & 336.1 & 332.7 & -3.5 \\
\hline Bosnia-Herzegovina & $\ldots$ & $\ldots$ & $\ldots$ & $\ldots$ & & $\ldots$ & $\ldots$ \\
\hline Bulgaria & & $\ldots$ & & 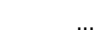 & 381.3 & & \\
\hline Croatia & 492.7 & 499.0 & 486.8 & 484.2 & 489.6 & 487.6 & -1.0 \\
\hline Cyprus & 630.4 & 610.5 & 579.6 & 578.9 & 581.1 & 572.9 & -9.1 \\
\hline Czech Republic & 393.1 & 371.6 & 364.8 & 368.6 & 374.8 & 379.5 & -3.5 \\
\hline Denmark & 196.3 & 192.6 & 191.2 & 190.0 & 186.3 & 184.1 & -6.2 \\
\hline Estonia & 337.2 & 330.4 & 319.7 & 310.8 & 297.8 & 298.6 & -11.5 \\
\hline Finland & 148.5 & 146.0 & 140.8 & 138.6 & 136.9 & 134.5 & -9.4 \\
\hline France & $\ldots$ & $\ldots$ & $\ldots$ & $\ldots$ & & 367.9 & $\ldots$ \\
\hline Georgia & & & & 448.4 & 506.4 & 513.4 & \\
\hline Germany & 319.1 & 320.6 & 321.5 & 321.1 & 320.5 & 319.1 & 0.0 \\
\hline Greece & & & & & & & \\
\hline Hungary & 345.3 & 367.5 & 367.6 & 368.9 & 374.3 & 378.8 & 9.7 \\
\hline Iceland & 204.7 & 205.3 & 203.2 & 200.5 & 198.4 & 194.3 & -5.1 \\
\hline Ireland & $\ldots$ & $\ldots$ & $\ldots$ & $\ldots$ & & & $\ldots$ \\
\hline Italy & $\ldots$ & $\ldots$ & $\ldots$ & $\ldots$ & 457.3 & 460.8 & $\ldots$ \\
\hline Kosovo (UN R/1244/99) & $\ldots$ & $\ldots$ & & $\ldots$ & & & $\ldots$ \\
\hline Latvia & & 420.3 & 405.1 & 458.5 & 458.2 & 460.9 & \\
\hline Lithuania & 325.2 & 317.8 & 317.1 & 323.5 & 311.7 & 287.8 & -11.5 \\
\hline Luxembourg & $\ldots$ & $\ldots$ & & $\ldots$ & & & $\ldots$ \\
\hline Malta & $\ldots$ & 0.0 & 0.0 & 0.0 & 0.0 & 510.6 & $\ldots$ \\
\hline Moldova & $\ldots$ & $\ldots$ & $\ldots$ & $\ldots$ & $\ldots$ & $\ldots$ & $\ldots$ \\
\hline Montenegro & & $\ldots$ & & $\ldots$ & $\ldots$ & & $\ldots$ \\
\hline Netherlands & 303.7 & 308.1 & 307.5 & 305.7 & 298.9 & 298.9 & -1.6 \\
\hline North Macedonia & $\ldots$ & $\ldots$ & 449.8 & 450.5 & 467.5 & 463.1 & $\ldots$ \\
\hline Norway & & $\ldots$ & & & & & \\
\hline Poland & 256.1 & 256.2 & 253.0 & 255.0 & 260.0 & 260.4 & 1.7 \\
\hline Portugal & 451.8 & 438.6 & 436.2 & 439.6 & 441.5 & 447.6 & -0.9 \\
\hline Romania & $\ldots$ & $\ldots$ & $\ldots$ & $\ldots$ & 64.3 & 58.0 & $\ldots$ \\
\hline Russian Federation & $\ldots$ & $\ldots$ & $\ldots$ & $\ldots$ & $\ldots$ & $\ldots$ & $\ldots$ \\
\hline Serbia & $\ldots$ & $\ldots$ & $\ldots$ & $\ldots$ & $\ldots$ & $\ldots$ & $\ldots$ \\
\hline Slovak Republic & & $\ldots$ & & $\ldots$ & $\ldots$ & $\ldots$ & $\ldots$ \\
\hline Slovenia & 372.2 & 358.6 & 350.3 & 340.3 & 345.5 & 346.8 & -6.8 \\
\hline Spain & 387.9 & 382.8 & 376.3 & 371.3 & 365.4 & 361.3 & -6.9 \\
\hline Sweden & 216.6 & 209.7 & 208.4 & 207.9 & 204.2 & 203.3 & -6.2 \\
\hline Switzerland & & & & & & 290.8 & \\
\hline Turkey & 315.6 & 324.2 & 331.3 & 335.1 & 335.5 & 320.0 & 1.4 \\
\hline Ukraine & 256.8 & 333.3 & 334.1 & 338.6 & 304.1 & 268.5 & 4.6 \\
\hline UK: England \& Wales & 247.7 & 237.1 & 227.5 & 222.8 & 219.1 & 212.5 & -14.2 \\
\hline UK: Northern Ireland & 392.4 & 384.1 & 372.5 & 371.7 & 368.7 & 363.2 & -7.5 \\
\hline UK: Scotland & 325.7 & 328.1 & 328.4 & 322.5 & 321.9 & 320.4 & -1.6 \\
\hline Mean & 329 & 319.5 & 319.9 & 325.8 & 325.0 & 336.9 & \\
\hline Median & 325 & 328.1 & 329.9 & 335.1 & 335.8 & 332.7 & \\
\hline Minimum & 148 & 0.0 & 0.0 & 0.0 & 0.0 & 58.0 & \\
\hline Maximum & 630 & 610.5 & 579.6 & 578.9 & 581.1 & 572.9 & \\
\hline
\end{tabular}


Table 1.2.4.2 Police staff: Number of civilians per 100000 population

\begin{tabular}{|c|c|c|c|c|c|c|c|}
\hline & 2011 & 2012 & 2013 & 2014 & 2015 & 2016 & $\begin{array}{l}\% \text { change } \\
2011-2016\end{array}$ \\
\hline Albania & $\ldots$ & $\ldots$ & $\ldots$ & $\ldots$ & $\ldots$ & $\ldots$ & $\ldots$ \\
\hline Armenia & $\ldots$ & $\ldots$ & $\ldots$ & $\ldots$ & $\ldots$ & $\ldots$ & $\ldots$ \\
\hline Austria & $\ldots$ & $\ldots$ & $\ldots$ & $\ldots$ & $\ldots$ & $\ldots$ & $\ldots$ \\
\hline Azerbaijan & $\ldots$ & $\ldots$ & $\ldots$ & $\ldots$ & $\ldots$ & $\ldots$ & $\ldots$ \\
\hline Belgium & 82.8 & 83.9 & 83.4 & 82.2 & 81.1 & 80.4 & -2.9 \\
\hline Bosnia-Herzegovina & $\ldots$ & $\ldots$ & $\ldots$ & $\ldots$ & $\ldots$ & $\ldots$ & $\ldots$ \\
\hline Bulgaria & & $\ldots$ & $\ldots$ & $\ldots$ & 74.4 & & \\
\hline Croatia & 126.3 & 126.1 & 123.1 & 120.5 & 118.0 & 116.1 & -8.1 \\
\hline Cyprus & & & & & & & \\
\hline Czech Republic & 91.2 & 87.5 & 87.9 & 88.5 & 88.8 & 91.2 & 0.0 \\
\hline Denmark & 67.5 & 64.7 & 62.6 & 63.9 & 66.1 & 71.7 & 6.3 \\
\hline Estonia & 130.0 & 119.5 & 120.7 & 117.6 & 100.4 & 96.6 & -25.7 \\
\hline Finland & 48.4 & 47.7 & 47.5 & 44.5 & 44.3 & 42.8 & -11.5 \\
\hline France & $\ldots$ & $\ldots$ & $\ldots$ & $\ldots$ & $\ldots$ & 50.9 & $\ldots$ \\
\hline Georgia & & & & & & & \\
\hline Germany & 50.5 & 50.2 & 49.5 & 49.3 & 48.5 & 48.4 & -4.1 \\
\hline Greece & & $\ldots$ & $\ldots$ & $\ldots$ & $\ldots$ & $\ldots$ & \\
\hline Hungary & 104.5 & 106.0 & 107.2 & 118.8 & 120.5 & 124.6 & 19.2 \\
\hline Iceland & $\ldots$ & $\ldots$ & $\ldots$ & 84.4 & 74.7 & 64.7 & $\ldots$ \\
\hline Ireland & $\ldots$ & $\ldots$ & $\ldots$ & $\ldots$ & $\ldots$ & $\ldots$ & $\ldots$ \\
\hline Italy & $\ldots$ & $\ldots$ & $\ldots$ & $\ldots$ & $\ldots$ & $\ldots$ & $\ldots$ \\
\hline Kosovo (UN R/1244/99) & $\ldots$ & $\ldots$ & $\ldots$ & $\ldots$ & $\ldots$ & $\ldots$ & $\ldots$ \\
\hline Latvia & $\ldots$ & $\ldots$ & $\ldots$ & $\ldots$ & $\ldots$ & $\ldots$ & $\ldots$ \\
\hline Lithuania & 78.1 & 75.5 & 78.3 & 80.6 & 78.2 & 79.0 & 1.2 \\
\hline Luxembourg & $\ldots$ & $\ldots$ & $\ldots$ & $\ldots$ & $\ldots$ & $\ldots$ & $\ldots$ \\
\hline Malta & $\ldots$ & $\ldots$ & $\ldots$ & $\ldots$ & $\ldots$ & 22.2 & $\ldots$ \\
\hline Moldova & $\ldots$ & $\ldots$ & $\ldots$ & $\ldots$ & $\ldots$ & $\ldots$ & $\ldots$ \\
\hline Montenegro & & $\ldots$ & $\ldots$ & $\ldots$ & $\ldots$ & $\ldots$ & $\ldots$ \\
\hline Netherlands & 75.9 & 73.1 & 61.5 & 56.1 & 53.0 & 52.9 & -30.4 \\
\hline North Macedonia & $\ldots$ & $\ldots$ & $\ldots$ & $\ldots$ & $\ldots$ & $\ldots$ & $\ldots$ \\
\hline Norway & & $\ldots$ & & & & & \\
\hline Poland & 65.5 & 65.4 & 65.1 & 66.1 & 66.0 & 66.1 & 0.9 \\
\hline Portugal & 27.6 & 24.2 & 18.1 & 20.7 & 28.6 & 22.3 & -19.4 \\
\hline Romania & $\ldots$ & $\ldots$ & $\ldots$ & $\ldots$ & $\ldots$ & $\ldots$ & $\ldots$ \\
\hline Russian Federation & $\ldots$ & $\ldots$ & $\ldots$ & $\ldots$ & $\ldots$ & $\ldots$ & $\ldots$ \\
\hline Serbia & $\ldots$ & $\ldots$ & $\ldots$ & $\ldots$ & $\ldots$ & $\ldots$ & $\ldots$ \\
\hline Slovak Republic & & $\ldots$ & & $\ldots$ & & $\ldots$ & \\
\hline Slovenia & 57.4 & 54.3 & 52.8 & 51.4 & 50.6 & 51.3 & -10.6 \\
\hline Spain & & & & & & & \\
\hline Sweden & 84.8 & 89.2 & 89.8 & 89.6 & 85.8 & 96.4 & 13.6 \\
\hline Switzerland & & & & $\ldots$ & & $\ldots$ & $\ldots$ \\
\hline Turkey & 17.9 & 17.4 & 17.4 & . & 16.2 & $\ldots$ & \\
\hline Ukraine & 105.9 & 100.3 & 82.7 & 81.9 & 73.5 & 44.0 & -58.4 \\
\hline UK: England \& Wales & 131.8 & 119.3 & 115.1 & 111.7 & 110.1 & 105.6 & -19.8 \\
\hline $\begin{array}{l}\text { UK: Northern Ireland } \\
\text { UK: Scotland }\end{array}$ & 137.9 & $\ldots$ & $\ldots$ & $\ldots$ & $\ldots$ & 119.6 & -13.3 \\
\hline Mean & 82 & 76.7 & 74.3 & 78.1 & 72.6 & 72.3 & \\
\hline Median & 80 & 75.5 & 78.3 & 81.9 & 74.4 & 68.9 & \\
\hline Minimum & 18 & 17.4 & 17.4 & 20.6 & 16.2 & 22.2 & \\
\hline Maximum & 138 & 126.1 & 123.1 & 120.5 & 120.5 & 124.6 & \\
\hline
\end{tabular}


Table 1.2.4.3 Police staff: Percentage of women and officers among the staff

\begin{tabular}{|c|c|c|}
\hline & Women & Officers at criminal investigation departments \\
\hline Albania & 9.5 & 15.6 \\
\hline Armenia & $\ldots$ & $\ldots$ \\
\hline Austria & $\ldots$ & $\ldots$ \\
\hline Azerbaijan & $\ldots$ & $\ldots$ \\
\hline Belgium & 21.6 & 10.0 \\
\hline Bosnia-Herzegovina & $\ldots$ & \\
\hline Bulgaria & $\ldots$ & 6.0 \\
\hline Croatia & 17.6 & $\ldots$ \\
\hline Cyprus & 24.7 & $\ldots$ \\
\hline Czech Republic & 15.1 & 22.7 \\
\hline Denmark & & \\
\hline Estonia & 34.7 & 19.5 \\
\hline Finland & $\ldots$ & $\ldots$ \\
\hline France & $\ldots$ & $\ldots$ \\
\hline Georgia & 15.8 & $\ldots$ \\
\hline Germany & 19.7 & $\ldots$ \\
\hline Greece & $\ldots$ & $\ldots$ \\
\hline Hungary & 22.4 & 21.4 \\
\hline Iceland & 15.5 & 17.0 \\
\hline Ireland & $\ldots$ & $\ldots$ \\
\hline Italy & $\ldots$ & $\ldots$ \\
\hline Kosovo (UN R/1244/99) & $\ldots$ & $\ldots$ \\
\hline Latvia & 35.6 & $\ldots$ \\
\hline Lithuania & 34.5 & $\ldots$ \\
\hline Luxembourg & $\ldots$ & $\ldots$ \\
\hline Malta & $\ldots$ & $\ldots$ \\
\hline Moldova & $\ldots$ & $\ldots$ \\
\hline Montenegro & $\ldots$ & $\ldots$ \\
\hline Netherlands & $\ldots$ & $\ldots$ \\
\hline North Macedonia & 11.9 & $\ldots$ \\
\hline Norway & $\ldots$ & $\ldots$ \\
\hline Poland & $\ldots$ & \\
\hline Portugal & 7.5 & 10.5 \\
\hline Romania & 18.6 & 76.6 \\
\hline Russian Federation & $\ldots$ & $\ldots$ \\
\hline Serbia & $\ldots$ & $\ldots$ \\
\hline Slovak Republic & $\ldots$ & $\ldots$ \\
\hline Slovenia & 16.9 & 13.6 \\
\hline Spain & 10.9 & 10.7 \\
\hline Sweden & 31.4 & 44.9 \\
\hline Switzerland & & $\ldots$ \\
\hline Turkey & 55.0 & $\ldots$ \\
\hline Ukraine & 15.6 & 10.9 \\
\hline UK: England \& Wales & 28.2 & $\ldots$ \\
\hline UK: Northern Ireland & 28.0 & $\ldots$ \\
\hline UK: Scotland & & \\
\hline Mean & 22 & 21 \\
\hline Median & 19 & 16 \\
\hline Minimum & 8 & 6 \\
\hline Maximum & 55 & 77 \\
\hline
\end{tabular}




\subsection{Technical Information}

Table 1.3.1 Data recording methods relating to Tables 1.2.1 - 1.2.1.6 and 1.2.1.8 1.2.1.23 (offences) $(1 / 2)$

$\begin{array}{lll}\text { Are there } & \text { When is the } & \text { What is the } \\ \text { written rules } & \text { data col- } & \text { counting princi- } \\ \text { regulating lected for } & \text { unit used in rule ap- } \\ \text { the way in the statis- } & \text { this table? plied? } \\ \text { which data tics? } & & \\ \text { is recorded? } & & \end{array}$

$\begin{array}{lll}\text { How are } & \text { How is an } & \text { Have the } \\ \text { multiple of- } & \text { offence } & \text { data record } \\ \text { fences } & \text { committed } & \text { ing methods } \\ \text { counted? } & \text { by more } & \text { described } \\ & \text { than one } & \text { above been } \\ & \text { person } & \text { substantially } \\ & \text { counted? } & \text { modified be }\end{array}$

tween 2011

\begin{tabular}{lllllll} 
& \multicolumn{3}{c}{ and 2016? } \\
\hline 1: Yes & 1: When re- & 1: Offence & 1: yes & 1: As one & 1: As one & 1: Yes \\
2: No & ported to & 2: Case & 2: No & offence & offence & 2: No
\end{tabular}

the police 3: Decision 2: As two or 2: As two or

2: Subseq. 4: Other more of- more of-

3: After in- fences fences

\begin{tabular}{|c|c|c|c|c|c|c|c|}
\hline & \multicolumn{2}{|c|}{ vestigation. } & \multicolumn{4}{|c|}{ 3: Uncertain } & \\
\hline Albania & $\ldots$ & 2 & 1 & 2 & 2 & 1 & $\ldots$ \\
\hline Armenia & 1 & 2 & 1 & 2 & 1 & 1 & 2 \\
\hline Austria & 1 & 3 & 1 & 2 & 2 & 1 & 2 \\
\hline Azerbaijan & 1 & 2 & 1 & 1 & 1 & 1 & 2 \\
\hline $\begin{array}{l}\text { Belgium } \\
\text { Bosnia-Her- }\end{array}$ & 1 & 1 & 1 & 2 & 2 & 1 & 2 \\
\hline zegovina & $\ldots$ & $\ldots$ & $\ldots$ & $\ldots$ & $\ldots$ & $\ldots$ & $\ldots$ \\
\hline Bulgaria & 2 & 2 & 1 & 2 & 2 & 1 & 2 \\
\hline Croatia & 1 & $\ldots$ & $\ldots$ & $\ldots$ & $\ldots$ & $\ldots$ & 2 \\
\hline Cyprus & 1 & 1 & 2 & 1 & 1 & 1 & 2 \\
\hline Czech Re- & & & & & & & \\
\hline public & 1 & 1 & 1 & 1 & 1 & 1 & 1 \\
\hline Denmark & 2 & 1 & 1 & 2 & 2 & 1 & 2 \\
\hline Estonia & 1 & 1 & 1 & 2 & $\ldots$ & 1 & $\ldots$ \\
\hline Finland & 2 & 1 & 1 & 2 & 2 & 1 & 2 \\
\hline France & 1 & 3 & 3 & 2 & 2 & 1 & 2 \\
\hline Georgia & 2 & 2 & 1 & $\ldots$ & 1 & 1 & $\ldots$ \\
\hline Germany & 1 & 3 & 1 & 1 & $\ldots$ & 1 & 2 \\
\hline Greece & 1 & 1 & 1 & 1 & 2 & 2 & 1 \\
\hline Hungary & 1 & 3 & 1 & 2 & 2 & 1 & 2 \\
\hline Iceland & 1 & 1 & 1 & 2 & 2 & 1 & 2 \\
\hline Ireland & $\ldots$ & $\ldots$ & $\ldots$ & $\ldots$ & $\ldots$ & $\ldots$ & $\ldots$ \\
\hline Italy & 2 & 2 & 1 & 1 & 1 & 1 & 2 \\
\hline Kosovo (UN & & & & & & & \\
\hline R/1244/99) & $\ldots$ & $\ldots$ & $\ldots$ & $\ldots$ & $\ldots$ & $\ldots$ & $\ldots$ \\
\hline Latvia & 2 & 2 & 1 & 1 & 2 & 1 & 2 \\
\hline Lithuania & 1 & 2 & 1 & 1 & 2 & 1 & 2 \\
\hline Luxembourg & $\ldots$ & $\ldots$ & $\ldots$ & $\ldots$ & $\ldots$ & $\ldots$ & $\ldots$ \\
\hline Malta & $\ldots$ & $\ldots$ & $\ldots$ & $\ldots$ & $\ldots$ & $\ldots$ & $\ldots$ \\
\hline Moldova & 1 & 2 & 1 & 2 & 1 & 1 & 2 \\
\hline Montenegro & 2 & 3 & 1 & 2 & 1 & 1 & 2 \\
\hline Netherlands & 1 & 2 & 1 & 1 & 1 & 1 & 2 \\
\hline North Mace- & & & & & & & \\
\hline donia & 1 & 1 & 1 & 2 & 2 & 1 & 2 \\
\hline Norway & $\ldots$ & $\ldots$ & $\ldots$ & $\ldots$ & $\ldots$ & $\ldots$ & $\ldots$ \\
\hline Poland & 1 & 3 & 1 & 1 & 1 & 1 & 1 \\
\hline Portugal & 1 & 2 & 3 & 1 & 1 & 1 & 2 \\
\hline
\end{tabular}


Table 1.3.1 Data recording methods relating to Tables 1.2.1 - 1.2.1.6 and 1.2.1.8 1.2.1.23 (offences) (2/2)

\begin{tabular}{|c|c|c|c|c|}
\hline $\begin{array}{l}\text { Are there } \\
\text { written rules } \\
\text { regulating } \\
\text { the way in } \\
\text { which data } \\
\text { is recorded? }\end{array}$ & $\begin{array}{l}\text { When is the } \\
\text { data col- } \\
\text { lected for } \\
\text { the statis- } \\
\text { tics? }\end{array}$ & $\begin{array}{l}\text { What is the } \\
\text { counting } \\
\text { unit used in } \\
\text { this table? }\end{array}$ & $\begin{array}{l}\text { Is a princi- } \\
\text { pal offence } \\
\text { rule ap- } \\
\text { plied? }\end{array}$ & $\begin{array}{l}\text { How are } \\
\text { multiple of- } \\
\text { fences } \\
\text { counted? }\end{array}$ \\
\hline
\end{tabular}

How is an Have the offence data recordcommitted ing methods by more described than one above been person substantially counted? modified between 2011 and $2016 ?$

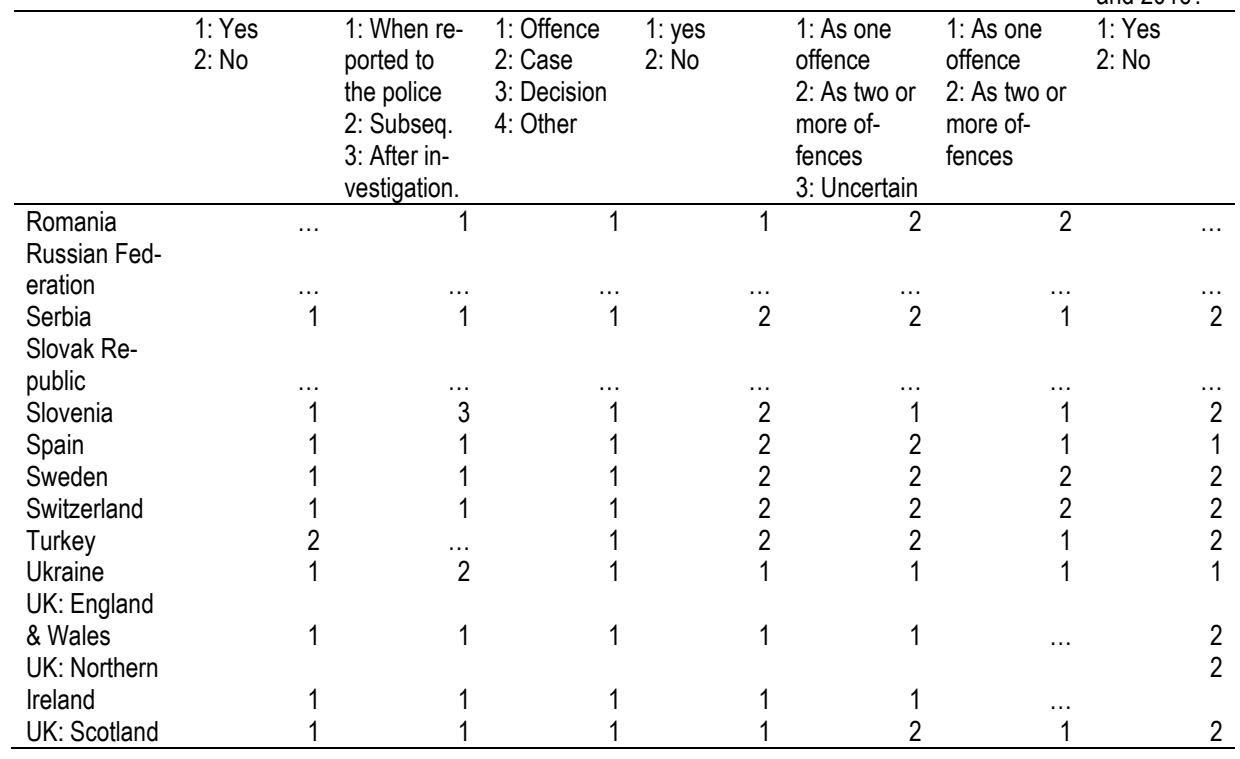

Are there written rules regulating the way in which data is recorded?

Of the countries that gave information 23 said they had written rules regulating the way in which the data is recorded. Seven countries said they did not have written rules. As pointed out in previous editions of the Sourcebook, it is most likely that those countries have instructions to guide how to count offences although they may not be considered as written rules.

\section{When are the data collected for the statistics?}

In 15 countries data is collected when the offence was reported to the police. Additional two countries report mixed counting rules. In the Czech Republic the data is based on the tactical-statistical classification but not on the criminal code. The classification is independent of the qualification according to the Criminal Code since if the paragraphs change, the TSC remains the same. In Spain most offences are initially recorded when the offence is reported to the police but in serious cases 
definitions of offence type can change in the course of the investigation. Seven countries report that offences are counted after an investigation is completed.

What is the counting unit used in this table?

Altogether 34 countries report the offence to be the counting unit in the data. Only one country used the case, and two countries used the decision as a counting unit.

\section{Is a principal offence rule applied?}

Fifteen countries reported that they applied a principal offence rule and 20 that they did not. In Greece the principal offence rule applied until 2012. after that all concurrent offences are recorded.

\section{How are multiple offences counted?}

13 counties counted multiple offences as one offence, whereas 20 countries reported that they count such an offence as two or more. Two countries reported mixed methods. In Montenegro multiple offences are counted as one unless they meet the conditions of being defined as an Extended Criminal Offence and in Slovenia, the general rule is to count multiple offences as one but, in some cases, they are counted as many.

\section{How is an offence that is committed by more than one person counted?}

Offences committed by more than one person are generally counted as one offence as 30 countries report. Montenegro reported mixed counting rules.

Have the data recording methods described above been substantially modified between 2011 and 2016 ?

Six countries reported changes in data recording methods.

Belgium

In the end of 2015 changes were made to the national database and persons could be registered for minor offences, but before they could only be registered for serious offences.

\section{Greece}

The informational system generating the statistics for the Hellenic Police was redesigned in 2013.

Iceland

Changes in working procedures regarding domestic violence has led to more cases being registered as violence. 


\section{Poland}

Data changes and system changes were made in 2012 and 2013 causing breaks in the data series.

\section{Sweden}

The statistics of persons suspected of offences were revised in 2017 leading to all persons suspected of offences to be included instead of only including persons still suspected of an offence after a crime investigation. Comparative data is available from 2007.

Ukraine

A new Criminal Procedural Code came into force in the end of 2012.

\section{Definition of foreigner}

Generally speaking. foreigners are persons who do not have the nationality of the country in which they commit an offence.

\section{Age Brackets used in Tables 1.2.3.1 to 1.2.3.22}

Most countries count minors as persons who are not yet 18 years old. In Austria, Azerbaijan, Poland, Slovenia, and Ukraine the maximum age for a minor was reported to be 17 years.

The lower age limit for treating a person as a minor varies among different countries. Many countries report the minimum age to be 14 but, however, it is possible that persons below the age of criminal responsibility are included in police statistics. 
Table 1.3.3 Minimum age for inclusion in Tables 1.2.3.1 to 1.2.3.22

\begin{tabular}{lc}
\hline Albania & $\ldots$ \\
Armenia & $\ldots$ \\
Austria & 1 \\
Azerbaijan & 14 \\
Belgium & 0 \\
Bosnia-Herzegovina & $\ldots$ \\
Bulgaria & 14 \\
Croatia & 14 \\
Cyprus & 14 \\
Czech Republic & 0 \\
Denmark & $\ldots$ \\
Estonia & 14 \\
Finland & 0 \\
France & 0 \\
Georgia & 14 \\
Germany & 0 \\
Greece & 8 \\
Hungary & 12 \\
Iceland & $\ldots$ \\
Ireland & $\ldots$ \\
Italy & 0 \\
Kosovo (UN R/1244/99) & $\ldots$ \\
Latvia & 14 \\
Lithuania & 14 \\
Luxembourg & $\ldots$ \\
Malta & $\ldots$ \\
Moldova & $\ldots$ \\
Montenegro & $\ldots$ \\
Netherlands & $\ldots$ \\
North Macedonia & $\ldots$ \\
Norway & $\ldots$ \\
Poland & $\ldots$ \\
Portugal & $\ldots$ \\
Romania & $\ldots$ \\
Russia & $\ldots$ \\
Serbia & $\ldots$ \\
Slovak Republic & $\ldots$ \\
Slovenia & $\ldots$ \\
Spain & 14 \\
Sweden & 14 \\
Switzerland & $\ldots$ \\
Turkey & $\ldots$ \\
Ukraine & $\ldots$ \\
UK: England \& Wales & 15 \\
UK: Northern Ireland & 10 \\
UK: Scotland & $\ldots$ \\
\hline & $\ldots$ \\
\hline
\end{tabular}

Notes on table 1.3.3

\begin{tabular}{ll}
\hline France & No legal minimum age and in police statistics all age groups are included. \\
Germany & Police statistics include all age groups, but offences committed by very young children \\
& are not likely to be recorded. \\
Hungary & The age of criminal responsibility is 12 years. \\
Lithuania & Age of criminal liability is 16 in most cases but can be 14 in some cases. \\
Turkey & Definition not clear. Age of criminal liability is 12 but the database includes younger \\
& suspects.
\end{tabular}


Table 1.3.4 Technical information on Table 1.2.4.1 - Police staff: Police officers

\begin{tabular}{|c|c|c|c|c|c|c|c|c|c|c|c|c|c|c|c|}
\hline & 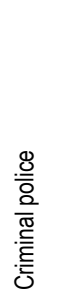 & 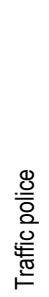 & 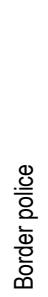 & 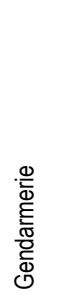 & 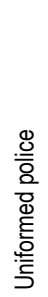 & 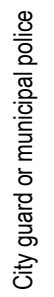 & 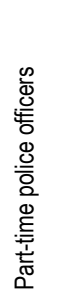 & 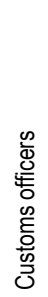 & 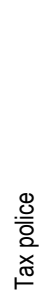 & 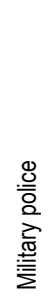 & 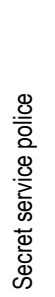 & 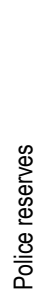 & 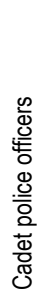 & 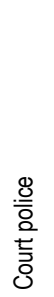 & 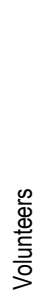 \\
\hline Albania & 1 & 1 & 1 & & 1 & 2 & $\ldots$ & 2 & 2 & 2 & 2 & 2 & 2 & 2 & 2 \\
\hline Armenia & $\ldots$ & $\ldots$ & $\ldots$ & $\ldots$ & $\ldots$ & $\ldots$ & $\ldots$ & $\ldots$ & $\ldots$ & $\ldots$ & $\ldots$ & $\ldots$ & $\ldots$ & $\ldots$ & $\ldots$ \\
\hline Austria & $\ldots$ & $\ldots$ & $\ldots$ & $\ldots$ & $\ldots$ & $\ldots$ & $\ldots$ & $\ldots$ & $\ldots$ & $\ldots$ & $\ldots$ & $\ldots$ & $\ldots$ & $\ldots$ & $\ldots$ \\
\hline Azerbaijan & $\ldots$ & $\ldots$ & $\ldots$ & $\ldots$ & $\ldots$ & $\ldots$ & $\ldots$ & $\ldots$ & $\ldots$ & $\ldots$ & $\ldots$ & $\ldots$ & $\ldots$ & $\ldots$ & $\ldots$ \\
\hline Belgium & 1 & 1 & 1 & 1 & 1 & 1 & $\ldots$ & 2 & 2 & 2 & 2 & 2 & 2 & 2 & 2 \\
\hline Bosnia-Herzegovina & $\cdots$ & $\ldots$ & $\ldots$ & $\ldots$ & $\ldots$ & $\ldots$ & $\ldots$ & $\ldots$ & $\ldots$ & $\ldots$ & $\ldots$ & $\ldots$ & $\ldots$ & $\ldots$ & $\ldots$ \\
\hline Bulgaria & 1 & 1 & 1 & 1 & 1 & 2 & 1 & 2 & 2 & $\ldots$ & 2 & 2 & 2 & 2 & 2 \\
\hline Croatia & 1 & 1 & 1 & 2 & 1 & 2 & 2 & 2 & 2 & 2 & 2 & 2 & 2 & 2 & 2 \\
\hline Cyprus & 1 & 1 & 2 & 2 & 1 & 2 & 2 & 2 & 2 & 2 & 1 & 2 & 1 & 1 & 2 \\
\hline Czech Republic & 1 & 1 & 1 & $\ldots$ & 1 & 2 & 1 & 2 & 2 & 2 & 2 & 2 & 2 & 2 & 2 \\
\hline Denmark & 1 & 1 & 1 & 2 & 1 & 2 & 1 & 2 & 2 & 2 & 1 & 2 & 2 & 2 & 2 \\
\hline Estonia & 1 & 2 & 3 & $\ldots$ & 1 & 2 & 1 & 2 & $\ldots$ & 2 & 2 & 2 & 2 & $\ldots$ & 2 \\
\hline Finland & 1 & 1 & 2 & 2 & 1 & 2 & 1 & 2 & $\ldots$ & 2 & 1 & 2 & 1 & 2 & 2 \\
\hline France & 1 & 1 & 1 & 1 & 1 & 2 & 1 & 2 & 2 & 1 & 2 & 2 & 2 & 2 & 2 \\
\hline Georgia & 1 & 1 & 1 & 2 & 1 & 1 & 2 & 2 & 2 & 2 & 2 & 2 & 1 & 2 & 2 \\
\hline Germany & 1 & 1 & 1 & $\ldots$ & 1 & 1 & 1 & 2 & 2 & 2 & 2 & 2 & 1 & 2 & $\ldots$ \\
\hline Greece & & . & & . & $\ldots$ & & $\ldots$ & $\cdots$ & $\cdots$ & $\ldots$ & & $\ldots$ & $\ldots$ & $\ldots$ & $\ldots$ \\
\hline Hungary & 1 & 1 & 1 & 2 & 1 & 2 & 2 & 2 & 2 & 2 & 2 & 2 & 1 & 2 & 2 \\
\hline Iceland & 1 & 1 & 1 & 2 & 1 & 1 & 1 & 2 & 2 & 2 & 2 & 2 & 2 & 2 & 2 \\
\hline Ireland & & & & & $\ldots$ & $\ldots$ & $\ldots$ & $\ldots$ & & $\ldots$ & $\ldots$ & $\ldots$ & & & \\
\hline $\begin{array}{l}\text { Italy } \\
\text { Kosovo (UN R/1244/99) }\end{array}$ & 1 & 1 & 1 & 2 & 1 & 2 & 2 & 2 & 1 & 2 & $\ldots$ & 2 & 2 & 2 & 2 \\
\hline Latvia & 1 & 1 & 1 & 2 & 1 & 2 & 2 & 2 & 2 & 2 & 2 & 2 & 2 & 2 & 2 \\
\hline Lithuania & 1 & 1 & 2 & 2 & 1 & 2 & 1 & 2 & 2 & 2 & 2 & 2 & 2 & 2 & 2 \\
\hline Luxembourg & $\ldots$ & $\ldots$ & $\ldots$ & $\ldots$ & $\ldots$ & $\ldots$ & $\ldots$ & $\ldots$ & $\ldots$ & $\ldots$ & $\ldots$ & $\ldots$ & $\ldots$ & $\ldots$ & $\ldots$ \\
\hline Malta & $\ldots$ & $\ldots$ & $\ldots$ & $\ldots$ & $\ldots$ & & $\ldots$ & $\ldots$ & $\ldots$ & $\ldots$ & $\ldots$ & $\ldots$ & $\ldots$ & $\ldots$ & $\ldots$ \\
\hline Moldova & $\ldots$ & $\ldots$ & . & $\ldots$ & $\ldots$ & $\ldots$ & $\ldots$ & $\ldots$ & $\ldots$ & $\ldots$ & $\ldots$ & $\ldots$ & $\ldots$ & $\ldots$ & $\ldots$ \\
\hline Montenegro & 1 & 1 & 1 & $\ldots$ & 1 & $\ldots$ & 2 & 2 & 2 & 2 & 2 & 2 & 2 & 2 & \\
\hline Netherlands & 1 & 1 & 1 & 1 & 1 & 1 & 1 & 2 & 2 & 2 & 2 & 2 & 2 & 2 & 2 \\
\hline North Macedonia & 1 & 1 & 1 & 1 & 1 & 2 & 2 & 2 & 2 & 2 & 2 & 2 & 2 & 2 & 2 \\
\hline Norway & & & & & & & $\ldots$ & $\ldots$ & & $\ldots$ & & & & & \\
\hline Poland & 1 & 1 & 2 & 2 & 1 & 2 & $\ldots$ & 2 & 2 & 2 & 2 & 2 & 2 & 2 & 2 \\
\hline Portugal & 1 & 1 & 1 & 1 & 1 & 1 & 2 & 2 & 1 & 2 & 2 & 2 & 2 & 2 & 2 \\
\hline Romania & 1 & 2 & 2 & 2 & 2 & 2 & 1 & 2 & 2 & 2 & 2 & 2 & 2 & 2 & $\ldots$ \\
\hline Russia & $\ldots$ & $\ldots$ & & $\ldots$ & $\ldots$ & $\ldots$ & $\ldots$ & $\ldots$ & $\ldots$ & $\ldots$ & $\ldots$ & $\ldots$ & $\ldots$ & $\ldots$ & $\ldots$ \\
\hline Serbia & 1 & 1 & 1 & 1 & 1 & 2 & 2 & 2 & 2 & 2 & 2 & 2 & 2 & 2 & 2 \\
\hline Slovak Republic & $\ldots$ & $\ldots$ & $\ldots$ & $\ldots$ & $\ldots$ & $\ldots$ & $\ldots$ & $\ldots$ & $\ldots$ & $\ldots$ & $\ldots$ & $\ldots$ & $\ldots$ & $\ldots$ & $\ldots$ \\
\hline Slovenia & 1 & 1 & 1 & 2 & 1 & 2 & $\ldots$ & 2 & 2 & 2 & 2 & 2 & 1 & 2 & 2 \\
\hline Spain & 1 & 1 & 1 & 1 & 1 & 2 & 2 & 1 & 1 & 1 & 1 & 1 & 1 & 2 & 2 \\
\hline Sweden & 1 & 1 & 1 & 1 & 1 & 1 & 1 & 2 & 1 & 2 & 2 & 2 & 2 & 2 & 2 \\
\hline Switzerland & 1 & 1 & 2 & 1 & 1 & 1 & 1 & & & & & & & & \\
\hline Turkey & 1 & 1 & 1 & 1 & 1 & 2 & $\ldots$ & 2 & 2 & 2 & 2 & 2 & 2 & 2 & 2 \\
\hline Ukraine & 1 & 1 & 2 & 2 & 2 & 1 & 1 & 2 & 2 & 2 & 1 & 2 & 1 & 1 & 2 \\
\hline UK: England \& Wales & 1 & 1 & 2 & 1 & 1 & 2 & $\ldots$ & 2 & 1 & 2 & 2 & 1 & 2 & 1 & $\ldots$ \\
\hline UK: Northern Ireland & 1 & 1 & 2 & 2 & 1 & 2 & $\ldots$ & 2 & 2 & 2 & 2 & 1 & 2 & $\ldots$ & $\ldots$ \\
\hline UK: Scotland & 1 & 1 & 2 & 2 & 1 & 1 & $\ldots$ & 2 & 2 & 2 & 2 & 2 & 2 & 1 & \\
\hline
\end{tabular}


Table 1.3.5 Technical information on Table 1.2.4.1 - Police staff: Civilians

\begin{tabular}{|c|c|c|c|c|c|c|c|}
\hline & 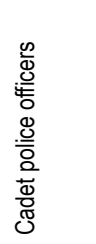 & 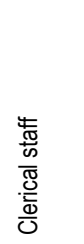 & 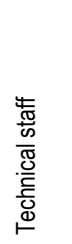 & 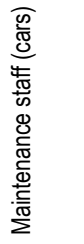 & 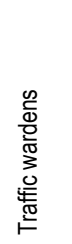 & 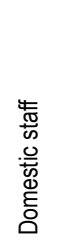 & 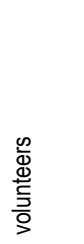 \\
\hline Albania & 2 & 1 & 1 & 1 & 2 & 2 & 2 \\
\hline Armenia & $\ldots$ & $\ldots$ & $\ldots$ & $\ldots$ & $\ldots$ & $\ldots$ & $\ldots$ \\
\hline Austria & $\ldots$ & $\ldots$ & $\ldots$ & $\ldots$ & $\ldots$ & $\ldots$ & $\cdots$ \\
\hline Azerbaijan & $\ldots$ & $\ldots$ & $\ldots$ & $\ldots$ & $\ldots$ & $\ldots$ & $\ldots$ \\
\hline Belgium & 2 & 2 & 1 & 1 & 2 & 2 & 2 \\
\hline $\begin{array}{l}\text { Bosnia-Herzegovina } \\
\text { Bulqaria }\end{array}$ & $\ldots$ & $\ldots$ & ... & $\ldots$ & $\ddot{1}$ & … & 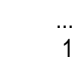 \\
\hline Croatia & 2 & 1 & 1 & $\begin{array}{l}2 \\
1\end{array}$ & 2 & 2 & 2 \\
\hline Cyprus & 1 & 1 & 1 & 1 & 2 & 2 & 2 \\
\hline Czech Republic & 2 & 1 & 1 & 1 & 2 & 1 & 2 \\
\hline Denmark & 1 & 1 & 1 & 1 & 2 & $\ldots$ & 2 \\
\hline Estonia & 2 & 2 & 2 & 2 & $\ldots$ & 2 & $\ldots$ \\
\hline Finland & 2 & 1 & 1 & 1 & 2 & 2 & 2 \\
\hline France & 1 & 1 & 1 & 1 & 2 & 1 & $\ldots$ \\
\hline Georgia & 2 & 2 & 2 & 2 & ... & 2 & $\ldots$ \\
\hline Germany & 2 & 1 & 1 & 1 & 2 & 2 & $\ldots$ \\
\hline Greece & & $\ldots$ & $\ldots$ & & $\ldots$ & $\ldots$ & $\ldots$ \\
\hline Hungary & 2 & 1 & 1 & 1.2 & 2 & 1 & 2 \\
\hline Iceland & 1 & 1 & 1 & 1 & 2 & 2 & 2 \\
\hline Ireland & . & & & $\cdots$ & & ... & $\ldots$ \\
\hline Italy & 2 & 2 & 2 & 2 & 2 & 2 & $\begin{array}{l}\cdots \\
\ldots\end{array}$ \\
\hline Kosovo (UN R/1244/99) & $\ldots$ & $\ldots$ & $\ldots$ & $\ldots$ & $\ldots$ & $\ldots$ & $\ldots$ \\
\hline Latvia & $\ldots$ & $\ldots$ & $\ldots$ & $\ldots$ & $\ldots$ & $\ldots$ & $\ldots$ \\
\hline Lithuania & 2 & 1 & 1 & 1 & 2 & 1 & 2 \\
\hline Luxembourg & $\ldots$ & $\ldots$ & $\ldots$ & $\ldots$ & $\ldots$ & $\ldots$ & $\ldots$ \\
\hline Malta & $\ldots$ & $\ldots$ & $\ldots$ & $\ldots$ & $\ldots$ & $\ldots$ & $\ldots$ \\
\hline Moldova & $\ldots$ & $\ldots$ & $\ldots$ & $\ldots$ & $\ldots$ & $\ldots$ & $\ldots$ \\
\hline Montenegro & 2 & 2 & 2 & $\ldots$ & 2 & 2 & $\ldots$ \\
\hline Netherlands & 2 & 1 & 1 & 1 & 2 & 2 & 2 \\
\hline North Macedonia & 2 & 2 & 1 & 1 & 1 & 1 & 2 \\
\hline Norway & $\ldots$ & $\ldots$ & $\ldots$ & $\ldots$ & & $\ldots$ & $\ldots$ \\
\hline Poland & 2 & 1 & 2 & 1 & 2 & 2 & 2 \\
\hline Portugal & 1 & 1 & 1 & 1 & 2 & 2 & 2 \\
\hline Romania & $\ldots$ & $\ldots$ & $\ldots$ & $\ldots$ & $\ldots$ & $\ldots$ & $\ldots$ \\
\hline Russia & $\ldots$ & $\ldots$ & $\ldots$ & $\ldots$ & $\ldots$ & $\ldots$ & $\ldots$ \\
\hline Serbia & 2 & 2 & 1 & 1 & 1 & 1 & 2 \\
\hline Slovak Republic & $\ldots$ & $\ldots$ & $\ldots$ & $\ldots$ & $\ldots$ & $\ldots$ & $\ldots$ \\
\hline Slovenia & 2 & 1 & 1 & 1 & 2 & 1 & 2 \\
\hline Spain & & $\ldots$ & & $\ldots$ & & $\ldots$ & $\ldots$ \\
\hline Sweden & 2 & 1 & 1 & 1 & 2 & 2 & 2 \\
\hline Switzerland & $\ldots$ & $\ldots$ & $\ldots$ & $\ldots$ & & $\ldots$ & $\ldots$ \\
\hline Turkey & 2 & 1 & 1 & 1 & 2 & 2 & 2 \\
\hline Ukraine & 2 & 2 & 1 & 1 & 1 & 1 & 2 \\
\hline UK: England \& Wales & 2 & 1 & 1 & 2 & 2 & 1 & $\ldots$ \\
\hline UK: Northern Ireland & 2 & 1 & 1 & 1 & 2 & 2 & $\ldots$ \\
\hline UK: Scotland & 2 & 1 & 1 & 1 & 2 & 2 & $\ldots$ \\
\hline
\end{tabular}




\subsection{Sources}

\begin{tabular}{ll}
\hline Albania & The General Directorate of State Police. \\
& Information Center. RA Police (non-published data). Publication - Social-economical Situa- \\
& tion in Armenia. January-December 2017. https://www.armstat.am/file/arti- \\
& cle/sv_12_16a_540.pdf. Publication - Social-economical Situation in Armenia. January-De- \\
Armenia & cember 2015. https://www.armstat.am/file/article/sv_12_14a_550.pdf. Publication - Social- \\
& economical Situation in Armenia. January-December 2013. https://www.armstat.am/file/arti- \\
& cle/sv_12_12a_570.pdf \\
& Statistics of Crime Reports in Austria 2011 - 2016 by Criminal Intelligence Service. Ministry \\
& of the Interior; "Report on the drug situation" (Bericht zur Drogensituation - Gesundheit Öster- \\
Austria & reich GmbH) \\
& Information about crimes 2013-2016 is available on the official website of the State Statistical \\
Azerbaijan & Committee of the Republic of Azerbaijan https://www.stat.gov.az/source/crimes/ and Ministry \\
& of Internal Affairs of the Republic of Azerbaijan https://mia.gov.az/?/az/content/29993/
\end{tabular}

Bosnia-Herzegovina

Bulgaria

Croatia

Cyprus

Czech Republic

Denmark

Estonia

Finland

France

Georgia
Germany
Greece
Hungary
Iceland
Ireland
Italy
Kosovo (UN R/1244/99)
Latvia

Lithuania
Data taken from "Annual Bulletins of Police Statistics 2011 - 2016". Ministry of Interior. Please go to: https://www.mvr.bg/министерството/programni-dokumenti-otcheti-analizi/статистика/годишен-бюлетин-полицейска-статистика (in Bulgarian only). Source regarding "Intentional homicide where firearm has been involved": Letter from the Ministry of Interior. National Police General Directorate. to the Bulgarian Association of Criminology. dated 08 August 2018. not published.

Croatian Bureau of Statistics. which collected the data from the prosecution office.

Statistical Reports of the Crime. The Police of the Czech Republic. published. www.mvcr.cz Ministry of Justice - special data files bought from Statistics Denmark http://www.kriminaalpoliitika.ee/et/statistika-ja-uuringud/kuritegevus-eestis - Ministry of Justice.

"Completed intentional homicide" - http://www.tai.ee/en/r-and-d/health-statistics - National Institute for Health Development. "Theft of a motor vehicle" and "Domestic burglary" - Police and Border Guard Board - not published.

Statistics Finland. Rikos- ja pakkokeinotilasto 1.7 .2018 http://pxnet2.stat.fi/ PXWeb/pxweb/fi/StatFin/StatFin_oik__pk/

In order to produce statistics in accordance with the standards of official statistics based on the European Statistics Code of Practice. it was decided to set up a ministerial statistical service within the Ministry of the Interior. Thus. the Ministerial Statistical Service for Internal Security (SSMSI) was created in 2014: it is placed under the joint functional authority of the Directors-General of the National Police (DGPN) and the National Gendarmerie (DGGN) and is organically attached to the Central Directorate of the Judicial Police of the DGPN. Since 06 October 2015. the Interstats website presents reference data. analyses. studies and series of figures on insecurity and delinquency. These data are put online by the ministerial statistical service for internal security (SSMSI). service statistique ministériel de la sécurité intérieure (SSMSI)

Ministry of Internal Affairs Unify Statistical Report

Bundeskriminalamt: Polizeiliche Kriminalstatistik Bundesrepublik Deutschland. 2011 - 2016. Wiesbaden 2012 - 2017

Statistical Yearbook of the Hellenic Police (2011-2016)

Standard Criminal Statistics of Investigation Authorities and Prosecutors

National commissioner of the Icelandic police - annual report

Italian Institute of statistics - http://www.istat.it - Ministry of Justice. Department of Statistics

Information Centre of the Ministry of Interior

Ministry of Internal Affairs - Department of Informatics and Communication - Section of Statistics: Departmental Register of Crimes. A number of various reports were used for the collection of relevant data. Published: Department of Informatics and Communication. website: 


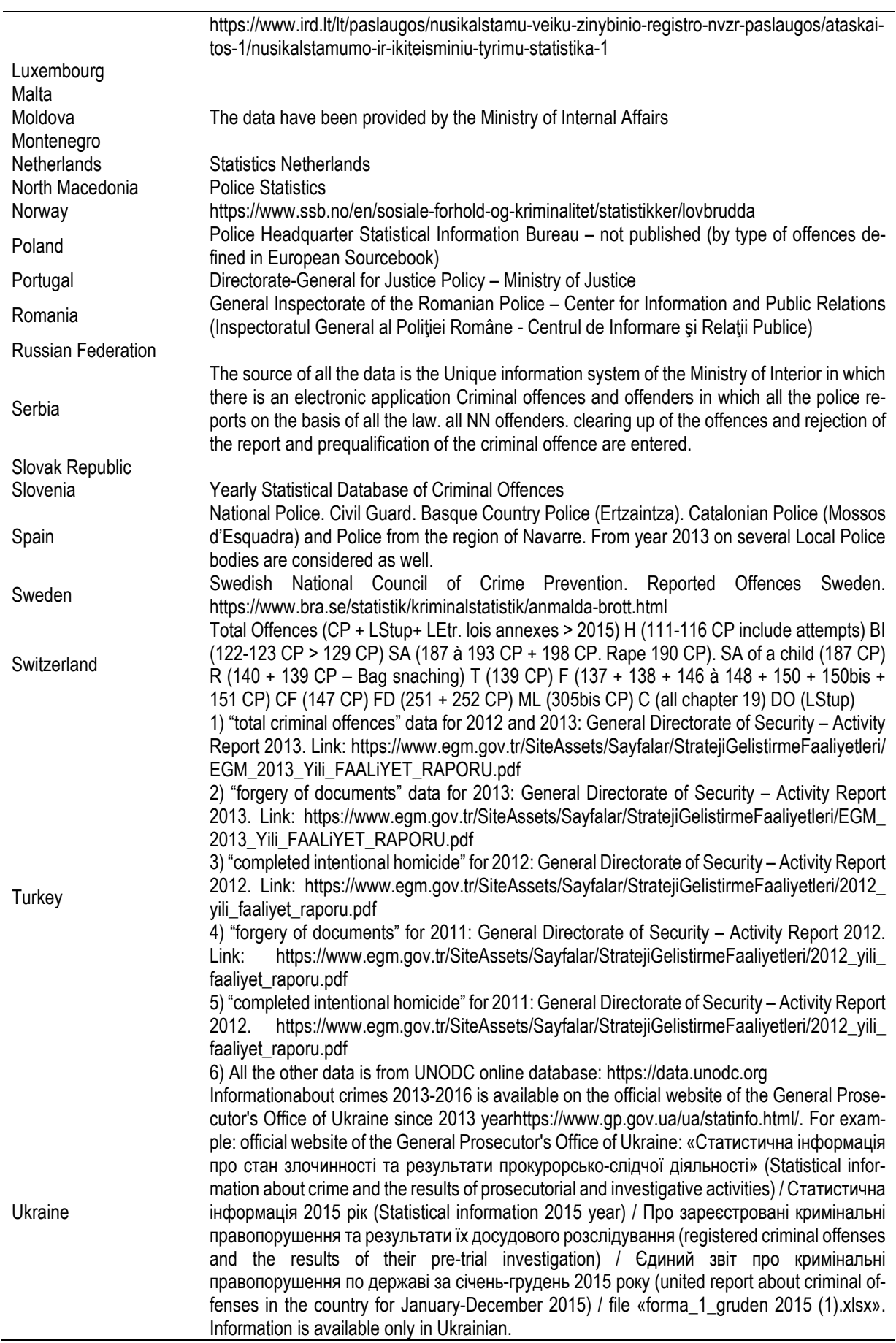




\begin{tabular}{ll}
\hline UK: England \& Wales & $\begin{array}{l}\text { Based on Reference table A4 which accompanied 'Crime in England and Wales. year ending } \\
\text { June 2016'. with the exception of firearm offences which is taken from a separate collection } \\
\text { of police recorded crime and excludes air weapons. }\end{array}$ \\
UK: Northern Ireland & $\begin{array}{l}\text { Statistics Branch. Police Service of Northern Ireland Disclosive } \\
\text { Based on data taken from 'Recorded Crime in Scotland. 2011-12' and 'Homicide in Scotland. }\end{array}$ \\
UK: Scotland & $\begin{array}{l}2011-12 \text { ' http://www.scotland.gov.uk/Topics/Statistics/Browse/Crime- Justice/PubRecorded- } \\
\text { Crime http://www.scotland.gov.uk/Topics/Statistics/Browse/Crime-Justice/PubHomicide }\end{array}$ \\
\hline
\end{tabular}




\section{Prosecution Statistics}

\subsection{General comments}

\subsubsection{Background}

\section{Object of data collection}

This chapter describes the outcome of procedures at the prosecutorial stage (prosecutors and examining judges) for the years 2011 - 2016. Taking into account the discretion at the prosecutor's level, various forms of disposals are differentiated for the year 2015 with a special focus on bringing a case to the court. Also restricted to 2015 , data on the breakdown by minors, women, foreigners and by offences are represented.

Concerning the variety of disposals at the prosecution stage data have been collected but only for the year 2015. Within the present category of a conditional disposal differentiations were made in terms of specific conditions imposed on the offender: this includes community-based measures as well as fines. Only a minority of countries have both this concept of and data on conditional disposals by the prosecution authority. More often, community sanctions and measures may result from a court sentence (see chapter 3) or be connected with the execution of a prison sentence (see chapter 5). 
The chapter also provides data on the staff of prosecuting authorities in the same years. In addition, data on the most important compulsory measures at this stage, police custody and pre-trial detention are presented. Pre-trial detention is also covered in chapter 4.

36 countries were able to provide any data for this chapter (and will be presented in the tables) and only 23 on the number of prosecutors / employees of the prosecuting authority.

\section{Definitions of the prosecution stage}

Once an offence has been reported to the police or another law enforcement authority and a suspect identified, the decision has to be taken whether or not to prosecute, i.e. to bring the case before a court.

In a narrow sense, the term prosecution refers only to carrying out a case in a criminal court. Here, the term is used in the broader sense of processing/disposing of cases (decision making) by the prosecuting authorities, thus including the decision to drop proceedings or to impose a sanction or measure, where this possibility is available to the prosecuting authorities.

The term prosecuting authority refers to the legal body which has as its main task to institute criminal proceedings, i.e. to decide, depending on national legislation and practice, whether or not to prosecute. The actual functions and denominators vary widely between countries. In most European countries, the prosecution of suspected offenders is dealt with by a special prosecuting authority: either a public prosecutor and/or an investigating judge.

There are many differences and many variations in the form this prosecutorial level takes within the different European countries. For the purpose of this Sourcebook, the prosecution stage is considered as an intermediate stage between the police and court levels. Accordingly, this chapter deals with the decisions taken at this intermediate stage.

\section{The role of the police in relation to the prosecution stage (case input)}

In some countries, the input into the prosecutorial level is identical to the output of the police level (including specialised authorities of public order, such as customs or tax authorities). This should be the case in countries (such as Germany) in which the police are regarded purely as a supporting institution to the public prosecutor, with no own powers to dispose of a criminal case. Consequently, they are obliged to transfer all cases to the prosecuting authority. This applies also to cases in which no suspect has been found. Thus, the prosecution input will appear disproportionally high in such systems, especially when cases without suspects are counted (e.g. in France).

However, in some European countries actual practice deviates from this model, i.e. the input at prosecutorial level is not identical to police level output because the police can exercise some discretion and decide on whether to prosecute or not. 
Thus, certain cases are not transferred to the prosecuting authority and are ended by a police decision. The following countries said that they included cases disposed of or sanctioned by the police or other law enforcement authorities: Armenia, Azerbaijan, Estonia, Hungary, Sweden, UK: Scotland. However, the powers of the police are always limited to minor cases, in some countries concerning only petty traffic offences.

These different structures influence the scale of the input and thus the prosecution system statistics. Furthermore, according to changes in definitions and counting rules from one level to another, these statistics at the prosecution level may show some difference with the police output.

\section{What is recorded?}

According to the standard definition, in principle, all offences defined as criminal by the law should be included. But there are some countries which follow a minor offence concept either excluding them from the criminal code (e.g. the wykroczenia in Poland in cases of minor thefts etc.) or making them subject to special proceedings (e.g. most contraventions in France which are handled by the police only) outside the criminal justice system. Included are major road traffic offences (e.g. drunk driving) and all other criminal offences subject to criminal proceedings. Excluded are minor traffic offences (e.g. parking offences), breaches of public order regulations and all other minor offences subject to proceedings outside the criminal justice system, even if defined as criminal by the law (i.e. misdemeanours, contraventions, wykeroczenia, faltas). Less than half of the countries were able to follow this definition in all respects, but deviations usually only refer to one or two items of the abovementioned include/exclude-categories. For details see Appendix I: Definitions.

A special problem refers to recording unknown offender cases. In some countries these are handled by police only, which means that they are not recorded at the prosecution level. If they are part of the input into prosecution statistics there are different modes of recording: In some countries they are not counted at all, in some countries they are included in the output, i.e. the total of cases disposed of. Dependent on these different modes of recording the amount of prosecutorial disposals varies strongly (see technical table 2.3.2).

The counting unit used here should be the case in the sense of proceedings against one defendant, not the offence. Thus, one case may combine several offences. In general, these cases are counted as single cases, but there are some exceptions (see as well technical table 2.3.7).

\section{Discretion at prosecutor's level (output)}

The data provided for the cases disposed of by the prosecuting authority (table 2.2.1.1) refer to the output at public prosecutor's level (tables 2.2.1.1 to 2.2.3.5), i.e. the type of decision taken. This means that pending cases are not included in the total of disposals. 
The structure of prosecuting authorities varies from country to country depending on the discretionary powers available to them. We developed some simple categories for disposals in order to make figures comparable: number of cases brought before a court, number of cases ended by a sanction imposed by the prosecutor that lead to a formal verdict and count as a conviction, number of conditional disposals, number of proceedings dropped in combination with a cautioning of the suspect, number of proceedings dropped unconditionally due to lack of public interest or for efficiency reasons, number of proceedings dropped for legal or factual reasons, number of proceedings dropped because offender remained unknown, number of other disposals. Some of these categories may not apply to every country considered.

Three basic structures are possible:

- There are countries in which the prosecuting authority has neither the power to drop a case nor to impose conditions / sanctions upon an offender; in accordance with a strict principle of legality the prosecuting authority merely has the function of preparing a case for court.

- In most of the countries dealt with in this chapter the prosecuting authority has the power to decide whether or not to prosecute (i.e. to drop a case completely). In some countries the prosecuting authority has not only the power to decide whether to prosecute or not, but also the possibility of dropping the case under conditions, i.e. to bind or sanction the suspected offender (only possible if he agrees to the measure - otherwise the case will go to court), usually to pay an amount of money.

- There are a few countries where the prosecutor can impose penal sanctions, that lead to a formal verdict and count as convictions.

The differentiation between "cases brought before a court", "sanctions imposed by the prosecutor that lead to a formal verdict and count as a conviction" and "conditional disposals" is not always as simple as it may appear. It is a matter of how far the court is involved in the public prosecutor's decision-making. In some countries, the court has to approve all decisions made by the prosecutor to end a prosecution without formally taking it to court, whereas in others the public prosecutor has more powers in this regard.

Sanctions imposed by the prosecutor (or by the court but on application of the prosecutor and without a formal court hearing) that lead to a formal verdict include the penal order (Strafbefeb) known in some countries, where the defendant is considered as convicted (and should be counted as such in chapter 3). Conditional disposals are usually administered in a rather informal way. The defendant agrees to pay a fine or to accept any restrictions or conditions in exchange to ending prosecution, implying that $\mathrm{s} /$ he will not be considered as formally convicted. Here, a breakdown by various forms of conditions is made.

According to the questionnaire, "other disposals" (e.g. cases that were transferred to another competent domestic jurisdiction) should be included in the total of cases handled by the prosecuting authorities. This may lead to some double 
counting and/or to a significant difference between the total and the sum of the output disposals. Some countries provided specific information in order to solve this difficulty or to explain the difference. For more explanations on other disposals see technical table 2.3.3.

\section{Exclusion of tables; statistical rules}

No separate input statistics are published in this chapter. Only for countries where output data were not available, data on the input total of proceedings or persons were used instead. See notes on table 2.2.1.1 to find out which countries are concerned. Data on the input total and on pending cases can, however, be found on the internet (bttps:// wp.unil.ch/europeansourcebook/)

Most of the countries reporting data on prosecution level apply written rules on recording. The majority of countries count proceedings if more than one person is involved as one case. Most countries do the same if multiple offences occurred. However, most countries record two (or more) cases if a person is subject to more than one proceedings in one year. Usually, data collected by other authorities than public prosecution are not included as well as cases disposed of by the police; see technical table 2.3.7 for more detailed information.

\subsubsection{Results}

\section{Trends}

Wide variations can be seen in the total rates of cases disposed of by the prosecution authorities from 477 disposals per 100000 population in Georgia to 6466 in France for 2015 (see table 2.2.1.1). Similar differences can be found on the police level. According to the different workload of the national prosecution authorities, different modes of handling the cases can be seen (see table 2.1.1).

Concerning the development of figures between 2011 and 2016 the picture is diverse. Only in a few countries the rates of all cases disposed of by prosecution authorities appear to be stable between 2011 and 2016, i.e. to show an increase or decrease in case numbers of less than ten percent. Other countries present a strong increase (between ten and $50 \%$ ), on the one hand: Balkan and South-Eastern countries like Kosovo, Montenegro, Serbia and Georgia, but Denmark as well; Albania and Armenia show an even higher increase (more than $50 \%$ ). On the other hand, Bulgaria, Czech Republic, Estonia, Finland, the Netherlands, Poland, Portugal, Slovak Republic and the UK demonstrate a strong decrease of between minus ten and $-50 \%$ (see table 2.2 .1 .1 ). These trends on prosecution level are only partly compatible to those on police level. 


\section{Total of disposals by public prosecution and cases brought before a court}

Table 2.1.1 demonstrates the rate of all cases disposed of and the percentage of cases brought before a court in 2015. Due to the unavailability of data, several countries had to be excluded. The idea behind table 2.1.1 is that there is a relationship between the two factors, namely that where a prosecution authority has to deal with a relatively low number of cases the percentage of cases brought before a court should be high, e.g. in Hungary, and that where the total of cases is high the percentage tends to be low, e.g. in Germany. There are only two countries which clearly deviate from this trend; in Turkey the percentage of cases brought before a court remains relatively high although the number of cases disposed of is also high, and in Armenia both the caseload and the percentage of cases brought before a court are low.

Table 2.1.1 Percentage of cases brought before a court by rate of all cases disposed of

\begin{tabular}{|c|c|c|c|c|}
\hline & & \multicolumn{3}{|c|}{$\begin{array}{l}\text { Cases brought before a court } \\
\text { per } 100.000 \text { population in } 2015\end{array}$} \\
\hline & & $\begin{array}{l}\text { low: up to } 25 \% \text { of } \\
\text { total cases dis- } \\
\text { posed of }\end{array}$ & $\begin{array}{l}\text { middle: more than } \\
25 \% \text { up to } 50 \% \text { of } \\
\text { total cases dis- } \\
\text { posed of }\end{array}$ & $\begin{array}{l}\text { high: more than } 50 \% \\
\text { of total cases dis- } \\
\text { posed of }\end{array}$ \\
\hline \multirow[t]{3}{*}{$\begin{array}{l}\text { Cases disposed of } \\
\text { per } 100.000 \text { popu- } \\
\text { lation in } 2015\end{array}$} & $\begin{array}{l}\text { low: } \\
\text { up to } 1500\end{array}$ & Armenia* & $\begin{array}{l}\text { Albania* } \\
\text { Serbia** }\end{array}$ & $\begin{array}{l}\text { Czech Republic } \\
\text { Denmark } \\
\text { Georgia* } \\
\text { Hungary* } \\
\text { Latvia* }^{*} \\
\text { Lithuania } \\
\text { Luxembourg } \\
\text { Montenegro* } \\
\text { Netherlands }\end{array}$ \\
\hline & $\begin{array}{l}\text { middle: } \\
\text { more than } 1500 \text { up } \\
\text { to } 5000\end{array}$ & $\begin{array}{l}\text { Austria* } \\
\text { Estonia* } \\
\text { Portugal } \\
\text { Romania* }\end{array}$ & $\begin{array}{l}\text { Bulgaria* } \\
\text { Finland } \\
\text { Poland* } \\
\text { Slovenia* } \\
\text { UK: Scotland }\end{array}$ & $\begin{array}{l}\text { UK: England \& } \\
\text { Wales } \\
\text { Iceland* } \\
\text { Lithuania* }^{*}\end{array}$ \\
\hline & $\begin{array}{l}\text { high: } \\
\text { more than } 5000\end{array}$ & $\begin{array}{l}\text { Belgium* } \\
\text { France* } \\
\text { Germany }\end{array}$ & Sweden & Turkey* \\
\hline
\end{tabular}

* Cases disposed of include proceedings against unknown offenders.

One indicator for attrition between the police and court level can be seen in the percentage of cases brought before a court by the public prosecutor. One might assume that this percentage not only depends on the workload of the public prosecution but differs in terms of the offences concerned. The public prosecutor has broader possibilities to drop cases of minor offences because of a lack of public interest or to discontinue criminal proceedings after the defendant has voluntarily fulfilled a condition, such as community service. On the other hand, these possibilities shrink for serious offences. Table 2.1.2 demonstrates the percentage of cases 
brought before a court broken down by some offences: Most serious ones, i.e. intentional homicide, seriousness of middle range, robbery, and lower level range, theft. As only a minority of countries could provide data on that the results cannot be generalized but show some evidence for the assumption made: The percentage of homicide cases brought before a court is much higher than that of theft cases. On the other hand, the minimum and maximum value show a huge range.

Table 2.1.2 Percentage of cases brought before a court by offence groups in 2015*

\begin{tabular}{|l|r|r|r|r|r|}
\hline & \multicolumn{1}{|c|}{ Homicide } & \multicolumn{1}{c|}{ Robbery } & \multicolumn{1}{c|}{ Bodily Injury } & \multicolumn{1}{c|}{ Theft } & Drug Trafficking \\
\hline Mean & $76 \%$ & $71 \%$ & $55 \%$ & $46 \%$ & $54 \%$ \\
\hline Minimum & 22 & 10 & 6 & 3 & 14 \\
\hline Maximum & 100 & 97 & 88 & 99 & 93 \\
\hline
\end{tabular}

* Mean of 17 countries (robbery), 18 countries (homicide, drug offences), 19 countries (bodily injury, theft); see tables 2.2.3.2, 2.2.3.4 and 2.2.3.5

\section{Conditional disposals and community measures}

A conditional disposal at the prosecution stage means that the defendant agrees to pay a fine or accepts conditions in exchange to ending prosecution. 16 countries could provide some data on conditional disposals, but only eleven could provide a breakdown by various forms of conditions. There is less data on minors, not because such concepts do not exist but because the statistics often do not count minors separately.

\section{Minors, women and foreigners}

Statistical data on the breakdown by minors, women and foreigners is poor (see table 2.2.2.1). Only eleven countries could provide separate data on minors. In contrast to the suspects recorded at police level the percentage of minors handled by the public prosecution is very low. This is due to the fact that in some countries criminal cases of minors are mostly handled outside the criminal justice system. Only nine or eight resp. countries could provide separate data for women and foreigners.

\section{Staff of the prosecuting authorities; workload}

20 countries could provide data on the number of prosecutors/employees of the prosecuting authorities. The rates of public prosecutors per 100000 population in these countries for the year 2015 show a wide variation from 25 in Bulgaria to three in France (see tables 2.2.3.1 and 2.2.3.2). Remarkably, more than $50 \%$ of the prosecutors are women. Between 2011 and 2016 the numbers of prosecutors mostly remain stable. Only in Bulgaria and Slovenia is there an increase of more than ten percent.

In table 2.1.3 three categories of low, middle and high rates of prosecutors are established and correlated to the rate of all cases disposed of. Under the category 
of a relatively low rate of prosecutors per 100000 population mostly Western and Northern European countries, and under the opposing category of a relatively high rate of prosecutors only Central and Eastern European countries can be found. These rates do not correlate with the crime situation or with the number of police officers under the supervision of the prosecuting authorities and are especially not in line with the number of disposals made by public prosecution. On the contrary, in the group with a relatively low rate of total disposals and with a relatively high rate of prosecutors one can find only Central and East European countries whereas in the group with a high rate of disposals and a relatively low rate of prosecutors only West European countries are represented (except or Turkey). Evidently, the number of prosecutors depends on different factors, particularly on their competence and tasks in the different national systems of criminal justice and state administration.

Table 2.1.3 Rate of prosecutors by rate of all cases disposed of

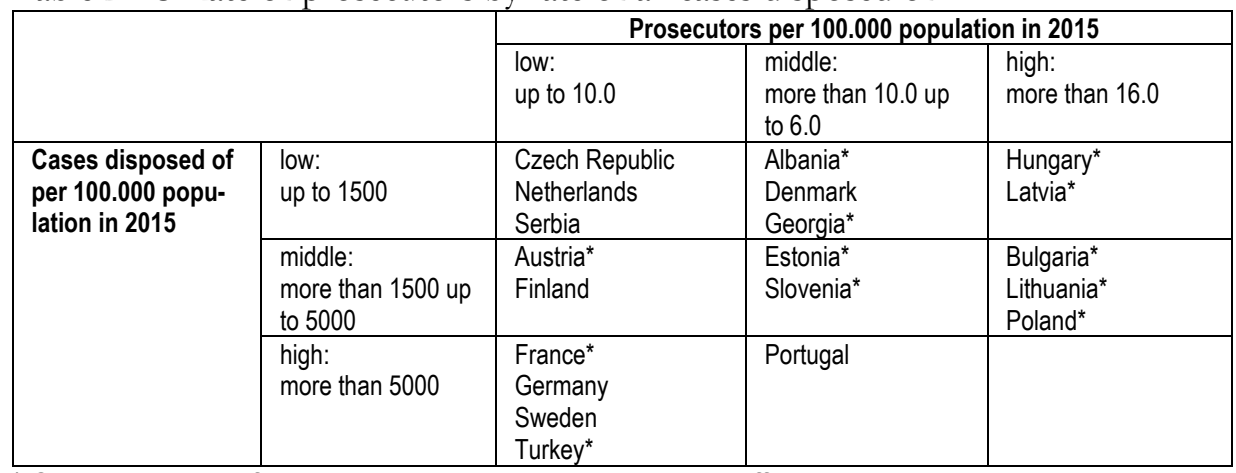

${ }^{*}$ Cases disposed of include proceedings against unknown offenders.

\section{Persons whose freedom of movement was restricted}

Data on "persons whose freedom of movement was restricted" refer to decisions made before the final conviction of defendants and while they were under criminal investigation. In the former edition we differentiated four categories: Besides persons in police custody and persons in pre-trial detention also persons under bail and persons under electronic monitoring. But regarding the latter categories the statistical data were poor. So, this time only data on persons in police custody and in pre-trial detention were collected.

Twelve countries could provide data on persons in police custody, here the order was mostly made by the police but also by the prosecuting authority. In 19 countries data were available on pre-trial detention (see tables 2.2.4). Further data on pre-trial detention can be found in the chapter 4 on prisons. 


\subsection{Tables}

2.2.1 Criminal cases handled by the prosecuting authorities 2011-2016

Table 2.2.1.1 Criminal cases handled by the prosecuting authorities per 100000 population - Output cases: Total

\begin{tabular}{|c|c|c|c|c|c|c|c|}
\hline & 2011 & 2012 & 2013 & 2014 & 2015 & 2016 & $\begin{array}{c}\% \text { change } \\
2011-2016\end{array}$ \\
\hline Albania & 675.2 & 744.9 & 841.6 & 1127.0 & 1188.8 & 1121.4 & 66.1 \\
\hline Armenia & 379.3 & 308.3 & 463.9 & 587.5 & 558.6 & 602.3 & 58.8 \\
\hline Austria & 3390.4 & 3407.5 & 3395.1 & 3289.0 & 3417.6 & & \\
\hline Azerbaijan & & & & 18.2 & 19.5 & 19.2 & \\
\hline Belgium & 6559.1 & 6437.2 & 6264.0 & 5932.5 & 5463.6 & & \\
\hline Bosnia-Herzegovina & 531.2 & 538.2 & 578.2 & 566.6 & 582.4 & 515.3 & -3.0 \\
\hline Bulgaria & 2182.6 & 1978.2 & 2002.7 & 1920.5 & 1814.2 & 1800.9 & -17.5 \\
\hline \multicolumn{8}{|l|}{ Croatia } \\
\hline \multicolumn{8}{|l|}{ Cyprus } \\
\hline Czech Republic & 1050.5 & 1044.8 & 1072.3 & 1051.3 & 952.3 & 859.7 & -18.2 \\
\hline Denmark & 1282.2 & 1257.6 & 1196.7 & 1144.9 & 1069.8 & 1048.6 & -18.2 \\
\hline Estonia & 3265.1 & 2999.1 & 2655.3 & 2494.3 & 2481.1 & 1732.8 & -46.9 \\
\hline Finland & 3968.4 & 3743.8 & 3556.1 & 3359.3 & 3499.4 & 3065.7 & -22.7 \\
\hline France & & 6935.3 & 6680.3 & 6638.9 & 6466.4 & 6722.6 & \\
\hline Georgia & 391.3 & 249.4 & 464.2 & 428.2 & 477.9 & 453.6 & 15.9 \\
\hline Germany & 5751.8 & 5678.1 & 5640.1 & 5820.0 & 6147.1 & 6308.6 & 9.7 \\
\hline \multicolumn{8}{|l|}{ Greece } \\
\hline Hungary & 1225.8 & 1133.7 & 1179.6 & 1161.7 & 1121.8 & 1093.8 & -10.8 \\
\hline Iceland & 1950.7 & 1787.1 & 1854.2 & 1556.5 & 1553.0 & 2038.0 & 4.5 \\
\hline \multicolumn{8}{|l|}{ Ireland } \\
\hline Italy & 5553.0 & 5422.6 & 5241.4 & 4924.9 & & & \\
\hline Kosovo (UN R/1244/99) & 1389.8 & 1336.2 & 1286.5 & 1539.7 & 1356.2 & 1615.8 & 16.3 \\
\hline Latvia & & 571.2 & 568.3 & 573.7 & 616.2 & 644.7 & \\
\hline Lithuania & 1166.2 & 1427.7 & 1559.0 & 1565.6 & 1362.0 & 1151.6 & -1.2 \\
\hline Luxembourg & & & & & 2883.3 & & \\
\hline \multicolumn{8}{|l|}{ Malta } \\
\hline \multicolumn{8}{|l|}{ Moldova } \\
\hline Montenegro & 935.2 & 1212.0 & 1065.1 & 1242.0 & 1162.8 & 1153.1 & 23.3 \\
\hline Netherlands & 1302.9 & 1345.5 & 1274.4 & 1259.6 & 1163.0 & 1143.6 & -12.2 \\
\hline \multicolumn{8}{|l|}{ North Macedonia } \\
\hline \multicolumn{8}{|l|}{ Norway } \\
\hline Poland & 2457.0 & 2364.0 & 2357.2 & 2139.3 & 1822.8 & 1883.5 & -23.3 \\
\hline Portugal & 5437.8 & 5420.8 & 5141.1 & 6222.1 & 4714.7 & 4352.7 & -20.0 \\
\hline Romania & & & & & 3242.9 & & \\
\hline Russian Federation & 733.7 & 687.7 & 682.9 & 667.6 & 685.7 & 679.9 & -7.3 \\
\hline Serbia & 1126.1 & 1181.2 & 1089.7 & 1258.1 & 1413.7 & 1543.9 & 37.1 \\
\hline Slovak Republic & 709.2 & 800.0 & 806.5 & 768.1 & 675.1 & 613.7 & -13.5 \\
\hline Slovenia & 1602.6 & 1575.3 & 1528.2 & 1614.0 & 1599.6 & 1460.6 & -8.9 \\
\hline \multicolumn{8}{|l|}{ Spain } \\
\hline Sweden & & & & & 5615.2 & & \\
\hline \multicolumn{8}{|l|}{ Switzerland } \\
\hline Turkey & 5816.2 & 5774.7 & 6048.5 & 6214.7 & 6413.0 & 5698.3 & -2.0 \\
\hline Ukraine & & & & & 1244.7 & 1256.5 & \\
\hline UK: England \& Wales & 2265.6 & 1978.4 & 1772.9 & 1694.4 & 1579.5 & 1482.1 & -34.6 \\
\hline UK: Northern Ireland & 3507.0 & 3397.3 & 3133.0 & 2933.3 & 2801.4 & 2742.5 & -21.8 \\
\hline UK: Scotland & 4758.4 & 4747.4 & 4954.3 & 4746.5 & 4324.0 & 3973.0 & -16.5 \\
\hline Mean & 2460.8 & 2499.5 & 2463.0 & 2389.4 & 2311.9 & 1959.3 & \\
\hline Median & 1602.6 & 1575.3 & 1559.0 & 1561.1 & 1483.4 & 1358.6 & \\
\hline Minimum & 379.3 & 249.4 & 463.9 & 18.2 & 19.5 & 19.2 & \\
\hline Maximum & 6559.1 & 6935.3 & 6680.3 & 6638.9 & 6466.4 & 6722.6 & \\
\hline
\end{tabular}


Table 2.2.1.2 Percentage brought before a court of the total output of criminal cases handled by the prosecuting authorities

\begin{tabular}{|c|c|c|c|c|c|c|c|}
\hline & 2011 & 2012 & 2013 & 2014 & 2015 & 2016 & $\begin{array}{c}\% \text { change } \\
2011-2016\end{array}$ \\
\hline Albania & 37.8 & 33.7 & 33.5 & 41.7 & 42.7 & 40.3 & 6.8 \\
\hline Armenia & 21.7 & 24.0 & 17.1 & 13.3 & 15.7 & 15.3 & -29.6 \\
\hline Austria & 24.4 & 24.4 & 24.0 & 23.8 & 22.1 & & \\
\hline Azerbaijan & & & & 51.4 & 48.2 & 44.8 & \\
\hline Belgium & 5.3 & 5.0 & 5.0 & 5.3 & 5.5 & & \\
\hline \multicolumn{8}{|l|}{ Bosnia-Herzegovina } \\
\hline $\begin{array}{l}\text { Bulgaria } \\
\text { Croatia }\end{array}$ & \multicolumn{7}{|c|}{ Croatia } \\
\hline \multicolumn{8}{|l|}{ Cyprus } \\
\hline Czech Republic & 75.9 & 76.5 & 77.3 & 77.6 & 84.1 & 77.4 & 1.9 \\
\hline Denmark & 60.5 & 57.5 & 56.2 & 55.7 & 56.2 & 55.0 & -9.1 \\
\hline Estonia & 21.7 & 21.9 & 21.2 & 21.2 & 21.0 & 31.3 & 44.4 \\
\hline Finland & 32.1 & 33.7 & 32.9 & 34.2 & 31.7 & 34.6 & 7.9 \\
\hline France & & 13.3 & 13.6 & 13.5 & 13.8 & 13.3 & \\
\hline Georgia & 104.1 & 98.4 & 81.1 & 87.9 & 86.2 & 95.2 & -8.6 \\
\hline Germany & 11.7 & 11.3 & 10.6 & 9.9 & 9.1 & 8.9 & -24.2 \\
\hline \multicolumn{8}{|l|}{ Greece } \\
\hline Hungary & 53.0 & 52.1 & 53.0 & 54.0 & 53.5 & 56.0 & 5.7 \\
\hline Iceland & 74.8 & 79.1 & 76.2 & 73.6 & 76.0 & 82.9 & 10.8 \\
\hline \multirow{2}{*}{\multicolumn{8}{|c|}{$\begin{array}{l}\text { Ireland } \\
\text { Italy }\end{array}$}} \\
\hline & & & & & & & \\
\hline \multicolumn{8}{|l|}{ Kosovo (UN R/1244/99) } \\
\hline Latvia & & 78.9 & 77.1 & 79.1 & 80.3 & 79.0 & \\
\hline Lithuania & 88.2 & 83.2 & 80.9 & 80.6 & 79.9 & 80.2 & -9.1 \\
\hline \multicolumn{8}{|l|}{ Luxembourg } \\
\hline \multicolumn{8}{|l|}{ Malta } \\
\hline \multicolumn{8}{|l|}{ Moldova } \\
\hline Montenegro & & & & & & & -51.7 \\
\hline Netherlands & 53.6 & 47.5 & 46.8 & 48.3 & 51.2 & 51.7 & -3.5 \\
\hline \multicolumn{8}{|l|}{ North Macedonia } \\
\hline Norway & & & & & & & -9.8 \\
\hline Poland & 40.9 & 40.1 & 37.7 & 34.7 & 25.9 & 36.9 & -16.0 \\
\hline Portugal & 13.4 & 13.6 & 13.2 & 8.4 & 11.6 & 11.2 & \\
\hline Romania & & & & & 6.3 & & \\
\hline \multicolumn{8}{|l|}{$\begin{array}{l}\text { Romania } \\
\text { Russian Federation }\end{array}$} \\
\hline Serbia & 66.4 & 68.3 & 67.7 & 44.2 & 42.2 & 40.2 & \\
\hline \multicolumn{5}{|l|}{ Slovak Republic } & & & -25.4 \\
\hline Slovenia & 49.7 & 46.6 & 44.0 & 42.6 & 36.1 & 37.1 & \\
\hline \multicolumn{8}{|l|}{ Spain } \\
\hline Sweden & & & & & 35.6 & & \\
\hline \multicolumn{8}{|l|}{ Switzerland } \\
\hline Turkey & 68.2 & 67.4 & 67.2 & 61.5 & 62.2 & 56.7 & -16.8 \\
\hline \multicolumn{8}{|l|}{ Ukraine } \\
\hline UK: England \& Wales & 70.3 & 71.9 & 73.0 & 68.3 & 69.8 & 68.0 & -3.3 \\
\hline \multicolumn{8}{|l|}{ UK: Northern Ireland } \\
\hline UK: Scotland & 44.0 & 40.3 & 35.1 & 38.2 & 42.5 & 42.0 & -4.5 \\
\hline Mean & 53.8 & 50.3 & 48.5 & 46.4 & 44.2 & 49.0 & \\
\hline Median & 49.7 & 46.6 & 44.0 & 43.4 & 42.3 & 43.4 & \\
\hline Minimum & 5.3 & 5.0 & 5.0 & 5.3 & 5.5 & 8.9 & \\
\hline Maximum & 191.6 & 140.2 & 140.1 & 111.4 & 102.2 & 95.2 & \\
\hline
\end{tabular}


Notes on tables 2.2.1.1 and table 2.2.1.2

Azerbaijan The figures only refer to cases in which the investigation was carried out by the prosecutor. The vast majority of cases where other law enforcement agencies carried out the investigation are not included.

Belgium For the minors, the counting unit is the person and not the case. They cannot be added in this table

Bulgaria The relevant figures are introduced in the Excel file.

It is to be noted here, as well as in connection with Question D2SCR16, that all types of cases (i. e. input cases, output cases and pending cases) are monitored and recorded by prosecution statistics. Every year the relevant figures are reported in the annual reports on the activities of the prosecution authorities in Bulgaria.

The probable deviations from the data concerning the specific items and provided for the 5 th Edition of the European Sourcebook cannot be explained without consulting the primary source of information used for the 5th Edition. Nor could they be comprehensively explained without conducting specific criminological research.

Denmark In order to make the Danish prosecution data comparable to data from other countries, cases that are administratively settled with fines, handled by the police, are not included in the data. Judgements rendered in absentia and settled with a fine are not included either.

Estonia Decrease in 2016 can be associated with the rise of the legal upper limit for the "small value" and decriminalisation of several offences from January 2015 , but also due to technical changes in the databases.

Hungary The source of data for Tables 2.2.1.1. 2.2.1.2, 2.2.2.1, and 2.2.2.2 (Prosecution Caseload Statistics) is different from the source of the data in Table 2.2.2.3 (Standard Criminal Statistics of Investigation Authorities and Prosecutors).

The data included in Standard Criminal Statistics of Investigation Authorities and Prosecutors is recorded at the output stage: data is collected when the public prosecutor or the investigating authorities complete the investigation. Data included in Prosecution Caseload Statistics is collected at different stages: data is recorded regarding input, output and pending cases.

The counting unit used is also different in the two databases (see section 2.3). The counting unit used in Prosecution Caseload Statistics is number of cases, while the counting unit in the data provided using the Standard Criminal Statistics of Investigation Authorities and Prosecutors is number of offences. This means that the data included in the two databases are not comparable to each other.

Netherlands Statistics Netherlands stopped providing Prosecution and Court statistics. Therefore figures starting in 2010 are slightly different from the years before that

Romania The data was provided in word and pdf format (different from the ones used for the LINCS study), following the translation into Romanian language.

Serbia $\quad$ Cases pending on 31st December 2014 T21PB14: For adult offenders: in the public prosecutors offices $-29465+$ at other agencies $74778=104243$; for juvenile offenders: 98 in the public prosecutors' offices +599 at other agencies $=697$; for unknown offenders that remained unknown: 55.890 Input cases for 2015 T21PA15: 115398 reported known adult offenders; 8.330 reported juvenile offenders and 57.771 reported unknown offenders $=181499$

Output cases total include charged adult and juvenile offenders and dismissals of criminal complaints.

Cases brought before a court include both adult and juvenile offenders.

Turkey "Cases brought before court" refers to number of "decisions", while all other data in this table refers to number of "suspects". Approximately $48 \%$ of all cases involve unknown suspects.

UK: England Data are inclusive of youth defendants. The Crown Prosecution Service collate data on defendant \& Wales offender types: adult or youth. A youth defendant is aged 10 to 17 inclusive at the time of the commission of the offence and is prosecuted in youth courts.

UK: Scotland The Crown Office and Procurator Fiscal Service is a live database and is not suited to producing the data on pending and output cases. All data are given on a financial year basis i.e $2011=2011-12$ (1 April to $31 \mathrm{March}$ ) Overall statistics can be found at http://www.copfs.gov.uk/images/Documents/Statistics/Statistics\%20on\%20Case\%20Processing\%20Last\%205\%20Years\%20201015.pdf 
2.2.2 Criminal cases handled by the prosecuting authorities in 2015

Table 2.2.2.1 Percentage of cases relating to minors, women and foreigners among criminal cases handled by the prosecuting authorities - Output cases: Total

\begin{tabular}{|c|c|c|c|c|c|}
\hline & $\begin{array}{l}\text { Total per } 100,000 \\
\text { population }\end{array}$ & $\begin{array}{l}\text { of which } \% \\
\text { of minors }\end{array}$ & $\begin{array}{l}\text { of which } \% \\
\text { of women }\end{array}$ & $\begin{array}{l}\text { of which } \% \\
\text { of foreigners }\end{array}$ & $\begin{array}{l}\% \text { of EU-citizens } \\
\text { among foreigners }\end{array}$ \\
\hline Albania & 1188.8 & & & & \\
\hline Armenia & 558.6 & & & & \\
\hline Austria & 3417.6 & & & & \\
\hline \multicolumn{6}{|l|}{ Azerbaijan } \\
\hline Belgium & 5463.6 & & & & \\
\hline Bosnia-Herzegovina & 582.4 & & & & \\
\hline Bulgaria & 1814.2 & 1.5 & & & \\
\hline \multicolumn{6}{|l|}{ Croatia } \\
\hline \multicolumn{6}{|l|}{ Cyprus } \\
\hline Czech Republic & 952.3 & 2.5 & 15.5 & 6.9 & 62.4 \\
\hline Denmark & 1069.8 & 13.4 & 10.0 & 16.4 & 35.9 \\
\hline Estonia & 2481.1 & & & & \\
\hline Finland & 3499.4 & 4.8 & 20.7 & 11.9 & 47.5 \\
\hline France & 6466.4 & & & & \\
\hline Georgia & 477.9 & 3.7 & 4.8 & 5.3 & 1.4 \\
\hline Germany & 6147.1 & & & & \\
\hline \multicolumn{6}{|l|}{ Greece } \\
\hline Hungary & 1121.8 & 9.0 & & & \\
\hline Iceland & 1553.0 & & & & \\
\hline \multicolumn{6}{|l|}{ Ireland } \\
\hline \multicolumn{6}{|l|}{ Italy } \\
\hline Kosovo (UN R/1244/99) & 1356.2 & & & & \\
\hline Latvia & 616.2 & & & & \\
\hline Lithuania & 1362.0 & 6.5 & 12.2 & 0.9 & \\
\hline Luxembourg & 2883.3 & 7.3 & 26.3 & 63.6 & \\
\hline \multicolumn{6}{|l|}{ Malta } \\
\hline \multicolumn{6}{|l|}{ Moldova } \\
\hline Montenegro & 1162.8 & & & & \\
\hline Netherlands & 1163.0 & 7.8 & 15.9 & & \\
\hline \multicolumn{6}{|l|}{ North Macedonia } \\
\hline \multicolumn{6}{|l|}{ Norway } \\
\hline Poland & 1822.8 & & & & \\
\hline Portugal & 4714.7 & & & & \\
\hline Romania & 3242.9 & & & & \\
\hline Russian Federation & 685.7 & & & & \\
\hline Serbia & 1413.7 & 5.3 & & & \\
\hline Slovak Republic & 675.1 & & & & \\
\hline Slovenia & 1599.6 & 4.5 & 17.5 & 6.1 & 29.7 \\
\hline \multicolumn{6}{|l|}{ Spain } \\
\hline Sweden & 5615.2 & 16.7 & 6.7 & & \\
\hline \multicolumn{6}{|l|}{ Switzerland } \\
\hline Turkey & 6413.0 & & 12.6 & 1.3 & \\
\hline Ukraine & 1244.7 & & & & \\
\hline UK: England \& Wales & 1579.5 & & & & \\
\hline UK: Northern Ireland & 2801.4 & & & & \\
\hline UK: Scotland & 4324.0 & & & & \\
\hline Mean & 2433.5 & 6.3 & 14.2 & 14.0 & 35.4 \\
\hline Median & 1579.5 & 5.0 & 14.1 & 6.5 & 35.9 \\
\hline Minimum & 477.9 & 1.2 & 4.8 & 0.9 & 1.4 \\
\hline Maximum & 6466.4 & 16.7 & 26.3 & 63.6 & 62.4 \\
\hline
\end{tabular}


Table 2.2.2.2 Percentage of cases relating to minors, women and foreigners among all criminal cases handled by the prosecuting authorities - Output cases: Cases brought before a court

\begin{tabular}{|c|c|c|c|c|c|}
\hline & $\begin{array}{l}\text { Total per } 100,000 \\
\text { population }\end{array}$ & $\begin{array}{l}\text { of which } \% \\
\text { of minors }\end{array}$ & $\begin{array}{l}\text { of which } \% \\
\text { of women }\end{array}$ & $\begin{array}{l}\text { of which } \% \\
\text { of foreigners }\end{array}$ & $\begin{array}{l}\% \text { of EU-citizens } \\
\text { among foreigners }\end{array}$ \\
\hline Albania & 507.1 & & & & \\
\hline Armenia & 87.4 & 4.0 & & & \\
\hline \multicolumn{6}{|l|}{ Austria } \\
\hline \multicolumn{6}{|l|}{ Azerbaijan } \\
\hline \multicolumn{6}{|c|}{ Belgium } \\
\hline \multicolumn{6}{|c|}{ Bosnia-Herzegovina } \\
\hline Bulgaria & 459.3 & 3.4 & & & \\
\hline Croatia & 375.4 & 3.1 & 12.2 & 3.0 & 38.6 \\
\hline \multicolumn{6}{|l|}{ Cyprus } \\
\hline Czech Republic & 801.3 & 2.2 & 14.7 & 6.8 & 61.2 \\
\hline Denmark & 601.1 & 12.0 & 8.2 & 15.2 & 38.9 \\
\hline Estonia & 522.3 & & & & \\
\hline Finland & 1108.1 & 4.5 & 17.0 & 10.6 & 48.7 \\
\hline \multicolumn{6}{|l|}{ France } \\
\hline Georgia & 412.0 & 1.8 & 5.1 & & \\
\hline Germany & 560.0 & 34.1 & & & \\
\hline \multicolumn{6}{|l|}{ Greece } \\
\hline Hungary & 600.1 & 6.1 & & & \\
\hline Iceland & 1179.9 & 8.5 & 10.3 & 9.2 & 27.9 \\
\hline \multicolumn{6}{|l|}{ Ireland } \\
\hline \multicolumn{6}{|c|}{ Italy } \\
\hline \multirow{2}{*}{\multicolumn{6}{|c|}{$\begin{array}{l}\text { Kosovo (UN R/1244/99) } \\
\text { Latvia }\end{array}$}} \\
\hline \multicolumn{2}{|c|}{ Latvia } & & & & \\
\hline Lithuania & 1088.7 & 6.8 & 8.0 & 0.2 & \\
\hline \multicolumn{6}{|l|}{ Luxembourg } \\
\hline \multicolumn{6}{|l|}{ Malta } \\
\hline \multicolumn{6}{|l|}{ Moldova } \\
\hline \multicolumn{6}{|l|}{ Montenegro } \\
\hline Netherlands & 595.7 & 6.9 & 11.8 & & \\
\hline \multicolumn{6}{|l|}{ North Macedonia } \\
\hline \multicolumn{6}{|l|}{ Norway } \\
\hline Poland & 472.6 & & & & \\
\hline Portugal & 548.9 & & & & \\
\hline \multicolumn{6}{|c|}{ Romania } \\
\hline \multicolumn{6}{|c|}{ Russian Federation } \\
\hline Serbia & 596.4 & 6.3 & 7.9 & & \\
\hline \multicolumn{6}{|l|}{ Slovak Republic } \\
\hline Slovenia & 577.4 & 4.9 & 11.3 & 7.2 & 28.2 \\
\hline \multicolumn{6}{|l|}{ Spain } \\
\hline Sweden & 2000.1 & 5.4 & 13.4 & & \\
\hline Switzerland & & & & & \\
\hline Turkey & 3987.4 & & & & \\
\hline Ukraine & 392.8 & 4.3 & & 1.1 & \\
\hline UK: England \& V & & & & & \\
\hline UK: Northern Ire & & & & & \\
\hline UK: Scotland & & & & & \\
\hline Mean & 832.0 & 7.1 & 10.9 & 6.7 & 40.6 \\
\hline Median & 577.4 & 5.2 & 11.3 & 7.0 & 38.7 \\
\hline Minimum & 87.4 & 1.8 & 5.1 & 0.2 & 27.9 \\
\hline Maximum & 3987.4 & 34.1 & 17.0 & 15.2 & 61.2 \\
\hline
\end{tabular}


Notes on table 2.2.2.1 and 2.2.2.2

Belgium The counting unit is the proceedings relating to one person only: that explains the difference with the figure in the table 2.2.1.1. Offenders for which the nationality is unknown are included.

Czech Republic Counting unit-a person.

Denmark In order to make the Danish prosecution data comparable to data from other countries, cases that are administratively settled with fines, handled by the police, are not included in the data. Judgements rendered in absentia and settled with a fine are not included either.

Germany Data on minors are only separately available for cases brought before a court. No published data available on the number of females or foreigners.

Netherlands Statistics Netherlands stopped providing Prosecution and Court statistics. Therefore, figures starting in 2010 are slightly different from the years before that

Serbia The data about reported female offenders relate only to adult persons.

Turkey "Cases brought before court" are number of decisions; other are number of "suspects"

UK: England \& The CPS does not collect data on the nationality of defendants.

Wales 
Table 2.2.2.3 Percentage of different types of disposals by the prosecuting authorities in 2015: Total $(1 / 2)$

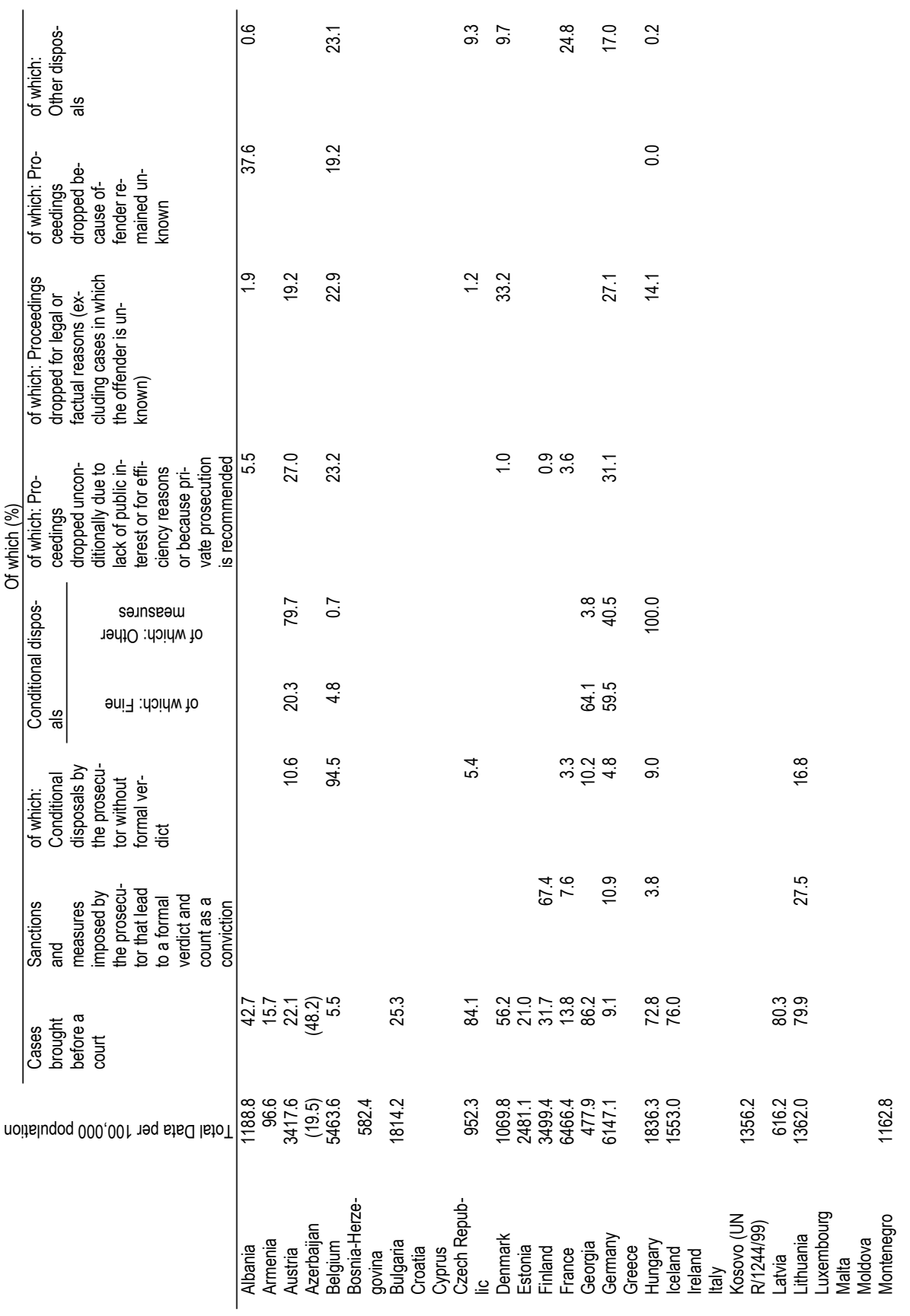


Table 2.2.2.3 Percentage of different types of disposals by the prosecuting authorities in 2015: Total (2/2)

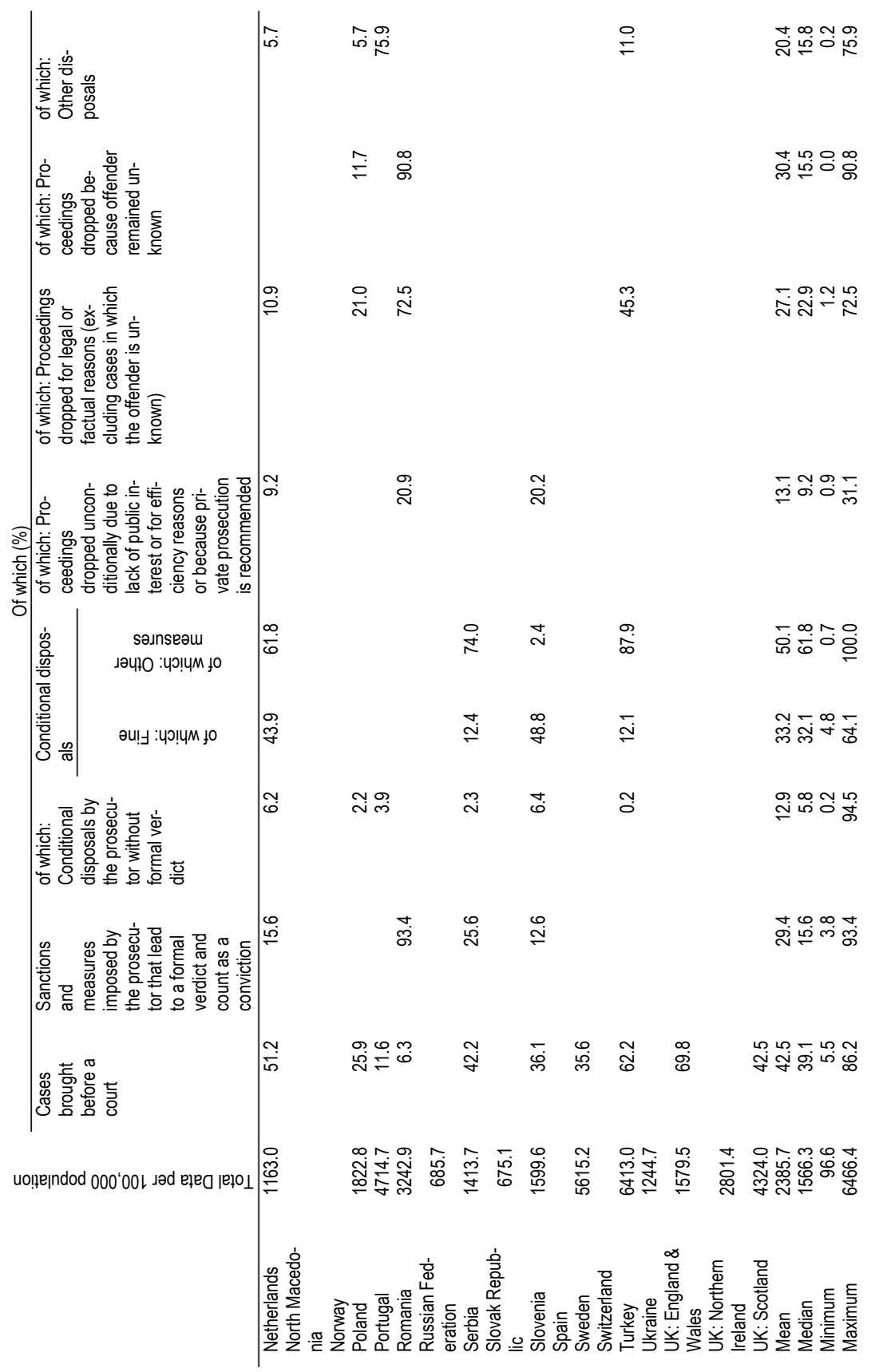


Notes on table 2.2.2.3

Austria

"Proceedings dropped unconditionally due to lack of public interest or for efficiency reasons or because private prosecution is recommended": $§ 190$ Z 2 StPO; "Proceedings dropped for legal or factual reasons (excluding cases in which the offender is unknown)": $§ 190 \mathrm{Z} 1 \mathrm{StPO}$.

Azerbaijan The figures only refer to cases in which the investigation was carried out by the prosecutor. The vast majority of cases where other law enforcement agencies carried out the investigation are not included.

Belgium This table concerns only adults.

Bulgaria According to Bulgarian law, criminal proceedings cannot be unconditionally dropped because the offender remained unknown. When the offender is unknown, the criminal proceedings are temporarily suspended until the offender is found or until the proceedings can be unconditionally dropped on other grounds (most often on the ground of statute of limitation). The figure shows the number of proceedings with unknown offenders, which were suspended in 2015.

Czech Republic Other disposals $=$ proceedings postponed, transferred, discontinued

Finland $\quad$ All dropped cases are included in Proceedings dropped unconditionally due to lack of public interest or for efficiency reasons or because private prosecution is recommended.

Germany Separate data on minors only available for a few items.

Hungary Please note that we are unable to divide the disposals by age that is why there is no data relating minors.

Netherlands Statistics Netherlands stopped providing Prosecution and Court statistics. Therefore, figures starting in 2010 are slightly different from the years before that.

Poland Conditional disposals means disposal ordered by court but motioned by prosecutors.

Portugal Sanctions imposed by the prosecutor (or by the court but without a formal court hearing) based on the defendant's admission of guilt and sanctions negotiated between the prosecutor and the defendant without admission of guilt have no correspondence in Portuguese Law. The 1997 Code of Penal Procedure (281. ${ }^{\circ}$ article) has introduced provisional suspension of proceedings under the responsibility of the prosecuting authorities for less serious offences. This last possibility has been understood here has conditional disposals whenever the defendant meet the conditions and the prosecuting authorities dispose of the case.

Proceedings dropped for legal or factual reasons include cases in which the offender is unknown. Plea Agreement concluded, accepted by the court, Deferring Criminal Prosecution (principle of opportunity, diversion)

Turkey Counting unit is Decision Rendered.

UK: Scotland Proceedings dropped unconditionally due to lack of public interest or for efficiency reasons included in Proceedings dropped unconditionally due to lack of public interest or for efficiency reasons. Information on minors not available 
2.2.3 Criminal cases handled by the prosecuting authorities in 2015 by offence groups

Table 2.2.3.1 Criminal cases total and major road traffic offences

\begin{tabular}{|c|c|c|c|c|}
\hline & \multicolumn{2}{|c|}{ Criminal offences total } & \multicolumn{2}{|c|}{ Major road traffic offences } \\
\hline & $\begin{array}{l}\text { Total per } 100,000 \\
\text { population }\end{array}$ & $\begin{array}{l}\text { of which \% of cases } \\
\text { brought before a court }\end{array}$ & $\begin{array}{l}\text { Total per } 100.000 \\
\text { population }\end{array}$ & $\begin{array}{l}\text { of which } \% \text { of cases } \\
\text { brought before a court }\end{array}$ \\
\hline Albania & 1188.8 & 42.7 & 123.5 & 86.4 \\
\hline Armenia & 558.6 & 15.7 & & \\
\hline Austria & 3417.6 & & & \\
\hline Azerbaijan & $(19.5)$ & $(48.2)$ & & \\
\hline Belgium & 5463.6 & 5.5 & & \\
\hline $\begin{array}{l}\text { Bosnia-Herze- } \\
\text { govina }\end{array}$ & 582.4 & & & \\
\hline Bulgaria & 1814.2 & 25.3 & & \\
\hline \multicolumn{5}{|l|}{ Croatia } \\
\hline \multicolumn{5}{|l|}{ Cyprus } \\
\hline Czech Republic & 952.3 & 84.1 & 203.6 & 90.6 \\
\hline Denmark & 1069.8 & 56.2 & & \\
\hline Estonia & 2481.1 & 21.0 & 271.1 & 92.5 \\
\hline Finland & 3499.4 & 31.7 & 1943.5 & 17.8 \\
\hline France & 6466.4 & & & \\
\hline Georgia & 477.9 & 77.7 & 12.2 & 94.3 \\
\hline Germany & 6147.1 & 9.1 & 1018.5 & 6.2 \\
\hline \multicolumn{5}{|l|}{ Greece } \\
\hline Hungary & 2842.2 & 47.1 & 179.5 & 84.7 \\
\hline Iceland & 1553.0 & 76.0 & & \\
\hline \multicolumn{5}{|l|}{$\begin{array}{l}\text { Ireland } \\
\text { Italy }\end{array}$} \\
\hline Italy & & & & \\
\hline Kosovo & 1356.2 & & & \\
\hline \multicolumn{5}{|l|}{ (UN R/1244/99) } \\
\hline Latvia & 616.2 & & & \\
\hline Lithuania & 1362.0 & 79.9 & 35.1 & 45.1 \\
\hline \multicolumn{5}{|l|}{ Luxembourg } \\
\hline \multirow{2}{*}{\multicolumn{5}{|c|}{$\begin{array}{l}\text { Malta } \\
\text { Moldova }\end{array}$}} \\
\hline \multicolumn{3}{|l|}{ Moldova } & & \\
\hline Montenegro & 1162.8 & 52.0 & 112.4 & 90.0 \\
\hline Netherlands & 1163.0 & 51.2 & 182.9 & 48.0 \\
\hline North Macedonia & & & 255.9 & \\
\hline \multicolumn{5}{|l|}{ Norway } \\
\hline Poland & 1822.8 & & & \\
\hline \multicolumn{5}{|l|}{ Portugal } \\
\hline Romania & 3242.9 & 6.3 & 193.0 & 43.8 \\
\hline $\begin{array}{l}\text { Russian Federa- } \\
\text { tion }\end{array}$ & 685.7 & & & \\
\hline Serbia & 1413.7 & 42.2 & 124.6 & 28.9 \\
\hline Slovak Republic & 675.1 & & & \\
\hline Slovenia & 1599.6 & 36.1 & 26.8 & 58.8 \\
\hline \multicolumn{5}{|l|}{ Spain } \\
\hline Sweden & 5615.2 & 35.6 & 591.7 & 13.5 \\
\hline \multicolumn{5}{|l|}{ Switzerland } \\
\hline Turkey & 6413.0 & 62.2 & 219.4 & 54.0 \\
\hline Ukraine & 1244.7 & & & \\
\hline UK: England \& & 1576.5 & & & \\
\hline Wales & & & & \\
\hline $\begin{array}{l}\text { UK: Northern Ire- } \\
\text { land }\end{array}$ & 2801.4 & & & \\
\hline UK: Scotland & 4324.0 & & & \\
\hline Mean & 2291.3 & 41.8 & 343.4 & 57.0 \\
\hline Median & 1553.0 & 42.2 & 187.9 & 54.0 \\
\hline Minimum & 19.5 & 5.5 & 12.2 & 6.2 \\
\hline Maximum & 6466.4 & 84.1 & 1943.5 & 94.3 \\
\hline
\end{tabular}


Table 2.2.3.2 Homicide and bodily injury

\begin{tabular}{|c|c|c|c|c|c|c|c|c|}
\hline & \multicolumn{2}{|c|}{ Intentional homicide } & \multicolumn{2}{|c|}{ Homicide completed } & \multicolumn{2}{|c|}{ Bodily injury } & \multicolumn{2}{|c|}{ Aggravated bodily injury } \\
\hline & $\begin{array}{l}\text { Total } \\
\text { per } \\
100 \\
000 \\
\end{array}$ & $\begin{array}{l}\text { of which } \% \\
\text { of cases } \\
\text { brought be- } \\
\text { fore a court }\end{array}$ & $\begin{array}{c}\text { Total } \\
\text { per } \\
100 \\
000 \\
\end{array}$ & $\begin{array}{c}\text { of which } \% \\
\text { of cases } \\
\text { brought before } \\
\text { a court }\end{array}$ & $\begin{array}{l}\text { Total } \\
\text { per } \\
100 \\
000 \\
\end{array}$ & $\begin{array}{l}\text { of which } \% \\
\text { of cases } \\
\text { brought be- } \\
\text { fore a court }\end{array}$ & $\begin{array}{l}\text { Total } \\
\text { per } \\
100 \\
000 \\
\end{array}$ & $\begin{array}{l}\text { of which \% } \\
\text { of cases } \\
\text { brought be- } \\
\text { fore a court }\end{array}$ \\
\hline $\begin{array}{l}\text { Albania } \\
\text { Armenia } \\
\text { Austria } \\
\text { Azerbaijan }\end{array}$ & 7.3 & 41.0 & 1.8 & 32.1 & 30.6 & 49.0 & 3.9 & 67.0 \\
\hline $\begin{array}{l}\text { Belgium } \\
\text { Bosnia-Herze- } \\
\text { govina } \\
\text { Bulgaria } \\
\text { Croatia } \\
\text { Cyprus }\end{array}$ & 10.9 & 53.3 & 2.7 & 54.3 & 598.2 & 8.3 & & \\
\hline $\begin{array}{l}\text { Czech Repub- } \\
\text { lic }\end{array}$ & 1.7 & 79.9 & & & 46.2 & 79.9 & 6.9 & 96.3 \\
\hline $\begin{array}{l}\text { Denmark } \\
\text { Estonia }\end{array}$ & $\begin{array}{l}3.0 \\
4.1\end{array}$ & $\begin{array}{l}47.3 \\
85.2\end{array}$ & 0.9 & 56.0 & $\begin{array}{l}137.7 \\
413.8\end{array}$ & $\begin{array}{l}65.3 \\
25.1\end{array}$ & $\begin{array}{r}21.8 \\
7.6\end{array}$ & $\begin{array}{l}69.3 \\
54.0\end{array}$ \\
\hline $\begin{array}{l}\text { Finland } \\
\text { France }\end{array}$ & 3.0 & 100.0 & 1.1 & 100.0 & 186.0 & 88.2 & 12.4 & 98.7 \\
\hline $\begin{array}{l}\text { Georgia } \\
\text { Germany } \\
\text { Greece }\end{array}$ & $\begin{array}{l}4.8 \\
5.1\end{array}$ & 94.9 & 3.0 & 98.2 & $\begin{array}{r}73.0 \\
527.8\end{array}$ & $\begin{array}{l}47.0 \\
12.7\end{array}$ & 3.6 & 97.0 \\
\hline Hungary & 1.9 & 87.0 & 1.0 & 83.8 & 127.9 & 58.2 & 60.2 & 63.9 \\
\hline $\begin{array}{l}\text { Iceland } \\
\text { Ireland }\end{array}$ & 2.1 & 71.4 & 1.2 & 0.0 & 0.0 & & 15.5 & 35.3 \\
\hline $\begin{array}{l}\text { Italy } \\
\text { Kosovo (UN } \\
\text { R/1244/99) } \\
\text { Latvia }\end{array}$ & 4.8 & 71.4 & 1.3 & 55.9 & 79.2 & 161.0 & & \\
\hline $\begin{array}{l}\text { Lithuania } \\
\text { Luxembourg } \\
\text { Malta } \\
\text { Moldova }\end{array}$ & 5.0 & 88.4 & & & 342.4 & 60.9 & 5.5 & 96.9 \\
\hline Montenegro & 11.7 & 216.4 & 2.9 & 283.3 & 67.2 & 87.1 & 28.9 & 99.4 \\
\hline $\begin{array}{l}\text { Netherlands } \\
\text { North Macedo- } \\
\text { nia } \\
\text { Norway } \\
\text { Poland } \\
\text { Portugal }\end{array}$ & 8.9 & 78.4 & 2.8 & & $\begin{array}{r}151.4 \\
14.6\end{array}$ & $\begin{array}{l}52.4 \\
61.7\end{array}$ & 19.0 & 83.0 \\
\hline $\begin{array}{l}\text { Romania } \\
\text { Russian Fed- } \\
\text { eration }\end{array}$ & 20.0 & 22.3 & 12.5 & 13.6 & 405.3 & 6.2 & 2.6 & 48.1 \\
\hline $\begin{array}{l}\text { Serbia } \\
\text { Slovak Repub- } \\
\text { lic }\end{array}$ & 4.1 & 79.2 & 4.1 & 79.2 & 44.3 & 44.5 & 17.0 & 51.4 \\
\hline $\begin{array}{l}\text { Slovenia } \\
\text { Spain }\end{array}$ & 1.9 & 75.0 & 1.1 & 60.9 & 79.1 & 46.5 & 0.7 & 86.7 \\
\hline $\begin{array}{l}\text { Sweden } \\
\text { Switzerland }\end{array}$ & 10.2 & 32.9 & 3.1 & 30.1 & 565.8 & 20.3 & & \\
\hline $\begin{array}{l}\text { Turkey } \\
\text { Ukraine } \\
\text { UK: England \& } \\
\text { Wales } \\
\text { UK: Northern } \\
\text { Ireland } \\
\text { UK: Scotland }\end{array}$ & 45.5 & 36.9 & & & 1029.0 & 70.2 & 12.4 & 90.3 \\
\hline Mean & 8.2 & 75.6 & 2.8 & 72.9 & 246.0 & 55.0 & 14.5 & 75.8 \\
\hline Median & 4.8 & 76.7 & 2.3 & 56.0 & 132.8 & 52.4 & 12.4 & 83.0 \\
\hline Minimum & 1.7 & 22.3 & 0.9 & 0.0 & 0.0 & 6.2 & 0.7 & 35.3 \\
\hline Maximum & 45.5 & 216.4 & 12.5 & 283.3 & 1029.0 & 161.0 & 60.2 & 99.4 \\
\hline
\end{tabular}


Table 2.2.3.3 Sexual offences

\begin{tabular}{|c|c|c|c|c|c|c|}
\hline & \multicolumn{2}{|c|}{ Sexual assault } & \multicolumn{2}{|c|}{ Rape } & \multicolumn{2}{|c|}{ Sexual abuse of a child } \\
\hline & $\begin{array}{l}\text { Total per ‘ } \\
100000\end{array}$ & $\begin{array}{l}\text { of which } \% \text { of } \\
\text { cases brought } \\
\text { before a court }\end{array}$ & $\begin{array}{l}\text { Total per } \\
100000\end{array}$ & $\begin{array}{l}\text { of which } \% \text { of } \\
\text { cases brought } \\
\text { before a court }\end{array}$ & $\begin{array}{l}\text { Total per } \\
100000\end{array}$ & $\begin{array}{l}\text { of which } \% \text { of } \\
\text { cases brought } \\
\text { before a court }\end{array}$ \\
\hline $\begin{array}{l}\text { Albania } \\
\text { Armenia } \\
\text { Austria } \\
\text { Azerbaijan }\end{array}$ & 4.0 & 59.1 & 0.7 & 26.3 & 0.5 & 64.3 \\
\hline $\begin{array}{l}\text { Belgium } \\
\text { Bosnia-Herze- } \\
\text { govina } \\
\text { Bulgaria } \\
\text { Croatia } \\
\text { Cyprus }\end{array}$ & 77.0 & 14.1 & 34.9 & 16.5 & 7.0 & 16.8 \\
\hline $\begin{array}{l}\text { Czech Repub- } \\
\text { lic }\end{array}$ & 10.3 & 72.8 & 4.3 & 75.8 & 5.7 & 69.4 \\
\hline Denmark & 19.2 & 44.3 & 5.0 & 30.0 & 4.7 & 46.2 \\
\hline Estonia & 13.0 & 47.4 & 9.3 & 38.5 & 1.8 & 66.7 \\
\hline $\begin{array}{l}\text { Finland } \\
\text { France }\end{array}$ & 13.6 & 98.1 & 4.8 & 98.8 & 7.3 & 100.0 \\
\hline $\begin{array}{l}\text { Georgia } \\
\text { Germany } \\
\text { Greece }\end{array}$ & 12.1 & 77.3 & 0.9 & 97.1 & 0.7 & 63.0 \\
\hline $\begin{array}{l}\text { Hungary } \\
\text { Iceland } \\
\text { Ireland }\end{array}$ & $\begin{array}{r}13.8 \\
0.0\end{array}$ & 63.7 & $\begin{array}{r}4.2 \\
14.0\end{array}$ & $\begin{array}{r}75.0 \\
8.7\end{array}$ & $\begin{array}{r}0.7 \\
17.9\end{array}$ & $\begin{array}{l}54.9 \\
18.6\end{array}$ \\
\hline $\begin{array}{l}\text { Italy } \\
\text { Kosovo (UN } \\
\text { R/1244/99) } \\
\text { Latvia }\end{array}$ & 11.2 & 51.6 & & & 1.6 & 40.6 \\
\hline $\begin{array}{l}\text { Lithuania } \\
\text { Luxembourg } \\
\text { Malta } \\
\text { Moldova }\end{array}$ & 8.7 & 95.3 & 3.1 & 92.4 & 5.5 & 93.2 \\
\hline Montenegro & 6.1 & 18.4 & 1.1 & 128.6 & 0.3 & 100.0 \\
\hline Netherlands & 17.1 & 46.3 & 3.3 & 41.0 & 0.9 & 57.7 \\
\hline $\begin{array}{l}\text { North Macedo- } \\
\text { nia } \\
\text { Norway } \\
\text { Poland } \\
\text { Portugal }\end{array}$ & 3.2 & 59.7 & 1.9 & 46.2 & 1.4 & 78.6 \\
\hline $\begin{array}{l}\text { Romania } \\
\text { Russian Feder- } \\
\text { ation }\end{array}$ & 22.1 & 16.7 & 11.9 & 18.4 & 8.2 & 15.1 \\
\hline $\begin{array}{l}\text { Serbia } \\
\text { Slovak Repub- } \\
\text { lic }\end{array}$ & 4.8 & 55.4 & 1.8 & 52.3 & 0.5 & 86.1 \\
\hline $\begin{array}{l}\text { Slovenia } \\
\text { Spain }\end{array}$ & 15.7 & 52.5 & 3.0 & 51.6 & 6.4 & 47.0 \\
\hline $\begin{array}{l}\text { Sweden } \\
\text { Switzerland }\end{array}$ & 107.6 & 34.4 & 40.6 & 22.5 & 39.6 & 46.5 \\
\hline $\begin{array}{l}\text { Turkey } \\
\text { Ukraine } \\
\text { UK: England \& } \\
\text { Wales } \\
\text { UK: Northern } \\
\text { Ireland } \\
\text { UK: Scotland }\end{array}$ & 81.5 & 38.4 & & & & \\
\hline Mean & 23.2 & 52.5 & 8.5 & 54.1 & 6.2 & 59.1 \\
\hline Median & 13.0 & 52.0 & 4.2 & 46.2 & 3.2 & 60.3 \\
\hline Minimum & 0.0 & 14.1 & 0.7 & 8.7 & 0.3 & 15.1 \\
\hline Maximum & 107.6 & 98.1 & 40.6 & 128.6 & 39.6 & 100.0 \\
\hline
\end{tabular}


Table 2.2.3.4 Robbery and theft

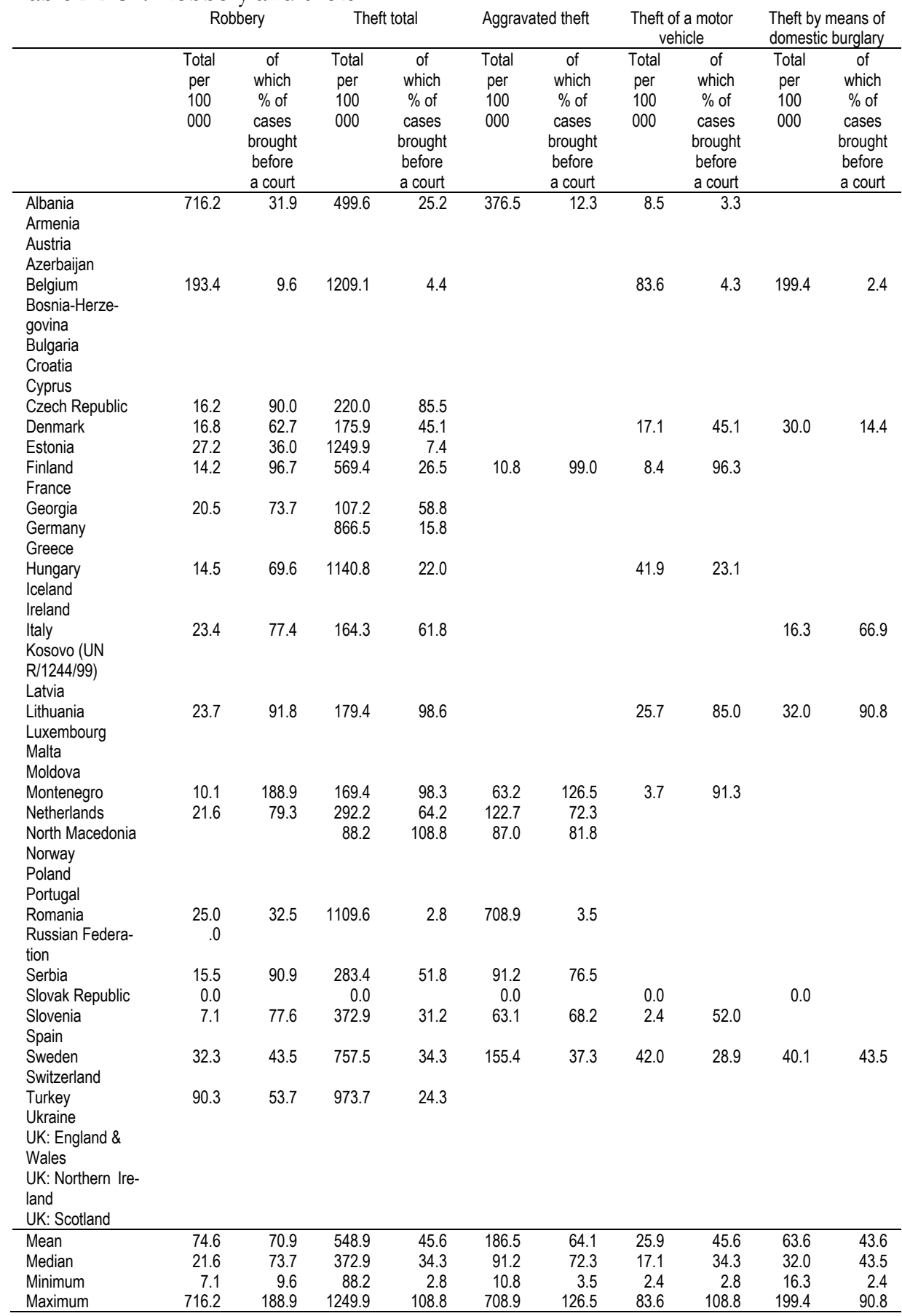


Table 2.2.3.5 Fraud, forgery, money laundering, corruption

\begin{tabular}{|c|c|c|c|c|c|c|c|c|c|c|}
\hline & \multicolumn{2}{|c|}{ Fraud } & \multicolumn{2}{|c|}{ Cyber fraud } & \multicolumn{2}{|c|}{$\begin{array}{l}\text { Forgery of } \\
\text { documents }\end{array}$} & \multicolumn{2}{|c|}{ Money laundering } & \multicolumn{2}{|c|}{$\begin{array}{l}\text { Corruption in the } \\
\text { public sector }\end{array}$} \\
\hline & $\begin{array}{c}\text { Total } \\
\text { per } \\
100 \\
000\end{array}$ & $\begin{array}{c}\text { of } \\
\text { which } \\
\% \text { of } \\
\text { cases } \\
\text { brought } \\
\text { before } \\
\text { a court }\end{array}$ & $\begin{array}{l}\text { Total } \\
\text { per } \\
100 \\
000\end{array}$ & $\begin{array}{l}\text { of } \\
\text { which } \\
\% \text { of } \\
\text { cases } \\
\text { brought } \\
\text { before } \\
\text { a court }\end{array}$ & $\begin{array}{l}\text { Total } \\
\text { per } \\
100 \\
000\end{array}$ & $\begin{array}{l}\text { of } \\
\text { which } \\
\% \text { of } \\
\text { cases } \\
\text { brought } \\
\text { before } \\
\text { a court }\end{array}$ & $\begin{array}{l}\text { Total } \\
\text { per } \\
100 \\
000\end{array}$ & $\begin{array}{c}\text { of } \\
\text { which } \\
\% \text { of } \\
\text { cases } \\
\text { brought } \\
\text { before } \\
\text { a court }\end{array}$ & $\begin{array}{l}\text { Total } \\
\text { per } \\
100 \\
000\end{array}$ & $\begin{array}{c}\text { of } \\
\text { which } \\
\% \text { of } \\
\text { cases } \\
\text { brought } \\
\text { before } \\
\text { a court }\end{array}$ \\
\hline $\begin{array}{l}\text { Albania } \\
\text { Armenia } \\
\text { Austria } \\
\text { Azerbaijan }\end{array}$ & 36.4 & 48.7 & 1.9 & 3.6 & 19.3 & 28.5 & 5.9 & 9.9 & 1.9 & 87.0 \\
\hline $\begin{array}{l}\text { Belgium } \\
\text { Bosnia-Herze- } \\
\text { govina }\end{array}$ & 149.3 & 2.6 & 141.8 & 1.9 & 74.8 & 10.8 & 17.3 & 10.0 & 1.8 & 17.4 \\
\hline $\begin{array}{l}\text { Bulgaria } \\
\text { Croatia } \\
\text { Cyprus }\end{array}$ & 0.0 & & & & & & 1.7 & 32.8 & $\begin{array}{r}21.8 \\
0.0\end{array}$ & 30.8 \\
\hline Czech Republic & 53.9 & 81.2 & & & 5.8 & 72.7 & 1.8 & 88.5 & 2.1 & 88.3 \\
\hline Denmark & 47.4 & 51.9 & & & 12.8 & 62.0 & & & 0.4 & 55.0 \\
\hline Estonia & 62.8 & 26.9 & & & 35.8 & 35.0 & 2.6 & 52.9 & 3.2 & 35.7 \\
\hline $\begin{array}{l}\text { Finland } \\
\text { France }\end{array}$ & 104.7 & 78.3 & & & 17.2 & 61.8 & 2.9 & 97.5 & 0.2 & 100.0 \\
\hline Georgia & 35.2 & 58.3 & & & 5.6 & 100.0 & & & 3.9 & 59.2 \\
\hline $\begin{array}{l}\text { Germany } \\
\text { Greece }\end{array}$ & 1283.3 & 8.5 & & & & & 48.5 & & 2.1 & \\
\hline $\begin{array}{l}\text { Hungary } \\
\text { Iceland } \\
\text { Ireland }\end{array}$ & 324.4 & 84.9 & 22.1 & 16.8 & 230.0 & 69.6 & 0.3 & 55.6 & 7.7 & 94.2 \\
\hline $\begin{array}{l}\text { Italy } \\
\text { Kosovo (UN } \\
\text { R/1244/99) } \\
\text { Latvia }\end{array}$ & & & & & & & 4.3 & 54.9 & 2.7 & 46.0 \\
\hline $\begin{array}{l}\text { Lithuania } \\
\text { Luxembourg } \\
\text { Malta } \\
\text { Moldova }\end{array}$ & 106.6 & 89.4 & & & 71.1 & 82.3 & 2.9 & 71.8 & 36.6 & 93.4 \\
\hline Montenegro & 44.8 & 65.9 & 0.5 & 100.0 & 47.1 & 67.6 & 0.5 & 33.3 & 112.4 & 21.6 \\
\hline $\begin{array}{l}\text { Netherlands } \\
\text { North Macedonia } \\
\text { Norway }\end{array}$ & 12.8 & 47.1 & & & 18.5 & 59.1 & $\begin{array}{l}6.5 \\
0.2\end{array}$ & 53.0 & 0.1 & 30.4 \\
\hline $\begin{array}{l}\text { Poland } \\
\text { Portugal }\end{array}$ & & & & & 0.0 & & & & & \\
\hline $\begin{array}{l}\text { Romania } \\
\text { Russian Federation }\end{array}$ & $\begin{array}{r}178.4 \\
0.0\end{array}$ & 4.0 & $\begin{array}{l}1.3 \\
0.0\end{array}$ & 10.7 & $\begin{array}{r}50.8 \\
0.0\end{array}$ & 3.4 & 1.7 & 19.3 & 24.2 & 14.6 \\
\hline $\begin{array}{l}\text { Serbia } \\
\text { Slovak Republic }\end{array}$ & 55.4 & 27.9 & 0.1 & 50.0 & 43.7 & 27.9 & 0.2 & 26.7 & 2.7 & 51.0 \\
\hline $\begin{array}{l}\text { Slovenia } \\
\text { Spain }\end{array}$ & 292.0 & 33.1 & & & 71.7 & 35.4 & 5.2 & 48.6 & 4.0 & 17.1 \\
\hline $\begin{array}{l}\text { Sweden } \\
\text { Switzerland }\end{array}$ & 613.8 & 64.1 & 99.2 & 32.4 & 39.8 & 111.2 & 18.9 & 30.5 & 1.3 & 19.4 \\
\hline $\begin{array}{l}\text { Turkey } \\
\text { Ukraine } \\
\text { UK: England \& } \\
\text { Wales } \\
\text { UK: Northern Ire- } \\
\text { land } \\
\text { UK: Scotland }\end{array}$ & 488.2 & 22.3 & & & 336.8 & 30.6 & 1.7 & 44.8 & 7.4 & 35.8 \\
\hline Mean & 228.8 & 46.8 & 38.1 & 30.8 & 67.6 & 53.5 & 6.8 & 45.6 & 12.4 & 49.8 \\
\hline Median & 104.7 & 48.7 & 1.9 & 16.8 & 41.8 & 60.5 & 2.7 & 46.7 & 2.7 & 40.9 \\
\hline Minimum & 12.8 & 2.6 & 0.1 & 1.9 & 5.6 & 3.4 & 0.2 & 9.9 & 0.1 & 14.6 \\
\hline Maximum & 1283.3 & 89.4 & 141.8 & 100.0 & 336.8 & 111.2 & 48.5 & 97.5 & 112.4 & 100.0 \\
\hline
\end{tabular}


Table 2.2.3.6 Drug offences

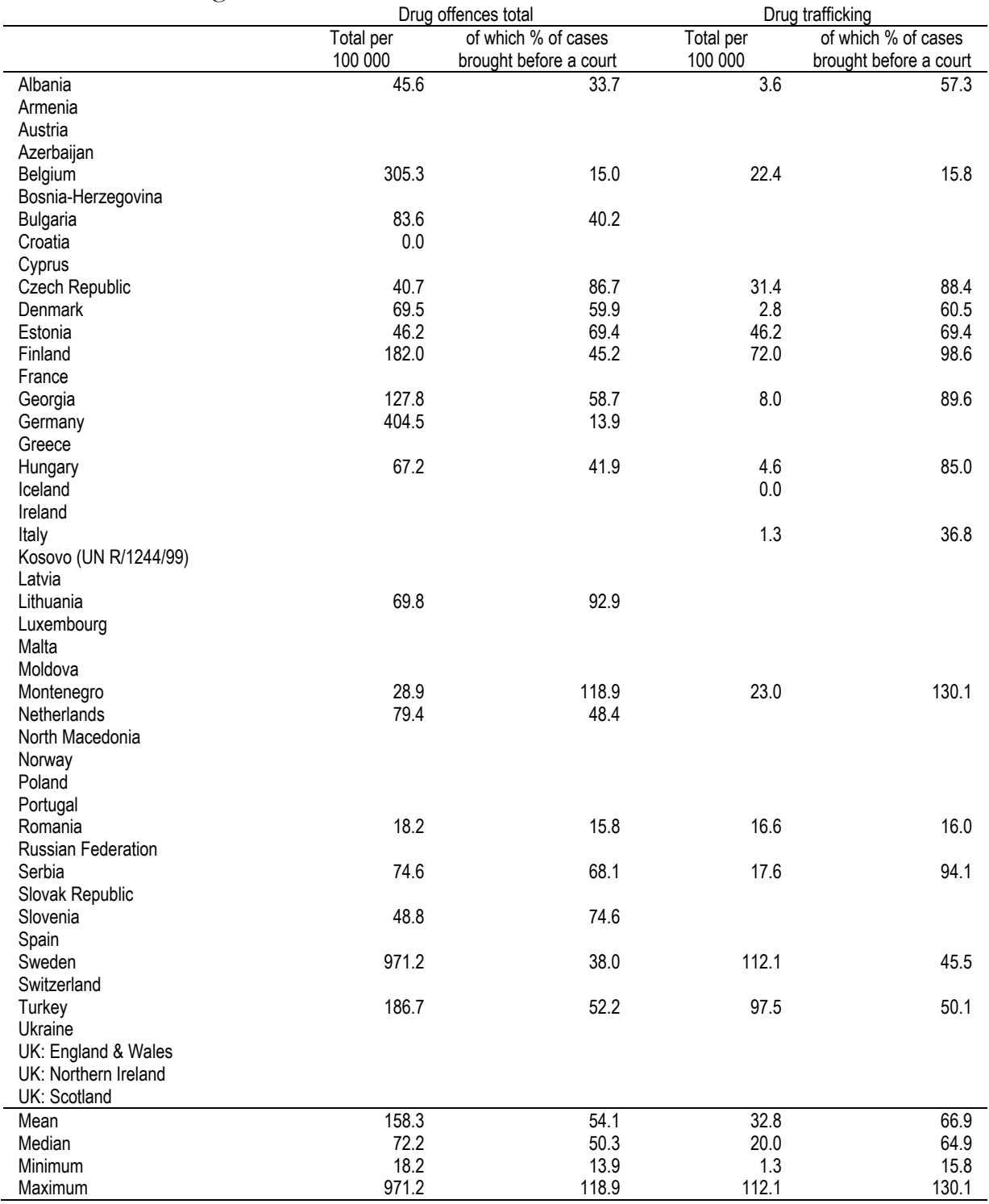




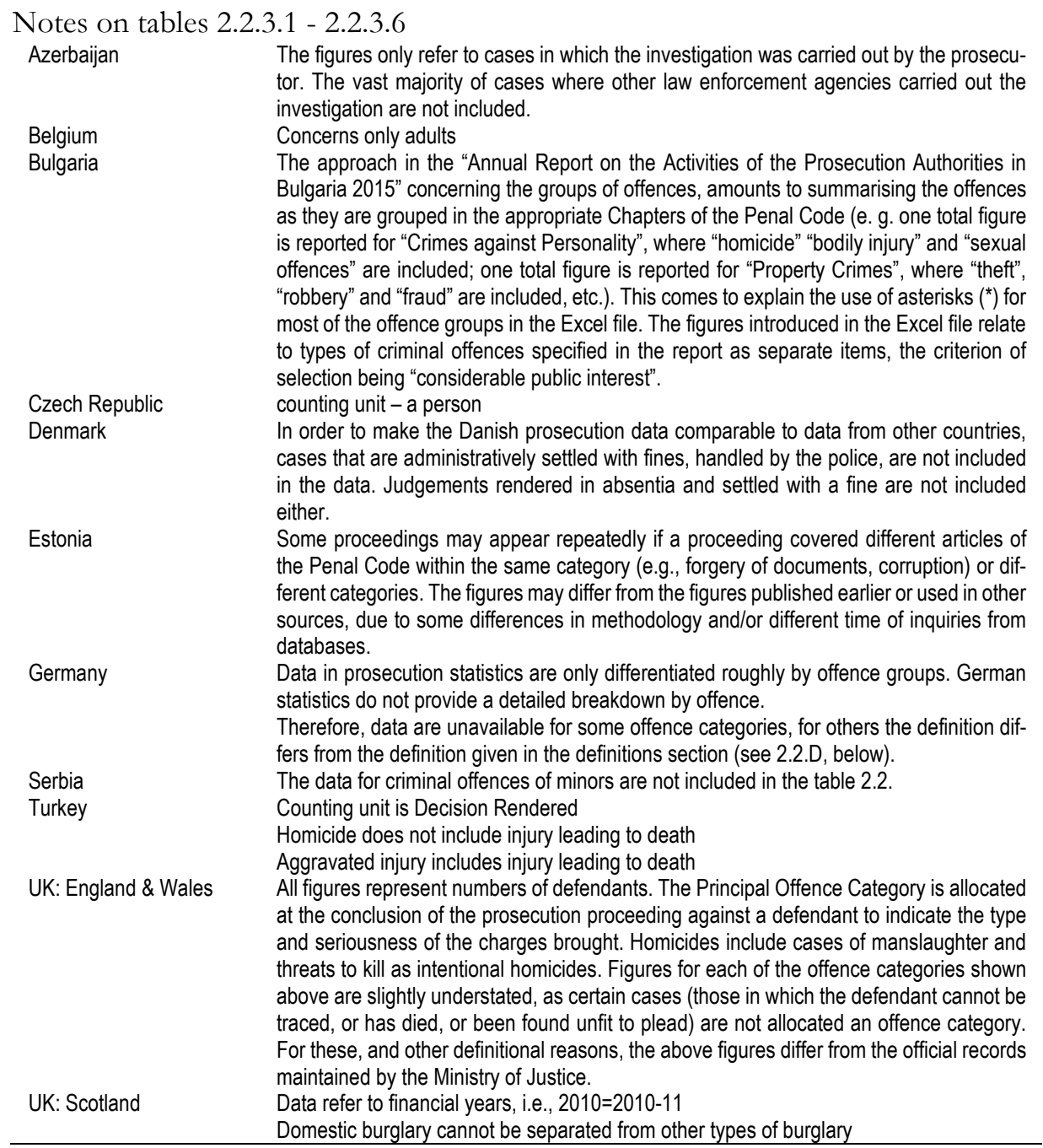




\subsubsection{Police custody and pre-trial detention}

Table 2.2.4.1 Persons whose freedom of movement was restricted in 2015 - per 100,000 population

\begin{tabular}{|c|c|c|}
\hline 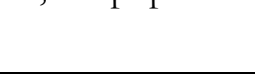 & Persons sent to police custody & $\begin{array}{l}\text { Persons sent to pre-trial detention } \\
\text { (ordered by the court) }\end{array}$ \\
\hline Albania & 289.9 & 162.2 \\
\hline Armenia & 28.8 & 33.8 \\
\hline Austria & & 98.7 \\
\hline \multicolumn{3}{|l|}{ Azerbaijan } \\
\hline Belgium & 88.5 & \\
\hline \multicolumn{3}{|l|}{ Bosnia-Herzegovina } \\
\hline Bulgaria & 47.1 & \\
\hline \multicolumn{3}{|l|}{ Croatia } \\
\hline \multicolumn{3}{|l|}{ Cyprus } \\
\hline Czech Republic & & 31.9 \\
\hline Denmark & $\ldots$ & \\
\hline Estonia & $\cdots$ & 53.2 \\
\hline Finland & 450.7 & 41.4 \\
\hline France & & 75.8 \\
\hline Georgia & 160.2 & 107.6 \\
\hline \multirow{2}{*}{\multicolumn{3}{|c|}{ Germany }} \\
\hline \multicolumn{2}{|l|}{ Greece } & \\
\hline Hungary & 66.4 & 45.2 \\
\hline Iceland & 728.7 & 1027 \\
\hline \multicolumn{3}{|l|}{ Ireland } \\
\hline Italy & & 27.5 \\
\hline \multicolumn{3}{|l|}{ Kosovo (UN R/1244/99) } \\
\hline \multicolumn{3}{|l|}{ Latvia } \\
\hline \multirow{2}{*}{\multicolumn{3}{|c|}{ Luxembourg }} \\
\hline & & \\
\hline \multicolumn{3}{|l|}{ Malta } \\
\hline \multicolumn{3}{|l|}{ Moldova } \\
\hline \multicolumn{3}{|l|}{ Montenegro } \\
\hline \multicolumn{3}{|l|}{ Netherlands } \\
\hline \multirow{2}{*}{\multicolumn{3}{|c|}{ North Macedonia }} \\
\hline & & \\
\hline Poland & 559.1 & 33.1 \\
\hline \multicolumn{3}{|l|}{ Portugal } \\
\hline Romania & 52.2 & 38.8 \\
\hline \multicolumn{3}{|l|}{ Russian Federation } \\
\hline Serbia & & 79.8 \\
\hline \multicolumn{3}{|l|}{ Slovak Republic } \\
\hline Slovenia & & 22.8 \\
\hline \multicolumn{3}{|l|}{ Spain } \\
\hline Sweden & 296.0 & 92.9 \\
\hline \multicolumn{3}{|l|}{ Switzerland } \\
\hline Turkey & & 32.5 \\
\hline \multicolumn{3}{|l|}{ Ukraine } \\
\hline UK: England \& Wales & & \\
\hline UK: Northern Ireland & & \\
\hline UK: Scotland & & \\
\hline Mean & 230.3 & 66.7 \\
\hline Median & 131.5 & 45.2 \\
\hline Minimum & 28.8 & 22.8 \\
\hline Maximum & 621.8 & 174.2 \\
\hline
\end{tabular}


Notes on Table 2.2.4.1

Albania Concerns arrests in flagrante delicto and judicial police detention orders

Concerns security measures of imprisonment issued by the courts

France Ordered by court = decisions from the "Juge des libertés et de la detention" and from the courts (tribunal correctionnel and tribunaux et juges pour enfants).

Italy The sample is from $60 \%$ of Italian Criminal Court

Poland 1) Persons in police custody ordered by police - are related to the number of persons in custody until 48 hours.

2) Persons in pre-trial detention represent number of persons for whom detention was ordered by court but on prosecutors' motion. 


\subsubsection{Prosecution staff}

Table 2.2.5.1 Staff of the prosecuting authority per 100,000 population: Number of employees: Total

\begin{tabular}{|c|c|c|c|c|c|c|c|}
\hline & 2011 & 2012 & 2013 & 2014 & 2015 & 2016 & $\%$ change 2011-2016 \\
\hline Albania & & 28.1 & 18.1 & 28.5 & 29.4 & 30.0 & \\
\hline \multicolumn{8}{|l|}{ Armenia } \\
\hline \multicolumn{8}{|l|}{ Austria } \\
\hline \multicolumn{8}{|l|}{ Azerbaijan } \\
\hline \multicolumn{8}{|l|}{ Belgium } \\
\hline \multicolumn{8}{|l|}{ Bosnia-Herzegovina } \\
\hline Bulgaria & & & 65.6 & 67.0 & & & \\
\hline Croatia & 38.4 & 40.0 & 39.2 & 38.4 & 39.7 & 41.3 & 7.7 \\
\hline \multicolumn{8}{|l|}{ Cyprus } \\
\hline Czech Republic & 13.3 & 13.3 & 13.4 & 13.3 & 13.4 & 11.2 & -16.2 \\
\hline Denmark & & 21.0 & 21.4 & 21.2 & 21.5 & 21.5 & \\
\hline Estonia & 19.5 & 18.7 & 19.3 & & & & \\
\hline Finland & 9.8 & 10.1 & 10.0 & 9.9 & 9.4 & 9.1 & -6.9 \\
\hline \multicolumn{8}{|l|}{ France } \\
\hline Georgia & & & & 19.0 & 23.3 & 23.1 & \\
\hline Germany & 19.1 & 18.9 & 18.8 & 18.8 & 18.6 & 18.7 & -2.2 \\
\hline \multicolumn{8}{|l|}{ Greece } \\
\hline Hungary & 41.5 & 45.2 & 45.5 & 46.4 & 46.1 & 45.8 & 10.2 \\
\hline \multicolumn{8}{|l|}{ Iceland } \\
\hline \multicolumn{8}{|l|}{ Ireland } \\
\hline & & & & & & & \\
\hline \multicolumn{8}{|l|}{ Kosovo (UN R/1244/99) } \\
\hline \multicolumn{8}{|l|}{ Latvia } \\
\hline Lithuania & & 42.9 & 42.9 & 43.9 & 43.6 & 43.1 & \\
\hline Luxembourg & & & & & & 8.3 & \\
\hline \multicolumn{8}{|l|}{ Malta } \\
\hline \multicolumn{8}{|l|}{ Moldova } \\
\hline Montenegro & & 40.0 & 41.7 & 43.4 & 45.5 & 49.7 & \\
\hline Netherlands & & 28.5 & & 26.9 & & 27.2 & \\
\hline \multicolumn{8}{|l|}{ North Macedonia } \\
\hline \multicolumn{8}{|l|}{ Norway } \\
\hline Poland & & 35.3 & 35.4 & 35.3 & 35.1 & 35.4 & \\
\hline \multicolumn{8}{|l|}{ Portugal } \\
\hline \multicolumn{8}{|l|}{ Romania } \\
\hline \multicolumn{8}{|l|}{ Russian Federation } \\
\hline Serbia & & 25.3 & 25.3 & 28.2 & 29.3 & 30.8 & \\
\hline \multicolumn{8}{|l|}{ Slovak Republic } \\
\hline Slovenia & 21.8 & 21.1 & 20.4 & 15.8 & 17.8 & 24.5 & 12.7 \\
\hline Spain & & & & & & & \\
\hline Sweden & & 14.1 & 14.0 & 13.9 & 14.0 & 14.4 & \\
\hline Switzerland & & & & & & & \\
\hline Turkey & & & & & & & \\
\hline Ukraine & & & & & 35.1 & 35.2 & \\
\hline UK: England \& Wales & & & & & 10.2 & & \\
\hline UK: Northern Ireland & 31.3 & 29.6 & 29.8 & 29.8 & 27.5 & 25.8 & -17.3 \\
\hline UK: Scotland & & & & & 28.5 & & \\
\hline Mean & 24.3 & 27.0 & 28.8 & 29.4 & 27,1 & 27.5 & \\
\hline Median & 20.7 & 26.7 & 23.4 & 28.2 & 23,3 & 26.5 & \\
\hline Minimum & 9.8 & 10.1 & 10.0 & 9.9 & 9.4 & 8.3 & \\
\hline Maximum & 41.5 & 45.2 & 65.6 & 67.0 & 46.1 & 49.7 & \\
\hline
\end{tabular}


Table 2.2.5.2 Staff of the prosecuting authority: Number of prosecutors per 100,000 population

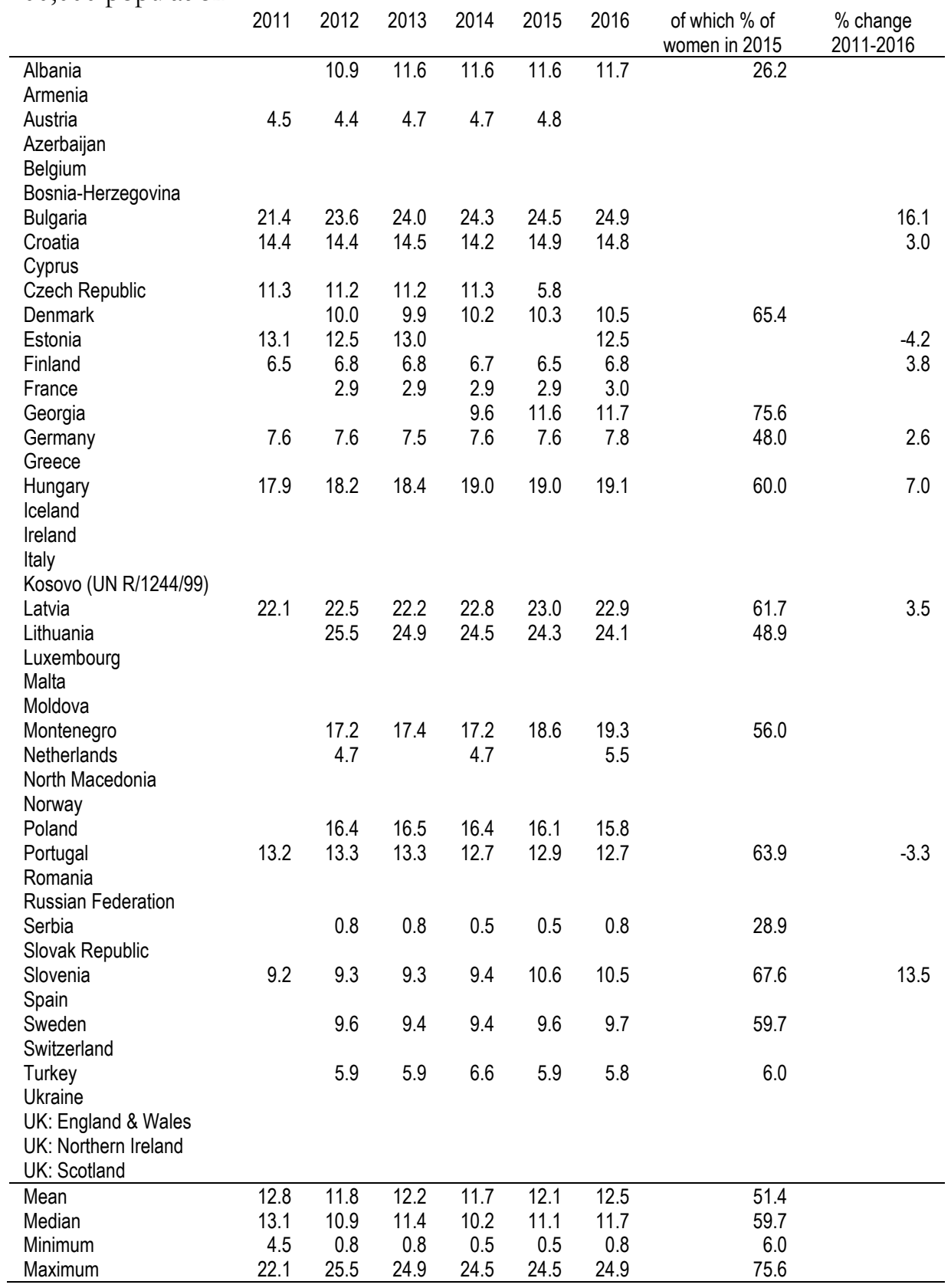


Notes on tables 2.2.5.1 and 2.2.5.2

Serbia Total number of employees presents a sum of employees in the public prosecutors' offices: public prosecutors and their deputies, civil servants and appointees. Number of prosecutors: these are the numbers of public prosecutors but the number of those with the function of public prosecution (holders of public prosecution function), which includes public prosecutors, and their deputies is higher: 2012$707 ; 2013-679 ; 2014-684 ; 2015-695 ; 2016-725$. And for women: 376 public prosecutors and their dep-

UK: Eng-

land \& The above figures are inclusive of staff employed within CPS Headquarters as well as those working Wales within the regions of the Service. Numbers are shown as full-time equivalents.

UK: Scot- 


\subsection{Technical information}

Table 2.3.1 What is the counting unit used?

\begin{tabular}{|c|c|c|c|c|c|c|}
\hline & Case & Proceedings & Person & Other & Offence & If other, please explain \\
\hline Albania & & $\mathrm{X}$ & & & & \\
\hline Armenia & & $\mathrm{x}$ & & & & \\
\hline Austria & & $\mathrm{x}$ & & & & \\
\hline \multicolumn{7}{|l|}{ Azerbaijan } \\
\hline Belgium & & $x$ & & & & \\
\hline \multicolumn{7}{|l|}{ Bosnia-Herzegovina } \\
\hline Bulgaria & & $x$ & & & & \\
\hline \multicolumn{7}{|l|}{ Croatia } \\
\hline \multicolumn{7}{|l|}{ Cyprus } \\
\hline Czech Republic & & $x$ & $x$ & & & \\
\hline Denmark & $x$ & & & & & \\
\hline Estonia & & $x$ & & & & \\
\hline Finland & $\mathrm{x}$ & & & & & \\
\hline France & & $\mathrm{x}$ & & & & \\
\hline Georgia & & $\mathrm{x}$ & & & & \\
\hline Germany & & $x$ & & & & \\
\hline \multicolumn{7}{|l|}{ Greece } \\
\hline Hungary & $x$ & & & & & \\
\hline \multirow{2}{*}{\multicolumn{7}{|c|}{$\begin{array}{l}\text { Iceland } \\
\text { Ireland } \\
\text { Italy }\end{array}$}} \\
\hline & & & & & & \\
\hline & & & & & & \\
\hline \multicolumn{7}{|l|}{ Kosovo } \\
\hline Latvia & $x$ & & & & & \\
\hline Lithuania & & & & $\mathrm{x}$ & & \\
\hline \multicolumn{7}{|l|}{ Luxembourg } \\
\hline \multicolumn{7}{|l|}{ Malta } \\
\hline \multicolumn{7}{|l|}{ Moldova } \\
\hline Montenegro & $x$ & & & & & \\
\hline Netherlands & $x$ & & & & & \\
\hline North Macedonia & & & $x$ & & & \\
\hline \multicolumn{7}{|l|}{ Norway } \\
\hline Poland & & $\mathrm{X}$ & & & & \\
\hline Portugal & & $x$ & & & & \\
\hline \multirow{2}{*}{\multicolumn{7}{|c|}{ Russian Federation }} \\
\hline & & & & & & \\
\hline Serbia & & $\mathrm{x}$ & & & & \\
\hline \multicolumn{7}{|l|}{ Slovak Republic } \\
\hline Slovenia* & $\mathrm{x}$ & & & & & \\
\hline Spain & & & & $x$ & & \\
\hline \multicolumn{7}{|l|}{ Sweden ${ }^{\star *}$} \\
\hline \multicolumn{7}{|l|}{ Switzerland } \\
\hline Turkey & & & & $x$ & & \\
\hline \multicolumn{7}{|l|}{ Ukraine } \\
\hline \multirow{2}{*}{\multicolumn{7}{|c|}{ UK: Northern Ireland }} \\
\hline & & & & & & \\
\hline UK: Scotland & $x$ & & & & & \\
\hline
\end{tabular}


Table 2.3.2 At what stage cases are recorded

\begin{tabular}{|c|c|c|c|}
\hline & Input cases & Output cases & Pending cases \\
\hline \multicolumn{4}{|l|}{ Albania } \\
\hline \multicolumn{4}{|l|}{ Armenia } \\
\hline Austria** & $\mathrm{x}$ & $x$ & $\mathrm{x}$ \\
\hline Azerbaijan & & $x$ & \\
\hline \multicolumn{4}{|l|}{ Belgium } \\
\hline \multicolumn{4}{|l|}{ Bosnia-Herzegovina } \\
\hline Bulgaria & $\mathrm{x}$ & $\mathrm{x}$ & $x$ \\
\hline Croatia & & $\mathrm{X}$ & \\
\hline \multicolumn{4}{|l|}{ Cyprus } \\
\hline Czech Republic & $x$ & $\mathrm{X}$ & $\mathrm{X}$ \\
\hline Denmark & $\mathrm{x}$ & $\mathrm{X}$ & $\mathrm{X}$ \\
\hline Estonia & & $x$ & \\
\hline \multicolumn{4}{|l|}{ Finland } \\
\hline France & $x$ & & \\
\hline \multicolumn{4}{|l|}{ Georgia } \\
\hline Germany & $x$ & $\mathrm{X}$ & $\mathrm{X}$ \\
\hline \multicolumn{4}{|l|}{ Greece } \\
\hline Hungary & $x$ & $\mathrm{X}$ & $\mathrm{X}$ \\
\hline \multicolumn{4}{|l|}{ Iceland } \\
\hline \multirow{2}{*}{\multicolumn{4}{|c|}{$\begin{array}{l}\text { Ireland } \\
\text { Italy }\end{array}$}} \\
\hline & & & \\
\hline \multicolumn{4}{|l|}{ Kosovo } \\
\hline Latvia & $x$ & & \\
\hline Lithuania & & $\mathrm{X}$ & \\
\hline \multicolumn{4}{|l|}{ Luxembourg } \\
\hline \multicolumn{4}{|l|}{ Malta } \\
\hline \multicolumn{4}{|l|}{ Moldova } \\
\hline Montenegro & $x$ & $\mathrm{X}$ & \\
\hline \multicolumn{4}{|l|}{ Netherlands } \\
\hline North Macedonia & $x$ & $\mathrm{X}$ & $\mathrm{x}$ \\
\hline \multicolumn{4}{|l|}{ Norway } \\
\hline Poland & & $\mathrm{x}$ & \\
\hline Portugal & $\mathrm{X}$ & $x$ & $\mathrm{X}$ \\
\hline Romania & $x$ & & \\
\hline \multicolumn{4}{|l|}{ Russian Federation } \\
\hline Serbia & $\mathrm{X}$ & $\mathrm{X}$ & $\mathrm{x}$ \\
\hline \multicolumn{4}{|l|}{ Slovak Republic } \\
\hline Slovenia & $x$ & & \\
\hline \multicolumn{4}{|l|}{ Spain } \\
\hline Sweden* & & $\mathrm{x}$ & \\
\hline \multicolumn{4}{|l|}{ Switzerland } \\
\hline \multicolumn{4}{|l|}{ Turkey** } \\
\hline Ukraine & & $\mathrm{X}$ & \\
\hline \multicolumn{4}{|l|}{ UK: England \& Wales } \\
\hline UK: Northern Ireland & & & \\
\hline UK: Scotland & & & \\
\hline
\end{tabular}


Table 2.3.3 Concerning the criminal cases handled by the prosecuting authority

\begin{tabular}{|c|c|c|c|}
\hline $\begin{array}{l}1=\text { Included } \\
2=\text { Excluded }\end{array}$ & $\begin{array}{l}\text { Cases reported to the } \\
\text { prosecuting authority by } \\
\text { other institutions }\end{array}$ & $\begin{array}{l}\text { Cases where the offender } \\
\text { remained unknown }\end{array}$ & $\begin{array}{l}\text { Cases dropped, condition- } \\
\text { ally disposed of or } \\
\text { sanctioned by the police }\end{array}$ \\
\hline Albania & 1 & 1 & 2 \\
\hline Armenia & 1 & 1 & 2 \\
\hline Austria & 1 & 1 & 2 \\
\hline Azerbaijan & 1 & 1 & 1 \\
\hline Belgium & 1 & 1 & 2 \\
\hline \multicolumn{4}{|l|}{ Bosnia-Herzegovina } \\
\hline Bulgaria & 1 & 1 & 2 \\
\hline Croatia & 1 & 1 & 2 \\
\hline Cyprus & 1 & 1 & 2 \\
\hline Czech Republic & 1 & 2 & 1 \\
\hline Denmark & 1 & 2 & 2 \\
\hline Estonia & 1 & 1 & 2 \\
\hline Finland & 1 & 2 & 2 \\
\hline France & 1 & 1 & 2 \\
\hline Georgia & 1 & 1 & 2 \\
\hline Germany & 1 & 2 & $\ldots$ \\
\hline \multicolumn{4}{|l|}{ Greece } \\
\hline Hungary & 1 & 1 & 2 \\
\hline Iceland & 1 & 1 & 2 \\
\hline \multicolumn{4}{|l|}{ Ireland } \\
\hline Italy & 2 & 1 & 2 \\
\hline \multicolumn{4}{|l|}{ Kosovo } \\
\hline Latvia & 1 & 1 & 2 \\
\hline Lithuania & 1 & 1 & 1 \\
\hline \multicolumn{4}{|l|}{ Luxembourg } \\
\hline \multicolumn{4}{|l|}{ Malta } \\
\hline \multicolumn{4}{|l|}{ Moldova } \\
\hline Montenegro & 1 & 1 & \\
\hline Netherlands & 1 & $\ldots$ & 2 \\
\hline North Macedonia & 1 & 1 & 1 \\
\hline \multicolumn{4}{|l|}{ Norway } \\
\hline Poland & 1 & 1 & 2 \\
\hline Portugal & 1 & 1 & 1 \\
\hline Romania & 1 & 1 & \\
\hline \multicolumn{4}{|l|}{ Russian Federation } \\
\hline \multirow{2}{*}{\multicolumn{4}{|c|}{ Slovak Republic }} \\
\hline & & & \\
\hline Slovenia & 1 & 1 & 2 \\
\hline \multicolumn{4}{|l|}{ Spain } \\
\hline Sweden & 1 & 2 & 1 \\
\hline \multicolumn{4}{|l|}{ Switzerland } \\
\hline Turkey & 1 & 1 & 2 \\
\hline Ukraine & 1 & 1 & 1 \\
\hline UK: England \& Wales & 1 & 2 & $\ldots$ \\
\hline \multicolumn{4}{|l|}{ UK: Northern Ireland } \\
\hline UK: Scotland & 1 & 2 & 3 \\
\hline
\end{tabular}


Table 2.3.4 Disposal categories (output data) (1/2)

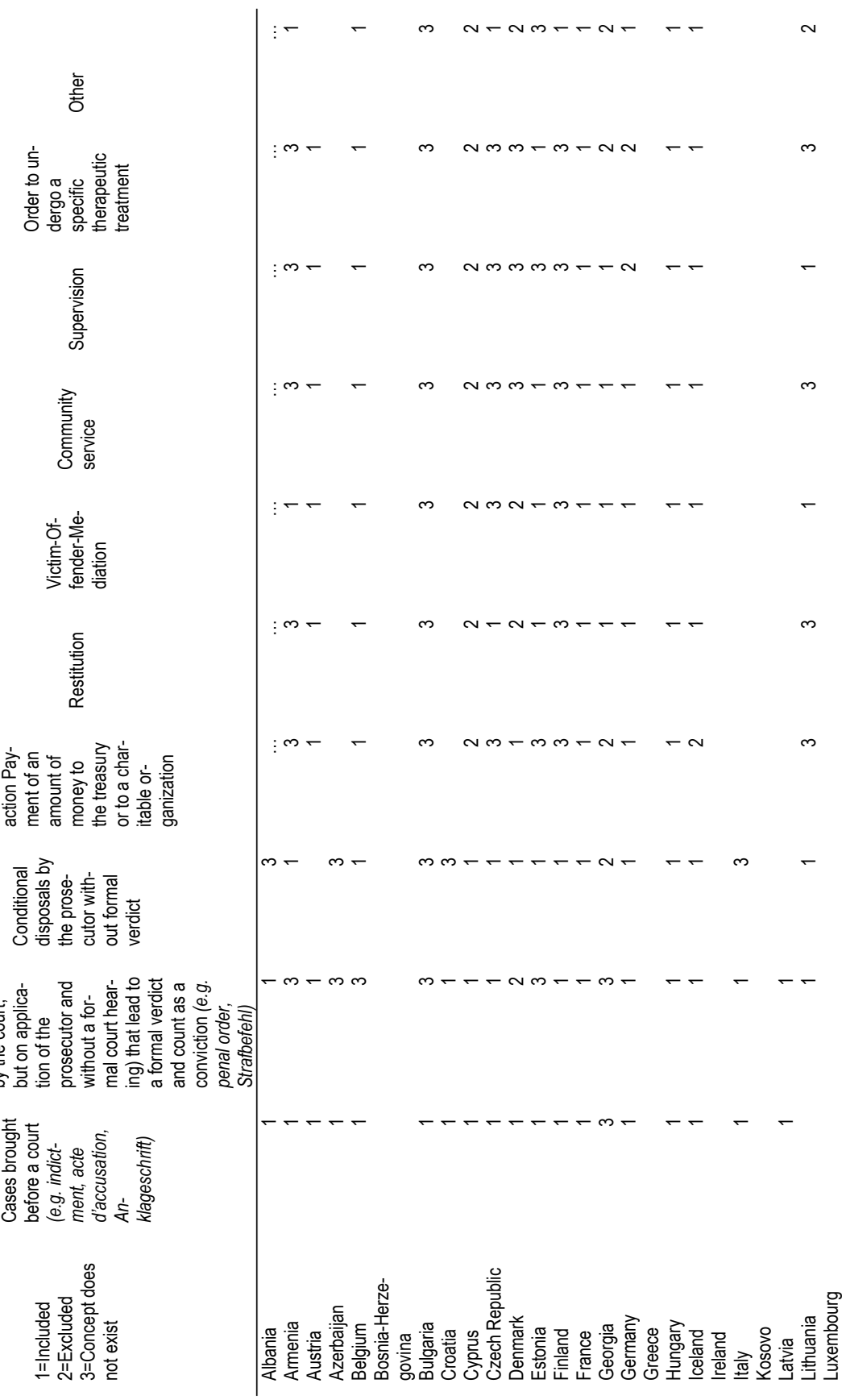


Table 2.3.4 Disposal categories (output data) (2/2)

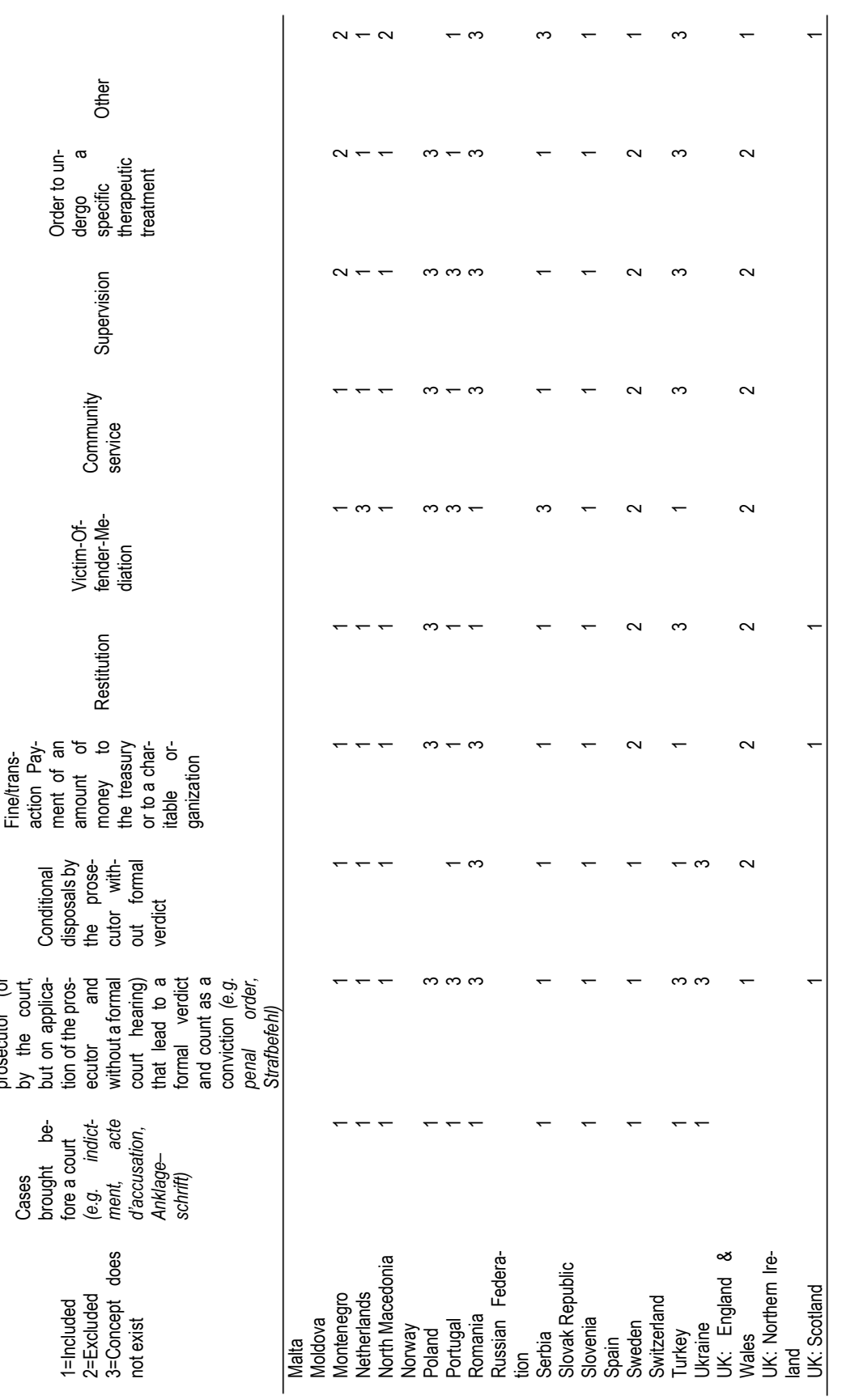

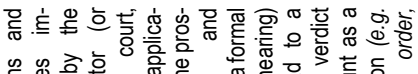

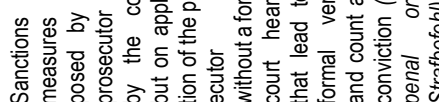

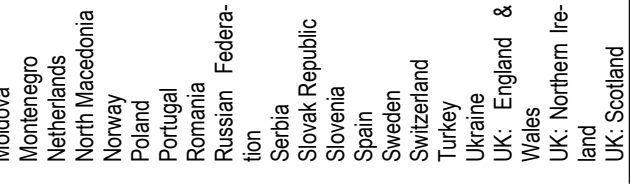


Table 2.3.4 (cont.) Disposal categories (output data) (1/3)

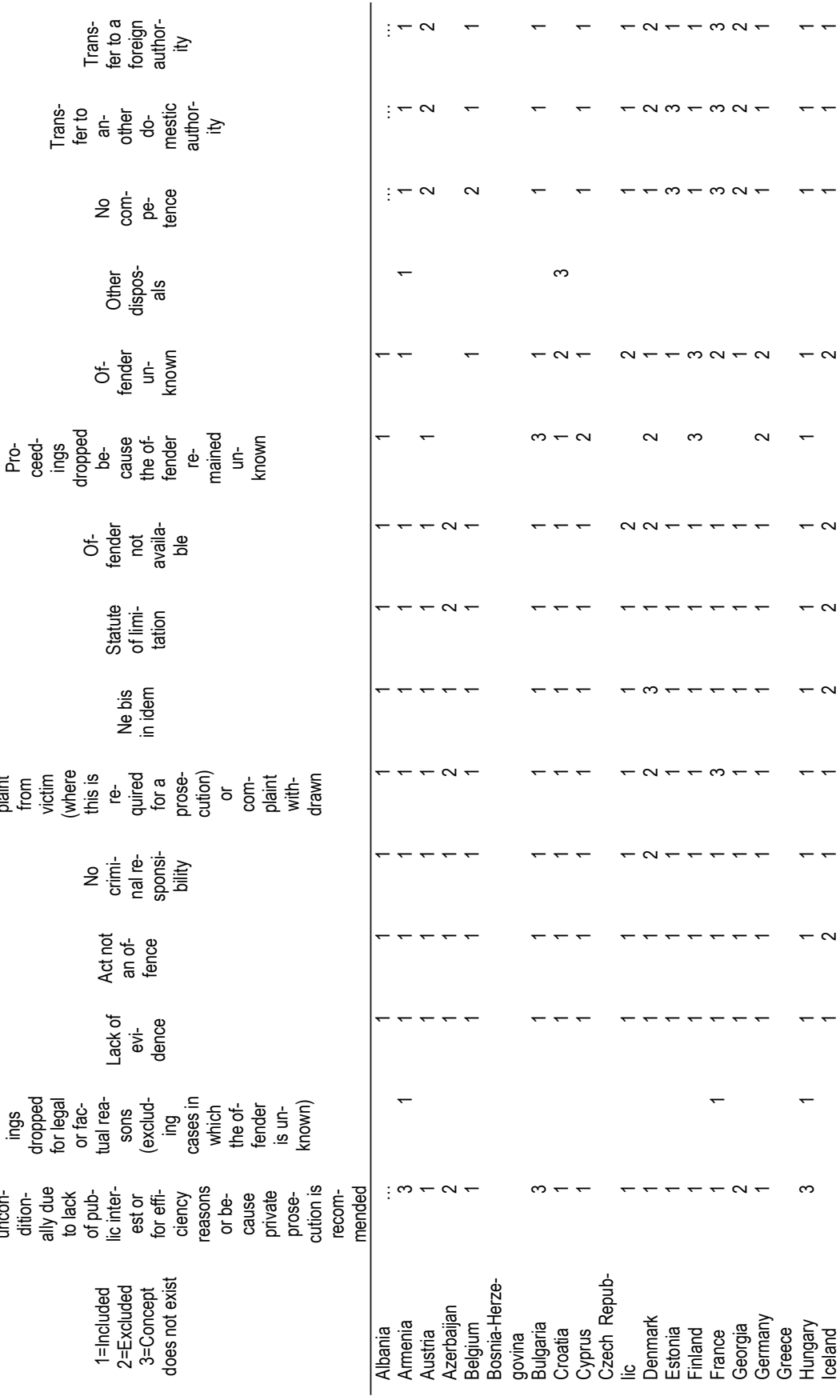


Table 2.3.4 (cont.) Disposal categories (output data) (2/3)

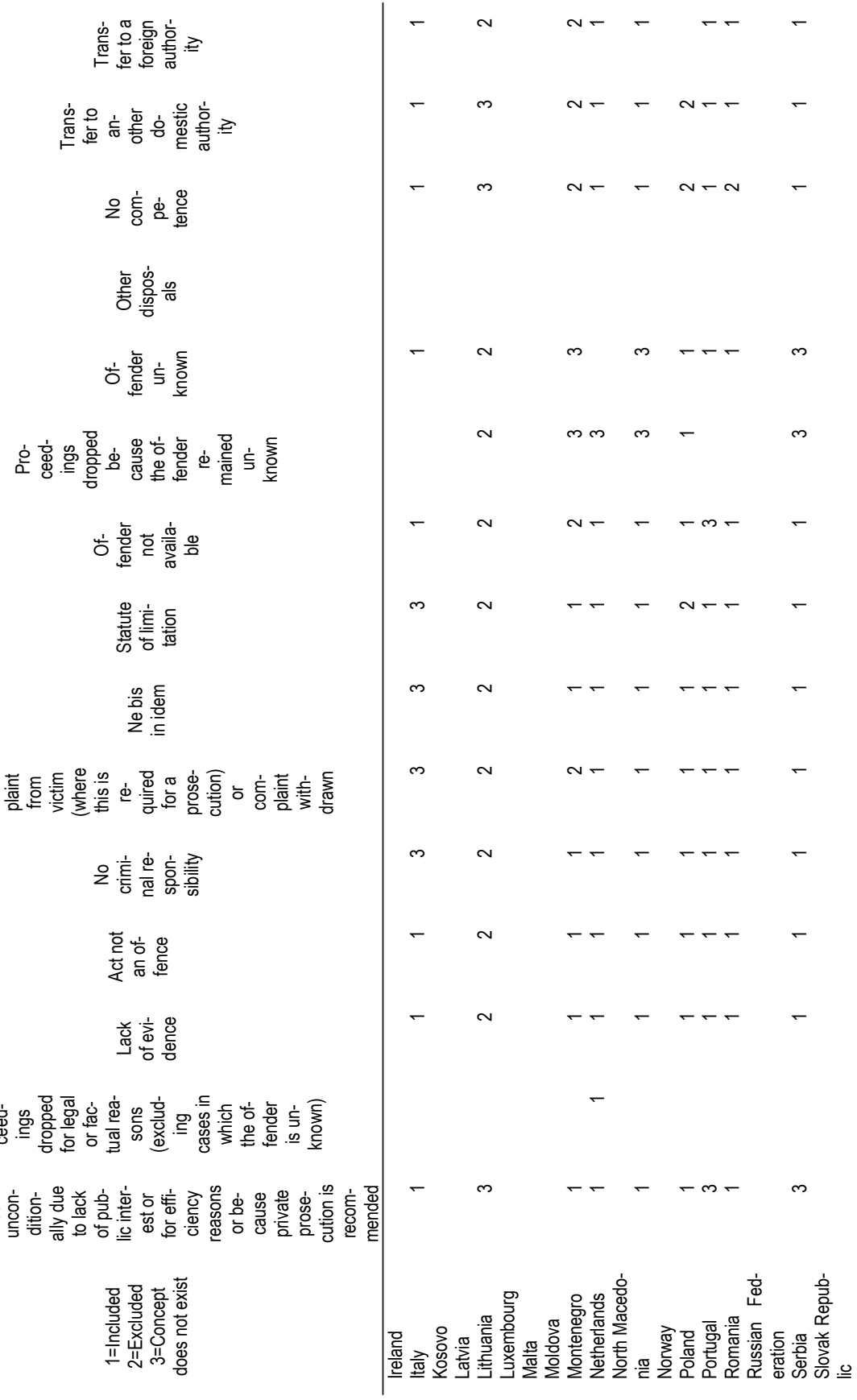


Table 2.3.4 (cont.) Disposal categories (output data) (3/3)

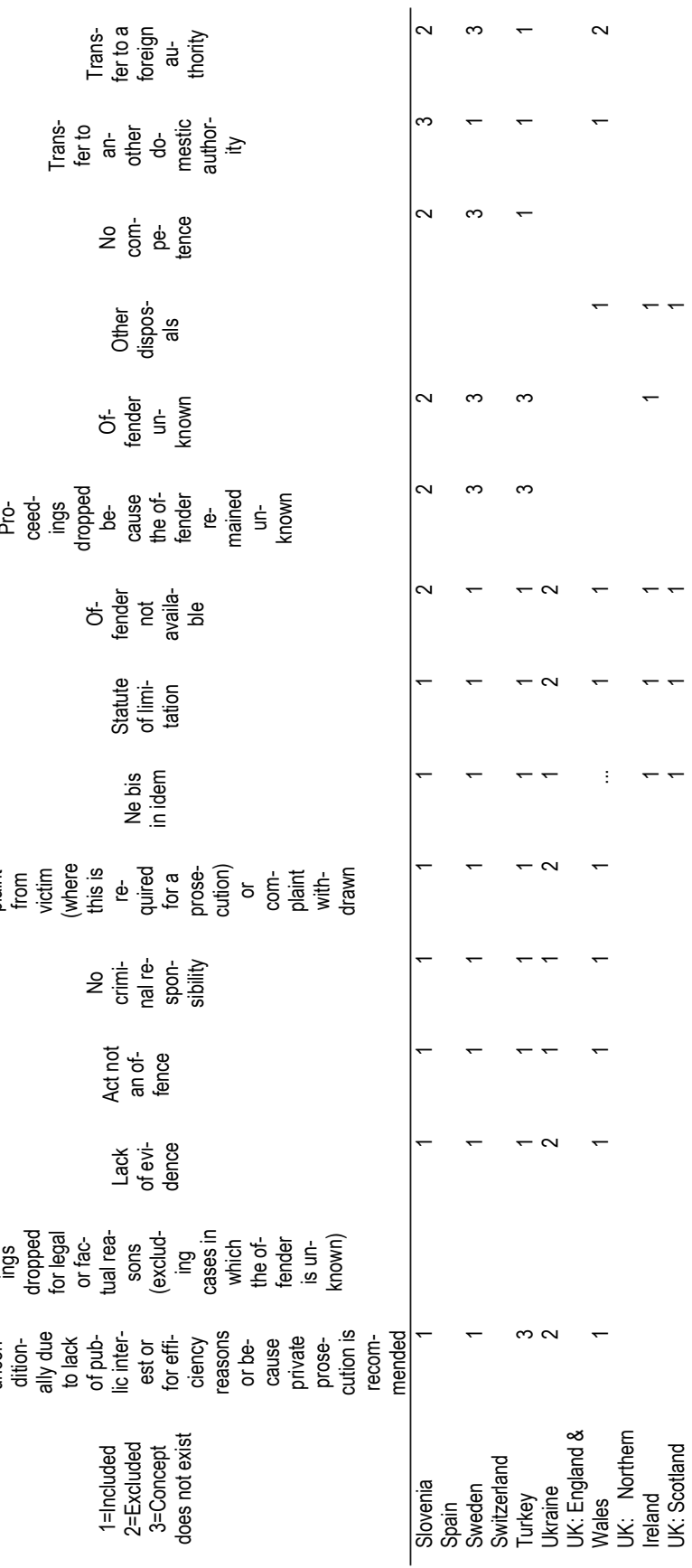


Explanation of options available to prosecutors

Albania Article 328 of the Albanian Code of Criminal Procedure provides the grounds for dismissal of a case by the prosecution authorities, such as when:

a) it is clear that the fact does not exist;

b) the fact is not provided for by law as a criminal offence;

c) the victim has not lodged a complaint or waives it, in cases where the proceedings are initiated on his request;

d) the person cannot be taken as a defendant or he may not be punished;

e) there exists a reason that extinguishes the criminal offence or for which the criminal proceedings should not be initiated or continued;

f) it is proven that the defendant has not committed the offence or it is not proven that the defendant has committed the offence;

g) the defendant has been adjudicated by a final court decision for the same act

h) the defendant dies;

i) in other cases provided for by the law.

Armenia The majority of the cases mentioned- fines, restitution, etc. are not available to prosecutors, thus no such statistics exist.

Belgium Proceedings can be dropped for three kinds of reasons: - technic reasons (offender unknown, no competence) - opportunity reasons (for example : other priorities, behaviour of the victim, ..) - other reasons (administrative fine, praetorian probation, ...) Other possible decisions by the prosecutor are: - junction with another proceeding - transfer to another district - transaction - mediation - transfer to the examining magistrate - direct transfer to the court

Bulgaria After the completion of the investigation the public prosecutor has the following options: 1) to terminate the proceedings; 2) to temporarily suspend the proceedings; 3 ) to submit to the court a proposal for releasing the offender of criminal responsibility by imposing administrative sanctions; 4) to submit to the court a proposal for a plea bargain agreement; or 5) to submit the case to court through a bill of indictment.

Croatia Other disposals are not possible because we used prosecution data from the court statistics.

Czech Conditional disposals by the prosecutor without formal verdict are possible in minors' cases Other $=$ ap-

Republic propriate restrictions and obligations

No private prosecution complaint from victim $=$ if the criminal prosecution is subject to the consent of the victim

Offender unknown = deferral proceedings

Offender not available $=$ proceedings are discontinued, not dropped

Estonia $\quad$ https://www.riigiteataja.ee/en/eli/506062018001/consolide CCP \$§ 200-205.2.

Finland To sue (bring a case before a court), to convict a defendant to a fine, to drop a case

France $\quad$ France Sanctions imposed by PP = composition pénale + ordonnance pénale + comparution sur reconnaissance préalable de culpabilité. In particular, the « composition pénale » is included though according to French it does not lead to a formal conviction (but court agreement is necessary and the case is recorded in national criminal record). These sanctions are included in the conviction chapter. Cases transmitted by the prosecutor to the examining magistrate: if the offender remains unknown, the case is counted within "unknown offender", the other cases are counted within "cases brought before a court". Pending cases are not counted.

Germany Cases brought before a court: Included are normal indictments, applications for summary decisions („beschleunigtes Verfahren“) according to section 417 Code of Criminal Procedure, applications for simplified juvenile proceedings („vereinfachtes Jugendverfahren“) according to section 76 Act on Juvenile Courts and applications for a special kind of proceeding („Sicherungsverfahren“) according to section 413 Code of Criminal Procedure designed for persons who are dangerous but obviously not criminally responsible for their deeds, e.g. due to a mental illness.

Sanctions imposed by the prosecutor (or by the court, but on application of the prosecutor and without a formal court hearing) that lead to a formal verdict and count as a conviction: Counted are all cases in which the Public Prosecution Office applies by the court for a "Strafbefehl“ (penal order) with a special sanction (mostly fines). The court issues the penal order after a summary review of the case and without a court hearing. If the accused raises an objection, a court hearing takes place.

Conditional disposals: Counted are cases in which the prosecutor makes use of his limited discretionary power whether or not to prosecute and suspends prosecution with the court's and the defendant's consent on the condition that the defendant for example:

- $\quad$ restores the damage resulting from the offence, 
- $\quad$ pays a fine,

- does community work,

- $\quad$ pays alimony,

- $\quad$ seriously tries to achieve a settlement with the victim by victim-offender mediation.

Supervision or therapeutic treatment are not possible as a condition for such a disposal.

Proceedings dropped because offender remained unknown: The category of "offender unknown" is only counted on an input basis in German prosecution statistics; cases where the offender remained unknown are not at all counted in output data for Germany. Therefore, this category is excluded from the tables in the prosecution chapter.

Latvia It is difficult to choose from given categories. According to Criminal Procedure Law:

Section 377. Circumstances that Exclude Criminal Proceedings

The initiation of criminal proceedings shall not be permitted, and initiated criminal proceedings shall be terminated, if:

9) a settlement between a victim and a suspect or accused has taken place in criminal proceedings that may be initiated only on the basis of an application of a victim and the harm inflicted by the criminal offence has been completely eliminated or reimbursed;

Section 379. Termination of Criminal Proceedings, Releasing a Person from Criminal Liability

(1) An investigator with a consent of a supervising public prosecutor, public prosecutor or a court may terminate criminal proceedings, if:

1) a criminal offence has been committed that has the features of a criminal offence, but which has not caused harm that would warrant the application of a criminal punishment;

2) the person who has committed a criminal violation or a less serious crime has made a settlement with the victim or his or her representative in the cases determined in the Criminal Law;

3 ) a criminal offence has been committed by a minor and special circumstances of the committing of the criminal offence have been determined, and information has been acquired regarding the minor that mitigates his or her liability;

4) it is not possible to complete the criminal proceedings within reasonable term;

5) the person committed the criminal offence during the time period when he or she was subject to human trafficking and was forced to commit the offence.

(2) An investigator, with the consent of a supervising public prosecutor, or a public prosecutor may terminate criminal proceedings, and send materials regarding a minor for the application of a compulsory measure of a correctional nature.

(3) A public prosecutor may terminate criminal proceedings, conditionally releasing from criminal liability. Section 415. Termination of Criminal Proceedings, Conditionally Releasing from Criminal Liability

(1) If a public prosecutor, taking into account the nature of and harm caused by a committed crimina offence, personal characterising data, and other conditions of a case, achieves conviction that an accused will hereinafter not commit criminal offences, the prosecutor may terminate criminal proceedings, conditionally releasing from criminal liability.

Lithuania Sanctions imposed by the prosecutor: The prosecutor can demand a penal order (CCP 418). It is a summary process when a court trial does not exist. A penal order is written by a judge with a demand of a prosecutor (prosecutor states a demand with all pretrial material). Therefore in summary process the role of a prosecutor is very important. Lithuanian Criminal Procedure Code also establishes a special accelerated procedure, in which the prosecutor has a large role to act. The law provides for the following main conditions to apply such procedure: 1 . apparent circumstances of the offense; 2 . criminal proceedings for the offense shall be dealt with in the District Court; 3. prosecutor should apply to court the day offense was committed or not later than ten days after the offense was committed. This procedure differs from the normal process, because: 1) the prosecutor does not write the indictment, but provides a statement to the court along with the pre-trial investigation material. However, although such procedure is simplified, the case is investigated also in a court hearing. Therefore, the number of pre-trial investigations that were finished by such simplified and accelerated procedure, is provided in a column "cases brought before a court. " Conditional disposals The following conditional disposals are entrenched in CCP: 1) Release from criminal liability after reconciliation is reached between the culprit and the victim. (CCP 212.5). Person who commits a misdemeanor or a minor crime, or commits a negligent crime, may be released from criminal liability if the victim and the culprit reach reconciliation and voluntarily agree on the making of restitution for damage caused by the commission of the crime. A habitual offender, a dangerous habitual offender or a person who has already been released from criminal liability on the basis of reconciliation between the culprit and the victim may not be released from criminal liability. 2) Release from criminal liability when a person is given to another person who deserves court trust (on bail). A person must be convicted for the 
first time, (s)he must regret and confess, also agree to restitute for damage and there should be a ground upon the court could suppose that a culprit will not commit further crimes. In 1 st and 2 nd cases - if a culprit makes new crime (misdemeanor), the process is resumed.

North Regarding data for proceedings dropped unconditionally due to lack of public interest or for efficiency reaMacedo- $\quad$ sons or because private prosecution is recommended - it should be noted that part of the criminal offences nia of this category are prosecuted with private criminal lawsuit therefore those cases are not included in the prosecutor's statistics

Poland The following are disposal categories available to public prosecutors. Within these categories there may be "subcategories" such as mentioned in the tables above.

According to Polish Criminal Code of Procedure (CCP), the case (i.e. formally instituted criminal proceedings) may be either brought to the court or dropped. The case may be dropped in the following circumstances: no offence has been committed/no sufficient grounds to suspect, that the offence has been committed; an offence has formally been committed but it is negligible (e.g. theft of a quarter dollar coin); the perpetrator is not liable to be held guilty or punished (e.g. due to his or her insanity); the suspect deceased; the applicable statute of limitation prevents the proceedings be conducted/continued; res iudicata; no Polish court has jurisdiction; lack of charges by competent prosecutor (the provision addressed to courts); lack of complaint by the victim (where it is required); other grounds preventing criminal prosecution. Moreover, there are two specific modes of disposal:

a) By the court: the so-called "penal order". In cases where summary proceedings are allowable, the court may give up such proceedings and instead impose a penalty in the form of order, without formal hearing. A subsequent objection by the defendant makes it null and void.

b) By court/public prosecutor. Public prosecutor may, having the consent by the suspect/accused obtained, if the offence is liable to punishment of up to 5 years imprisonment, and some other conditions fulfilled, enclose to the charge sheet a motion (request) for sentencing without a hearing. In this mode, only a "mitigated" sentence may be passed. By "mitigated" we understand: no penalty at all or; mitigated penalty; or suspended prison sentence.

Portugal 1) Persons in police custody ordered by police - are related to the number of persons in custody until 48 hours.

2) Persons in pre-trial detention represent the number of persons for whom detention was ordered by court but on prosecutors motion.

(a) In the Portuguese legal system it's not possible for the police to drop, apply a sanction or conditionally dispose of a criminal case.

Serbia The abandonment from prosecution of an unknown offender of a criminal offence is possible only after expiration of the statutory deadline for prosecution for a particular criminal offense, when a special decision is made.

Sweden The statistics of processed offences linked to a suspect is based on offences and suspects registered and processed by Swedish Police, Swedish Customs and Swedish Prosecution Authority. A processed offence refers to an offence were a decision has been taken which entails that the processing of the offence was completed. Offences with person-based clearances are processed offences where a conviction decision (a decision to indict, issue a summary sanction order, or waive prosecution) has been made. All cases of criminal offences also the cases handled only by the police and not passed to the prosecuting authority.

Turkey "Proceedings dropped because offender remained unknown" - in Turkey cases do not get disposed BECAUSE offender is unknown. Such cases will either wait for the state of limitations, or the prosecutor can dismiss it on other grounds (such as lack of evidence). "D2DC16R" - box below is not clickable. I could not exclude it due to difference in counting units. "other disposals" - cases where the case was transferred to a different prosecution office were included here as well. Also lack of venue decisions are included in this category.

UK: $\quad$ Pre charge the prosecutor has the options of deciding that a case is suitable for: $\bullet$ Charge and prosecution; England $\quad$ Caution; $\bullet$ Reprimand, final warning or offence taken into consideration; $\bullet$ Request for further evidence $\&$ Wales from the police; or - No charge either on the grounds of the evidence or the public interest. Post-charge proceedings are subject to a process of continual review, and the prosecutor may decide at any time before the commencement of a trial to discontinue proceedings on consideration of the evidence or the public interest. 


\section{Other technical information on the tables}

Table 2.3.5 Rules of statistical recording applied for Table 2.2.1: Are decisions made outside a criminal procedure (such as, e.g., measures of constraint against illegal immigrants) excluded?

\begin{tabular}{|l|l|l|l|}
\hline \multicolumn{2}{|l|}{ Yes } & No \\
\hline Armenia & Denmark & Montenegro & France* $^{*}$ \\
Austria & Estonia* & North Macedonia & UK: Scotland** \\
Belgium & Finland & Poland & \\
Bulgaria & Georgia & Romania & \\
Croatia & Hungary & Serbia & \\
Czech Republic & Italy & & \\
Turkey & Lithuania & & \\
\hline
\end{tabular}

${ }^{*}$ Constraints against illegal immigrants are considered as administrative measures ("retention administrative"). lllegal immigrants can be detained in administrative centres (different from ordinary prisons, depending on the ministry of the interior) before the expulsion from the national territory.

** Information on persons held as suspects is not available.

Table 2.3.6 Are minors included in Tables in the total of cases?

\begin{tabular}{|l|l|l|l|l|}
\hline Yes & Estonia* & Netherlands & Belgium & Partially \\
\hline Albania & Finland & Romania & Denmark & North Macedonia \\
Austria & France & Slovenia & France & Poland $^{*}$ \\
Azerbaijan & Georgia & Sweden & Italy & Portugal $^{* *}$ \\
Bulgaria & Germany & Turkey*** & Montenegro & Serbia** $^{* *}$ \\
Croatia & Hungary & UK: England \& & & \\
Czech Republic & Latvia & Wales & & \\
& Lithuania & UK: Scotland & & \\
\hline
\end{tabular}

* Cases of minors are related only to the most serious offences (e.g. Homicide, rape).

** Only minors between $16-17$ years old.

*** The records on criminal offences of minors are not recorded separately for each criminal offence in the prosecution statistics, but rather the records contain only the number of persons against whom complaints were filed, who have been charged or convicted.

${ }^{* * * *}$ No separate statistics for minors are available, but totals include minors (even though this is not clearly specified). 
Table 2.3.7 Age bracket used for minors

\begin{tabular}{|c|c|c|c|c|}
\hline $\begin{array}{l}1=\text { Yes } \\
2=\text { No }\end{array}$ & $\begin{array}{l}\text { Same as } \\
\text { the one } \\
\text { used in Ta- } \\
\text { ble } 1.2 .2\end{array}$ & $\begin{array}{l}\text { If no, mini- } \\
\text { mum age }\end{array}$ & $\begin{array}{l}\text { If no, maxi- } \\
\text { mum age }\end{array}$ & Comments \\
\hline Albania & & $\ldots$ & $\ldots$ & \\
\hline Armenia & 1 & 14 & 18 & \\
\hline Austria & & & & \\
\hline Azerbaijan & 2 & 14 & 18 & \\
\hline Belgium & & & & \\
\hline Bosnia-Herzegovina & & & & \\
\hline Bulgaria & 1 & & & \\
\hline Croatia & 1 & 14 & 18 & \\
\hline Cyprus & & & & \\
\hline Czech Republic & 2 & 15 & 18 & \\
\hline Denmark & 1 & & & \\
\hline Estonia & 1 & & & \\
\hline Finland & 2 & 15 & 18 & $\begin{array}{l}\text { Minors less than } 15 \text { years old do not have crimi- } \\
\text { nal responsibility and cannot be prosecuted. }\end{array}$ \\
\hline France & 1 & & & \\
\hline Georgia & & & & $\begin{array}{l}\text { Young adults are included in the data on minors } \\
\text { if they have been prosecuted based on the rules }\end{array}$ \\
\hline Germany & 2 & 14 & $18 / 21$ & $\begin{array}{l}\text { of juvenile criminal law. In practice, the majority } \\
\text { of young offenders below } 21 \text { is treated in accord- } \\
\text { ance with juvenile criminal law. }\end{array}$ \\
\hline Greece & & & & \\
\hline $\begin{array}{l}\text { Hungary } \\
\text { Iceland } \\
\text { Ireland }\end{array}$ & 1 & & & \\
\hline Italy & 1 & & & \\
\hline Kosovo (UN & & & & \\
\hline R/1244/99) & & & & \\
\hline Latvia & 1 & & & \\
\hline Lithuania & 1 & & & \\
\hline Luxembourg & & & & \\
\hline Malta & & & & \\
\hline Moldova & & & & \\
\hline Montenegro & & 14 & 18 & \\
\hline Netherlands & 2 & 12 & 18 & \\
\hline North Macedonia & 1 & & & \\
\hline Norway & & & & \\
\hline Poland & 2 & 15 & 17 & $\begin{array}{l}\text { It includes only the most serious offences (e.g. } \\
\text { homicide) }\end{array}$ \\
\hline Portugal & & & & \\
\hline Romania & 1 & & & \\
\hline Russian Federation & & & & \\
\hline Serbia & 1 & & & \\
\hline Slovak Republic & & & & \\
\hline Slovenia & 1 & 14 & 18 & \\
\hline Spain & & & & \\
\hline Sweden & 1 & & & \\
\hline Switzerland & & & & \\
\hline Turkey & & & & No data for minors was available in this section \\
\hline Ukraine & & & & \\
\hline UK: England \& Wales & & & & \\
\hline UK: Northern Ireland & & & & \\
\hline UK: Scotland & 1 & & & \\
\hline
\end{tabular}


Table 2.3.8 Rules of statistical recording

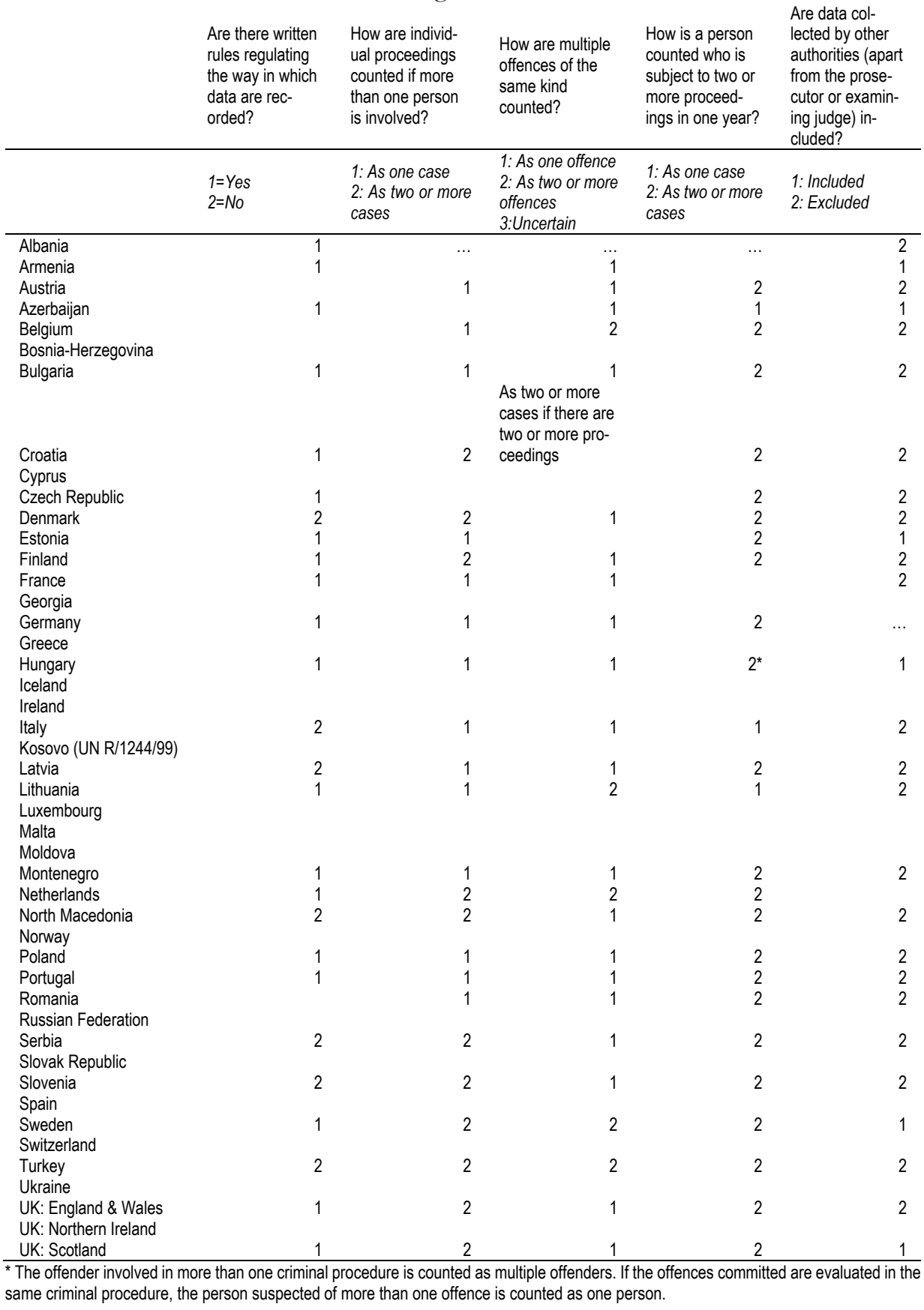


Table 2.3.8 (cont.) Rules of statistical recording: Do the police have separate powers to drop proceedings, conditionally dispose of them or issue a penal order that counts as a conviction? If yes, which powers do they have?

Yes, they have the following powers

$1=$ true

$\begin{array}{lllllll}\text { No, none of } & & \text { Drop } & \text { be- } & \text { Drop for } & \text { Drop for pub- } & \\ \text { these } & \text { cause } & \text { of- } & \text { other factual } & \text { lic interest } & \text { Conditional } & \text { Penal order } \\ 1=\text { true } & \text { fender } & \text { re- } & \text { or for legal } & \text { reasons/sim- } & \text { disposal } & \\ & \text { mains } & \text { un- } & \text { reasons } & \text { ple caution } & & \\ & \text { known } & & & & & \end{array}$

\begin{tabular}{|c|c|c|c|c|c|c|}
\hline \multirow{3}{*}{$\begin{array}{l}\text { Albania } \\
\text { Armenia }\end{array}$} & \multicolumn{2}{|l|}{1} & \multirow{3}{*}{1} & & \\
\hline & & & & & & \\
\hline & 1 & & & & & \\
\hline Azerbaijan & & & & & & \\
\hline Belgium & 1 & & & & & \\
\hline Bosnia-Herzegovina & & & & & & \\
\hline Bulgaria & 1 & & & & & \\
\hline Croatia & 1 & & & & & \\
\hline Cyprus & & & & & & \\
\hline Czech Republic & & 1 & 1 & 1 & & \\
\hline Denmark & & 1 & & & & 1 \\
\hline Estonia & 1 & & & & & \\
\hline Finland & & 1 & 1 & 1 & 1 & 1 \\
\hline France & & & & & & \\
\hline Georgia & 1 & & & & & \\
\hline Germany & 1 & & & & & \\
\hline Greece & & & & & & \\
\hline Hungary & & 1 & 1 & & & \\
\hline $\begin{array}{l}\text { Ireland } \\
\text { Ireland }\end{array}$ & & & & & & \\
\hline Italy & 1 & & & & & \\
\hline Kosovo & & & & & & \\
\hline$R / 1244 / 99)$ & & & & & & \\
\hline Latvia & & & & & & \\
\hline Lithuania & & & & & & \\
\hline Luxembourg & & & & & & \\
\hline Malta & & & & & & \\
\hline Moldova & & & & & & \\
\hline Montenegro & 1 & & & & & \\
\hline Netherlands & & 1 & & & 1 & \\
\hline North Macedonia & 1 & & & & & \\
\hline Norway & & & & & & \\
\hline Poland & & 1 & 1 & 1 & & \\
\hline Portugal & 1 & & & & & \\
\hline Romania & 1 & & & & & \\
\hline Russian Federation & & & & & & \\
\hline $\begin{array}{l}\text { Serbia } \\
\text {. }\end{array}$ & 1 & & & & & \\
\hline Slovak Republic & & & & & & \\
\hline $\begin{array}{l}\text { Slovenia } \\
\text { Sour }\end{array}$ & 1 & & & & & \\
\hline Spain & & & & & & \\
\hline Sweden & & & 1 & 1 & & 1 \\
\hline Switzerland & & & & & & \\
\hline Turkey & 1 & & & & & \\
\hline Ukraine & 1 & & & & & \\
\hline UK: England \& Wales & 1 & & & & & \\
\hline $\begin{array}{l}\text { UK: Northern Ireland } \\
\text { UK : Scotland }\end{array}$ & & & & & 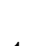 & \\
\hline
\end{tabular}


Table 2.3.8 (cont.) Rules of statistical recording: Do the police have separate powers to drop proceedings, conditionally dispose of them or issue a penal order that counts as a conviction?

Please explain the options available

The police investigators have the right to drop the cases, when the victim decided

Armenia to go for mediation in cases when the victim 's complaint is a mandatory requirement, as well as when the act constituted no crime Actually, the police have no powers to drop at all. But in practice drops and disposals

Netherlands are used under the responsibility of the prosecutor (but they do not appear in the

Poland prosecution statistics). Police can only apply, in term of disposal above, and the confirmation by the prose-

Sweden cutors is obligatory. Kommentar FUB och OBOT...

Table 2.3.8 (cont.) Rules of statistical recording: Have the data recording methods described above been substantially modified between 2011 and 2016?

This applies to three countries:

\begin{tabular}{ll}
\hline Hungary & There were some changes in the categories used after the New Criminal Code came into force \\
Sweden & The statistics of processed offences linked to a suspect is based on offences and suspects registered \\
and processed by Swedish Police, Swedish Customs and Swedish Prosecution Authority. A processed \\
offence refers to an offence where a decision has been taken which entails that the processing of the \\
offence was completed. Offences with person-based clearances are processed offences where a con- \\
viction decision (a decision to indict, issue a summary sanction order, or waive prosecution) has been \\
made. \\
In accordance with the Criminal Procedural Code of Ukraine 2012 (article 214) the investigator or pros- \\
ecutor shall immediately, but not later than 24 hours after the submission of the application, notification \\
of a criminal offence or after an independent identification of circumstances which may indicate a crimi- \\
nal offence, from any source, shall be obliged to enter the relevant information into the Unified Register \\
of Pre-trial Investigations.
\end{tabular}




\subsection{Sources}

\subsubsection{Sources of tables in sections 2.2.1-2.2.4}

\begin{tabular}{|c|c|}
\hline Albania & Statistics reported by District Prosecutions to the General Prosecution for 2015 \\
\hline Armenia & $\begin{array}{l}\text { Publication - Social-economical Situation in Armenia, January } 2016 \\
\text { https://www.armstat.am/file/article/sv_01_16a_520.pdfST26 }\end{array}$ \\
\hline Austria & Security Reports, Ministry of Justice (Sicherheitsbericht 2015, Bericht über die Tätigkeit der Strafjustiz) \\
\hline Azerbaijan & $\begin{array}{l}\text { Information about crimes } 2013-2016 \text { is available on the official website of the State Statistical Committee of } \\
\text { the Republic of Azerbaijan https://www.stat.gov.az/source/crimes/ and The General Prosecutor's Office of } \\
\text { Azerbaijan }\end{array}$ \\
\hline Belgium & College of general Prosecutors - Statistical analysts http://www.om-mp.be/sa/start/n/home.html \\
\hline Bulgaria & $\begin{array}{l}\text { Letter from the Supreme Prosecutor's Office of Cassation to the National Correspondent dated } 10 \text { August } \\
2018 \text {, not published. Source relating to the number of proceedings concerning minors dropped for legal or } \\
\text { factual reasons (excluding cases in which the offender is unknown): Annual Report on the Activities of the } \\
\text { Prosecution Authorities in Bulgaria 2015. See https://www.prb.bg/media/filer_public/32/f6/32f603e3-9c3e- } \\
\text { 483d-aa29-aa2c93e693f1/doklad_za_prilozhenieto_na_zakona_i_deinostta_na_prokuraturata___razs- } \\
\text { ledvashchite_organi_za_2015_g.pdf (in Bulgarian only). }\end{array}$ \\
\hline Croatia & Croatian Bureau of Statistics - data provided by the court \\
\hline Czech Republic & $\begin{array}{l}\text { Statement of the Ministry of Justice No. V(MS) } 001 \text { a V(MS) 002, counting unit = matter (proceedings)! } \\
\text { statistical sheet of the Ministry of Justice, overview No. 6, counting unit - a person }\end{array}$ \\
\hline Denmark & Prosecutor general \\
\hline Estonia & $\begin{array}{l}\text { Ministry of Justice - not published. } \\
\text { Kuritegevus Eestis 2017. Justiitsministeerium. Tallinn, 2018. www.just.ee }\end{array}$ \\
\hline Finland & $\begin{array}{l}\text { Statistics Finland, Syytetyt, tuomitut ja rangaistukset 7.8.2018 } \\
\text { http://pxnet2.stat.fi/PXWeb/pxweb/fi/StatFin/StatFin_oik_syyttr/Statistics Finland, Rikos- ja pakkokeino- } \\
\text { tilasto 7.8.2018 http://pxnet2.stat.fi/PXWeb/pxweb/fi/StatFin/StatFin_oik_rpk/ }\end{array}$ \\
\hline France & $\begin{array}{l}\text { Ministère de la Justice / SG / SEM / SDSE / Cadres du parquet, SID statistiques pénales } \\
\text { Source for the pre-trial detention : Ministère de la justice / DAP/ Me5/ Infocentre penitencier }\end{array}$ \\
\hline Georgia & Report of Main Prosecutor office of Georgia 2015, 2016 \\
\hline Germany & Statistisches Bundesamt, Staatsanwaltschaften 2011-2016, Wiesbaden 2012-2017. \\
\hline Hungary & $\begin{array}{l}\text { Prosecution Caseload Statistics } \\
\text { Standard Criminal Statistics of Investigation Authorities and Prosecutors }\end{array}$ \\
\hline Iceland & The National Prosecutor annual report \\
\hline Italy & Italian Institute of statistics - http://www.istat.it - Ministry of Justice. Department of Statistics \\
\hline Latvia & The Prosecution Office \\
\hline Lithuania & $\begin{array}{l}\text { Information Technology and Communications Department under the Ministry of the Interior of the Republic of } \\
\text { Lithuania - Information Processing and Statistics Division. } \\
\text { Prison Department under the Ministry of Justice of the Republic of Lithuania - General Unit. }\end{array}$ \\
\hline Netherlands & Ministry of Justice / WODC \\
\hline North Macedonia & Prosecution Statistics \\
\hline Poland & General Prosecution, Department of Statistics \\
\hline Portugal & Directorate-General for Justice Policy - Ministry of Justice \\
\hline Romania & Public Ministry - General Prosecutor's Office (www.mpublic.ro) \\
\hline Serbia & Annual report on the work of public prosecutors' offices \\
\hline Slovenia & Source is IT system of state prosecutor office \\
\hline Sweden & $\begin{array}{l}\text { Swedish National Council of Crime Prevention, Processed offences linked to a suspect } \\
\text { Sweden, Official Crime statistics. https://bra.se/statistik/kriminalstatistik/handlagda-brottsmisstankar.html } \\
\text { The Swedish Prosecution Authority www.aklagare.se }\end{array}$ \\
\hline Turkey & $\begin{array}{l}\text { Ministry of Justice, General Directorate for Judicial Records and Statistics http://www.adlisicil.adalet.gov.tr/ar- } \\
\text { siv.html }\end{array}$ \\
\hline Ukraine & $\begin{array}{l}\text { Ministry of Justice, General Directorate of Prisons and Detention Houses http://www.cte.adalet.gov.tr/ } \\
\text { website of the General Prosecutor's Office of Ukraine since } 2013 \text { https://www.gp.gov.ua/ua/statinfo.html/ }\end{array}$ \\
\hline UK: England \& Wales & $\begin{array}{l}\text { The above figures are collected through a single national computer system (Compass), and are derived from } \\
\text { a related Management Information System capable of inter-relational analyses of the database. }\end{array}$ \\
\hline UK: Scotland & $\begin{array}{l}\text { Crown Office and Procurator Fiscal Service (from data published on website at http://www.copfs.gov.uk/ } \\
\text { About/corporate-info/Caseproclast5) }\end{array}$ \\
\hline
\end{tabular}


Source of the data in Tables 2.2.5.1, 2.2.5.2

\begin{tabular}{|c|c|}
\hline Albania & Statistics reported by District Prosecutions to the General Prosecution for 2015 \\
\hline Austria & Security Reports, Ministry of Justice (Sicherheitsbericht, Bericht über die Tätigkeit der Strafjustiz) \\
\hline Bulgaria & $\begin{array}{l}\text { Letter from the Supreme Prosecutor's Office of Cassation to the National Correspondent dated } 10 \text { August } 2018 \text {, } \\
\text { not published. }\end{array}$ \\
\hline Croatia & Report from the prosecution office. \\
\hline Czech Republic & Economic department of the Ministry of Justice \\
\hline Denmark & Prosecutor general \\
\hline Estonia & Office of the Prosecutor General - not published \\
\hline Finland & $\begin{array}{l}\text { Valtakunnansyyttäjälaitos. Vuosikertomukset } 2015 \text { \& 2013. Henkilöstötilinpäätös } 2016 \\
\text { http://www.vksv.fi/fi/index/julkaisutjaohjeet/vuosikertomukset.html }\end{array}$ \\
\hline France & Ministère de la Justice / Direction des Services Judiciaires/Conseil d'État/Enquête CE PEJ \\
\hline Georgia & Georgia Main Prosecutor Office Reports: 2014,2015,2016 \\
\hline Germany & $\begin{array}{l}\text { Personalbestand der Staats- und Amtsanwaltschaften bei den Landgerichten, Bundesamt für Justiz. } \\
\text { Personalbestand der Staatsanwaltschaften bei den Oberlandesgerichten, Bundesamt für Justiz. }\end{array}$ \\
\hline Hungary & OFFICE OF THE PROSECUTOR GENERAL - Human Resource System \\
\hline Latvia & The Prosecution Office \\
\hline Lithuania & Prosecutor General's Office of the Republic of Lithuania. \\
\hline Netherlands & CEPEJ \\
\hline North Macedonia & Prosecution statistics \\
\hline Poland & General Prosecution, Department of Statistics \\
\hline Serbia & State council of public prosecutors and the Ministry of Justice - Personnel service \\
\hline Slovenia & MFERac - IT system for stuff recording for public authorities \\
\hline Sweden & The Swedish Prosecution Authority www.aklagare.se \\
\hline Turkey & $\begin{array}{l}\text { Ministry of Justice, Directorate for Criminal Records and Statistics, Judicial Statistics Archive } \\
\text { http://www.adlisicil.adalet.gov.tr/en/statarchive2.html }\end{array}$ \\
\hline Ukraine & $\begin{array}{l}\text { The Law of Ukraine "About the prosecutor's office" on 14.10.2014, article } 14 \text { https://zakon. } \\
\text { rada.gov.ua/laws/show/1697-18. The official website of the GeneralProsecutor's Office of Ukraine: } \\
\text { https://www.gp.gov.ua/ }\end{array}$ \\
\hline $\begin{array}{l}\text { UK: England \& } \\
\text { Wales }\end{array}$ & Staff records are held centrally within a CPS Corporate Information System. \\
\hline UK: Scotland & $\begin{array}{l}\text { Crown Office and Procurator Fiscal Service. Staff in Post figures (Including Temporary, Permanent \& Paid Ab- } \\
\text { sence), mid year. }\end{array}$ \\
\hline
\end{tabular}





\section{Conviction Statistics}

\subsection{General comments}

\subsubsection{Introduction}

The tables in this chapter refer to persons who have been convicted and the sanctions and measures imposed on them. Information is presented on the type of offence for which they were convicted (2011-2016) and the sex, age, and nationality of the offender (2015). Information on persons receiving sanctions and measures (2015) looks at minors and all offenders separately for each offence type. The unit for the table on sanctions and measures is the person on whom the sanction is imposed, not the sanction itself. Sentence lengths (2015) for custodial sentences for each offence type are also presented but only for all offenders and not separately for minors. For 8 countries data is available on the number of offenders that were held in pre-trial detention before their conviction. New in this edition is information on the number of judges. However, only a few countries could give separate data on judges in criminal courts.

Three countries (Greece, Ireland, and Malta) did not provide any information on convictions and are therefore not included in the tables.

Interpretation of such information is more difficult than for police statistics because conviction statistics closely reflect the different criminal justice systems in each country. These differences affect the likelihood that a suspect will appear 
before a court, the type of court and how this relates to the age of the suspect. Similarly, there are differences in recording due to the inclusion or not of all possible convictions (e.g., including guilty pleas at the police/prosecutor stage) and the availability of data. The range of sentencing options for the court may also differ as once again they reflect the criminal code in question. For some countries short custodial sentences will have automatically been converted to non-custodial alternatives through administrative procedures. These are not shown here as the statistics only reflect the initial court decision.

It is also important to note that the offence for which an offender is convicted may often differ substantially from the initial offence recorded by the police or for which the offender was initially charged. Often at the court stage, an offender may agree to plead guilty to a less serious offence or the prosecutor may decide there is insufficient evidence to convict for the original offence.

\subsubsection{Offence definitions}

The definitions used in the various police statistics presented here show some uniformity between countries. In contrast, those for sanctions/measures often vary substantially in definition as they are based on the judicial system of each country and are entirely dependent on the definitions provided in national penal statutes. For this reason, the breakdown of data in this chapter does not follow that in Chapter 1 . Thus 'burglary' and 'car theft' are often not identified as separate offences, for example in the Netherlands, but are included in the general category 'theft'. For other offences the scope of the offence may vary; for example, classifying the offence as theft as opposed to theft of a motor vehicle depends on whether the owner was permanently deprived of an article or not.

\subsubsection{Definition of a conviction}

When preparing the questionnaire, an attempt was made to provide a definition for a 'conviction' of an offender that was acceptable to most criminal justice systems. The need for such a definition was created by the fact that (a) offenders in certain jurisdictions are not always convicted by a court and (b) sanctions/measures may be imposed by another authority (police or prosecutor). Therefore, the definition of 'persons convicted' included sanctions/measures imposed by a prosecutor based on an admission of guilt by the defendant. However, this definition did not include cases where (a) a prosecutor imposed sanctions/measures not based on the admission of guilt by the defendant, (b) the sanctions were imposed by the police and (c) other state authorities imposed the sanction/measure. In addition, there is a system of police cautioning or issuing a fixed penalty in many countries (e.g., the United Kingdom) while other countries such as the Dutch and the French have systems for diverting offenders from the courts. These cases are excluded from the convictions statistics. This position is more complex for offences committed by minors which are counted in many different ways for all offence types. 
The information presented here cannot therefore be said to give an accurate measure of either how many crimes recorded by the police result in a conviction or how many suspected offenders are convicted, except for the most serious offences, e.g., homicide. However, even in such cases it should be noted that offenders may eventually be convicted for a less serious offence than the one for which they were initially prosecuted by the courts.

In some countries legal persons could be convicted as well. However, except for crimes like fraud, forgery of documents and corruption, the numbers of legal persons convicted were negligible.

The definition of a minor varies. For example, in Germany, 'minor' covers all those under 18 years of age when they committed the crime. However, for Germany this will also include a proportion of those aged between 18 to 20 years who are also covered by juvenile laws. This applies to other countries as well.

\subsubsection{Minimum age of conviction}

The sentencing options for convicted offenders depend upon their age as well as the scope of juvenile law. Usually, the same minimum and maximum age are used as by the police, and is reported in chapter 1. Only 5 countries apply other age brackets, mostly for the minimum age. Below these minimum ages many countries have alternative ways of dealing with minors. In some cases, they are offence dependent, with the aim of diverting young offenders from the formal criminal justice system.

\subsubsection{Validation checks}

Once the term 'convictions' had been defined, it was expected that the number of persons convicted would be equal to or less than the number of suspected offenders. Similarly, the number of offenders convicted should be equal to the number of persons receiving a sanction or measure. Due to time delays and use of other sources this is not always the case. Also, for some countries there can be a conviction without a sanction or measure.

Finally, the number of custodial sentences given in the sentencing tables should be equal to the totals for which sentence lengths are shown. Some small differences in some countries arose as a result of the different times at which such statistics were recorded.

Although validation checks identified many errors in the figures, and in some cases called for further explanation, it is possible that some errors have gone undetected.

\subsubsection{Methodology}

Most countries apply some form of written rules to regulate the collection of conviction data. This normally includes some form of 'principal offence rule' so that an 
offender convicted at one court appearance for more than one offence will be shown only once in the statistics. However, for a few countries no principal offence rule applies, and a person convicted for several offences during the same trial will be counted several times in each table. While most countries count the most serious offence, it was often not clear whether they determined the seriousness of the offence based upon a) the nature of the offence, b) the punishment imposed or c) the maximum sentence applicable. While most countries count each court conviction separately, 6 countries (Armenia, Bulgaria, Georgia, Italy, Latvia, and Spain) count different court convictions in the same year as only one conviction.

There were two different procedures identified with respect to the point at which statistics on court decisions were recorded. Thirteen countries replied that the information they provided was related to the position before any appeal on either the verdict or the sentence. For sixteen countries, information was collected only after any such appeals were completed. Variations in the point at which data was collected will affect any comparisons between court statistics. The remaining fourteen countries gave no information on this issue.

\subsubsection{Results}

The tables cover convictions for the period 2011-2016 and sanctions/measures for the year 2015. The commentary draws on the definitional material collected in this survey although a full analysis would require additional research in each country. In some countries, limitations on the data available (e.g., type of thefts) reflects the absence of such a breakdown in their criminal code. Also, for some countries minors are completely or partially excluded from the tables with total persons convicted or receiving sanctions/measures.

Different migration patterns are reflected in the proportion of foreigners among those convicted, with Luxembourg, Switzerland and Austria having the highest proportions. Thirteen countries could identify those foreigners with EU citizenship. In some countries, it is the ethnic origin of the suspect rather than nationality that is recorded for court decisions. In view of such variations, there is no discussion in this chapter of conviction rates for foreigners.

\subsubsection{Total crimes}

\section{Convictions}

Cyprus, Finland, and Norway show the highest number of convictions (6 387, 3321 and 5026 per 100000 inhabitants in 2015). England \& Wales also had a high number of convictions (2 158), while Armenia (94 in 2015) and Azerbaijan (138 in 2015) had the lowest levels. Many of the differences reflect both the way that major road traffic offences and minors are dealt with within the formal criminal justice system and whether they are recorded in the court statistics. Because of the high number of traffic convictions in Norway and Finland, when these are excluded the rates 
would be comparable with many other countries such as England \& Wales, Turkey, Belgium, Denmark, and others. In general, the number of convictions show a decrease over the period 2011 - 2016, with an increase for a few countries only (Albania with 60\%, Bosnia-Herzegovina and Spain with 23\% and 8 other countries with lower percentages) The largest decreases were found in Cyprus (-48\%), Ukraine $(-47 \%)$ and Croatia $(-42 \%)$.

Wide variations in the percentage of minors measured under total crimes will also be indicative of the number of traffic offences that are included. Typically, the percentage of minors is about $5 \%$ or a little lower in most countries. The percentage of women measured under total crimes ranges between 5.4\% (Turkey) and 29.5\% (England \& Wales).

\section{Sanctions and measures}

For all countries, fines were the most frequently used sanction $(38 \%$ of all sanctions), followed by suspended custodial sanctions and measures (25\%). The highest proportions of unsuspended custodial sanctions can be found in Armenia (36\%) and Latvia (34\%).

For minors, non-custodial sanctions were most frequently used (48\%).

\subsubsection{Major road traffic offences}

\section{Convictions}

The number of convictions for major road traffic offences varied widely between countries, from very low rates in Armenia, Italy, and England \& Wales (less than 8 per 100000 population in 2015) to almost 4000 in Norway. The percentage of those convicted for traffic offences who were minors was below $7 \%$ in all countries except Albania (30\%) and Ukraine (10\%). The differences may reflect the age at which driving is permitted in each country and the seriousness of offences dealt with by fixed penalties but outside the court system.

\section{Sanctions and measures}

Offenders were usually fined (44\%) with only $12 \%$ sentenced to custody. Armenia (37\%) and England \& Wales (43\%) had the highest rates of custody, although this may reflect the more serious nature of offences included.

For minors, the sanctions used in the main were fines (37\%) and non-custodial sentences (44\%). Bulgaria and England \& Wales had a relatively high rate of custody at $42 \%$ and $18 \%$. 


\subsubsection{Homicide}

\section{Convictions}

Since the numbers of homicides in most countries are relatively small, conviction rates may fluctuate substantially. Turkey showed the highest levels of total homicide convictions (this included attempted homicide) at 20 per 100000 population (in 2015), but provided no data for homicides when attempted homicides were excluded. With 4.5 convictions per 100000 population Georgia had the highest level for completed homicide. Many countries had conviction rates of about 1 per 100 000 population for completed homicide.

The mean percentage of minors among homicide convictions for all countries was a little under 5\%. High proportions were found in the Netherlands $(9.4 \%)$ and Austria $(10.0 \%)$. On average about $10 \%$ of the convicted offenders for homicide were women.

\section{Sanctions and measures}

For all countries, custody was the main sanction for completed and attempted homicides. Only in four countries, Belgium, Portugal, Switzerland, and Turkey the rates for unsuspended custody in homicides were somewhat lower, where this reflects the use of alternative sanctions. Minors were mainly sentenced to custody as well.

\subsubsection{Bodily inujries}

\section{Convictions}

Variations in conviction rates for bodily injuries have been explained in previous reports by whether less serious assaults are included. In this report, as in the fourth and fifth edition, aggravated bodily injuries are shown separately and, other than in previous editions, all countries (with the exception of Northern Ireland and Spain) were able to make the distinction between bodily injury (total) and aggravated bodily injury. In 2015 the highest conviction rates for aggravated bodily injury were in Hungary (45 per 100 000), Montenegro (25) and Germany (23), while very low rates were recorded in Turkey, Albania, Armenia, and Poland (under 3). As with total crime, the majority of countries show a decrease in the number of convictions over the period 2011-2016.

In the majority of countries, less than $10 \%$ of aggravated bodily injuries were committed by women with Finland (15.2\%) and Portugal (14.7\%) among the exceptions. The average proportion of minor offenders was $5.2 \%$ with Germany $(15.7 \%)$ well above this average. 


\section{Sanctions and measures}

Custody and suspended custodial sanctions and measures were the main sanctions for aggravated bodily injury, each with about $40 \%$ of the total convictions. Portugal (with 36\% fines) and Switzerland (66\% fines) were the exceptions. For minors, noncustodial sanctions were the main measure used (about $40 \%$ of the total).

\subsubsection{Rape}

\section{Convictions}

There were wide variations between countries in the rape conviction rate per 100 000 population, possibly reflecting both social as well as criminal justice variations. High levels were recorded in 2015 in Lithuania (7.1), Moldova (4.2), and Estonia (3.6). Very low levels were recorded in Armenia (0.1) and Ukraine (0.2). No clear trend was found for the period 2011-2016.

About $8 \%$ of those convicted were minors, with the highest proportions in France $(30 \%)$ and Hungary $(16.7 \%)$. As expected, the percentage, with an average of $1 \%$ the number of convicted women for rape is very low, with Serbia $(5.6 \%)$ and the Netherlands $(4.8 \%)$ being the highest.

\section{Sanctions and measures}

The majority (typically more than 90\%) of those offenders convicted of rape offences were sentenced to custody, of which about $70 \%$ unsuspended. For minors, custody and suspended sentences were the main sanctions used, each with a little over $40 \%$.

\subsubsection{Sexual assaults}

\section{Convictions}

Sexual assaults also include rapes. Conviction rates for sexual assault vary from about 1 (or even less) per 100000 in Ukraine (0.4), Albania (1.1) and Bulgaria (1.8) to more than 15 in Norway (15.5), Scotland (21.4) and Turkey (25.9). The trend over the period 2011-2016 is slightly increasing. Typically, about one third of the sexual assaults refer to sexual abuse of a child (minor). With an average of about $10 \%$, the highest proportion of minors convicted were in Czech Republic $(24.5 \%)$ and Switzerland $(19.2 \%)$.

\section{Sanctions and measures}

About half of the sanctions and measures for sexual assault were unsuspended custodial sanctions and measures with little variations between countries. For minors suspended custodial sanctions and measures were used most often. 


\subsubsection{Robbery}

\section{Convictions}

The highest numbers of robbery convictions per 100000 population were in Lithuania (29), Turkey and Moldova (28) with the lowest rates in France (0.8), Armenia (3.3) and Azerbaijan (3.4). Almost all countries showed a considerable decrease in the number of convictions in the period 2011-2016.

With $16 \%$ the number of minors convicted for robbery was high compared to most other crimes. Austria (34\%), Switzerland, England \& Wales, and Hungary (all $28 \%$ ) were the highest. The average number of women convicted for robbery was somewhat under $6 \%$.

\section{Sanctions and measures}

About $60 \%$ of all offenders received unsuspended custodial sanctions. However, this fell to about one third or lower in Germany, Portugal, and Switzerland. For minors, unsuspended custodial sentences were the main sanctions used (37\%).

\subsubsection{Theft}

It is important to note that this group includes burglaries, which in countries such as the UK are normally considered separately. Also, it excludes theft with violence (robbery), which in some countries will be (partly) included. The figures here therefore could relate to another range of offences than is often seen in international comparisons of police statistics. In this edition a new table on aggravated theft was included since many countries in Europe have this concept of aggravated theft in their legislation (which could include theft by means of burglary as well). Only a few countries provided figures for theft of a motor vehicle and (domestic) burglary separately.

\section{Convictions}

The highest rates for theft convictions were found in Finland (545 per 100000 population), a much higher rate than in the next group with Denmark (297), Turkey (226) and Scotland (233). Very low levels of theft convictions were found in Armenia (17) and Azerbaijan (20). In general, the number of theft convictions has decreased a little over this period.

Wide variations in convictions for minors reflect how the criminal justice system in each country deals with minors. England \& Wales (42\%), France (22\%) and Turkey $(21 \%)$ have the highest proportions of minors. A much higher proportion $(15 \%)$ of theft offenders were women than for most other offences, in particular in Finland (30\%), Scotland (29\%), Spain (38\%) and Sweden (33\%). 


\section{Sanctions and measures}

For thefts, unsuspended custody was the most frequently applied sanction for offenders (31\%) followed by suspended sentences (28\%) and fines (27\%). Only Armenia, Finland, Germany, Norway, and Switzerland showed a high use of fines, while non-custodial sanctions were applied most frequently in Croatia, Poland, and Serbia.

For minors, non-custodial sanctions were mainly used, although Bulgaria (40\%) and Turkey $(41 \%)$ had a high use of custody.

\subsubsection{Fraud}

Next to fraud, in this edition tables for cyber fraud and forgery of documents were introduced.

\section{Convictions}

The highest rates for fraud convictions were found in Germany (110), Finland (84) and Turkey (83), with very low levels in Ukraine (6), the Netherlands (5) and Armenia (3). Only a few countries could provide figures for cyber fraud. For forgery of documents the conviction rates vary from 2.1 (England \& Wales) to 63.4 (Hungary). There was no clear trend over the period 2011-2016.

A very low percentage of fraud offenders were minors, with the exception of Sweden and England \& Wales (6\%). A relatively high proportion (23\%) of offenders were women, in particular in Scotland (49\%), Germany, Finland, and Czech Republic (34\%).

\section{Sanctions and measures}

Suspended sentences were the most frequently used sanctions for fraud offences, with unsuspended custodial sanctions the next most frequent. Armenia and Georgia have a high use of custody.

The largest part (47\%) of minors were given non-custodial sanctions.

\subsubsection{Money laundering}

\section{Convictions}

While most countries provided data, only a few showed any significant level of convictions. Spain (5.9), Belgium (4.2), Switzerland (3.8) and Italy (3.1) were the highest. There were very few minors convicted of money laundering. About $25 \%$ of the offenders were women. In the Netherlands $5 \%$ of the convicted offenders for money laundering were legal persons. 


\section{Sanctions and measures}

Due to the small number of sanctions for this crime it is hard to draw any conclusions. Custodial sanctions, either suspended or unsuspended seem to be used the most. Too few minors were convicted to include any analysis.

\subsubsection{Corruption}

\section{Convictions}

By far the highest number of convictions for corruption were found in Lithuania (26.8). Other countries had a conviction rate of less than 5 , with many countries even below 1.

Only France $(10 \%)$ had any significant number of minors convicted. Corruption convictions were over 80\% males, except in Croatia and Sweden. Some convictions for legal persons were found in Finland and Romania.

\section{Sanctions and measures}

Suspended sentences were the most frequent sanctions used (about 50\%). Again, there were too few minors convicted to allow for analysis.

\subsubsection{Drug trafficking}

\section{Convictions}

The highest conviction rates were found in Finland (65 per 100000 population), Turkey (69) and Switzerland (99). While some countries showed a considerable increase (Sweden and France) there was no clear overall trend for the period 20112016.

Under $4 \%$ of those convicted for drug trafficking were minors. The average for women was between $8 \%$ and $9 \%$ with the highest proportion in Czech Republic $(17 \%)$.

\section{Sanctions and measures}

For the majority of countries custody was the most frequently used sanction for drug trafficking, with the exception of Finland and Switzerland.

Non-custodial sanctions and measures were frequently used for minors.

\subsubsection{Attrition and punitivity}

Attrition is defined as:

The "loss" of cases or, more technically, the filtering out of cases during the criminal justice process. Because the Sourcebook collects data on different aspects of the criminal justice process, this enabled - while producing the previous (fifth) edition of the 
Sourcebook - a study of attrition rates in the different countries of Europe. However, to describe attrition exactly it would be necessary to rely on case-flow statistics which follows the path of individual cases throughout the system. Few such statistics are available and true attrition rates are not collected at present. However, the study was able to thoroughly scrutinize the available attrition indicators and assess their quality and usability, taking into account the status quo of attrition research. Full results were reported in Heiskanen et al (2014). ${ }^{26}$

In summary, twelve possible indicators for attrition on the level of police, prosecution, courts, and prisons were identified, differentiating between intra level and inter level indicators. In the end, four indicators were proposed: the rate of offences, suspects, convicted persons and those sentenced to an unsuspended prison sentence. Their relation to each other reflects the different processes of attrition: Suspects per recorded offences (offender ratio), convicted per suspected persons (conviction ratio) and persons sentenced to unsuspended prison sentences per all persons convicted (punitivity ratio 1). Alternatively, while this last ratio gives a clear view of attrition on the conviction level, the punitivity ratio 3 (the number of prisoners divided by convicted persons) is better suited to look at punitivity itself because it combines both the ratio of unsuspended prison sentences and the length of the sentence actually served. See also Smit et al (2012). ${ }^{27}$

Using data from the first four editions of the Sourcebook, both the offender ratio and the conviction ratio have been calculated for several countries from 1900 to 2006. See Aebi \& Linde (2012). ${ }^{28}$ For a discussion on punitivity and other attrition indicators see also Blumstein et al. (2005), ${ }^{29}$ where punitivity is seen in two ways: in a broad sense it relates prison sentences to recorded crimes and in a narrow sense it is defined as the ratio between persons committed to prison and persons convicted multiplied by the average time served. This 'narrow punitiveness' is actually theoretically similar to the punitivity ratio 3 as defined here. However, in practice it is generally easier to get data for the number of prisoners than for the average time served. In the Sourcebook tables 3.2.5.1 - 3.2.5.21 only the average sentence imposed is available, not the average time served. And there are many missing values here.

We show below how the data collected in this edition enabled good estimates to be made of both the conviction ratio and the punitivity ratio (ratio 3 as mentioned

\footnotetext{
${ }^{26}$ Heiskanen, M., Aebi, M., van der Brugge, W. \& Jeble J.-M. (Eds.) Recording Community Sanctions and Measures and Assessing Attrition A Methodological Study on Comparative Data in Europe, published by HEUNI, 2014.

27 Smit, P., van Eijk, A. \& Decae, R. (2012). Trends in the Reaction on Crime in Criminal justice Systems in Europe in 1990-2007. European Journal on Criminal policy and Research, 18, 55-82.

28 Aebi, M.F. \& Linde, A. (2012). Crime Trends in Western Europe according to Official Statistics from 1990 to 2007. In van Dijk J., Tseloni A. and Farrell G. (Eds.). The International Crime Drop: New Directions in Research (pp. 37-75). New York, Houndmills: Palgrave Macmillan.

${ }^{29}$ Blumstein, A., Tonry, M. \& van Ness, A. (2005) Cross-National Measures of Punitiveness. Crime and Justice, 33 (Crime and Punishment in Western Countries, 1980-1999), pp.347-376.
} 
above) for various countries for the year 2016. Not all countries were able to provide data needed for the calculation of such ratios. A small number of countries with conviction ratios over 1.0 were also excluded as this almost certainly meant a statistical misalignment between the definitions for suspects and convictions. For the punitivity ratio it is perfectly all right for the ratio to be greater than 1 . However, in practice it was not possible to compute the punitivity ratio for different crime types, so only the ratio for total crime is given. Tables $3 \mathrm{~A}$ and $3 \mathrm{~B}$ summarize the information collected for 2016.

Table 3A Attrition: Examples of conviction ratios for main offence groups: Europe, 2016

\begin{tabular}{lrrrr} 
& $\begin{array}{c}\text { Number of countries } \\
\text { for which a convic- } \\
\text { tion ratio was calcu- } \\
\text { lated }\end{array}$ & $\begin{array}{c}\text { Low } \\
\text { Conviction ratio }\end{array}$ & $\begin{array}{c}\text { Medium } \\
\text { Conviction ratio }\end{array}$ & \multicolumn{1}{c}{$\begin{array}{c}\text { High } \\
\text { Conviction ratio }\end{array}$} \\
\hline Intentional homicide & 21 & 0.16 (Sweden) & 0.45 (Ukraine) & 1.00 (Hungary) \\
Bodily injury & 20 & 0.11 (Portugal) & 0.28 (France) & 0.87 (Poland) \\
Rape & 19 & 0.08 (Germany) & 0.37 (Italy) & 0.91 (Bulgaria) \\
Robbery & 21 & 0.03 (France) & 0.41 (Netherlands) & 0.98 (Azerbaijan) \\
Total theft & 23 & 0.10 (Austria) & 0.46 (Moldova) & 0.93 (Lithua- \\
& & & & nia) \\
\hline
\end{tabular}

Table 3B Punitivity: Examples of punitivity ratios for Total Crime: Europe, 2016

\begin{tabular}{lrrrr} 
& $\begin{array}{l}\text { Number of countries } \\
\text { for which a punitivity } \\
\text { ratio was calculated }\end{array}$ & $\begin{array}{c}\text { Low } \\
\text { Punitivity ratio }\end{array}$ & $\begin{array}{c}\text { Medium } \\
\text { Punitivity ratio }\end{array}$ & \multicolumn{1}{c}{$\begin{array}{c}\text { High } \\
\text { Punitivity ratio }\end{array}$} \\
\hline Total crime & 35 & 0.02 (Finland) & 0.23 (Portugal) & 1.12 (Ukraine) \\
& & 0.04 (Denmark) & 0.25 (Poland) & 1.51 (Armenia) \\
& 0.05 (Belgium) & 0.25 (Hungary) & 1.67 (Azerbaijan) \\
\hline
\end{tabular}

\subsubsection{Crime types, relative number of convicted persons}

Table 3C presents the relative position of eight of the above-mentioned crime types for persons convicted. Because of the variation in the way traffic offences are dealt with in different countries, the relative positions were computed using total offences excluding traffic offences.

Typically, theft is the most common crime with up to $46 \%$ (Ukraine) of the total. Next comes drugs crimes with an average of about twelve percent, followed by bodily injury with an average of eleven percent. As expected, the percentage of homicide convictions is low, with some exceptions only about a half percent. 
Table 3C Persons convicted by type of offence in percentage (excluding traffic offences), 2015:

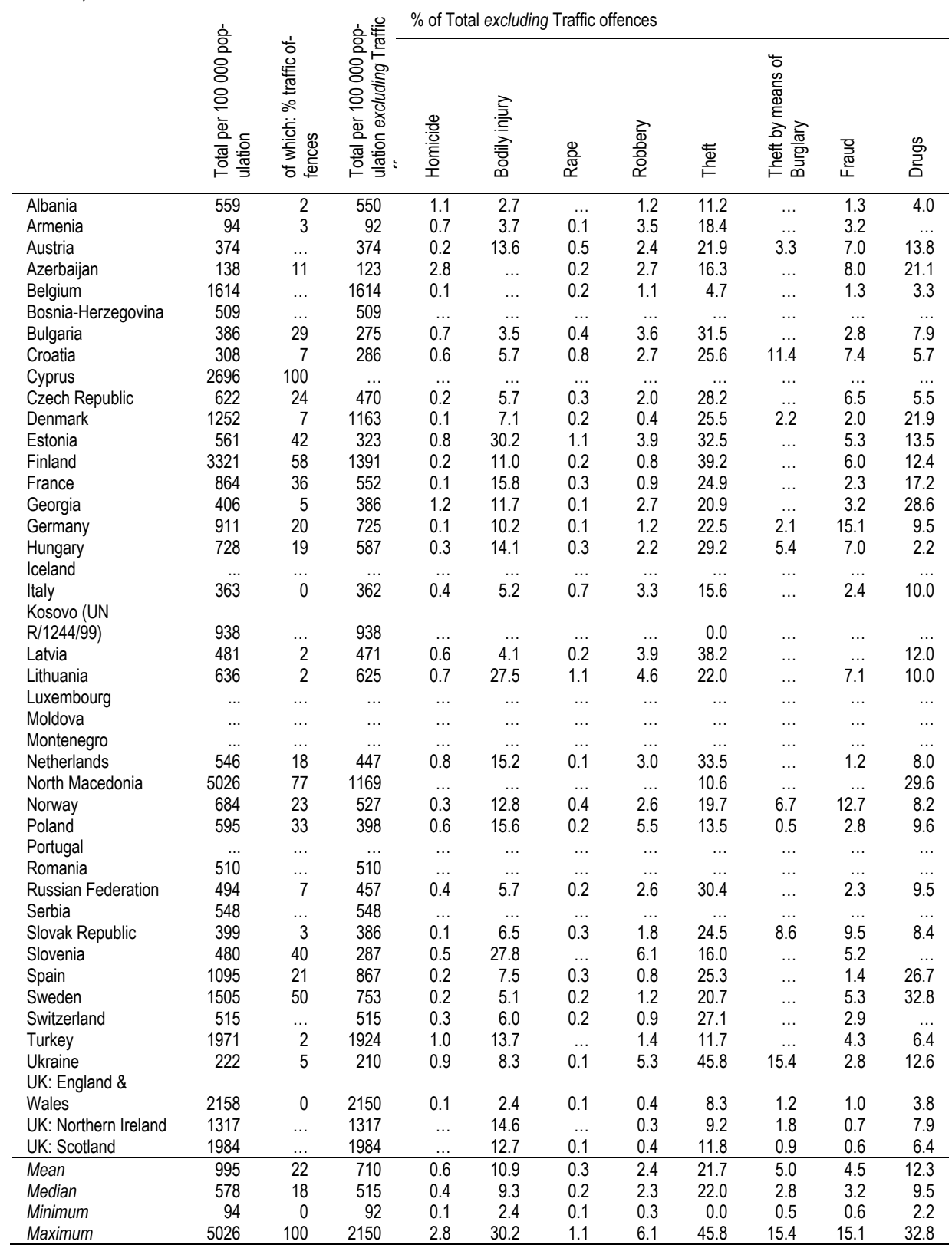




\subsection{Tables}

3.2.1 Total number of convictions per 100000 population

Table 3.2.1.1 Persons convicted per 100000 population - Criminal offences: Total

\begin{tabular}{|c|c|c|c|c|c|c|c|}
\hline & 2011 & 2012 & 2013 & 2014 & 2015 & 2016 & $\begin{array}{l}\% \text { change } \\
2011-2016\end{array}$ \\
\hline Albania & 312 & 299 & 296 & 436 & 559 & 521 & 67 \\
\hline Armenia & 121 & 114 & 120 & 101 & 94 & 84 & -30 \\
\hline Austria & 435 & 423 & 407 & 388 & 374 & 350 & -20 \\
\hline Azerbaijan & 148 & 140 & 139 & 141 & 138 & 142 & -4 \\
\hline Belgium & 2002 & 1974 & 1907 & 1529 & 1614 & 2184 & 9 \\
\hline $\begin{array}{l}\text { Bosnia-Herze- } \\
\text { govina }\end{array}$ & 409 & 465 & 537 & 530 & 509 & 490 & 20 \\
\hline Bulgaria & 557 & 519 & 468 & 440 & 386 & 396 & -29 \\
\hline Croatia & 567 & 500 & 406 & 367 & 308 & 330 & -42 \\
\hline Cyprus & 10338 & 8300 & 7024 & 8008 & 6387 & 5343 & -48 \\
\hline Czech Republic & 669 & 680 & 741 & 693 & 622 & 582 & -13 \\
\hline Denmark & 1195 & 1236 & 1151 & 1024 & 1252 & 1351 & 13 \\
\hline Estonia & 769 & 727 & 644 & 585 & 561 & 582 & -24 \\
\hline Finland & 3776 & 3537 & 3367 & 3175 & 3321 & 2899 & -23 \\
\hline France & 930 & 935 & 913 & 874 & 864 & 874 & -6 \\
\hline Georgia & 406 & 243 & 375 & 374 & 406 & 420 & 3 \\
\hline Germany & 1007 & 963 & 939 & 927 & 911 & 898 & -11 \\
\hline Greece & $\ldots$ & $\ldots$ & $\ldots$ & $\ldots$ & $\ldots$ & $\ldots$ & $\ldots$ \\
\hline Hungary & 852 & 758 & 733 & 773 & 728 & 729 & -15 \\
\hline Iceland & $\ldots$ & $\ldots$ & $\ldots$ & $\ldots$ & $\ldots$ & $\ldots$ & $\ldots$ \\
\hline Italy & 448 & 438 & 414 & 373 & 363 & 346 & -23 \\
\hline Kosovo (UN & & & & & & & 2 \\
\hline R/1244/99) & 1024 & 1163 & 868 & 1006 & 938 & 1047 & 2 \\
\hline Latvia & 443 & 438 & 427 & 460 & 481 & 453 & 2 \\
\hline Lithuania & 574 & 655 & 691 & 721 & 636 & 563 & -2 \\
\hline Luxembourg & $\ldots$ & $\ldots$ & $\ldots$ & $\ldots$ & $\ldots$ & 1463 & $\ldots$ \\
\hline Moldova & $\ldots$ & $\ldots$ & $\ldots$ & $\ldots$ & $\ldots$ & $\ldots$ & $\ldots$ \\
\hline Montenegro & $\ldots$ & $\ldots$ & $\ldots$ & $\ldots$ & $\ldots$ & $\ldots$ & $\ldots$ \\
\hline Netherlands & 589 & 555 & 553 & 534 & 546 & 489 & -17 \\
\hline North Macedonia & 512 & 466 & 485 & 588 & 515 & 417 & -19 \\
\hline Norway & 5652 & 5611 & 5430 & 5250 & 5026 & 4973 & -12 \\
\hline Poland & 1113 & 1072 & 928 & 773 & 684 & 763 & -31 \\
\hline Portugal & 763 & 785 & 711 & 532 & 597 & 570 & -25 \\
\hline Romania & $\ldots$ & $\ldots$ & $\ldots$ & $\ldots$ & $\ldots$ & 169 & $\ldots$ \\
\hline $\begin{array}{l}\text { Russian Federa- } \\
\text { tion }\end{array}$ & 548 & 517 & 513 & 501 & 510 & 513 & -6 \\
\hline Serbia & 456 & 466 & 486 & 523 & 494 & 488 & 7 \\
\hline Slovak Republic & 558 & 649 & 667 & 621 & 548 & 501 & -10 \\
\hline Slovenia & 389 & 429 & 571 & 472 & 399 & 339 & -13 \\
\hline Spain & 587 & 588 & 589 & 598 & 622 & 786 & 34.0 \\
\hline Sweden & 1448 & 1372 & 1221 & 1140 & 1095 & 999 & -31 \\
\hline Switzerland & 1417 & 1528 & 1551 & 1543 & 1505 & 1481 & 4 \\
\hline Turkey & 1683 & 2027 & 2123 & 1899 & 1971 & 1816 & 8 \\
\hline Ukraine & 339 & 358 & 271 & 226 & 222 & 179 & -47 \\
\hline UK: England \& & & & & & & & -9 \\
\hline Wales & 2339 & 2177 & 2071 & 2121 & 2158 & 2124 & -9 \\
\hline $\begin{array}{l}\text { UK: Northern Ire- } \\
\text { land }\end{array}$ & 1832 & 1725 & 1576 & 1446 & 1317 & 1269 & -31 \\
\hline UK: Scotland & 2181 & 2040 & 1896 & 1976 & 1984 & 1849 & -15 \\
\hline Mean & 1300 & 1233 & 1163 & 1149 & 1096 & 1044 & \\
\hline Median & 629 & 668 & 679 & 609 & 608 & 575 & \\
\hline Minimum & 121 & 114 & 120 & 101 & 94 & 84 & \\
\hline Maximum & 10338 & 8300 & 7024 & 8008 & 6387 & 5343 & \\
\hline
\end{tabular}


Table 3.2.1.2 Persons convicted per 100000 population - Major road traffic offences

\begin{tabular}{|c|c|c|c|c|c|c|c|}
\hline & 2011 & 2012 & 2013 & 2014 & 2015 & 2016 & $\begin{array}{l}\% \text { change } \\
2011-2016\end{array}$ \\
\hline Albania & 26 & 23 & 25 & 10 & 10 & 99 & 283 \\
\hline Armenia & 3 & 4 & 4 & 4 & 3 & 4 & 23 \\
\hline Austria & $\ldots$ & $\ldots$ & $\ldots$ & $\ldots$ & $\ldots$ & $\ldots$ & $\ldots$ \\
\hline Azerbaijan & 15 & 16 & 19 & 16 & 15 & 12 & -21 \\
\hline $\begin{array}{l}\text { Belgium } \\
\text { Bosnia-Herze- }\end{array}$ & 1428 & 1570 & $\ldots$ & $\ldots$ & $\ldots$ & $\ldots$ & $\ldots$ \\
\hline Bulgaria & 144 & 127 & 113 & 108 & 111 & 130 & -10 \\
\hline Croatia & 38 & 35 & 30 & 25 & 22 & 24 & -37 \\
\hline Cyprus & 6190 & 4460 & 3840 & 4204 & 2696 & 2410 & -61 \\
\hline Czech Republic & 162 & 155 & 161 & 159 & 152 & 140 & -14 \\
\hline Denmark & 147 & 149 & 125 & 107 & 89 & 77 & -47 \\
\hline Estonia & 254 & 245 & 234 & 221 & 238 & 242 & -5 \\
\hline Finland & 2222 & 2068 & 1961 & 1858 & 1930 & 1682 & -24 \\
\hline France & 368 & 349 & 335 & 319 & 313 & 315 & -14 \\
\hline Georgia & 18 & 14 & 15 & 17 & 20 & 17 & -5 \\
\hline Germany & 215 & 208 & 198 & 194 & 186 & 188 & -13 \\
\hline Hungary & 155 & 146 & 102 & 134 & 141 & 159 & 3 \\
\hline $\begin{array}{l}\text { Iceland } \\
\text { Italy }\end{array}$ & $\begin{array}{l}\ldots \\
2\end{array}$ & $\begin{array}{l}\ldots \\
2\end{array}$ & $\begin{array}{l}\ldots \\
2\end{array}$ & $\begin{array}{l}\ldots \\
2\end{array}$ & $\begin{array}{l}\ldots \\
2\end{array}$ & $\begin{array}{l}\ldots \\
2\end{array}$ & .. \\
\hline Kosovo (UN & & & & & & & \\
\hline R/1244/99) & $\ldots$ & $\ldots$ & $\ldots$ & $\ldots$ & $\ldots$ & $\ldots$ & $\cdots$ \\
\hline Latvia & 9 & 9 & 8 & 10 & 10 & 10 & 16 \\
\hline Lithuania & 13 & 12 & 12 & 11 & 12 & 10 & -27 \\
\hline Luxembourg & $\ldots$ & $\ldots$ & $\ldots$ & $\ldots$ & $\ldots$ & $\ldots$ & $\ldots$ \\
\hline Moldova & 45 & 55 & 61 & 78 & 90 & 76 & 69 \\
\hline Montenegro & & 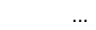 & $\ldots$ & $\ldots$ & & $\ldots$ & $\ldots$ \\
\hline Netherlands & 92 & 91 & 97 & 89 & 98 & 69 & -25 \\
\hline North Macedonia & $\ldots$ & $\ldots$ & $\ldots$ & $\ldots$ & $\ldots$ & $\ldots$ & $\ldots$ \\
\hline Norway & 4392 & 4376 & 4174 & 4063 & 3857 & 3840 & -13 \\
\hline Poland & 365 & 350 & 264 & 190 & 157 & 168 & -54 \\
\hline Portugal & 324 & 307 & 251 & 171 & 197 & 186 & -43 \\
\hline Romania & $\ldots$ & $\ldots$ & $\ldots$ & $\ldots$ & $\ldots$ & 56 & $\ldots$ \\
\hline $\begin{array}{l}\text { Russian Federa- } \\
\text { tion }\end{array}$ & & $\ldots$ & & $\ldots$ & $\ldots$ & $\ldots$ & $\cdots$ \\
\hline Serbia & 52 & 47 & 50 & 49 & 37 & 31 & -40 \\
\hline Slovak Republic & $\ldots$ & $\ldots$ & $\ldots$ & $\ldots$ & $\ldots$ & $\ldots$ & $\ldots$ \\
\hline Slovenia & 15 & 15 & 20 & 16 & 13 & 17 & 13 \\
\hline Spain & 247 & 227 & 217 & 208 & 193 & 187 & -24 \\
\hline Sweden & 303 & 282 & 250 & 234 & 229 & 211 & -31 \\
\hline Switzerland & 723 & 745 & 733 & 768 & 752 & 737 & 2 \\
\hline Turkey & 7 & 10 & 16 & 34 & 47 & 48 & 549 \\
\hline Ukraine & 12 & 14 & 13 & 13 & 12 & 10 & -21 \\
\hline UK: England \& & & & & & & & 12 \\
\hline Wales & 8 & 7 & 7 & 7 & 8 & 9 & 12 \\
\hline UK: Northern Ire- & & & & & & & \\
\hline land & $\ldots$ & $\ldots$ & $\ldots$ & $\ldots$ & $\ldots$ & $\ldots$ & $\cdots$ \\
\hline UK: Scotland & $\ldots$ & $\ldots$ & $\ldots$ & $\ldots$ & $\ldots$ & $\ldots$ & $\ldots$ \\
\hline Mean & 580 & 520 & 445 & 444 & 388 & 360 & \\
\hline Median & 144 & 127 & 100 & 98 & 94 & 77 & \\
\hline Minimum & 2 & 2 & 2 & 2 & 2 & 2 & \\
\hline Maximum & 6190 & 4460 & 4174 & 4204 & 3857 & 3840 & \\
\hline
\end{tabular}


Table 3.2.1.3 Persons convicted per 100000 population - Intentional homicide: Total

\begin{tabular}{|c|c|c|c|c|c|c|c|}
\hline & 2011 & 2012 & 2013 & 2014 & 2015 & 2016 & $\begin{array}{l}\% \text { change } \\
2011-2016\end{array}$ \\
\hline Albania & 7.3 & 6.6 & 5.2 & 6.2 & 5.9 & 4.8 & -34 \\
\hline Armenia & 1.7 & 1.5 & 1.3 & 1.3 & 0.6 & 0.8 & -53 \\
\hline Austria & 0.8 & 0.7 & 0.6 & 0.9 & 0.7 & 0.7 & -4 \\
\hline Azerbaijan & 2.8 & 3.2 & 3.7 & 3.0 & 3.5 & 3.0 & 10 \\
\hline Belgium & 2.3 & 2.7 & 2.3 & 2.1 & 2.3 & 2.2 & -4 \\
\hline \multicolumn{8}{|l|}{$\begin{array}{l}\text { Bosnia-Herze- } \\
\text { govina }\end{array}$} \\
\hline Bulgaria & 2.0 & 1.9 & 1.5 & 1.5 & 1.8 & 1.4 & -30 \\
\hline Croatia & 3.5 & 2.5 & 2.9 & 2.7 & 1.8 & 1.8 & -50 \\
\hline \multicolumn{8}{|l|}{ Cyprus } \\
\hline Czech Republic & 1.2 & 1.1 & 1.2 & 1.3 & 1.1 & 0.9 & -25 \\
\hline Denmark & 1.1 & 1.2 & 1.3 & 0.9 & 1.2 & 1.0 & -6 \\
\hline Estonia & 3.0 & 4.5 & 5.2 & 2.4 & 2.7 & 2.7 & -9 \\
\hline Finland & 3.6 & 3.3 & 3.3 & 3.6 & 2.6 & 2.7 & -25 \\
\hline France & 0.6 & 0.7 & 0.6 & 0.6 & 0.6 & 0.7 & 9 \\
\hline Georgia & 4.5 & 5.5 & 4.7 & 3.6 & 4.5 & 6.4 & 42 \\
\hline Germany & 0.8 & 0.8 & 0.7 & 0.7 & 0.7 & 0.7 & -12 \\
\hline Hungary & 2.0 & 2.6 & 2.7 & 2.2 & 1.9 & 2.1 & 3 \\
\hline Iceland & & $\ldots$ & & & $\ldots$ & $\ldots$ & $\ldots$ \\
\hline Italy & 1.6 & 1.6 & 1.7 & 1.7 & 1.6 & 1.8 & 10 \\
\hline \multicolumn{8}{|l|}{ Kosovo (UN } \\
\hline R/1244/99) & $\ldots$ & $\ldots$ & $\ldots$ & & & & $\cdots$ \\
\hline Latvia & 3.1 & 4.1 & 3.1 & 3.7 & 2.7 & 2.8 & -8 \\
\hline Lithuania & 7.1 & 6.3 & 5.8 & 6.7 & 4.5 & 5.0 & -29 \\
\hline Luxembourg & $\ldots$ & $\ldots$ & $\ldots$ & $\ldots$ & $\ldots$ & 9.5 & $\ldots$ \\
\hline Moldova & 4.9 & 4.5 & 3.9 & 4.1 & 3.4 & 4.2 & -15 \\
\hline \multicolumn{8}{|l|}{ Montenegro } \\
\hline Netherlands & 5.5 & 4.9 & 4.7 & 3.9 & 3.6 & 3.2 & -41 \\
\hline North Macedonia & 1.7 & 1.8 & 1.5 & 1.5 & 1.5 & 1.4 & -21 \\
\hline Norway & $\ldots$ & $\ldots$ & $\ldots$ & $\ldots$ & $\ldots$ & $\ldots$ & $\ldots$ \\
\hline Poland & 1.8 & 1.8 & 1.8 & 1.4 & 1.5 & 1.4 & -22 \\
\hline Portugal & 2.9 & 3.1 & 2.8 & 2.5 & 2.3 & 2.1 & -28 \\
\hline Romania & $\ldots$ & $\ldots$ & $\ldots$ & $\ldots$ & $\ldots$ & 4.6 & $\ldots$ \\
\hline \multicolumn{8}{|l|}{$\begin{array}{l}\text { Russian Federa- } \\
\text { tion }\end{array}$} \\
\hline Serbia & 2.8 & 2.8 & 2.6 & 2.8 & 1.9 & 2.5 & -10 \\
\hline Slovak Republic & $\ldots$ & $\ldots$ & $\ldots$ & $\ldots$ & $\ldots$ & $\ldots$ & $\ldots$ \\
\hline Slovenia & 0.3 & 0.4 & 0.5 & 0.7 & 0.5 & 0.3 & -1 \\
\hline Spain & $\ldots$ & $\ldots$ & 1.7 & 1.6 & 1.6 & 1.4 & $\ldots$ \\
\hline Sweden & 1.4 & 1.4 & 1.5 & 1.4 & 1.6 & 1.7 & 20 \\
\hline Switzerland & 1.1 & 1.5 & 1.6 & 1.6 & 1.5 & 1.5 & 31 \\
\hline Turkey & 20.6 & 23.8 & 27.6 & 18.9 & 19.7 & 21.1 & 2 \\
\hline Ukraine & 3.1 & 3.3 & 2.9 & 2.0 & 1.9 & 1.5 & -50 \\
\hline \multicolumn{8}{|l|}{ UK: England \& } \\
\hline Wales & 2.7 & 2.5 & 2.4 & 2.5 & 2.5 & 2.6 & -2 \\
\hline \multirow{2}{*}{\multicolumn{8}{|c|}{$\begin{array}{l}\text { UK: Northern Ire- } \\
\text { land }\end{array}$}} \\
\hline & $\ldots$ & $\ldots$ & $\ldots$ & $\ldots$ & $\ldots$ & $\ldots$ & $\cdots$ \\
\hline UK: Scotland & $\ldots$ & $\ldots$ & $\ldots$ & $\ldots$ & $\ldots$ & $\ldots$ & $\ldots$ \\
\hline Mean & 3.3 & 3.4 & 3.3 & 2.9 & 2.7 & 3.1 & \\
\hline Median & 2.5 & 2.6 & 2.4 & 2.1 & 1.9 & 2.1 & \\
\hline Minimum & 0.3 & 0.4 & 0.5 & 0.6 & 0.5 & 0.3 & \\
\hline Maximum & 20.6 & 23.8 & 27.6 & 18.9 & 19.7 & 21.1 & \\
\hline
\end{tabular}


Table 3.2.1.4 Persons convicted per 100000 population - Intentional homicide: Completed

\begin{tabular}{|c|c|c|c|c|c|c|c|}
\hline & 2011 & 2012 & 2013 & 2014 & 2015 & 2016 & $\begin{array}{l}\% \text { change } \\
2011-2016\end{array}$ \\
\hline Albania & & $\ldots$ & $\ldots$ & $\ldots$ & $\ldots$ & $\ldots$ & $\ldots$ \\
\hline Armenia & 1.2 & $\ldots$ & $\ldots$ & $\ldots$ & $\ldots$ & 0.6 & -53 \\
\hline Austria & 0.3 & 0.5 & 0.4 & 0.4 & 0.3 & 0.4 & 6 \\
\hline Azerbaijan & $\ldots$ & $\ldots$ & $\ldots$ & $\ldots$ & $\ldots$ & $\ldots$ & $\ldots$ \\
\hline $\begin{array}{l}\text { Belgium } \\
\text { Bosnia-Herze- } \\
\text { govina }\end{array}$ & $\ldots$ & $\ldots$ & $\ldots$ & $\ldots$ & $\ldots$ & $\ldots$ & $\ldots$ \\
\hline Bulgaria & 1.5 & 1.5 & 1.0 & 1.0 & 1.4 & 1.1 & -26 \\
\hline Croatia & 1.3 & 1.2 & 1.6 & 1.2 & 0.8 & 0.7 & -48 \\
\hline $\begin{array}{l}\text { Cyprus } \\
\text { Czech Republic }\end{array}$ & $\begin{array}{l}\ldots \\
\ldots\end{array}$ & $\begin{array}{l}\ldots \\
\ldots\end{array}$ & $\begin{array}{l}\ldots \\
\ldots\end{array}$ & $\begin{array}{l}\ldots \\
\ldots\end{array}$ & $\begin{array}{l}\ldots \\
\ldots\end{array}$ & $\begin{array}{l}\ldots \\
\ldots\end{array}$ & $\begin{array}{l}\ldots \\
\ldots\end{array}$ \\
\hline Denmark & 0.6 & 0.8 & 0.5 & 0.4 & 0.6 & 0.4 & -36 \\
\hline Estonia & $\ldots$ & $\ldots$ & $\ldots$ & $\ldots$ & $\ldots$ & $\ldots$ & $\ldots$ \\
\hline Finland & 1.5 & 1.3 & 1.2 & 1.4 & 1.0 & 1.0 & -35 \\
\hline France & 0.2 & 0.2 & 0.2 & 0.2 & 0.2 & 0.2 & -10 \\
\hline Georgia & 4.5 & 5.5 & 4.7 & 3.6 & 4.5 & 6.4 & 42 \\
\hline Germany & 0.4 & 0.4 & 0.4 & 0.4 & 0.4 & 0.4 & -4 \\
\hline $\begin{array}{l}\text { Hungary } \\
\text { Iceland }\end{array}$ & $\begin{array}{r}1.1 \\
\ldots\end{array}$ & $\begin{array}{r}1.3 \\
\ldots\end{array}$ & $\begin{array}{r}1.3 \\
\ldots\end{array}$ & $\begin{array}{r}1.1 \\
\ldots\end{array}$ & $\begin{array}{r}1.0 \\
\ldots\end{array}$ & $\begin{array}{r}1.2 \\
\ldots\end{array}$ & $\begin{array}{l}9 \\
\ldots\end{array}$ \\
\hline $\begin{array}{l}\text { Italy } \\
\text { Kosovo (UN }\end{array}$ & 0.8 & 0.8 & 0.9 & 1.0 & 0.8 & 1.0 & 34 \\
\hline$R / 1244 / 99)$ & $\ldots$ & $\ldots$ & $\ldots$ & $\ldots$ & $\ldots$ & $\ldots$ & $\ldots$ \\
\hline Latvia & $\ldots$ & $\ldots$ & $\ldots$ & $\ldots$ & $\ldots$ & $\ldots$ & $\cdots$ \\
\hline Lithuania & $\ldots$ & $\ldots$ & $\ldots$ & $\ldots$ & $\ldots$ & $\ldots$ & $\ldots$ \\
\hline Luxembourg & $\ldots$ & $\ldots$ & $\ldots$ & $\ldots$ & $\ldots$ & 0.3 & $\ldots$ \\
\hline Moldova & 4.9 & 4.5 & 3.9 & 4.1 & 3.4 & 4.2 & -15 \\
\hline Montenegro & $\ldots$ & $\ldots$ & $\ldots$ & $\ldots$ & $\ldots$ & $\ldots$ & $\ldots$ \\
\hline Netherlands & $\ldots$ & $\ldots$ & $\ldots$ & $\ldots$ & $\ldots$ & $\ldots$ & $\ldots$ \\
\hline North Macedonia & $\ldots$ & $\ldots$ & $\ldots$ & $\ldots$ & $\ldots$ & $\ldots$ & $\ldots$ \\
\hline Norway & $\ldots$ & $\ldots$ & $\ldots$ & $\ldots$ & $\ldots$ & $\ldots$ & $\ldots$ \\
\hline Poland & 1.5 & 1.4 & $\ldots$ & $\ldots$ & 1.1 & 1.1 & -24 \\
\hline Portugal & 1.3 & 1.3 & 1.3 & 1.1 & 1.1 & 0.9 & -33 \\
\hline $\begin{array}{l}\text { Romania } \\
\text { Russian Federa- } \\
\text { tion }\end{array}$ & $\ldots$ & $\ldots$ & $\ldots$ & $\ldots$ & $\ldots$ & $\ldots$ & $\ldots$ \\
\hline Serbia & 1.9 & 1.7 & 1.7 & 2.0 & 1.3 & 1.5 & -22 \\
\hline Slovak Republic & $\ldots$ & $\ldots$ & $\ldots$ & & & $\ldots$ & $\ldots$ \\
\hline Slovenia & 0.3 & 0.4 & 0.5 & 0.7 & 0.5 & 0.3 & -1 \\
\hline Spain & $\ldots$ & $\ldots$ & 0.7 & 0.7 & 0.7 & 0.5 & $\ldots$ \\
\hline Sweden & $\ldots$ & $\ldots$ & $\ldots$ & $\ldots$ & $\ldots$ & $\ldots$ & $\ldots$ \\
\hline Switzerland & 0.4 & 0.5 & 0.5 & 0.6 & 0.6 & 0.5 & 21 \\
\hline Turkey & $\ldots$ & $\ldots$ & $\ldots$ & $\ldots$ & $\ldots$ & $\ldots$ & $\ldots$ \\
\hline $\begin{array}{l}\text { Ukraine } \\
\text { UK: England \& }\end{array}$ & $\ldots$ & $\ldots$ & $\ldots$ & 0.0 & $\ldots$ & $\ldots$ & $\ldots$ \\
\hline $\begin{array}{l}\text { Wales } \\
\text { UK: Northern Ire- } \\
\text { land }\end{array}$ & 0.6 & 0.6 & 0.6 & 0.6 & 0.5 & 0.5 & -19 \\
\hline UK: Scotland & 2.2 & 2.1 & 2.2 & 1.7 & 1.5 & 1.6 & -30 \\
\hline Mean & 1.4 & 1.4 & 1.3 & 1.2 & 1.1 & 1.2 & \\
\hline Median & 1.2 & 1.3 & 1.0 & 1.0 & 0.8 & 0.7 & \\
\hline Minimum & 0.2 & 0.2 & 0.2 & 0.0 & 0.2 & 0.2 & \\
\hline Maximum & 4.9 & 5.5 & 4.7 & 4.1 & 4.5 & 6.4 & \\
\hline
\end{tabular}


Table 3.2.1.5 Persons convicted per 100000 population - Bodily injury

\begin{tabular}{|c|c|c|c|c|c|c|c|}
\hline & 2011 & 2012 & 2013 & 2014 & 2015 & 2016 & $\begin{array}{l}\% \text { change } \\
2011-2016\end{array}$ \\
\hline Albania & 18 & 18 & 13 & 11 & 15 & 13 & -30 \\
\hline Armenia & 6 & 4 & 5 & 4 & 3 & 4 & -26 \\
\hline Austria & 67 & 66 & 60 & 55 & 51 & 49 & -27 \\
\hline Azerbaijan & $\ldots$ & & $\ldots$ & $\ldots$ & $\ldots$ & $\ldots$ & $\ldots$ \\
\hline $\begin{array}{l}\text { Belgium } \\
\text { Bosnia-Herze- }\end{array}$ & 59 & 55 & 53 & 52 & $\ldots$ & $\ldots$ & $\ldots$ \\
\hline govina & & & & $\ldots$ & & & \\
\hline Bulgaria & 14 & 13 & 10 & 11 & 10 & 10 & -23 \\
\hline Croatia & 22 & 20 & 21 & 19 & 16 & 18 & -19 \\
\hline Cyprus & & & & & & & \\
\hline Czech Republic & 26 & 30 & 31 & 28 & 27 & 28 & 10 \\
\hline Denmark & 114 & 109 & 94 & 83 & 83 & 83 & -27 \\
\hline Estonia & 121 & 114 & 105 & 93 & 98 & 110 & -10 \\
\hline Finland & 199 & 209 & 193 & 169 & 153 & 142 & -29 \\
\hline France & 88 & 93 & 90 & 86 & 87 & $\begin{array}{l}88 \\
88\end{array}$ & 0 \\
\hline Georgia & 35 & 23 & 16 & 30 & 45 & 16 & -55 \\
\hline Germany & 96 & 91 & 86 & 79 & 74 & 74 & -23 \\
\hline Hungary & 52 & 48 & 84 & 89 & 83 & 77 & 47 \\
\hline Iceland & & & & & & & \\
\hline Italy & 23 & 21 & 21 & 18 & 19 & 20 & -14 \\
\hline $\begin{array}{l}\text { Kosovo } \\
\text { (UN R/1244/99) }\end{array}$ & & & & $\ldots$ & & & ... \\
\hline Latvia & 17 & 15 & 19 & 19 & 19 & 17 & 3 \\
\hline Lithuania & 52 & 127 & 164 & 174 & 172 & 170 & 227 \\
\hline Luxembourg & & & & & & 802 & \\
\hline $\begin{array}{l}\text { Moldova } \\
\text { la }\end{array}$ & 8 & 6 & 6 & 6 & 5 & 5 & -41 \\
\hline Montenegro & & & & & & & \\
\hline Netherlands & 78 & 74 & 71 & 68 & 68 & 62 & -21 \\
\hline North Macedonia & 37 & 34 & 36 & 36 & 31 & 31 & -18 \\
\hline Norway & & & & & & & \\
\hline Poland & 88 & 84 & 79 & 72 & 67 & 71 & -20 \\
\hline Portugal & 68 & 70 & 70 & 57 & 62 & 61 & -11 \\
\hline Romania & $\ldots$ & $\ldots$ & $\ldots$ & $\ldots$ & $\ldots$ & 13 & $\ldots$ \\
\hline $\begin{array}{l}\text { Russian Federa- } \\
\text { tion }\end{array}$ & & & & & & & \\
\hline Serbia & 28 & 28 & 29 & 31 & 26 & 24 & -15 \\
\hline Slovak Republic & & & & & & & \\
\hline Slovenia & 32 & 28 & 35 & 27 & 25 & 20 & -36 \\
\hline Spain & 72 & 72 & 73 & 72 & 80 & 119 & 65 \\
\hline Sweden & 100 & 87 & 79 & 66 & 65 & 57 & -43 \\
\hline Switzerland & 44 & 45 & 44 & 42 & 39 & 38 & -13 \\
\hline Turkey & 133 & 168 & 218 & 217 & 263 & 240 & 81 \\
\hline Ukraine & $\ldots$ & $\ldots$ & $\ldots$ & $\ldots$ & 17 & $\ldots$ & $\ldots$ \\
\hline UK: England \& & & & & & & & \\
\hline Wales & 55 & 47 & 43 & 47 & 51 & 50 & -8 \\
\hline UK: Northern Ire- & & & & & & 182 & \\
\hline $\begin{array}{l}\text { land } \\
\text { UK: Scotland }\end{array}$ & 286 & $\begin{array}{l}223 \\
305\end{array}$ & $\begin{array}{l}212 \\
259\end{array}$ & $\begin{array}{l}185 \\
243\end{array}$ & $\begin{array}{l}192 \\
252\end{array}$ & $\begin{array}{l}182 \\
260\end{array}$ & 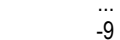 \\
\hline Mean & 68 & 75 & 75 & 71 & 71 & 92 & \\
\hline Median & 53 & 55 & 60 & 55 & 51 & 54 & \\
\hline Minimum & 6 & 4 & 5 & 4 & 3 & 4 & \\
\hline Maximum & 286 & 305 & 259 & 243 & 263 & 802 & \\
\hline
\end{tabular}


Table 3.2.1.6 Persons convicted per 100000 population - Aggravated bodily injury

\begin{tabular}{|c|c|c|c|c|c|c|c|}
\hline & 2011 & 2012 & 2013 & 2014 & 2015 & 2016 & $\begin{array}{l}\% \text { change } \\
2011-2016\end{array}$ \\
\hline Albania & 3.4 & 4.2 & 3.2 & 3.2 & 2.5 & 2.3 & -34 \\
\hline Armenia & 3.4 & 2.9 & 4.0 & 3.6 & 2.9 & 2.6 & -22 \\
\hline Austria & 14.0 & 15.8 & 14.6 & 12.2 & 12.0 & 11.2 & -20 \\
\hline Azerbaijan & 2.5 & 2.9 & 3.1 & 4.7 & 3.1 & 3.1 & 23 \\
\hline \multicolumn{7}{|l|}{ Bosnia-Herze- } & $\ldots$ \\
\hline govina & $\ldots$ & $\ldots$ & $\ldots$ & $\ldots$ & $\ldots$ & $\ldots$ & $\ldots$ \\
\hline Bulgaria & $\ldots$ & $\ldots$ & $\ldots$ & $\ldots$ & $\ldots$ & 0.4 & $\ldots$ \\
\hline Croatia & 13.2 & 13.5 & 12.9 & 10.6 & 8.8 & 10.5 & -20 \\
\hline \multicolumn{8}{|l|}{ Cyprus } \\
\hline Czech Republic & 4.6 & 4.9 & 4.8 & 3.9 & 4.2 & 4.6 & 1 \\
\hline Denmark & 17.7 & 16.7 & 15.4 & 12.0 & 12.0 & 12.5 & -29 \\
\hline Estonia & 4.9 & 6.7 & 4.0 & 4.2 & 3.0 & 4.9 & 1 \\
\hline Finland & 12.2 & 11.6 & 10.6 & 9.4 & 9.9 & 8.9 & -27 \\
\hline France & 13.7 & 13.5 & 13.2 & 12.3 & 12.7 & 12.5 & -9 \\
\hline Georgia & 2.0 & 1.5 & 5.2 & 6.0 & 6.1 & 4.0 & 102 \\
\hline Germany & 35.3 & 32.0 & 28.4 & 25.1 & 23.4 & 22.9 & -35 \\
\hline $\begin{array}{l}\text { Hungary } \\
\text { Iceland }\end{array}$ & 39.3 & 36.4 & 46.0 & 49.7 & 45.2 & 41.1 & $\begin{array}{c}5 \\
\ldots\end{array}$ \\
\hline Italy & 12.7 & 12.3 & 12.2 & 11.0 & 11.9 & 12.8 & 1 \\
\hline \multicolumn{8}{|l|}{ Kosovo (UN } \\
\hline \multicolumn{8}{|l|}{ R/1244/99) } \\
\hline Latvia & 7.9 & 7.0 & 7.9 & 7.7 & 8.3 & 7.2 & -8 \\
\hline Lithuania & 8.1 & 6.3 & 7.4 & 8.0 & 6.3 & 6.5 & -19 \\
\hline Luxembourg & $\ldots$ & $\ldots$ & $\ldots$ & $\ldots$ & $\ldots$ & $\ldots$ & $\ldots$ \\
\hline Moldova & $\ldots$ & $\ldots$ & $\ldots$ & $\ldots$ & $\ldots$ & $\ldots$ & $\ldots$ \\
\hline Montenegro & 18.4 & 27.7 & 28.8 & 25.4 & 25.2 & 25.1 & 36 \\
\hline Netherlands & 11.3 & 10.4 & 9.4 & 8.5 & 7.3 & 6.5 & -43 \\
\hline North Macedonia & 11.4 & 8.4 & 9.2 & 10.2 & 8.2 & 7.0 & -38 \\
\hline Norway & & $\ldots$ & $\ldots$ & $\ldots$ & $\ldots$ & $\ldots$ & $\ldots$ \\
\hline Poland & 2.7 & 2.6 & 2.5 & 1.8 & 2.2 & 2.3 & -15 \\
\hline Portugal & 9.6 & 12.2 & 11.2 & 9.4 & 9.6 & 10.2 & 6 \\
\hline Romania & $\ldots$ & $\ldots$ & $\ldots$ & $\ldots$ & $\ldots$ & 1.6 & $\ldots$ \\
\hline \multicolumn{8}{|l|}{$\begin{array}{l}\text { Russian Federa- } \\
\text { tion }\end{array}$} \\
\hline Serbia & 11.1 & 11.5 & 12.0 & 12.4 & 10.8 & 10.6 & -4 \\
\hline Slovak Republic & $\ldots$ & & $\ldots$ & $\ldots$ & & 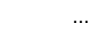 & $\ldots$ \\
\hline Slovenia & 7.1 & 5.7 & 8.1 & 5.4 & 5.7 & 5.0 & -29 \\
\hline Spain & $\ldots$ & $\ldots$ & $\ldots$ & $\ldots$ & $\ldots$ & $\ldots$ & $\ldots$ \\
\hline Sweden & 7.9 & 7.3 & 6.1 & 6.1 & 6.2 & 5.8 & -28 \\
\hline Switzerland & 9.5 & 9.9 & 9.8 & 9.5 & 9.3 & 10.1 & 6 \\
\hline Turkey & 1.8 & 2.2 & 2.3 & 1.8 & 2.2 & 2.0 & 13 \\
\hline Ukraine & 6.6 & 6.1 & 5.7 & 3.9 & 3.6 & 3.0 & -54 \\
\hline \multicolumn{8}{|l|}{ UK: England \& } \\
\hline Wales & 11.3 & 10.2 & 9.1 & 9.2 & 9.3 & 8.5 & -25 \\
\hline \multicolumn{8}{|l|}{$\begin{array}{l}\text { UK: Northern Ire- } \\
\text { land }\end{array}$} \\
\hline UK: Scotland & 26.8 & 25.7 & 24.1 & 19.5 & 19.5 & 20.6 & -23 \\
\hline Mean & 12.1 & 12.0 & 12.1 & 11.3 & 10.0 & 9.2 & \\
\hline Median & 10.3 & 10.1 & 9.3 & 9.3 & 8.3 & 7.0 & \\
\hline Minimum & 1.8 & 1.5 & 2.3 & 1.8 & 2.2 & 0.4 & \\
\hline Maximum & 39.3 & 36.4 & 46.0 & 49.7 & 45.2 & 41.1 & \\
\hline
\end{tabular}


Table 3.2.1.7 Persons convicted per 100000 population - Sexual assault

\begin{tabular}{|c|c|c|c|c|c|c|c|}
\hline & 2011 & 2012 & 2013 & 2014 & 2015 & 2016 & $\begin{array}{l}\% \text { change } \\
2011-2016\end{array}$ \\
\hline Albania & 0.5 & 0.5 & 0.6 & 0.9 & 1.1 & & \\
\hline Armenia & 0.9 & $\ldots$ & $\ldots$ & $\ldots$ & $\ldots$ & 1.9 & 118 \\
\hline Austria & 4.9 & 4.4 & 4.5 & 4.3 & 4.3 & 4.4 & -9 \\
\hline Azerbaijan & $\ldots$ & $\ldots$ & $\ldots$ & $\ldots$ & & $\ldots$ & $\ldots$ \\
\hline $\begin{array}{l}\text { Belgium } \\
\text { Bosnia-Herze- }\end{array}$ & 7.1 & 6.5 & 6.1 & 5.6 & 5.8 & 5.3 & -25 \\
\hline govina & & & & & & & \\
\hline Bulgaria & 2.9 & 3.2 & 3.2 & 2.6 & 1.8 & 2.3 & -22 \\
\hline Croatia & 5.1 & 4.7 & 4.5 & 4.7 & 4.0 & 4.6 & -11 \\
\hline Cyprus & & & & & & & . \\
\hline Czech Republic & 4.7 & 5.0 & 5.2 & 5.0 & 4.9 & 5.6 & 20 \\
\hline Denmark & 5.5 & 6.0 & 5.8 & 5.0 & 5.6 & 5.9 & 7 \\
\hline Estonia & 3.5 & 3.5 & 4.3 & 3.8 & 5.4 & 4.0 & 14 \\
\hline Finland & 9.4 & 10.2 & 9.0 & 10.0 & 9.6 & 10.2 & 9 \\
\hline France & 15.2 & 15.7 & 14.7 & 13.3 & 13.5 & 13.3 & -12 \\
\hline Georgia & 1.2 & 1.5 & 1.4 & 1.4 & 3.7 & 1.9 & 53 \\
\hline Germany & 4.4 & 4.3 & 4.0 & 3.7 & 3.5 & 3.4 & -24 \\
\hline $\begin{array}{l}\text { Hungary } \\
\text { Iceland }\end{array}$ & 1.9 & 2.2 & $\begin{array}{r}2.0 \\
\ldots\end{array}$ & $\begin{array}{r}2.3 \\
\ldots\end{array}$ & $\begin{array}{r}3.9 \\
\ldots\end{array}$ & $\begin{array}{r}2.8 \\
\ldots\end{array}$ & $\begin{array}{r}50 \\
\ldots\end{array}$ \\
\hline Italy & 3.8 & 3.9 & 3.8 & 3.3 & 3.4 & 3.2 & -16 \\
\hline Kosovo (UN & & & & & & & \\
\hline R/1244/99) & $\ldots$ & $\ldots$ & $\ldots$ & $\ldots$ & $\ldots$ & $\ldots$ & $\ldots$ \\
\hline Latvia & $\ldots$ & $\ldots$ & $\ldots$ & $\ldots$ & $\ldots$ & $\ldots$ & $\ldots$ \\
\hline Lithuania & 10.5 & 8.7 & 6.4 & 7.7 & 9.0 & 7.2 & -32 \\
\hline Luxembourg & & & $\ldots$ & $\ldots$ & & 8.5 & $\ldots$ \\
\hline Moldova & 5.4 & 4.5 & 5.3 & 4.4 & 5.8 & 5.2 & -4 \\
\hline Montenegro & & & & & & & \\
\hline Netherlands & 6.1 & 6.0 & 6.3 & 6.0 & 6.0 & 5.1 & -18 \\
\hline North Macedonia & 2.6 & 2.3 & 3.1 & 2.4 & 2.7 & 1.9 & -28 \\
\hline Norway & 18.3 & 16.8 & 17.7 & 15.1 & 15.5 & 16.6 & -9 \\
\hline Poland & 3.8 & 3.8 & 3.8 & 3.5 & 3.7 & 3.8 & -2 \\
\hline Portugal & 3.5 & 4.0 & 4.0 & 3.4 & 4.7 & 4.5 & 29 \\
\hline Romania & $\ldots$ & $\ldots$ & $\ldots$ & $\ldots$ & $\ldots$ & 3.0 & $\ldots$ \\
\hline $\begin{array}{l}\text { Russian Federa- } \\
\text { tion }\end{array}$ & $\ldots$ & $\ldots$ & $\ldots$ & $\ldots$ & $\ldots$ & $\ldots$ & $\ldots$ \\
\hline Serbia & 2.5 & 2.7 & 3.1 & 3.4 & 2.0 & 2.4 & -2 \\
\hline Slovak Republic & & & $\ldots$ & $\ldots$ & . & & $\ldots$ \\
\hline Slovenia & 4.2 & 4.6 & 6.3 & 4.4 & 4.2 & 3.6 & -14 \\
\hline Spain & 1.3 & 1.3 & 1.3 & 1.1 & 1.1 & 0.9 & -30.1 \\
\hline Sweden & 5.0 & 4.9 & 5.0 & 4.5 & 4.1 & 4.1 & -18 \\
\hline Switzerland & 7.3 & 7.6 & 8.3 & 8.1 & 8.1 & 7.6 & 5 \\
\hline Turkey & 12.4 & 20.4 & 26.3 & 25.4 & 25.9 & 23.4 & 88 \\
\hline Ukraine & $\ldots$ & $\ldots$ & $\ldots$ & 0.7 & 0.4 & 0.4 & $\ldots$ \\
\hline UK: England \& & & & & & & & \\
\hline Wales & 10.6 & 10.1 & 9.9 & 10.9 & 11.9 & 12.9 & 21 \\
\hline UK: Northern Ire- & & & & & 88 & 96 & \\
\hline UK: Scotland & 14.3 & $\begin{array}{l}12.0 \\
14.8\end{array}$ & $\begin{array}{l}10.8 \\
16.2\end{array}$ & $\begin{array}{l}10.1 \\
19.8\end{array}$ & $\begin{array}{r}8.8 \\
21.4\end{array}$ & $\begin{array}{r}9.6 \\
21.4\end{array}$ & $\begin{array}{l}\ldots \\
50\end{array}$ \\
\hline Mean & 6.0 & 6.5 & 6.8 & 6.3 & 6.6 & 6.4 & \\
\hline Median & 4.8 & 4.6 & 5.1 & 4.4 & 4.7 & 4.5 & \\
\hline Minimum & 0.5 & 0.5 & 0.6 & 0.7 & 0.4 & 0.4 & \\
\hline Maximum & 18.3 & 20.4 & 26.3 & 25.4 & 25.9 & 23.4 & \\
\hline
\end{tabular}


Table 3.2.1.8 Persons convicted per 100000 population - Rape

\begin{tabular}{|c|c|c|c|c|c|c|c|}
\hline & 2011 & 2012 & 2013 & 2014 & 2015 & 2016 & $\begin{array}{l}\% \text { change } \\
2011-2016\end{array}$ \\
\hline Albania & & & & & & & \\
\hline Armenia & 0.2 & 0.6 & 0.4 & 0.3 & 0.1 & 0.2 & -18 \\
\hline Austria & 1.8 & 1.8 & 1.7 & 1.7 & 1.7 & 1.7 & -6 \\
\hline Azerbaijan & 0.2 & 0.1 & 0.1 & 0.3 & 0.3 & 0.3 & 63 \\
\hline Belgium & 4.3 & 3.8 & 3.3 & 3.3 & 3.5 & 3.0 & -30 \\
\hline \multicolumn{8}{|l|}{$\begin{array}{l}\text { Bosnia-Herze- } \\
\text { govina }\end{array}$} \\
\hline Bulgaria & 1.2 & 1.6 & 1.8 & 1.4 & 1.0 & 1.1 & -3 \\
\hline Croatia & 2.4 & 2.5 & 2.3 & 2.7 & 2.3 & 2.3 & -7 \\
\hline \multicolumn{8}{|l|}{ Cyprus } \\
\hline Czech Republic & 1.7 & 1.9 & 1.9 & 1.6 & 1.6 & 2.2 & 29 \\
\hline Denmark & 2.4 & 2.5 & 2.3 & 2.0 & 2.2 & 2.4 & 0 \\
\hline Estonia & 1.4 & 2.2 & 2.5 & 1.7 & 3.6 & 2.5 & 75 \\
\hline Finland & 2.4 & 3.5 & 2.7 & 2.7 & 3.0 & 3.8 & 56 \\
\hline France & 1.9 & 1.9 & 1.8 & 1.6 & 1.5 & 1.5 & -21 \\
\hline Georgia & 0.6 & 0.7 & 0.5 & 0.3 & 0.3 & 0.9 & 63 \\
\hline Germany & 0.9 & 0.8 & 0.7 & 0.7 & 0.7 & 0.6 & -31 \\
\hline Hungary & 0.8 & 0.9 & 0.9 & 1.3 & 1.7 & 2.2 & 184 \\
\hline $\begin{array}{l}\text { Iceland } \\
\text { Italy }\end{array}$ & 29 & 29 & 29 & 24 & 26 & 24 & -17 \\
\hline \multirow{2}{*}{\multicolumn{8}{|c|}{$\begin{array}{l}\text { Kosovo (UN } \\
\text { R/1244/99) }\end{array}$}} \\
\hline & & & & & & & \\
\hline Latvia & 1.0 & 1.1 & 0.8 & 1.6 & 0.8 & 0.8 & -16 \\
\hline Lithuania & 8.7 & 6.8 & 4.9 & 5.8 & 7.1 & 5.3 & -39 \\
\hline Luxembourg & & & & & & 2.6 & \\
\hline $\begin{array}{l}\text { Moldova } \\
\text { la }\end{array}$ & 4.4 & 3.3 & 3.7 & 3.1 & 4.2 & 3.7 & -15 \\
\hline Montenegro & 0.8 & 1.5 & 2.6 & 1.1 & 0.3 & 1.3 & 59 \\
\hline Netherlands & 0.8 & 0.9 & 0.7 & 0.7 & 0.6 & 0.6 & -19 \\
\hline North Macedonia & 0.9 & 0.6 & 1.0 & 0.7 & 1.2 & 0.7 & -23 \\
\hline \multicolumn{8}{|l|}{ Norway } \\
\hline Poland & 2.1 & 2.1 & 2.1 & 1.8 & 1.9 & 1.8 & -10 \\
\hline Portugal & 0.9 & 0.8 & 0.8 & 0.7 & 0.9 & 1.0 & 20 \\
\hline \multirow{3}{*}{\multicolumn{8}{|c|}{$\begin{array}{l}\text { Russian Federa- } \\
\text { tion }\end{array}$}} \\
\hline & & & & & & & \\
\hline tion & & & & & & & \\
\hline $\begin{array}{l}\text { Serbia } \\
\text { Slovak Republic }\end{array}$ & 0.9 & 1.0 & 1.0 & 1.2 & 0.8 & 0.8 & -13 \\
\hline $\begin{array}{l}\text { Slovenia } \\
\text { Pow }\end{array}$ & 0.7 & 1.0 & 1.2 & 0.6 & 1.0 & 0.5 & -29 \\
\hline Spain & & & & & & & \\
\hline Sweden & 3.5 & 3.4 & 3.3 & 3.3 & 3.0 & 2.9 & -17 \\
\hline Switzerland & 1.2 & 1.5 & 1.5 & 1.5 & 1.4 & 1.5 & 28 \\
\hline Turkey & & & & & & & \\
\hline Ukraine & 0.8 & 0.7 & 0.5 & 0.4 & 0.2 & 0.2 & -72 \\
\hline $\begin{array}{l}\text { UK: England \& } \\
\text { Wales }\end{array}$ & 20 & 20 & 20 & 19 & 22 & 23 & 15 \\
\hline $\begin{array}{l}\text { UK: Northern Ire- } \\
\text { land }\end{array}$ & & & & & & & \\
\hline UK: Scotland & 0.7 & 0.9 & 1.4 & 1.7 & 2.3 & 1.9 & 183 \\
\hline Mean & 1.8 & 1.8 & 1.8 & 1.7 & 1.8 & 1.8 & \\
\hline Median & 1.2 & 1.6 & 1.7 & 1.6 & 1.6 & 1.7 & \\
\hline Minimum & 0.2 & 0.1 & 0.1 & 0.3 & 0.1 & 0.2 & \\
\hline Maximum & 8.7 & 6.8 & 4.9 & 5.8 & 7.1 & 5.3 & \\
\hline
\end{tabular}


Table 3.2.1.9 Persons convicted per 100000 population - Sexual abuse of a child

\begin{tabular}{|c|c|c|c|c|c|c|c|}
\hline & 2011 & 2012 & 2013 & 2014 & 2015 & 2016 & $\begin{array}{l}\% \text { change } \\
2011-2016\end{array}$ \\
\hline $\begin{array}{l}\text { Albania } \\
\text { Armenia }\end{array}$ & $\ldots$ & $\ldots$ & $\cdots$ & $\ldots$ & $\ldots$ & $\ldots$ & $\ldots$ \\
\hline Austria & 1.8 & 1.5 & 1.7 & 1.6 & 1.5 & 1.6 & -11 \\
\hline Azerbaijan & & & & & & & \\
\hline $\begin{array}{l}\text { Belgium } \\
\text { Bosnia-Herze- }\end{array}$ & 4.1 & 3.5 & 3.6 & 3.2 & 3.2 & 2.8 & -32 \\
\hline $\begin{array}{l}\text { govina } \\
\text { Bularia }\end{array}$ & $\ldots$ & $\ldots$ & $\cdots$ & $\ldots$ & $\ldots$ & $\ldots$ & $\ldots$ \\
\hline Croatia & 1.8 & 1.4 & 0.1 & 0.3 & 0.4 & 0.6 & -67 \\
\hline Cyprus & & & & & & & \\
\hline Czech Republic & 2.9 & 3.0 & 3.1 & 3.2 & 3.2 & 3.3 & 13 \\
\hline Denmark & 0.9 & 1.1 & 1.2 & 1.0 & 1.0 & 1.3 & 44 \\
\hline Estonia & 1.0 & 1.1 & 1.2 & 1.6 & 1.4 & 0.7 & -30 \\
\hline Finland & 5.1 & 5.4 & 5.4 & 6.1 & 5.5 & 4.7 & -8 \\
\hline France & 5.1 & 5.1 & 4.8 & 4.4 & 4.6 & 4.6 & -9 \\
\hline Georgia & & & & & & & \\
\hline Germany & 2.2 & 2.2 & 2.1 & 2.0 & 1.8 & 1.7 & -24 \\
\hline Hungary & 0.9 & 1.0 & 0.9 & 1.2 & 1.5 & 2.1 & 148 \\
\hline $\begin{array}{l}\text { Iceland } \\
\text { Italy }\end{array}$ & 0.3 & 0.4 & 0.3 & 0.3 & 0.3 & 0.3 & -13 \\
\hline Kosovo (UN & & & & & & & \\
\hline R/1244/99) & $\ldots$ & $\ldots$ & $\ldots$ & $\ldots$ & $\ldots$ & $\ldots$ & $\ldots$ \\
\hline Latvia & $\ldots$ & & & $\ldots$ & & $\ldots$ & \\
\hline Lithuania & 1.4 & 1.5 & 1.2 & 1.4 & 1.5 & 1.6 & 16 \\
\hline Luxembourg & $\ldots$ & $\ldots$ & $\ldots$ & $\ldots$ & $\ldots$ & $\ldots$ & $\ldots$ \\
\hline Moldova & & & & & & & \\
\hline Montenegro & 0.2 & 0.6 & 0.6 & 0.3 & 0.5 & 0.5 & 199 \\
\hline Netherlands & 0.1 & 0.1 & 0.1 & 0.2 & 0.4 & 0.3 & 122 \\
\hline $\begin{array}{l}\text { North Macedonia } \\
\text { Norway }\end{array}$ & $\ldots$ & $\ldots$ & $\ldots$ & $\ldots$ & $\ldots$ & $\ldots$ & $\ldots$ \\
\hline $\begin{array}{l}\text { Poland } \\
\text { Pond }\end{array}$ & 1.8 & 1.7 & 1.7 & 1.7 & 1.7 & 10 & 7 \\
\hline Portugal & 2.2 & 2.7 & 2.9 & 2.2 & 3.3 & 3.0 & 32 \\
\hline $\begin{array}{l}\text { Romania } \\
\text { Russian Federa- }\end{array}$ & $\ldots$ & $\ldots$ & $\ldots$ & $\ldots$ & $\ldots$ & 1.1 & $\ldots$ \\
\hline tion & & & & & & & \\
\hline Serbia & 0.5 & 0.5 & 0.7 & 0.7 & 0.3 & 0.3 & -29 \\
\hline $\begin{array}{l}\text { Slovak Republic } \\
\text { Slovenia }\end{array}$ & 24 & & & & & 25 & 3 \\
\hline $\begin{array}{l}\text { Slovenia } \\
\text { Spain }\end{array}$ & $\begin{array}{r}2.4 \\
\ldots\end{array}$ & $\begin{array}{l}2.2 \\
0.1\end{array}$ & $\begin{array}{l}3.4 \\
0.3\end{array}$ & $\begin{array}{l}2.1 \\
0.5\end{array}$ & $\begin{array}{l}1.8 \\
0.5\end{array}$ & $\begin{array}{l}2.5 \\
0.7\end{array}$ & 3 \\
\hline Sweden & 1.4 & 1.3 & 1.5 & 1.0 & 1.0 & 1.0 & -29 \\
\hline Switzerland & 4.3 & 4.6 & 5.0 & 4.7 & 5.4 & 4.7 & 8 \\
\hline Turkey & & & & & & & \\
\hline $\begin{array}{l}\text { Ukraine } \\
\text { UK: England \& }\end{array}$ & 0.1 & 0.1 & 0.1 & 0.1 & 0.0 & 0.0 & -49 \\
\hline Wales & 7.2 & 7.0 & 7.2 & 7.8 & 9.2 & 11.6 & 61 \\
\hline $\begin{array}{l}\text { UK: Northern Ire- } \\
\text { land } \\
\text { UK: Scotland }\end{array}$ & $\ldots$ & $\cdots$ & $\cdots$ & $\cdots$ & $\ldots$ & $\cdots$ & $\begin{array}{l}\ldots \\
\ldots\end{array}$ \\
\hline Mean & 2.2 & 2.1 & 2.1 & 2.1 & 2.2 & 2.1 & \\
\hline Median & 1.8 & 1.5 & 1.5 & 1.6 & 1.5 & 1.6 & \\
\hline Minimum & 0.1 & 0.1 & 0.1 & 0.1 & 0.0 & 0.0 & \\
\hline Maximum & 7.2 & 7.0 & 7.2 & 7.8 & 9.2 & 11.6 & \\
\hline
\end{tabular}


Table 3.2.1.10 Persons convicted per 100000 population - Robbery: Total

\begin{tabular}{|c|c|c|c|c|c|c|c|}
\hline & 2011 & 2012 & 2013 & 2014 & 2015 & 2016 & $\begin{array}{l}\% \text { change } \\
2011-2016\end{array}$ \\
\hline Albania & 4.2 & 5.1 & 5.3 & 5.8 & 6.5 & 3.6 & -15 \\
\hline Armenia & 4.3 & 3.2 & 3.7 & 2.9 & 3.3 & 2.6 & -39 \\
\hline Austria & 8.9 & 8.8 & 8.3 & 7.8 & 8.8 & 7.4 & -17 \\
\hline Azerbaijan & 3.4 & 2.8 & 2.6 & 3.3 & 3.4 & 4.6 & 35 \\
\hline Belgium & 24.9 & 24.5 & 23.8 & 21.6 & 18.4 & 18.6 & -25 \\
\hline \multicolumn{8}{|l|}{$\begin{array}{l}\text { Bosnia-Herze- } \\
\text { govina }\end{array}$} \\
\hline Bulgaria & 18.0 & 16.0 & 13.2 & 11.7 & 9.8 & 9.3 & -48 \\
\hline Croatia & 10.0 & 9.8 & 9.6 & 9.9 & 7.6 & 6.9 & -31 \\
\hline \multicolumn{8}{|l|}{ Cyprus } \\
\hline Czech Republic & 12.9 & 13.2 & 13.2 & 10.5 & 9.6 & 8.6 & -33 \\
\hline Denmark & 7.0 & 6.9 & 6.7 & 4.8 & 4.7 & 4.2 & -40 \\
\hline Estonia & 20.5 & 21.7 & 14.7 & 12.8 & 12.5 & 13.3 & -35 \\
\hline Finland & 10.5 & 9.8 & 9.7 & 10.5 & 11.8 & 10.3 & -2 \\
\hline France & & 7.4 & 6.4 & 5.5 & 5.2 & 5.0 & \\
\hline Georgia & 9.6 & 5.5 & 13.3 & 10.5 & 10.6 & 9.0 & -7 \\
\hline Germany & 12.0 & 11.3 & 10.7 & 9.8 & 9.0 & 8.4 & -30 \\
\hline Hungary & 15.4 & 12.9 & 13.3 & 14.1 & 12.9 & 11.0 & -29 \\
\hline Italy & 14.0 & 13.9 & 13.6 & 12.5 & 12.0 & 13.0 & -7 \\
\hline \multirow{2}{*}{\multicolumn{8}{|c|}{$\begin{array}{l}\text { Kosovo (UN } \\
\text { R/1244/99) }\end{array}$}} \\
\hline & & & & & & & \\
\hline $\begin{array}{l}\text { Latvia } \\
\end{array}$ & 20.0 & 14.9 & 21.9 & 19.9 & 18.5 & 14.7 & -26 \\
\hline Lithuania & 39.7 & 34.9 & 26.5 & 31.2 & 28.5 & 22.7 & -43 \\
\hline Luxembourg & & & & & & 10.9 & \\
\hline \multirow{2}{*}{\multicolumn{8}{|c|}{ Montenegro }} \\
\hline & & & & & & & \\
\hline Netherlands & 18.2 & 19.6 & 18.0 & 15.4 & 13.5 & 12.2 & -33 \\
\hline North Macedonia & 6.6 & 5.9 & 5.8 & 6.8 & 4.8 & 2.9 & -56 \\
\hline \multicolumn{8}{|l|}{ Norwa } \\
\hline Poland & 21.1 & 20.1 & 17.7 & 15.4 & 13.5 & 14.9 & -29 \\
\hline Portugal & 30.2 & 32.9 & 27.9 & 19.3 & 22.1 & 22.1 & -27 \\
\hline Romania & $\ldots$ & $\ldots$ & $\ldots$ & $\ldots$ & $\ldots$ & 7.8 & $\ldots$ \\
\hline \multicolumn{8}{|l|}{$\begin{array}{l}\text { Russian Federa- } \\
\text { tion }\end{array}$} \\
\hline Serbia & 10.9 & 12.3 & 13.2 & 13.7 & 11.9 & 13.0 & 20 \\
\hline \multicolumn{8}{|l|}{ Slovak Republic } \\
\hline Slovenia & 6.9 & 7.0 & 10.5 & 7.5 & 6.8 & 4.3 & -38 \\
\hline Spain & & & 19.6 & 18.8 & 17.6 & 17.0 & \\
\hline Sweden & 10.4 & 9.7 & 7.5 & 8.6 & 6.6 & 7.5 & -28 \\
\hline Switzerland & 9.5 & 10.7 & 12.8 & 10.3 & 9.0 & 7.9 & -17 \\
\hline Turkey & 25.8 & 26.1 & 33.3 & 23.6 & 27.7 & 31.0 & 20 \\
\hline \multirow{2}{*}{\multicolumn{8}{|c|}{ UK: England \& }} \\
\hline & & & & & & & \\
\hline Wales & 16.6 & 14.7 & 11.9 & 9.7 & 8.2 & 7.0 & -58 \\
\hline \multicolumn{7}{|l|}{ UK: Northern Ire- } & \\
\hline UK: Scotland & 9.9 & 11.4 & 9.8 & 8.4 & 7.2 & 7.0 & -29 \\
\hline Mean & 15.2 & 14.2 & 14.0 & 12.3 & 11.7 & 10.8 & \\
\hline Median & 12.4 & 11.8 & 13.2 & 10.5 & 9.8 & 9.0 & \\
\hline Minimum & 3.4 & 2.8 & 2.6 & 2.9 & 3.3 & 2.5 & \\
\hline Maximum & 39.7 & 34.9 & 33.3 & 31.2 & 28.5 & 31.0 & \\
\hline
\end{tabular}


Table 3.2.1.11 Persons convicted per 100000 population - Theft

\begin{tabular}{|c|c|c|c|c|c|c|c|}
\hline & 2011 & 2012 & 2013 & 2014 & 2015 & 2016 & $\begin{array}{l}\% \text { change } \\
2011-2016\end{array}$ \\
\hline Albania & 64 & 70 & 68 & 72 & 61 & 52 & -19 \\
\hline Armenia & 24 & 18 & 17 & 16 & 17 & 16 & -34 \\
\hline Austria & 87 & 90 & 92 & 87 & 82 & 72 & -17 \\
\hline Azerbaijan & 18 & 17 & 16 & 18 & 20 & 25 & 38 \\
\hline Belgium & 81 & 85 & 86 & 80 & 76 & 72 & -11 \\
\hline \multicolumn{8}{|l|}{$\begin{array}{l}\text { Bosnia-Herze- } \\
\text { govina }\end{array}$} \\
\hline Bulgaria & 201 & 175 & 138 & 110 & 87 & 77 & -62 \\
\hline Croatia & 122 & 103 & 98 & 86 & 73 & 85 & -31 \\
\hline Cyprus & $\ldots$ & $\ldots$ & $\ldots$ & $\ldots$ & $\ldots$ & $\ldots$ & $\ldots$ \\
\hline Czech Republic & 154 & 170 & 182 & 167 & 133 & 115 & -25 \\
\hline Denmark & 347 & 350 & 337 & 314 & 297 & 272 & -22 \\
\hline Estonia & 222 & 199 & 157 & 131 & 105 & 105 & -53 \\
\hline Finland & 616 & 560 & 539 & 491 & 545 & 429 & -30 \\
\hline France & 140 & 149 & 151 & 144 & 138 & 137 & -2 \\
\hline Georgia & 68 & 57 & 77 & 74 & 81 & 68 & 0 \\
\hline Germany & 171 & 164 & 165 & 163 & 163 & 161 & -5 \\
\hline Hungary & 224 & 207 & 194 & 195 & 172 & 151 & -32 \\
\hline Iceland & $\ldots$ & & $\ldots$ & $\ldots$ & $\ldots$ & $\ldots$ & $\ldots$ \\
\hline Italy & 59 & 60 & 57 & 56 & 56 & 57 & -3 \\
\hline \multicolumn{8}{|l|}{ Kosovo (UN } \\
\hline $\mathrm{R} / 1244 / 99)$ & 0 & 0 & 0 & 0 & 0 & 0 & $\ldots$ \\
\hline Latvia & 179 & 182 & 174 & 188 & 180 & 159 & -11 \\
\hline Lithuania & 196 & 183 & 179 & 190 & 138 & 112 & -43 \\
\hline Luxembourg & $\ldots$ & & $\ldots$ & $\ldots$ & $\ldots$ & 116 & $\ldots$ \\
\hline Moldova & 77 & 78 & 77 & 65 & 78 & 66 & -15 \\
\hline \multicolumn{8}{|l|}{ Montenegro } \\
\hline Netherlands & 150 & 145 & 153 & 153 & 150 & 146 & -3 \\
\hline North Macedonia & 139 & 137 & 154 & 133 & 139 & 90 & -35 \\
\hline Norway & 140 & 135 & 143 & 128 & 124 & 106 & -24 \\
\hline Poland & 167 & 174 & 153 & 123 & 104 & 113 & -32 \\
\hline Portugal & 62 & 70 & 65 & 49 & 54 & 48 & -23 \\
\hline Romania & $\ldots$ & $\ldots$ & $\ldots$ & $\ldots$ & $\ldots$ & 24 & $\ldots$ \\
\hline \multirow{2}{*}{\multicolumn{8}{|c|}{ Russian Federa- }} \\
\hline & $\ldots$ & $\ldots$ & $\ldots$ & $\ldots$ & $\ldots$ & $\ldots$ & $\ldots$ \\
\hline Serbia & 80 & 98 & 118 & 133 & 139 & 138 & 74 \\
\hline \multicolumn{8}{|l|}{ Slovak Republic } \\
\hline Slovenia & 84 & 96 & 135 & 115 & 95 & 77 & -8 \\
\hline Spain & $\ldots$ & $\ldots$ & 74 & 77 & 95 & 168 & $\ldots$ \\
\hline Sweden & 274 & 262 & 228 & 222 & 220 & 198 & -28 \\
\hline Switzerland & 167 & 197 & 201 & 177 & 156 & 153 & -8 \\
\hline Turkey & 159 & 181 & 244 & 215 & 226 & 199 & 25 \\
\hline Ukraine & 130 & 145 & 97 & 85 & 96 & 81 & -38 \\
\hline \multicolumn{8}{|l|}{ UK: England \& } \\
\hline Wales & 249 & 225 & 215 & 204 & 179 & 153 & -39 \\
\hline \multirow{2}{*}{\multicolumn{8}{|c|}{ UK: Northern Ire- }} \\
\hline & $\ldots$ & 144 & 135 & 130 & 122 & 104 & $\ldots$ \\
\hline UK: Scotland & 295 & 278 & 249 & 235 & 233 & 214 & -27 \\
\hline Mean & 156 & 153 & 148 & 138 & 132 & 118 & \\
\hline Median & 140 & 145 & 143 & 130 & 122 & 106 & \\
\hline Minimum & 0 & 0 & 0 & 0 & 0 & 0 & \\
\hline Maximum & 616 & 560 & 539 & 491 & 545 & 429 & \\
\hline
\end{tabular}


Table 3.2.1.12 Persons convicted per 100000 population - Aggravated theft

\begin{tabular}{|c|c|c|c|c|c|c|c|}
\hline & 2011 & 2012 & 2013 & 2014 & 2015 & 2016 & $\begin{array}{c}\% \text { change } \\
2011-2016\end{array}$ \\
\hline Albania & 0 & 0 & 0 & 0 & 0 & 0 & 14 \\
\hline Armenia & $\ldots$ & $\ldots$ & $\ldots$ & $\ldots$ & $\ldots$ & $\ldots$ & $\ldots$ \\
\hline Austria & 49 & 53 & 55 & 51 & 48 & 38 & -24 \\
\hline Azerbaijan & $\ldots$ & $\ldots$ & $\ldots$ & $\ldots$ & $\ldots$ & $\ldots$ & $\ldots$ \\
\hline Belgium & 39 & 39 & 40 & 38 & 35 & 33 & -14 \\
\hline Bosnia-Herze- & & & & & & & \\
\hline govina & $\ldots$ & $\ldots$ & $\ldots$ & $\ldots$ & $\ldots$ & $\ldots$ & $\ldots$ \\
\hline Bulgaria & $\ldots$ & $\ldots$ & $\ldots$ & $\ldots$ & $\ldots$ & 31 & $\ldots$ \\
\hline Croatia & 70 & 58 & 52 & 48 & 35 & 39 & -45 \\
\hline Cyprus & $\ldots$ & $\ldots$ & $\ldots$ & $\ldots$ & $\ldots$ & $\ldots$ & $\ldots$ \\
\hline Czech Republic & $\ldots$ & $\ldots$ & $\ldots$ & $\ldots$ & $\ldots$ & $\ldots$ & $\ldots$ \\
\hline Denmark & 60 & 53 & 46 & 38 & 34 & 33 & -45 \\
\hline Estonia & $\ldots$ & $\ldots$ & $\ldots$ & $\ldots$ & $\ldots$ & $\ldots$ & $\ldots$ \\
\hline Finland & 11 & 12 & 10 & 10 & 8 & 9 & -19 \\
\hline France & $\ldots$ & $\ldots$ & $\ldots$ & $\ldots$ & $\ldots$ & $\ldots$ & $\ldots$ \\
\hline Georgia & $\ldots$ & $\ldots$ & $\ldots$ & $\ldots$ & $\ldots$ & $\ldots$ & $\ldots$ \\
\hline Germany & 32 & 32 & 32 & 30 & 29 & 31 & -1 \\
\hline Hungary & 224 & 207 & 194 & 195 & 172 & 151 & -32 \\
\hline Iceland & $\ldots$ & $\ldots$ & $\ldots$ & $\ldots$ & $\ldots$ & $\ldots$ & $\ldots$ \\
\hline Italy & $\ldots$ & $\ldots$ & $\ldots$ & $\ldots$ & $\ldots$ & $\ldots$ & $\ldots$ \\
\hline Kosovo (UN & & & & & & & \\
\hline R/1244/99) & $\ldots$ & $\ldots$ & $\ldots$ & $\ldots$ & $\ldots$ & $\ldots$ & $\ldots$ \\
\hline Latvia & $\ldots$ & $\ldots$ & $\ldots$ & $\ldots$ & $\ldots$ & $\ldots$ & $\ldots$ \\
\hline Lithuania & $\ldots$ & $\ldots$ & $\ldots$ & $\ldots$ & $\ldots$ & $\ldots$ & $\ldots$ \\
\hline Luxembourg & $\ldots$ & $\ldots$ & $\ldots$ & $\ldots$ & $\ldots$ & $\ldots$ & $\ldots$ \\
\hline Moldova & 36 & 38 & 37 & 32 & 37 & 31 & -15 \\
\hline Montenegro & 47 & 57 & 66 & 64 & 60 & 57 & 21 \\
\hline Netherlands & 71 & 72 & 75 & 71 & 66 & 60 & -16 \\
\hline North Macedonia & 89 & 83 & 89 & 79 & 82 & 50 & -45 \\
\hline Norway & $\ldots$ & $\ldots$ & $\ldots$ & $\ldots$ & $\ldots$ & $\ldots$ & $\ldots$ \\
\hline Poland & 51 & 52 & 45 & 41 & 35 & 37 & -28 \\
\hline Portugal & 36 & 40 & 38 & 29 & 32 & 28 & -22 \\
\hline Romania & $\ldots$ & $\ldots$ & $\ldots$ & $\ldots$ & $\ldots$ & 15 & $\ldots$ \\
\hline Russian Federa- & & & & & & & \\
\hline tion & $\ldots$ & $\ldots$ & $\ldots$ & $\ldots$ & $\ldots$ & $\ldots$ & $\ldots$ \\
\hline Serbia & 41 & 50 & 56 & 59 & 69 & 65 & 59 \\
\hline Slovak Republic & $\ldots$ & $\ldots$ & $\ldots$ & $\ldots$ & $\ldots$ & $\ldots$ & $\ldots$ \\
\hline Slovenia & $\ldots$ & $\ldots$ & $\ldots$ & $\ldots$ & $\ldots$ & $\ldots$ & ... \\
\hline Spain & $\ldots$ & $\ldots$ & $\ldots$ & $\ldots$ & $\ldots$ & $\ldots$ & $\ldots$ \\
\hline Sweden & $\ldots$ & $\ldots$ & $\ldots$ & $\ldots$ & $\ldots$ & $\ldots$ & $\ldots$ \\
\hline Switzerland & 9 & 10 & 13 & 13 & 12 & 11 & 23 \\
\hline Turkey & $\ldots$ & $\ldots$ & $\ldots$ & $\ldots$ & $\ldots$ & $\ldots$ & $\ldots$ \\
\hline Ukraine & $\ldots$ & $\ldots$ & $\ldots$ & $\ldots$ & $\ldots$ & $\ldots$ & $\ldots$ \\
\hline UK: England \& & & & & & & & \\
\hline Wales & $\ldots$ & $\cdots$ & $\ldots$ & $\ldots$ & $\ldots$ & $\ldots$ & $\cdots$ \\
\hline UK: Northern Ire- & & & & & & & \\
\hline land & $\ldots$ & $\ldots$ & $\ldots$ & $\ldots$ & $\ldots$ & $\ldots$ & $\ldots$ \\
\hline UK: Scotland & $\ldots$ & $\ldots$ & $\ldots$ & $\ldots$ & $\ldots$ & $\ldots$ & $\ldots$ \\
\hline Mean & 54 & 53 & 53 & 50 & 47 & 40 & \\
\hline Median & 44 & 51 & 46 & 40 & 35 & 33 & \\
\hline Minimum & 0 & 0 & 0 & 0 & 0 & 0 & \\
\hline Maximum & 224 & 207 & 194 & 195 & 172 & 151 & \\
\hline
\end{tabular}


Table 3.2.1.13 Persons convicted per 100000 population - Theft of a motor vehicle

\begin{tabular}{|c|c|c|c|c|c|c|c|}
\hline & 2011 & 2012 & 2013 & 2014 & 2015 & 2016 & $\begin{array}{l}\% \text { change } \\
2011-2016\end{array}$ \\
\hline Armenia & 0.2 & 0.2 & 0.2 & 0.2 & 0.1 & 0.1 & -35 \\
\hline Bulgaria & 3.6 & 2.8 & 2.5 & 2.3 & 2.5 & 2.4 & -33 \\
\hline Denmark & 15.7 & 13.0 & 11.0 & 9.2 & 7.9 & 8.1 & -48 \\
\hline Finland & 9.2 & 9.1 & 7.0 & 6.4 & 5.9 & 6.1 & -33 \\
\hline Hungary & 5.2 & 4.9 & 4.8 & 5.3 & 5.0 & 5.2 & 0 \\
\hline \multicolumn{8}{|c|}{ North Mace- } \\
\hline $\begin{array}{l}\text { donla } \\
\text { Portugal }\end{array}$ & $\begin{array}{l}3.9 \\
1.5\end{array}$ & $\begin{array}{r}13.2 \\
1.3\end{array}$ & $\begin{array}{l}1.1 \\
1.0\end{array}$ & $\begin{array}{l}3.1 \\
0.7\end{array}$ & $\begin{array}{l}.5 \\
0.9\end{array}$ & $\begin{array}{l}1.6 \\
0.6\end{array}$ & $\begin{array}{l}-58 \\
-57\end{array}$ \\
\hline Serbia & 3.8 & 4.3 & 3.9 & 4.3 & 3.3 & 3.6 & -6 \\
\hline Spain & 5.6 & 5.7 & 5.2 & 5.0 & 4.4 & 4.2 & -25 \\
\hline Sweden & 5.9 & 4.8 & 3.7 & 3.5 & 3.2 & 2.5 & -57 \\
\hline Ukraine & 4.8 & 5.8 & 5.6 & 5.3 & 5.7 & 4.6 & -3 \\
\hline \multicolumn{8}{|c|}{ UK: England } \\
\hline \& Wales & 9.0 & 7.6 & 6.5 & 6.3 & 6.1 & 5.9 & -35 \\
\hline $\begin{array}{l}\text { UK: Scot- } \\
\text { land }\end{array}$ & 9.1 & 8.5 & 7.0 & 5.1 & 6.0 & 5.5 & -39 \\
\hline Mean & 5.9 & 6.2 & 4.6 & 4.4 & 4.1 & 3.9 & \\
\hline Median & 5.2 & 5.7 & 4.8 & 5.0 & 4.4 & 4.2 & \\
\hline Minimum & 0.2 & 0.2 & 0.2 & 0.2 & 0.1 & 0.1 & \\
\hline Maximum & 15.7 & 13.2 & 11.0 & 9.2 & 7.9 & 8.1 & \\
\hline
\end{tabular}

Table 3.2.1.14 Persons convicted per 100000 population - Theft: Burglary

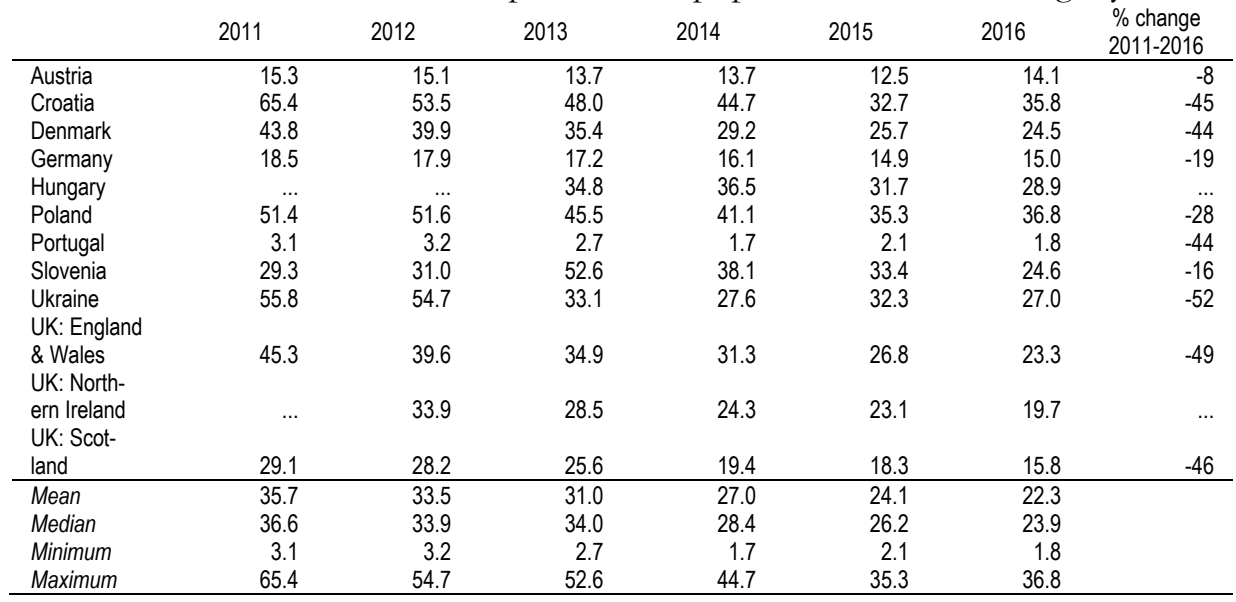

Table 3.2.1.15 Persons convicted per 100000 population - Theft: Domestic burglary

\begin{tabular}{|c|c|c|c|c|c|c|c|}
\hline & 2011 & 2012 & 2013 & 2014 & 2015 & 2016 & $\begin{array}{c}\% \text { change } \\
2011-2016\end{array}$ \\
\hline Denmark & 21.6 & 21.9 & 19.1 & 15.2 & 12.9 & 13.6 & -37 \\
\hline Germany & 3.1 & 3.5 & 3.6 & 3.5 & 3.4 & 3.6 & 14 \\
\hline Hungary & $\ldots$ & $\ldots$ & 2.0 & 2.1 & 1.9 & 2.0 & $\ldots$ \\
\hline $\begin{array}{l}\text { Portugal } \\
\text { UK: England }\end{array}$ & 1.4 & 1.6 & 1.3 & 0.9 & 1.3 & 1.0 & -27 \\
\hline$\&$ Wales & 25.9 & 23.1 & 20.5 & 18.0 & 15.0 & 12.4 & -52 \\
\hline
\end{tabular}


Table 3.2.1.16 Persons convicted per 100000 population - Fraud

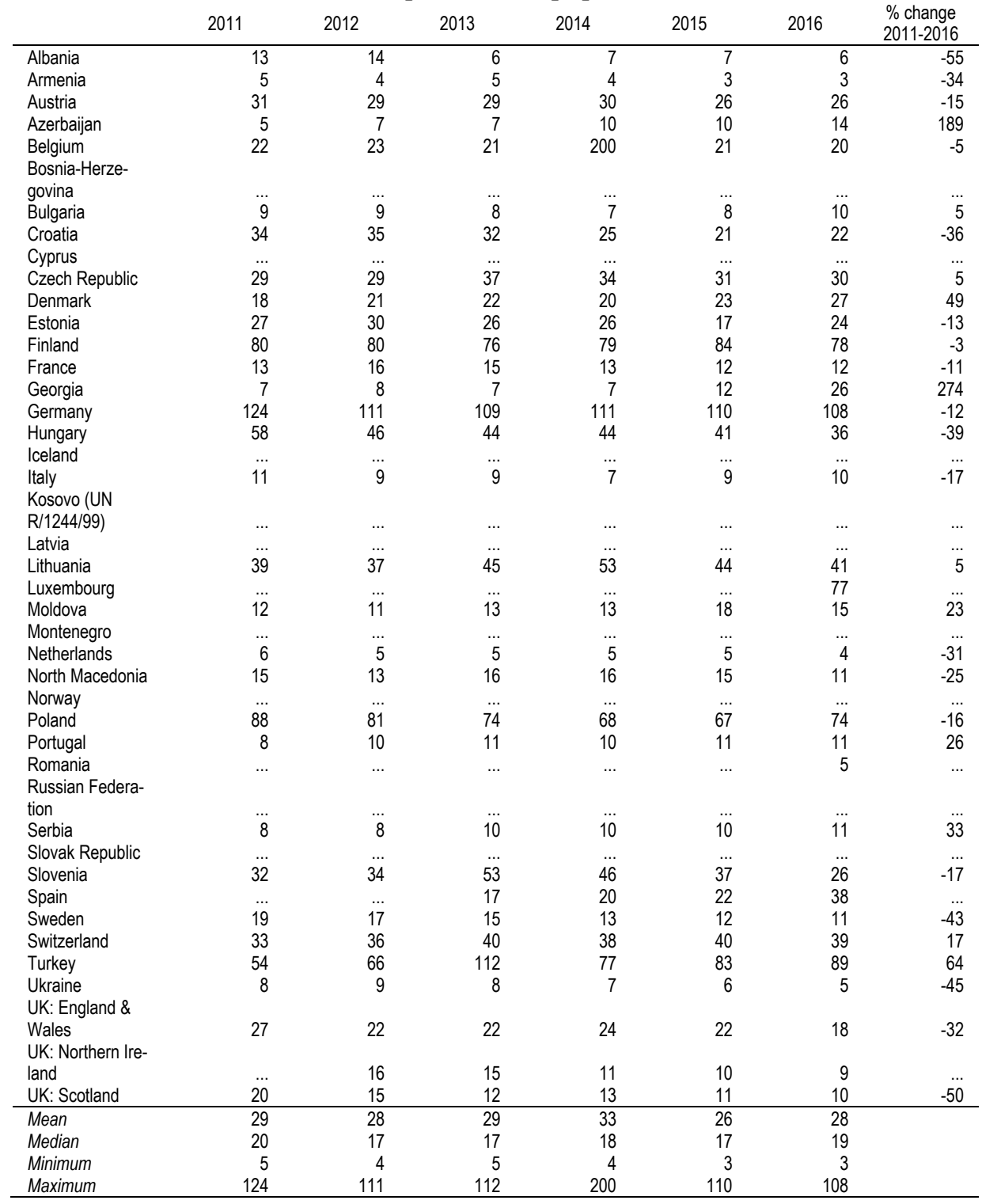


Table 3.2.1.17 Persons convicted per 100000 population - Cyber fraud

\begin{tabular}{|c|c|c|c|c|c|c|c|}
\hline & 2011 & 2012 & 2013 & 2014 & 2015 & 2016 & $\begin{array}{c}\% \text { change } \\
2011-2016\end{array}$ \\
\hline Denmark & 2.0 & 2.3 & 2.7 & 2.6 & 5.0 & 8.1 & 309 \\
\hline Hungary & $\ldots$ & $\ldots$ & 1.2 & 3.2 & 3.7 & 4.4 & $\ldots$ \\
\hline Luxembourg & $\ldots$ & $\ldots$ & $\ldots$ & $\ldots$ & $\ldots$ & 77.4 & $\ldots$ \\
\hline Montenegro & 0.0 & 0.2 & 0.0 & 0.3 & 1.8 & 0.0 & $\ldots$ \\
\hline Portugal & 1.3 & 1.5 & 2.1 & 1.5 & 1.9 & 1.8 & 35 \\
\hline Romania & $\ldots$ & $\ldots$ & $\ldots$ & $\ldots$ & $\ldots$ & 0.0 & $\ldots$ \\
\hline Serbia & 0.0 & 0.0 & 0.0 & 0.0 & 0.0 & 0.0 & 2 \\
\hline Switzerland & 9.3 & 10.0 & 9.6 & 8.6 & 8.7 & 8.2 & -12 \\
\hline $\begin{array}{l}\text { North Mace- } \\
\text { donia }\end{array}$ & & & 0.1 & & & & $\ldots$ \\
\hline Mean & 2.5 & 2.8 & 2.3 & 2.7 & 3.5 & 12.5 & \\
\hline Median & 1.3 & 1.5 & 1.2 & 2.1 & 2.8 & 3.1 & \\
\hline Minimum & 0.0 & 0.0 & 0.0 & 0.0 & 0.0 & 0.0 & \\
\hline Maximum & 9.3 & 10.0 & 9.6 & 8.6 & 8.7 & 77.4 & \\
\hline
\end{tabular}


Table 3.2.1.18 Persons convicted per 100000 population - Forgery of documents

\begin{tabular}{|c|c|c|c|c|c|c|c|}
\hline & 2011 & 2012 & 2013 & 2014 & 2015 & 2016 & $\begin{array}{l}\% \text { change } \\
2011-2016\end{array}$ \\
\hline Albania & 15.7 & 19.5 & 16.5 & 11.9 & 14.3 & 16.0 & 2 \\
\hline Armenia & & & & & & & \\
\hline Austria & 9.3 & 9.1 & 8.7 & 9.0 & 9.6 & 10.9 & 17 \\
\hline Azerbaijan & $\ldots$ & $\ldots$ & $\ldots$ & $\ldots$ & $\ldots$ & $\ldots$ & $\ldots$ \\
\hline $\begin{array}{l}\text { Belgium } \\
\text { Bosnia-Herze- }\end{array}$ & 17.3 & 18.7 & 16.1 & 15.3 & 14.7 & 14.7 & -15 \\
\hline $\begin{array}{l}\text { govina } \\
\text { Bulgaria }\end{array}$ & $\begin{array}{l}\ldots \\
\ldots\end{array}$ & $\begin{array}{l}\cdots \\
\ldots\end{array}$ & $\begin{array}{l}\cdots \\
\ldots\end{array}$ & $\begin{array}{l}\ldots \\
\ldots\end{array}$ & $\begin{array}{l}\ldots \\
\ldots\end{array}$ & $\begin{array}{l}\ldots \\
\ldots\end{array}$ & $\begin{array}{l}\ldots \\
\ldots\end{array}$ \\
\hline Croatia & 32.4 & 27.2 & 24.5 & 22.2 & 18.4 & 17.9 & -45 \\
\hline Cyprus & $\ldots$ & & . & $\ldots$ & $\ldots$ & $\ldots$ & $\ldots$ \\
\hline Czech Republic & 3.2 & 3.3 & 2.6 & 2.9 & 3.1 & 6.2 & 96 \\
\hline Denmark & 12.0 & 12.4 & 13.2 & 9.2 & 10.2 & 10.2 & -15 \\
\hline Estonia & 9.1 & 7.8 & 6.7 & 8.7 & 6.9 & 9.7 & 6 \\
\hline Finland & 25.1 & 20.1 & 20.0 & 16.4 & 14.2 & 11.0 & -56 \\
\hline France & 6.2 & 7.5 & 7.3 & 7.0 & 7.0 & 6.7 & 7 \\
\hline Georgia & 4.0 & 4.4 & 6.3 & 5.2 & 3.1 & 5.4 & 36 \\
\hline Germany & 21.4 & 21.1 & 20.5 & 20.2 & 19.2 & 19.6 & -8 \\
\hline $\begin{array}{l}\text { Hungary } \\
\text { Iceland }\end{array}$ & 57.7 & 58.5 & 76.8 & 70.7 & 63.4 & 57.1 & -1 \\
\hline $\begin{array}{l}\text { Italy } \\
\text { Kosovo (UN }\end{array}$ & 17.6 & 17.2 & 15.7 & 14.1 & 15.3 & 13.9 & -21 \\
\hline$R / 1244 / 99)$ & $\ldots$ & $\ldots$ & $\ldots$ & $\ldots$ & $\ldots$ & $\ldots$ & $\ldots$ \\
\hline Latvia & $\ldots$ & $\ldots$ & $\ldots$ & $\ldots$ & $\ldots$ & $\ldots$ & $\ldots$ \\
\hline Lithuania & 28.0 & 32.0 & 31.9 & 31.4 & 29.3 & 26.4 & -6 \\
\hline Luxembourg & $\ldots$ & $\ldots$ & $\ldots$ & $\ldots$ & $\ldots$ & $\ldots$ & $\ldots$ \\
\hline Moldova & $\ldots$ & $\ldots$ & $\ldots$ & $\ldots$ & $\ldots$ & $\ldots$ & $\ldots$ \\
\hline Montenegro & 26.3 & 27.6 & 24.5 & 20.4 & 17.4 & 16.6 & -37 \\
\hline Netherlands & 13.4 & 12.2 & 10.1 & 9.0 & 9.4 & 9.1 & -32 \\
\hline $\begin{array}{l}\text { North Macedonia } \\
\text { Norway }\end{array}$ & 21.7 & 16.7 & 12.8 & 11.7 & 10.0 & 10.1 & -54 \\
\hline Poland & 20.3 & 19.8 & 18.3 & 16.7 & 15.7 & 19.6 & -3 \\
\hline Portugal & 10.0 & 9.7 & 9.8 & 7.3 & 7.7 & 6.0 & -40 \\
\hline Romania & $\ldots$ & $\ldots$ & $\ldots$ & $\ldots$ & $\ldots$ & 1.3 & $\ldots$ \\
\hline $\begin{array}{l}\text { Russian Federa- } \\
\text { tion }\end{array}$ & $\ldots$ & $\ldots$ & $\ldots$ & $\ldots$ & $\ldots$ & $\ldots$ & $\ldots$ \\
\hline Serbia & 26.6 & 25.0 & 21.1 & 21.6 & 15.3 & 12.5 & -53 \\
\hline Slovak Republic & $\ldots$ & $\ldots$ & $\ldots$ & $\ldots$ & $\ldots$ & $\ldots$ & $\ldots$ \\
\hline Slovenia & $\ldots$ & $\ldots$ & $\ldots$ & $\ldots$ & & $\ldots$ & $\ldots$ \\
\hline Spain & 12.4 & 13.9 & 13.7 & 15.1 & 15.3 & 16.3 & 31 \\
\hline Sweden & 8.5 & 7.6 & 7.1 & 7.8 & 7.4 & 6.2 & -27 \\
\hline Switzerland & 42.5 & 43.7 & 50.7 & 47.9 & 49.8 & 46.0 & 8 \\
\hline Turkey & 31.7 & 38.7 & 52.2 & 38.1 & 36.9 & 38.5 & 21 \\
\hline Ukraine & 3.3 & 3.4 & 3.1 & 3.1 & 2.3 & 1.5 & -55 \\
\hline UK: England \& & & & & & & & \\
\hline Wales & 3.7 & 3.3 & 3.2 & 2.5 & 2.1 & 1.9 & -47 \\
\hline UK: Northern Ire- & & & & & & & \\
\hline $\begin{array}{l}\text { land } \\
\text { UK: Scotland }\end{array}$ & $\ldots$ & $\cdots$ & $\ldots$ & $\cdots$ & $\ldots$ & $\ldots$ & $\cdots$ \\
\hline Mean & 18.4 & 18.5 & 19.0 & 17.1 & 16.1 & 15.2 & \\
\hline Median & 16.5 & 17.0 & 14.7 & 13.0 & 14.3 & 11.0 & \\
\hline Minimum & 3.2 & 3.3 & 2.6 & 2.5 & 2.1 & 1.3 & \\
\hline Maximum & 57.7 & 58.5 & 76.8 & 70.7 & 63.4 & 57.1 & \\
\hline
\end{tabular}


Table 3.2.1.19 Persons convicted per 100000 population - Money laundering

\begin{tabular}{|c|c|c|c|c|c|c|c|}
\hline & 2011 & 2012 & 2013 & 2014 & 2015 & 2016 & $\begin{array}{l}\% \text { change } \\
2011-2016\end{array}$ \\
\hline Albania & 0.9 & 0.9 & 0.8 & 1.8 & 1.9 & 1.2 & 38 \\
\hline Armenia & 0.0 & & & & & 0.0 & -100 \\
\hline Austria & 0.1 & 0.1 & 0.1 & 0.3 & 0.4 & 0.3 & 285 \\
\hline Azerbaijan & & & & & & & \\
\hline $\begin{array}{l}\text { Belgium } \\
\text { Bosnia-Herze- }\end{array}$ & 2.4 & 2.0 & 2.3 & 2.9 & 4.2 & 5.2 & 120 \\
\hline $\begin{array}{l}\text { govina } \\
\text { Bulaaria }\end{array}$ & & & & & & & \\
\hline $\begin{array}{l}\text { Bulgaria } \\
\text { Croatia }\end{array}$ & $\begin{array}{l}0.2 \\
0.0\end{array}$ & $\begin{array}{l}0.1 \\
0.0\end{array}$ & $\begin{array}{l}0.1 \\
0.0\end{array}$ & $\begin{array}{l}0.1 \\
0.0\end{array}$ & $\begin{array}{l}0.3 \\
0.2\end{array}$ & $\begin{array}{l}0.2 \\
0.2\end{array}$ & 46 \\
\hline Cyprus & & & & & & & \\
\hline Czech Republic & 0.2 & 0.2 & 0.3 & 0.5 & 0.6 & 0.6 & 160 \\
\hline $\begin{array}{l}\text { Denmark } \\
\text { Estonia }\end{array}$ & 4.7 & 3.4 & 2.0 & 3.3 & 2.8 & 2.6 & -45 \\
\hline Finland & 0.7 & 0.9 & 1.2 & 1.5 & 1.8 & 2.6 & 248 \\
\hline $\begin{array}{l}\text { France } \\
\text { Georgia }\end{array}$ & & $\ldots$ & & & $\ldots$ & & \\
\hline $\begin{array}{l}\text { Georgia } \\
\text { Germany }\end{array}$ & 1.1 & 1.1. & 1.0 & 1.0 & 0.9 & 1.0 & -8 \\
\hline $\begin{array}{l}\text { Hungary } \\
\text { Iceland }\end{array}$ & 0.1 & 0.1 & 0.1 & 0.1 & 0.1 & 0.3 & 81 \\
\hline Italy & 3.9 & 3.7 & 3.5 & 3.1 & 3.1 & 3.4 & -13 \\
\hline Kosovo (UN & & & & & & & \\
\hline R/1244/99) & $\ldots$ & $\ldots$ & $\ldots$ & $\ldots$ & $\ldots$ & $\ldots$ & ... \\
\hline Latvia & & & & & & & \\
\hline Lithuania & 0.3 & 0.3 & 0.2 & 0.5 & 0.7 & 0.6 & 69 \\
\hline Luxembourg & & & & & & & \\
\hline $\begin{array}{l}\text { Moldova } \\
\text { S }\end{array}$ & 0.1 & 0.0 & 0.0 & 0.0 & 0.1 & 0.1 & -24 \\
\hline Montenegro & 0.0 & 0.0 & 0.5 & 0.0 & 0.0 & 0.0 & \\
\hline Netherlands & 2.0 & 2.2 & 2.3 & 2.4 & 2.5 & 2.0 & 2 \\
\hline North Macedonia & 0.3 & 0.4 & 1.0 & 1.3 & 0.7 & 0.2 & -34 \\
\hline Norway & & & & & & & \\
\hline Poland & 0.3 & 0.3 & 0.4 & 0.3 & 0.3 & 0.2 & -26 \\
\hline Portugal & 0.1 & 0.2 & 0.3 & 0.2 & 0.3 & 0.3 & 343 \\
\hline Romania & & $\ldots$ & $\ldots$ & 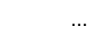 & $\ldots$ & 0.1 & ... \\
\hline $\begin{array}{l}\text { Russian Federa- } \\
\text { tion }\end{array}$ & & & & & & & \\
\hline Serbia & 0.0 & 0.0 & 0.0 & 0.0 & 0.0 & 0.2 & 276 \\
\hline Slovak Republic & & & & & & & \\
\hline Slovenia & 0.0 & 0.3 & 0.4 & 0.6 & 1.0 & 0.2 & 297 \\
\hline Spain & 3.1 & 3.4 & 4.3 & 5.4 & 5.9 & 6.5 & 110 \\
\hline Sweden & 1.1 & 1.0 & 1.9 & 1.9 & 1.7 & 1.5 & 45 \\
\hline Switzerland & 2.6 & 3.0 & 3.0 & 3.7 & 3.8 & 4.3 & 66 \\
\hline Turkey & 0.1 & 0.1 & 0.2 & 0.2 & 0.1 & 0.1 & -36 \\
\hline Ukraine & 0.1 & 0.1 & 0.1 & 0.1 & 0.0 & 0.0 & -94 \\
\hline UK: England \& & & & & & & & \\
\hline Wales & 2.7 & 2.5 & 2.2 & 2.0 & 2.3 & 2.5 & -9 \\
\hline $\begin{array}{l}\text { UK: Northern Ire- } \\
\text { land }\end{array}$ & & & & & & & \\
\hline UK: Scotland & 0.0 & 0.0 & 0.0 & 0.0 & 0.0 & 0.0 & \\
\hline Mean & 1.0 & 1.0 & 1.0 & 1.2 & 1.3 & 1.3 & \\
\hline Median & 0.3 & 0.3 & 0.4 & 0.5 & 0.7 & 0.3 & \\
\hline Minimum & 0.0 & 0.0 & 0.0 & 0.0 & 0.0 & 0.0 & \\
\hline Maximum & 4.7 & 3.7 & 4.3 & 5.4 & 5.9 & 6.5 & \\
\hline
\end{tabular}


Table 3.2.1.20 Persons convicted per 100000 population - Corruption in the public sector

\begin{tabular}{|c|c|c|c|c|c|c|c|}
\hline & 2011 & 2012 & 2013 & 2014 & 2015 & 2016 & $\begin{array}{l}\% \text { change } \\
2011-2016\end{array}$ \\
\hline Albania & 1.7 & 1.0 & 1.1 & 0.9 & 2.9 & 2.4 & 45 \\
\hline Armenia & 1.1 & $\ldots$ & $\ldots$ & $\ldots$ & $\ldots$ & 1.4 & 27 \\
\hline Austria & 1.1 & 0.9 & 1.5 & 2.2 & 1.5 & 0.7 & -38 \\
\hline Azerbaijan & 0.3 & 0.7 & 0.4 & 0.4 & 0.2 & 0.4 & 36 \\
\hline Belgium & 0.2 & 0.2 & 0.4 & 0.3 & 0.5 & 0.1 & -63 \\
\hline \multicolumn{8}{|l|}{ Bosnia-Herze- } \\
\hline Bulgaria & 1.5 & 1.6 & 1.4 & 1.0 & 1.1 & 1.7 & 12 \\
\hline Croatia & 6.0 & 7.9 & 5.7 & 11.8 & 5.1 & 3.4 & -43 \\
\hline \multicolumn{8}{|l|}{ Cyprus } \\
\hline Czech Republic & 1.0 & 1.1 & 1.1 & 1.4 & 0.9 & 0.9 & -9 \\
\hline Denmark & 0.0 & 0.2 & 0.0 & 0.0 & 0.1 & 0.1 & 192 \\
\hline Estonia & 3.0 & 2.7 & 4.7 & 4.2 & 2.3 & 2.2 & -27 \\
\hline Finland & 0.0 & 0.1 & 0.1 & 0.1 & 0.1 & 0.0 & -51 \\
\hline France & 0.4 & 0.5 & 0.4 & 0.5 & 0.4 & 0.5 & 23 \\
\hline Georgia & 2.1 & 1.0 & 2.6 & 1.7 & 2.5 & 3.0 & 43 \\
\hline Germany & 0.3 & 0.3 & 0.2 & 0.2 & 0.2 & 0.2 & -42 \\
\hline Hungary & 1.3 & 1.2 & 2.0 & 1.5 & 1.5 & 1.8 & 42 \\
\hline Iceland & $\ldots$ & $\ldots$ & $\ldots$ & $\ldots$ & $\ldots$ & $\ldots$ & $\ldots$ \\
\hline \multirow{2}{*}{\multicolumn{8}{|c|}{ Kosovo (UN }} \\
\hline & & & & & & & \\
\hline$R / 1244 / 99)$ & $\ldots$ & $\ldots$ & $\ldots$ & $\ldots$ & $\ldots$ & $\ldots$ & $\ldots$ \\
\hline Latvia & $\ldots$ & $\ldots$ & $\ldots$ & $\ldots$ & $\ldots$ & $\ldots$ & $\ldots$ \\
\hline Lithuania & 12.2 & 19.7 & 25.2 & 30.5 & 26.8 & 16.7 & 36 \\
\hline Luxembourg & $\ldots$ & $\ldots$ & $\ldots$ & $\ldots$ & $\ldots$ & 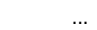 & $\ldots$ \\
\hline Moldova & 1.0 & 1.3 & 1.5 & 1.3 & 1.9 & 1.7 & 65 \\
\hline Montenegro & $\ldots$ & $\ldots$ & $\ldots$ & $\ldots$ & $\ldots$ & $\ldots$ & $\ldots$ \\
\hline Netherlands & 0.1 & 0.0 & 0.1 & 0.0 & 0.0 & 0.0 & -51 \\
\hline North Macedonia & $\ldots$ & $\ldots$ & $\ldots$ & $\ldots$ & $\ldots$ & $\ldots$ & $\ldots$ \\
\hline Norway & $\ldots$ & $\ldots$ & $\ldots$ & $\ldots$ & $\ldots$ & $\ldots$ & $\ldots$ \\
\hline Poland & 7.0 & 6.0 & 5.8 & 5.3 & 4.6 & 4.7 & -33 \\
\hline Portugal & 0.6 & 0.5 & 0.5 & 0.4 & 0.3 & 0.6 & -9 \\
\hline Romania & $\ldots$ & $\ldots$ & $\ldots$ & $\ldots$ & $\ldots$ & 3.0 & $\ldots$ \\
\hline \multicolumn{8}{|l|}{$\begin{array}{l}\text { Russian Federa- } \\
\text { tion }\end{array}$} \\
\hline Serbia & 0.7 & 1.6 & 1.4 & 1.1 & 1.2 & 1.4 & 109 \\
\hline Slovak Republic & & & $\ldots$ & $\ldots$ & & $\ldots$ & $\ldots$ \\
\hline Slovenia & 0.2 & 0.2 & 1.0 & 0.8 & 0.8 & 1.1 & 446 \\
\hline Spain & $\ldots$ & $\ldots$ & $\ldots$ & $\ldots$ & $\ldots$ & $\ldots$ & $\ldots$ \\
\hline Sweden & 0.1 & 0.2 & 0.1 & 0.2 & 0.1 & 0.1 & -52 \\
\hline Switzerland & 0.1 & 0.2 & 0.2 & 0.2 & 0.7 & 0.3 & 163 \\
\hline Turkey & 0.8 & 1.8 & 2.0 & 1.5 & 1.1 & 1.4 & 71 \\
\hline Ukraine & 1.7 & 1.5 & 1.6 & 1.0 & 0.9 & 0.6 & -63 \\
\hline \multicolumn{8}{|l|}{ UK: England \& } \\
\hline Wales & $\ldots$ & $\ldots$ & $\ldots$ & $\ldots$ & $\ldots$ & $\ldots$ & $\ldots$ \\
\hline \multicolumn{8}{|l|}{ UK: Northern Ire- } \\
\hline UK: Scotland & 0.0 & 0.0 & 0.0 & 0.0 & 0.0 & 0.0 & $\begin{array}{l}\cdots \\
\ldots\end{array}$ \\
\hline Mean & 1.6 & 2.0 & 2.3 & 2.6 & 2.2 & 1.8 & \\
\hline Median & 0.8 & 0.9 & 1.1 & 1.0 & 0.9 & 1.0 & \\
\hline Minimum & 0.0 & 0.0 & 0.0 & 0.0 & 0.0 & 0.0 & \\
\hline Maximum & 12.2 & 19.7 & 25.2 & 30.5 & 26.8 & 16.7 & \\
\hline
\end{tabular}


Table 3.2.1.21 Persons convicted per 100000 population - Drug offences: Total

\begin{tabular}{|c|c|c|c|c|c|c|c|}
\hline & 2011 & 2012 & 2013 & 2014 & 2015 & 2016 & $\begin{array}{c}\% \text { change } \\
2011-2016\end{array}$ \\
\hline Albania & 18 & 12 & 23 & 22 & 22 & 29 & 64 \\
\hline Armenia & 15 & $\ldots$ & $\ldots$ & $\ldots$ & $\ldots$ & 10 & -36 \\
\hline Austria & 53 & 51 & 50 & 51 & 52 & 46 & -14 \\
\hline Azerbaijan & 25 & 23 & 23 & 25 & 26 & 25 & 1 \\
\hline Belgium & 50 & 48 & 47 & 52 & 54 & 54 & 8 \\
\hline \multicolumn{8}{|l|}{$\begin{array}{l}\text { Bosnia-Herze- } \\
\text { govina }\end{array}$} \\
\hline Bulgaria & 19 & 19 & 20 & 19 & 22 & 27 & 37 \\
\hline Croatia & 22 & 19 & 20 & 22 & 16 & 18 & -19 \\
\hline Cyprus & $\ldots$ & $\ldots$ & $\ldots$ & $\ldots$ & $\ldots$ & $\ldots$ & $\ldots$ \\
\hline Czech Republic & 18 & 20 & $\dddot{24}$ & 25 & 26 & 27 & 53 \\
\hline Denmark & 244 & 272 & 271 & 292 & 254 & 217 & -11 \\
\hline Estonia & 37 & 36 & 39 & 46 & 44 & 54 & 48 \\
\hline Finland & 155 & 145 & 156 & 151 & 173 & 162 & 4 \\
\hline France & 77 & 81 & 86 & 90 & 95 & 98 & 28 \\
\hline Georgia & 57 & 27 & 164 & 148 & 110 & 56 & -2 \\
\hline Germany & 69 & 67 & 66 & 69 & 69 & 70 & 1 \\
\hline $\begin{array}{l}\text { Hungary } \\
\text { Iceland }\end{array}$ & 23 & 24 & 22 & 17 & 13 & 10 & -56 \\
\hline Italy & $\dddot{53}$ & 52 & $\dddot{46}$ & 39 & 36 & 37 & $\begin{array}{l}\cdots \\
-29\end{array}$ \\
\hline \multicolumn{8}{|l|}{ Kosovo (UN } \\
\hline $\mathrm{R} / 1244 / 99)$ & $\ldots$ & $\ldots$ & $\ldots$ & $\ldots$ & $\ldots$ & $\ldots$ & $\ldots$ \\
\hline Latvia & 47 & 49 & 43 & 42 & 57 & 61 & 31 \\
\hline Lithuania & 47 & 48 & 48 & 57 & 62 & 53 & 13 \\
\hline Luxembourg & $\ldots$ & & $\ldots$ & ... & $\ldots$ & 37 & $\ldots$ \\
\hline Moldova & 26 & 26 & 20 & 19 & 21 & 16 & -38 \\
\hline \multicolumn{8}{|l|}{ Montenegro } \\
\hline Netherlands & 37 & 35 & 37 & 35 & 36 & 35 & -4 \\
\hline North Macedonia & $\ldots$ & $\ldots$ & $\ldots$ & $\ldots$ & $\ldots$ & $\ldots$ & $\ldots$ \\
\hline Norway & 335 & 322 & 366 & 342 & 346 & 321 & -4 \\
\hline Poland & 55 & 51 & 48 & 46 & 43 & 51 & -7 \\
\hline Portugal & 39 & 43 & 39 & 33 & 38 & 39 & 0 \\
\hline Romania & $\ldots$ & $\ldots$ & $\ldots$ & ... & $\ldots$ & 4 & $\ldots$ \\
\hline \multicolumn{8}{|l|}{ Russian Federa- } \\
\hline tion & $\ldots$ & $\ldots$ & $\ldots$ & $\ldots$ & $\ldots$ & $\ldots$ & $\ldots$ \\
\hline Serbia & 51 & 45 & 42 & 43 & 43 & 47 & -8 \\
\hline \multicolumn{8}{|l|}{ Slovak Republic } \\
\hline Slovenia & 25 & 29 & 45 & 36 & 32 & 26 & 5 \\
\hline \multicolumn{8}{|l|}{ Spain } \\
\hline Sweden & 239 & 256 & 234 & 236 & 232 & 218 & -9 \\
\hline Switzerland & 202 & 226 & 239 & 244 & 247 & 244 & 21 \\
\hline Turkey & 154 & 181 & 234 & 193 & 123 & 120 & -22 \\
\hline Ukraine & 56 & 56 & 40 & 30 & 26 & 21 & -62 \\
\hline \multicolumn{8}{|l|}{ UK: England \& } \\
\hline Wales & 110 & 103 & 100 & 90 & 81 & 73 & -33 \\
\hline \multicolumn{8}{|l|}{ UK: Northern Ire- } \\
\hline land & $\ldots$ & 91 & 102 & 93 & 104 & 101 & $\ldots$ \\
\hline UK: Scotland & 142 & 132 & 121 & 126 & 128 & 132 & -7 \\
\hline Mean & 81 & 83 & 91 & 88 & 85 & 75 & \\
\hline Median & 51 & 49 & 47 & 46 & 52 & 49 & \\
\hline Minimum & 15 & 12 & 20 & 17 & 13 & 4 & \\
\hline Maximum & 335 & 322 & 366 & 342 & 346 & 321 & \\
\hline
\end{tabular}


Table 3.2.1.22 Persons convicted per 100000 population - Drug trafficking

\begin{tabular}{|c|c|c|c|c|c|c|c|}
\hline & 2011 & 2012 & 2013 & 2014 & 2015 & 2016 & $\begin{array}{c}\% \text { change } \\
2011-2016\end{array}$ \\
\hline Albania & 2.5 & 2.5 & 6.9 & 4.6 & 4.6 & 3.6 & 44 \\
\hline Armenia & 4.2 & 3.4 & 3.7 & 2.2 & 1.5 & 1.4 & -68 \\
\hline Austria & 12.3 & 14.7 & 13.7 & 13.6 & 14.8 & 15.4 & 26 \\
\hline Azerbaijan & $\ldots$ & $\ldots$ & $\ldots$ & $\ldots$ & $\ldots$ & $\ldots$ & $\ldots$ \\
\hline Belgium & $\ldots$ & $\ldots$ & $\ldots$ & $\ldots$ & $\ldots$ & $\ldots$ & $\ldots$ \\
\hline Bosnia-Herze- & & & & & & & \\
\hline govina & $\cdots$ & $\cdots$ & $\cdots$ & $\cdots$ & $\cdots$ & $\cdots$ & $\cdots$ \\
\hline Croatia & 221 & $18 \ddot{8}$ & 19.6 & 223 & $16 \ddot{4}$ & $\begin{array}{ll}\ldots \\
170\end{array}$ & $\ldots$ \\
\hline Cyprus & $\ldots$ & $\ldots$ & $\ldots$ & $\ldots$ & $\begin{array}{r}10.4 \\
\ldots\end{array}$ & 11.9 & -19 \\
\hline Czech Republic & 14.3 & 15.5 & 18.7 & 18.6 & 19.9 & 21.2 & 48 \\
\hline Denmark & 34.2 & 35.3 & 36.8 & 32.5 & 31.9 & 28.6 & -16 \\
\hline Estonia & 36.6 & 36.4 & 38.7 & 46.1 & 43.5 & 54.1 & 48 \\
\hline Finland & 66.4 & 64.0 & 67.2 & 68.5 & 65.1 & 64.2 & -3 \\
\hline France & 32.0 & 42.7 & 45.3 & 46.7 & 49.3 & 51.1 & 60 \\
\hline Georgia & 0.6 & 0.3 & 1.3 & 2.9 & 3.2 & 0.4 & -31 \\
\hline Germany & 11.2 & 11.3 & 10.5 & 10.7 & 10.9 & 11.2 & 0 \\
\hline Hungary & $\ldots$ & $\ldots$ & 4.3 & 4.2 & 4.2 & 4.0 & $\ldots$ \\
\hline Iceland & $\ldots$ & $\ldots$ & $\ldots$ & $\ldots$ & $\ldots$ & $\ldots$ & $\ldots$ \\
\hline Italy & $\ldots$ & $\ldots$ & $\ldots$ & $\ldots$ & $\ldots$ & $\ldots$ & $\ldots$ \\
\hline \multicolumn{8}{|l|}{ Kosovo (UN } \\
\hline $\mathrm{R} / 1244 / 99)$ & $\ldots$ & $\ldots$ & $\ldots$ & $\ldots$ & $\ldots$ & $\ldots$ & $\ldots$ \\
\hline Latvia & $\ldots$ & $\ldots$ & $\ldots$ & $\ldots$ & $\ldots$ & $\ldots$ & $\ldots$ \\
\hline Lithuania & 15.2 & 15.1 & 14.0 & 17.8 & 18.4 & 16.2 & 6 \\
\hline Luxembourg & $\ldots$ & $\ldots$ & $\ldots$ & $\ldots$ & $\ldots$ & 30.9 & $\ldots$ \\
\hline Moldova & $\ldots$ & $\ldots$ & $\ldots$ & $\ldots$ & $\ldots$ & $\ldots$ & $\ldots$ \\
\hline Montenegro & $\ldots$ & $\ldots$ & $\ldots$ & $\ldots$ & $\ldots$ & $\ldots$ & $\ldots$ \\
\hline Netherlands & $\ldots$ & $\ldots$ & $\ldots$ & $\ldots$ & $\ldots$ & $\ldots$ & $\ldots$ \\
\hline North Macedonia & $\ldots$ & $\ldots$ & $\ldots$ & $\ldots$ & $\ldots$ & $\ldots$ & $\ldots$ \\
\hline Norway & $\ldots$ & $\ldots$ & $\ldots$ & $\ldots$ & $\ldots$ & $\ldots$ & $\ldots$ \\
\hline Poland & 5.3 & 5.6 & 5.2 & 4.7 & 4.7 & 5.5 & 3 \\
\hline Portugal & 31 & 35 & 31.3 & 27.1 & 29.4 & 27.8 & -10 \\
\hline Romania & $\ldots$ & $\ldots$ & $\ldots$ & $\ldots$ & $\ldots$ & 3.9 & $\ldots$ \\
\hline \multicolumn{8}{|l|}{ Russian Federa- } \\
\hline tion & $\ldots$ & $\ldots$ & $\ldots$ & $\ldots$ & $\ldots$ & $\ldots$ & $\ldots$ \\
\hline Serbia & 28.9 & 22.8 & 19.0 & 17.1 & 12.6 & 14.5 & -50 \\
\hline Slovak Republic & $\ldots$ & $\ldots$ & $\ldots$ & $\ldots$ & $\ldots$ & $\ldots$ & $\ldots$ \\
\hline Slovenia & 21.8 & 25.8 & 42.5 & 34.2 & 30.4 & 24.8 & 14 \\
\hline Spain & $\ldots$ & $\ldots$ & $\ldots$ & $\ldots$ & ... & $\ldots$ & $\ldots$ \\
\hline Sweden & 11.3 & 16.5 & 16.8 & 13.6 & 25.8 & 23.8 & 110 \\
\hline Switzerland & 70.6 & 83.3 & 89.4 & 94.0 & 99.4 & 94.4 & 34 \\
\hline Turkey & 47.9 & 59.9 & 79.5 & 65.6 & 69.3 & 66.9 & 40 \\
\hline Ukraine & 11.4 & 10.4 & 7.4 & 5.0 & 3.7 & 1.7 & -85 \\
\hline \multicolumn{8}{|l|}{ UK: England \& } \\
\hline Wales & 1.2 & 1.0 & 0.9 & 0.9 & 0.9 & 0.7 & -38 \\
\hline \multicolumn{8}{|l|}{ UK: Northern Ire- } \\
\hline land & $\ldots$ & $\ldots$ & $\ldots$ & $\ldots$ & $\ldots$ & $\ldots$ & $\ldots$ \\
\hline UK: Scotland & $\ldots$ & $\ldots$ & $\ldots$ & $\ldots$ & $\ldots$ & $\ldots$ & $\ldots$ \\
\hline Mean & 22.9 & 24.8 & 26.0 & 25.1 & 25.4 & 24.3 & \\
\hline Median & 15.2 & 16.5 & 17.7 & 17.4 & 17.4 & 17.1 & \\
\hline Minimum & 0.6 & 0.3 & 0.9 & 0.9 & 0.9 & 0.4 & \\
\hline Maximum & 70.6 & 83.3 & 89.4 & 94.0 & 99.4 & 94.4 & \\
\hline
\end{tabular}


Notes on tables 3.2.1.1 to 3.2.1.22

Belgium Reliable data are not (yet) available for traffic offences 2013-2016 and (aggravated) assault

Bulgaria Cyber fraud is not monitored as a separate item but is included in the total figure of fraud. For some crimes the number of convicted persons is higher than the number of suspects. This might be due to the duration of criminal proceedings, which usually exceeds one calendar year.

Czech Republic Due to requalification of offences, the 2011 figures for intentional homicide, sexual assault total, rape and drug offences total are different from the fifth edition.

Denmark Police tickets are included. Regarding appeal: If an appeal case is settled within the same year as the first conviction, the data refers to the appeal case. In other cases, the data refers to the first conviction.

Drug offences include both some according to the penal code and some according to a special law on (less severe) drug offences.

Part of the increase in both fraud and cyber fraud is caused by changes in the police registration practice in these types of cases. Cyber fraud includes violations of $\S 279$ a in the Penal Code exclusively, as this is currently the best approximation available of cyber fraud in a Danish context. As a result, some types of cyber fraud are not encompassed by the definition, and the definition may encompass offences, which are not 'cyber' fraud per se.

Estonia All offence types within the same conviction are counted separately, but each offence type is counted only once, regardless of the number of offences. Accordingly, the total of convictions for different offence types exceeds the total number of persons convicted.

Finland $\quad$ For sexual assault (total), those are exploitation of a person object to sex trade, buying sexual services from a minor, crimes related to child pornography, grooming and pimping.

For robbery, extortion is also included.

For fraud, incurrence and payment instrument frauds are also included

For forgery of documents, forgery of money is also included.

Georgia Assault excludes violence in family

Hungary From 2013 on, the principal offence rule is not applied in recording convicted persons; therefore, data of 2011-2012 are not completely comparable with those of 2013-2016, according to the National Office for the Judiciary.

Lithuania In 2011, sexual abuse of a child refers to two crimes: sexual abuse of a child who is under 14 years of age and satisfaction of sexual desires in violation of a minor's sexual self-determination, and(or) t integrity).

Netherlands Statistics Netherlands stopped providing Prosecution and Court statistics. Therefore, figures starting in 2010 are slightly different from the years before that

Poland Numbers do not include minors convicted in juvenile criminal proceedings. Minors in this tables are only those who committed an offence as a minor (under 17 years old) but were sentenced when they were 17,18 or more years old.

Portugal There was a change in the method of collection of statistics of the courts in 2007 and since then it became possible to determine the number of convicted of some crimes more detailed.

Serbia Sexual abuse of a child includes the following criminal offences: sexual Intercourse with a child and sexual intercourse through abuse of position.

Theft of a motor vehicle includes the criminal offence unauthorised use of another's vehicle.

Spain For Total Criminal Offences the counting unit is the person convicted. A person convicted two or more times in the same year is counted only once in the total. For all the other categories, the counting unit is the main offence for which a person was convicted

Sweden Convictions for offences listed include attempts, preparation, and conspiracy to commit an offence.

Fraud: Data previously reported for the period 2007-2011 includes receiving/handling a stolen property. Data in this edition excludes this offence.

Money laundering: In 2012, a new article concerning financing of bribery offences was added and data for persons convicted for this article is included. As of 2014, there is also a new law regarding money laundering, and data includes convictions accordingly.

Drug trafficking: As of 2015 , it is possible to distinguish drug trafficking from total drug offences to a larger extent than previously. 


\begin{tabular}{ll}
\hline Turkey & Statistics do not refer to the number of persons, but to the total numbers of sanctions rendered \\
by the court. So, if 1 person got 2 different sanction for the same crime (for example a fine and \\
a suspended sentence), those would be counted as 2 . \\
Homicide does not include injury leading to death, aggravated assault includes injury leading to \\
death \\
Sexual assault includes "sex with a minor" which in Turkey is separate from "child sexual abuse", \\
and refers to cases where victim is age 15-18, and no violence was used. \\
$\begin{array}{l}\text { Non-Penal code convictions account to about 15\% of all convictions. } \\
\text { UK: England \& }\end{array}$ \\
$\begin{array}{l}\text { Sexual Assault refers to all sexual offences. } \\
\text { Wales }\end{array}$ \\
$\begin{array}{l}\text { The various types of Burglary are not subsets of Theft, but standalone categories. } \\
\text { UK: Scotland } \\
\text { Data provided is for financial years i.e., 2010=2010-11 } \\
\text { Domestic burglary is not separately identifiable from other types of burglary. }\end{array}$ \\
\hline
\end{tabular}


3.2.2 Percentage of women, minors, and foreigners among convicted persons in 2015

Table 3.2.2.1 Percentage of women, minors, foreigners, and legal persons among convicted persons in 2015 - Criminal offences: Total

\begin{tabular}{|c|c|c|c|c|c|c|}
\hline & $\begin{array}{c}\text { Total offenders } \\
\text { per } 100000 \\
\text { pop. }\end{array}$ & $\begin{array}{l}\text { of which \% } \\
\text { of women }\end{array}$ & $\begin{array}{l}\text { of which \% } \\
\text { of minors }\end{array}$ & $\begin{array}{l}\text { of which } \% \\
\text { of foreigners }\end{array}$ & $\begin{array}{l}\% \text { of EU citi- } \\
\text { zens amongst } \\
\text { foreigners }\end{array}$ & $\begin{array}{l}\text { of which } \\
\% \text { of legal } \\
\text { persons }\end{array}$ \\
\hline Albania & 559 & 5.5 & 3.7 & & $\ldots$ & $\ldots$ \\
\hline Armenia & 94 & 7.7 & 2.8 & 1.9 & $\ldots$ & $\ldots$ \\
\hline Austria & 374 & 14.2 & 5.0 & 40.0 & 38.6 & $\ldots$ \\
\hline Azerbaijan & 138 & $\ldots$ & $\ldots$ & $\ldots$ & $\ldots$ & $\ldots$ \\
\hline Belgium & 1614 & 18.3 & 0.1 & 23.2 & 60.8 & $\ldots$ \\
\hline $\begin{array}{l}\text { Bosnia- } \\
\text { Herzegovina }\end{array}$ & 509 & $\ldots$ & 1.7 & $\ldots$ & $\ldots$ & ... \\
\hline Bulgaria & 386 & 8.4 & 4.5 & 11.7 & $\ldots$ & $\ldots$ \\
\hline Croatia & 308 & 11.4 & 3.2 & 3.3 & 37.4 & 0.4 \\
\hline Cyprus & 6387 & 20.0 & 0.6 & $\ldots$ & $\ldots$ & $\ldots$ \\
\hline $\begin{array}{l}\text { Czech } \\
\text { Republic }\end{array}$ & 622 & 15.1 & 2.1 & 7.4 & 60.2 & 0.1 \\
\hline $\begin{array}{l}\text { Denmark } \\
\text { Estonia }\end{array}$ & $\ldots$ & $\ldots$ & $\begin{array}{l}\ldots \\
\ldots\end{array}$ & $\begin{array}{l}\ldots \\
\ldots\end{array}$ & $\ldots$ & $\ldots$ \\
\hline Finland & 3321 & 20.8 & 4.8 & 11.8 & 47.3 & 0.0 \\
\hline France & 864 & 10.1 & 7.8 & 13.7 & $\ldots$ & $\ldots$ \\
\hline Georgia & 406 & 6.3 & 1.9 & 2.7 & $\ldots$ & $\ldots$ \\
\hline Germany & 911 & 19.8 & 4.2 & 28.3 & 40.5 & $\ldots$ \\
\hline Hungary & 728 & 11.8 & 6.4 & 4.0 & 41.8 & ... \\
\hline Iceland & $\ldots$ & $\ldots$ & $\ldots$ & $\ldots$ & $\ldots$ & $\ldots$ \\
\hline Italy & 363 & 16.6 & $\ldots$ & 32.5 & 45.7 & ... \\
\hline $\begin{array}{l}\text { Kosovo (UN } \\
\text { R/1244/99) }\end{array}$ & 938 & $\ldots$ & 3.3 & 0.5 & $\ldots$ & $\cdots$ \\
\hline Latvia & 481 & 11.8 & 4.3 & $\ldots$ & $\ldots$ & $\ldots$ \\
\hline Lithuania & 636 & 9.6 & 6.1 & $\ldots$ & $\ldots$ & 0.1 \\
\hline Luxembourg & 1498 & 20.8 & 6.5 & 60.4 & $\ldots$ & $\ldots$ \\
\hline Moldova & $\ldots$ & $\ldots$ & $\ldots$ & $\ldots$ & $\ldots$ & $\ldots$ \\
\hline Montenegro & $\ldots$ & $\ldots$ & $\ldots$ & $\ldots$ & $\ldots$ & $\ldots$ \\
\hline $\begin{array}{l}\text { Netherlands } \\
\text { North }\end{array}$ & 546 & 12.6 & 5.3 & $\ldots$ & $\ldots$ & 0.8 \\
\hline Macedonia & $\cdots$ & $\ldots$ & $\ldots$ & $\cdots$ & $\cdots$ & $\cdots$ \\
\hline Norway & $\ldots$ & $\ldots$ & $\ldots$ & $\ldots$ & 49.1 & $\ldots$ \\
\hline Poland & 684 & 10.3 & 0.3 & 2.7 & $\ldots$ & $\ldots$ \\
\hline Portugal & 597 & 12.2 & 1.8 & 10.4 & 20.0 & 4.1 \\
\hline Romania & 168 & $\ldots$ & 2.8 & 0.0 & $\ldots$ & 0.2 \\
\hline $\begin{array}{l}\text { Russian } \\
\text { Federation }\end{array}$ & 510 & $\ldots$ & 3.1 & 3.8 & $\ldots$ & ... \\
\hline Serbia & 494 & 9.2 & 5.5 & 2.1 & 50.1 & $\ldots$ \\
\hline $\begin{array}{l}\text { Slovak } \\
\text { Republic }\end{array}$ & 548 & $\ldots$ & 4.4 & 2.6 & $\ldots$ & ... \\
\hline Slovenia & $\ldots$ & $\ldots$ & & $\ldots$ & $\ldots$ & $\ldots$ \\
\hline Spain & 673 & 13.6 & 7.7 & 17.6 & 31.1 & $\ldots$ \\
\hline Sweden & 1095 & 17.3 & 8.2 & $\ldots$ & & $\ldots$ \\
\hline Switzerland & 1505 & 16.8 & 9.7 & 56.0 & 41.7 & $\ldots$ \\
\hline Turkey & 1971 & 5.4 & 6.9 & 1.1 & $\ldots$ & 0.0 \\
\hline Ukraine & 222 & 11.6 & 4.8 & 0.9 & $\ldots$ & $\ldots$ \\
\hline $\begin{array}{l}\text { UK: England \& } \\
\text { Wales }\end{array}$ & 2158 & 29.5 & 23.1 & $\ldots$ & $\ldots$ & 0.6 \\
\hline $\begin{array}{l}\text { UK: Northern } \\
\text { Ireland }\end{array}$ & 1317 & 16.8 & 4.7 & $\ldots$ & $\cdots$ & 0.0 \\
\hline UK: Scotland & 1860 & 16.9 & $\ldots$ & $\ldots$ & $\ldots$ & $\ldots$ \\
\hline Mean & 1014 & 13.8 & 4.9 & 14.1 & 43.4 & 0.6 \\
\hline Median & 622 & 12.6 & 4.5 & 5.7 & 41.8 & 0.2 \\
\hline Minimum & 94 & 5.4 & 0.1 & 0.0 & 20.0 & 0.0 \\
\hline Maximum & 6387 & 29.5 & 23.1 & 60.4 & 60.8 & 4.1 \\
\hline
\end{tabular}


Table 3.2.2.2 Percentage of women, minors, foreigners, and legal persons among convicted persons in 2015 - Criminal offences: Major traffic offences

\begin{tabular}{|c|c|c|c|c|c|c|}
\hline & $\begin{array}{c}\text { Total offenders } \\
\text { per } 100000 \\
\text { pop. }\end{array}$ & $\begin{array}{l}\text { of which \% } \\
\text { of women }\end{array}$ & $\begin{array}{l}\text { of which } \% \\
\text { of minors }\end{array}$ & $\begin{array}{l}\text { of which \% } \\
\text { of foreigners }\end{array}$ & $\begin{array}{l}\% \text { of EU citi- } \\
\text { zens amongst } \\
\text { foreigners }\end{array}$ & $\begin{array}{l}\text { of which } \\
\% \text { of legal } \\
\text { persons }\end{array}$ \\
\hline Albania & 10 & 5.0 & 29.9 & $\ldots$ & $\ldots$ & $\ldots$ \\
\hline Armenia & 3 & 1.2 & 1.2 & 2.4 & $\ldots$ & $\ldots$ \\
\hline Austria & $\ldots$ & $\ldots$ & $\ldots$ & $\ldots$ & $\ldots$ & $\ldots$ \\
\hline Azerbaijan & 15 & $\ldots$ & $\ldots$ & ... & $\ldots$ & ... \\
\hline $\begin{array}{l}\text { Belgium } \\
\text { Bosnia- }\end{array}$ & $\ldots$ & $\ldots$ & $\ldots$ & $\cdots$ & $\ldots$ & $\ldots$ \\
\hline Herzegovina & $\ldots$ & $\ldots$ & $\ldots$ & $\ldots$ & $\ldots$ & $\ldots$ \\
\hline Bulgaria & 111 & 2.8 & 0.5 & 1.8 & $\ldots$ & $\ldots$ \\
\hline Croatia & 22 & 17.3 & 0.3 & 2.6 & 29.2 & 0.0 \\
\hline $\begin{array}{l}\text { Cyprus } \\
\text { Czech }\end{array}$ & 2696 & 19.6 & $\ldots$ & $\ldots$ & $\ldots$ & $\ldots$ \\
\hline Republic & 152 & 9.5 & 0.2 & 7.0 & 64.3 & 0.0 \\
\hline $\begin{array}{l}\text { Denmark } \\
\text { Estonia }\end{array}$ & $\begin{array}{l}\ldots \\
\ldots\end{array}$ & $\begin{array}{l}\ldots \\
\ldots\end{array}$ & $\begin{array}{l}\ldots \\
\ldots\end{array}$ & $\begin{array}{l}\ldots \\
\ldots\end{array}$ & $\begin{array}{l}\ldots \\
\ldots\end{array}$ & $\begin{array}{l}\ldots \\
\ldots\end{array}$ \\
\hline Finland & 1930 & 20.1 & 4.0 & 10.5 & 53.4 & 0.0 \\
\hline France & 313 & 8.9 & 0.8 & 10.1 & $\ldots$ & $\ldots$ \\
\hline Georgia & 20 & $\ldots$ & $\ldots$ & $\ldots$ & $\ldots$ & $\ldots$ \\
\hline Germany & 186 & 16.1 & 1.2 & 24.0 & 55.9 & $\ldots$ \\
\hline Hungary & 141 & 6.1 & 0.9 & 3.2 & 79.8 & ... \\
\hline Iceland & $\ldots$ & $\ldots$ & $\ldots$ & $\ldots$ & $\ldots$ & $\ldots$ \\
\hline $\begin{array}{l}\text { Italy } \\
\text { Kosovo (UN }\end{array}$ & 2 & 14.7 & 0.1 & 27.1 & $\ldots$ & $\ldots$ \\
\hline R/1244/99) & $\ldots$ & .... & $\ldots$ & $\ldots$ & $\ldots$ & $\ldots$ \\
\hline Latvia & 10 & 14.7 & 1.0 & $\ldots$ & $\ldots$ & $\ldots$ \\
\hline Lithuania & 12 & 15.5 & 0.3 & $\ldots$ & ... & 0.0 \\
\hline Luxembourg & $\ldots$ & $\ldots$ & $\ldots$ & $\ldots$ & $\ldots$ & $\ldots$ \\
\hline Moldova & 90 & 1.1 & 0.3 & $\ldots$ & $\ldots$ & $\ldots$ \\
\hline Montenegro & $\ldots$ & $\ldots$ & $\ldots$ & $\ldots$ & ... & $\ldots$ \\
\hline $\begin{array}{l}\text { Netherlands } \\
\text { North }\end{array}$ & 98 & 8.9 & 1.0 & $\ldots$ & $\ldots$ & 0.0 \\
\hline Macedonia & $\ldots$ & $\ldots$ & $\ldots$ & $\ldots$ & $\ldots$ & $\ldots$ \\
\hline Norway & $\ldots$ & $\ldots$ & $\ldots$ & $\ldots$ & 55.7 & $\ldots$ \\
\hline Poland & 157 & 5.8 & 0.0 & 1.8 & $\ldots$ & $\ldots$ \\
\hline Portugal & 197 & 5.4 & 0.5 & 12.0 & 18.9 & $\ldots$ \\
\hline $\begin{array}{l}\text { Romania } \\
\text { Russian }\end{array}$ & 56 & $\ldots$ & $\ldots$ & $\ldots$ & $\ldots$ & $\ldots$ \\
\hline Federation & $\ldots$ & & $\ldots$ & $\ldots$ & & $\ldots$ \\
\hline Serbia & 37 & 6.5 & 1.1 & 1.9 & 58.8 & ... \\
\hline Slovak & & & & & & \\
\hline Republic & $\ldots$ & $\ldots$ & $\ldots$ & $\ldots$ & $\ldots$ & $\ldots$ \\
\hline Slovenia & $\ldots$ & $\ldots$ & $\ldots$ & $\ldots$ & $\ldots$ & $\ldots$ \\
\hline Spain & 195 & 9.1 & 1.1 & 21.5 & $\ldots$ & ... \\
\hline Sweden & 229 & 11.5 & 6.5 & & $\ldots$ & $\ldots$ \\
\hline Switzerland & 752 & 16.0 & 3.4 & 49.6 & 65.0 & $\ldots$ \\
\hline Turkey & 47 & 1.8 & 0.6 & 0.0 & $\ldots$ & 0.0 \\
\hline $\begin{array}{l}\text { Ukraine } \\
\text { SK. Enaland } 8\end{array}$ & 12 & 3.1 & 10.3 & 0.8 & $\ldots$ & $\ldots$ \\
\hline $\begin{array}{l}\text { UK: England \& } \\
\text { Wales }\end{array}$ & 8 & 5.9 & 3.9 & $\ldots$ & $\ldots$ & 0.0 \\
\hline UK: Northern & & & & & & \\
\hline Ireland & $\ldots$ & $\ldots$ & $\ldots$ & $\ldots$ & $\ldots$ & $\ldots$ \\
\hline UK: Scotland & $\ldots$ & $\ldots$ & $\ldots$ & $\ldots$ & $\ldots$ & $\ldots$ \\
\hline Mean & 278 & 9.4 & 3.0 & 11.0 & 53.4 & 0.0 \\
\hline Median & 90 & 8.9 & 1.0 & 5.1 & 55.9 & 0.0 \\
\hline Minimum & 2 & 1.1 & 0.0 & 0.0 & 18.9 & 0.0 \\
\hline Maximum & 2696 & 20.1 & 29.9 & 49.6 & 79.8 & 0.0 \\
\hline
\end{tabular}


Table 3.2.2.3 Percentage of women, minors, foreigners, and legal persons among convicted persons in 2015 - Intentional homicide: Total

\begin{tabular}{|c|c|c|c|c|c|c|}
\hline & $\begin{array}{c}\text { Total offenders } \\
\text { per } 100000 \\
\text { pop. }\end{array}$ & $\begin{array}{l}\text { of which \% } \\
\text { of women }\end{array}$ & $\begin{array}{l}\text { of which } \% \\
\text { of minors }\end{array}$ & $\begin{array}{l}\text { of which \% } \\
\text { of foreigners }\end{array}$ & $\begin{array}{l}\% \text { of EU citi- } \\
\text { zens amongst } \\
\text { foreigners }\end{array}$ & $\begin{array}{l}\text { of which } \\
\% \text { of legal } \\
\text { persons }\end{array}$ \\
\hline Albania & 5.9 & 2.9 & 0.6 & & $\ldots$ & $\ldots$ \\
\hline Armenia & 0.6 & 10.5 & 0.0 & 5.3 & $\ldots$ & $\ldots$ \\
\hline Austria & 0.7 & 16.7 & 10.0 & 40.0 & $\ldots$ & $\ldots$ \\
\hline Azerbaijan & $\ldots$ & $\ldots$ & $\ldots$ & $\ldots$ & $\ldots$ & $\ldots$ \\
\hline $\begin{array}{l}\text { Belgium } \\
\text { Bosnia- }\end{array}$ & 2.3 & 10.1 & 0.0 & 28.8 & 43.2 & $\ldots$ \\
\hline Herzegovina & $\ldots$ & $\ldots$ & $\ldots$ & $\ldots$ & $\ldots$ & $\ldots$ \\
\hline Bulgaria & 1.8 & 4.5 & 7.6 & 3.8 & $\ldots$ & $\ldots$ \\
\hline Croatia & 1.8 & 9.0 & 1.3 & 2.6 & 0.0 & 0.0 \\
\hline $\begin{array}{l}\text { Cyprus } \\
\text { Czech }\end{array}$ & \multicolumn{6}{|c|}{ Czech } \\
\hline Republic & 1.1 & 11.3 & 5.2 & 13.0 & 60.0 & 0.0 \\
\hline $\begin{array}{l}\text { Denmark } \\
\text { Estonia }\end{array}$ & $\begin{array}{l}\ldots \\
\ldots\end{array}$ & $\begin{array}{l}\ldots \\
\ldots\end{array}$ & $\begin{array}{l}\ldots \\
\ldots\end{array}$ & $\begin{array}{l}\ldots \\
\ldots\end{array}$ & $\begin{array}{l}\ldots \\
\ldots\end{array}$ & $\begin{array}{l}\ldots \\
\ldots\end{array}$ \\
\hline Finland & 2.6 & 16.6 & 2.8 & 5.5 & 12.5 & 0.0 \\
\hline France & 0.6 & 11.2 & 6.9 & 18.3 & $\ldots$ & $\ldots$ \\
\hline Georgia & 3.6 & 8.1 & 5.9 & $\ldots$ & $\ldots$ & $\ldots$ \\
\hline Germany & 0.7 & 10.5 & 5.7 & 34.4 & $\ldots$ & $\ldots$ \\
\hline Hungary & 1.9 & 12.6 & 3.7 & 4.7 & 77.8 & $\ldots$ \\
\hline Iceland & $\ldots$ & $\ldots$ & $\ldots$ & $\ldots$ & $\ldots$ & $\ldots$ \\
\hline $\begin{array}{l}\text { Italy } \\
\text { Kosovo (UN }\end{array}$ & \multicolumn{5}{|c|}{ Kosovo (UN } & ... \\
\hline $\mathrm{R} / 1244 / 99)$ & 0.0 & $\ldots$ & $\ldots$ & $\ldots$ & $\ldots$ & $\ldots$ \\
\hline Latvia & 2.7 & 11.1 & 5.6 & $\ldots$ & $\ldots$ & $\ldots$ \\
\hline Lithuania & 4.5 & 7.7 & 8.5 & $\ldots$ & $\ldots$ & 0.0 \\
\hline Luxembourg & 9.8 & $\ldots$ & $\ldots$ & ... & $\ldots$ & $\ldots$ \\
\hline Moldova & 3.4 & 10.0 & 4.2 & $\ldots$ & $\ldots$ & $\ldots$ \\
\hline Montenegro & $\ldots$ & $\ldots$ & $\ldots$ & $\ldots$ & $\ldots$ & $\ldots$ \\
\hline $\begin{array}{l}\text { Netherlands } \\
\text { North }\end{array}$ & 3.6 & 6.7 & 9.4 & $\ldots$ & $\ldots$ & 0.0 \\
\hline Macedonia & $\ldots$ & $\ldots$ & $\ldots$ & $\ldots$ & $\ldots$ & $\ldots$ \\
\hline Norway & $\ldots$ & $\ldots$ & $\ldots$ & $\ldots$ & $\ldots$ & $\ldots$ \\
\hline Poland & 1.5 & 14.0 & 1.2 & 0.9 & $\ldots$ & $\ldots$ \\
\hline Portugal & 2.3 & 7.2 & $\ldots$ & 11.4 & $\ldots$ & $\ldots$ \\
\hline $\begin{array}{l}\text { Romania } \\
\text { Russian }\end{array}$ & \multicolumn{6}{|c|}{ Russian } \\
\hline Federation & $\ldots$ & $\ldots$ & $\ldots$ & $\ldots$ & $\ldots$ & $\ldots$ \\
\hline Serbia & 1.9 & 9.8 & 7.5 & 2.3 & 33.3 & $\ldots$ \\
\hline \multicolumn{7}{|l|}{ Slovak } \\
\hline Republic & $\ldots$ & $\ldots$ & $\ldots$ & $\ldots$ & $\ldots$ & $\ldots$ \\
\hline Slovenia & $\ldots$ & $\ldots$ & $\ldots$ & $\ldots$ & $\ldots$ & $\ldots$ \\
\hline Spain & 1.6 & 8.0 & $\ldots$ & 27.8 & 21.8 & $\ldots$ \\
\hline Sweden & 1.6 & 6.4 & 4.5 & $\ldots$ & $\ldots$ & $\ldots$ \\
\hline Switzerland & 1.5 & 11.4 & 4.9 & 48.0 & 35.6 & $\ldots$ \\
\hline Turkey & 19.7 & 2.6 & 4.6 & 0.6 & $\ldots$ & 0.0 \\
\hline Ukraine & 1.9 & 12.5 & 2.9 & 2.2 & $\ldots$ & $\ldots$ \\
\hline \multicolumn{7}{|l|}{ UK: England \& } \\
\hline Wales & 2.5 & 10.1 & 3.3 & $\ldots$ & $\ldots$ & 0.5 \\
\hline \multicolumn{7}{|l|}{ UK: Northern } \\
\hline Ireland & $\ldots$ & $\ldots$ & $\ldots$ & $\ldots$ & $\ldots$ & $\ldots$ \\
\hline UK: Scotland & $\ldots$ & $\ldots$ & $\ldots$ & $\ldots$ & $\ldots$ & $\ldots$ \\
\hline Mean & 3.0 & 9.5 & 4.7 & 15.5 & 35.5 & 0.1 \\
\hline Median & 1.9 & 10.0 & 4.6 & 8.5 & 34.5 & 0.0 \\
\hline Minimum & 0.0 & 2.6 & 0.0 & 0.6 & 0.0 & 0.0 \\
\hline Maximum & 19.7 & 16.7 & 10.0 & 48.0 & 77.8 & 0.5 \\
\hline
\end{tabular}


Table 3.2.2.4 Percentage of women, minors, foreigners, and legal persons among convicted persons in 2015 - Intentional homicide: Completed

\begin{tabular}{|c|c|c|c|c|c|c|}
\hline & $\begin{array}{c}\text { Total offenders } \\
\text { per } 100000 \\
\text { pop. }\end{array}$ & $\begin{array}{l}\text { of which \% } \\
\text { of women }\end{array}$ & $\begin{array}{c}\text { of which } \% \\
\text { of minors }\end{array}$ & $\begin{array}{l}\text { of which \% } \\
\text { of foreigners }\end{array}$ & $\begin{array}{l}\% \text { of EU citi- } \\
\text { zens amongst } \\
\text { foreigners }\end{array}$ & $\begin{array}{l}\text { of which } \\
\% \text { of legal } \\
\text { persons }\end{array}$ \\
\hline Albania & $\ldots$ & $\ldots$ & $\ldots$ & $\ldots$ & $\ldots$ & $\ldots$ \\
\hline Armenia & $\ldots$ & $\ldots$ & $\ldots$ & $\ldots$ & $\ldots$ & $\ldots$ \\
\hline Austria & 0.3 & 16.0 & 8.0 & 36.0 & $\ldots$ & $\ldots$ \\
\hline Azerbaijan & 3.5 & $\ldots$ & $\ldots$ & $\ldots$ & $\ldots$ & $\ldots$ \\
\hline $\begin{array}{l}\text { Belgium } \\
\text { Bosnia- }\end{array}$ & $\ldots$ & $\ldots$ & $\ldots$ & $\ldots$ & $\ldots$ & $\ldots$ \\
\hline Herzegovina & $\ldots$ & & $\ldots$ & $\ldots$ & $\ldots$ & $\ldots$ \\
\hline Bulgaria & 1.4 & 5.1 & 9.2 & 1.0 & $\ldots$ & $\ldots$ \\
\hline Croatia & 0.8 & 3.1 & 0.0 & 0.0 & $\ldots$ & 0.0 \\
\hline \multicolumn{6}{|l|}{ Czech } & $\ldots$ \\
\hline Republic & $\ldots$ & ... & $\ldots$ & $\ldots$ & $\ldots$ & $\ldots$ \\
\hline Denmark & $\ldots$ & $\ldots$ & $\ldots$ & $\ldots$ & $\ldots$ & $\ldots$ \\
\hline Estonia & $\ldots$ & $\ldots$ & $\ldots$ & $\ldots$ & $\ldots$ & $\ldots$ \\
\hline Finland & 1.0 & 14.5 & 3.6 & $\ldots$ & $\ldots$ & 0.0 \\
\hline France & 0.2 & 13.8 & 8.5 & 16.9 & $\ldots$ & $\ldots$ \\
\hline Georgia & 2.6 & 3.1 & 2.1 & $\ldots$ & $\ldots$ & $\ldots$ \\
\hline Germany & 0.4 & $\ldots$ & $\ldots$ & $\ldots$ & $\ldots$ & $\ldots$ \\
\hline Hungary & 1.0 & 10.6 & 2.1 & 7.4 & 71.4 & $\ldots$ \\
\hline Iceland & $\ldots$ & $\ldots$ & $\ldots$ & $\ldots$ & $\ldots$ & $\ldots$ \\
\hline Italy & 0.8 & 5.2 & 1.7 & 24.0 & $\ldots$ & $\ldots$ \\
\hline \multicolumn{7}{|l|}{ Kosovo (UN } \\
\hline $\mathrm{R} / 1244 / 99)$ & $\ldots$ & $\ldots$ & $\ldots$ & $\ldots$ & $\ldots$ & $\ldots$ \\
\hline Latvia & $\ldots$ & $\ldots$ & $\ldots$ & $\ldots$ & $\ldots$ & $\ldots$ \\
\hline Lithuania & $\ldots$ & $\ldots$ & $\ldots$ & $\ldots$ & $\ldots$ & $\ldots$ \\
\hline Luxembourg & 0.4 & 50.0 & $\ldots$ & $\ldots$ & $\ldots$ & $\ldots$ \\
\hline Moldova & $\ldots$ & $\ldots$ & $\ldots$ & $\ldots$ & $\ldots$ & $\ldots$ \\
\hline Montenegro & $\ldots$ & $\ldots$ & $\ldots$ & $\ldots$ & $\ldots$ & $\ldots$ \\
\hline Netherlands & $\ldots$ & $\ldots$ & $\ldots$ & $\ldots$ & $\ldots$ & $\ldots$ \\
\hline \multicolumn{7}{|l|}{ North } \\
\hline Macedonia & $\ldots$ & $\ldots$ & $\ldots$ & $\ldots$ & $\ldots$ & $\ldots$ \\
\hline Norway & $\ldots$ & $\ldots$ & $\ldots$ & $\ldots$ & $\ldots$ & $\ldots$ \\
\hline Poland & 1.1 & $\ldots$ & $\ldots$ & $\ldots$ & $\ldots$ & $\ldots$ \\
\hline Portugal & 1.1 & 12.8 & $\ldots$ & 9.2 & $\ldots$ & $\ldots$ \\
\hline \multicolumn{7}{|l|}{ Russian } \\
\hline Federation & $\ldots$ & $\ldots$ & $\ldots$ & $\ldots$ & $\ldots$ & $\ldots$ \\
\hline Serbia & 1.3 & 13.3 & 4.4 & 3.3 & 100.0 & $\ldots$ \\
\hline \multicolumn{7}{|l|}{ Slovak } \\
\hline Republic & $\ldots$ & $\ldots$ & $\ldots$ & $\ldots$ & $\ldots$ & $\ldots$ \\
\hline Slovenia & $\ldots$ & $\ldots$ & $\ldots$ & $\ldots$ & $\ldots$ & $\ldots$ \\
\hline Spain & 0.3 & $\ldots$ & $\ldots$ & $\ldots$ & $\ldots$ & $\ldots$ \\
\hline Sweden & $\ldots$ & $\ldots$ & $\ldots$ & $\ldots$ & $\ldots$ & $\ldots$ \\
\hline Switzerland & 0.6 & 11.3 & 3.8 & 45.3 & 41.7 & $\ldots$ \\
\hline Turkey & $\ldots$ & $\ldots$ & $\ldots$ & $\ldots$ & $\ldots$ & $\ldots$ \\
\hline Ukraine & $\ldots$ & $\ldots$ & $\ldots$ & $\ldots$ & $\ldots$ & $\ldots$ \\
\hline UK: England \& & & & & & & \\
\hline Wales & 0.5 & 5.3 & 4.9 & $\ldots$ & $\ldots$ & 0.0 \\
\hline \multicolumn{7}{|l|}{ UK: Northern } \\
\hline Ireland & $\ldots$ & & $\ldots$ & $\ldots$ & $\ldots$ & $\ldots$ \\
\hline UK: Scotland & 1.6 & 17.9 & 0.0 & $\ldots$ & $\ldots$ & $\ldots$ \\
\hline Mean & 1.1 & 13.0 & 4.0 & 15.9 & 71.0 & 0.0 \\
\hline Median & 0.9 & 12.1 & 3.7 & 9.2 & 71.4 & 0.0 \\
\hline Minimum & 0.2 & 3.1 & 0.0 & 0.0 & 41.7 & 0.0 \\
\hline Maximum & 3.5 & 50.0 & 9.2 & 45.3 & 100.0 & 0.0 \\
\hline
\end{tabular}


Table 3.2.2.5 Percentage of women, minors, foreigners, and legal persons among convicted persons in 2015 - Bodily injury

\begin{tabular}{|c|c|c|c|c|c|c|}
\hline & $\begin{array}{c}\text { Total offenders } \\
\text { per } 100000 \\
\text { pop. }\end{array}$ & $\begin{array}{l}\text { of which \% } \\
\text { of women }\end{array}$ & $\begin{array}{l}\text { of which } \% \\
\text { of minors }\end{array}$ & $\begin{array}{l}\text { of which \% } \\
\text { of foreigners }\end{array}$ & $\begin{array}{l}\% \text { of EU citi- } \\
\text { zens amongst } \\
\text { foreigners }\end{array}$ & $\begin{array}{l}\text { of which } \\
\% \text { of legal } \\
\text { persons }\end{array}$ \\
\hline Albania & 15 & 3.9 & 3.0 & $\ldots$ & $\ldots$ & $\ldots$ \\
\hline Armenia & 3 & 22.5 & 0.0 & 2.9 & $\ldots$ & $\ldots$ \\
\hline Austria & 51 & 8.6 & 7.5 & 29.9 & $\ldots$ & $\ldots$ \\
\hline Azerbaijan & $\ldots$ & $\ldots$ & $\ldots$ & $\ldots$ & $\ldots$ & $\ldots$ \\
\hline $\begin{array}{l}\text { Belgium } \\
\text { Bosnia- }\end{array}$ & $\ldots$ & $\ldots$ & $\ldots$ & $\ldots$ & $\ldots$ & $\ldots$ \\
\hline Herzegovina & $\ldots$ & $\ldots$ & $\ldots$ & $\ldots$ & $\ldots$ & $\ldots$ \\
\hline Bulgaria & 10 & 3.1 & 6.4 & 1.3 & $\ldots$ & $\ldots$ \\
\hline Croatia & 16 & 6.3 & 5.0 & 1.3 & 44.4 & 0.0 \\
\hline $\begin{array}{l}\text { Cyprus } \\
\text { Czech }\end{array}$ & \multicolumn{6}{|c|}{ Czech } \\
\hline Republic & 27 & 6.3 & 5.3 & 9.0 & 58.0 & 0.0 \\
\hline Denmark & $\ldots$ & $\ldots$ & $\ldots$ & $\ldots$ & $\ldots$ & $\ldots$ \\
\hline Estonia & $\ldots$ & $\ldots$ & $\ldots$ & $\ldots$ & $\ldots$ & $\ldots$ \\
\hline Finland & 153 & 15.2 & 5.7 & 9.8 & 33.2 & 0.0 \\
\hline France & 87 & 9.6 & 11.6 & 13.1 & $\ldots$ & $\ldots$ \\
\hline Georgia & 45 & 1.7 & 2.1 & $\ldots$ & $\ldots$ & $\ldots$ \\
\hline Germany & 74 & 10.4 & 10.7 & 26.9 & $\ldots$ & $\ldots$ \\
\hline Hungary & 83 & 9.1 & 10.7 & 1.7 & 71.8 & $\ldots$ \\
\hline Iceland & $\ldots$ & $\ldots$ & $\ldots$ & $\ldots$ & $\ldots$ & $\ldots$ \\
\hline Italy & 19 & 13.2 & 1.4 & 30.3 & $\ldots$ & $\ldots$ \\
\hline \multicolumn{7}{|l|}{ Kosovo (UN } \\
\hline $\mathrm{R} / 1244 / 99)$ & 0 & $\ldots$ & $\ldots$ & $\ldots$ & $\ldots$ & $\ldots$ \\
\hline Latvia & 19 & 7.3 & 5.2 & $\ldots$ & $\ldots$ & $\ldots$ \\
\hline Lithuania & 172 & 5.5 & 2.4 & $\ldots$ & $\ldots$ & 0.0 \\
\hline Luxembourg & 821 & $\ldots$ & $\ldots$ & $\ldots$ & $\ldots$ & $\ldots$ \\
\hline Moldova & 5 & 9.8 & 1.2 & $\ldots$ & $\ldots$ & $\ldots$ \\
\hline Montenegro & $\ldots$ & $\ldots$ & $\ldots$ & $\ldots$ & $\ldots$ & $\ldots$ \\
\hline Netherlands & 68 & 10.1 & 7.0 & $\ldots$ & $\ldots$ & 0.0 \\
\hline \multicolumn{7}{|l|}{ North } \\
\hline Macedonia & $\ldots$ & $\ldots$ & $\ldots$ & $\ldots$ & $\ldots$ & $\ldots$ \\
\hline Norway & $\ldots$ & $\ldots$ & $\ldots$ & $\ldots$ & $\ldots$ & $\ldots$ \\
\hline Poland & 67 & 5.8 & 0.3 & 0.6 & $\ldots$ & $\ldots$ \\
\hline Portugal & 62 & 16.7 & 2.3 & 7.3 & 14.6 & $\ldots$ \\
\hline Romania & 13 & $\ldots$ & 2.3 & $\ldots$ & $\ldots$ & 0.0 \\
\hline \multicolumn{7}{|l|}{ Russian } \\
\hline Federation & $\ldots$ & $\ldots$ & $\ldots$ & $\ldots$ & $\ldots$ & $\ldots$ \\
\hline Serbia & 26 & 6.5 & 8.5 & 1.0 & 38.9 & $\ldots$ \\
\hline \multicolumn{7}{|l|}{ Slovak } \\
\hline Republic & $\ldots$ & $\ldots$ & $\ldots$ & $\ldots$ & $\ldots$ & $\ldots$ \\
\hline Slovenia & $\ldots$ & $\ldots$ & $\ldots$ & $\ldots$ & $\ldots$ & $\ldots$ \\
\hline Spain & 85 & 10.6 & 5.8 & 24.4 & $\ldots$ & $\ldots$ \\
\hline Sweden & 65 & 14.8 & 12.4 & & $\ldots$ & $\ldots$ \\
\hline Switzerland & 39 & 9.7 & 11.9 & 52.5 & 37.8 & $\ldots$ \\
\hline Turkey & 263 & 4.8 & 4.8 & 0.1 & $\ldots$ & 0.0 \\
\hline Ukraine & 17 & 12.2 & 2.2 & 0.7 & $\ldots$ & $\ldots$ \\
\hline \multicolumn{7}{|l|}{ UK: England \& } \\
\hline Wales & 51 & 4.9 & 4.4 & $\ldots$ & $\ldots$ & 0.0 \\
\hline \multicolumn{7}{|l|}{ UK: Northern } \\
\hline Ireland & & & $\ldots$ & $\ldots$ & $\ldots$ & $\ldots$ \\
\hline UK: Scotland & 196 & 25.2 & 0.0 & $\ldots$ & $\ldots$ & $\ldots$ \\
\hline Mean & 88 & 9.8 & 5.2 & 12.5 & 42.7 & 0.0 \\
\hline Median & 51 & 9.4 & 5.0 & 7.3 & 38.9 & 0.0 \\
\hline Minimum & 0 & 1.7 & 0.0 & 0.1 & 14.6 & 0.0 \\
\hline Maximum & 821 & 25.2 & 12.4 & 52.5 & 71.8 & 0.0 \\
\hline
\end{tabular}


Table 3.2.2.6 Percentage of women, minors, foreigners, and legal persons among convicted persons in 2015 - Aggravated bodily injury

\begin{tabular}{|c|c|c|c|c|c|c|}
\hline & $\begin{array}{c}\text { Total offenders } \\
\text { per } 100000 \\
\text { pop. }\end{array}$ & $\begin{array}{l}\text { of which \% } \\
\text { of women }\end{array}$ & $\begin{array}{l}\text { of which \% } \\
\text { of minors }\end{array}$ & $\begin{array}{l}\text { of which \% } \\
\text { of foreigners }\end{array}$ & $\begin{array}{l}\% \text { of EU citi- } \\
\text { zens amongst } \\
\text { foreigners }\end{array}$ & $\begin{array}{l}\text { of which } \\
\% \text { of legal } \\
\text { persons }\end{array}$ \\
\hline Albania & 2.5 & 1.4 & 7.0 & $\ldots$ & $\ldots$ & $\ldots$ \\
\hline Armenia & 2.9 & 9.3 & 0.0 & 2.3 & 0.0 & $\ldots$ \\
\hline Austria & 12.0 & 5.4 & 11.3 & 35.0 & $\ldots$ & $\ldots$ \\
\hline Azerbaijan & 3.1 & $\ldots$ & $\ldots$ & $\ldots$ & $\ldots$ & $\ldots$ \\
\hline $\begin{array}{l}\text { Belgium } \\
\text { Bosnia- }\end{array}$ & $\ldots$ & $\ldots$ & $\ldots$ & $\ldots$ & $\ldots$ & ... \\
\hline Herzegovina & $\ldots$ & $\ldots$ & $\ldots$ & $\ldots$ & $\ldots$ & $\ldots$ \\
\hline Bulgaria & $\ldots$ & $\ldots$ & $\ldots$ & $\ldots$ & $\ldots$ & $\ldots$ \\
\hline Croatia & 8.8 & 3.5 & 5.6 & 1.9 & 57.1 & 0.0 \\
\hline \multicolumn{6}{|l|}{ Czech } & $\ldots$ \\
\hline Republic & 4.2 & 9.0 & 1.6 & 13.0 & 62.1 & 0.0 \\
\hline Denmark & $\ldots$ & $\ldots$ & $\ldots$ & $\ldots$ & $\ldots$ & $\ldots$ \\
\hline Estonia & $\ldots$ & $\ldots$ & $\ldots$ & $\ldots$ & $\ldots$ & $\ldots$ \\
\hline Finland & 9.9 & 15.2 & 3.5 & 5.9 & 37.5 & 0.0 \\
\hline France & 12.7 & 8.8 & 11.1 & 15.2 & $\ldots$ & $\ldots$ \\
\hline Georgia & 6.1 & 1.8 & 2.2 & & $\ldots$ & $\ldots$ \\
\hline Germany & 23.4 & 10.5 & 15.7 & 28.7 & $\ldots$ & $\ldots$ \\
\hline Hungary & 45.2 & 5.5 & 9.5 & 1.9 & 77.1 & $\ldots$ \\
\hline Iceland & $\ldots$ & $\ldots$ & $\ldots$ & $\ldots$ & $\ldots$ & $\ldots$ \\
\hline Italy & 11.9 & 12.4 & 2.1 & 30.4 & $\ldots$ & $\ldots$ \\
\hline \multicolumn{7}{|l|}{ Kosovo (UN } \\
\hline R/1244/99) & $\ldots$ & $\ldots$ & $\ldots$ & $\ldots$ & $\ldots$ & $\ldots$ \\
\hline Latvia & 8.3 & 12.1 & 1.8 & $\ldots$ & $\ldots$ & $\ldots$ \\
\hline Lithuania & 6.3 & 8.1 & 4.3 & $\ldots$ & $\ldots$ & 0.0 \\
\hline Luxembourg & $\ldots$ & $\ldots$ & $\ldots$ & $\ldots$ & $\ldots$ & $\ldots$ \\
\hline Moldova & $\ldots$ & $\ldots$ & $\ldots$ & $\ldots$ & $\ldots$ & $\ldots$ \\
\hline Montenegro & 25.2 & 1.9 & 3.8 & 1.9 & 33.3 & $\ldots$ \\
\hline Netherlands & 7.4 & 9.3 & 10.1 & $\ldots$ & $\ldots$ & 0.0 \\
\hline \multicolumn{7}{|l|}{ North } \\
\hline Macedonia & $\ldots$ & $\ldots$ & $\ldots$ & $\ldots$ & $\ldots$ & $\ldots$ \\
\hline Norway & $\ldots$ & $\ldots$ & $\ldots$ & $\ldots$ & $\ldots$ & $\ldots$ \\
\hline Poland & 2.2 & 8.3 & 0.0 & 0.8 & $\ldots$ & $\ldots$ \\
\hline Portugal & 9.6 & 14.7 & 4.2 & 11.3 & 12.5 & $\ldots$ \\
\hline Romania & 1.2 & $\ldots$ & 2.2 & $\ldots$ & $\ldots$ & 0.0 \\
\hline \multicolumn{7}{|l|}{ Russian } \\
\hline \multicolumn{7}{|l|}{ Federation } \\
\hline Serbia & 10.8 & 1.7 & 9.7 & 1.3 & 20.0 & $\ldots$ \\
\hline \multicolumn{7}{|l|}{ Slovak } \\
\hline Republic & $\ldots$ & $\ldots$ & $\ldots$ & $\ldots$ & $\ldots$ & $\ldots$ \\
\hline Slovenia & $\ldots$ & $\ldots$ & $\ldots$ & $\ldots$ & $\ldots$ & $\ldots$ \\
\hline Spain & $\ldots$ & $\ldots$ & $\ldots$ & $\ldots$ & $\ldots$ & $\ldots$ \\
\hline Sweden & 6.2 & 7.2 & 9.8 & $\ldots$ & $\ldots$ & $\ldots$ \\
\hline Switzerland & 9.3 & 9.7 & 7.2 & 56.4 & 31.2 & $\ldots$ \\
\hline Turkey & 2.2 & 2.3 & 3.4 & 0.8 & $\ldots$ & 0.0 \\
\hline Ukraine & 3.6 & 12.7 & 3.0 & 0.9 & $\ldots$ & $\ldots$ \\
\hline \multicolumn{7}{|l|}{ UK: England \& } \\
\hline Wales & 9.3 & 4.7 & 1.5 & $\ldots$ & $\ldots$ & 0.0 \\
\hline \multicolumn{7}{|l|}{ UK: Northern } \\
\hline Ireland & & & & $\ldots$ & $\ldots$ & $\ldots$ \\
\hline UK: Scotland & 47.9 & 3.2 & 0.0 & $\ldots$ & $\ldots$ & $\ldots$ \\
\hline Mean & 11.2 & 7.4 & 5.2 & 13.0 & 36.8 & 0.0 \\
\hline Median & 8.6 & 8.2 & 3.8 & 4.1 & 33.3 & 0.0 \\
\hline Minimum & 1.2 & 1.4 & 0.0 & 0.8 & 0.0 & 0.0 \\
\hline Maximum & 47.9 & 15.2 & 15.7 & 56.4 & 77.1 & 0.0 \\
\hline
\end{tabular}


Table 3.2.2.7 Percentage of women, minors, foreigners, and legal persons among convicted persons in 2015 - Sexual assault

\begin{tabular}{|c|c|c|c|c|c|c|}
\hline & $\begin{array}{c}\text { Total offenders } \\
\text { per } 100000 \\
\text { pop. }\end{array}$ & $\begin{array}{l}\text { of which \% } \\
\text { of women }\end{array}$ & $\begin{array}{l}\text { of which } \% \\
\text { of minors }\end{array}$ & $\begin{array}{l}\text { of which \% } \\
\text { of foreigners }\end{array}$ & $\begin{array}{l}\% \text { of EU citi- } \\
\text { zens amongst } \\
\text { foreigners }\end{array}$ & $\begin{array}{l}\text { of which } \\
\% \text { of legal } \\
\text { persons }\end{array}$ \\
\hline Albania & 1.1 & 0.0 & 15.6 & $\ldots$ & $\ldots$ & $\ldots$ \\
\hline Armenia & $\ldots$ & $\ldots$ & $\ldots$ & $\ldots$ & $\ldots$ & $\ldots$ \\
\hline Austria & 4.3 & 1.6 & 8.9 & 26.1 & $\ldots$ & $\ldots$ \\
\hline Azerbaijan & & $\ldots$ & & - & & $\ldots$ \\
\hline $\begin{array}{l}\text { Belgium } \\
\text { Bosnia- }\end{array}$ & 5.8 & 1.2 & 0.3 & 20.4 & 45.5 & $\ldots$ \\
\hline Herzegovina & & & & & $\ldots$ & $\ldots$ \\
\hline Bulgaria & 1.8 & 0.0 & 14.0 & 0.8 & $\ldots$ & $\ldots$ \\
\hline Croatia & 4.0 & 0.0 & 4.8 & 4.2 & 14.3 & 0.0 \\
\hline Cyprus & 3.9 & 3.0 & $\ldots$ & $\ldots$ & $\ldots$ & $\ldots$ \\
\hline \multicolumn{7}{|l|}{ Czech } \\
\hline Republic & 4.9 & 1.4 & 24.5 & 9.7 & 52.0 & 0.0 \\
\hline Denmark & $\ldots$ & $\ldots$ & $\ldots$ & $\ldots$ & $\ldots$ & $\ldots$ \\
\hline Estonia & $\ldots$ & $\ldots$ & $\ldots$ & $\ldots$ & $\ldots$ & $\ldots$ \\
\hline Finland & 9.6 & 0.9 & 7.4 & 15.3 & 16.0 & 0.0 \\
\hline France & 13.5 & 4.0 & 18.5 & 13.6 & $\ldots$ & $\ldots$ \\
\hline Georgia & 3.7 & $\ldots$ & & & $\ldots$ & $\ldots$ \\
\hline Germany & 3.5 & 1.3 & 12.2 & 19.8 & $\ldots$ & $\ldots$ \\
\hline Hungary & 3.9 & 1.6 & 11.7 & 2.6 & 80.0 & $\ldots$ \\
\hline Iceland & $\ldots$ & $\ldots$ & $\ldots$ & $\ldots$ & $\ldots$ & $\ldots$ \\
\hline Italy & 3.4 & 1.9 & 3.0 & 36.7 & $\ldots$ & $\ldots$ \\
\hline \multicolumn{7}{|l|}{ Kosovo (UN } \\
\hline R/1244/99) & $\ldots$ & $\ldots$ & $\ldots$ & $\ldots$ & $\ldots$ & $\ldots$ \\
\hline Latvia & $\ldots$ & $\ldots$ & $\ldots$ & $\ldots$ & $\ldots$ & $\ldots$ \\
\hline Lithuania & 9.0 & 3.0 & 14.1 & $\ldots$ & $\ldots$ & 0.0 \\
\hline Luxembourg & 8.7 & 2.0 & & $\ldots$ & $\ldots$ & $\ldots$ \\
\hline Moldova & 5.8 & 0.5 & 8.7 & $\ldots$ & $\ldots$ & $\ldots$ \\
\hline Montenegro & $\ldots$ & $\ldots$ & $\ldots$ & $\ldots$ & $\ldots$ & $\ldots$ \\
\hline Netherlands & 6.0 & 3.3 & 8.8 & $\ldots$ & $\ldots$ & 0.0 \\
\hline \multicolumn{7}{|l|}{ North } \\
\hline Macedonia & $\ldots$ & $\ldots$ & $\ldots$ & $\ldots$ & $\ldots$ & $\ldots$ \\
\hline Norway & $\ldots$ & $\ldots$ & $\ldots$ & $\ldots$ & 51.5 & $\ldots$ \\
\hline Poland & 3.7 & 1.2 & 0.3 & 0.6 & $\ldots$ & $\ldots$ \\
\hline Portugal & 4.7 & 3.1 & 2.9 & 9.8 & 8.3 & $\ldots$ \\
\hline Romania & 3.0 & 0.0 & 6.9 & $\ldots$ & $\ldots$ & 0.0 \\
\hline \multicolumn{7}{|l|}{ Russian } \\
\hline Federation & $\ldots$ & $\ldots$ & $\ldots$ & $\ldots$ & $\ldots$ & $\ldots$ \\
\hline Serbia & 2.0 & 2.1 & 7.6 & 1.4 & 50.0 & ... \\
\hline \multicolumn{7}{|l|}{ Slovak } \\
\hline Republic & $\ldots$ & $\ldots$ & $\ldots$ & $\ldots$ & $\ldots$ & ... \\
\hline Slovenia & $\ldots$ & $\ldots$ & $\ldots$ & $\ldots$ & $\ldots$ & $\ldots$ \\
\hline Spain & 0.2 & 0.0 & $\ldots$ & 35.9 & $\ldots$ & $\ldots$ \\
\hline Sweden & 4.1 & 1.2 & 13.9 & $\ldots$ & $\ldots$ & $\ldots$ \\
\hline Switzerland & 8.1 & 1.8 & 19.2 & 22.9 & 39.9 & $\ldots$ \\
\hline Turkey & 25.9 & 1.4 & 11.9 & 1.0 & $\ldots$ & 0.0 \\
\hline Ukraine & 0.4 & 0.0 & 4.7 & 2.6 & $\ldots$ & $\ldots$ \\
\hline \multicolumn{7}{|l|}{ UK: England \& } \\
\hline Wales & 11.9 & 1.0 & 6.6 & $\ldots$ & $\ldots$ & 0.0 \\
\hline \multicolumn{7}{|l|}{ UK: Northern } \\
\hline Ireland & & & $\ldots$ & $\ldots$ & $\ldots$ & $\ldots$ \\
\hline UK: Scotland & 20.2 & 6.4 & $\ldots$ & $\ldots$ & $\ldots$ & $\ldots$ \\
\hline Mean & 6.3 & 1.6 & 9.8 & 13.1 & 39.7 & 0.0 \\
\hline Median & 4.2 & 1.4 & 8.8 & 9.8 & 45.5 & 0.0 \\
\hline Minimum & 0.2 & 0.0 & 0.3 & 0.6 & 8.3 & 0.0 \\
\hline Maximum & 25.9 & 6.4 & 24.5 & 36.7 & 80.0 & 0.0 \\
\hline
\end{tabular}


Table 3.2.2.8 Percentage of women, minors, foreigners, and legal persons among convicted persons in 2015 - Rape

\begin{tabular}{|c|c|c|c|c|c|c|}
\hline & $\begin{array}{l}\text { Total offenders } \\
\text { per } 100000 \\
\text { pop. }\end{array}$ & $\begin{array}{l}\text { of which \% } \\
\text { of women }\end{array}$ & $\begin{array}{l}\text { of which \% } \\
\text { of minors }\end{array}$ & $\begin{array}{l}\text { of which \% } \\
\text { of foreigners }\end{array}$ & $\begin{array}{l}\% \text { of EU citi- } \\
\text { zens amongst } \\
\text { foreigners }\end{array}$ & $\begin{array}{l}\text { of which } \\
\% \text { of legal } \\
\text { persons }\end{array}$ \\
\hline Albania & & & & & $\ldots$ & $\ldots$ \\
\hline Armenia & 0.1 & 0.0 & 0.0 & 0.0 & $\ldots$ & $\ldots$ \\
\hline Austria & 1.7 & 0.7 & 8.7 & 41.6 & $\ldots$ & ... \\
\hline Azerbaijan & 0.3 & & & & & ... \\
\hline $\begin{array}{l}\text { Belgium } \\
\text { Bosnia- }\end{array}$ & 3.5 & 1.0 & 0.5 & 26.5 & 43.7 & $\ldots$ \\
\hline Herzegovina & & & & & $\ldots$ & $\ldots$ \\
\hline Bulgaria & 1.0 & 0.0 & 16.7 & 1.4 & & \\
\hline Croatia & 2.3 & 0.0 & 7.1 & 6.1 & 16.7 & 0.0 \\
\hline Cyprus & & . & $\ldots$ & $\ldots$ & $\ldots$ & $\ldots$ \\
\hline Czech & & & & & & \\
\hline Republic & 1.6 & 0.6 & 8.4 & 17.5 & 65.5 & 0.0 \\
\hline Denmark & $\ldots$ & $\ldots$ & $\ldots$ & $\ldots$ & $\ldots$ & $\ldots$ \\
\hline Estonia & $\cdots$ & $\ldots$ & $\ldots$ & & $\ldots$ & $\cdots$ \\
\hline Finland & 3.0 & 1.2 & 7.4 & 28.4 & 17.4 & 0.0 \\
\hline France & 1.5 & 1.5 & 30.0 & 14.2 & $\ldots$ & $\ldots$ \\
\hline Georgia & 0.3 & & 8.3 & & $\ldots$ & ... \\
\hline Germany & 0.7 & 0.7 & 7.6 & 31.1 & & \\
\hline $\begin{array}{l}\text { Hungary } \\
\text { Iceland }\end{array}$ & 1.7 & 1.2 & 15.7 & 2.3 & 75.0 & $\ldots$ \\
\hline Italy & 2.6 & 0.9 & 3.6 & 37.9 & & \\
\hline Kosovo (UN & & & & & & \\
\hline R/1244/99) & & & & $\cdots$ & $\ldots$ & $\cdots$ \\
\hline Latvia & 0.8 & 0.0 & 0.0 & $\cdots$ & $\cdots$ & \\
\hline Lithuania & 7.1 & 1.9 & 15.0 & $\ldots$ & $\ldots$ & 0.0 \\
\hline Luxembourg & 2.7 & 0.0 & & $\ldots$ & $\ldots$ & $\ldots$ \\
\hline Moldova & 4.2 & 0.0 & 7.3 & $\ldots$ & $\ldots$ & $\ldots$ \\
\hline Montenegro & 0.3 & 0.0 & 0.0 & 50.0 & 0.0 & . \\
\hline Netherlands & 0.6 & 4.8 & 10.6 & $\ldots$ & $\ldots$ & 0.0 \\
\hline North & & & & & & \\
\hline Macedonia & $\ldots$ & $\ldots$ & $\ldots$ & $\ldots$ & $\ldots$ & $\ldots$ \\
\hline Norway & & & & & $\ldots$ & $\ldots$ \\
\hline Poland & 1.9 & 2.3 & 0.5 & 1.0 & & \\
\hline Portugal & 0.9 & & 3.4 & 23.6 & $\ldots$ & $\cdots$ \\
\hline Romania & 1.8 & 0.0 & 10.2 & 0.0 & $\ldots$ & 0.0 \\
\hline Russian & & & & & & \\
\hline Federation & & & & & & $\ldots$ \\
\hline $\begin{array}{l}\text { Serbia } \\
\text { Slovak }\end{array}$ & 0.8 & 5.6 & 7.4 & 3.7 & 50.0 & $\ldots$ \\
\hline $\begin{array}{l}\text { Slovak } \\
\text { Republic }\end{array}$ & $\ldots$ & $\ldots$ & $\ldots$ & $\ldots$ & $\ldots$ & ... \\
\hline Slovenia & $\ldots$ & $\ldots$ & $\ldots$ & $\ldots$ & $\ldots$ & ... \\
\hline Spain & & & & $\ldots$ & $\ldots$ & ... \\
\hline Sweden & 3.0 & 1.0 & 10.7 & & & $\ldots$ \\
\hline Switzerland & 1.4 & 0.0 & 6.0 & 59.5 & 36.2 & $\ldots$ \\
\hline Turkey & & & & & & $\ldots$ \\
\hline Ukraine & 0.2 & 0.0 & 5.6 & 2.2 & $\ldots$ & $\ldots$ \\
\hline $\begin{array}{l}\text { UK: England \& } \\
\text { Wales }\end{array}$ & 22 & 10 & 93 & 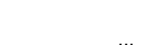 & & 0 \\
\hline $\begin{array}{l}\text { Wales } \\
\text { UK: Northern }\end{array}$ & 2.2 & 1.0 & 9.3 & $\cdots$ & $\ldots$ & 0.0 \\
\hline Ireland & & & $\ldots$ & $\ldots$ & & ... \\
\hline UK: Scotland & 1.9 & 0.0 & $\ldots$ & $\cdots$ & $\ldots$ & \\
\hline Mean & 1.8 & 1.0 & 8.0 & 19.3 & 38.1 & 0.0 \\
\hline Median & 1.7 & 0.7 & 7.4 & 15.8 & 40.0 & 0.0 \\
\hline Minimum & 0.1 & 0.0 & 0.0 & 0.0 & 0.0 & 0.0 \\
\hline Maximum & 7.1 & 5.6 & 30.0 & 59.5 & 75.0 & 0.0 \\
\hline
\end{tabular}


Table 3.2.2.9 Percentage of women, minors, foreigners, and legal persons among convicted persons in 2015 - Sexual abuse of a child

\begin{tabular}{|c|c|c|c|c|c|c|}
\hline & $\begin{array}{c}\text { Total offenders } \\
\text { per } 100000 \\
\text { pop. }\end{array}$ & $\begin{array}{l}\text { of which } \% \\
\text { of women }\end{array}$ & $\begin{array}{l}\text { of which } \% \\
\text { of minors }\end{array}$ & $\begin{array}{l}\text { of which \% } \\
\text { of foreigners }\end{array}$ & $\begin{array}{l}\% \text { of EU citi- } \\
\text { zens amongst } \\
\text { foreigners }\end{array}$ & $\begin{array}{l}\text { of which } \\
\% \text { of legal } \\
\text { persons }\end{array}$ \\
\hline Albania & $\ldots$ & $\ldots$ & $\ldots$ & $\ldots$ & $\ldots$ & $\ldots$ \\
\hline Armenia & $\ldots$ & $\ldots$ & $\ldots$ & $\ldots$ & $\ldots$ & $\ldots$ \\
\hline Austria & 1.5 & 1.5 & 14.4 & 10.6 & $\ldots$ & $\ldots$ \\
\hline Azerbaijan & $\ldots$ & $\ldots$ & & & & $\ldots$ \\
\hline Belgium & 3.2 & 1.4 & 0.0 & 13.5 & 66.7 & $\ldots$ \\
\hline Bosnia- & & & & & & \\
\hline Herzegovina & $\ldots$ & $\ldots$ & $\ldots$ & $\ldots$ & $\ldots$ & $\ldots$ \\
\hline Bulgaria & $\ldots$ & $\ldots$ & $\ldots$ & $\ldots$ & $\ldots$ & $\ldots$ \\
\hline Croatia & 0.4 & 0.0 & 5.6 & 0.0 & $\ldots$ & 0.0 \\
\hline Cyprus & $\ldots$ & $\ldots$ & $\ldots$ & $\ldots$ & $\ldots$ & $\ldots$ \\
\hline \multicolumn{7}{|l|}{ Czech } \\
\hline Republic & 3.2 & 1.8 & 32.8 & 3.3 & 72.7 & 0.0 \\
\hline Denmark & $\ldots$ & $\ldots$ & $\ldots$ & $\ldots$ & $\ldots$ & $\ldots$ \\
\hline Estonia & $\ldots$ & $\ldots$ & $\ldots$ & $\ldots$ & $\ldots$ & $\ldots$ \\
\hline Finland & 5.5 & 1.0 & 8.0 & 11.6 & 14.3 & 0.0 \\
\hline France & 4.6 & 1.2 & 31.5 & 6.4 & $\ldots$ & $\ldots$ \\
\hline Georgia & & $\ldots$ & & $\ldots$ & $\ldots$ & $\ldots$ \\
\hline Germany & 1.8 & 1.5 & 14.8 & 11.4 & $\ldots$ & $\ldots$ \\
\hline Hungary & 1.5 & 2.6 & 4.6 & 2.6 & 100.0 & $\ldots$ \\
\hline Iceland & $\ldots$ & $\ldots$ & $\ldots$ & $\ldots$ & $\ldots$ & $\ldots$ \\
\hline Italy & 0.3 & 1.7 & 1.1 & 17.0 & $\ldots$ & $\ldots$ \\
\hline \multicolumn{7}{|l|}{ Kosovo (UN } \\
\hline R/1244/99) & $\ldots$ & $\ldots$ & $\ldots$ & ... & $\ldots$ & $\ldots$ \\
\hline Latvia & $\ldots$ & $\ldots$ & $\ldots$ & $\ldots$ & $\ldots$ & $\ldots$ \\
\hline Lithuania & 1.6 & 6.5 & 6.5 & $\ldots$ & $\ldots$ & 0.0 \\
\hline Luxembourg & $\ldots$ & $\ldots$ & $\ldots$ & $\ldots$ & $\ldots$ & $\ldots$ \\
\hline Moldova & $\ldots$ & $\ldots$ & $\ldots$ & $\ldots$ & $\ldots$ & $\ldots$ \\
\hline Montenegro & 0.5 & 0.0 & 0.0 & 0.0 & $\ldots$ & $\ldots$ \\
\hline Netherlands & 0.4 & 0.0 & 0.0 & $\ldots$ & $\ldots$ & 0.0 \\
\hline \multicolumn{7}{|l|}{ North } \\
\hline Macedonia & $\ldots$ & $\ldots$ & $\ldots$ & $\ldots$ & $\ldots$ & $\ldots$ \\
\hline Norway & $\ldots$ & $\ldots$ & $\ldots$ & $\ldots$ & $\ldots$ & $\ldots$ \\
\hline Poland & 1.7 & 1.5 & 0.0 & 0.3 & $\ldots$ & $\ldots$ \\
\hline Portugal & 3.3 & 3.8 & 3.2 & 7.6 & $\ldots$ & $\ldots$ \\
\hline Romania & 1.1 & $\ldots$ & 1.9 & $\ldots$ & $\ldots$ & 0.0 \\
\hline \multicolumn{7}{|l|}{ Russian } \\
\hline Federation & $\ldots$ & $\ldots$ & $\ldots$ & $\ldots$ & $\ldots$ & $\ldots$ \\
\hline Serbia & 0.3 & 0.0 & 13.6 & 0.0 & $\ldots$ & $\ldots$ \\
\hline \multicolumn{7}{|l|}{ Slovak } \\
\hline Republic & $\ldots$ & $\ldots$ & $\ldots$ & $\ldots$ & $\ldots$ & $\ldots$ \\
\hline Slovenia & $\ldots$ & $\ldots$ & $\ldots$ & $\ldots$ & $\ldots$ & $\ldots$ \\
\hline Spain & $\ldots$ & $\ldots$ & $\ldots$ & $\ldots$ & $\ldots$ & $\ldots$ \\
\hline Sweden & 1.0 & 1.0 & 23.0 & $\ldots$ & $\ldots$ & $\ldots$ \\
\hline Switzerland & 5.4 & 1.8 & 20.8 & 26.6 & 56.3 & $\ldots$ \\
\hline Turkey & $\ldots$ & $\ldots$ & & $\ldots$ & $\ldots$ & $\ldots$ \\
\hline Ukraine & 0.0 & 0.0 & 0.0 & 0.0 & $\ldots$ & $\ldots$ \\
\hline \multicolumn{7}{|l|}{ UK: England \& } \\
\hline Wales & 9.2 & 0.7 & 5.7 & $\ldots$ & $\ldots$ & 0.0 \\
\hline \multicolumn{7}{|l|}{ UK: Northern } \\
\hline Ireland & $\ldots$ & $\ldots$ & $\ldots$ & $\ldots$ & $\ldots$ & $\ldots$ \\
\hline UK: Scotland & $\ldots$ & $\ldots$ & $\ldots$ & $\ldots$ & $\ldots$ & \\
\hline Mean & 2.3 & 1.5 & 9.4 & 7.4 & 62.0 & 0.0 \\
\hline Median & 1.6 & 1.4 & 5.6 & 6.4 & 66.7 & 0.0 \\
\hline Minimum & 0.0 & 0.0 & 0.0 & 0.0 & 14.3 & 0.0 \\
\hline Maximum & 9.2 & 6.5 & 32.8 & 26.6 & 100.0 & 0.0 \\
\hline
\end{tabular}


Table 3.2.2.10 Percentage of women, minors, foreigners, and legal persons among convicted persons in 2015 - Robbery

\begin{tabular}{|c|c|c|c|c|c|c|}
\hline & $\begin{array}{c}\text { Total offenders } \\
\text { per } 100000 \\
\text { pop. }\end{array}$ & $\begin{array}{l}\text { of which \% } \\
\text { of women }\end{array}$ & $\begin{array}{l}\text { of which \% } \\
\text { of minors }\end{array}$ & $\begin{array}{l}\text { of which \% } \\
\text { of foreigners }\end{array}$ & $\begin{array}{l}\% \text { of EU citi- } \\
\text { zens amongst } \\
\text { foreigners }\end{array}$ & $\begin{array}{l}\text { of which } \\
\% \text { of legal } \\
\text { persons }\end{array}$ \\
\hline Albania & 6.5 & 0.0 & 8.0 & $\ldots$ & $\ldots$ & $\ldots$ \\
\hline Armenia & 3.3 & 1.0 & 2.0 & 4.1 & $\ldots$ & $\ldots$ \\
\hline Austria & 8.8 & 7.5 & 33.6 & 54.0 & $\ldots$ & $\ldots$ \\
\hline Azerbaijan & 3.4 & $\ldots$ & $\ldots$ & $\ldots$ & $\ldots$ & $\ldots$ \\
\hline Belgium & 18.4 & 8.5 & 0.1 & 38.5 & 42.7 & $\ldots$ \\
\hline \multicolumn{7}{|l|}{ Bosnia- } \\
\hline \multicolumn{7}{|l|}{ Herzegovina } \\
\hline Bulgaria & 9.8 & 3.1 & 15.2 & 1.4 & $\ldots$ & $\ldots$ \\
\hline Croatia & 7.6 & 9.0 & 11.5 & 2.5 & 12.5 & 0.0 \\
\hline Cyprus & $\ldots$ & $\ldots$ & $\ldots$ & $\ldots$ & $\ldots$ & $\ldots$ \\
\hline \multicolumn{7}{|l|}{ Czech } \\
\hline Republic & 9.6 & 6.2 & 15.3 & 9.1 & 71.7 & 0.0 \\
\hline Denmark & $\ldots$ & $\ldots$ & $\ldots$ & $\ldots$ & $\ldots$ & $\ldots$ \\
\hline Estonia & $\ldots$ & $\ldots$ & $\ldots$ & $\ldots$ & $\ldots$ & $\ldots$ \\
\hline Finland & 11.8 & 10.0 & 17.9 & 11.5 & 39.2 & 0.0 \\
\hline France & 5.2 & 2.7 & 21.7 & 10.8 & $\ldots$ & $\ldots$ \\
\hline Georgia & 10.6 & 0.5 & 11.6 & $\ldots$ & $\ldots$ & $\ldots$ \\
\hline Germany & 9.0 & 6.8 & 24.5 & 31.2 & $\ldots$ & $\ldots$ \\
\hline Hungary & 12.9 & 5.2 & 28.0 & 2.2 & 85.7 & $\ldots$ \\
\hline Iceland & & & & $\ldots$ & $\ldots$ & $\ldots$ \\
\hline Italy & 12.0 & 8.7 & 6.3 & 43.0 & $\ldots$ & $\ldots$ \\
\hline \multicolumn{7}{|l|}{ Kosovo (UN } \\
\hline R/1244/99) & $\ldots$ & & $\ldots$ & $\ldots$ & $\ldots$ & $\ldots$ \\
\hline Latvia & 18.5 & 5.7 & 15.3 & $\ldots$ & $\ldots$ & $\ldots$ \\
\hline Lithuania & 30.2 & 5.5 & 26.3 & $\ldots$ & $\ldots$ & 0.0 \\
\hline Luxembourg & 11.2 & & $\ldots$ & $\ldots$ & $\ldots$ & $\ldots$ \\
\hline Moldova & 27.5 & 3.6 & 5.6 & $\ldots$ & $\ldots$ & $\ldots$ \\
\hline Montenegro & $\ldots$ & $\ldots$ & $\ldots$ & $\ldots$ & $\ldots$ & $\ldots$ \\
\hline Netherlands & 13.5 & 7.9 & 25.6 & $\ldots$ & $\ldots$ & 0.0 \\
\hline \multicolumn{7}{|l|}{ North } \\
\hline Macedonia & $\ldots$ & $\ldots$ & $\ldots$ & $\ldots$ & $\ldots$ & $\ldots$ \\
\hline Norway & $\ldots$ & . & $\ldots$ & $\ldots$ & $\ldots$ & $\ldots$ \\
\hline Poland & 13.5 & 5.2 & 0.3 & 0.5 & $\ldots$ & $\ldots$ \\
\hline Portugal & 22.1 & 8.7 & 14.5 & 15.6 & 8.1 & $\ldots$ \\
\hline Romania & 7.8 & $\ldots$ & 14.4 & $\ldots$ & $\ldots$ & 0.0 \\
\hline \multicolumn{7}{|l|}{ Russian } \\
\hline Federation & $\ldots$ & $\ldots$ & $\ldots$ & $\ldots$ & $\ldots$ & $\ldots$ \\
\hline Serbia & 11.9 & 3.5 & 19.0 & 1.3 & 9.1 & $\ldots$ \\
\hline \multicolumn{7}{|l|}{ Slovak } \\
\hline Republic & $\ldots$ & $\ldots$ & $\ldots$ & $\ldots$ & $\ldots$ & $\ldots$ \\
\hline Slovenia & $\ldots$ & $\ldots$ & $\ldots$ & $\ldots$ & $\ldots$ & $\ldots$ \\
\hline Spain & 23.0 & 10.9 & 23.4 & 61.5 & $\ldots$ & $\ldots$ \\
\hline Sweden & 6.6 & 4.9 & 22.5 & $\ldots$ & $\ldots$ & $\ldots$ \\
\hline Switzerland & 9.0 & 5.9 & 28.2 & 57.3 & 28.6 & $\ldots$ \\
\hline Turkey & 27.7 & 2.6 & 16.7 & 4.2 & $\ldots$ & 0.0 \\
\hline Ukraine & 11.2 & 5.1 & 9.4 & 0.9 & $\ldots$ & $\ldots$ \\
\hline \multicolumn{7}{|l|}{ UK: England \& } \\
\hline Wales & 8.2 & 6.1 & 28.0 & $\ldots$ & $\ldots$ & 0.3 \\
\hline \multicolumn{7}{|l|}{ UK: Northern } \\
\hline Ireland & $\ldots$ & & $\ldots$ & $\ldots$ & $\ldots$ & $\ldots$ \\
\hline UK: Scotland & 6.2 & 13.8 & $\ldots$ & $\ldots$ & $\ldots$ & $\ldots$ \\
\hline Mean & & 6.1 & 16.8 & 19.8 & 38.3 & 0.0 \\
\hline Median & 10.9 & 5.9 & 15.3 & 10.3 & 39.2 & 0.0 \\
\hline Minimum & 3.3 & 0.0 & 0.1 & 0.5 & 8.1 & 0.0 \\
\hline Maximum & 30.2 & 13.8 & 33.6 & 61.5 & 85.7 & 0.3 \\
\hline
\end{tabular}


Table 3.2.2.11 Percentage of women, minors, foreigners, and legal persons among convicted persons in 2015 - Theft

\begin{tabular}{|c|c|c|c|c|c|c|}
\hline & $\begin{array}{c}\text { Total offenders } \\
\text { per } 100000 \\
\text { pop. }\end{array}$ & $\begin{array}{l}\text { of which \% } \\
\text { of women }\end{array}$ & $\begin{array}{l}\text { of which \% } \\
\text { of minors }\end{array}$ & $\begin{array}{l}\text { of which \% } \\
\text { of foreigners }\end{array}$ & $\begin{array}{l}\% \text { of EU citi- } \\
\text { zens amongst } \\
\text { foreigners }\end{array}$ & $\begin{array}{l}\text { of which } \\
\% \text { of legal } \\
\text { persons }\end{array}$ \\
\hline Albania & 61 & 3.6 & 16.5 & $\ldots$ & $\ldots$ & $\ldots$ \\
\hline Armenia & 17 & 6.1 & 9.1 & 0.0 & $\ldots$ & $\ldots$ \\
\hline Austria & 82 & 22.2 & 8.0 & 56.6 & $\ldots$ & $\ldots$ \\
\hline Azerbaijan & 20 & & $\ldots$ & $\ldots$ & $\ldots$ & $\ldots$ \\
\hline $\begin{array}{l}\text { Belgium } \\
\text { Bosnia- }\end{array}$ & 76 & 13.7 & 0.1 & 44.8 & 56.7 & $\ldots$ \\
\hline Herzegovina & $\ldots$ & $\ldots$ & $\ldots$ & & $\ldots$ & $\ldots$ \\
\hline Bulgaria & 87 & 5.6 & 12.1 & 0.3 & $\ldots$ & $\ldots$ \\
\hline Croatia & 73 & 9.6 & 6.8 & 2.6 & 59.3 & 0.0 \\
\hline $\begin{array}{l}\text { Cyprus } \\
\text { Czech }\end{array}$ & $\ldots$ & $\ldots$ & $\ldots$ & $\ldots$ & $\ldots$ & $\ldots$ \\
\hline Republic & 133 & 15.5 & 3.7 & 6.3 & 79.3 & 0.0 \\
\hline Denmark & $\ldots$ & $\ldots$ & $\ldots$ & $\ldots$ & $\ldots$ & $\ldots$ \\
\hline Estonia & $\ldots$ & $\ldots$ & $\ldots$ & $\ldots$ & $\ldots$ & $\ldots$ \\
\hline Finland & 545 & 30.1 & 7.2 & 15.4 & 49.2 & 0.0 \\
\hline France & 138 & 11.8 & 21.8 & 22.1 & $\ldots$ & $\ldots$ \\
\hline Georgia & 81 & 3.7 & 4.7 & & $\ldots$ & $\ldots$ \\
\hline Germany & 163 & 25.4 & 7.2 & 43.3 & 43.3 & $\ldots$ \\
\hline Hungary & 172 & 11.9 & 13.1 & 1.0 & 83.4 & $\ldots$ \\
\hline Iceland & $\ldots$ & $\ldots$ & $\ldots$ & $\ldots$ & $\ldots$ & $\ldots$ \\
\hline Italy & 56 & 24.4 & 3.9 & 46.5 & $\ldots$ & $\ldots$ \\
\hline \multicolumn{7}{|l|}{ Kosovo (UN } \\
\hline R/1244/99) & $\ldots$ & $\ldots$ & $\ldots$ & $\ldots$ & $\ldots$ & $\ldots$ \\
\hline Latvia & 180 & 11.9 & 6.5 & $\ldots$ & $\ldots$ & $\ldots$ \\
\hline Lithuania & 138 & 7.8 & 15.1 & $\ldots$ & $\ldots$ & 0.0 \\
\hline Luxembourg & 118 & $\ldots$ & $\ldots$ & $\ldots$ & $\ldots$ & $\ldots$ \\
\hline Moldova & 78 & 7.2 & 13.7 & $\ldots$ & $\ldots$ & 0.0 \\
\hline Montenegro & $\ldots$ & $\ldots$ & $\ldots$ & $\ldots$ & $\ldots$ & $\ldots$ \\
\hline Netherlands & 150 & 17.9 & 4.9 & $\ldots$ & $\ldots$ & 0.0 \\
\hline \multicolumn{7}{|l|}{ North } \\
\hline Macedonia & $\ldots$ & $\ldots$ & $\ldots$ & $\ldots$ & $\ldots$ & $\ldots$ \\
\hline Norway & 0 & $\ldots$ & $\ldots$ & $\ldots$ & 77.3 & $\ldots$ \\
\hline Poland & 104 & 10.9 & 0.4 & 1.0 & $\ldots$ & $\ldots$ \\
\hline Portugal & 54 & 17.2 & 4.9 & 11.1 & 47.9 & $\ldots$ \\
\hline Romania & 24 & $\ldots$ & 7.9 & $\ldots$ & $\ldots$ & 0.0 \\
\hline \multicolumn{7}{|l|}{ Russian } \\
\hline Federation & $\ldots$ & $\ldots$ & $\ldots$ & $\ldots$ & $\ldots$ & $\ldots$ \\
\hline Serbia & 139 & 9.1 & 8.9 & 1.6 & 56.2 & $\ldots$ \\
\hline \multicolumn{7}{|l|}{ Slovak } \\
\hline Republic & $\ldots$ & $\ldots$ & $\ldots$ & $\ldots$ & $\ldots$ & $\ldots$ \\
\hline Slovenia & $\ldots$ & $\ldots$ & $\ldots$ & $\ldots$ & $\ldots$ & $\ldots$ \\
\hline Spain & 47 & 38.0 & 4.6 & 32.1 & $\ldots$ & $\ldots$ \\
\hline Sweden & 220 & 33.2 & 13.6 & $\ldots$ & $\ldots$ & $\ldots$ \\
\hline Switzerland & 156 & 22.2 & 19.7 & 66.6 & 25.0 & $\ldots$ \\
\hline Turkey & 226 & 6.8 & 21.4 & 1.1 & $\ldots$ & 0.0 \\
\hline Ukraine & 96 & 12.7 & 7.0 & 0.8 & $\ldots$ & $\ldots$ \\
\hline \multicolumn{7}{|l|}{ UK: England \& } \\
\hline Wales & 179 & 20.3 & 42.2 & $\ldots$ & $\ldots$ & 0.0 \\
\hline \multicolumn{7}{|l|}{ UK: Northern } \\
\hline Ireland & & & $\ldots$ & $\ldots$ & $\ldots$ & $\ldots$ \\
\hline UK: Scotland & 167 & 29.1 & $\ldots$ & $\ldots$ & $\ldots$ & $\ldots$ \\
\hline Mean & 122 & 15.8 & 10.6 & 19.6 & 57.8 & 0.0 \\
\hline Median & 104 & 12.7 & 7.9 & 8.7 & 56.5 & 0.0 \\
\hline Minimum & 0 & 3.6 & 0.1 & 0.0 & 25.0 & 0.0 \\
\hline Maximum & 545 & 38.0 & 42.2 & 66.6 & 83.4 & 0.0 \\
\hline
\end{tabular}


Table 3.2.2.12 Percentage of women, minors, foreigners, and legal persons among convicted persons in 2015 -Aggravated theft

\begin{tabular}{|c|c|c|c|c|c|c|}
\hline & $\begin{array}{l}\text { Total offenders } \\
\text { per } 100000 \\
\text { pop. }\end{array}$ & $\begin{array}{l}\text { of which \% } \\
\text { of women }\end{array}$ & $\begin{array}{l}\text { of which \% } \\
\text { of minors }\end{array}$ & $\begin{array}{l}\text { of which } \% \\
\text { of foreigners }\end{array}$ & $\begin{array}{l}\% \text { of EU citi- } \\
\text { zens amongst } \\
\text { foreigners }\end{array}$ & $\begin{array}{l}\text { of which } \\
\% \text { of legal per- } \\
\text { sons }\end{array}$ \\
\hline Albania & 0.1 & 0.0 & 0.0 & $\ldots$ & $\ldots$ & $\ldots$ \\
\hline Armenia & & & & & & $\ldots$ \\
\hline Austria & 47.8 & 13.3 & 9.8 & 69.4 & 0.0 & $\ldots$ \\
\hline Azerbaijan & & & & & & $\ldots$ \\
\hline $\begin{array}{l}\text { Belgium } \\
\text { Bosnia- }\end{array}$ & 35.1 & 5.5 & 0.3 & 44.2 & 52.8 & ... \\
\hline Herzegovina & $\ldots$ & $\ldots$ & $\ldots$ & $\ldots$ & $\ldots$ & $\ldots$ \\
\hline Bulgaria & & & & & & \\
\hline Croatia & 34.7 & 5.6 & 10.8 & 1.9 & 60.7 & 0.0 \\
\hline \multirow{2}{*}{\multicolumn{7}{|c|}{ Czech }} \\
\hline & & & & & & \\
\hline Republic & $\ldots$ & $\ldots$ & $\ldots$ & $\ldots$ & $\ldots$ & $\ldots$ \\
\hline Denmark & $\ldots$ & $\ldots$ & $\ldots$ & $\ldots$ & $\ldots$ & $\ldots$ \\
\hline Estonia & $\ldots$ & & & $\ldots$ & $\ldots$ & ... \\
\hline Finland & 7.9 & 9.3 & 6.7 & $\ldots$ & $\ldots$ & 0.0 \\
\hline France & $\ldots$ & $\ldots$ & $\ldots$ & $\ldots$ & $\ldots$ & $\ldots$ \\
\hline Georgia & & & & & $\ldots$ & $\ldots$ \\
\hline Germany & 29.2 & 9.2 & 10.6 & 46.3 & & $\ldots$ \\
\hline Hungary & 171.6 & 11.9 & 13.1 & 1.0 & 83.4 & $\ldots$ \\
\hline Iceland & $\ldots$ & $\ldots$ & $\ldots$ & $\ldots$ & $\ldots$ & $\ldots$ \\
\hline Italy & $\ldots$ & $\ldots$ & $\ldots$ & $\ldots$ & $\ldots$ & $\ldots$ \\
\hline \multicolumn{7}{|l|}{ Kosovo (UN } \\
\hline R/1244/99) & $\ldots$ & $\ldots$ & $\ldots$ & $\ldots$ & $\ldots$ & $\ldots$ \\
\hline Latvia & $\ldots$ & $\ldots$ & $\ldots$ & $\ldots$ & $\ldots$ & $\ldots$ \\
\hline Lithuania & $\ldots$ & & $\ldots$ & $\ldots$ & $\ldots$ & $\ldots$ \\
\hline Luxembourg & & & & $\ldots$ & $\ldots$ & $\ldots$ \\
\hline Moldova & 37.4 & 6.8 & 13.8 & & & $\ldots$ \\
\hline Montenegro & 60.0 & 4.6 & 19.8 & 6.2 & 8.7 & $\ldots$ \\
\hline Netherlands & 65.9 & 15.4 & 8.1 & $\ldots$ & $\ldots$ & 0.0 \\
\hline \multicolumn{7}{|l|}{ North } \\
\hline Macedonia & $\ldots$ & $\ldots$ & $\ldots$ & $\ldots$ & $\ldots$ & $\ldots$ \\
\hline Norway & & & & & $\ldots$ & $\ldots$ \\
\hline Poland & 35.3 & 4.0 & 0.6 & 0.6 & $\ldots$ & $\ldots$ \\
\hline Portugal & 32.4 & 8.2 & 5.8 & 8.4 & 44.5 & $\ldots$ \\
\hline \multirow{2}{*}{\multicolumn{7}{|c|}{ Russian }} \\
\hline & & & & & & \\
\hline Federation & & & & & & $\ldots$ \\
\hline Serbia & 69.1 & 4.3 & 11.8 & 1.2 & 68.9 & $\ldots$ \\
\hline \multicolumn{7}{|l|}{ Slovak } \\
\hline Republic & $\ldots$ & $\ldots$ & $\ldots$ & $\ldots$ & $\ldots$ & $\ldots$ \\
\hline Slovenia & $\ldots$ & $\ldots$ & $\ldots$ & $\ldots$ & $\ldots$ & $\ldots$ \\
\hline Spain & $\ldots$ & & & & $\ldots$ & $\ldots$ \\
\hline Sweden & $\ldots$ & & & & 10 & $\ldots$ \\
\hline Switzerland & 12.1 & 11.7 & 5.8 & 84.8 & 19.3 & $\ldots$ \\
\hline Turkey & $\ldots$ & & & & $\ldots$ & $\ldots$ \\
\hline $\begin{array}{l}\text { Ukraine } \\
\text { UK: England \& }\end{array}$ & $\ldots$ & $\ldots$ & $\ldots$ & $\ldots$ & $\ldots$ & ... \\
\hline Wales & $\ldots$ & $\ldots$ & $\ldots$ & $\ldots$ & $\ldots$ & $\ldots$ \\
\hline UK: Northern & & & & & & \\
\hline $\begin{array}{l}\text { Ireland } \\
\text { UK : Scotland }\end{array}$ & $\cdots$ & $\ldots$ & $\cdots$ & $\ldots$ & $\cdots$ & $\cdots$ \\
\hline Mean & 43.6 & 7.8 & 8.4 & 26.4 & 42.3 & 0.0 \\
\hline Median & 35.1 & 7.5 & 8.9 & 7.3 & 48.6 & 0.0 \\
\hline Minimum & 0.1 & 0.0 & 0.0 & 0.6 & 0.0 & 0.0 \\
\hline Maximum & 171.6 & 15.4 & 19.8 & 84.8 & 83.4 & 0.0 \\
\hline
\end{tabular}


Table 3.2.2.13 Percentage of women, minors, foreigners, and legal persons among convicted persons in 2015 -Theft of a motor vehicle

\begin{tabular}{|c|c|c|c|c|c|c|}
\hline & $\begin{array}{c}\text { Total offenders } \\
\text { per } 100000 \\
\text { pop. }\end{array}$ & $\begin{array}{l}\text { of which \% } \\
\text { of women }\end{array}$ & $\begin{array}{l}\text { of which \% } \\
\text { of minors }\end{array}$ & $\begin{array}{l}\text { of which \% } \\
\text { of foreigners }\end{array}$ & $\begin{array}{l}\% \text { of EU citi- } \\
\text { zens amongst } \\
\text { foreigners }\end{array}$ & $\begin{array}{l}\text { of which } \\
\% \text { of legal } \\
\text { persons }\end{array}$ \\
\hline Armenia & 0.1 & 0.0 & 0.0 & 0.0 & $\ldots$ & $\ldots$ \\
\hline Bulgaria & 2.5 & 0.0 & 22.5 & 1.1 & $\ldots$ & $\ldots$ \\
\hline Finland & 5.9 & 8.4 & 17.4 & 2.8 & 44.4 & 0.0 \\
\hline Hungary & 5.0 & 3.2 & 11.9 & 2.2 & 100.0 & $\ldots$ \\
\hline Portugal & 0.9 & 5.7 & 17.0 & 4.5 & $\ldots$ & $\ldots$ \\
\hline Serbia & 3.3 & 1.7 & 16.0 & 0.8 & 100.0 & $\ldots$ \\
\hline Spain & 5.1 & 4.5 & 14.5 & 15.6 & & \\
\hline Sweden & 3.2 & 7.0 & 31.1 & & $\ldots$ & $\ldots$ \\
\hline $\begin{array}{l}\text { Ukraine } \\
\text { UK: England \& }\end{array}$ & 5.7 & 1.1 & 20.4 & 0.7 & ... & ... \\
\hline Wales & 6.1 & 6.4 & 54.3 & $\ldots$ & $\ldots$ & 0.9 \\
\hline UK: Scotland & 5.3 & 3.8 & 0.0 & $\ldots$ & $\ldots$ & $\ldots$ \\
\hline Mean & 3.9 & 3.8 & 18.7 & 3.5 & 81.5 & 0.5 \\
\hline Median & 5.0 & 3.8 & 17.0 & 1.7 & 100.0 & 0.5 \\
\hline Minimum & 0.1 & 0.0 & 0.0 & 0.0 & 44.4 & 0.0 \\
\hline Maximum & 6.1 & 8.4 & 54.3 & 15.6 & 100.0 & 0.9 \\
\hline
\end{tabular}

Table 3.2.2.14 Percentage of women, minors, foreigners, and legal persons among convicted persons in 2015 - Theft by means of burglary

\begin{tabular}{|c|c|c|c|c|c|c|}
\hline & $\begin{array}{c}\text { Total offenders } \\
\text { per } 100000 \\
\text { pop. }\end{array}$ & $\begin{array}{l}\text { of which \% } \\
\text { of women }\end{array}$ & $\begin{array}{l}\text { of which } \% \\
\text { of minors }\end{array}$ & $\begin{array}{l}\text { of which } \% \\
\text { of foreigners }\end{array}$ & $\begin{array}{l}\% \text { of EU citi- } \\
\text { zens amongst } \\
\text { foreigners }\end{array}$ & $\begin{array}{l}\text { of which } \\
\% \text { of legal } \\
\text { persons }\end{array}$ \\
\hline Austria & 12.5 & 5.8 & 18.7 & 53.0 & & \\
\hline Croatia & 32.7 & 5.4 & 10.7 & 1.8 & 60.0 & 0.0 \\
\hline Germany & 14.9 & 6.5 & 12.9 & 41.2 & 48.1 & $\ldots$ \\
\hline Hungary & 31.7 & 7.4 & 20.4 & 0.4 & 100.0 & $\ldots$ \\
\hline Poland & 35.3 & 4.0 & 0.6 & 0.6 & & $\ldots$ \\
\hline Portugal & 2.1 & 4.7 & 8.4 & 7.5 & 50.0 & $\ldots$ \\
\hline $\begin{array}{l}\text { Ukraine } \\
\text { UK: England \& }\end{array}$ & 32.3 & 5.3 & 10.6 & 0.7 & $\ldots$ & $\ldots$ \\
\hline Wales & 26.8 & 5.0 & 28.8 & $\ldots$ & $\ldots$ & 0.0 \\
\hline UK: Scotland & 15.4 & 2.8 & $\ldots$ & $\ldots$ & $\ldots$ & $\ldots$ \\
\hline Mean & 22.6 & 5.2 & 13.9 & 15.0 & 64.5 & 0.0 \\
\hline Median & 26.8 & 5.3 & 11.8 & 1.8 & 55.0 & 0.0 \\
\hline Minimum & 2.1 & 2.8 & 0.6 & 0.4 & 48.1 & 0.0 \\
\hline Maximum & 35.3 & 7.4 & 28.8 & 53.0 & 100.0 & 0.0 \\
\hline
\end{tabular}

Table 3.2.2.15 Percentage of women, minors, foreigners, and legal persons among convicted persons in 2015 - Theft by means of domestic burglary

\begin{tabular}{|c|c|c|c|c|c|c|}
\hline & $\begin{array}{c}\text { Total offenders } \\
\text { per } 100000 \\
\text { pop. }\end{array}$ & $\begin{array}{l}\text { of which \% } \\
\text { of women }\end{array}$ & $\begin{array}{l}\text { of which } \% \\
\text { of minors }\end{array}$ & $\begin{array}{l}\text { of which \% } \\
\text { of foreigners }\end{array}$ & $\begin{array}{l}\% \text { of EU citi- } \\
\text { zens amongst } \\
\text { foreigners }\end{array}$ & $\begin{array}{l}\text { of which } \\
\% \text { of legal } \\
\text { persons }\end{array}$ \\
\hline Germany & 3.4 & 9.0 & 12.2 & 48.6 & & $\ldots$ \\
\hline Hungary & 1.9 & 20.6 & 28.6 & 0.5 & 100.0 & $\ldots$ \\
\hline Portugal & 1.3 & 5.3 & 7.6 & 6.9 & $\ldots$ & ... \\
\hline Wales & 15.0 & 6.2 & 17.1 & $\ldots$ & $\ldots$ & 0.0 \\
\hline
\end{tabular}


Table 3.2.2.16 Percentage of women, minors, foreigners, and legal persons among convicted persons in 2015 - Fraud

\begin{tabular}{|c|c|c|c|c|c|c|}
\hline & $\begin{array}{c}\text { Total offenders } \\
\text { per } 100000 \\
\text { pop. }\end{array}$ & $\begin{array}{l}\text { of which \% } \\
\text { of women }\end{array}$ & $\begin{array}{l}\text { of which \% } \\
\text { of minors }\end{array}$ & $\begin{array}{l}\text { of which \% } \\
\text { of foreigners }\end{array}$ & $\begin{array}{l}\% \text { of EU citi- } \\
\text { zens amongst } \\
\text { foreigners }\end{array}$ & $\begin{array}{l}\text { of which } \\
\% \text { of legal } \\
\text { persons }\end{array}$ \\
\hline Albania & 7.0 & 14.4 & 2.0 & $\ldots$ & $\ldots$ & $\ldots$ \\
\hline Armenia & 3.0 & 13.5 & 1.1 & 0.0 & $\ldots$ & $\ldots$ \\
\hline Austria & 26.3 & 23.4 & 2.0 & 31.5 & $\ldots$ & $\ldots$ \\
\hline Azerbaijan & 9.9 & & $\ldots$ & $\ldots$ & $\ldots$ & $\ldots$ \\
\hline Belgium & 20.6 & 18.3 & 0.0 & 31.3 & 66.2 & $\ldots$ \\
\hline \multicolumn{7}{|l|}{ Bosnia- } \\
\hline Herzegovina & & & & $\ldots$ & $\ldots$ & $\ldots$ \\
\hline Bulgaria & 7.8 & 24.0 & 0.9 & 1.4 & $\ldots$ & $\ldots$ \\
\hline Croatia & 21.1 & 16.3 & 0.3 & 3.7 & 48.5 & 1.8 \\
\hline Cyprus & $\ldots$ & $\ldots$ & $\ldots$ & $\ldots$ & $\ldots$ & $\ldots$ \\
\hline \multicolumn{7}{|l|}{ Czech } \\
\hline Republic & 30.7 & 34.1 & 0.7 & 4.0 & 72.5 & 0.0 \\
\hline Denmark & $\ldots$ & $\ldots$ & $\ldots$ & $\ldots$ & $\ldots$ & $\ldots$ \\
\hline Estonia & $\ldots$ & $\ldots$ & $\ldots$ & $\ldots$ & $\ldots$ & $\ldots$ \\
\hline Finland & 83.7 & 33.8 & 2.3 & 10.5 & 40.5 & 0.0 \\
\hline France & 12.5 & 26.8 & 3.3 & 18.8 & $\ldots$ & $\ldots$ \\
\hline Georgia & 12.2 & 0.4 & 1.3 & & $\ldots$ & $\ldots$ \\
\hline Germany & 109.6 & 33.9 & 1.0 & 21.3 & 36.6 & $\ldots$ \\
\hline Hungary & 41.3 & 23.0 & 2.0 & 1.7 & 77.1 & $\ldots$ \\
\hline Iceland & $\ldots$ & & $\ldots$ & $\ldots$ & $\ldots$ & $\ldots$ \\
\hline Italy & 8.6 & 21.7 & 0.2 & 12.8 & $\ldots$ & $\ldots$ \\
\hline \multicolumn{7}{|l|}{ Kosovo (UN } \\
\hline R/1244/99) & $\ldots$ & $\ldots$ & $\ldots$ & $\ldots$ & $\ldots$ & $\ldots$ \\
\hline Latvia & $\ldots$ & $\ldots$ & $\ldots$ & $\ldots$ & $\ldots$ & $\ldots$ \\
\hline Lithuania & 44.4 & 18.8 & 3.5 & $\ldots$ & $\ldots$ & 0.7 \\
\hline Luxembourg & 79.2 & $\ldots$ & $\ldots$ & $\ldots$ & $\ldots$ & $\ldots$ \\
\hline Moldova & 17.6 & 15.8 & 1.3 & $\ldots$ & $\ldots$ & $\ldots$ \\
\hline Montenegro & $\ldots$ & $\ldots$ & $\ldots$ & $\ldots$ & $\ldots$ & $\ldots$ \\
\hline Netherlands & 5.2 & 20.0 & 2.3 & $\ldots$ & $\ldots$ & 0.0 \\
\hline \multicolumn{7}{|l|}{ North } \\
\hline Macedonia & $\ldots$ & $\ldots$ & $\ldots$ & $\ldots$ & $\ldots$ & $\ldots$ \\
\hline Norway & $\ldots$ & $\ldots$ & $\ldots$ & $\ldots$ & $\ldots$ & $\ldots$ \\
\hline Poland & 67.0 & 26.7 & 0.2 & 0.7 & $\ldots$ & $\ldots$ \\
\hline Portugal & 11.1 & 29.5 & 0.5 & 5.9 & 4.5 & 1.9 \\
\hline Romania & 5.2 & $\ldots$ & 0.3 & $\ldots$ & $\ldots$ & 0.7 \\
\hline \multicolumn{7}{|l|}{ Russian } \\
\hline Federation & $\ldots$ & $\ldots$ & $\ldots$ & $\ldots$ & $\ldots$ & $\ldots$ \\
\hline Serbia & 10.4 & 15.3 & 1.5 & 2.0 & 66.7 & $\ldots$ \\
\hline \multicolumn{7}{|l|}{ Slovak } \\
\hline Republic & $\ldots$ & $\ldots$ & $\ldots$ & $\ldots$ & $\ldots$ & $\ldots$ \\
\hline Slovenia & $\ldots$ & $\ldots$ & $\ldots$ & $\ldots$ & $\ldots$ & $\ldots$ \\
\hline Spain & 14.9 & 25.3 & 0.0 & 13.9 & $\ldots$ & $\ldots$ \\
\hline Sweden & 12.4 & 29.2 & 5.8 & $\ldots$ & $\ldots$ & $\ldots$ \\
\hline Switzerland & 40.2 & 31.9 & 4.4 & 55.5 & 41.2 & $\ldots$ \\
\hline Turkey & 82.7 & 7.0 & 0.6 & 0.4 & $\ldots$ & 0.0 \\
\hline Ukraine & 5.9 & 22.7 & 3.1 & 0.4 & $\ldots$ & $\ldots$ \\
\hline \multicolumn{7}{|l|}{ UK: England \& } \\
\hline Wales & 21.9 & 32.7 & 5.6 & $\ldots$ & $\ldots$ & 0.1 \\
\hline \multicolumn{7}{|l|}{ UK: Northern } \\
\hline Ireland & & & $\ldots$ & $\ldots$ & $\ldots$ & $\ldots$ \\
\hline UK: Scotland & 6.8 & 48.6 & $\ldots$ & 0.5 & $\ldots$ & $\ldots$ \\
\hline Mean & 28.2 & 23.4 & 1.8 & 11.4 & 50.4 & 0.6 \\
\hline Median & 14.9 & 23.2 & 1.3 & 4.0 & 48.5 & 0.1 \\
\hline Minimum & 3.0 & 0.4 & 0.0 & 0.0 & 4.5 & 0.0 \\
\hline Maximum & 109.6 & 48.6 & 5.8 & 55.5 & 77.1 & 1.9 \\
\hline
\end{tabular}


Table 3.2.2.17 Percentage of women, minors, foreigners, and legal persons among convicted persons in 2015 - Cyber fraud

\begin{tabular}{|c|c|c|c|c|c|c|}
\hline & $\begin{array}{c}\text { Total offenders } \\
\text { per } 100000 \\
\text { pop. }\end{array}$ & $\begin{array}{l}\text { of which \% } \\
\text { of women }\end{array}$ & $\begin{array}{l}\text { of which \% } \\
\text { of minors }\end{array}$ & $\begin{array}{l}\text { of which \% } \\
\text { of foreigners }\end{array}$ & $\begin{array}{l}\% \text { of EU citi- } \\
\text { zens amongst } \\
\text { foreigners }\end{array}$ & $\begin{array}{l}\text { of which } \\
\% \text { of legal } \\
\text { persons }\end{array}$ \\
\hline Albania & 0.5 & 26.7 & 0.0 & & & $\ldots$ \\
\hline Hungary & 3.7 & 19.3 & 10.9 & 4.3 & 75.0 & $\ldots$ \\
\hline Montenegro & 1.8 & 18.2 & 0.0 & 9.1 & 0.0 & $\ldots$ \\
\hline Portugal & 1.9 & 34.9 & $\ldots$ & 13.8 & $\ldots$ & $\ldots$ \\
\hline Romania & 0.0 & $\ldots$ & 0.0 & $\ldots$ & $\ldots$ & 0.0 \\
\hline Serbia & 0.0 & $\ldots$ & $\ldots$ & $\ldots$ & $\ldots$ & $\ldots$ \\
\hline Switzerland & 8.7 & 24.3 & 8.0 & 63.7 & 40.1 & $\ldots$ \\
\hline Mean & 2.4 & 24.7 & 3.8 & 22.7 & 38.4 & 0.0 \\
\hline Median & 1.8 & 24.3 & 0.0 & 11.5 & 40.1 & 0.0 \\
\hline Minimum & 0.0 & 18.2 & 0.0 & 4.3 & 0.0 & 0.0 \\
\hline Maximum & 8.7 & 34.9 & 10.9 & 63.7 & 75.0 & 0.0 \\
\hline
\end{tabular}


Table 3.2.2.18 Percentage of women, minors, foreigners, and legal persons among convicted persons in 2015 - Forgery of documents

\begin{tabular}{|c|c|c|c|c|c|c|}
\hline & $\begin{array}{c}\text { Total offenders } \\
\text { per } 100000 \\
\text { pop. }\end{array}$ & $\begin{array}{l}\text { of which \% } \\
\text { of women }\end{array}$ & $\begin{array}{l}\text { of which \% } \\
\text { of minors }\end{array}$ & $\begin{array}{l}\text { of which \% } \\
\text { of foreigners }\end{array}$ & $\begin{array}{l}\% \text { of EU citi- } \\
\text { zens amongst } \\
\text { foreigners }\end{array}$ & $\begin{array}{l}\text { of which } \\
\% \text { of legal } \\
\text { persons }\end{array}$ \\
\hline Albania & 14.3 & 4.3 & 1.4 & $\ldots$ & $\ldots$ & $\ldots$ \\
\hline Armenia & $\ldots$ & $\ldots$ & $\ldots$ & $\ldots$ & $\ldots$ & $\ldots$ \\
\hline Austria & 9.6 & 12.3 & 3.4 & 67.7 & $\ldots$ & $\ldots$ \\
\hline Azerbaijan & $\ldots$ & & $\ldots$ & $\ldots$ & $\ldots$ & $\ldots$ \\
\hline Belgium & 14.7 & 15.8 & 0.1 & 34.6 & 55.1 & $\ldots$ \\
\hline \multicolumn{7}{|l|}{ Bosnia- } \\
\hline Herzegovina & $\ldots$ & $\ldots$ & $\ldots$ & $\ldots$ & $\ldots$ & $\ldots$ \\
\hline Bulgaria & $\ldots$ & $\ldots$ & $\ldots$ & $\ldots$ & $\ldots$ & $\ldots$ \\
\hline Croatia & 18.4 & 9.6 & 0.1 & 15.0 & 11.1 & 0.0 \\
\hline Cyprus & 11.1 & 14.9 & $\ldots$ & $\ldots$ & $\ldots$ & $\ldots$ \\
\hline \multicolumn{7}{|l|}{ Czech } \\
\hline Republic & 3.1 & 16.7 & 0.3 & 62.7 & 12.6 & 0.3 \\
\hline Denmark & $\ldots$ & $\ldots$ & $\ldots$ & $\ldots$ & $\ldots$ & $\ldots$ \\
\hline Estonia & $\ldots$ & $\ldots$ & $\ldots$ & $\ldots$ & $\ldots$ & $\ldots$ \\
\hline Finland & 14.2 & 21.3 & 12.6 & 35.3 & 31.6 & 0.0 \\
\hline France & 7.0 & 26.5 & 1.3 & 40.6 & $\ldots$ & $\ldots$ \\
\hline Georgia & 4.7 & $\ldots$ & $\ldots$ & $\ldots$ & $\ldots$ & $\ldots$ \\
\hline Germany & 19.2 & 20.3 & 2.0 & 36.8 & $\ldots$ & $\ldots$ \\
\hline Hungary & 63.4 & 22.8 & 1.7 & 4.8 & 37.2 & $\ldots$ \\
\hline Iceland & & & $\ldots$ & $\ldots$ & $\ldots$ & $\ldots$ \\
\hline Italy & 15.3 & 19.7 & 0.1 & 30.8 & $\ldots$ & $\ldots$ \\
\hline \multicolumn{7}{|l|}{ Kosovo (UN } \\
\hline R/1244/99) & $\ldots$ & $\ldots$ & $\ldots$ & $\ldots$ & $\ldots$ & $\ldots$ \\
\hline Latvia & $\ldots$ & $\ldots$ & $\ldots$ & $\ldots$ & $\ldots$ & $\ldots$ \\
\hline Lithuania & 29.3 & 16.8 & 2.0 & $\ldots$ & $\ldots$ & 1.2 \\
\hline Luxembourg & $\ldots$ & $\ldots$ & $\ldots$ & $\ldots$ & $\ldots$ & $\ldots$ \\
\hline Moldova & $\ldots$ & $\ldots$ & $\ldots$ & $\ldots$ & $\ldots$ & $\ldots$ \\
\hline Montenegro & 17.4 & 5.6 & 0.9 & 21.3 & 4.3 & $\ldots$ \\
\hline Netherlands & 9.4 & 20.2 & 0.4 & $\ldots$ & $\ldots$ & 1.1 \\
\hline \multicolumn{7}{|l|}{ North } \\
\hline Macedonia & $\ldots$ & $\ldots$ & $\ldots$ & $\ldots$ & $\ldots$ & $\ldots$ \\
\hline Norway & $\ldots$ & $\ldots$ & $\ldots$ & $\ldots$ & $\ldots$ & $\ldots$ \\
\hline Poland & 15.7 & 26.2 & 0.9 & 26.3 & $\ldots$ & $\ldots$ \\
\hline Portugal & 7.7 & 20.3 & 0.9 & 22.1 & 9.1 & 2.3 \\
\hline Romania & 1.3 & $\ldots$ & 0.0 & $\ldots$ & $\ldots$ & 0.4 \\
\hline \multicolumn{7}{|l|}{ Russian } \\
\hline Federation & $\ldots$ & $\ldots$ & $\ldots$ & $\ldots$ & $\ldots$ & $\ldots$ \\
\hline Serbia & 15.3 & 11.6 & 0.4 & 5.9 & 10.9 & $\ldots$ \\
\hline \multicolumn{7}{|l|}{ Slovak } \\
\hline Republic & $\ldots$ & $\ldots$ & $\ldots$ & $\ldots$ & $\ldots$ & $\ldots$ \\
\hline Slovenia & $\ldots$ & $\ldots$ & $\ldots$ & $\ldots$ & $\ldots$ & $\ldots$ \\
\hline Spain & 15.4 & 16.9 & 0.6 & 44.3 & $\ldots$ & $\ldots$ \\
\hline Sweden & 7.4 & 17.4 & 4.4 & $\ldots$ & $\ldots$ & $\ldots$ \\
\hline Switzerland & 49.8 & 26.4 & 9.8 & 66.8 & 22.9 & $\ldots$ \\
\hline Turkey & 36.9 & 0.5 & 0.3 & 0.4 & $\ldots$ & 0.0 \\
\hline Ukraine & 2.3 & 33.2 & 0.2 & 16.0 & $\ldots$ & 0.0 \\
\hline \multicolumn{7}{|l|}{ UK: England \& } \\
\hline Wales & 2.1 & 10.0 & 11.1 & $\ldots$ & $\ldots$ & 0.2 \\
\hline \multicolumn{7}{|l|}{ UK: Northern } \\
\hline $\begin{array}{l}\text { Ireland } \\
\text { KK. S }\end{array}$ & $\ldots$ & $\cdots$ & $\ldots$ & $\ldots$ & $\ldots$ & $\cdots$ \\
\hline UK: Scotland & & & & & & \\
\hline Mean & 16.2 & 16.9 & 2.4 & 31.3 & 21.7 & 0.6 \\
\hline Median & 14.3 & 16.9 & 0.9 & 30.8 & 12.6 & 0.3 \\
\hline Minimum & 1.3 & 0.5 & 0.0 & 0.4 & 4.3 & 0.0 \\
\hline Maximum & 63.4 & 33.2 & 12.6 & 67.7 & 55.1 & 2.3 \\
\hline
\end{tabular}


Table 3.2.2.19 Percentage of women, minors, foreigners, and legal persons among convicted persons in 2015 - Money laundering

\begin{tabular}{|c|c|c|c|c|c|c|}
\hline & $\begin{array}{c}\text { Total offenders } \\
\text { per } 100000 \\
\text { pop. }\end{array}$ & $\begin{array}{l}\text { of which \% } \\
\text { of women }\end{array}$ & $\begin{array}{l}\text { of which \% } \\
\text { of minors }\end{array}$ & $\begin{array}{l}\text { of which \% } \\
\text { of foreigners }\end{array}$ & $\begin{array}{l}\% \text { of EU citi- } \\
\text { zens amongst } \\
\text { foreigners }\end{array}$ & $\begin{array}{l}\text { of which } \\
\% \text { of legal } \\
\text { persons }\end{array}$ \\
\hline Albania & 1.9 & 5.5 & 12.7 & $\ldots$ & $\ldots$ & $\ldots$ \\
\hline Armenia & $\ldots$ & $\ldots$ & $\ldots$ & $\ldots$ & $\ldots$ & $\ldots$ \\
\hline Austria & 0.4 & 32.3 & 0.0 & 41.9 & $\ldots$ & $\ldots$ \\
\hline Azerbaijan & $\ldots$ & $\ldots$ & $\ldots$ & & $\ldots$ & $\ldots$ \\
\hline Belgium & 4.2 & 16.4 & 0.0 & 48.6 & 41.7 & $\ldots$ \\
\hline \multicolumn{7}{|l|}{ Bosnia- } \\
\hline Herzegovina & ... & $\ldots$ & 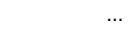 & $\ldots$ & $\ldots$ & $\ldots$ \\
\hline Bulgaria & 0.3 & $\ldots$ & 0.0 & $\ldots$ & $\ldots$ & $\ldots$ \\
\hline Croatia & 0.2 & 25.0 & 0.0 & 0.0 & $\ldots$ & 0.0 \\
\hline \\
\hline Republic & 0.6 & 13.4 & 0.0 & 13.4 & 44.4 & 0.0 \\
\hline Denmark & $\ldots$ & $\ldots$ & $\ldots$ & $\ldots$ & $\ldots$ & $\ldots$ \\
\hline Estonia & $\ldots$ & $\ldots$ & $\ldots$ & $\ldots$ & $\ldots$ & $\ldots$ \\
\hline Finland & 1.8 & 16.7 & 1.0 & $\ldots$ & $\ldots$ & 0.0 \\
\hline France & $\ldots$ & $\ldots$ & $\ldots$ & $\ldots$ & ... & $\ldots$ \\
\hline Georgia & $\ldots$ & $\ldots$ & $\ldots$ & $\ldots$ & $\ldots$ & $\ldots$ \\
\hline Germany & 0.9 & 24.7 & 0.1 & 32.4 & $\ldots$ & $\ldots$ \\
\hline Hungary & 0.1 & 14.3 & 0.0 & 14.3 & 0.0 & $\ldots$ \\
\hline Iceland & $\ldots$ & & & & $\ldots$ & $\ldots$ \\
\hline Italy & 3.1 & 18.6 & 0.5 & 37.7 & $\ldots$ & $\ldots$ \\
\hline \multicolumn{7}{|l|}{ Kosovo (UN } \\
\hline R/1244/99) & $\ldots$ & $\ldots$ & $\ldots$ & $\ldots$ & $\ldots$ & $\ldots$ \\
\hline Latvia & $\ldots$ & $\ldots$ & $\ldots$ & $\ldots$ & $\ldots$ & $\ldots$ \\
\hline Lithuania & 0.7 & 38.1 & 0.0 & $\ldots$ & $\ldots$ & 0.0 \\
\hline Luxembourg & & & . & $\ldots$ & $\ldots$ & $\ldots$ \\
\hline Moldova & 0.1 & 25.0 & 0.0 & $\ldots$ & $\ldots$ & $\ldots$ \\
\hline Montenegro & 0.0 & $\ldots$ & $\ldots$ & $\ldots$ & $\ldots$ & $\ldots$ \\
\hline Netherlands & 2.5 & 20.0 & 1.7 & $\ldots$ & $\ldots$ & 4.8 \\
\hline \multicolumn{7}{|l|}{ North } \\
\hline Macedonia & $\ldots$ & $\ldots$ & $\ldots$ & $\ldots$ & $\ldots$ & $\ldots$ \\
\hline Norway & $\ldots$ & $\ldots$ & $\ldots$ & $\ldots$ & $\ldots$ & $\ldots$ \\
\hline Poland & 0.3 & 18.3 & 0.0 & 2.5 & $\ldots$ & $\ldots$ \\
\hline Portugal & 0.3 & 50.0 & $\ldots$ & 26.5 & $\ldots$ & $\ldots$ \\
\hline Romania & 0.1 & $\ldots$ & 0.0 & $\ldots$ & $\ldots$ & 0.0 \\
\hline \multicolumn{7}{|l|}{ Russian } \\
\hline Federation & $\ldots$ & $\ldots$ & $\ldots$ & $\ldots$ & $\ldots$ & $\ldots$ \\
\hline Serbia & 0.0 & 50.0 & 0.0 & 0.0 & $\ldots$ & $\ldots$ \\
\hline \multicolumn{7}{|l|}{ Slovak } \\
\hline Republic & $\ldots$ & $\ldots$ & $\ldots$ & $\ldots$ & $\ldots$ & $\ldots$ \\
\hline Slovenia & $\ldots$ & $\ldots$ & $\ldots$ & $\ldots$ & $\ldots$ & $\ldots$ \\
\hline Spain & 6.2 & 14.4 & 5.4 & 28.3 & ... & $\ldots$ \\
\hline Sweden & 1.7 & 25.3 & 3.1 & $\ldots$ & $\ldots$ & $\ldots$ \\
\hline Switzerland & 3.8 & 19.1 & 0.0 & 73.1 & 26.5 & $\ldots$ \\
\hline Turkey & 0.1 & 7.7 & 0.0 & 0.0 & $\ldots$ & 0.0 \\
\hline Ukraine & 0.0 & 60.0 & 0.0 & 0.0 & $\ldots$ & $\ldots$ \\
\hline \multicolumn{7}{|l|}{ UK: England \& } \\
\hline Wales & 2.3 & 20.3 & 2.3 & $\ldots$ & $\ldots$ & 0.6 \\
\hline \multicolumn{7}{|l|}{ UK: Northern } \\
\hline Ireland & & $\ldots$ & $\ldots$ & $\ldots$ & $\ldots$ & $\ldots$ \\
\hline UK: Scotland & 0.0 & $\ldots$ & . & . & $\ldots$ & $\ldots$ \\
\hline Mean & 1.3 & 24.5 & 1.2 & 22.8 & 28.2 & 0.7 \\
\hline Median & 0.4 & 20.0 & 0.0 & 20.4 & 34.1 & 0.0 \\
\hline Minimum & 0.0 & 5.5 & 0.0 & 0.0 & 0.0 & 0.0 \\
\hline Maximum & 6.2 & 60.0 & 12.7 & 73.1 & 44.4 & 4.8 \\
\hline
\end{tabular}


Table 3.2.2.20 Percentage of women, minors, foreigners, and legal persons among convicted persons in 2015 - Corruption

\begin{tabular}{|c|c|c|c|c|c|c|}
\hline & $\begin{array}{c}\text { Total offenders } \\
\text { per } 100000 \\
\text { pop. }\end{array}$ & $\begin{array}{l}\text { of which \% } \\
\text { of women }\end{array}$ & $\begin{array}{l}\text { of which \% } \\
\text { of minors }\end{array}$ & $\begin{array}{l}\text { of which \% } \\
\text { of foreigners }\end{array}$ & $\begin{array}{l}\% \text { of EU citi- } \\
\text { zens amongst } \\
\text { foreigners }\end{array}$ & $\begin{array}{l}\text { of which } \\
\% \text { of legal } \\
\text { persons }\end{array}$ \\
\hline Albania & 2.9 & 7.1 & 0.0 & $\ldots$ & $\ldots$ & $\ldots$ \\
\hline Armenia & $\ldots$ & $\ldots$ & $\ldots$ & $\ldots$ & $\ldots$ & $\ldots$ \\
\hline Austria & 1.5 & 19.8 & 0.8 & 10.7 & $\ldots$ & $\ldots$ \\
\hline Azerbaijan & 0.2 & rop & $\ldots$ & $\ldots$ & $\ldots$ & $\ldots$ \\
\hline Belgium & 0.5 & 7.1 & 0.0 & 8.9 & 60.0 & $\ldots$ \\
\hline \multicolumn{7}{|l|}{ Bosnia- } \\
\hline Herzegovina & $\ldots$ & & $\ldots$ & & $\ldots$ & $\ldots$ \\
\hline Bulgaria & 1.1 & 12.8 & 0.0 & 9.0 & $\ldots$ & $\ldots$ \\
\hline Croatia & 5.1 & 28.4 & 0.0 & 5.1 & 9.1 & 0.5 \\
\hline $\begin{array}{l}\text { Cyprus } \\
\text { Czech }\end{array}$ & $\ldots$ & $\ldots$ & $\ldots$ & $\ldots$ & $\ldots$ & $\ldots$ \\
\hline Republic & 0.9 & 8.4 & 0.0 & 15.8 & 13.3 & 0.0 \\
\hline Denmark & $\ldots$ & $\ldots$ & $\ldots$ & $\ldots$ & $\ldots$ & $\ldots$ \\
\hline Estonia & $\ldots$ & $\ldots$ & $\ldots$ & $\ldots$ & $\ldots$ & $\ldots$ \\
\hline Finland & 0.1 & 0.0 & 0.0 & $\ldots$ & $\ldots$ & 33.3 \\
\hline France & 0.4 & 9.0 & 9.7 & 10.1 & $\ldots$ & $\ldots$ \\
\hline Georgia & 2.5 & 4.3 & $\ldots$ & $\ldots$ & $\ldots$ & $\ldots$ \\
\hline Germany & 0.2 & 13.5 & 0.0 & 27.5 & $\ldots$ & $\ldots$ \\
\hline Hungary & 1.5 & 10.5 & 0.0 & 9.9 & 73.3 & $\ldots$ \\
\hline Iceland & $\ldots$ & $\ldots$ & $\ldots$ & $\ldots$ & $\ldots$ & $\ldots$ \\
\hline Italy & $\ldots$ & $\ldots$ & $\ldots$ & $\ldots$ & $\ldots$ & $\ldots$ \\
\hline \multicolumn{7}{|l|}{ Kosovo (UN } \\
\hline R/1244/99) & $\ldots$ & $\ldots$ & $\ldots$ & $\ldots$ & $\ldots$ & $\ldots$ \\
\hline Latvia & $\ldots$ & $\ldots$ & $\ldots$ & $\ldots$ & $\ldots$ & $\ldots$ \\
\hline Lithuania & 26.8 & 7.8 & 0.3 & $\ldots$ & $\ldots$ & 0.0 \\
\hline Luxembourg & $\ldots$ & $\ldots$ & $\ldots$ & $\ldots$ & $\ldots$ & $\ldots$ \\
\hline Moldova & 1.9 & 20.6 & 0.0 & $\ldots$ & $\ldots$ & $\ldots$ \\
\hline Montenegro & $\ldots$ & $\ldots$ & $\ldots$ & $\ldots$ & $\ldots$ & $\ldots$ \\
\hline Netherlands & 0.0 & 0.0 & 0.0 & $\ldots$ & $\ldots$ & 0.0 \\
\hline \multicolumn{7}{|l|}{ North } \\
\hline Macedonia & $\ldots$ & $\ldots$ & $\ldots$ & $\ldots$ & $\ldots$ & $\ldots$ \\
\hline Norway & $\ldots$ & $\ldots$ & $\ldots$ & $\ldots$ & $\ldots$ & $\ldots$ \\
\hline Poland & 4.6 & 14.4 & 0.2 & 5.5 & $\ldots$ & $\ldots$ \\
\hline Portugal & 0.3 & $\ldots$ & $\ldots$ & 11.1 & $\ldots$ & $\ldots$ \\
\hline Romania & 3.0 & $\ldots$ & 0.0 & $\ldots$ & $\ldots$ & 1.7 \\
\hline \multicolumn{7}{|l|}{ Russian } \\
\hline Federation & $\ldots$ & $\ldots$ & $\ldots$ & $\ldots$ & $\ldots$ & $\ldots$ \\
\hline Serbia & 1.2 & 7.2 & 0.0 & 1.2 & 0.0 & $\ldots$ \\
\hline \multicolumn{7}{|l|}{ Slovak } \\
\hline Republic & $\ldots$ & $\ldots$ & $\ldots$ & $\ldots$ & $\ldots$ & $\ldots$ \\
\hline Slovenia & $\ldots$ & $\ldots$ & $\ldots$ & $\ldots$ & $\ldots$ & $\ldots$ \\
\hline Spain & $\ldots$ & $\ldots$ & $\ldots$ & $\ldots$ & $\ldots$ & $\ldots$ \\
\hline Sweden & 0.1 & 27.3 & 0.0 & $\ldots$ & $\ldots$ & $\ldots$ \\
\hline Switzerland & 0.7 & 20.4 & 0.0 & 68.5 & 2.7 & $\ldots$ \\
\hline Turkey & 1.1 & 4.1 & 0.6 & 1.0 & $\ldots$ & 0.0 \\
\hline Ukraine & 0.9 & 17.4 & 0.0 & 0.5 & $\ldots$ & $\ldots$ \\
\hline \multicolumn{7}{|l|}{ UK: England \& } \\
\hline Wales & $\ldots$ & $\ldots$ & $\ldots$ & $\ldots$ & $\ldots$ & $\ldots$ \\
\hline \multicolumn{7}{|l|}{ UK: Northern } \\
\hline Ireland & $\ldots$ & $\ldots$ & $\ldots$ & $\ldots$ & $\ldots$ & $\ldots$ \\
\hline UK: Scotland & 0.0 & $\ldots$ & $\ldots$ & $\ldots$ & $\ldots$ & $\ldots$ \\
\hline Mean & 2.4 & 12.0 & 0.6 & 13.2 & 26.4 & 5.1 \\
\hline Median & 1.0 & 9.8 & 0.0 & 9.4 & 11.2 & 0.0 \\
\hline Minimum & 0.0 & 0.0 & 0.0 & 0.5 & 0.0 & 0.0 \\
\hline Maximum & 26.8 & 28.4 & 9.7 & 68.5 & 73.3 & 33.3 \\
\hline
\end{tabular}


Table 3.2.2.21 Percentage of women, minors, foreigners, and legal persons among convicted persons in 2015 - Drug offences: Total

\begin{tabular}{|c|c|c|c|c|c|c|}
\hline & $\begin{array}{c}\text { Total offenders } \\
\text { per } 100000 \\
\text { pop. }\end{array}$ & $\begin{array}{l}\text { of which \% } \\
\text { of women }\end{array}$ & $\begin{array}{l}\text { of which } \% \\
\text { of minors }\end{array}$ & $\begin{array}{l}\text { of which \% } \\
\text { of foreigners }\end{array}$ & $\begin{array}{l}\% \text { of EU citi- } \\
\text { zens amongst } \\
\text { foreigners }\end{array}$ & $\begin{array}{l}\text { of which } \\
\% \text { of legal } \\
\text { persons }\end{array}$ \\
\hline Albania & 22 & 3.2 & 2.1 & $\ldots$ & $\ldots$ & $\ldots$ \\
\hline Armenia & $\ldots$ & $\ldots$ & $\ldots$ & $\ldots$ & $\ldots$ & $\ldots$ \\
\hline Austria & 52 & 7.9 & 6.3 & 44.0 & $\ldots$ & $\ldots$ \\
\hline Azerbaijan & 26 & $\ldots$ & . & . & $\ldots$ & $\ldots$ \\
\hline $\begin{array}{l}\text { Belgium } \\
\text { Bosnia- }\end{array}$ & 54 & 8.6 & 0.1 & 32.7 & 44.5 & $\ldots$ \\
\hline Herzegovina & $\ldots$ & $\ldots$ & & & $\ldots$ & $\ldots$ \\
\hline Bulgaria & 22 & 9.4 & 3.6 & 1.7 & $\ldots$ & $\ldots$ \\
\hline Croatia & 16 & 5.9 & 5.9 & 6.6 & 54.3 & 0.0 \\
\hline $\begin{array}{l}\text { Cyprus } \\
\text { Czech }\end{array}$ & $\ldots$ & $\ldots$ & $\ldots$ & $\ldots$ & $\ldots$ & $\ldots$ \\
\hline Republic & 26 & 16.0 & 3.0 & 17.3 & 17.5 & 0.0 \\
\hline Denmark & $\ldots$ & $\ldots$ & $\ldots$ & $\ldots$ & $\ldots$ & $\ldots$ \\
\hline Estonia & $\ldots$ & $\ldots$ & $\ldots$ & $\ldots$ & $\ldots$ & $\ldots$ \\
\hline Finland & 173 & 13.0 & 3.3 & 10.3 & 39.5 & 0.0 \\
\hline France & 95 & 6.1 & 8.1 & 8.5 & $\ldots$ & $\ldots$ \\
\hline Georgia & 110 & 0.8 & 0.4 & $\ldots$ & $\ldots$ & $\ldots$ \\
\hline Germany & 69 & 10.2 & 6.1 & 21.5 & 33.9 & $\ldots$ \\
\hline Hungary & 13 & 7.1 & 5.8 & 4.9 & 33.3 & $\ldots$ \\
\hline Iceland & $\ldots$ & $\ldots$ & $\ldots$ & $\ldots$ & $\ldots$ & $\ldots$ \\
\hline Italy & 36 & 7.1 & 1.4 & 43.1 & $\ldots$ & $\ldots$ \\
\hline \multicolumn{7}{|l|}{ Kosovo (UN } \\
\hline R/1244/99) & $\ldots$ & $\ldots$ & $\ldots$ & $\ldots$ & $\ldots$ & $\ldots$ \\
\hline Latvia & 57 & 18.0 & 1.6 & $\ldots$ & $\ldots$ & $\ldots$ \\
\hline Lithuania & 62 & 10.3 & 3.6 & $\ldots$ & $\ldots$ & 0.0 \\
\hline Luxembourg & 38 & 17.8 & $\ldots$ & $\ldots$ & $\ldots$ & $\ldots$ \\
\hline Moldova & 21 & 9.7 & 3.1 & $\ldots$ & $\ldots$ & $\ldots$ \\
\hline Montenegro & $\ldots$ & $\ldots$ & $\ldots$ & $\ldots$ & $\ldots$ & $\ldots$ \\
\hline Netherlands & 36 & 13.7 & 2.1 & $\ldots$ & $\ldots$ & 0.0 \\
\hline \multicolumn{7}{|l|}{ North } \\
\hline Macedonia & $\ldots$ & $\ldots$ & $\ldots$ & $\ldots$ & $\ldots$ & $\ldots$ \\
\hline Norway & 0 & $\ldots$ & $\ldots$ & $\ldots$ & 73.0 & $\ldots$ \\
\hline Poland & 43 & 4.7 & 0.8 & 1.2 & $\ldots$ & $\ldots$ \\
\hline Portugal & 38 & 11.7 & 2.2 & 17.1 & 21.6 & $\ldots$ \\
\hline Romania & 4 & $\ldots$ & 0.6 & $\ldots$ & $\ldots$ & 0.0 \\
\hline \multicolumn{7}{|l|}{ Russian } \\
\hline Federation & $\ldots$ & $\ldots$ & $\ldots$ & $\ldots$ & $\ldots$ & $\ldots$ \\
\hline Serbia & 43 & 7.8 & 5.0 & 5.1 & 46.2 & $\ldots$ \\
\hline \multicolumn{7}{|l|}{ Slovak } \\
\hline Republic & $\ldots$ & $\ldots$ & $\ldots$ & $\ldots$ & $\ldots$ & $\ldots$ \\
\hline Slovenia & $\ldots$ & $\ldots$ & $\ldots$ & $\ldots$ & $\ldots$ & $\ldots$ \\
\hline Spain & $\ldots$ & $\ldots$ & $\ldots$ & $\ldots$ & $\ldots$ & $\ldots$ \\
\hline Sweden & 232 & 13.2 & 6.8 & $\ldots$ & $\ldots$ & $\ldots$ \\
\hline Switzerland & 247 & 10.0 & 27.6 & 46.8 & 33.8 & $\ldots$ \\
\hline Turkey & 123 & 4.1 & 6.9 & 2.1 & $\ldots$ & 0.0 \\
\hline Ukraine & 26 & 11.9 & 1.5 & 0.7 & $\ldots$ & $\ldots$ \\
\hline \multicolumn{7}{|l|}{ UK: England \& } \\
\hline Wales & 81 & 7.9 & 17.3 & $\ldots$ & $\ldots$ & 0.0 \\
\hline \multicolumn{7}{|l|}{ UK: Northern } \\
\hline Ireland & $\ldots$ & $\ldots$ & $\ldots$ & $\ldots$ & $\ldots$ & $\ldots$ \\
\hline UK: Scotland & 118 & 13.0 & $\ldots$ & $\ldots$ & $\ldots$ & $\ldots$ \\
\hline Mean & 65 & 9.6 & 5.0 & 16.5 & 39.8 & 0.0 \\
\hline Median & 43 & 9.5 & 3.3 & 9.4 & 36.7 & 0.0 \\
\hline Minimum & 0 & 0.8 & 0.1 & 0.7 & 17.5 & 0.0 \\
\hline Maximum & 247 & 18.0 & 27.6 & 46.8 & 73.0 & 0.0 \\
\hline
\end{tabular}


Table 3.2.2.22 Percentage of women, minors, foreigners, and legal persons among convicted persons in 2015 - Drug trafficking

\begin{tabular}{|c|c|c|c|c|c|c|}
\hline & $\begin{array}{l}\text { Total offenders } \\
\text { per } 100000 \\
\text { pop. }\end{array}$ & $\begin{array}{l}\text { of which \% } \\
\text { of women }\end{array}$ & $\begin{array}{l}\text { of which \% } \\
\text { of minors }\end{array}$ & $\begin{array}{l}\text { of which } \% \\
\text { of foreigners }\end{array}$ & $\begin{array}{l}\% \text { of EU citi- } \\
\text { zens amongst } \\
\text { foreigners }\end{array}$ & $\begin{array}{l}\text { of which } \\
\% \text { of legal } \\
\text { persons }\end{array}$ \\
\hline Albania & 4.6 & 0.0 & 0.0 & & $\ldots$ & $\ldots$ \\
\hline Armenia & 1.5 & 11.4 & 4.5 & 27.3 & $\ldots$ & $\ldots$ \\
\hline Austria & 14.8 & 8.4 & $\ldots$ & $\ldots$ & $\ldots$ & $\ldots$ \\
\hline Azerbaijan & $\ldots$ & $\ldots$ & $\ldots$ & $\ldots$ & $\ldots$ & $\ldots$ \\
\hline $\begin{array}{l}\text { Belgium } \\
\text { Bosnia- }\end{array}$ & $\ldots$ & $\ldots$ & $\ldots$ & $\ldots$ & $\ldots$ & $\ldots$ \\
\hline Herzegovina & $\ldots$ & $\ldots$ & $\ldots$ & $\ldots$ & $\ldots$ & $\ldots$ \\
\hline $\begin{array}{l}\text { Bulgaria } \\
\text { la }\end{array}$ & $\cdots$ & $\cdots$ & $\cdots$ & $\cdots$ & $\cdots$ & $\cdots$ \\
\hline Croatia & 16.4 & 5.9 & 5.9 & 6.6 & 54.3 & 0.0 \\
\hline $\begin{array}{l}\text { Cyprus } \\
\text { Czech }\end{array}$ & $\ldots$ & $\ldots$ & $\ldots$ & $\ldots$ & $\ldots$ & $\ldots$ \\
\hline $\begin{array}{l}\text { Czech } \\
\text { Republic }\end{array}$ & 19.9 & 17.1 & 3.4 & 14.8 & 19.3 & 00 \\
\hline Denmark & $\ldots$ & $\ldots$ & $\ldots$ & $\ldots$ & $\ldots$ & $\ldots$ \\
\hline Estonia & & & & & $\ldots$ & \\
\hline Finland & 65.1 & 10.5 & 2.9 & & $\ldots$ & 0.0 \\
\hline France & 49.3 & 6.3 & 11.4 & 9.8 & $\ldots$ & $\ldots$ \\
\hline Georgia & 3.2 & 1.7 & & & $\ldots$ & $\ldots$ \\
\hline Germany & 10.9 & 9.5 & 1.3 & 28.8 & & $\ldots$ \\
\hline Hungary & 4.2 & 7.7 & 2.2 & 7.0 & 13.8 & $\ldots$ \\
\hline Iceland & $\ldots$ & $\ldots$ & $\ldots$ & $\ldots$ & $\ldots$ & $\ldots$ \\
\hline $\begin{array}{l}\text { Italy } \\
\text { Kosovo (UN }\end{array}$ & $\ldots$ & $\ldots$ & $\ldots$ & $\ldots$ & $\ldots$ & ... \\
\hline R/1244/99) & $\ldots$ & $\ldots$ & $\ldots$ & $\ldots$ & $\ldots$ & $\ldots$ \\
\hline Latvia & $\ldots$ & & & $\ldots$ & $\ldots$ & $\ldots$ \\
\hline Lithuania & 18.4 & 14.5 & 5.6 & $\ldots$ & $\ldots$ & 0.0 \\
\hline Luxembourg & 31.6 & 3.4 & $\ldots$ & $\ldots$ & $\ldots$ & $\ldots$ \\
\hline Moldova & $\ldots$ & $\ldots$ & $\ldots$ & $\ldots$ & $\ldots$ & $\ldots$ \\
\hline Montenegro & $\ldots$ & $\ldots$ & $\ldots$ & $\ldots$ & $\ldots$ & $\ldots$ \\
\hline Netherlands & $\ldots$ & $\ldots$ & $\ldots$ & $\ldots$ & $\ldots$ & $\ldots$ \\
\hline North & & & & & & \\
\hline Macedonia & $\ldots$ & & & & $\ldots$ & $\ldots$ \\
\hline Norway & & & & & $\ldots$ & $\ldots$ \\
\hline Poland & 4.7 & 5.2 & 0.9 & 3.5 & $\ldots$ & $\ldots$ \\
\hline Portugal & 30.0 & 13.6 & 2.1 & 18.7 & 21.5 & $\ldots$ \\
\hline $\begin{array}{l}\text { Romania } \\
\text { Russian }\end{array}$ & 3.9 & $\ldots$ & 0.7 & $\ldots$ & $\ldots$ & 0.0 \\
\hline Federation & & & & & & $\ldots$ \\
\hline Serbia & 12.6 & 4.0 & 5.4 & 5.1 & 47.8 & $\ldots$ \\
\hline Slovak & & & & & & \\
\hline Republic & $\ldots$ & $\ldots$ & $\ldots$ & $\ldots$ & $\ldots$ & $\ldots$ \\
\hline Slovenia & $\ldots$ & $\ldots$ & $\ldots$ & $\ldots$ & $\ldots$ & $\ldots$ \\
\hline Spain & & & & $\ldots$ & $\ldots$ & $\ldots$ \\
\hline Sweden & 25.8 & 9.0 & 2.4 & - & $\ldots$ & $\ldots$ \\
\hline Switzerland & 99.4 & 9.0 & 12.3 & 58.1 & 21.2 & $\ldots$ \\
\hline Turkey & 69.3 & 5.9 & 5.2 & 3.6 & $\ldots$ & 0.0 \\
\hline Ukraine & 3.7 & 13.5 & 2.5 & 0.8 & $\ldots$ & $\ldots$ \\
\hline UK: England \& & & & & & & \\
\hline Wales & 0.9 & 12.9 & 0.4 & & $\ldots$ & 0.0 \\
\hline $\begin{array}{l}\text { UK: Northern } \\
\text { Ireland } \\
\text { UK: Scotland }\end{array}$ & $\cdots$ & $\ldots$ & $\ldots$ & $\ldots$ & $\ldots$ & $\ldots$ \\
\hline Mean & 23.3 & 8.5 & 3.8 & 15.4 & 29.7 & 0.0 \\
\hline Median & 14.8 & 8.7 & 2.7 & 8.4 & 21.4 & 0.0 \\
\hline Minimum & 0.9 & 0.0 & 0.0 & 0.8 & 13.8 & 0.0 \\
\hline Maximum & 99.4 & 17.1 & 12.3 & 58.1 & 54.3 & 0.0 \\
\hline
\end{tabular}


Notes on tables 3.2.2.1 to 3.2.2.22

In general, the notes for tables 3.2.1.1 to 3.2.1.22 also apply here.

Belgium

Only criminal offences committed by minors over the age of 16 , who were convicted by jurisdiction that applies the criminal law for adults on decision of the juvenile court, are included.

Bulgaria The others are excluded.

Finland Legal persons are not subject to criminal liability.

Portugal Some figures for foreigners include more crime types than other figures due to different grouping in data sources.

Romania EU citizens according to the present configuration of the EU.

Romania
Spain Criminal liability of legal persons was provided for in the Portuguese Criminal Code in 2007. Data refer to 2016, not 2015.

are included.

Turkey Number of women: for 179 cases (all crimes) gender of the offender is not known.

UK: Scotland Data on foreigners is not held. 


\subsubsection{Total persons receiving sanctions/measures in 2015}

Table 3.2.3.1. Total persons receiving sanctions/measures in 2015 - Criminal offences: Total

\begin{tabular}{|c|c|c|c|c|c|c|c|c|c|c|c|}
\hline & \multirow{2}{*}{ 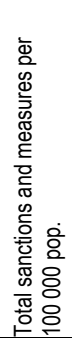 } & \multirow{2}{*}{ 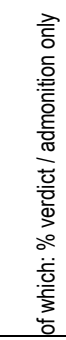 } & \multirow[b]{2}{*}{ 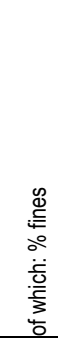 } & \multicolumn{2}{|c|}{$\begin{array}{l}\text { of which: \% } \\
\text { non-custodial } \\
\text { sanctions and } \\
\text { measures }\end{array}$} & \multicolumn{3}{|c|}{$\begin{array}{l}\text { of which: \% suspended } \\
\text { custodial sanctions and } \\
\text { measures }\end{array}$} & \multicolumn{2}{|c|}{$\begin{array}{l}\text { of which: \% un- } \\
\text { suspended custo- } \\
\text { dial sanctions and } \\
\text { measures }\end{array}$} & \multirow[b]{2}{*}{ 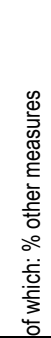 } \\
\hline & & & & $\begin{array}{l}\overline{\mathbb{\pi}} \\
\stackrel{0}{\circ}\end{array}$ & 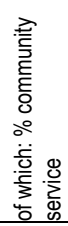 & 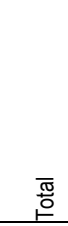 & 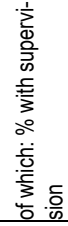 & 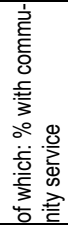 & 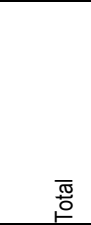 & 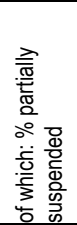 & \\
\hline Albania & & $\ldots$ & & & $\ldots$ & & $\ldots$ & $\ldots$ & $\ldots$ & $\ldots$ & $\ldots$ \\
\hline Armenia & 98 & $\ldots$ & 27.5 & 0.0 & $\ldots$ & 33.2 & $\ldots$ & $\ldots$ & 35.9 & $\ldots$ & $\ldots$ \\
\hline Austria & 374 & $\ldots$ & 27.6 & $\ldots$ & $\ldots$ & 38.0 & $\ldots$ & $\ldots$ & 29.1 & 34.8 & 5.3 \\
\hline Azerbaijan & $\ldots$ & $\ldots$ & $\ldots$ & $\ldots$ & $\ldots$ & $\ldots$ & $\ldots$ & $\ldots$ & $\ldots$ & $\ldots$ & $\ldots$ \\
\hline Belgium & 1978 & $\ldots$ & 84.0 & 4.6 & 100.0 & 5.1 & 22.6 & $\ldots$ & 6.1 & $\ldots$ & 0.2 \\
\hline Bosnia-Herzegovina & $\ldots$ & $\ldots$ & $\ldots$ & $\ldots$ & $\ldots$ & $\ldots$ & $\ldots$ & $\ldots$ & $\ldots$ & $\ldots$ & $\ldots$ \\
\hline Bulgaria & 386 & $\ldots$ & 3.2 & 28.4 & $\ldots$ & 47.6 & $\ldots$ & $\ldots$ & 20.0 & $\ldots$ & 0.8 \\
\hline Croatia & 308 & 1.5 & 3.4 & 1.8 & $\ldots$ & 71.4 & 9.7 & 10.4 & 21.8 & 15.3 & $\ldots$ \\
\hline Cyprus & 6387 & & 94.7 & & $\ldots$ & & & $\ldots$ & & $\ldots$ & $\ldots$ \\
\hline Czech Republic & 622 & 1.8 & 3.6 & 13.2 & 88.8 & 66.8 & 9.7 & $\ldots$ & 14.5 & $\ldots$ & 0.1 \\
\hline Denmark & $\ldots$ & $\ldots$ & $\ldots$ & $\ldots$ & $\ldots$ & $\ldots$ & $\ldots$ & $\ldots$ & $\ldots$ & $\ldots$ & $\ldots$ \\
\hline Estonia & $\ldots$ & $\ldots$ & $\ldots$ & $\ldots$ & $\ldots$ & $\ldots$ & $\ldots$ & $\ldots$ & $\ldots$ & $\ldots$ & $\ldots$ \\
\hline Finland & 3321 & 0.0 & 88.4 & 1.1 & 90.6 & 7.3 & 5.9 & 2.1 & 2.8 & $\ldots$ & 0.4 \\
\hline France & 864 & 0.8 & 35.7 & 14.9 & 19.5 & 26.5 & 0.6 & $\ldots$ & 22.1 & 20.3 & $\ldots$ \\
\hline Georgia & 406 & $\ldots$ & 19.9 & $\ldots$ & $\ldots$ & 45.7 & $\ldots$ & 10.9 & 29.3 & $\ldots$ & 0.1 \\
\hline Germany & 922 & 1.2 & 75.8 & 7.3 & $\ldots$ & 10.9 & $\ldots$ & $\ldots$ & 4.8 & $\ldots$ & $\ldots$ \\
\hline Hungary & 852 & 1.3 & 24.0 & 45.8 & 31.3 & 18.3 & 16.4 & 0.0 & 10.7 & 0.0 & 0.0 \\
\hline Iceland & 644 & 67.1 & 32.9 & 57.2 & 11.5 & 21.8 & $\ldots$ & 24.9 & 23.1 & 11.0 & 0.0 \\
\hline $\begin{array}{l}\text { Italy } \\
\text { Kosovo (UN }\end{array}$ & $\ldots$ & $\ldots$ & $\ldots$ & $\ldots$ & $\ldots$ & $\ldots$ & $\ldots$ & $\ldots$ & $\ldots$ & $\ldots$ & $\ldots$ \\
\hline$R / 1244 / 99)$ & ... & $\ldots$ & $\ldots$ & $\ldots$ & $\ldots$ & $\ldots$ & $\ldots$ & $\ldots$ & $\ldots$ & $\ldots$ & $\ldots$ \\
\hline Latvia & 504 & $\ldots$ & 1.6 & $\ldots$ & $\ldots$ & $\ldots$ & $\ldots$ & $\ldots$ & 34.1 & $\ldots$ & $\ldots$ \\
\hline Lithuania & 636 & 0.5 & 27.2 & 32.8 & 21.1 & 7.2 & $\ldots$ & $\ldots$ & 28.4 & $\ldots$ & 1.3 \\
\hline Luxembourg & & & & & & $\ldots$ & $\ldots$ & $\ldots$ & $\ldots$ & $\ldots$ & $\ldots$ \\
\hline Moldova & 314 & 100.0 & 33.2 & 78.9 & 24.9 & $\ldots$ & $\ldots$ & $\ldots$ & $\ldots$ & $\ldots$ & $\ldots$ \\
\hline Montenegro & $\ldots$ & $\ldots$ & $\ldots$ & $\ldots$ & $\ldots$ & $\ldots$ & $\ldots$ & $\ldots$ & $\ldots$ & $\ldots$ & $\ldots$ \\
\hline Netherlands & 527 & $\ldots$ & 28.0 & 29.2 & 95.6 & 14.3 & $\ldots$ & 52.3 & 28.5 & 34.1 & $\ldots$ \\
\hline North Macedonia & & $\ldots$ & $\ldots$ & $\ldots$ & $\ldots$ & $\ldots$ & $\ldots$ & $\ldots$ & $\ldots$ & $\ldots$ & $\ldots$ \\
\hline Norway & 5649 & $\ldots$ & 0.6 & $\ldots$ & $\ldots$ & 2.8 & $\ldots$ & $\ldots$ & 3.7 & $\ldots$ & $\ldots$ \\
\hline Poland & 684 & $\ldots$ & 23.6 & 12.0 & 100.0 & 51.2 & 29.1 & $\ldots$ & 13.1 & $\ldots$ & 0.1 \\
\hline Portugal & 595 & 0.5 & 61.8 & 3.6 & 99.6 & 23.2 & 50.7 & $\ldots$ & 9.5 & $\ldots$ & 1.5 \\
\hline Romania & $\ldots$ & $\ldots$ & $\ldots$ & $\ldots$ & $\ldots$ & $\ldots$ & $\ldots$ & $\ldots$ & $\ldots$ & $\ldots$ & $\ldots$ \\
\hline Russian Federation & & & & $\ldots$ & & & $\ldots$ & $\ldots$ & $\ldots$ & $\ldots$ & $\ldots$ \\
\hline Serbia & 467 & 2.1 & 8.2 & 1.1 & 98.3 & 61.5 & 5.6 & $\ldots$ & 26.6 & $\ldots$ & 0.5 \\
\hline Slovak Republic & $\ldots$ & $\ldots$ & $\ldots$ & $\ldots$ & $\ldots$ & $\ldots$ & $\ldots$ & $\cdots$ & $\ldots$ & $\ldots$ & $\ldots$ \\
\hline Slovenia & $\ldots$ & $\ldots$ & $\ldots$ & $\ldots$ & $\ldots$ & $\ldots$ & $\ldots$ & $\ldots$ & $\cdots$ & $\ldots$ & $\ldots$ \\
\hline Spain & 1379 & $\ldots$ & $\ldots$ & $\ldots$ & $\ldots$ & $\ldots$ & $\ldots$ & $\ldots$ & $\ldots$ & $\ldots$ & $\ldots$ \\
\hline Sweden & 1095 & 0.0 & 53.8 & 4.6 & 20.5 & 11.4 & $\ldots$ & 31.3 & 10.2 & 1.4 & 19.9 \\
\hline Switzerland & 1358 & $\ldots$ & 85.5 & 2.5 & 93.9 & 2.4 & $\ldots$ & $\ldots$ & 9.6 & 8.0 & 0.0 \\
\hline Turkey & 1971 & $\ldots$ & 26.4 & 19.8 & $\ldots$ & 6.0 & $\ldots$ & $\ldots$ & 28.1 & $\ldots$ & 19.6 \\
\hline Ukraine & 222 & $\ldots$ & 19.7 & $\ldots$ & $\ldots$ & $\ldots$ & $\ldots$ & $\ldots$ & 20.8 & $\ldots$ & 3.7 \\
\hline UK: England \& Wales & 2154 & $\ldots$ & 71.5 & 92.8 & 9.9 & 4.6 & $\ldots$ & $\ldots$ & 7.2 & $\ldots$ & 7.5 \\
\hline UK: Northern Ireland & 1317 & $\ldots$ & 53.9 & 13.0 & 47.8 & 15.3 & $\ldots$ & $\ldots$ & 12.4 & $\ldots$ & 5.5 \\
\hline UK: Scotland & 1860 & 17.3 & 49.2 & 19.0 & 88.6 & 0.0 & $\ldots$ & $\ldots$ & 19.0 & 0.0 & $\ldots$ \\
\hline Mean & 1307 & 14.9 & 38.0 & 22.0 & 61.3 & 24.7 & 16.7 & 18.9 & 18.1 & 13.9 & 3.7 \\
\hline Median & 684 & 1.3 & 27.8 & 13.1 & 88.6 & 16.8 & 9.7 & 10.9 & 19.5 & 11.0 & 0.7 \\
\hline Minimum & 98 & 0.0 & 0.6 & 0.0 & 9.9 & 0.0 & 0.6 & 0.0 & 2.8 & 0.0 & 0.0 \\
\hline Maximum & 6387 & 100.0 & 94.7 & 92.8 & 100.0 & 71.4 & 50.7 & 52.3 & 35.9 & 34.8 & 19.9 \\
\hline
\end{tabular}


Table 3.2.3.2 Total persons receiving sanctions/measures in 2015 - Major road traffic offences

\begin{tabular}{|c|c|c|c|c|c|c|c|c|c|c|c|}
\hline & \multirow[b]{2}{*}{ 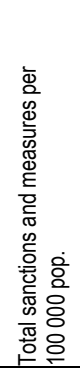 } & \multirow{2}{*}{ 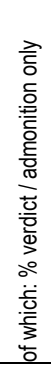 } & \multirow[b]{2}{*}{ 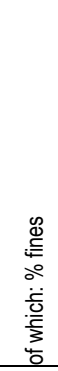 } & \multicolumn{2}{|c|}{$\begin{array}{l}\text { of which: } \% \\
\text { non-custodial } \\
\text { sanctions and } \\
\text { measures }\end{array}$} & \multicolumn{3}{|c|}{$\begin{array}{l}\text { of which: \% suspended } \\
\text { custodial sanctions and } \\
\text { measures }\end{array}$} & \multicolumn{2}{|c|}{$\begin{array}{l}\text { of which: \% un- } \\
\text { suspended custo- } \\
\text { dial sanctions and } \\
\text { measures }\end{array}$} & \multirow[b]{2}{*}{ 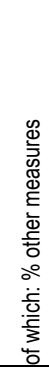 } \\
\hline & & & & 嵒 & 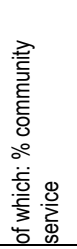 & 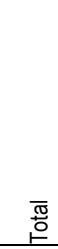 & 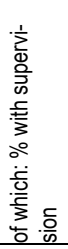 & 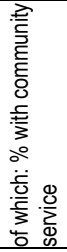 & 蕇 & 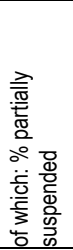 & \\
\hline Albania & & $\ldots$ & & & $\ldots$ & & $\ldots$ & $\ldots$ & & $\ldots$ & $\ldots$ \\
\hline Armenia & 2.7 & $\ldots$ & 6.1 & 0.0 & $\ldots$ & 57.3 & $\ldots$ & $\ldots$ & 36.6 & $\ldots$ & $\ldots$ \\
\hline Austria & $\ldots$ & $\ldots$ & $\ldots$ & $\ldots$ & $\ldots$ & $\ldots$ & $\ldots$ & $\ldots$ & $\ldots$ & $\ldots$ & $\ldots$ \\
\hline Azerbaijan & $\ldots$ & $\ldots$ & $\ldots$ & $\ldots$ & $\ldots$ & $\ldots$ & $\ldots$ & $\ldots$ & $\ldots$ & $\ldots$ & $\ldots$ \\
\hline Belgium & $\ldots$ & $\ldots$ & $\ldots$ & $\ldots$ & $\ldots$ & $\ldots$ & $\ldots$ & $\ldots$ & $\ldots$ & $\ldots$ & $\ldots$ \\
\hline Bosnia-Herzegovina & $\ldots$ & $\ldots$ & $\ldots$ & $\ldots$ & $\ldots$ & $\ldots$ & $\ldots$ & $\ldots$ & $\ldots$ & $\ldots$ & $\ldots$ \\
\hline Bulgaria & 110.5 & $\ldots$ & 0.8 & 51.9 & $\ldots$ & 39.3 & $\ldots$ & $\ldots$ & 7.9 & $\ldots$ & 0.1 \\
\hline Croatia & 22.1 & 1.1 & 12.1 & 0.3 & $\ldots$ & 75.5 & 1.4 & 5.8 & 11.0 & 0.0 & $\ldots$ \\
\hline Cyprus & $\ldots$ & $\ldots$ & $\ldots$ & $\ldots$ & $\ldots$ & $\ldots$ & $\ldots$ & $\ldots$ & $\ldots$ & $\ldots$ & $\ldots$ \\
\hline Czech Republic & 152.3 & 0.4 & 10.1 & 11.6 & 87.4 & 71.3 & 3.8 & $\ldots$ & 6.5 & $\ldots$ & 0.0 \\
\hline Denmark & $\ldots$ & $\ldots$ & $\ldots$ & $\ldots$ & $\ldots$ & $\ldots$ & $\ldots$ & $\cdots$ & $\ldots$ & $\ldots$ & $\ldots$ \\
\hline Estonia & & $\ldots$ & & & $\ldots$ & $\ldots$ & & $\ldots$ & $\ldots$ & $\ldots$ & $\ldots$ \\
\hline Finland & 1929.9 & 0.0 & 92.2 & 1.1 & 89.0 & 5.4 & 3.0 & 0.1 & 1.2 & $\ldots$ & 0.1 \\
\hline France & 312.5 & 0.2 & 53.7 & 16.0 & 10.0 & 19.4 & 0.9 & $\ldots$ & 10.8 & 14.0 & $\ldots$ \\
\hline Georgia & 20.0 & $\ldots$ & $\ldots$ & $\ldots$ & $\ldots$ & $\ldots$ & $\ldots$ & $\ldots$ & $\ldots$ & $\ldots$ & $\ldots$ \\
\hline Germany & 186.7 & 0.4 & 90.5 & 3.3 & $\ldots$ & 4.5 & $\ldots$ & $\ldots$ & 1.3 & $\ldots$ & $\ldots$ \\
\hline Hungary & 259.8 & 0.1 & 40.4 & 53.3 & 10.0 & 4.8 & 7.5 & 0.0 & 1.3 & 0.0 & 0.0 \\
\hline Iceland & $\ldots$ & $\ldots$ & $\ldots$ & $\ldots$ & $\ldots$ & $\ldots$ & $\ldots$ & $\ldots$ & $\ldots$ & $\ldots$ & $\ldots$ \\
\hline Italy & $\ldots$ & $\ldots$ & $\ldots$ & $\ldots$ & $\ldots$ & $\ldots$ & $\ldots$ & $\ldots$ & $\ldots$ & $\ldots$ & $\ldots$ \\
\hline Kosovo (UN & $\ldots$ & & & & & & & & & & \\
\hline $\mathrm{R} / 1244 / 99)$ & & $\ldots$ & $\ldots$ & $\ldots$ & $\ldots$ & $\ldots$ & $\ldots$ & $\ldots$ & $\ldots$ & $\ldots$ & $\ldots$ \\
\hline Latvia & $\ldots$ & $\ldots$ & $\ldots$ & $\ldots$ & $\ldots$ & $\ldots$ & $\ldots$ & $\ldots$ & $\ldots$ & $\ldots$ & $\ldots$ \\
\hline Lithuania & 11.7 & $\ldots$ & $\ldots$ & $\ldots$ & $\ldots$ & $\ldots$ & $\ldots$ & $\ldots$ & $\ldots$ & $\ldots$ & 0.0 \\
\hline Luxembourg & $\ldots$ & $\ldots$ & $\ldots$ & $\ldots$ & $\ldots$ & $\ldots$ & $\ldots$ & $\ldots$ & $\ldots$ & $\ldots$ & $\ldots$ \\
\hline Moldova & $\ldots$ & $\ldots$ & $\ldots$ & $\ldots$ & $\ldots$ & $\ldots$ & $\ldots$ & $\ldots$ & $\ldots$ & $\ldots$ & $\ldots$ \\
\hline Montenegro & $\ldots$ & $\ldots$ & $\ldots$ & $\ldots$ & $\ldots$ & $\ldots$ & $\ldots$ & $\ldots$ & $\ldots$ & $\ldots$ & $\ldots$ \\
\hline Netherlands & 95.1 & $\ldots$ & 57.6 & 21.3 & 92.9 & 9.9 & $\ldots$ & 42.3 & 11.1 & 12.5 & $\ldots$ \\
\hline North Macedonia & $\ldots$ & $\ldots$ & $\ldots$ & $\ldots$ & $\ldots$ & $\ldots$ & $\ldots$ & $\ldots$ & $\ldots$ & $\ldots$ & $\ldots$ \\
\hline Norway & 12.0 & $\ldots$ & 28.0 & $\ldots$ & $\ldots$ & 5.0 & $\ldots$ & $\ldots$ & 0.0 & $\ldots$ & $\ldots$ \\
\hline Poland & 157.4 & $\ldots$ & 39.4 & 9.2 & 100.0 & 43.1 & 8.7 & $\ldots$ & 8.3 & $\ldots$ & 0.0 \\
\hline Portugal & 196.5 & 0.5 & 75.9 & 4.9 & 68.1 & 13.3 & 39.9 & $\ldots$ & 5.4 & $\ldots$ & 0.2 \\
\hline Romania & $\ldots$ & $\ldots$ & $\ldots$ & $\ldots$ & $\ldots$ & $\ldots$ & $\ldots$ & $\ldots$ & $\ldots$ & $\ldots$ & $\ldots$ \\
\hline Russian Federation & $\ldots$ & $\ldots$ & $\ldots$ & & $\ldots$ & $\ldots$ & $\ldots$ & $\ldots$ & $\ldots$ & $\ldots$ & $\ldots$ \\
\hline Serbia & 36.5 & 0.4 & 15.2 & 0.7 & 83.3 & 70.4 & 6.7 & $\ldots$ & 12.6 & $\ldots$ & 0.7 \\
\hline Slovak Republic & $\ldots$ & $\ldots$ & $\ldots$ & $\ldots$ & $\ldots$ & $\ldots$ & $\ldots$ & $\ldots$ & $\ldots$ & $\ldots$ & $\ldots$ \\
\hline Slovenia & $\ldots$ & $\ldots$ & $\ldots$ & $\ldots$ & $\ldots$ & $\ldots$ & $\ldots$ & $\ldots$ & $\ldots$ & $\ldots$ & $\ldots$ \\
\hline Spain & & $\ldots$ & $\ldots$ & $\ldots$ & $\ldots$ & $\ldots$ & $\ldots$ & $\ldots$ & $\ldots$ & $\ldots$ & $\ldots$ \\
\hline Sweden & 228.5 & 0.0 & 65.0 & 2.9 & 37.7 & 4.6 & $\ldots$ & 89.3 & 12.7 & 0.1 & 14.7 \\
\hline Switzerland & 614.4 & $\ldots$ & 96.9 & 2.0 & 99.3 & 0.7 & $\ldots$ & $\ldots$ & 0.4 & 10.3 & 0.0 \\
\hline Turkey & 47.2 & $\ldots$ & 55.4 & 13.3 & $\ldots$ & 3.4 & $\ldots$ & $\ldots$ & 18.4 & $\ldots$ & 9.5 \\
\hline Ukraine & 11.7 & $\ldots$ & 12.8 & $\ldots$ & $\ldots$ & $\ldots$ & $\ldots$ & $\ldots$ & 22.8 & $\ldots$ & $\ldots$ \\
\hline UK: England \& Wales & 6.8 & $\ldots$ & 2.5 & 19.2 & $\ldots$ & 35.1 & $\ldots$ & $\ldots$ & 43.0 & $\ldots$ & 2.7 \\
\hline UK: Northern Ireland & & $\ldots$ & $\ldots$ & & $\ldots$ & $\ldots$ & $\ldots$ & $\ldots$ & $\ldots$ & $\ldots$ & $\ldots$ \\
\hline UK: Scotland & 132.3 & 1.4 & 83.5 & 11.7 & $\ldots$ & $\ldots$ & $\ldots$ & $\ldots$ & 11.7 & $\ldots$ & $\ldots$ \\
\hline Mean & 216.5 & 0.4 & 44.1 & 13.1 & 67.8 & 27.2 & 9.0 & 27.5 & 11.7 & 6.2 & 2.3 \\
\hline Median & 110.5 & 0.4 & 40.4 & 9.2 & 85.4 & 13.3 & 5.2 & 5.8 & 10.8 & 5.2 & 0.1 \\
\hline Minimum & 2.7 & 0.0 & 0.8 & 0.0 & 10.0 & 0.7 & 0.9 & 0.0 & 0.0 & 0.0 & 0.0 \\
\hline Maximum & 1929.9 & 1.4 & 96.9 & 53.3 & 100.0 & 75.5 & 39.9 & 89.3 & 43.0 & 14.0 & 14.7 \\
\hline
\end{tabular}


Table 3.2.3.3 Total persons receiving sanctions/measures in 2015 - Intentional homicide: Total

\begin{tabular}{|c|c|c|c|c|c|c|c|c|c|c|c|}
\hline & \multirow[b]{2}{*}{ 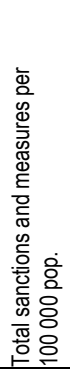 } & \multirow{2}{*}{ 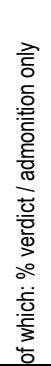 } & \multirow[b]{2}{*}{ 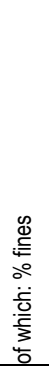 } & \multicolumn{2}{|c|}{$\begin{array}{l}\text { of which: \% } \\
\text { non-custodial } \\
\text { sanctions and } \\
\text { measures }\end{array}$} & \multicolumn{3}{|c|}{$\begin{array}{l}\text { of which: \% suspended } \\
\text { custodial sanctions and } \\
\text { measures }\end{array}$} & \multicolumn{2}{|c|}{$\begin{array}{l}\text { of which: } \% \text { un- } \\
\text { suspended custo- } \\
\text { dial sanctions and } \\
\text { measures }\end{array}$} & \multirow[b]{2}{*}{ 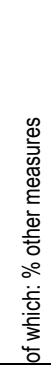 } \\
\hline & & & & $\begin{array}{l}\text { 퓽 } \\
\text { 은 }\end{array}$ & 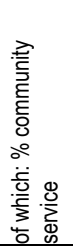 & 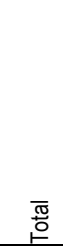 & 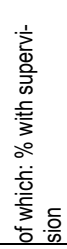 & 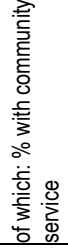 & 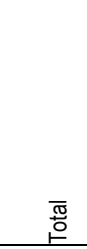 & 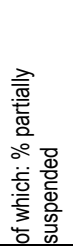 & \\
\hline Albania & & $\ldots$ & & & $\ldots$ & & $\ldots$ & $\ldots$ & ב & $\ldots$ & $\ldots$ \\
\hline Armenia & 0.9 & $\ldots$ & 0.0 & 0.0 & $\ldots$ & 0.0 & $\ldots$ & $\ldots$ & 100.0 & . & $\ldots$ \\
\hline Austria & 0.5 & $\ldots$ & $\ldots$ & 0.0 & $\ldots$ & 0.0 & $\ldots$ & $\ldots$ & 100.0 & 5.0 & 0.0 \\
\hline Azerbaijan & & $\ldots$ & & & & & & $\ldots$ & & $\ldots$ & \\
\hline Belgium & 2.3 & $\ldots$ & 0.0 & 1.6 & 100.0 & 31.4 & 55.6 & $\ldots$ & 67.1 & $\ldots$ & 0.0 \\
\hline Bosnia-Herzegovina & $\ldots$ & $\ldots$ & $\ldots$ & $\ldots$ & $\ldots$ & $\ldots$ & $\ldots$ & $\ldots$ & $\ldots$ & $\ldots$ & $\ldots$ \\
\hline Bulgaria & 1.8 & $\ldots$ & 0.0 & 0.0 & $\ldots$ & 3.8 & $\ldots$ & $\ldots$ & 96.2 & $\ldots$ & 0.0 \\
\hline Croatia & 1.8 & 0.0 & 0.0 & 1.3 & $\ldots$ & 5.1 & 0.0 & 0.0 & 93.6 & 17.8 & $\ldots$ \\
\hline Cyprus & $\ldots$ & $\ldots$ & $\ldots$ & $\ldots$ & $\ldots$ & $\ldots$ & $\ldots$ & $\ldots$ & $\ldots$ & $\ldots$ & $\ldots$ \\
\hline Czech Republic & 1.1 & 0.0 & 0.0 & 0.9 & 100.0 & 2.6 & 33.3 & $\ldots$ & 97.4 & $\ldots$ & 0.0 \\
\hline Denmark & $\ldots$ & $\ldots$ & $\ldots$ & $\ldots$ & $\ldots$ & $\ldots$ & $\ldots$ & $\ldots$ & $\ldots$ & $\ldots$ & $\ldots$ \\
\hline Estonia & $\ldots$ & $\ldots$ & $\ldots$ & $\ldots$ & $\ldots$ & $\ldots$ & $\ldots$ & $\ldots$ & $\ldots$ & $\ldots$ & $\ldots$ \\
\hline Finland & 2.6 & 0.0 & 0.0 & 0.0 & $\ldots$ & 2.1 & 66.7 & 33.3 & 87.6 & $\ldots$ & 10.3 \\
\hline France & 0.6 & 0.0 & 0.0 & 0.0 & $\ldots$ & 1.7 & 0.0 & $\ldots$ & 98.3 & 3.6 & $\ldots$ \\
\hline Georgia & 4.0 & $\ldots$ & $\ldots$ & $\ldots$ & $\ldots$ & $\ldots$ & $\ldots$ & $\ldots$ & 98.7 & 1.4 & $\ldots$ \\
\hline Germany & 0.7 & 0.3 & 0.2 & 0.2 & $\ldots$ & 3.9 & $\ldots$ & $\ldots$ & 95.4 & $\ldots$ & $\ldots$ \\
\hline Hungary & 2.0 & 0.0 & 0.0 & 5.5 & 0.0 & 5.5 & 18.2 & 0.0 & 89.0 & 0.0 & 0.0 \\
\hline Iceland & $\ldots$ & $\ldots$ & $\ldots$ & $\ldots$ & $\ldots$ & $\ldots$ & $\ldots$ & $\ldots$ & $\ldots$ & $\ldots$ & $\ldots$ \\
\hline Italy & $\ldots$ & $\ldots$ & $\ldots$ & $\ldots$ & $\ldots$ & $\ldots$ & $\ldots$ & $\ldots$ & $\ldots$ & $\ldots$ & $\ldots$ \\
\hline Kosovo (UN & $\ldots$ & & & & & & & & & & \\
\hline $\mathrm{R} / 1244 / 99)$ & & $\ldots$ & $\ldots$ & $\ldots$ & $\ldots$ & $\ldots$ & $\ldots$ & $\ldots$ & $\ldots$ & $\ldots$ & $\ldots$ \\
\hline Latvia & $\ldots$ & $\ldots$ & $\ldots$ & $\ldots$ & $\ldots$ & $\ldots$ & $\ldots$ & $\ldots$ & $\ldots$ & $\ldots$ & $\ldots$ \\
\hline Lithuania & 4.5 & $\ldots$ & $\ldots$ & $\ldots$ & $\ldots$ & $\ldots$ & $\ldots$ & $\ldots$ & $\ldots$ & $\ldots$ & 3.1 \\
\hline Luxembourg & $\ldots$ & $\ldots$ & $\ldots$ & $\ldots$ & $\ldots$ & $\ldots$ & $\ldots$ & $\ldots$ & $\ldots$ & $\ldots$ & $\ldots$ \\
\hline Moldova & $\ldots$ & $\ldots$ & $\ldots$ & $\ldots$ & $\ldots$ & $\ldots$ & ... & $\ldots$ & $\ldots$ & $\ldots$ & $\ldots$ \\
\hline Montenegro & $\ldots$ & $\ldots$ & $\ldots$ & $\ldots$ & $\ldots$ & $\ldots$ & $\ldots$ & $\ldots$ & $\ldots$ & $\ldots$ & $\ldots$ \\
\hline Netherlands & $\ldots$ & $\ldots$ & 0.0 & 10.3 & 31.7 & 5.4 & $\ldots$ & 84.8 & 84.0 & 38.5 & $\ldots$ \\
\hline North Macedonia & $\ldots$ & $\ldots$ & $\ldots$ & $\ldots$ & $\ldots$ & $\ldots$ & $\ldots$ & $\ldots$ & $\ldots$ & $\ldots$ & $\ldots$ \\
\hline Norway & & $\ldots$ & $\ldots$ & $\ldots$ & $\ldots$ & $\ldots$ & $\ldots$ & $\ldots$ & $\ldots$ & $\ldots$ & $\ldots$ \\
\hline Poland & 1.5 & $\ldots$ & 0.0 & 0.2 & 100.0 & 3.6 & 85.0 & $\ldots$ & 96.3 & $\ldots$ & 0.0 \\
\hline Portugal & 2.3 & $\ldots$ & $\ldots$ & $\ldots$ & $\ldots$ & 20.8 & 79.6 & $\ldots$ & 75.0 & $\ldots$ & 3.8 \\
\hline Romania & $\ldots$ & $\ldots$ & $\ldots$ & $\ldots$ & $\ldots$ & $\ldots$ & $\ldots$ & $\ldots$ & $\ldots$ & $\ldots$ & $\ldots$ \\
\hline Russian Federation & & $\ldots$ & $\ldots$ & $\ldots$ & $\ldots$ & $\ldots$ & $\ldots$ & $\ldots$ & & $\ldots$ & $\ldots$ \\
\hline Serbia & 1.7 & 0.0 & 0.0 & 0.0 & $\ldots$ & 1.6 & 100.0 & $\ldots$ & 95.9 & $\ldots$ & 2.4 \\
\hline Slovak Republic & $\ldots$ & $\ldots$ & $\ldots$ & $\ldots$ & $\ldots$ & $\ldots$ & $\ldots$ & $\ldots$ & $\ldots$ & $\ldots$ & ... \\
\hline Slovenia & $\ldots$ & $\ldots$ & $\ldots$ & $\ldots$ & $\ldots$ & $\ldots$ & $\ldots$ & $\ldots$ & $\ldots$ & $\ldots$ & $\ldots$ \\
\hline Spain & $\ldots$ & $\ldots$ & $\ldots$ & $\ldots$ & $\ldots$ & $\ldots$ & $\ldots$ & $\ldots$ & $\ldots$ & $\ldots$ & $\ldots$ \\
\hline Sweden & 1.6 & 0.0 & 0.0 & 0.0 & $\ldots$ & 0.0 & $\ldots$ & $\ldots$ & 80.8 & 0.0 & 19.2 \\
\hline Switzerland & 0.5 & $\ldots$ & 0.0 & 26.3 & 0.0 & 5.3 & $\ldots$ & $\ldots$ & 68.4 & 26.9 & 0.0 \\
\hline Turkey & 19.8 & $\ldots$ & 0.2 & 36.6 & $\ldots$ & 0.3 & $\ldots$ & $\ldots$ & 51.0 & $\ldots$ & 11.9 \\
\hline Ukraine & 1.9 & $\ldots$ & $\ldots$ & $\ldots$ & $\ldots$ & $\ldots$ & $\ldots$ & $\ldots$ & 89.6 & $\ldots$ & $\ldots$ \\
\hline UK: England \& Wales & 2.4 & $\ldots$ & 1.1 & 10.3 & $\ldots$ & 16.3 & $\ldots$ & $\ldots$ & 67.4 & $\ldots$ & 6.0 \\
\hline UK: Northern Ireland & $\ldots$ & $\ldots$ & $\ldots$ & $\ldots$ & $\ldots$ & $\ldots$ & $\ldots$ & $\ldots$ & $\ldots$ & $\ldots$ & $\ldots$ \\
\hline UK: Scotland & & $\ldots$ & $\ldots$ & $\ldots$ & $\ldots$ & $\ldots$ & $\ldots$ & $\ldots$ & $\ldots$ & $\ldots$ & $\ldots$ \\
\hline Mean & 2.7 & 0.0 & 0.1 & 5.5 & 55.3 & 6.1 & 48.7 & 29.5 & 86.6 & 11.7 & 4.1 \\
\hline Median & 1.8 & 0.0 & 0.0 & 0.2 & 65.9 & 3.7 & 55.6 & 16.7 & 91.6 & 4.3 & 1.2 \\
\hline Minimum & 0.5 & 0.0 & 0.0 & 0.0 & 0.0 & 0.0 & 0.0 & 0.0 & 51.0 & 0.0 & 0.0 \\
\hline Maximum & 19.8 & 0.3 & 1.1 & 36.6 & 100.0 & 31.4 & 100.0 & 84.8 & 100.0 & 38.5 & 19.2 \\
\hline
\end{tabular}


Table 3.2.3.4 Total persons receiving sanctions/measures in 2015 - Intentional homicide: Completed

\begin{tabular}{|c|c|c|c|c|c|c|c|c|c|c|c|}
\hline & \multirow{2}{*}{ 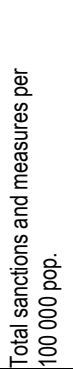 } & \multirow{2}{*}{ 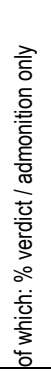 } & \multirow[b]{2}{*}{ 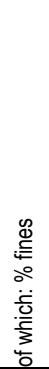 } & \multicolumn{2}{|c|}{$\begin{array}{l}\text { of which: \% } \\
\text { non-custodial } \\
\text { sanctions and } \\
\text { measures } \\
\end{array}$} & \multicolumn{3}{|c|}{$\begin{array}{l}\text { of which: } \% \text { suspended } \\
\text { custodial sanctions and } \\
\text { measures }\end{array}$} & \multicolumn{2}{|c|}{$\begin{array}{l}\text { of which: \% un- } \\
\text { suspended custo- } \\
\text { dial sanctions and } \\
\text { measures }\end{array}$} & \multirow[b]{2}{*}{ 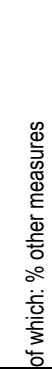 } \\
\hline & & & & 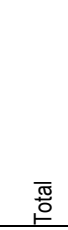 & 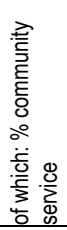 & 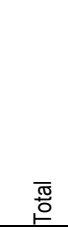 & 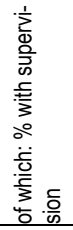 & 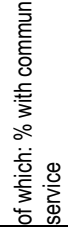 & $\begin{array}{l}\overline{\underline{0}} \\
\text { 吾 }\end{array}$ & 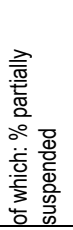 & \\
\hline Albania & $\ldots$ & $\ldots$ & $\ldots$ & $\ldots$ & $\ldots$ & $\ldots$ & $\ldots$ & $\ldots$ & $\ldots$ & $\ldots$ & $\ldots$ \\
\hline Armenia & $\ldots$ & $\ldots$ & $\ldots$ & $\ldots$ & $\cdots$ & $\ldots$ & $\ldots$ & $\ldots$ & $\ldots$ & $\ldots$ & $\ldots$ \\
\hline Austria & 0.2 & $\ldots$ & $\ldots$ & 0.0 & $\ldots$ & 0.0 & $\ldots$ & $\ldots$ & 100.0 & 5.0 & 0.0 \\
\hline Azerbaijan & $\ldots$ & $\ldots$ & $\ldots$ & $\ldots$ & $\ldots$ & $\ldots$ & $\ldots$ & $\ldots$ & $\ldots$ & $\ldots$ & $\ldots$ \\
\hline Belgium & $\ldots$ & $\ldots$ & $\ldots$ & $\ldots$ & $\ldots$ & $\ldots$ & $\ldots$ & $\ldots$ & $\ldots$ & $\ldots$ & $\ldots$ \\
\hline Bosnia-Herzegovina & $\ldots$ & $\ldots$ & $\ldots$ & $\ldots$ & $\ldots$ & $\ldots$ & $\ldots$ & $\ldots$ & $\ldots$ & $\ldots$ & $\ldots$ \\
\hline Bulgaria & 1.4 & 0.0 & 0.0 & 0.0 & $\ldots$ & 4.1 & $\ldots$ & $\ldots$ & 95.9 & $\ldots$ & 0.0 \\
\hline Croatia & 0.8 & 0.0 & 0.0 & 0.0 & $\ldots$ & 3.1 & 0.0 & 0.0 & 96.9 & 3.2 & $\ldots$ \\
\hline Cyprus & $\ldots$ & $\ldots$ & $\ldots$ & $\ldots$ & $\ldots$ & $\ldots$ & $\ldots$ & $\ldots$ & $\ldots$ & $\ldots$ & $\ldots$ \\
\hline Czech Republic & $\ldots$ & $\ldots$ & $\ldots$ & $\ldots$ & $\ldots$ & $\ldots$ & $\ldots$ & $\ldots$ & $\ldots$ & $\ldots$ & $\ldots$ \\
\hline Denmark & $\ldots$ & $\ldots$ & $\ldots$ & $\ldots$ & $\ldots$ & $\ldots$ & $\ldots$ & $\ldots$ & $\ldots$ & $\ldots$ & $\ldots$ \\
\hline Estonia & $\ldots$ & $\ldots$ & $\ldots$ & $\ldots$ & $\ldots$ & $\ldots$ & $\ldots$ & $\ldots$ & $\ldots$ & $\ldots$ & $\ldots$ \\
\hline Finland & 1.0 & 0.0 & 0.0 & 0.0 & $\ldots$ & 0.0 & $\ldots$ & $\ldots$ & 85.5 & $\ldots$ & 14.5 \\
\hline France & 0.2 & 0.0 & 0.0 & 0.0 & $\ldots$ & 0.0 & $\ldots$ & $\ldots$ & 100.0 & 4.6 & $\ldots$ \\
\hline Georgia & $\ldots$ & $\ldots$ & $\ldots$ & $\ldots$ & $\ldots$ & $\ldots$ & $\ldots$ & $\ldots$ & $\ldots$ & $\ldots$ & $\ldots$ \\
\hline Germany & $\ldots$ & $\ldots$ & $\ldots$ & $\ldots$ & $\ldots$ & $\ldots$ & $\ldots$ & $\ldots$ & $\ldots$ & $\ldots$ & $\ldots$ \\
\hline Hungary & 1.0 & 0.0 & 0.0 & 7.0 & 0.0 & 1.0 & 0.0 & 0.0 & 92.0 & 0.0 & 0.0 \\
\hline Iceland & $\ldots$ & $\ldots$ & $\ldots$ & $\ldots$ & $\ldots$ & $\ldots$ & $\ldots$ & $\ldots$ & $\ldots$ & $\ldots$ & $\ldots$ \\
\hline Italy & $\ldots$ & $\ldots$ & $\ldots$ & $\ldots$ & $\ldots$ & $\ldots$ & $\ldots$ & $\ldots$ & $\ldots$ & $\ldots$ & $\ldots$ \\
\hline Kosovo & $\ldots$ & & & & & & & & & & \\
\hline $\mathrm{R} / 1244 / 99)$ & & $\ldots$ & $\ldots$ & $\ldots$ & $\ldots$ & $\ldots$ & $\ldots$ & $\ldots$ & $\ldots$ & $\ldots$ & $\ldots$ \\
\hline Latvia & $\ldots$ & $\ldots$ & $\ldots$ & $\ldots$ & $\ldots$ & $\ldots$ & $\ldots$ & ... & $\ldots$ & $\ldots$ & $\ldots$ \\
\hline Lithuania & $\ldots$ & $\ldots$ & $\ldots$ & $\ldots$ & $\ldots$ & $\ldots$ & $\ldots$ & $\ldots$ & $\ldots$ & $\ldots$ & $\ldots$ \\
\hline Luxembourg & $\ldots$ & $\ldots$ & $\ldots$ & $\ldots$ & ... & $\ldots$ & $\ldots$ & $\ldots$ & $\ldots$ & $\ldots$ & $\ldots$ \\
\hline Moldova & $\ldots$ & $\ldots$ & $\ldots$ & $\ldots$ & $\ldots$ & $\ldots$ & $\ldots$ & ... & $\ldots$ & $\ldots$ & $\ldots$ \\
\hline Montenegro & $\ldots$ & $\ldots$ & $\ldots$ & $\ldots$ & $\ldots$ & $\ldots$ & $\ldots$ & $\ldots$ & $\ldots$ & $\ldots$ & $\ldots$ \\
\hline Netherlands & $\ldots$ & $\ldots$ & $\ldots$ & $\ldots$ & $\ldots$ & $\ldots$ & $\ldots$ & ... & $\ldots$ & $\ldots$ & $\ldots$ \\
\hline North Macedonia & $\ldots$ & $\ldots$ & $\ldots$ & $\ldots$ & $\ldots$ & $\ldots$ & $\ldots$ & ... & $\ldots$ & $\ldots$ & ... \\
\hline Norway & $\ldots$ & $\ldots$ & $\ldots$ & $\ldots$ & $\ldots$ & $\ldots$ & $\ldots$ & $\ldots$ & $\ldots$ & $\ldots$ & $\ldots$ \\
\hline Poland & $\ldots$ & $\ldots$ & $\ldots$ & $\ldots$ & $\ldots$ & $\ldots$ & $\ldots$ & $\ldots$ & $\ldots$ & $\ldots$ & $\ldots$ \\
\hline Portugal & 1.1 & $\ldots$ & $\ldots$ & $\ldots$ & $\ldots$ & 11.9 & 53.8 & ... & 84.4 & $\ldots$ & 3.7 \\
\hline Romania & $\ldots$ & $\ldots$ & $\ldots$ & $\ldots$ & $\ldots$ & $\ldots$ & $\ldots$ & $\ldots$ & $\ldots$ & $\ldots$ & $\ldots$ \\
\hline Russian Federation & $\ldots$ & $\ldots$ & $\ldots$ & $\ldots$ & $\ldots$ & $\ldots$ & $\ldots$ & $\ldots$ & $\ldots$ & $\ldots$ & $\ldots$ \\
\hline Serbia & 1.2 & $\ldots$ & $\ldots$ & $\ldots$ & $\ldots$ & $\ldots$ & $\ldots$ & $\ldots$ & $\ldots$ & $\ldots$ & $\ldots$ \\
\hline Slovak Republic & $\ldots$ & $\ldots$ & $\ldots$ & $\ldots$ & $\ldots$ & $\ldots$ & $\ldots$ & $\ldots$ & $\ldots$ & $\ldots$ & $\ldots$ \\
\hline Slovenia & $\ldots$ & $\ldots$ & $\ldots$ & $\ldots$ & $\ldots$ & $\ldots$ & $\ldots$ & $\ldots$ & $\ldots$ & $\ldots$ & $\ldots$ \\
\hline Spain & $\ldots$ & $\ldots$ & $\ldots$ & $\ldots$ & $\ldots$ & $\ldots$ & $\ldots$ & $\ldots$ & $\ldots$ & $\ldots$ & $\ldots$ \\
\hline Sweden & $\ldots$ & $\ldots$ & $\ldots$ & $\ldots$ & $\ldots$ & $\ldots$ & $\ldots$ & $\ldots$ & $\ldots$ & $\ldots$ & $\ldots$ \\
\hline Switzerland & 0.2 & $\ldots$ & 0.0 & 40.0 & 0.0 & 0.0 & $\ldots$ & $\ldots$ & 60.0 & 0.0 & 0.0 \\
\hline Turkey & $\ldots$ & $\ldots$ & $\ldots$ & $\ldots$ & $\ldots$ & $\ldots$ & $\ldots$ & $\ldots$ & $\ldots$ & $\ldots$ & $\ldots$ \\
\hline Ukraine & $\ldots$ & $\ldots$ & $\ldots$ & $\ldots$ & $\ldots$ & $\ldots$ & $\ldots$ & $\ldots$ & $\ldots$ & $\ldots$ & $\ldots$ \\
\hline UK: England \& Wales & 0.5 & $\ldots$ & 0.0 & 0.0 & $\ldots$ & 0.0 & $\ldots$ & $\ldots$ & 100.0 & $\ldots$ & 0.0 \\
\hline UK: Northern Ireland & $\ldots$ & $\ldots$ & $\ldots$ & $\ldots$ & $\ldots$ & $\ldots$ & $\ldots$ & $\ldots$ & $\ldots$ & $\ldots$ & $\ldots$ \\
\hline UK: Scotland & 1.6 & 1.2 & 4.8 & 16.7 & 0.0 & 0.0 & $\ldots$ & $\ldots$ & 77.4 & $\ldots$ & $\ldots$ \\
\hline Mean & 0.8 & 0.2 & 0.6 & 7.1 & 0.0 & 2.0 & 17.9 & 0.0 & 89.2 & 2.6 & 2.6 \\
\hline Median & 1.0 & 0.0 & 0.0 & 0.0 & 0.0 & 0.0 & 0.0 & 0.0 & 94.0 & 3.2 & 0.0 \\
\hline Minimum & 0.2 & 0.0 & 0.0 & 0.0 & 0.0 & 0.0 & 0.0 & 0.0 & 60.0 & 0.0 & 0.0 \\
\hline Maximum & 1.6 & 1.2 & 4.8 & 40.0 & 0.0 & 11.9 & 53.8 & 0.0 & 100.0 & 5.0 & 14.5 \\
\hline
\end{tabular}


Table 3.2.3.5 Total persons receiving sanctions/measures in 2015 - Bodily injury

\begin{tabular}{|c|c|c|c|c|c|c|c|c|c|c|c|}
\hline & \multirow{2}{*}{ 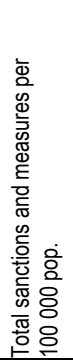 } & \multirow{2}{*}{ 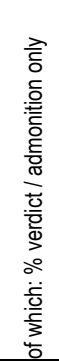 } & \multirow[b]{2}{*}{ 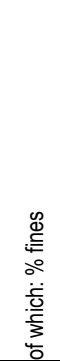 } & \multicolumn{2}{|c|}{$\begin{array}{l}\text { of which: } \% \\
\text { non-custodial } \\
\text { sanctions and } \\
\text { measures }\end{array}$} & \multicolumn{3}{|c|}{$\begin{array}{l}\text { of which: \% suspended } \\
\text { custodial sanctions and } \\
\text { measures }\end{array}$} & \multicolumn{2}{|c|}{$\begin{array}{l}\text { of which: } \% \text { un- } \\
\text { suspended custo- } \\
\text { dial sanctions and } \\
\text { measures }\end{array}$} & \multirow[b]{2}{*}{ 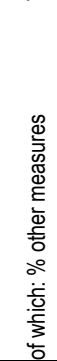 } \\
\hline & & & & 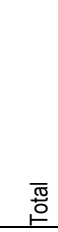 & 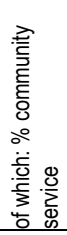 & 氶 & 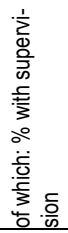 & 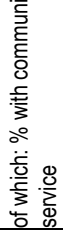 & 䄏 & 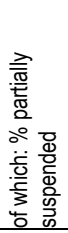 & \\
\hline Albania & $\ldots$ & $\ldots$ & $\ldots$ & $\ldots$ & $\ldots$ & $\ldots$ & $\ldots$ & $\ldots$ & $\ldots$ & $\ldots$ & $\ldots$ \\
\hline Armenia & $\ldots$ & $\ldots$ & $\ldots$ & $\ldots$ & $\ldots$ & $\ldots$ & $\ldots$ & $\begin{array}{l}\cdots \\
\ldots\end{array}$ & $\cdots$ & $\begin{array}{l}\cdots \\
\ldots\end{array}$ & $\cdots$ \\
\hline Austria & 49.9 & $\ldots$ & 45.0 & $\ldots$ & $\ldots$ & 33.8 & $\ldots$ & $\ldots$ & 17.2 & 22.4 & 4.0 \\
\hline Azerbaijan & $\ldots$ & $\ldots$ & $\ldots$ & $\ldots$ & $\ldots$ & $\ldots$ & $\ldots$ & $\ldots$ & $\ldots$ & $\ldots$ & $\ldots$ \\
\hline Belgium & $\ldots$ & $\ldots$ & $\ldots$ & $\ldots$ & $\ldots$ & $\ldots$ & $\ldots$ & $\ldots$ & $\ldots$ & $\ldots$ & $\ldots$ \\
\hline Bosnia-Herzegovina & & $\ldots$ & $\ldots$ & $\ldots$ & $\ldots$ & $\ldots$ & $\ldots$ & $\ldots$ & $\ldots$ & $\ldots$ & $\ldots$ \\
\hline Bulgaria & 9.7 & $\ldots$ & 0.7 & 41.1 & $\ldots$ & 43.8 & $\ldots$ & $\ldots$ & 13.4 & $\ldots$ & 1.0 \\
\hline Croatia & 16.4 & 3.5 & 1.4 & 2.4 & $\ldots$ & 76.3 & 1.5 & 9.2 & 16.4 & 13.2 & $\ldots$ \\
\hline Cyprus & $\ldots$ & $\ldots$ & $\ldots$ & $\ldots$ & $\ldots$ & $\ldots$ & $\ldots$ & $\ldots$ & $\ldots$ & $\ldots$ & $\ldots$ \\
\hline Czech Republic & 27.0 & 1.6 & 1.5 & 9.3 & 95.5 & 75.7 & 9.7 & $\ldots$ & 11.8 & $\ldots$ & 0.0 \\
\hline Denmark & $\ldots$ & $\ldots$ & $\ldots$ & $\ldots$ & $\ldots$ & $\ldots$ & $\ldots$ & $\ldots$ & $\ldots$ & $\ldots$ & $\ldots$ \\
\hline Estonia & $\ldots$ & $\ldots$ & $\ldots$ & $\ldots$ & $\ldots$ & $\ldots$ & $\ldots$ & $\ldots$ & $\ldots$ & $\ldots$ & $\ldots$ \\
\hline Finland & 153.3 & 0.0 & 65.0 & 3.4 & 92.4 & 21.0 & 8.9 & 3.0 & 8.8 & $\ldots$ & 1.8 \\
\hline France & 87.2 & 1.2 & 6.4 & 13.0 & 22.3 & 47.8 & 0.8 & $\ldots$ & 31.6 & 21.1 & $\ldots$ \\
\hline Georgia & 45.3 & $\ldots$ & 29.0 & $\ldots$ & $\ldots$ & 52.7 & $\ldots$ & $\ldots$ & 4.7 & $\ldots$ & $\ldots$ \\
\hline Germany & 75.9 & 2.1 & 51.6 & 16.5 & $\ldots$ & 22.5 & $\ldots$ & $\ldots$ & 7.2 & $\ldots$ & $\ldots$ \\
\hline Hungary & 82.9 & 1.7 & 13.5 & 34.6 & 44.4 & 34.8 & 20.5 & 0.0 & 15.4 & 0.0 & 0.0 \\
\hline Iceland & $\ldots$ & $\ldots$ & $\ldots$ & $\ldots$ & $\ldots$ & $\ldots$ & $\ldots$ & $\ldots$ & $\ldots$ & $\ldots$ & $\ldots$ \\
\hline Italy & $\ldots$ & $\ldots$ & $\ldots$ & $\ldots$ & $\ldots$ & $\ldots$ & $\ldots$ & $\ldots$ & $\ldots$ & $\ldots$ & $\ldots$ \\
\hline Kosovo (UN & $\ldots$ & & & & & & & & & & \\
\hline R/1244/99) & & $\ldots$ & $\ldots$ & $\ldots$ & $\ldots$ & $\ldots$ & $\ldots$ & $\ldots$ & $\ldots$ & $\ldots$ & $\ldots$ \\
\hline Latvia & $\ldots$ & $\ldots$ & $\ldots$ & $\ldots$ & $\ldots$ & $\ldots$ & $\ldots$ & $\ldots$ & $\ldots$ & $\ldots$ & $\ldots$ \\
\hline Lithuania & 172.0 & $\ldots$ & $\ldots$ & $\ldots$ & $\ldots$ & $\ldots$ & $\ldots$ & $\ldots$ & $\ldots$ & $\ldots$ & 1.7 \\
\hline Luxembourg & $\ldots$ & $\ldots$ & $\ldots$ & $\ldots$ & $\ldots$ & $\ldots$ & $\ldots$ & $\ldots$ & $\ldots$ & $\ldots$ & $\ldots$ \\
\hline Moldova & $\ldots$ & $\ldots$ & $\ldots$ & $\ldots$ & $\ldots$ & $\ldots$ & $\ldots$ & $\ldots$ & $\ldots$ & $\ldots$ & $\ldots$ \\
\hline Montenegro & $\ldots$ & $\ldots$ & $\ldots$ & $\ldots$ & $\ldots$ & $\ldots$ & $\ldots$ & $\ldots$ & $\ldots$ & $\ldots$ & $\ldots$ \\
\hline Netherlands & 64.8 & $\ldots$ & 20.9 & 46.6 & 96.9 & 16.1 & $\ldots$ & 60.3 & 16.4 & 53.5 & ... \\
\hline North Macedonia & $\ldots$ & $\ldots$ & $\ldots$ & $\ldots$ & $\ldots$ & $\ldots$ & $\ldots$ & $\ldots$ & $\ldots$ & $\ldots$ & $\ldots$ \\
\hline Norway & $\ldots$ & $\ldots$ & $\ldots$ & $\ldots$ & $\ldots$ & $\ldots$ & $\ldots$ & $\ldots$ & $\ldots$ & $\ldots$ & $\ldots$ \\
\hline Poland & 67.2 & $\ldots$ & 10.8 & 11.5 & 100.0 & 65.4 & 60.1 & $\ldots$ & 12.3 & $\ldots$ & 0.2 \\
\hline Portugal & 62.4 & 0.3 & 52.3 & 2.4 & 100.0 & 36.5 & 50.3 & $\ldots$ & 5.1 & $\ldots$ & 3.4 \\
\hline Romania & $\ldots$ & $\ldots$ & $\ldots$ & $\ldots$ & $\ldots$ & $\ldots$ & $\ldots$ & $\ldots$ & $\ldots$ & $\ldots$ & $\ldots$ \\
\hline Russian Federation & $\ldots$ & $\ldots$ & $\ldots$ & $\ldots$ & $\ldots$ & $\ldots$ & $\ldots$ & $\ldots$ & $\ldots$ & $\ldots$ & $\ldots$ \\
\hline Serbia & 23.6 & 1.3 & 7.6 & 1.0 & 100.0 & 69.9 & 4.1 & $\ldots$ & 19.4 & $\ldots$ & 0.7 \\
\hline Slovak Republic & $\ldots$ & $\ldots$ & $\ldots$ & $\ldots$ & $\ldots$ & $\ldots$ & $\ldots$ & $\ldots$ & $\ldots$ & $\ldots$ & ... \\
\hline Slovenia & $\ldots$ & $\ldots$ & $\ldots$ & $\ldots$ & ... & $\ldots$ & $\ldots$ & $\ldots$ & $\ldots$ & $\ldots$ & $\ldots$ \\
\hline Spain & $\ldots$ & $\ldots$ & $\ldots$ & $\ldots$ & $\ldots$ & $\ldots$ & $\ldots$ & $\ldots$ & $\ldots$ & $\ldots$ & $\ldots$ \\
\hline Sweden & 64.6 & 0.1 & 15.1 & 13.3 & 31.3 & 34.2 & $\ldots$ & 66.1 & 19.2 & 2.8 & 18.1 \\
\hline Switzerland & 11.9 & $\ldots$ & 83.6 & 3.6 & 82.9 & 5.9 & $\ldots$ & $\ldots$ & 6.9 & 13.2 & 0.0 \\
\hline Turkey & 262.9 & $\ldots$ & 41.5 & 16.8 & $\ldots$ & 6.3 & $\ldots$ & $\ldots$ & 23.3 & $\ldots$ & 12.1 \\
\hline Ukraine & 17.3 & $\ldots$ & $\ldots$ & $\ldots$ & $\ldots$ & $\ldots$ & $\ldots$ & $\ldots$ & $\ldots$ & $\ldots$ & $\ldots$ \\
\hline UK: England \& Wales & 23.3 & $\ldots$ & 1.2 & 43.3 & $\ldots$ & 56.3 & $\ldots$ & $\ldots$ & 88.0 & $\ldots$ & 14.9 \\
\hline UK: Northern Ireland & & & & & & $\ldots$ & $\ldots$ & $\ldots$ & $\ldots$ & $\ldots$ & $\ldots$ \\
\hline UK: Scotland & 257.7 & 20.5 & 27.1 & 27.9 & 98.5 & $\ldots$ & $\ldots$ & $\ldots$ & 23.9 & $\ldots$ & $\ldots$ \\
\hline Mean & 78.8 & 3.2 & 26.3 & 17.9 & 78.6 & 41.1 & 19.5 & 27.7 & 18.9 & 18.0 & 4.4 \\
\hline Median & 63.5 & 1.4 & 18.0 & 13.2 & 95.5 & 36.5 & 9.3 & 9.2 & 15.9 & 13.2 & 1.7 \\
\hline Minimum & 9.7 & 0.0 & 0.7 & 1.0 & 22.3 & 5.9 & 0.8 & 0.0 & 4.7 & 0.0 & 0.0 \\
\hline Maximum & 262.9 & 20.5 & 83.6 & 46.6 & 100.0 & 76.3 & 60.1 & 66.1 & 88.0 & 53.5 & 18.1 \\
\hline
\end{tabular}


Table 3.2.3.6 Total persons receiving sanctions/measures in 2015 - Aggravated bodily injury

\begin{tabular}{|c|c|c|c|c|c|c|c|c|c|c|c|}
\hline & \multirow{2}{*}{ 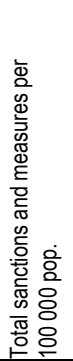 } & \multirow{2}{*}{ 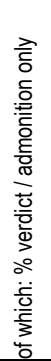 } & \multirow[b]{2}{*}{ 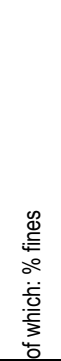 } & \multicolumn{2}{|c|}{$\begin{array}{l}\text { of which: \% } \\
\text { non-custodial } \\
\text { sanctions and } \\
\text { measures }\end{array}$} & \multicolumn{3}{|c|}{$\begin{array}{l}\text { of which: \% suspended } \\
\text { custodial sanctions and } \\
\text { measures }\end{array}$} & \multicolumn{2}{|c|}{$\begin{array}{l}\text { of which: \% un- } \\
\text { suspended custo- } \\
\text { dial sanctions and } \\
\text { measures }\end{array}$} & \multirow[b]{2}{*}{ 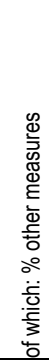 } \\
\hline & & & & 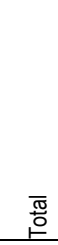 & 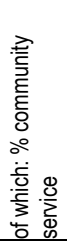 & $\begin{array}{l}\text { 要 } \\
\text { 上 }\end{array}$ & 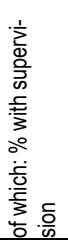 & 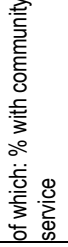 & 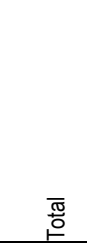 & 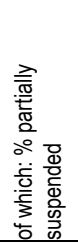 & \\
\hline Albania & & $\ldots$ & $\ldots$ & & $\ldots$ & $\ldots$ & $\ldots$ & $\ldots$ & $\ldots$ & $\ldots$ & $\ldots$ \\
\hline Armenia & 3.0 & $\ldots$ & 3.3 & 0.0 & $\ldots$ & 18.9 & $\ldots$ & $\ldots$ & 75.6 & $\ldots$ & $\ldots$ \\
\hline Austria & 11.7 & $\ldots$ & 12.2 & $\ldots$ & $\ldots$ & 45.9 & $\ldots$ & $\ldots$ & 32.9 & 45.5 & 9.1 \\
\hline Azerbaijan & $\ldots$ & $\ldots$ & $\ldots$ & $\ldots$ & $\ldots$ & $\ldots$ & $\ldots$ & $\ldots$ & $\ldots$ & $\ldots$ & $\ldots$ \\
\hline Belgium & $\ldots$ & $\ldots$ & $\ldots$ & $\ldots$ & $\ldots$ & $\ldots$ & $\ldots$ & $\ldots$ & $\ldots$ & $\ldots$ & $\ldots$ \\
\hline Bosnia-Herzegovina & $\ldots$ & $\ldots$ & $\ldots$ & $\ldots$ & $\ldots$ & $\ldots$ & $\ldots$ & $\ldots$ & $\ldots$ & $\ldots$ & $\ldots$ \\
\hline Bulgaria & $\ldots$ & $\ldots$ & $\ldots$ & $\ldots$ & $\ldots$ & $\ldots$ & $\ldots$ & $\ldots$ & $\ldots$ & $\ldots$ & \\
\hline Croatia & 8.8 & 3.2 & 0.0 & 2.4 & $\ldots$ & 71.0 & 1.5 & 13.2 & 23.3 & 16.1 & 0.0 \\
\hline Cyprus & $\ldots$ & $\ldots$ & $\ldots$ & $\ldots$ & $\ldots$ & $\ldots$ & $\ldots$ & $\ldots$ & $\ldots$ & $\ldots$ & $\ldots$ \\
\hline Czech Republic & 4.2 & 0.2 & 0.0 & 0.0 & $\ldots$ & 66.3 & 22.7 & $\ldots$ & 33.5 & $\ldots$ & $\ldots$ \\
\hline Denmark & $\ldots$ & $\ldots$ & $\ldots$ & $\ldots$ & $\ldots$ & $\ldots$ & $\ldots$ & $\ldots$ & $\ldots$ & $\ldots$ & $\ldots$ \\
\hline Estonia & $\ldots$ & $\ldots$ & $\ldots$ & $\ldots$ & $\ldots$ & $\ldots$ & $\ldots$ & $\ldots$ & $\ldots$ & $\ldots$ & $\ldots$ \\
\hline Finland & 9.9 & 0.0 & 0.2 & 0.7 & 100.0 & 47.9 & 12.0 & 17.8 & 49.9 & $\ldots$ & 1.3 \\
\hline France & 12.7 & 0.6 & 3.4 & 8.1 & 22.8 & 42.1 & 0.6 & $\ldots$ & 45.8 & 48.0 & $\ldots$ \\
\hline Georgia & 6.1 & $\ldots$ & 1.8 & $\ldots$ & $\ldots$ & 38.5 & $\ldots$ & $\ldots$ & 55.3 & $\ldots$ & $\ldots$ \\
\hline Germany & 23.9 & 2.0 & 18.7 & 22.3 & $\ldots$ & 45.4 & $\ldots$ & $\ldots$ & 11.6 & $\ldots$ & $\ldots$ \\
\hline Hungary & 45.3 & 0.4 & 11.2 & 24.6 & 54.0 & 43.4 & 17.1 & 0.0 & 20.4 & 0.0 & 0.0 \\
\hline Iceland & $\ldots$ & $\ldots$ & $\ldots$ & $\ldots$ & $\ldots$ & $\ldots$ & $\ldots$ & $\ldots$ & $\ldots$ & $\ldots$ & $\ldots$ \\
\hline Italy & $\ldots$ & $\ldots$ & $\ldots$ & $\ldots$ & $\ldots$ & $\ldots$ & $\ldots$ & $\ldots$ & $\ldots$ & $\ldots$ & $\ldots$ \\
\hline Kosovo (UN & $\ldots$ & & & & & & & & & & \\
\hline R/1244/99) & & $\ldots$ & $\ldots$ & $\ldots$ & $\ldots$ & $\ldots$ & $\ldots$ & $\ldots$ & $\ldots$ & $\ldots$ & $\ldots$ \\
\hline Latvia & $\ldots$ & $\ldots$ & $\ldots$ & $\ldots$ & $\ldots$ & $\ldots$ & $\ldots$ & $\ldots$ & $\ldots$ & $\ldots$ & $\ldots$ \\
\hline Lithuania & 6.3 & $\ldots$ & $\ldots$ & $\ldots$ & $\ldots$ & $\ldots$ & $\ldots$ & $\ldots$ & $\ldots$ & $\ldots$ & 1.1 \\
\hline Luxembourg & $\ldots$ & $\ldots$ & $\ldots$ & $\ldots$ & $\ldots$ & $\ldots$ & $\ldots$ & $\ldots$ & $\ldots$ & $\ldots$ & $\ldots$ \\
\hline Moldova & $\ldots$ & $\ldots$ & $\ldots$ & $\ldots$ & $\ldots$ & $\ldots$ & $\ldots$ & $\ldots$ & $\ldots$ & $\ldots$ & $\ldots$ \\
\hline Montenegro & 31.0 & $\ldots$ & $\ldots$ & $\ldots$ & $\ldots$ & $\ldots$ & $\ldots$ & $\ldots$ & $\ldots$ & $\ldots$ & $\ldots$ \\
\hline Netherlands & 7.3 & $\ldots$ & 0.6 & 34.1 & 93.3 & 23.0 & $\ldots$ & 81.6 & 42.3 & 63.3 & $\ldots$ \\
\hline North Macedonia & $\ldots$ & $\cdots$ & $\ldots$ & $\ldots$ & $\ldots$ & $\ldots$ & $\cdots$ & $\ldots$ & $\ldots$ & $\ldots$ & $\begin{array}{l}\cdots \\
\ldots\end{array}$ \\
\hline Norway & $\ldots$ & $\ldots$ & $\ldots$ & $\ldots$ & $\ldots$ & $\ldots$ & $\ldots$ & $\ldots$ & $\ldots$ & $\ldots$ & $\ldots$ \\
\hline Poland & 2.2 & $\ldots$ & 3.6 & 0.6 & 100.0 & 58.7 & 44.1 & $\cdots$ & 36.7 & $\ldots$ & 0.4 \\
\hline Portugal & 9.6 & $\ldots$ & 36.2 & 8.0 & 100.0 & 45.3 & 48.0 & $\ldots$ & 8.6 & $\ldots$ & 1.8 \\
\hline Romania & $\ldots$ & $\ldots$ & $\ldots$ & $\ldots$ & $\ldots$ & $\ldots$ & $\ldots$ & $\ldots$ & $\ldots$ & $\ldots$ & $\ldots$ \\
\hline Russian Federation & & 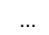 & $\ldots$ & & $\ldots$ & $\ldots$ & & $\ldots$ & $\ldots$ & $\ldots$ & \\
\hline Serbia & 9.8 & 0.3 & 1.0 & 0.3 & 100.0 & 71.1 & 8.3 & $\ldots$ & 26.6 & $\ldots$ & 0.7 \\
\hline Slovak Republic & $\ldots$ & $\ldots$ & $\ldots$ & $\ldots$ & $\ldots$ & $\ldots$ & $\ldots$ & $\ldots$ & $\ldots$ & $\ldots$ & $\ldots$ \\
\hline Slovenia & $\ldots$ & $\ldots$ & $\ldots$ & $\ldots$ & $\ldots$ & $\ldots$ & $\ldots$ & $\ldots$ & $\ldots$ & $\ldots$ & $\ldots$ \\
\hline Spain & $\ldots$ & $\ldots$ & $\ldots$ & $\ldots$ & $\ldots$ & $\ldots$ & $\ldots$ & $\ldots$ & $\ldots$ & $\ldots$ & $\ldots$ \\
\hline Sweden & 6.2 & 0.2 & 0.0 & 5.3 & 25.0 & 3.5 & $\ldots$ & 85.7 & 71.8 & 3.5 & 19.2 \\
\hline Switzerland & 2.5 & $\ldots$ & 65.8 & 3.5 & 57.1 & 18.3 & $\ldots$ & $\ldots$ & 12.4 & 36.0 & 0.0 \\
\hline Turkey & 2.2 & $\ldots$ & 10.1 & 26.9 & $\ldots$ & 11.5 & $\ldots$ & $\ldots$ & 38.0 & $\ldots$ & 13.4 \\
\hline Ukraine & 3.6 & $\ldots$ & 0.1 & $\ldots$ & $\ldots$ & $\ldots$ & $\ldots$ & $\ldots$ & 56.3 & $\ldots$ & $\ldots$ \\
\hline UK: England \& Wales & $\ldots$ & $\ldots$ & $\ldots$ & $\ldots$ & $\ldots$ & $\ldots$ & $\ldots$ & $\ldots$ & $\ldots$ & $\ldots$ & $\ldots$ \\
\hline UK: Northern Ireland & & & & & & $\ldots$ & $\ldots$ & $\ldots$ & $\ldots$ & $\ldots$ & $\ldots$ \\
\hline UK: Scotland & 32.8 & 3.5 & 4.8 & 27.4 & 97.3 & $\ldots$ & $\ldots$ & $\ldots$ & 54.4 & $\ldots$ & $\ldots$ \\
\hline Mean & 11.2 & 1.2 & 9.6 & 11.0 & 75.0 & 40.7 & 19.3 & 39.7 & 38.6 & 30.3 & 4.3 \\
\hline Median & 7.5 & 0.4 & 3.3 & 5.3 & 95.3 & 44.3 & 14.5 & 17.8 & 37.3 & 36.0 & 1.1 \\
\hline Minimum & 2.2 & 0.0 & 0.0 & 0.0 & 22.8 & 3.5 & 0.6 & 0.0 & 8.6 & 0.0 & 0.0 \\
\hline Maximum & 45.3 & 3.5 & 65.8 & 34.1 & 100.0 & 71.1 & 48.0 & 85.7 & 75.6 & 63.3 & 19.2 \\
\hline
\end{tabular}


Table 3.2.3.7 Total persons receiving sanctions/measures in 2015 - Sexual assault

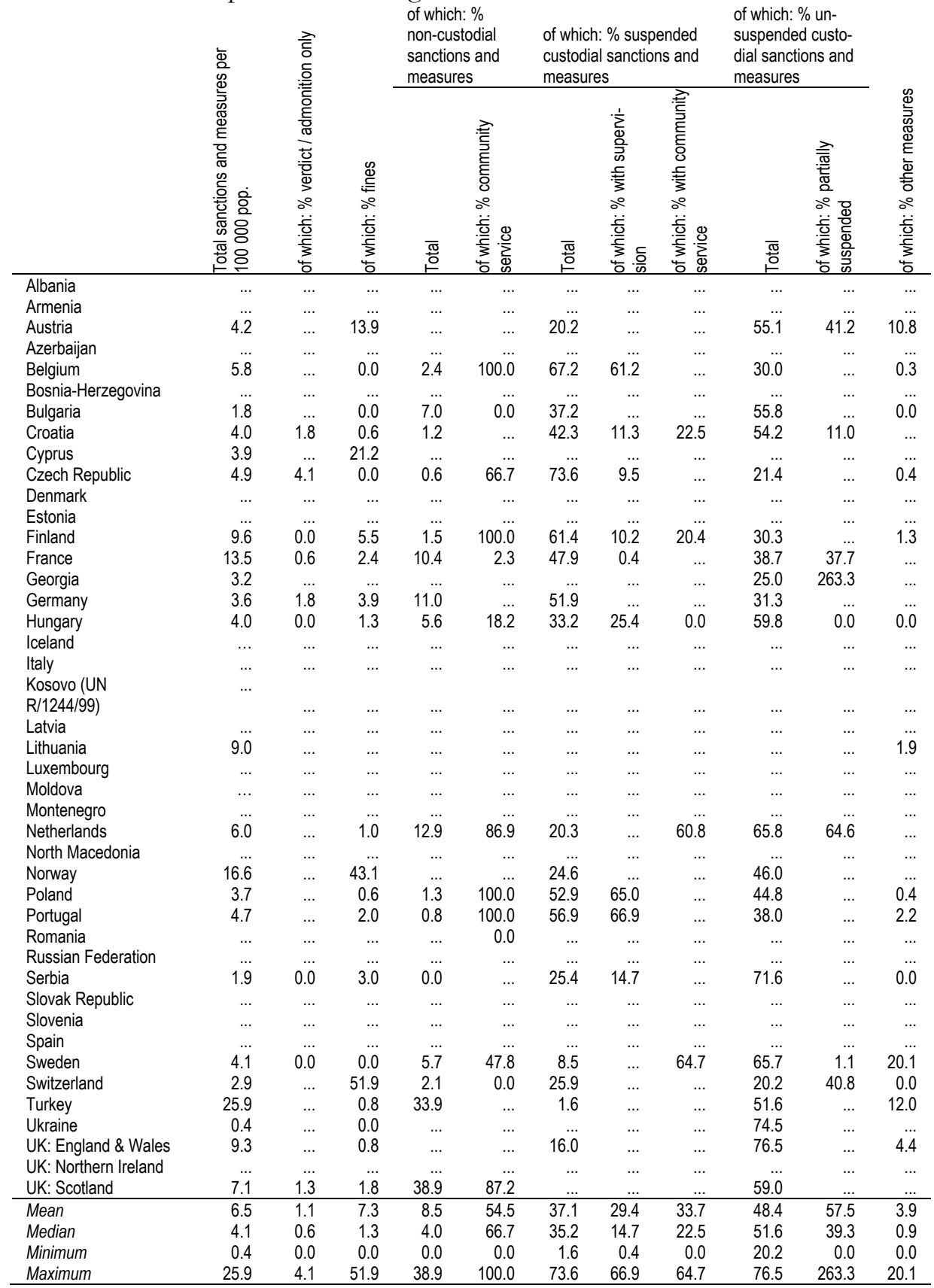


Table 3.2.3.8 Total persons receiving sanctions/measures in 2015 - Rape

\begin{tabular}{|c|c|c|c|c|c|c|c|c|c|c|c|}
\hline & \multirow[b]{2}{*}{ 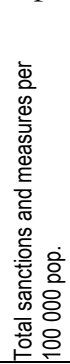 } & \multirow{2}{*}{ 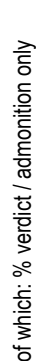 } & \multirow[b]{2}{*}{ 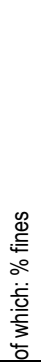 } & \multicolumn{2}{|c|}{$\begin{array}{l}\text { of which: \% } \\
\text { non-custodial } \\
\text { sanctions and } \\
\text { measures }\end{array}$} & \multicolumn{3}{|c|}{$\begin{array}{l}\text { of which: } \% \text { suspended } \\
\text { custodial sanctions and } \\
\text { measures }\end{array}$} & \multicolumn{2}{|c|}{$\begin{array}{l}\text { of which: } \% \text { un- } \\
\text { suspended custo- } \\
\text { dial sanctions and } \\
\text { measures }\end{array}$} & \multirow[b]{2}{*}{ 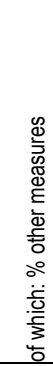 } \\
\hline & & & & 要 & 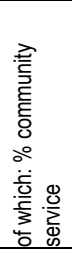 & 要 & 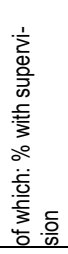 & 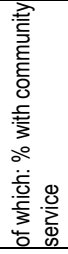 & $\begin{array}{l}\overline{\mathbb{5}} \\
\text { 음 }\end{array}$ & 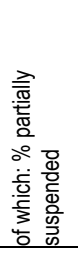 & \\
\hline Albania & & $\ldots$ & 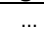 & & $\ldots$ & & $\ldots$ & $\ldots$ & & $\ldots$ & $\ldots$ \\
\hline Armenia & 0.2 & $\ldots$ & 0.0 & 0.0 & $\ldots$ & 0.0 & $\ldots$ & $\ldots$ & 100.0 & $\ldots$ & $\ldots$ \\
\hline Austria & 1.7 & $\ldots$ & 0.0 & $\ldots$ & $\ldots$ & 13.4 & $\ldots$ & $\ldots$ & 75.4 & 38.3 & 11.3 \\
\hline Azerbaijan & $\ldots$ & $\ldots$ & $\ldots$ & $\ldots$ & $\ldots$ & & $\ldots$ & $\ldots$ & $\ldots$ & $\ldots$ & $\ldots$ \\
\hline Belgium & 3.4 & $\ldots$ & 0.0 & 0.3 & 100.0 & 65.6 & 59.1 & $\ldots$ & 34.1 & $\ldots$ & 0.0 \\
\hline Bosnia-Herzegovina & $\ldots$ & $\ldots$ & $\ldots$ & $\ldots$ & $\ldots$ & & $\ldots$ & $\ldots$ & & $\ldots$ & \\
\hline Bulgaria & 1.0 & $\ldots$ & 0.0 & 4.2 & $\ldots$ & 18.1 & $\ldots$ & $\ldots$ & 77.8 & $\ldots$ & 0.0 \\
\hline Croatia & 2.3 & 2.0 & 0.0 & 2.0 & $\ldots$ & 26.5 & 26.9 & 30.8 & 69.4 & 0.0 & $\ldots$ \\
\hline Cyprus & & & $\ldots$ & & $\ldots$ & & & $\ldots$ & & $\ldots$ & \\
\hline Czech Republic & 1.6 & 1.8 & 0.0 & 0.6 & 0.0 & 52.4 & 13.8 & $\ldots$ & 44.0 & $\ldots$ & 1.2 \\
\hline Denmark & $\ldots$ & $\ldots$ & $\ldots$ & $\ldots$ & $\ldots$ & $\ldots$ & $\ldots$ & $\ldots$ & $\ldots$ & $\ldots$ & $\ldots$ \\
\hline Estonia & $\ldots$ & $\ldots$ & $\ldots$ & $\ldots$ & $\ldots$ & $\ldots$ & $\ldots$ & $\ldots$ & $\ldots$ & $\ldots$ & $\ldots$ \\
\hline Finland & 3.0 & 0.0 & 0.0 & 1.2 & 100.0 & 59.3 & 11.5 & 32.3 & 37.7 & $\ldots$ & 1.9 \\
\hline France & 1.5 & 0.0 & 0.0 & 3.6 & 0.0 & 14.7 & 0.0 & 0.0 & 81.6 & 14.7 & $\ldots$ \\
\hline Georgia & 0.3 & $\ldots$ & $\ldots$ & $\ldots$ & $\ldots$ & & $\ldots$ & $\ldots$ & $\ldots$ & $\ldots$ & $\ldots$ \\
\hline Germany & 0.7 & 1.0 & 0.3 & 2.8 & $\ldots$ & 37.7 & $\ldots$ & $\ldots$ & 58.1 & $\ldots$ & $\ldots$ \\
\hline Hungary & 1.8 & 0.0 & 0.0 & 3.4 & 0.0 & 13.7 & 41.7 & 0.0 & 82.9 & 0.0 & 0.0 \\
\hline Iceland & $\ldots$ & $\ldots$ & $\ldots$ & $\ldots$ & $\ldots$ & $\ldots$ & $\ldots$ & $\ldots$ & $\ldots$ & $\ldots$ & $\ldots$ \\
\hline Italy & $\cdots$ & $\cdots$ & $\cdots$ & $\cdots$ & $\cdots$ & $\ldots$ & $\ldots$ & $\ldots$ & $\ldots$ & $\ldots$ & $\cdots$ \\
\hline Kosovo (UN & $\ldots$ & & & & & & & & & & \\
\hline $\mathrm{R} / 1244 / 99)$ & & $\cdots$ & $\cdots$ & $\cdots$ & $\cdots$ & $\cdots$ & $\cdots$ & $\cdots$ & $\cdots$ & $\cdots$ & $\cdots$ \\
\hline Latvia & $\cdots$ & $\cdots$ & $\ldots$ & $\cdots$ & $\cdots$ & $\cdots$ & $\ldots$ & $\cdots$ & $\ldots$ & $\ldots$ & $\ldots$ \\
\hline Lithuania & 7.1 & $\cdots$ & $\ldots$ & $\ldots$ & $\cdots$ & $\ldots$ & $\ldots$ & $\ldots$ & $\ldots$ & $\ldots$ & 1.5 \\
\hline Luxembourg & $\ldots$ & $\ldots$ & $\ldots$ & $\ldots$ & $\ldots$ & $\cdots$ & $\ldots$ & $\ldots$ & $\ldots$ & $\ldots$ & $\ldots$ \\
\hline Moldova & $\ldots$ & $\ldots$ & $\ldots$ & $\ldots$ & $\ldots$ & $\ldots$ & $\ldots$ & $\ldots$ & $\ldots$ & $\ldots$ & $\ldots$ \\
\hline Montenegro & 0.5 & $\ldots$ & $\ldots$ & $\ldots$ & $\ldots$ & $\ldots$ & $\ldots$ & $\ldots$ & $\ldots$ & $\ldots$ & $\ldots$ \\
\hline Netherlands & 0.6 & $\ldots$ & 0.0 & 4.8 & 0.0 & 7.7 & $\ldots$ & 87.5 & 87.5 & 51.6 & $\ldots$ \\
\hline North Macedonia & $\ldots$ & $\ldots$ & $\ldots$ & $\ldots$ & $\ldots$ & $\ldots$ & $\ldots$ & $\ldots$ & $\ldots$ & $\ldots$ & $\ldots$ \\
\hline Norway & $\ldots$ & $\ldots$ & $\ldots$ & $\ldots$ & $\ldots$ & $\ldots$ & $\ldots$ & $\ldots$ & $\ldots$ & $\ldots$ & $\ldots$ \\
\hline Poland & 1.9 & $\ldots$ & 0.3 & 0.5 & 100.0 & 42.9 & 58.5 & $\ldots$ & 55.6 & $\ldots$ & 0.7 \\
\hline Portugal & 0.9 & $\ldots$ & $\ldots$ & $\ldots$ & $\ldots$ & 31.5 & 53.6 & $\ldots$ & 61.8 & $\ldots$ & 4.5 \\
\hline Romania & $\ldots$ & $\ldots$ & $\ldots$ & $\ldots$ & ... & $\ldots$ & $\ldots$ & $\ldots$ & $\ldots$ & $\ldots$ & $\ldots$ \\
\hline Russian Federation & & $\cdots$ & $\ldots$ & $\ldots$ & $\ldots$ & $\ldots$ & $\ldots$ & $\ldots$ & $\ldots$ & $\cdots$ & $\ldots$ \\
\hline Serbia & 0.7 & 0.0 & 0.0 & 0.0 & $\ldots$ & 6.0 & 0.0 & $\ldots$ & 94.0 & $\ldots$ & 0.0 \\
\hline Slovak Republic & $\ldots$ & $\ldots$ & $\ldots$ & $\ldots$ & $\ldots$ & $\ldots$ & $\ldots$ & $\ldots$ & $\ldots$ & $\ldots$ & $\ldots$ \\
\hline Slovenia & $\ldots$ & $\ldots$ & $\ldots$ & $\ldots$ & $\ldots$ & $\ldots$ & $\ldots$ & $\ldots$ & $\ldots$ & $\ldots$ & $\ldots$ \\
\hline Spain & $\ldots$ & $\ldots$ & $\ldots$ & $\ldots$ & $\ldots$ & $\ldots$ & $\ldots$ & $\ldots$ & $\ldots$ & $\ldots$ & $\ldots$ \\
\hline Sweden & 3.0 & 0.0 & 0.0 & 2.1 & 50.0 & 3.1 & $\ldots$ & 44.4 & 79.7 & 0.9 & 10.7 \\
\hline Switzerland & 1.4 & $\ldots$ & 0.0 & 0.0 & $\ldots$ & 5.2 & $\ldots$ & $\ldots$ & 0.9 & 0.0 & 0.0 \\
\hline Turkey & & $\ldots$ & $\ldots$ & $\ldots$ & $\ldots$ & $\ldots$ & $\ldots$ & $\ldots$ & $\ldots$ & $\ldots$ & $\ldots$ \\
\hline Ukraine & 0.2 & $\ldots$ & $\ldots$ & $\ldots$ & $\ldots$ & $\ldots$ & $\ldots$ & $\ldots$ & 79.8 & $\ldots$ & $\ldots$ \\
\hline UK: England \& Wales & 2.4 & $\ldots$ & 0.0 & 4.6 & $\ldots$ & 0.6 & $\ldots$ & $\ldots$ & 85.7 & $\ldots$ & 9.1 \\
\hline UK: Northern Ireland & $\ldots$ & $\ldots$ & $\ldots$ & $\ldots$ & $\ldots$ & $\ldots$ & $\ldots$ & $\ldots$ & $\ldots$ & $\ldots$ & $\ldots$ \\
\hline UK: Scotland & 1.9 & 0.0 & 0.0 & 8.7 & 88.9 & $\ldots$ & $\ldots$ & $\ldots$ & 91.3 & $\ldots$ & $\ldots$ \\
\hline Mean & 1.8 & 0.5 & 0.0 & 2.4 & 48.8 & 23.4 & 29.4 & 32.5 & 68.3 & 15.1 & 3.1 \\
\hline Median & 1.6 & 0.0 & 0.0 & 2.1 & 50.0 & 14.7 & 26.9 & 31.5 & 77.8 & 0.9 & 1.2 \\
\hline Minimum & 0.2 & 0.0 & 0.0 & 0.0 & 0.0 & 0.0 & 0.0 & 0.0 & 0.9 & 0.0 & 0.0 \\
\hline Maximum & 7.1 & 2.0 & 0.3 & 8.7 & 100.0 & 65.6 & 59.1 & 87.5 & 100.0 & 51.6 & 11.3 \\
\hline
\end{tabular}


Table 3.2.3.9 Total persons receiving sanctions/measures in 2015 - Sexual abuse of a child

\begin{tabular}{|c|c|c|c|c|c|c|c|c|c|c|c|}
\hline & \multirow{2}{*}{ 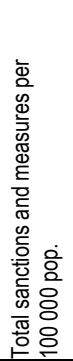 } & \multirow{2}{*}{ 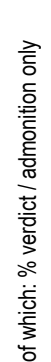 } & \multirow[b]{2}{*}{ 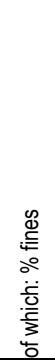 } & \multicolumn{2}{|c|}{$\begin{array}{l}\text { of which: } \% \\
\text { non-custodial } \\
\text { sanctions and } \\
\text { measures }\end{array}$} & \multicolumn{3}{|c|}{$\begin{array}{l}\text { of which: } \% \text { suspended } \\
\text { custodial sanctions and } \\
\text { measures }\end{array}$} & \multicolumn{2}{|c|}{$\begin{array}{l}\text { of which: \% un- } \\
\text { suspended custo- } \\
\text { dial sanctions and } \\
\text { measures }\end{array}$} & \multirow[b]{2}{*}{ 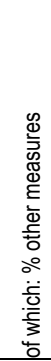 } \\
\hline & & & & 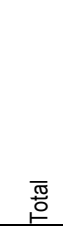 & 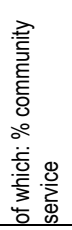 & 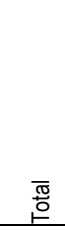 & 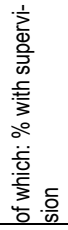 & 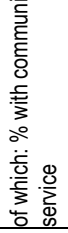 & 氶 & 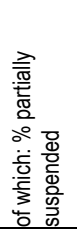 & \\
\hline Albania & $\ldots$ & $\ldots$ & $\ldots$ & $\ldots$ & $\ldots$ & $\ldots$ & $\ldots$ & $\ldots$ & $\ldots$ & $\ldots$ & $\ldots$ \\
\hline Armenia & $\ldots$ & $\ldots$ & $\ldots$ & $\ldots$ & $\ldots$ & $\ldots$ & $\ldots$ & $\ldots$ & $\ldots$ & $\ldots$ & $\ldots$ \\
\hline Austria & 1.5 & $\ldots$ & 0.0 & $\ldots$ & $\ldots$ & 24.0 & $\ldots$ & $\ldots$ & 63.6 & 45.1 & 12.4 \\
\hline Azerbaijan & & $\ldots$ & & & & & & $\ldots$ & & $\ldots$ & \\
\hline Belgium & 3.2 & $\ldots$ & 0.0 & 2.5 & 100.0 & 70.4 & 68.8 & $\ldots$ & 26.8 & $\ldots$ & 0.3 \\
\hline Bosnia-Herzegovina & $\ldots$ & $\ldots$ & $\ldots$ & $\ldots$ & $\ldots$ & $\ldots$ & $\ldots$ & $\ldots$ & $\ldots$ & $\ldots$ & $\ldots$ \\
\hline Bulgaria & $\ldots$ & 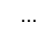 & $\ldots$ & $\ldots$ & $\ldots$ & $\ldots$ & $\ldots$ & $\ldots$ & $\ldots$ & & $\ldots$ \\
\hline Croatia & 0.4 & 5.6 & 0.0 & 0.0 & $\ldots$ & 50.0 & 0.0 & 0.0 & 44.4 & 37.5 & $\ldots$ \\
\hline Cyprus & $\ldots$ & $\ldots$ & $\ldots$ & $\ldots$ & $\ldots$ & $\ldots$ & $\ldots$ & $\ldots$ & $\ldots$ & $\ldots$ & $\ldots$ \\
\hline Czech Republic & 3.2 & 5.3 & 0.0 & 0.6 & 100.0 & 83.4 & 7.1 & $\ldots$ & 10.7 & $\ldots$ & 0.0 \\
\hline Denmark & $\ldots$ & $\ldots$ & $\ldots$ & $\ldots$ & $\ldots$ & $\ldots$ & $\ldots$ & $\ldots$ & $\ldots$ & $\ldots$ & $\ldots$ \\
\hline Estonia & $\ldots$ & $\ldots$ & $\ldots$ & $\ldots$ & $\ldots$ & $\ldots$ & $\ldots$ & $\ldots$ & $\ldots$ & $\ldots$ & $\ldots$ \\
\hline Finland & 5.5 & 0.0 & 1.7 & 1.7 & 100.0 & 64.8 & 10.3 & 17.9 & 30.9 & $\ldots$ & 1.0 \\
\hline France & 4.6 & 0.7 & 0.3 & 13.9 & 0.7 & 48.9 & 0.0 & $\ldots$ & 36.1 & 50.4 & $\ldots$ \\
\hline Georgia & $\ldots$ & $\ldots$ & $\ldots$ & $\ldots$ & $\ldots$ & $\ldots$ & $\ldots$ & $\ldots$ & $\ldots$ & $\ldots$ & $\ldots$ \\
\hline Germany & 1.9 & 2.2 & 3.0 & 15.5 & $\ldots$ & 50.4 & $\ldots$ & $\ldots$ & 28.9 & $\ldots$ & $\ldots$ \\
\hline Greece & & & & & & & & & & & \\
\hline Hungary & 1.6 & 0.0 & 3.2 & 10.3 & 25.0 & 57.1 & 15.7 & 0.0 & 29.5 & 0.0 & 0.0 \\
\hline Iceland & $\ldots$ & $\ldots$ & $\ldots$ & $\ldots$ & $\ldots$ & $\ldots$ & $\ldots$ & $\ldots$ & $\ldots$ & $\ldots$ & $\ldots$ \\
\hline Italy & $\ldots$ & $\ldots$ & $\ldots$ & $\ldots$ & $\ldots$ & $\ldots$ & $\ldots$ & $\ldots$ & $\ldots$ & $\ldots$ & $\ldots$ \\
\hline Kosovo (UN & $\ldots$ & & & & & & & & & & \\
\hline R/1244/99) & & $\ldots$ & $\ldots$ & $\ldots$ & $\ldots$ & $\ldots$ & $\ldots$ & $\ldots$ & $\ldots$ & $\ldots$ & $\ldots$ \\
\hline Latvia & & $\ldots$ & $\ldots$ & $\ldots$ & $\ldots$ & $\ldots$ & $\ldots$ & $\ldots$ & $\ldots$ & $\ldots$ & $\ldots$ \\
\hline Lithuania & 1.5 & $\ldots$ & $\ldots$ & $\ldots$ & $\ldots$ & $\ldots$ & $\ldots$ & $\ldots$ & $\ldots$ & ... & 4.4 \\
\hline Luxembourg & $\ldots$ & $\ldots$ & $\ldots$ & $\ldots$ & $\ldots$ & $\ldots$ & $\ldots$ & $\ldots$ & $\ldots$ & $\ldots$ & $\ldots$ \\
\hline Moldova & $\ldots$ & $\ldots$ & $\ldots$ & $\ldots$ & $\ldots$ & $\ldots$ & $\ldots$ & $\ldots$ & $\ldots$ & $\ldots$ & $\ldots$ \\
\hline Montenegro & $\ldots$ & $\ldots$ & $\ldots$ & $\ldots$ & $\ldots$ & $\ldots$ & $\ldots$ & $\ldots$ & $\ldots$ & $\ldots$ & $\ldots$ \\
\hline Netherlands & 0.4 & $\ldots$ & 0.0 & 15.9 & 90.0 & 17.5 & $\ldots$ & 45.5 & 68.3 & 37.2 & $\ldots$ \\
\hline North Macedonia & $\ldots$ & $\ldots$ & $\ldots$ & $\ldots$ & $\ldots$ & $\ldots$ & $\ldots$ & $\ldots$ & $\ldots$ & $\ldots$ & $\ldots$ \\
\hline Norway & $\ldots$ & $\ldots$ & $\ldots$ & $\ldots$ & $\ldots$ & $\ldots$ & $\ldots$ & $\ldots$ & $\ldots$ & $\ldots$ & $\ldots$ \\
\hline Poland & 1.7 & $\ldots$ & 0.9 & 2.1 & 100.0 & 64.0 & 69.8 & $\ldots$ & 32.9 & $\ldots$ & 0.2 \\
\hline Portugal & 3.3 & $\ldots$ & 2.0 & $\ldots$ & $\ldots$ & 61.5 & 70.6 & $\ldots$ & 33.8 & $\ldots$ & 2.0 \\
\hline Romania & $\ldots$ & $\ldots$ & $\ldots$ & $\ldots$ & $\ldots$ & $\ldots$ & $\ldots$ & $\ldots$ & $\ldots$ & $\ldots$ & $\ldots$ \\
\hline Russian Federation & $\ldots$ & $\ldots$ & $\ldots$ & $\ldots$ & $\ldots$ & $\ldots$ & $\ldots$ & $\ldots$ & $\ldots$ & $\ldots$ & $\ldots$ \\
\hline Serbia & 0.3 & 0.0 & 0.0 & 0.0 & $\ldots$ & 10.5 & 0.0 & $\ldots$ & 89.5 & $\ldots$ & 0.0 \\
\hline Slovak Republic & $\ldots$ & $\ldots$ & $\ldots$ & $\ldots$ & $\ldots$ & $\ldots$ & $\ldots$ & $\ldots$ & $\ldots$ & $\ldots$ & $\ldots$ \\
\hline Slovenia & $\ldots$ & $\ldots$ & $\ldots$ & $\ldots$ & $\ldots$ & $\ldots$ & $\ldots$ & $\ldots$ & $\ldots$ & $\ldots$ & $\ldots$ \\
\hline Spain & $\ldots$ & $\ldots$ & $\ldots$ & $\ldots$ & $\ldots$ & $\ldots$ & $\ldots$ & $\ldots$ & $\ldots$ & $\ldots$ & $\ldots$ \\
\hline Sweden & 1.0 & 0.0 & 0.0 & 15.0 & 53.3 & 22.0 & $\ldots$ & 72.7 & 28.0 & 3.6 & 35.0 \\
\hline Switzerland & 5.4 & $\ldots$ & 22.8 & 0.7 & 66.7 & 7.1 & $\ldots$ & $\ldots$ & 2.2 & 50.0 & 0.0 \\
\hline Turkey & $\ldots$ & & $\ldots$ & $\ldots$ & $\ldots$ & $\ldots$ & & $\ldots$ & $\ldots$ & $\ldots$ & $\ldots$ \\
\hline Ukraine & 0.0 & $\ldots$ & $\ldots$ & & $\ldots$ & $\ldots$ & $\ldots$ & $\ldots$ & 30.0 & $\ldots$ & $\ldots$ \\
\hline UK: England \& Wales & 4.8 & $\ldots$ & 0.1 & 19.7 & $\ldots$ & 9.8 & $\ldots$ & $\ldots$ & 60.7 & $\ldots$ & 9.7 \\
\hline UK: Northern Ireland & $\ldots$ & $\ldots$ & $\ldots$ & $\ldots$ & $\ldots$ & $\ldots$ & $\ldots$ & $\ldots$ & $\ldots$ & $\ldots$ & $\ldots$ \\
\hline UK: Scotland & $\ldots$ & $\ldots$ & $\ldots$ & $\ldots$ & $\ldots$ & $\ldots$ & $\ldots$ & $\ldots$ & $\ldots$ & $\ldots$ & $\ldots$ \\
\hline Mean & 2.4 & 1.7 & 2.3 & 7.5 & 70.6 & 42.8 & 26.9 & 27.2 & 38.5 & 32.0 & 5.4 \\
\hline Median & 1.8 & 0.4 & 0.1 & 2.5 & 90.0 & 50.0 & 10.3 & 17.9 & 31.9 & 37.5 & 0.6 \\
\hline Minimum & 0.0 & 0.0 & 0.0 & 0.0 & 0.7 & 7.1 & 0.0 & 0.0 & 2.2 & 0.0 & 0.0 \\
\hline Maximum & 5.5 & 5.6 & 22.8 & 19.7 & 100.0 & 83.4 & 70.6 & 72.7 & 89.5 & 50.4 & 35.0 \\
\hline
\end{tabular}


Table 3.2.3.10 Total persons receiving sanctions/measures in 2015 - Robbery

\begin{tabular}{|c|c|c|c|c|c|c|c|c|c|c|c|}
\hline & \multirow[b]{2}{*}{ 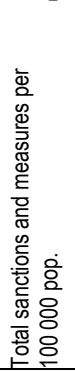 } & \multirow{2}{*}{ 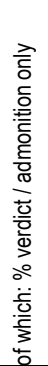 } & \multirow[b]{2}{*}{ 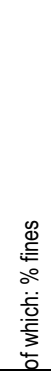 } & \multicolumn{2}{|c|}{$\begin{array}{l}\text { of which: \% } \\
\text { non-custodial } \\
\text { sanctions and } \\
\text { measures }\end{array}$} & \multicolumn{3}{|c|}{$\begin{array}{l}\text { of which: \% suspended } \\
\text { custodial sanctions and } \\
\text { measures }\end{array}$} & \multicolumn{2}{|c|}{$\begin{array}{l}\text { of which: \% un- } \\
\text { suspended custo- } \\
\text { dial sanctions and } \\
\text { measures }\end{array}$} & \multirow[b]{2}{*}{ 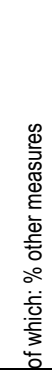 } \\
\hline & & & & 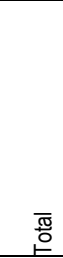 & 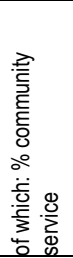 & 䔊 & 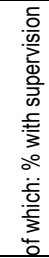 & 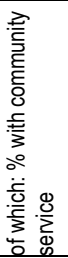 & 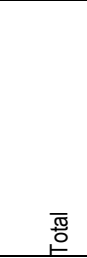 & 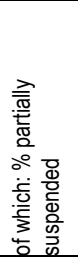 & \\
\hline Albania & & $\ldots$ & & & $\ldots$ & $\ldots$ & $\ldots$ & $\ldots$ & $\ldots$ & $\ldots$ & $\ldots$ \\
\hline Armenia & 2.6 & $\ldots$ & 28.6 & 0.0 & $\ldots$ & 1.3 & $\ldots$ & $\ldots$ & 93.5 & $\ldots$ & $\ldots$ \\
\hline Austria & 8.7 & $\ldots$ & 0.4 & $\ldots$ & $\ldots$ & $\ldots$ & $\ldots$ & $\ldots$ & 70.6 & 30.7 & 3.1 \\
\hline Azerbaijan & & $\ldots$ & $\ldots$ & $\ldots$ & $\ldots$ & $\ldots$ & $\ldots$ & $\ldots$ & $\ldots$ & $\ldots$ & $\ldots$ \\
\hline Belgium & 18.3 & $\ldots$ & 0.0 & 22.1 & 100.0 & 34.5 & 26.4 & $\ldots$ & 43.1 & $\ldots$ & 0.2 \\
\hline Bosnia-Herzegovina & & $\ldots$ & $\ldots$ & & $\ldots$ & $\ldots$ & $\ldots$ & $\ldots$ & & $\ldots$ & $\ldots$ \\
\hline Bulgaria & 9.8 & $\ldots$ & 0.0 & 4.5 & $\ldots$ & 36.8 & $\ldots$ & $\ldots$ & 56.2 & $\ldots$ & 2.4 \\
\hline Croatia & 7.6 & 1.2 & 0.0 & 3.4 & $\ldots$ & 24.9 & 21.3 & 63.8 & 70.4 & 18.6 & $\ldots$ \\
\hline Cyprus & $\ldots$ & $\ldots$ & $\ldots$ & $\ldots$ & $\ldots$ & $\ldots$ & $\ldots$ & $\ldots$ & $\ldots$ & $\ldots$ & $\ldots$ \\
\hline Czech Republic & 9.6 & 0.6 & 0.0 & 0.0 & $\ldots$ & 49.5 & 25.5 & $\ldots$ & 49.5 & $\ldots$ & 0.1 \\
\hline Denmark & $\ldots$ & $\ldots$ & $\ldots$ & $\ldots$ & $\ldots$ & $\ldots$ & $\ldots$ & $\ldots$ & $\ldots$ & $\ldots$ & $\ldots$ \\
\hline Estonia & $\ldots$ & $\ldots$ & $\ldots$ & $\ldots$ & $\ldots$ & $\ldots$ & $\ldots$ & $\ldots$ & $\ldots$ & $\ldots$ & $\ldots$ \\
\hline Finland & 11.8 & 0.0 & 0.5 & 3.6 & 91.3 & 46.5 & 40.1 & 10.0 & 49.0 & $\ldots$ & 0.5 \\
\hline France & 5.2 & $\ldots$ & 3.6 & $\ldots$ & $\ldots$ & $\ldots$ & $\ldots$ & $\ldots$ & 81.1 & $\ldots$ & $\ldots$ \\
\hline Georgia & 10.6 & $\ldots$ & 4.1 & $\ldots$ & $\ldots$ & 25.1 & $\ldots$ & $\ldots$ & 70.9 & $\ldots$ & $\ldots$ \\
\hline Germany & 9.3 & 3.4 & 1.2 & 17.2 & $\ldots$ & 39.4 & $\ldots$ & $\ldots$ & 38.8 & $\ldots$ & $\ldots$ \\
\hline Hungary & 13.1 & 0.1 & 0.7 & 2.5 & 9.1 & 15.7 & 63.5 & 0.0 & 81.0 & 0.0 & 0.0 \\
\hline Iceland & $\ldots$ & $\ldots$ & $\ldots$ & $\ldots$ & $\ldots$ & $\ldots$ & $\ldots$ & $\ldots$ & $\ldots$ & $\ldots$ & $\ldots$ \\
\hline Italy & $\ldots$ & $\ldots$ & $\ldots$ & ... & $\ldots$ & $\ldots$ & $\ldots$ & $\ldots$ & $\ldots$ & $\ldots$ & $\ldots$ \\
\hline Kosovo (UN & & & & & & & & & & & \\
\hline R/1244/99) & $\ldots$ & $\ldots$ & $\ldots$ & $\ldots$ & $\ldots$ & $\ldots$ & $\ldots$ & $\ldots$ & $\ldots$ & $\ldots$ & $\ldots$ \\
\hline Latvia & $\ldots$ & $\ldots$ & $\ldots$ & $\ldots$ & $\ldots$ & $\ldots$ & $\ldots$ & $\ldots$ & $\ldots$ & $\ldots$ & $\ldots$ \\
\hline Lithuania & 28.5 & $\ldots$ & $\ldots$ & $\ldots$ & $\ldots$ & $\ldots$ & $\ldots$ & $\ldots$ & $\ldots$ & $\ldots$ & 0.1 \\
\hline Luxembourg & $\ldots$ & $\ldots$ & $\ldots$ & $\ldots$ & $\ldots$ & $\ldots$ & $\ldots$ & $\ldots$ & $\ldots$ & $\ldots$ & $\ldots$ \\
\hline Moldova & $\ldots$ & $\ldots$ & $\ldots$ & $\ldots$ & $\ldots$ & $\ldots$ & $\ldots$ & $\ldots$ & $\ldots$ & $\ldots$ & $\ldots$ \\
\hline Montenegro & $\ldots$ & $\ldots$ & $\ldots$ & $\ldots$ & $\ldots$ & $\ldots$ & $\ldots$ & $\ldots$ & $\ldots$ & $\ldots$ & $\ldots$ \\
\hline Netherlands & 13.4 & $\ldots$ & 0.7 & 19.7 & 84.8 & 11.9 & $\ldots$ & 72.5 & 67.8 & 51.5 & $\ldots$ \\
\hline North Macedonia & $\ldots$ & $\ldots$ & $\ldots$ & $\ldots$ & $\ldots$ & $\ldots$ & $\ldots$ & $\ldots$ & $\ldots$ & $\ldots$ & $\ldots$ \\
\hline Norway & $\ldots$ & $\ldots$ & $\ldots$ & $\ldots$ & $\ldots$ & $\ldots$ & $\ldots$ & $\ldots$ & $\ldots$ & $\ldots$ & $\ldots$ \\
\hline Poland & 13.5 & $\ldots$ & 0.8 & 1.8 & 100.0 & 44.6 & 69.2 & $\ldots$ & 51.7 & $\ldots$ & 1.1 \\
\hline Portugal & 22.1 & $\ldots$ & 2.5 & 5.0 & 97.4 & 58.5 & 78.5 & $\ldots$ & 33.0 & $\ldots$ & 1.0 \\
\hline Romania & $\ldots$ & $\ldots$ & $\ldots$ & $\ldots$ & 0.0 & $\ldots$ & $\ldots$ & $\ldots$ & $\ldots$ & $\ldots$ & $\ldots$ \\
\hline Russian Federation & $\ldots$ & $\ldots$ & $\ldots$ & $\ldots$ & $\ldots$ & $\ldots$ & $\ldots$ & $\ldots$ & $\ldots$ & $\ldots$ & $\ldots$ \\
\hline Serbia & 9.6 & 0.0 & 0.4 & 0.1 & 0.0 & 18.8 & 64.3 & $\ldots$ & 80.0 & $\ldots$ & 0.6 \\
\hline Slovak Republic & $\ldots$ & $\ldots$ & $\ldots$ & $\ldots$ & $\ldots$ & $\ldots$ & $\ldots$ & $\ldots$ & $\ldots$ & $\ldots$ & $\ldots$ \\
\hline Slovenia & $\ldots$ & $\ldots$ & $\ldots$ & $\ldots$ & $\ldots$ & $\ldots$ & $\ldots$ & $\ldots$ & $\ldots$ & $\ldots$ & $\ldots$ \\
\hline Spain & $\ldots$ & $\ldots$ & $\ldots$ & $\ldots$ & $\ldots$ & $\ldots$ & $\ldots$ & $\ldots$ & $\ldots$ & $\ldots$ & $\ldots$ \\
\hline Sweden & 6.6 & 0.0 & 0.0 & 7.9 & 39.2 & 1.9 & $\ldots$ & 83.3 & 59.0 & 9.4 & 31.3 \\
\hline Switzerland & 1.3 & $\ldots$ & 27.4 & 0.9 & 0.0 & 35.8 & $\ldots$ & $\ldots$ & 35.8 & 23.7 & 0.0 \\
\hline Turkey & 27.7 & $\ldots$ & 0.7 & 32.4 & $\ldots$ & 3.3 & $\ldots$ & $\ldots$ & 50.1 & $\ldots$ & 13.4 \\
\hline Ukraine & 11.2 & $\ldots$ & 8.2 & & $\ldots$ & $\ldots$ & $\ldots$ & $\ldots$ & 46.1 & $\ldots$ & $\ldots$ \\
\hline UK: England \& Wales & 8.2 & $\ldots$ & $\ldots$ & 20.8 & $\ldots$ & 7.7 & $\ldots$ & $\ldots$ & 68.2 & $\ldots$ & 3.2 \\
\hline UK: Northern Ireland & $\ldots$ & $\ldots$ & $\ldots$ & & $\ldots$ & $\ldots$ & $\ldots$ & $\ldots$ & $\ldots$ & $\ldots$ & $\ldots$ \\
\hline UK: Scotland & 7.1 & 2.9 & 2.1 & 15.6 & 76.3 & $\ldots$ & $\ldots$ & $\ldots$ & 78.4 & $\ldots$ & $\ldots$ \\
\hline Mean & 11.6 & 1.0 & 4.1 & 9.3 & 54.4 & 26.8 & 48.6 & 45.9 & 60.7 & 22.3 & 4.1 \\
\hline Median & 9.7 & 0.3 & 0.7 & 4.5 & 76.3 & 25.1 & 51.8 & 63.8 & 59.0 & 21.1 & 0.8 \\
\hline Minimum & 1.3 & 0.0 & 0.0 & 0.0 & 0.0 & 1.3 & 21.3 & 0.0 & 33.0 & 0.0 & 0.0 \\
\hline Maximum & 28.5 & 3.4 & 28.6 & 32.4 & 100.0 & 58.5 & 78.5 & 83.3 & 93.5 & 51.5 & 31.3 \\
\hline
\end{tabular}


Table 3.2.3.11 Total persons receiving sanctions/measures in 2015 - Theft

\begin{tabular}{|c|c|c|c|c|c|c|c|c|c|c|c|}
\hline & \multirow[b]{2}{*}{ 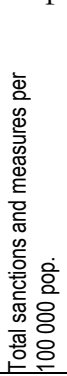 } & \multirow[b]{2}{*}{ 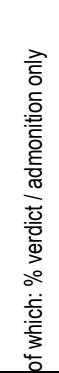 } & \multirow[b]{2}{*}{ 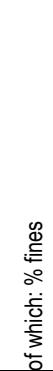 } & \multicolumn{2}{|c|}{$\begin{array}{l}\text { of which: \% } \\
\text { non-custodial } \\
\text { sanctions and } \\
\text { measures }\end{array}$} & \multicolumn{3}{|c|}{$\begin{array}{l}\text { of which: } \% \text { suspended } \\
\text { custodial sanctions and } \\
\text { measures }\end{array}$} & \multicolumn{2}{|c|}{$\begin{array}{l}\text { of which: \% un- } \\
\text { suspended custo- } \\
\text { dial sanctions and } \\
\text { measures }\end{array}$} & \multirow[b]{2}{*}{ 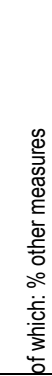 } \\
\hline & & & & 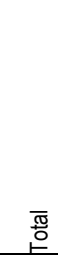 & 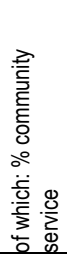 & 要 & 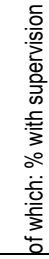 & 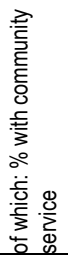 & 焉 & 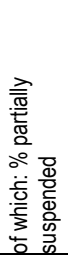 & \\
\hline Albania & & $\ldots$ & & & $\ldots$ & & $\ldots$ & $\ldots$ & & $\ldots$ & $\ldots$ \\
\hline Armenia & 9.7 & $\ldots$ & 76.8 & 0.0 & $\ldots$ & 37.9 & $\ldots$ & $\ldots$ & 60.8 & $\ldots$ & $\ldots$ \\
\hline Austria & 81.3 & $\ldots$ & 22.8 & $\ldots$ & $\ldots$ & 29.3 & $\ldots$ & $\ldots$ & 45.3 & 38.1 & 2.6 \\
\hline Azerbaijan & & $\ldots$ & $\ldots$ & $\ldots$ & $\ldots$ & $\ldots$ & $\ldots$ & $\ldots$ & $\ldots$ & $\ldots$ & $\ldots$ \\
\hline Belgium & 76.1 & $\ldots$ & 0.7 & 19.7 & 100.0 & 29.8 & 14.1 & $\ldots$ & 49.3 & $\ldots$ & 0.4 \\
\hline Bosnia-Herzegovina & & $\ldots$ & $\ldots$ & $\ldots$ & $\ldots$ & $\ldots$ & $\ldots$ & $\ldots$ & $\ldots$ & $\ldots$ & $\ldots$ \\
\hline Bulgaria & 86.6 & & 1.8 & 17.2 & $\ldots$ & 33.4 & 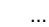 & . & 45.0 & & 2.5 \\
\hline Croatia & 73.3 & 2.5 & 0.3 & 4.0 & $\ldots$ & 66.8 & 7.9 & 13.6 & 26.4 & 12.6 & 0.0 \\
\hline Cyprus & & & & & $\ldots$ & & & $\ldots$ & & $\ldots$ & \\
\hline Czech Republic & 132.7 & 3.2 & 0.8 & 19.6 & 91.2 & 47.1 & 15.2 & $\ldots$ & 29.2 & $\ldots$ & 0.1 \\
\hline Denmark & $\ldots$ & $\ldots$ & $\ldots$ & $\ldots$ & $\ldots$ & $\ldots$ & $\ldots$ & $\ldots$ & $\ldots$ & $\ldots$ & $\ldots$ \\
\hline Estonia & $\ldots$ & $\ldots$ & $\ldots$ & $\ldots$ & $\ldots$ & $\ldots$ & $\ldots$ & $\ldots$ & $\ldots$ & $\ldots$ & $\ldots$ \\
\hline Finland & 544.9 & 0.0 & 94.1 & 0.5 & 92.4 & 2.6 & 12.6 & 0.9 & 2.5 & $\ldots$ & 0.4 \\
\hline France & 137.6 & 0.8 & 10.9 & 19.7 & 28.3 & 29.9 & 0.5 & $\ldots$ & 38.7 & 14.9 & $\ldots$ \\
\hline Georgia & 80.8 & $\ldots$ & 1.5 & $\ldots$ & $\ldots$ & 41.5 & $\ldots$ & $\ldots$ & 58.5 & $\ldots$ & $\ldots$ \\
\hline Germany & 164.5 & 0.7 & 67.0 & 10.1 & $\ldots$ & 13.2 & $\ldots$ & $\ldots$ & 9.0 & $\ldots$ & $\ldots$ \\
\hline Hungary & 176.4 & 0.6 & 10.5 & 44.5 & 52.8 & 19.3 & 27.3 & 0.0 & 25.1 & 0.0 & 0.0 \\
\hline Iceland & $\ldots$ & $\ldots$ & $\ldots$ & $\ldots$ & $\ldots$ & $\ldots$ & $\ldots$ & $\ldots$ & $\ldots$ & $\ldots$ & $\ldots$ \\
\hline Italy & $\cdots$ & $\ldots$ & $\ldots$ & $\cdots$ & $\ldots$ & $\cdots$ & $\cdots$ & $\cdots$ & $\ldots$ & $\cdots$ & $\ldots$ \\
\hline Kosovo (UN & & & & & & & & & & & \\
\hline $\mathrm{R} / 1244 / 99)$ & $\cdots$ & $\ldots$ & $\cdots$ & $\cdots$ & $\cdots$ & $\cdots$ & $\cdots$ & $\cdots$ & $\ldots$ & $\cdots$ & $\ldots$ \\
\hline Latvia & $\ldots$ & $\ldots$ & $\ldots$ & $\cdots$ & $\cdots$ & $\cdots$ & $\ldots$ & $\ldots$ & $\ldots$ & $\ldots$ & $\ldots$ \\
\hline Lithuania & 137.7 & $\ldots$ & $\ldots$ & $\ldots$ & $\ldots$ & $\ldots$ & $\ldots$ & $\ldots$ & $\ldots$ & $\ldots$ & 0.6 \\
\hline Luxembourg & $\ldots$ & $\ldots$ & $\ldots$ & $\ldots$ & $\ldots$ & $\ldots$ & $\ldots$ & $\ldots$ & $\ldots$ & $\ldots$ & $\ldots$ \\
\hline Moldova & ... & $\ldots$ & $\ldots$ & $\ldots$ & ... & $\ldots$ & ... & $\ldots$ & $\ldots$ & ... & $\ldots$ \\
\hline Montenegro & & $\ldots$ & $\ldots$ & $\ldots$ & $\ldots$ & $\ldots$ & $\ldots$ & $\ldots$ & $\ldots$ & . & $\ldots$ \\
\hline Netherlands & 147.0 & $\ldots$ & 13.6 & 24.1 & 94.3 & 17.7 & ... & 47.2 & 44.7 & 28.5 & $\ldots$ \\
\hline North Macedonia & $\ldots$ & $\ldots$ & $\ldots$ & $\ldots$ & $\ldots$ & $\ldots$ & $\ldots$ & $\ldots$ & $\ldots$ & $\ldots$ & $\ldots$ \\
\hline Norway & 149.6 & $\ldots$ & 70.8 & 0.0 & $\ldots$ & 0.0 & $\ldots$ & $\ldots$ & 16.9 & $\ldots$ & $\ldots$ \\
\hline Poland & 103.6 & $\ldots$ & 7.4 & 16.7 & 100.0 & 54.0 & 40.7 & $\ldots$ & 21.7 & $\ldots$ & 0.3 \\
\hline Portugal & 54.0 & 0.3 & 37.7 & 4.9 & 98.2 & 35.8 & 58.3 & $\ldots$ & 20.1 & $\ldots$ & 1.1 \\
\hline Romania & $\ldots$ & $\ldots$ & $\ldots$ & $\ldots$ & $\ldots$ & $\ldots$ & $\ldots$ & $\ldots$ & $\ldots$ & $\ldots$ & $\ldots$ \\
\hline Russian Federation & & & & & & $\ldots$ & & $\ldots$ & & $\ldots$ & \\
\hline Serbia & 126.3 & 0.1 & 4.5 & 1.5 & 99.3 & 56.4 & 4.3 & $\ldots$ & 37.2 & $\ldots$ & 0.2 \\
\hline Slovak Republic & $\ldots$ & $\ldots$ & $\ldots$ & $\ldots$ & $\ldots$ & $\ldots$ & $\ldots$ & $\ldots$ & $\ldots$ & $\ldots$ & $\ldots$ \\
\hline Slovenia & $\ldots$ & $\ldots$ & $\ldots$ & $\ldots$ & $\ldots$ & $\ldots$ & ... & $\ldots$ & $\ldots$ & $\ldots$ & $\ldots$ \\
\hline Spain & & $\ldots$ & $\ldots$ & $\ldots$ & $\ldots$ & $\ldots$ & $\ldots$ & $\ldots$ & $\ldots$ & $\ldots$ & $\ldots$ \\
\hline Sweden & 219.6 & 0.0 & 38.7 & 5.6 & 6.3 & 15.7 & $\ldots$ & 2.4 & 9.6 & 0.5 & 30.4 \\
\hline Switzerland & 39.5 & $\ldots$ & 75.3 & 2.2 & 90.1 & 2.0 & $\ldots$ & $\ldots$ & 20.5 & 1.2 & 0.0 \\
\hline Turkey & 225.8 & $\ldots$ & 9.3 & 26.9 & $\ldots$ & 6.7 & $\ldots$ & $\ldots$ & 43.9 & $\ldots$ & 13.3 \\
\hline Ukraine & 96.2 & $\ldots$ & 14.9 & & $\ldots$ & $\ldots$ & $\ldots$ & $\ldots$ & 22.1 & $\ldots$ & $\ldots$ \\
\hline UK: England \& Wales & 152.1 & $\ldots$ & 15.9 & 27.7 & $\ldots$ & 13.6 & $\ldots$ & $\ldots$ & 31.2 & $\ldots$ & 27.4 \\
\hline UK: Northern Ireland & & & & & & $\ldots$ & $\ldots$ & $\ldots$ & & $\ldots$ & $\ldots$ \\
\hline UK: Scotland & 215.5 & 21.8 & 18.9 & 25.3 & 81.9 & $\ldots$ & $\ldots$ & $\ldots$ & 31.9 & $\ldots$ & $\ldots$ \\
\hline Mean & 140.5 & 3.0 & 27.0 & 14.2 & 77.9 & 27.6 & 20.1 & 12.8 & 31.3 & 13.7 & 5.3 \\
\hline Median & 132.7 & 0.6 & 14.2 & 16.7 & 91.8 & 29.6 & 14.1 & 2.4 & 30.2 & 12.6 & 0.4 \\
\hline Minimum & 9.7 & 0.0 & 0.3 & 0.0 & 6.3 & 0.0 & 0.5 & 0.0 & 2.5 & 0.0 & 0.0 \\
\hline Maximum & 544.9 & 21.8 & 94.1 & 44.5 & 100.0 & 66.8 & 58.3 & 47.2 & 60.8 & 38.1 & 30.4 \\
\hline
\end{tabular}


Table 3.2.3.12 Total persons receiving sanctions/measures in 2015-Aggravated theft

\begin{tabular}{|c|c|c|c|c|c|c|c|c|c|c|c|}
\hline & \multirow[b]{2}{*}{ 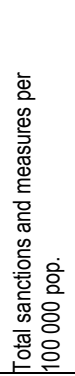 } & \multirow[b]{2}{*}{ 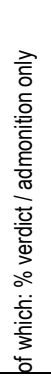 } & \multirow[b]{2}{*}{ 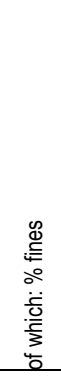 } & \multicolumn{2}{|c|}{$\begin{array}{l}\text { of which: \% } \\
\text { non-custodial } \\
\text { sanctions and } \\
\text { measures }\end{array}$} & \multicolumn{3}{|c|}{$\begin{array}{l}\text { of which: \% suspended } \\
\text { custodial sanctions and } \\
\text { measures }\end{array}$} & \multicolumn{2}{|c|}{$\begin{array}{l}\text { of which: \% un- } \\
\text { suspended custo- } \\
\text { dial sanctions and } \\
\text { measures }\end{array}$} & \multirow[b]{2}{*}{ 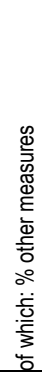 } \\
\hline & & & & 呼 & 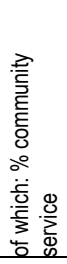 & $\begin{array}{l}\text { 受 } \\
\end{array}$ & 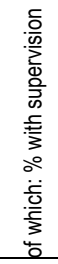 & 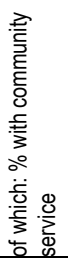 & 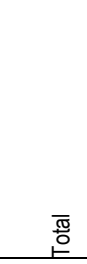 & 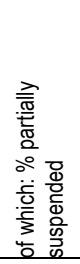 & \\
\hline Albania & $\ldots$ & $\ldots$ & $\ldots$ & $\ldots$ & $\ldots$ & $\ldots$ & $\ldots$ & $\ldots$ & $\ldots$ & $\ldots$ & $\ldots$ \\
\hline Armenia & $\ldots$ & $\ldots$ & $\ldots$ & $\ldots$ & $\ldots$ & $\ldots$ & $\ldots$ & $\ldots$ & $\ldots$ & $\ldots$ & $\ldots$ \\
\hline Austria & 47.5 & $\ldots$ & 1.8 & $\ldots$ & $\ldots$ & 0.0 & $\ldots$ & $\ldots$ & 67.1 & 44.0 & 3.3 \\
\hline Azerbaijan & & $\ldots$ & $\ldots$ & $\ldots$ & $\ldots$ & $\ldots$ & $\ldots$ & $\ldots$ & $\ldots$ & $\ldots$ & $\ldots$ \\
\hline Belgium & 35.1 & $\ldots$ & 0.1 & 21.0 & 100.0 & 30.9 & 16.0 & $\ldots$ & 47.6 & $\ldots$ & 0.5 \\
\hline $\begin{array}{l}\text { Bosnia-Herzegovina } \\
\text { Bulgaria }\end{array}$ & $\ldots$ & $\begin{array}{l}\ldots \\
\ldots\end{array}$ & $\begin{array}{l}\ldots \\
\ldots\end{array}$ & $\begin{array}{l}\ldots \\
\ldots\end{array}$ & $\begin{array}{l}\ldots \\
\ldots\end{array}$ & $\ldots$ & $\begin{array}{l}\ldots \\
\ldots\end{array}$ & $\ldots$ & $\ldots$ & $\begin{array}{l}\ldots \\
\ldots\end{array}$ & $\begin{array}{l}\cdots \\
\ldots\end{array}$ \\
\hline Croatia & 34.7 & 4.2 & 0.0 & 5.5 & $\ldots$ & 55.5 & 8.8 & 18.7 & 34.8 & 14.7 & 0.0 \\
\hline Cyprus & $\ldots$ & $\ldots$ & $\ldots$ & $\ldots$ & $\ldots$ & $\ldots$ & $\ldots$ & $\ldots$ & $\ldots$ & $\ldots$ & $\ldots$ \\
\hline Czech Republic & $\ldots$ & $\ldots$ & $\ldots$ & $\ldots$ & $\ldots$ & $\ldots$ & $\ldots$ & $\ldots$ & $\ldots$ & $\ldots$ & ... \\
\hline Denmark & $\ldots$ & $\ldots$ & $\ldots$ & $\ldots$ & $\ldots$ & $\ldots$ & $\ldots$ & $\ldots$ & $\ldots$ & $\ldots$ & $\ldots$ \\
\hline Estonia & $\ldots$ & $\ldots$ & $\ldots$ & $\ldots$ & $\ldots$ & $\ldots$ & $\ldots$ & $\ldots$ & $\ldots$ & $\ldots$ & $\ldots$ \\
\hline Finland & 7.9 & 0.0 & 0.7 & 4.6 & 90.0 & 45.7 & 11.2 & 3.6 & 48.7 & $\ldots$ & 0.2 \\
\hline France & $\ldots$ & $\ldots$ & $\ldots$ & $\ldots$ & $\ldots$ & $\ldots$ & $\ldots$ & $\ldots$ & $\ldots$ & $\ldots$ & $\ldots$ \\
\hline Georgia & $\ldots$ & $\ldots$ & $\ldots$ & $\ldots$ & $\ldots$ & $\ldots$ & $\ldots$ & $\ldots$ & $\ldots$ & $\ldots$ & $\ldots$ \\
\hline Germany & 29.6 & 1.3 & 20.8 & 13.7 & $\ldots$ & 38.5 & $\ldots$ & & 25.7 & $\ldots$ & $\ldots$ \\
\hline Hungary & 176.4 & 0.6 & 10.5 & 44.5 & 52.8 & 19.3 & 27.3 & 0.0 & 25.1 & 0.0 & ... \\
\hline Iceland & $\ldots$ & $\ldots$ & $\ldots$ & $\ldots$ & $\ldots$ & $\ldots$ & $\ldots$ & $\ldots$ & $\ldots$ & $\ldots$ & ... \\
\hline $\begin{array}{l}\text { Italy } \\
\text { Kosovo (UN }\end{array}$ & $\ldots$ & $\ldots$ & $\ldots$ & $\ldots$ & $\ldots$ & $\ldots$ & $\ldots$ & $\ldots$ & $\ldots$ & $\ldots$ & $\ldots$ \\
\hline $\mathrm{R} / 1244 / 99)$ & $\ldots$ & $\cdots$ & $\ldots$ & $\ldots$ & $\cdots$ & $\ldots$ & $\ldots$ & $\ldots$ & $\ldots$ & $\ldots$ & $\cdots$ \\
\hline Latvia & $\ldots$ & $\ldots$ & $\ldots$ & $\ldots$ & $\ldots$ & $\ldots$ & $\ldots$ & $\ldots$ & $\ldots$ & $\ldots$ & $\ldots$ \\
\hline Lithuania & $\ldots$ & $\ldots$ & $\ldots$ & $\ldots$ & $\ldots$ & $\ldots$ & $\ldots$ & $\ldots$ & $\ldots$ & $\ldots$ & $\ldots$ \\
\hline Luxembourg & $\ldots$ & $\ldots$ & $\ldots$ & $\ldots$ & ... & ... & $\ldots$ & $\ldots$ & $\ldots$ & $\ldots$ & ... \\
\hline Moldova & $\ldots$ & $\ldots$ & $\ldots$ & $\ldots$ & $\ldots$ & $\ldots$ & $\ldots$ & $\ldots$ & $\ldots$ & $\ldots$ & $\ldots$ \\
\hline Montenegro & 66.4 & $\ldots$ & & $\ldots$ & $\ldots$ & $\ldots$ & $\ldots$ & $\ldots$ & $\ldots$ & $\ldots$ & $\ldots$ \\
\hline Netherlands & 65.1 & 1.3 & 8.2 & 27.9 & 95.3 & 18.0 & $\ldots$ & 66.6 & 45.9 & 31.8 & $\ldots$ \\
\hline North Macedonia & $\ldots$ & $\ldots$ & $\ldots$ & $\ldots$ & $\ldots$ & $\ldots$ & $\ldots$ & $\ldots$ & $\ldots$ & $\ldots$ & $\ldots$ \\
\hline Norway & $\ldots$ & $\ldots$ & $\ldots$ & $\ldots$ & $\ldots$ & $\ldots$ & $\ldots$ & $\ldots$ & $\ldots$ & $\ldots$ & $\ldots$ \\
\hline Poland & 35.3 & $\ldots$ & 1.2 & 5.9 & 100.0 & 63.2 & 52.2 & $\ldots$ & 29.1 & $\ldots$ & 0.5 \\
\hline Portugal & 32.4 & $\ldots$ & 17.0 & 5.5 & 97.3 & 49.6 & 59.2 & $\ldots$ & 26.9 & $\ldots$ & 1.0 \\
\hline Romania & $\ldots$ & $\ldots$ & $\ldots$ & $\ldots$ & $\ldots$ & $\ldots$ & $\ldots$ & ... & $\ldots$ & $\ldots$ & $\ldots$ \\
\hline Russian Federation & & & & $\ldots$ & & & & $\ldots$ & $\ldots$ & $\ldots$ & $\ldots$ \\
\hline Serbia & 61.0 & 0.0 & 0.1 & 0.1 & 100.0 & 49.7 & 6.7 & $\ldots$ & 49.9 & $\ldots$ & 0.3 \\
\hline Slovak Republic & $\ldots$ & $\ldots$ & $\ldots$ & $\ldots$ & $\ldots$ & $\ldots$ & $\ldots$ & $\ldots$ & $\ldots$ & $\ldots$ & $\ldots$ \\
\hline Slovenia & $\ldots$ & $\ldots$ & $\ldots$ & $\ldots$ & $\ldots$ & $\ldots$ & $\ldots$ & ... & $\ldots$ & $\ldots$ & $\ldots$ \\
\hline Spain & $\ldots$ & $\ldots$ & $\ldots$ & $\ldots$ & $\ldots$ & $\ldots$ & $\ldots$ & $\ldots$ & $\ldots$ & $\ldots$ & $\ldots$ \\
\hline Sweden & $\ldots$ & $\ldots$ & $\ldots$ & $\ldots$ & $\ldots$ & $\ldots$ & $\ldots$ & $\ldots$ & $\ldots$ & $\ldots$ & $\ldots$ \\
\hline Switzerland & 1.8 & $\ldots$ & 36.9 & 0.7 & 100.0 & 25.5 & $\ldots$ & $\ldots$ & 36.9 & 10.9 & 0.0 \\
\hline Turkey & $\ldots$ & $\ldots$ & $\ldots$ & $\ldots$ & $\ldots$ & $\ldots$ & $\ldots$ & ... & $\ldots$ & $\ldots$ & $\ldots$ \\
\hline Ukraine & $\ldots$ & $\ldots$ & $\ldots$ & $\ldots$ & $\ldots$ & $\ldots$ & $\ldots$ & $\ldots$ & $\ldots$ & $\ldots$ & $\ldots$ \\
\hline UK: England \& Wales & $\ldots$ & $\ldots$ & $\ldots$ & $\ldots$ & ... & $\ldots$ & $\ldots$ & $\ldots$ & $\ldots$ & $\ldots$ & $\ldots$ \\
\hline $\begin{array}{l}\text { UK: Northern Ireland } \\
\text { UK: Scotland }\end{array}$ & $\ldots$ & $\ldots$ & $\ldots$ & $\begin{array}{l}\ldots \\
\ldots\end{array}$ & $\ldots$ & $\begin{array}{l}\ldots \\
\ldots\end{array}$ & $\begin{array}{l}\ldots \\
\ldots\end{array}$ & $\begin{array}{l}\ldots \\
\ldots\end{array}$ & $\begin{array}{l}\ldots \\
\ldots \\
\end{array}$ & $\begin{array}{l}\ldots \\
\ldots\end{array}$ & $\begin{array}{l}\cdots \\
\ldots\end{array}$ \\
\hline Mean & 49.4 & 1.2 & 8.8 & 12.9 & 91.9 & 36.0 & 25.9 & 22.2 & 39.8 & 20.3 & 0.7 \\
\hline Median & 35.2 & 0.9 & 1.8 & 5.7 & 98.6 & 38.5 & 16.0 & 11.1 & 36.9 & 14.7 & 0.4 \\
\hline Minimum & 1.8 & 0.0 & 0.0 & 0.1 & 52.8 & 0.0 & 6.7 & 0.0 & 25.1 & 0.0 & 0.0 \\
\hline Maximum & 176.4 & 4.2 & 36.9 & 44.5 & 100.0 & 63.2 & 59.2 & 66.6 & 67.1 & 44.0 & 3.3 \\
\hline
\end{tabular}


Table 3.2.3.13 Total persons receiving sanctions/measures in 2015 - Theft of a motor vehicle

\begin{tabular}{|c|c|c|c|c|c|c|c|c|c|c|c|}
\hline & \multirow{2}{*}{ 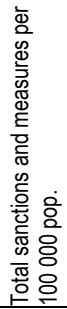 } & \multirow{2}{*}{ 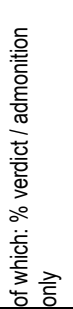 } & \multirow[b]{2}{*}{ 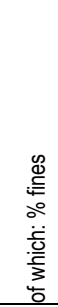 } & \multicolumn{2}{|c|}{$\begin{array}{l}\text { of which: \% } \\
\text { non-custodial } \\
\text { sanctions and } \\
\text { measures }\end{array}$} & \multicolumn{3}{|c|}{$\begin{array}{l}\text { of which: \% suspended } \\
\text { custodial sanctions and } \\
\text { measures }\end{array}$} & \multicolumn{2}{|c|}{$\begin{array}{l}\text { of which: } \% \text { un- } \\
\text { suspended cus- } \\
\text { todial sanctions } \\
\text { and measures }\end{array}$} & \multirow{2}{*}{ 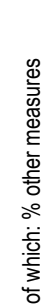 } \\
\hline & & & & 要 & 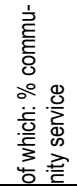 & 丞 & 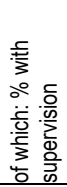 & 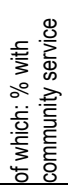 & 䙲 & 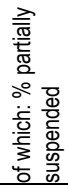 & \\
\hline Armenia & 0.1 & & 0.0 & 0.0 & & 50.0 & & & 50.0 & $\ldots$ & \\
\hline Finland & 5.9 & 0.0 & 53.6 & 3.7 & 75.0 & 17.1 & 25.5 & 0.0 & 21.2 & $\ldots$ & 4.4 \\
\hline Hungary & 6.8 & 0.3 & 15.2 & 49.5 & 34.8 & 20.0 & 28.6 & 0.0 & 15.0 & 0.0 & 0.0 \\
\hline Portugal & 0.9 & & 52.3 & 6.8 & 83.3 & 17.0 & 33.3 & $\ldots$ & 19.3 & $\ldots$ & 4.5 \\
\hline Serbia & 2.8 & 0.0 & 10.1 & 2.0 & 100.0 & 48.7 & 5.2 & & 39.2 & & 0.0 \\
\hline Sweden & 3.2 & 0.0 & 2.2 & 17.1 & 0.0 & 15.9 & $\ldots$ & 6.0 & 14.9 & 0.0 & 49.8 \\
\hline Ukraine & 5.7 & $\ldots$ & 2.9 & & $\ldots$ & $\ldots$ & $\ldots$ & $\ldots$ & 33.6 & $\ldots$ & \\
\hline UK: England \& Wales & 6.2 & $\ldots$ & 11.8 & 56.8 & $\ldots$ & 8.5 & $\ldots$ & $\ldots$ & 14.1 & $\ldots$ & 20.5 \\
\hline UK: Scotland & 5.5 & 8.1 & 20.9 & 37.5 & 86.5 & $\ldots$ & $\ldots$ & $\ldots$ & 31.4 & $\ldots$ & $\ldots$ \\
\hline Mean & 4.1 & 1.7 & 18.8 & 21.7 & 63.3 & 25.3 & 23.1 & 2.0 & 26.5 & 0.0 & 13.2 \\
\hline Median & 5.5 & 0.0 & 11.8 & 12.0 & 79.2 & 17.1 & 27.0 & 0.0 & 21.2 & 0.0 & 4.5 \\
\hline Minimum & 0.1 & 0.0 & 0.0 & 0.0 & 0.0 & 8.5 & 5.2 & 0.0 & 14.1 & 0.0 & 0.0 \\
\hline Maximum & 6.8 & 8.1 & 53.6 & 56.8 & 100.0 & 50.0 & 33.3 & 6.0 & 50.0 & 0.0 & 49.8 \\
\hline
\end{tabular}

Table 3.2.3.14 Total persons receiving sanctions/measures in 2015 - Theft by means of burglary

\begin{tabular}{|c|c|c|c|c|c|c|c|c|c|c|c|}
\hline Austria & 12.3 & & 4.5 & & $\ldots$ & 39.4 & & & 50.7 & 46.9 & 5.3 \\
\hline Croatia & 32.7 & 4.3 & 0.0 & 5.4 & $\ldots$ & 55.3 & 8.8 & 18.8 & 35.0 & 14.3 & $\ldots$ \\
\hline Germany & 15.2 & 1.6 & 17.5 & 16.7 & $\ldots$ & 38.5 & $\ldots$ & 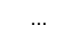 & 25.6 & $\ldots$ & $\ldots$ \\
\hline Hungary & 32.2 & 0.5 & 6.8 & 43.9 & 56.0 & 17.9 & 40.6 & 0.0 & 30.8 & 0.0 & 0.0 \\
\hline Poland & 35.3 & $\ldots$ & 1.2 & 5.9 & 100.0 & 63.2 & 52.2 & $\ldots$ & 29.1 & $\ldots$ & 0.5 \\
\hline Portugal & 2.1 & $\ldots$ & 7.0 & 5.6 & 100.0 & 47.2 & 67.3 & $\ldots$ & 38.3 & $\ldots$ & 1.9 \\
\hline Ukraine & 32.3 & $\ldots$ & 0.6 & & $\ldots$ & $\ldots$ & $\ldots$ & $\ldots$ & 33.8 & $\ldots$ & \\
\hline UK: England \& Wales & 26.5 & $\ldots$ & 1.6 & 22.6 & $\ldots$ & 16.8 & $\ldots$ & $\ldots$ & 55.3 & $\ldots$ & 5.3 \\
\hline UK: Scotland & 15.9 & 4.1 & 2.9 & 30.6 & 74.3 & $\ldots$ & $\ldots$ & $\ldots$ & 62.1 & $\ldots$ & \\
\hline Mean & 22.7 & 2.6 & 4.7 & 18.7 & 82.6 & 39.8 & 42.2 & 9.4 & 40.1 & 20.4 & 2.6 \\
\hline Median & 26.5 & 2.9 & 2.9 & 16.7 & 87.2 & 39.4 & 46.4 & 9.4 & 35.0 & 14.3 & 1.9 \\
\hline Minimum & 2.1 & 0.5 & 0.0 & 5.4 & 56.0 & 16.8 & 8.8 & 0.0 & 25.6 & 0.0 & 0.0 \\
\hline Maximum & 35.3 & 4.3 & 17.5 & 43.9 & 100.0 & 63.2 & 67.3 & 18.8 & 62.1 & 46.9 & 5.3 \\
\hline
\end{tabular}

Table 3.2.3.15 Total persons receiving sanctions/measures in 2015 - Theft by means of domestic burglary

\begin{tabular}{|c|c|c|c|c|c|c|c|c|c|c|c|}
\hline Germany & 3.5 & 1.9 & 5.4 & 14.8 & $\ldots$ & 44.6 & $\ldots$ & $\ldots$ & 33.3 & $\ldots$ & \\
\hline Hungary & 1.9 & 2.6 & 7.9 & 54.5 & 41.3 & 13.6 & 34.6 & 0.0 & 21.5 & 0.0 & 0.0 \\
\hline Portugal & 2.1 & $\ldots$ & 4.6 & 6.9 & 66.7 & 42.7 & 75.0 & $\ldots$ & 42.7 & $\ldots$ & 3.1 \\
\hline UK: England \& Wales & 14.9 & $\ldots$ & 0.5 & 17.5 & $\ldots$ & 15.7 & $\ldots$ & $\ldots$ & 64.1 & $\ldots$ & 2.6 \\
\hline
\end{tabular}

Table 3.2.3.17 Total persons receiving sanctions/measures in 2015 - Cyber fraud

\begin{tabular}{|c|c|c|c|c|c|c|c|c|c|c|c|}
\hline Hungary & 3.9 & 1.3 & 17.1 & 34.9 & 32.3 & 24.1 & 21.7 & 0.0 & 22.6 & 0.0 & 0.0 \\
\hline Portugal & 1.9 & & 49.7 & & $\ldots$ & 33.3 & 44.6 & $\ldots$ & 14.9 & $\ldots$ & 1.5 \\
\hline Serbia & 0.0 & 0.0 & 0.0 & 0.0 & $\ldots$ & 50.0 & 0.0 & $\ldots$ & 50.0 & $\ldots$ & 0.0 \\
\hline Switzerland & 1.7 & $\ldots$ & 87.0 & 2.9 & 100.0 & 3.6 & $\ldots$ & $\ldots$ & 6.5 & 11.1 & 0.0 \\
\hline
\end{tabular}


Table 3.2.3.16 Total persons receiving sanctions/measures in 2015 - Fraud

\begin{tabular}{|c|c|c|c|c|c|c|c|c|c|c|c|}
\hline & \multirow{2}{*}{ 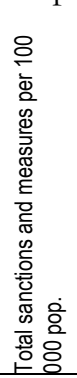 } & \multirow[b]{2}{*}{ 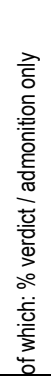 } & \multicolumn{3}{|c|}{$\begin{array}{l}\text { of which: \% } \\
\text { non-custodial } \\
\text { sanctions and } \\
\text { measures }\end{array}$} & \multicolumn{3}{|c|}{$\begin{array}{l}\text { of which: \% suspended } \\
\text { custodial sanctions and } \\
\text { measures }\end{array}$} & \multicolumn{2}{|c|}{$\begin{array}{l}\text { of which: \% un- } \\
\text { suspended custo- } \\
\text { dial sanctions and } \\
\text { measures }\end{array}$} & \multirow[b]{2}{*}{ 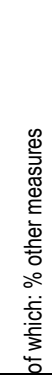 } \\
\hline & & & 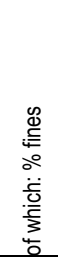 & 몽 & 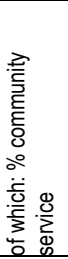 & 要 & 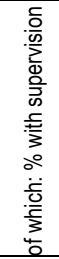 & 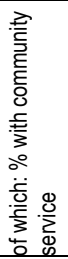 & 要 & 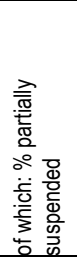 & \\
\hline Albania & & $\ldots$ & & & $\ldots$ & & & & & & \\
\hline Armenia & 1.7 & $\ldots$ & 0.0 & 0.0 & $\ldots$ & 10.0 & 0.0 & 0.0 & 90.0 & 0.0 & 0.0 \\
\hline Austria & 26.3 & $\ldots$ & 21.1 & $\ldots$ & $\ldots$ & 44.4 & $\ldots$ & $\ldots$ & 28.6 & 35.8 & 5.9 \\
\hline Azerbaijan & $\ldots$ & $\ldots$ & $\ldots$ & $\ldots$ & $\ldots$ & $\ldots$ & $\ldots$ & $\ldots$ & $\ldots$ & $\ldots$ & $\ldots$ \\
\hline Belgium & 20.6 & $\ldots$ & 2.6 & 17.2 & 100.0 & 37.1 & 7.0 & $\ldots$ & 40.4 & $\ldots$ & 2.8 \\
\hline Bosnia-Herzegovina & $\ldots$ & $\ldots$ & $\ldots$ & $\ldots$ & $\ldots$ & $\ldots$ & $\ldots$ & $\ldots$ & $\ldots$ & $\ldots$ & $\ldots$ \\
\hline Bulgaria & 7.8 & 0.0 & 1.8 & 9.3 & 0.0 & 60.6 & $\ldots$ & $\ldots$ & 28.3 & 0.0 & 0.0 \\
\hline Croatia & 21.1 & 0.1 & 1.8 & 0.4 & $\ldots$ & 73.2 & 18.5 & 7.0 & 24.4 & 13.8 & 0.0 \\
\hline Cyprus & $\ldots$ & $\ldots$ & $\ldots$ & $\ldots$ & $\ldots$ & $\ldots$ & $\ldots$ & $\ldots$ & $\ldots$ & $\ldots$ & $\ldots$ \\
\hline Czech Republic & 30.7 & 2.8 & 0.6 & 4.5 & 97.3 & 80.2 & 7.6 & $\ldots$ & 11.7 & $\ldots$ & $\ldots$ \\
\hline Denmark & $\ldots$ & $\ldots$ & $\ldots$ & $\ldots$ & $\ldots$ & $\ldots$ & $\ldots$ & $\ldots$ & $\ldots$ & $\ldots$ & $\ldots$ \\
\hline Estonia & & & 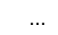 & & $\ldots$ & $\ldots$ & $\ldots$ & $\ldots$ & $\ldots$ & $\ldots$ & $\ldots$ \\
\hline Finland & 83.7 & 0.0 & 69.9 & 2.2 & 97.0 & 20.4 & 4.1 & 1.9 & 6.1 & $\ldots$ & 1.3 \\
\hline France & 12.5 & 1.0 & 11.4 & 10.0 & 31.0 & 46.3 & 0.2 & $\ldots$ & 31.3 & 18.9 & $\ldots$ \\
\hline Georgia & 12.2 & & 5.7 & & $\ldots$ & 44.1 & $\ldots$ & $\ldots$ & 50.2 & $\ldots$ & $\ldots$ \\
\hline Germany & 111.8 & 1.9 & 81.2 & 2.7 & $\ldots$ & 11.0 & $\ldots$ & $\ldots$ & 3.2 & $\ldots$ & $\ldots$ \\
\hline Hungary & 39.5 & 1.1 & 18.9 & 24.7 & 48.6 & 36.4 & 7.4 & 0.0 & 18.8 & 0.0 & 0.0 \\
\hline Iceland & $\ldots$ & $\ldots$ & $\ldots$ & $\ldots$ & $\ldots$ & $\ldots$ & $\ldots$ & $\ldots$ & $\ldots$ & $\ldots$ & $\ldots$ \\
\hline $\begin{array}{l}\text { Italy } \\
\text { Kosovo (UN }\end{array}$ & $\ldots$ & $\ldots$ & $\ldots$ & $\ldots$ & $\ldots$ & $\cdots$ & $\ldots$ & $\ldots$ & $\ldots$ & $\ldots$ & $\ldots$ \\
\hline $\mathrm{R} / 1244 / 99)$ & $\ldots$ & $\ldots$ & $\ldots$ & $\ldots$ & $\ldots$ & $\ldots$ & $\ldots$ & $\ldots$ & $\ldots$ & $\ldots$ & $\ldots$ \\
\hline Latvia & $\ldots$ & $\ldots$ & $\ldots$ & $\ldots$ & $\ldots$ & $\ldots$ & $\ldots$ & $\ldots$ & $\ldots$ & $\ldots$ & $\ldots$ \\
\hline Lithuania & 44.4 & $\ldots$ & $\ldots$ & $\ldots$ & $\ldots$ & $\ldots$ & $\ldots$ & $\ldots$ & $\ldots$ & $\ldots$ & 0.2 \\
\hline Luxembourg & $\ldots$ & $\ldots$ & $\ldots$ & $\ldots$ & $\ldots$ & ... & $\ldots$ & $\ldots$ & $\ldots$ & $\ldots$ & $\ldots$ \\
\hline Moldova & $\ldots$ & $\ldots$ & $\ldots$ & $\ldots$ & $\ldots$ & $\ldots$ & $\ldots$ & $\ldots$ & $\ldots$ & $\ldots$ & $\ldots$ \\
\hline Montenegro & $\ldots$ & $\ldots$ & & $\ldots$ & $\ldots$ & $\ldots$ & $\ldots$ & $\ldots$ & $\ldots$ & & $\ldots$ \\
\hline Netherlands & 5.0 & $\ldots$ & 15.8 & 34.7 & 97.6 & 16.2 & $\ldots$ & 57.7 & 33.4 & 38.9 & $\ldots$ \\
\hline North Macedonia & $\ldots$ & $\ldots$ & $\ldots$ & $\ldots$ & $\ldots$ & $\ldots$ & $\ldots$ & $\ldots$ & $\ldots$ & $\ldots$ & $\ldots$ \\
\hline Norway & $\ldots$ & $\ldots$ & $\ldots$ & $\ldots$ & $\ldots$ & $\ldots$ & $\ldots$ & $\ldots$ & $\ldots$ & $\ldots$ & $\ldots$ \\
\hline Poland & 67.0 & $\ldots$ & 7.6 & 5.9 & 100.0 & 72.5 & 18.6 & $\ldots$ & 13.9 & $\ldots$ & 0.2 \\
\hline Portugal & 11.1 & $\ldots$ & 42.9 & 0.9 & 100.0 & 37.4 & 39.5 & $\ldots$ & 17.9 & $\ldots$ & 0.9 \\
\hline Romania & $\ldots$ & $\ldots$ & $\ldots$ & $\ldots$ & 0.0 & $\ldots$ & $\ldots$ & $\ldots$ & $\ldots$ & 0.0 & $\ldots$ \\
\hline Russian Federation & $\ldots$ & $\ldots$ & $\ldots$ & $\ldots$ & & $\ldots$ & $\ldots$ & $\ldots$ & $\ldots$ & $\ldots$ & $\ldots$ \\
\hline Serbia & 10.3 & 0.0 & 4.2 & 0.3 & 100.0 & 65.8 & 7.3 & $\ldots$ & 29.2 & $\ldots$ & 0.4 \\
\hline Slovak Republic & $\ldots$ & $\ldots$ & $\ldots$ & $\ldots$ & $\ldots$ & $\ldots$ & $\ldots$ & $\cdots$ & $\ldots$ & $\ldots$ & $\ldots$ \\
\hline Slovenia & $\ldots$ & $\ldots$ & $\cdots$ & $\cdots$ & $\cdots$ & ... & $\cdots$ & $\cdots$ & $\cdots$ & $\cdots$ & $\cdots$ \\
\hline Spain & $\ldots$ & & $\ldots$ & $\ldots$ & $\ldots$ & $\ldots$ & $\ldots$ & $\ldots$ & $\ldots$ & $\ldots$ & $\ldots$ \\
\hline Sweden & 12.4 & 0.0 & 8.4 & 13.0 & 16.5 & 37.4 & $\ldots$ & 9.3 & 22.0 & 1.5 & 19.1 \\
\hline Switzerland & 17.5 & $\ldots$ & 85.5 & 3.6 & 98.1 & 5.7 & $\ldots$ & $\ldots$ & 5.2 & 13.3 & 0.0 \\
\hline Turkey & 82.7 & $\ldots$ & 33.3 & 23.1 & $\ldots$ & 3.4 & $\ldots$ & $\ldots$ & 29.9 & $\ldots$ & 10.3 \\
\hline Ukraine & 5.9 & $\ldots$ & 34.8 & $\ldots$ & $\ldots$ & $\ldots$ & $\ldots$ & $\ldots$ & 17.4 & $\ldots$ & $\ldots$ \\
\hline UK: England \& Wales & 20.4 & $\ldots$ & 11.2 & 33.2 & $\ldots$ & 11.9 & $\ldots$ & $\ldots$ & 18.8 & $\ldots$ & 36.2 \\
\hline UK: Northern Ireland & & $\ldots$ & & & $\ldots$ & $\ldots$ & $\ldots$ & $\ldots$ & $\ldots$ & $\ldots$ & $\ldots$ \\
\hline UK: Scotland & 10.1 & 9.6 & 23.0 & 31.3 & 90.0 & $\ldots$ & $\ldots$ & $\ldots$ & 30.3 & $\ldots$ & $\ldots$ \\
\hline Mean & 29.8 & 1.7 & 22.9 & 12.1 & 69.7 & 37.6 & 11.0 & 12.6 & 26.2 & 12.2 & 5.1 \\
\hline Median & 18.9 & 0.6 & 11.4 & 7.6 & 97.1 & 37.4 & 7.3 & 4.5 & 24.4 & 7.4 & 0.4 \\
\hline Minimum & 1.7 & 0.0 & 0.0 & 0.0 & 0.0 & 3.4 & 0.0 & 0.0 & 3.2 & 0.0 & 0.0 \\
\hline Maximum & 111.8 & 9.6 & 85.5 & 34.7 & 100.0 & 80.2 & 39.5 & 57.7 & 90.0 & 38.9 & 36.2 \\
\hline
\end{tabular}


Table 3.2.3.18 Total persons receiving sanctions/measures in 2015 - Forgery of documents

\begin{tabular}{|c|c|c|c|c|c|c|c|c|c|c|c|}
\hline & \multirow[b]{2}{*}{ 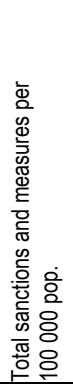 } & \multirow[b]{2}{*}{ 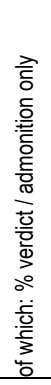 } & \multirow[b]{2}{*}{ 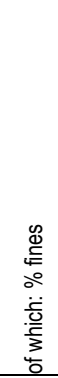 } & \multicolumn{2}{|c|}{$\begin{array}{l}\text { of which: \% } \\
\text { non-custodial } \\
\text { sanctions and } \\
\text { measures }\end{array}$} & \multicolumn{3}{|c|}{$\begin{array}{l}\text { of which: \% suspended } \\
\text { custodial sanctions and } \\
\text { measures }\end{array}$} & \multicolumn{2}{|c|}{$\begin{array}{l}\text { of which: \% un- } \\
\text { suspended custo- } \\
\text { dial sanctions and } \\
\text { measures }\end{array}$} & \multirow[b]{2}{*}{ 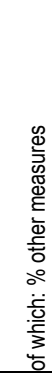 } \\
\hline & & & & 要 & 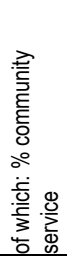 & 要 & 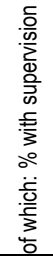 & 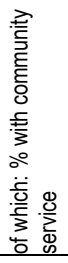 & 要 & 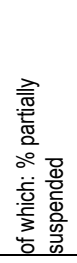 & \\
\hline Albania & $\ldots$ & $\ldots$ & $\ldots$ & $\ldots$ & $\ldots$ & $\ldots$ & $\ldots$ & $\ldots$ & $\ldots$ & $\ldots$ & $\ldots$ \\
\hline Armenia & $\ldots$ & $\ldots$ & $\ldots$ & $\ldots$ & $\ldots$ & $\ldots$ & $\ldots$ & $\ldots$ & $\ldots$ & $\ldots$ & $\ldots$ \\
\hline Austria & 9.5 & $\ldots$ & 19.3 & $\ldots$ & $\ldots$ & 0.0 & $\ldots$ & $\ldots$ & 5.5 & 8.9 & 1.6 \\
\hline Azerbaijan & & $\ldots$ & $\ldots$ & $\ldots$ & $\ldots$ & $\ldots$ & $\ldots$ & $\ldots$ & $\ldots$ & $\ldots$ & $\ldots$ \\
\hline Belgium & 14.7 & $\ldots$ & 3.5 & 15.3 & 100.0 & 39.2 & 2.6 & $\ldots$ & 35.4 & $\ldots$ & 6.5 \\
\hline $\begin{array}{l}\text { Bosnia-Herzegovina } \\
\text { Bulqaria }\end{array}$ & $\cdots$ & $\cdots$ & $\cdots$ & $\cdots$ & $\cdots$ & $\cdots$ & $\cdots$ & $\ldots$ & $\cdots$ & $\ldots$ & $\cdots$ \\
\hline $\begin{array}{l}\text { Bulgaria } \\
\text { Croatia }\end{array}$ & 18.4 & 0.0 & 0.5 & 0.5 & $\begin{array}{l}\cdots \\
\ldots\end{array}$ & 88.9 & 0.4 & $\begin{array}{l}\cdots \\
5.6\end{array}$ & $\begin{array}{r}\ldots \\
10.0\end{array}$ & $\begin{array}{r}\cdots \\
3.8\end{array}$ & 0.0 \\
\hline Cyprus & $\ldots$ & & $\ldots$ & $\ldots$ & $\ldots$ & & $\ldots$ & $\ldots$ & $\ldots$ & $\ldots$ & \\
\hline Czech Republic & 3.1 & 0.9 & 3.0 & 31.2 & 12.6 & 51.5 & 3.5 & $\ldots$ & 13.3 & $\ldots$ & 0.0 \\
\hline Denmark & $\ldots$ & $\ldots$ & $\ldots$ & $\ldots$ & $\ldots$ & $\ldots$ & $\ldots$ & $\ldots$ & $\ldots$ & $\ldots$ & $\ldots$ \\
\hline Estonia & $\ldots$ & $\ldots$ & $\ldots$ & $\ldots$ & $\ldots$ & $\ldots$ & $\ldots$ & $\ldots$ & $\ldots$ & $\ldots$ & $\ldots$ \\
\hline Finland & 14.2 & 0.0 & 78.6 & 1.4 & 90.9 & 10.3 & 1.3 & 2.5 & 8.3 & $\ldots$ & 1.4 \\
\hline France & 7.0 & 2.0 & 22.4 & 9.5 & 24.5 & 48.9 & 0.1 & $\ldots$ & 17.2 & 10.1 & $\ldots$ \\
\hline Georgia & 3.1 & $\ldots$ & $\ldots$ & $\ldots$ & $\ldots$ & $\ldots$ & $\ldots$ & $\ldots$ & $\ldots$ & $\ldots$ & $\ldots$ \\
\hline Germany & 19.5 & 1.4 & 77.9 & 4.3 & $\ldots$ & 12.3 & $\ldots$ & $\ldots$ & 4.2 & $\ldots$ & $\ldots$ \\
\hline Hungary & 66.1 & 3.6 & 28.0 & 39.0 & 30.1 & 21.1 & 5.7 & 0.0 & 8.2 & 0.0 & 0.0 \\
\hline Iceland & $\ldots$ & $\ldots$ & $\ldots$ & $\ldots$ & $\ldots$ & $\ldots$ & $\ldots$ & $\ldots$ & $\ldots$ & $\ldots$ & $\ldots$ \\
\hline $\begin{array}{l}\text { Italy } \\
\text { Kosovo (UN }\end{array}$ & $\ldots$ & $\ldots$ & $\ldots$ & $\ldots$ & $\ldots$ & $\ldots$ & $\ldots$ & $\ldots$ & $\ldots$ & $\ldots$ & $\ldots$ \\
\hline$R / 1244 / 99)$ & $\ldots$ & $\ldots$ & $\ldots$ & $\ldots$ & $\cdots$ & $\ldots$ & $\ldots$ & $\ldots$ & $\ldots$ & $\ldots$ & $\ldots$ \\
\hline Latvia & $\ldots$ & $\ldots$ & $\ldots$ & $\ldots$ & $\ldots$ & $\ldots$ & $\ldots$ & $\ldots$ & $\ldots$ & $\ldots$ & $\ldots$ \\
\hline Lithuania & 29.3 & $\ldots$ & $\ldots$ & $\ldots$ & $\ldots$ & $\ldots$ & $\ldots$ & $\ldots$ & $\ldots$ & $\ldots$ & 0.0 \\
\hline Luxembourg & $\ldots$ & $\ldots$ & $\ldots$ & $\ldots$ & $\ldots$ & $\ldots$ & $\ldots$ & $\ldots$ & $\ldots$ & $\ldots$ & $\ldots$ \\
\hline Moldova & $\ldots$ & $\ldots$ & $\ldots$ & $\ldots$ & ... & ... & $\ldots$ & $\ldots$ & $\ldots$ & $\ldots$ & $\ldots$ \\
\hline Montenegro & $\ldots$ & $\ldots$ & $\ldots$ & $\ldots$ & $\ldots$ & $\ldots$ & $\ldots$ & $\ldots$ & $\ldots$ & $\ldots$ & $\ldots$ \\
\hline Netherlands & 9.3 & $\ldots$ & 6.2 & 24.9 & 98.7 & 20.5 & $\ldots$ & 67.1 & 48.4 & 24.3 & $\ldots$ \\
\hline North Macedonia & $\ldots$ & $\ldots$ & $\ldots$ & $\ldots$ & $\ldots$ & $\ldots$ & $\ldots$ & $\ldots$ & $\ldots$ & $\ldots$ & $\ldots$ \\
\hline Norway & $\ldots$ & $\ldots$ & $\ldots$ & $\ldots$ & $\ldots$ & $\ldots$ & $\ldots$ & $\ldots$ & $\ldots$ & $\ldots$ & $\ldots$ \\
\hline Poland & 15.7 & $\ldots$ & 46.1 & 8.2 & 100.0 & 42.2 & 8.6 & $\ldots$ & 3.6 & $\ldots$ & 0.0 \\
\hline Portugal & 7.7 & 2.4 & 74.1 & 1.8 & 100.0 & 14.9 & 26.3 & $\ldots$ & 5.9 & $\ldots$ & 0.9 \\
\hline Romania & $\ldots$ & $\ldots$ & $\ldots$ & $\ldots$ & $\ldots$ & $\ldots$ & $\ldots$ & $\ldots$ & $\ldots$ & $\ldots$ & $\ldots$ \\
\hline Russian Federation & $\ldots$ & $\ldots$ & $\ldots$ & $\ldots$ & $\ldots$ & $\ldots$ & $\ldots$ & $\ldots$ & $\ldots$ & $\ldots$ & $\ldots$ \\
\hline Serbia & 15.3 & 0.1 & 1.6 & 11.8 & 97.7 & 70.0 & 2.6 & $\ldots$ & 16.3 & $\ldots$ & 0.2 \\
\hline Slovak Republic & $\ldots$ & $\ldots$ & $\ldots$ & $\ldots$ & $\ldots$ & $\ldots$ & $\ldots$ & $\ldots$ & $\ldots$ & $\ldots$ & $\ldots$ \\
\hline Slovenia & $\ldots$ & $\ldots$ & $\ldots$ & $\ldots$ & $\ldots$ & $\ldots$ & $\ldots$ & $\ldots$ & $\ldots$ & $\ldots$ & $\ldots$ \\
\hline Spain & $\ldots$ & & $\ldots$ & $\ldots$ & $\ldots$ & $\ldots$ & $\ldots$ & $\ldots$ & $\ldots$ & $\ldots$ & $\ldots$ \\
\hline Sweden & 7.4 & 0.0 & 6.7 & 7.9 & 8.8 & 60.4 & $\ldots$ & 2.1 & 17.5 & 1.6 & 7.5 \\
\hline Switzerland & 9.9 & $\ldots$ & 94.9 & 2.1 & 100.0 & 0.2 & $\ldots$ & $\ldots$ & 2.8 & 4.3 & 0.0 \\
\hline Turkey & 36.9 & $\ldots$ & 4.7 & 32.4 & $\ldots$ & 6.4 & $\ldots$ & $\ldots$ & 42.1 & $\ldots$ & 14.5 \\
\hline Ukraine & 2.3 & $\ldots$ & 57.6 & $\ldots$ & $\ldots$ & $\ldots$ & $\ldots$ & $\ldots$ & 1.0 & $\ldots$ & $\ldots$ \\
\hline UK: England \& Wales & 1.0 & $\ldots$ & 7.6 & 11.4 & $\ldots$ & 13.8 & $\ldots$ & $\ldots$ & 20.4 & $\ldots$ & 54.4 \\
\hline $\begin{array}{l}\text { UK: Northern Ireland } \\
\text { UK: Scotland }\end{array}$ & $\cdots$ & $\ldots$ & $\ldots$ & $\cdots$ & $\cdots$ & $\cdots$ & $\cdots$ & $\cdots$ & $\ldots$ & $\cdots$ & $\ldots$ \\
\hline Mean & 15.3 & 1.2 & 31.3 & 13.4 & 69.4 & 31.3 & 5.7 & 15.5 & 15.3 & 7.6 & 6.2 \\
\hline Median & 9.9 & 0.9 & 19.3 & 9.5 & 97.7 & 20.8 & 2.6 & 2.5 & 10.0 & 4.3 & 0.5 \\
\hline Minimum & 1.0 & 0.0 & 0.5 & 0.5 & 8.8 & 0.0 & 0.1 & 0.0 & 1.0 & 0.0 & 0.0 \\
\hline Maximum & 66.1 & 3.6 & 94.9 & 39.0 & 100.0 & 88.9 & 26.3 & 67.1 & 48.4 & 24.3 & 54.4 \\
\hline
\end{tabular}


Table 3.2.3.19 Total persons receiving sanctions/measures in 2015 - Money laundering

\begin{tabular}{|c|c|c|c|c|c|c|c|c|c|c|c|}
\hline & \multirow[b]{2}{*}{ 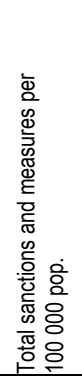 } & \multirow{2}{*}{ 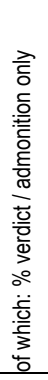 } & \multirow[b]{2}{*}{ 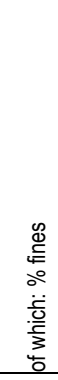 } & \multicolumn{2}{|c|}{$\begin{array}{l}\text { of which: } \% \\
\text { non-custodial } \\
\text { sanctions and } \\
\text { measures }\end{array}$} & \multicolumn{3}{|c|}{$\begin{array}{l}\text { of which: } \% \text { suspended } \\
\text { custodial sanctions and } \\
\text { measures }\end{array}$} & \multicolumn{2}{|c|}{$\begin{array}{l}\text { of which: \% un- } \\
\text { suspended custo- } \\
\text { dial sanctions and } \\
\text { measures }\end{array}$} & \multirow[b]{2}{*}{ 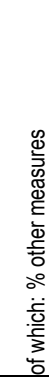 } \\
\hline & & & & 푬 & 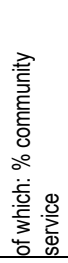 & 푬 & 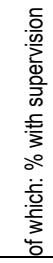 & 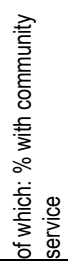 & 要 & 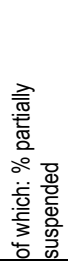 & \\
\hline Albania & $\ldots$ & $\ldots$ & $\ldots$ & $\ldots$ & $\ldots$ & $\ldots$ & $\ldots$ & $\ldots$ & $\ldots$ & $\ldots$ & $\ldots$ \\
\hline Armenia & $\ldots$ & $\ldots$ & $\ldots$ & $\ldots$ & $\ldots$ & $\ldots$ & $\ldots$ & $\ldots$ & $\ldots$ & $\ldots$ & $\ldots$ \\
\hline Austria & 0.4 & $\ldots$ & 6.5 & $\ldots$ & $\ldots$ & 58.1 & $\ldots$ & $\ldots$ & 25.8 & 50.0 & 9.7 \\
\hline Azerbaijan & $\ldots$ & $\ldots$ & $\ldots$ & $\ldots$ & $\ldots$ & $\ldots$ & $\ldots$ & $\ldots$ & $\ldots$ & $\ldots$ & $\ldots$ \\
\hline Belgium & 5.5 & $\ldots$ & 20.8 & 11.5 & 100.0 & 31.3 & 1.6 & $\ldots$ & 33.1 & $\ldots$ & 3.2 \\
\hline Bosnia-Herzegovina & $\ldots$ & $\ldots$ & $\ldots$ & $\ldots$ & $\ldots$ & $\ldots$ & $\ldots$ & $\ldots$ & $\cdots$ & $\ldots$ & $\ldots$ \\
\hline Bulgaria & 0.3 & 0.0 & 0.0 & 0.0 & $\ldots$ & 78.3 & $\ldots$ & $\ldots$ & 21.7 & $\ldots$ & 0.0 \\
\hline Croatia & 0.2 & 0.0 & 0.0 & 0.0 & $\ldots$ & 87.5 & 0.0 & 0.0 & 12.5 & 100.0 & $\ldots$ \\
\hline Cyprus & $\ldots$ & $\ldots$ & $\ldots$ & $\ldots$ & $\ldots$ & $\ldots$ & $\ldots$ & $\ldots$ & $\ldots$ & $\ldots$ & $\ldots$ \\
\hline Czech Republic & 0.6 & 0.0 & 0.0 & 1.5 & 100.0 & 80.6 & 11.1 & $\ldots$ & 16.4 & $\ldots$ & 3.0 \\
\hline Denmark & $\ldots$ & $\ldots$ & $\cdots$ & $\cdots$ & $\ldots$ & $\ldots$ & $\ldots$ & $\ldots$ & $\ldots$ & $\ldots$ & $\ldots$ \\
\hline $\begin{array}{l}\text { Estonia } \\
\text { Finland }\end{array}$ & $\ldots$ & $\ldots$ & $\cdots$ & $\ldots$ & $\ldots$ & $\ldots$ & $\ldots$ & $\ldots$ & & $\ldots$ & $\because \cdots$ \\
\hline $\begin{array}{l}\text { Finland } \\
\text { France }\end{array}$ & 1.8 & 0.0 & 2.1 & 5.2 & 100.0 & 83.3 & 2.5 & 1.3 & 20.8 & $\ldots$ & 2.1 \\
\hline $\begin{array}{l}\text { France } \\
\text { Georgia }\end{array}$ & $\ldots$ & $\ldots$ & $\ldots$ & $\ldots$ & $\ldots$ & $\ldots$ & $\ldots$ & $\ldots$ & $\ldots$ & $\ldots$ & $\ldots$ \\
\hline $\begin{array}{l}\text { Georgia } \\
\text { Germany }\end{array}$ & $\ldots$ & $\ldots$ & $\ldots$ & $\ldots$ & $\ldots$ & $\ldots$ & $\ldots$ & $\ldots$ & $\ldots$ & $\ldots$ & $\ldots$ \\
\hline Germany & 1.0 & 7.9 & 70.4 & 2.0 & $\ldots$ & 17.7 & $\ldots$ & $\ldots$ & 2.0 & $\ldots$ & $\ldots$ \\
\hline Hungary & 0.2 & 6.7 & 13.3 & 26.7 & 50.0 & 46.7 & 0.0 & 0.0 & 6.7 & 0.0 & 0.0 \\
\hline Iceland & $\ldots$ & $\ldots$ & $\ldots$ & $\ldots$ & $\ldots$ & $\ldots$ & $\ldots$ & $\ldots$ & $\ldots$ & $\ldots$ & $\ldots$ \\
\hline $\begin{array}{l}\text { Italy } \\
\text { Kosovo (UN }\end{array}$ & $\ldots$ & $\ldots$ & $\ldots$ & ... & ... & $\ldots$ & $\ldots$ & $\ldots$ & $\ldots$ & $\ldots$ & $\ldots$ \\
\hline $\mathrm{R} / 1244 / 99)$ & $\ldots$ & $\ldots$ & $\ldots$ & $\ldots$ & $\ldots$ & $\ldots$ & $\ldots$ & $\ldots$ & $\ldots$ & $\ldots$ & $\ldots$ \\
\hline Latvia & $\ldots$ & $\ldots$ & $\ldots$ & $\ldots$ & $\ldots$ & $\ldots$ & $\ldots$ & $\ldots$ & $\ldots$ & $\ldots$ & $\ldots$ \\
\hline Lithuania & 0.7 & $\ldots$ & $\ldots$ & $\ldots$ & $\ldots$ & $\ldots$ & $\ldots$ & $\ldots$ & $\ldots$ & $\ldots$ & 0.0 \\
\hline Luxembourg & $\ldots$ & $\ldots$ & $\ldots$ & $\ldots$ & $\ldots$ & $\ldots$ & $\ldots$ & $\ldots$ & $\ldots$ & $\ldots$ & $\ldots$ \\
\hline Moldova & $\ldots$ & $\ldots$ & $\ldots$ & $\ldots$ & $\ldots$ & $\ldots$ & $\ldots$ & $\ldots$ & $\ldots$ & $\ldots$ & $\ldots$ \\
\hline Montenegro & $\ldots$ & $\ldots$ & $\ldots$ & $\ldots$ & $\ldots$ & $\ldots$ & $\ldots$ & $\ldots$ & $\ldots$ & $\ldots$ & $\ldots$ \\
\hline Netherlands & 2.4 & $\ldots$ & 6.5 & 31.1 & 99.2 & 21.8 & $\ldots$ & 67.8 & 40.6 & 32.7 & $\ldots$ \\
\hline North Macedonia & $\ldots$ & $\ldots$ & $\ldots$ & $\ldots$ & $\ldots$ & $\ldots$ & $\ldots$ & $\ldots$ & $\ldots$ & $\ldots$ & $\ldots$ \\
\hline Norway & $\ldots$ & $\ldots$ & $\ldots$ & $\ldots$ & $\ldots$ & $\ldots$ & $\ldots$ & $\ldots$ & $\ldots$ & $\ldots$ & $\ldots$ \\
\hline Poland & 0.3 & $\ldots$ & 1.7 & 4.2 & 100.0 & 89.2 & 25.2 & $\ldots$ & 10.8 & $\ldots$ & 0.0 \\
\hline Portugal & 0.3 & $\ldots$ & $\ldots$ & $\ldots$ & $\ldots$ & 79.4 & 44.4 & $\ldots$ & 20.6 & $\ldots$ & $\ldots$ \\
\hline Romania & $\ldots$ & $\ldots$ & $\ldots$ & $\ldots$ & $\ldots$ & $\ldots$ & $\ldots$ & $\ldots$ & $\ldots$ & $\ldots$ & $\ldots$ \\
\hline Russian Federation & $\ldots$ & $\ldots$ & $\ldots$ & $\ldots$ & $\ldots$ & $\ldots$ & $\ldots$ & $\ldots$ & $\ldots$ & $\ldots$ & $\ldots$ \\
\hline Serbia & 0.0 & 0.0 & 0.0 & 0.0 & $\ldots$ & 100.0 & 0.0 & $\ldots$ & 0.0 & $\ldots$ & 0.0 \\
\hline Slovak Republic & $\ldots$ & $\ldots$ & $\ldots$ & $\ldots$ & $\ldots$ & $\ldots$ & $\ldots$ & $\ldots$ & $\ldots$ & $\ldots$ & $\ldots$ \\
\hline Slovenia & $\ldots$ & $\ldots$ & $\ldots$ & $\cdots$ & $\cdots$ & $\cdots$ & $\cdots$ & $\cdots$ & $\cdots$ & $\cdots$ & $\ldots$ \\
\hline Spain & & & & & & 120 & $\cdots$ & $\ldots$ & & & \\
\hline Sweden & 1.7 & 0.0 & 8.0 & 15.4 & 8.0 & 42.0 & $\ldots$ & 8.8 & 24.7 & 0.0 & 9.9 \\
\hline Switzerland & 0.9 & $\ldots$ & 84.2 & 5.3 & 25.0 & 7.9 & $\ldots$ & $\ldots$ & 2.6 & 0.0 & 0.0 \\
\hline Turkey & 0.1 & $\ldots$ & 21.5 & 26.2 & $\ldots$ & 4.6 & $\ldots$ & $\ldots$ & 35.4 & $\ldots$ & 12.3 \\
\hline Ukraine & 0.0 & $\ldots$ & 0.0 & $\ldots$ & $\ldots$ & $\ldots$ & $\ldots$ & $\ldots$ & 40.0 & $\ldots$ & 0.0 \\
\hline UK: England \& Wales & 1.9 & $\ldots$ & 5.4 & 22.4 & $\ldots$ & 36.3 & $\ldots$ & $\ldots$ & 43.8 & $\ldots$ & 0.0 \\
\hline $\begin{array}{l}\text { UK: Northern Ireland } \\
\text { UK: Scotland }\end{array}$ & $\ldots$ & $\begin{array}{l}\ldots \\
\ldots\end{array}$ & $\cdots$ & $\begin{array}{l}\ldots \\
\ldots \\
\end{array}$ & $\begin{array}{l}\ldots \\
\ldots\end{array}$ & $\begin{array}{l}\ldots \\
\ldots \\
\end{array}$ & $\begin{array}{l}\ldots \\
\ldots\end{array}$ & $\begin{array}{l}\ldots \\
\ldots\end{array}$ & $\begin{array}{l}\ldots \\
\ldots\end{array}$ & $\begin{array}{l}\ldots \\
\ldots\end{array}$ & $\cdots$ \\
\hline Mean & 1.0 & 1.8 & 15.0 & 10.8 & 72.8 & 54.0 & 10.6 & 15.6 & 21.0 & 30.5 & 2.9 \\
\hline Median & 0.5 & 0.0 & 5.9 & 5.2 & 99.6 & 52.4 & 2.0 & 1.3 & 20.8 & 16.4 & 0.0 \\
\hline Minimum & 0.0 & 0.0 & 0.0 & 0.0 & 8.0 & 4.6 & 0.0 & 0.0 & 0.0 & 0.0 & 0.0 \\
\hline Maximum & 5.5 & 7.9 & 84.2 & 31.1 & 100.0 & 100.0 & 44.4 & 67.8 & 43.8 & 100.0 & 12.3 \\
\hline
\end{tabular}


Table 3.2.3.20 Total persons receiving sanctions/measures in 2015 - Corruption in the public sector

\begin{tabular}{|c|c|c|c|c|c|c|c|c|c|c|c|}
\hline & \multirow[b]{2}{*}{ 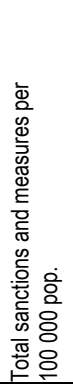 } & \multirow{2}{*}{ 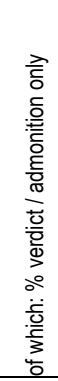 } & \multirow[b]{2}{*}{ 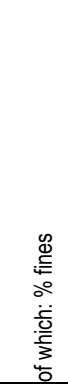 } & \multicolumn{2}{|c|}{$\begin{array}{l}\text { of which: \% } \\
\text { non-custodial } \\
\text { sanctions and } \\
\text { measures }\end{array}$} & \multicolumn{3}{|c|}{$\begin{array}{l}\text { of which: \% suspended } \\
\text { custodial sanctions and } \\
\text { measures }\end{array}$} & \multicolumn{2}{|c|}{$\begin{array}{l}\text { of which: } \% \text { un- } \\
\text { suspended custo- } \\
\text { dial sanctions and } \\
\text { measures }\end{array}$} & \multirow[b]{2}{*}{ 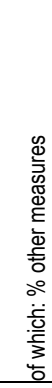 } \\
\hline & & & & 要 & 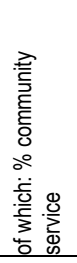 & 퓸 & 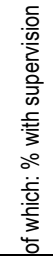 & 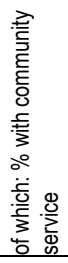 & 푱 & 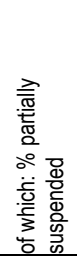 & \\
\hline Albania & $\ldots$ & $\ldots$ & $\ldots$ & $\ldots$ & $\ldots$ & $\ldots$ & $\ldots$ & $\ldots$ & $\ldots$ & $\ldots$ & $\ldots$ \\
\hline Armenia & $\ldots$ & $\ldots$ & $\ldots$ & $\ldots$ & $\ldots$ & $\ldots$ & $\ldots$ & $\ldots$ & $\ldots$ & $\ldots$ & $\ldots$ \\
\hline Austria & 1.5 & $\ldots$ & 10.7 & $\ldots$ & $\ldots$ & 64.9 & $\ldots$ & $\ldots$ & 6.9 & 66.7 & 17.6 \\
\hline Azerbaijan & $\ldots$ & $\ldots$ & $\ldots$ & $\ldots$ & $\ldots$ & $\ldots$ & $\ldots$ & $\ldots$ & $\ldots$ & $\ldots$ & $\ldots$ \\
\hline Belgium & 0.5 & $\ldots$ & 8.9 & 5.4 & 100.0 & 66.1 & 0.0 & $\ldots$ & 8.9 & $\ldots$ & 10.7 \\
\hline Bosnia-Herzegovina & $\ldots$ & $\ldots$ & $\ldots$ & $\ldots$ & $\ldots$ & & $\ldots$ & $\ldots$ & $\ldots$ & $\ldots$ & $\ldots$ \\
\hline Bulgaria & 1.1 & $\ldots$ & 0.0 & 24.4 & $\ldots$ & 69.2 & $\ldots$ & $\ldots$ & 6.4 & $\ldots$ & 0.0 \\
\hline Croatia & 5.1 & 0.9 & 0.9 & 0.0 & $\ldots$ & 59.1 & 4.7 & 42.5 & 39.1 & 13.1 & $\ldots$ \\
\hline Cyprus & & $\ldots$ & & $\ldots$ & $\ldots$ & & & $\ldots$ & & $\ldots$ & $\ldots$ \\
\hline Czech Republic & 0.9 & 0.0 & 12.6 & 0.0 & $\ldots$ & 73.7 & 5.7 & $\ldots$ & 12.6 & $\ldots$ & 1.1 \\
\hline Denmark & $\ldots$ & $\ldots$ & $\ldots$ & $\ldots$ & $\ldots$ & $\ldots$ & $\ldots$ & $\ldots$ & $\ldots$ & $\ldots$ & $\ldots$ \\
\hline Estonia & $\ldots$ & $\ldots$ & $\ldots$ & $\ldots$ & $\ldots$ & & $\ldots$ & $\ldots$ & & $\ldots$ & $\ldots$ \\
\hline Finland & 0.1 & 0.0 & 33.3 & 0.0 & $\ldots$ & 66.7 & 0.0 & 0.0 & 0.0 & $\ldots$ & 0.0 \\
\hline France & 0.3 & 2.0 & 13.6 & 23.6 & 27.7 & 15.1 & 0.0 & 0.0 & 36.2 & 4.2 & $\ldots$ \\
\hline Georgia & 3.7 & $\ldots$ & 11.6 & $\ldots$ & $\ldots$ & 39.1 & $\ldots$ & $\ldots$ & 49.3 & 0.0 & $\ldots$ \\
\hline Germany & 0.2 & 4.5 & 51.4 & 3.4 & $\ldots$ & 33.0 & $\ldots$ & $\ldots$ & 7.8 & $\ldots$ & $\ldots$ \\
\hline Hungary & 1.8 & 22.2 & 15.3 & 9.1 & 18.8 & 37.5 & 0.0 & 0.0 & 15.9 & 0.0 & 0.0 \\
\hline Iceland & $\ldots$ & $\ldots$ & $\ldots$ & $\ldots$ & $\ldots$ & $\ldots$ & $\ldots$ & $\ldots$ & $\ldots$ & $\ldots$ & $\ldots$ \\
\hline $\begin{array}{l}\text { Italy } \\
\text { Kosovo (UN }\end{array}$ & $\ldots$ & $\ldots$ & $\ldots$ & $\ldots$ & $\ldots$ & $\ldots$ & $\ldots$ & $\ldots$ & $\ldots$ & $\ldots$ & $\ldots$ \\
\hline $\mathrm{R} / 1244 / 99)$ & $\ldots$ & $\ldots$ & $\ldots$ & $\ldots$ & $\ldots$ & $\ldots$ & $\ldots$ & $\ldots$ & $\ldots$ & $\ldots$ & $\ldots$ \\
\hline Latvia & $\ldots$ & $\ldots$ & $\ldots$ & $\ldots$ & $\ldots$ & $\ldots$ & $\ldots$ & $\ldots$ & $\ldots$ & $\ldots$ & $\ldots$ \\
\hline Lithuania & 26.8 & $\ldots$ & $\ldots$ & $\ldots$ & $\ldots$ & $\ldots$ & $\ldots$ & $\ldots$ & $\ldots$ & $\ldots$ & 0.4 \\
\hline Luxembourg & $\ldots$ & $\ldots$ & $\ldots$ & $\ldots$ & $\ldots$ & $\ldots$ & $\ldots$ & $\ldots$ & $\ldots$ & $\ldots$ & $\ldots$ \\
\hline Moldova & $\ldots$ & $\ldots$ & $\ldots$ & $\ldots$ & $\ldots$ & $\ldots$ & $\ldots$ & $\ldots$ & ... & ... & $\ldots$ \\
\hline Montenegro & $\ldots$ & $\ldots$ & $\ldots$ & $\ldots$ & $\ldots$ & $\ldots$ & $\ldots$ & $\ldots$ & $\ldots$ & $\ldots$ & $\ldots$ \\
\hline Netherlands & 0.0 & $\ldots$ & $\ldots$ & $\ldots$ & $\ldots$ & $\ldots$ & $\ldots$ & $\ldots$ & $\ldots$ & $\ldots$ & $\ldots$ \\
\hline North Macedonia & $\ldots$ & $\ldots$ & $\ldots$ & $\ldots$ & $\ldots$ & $\ldots$ & $\ldots$ & $\ldots$ & $\ldots$ & $\ldots$ & $\ldots$ \\
\hline Norway & $\ldots$ & $\ldots$ & $\ldots$ & $\ldots$ & $\ldots$ & $\ldots$ & $\ldots$ & $\ldots$ & $\ldots$ & $\ldots$ & $\ldots$ \\
\hline Poland & 4.6 & $\ldots$ & 6.9 & 0.4 & 100.0 & 86.9 & 7.8 & $\ldots$ & 5.8 & $\ldots$ & 0.1 \\
\hline Portugal & 0.3 & $\ldots$ & 19.4 & $\ldots$ & $\ldots$ & 61.1 & 40.9 & $\ldots$ & 16.7 & ... & $\ldots$ \\
\hline Romania & $\ldots$ & $\ldots$ & $\ldots$ & $\ldots$ & $\ldots$ & $\ldots$ & $\ldots$ & $\ldots$ & $\ldots$ & $\ldots$ & $\ldots$ \\
\hline Russian Federation & & $\ldots$ & & $\ldots$ & $\ldots$ & & & $\ldots$ & & $\ldots$ & $\ldots$ \\
\hline Serbia & 1.2 & 0.0 & 4.8 & 0.0 & $\ldots$ & 59.0 & 32.7 & $\ldots$ & 32.5 & $\ldots$ & 3.6 \\
\hline Slovak Republic & $\ldots$ & $\ldots$ & $\ldots$ & $\ldots$ & $\ldots$ & $\ldots$ & $\ldots$ & $\ldots$ & $\ldots$ & $\ldots$ & $\ldots$ \\
\hline Slovenia & $\ldots$ & $\ldots$ & $\ldots$ & $\ldots$ & $\ldots$ & $\ldots$ & $\ldots$ & $\ldots$ & $\ldots$ & $\ldots$ & $\ldots$ \\
\hline Spain & $\ldots$ & $\ldots$ & $\ldots$ & $\ldots$ & $\ldots$ & $\ldots$ & $\ldots$ & $\ldots$ & $\ldots$ & $\ldots$ & $\ldots$ \\
\hline Sweden & 0.1 & 0.0 & 36.4 & 0.0 & $\ldots$ & 63.6 & $\ldots$ & 14.3 & 0.0 & $\ldots$ & 0.0 \\
\hline Switzerland & 0.6 & $\ldots$ & 100.0 & 0.0 & $\ldots$ & 0.0 & $\ldots$ & $\ldots$ & 0.0 & $\ldots$ & 0.0 \\
\hline Turkey & 1.1 & $\ldots$ & 3.1 & 32.6 & $\ldots$ & 2.1 & $\ldots$ & $\ldots$ & 41.5 & $\ldots$ & 20.7 \\
\hline Ukraine & 0.9 & $\ldots$ & 47.6 & $\ldots$ & $\ldots$ & $\ldots$ & $\ldots$ & $\ldots$ & 15.8 & $\ldots$ & $\ldots$ \\
\hline UK: England \& Wales & $\ldots$ & $\ldots$ & $\ldots$ & $\ldots$ & $\ldots$ & $\ldots$ & $\ldots$ & $\ldots$ & $\ldots$ & $\ldots$ & $\ldots$ \\
\hline UK: Northern Ireland & $\ldots$ & $\ldots$ & $\ldots$ & $\ldots$ & $\ldots$ & $\ldots$ & $\ldots$ & $\ldots$ & $\ldots$ & $\ldots$ & $\ldots$ \\
\hline UK: Scotland & $\ldots$ & $\ldots$ & $\ldots$ & $\ldots$ & $\ldots$ & $\ldots$ & $\ldots$ & $\ldots$ & $\ldots$ & $\ldots$ & $\ldots$ \\
\hline Mean & 2.7 & 3.7 & 22.2 & 7.6 & 61.6 & 49.8 & 10.2 & 11.4 & 17.4 & 16.8 & 4.5 \\
\hline Median & 0.9 & 0.5 & 12.6 & 0.4 & 63.8 & 60.1 & 4.7 & 0.0 & 12.6 & 4.2 & 0.2 \\
\hline Minimum & 0.0 & 0.0 & 0.0 & 0.0 & 18.8 & 0.0 & 0.0 & 0.0 & 0.0 & 0.0 & 0.0 \\
\hline Maximum & 26.8 & 22.2 & 100.0 & 32.6 & 100.0 & 86.9 & 40.9 & 42.5 & 49.3 & 66.7 & 20.7 \\
\hline
\end{tabular}


Table 3.2.3.21 Total persons receiving sanctions/measures in 2015 - Drug offences: Total

\begin{tabular}{|c|c|c|c|c|c|c|c|c|c|c|c|}
\hline & \multirow[b]{2}{*}{ 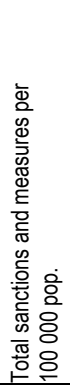 } & \multirow[b]{2}{*}{ 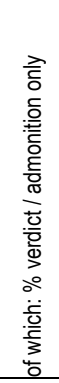 } & \multirow[b]{2}{*}{ 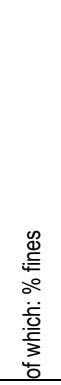 } & \multicolumn{2}{|c|}{$\begin{array}{l}\text { of which: \% } \\
\text { non-custodial } \\
\text { sanctions and } \\
\text { measures }\end{array}$} & \multicolumn{3}{|c|}{$\begin{array}{l}\text { of which: } \% \text { suspended } \\
\text { custodial sanctions and } \\
\text { measures }\end{array}$} & \multicolumn{2}{|c|}{$\begin{array}{l}\text { of which: \% un- } \\
\text { suspended custo- } \\
\text { dial sanctions and } \\
\text { measures }\end{array}$} & \multirow[b]{2}{*}{ 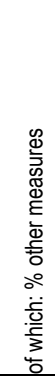 } \\
\hline & & & & 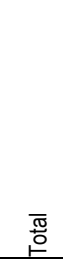 & 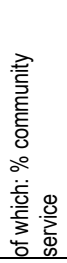 & 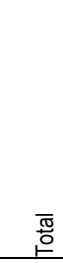 & 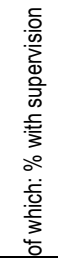 & 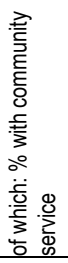 & 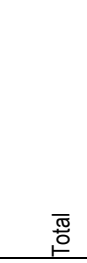 & 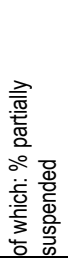 & \\
\hline Albania & $\ldots$ & $\ldots$ & $\ldots$ & $\ldots$ & $\ldots$ & $\ldots$ & $\ldots$ & $\ldots$ & $\ldots$ & $\ldots$ & $\ldots$ \\
\hline Armenia & $\ldots$ & $\ldots$ & $\ldots$ & $\ldots$ & $\ldots$ & $\ldots$ & $\ldots$ & $\ldots$ & $\ldots$ & $\ldots$ & $\ldots$ \\
\hline Austria & 51.5 & $\ldots$ & 23.7 & $\ldots$ & $\ldots$ & 32.5 & $\ldots$ & $\ldots$ & 39.5 & 37.7 & 4.3 \\
\hline Azerbaijan & $\ldots$ & $\ldots$ & & $\ldots$ & $\ldots$ & $\ldots$ & $\ldots$ & $\ldots$ & $\ldots$ & $\ldots$ & $\ldots$ \\
\hline Belgium & 53.9 & $\ldots$ & 3.5 & 20.9 & 100.0 & 42.5 & 33.4 & $\ldots$ & 32.7 & $\ldots$ & 0.4 \\
\hline Bosnia-Herzegovina & $\ldots$ & $\ldots$ & $\ldots$ & $\ldots$ & $\ldots$ & $\ldots$ & $\ldots$ & $\ldots$ & $\ldots$ & $\ldots$ & $\ldots$ \\
\hline Bulgaria & 21.8 & $\ldots$ & 16.8 & 2.7 & $\ldots$ & 56.2 & $\ldots$ & $\ldots$ & 23.8 & $\ldots$ & 0.5 \\
\hline Croatia & 16.4 & 2.2 & 0.1 & 4.9 & $\ldots$ & 44.2 & 8.8 & 41.2 & 48.6 & 22.6 & $\ldots$ \\
\hline Cyprus & $\ldots$ & $\ldots$ & $\ldots$ & $\ldots$ & $\ldots$ & $\ldots$ & $\ldots$ & $\ldots$ & $\ldots$ & $\ldots$ & $\ldots$ \\
\hline Czech Republic & 25.7 & 1.3 & 1.1 & 6.1 & 85.4 & 66.5 & 17.1 & $\ldots$ & 25.0 & $\ldots$ & 0.0 \\
\hline Denmark & $\ldots$ & $\ldots$ & $\ldots$ & $\ldots$ & $\ldots$ & $\ldots$ & $\ldots$ & $\ldots$ & $\ldots$ & $\ldots$ & $\ldots$ \\
\hline Estonia & & & & $\ldots$ & & & & $\ldots$ & & $\ldots$ & $\ldots$ \\
\hline Finland & 172.7 & 0.0 & 80.5 & 1.0 & 91.4 & 11.3 & 6.3 & 3.4 & 6.6 & $\ldots$ & 0.6 \\
\hline France & 95.0 & 0.3 & 37.8 & 13.0 & 21.1 & 23.2 & 0.4 & $\ldots$ & 25.7 & 25.3 & $\ldots$ \\
\hline Georgia & 110.2 & $\ldots$ & 27.8 & $\ldots$ & $\ldots$ & 48.6 & $\ldots$ & $\ldots$ & 20.7 & $\ldots$ & $\ldots$ \\
\hline Germany & 69.6 & 1.1 & 60.0 & 13.1 & $\ldots$ & 17.6 & $\ldots$ & $\ldots$ & 8.2 & $\ldots$ & $\ldots$ \\
\hline Hungary & 13.6 & 1.4 & 9.5 & 40.9 & 60.3 & 24.5 & 17.4 & 0.0 & 23.6 & 0.0 & 0.0 \\
\hline Iceland & $\ldots$ & $\ldots$ & $\ldots$ & $\ldots$ & $\ldots$ & $\ldots$ & $\ldots$ & $\ldots$ & $\ldots$ & $\ldots$ & $\ldots$ \\
\hline $\begin{array}{l}\text { Italy } \\
\text { Kosovo (UN }\end{array}$ & $\ldots$ & $\ldots$ & $\ldots$ & $\ldots$ & $\ldots$ & $\ldots$ & $\ldots$ & $\cdots$ & $\ldots$ & $\ldots$ & $\ldots$ \\
\hline $\mathrm{R} / 1244 / 99)$ & $\ldots$ & $\ldots$ & $\ldots$ & $\ldots$ & $\ldots$ & $\ldots$ & $\ldots$ & $\ldots$ & $\ldots$ & $\ldots$ & $\ldots$ \\
\hline Latvia & $\ldots$ & $\ldots$ & $\ldots$ & $\ldots$ & $\ldots$ & $\ldots$ & $\ldots$ & $\ldots$ & $\ldots$ & $\ldots$ & $\ldots$ \\
\hline Lithuania & 62.3 & $\ldots$ & $\ldots$ & $\ldots$ & $\ldots$ & $\ldots$ & $\ldots$ & $\ldots$ & $\ldots$ & $\ldots$ & 0.5 \\
\hline Luxembourg & $\ldots$ & $\ldots$ & $\ldots$ & $\ldots$ & $\ldots$ & $\ldots$ & $\ldots$ & $\ldots$ & $\ldots$ & $\ldots$ & ... \\
\hline Moldova & $\ldots$ & $\ldots$ & $\ldots$ & $\ldots$ & $\ldots$ & $\ldots$ & $\ldots$ & $\ldots$ & $\ldots$ & $\ldots$ & $\ldots$ \\
\hline Montenegro & $\ldots$ & $\ldots$ & $\ldots$ & $\ldots$ & $\ldots$ & $\ldots$ & $\ldots$ & $\ldots$ & $\ldots$ & $\ldots$ & $\ldots$ \\
\hline Netherlands & 35.1 & $\ldots$ & 13.4 & 30.3 & 98.9 & 16.8 & $\ldots$ & 68.6 & 39.4 & 41.0 & $\ldots$ \\
\hline North Macedonia & $\ldots$ & $\ldots$ & $\ldots$ & $\ldots$ & $\ldots$ & $\ldots$ & $\ldots$ & $\ldots$ & $\ldots$ & $\ldots$ & $\ldots$ \\
\hline Norway & $\ldots$ & $\ldots$ & $\ldots$ & $\ldots$ & $\ldots$ & $\ldots$ & $\ldots$ & $\ldots$ & $\ldots$ & ... & $\ldots$ \\
\hline Poland & 43.2 & $\ldots$ & 25.1 & 13.0 & 100.0 & 50.6 & 43.9 & $\ldots$ & 11.1 & $\ldots$ & 0.2 \\
\hline Portugal & 38.3 & 0.6 & 23.8 & 3.5 & 100.0 & 44.0 & 63.8 & $\ldots$ & 27.4 & $\ldots$ & 0.7 \\
\hline Romania & $\ldots$ & $\ldots$ & $\ldots$ & $\ldots$ & $\ldots$ & $\ldots$ & $\ldots$ & $\ldots$ & $\ldots$ & $\ldots$ & $\ldots$ \\
\hline Russian Federation & $\ldots$ & $\ldots$ & $\ldots$ & $\ldots$ & $\ldots$ & $\ldots$ & $\ldots$ & $\ldots$ & $\ldots$ & $\ldots$ & $\ldots$ \\
\hline Serbia & 41.3 & 0.0 & 16.6 & 1.7 & 98.0 & 41.8 & 7.2 & $\ldots$ & 38.4 & ... & 1.4 \\
\hline Slovak Republic & $\ldots$ & $\ldots$ & $\ldots$ & $\ldots$ & $\ldots$ & $\ldots$ & $\ldots$ & $\ldots$ & $\ldots$ & $\ldots$ & $\ldots$ \\
\hline Slovenia & $\ldots$ & $\ldots$ & $\ldots$ & $\ldots$ & $\ldots$ & $\ldots$ & $\ldots$ & $\ldots$ & $\ldots$ & $\ldots$ & $\ldots$ \\
\hline Spain & & & & $\ldots$ & $\ldots$ & $\ldots$ & $\ldots$ & $\ldots$ & $\ldots$ & $\ldots$ & $\ldots$ \\
\hline Sweden & 231.7 & 0.0 & 63.3 & 3.8 & 20.9 & 3.2 & $\ldots$ & 56.6 & 6.4 & 1.5 & 23.3 \\
\hline Switzerland & 50.3 & $\ldots$ & 65.7 & 3.6 & 99.3 & 13.8 & $\ldots$ & $\ldots$ & 16.9 & 25.5 & 0.0 \\
\hline Turkey & 123.0 & $\ldots$ & 26.0 & 20.9 & $\ldots$ & 4.5 & $\ldots$ & $\ldots$ & 27.1 & $\ldots$ & 21.5 \\
\hline Ukraine & 26.4 & $\ldots$ & 30.2 & & $\ldots$ & $\ldots$ & $\ldots$ & $\ldots$ & 20.4 & $\ldots$ & $\ldots$ \\
\hline UK: England \& Wales & 79.9 & $\ldots$ & 35.6 & 14.5 & $\ldots$ & 12.3 & $\ldots$ & $\ldots$ & 18.6 & $\ldots$ & 19.0 \\
\hline UK: Northern Ireland & $\ldots$ & & & $\ldots$ & $\ldots$ & $\ldots$ & $\ldots$ & $\ldots$ & $\ldots$ & $\ldots$ & $\ldots$ \\
\hline UK: Scotland & 133.1 & 17.7 & 47.7 & 20.5 & 84.0 & $\ldots$ & $\ldots$ & $\ldots$ & 14.1 & $\ldots$ & $\ldots$ \\
\hline Mean & 71.2 & 2.5 & 30.4 & 12.6 & 80.0 & 30.8 & 22.0 & 33.9 & 23.7 & 21.9 & 5.2 \\
\hline Median & 51.5 & 0.8 & 25.5 & 13.0 & 94.7 & 28.5 & 17.1 & 41.2 & 23.7 & 25.3 & 0.6 \\
\hline Minimum & 13.6 & 0.0 & 0.1 & 1.0 & 20.9 & 3.2 & 0.4 & 0.0 & 6.4 & 0.0 & 0.0 \\
\hline Maximum & 231.7 & 17.7 & 80.5 & 40.9 & 100.0 & 66.5 & 63.8 & 68.6 & 48.6 & 41.0 & 23.3 \\
\hline
\end{tabular}


Table 3.2.3.22 Total persons receiving sanctions/measures in 2015 -Drug trafficking

\begin{tabular}{|c|c|c|c|c|c|c|c|c|c|c|c|}
\hline & \multirow{2}{*}{ 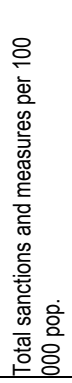 } & \multirow[b]{2}{*}{ 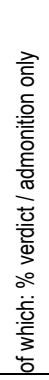 } & \multirow[b]{2}{*}{ 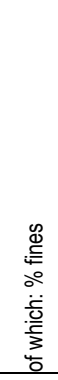 } & \multicolumn{2}{|c|}{$\begin{array}{l}\text { of which: \% } \\
\text { non-custodial } \\
\text { sanctions and } \\
\text { measures }\end{array}$} & \multicolumn{3}{|c|}{$\begin{array}{l}\text { of which: } \% \text { suspended } \\
\text { custodial sanctions and } \\
\text { measures }\end{array}$} & \multicolumn{2}{|c|}{$\begin{array}{l}\text { of which: } \% \text { un- } \\
\text { suspended custo- } \\
\text { dial sanctions and } \\
\text { measures }\end{array}$} & \multirow[b]{2}{*}{ 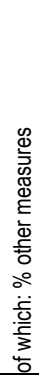 } \\
\hline & & & & 푬 & 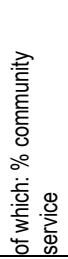 & 要 & 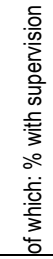 & 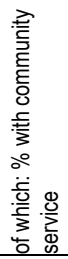 & 푬 & 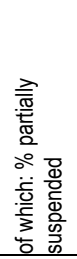 & \\
\hline Albania & & $\ldots$ & & & $\ldots$ & & & & & $\ldots$ & \\
\hline Armenia & 1.5 & $\ldots$ & 4.3 & 0.0 & $\ldots$ & 4.3 & 0.0 & 0.0 & 95.7 & 0.0 & 0.0 \\
\hline Austria & $\ldots$ & $\ldots$ & $\ldots$ & $\ldots$ & $\ldots$ & $\ldots$ & $\ldots$ & $\ldots$ & $\ldots$ & $\ldots$ & $\ldots$ \\
\hline Azerbaijan & $\ldots$ & $\ldots$ & $\ldots$ & $\ldots$ & $\ldots$ & $\ldots$ & $\ldots$ & $\ldots$ & $\ldots$ & $\ldots$ & $\ldots$ \\
\hline Belgium & $\ldots$ & $\ldots$ & $\ldots$ & $\ldots$ & $\ldots$ & $\ldots$ & $\ldots$ & $\ldots$ & $\ldots$ & $\ldots$ & $\ldots$ \\
\hline Bosnia-Herzegovina & $\ldots$ & $\ldots$ & $\ldots$ & $\ldots$ & $\ldots$ & $\ldots$ & $\ldots$ & $\ldots$ & $\ldots$ & $\ldots$ & $\ldots$ \\
\hline Bulgaria & $\ldots$ & $\ldots$ & $\ldots$ & $\ldots$ & $\ldots$ & $\ldots$ & $\ldots$ & $\ldots$ & $\ldots$ & $\ldots$ & $\ldots$ \\
\hline Croatia & 16.4 & 2.2 & 0.1 & 4.9 & $\ldots$ & 44.2 & 8.8 & 41.2 & 48.6 & 22.6 & $\ldots$ \\
\hline Cyprus & $\ldots$ & $\ldots$ & $\ldots$ & $\ldots$ & $\ldots$ & $\ldots$ & $\ldots$ & $\ldots$ & $\ldots$ & $\ldots$ & $\ldots$ \\
\hline Czech Republic & 19.9 & 1.4 & 0.6 & 4.8 & 88.1 & 65.4 & 19.1 & $\ldots$ & 26.1 & $\ldots$ & 0.0 \\
\hline Denmark & $\ldots$ & $\ldots$ & $\ldots$ & $\ldots$ & $\ldots$ & $\ldots$ & $\ldots$ & $\ldots$ & $\ldots$ & $\ldots$ & $\ldots$ \\
\hline Estonia & $\ldots$ & . & . & & . & $\ldots$ & $\ldots$ & $\ldots$ & $\ldots$ & $\ldots$ & \\
\hline Finland & 65.1 & 0.0 & 49.1 & 2.6 & 91.4 & 30.1 & 6.3 & 3.4 & 17.5 & $\ldots$ & 0.7 \\
\hline France & 49.3 & 0.3 & 5.8 & 12.3 & 29.8 & 37.6 & 0.0 & $\ldots$ & 44.1 & 27.8 & $\ldots$ \\
\hline Georgia & 3.2 & $\ldots$ & $\ldots$ & $\ldots$ & $\ldots$ & $\ldots$ & $\ldots$ & $\ldots$ & 100.0 & $\ldots$ & $\ldots$ \\
\hline Germany & 11.0 & 1.1 & 3.5 & 2.9 & $\ldots$ & 59.1 & $\ldots$ & $\ldots$ & 33.5 & $\ldots$ & $\ldots$ \\
\hline Hungary & 4.6 & 0.0 & 10.7 & 15.1 & 42.6 & 31.6 & 19.7 & 0.0 & 42.7 & 0.0 & 0.0 \\
\hline Iceland & $\ldots$ & $\ldots$ & $\ldots$ & $\ldots$ & $\ldots$ & $\ldots$ & $\ldots$ & $\ldots$ & $\ldots$ & $\ldots$ & $\ldots$ \\
\hline $\begin{array}{l}\text { Italy } \\
\text { Kosovo (UN }\end{array}$ & $\ldots$ & $\ldots$ & $\ldots$ & $\ldots$ & $\ldots$ & $\ldots$ & $\ldots$ & $\ldots$ & $\ldots$ & $\ldots$ & $\ldots$ \\
\hline $\mathrm{R} / 1244 / 99)$ & $\ldots$ & $\ldots$ & $\ldots$ & $\ldots$ & $\ldots$ & $\ldots$ & $\ldots$ & $\ldots$ & $\ldots$ & $\ldots$ & $\ldots$ \\
\hline Latvia & $\ldots$ & $\ldots$ & $\ldots$ & $\ldots$ & $\ldots$ & $\ldots$ & $\ldots$ & $\ldots$ & $\ldots$ & $\ldots$ & $\ldots$ \\
\hline Lithuania & 18.4 & $\ldots$ & $\ldots$ & $\ldots$ & $\ldots$ & $\ldots$ & $\ldots$ & $\ldots$ & $\ldots$ & $\ldots$ & 0.4 \\
\hline Luxembourg & $\ldots$ & $\ldots$ & $\ldots$ & $\ldots$ & $\ldots$ & $\ldots$ & $\ldots$ & ... & $\ldots$ & $\ldots$ & ... \\
\hline Moldova & $\ldots$ & $\ldots$ & $\ldots$ & $\ldots$ & $\ldots$ & $\ldots$ & $\ldots$ & $\ldots$ & $\ldots$ & $\ldots$ & $\ldots$ \\
\hline Montenegro & $\ldots$ & $\ldots$ & $\ldots$ & $\ldots$ & $\ldots$ & $\ldots$ & $\ldots$ & $\ldots$ & $\ldots$ & $\ldots$ & $\ldots$ \\
\hline Netherlands & $\ldots$ & $\ldots$ & $\ldots$ & $\ldots$ & $\ldots$ & ... & $\ldots$ & $\ldots$ & $\ldots$ & $\ldots$ & $\ldots$ \\
\hline North Macedonia & $\ldots$ & $\ldots$ & $\ldots$ & $\ldots$ & $\ldots$ & $\ldots$ & $\ldots$ & $\ldots$ & $\ldots$ & $\ldots$ & $\ldots$ \\
\hline Norway & $\ldots$ & $\ldots$ & $\ldots$ & $\ldots$ & $\ldots$ & $\ldots$ & $\ldots$ & $\ldots$ & $\ldots$ & $\ldots$ & $\ldots$ \\
\hline Poland & 4.7 & $\ldots$ & 8.0 & 1.7 & 100.0 & 53.0 & 46.2 & $\ldots$ & 37.1 & $\ldots$ & 0.2 \\
\hline Portugal & 29.4 & 0.1 & 5.2 & 3.4 & 100.0 & 54.8 & 64.1 & $\ldots$ & 35.7 & $\ldots$ & 0.8 \\
\hline Romania & $\ldots$ & $\ldots$ & $\ldots$ & $\ldots$ & $\ldots$ & $\ldots$ & $\ldots$ & $\ldots$ & $\ldots$ & $\ldots$ & $\ldots$ \\
\hline Russian Federation & $\ldots$ & $\ldots$ & $\ldots$ & $\ldots$ & $\ldots$ & $\ldots$ & $\ldots$ & $\ldots$ & $\ldots$ & $\ldots$ & $\ldots$ \\
\hline Serbia & 11.9 & 0.0 & 0.0 & 1.1 & 100.0 & 13.9 & 33.1 & $\ldots$ & 81.9 & $\ldots$ & 3.1 \\
\hline Slovak Republic & $\ldots$ & $\ldots$ & $\ldots$ & $\ldots$ & $\ldots$ & $\ldots$ & $\ldots$ & $\ldots$ & $\ldots$ & $\ldots$ & $\ldots$ \\
\hline Slovenia & $\ldots$ & $\ldots$ & $\ldots$ & $\ldots$ & $\ldots$ & $\ldots$ & $\ldots$ & $\ldots$ & $\ldots$ & $\ldots$ & $\ldots$ \\
\hline Spain & & $\ldots$ & $\ldots$ & $\ldots$ & & $\ldots$ & $\ldots$ & $\ldots$ & $\ldots$ & $\ldots$ & $\ldots$ \\
\hline Sweden & 25.8 & 0.0 & 34.4 & 13.0 & 24.7 & 13.1 & $\ldots$ & 60.5 & 32.3 & 1.6 & 7.1 \\
\hline Switzerland & 23.2 & $\ldots$ & 56.3 & 1.4 & 100.0 & 19.7 & $\ldots$ & $\ldots$ & 22.7 & 31.1 & 0.0 \\
\hline Turkey & 69.3 & $\ldots$ & 32.2 & 25.7 & $\ldots$ & 0.4 & $\ldots$ & $\ldots$ & 33.1 & $\ldots$ & 8.7 \\
\hline Ukraine & 3.7 & $\ldots$ & 0.5 & $\ldots$ & $\ldots$ & $\ldots$ & $\ldots$ & $\ldots$ & 61.0 & $\ldots$ & $\ldots$ \\
\hline UK: England \& Wales & 0.9 & $\ldots$ & 4.7 & 2.7 & $\ldots$ & 8.8 & $\ldots$ & $\ldots$ & 82.5 & $\ldots$ & 5.9 \\
\hline UK: Northern Ireland & $\ldots$ & $\ldots$ & $\ldots$ & $\ldots$ & $\ldots$ & $\ldots$ & $\ldots$ & $\ldots$ & $\ldots$ & $\ldots$ & $\ldots$ \\
\hline UK: Scotland & $\ldots$ & $\ldots$ & $\ldots$ & $\ldots$ & $\ldots$ & $\ldots$ & $\ldots$ & $\ldots$ & $\ldots$ & $\ldots$ & $\ldots$ \\
\hline Mean & 21.1 & 0.6 & 14.4 & 6.5 & 75.2 & 31.1 & 21.9 & 21.0 & 49.7 & 13.8 & 2.2 \\
\hline Median & 16.4 & 0.1 & 5.2 & 3.1 & 91.4 & 30.8 & 19.1 & 3.4 & 39.9 & 12.1 & 0.5 \\
\hline Minimum & 0.9 & 0.0 & 0.0 & 0.0 & 24.7 & 0.4 & 0.0 & 0.0 & 17.5 & 0.0 & 0.0 \\
\hline Maximum & 69.3 & 2.2 & 56.3 & 25.7 & 100.0 & 65.4 & 64.1 & 60.5 & 100.0 & 31.1 & 8.7 \\
\hline
\end{tabular}




\subsubsection{Minors receiving sanctions/measures in 2015}

Table 3.2.4.1 Minors receiving sanctions/measures in 2015 - Criminal offences: Total

\begin{tabular}{|c|c|c|c|c|c|c|c|c|c|c|c|}
\hline & \multirow{2}{*}{ 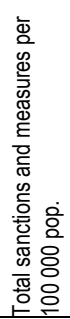 } & \multirow{2}{*}{ 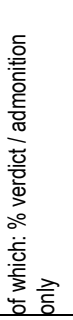 } & \multirow[b]{2}{*}{ 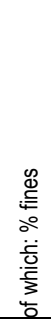 } & \multicolumn{2}{|c|}{$\begin{array}{l}\text { of which: \% } \\
\text { non-custodial } \\
\text { sanctions and } \\
\text { measures }\end{array}$} & \multicolumn{3}{|c|}{$\begin{array}{l}\text { of which: \% suspended } \\
\text { custodial sanctions and } \\
\text { measures }\end{array}$} & \multicolumn{2}{|c|}{$\begin{array}{l}\text { of which: \% un- } \\
\text { suspended cus- } \\
\text { todial sanctions } \\
\text { and measures }\end{array}$} & \multirow{2}{*}{ 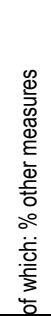 } \\
\hline & & & & 覀 & 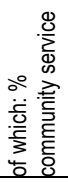 & 斝 & 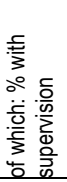 & 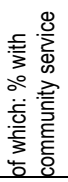 & 受 & 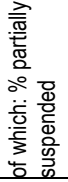 & \\
\hline Albania & & $\ldots$ & $\ldots$ & $\ldots$ & $\ldots$ & 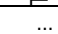 & $\ldots$ & 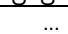 & $\ldots$ & $\ldots$ & \\
\hline Armenia & 2.7 & $\ldots$ & $\ldots$ & $\ldots$ & $\ldots$ & 61.3 & 0.0 & 0.0 & 66.3 & 0.0 & 33.8 \\
\hline Austria & 16.5 & $\ldots$ & 22.0 & $\ldots$ & $\ldots$ & 52.9 & $\ldots$ & $\ldots$ & 22.0 & 59.2 & 3.0 \\
\hline Azerbaijan & & $\ldots$ & $\ldots$ & $\ldots$ & $\ldots$ & $\ldots$ & $\ldots$ & $\ldots$ & $\ldots$ & $\ldots$ & \\
\hline Belgium & 2.2 & $\ldots$ & 69.8 & 22.2 & 100.0 & 4.0 & 0.0 & $\ldots$ & 4.0 & $\ldots$ & 0.0 \\
\hline Bosnia-Herzegovina & & $\ldots$ & $\ldots$ & $\ldots$ & $\ldots$ & $\ldots$ & $\ldots$ & $\ldots$ & $\ldots$ & $\ldots$ & \\
\hline Bulgaria & 17.3 & 0.0 & 0.1 & 0.0 & $\ldots$ & $\ldots$ & $\ldots$ & $\ldots$ & 46.3 & 0.0 & 18.4 \\
\hline Croatia & 9.9 & 38.1 & $\ldots$ & 36.9 & 0.0 & 10.7 & 44.4 & $\ldots$ & 14.3 & $\ldots$ & 0.0 \\
\hline Cyprus & & & & & & & & $\ldots$ & & $\ldots$ & \\
\hline Czech Republic & 13.3 & 15.0 & 0.0 & 19.2 & 97.4 & 60.0 & 13.3 & $\ldots$ & 5.4 & $\ldots$ & 0.4 \\
\hline Denmark & $\ldots$ & $\ldots$ & $\ldots$ & $\ldots$ & $\ldots$ & $\ldots$ & $\ldots$ & $\ldots$ & $\ldots$ & $\ldots$ & $\ldots$ \\
\hline Estonia & & $\ldots$ & $\ldots$ & $\ldots$ & $\ldots$ & $\ldots$ & $\ldots$ & $\ldots$ & $\ldots$ & $\ldots$ & $\ldots$ \\
\hline Finland & 159.6 & 0.0 & 93.1 & 0.1 & 100.0 & 5.3 & 52.7 & 5.0 & 0.4 & $\ldots$ & 1.2 \\
\hline France & 67.3 & 2.7 & 3.1 & 57.9 & $\ldots$ & 25.8 & $\ldots$ & $\ldots$ & 10.5 & 31.1 & $\ldots$ \\
\hline Georgia & 7.8 & $\ldots$ & $\ldots$ & $\ldots$ & $\ldots$ & 70.2 & $\ldots$ & $\ldots$ & 29.8 & $\ldots$ & $\ldots$ \\
\hline Germany & 82.6 & 2.6 & $\ldots$ & 81.7 & $\ldots$ & 9.5 & 100.0 & $\ldots$ & 6.2 & $\ldots$ & $\ldots$ \\
\hline Hungary & 46.1 & 1.7 & 1.5 & 66.5 & 30.8 & 19.3 & 84.9 & 0.0 & 11.0 & 0.0 & 0.0 \\
\hline Iceland & 6.4 & 47.6 & 52.4 & 76.2 & $\ldots$ & 42.9 & $\ldots$ & $\ldots$ & 0.0 & $\ldots$ & $\ldots$ \\
\hline Italy & $\ldots$ & $\ldots$ & $\ldots$ & $\ldots$ & $\cdots$ & $\ldots$ & $\ldots$ & $\ldots$ & $\ldots$ & $\cdots$ & $\ldots$ \\
\hline $\begin{array}{l}\text { Kosovo (UN } \\
\text { R/1244/99) }\end{array}$ & & $\ldots$ & $\ldots$ & $\ldots$ & & $\ldots$ & $\ldots$ & $\ldots$ & $\ldots$ & 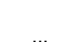 & 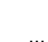 \\
\hline Latvia & 23.5 & $\ldots$ & 0.0 & 80.7 & 66.2 & $\ldots$ & $\ldots$ & $\ldots$ & 19.3 & $\ldots$ & $\ldots$ \\
\hline Lithuania & 38.9 & 5.6 & 4.1 & 72.1 & 2.7 & 13.0 & $\ldots$ & 0.0 & 27.3 & $\ldots$ & 21.0 \\
\hline Luxembourg & $\ldots$ & $\ldots$ & $\ldots$ & $\ldots$ & $\ldots$ & $\ldots$ & $\ldots$ & $\ldots$ & $\ldots$ & $\ldots$ & $\ldots$ \\
\hline Moldova & $\ldots$ & $\ldots$ & $\ldots$ & $\ldots$ & $\ldots$ & $\ldots$ & $\ldots$ & $\ldots$ & $\ldots$ & $\ldots$ & $\ldots$ \\
\hline Montenegro & & $\ldots$ & $\ldots$ & $\ldots$ & $\ldots$ & $\ldots$ & $\ldots$ & $\ldots$ & $\ldots$ & $\ldots$ & $\ldots$ \\
\hline Netherlands & 27.3 & $\ldots$ & 3.2 & 75.0 & 98.1 & 8.3 & $\ldots$ & 73.4 & 13.5 & 61.8 & $\ldots$ \\
\hline North Macedonia & $\ldots$ & $\ldots$ & $\ldots$ & $\ldots$ & $\ldots$ & $\ldots$ & $\ldots$ & $\ldots$ & $\ldots$ & $\ldots$ & $\ldots$ \\
\hline Norway & 75.0 & 39.7 & 0.3 & $\ldots$ & $\ldots$ & 6.2 & $\ldots$ & $\ldots$ & 0.6 & $\ldots$ & 1.2 \\
\hline Poland & 32.2 & $\ldots$ & $\ldots$ & 91.8 & $\ldots$ & 1.1 & $\ldots$ & $\ldots$ & 7.1 & $\ldots$ & $\ldots$ \\
\hline Portugal & 11.0 & 1.4 & 46.2 & 7.9 & 95.6 & 35.7 & 94.3 & $\ldots$ & 6.9 & $\ldots$ & 1.8 \\
\hline Romania & $\ldots$ & $\ldots$ & $\ldots$ & $\ldots$ & $\ldots$ & $\ldots$ & $\ldots$ & $\ldots$ & $\ldots$ & $\ldots$ & $\ldots$ \\
\hline Russian Federation & & $\ldots$ & $\ldots$ & $\ldots$ & $\ldots$ & ... & $\ldots$ & $\ldots$ & $\ldots$ & $\ldots$ & $\ldots$ \\
\hline Serbia & 27.1 & $\ldots$ & $\ldots$ & 99.5 & $\ldots$ & $\ldots$ & $\ldots$ & $\ldots$ & 0.5 & $\ldots$ & $\ldots$ \\
\hline Slovak Republic & $\ldots$ & $\ldots$ & $\ldots$ & $\ldots$ & $\ldots$ & ... & $\ldots$ & $\ldots$ & $\cdots$ & $\cdots$ & $\cdots$ \\
\hline Slovenia & $\ldots$ & $\ldots$ & $\ldots$ & $\ldots$ & $\ldots$ & $\ldots$ & $\ldots$ & $\ldots$ & $\ldots$ & $\ldots$ & $\ldots$ \\
\hline Spain & 49.6 & $\ldots$ & $\ldots$ & $\ldots$ & $\ldots$ & $\ldots$ & $\ldots$ & $\ldots$ & $\ldots$ & $\ldots$ & $\ldots$ \\
\hline Sweden & 195.4 & 0.0 & 47.1 & 3.6 & 18.1 & 5.9 & $\ldots$ & 31.6 & 3.0 & 9.2 & 40.4 \\
\hline Switzerland & 191.1 & 21.5 & 15.2 & 56.2 & 61.4 & 3.2 & $\ldots$ & $\ldots$ & 2.0 & 18.5 & 0.0 \\
\hline Turkey & 136.0 & $\ldots$ & 47.5 & 2.6 & $\ldots$ & 8.8 & $\ldots$ & $\ldots$ & 29.3 & $\ldots$ & 11.7 \\
\hline Ukraine & 10.7 & $\ldots$ & 8.4 & $\ldots$ & $\ldots$ & $\ldots$ & $\ldots$ & $\ldots$ & 13.4 & $\ldots$ & \\
\hline UK: England \& Wales & 168.3 & $\ldots$ & 10.7 & 65.7 & $\ldots$ & 0.0 & $\ldots$ & $\ldots$ & 6.0 & $\ldots$ & 28.3 \\
\hline $\begin{array}{l}\text { UK: Northern Ireland } \\
\text { UK: Scotland }\end{array}$ & $\ldots$ & $\begin{array}{l}\ldots \\
\ldots \\
\end{array}$ & $\begin{array}{l}\ldots \\
\ldots \\
\ldots\end{array}$ & $\begin{array}{l}\ldots \\
\ldots \\
\end{array}$ & $\begin{array}{l}\ldots \\
\ldots \\
\end{array}$ & $\begin{array}{l}\ldots \\
\ldots\end{array}$ & $\begin{array}{l}\ldots \\
\ldots \\
\end{array}$ & $\begin{array}{l}\ldots \\
\ldots \\
\end{array}$ & $\begin{array}{l}\ldots \\
\ldots \\
\end{array}$ & $\begin{array}{l}\ldots \\
\ldots \\
\end{array}$ & $\ldots$ \\
\hline Mean & 56.7 & 13.5 & 23.6 & 48.2 & 60.9 & 22.2 & 48.7 & 18.3 & 14.4 & 22.5 & 10.7 \\
\hline Median & 27.3 & 2.7 & 9.6 & 57.9 & 66.2 & 10.1 & 48.6 & 2.5 & 8.8 & 13.9 & 1.8 \\
\hline Minimum & 2.2 & 0.0 & 0.0 & 0.0 & 0.0 & 0.0 & 0.0 & 0.0 & 0.0 & 0.0 & 0.0 \\
\hline Maximum & 195.4 & 47.6 & 93.1 & 99.5 & 100.0 & 70.2 & 100.0 & 73.4 & 66.3 & 61.8 & 40.4 \\
\hline
\end{tabular}


Table 3.2.4.2 Minors receiving sanctions/measures in 2015 - Major road traffic offences

\begin{tabular}{|c|c|c|c|c|c|c|c|c|c|c|c|}
\hline & \multirow[b]{2}{*}{ 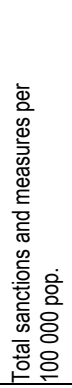 } & \multirow[b]{2}{*}{ 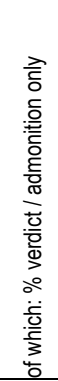 } & \multirow[b]{2}{*}{ 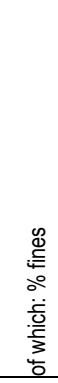 } & \multicolumn{2}{|c|}{$\begin{array}{l}\text { of which: \% } \\
\text { non-custodial } \\
\text { sanctions and } \\
\text { measures }\end{array}$} & \multicolumn{3}{|c|}{$\begin{array}{l}\text { of which: \% suspended } \\
\text { custodial sanctions and } \\
\text { measures }\end{array}$} & \multicolumn{2}{|c|}{$\begin{array}{l}\text { of which: \% un- } \\
\text { suspended custo- } \\
\text { dial sanctions } \\
\text { and measures }\end{array}$} & \multirow[b]{2}{*}{ 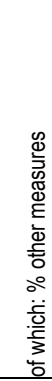 } \\
\hline & & & & 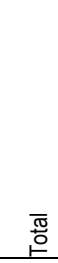 & 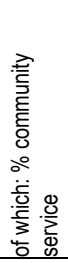 & 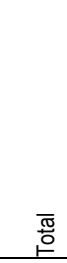 & 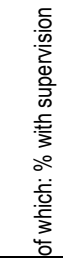 & 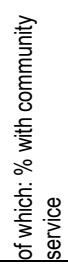 & $\begin{array}{l}\overline{\widetilde{\pi}} \\
\stackrel{0}{\circ}\end{array}$ & 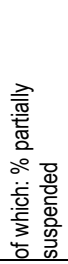 & \\
\hline Albania & & $\ldots$ & & & $\ldots$ & & & & & $\ldots$ & \\
\hline Armenia & 0.0 & $\ldots$ & 0.0 & 0.0 & $\ldots$ & 100.0 & 0.0 & 0.0 & 0.0 & $\ldots$ & 0.0 \\
\hline Austria & $\ldots$ & $\ldots$ & $\ldots$ & $\ldots$ & $\ldots$ & $\ldots$ & $\ldots$ & $\ldots$ & $\ldots$ & $\ldots$ & $\ldots$ \\
\hline Azerbaijan & $\ldots$ & $\ldots$ & $\ldots$ & $\ldots$ & $\ldots$ & $\ldots$ & $\ldots$ & $\ldots$ & $\ldots$ & $\ldots$ & $\ldots$ \\
\hline Belgium & $\ldots$ & $\ldots$ & $\ldots$ & $\ldots$ & $\ldots$ & $\ldots$ & $\ldots$ & $\ldots$ & $\ldots$ & $\ldots$ & $\ldots$ \\
\hline Bosnia-Herzegovina & $\ldots$ & $\ldots$ & $\ldots$ & $\ldots$ & $\ldots$ & $\ldots$ & $\ldots$ & $\ldots$ & $\ldots$ & $\ldots$ & $\ldots$ \\
\hline Bulgaria & 0.6 & 0.0 & 0.0 & 43.9 & 0.0 & $\ldots$ & $\ldots$ & $\ldots$ & 41.5 & 0.0 & 14.6 \\
\hline Croatia & 0.1 & 66.7 & $\ldots$ & 33.3 & 0.0 & 0.0 & $\ldots$ & $\ldots$ & 0.0 & $\ldots$ & 0.0 \\
\hline Cyprus & $\ldots$ & $\ldots$ & $\ldots$ & $\ldots$ & $\ldots$ & $\ldots$ & $\ldots$ & $\ldots$ & $\ldots$ & $\ldots$ & $\ldots$ \\
\hline Czech Republic & 0.4 & 10.8 & 0.0 & 0.0 & $\ldots$ & 64.9 & 16.7 & $\ldots$ & 2.7 & $\ldots$ & 21.6 \\
\hline Denmark & $\ldots$ & $\ldots$ & $\ldots$ & $\ldots$ & $\ldots$ & $\ldots$ & $\ldots$ & $\ldots$ & $\ldots$ & $\ldots$ & $\ldots$ \\
\hline Estonia & & & $\ldots$ & $\ldots$ & $\ldots$ & $\ldots$ & $\ldots$ & & $\ldots$ & $\ldots$ & $\ldots$ \\
\hline Finland & 77.2 & 0.0 & 98.1 & 0.0 & 100.0 & 1.6 & 41.2 & 0.0 & 0.0 & $\ldots$ & 0.2 \\
\hline France & 2.4 & 3.3 & 6.4 & 73.4 & $\ldots$ & 11.3 & 0.0 & $\ldots$ & 5.6 & 7.8 & $\ldots$ \\
\hline Georgia & $\ldots$ & $\ldots$ & $\ldots$ & $\ldots$ & $\ldots$ & $\ldots$ & $\ldots$ & $\ldots$ & $\ldots$ & $\ldots$ & $\ldots$ \\
\hline Germany & 6.5 & 0.9 & $\ldots$ & 95.2 & $\ldots$ & 2.6 & 100.0 & $\ldots$ & 1.4 & $\ldots$ & $\ldots$ \\
\hline Hungary & 1.5 & 0.7 & 4.0 & 80.1 & 16.5 & 13.2 & 75.0 & 0.0 & 2.0 & 0.0 & 0.0 \\
\hline Iceland & $\ldots$ & $\ldots$ & $\ldots$ & $\ldots$ & $\ldots$ & $\ldots$ & $\ldots$ & $\ldots$ & $\ldots$ & $\ldots$ & $\ldots$ \\
\hline $\begin{array}{l}\text { Italy } \\
\text { Kosovo (UN }\end{array}$ & $\ldots$ & $\ldots$ & $\ldots$ & $\cdots$ & $\ldots$ & $\ldots$ & $\cdots$ & $\ldots$ & $\ldots$ & $\ldots$ & $\ldots$ \\
\hline $\mathrm{R} / 1244 / 99)$ & $\ldots$ & $\ldots$ & $\ldots$ & $\ldots$ & $\ldots$ & $\ldots$ & $\ldots$ & $\ldots$ & $\ldots$ & $\ldots$ & $\ldots$ \\
\hline Latvia & $\ldots$ & $\ldots$ & $\ldots$ & $\ldots$ & $\ldots$ & $\ldots$ & $\ldots$ & $\ldots$ & $\ldots$ & $\ldots$ & ... \\
\hline Lithuania & 0.0 & $\ldots$ & $\ldots$ & $\ldots$ & $\ldots$ & $\ldots$ & $\ldots$ & $\ldots$ & ... & $\ldots$ & $\ldots$ \\
\hline Luxembourg & $\ldots$ & $\ldots$ & $\ldots$ & $\ldots$ & $\ldots$ & $\ldots$ & $\ldots$ & $\ldots$ & $\ldots$ & $\ldots$ & $\ldots$ \\
\hline Moldova & $\ldots$ & $\ldots$ & $\ldots$ & $\ldots$ & $\ldots$ & $\ldots$ & $\ldots$ & $\ldots$ & $\ldots$ & ... & $\ldots$ \\
\hline Montenegro & $\ldots$ & $\ldots$ & $\ldots$ & $\ldots$ & $\ldots$ & $\ldots$ & $\ldots$ & $\ldots$ & $\ldots$ & $\ldots$ & $\ldots$ \\
\hline Netherlands & $\ldots$ & $\ldots$ & 44.7 & 52.0 & 97.5 & 3.3 & $\ldots$ & 0.0 & 0.0 & $\ldots$ & $\ldots$ \\
\hline North Macedonia & 0.9 & $\ldots$ & $\ldots$ & $\ldots$ & $\ldots$ & $\ldots$ & $\ldots$ & $\ldots$ & $\ldots$ & $\ldots$ & $\ldots$ \\
\hline Norway & 24.1 & $\ldots$ & $\ldots$ & $\ldots$ & $\ldots$ & $\ldots$ & $\ldots$ & $\ldots$ & $\ldots$ & $\ldots$ & $\ldots$ \\
\hline Poland & 0.5 & $\ldots$ & $\ldots$ & 98.0 & $\ldots$ & 0.5 & $\ldots$ & $\ldots$ & 1.5 & $\ldots$ & $\ldots$ \\
\hline Portugal & 1.1 & 5.4 & 85.7 & 3.6 & 75.0 & 3.6 & 75.0 & $\ldots$ & $\ldots$ & $\ldots$ & $\ldots$ \\
\hline Romania & $\ldots$ & $\ldots$ & $\ldots$ & $\ldots$ & $\ldots$ & $\ldots$ & $\ldots$ & $\ldots$ & $\ldots$ & $\ldots$ & $\ldots$ \\
\hline Russian Federation & $\ldots$ & $\ldots$ & $\ldots$ & $\ldots$ & $\ldots$ & $\ldots$ & $\ldots$ & $\ldots$ & $\ldots$ & ... & $\ldots$ \\
\hline Serbia & 0.4 & $\ldots$ & $\ldots$ & 96.6 & $\ldots$ & $\ldots$ & $\ldots$ & $\ldots$ & 3.4 & ... & $\ldots$ \\
\hline Slovak Republic & $\ldots$ & $\ldots$ & $\ldots$ & $\ldots$ & $\ldots$ & $\ldots$ & $\ldots$ & $\ldots$ & $\ldots$ & $\ldots$ & $\ldots$ \\
\hline Slovenia & $\ldots$ & $\ldots$ & $\ldots$ & $\ldots$ & $\ldots$ & $\ldots$ & $\cdots$ & $\ldots$ & $\ldots$ & $\ldots$ & $\ldots$ \\
\hline Spain & & $\ldots$ & $\ldots$ & $\ldots$ & $\ldots$ & $\ldots$ & $\ldots$ & $\ldots$ & $\cdots$ & $\ldots$ & $\ldots$ \\
\hline Sweden & 29.1 & 0.1 & 81.9 & 1.6 & 33.3 & 2.6 & $\ldots$ & 91.8 & 1.0 & 0.0 & 12.8 \\
\hline Switzerland & $\ldots$ & $\ldots$ & $\ldots$ & $\ldots$ & $\ldots$ & $\ldots$ & $\ldots$ & $\ldots$ & $\ldots$ & $\ldots$ & $\ldots$ \\
\hline Turkey & 0.3 & $\ldots$ & 78.1 & 1.3 & $\ldots$ & 3.1 & $\ldots$ & $\ldots$ & 9.8 & $\ldots$ & 7.6 \\
\hline Ukraine & & $\ldots$ & & $\ldots$ & $\ldots$ & $\ldots$ & $\ldots$ & $\ldots$ & $\ldots$ & $\ldots$ & $\ldots$ \\
\hline UK: England \& Wales & 0.3 & $\ldots$ & 2.7 & 77.5 & $\ldots$ & 0.0 & $\ldots$ & $\ldots$ & 17.6 & $\ldots$ & 4.8 \\
\hline UK: Northern Ireland & $\ldots$ & $\ldots$ & $\ldots$ & $\ldots$ & $\ldots$ & $\ldots$ & $\ldots$ & $\ldots$ & $\ldots$ & $\ldots$ & $\ldots$ \\
\hline UK: Scotland & $\ldots$ & $\ldots$ & $\ldots$ & $\ldots$ & $\ldots$ & $\ldots$ & $\ldots$ & $\ldots$ & $\ldots$ & $\ldots$ & $\ldots$ \\
\hline Mean & 8.6 & 9.8 & 36.5 & 43.8 & 46.0 & 15.9 & 44.0 & 18.4 & 6.2 & 1.9 & 6.9 \\
\hline Median & 0.6 & 0.9 & 6.4 & 43.9 & 33.3 & 3.1 & 41.2 & 0.0 & 1.8 & 0.0 & 4.8 \\
\hline Minimum & 0.0 & 0.0 & 0.0 & 0.0 & 0.0 & 0.0 & 0.0 & 0.0 & 0.0 & 0.0 & 0.0 \\
\hline Maximum & 77.2 & 66.7 & 98.1 & 98.0 & 100.0 & 100.0 & 100.0 & 91.8 & 41.5 & 7.8 & 21.6 \\
\hline
\end{tabular}


Table 3.2.4.3 Minors receiving sanctions/measures in 2015 - Intentional homicide: Total

\begin{tabular}{|c|c|c|c|c|c|c|c|c|c|c|c|}
\hline & \multirow[b]{2}{*}{ 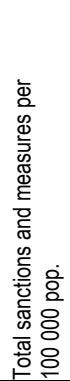 } & \multirow[b]{2}{*}{ 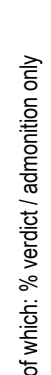 } & \multirow[b]{2}{*}{ 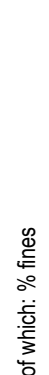 } & \multicolumn{2}{|c|}{$\begin{array}{l}\text { of which: \% } \\
\text { non-custodial } \\
\text { sanctions and } \\
\text { measures }\end{array}$} & \multicolumn{3}{|c|}{$\begin{array}{l}\text { of which: \% suspended } \\
\text { custodial sanctions and } \\
\text { measures }\end{array}$} & \multicolumn{2}{|c|}{$\begin{array}{l}\text { of which: \% un- } \\
\text { suspended custo- } \\
\text { dial sanctions } \\
\text { and measures }\end{array}$} & \multirow[b]{2}{*}{ 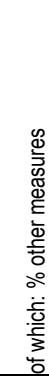 } \\
\hline & & & & $\begin{array}{l}\overline{\mathbb{J}} \\
\stackrel{\circ}{0}\end{array}$ & 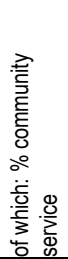 & 要 & 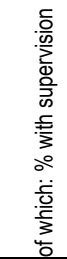 & 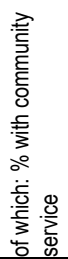 & 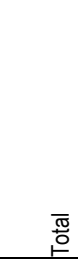 & 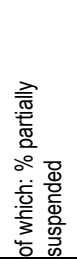 & \\
\hline Albania & & $\ldots$ & $\ldots$ & $\ldots$ & $\ldots$ & $\ldots$ & $\ldots$ & $\ldots$ & $\ldots$ & $\ldots$ & $\ldots$ \\
\hline Armenia & 0.0 & $\ldots$ & $\ldots$ & $\ldots$ & $\ldots$ & $\ldots$ & $\ldots$ & $\ldots$ & $\ldots$ & $\ldots$ & r \\
\hline Austria & 0.1 & $\ldots$ & 0.0 & $\ldots$ & $\ldots$ & 0.0 & $\ldots$ & $\ldots$ & 100.0 & 16.7 & 0.0 \\
\hline Azerbaijan & $\ldots$ & $\ldots$ & $\ldots$ & $\ldots$ & $\ldots$ & $\ldots$ & $\ldots$ & $\ldots$ & $\ldots$ & $\ldots$ & $\ldots$ \\
\hline Belgium & 0.0 & $\ldots$ & $\ldots$ & $\ldots$ & $\ldots$ & $\ldots$ & $\ldots$ & $\ldots$ & $\ldots$ & ... & $\ldots$ \\
\hline Bosnia-Herzegovina & & $\ldots$ & $\ldots$ & $\ldots$ & $\ldots$ & $\ldots$ & $\ldots$ & $\ldots$ & $\ldots$ & $\ldots$ & \\
\hline Bulgaria & 0.1 & 0.0 & 0.0 & 0.0 & $\ldots$ & $\ldots$ & $\ldots$ & $\ldots$ & 100.0 & 0.0 & 0.0 \\
\hline Croatia & 0.0 & 0.0 & $\ldots$ & 100.0 & 0.0 & 0.0 & $\ldots$ & $\ldots$ & 0.0 & $\ldots$ & 0.0 \\
\hline Cyprus & & & $\ldots$ & & $\ldots$ & $\ldots$ & $\ldots$ & $\ldots$ & $\ldots$ & $\ldots$ & \\
\hline Czech Republic & 0.1 & 0.0 & 0.0 & 0.0 & $\ldots$ & 0.0 & $\ldots$ & $\ldots$ & 100.0 & $\ldots$ & 0.0 \\
\hline Denmark & $\ldots$ & $\ldots$ & $\ldots$ & $\ldots$ & $\ldots$ & $\ldots$ & $\ldots$ & $\ldots$ & $\ldots$ & ... & $\ldots$ \\
\hline Estonia & $\ldots$ & $\ldots$ & $\ldots$ & $\ldots$ & $\ldots$ & $\ldots$ & $\ldots$ & $\ldots$ & $\ldots$ & $\ldots$ & $\ldots$ \\
\hline Finland & 0.1 & 0.0 & 0.0 & 0.0 & $\ldots$ & 50.0 & 100.0 & 50.0 & 50.0 & $\ldots$ & 0.0 \\
\hline France & 0.1 & 0.0 & 0.0 & 0.0 & $\ldots$ & 4.3 & 0.0 & $\ldots$ & 95.7 & 15.6 & $\ldots$ \\
\hline Georgia & 0.2 & $\ldots$ & $\ldots$ & $\ldots$ & $\ldots$ & $\ldots$ & $\ldots$ & $\ldots$ & 85.7 & $\ldots$ & $\ldots$ \\
\hline Germany & 0.1 & 0.0 & $\ldots$ & 2.0 & $\ldots$ & 10.0 & 100.0 & $\ldots$ & 88.0 & $\ldots$ & $\ldots$ \\
\hline Hungary & 0.1 & 0.0 & 0.0 & 0.0 & $\ldots$ & 14.3 & 100.0 & 0.0 & 85.7 & 0.0 & 0.0 \\
\hline Iceland & $\ldots$ & $\ldots$ & $\ldots$ & $\ldots$ & $\ldots$ & $\ldots$ & $\ldots$ & $\ldots$ & $\ldots$ & $\ldots$ & $\ldots$ \\
\hline $\begin{array}{l}\text { Italy } \\
\text { Kosovo (UN }\end{array}$ & $\ldots$ & $\ldots$ & ... & $\ldots$ & $\ldots$ & $\ldots$ & ... & $\ldots$ & $\ldots$ & $\ldots$ & $\ldots$ \\
\hline R/1244/99) & $\ldots$ & $\ldots$ & $\ldots$ & $\ldots$ & $\ldots$ & $\ldots$ & $\ldots$ & $\ldots$ & $\ldots$ & $\ldots$ & $\ldots$ \\
\hline Latvia & $\ldots$ & $\ldots$ & $\ldots$ & $\ldots$ & $\ldots$ & $\ldots$ & $\ldots$ & $\ldots$ & $\ldots$ & $\ldots$ & $\ldots$ \\
\hline Lithuania & 0.4 & $\ldots$ & $\ldots$ & $\ldots$ & $\ldots$ & $\ldots$ & $\ldots$ & $\ldots$ & $\ldots$ & $\ldots$ & $\ldots$ \\
\hline Luxembourg & $\ldots$ & $\ldots$ & $\ldots$ & $\ldots$ & $\ldots$ & $\ldots$ & $\ldots$ & $\ldots$ & $\ldots$ & $\ldots$ & $\ldots$ \\
\hline Moldova & $\ldots$ & $\ldots$ & $\ldots$ & $\ldots$ & $\ldots$ & $\ldots$ & $\ldots$ & $\ldots$ & $\ldots$ & $\ldots$ & $\ldots$ \\
\hline Montenegro & $\ldots$ & $\ldots$ & $\ldots$ & $\ldots$ & $\ldots$ & $\ldots$ & $\ldots$ & $\ldots$ & $\ldots$ & $\ldots$ & $\ldots$ \\
\hline Netherlands & . & $\ldots$ & 0.0 & 25.9 & 60.0 & 19.0 & $\ldots$ & 81.8 & 53.4 & 38.7 & $\ldots$ \\
\hline North Macedonia & 0.3 & $\ldots$ & $\ldots$ & $\ldots$ & $\ldots$ & $\ldots$ & $\ldots$ & $\ldots$ & $\ldots$ & $\ldots$ & ... \\
\hline Norway & $\ldots$ & $\ldots$ & $\ldots$ & $\ldots$ & $\ldots$ & $\ldots$ & $\ldots$ & $\ldots$ & $\ldots$ & $\ldots$ & ... \\
\hline Poland & 0.0 & $\ldots$ & $\ldots$ & 11.1 & $\ldots$ & 33.3 & $\ldots$ & $\ldots$ & 55.6 & $\ldots$ & $\ldots$ \\
\hline Portugal & $\ldots$ & $\ldots$ & $\ldots$ & $\ldots$ & $\ldots$ & $\ldots$ & $\ldots$ & $\cdots$ & $\cdots$ & $\ldots$ & $\ldots$ \\
\hline Romania & $\ldots$ & $\ldots$ & $\ldots$ & $\ldots$ & $\ldots$ & ... & $\ldots$ & $\ldots$ & $\ldots$ & $\ldots$ & $\ldots$ \\
\hline Russian Federation & $\ldots$ & $\ldots$ & ... & $\ldots$ & $\ldots$ & $\ldots$ & $\ldots$ & $\ldots$ & $\ldots$ & $\ldots$ & $\ldots$ \\
\hline Serbia & 0.1 & $\ldots$ & $\ldots$ & 80.0 & $\ldots$ & ... & $\ldots$ & $\ldots$ & 20.0 & $\ldots$ & $\ldots$ \\
\hline Slovak Republic & $\ldots$ & $\ldots$ & ... & $\ldots$ & $\ldots$ & $\ldots$ & $\ldots$ & $\ldots$ & $\ldots$ & $\ldots$ & ... \\
\hline Slovenia & $\ldots$ & $\ldots$ & ... & $\ldots$ & $\ldots$ & ... & $\ldots$ & $\ldots$ & $\ldots$ & $\ldots$ & ... \\
\hline Spain & $\ldots$ & $\ldots$ & $\ldots$ & $\ldots$ & $\ldots$ & $\ldots$ & $\ldots$ & $\ldots$ & $\ldots$ & $\ldots$ & \\
\hline Sweden & 0.2 & 0.0 & 0.0 & 0.0 & $\ldots$ & 0.0 & $\ldots$ & $\ldots$ & 73.9 & 0.0 & 26.1 \\
\hline Switzerland & $\ldots$ & $\ldots$ & $\ldots$ & $\ldots$ & $\ldots$ & $\ldots$ & $\ldots$ & $\ldots$ & $\ldots$ & $\ldots$ & $\ldots$ \\
\hline Turkey & 0.9 & $\ldots$ & 0.4 & 7.1 & $\ldots$ & 3.6 & $\ldots$ & $\ldots$ & 81.3 & $\ldots$ & 7.6 \\
\hline Ukraine & 0.1 & $\ldots$ & $\ldots$ & $\ldots$ & $\ldots$ & $\ldots$ & $\ldots$ & $\ldots$ & 97.5 & $\ldots$ & $\ldots$ \\
\hline UK: England \& Wales & 0.1 & $\ldots$ & 0.0 & 42.6 & $\ldots$ & 0.0 & $\ldots$ & $\ldots$ & 55.3 & $\ldots$ & $\ldots$ \\
\hline $\begin{array}{l}\text { UK: Northern Ireland } \\
\text { UK: Scotland }\end{array}$ & $\ldots$ & $\ldots$ & $\ldots$ & $\ldots$ & $\ldots$ & $\ldots$ & $\ldots$ & $\ldots$ & $\begin{array}{l}\ldots \\
\ldots\end{array}$ & $\ldots$ & $\ldots$ \\
\hline Mean & 0.2 & 0.0 & 0.0 & 20.7 & 30.0 & 11.2 & 75.0 & 43.9 & 71.4 & 11.8 & 4.2 \\
\hline Median & 0.1 & 0.0 & 0.0 & 2.0 & 30.0 & 3.9 & 100.0 & 50.0 & 83.5 & 7.8 & 0.0 \\
\hline Minimum & 0.0 & 0.0 & 0.0 & 0.0 & 0.0 & 0.0 & 0.0 & 0.0 & 0.0 & 0.0 & 0.0 \\
\hline Maximum & 0.9 & 0.0 & 0.4 & 100.0 & 60.0 & 50.0 & 100.0 & 81.8 & 100.0 & 38.7 & 26.1 \\
\hline
\end{tabular}


Table 3.2.4.4 Minors receiving sanctions/measures in 2015 - Intentional homicide: Completed

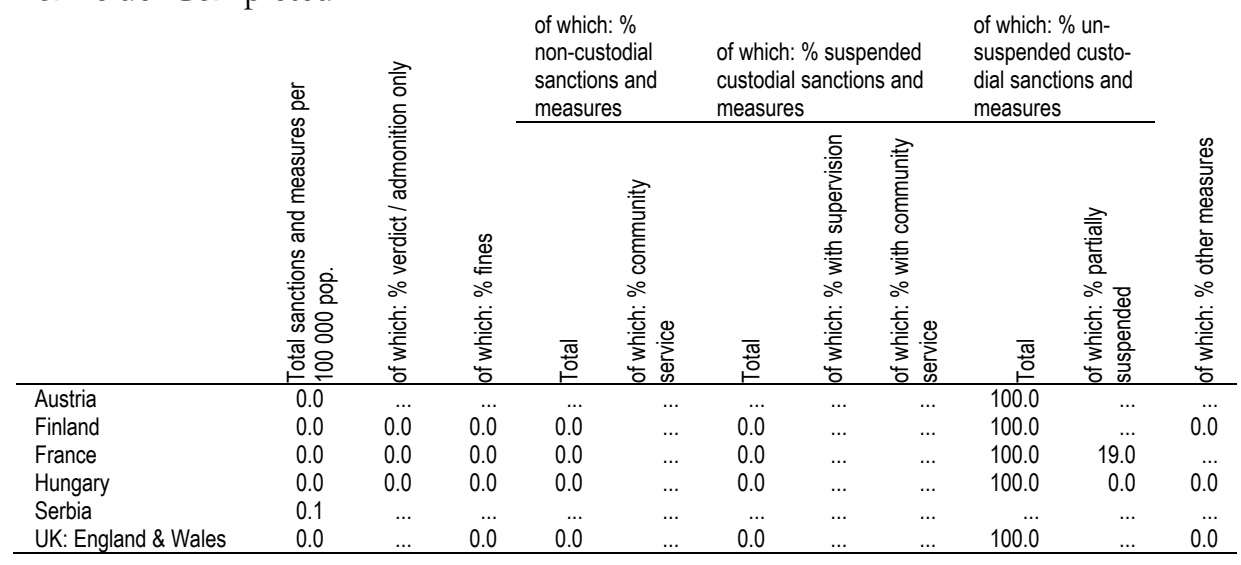


Table 3.2.4.5 Minors receiving sanctions/measures in 2015 - Bodily injury

\begin{tabular}{|c|c|c|c|c|c|c|c|c|c|c|c|}
\hline & \multirow[b]{2}{*}{ 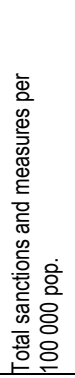 } & \multirow[b]{2}{*}{ 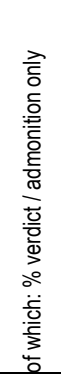 } & \multirow[b]{2}{*}{ 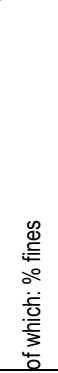 } & \multicolumn{2}{|c|}{$\begin{array}{l}\text { of which: \% } \\
\text { non-custodial } \\
\text { sanctions and } \\
\text { measures }\end{array}$} & \multicolumn{3}{|c|}{$\begin{array}{l}\text { of which: \% suspended } \\
\text { custodial sanctions and } \\
\text { measures }\end{array}$} & \multicolumn{2}{|c|}{$\begin{array}{l}\text { of which: } \% \text { un- } \\
\text { suspended cus- } \\
\text { todial sanctions } \\
\text { and measures }\end{array}$} & \multirow[b]{2}{*}{ 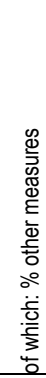 } \\
\hline & & & & 要 & 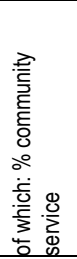 & 粟 & 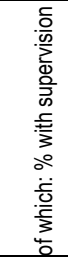 & 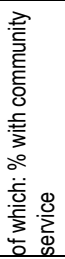 & 要 & 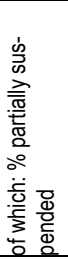 & \\
\hline Albania & & & & & $\ldots$ & & & & & & \\
\hline Armenia & 0.3 & 0.0 & 0.0 & 0.0 & $\ldots$ & 60.0 & 0.0 & 0.0 & 40.0 & 0.0 & 0.0 \\
\hline Austria & 3.3 & $\ldots$ & 41.5 & $\ldots$ & $\ldots$ & 49.3 & $\ldots$ & $\ldots$ & 7.4 & 42.9 & 1.8 \\
\hline Azerbaijan & $\ldots$ & $\ldots$ & $\ldots$ & $\ldots$ & $\ldots$ & $\ldots$ & $\ldots$ & $\ldots$ & $\ldots$ & $\ldots$ & $\ldots$ \\
\hline Belgium & $\ldots$ & $\ldots$ & $\ldots$ & $\ldots$ & $\ldots$ & $\ldots$ & $\ldots$ & $\ldots$ & $\ldots$ & $\ldots$ & $\ldots$ \\
\hline Bosnia-Herzegovina & $\ldots$ & $\ldots$ & $\ldots$ & $\ldots$ & $\ldots$ & $\ldots$ & $\ldots$ & $\ldots$ & $\ldots$ & $\ldots$ & $\ldots$ \\
\hline Bulgaria & & $\ldots$ & $\ldots$ & $\ldots$ & 0.0 & $\ldots$ & $\ldots$ & $\ldots$ & $\ldots$ & $\ldots$ & $\ldots$ \\
\hline Croatia & 0.8 & 54.3 & $\ldots$ & 31.4 & 0.0 & 8.6 & 33.3 & $\ldots$ & 5.7 & $\ldots$ & 0.0 \\
\hline Cyprus & $\ldots$ & $\ldots$ & $\ldots$ & $\ldots$ & $\ldots$ & $\ldots$ & $\ldots$ & $\ldots$ & $\ldots$ & $\ldots$ & $\ldots$ \\
\hline Czech Republic & 1.4 & 17.8 & 0.0 & 15.8 & 100.0 & 63.8 & 13.4 & $\ldots$ & 2.6 & $\ldots$ & 0.0 \\
\hline $\begin{array}{l}\text { Denmark } \\
\text { Estonia }\end{array}$ & $\begin{array}{l}\ldots \\
\ldots\end{array}$ & $\ldots$ & $\ldots$ & $\ldots$ & $\ldots$ & $\cdots$ & $\cdots$ & $\cdots$ & $\cdots$ & $\cdots$ & $\cdots$ \\
\hline $\begin{array}{l}\text { Estonia } \\
\text { Finland }\end{array}$ & 8.8 & $\begin{array}{l}\ldots .0 \\
0.0\end{array}$ & $\begin{array}{r}\ldots \\
73.8\end{array}$ & $\begin{array}{r}\ldots \\
0.6\end{array}$ & $\begin{array}{r}\ldots \\
100.0\end{array}$ & $\begin{array}{r}\ldots \\
19.4\end{array}$ & $\begin{array}{r}\ldots \\
53.8\end{array}$ & $\begin{array}{r}\ldots \\
1.1\end{array}$ & $\begin{array}{r}\ldots \\
1.0\end{array}$ & $\begin{array}{l}\cdots \\
\ldots\end{array}$ & $\begin{array}{r}\ldots \\
5.2\end{array}$ \\
\hline France & 10.2 & 3.0 & 1.1 & 59.9 & $\ldots$ & 26.6 & $\ldots$ & $\ldots$ & 9.4 & 36.9 & $\ldots$ \\
\hline Georgia & & $\ldots$ & $\ldots$ & & $\ldots$ & $\ldots$ & $\ldots$ & $\ldots$ & $\cdots$ & $\ldots$ & $\ldots$ \\
\hline Germany & 16.1 & 3.4 & $\ldots$ & 77.8 & $\ldots$ & 11.6 & 100.0 & $\ldots$ & 7.2 & $\ldots$ & $\ldots$ \\
\hline Hungary & 8.8 & 1.3 & 1.9 & 61.7 & 31.3 & 24.9 & 84.7 & 0.0 & 10.3 & 0.0 & 0.0 \\
\hline Iceland & $\ldots$ & $\ldots$ & $\ldots$ & $\ldots$ & $\ldots$ & $\ldots$ & $\ldots$ & $\ldots$ & $\ldots$ & $\ldots$ & $\ldots$ \\
\hline $\begin{array}{l}\text { Italy } \\
\text { Kosovo (UN }\end{array}$ & $\ldots$ & $\ldots$ & $\ldots$ & $\cdots$ & $\cdots$ & $\ldots$ & $\ldots$ & $\cdots$ & $\cdots$ & $\ldots$ & $\ldots$ \\
\hline $\mathrm{R} / 1244 / 99)$ & $\ldots$ & $\ldots$ & $\ldots$ & $\ldots$ & $\ldots$ & $\cdots$ & $\cdots$ & $\cdots$ & $\ldots$ & $\ldots$ & $\cdots$ \\
\hline Latvia & $\ldots$ & $\ldots$ & $\ldots$ & $\ldots$ & $\ldots$ & $\ldots$ & $\ldots$ & $\ldots$ & $\ldots$ & $\ldots$ & $\ldots$ \\
\hline Lithuania & 4.1 & $\ldots$ & $\ldots$ & $\ldots$ & $\ldots$ & $\ldots$ & $\ldots$ & $\ldots$ & $\ldots$ & $\cdots$ & $\ldots$ \\
\hline Luxembourg & $\ldots$ & $\ldots$ & $\ldots$ & $\ldots$ & $\ldots$ & $\ldots$ & $\ldots$ & $\ldots$ & $\ldots$ & $\ldots$ & ... \\
\hline Moldova & $\ldots$ & $\ldots$ & $\ldots$ & $\ldots$ & $\ldots$ & $\ldots$ & $\ldots$ & $\ldots$ & $\ldots$ & $\ldots$ & ... \\
\hline Montenegro & $\ldots$ & $\ldots$ & $\ldots$ & $\ldots$ & $\ldots$ & $\ldots$ & $\ldots$ & $\ldots$ & $\ldots$ & $\ldots$ & $\ldots$ \\
\hline Netherlands & $\ldots$ & $\ldots$ & 1.2 & 85.9 & 98.6 & 7.1 & $\ldots$ & 65.4 & 5.7 & 66.7 & ... \\
\hline North Macedonia & 4.3 & $\ldots$ & $\ldots$ & $\ldots$ & $\ldots$ & $\ldots$ & $\ldots$ & $\ldots$ & $\ldots$ & $\ldots$ & $\ldots$ \\
\hline Norway & & $\ldots$ & $\ldots$ & $\ldots$ & $\ldots$ & $\ldots$ & $\ldots$ & $\ldots$ & $\ldots$ & $\ldots$ & $\ldots$ \\
\hline Poland & 5.2 & $\ldots$ & $\ldots$ & 93.0 & $\ldots$ & 0.9 & $\ldots$ & $\ldots$ & 6.1 & $\ldots$ & $\ldots$ \\
\hline Portugal & 1.5 & $\ldots$ & 64.2 & 9.9 & 100.0 & 19.9 & 83.3 & $\ldots$ & 2.0 & $\ldots$ & 2.6 \\
\hline Romania & $\ldots$ & $\ldots$ & $\ldots$ & $\ldots$ & $\ldots$ & $\ldots$ & $\ldots$ & $\ldots$ & $\ldots$ & $\ldots$ & $\ldots$ \\
\hline Russian Federation & & $\ldots$ & $\ldots$ & & $\ldots$ & ... & $\ldots$ & $\ldots$ & $\ldots$ & $\ldots$ & $\ldots$ \\
\hline Serbia & 2.2 & $\cdots$ & $\ldots$ & 100.0 & $\ldots$ & ... & $\ldots$ & $\ldots$ & 0.0 & $\cdots$ & ... \\
\hline Slovak Republic & $\ldots$ & $\ldots$ & $\ldots$ & $\ldots$ & $\ldots$ & $\ldots$ & $\ldots$ & $\ldots$ & $\ldots$ & $\ldots$ & ... \\
\hline Slovenia & $\ldots$ & $\ldots$ & $\ldots$ & $\ldots$ & $\ldots$ & $\cdots$ & $\cdots$ & $\cdots$ & $\cdots$ & $\cdots$ & ... \\
\hline Spain & & $\ldots$ & $\ldots$ & $\ldots$ & $\ldots$ & $\ldots$ & $\ldots$ & $\ldots$ & $\ldots$ & $\ldots$ & $\ldots$ \\
\hline Sweden & 15.1 & 0.1 & 9.9 & 10.1 & 23.5 & 20.9 & $\ldots$ & 56.3 & 4.9 & 19.4 & 54.1 \\
\hline Switzerland & & $\ldots$ & & & $\ldots$ & $\ldots$ & $\ldots$ & $\ldots$ & $\ldots$ & $\ldots$ & \\
\hline Turkey & 12.7 & $\ldots$ & 70.5 & 2.2 & $\ldots$ & 6.7 & $\ldots$ & $\ldots$ & 9.6 & $\ldots$ & 10.9 \\
\hline Ukraine & & $\ldots$ & & $\ldots$ & $\ldots$ & $\ldots$ & $\ldots$ & $\ldots$ & $\ldots$ & $\ldots$ & . \\
\hline UK: England \& Wales & 8.9 & $\ldots$ & 0.7 & 76.4 & $\ldots$ & 0.0 & $\ldots$ & $\ldots$ & 18.2 & $\cdots$ & 5.5 \\
\hline $\begin{array}{l}\text { UK: Northern Ireland } \\
\text { UK: Scotland }\end{array}$ & $\ldots$ & $\begin{array}{l}\cdots \\
\ldots\end{array}$ & $\begin{array}{l}\ldots \\
\ldots\end{array}$ & $\begin{array}{l}\ldots \\
\ldots\end{array}$ & $\begin{array}{l}\cdots \\
\ldots\end{array}$ & $\begin{array}{l}\ldots \\
\ldots\end{array}$ & $\begin{array}{l}\ldots \\
\ldots\end{array}$ & $\begin{array}{l}\cdots \\
\ldots\end{array}$ & $\begin{array}{l}\ldots \\
\ldots\end{array}$ & $\begin{array}{l}\ldots \\
\ldots\end{array}$ & $\begin{array}{l}\ldots \\
\ldots\end{array}$ \\
\hline Mean & 6.5 & 10.0 & 24.1 & 44.6 & 56.7 & 22.8 & 52.6 & 24.6 & 8.7 & 27.6 & 8.0 \\
\hline Median & 4.8 & 2.1 & 1.9 & 45.7 & 65.0 & 19.6 & 53.8 & 1.1 & 6.1 & 28.1 & 2.2 \\
\hline Minimum & 0.3 & 0.0 & 0.0 & 0.0 & 0.0 & 0.0 & 0.0 & 0.0 & 0.0 & 0.0 & 0.0 \\
\hline Maximum & 16.1 & 54.3 & 73.8 & 100.0 & 100.0 & 63.8 & 100.0 & 65.4 & 40.0 & 66.7 & 54.1 \\
\hline
\end{tabular}


Table 3.2.4.6 Minors receiving sanctions/measures in 2015 - Aggravated bodily injury

\begin{tabular}{|c|c|c|c|c|c|c|c|c|c|c|c|}
\hline & \multirow[b]{2}{*}{ 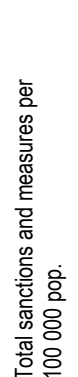 } & \multirow[b]{2}{*}{ 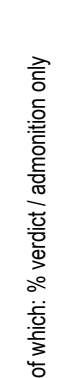 } & \multirow[b]{2}{*}{ 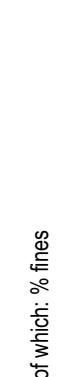 } & \multicolumn{2}{|c|}{$\begin{array}{l}\text { of which: \% } \\
\text { non-custodial } \\
\text { sanctions and } \\
\text { measures }\end{array}$} & \multicolumn{3}{|c|}{$\begin{array}{l}\text { of which: \% suspended } \\
\text { custodial sanctions and } \\
\text { measures }\end{array}$} & \multicolumn{2}{|c|}{$\begin{array}{l}\text { of which: \% un- } \\
\text { suspended custo- } \\
\text { dial sanctions } \\
\text { and measures }\end{array}$} & \multirow[b]{2}{*}{ 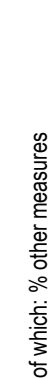 } \\
\hline & & & & 颉 & 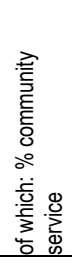 & 咞 & 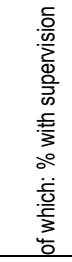 & 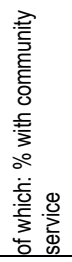 & 要 & 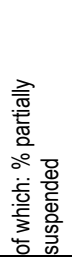 & \\
\hline Albania & & & & & $\ldots$ & & & & & & $\ldots$ \\
\hline Armenia & 0.3 & 0.0 & 0.0 & 0.0 & $\ldots$ & 60.0 & 0.0 & 0.0 & 40.0 & 0.0 & \\
\hline Austria & 1.4 & $\ldots$ & 14.7 & $\ldots$ & $\ldots$ & 71.6 & $\ldots$ & $\ldots$ & 12.9 & 60.0 & 0.9 \\
\hline Azerbaijan & $\ldots$ & $\ldots$ & $\ldots$ & $\ldots$ & $\ldots$ & $\ldots$ & $\ldots$ & $\ldots$ & $\ldots$ & $\ldots$ & $\ldots$ \\
\hline Belgium & $\ldots$ & $\ldots$ & $\ldots$ & $\ldots$ & $\ldots$ & $\ldots$ & $\ldots$ & $\ldots$ & $\ldots$ & $\ldots$ & ... \\
\hline Bosnia-Herzegovina & $\ldots$ & $\ldots$ & $\ldots$ & $\ldots$ & $\ldots$ & $\ldots$ & $\ldots$ & $\ldots$ & $\ldots$ & $\ldots$ & ... \\
\hline Bulgaria & & & & & & & & & & $\ldots$ & ... \\
\hline Croatia & 0.5 & 57.1 & $\ldots$ & 19.0 & 0.0 & 14.3 & 33.3 & $\ldots$ & 9.5 & $\ldots$ & ... \\
\hline Cyprus & & & & & $\ldots$ & & & $\ldots$ & & $\ldots$ & \\
\hline Czech Republic & 0.1 & 0.0 & 0.0 & 0.0 & $\ldots$ & 42.9 & 33.3 & $\ldots$ & 57.1 & $\ldots$ & 0.0 \\
\hline $\begin{array}{l}\text { Denmark } \\
\text { Estonia }\end{array}$ & $\ldots$ & $\ldots$ & $\ldots$ & $\ldots$ & $\ldots$ & $\ldots$ & $\ldots$ & $\ldots$ & $\ldots$ & $\ldots$ & ... \\
\hline Finland & 0.3 & 0.0 & 0.0 & 5.3 & 100.0 & 84.2 & 50.0 & 6.3 & 10.5 & $\cdots$ & 0.0 \\
\hline France & 1.4 & 1.4 & 0.7 & 44.8 & $\ldots$ & 34.8 & $\ldots$ & $\ldots$ & 18.3 & 59.8 & ... \\
\hline Georgia & 0.1 & & $\ldots$ & $\ldots$ & $\ldots$ & & $\ldots$ & $\ldots$ & 80.0 & $\ldots$ & ... \\
\hline Germany & 7.5 & 4.1 & & 71.1 & & 15.5 & 100.0 & & 9.2 & $\ldots$ & $\ldots$ \\
\hline Hungary & 4.3 & 0.0 & 1.2 & 56.8 & 34.9 & 27.2 & 82.5 & 0.0 & 14.8 & 0.0 & 0.0 \\
\hline Iceland & $\ldots$ & $\ldots$ & $\ldots$ & $\ldots$ & $\ldots$ & $\ldots$ & $\ldots$ & $\ldots$ & $\ldots$ & $\ldots$ & $\ldots$ \\
\hline $\begin{array}{l}\text { Italy } \\
\text { Kosovo (UN }\end{array}$ & $\ldots$ & $\ldots$ & $\ldots$ & $\ldots$ & $\ldots$ & $\ldots$ & $\ldots$ & $\ldots$ & $\ldots$ & $\ldots$ & $\ldots$ \\
\hline R/1244/99) & $\ldots$ & $\ldots$ & $\ldots$ & $\ldots$ & $\ldots$ & $\ldots$ & $\ldots$ & $\ldots$ & $\ldots$ & $\ldots$ & ... \\
\hline Latvia & & $\ldots$ & $\ldots$ & $\ldots$ & $\ldots$ & $\ldots$ & $\ldots$ & $\ldots$ & $\ldots$ & $\ldots$ & ... \\
\hline Lithuania & 0.3 & $\ldots$ & $\ldots$ & $\ldots$ & $\ldots$ & $\ldots$ & $\ldots$ & $\ldots$ & $\ldots$ & $\ldots$ & ... \\
\hline Luxembourg & $\ldots$ & & & $\ldots$ & & & $\ldots$ & & & $\ldots$ & ... \\
\hline Moldova & $\ldots$ & $\ldots$ & $\ldots$ & $\ldots$ & $\ldots$ & $\ldots$ & $\ldots$ & $\ldots$ & $\ldots$ & $\ldots$ & ... \\
\hline Montenegro & $\ldots$ & $\ldots$ & & $\ldots$ & & & $\ldots$ & & & & ... \\
\hline Netherlands & & $\ldots$ & 0.0 & 62.4 & 98.7 & 19.2 & $\ldots$ & 87.5 & 17.6 & 86.4 & ... \\
\hline North Macedonia & 0.7 & $\ldots$ & $\ldots$ & $\ldots$ & $\ldots$ & $\ldots$ & $\ldots$ & $\ldots$ & $\ldots$ & $\ldots$ & $\ldots$ \\
\hline Norway & & $\ldots$ & $\ldots$ & & $\ldots$ & & $\ldots$ & $\ldots$ & & $\ldots$ & $\ldots$ \\
\hline Poland & 0.1 & $\ldots$ & & 75.7 & & $\begin{array}{lll}5.4 & & \end{array}$ & 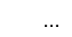 & $\ldots$ & 18.9 & $\ldots$ & ... \\
\hline Portugal & 0.4 & $\ldots$ & 31.0 & 23.8 & 100.0 & 38.1 & 87.5 & $\ldots$ & 7.1 & $\ldots$ & ... \\
\hline Romania & $\ldots$ & $\ldots$ & $\ldots$ & $\ldots$ & $\ldots$ & $\ldots$ & $\ldots$ & $\ldots$ & $\ldots$ & $\ldots$ & ... \\
\hline Russian Federation & . & $\ldots$ & $\ldots$ & $\ldots$ & $\ldots$ & $\ldots$ & $\ldots$ & $\ldots$ & . & $\ldots$ & ... \\
\hline Serbia & 1.1 & $\ldots$ & $\ldots$ & 100.0 & $\ldots$ & $\ldots$ & $\ldots$ & $\ldots$ & 0.0 & $\ldots$ & ... \\
\hline Slovak Republic & $\ldots$ & $\ldots$ & $\ldots$ & $\ldots$ & $\ldots$ & $\ldots$ & $\ldots$ & $\ldots$ & $\ldots$ & $\ldots$ & ... \\
\hline $\begin{array}{l}\text { Slovenia } \\
\text { Spain }\end{array}$ & $\ldots$ & $\ldots$ & $\ldots$ & $\ldots$ & $\ldots$ & $\ldots$ & $\cdots$ & $\ldots$ & $\ldots$ & $\cdots$ & $\ldots$ \\
\hline $\begin{array}{l}\text { Spain } \\
\text { Sweden }\end{array}$ & 1.3 & 0.0 & 0.0 & $14 . \ddot{6}$ & 21.1 & 7.7 & ... & 90.0 & 32.3 & 21.4 & 45.4 \\
\hline Switzerland & & . & & & $\ldots$ & & $\ldots$ & $\ldots$ & & & \\
\hline Turkey & 0.1 & $\ldots$ & 49.2 & 5.1 & $\ldots$ & 8.5 & $\ldots$ & $\ldots$ & 27.1 & $\ldots$ & 10.2 \\
\hline Ukraine & 0.1 & $\ldots$ & 2.1 & $\ldots$ & & & $\ldots$ & & 46.8 & $\ldots$ & ... \\
\hline UK: England \& Wales & $\ldots$ & $\ldots$ & $\ldots$ & $\ldots$ & $\ldots$ & $\ldots$ & $\ldots$ & $\ldots$ & $\ldots$ & $\ldots$ & ... \\
\hline $\begin{array}{l}\text { UK: Northern Ireland } \\
\text { UK: Scotland }\end{array}$ & $\ldots$ & $\ldots$ & $\ldots$ & $\ldots$ & $\ldots$ & $\ldots$ & $\ldots$ & $\ldots$ & $\ldots$ & $\ldots$ & ... \\
\hline Mean & 1.2 & 7.8 & 9.0 & 36.8 & 59.1 & 33.0 & 55.2 & 36.8 & 25.1 & 37.9 & 9.4 \\
\hline Median & 0.4 & 0.0 & 0.7 & 23.8 & 66.8 & 27.2 & 50.0 & 6.3 & 17.9 & 40.6 & 0.4 \\
\hline Minimum & 0.1 & 0.0 & 0.0 & 0.0 & 0.0 & 5.4 & 0.0 & 0.0 & 0.0 & 0.0 & 0.0 \\
\hline Maximum & 7.5 & 57.1 & 49.2 & 100.0 & 100.0 & 84.2 & 100.0 & 90.0 & 80.0 & 86.4 & 45.4 \\
\hline
\end{tabular}


Table 3.2.4.7 Minors receiving sanctions/measures in 2015 - Sexual assault

\begin{tabular}{|c|c|c|c|c|c|c|c|c|c|c|c|}
\hline & \multirow[b]{2}{*}{ 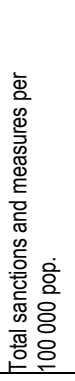 } & \multirow[b]{2}{*}{ 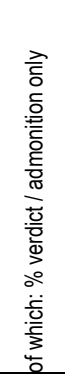 } & \multirow[b]{2}{*}{ 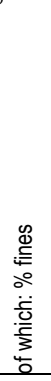 } & \multicolumn{2}{|c|}{$\begin{array}{l}\text { of which: \% } \\
\text { non-custodial } \\
\text { sanctions and } \\
\text { measures }\end{array}$} & \multicolumn{3}{|c|}{$\begin{array}{l}\text { of which: \% suspended } \\
\text { custodial sanctions and } \\
\text { measures }\end{array}$} & \multicolumn{2}{|c|}{$\begin{array}{l}\text { of which: \% un- } \\
\text { suspended custo- } \\
\text { dial sanctions } \\
\text { and measures }\end{array}$} & \multirow[b]{2}{*}{ 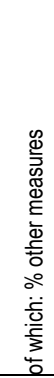 } \\
\hline & & & & 要 & 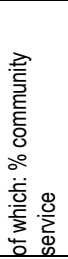 & 要 & 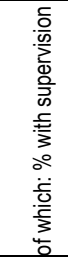 & 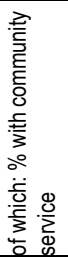 & 愛 & 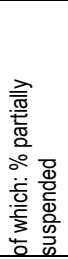 & \\
\hline Albania & $\ldots$ & $\ldots$ & $\ldots$ & $\ldots$ & $\ldots$ & $\ldots$ & $\ldots$ & $\ldots$ & $\ldots$ & $\ldots$ & $\ldots$ \\
\hline Armenia & $\ldots$ & $\ldots$ & $\ldots$ & $\ldots$ & $\ldots$ & $\ldots$ & $\ldots$ & $\ldots$ & $\ldots$ & $\ldots$ & $\ldots$ \\
\hline Austria & 0.3 & $\ldots$ & 0.0 & $\ldots$ & $\ldots$ & 63.3 & $\ldots$ & $\ldots$ & 30.0 & 66.7 & 6.7 \\
\hline Azerbaijan & & $\ldots$ & $\ldots$ & $\ldots$ & $\ldots$ & & $\ldots$ & $\ldots$ & $\ldots$ & $\ldots$ & $\ldots$ \\
\hline Belgium & 0.0 & $\ldots$ & 0.0 & 0.0 & $\ldots$ & 100.0 & 0.0 & $\ldots$ & 0.0 & ... & 0.0 \\
\hline Bosnia-Herzegovina & & $\ldots$ & $\ldots$ & $\ldots$ & $\ldots$ & $\ldots$ & $\ldots$ & $\ldots$ & $\ldots$ & $\ldots$ & $\ldots$ \\
\hline Bulgaria & 0.2 & $\ldots$ & 0.0 & 38.9 & $\ldots$ & $\ldots$ & $\ldots$ & $\ldots$ & 61.1 & 0.0 & 0.0 \\
\hline Croatia & 0.2 & 37.5 & $\ldots$ & 0.0 & $\ldots$ & 37.5 & 100.0 & $\ldots$ & 25.0 & $\ldots$ & $\ldots$ \\
\hline Cyprus & & $\ldots$ & $\ldots$ & $\ldots$ & $\ldots$ & $\ldots$ & $\ldots$ & $\ldots$ & $\ldots$ & $\ldots$ & $\ldots$ \\
\hline Czech Republic & 1.2 & 11.9 & 0.0 & 0.8 & 100.0 & 81.0 & 9.8 & $\ldots$ & 4.8 & $\ldots$ & 1.6 \\
\hline Denmark & $\ldots$ & $\ldots$ & $\ldots$ & $\ldots$ & $\ldots$ & $\ldots$ & $\ldots$ & $\ldots$ & $\ldots$ & $\ldots$ & $\ldots$ \\
\hline Estonia & & $\ldots$ & $\ldots$ & $\ldots$ & $\ldots$ & $\ldots$ & $\ldots$ & $\ldots$ & $\ldots$ & $\ldots$ & $\ldots$ \\
\hline Finland & 0.7 & 0.0 & 7.7 & 0.0 & $\ldots$ & 76.9 & 43.3 & 23.3 & 12.8 & $\ldots$ & 2.6 \\
\hline France & 2.5 & 1.3 & 0.1 & 41.5 & $\ldots$ & 43.0 & $\ldots$ & $\ldots$ & 14.0 & 61.9 & $\ldots$ \\
\hline Georgia & & $\ldots$ & $\ldots$ & & $\ldots$ & $\ldots$ & $\ldots$ & $\ldots$ & $\ldots$ & $\ldots$ & $\ldots$ \\
\hline Germany & 0.8 & 7.5 & $\ldots$ & 48.6 & $\ldots$ & 31.1 & 100.0 & $\ldots$ & 12.8 & $\ldots$ & $\ldots$ \\
\hline Hungary & 0.5 & 0.0 & 0.0 & 21.3 & 0.0 & 31.9 & 80.0 & 0.0 & 46.8 & 0.0 & 0.0 \\
\hline Iceland & $\ldots$ & $\ldots$ & $\ldots$ & $\ldots$ & $\ldots$ & $\ldots$ & $\ldots$ & $\ldots$ & $\ldots$ & $\ldots$ & $\ldots$ \\
\hline $\begin{array}{l}\text { Italy } \\
\text { Kosovo (UN }\end{array}$ & $\ldots$ & $\ldots$ & $\ldots$ & $\ldots$ & $\cdots$ & $\cdots$ & $\ldots$ & $\ldots$ & $\cdots$ & $\cdots$ & $\ldots$ \\
\hline $\mathrm{R} / 1244 / 99)$ & $\ldots$ & $\ldots$ & $\ldots$ & $\ldots$ & $\ldots$ & $\ldots$ & $\ldots$ & $\ldots$ & $\ldots$ & $\ldots$ & $\ldots$ \\
\hline Latvia & $\ldots$ & $\ldots$ & $\ldots$ & $\ldots$ & $\ldots$ & $\ldots$ & $\ldots$ & $\ldots$ & $\ldots$ & $\ldots$ & $\ldots$ \\
\hline Lithuania & 1.3 & $\ldots$ & $\ldots$ & $\ldots$ & ... & $\ldots$ & $\ldots$ & $\ldots$ & ... & $\ldots$ & $\ldots$ \\
\hline Luxembourg & $\ldots$ & $\ldots$ & $\ldots$ & $\ldots$ & $\ldots$ & $\ldots$ & $\ldots$ & $\ldots$ & $\ldots$ & ... & $\ldots$ \\
\hline Moldova & $\ldots$ & $\ldots$ & $\ldots$ & $\ldots$ & $\cdots$ & $\ldots$ & $\ldots$ & $\ldots$ & ... & ... & ... \\
\hline Montenegro & $\ldots$ & $\ldots$ & $\ldots$ & $\ldots$ & $\ldots$ & $\ldots$ & $\ldots$ & $\ldots$ & $\ldots$ & $\ldots$ & $\ldots$ \\
\hline Netherlands & $\ldots$ & $\ldots$ & 0.0 & 40.9 & 80.6 & 26.1 & $\ldots$ & 65.2 & 33.0 & 51.7 & $\ldots$ \\
\hline North Macedonia & 0.5 & $\ldots$ & $\ldots$ & $\ldots$ & $\ldots$ & $\ldots$ & $\ldots$ & $\ldots$ & $\ldots$ & $\ldots$ & $\ldots$ \\
\hline Norway & 1.0 & $\ldots$ & $\ldots$ & $\ldots$ & $\ldots$ & $\ldots$ & $\ldots$ & $\ldots$ & $\ldots$ & ... & $\ldots$ \\
\hline Poland & 0.5 & $\ldots$ & $\ldots$ & 84.7 & $\ldots$ & 3.9 & $\ldots$ & $\ldots$ & 11.3 & ... & $\ldots$ \\
\hline Portugal & 0.1 & $\ldots$ & $\ldots$ & $\ldots$ & $\ldots$ & 78.6 & 90.9 & $\ldots$ & $\ldots$ & $\ldots$ & $\ldots$ \\
\hline Romania & $\ldots$ & $\ldots$ & $\ldots$ & $\ldots$ & ... & $\ldots$ & $\ldots$ & $\ldots$ & $\ldots$ & ... & $\ldots$ \\
\hline Russian Federation & & $\cdots$ & $\ldots$ & $\ldots$ & ... & $\ldots$ & $\ldots$ & $\ldots$ & $\ldots$ & ... & $\ldots$ \\
\hline Serbia & 0.2 & $\ldots$ & $\ldots$ & 100.0 & $\ldots$ & $\ldots$ & $\ldots$ & $\ldots$ & 0.0 & $\ldots$ & $\ldots$ \\
\hline Slovak Republic & $\ldots$ & $\ldots$ & $\ldots$ & $\ldots$ & $\cdots$ & $\ldots$ & $\ldots$ & $\ldots$ & $\ldots$ & $\cdots$ & ... \\
\hline Slovenia & $\ldots$ & $\ldots$ & $\ldots$ & $\ldots$ & $\ldots$ & $\ldots$ & $\ldots$ & $\ldots$ & $\cdots$ & $\cdots$ & ... \\
\hline Spain & $\ldots$ & $\ldots$ & $\ldots$ & $\ldots$ & $\ldots$ & $\ldots$ & $\ldots$ & $\ldots$ & $\ldots$ & $\ldots$ & $\ldots$ \\
\hline Sweden & 1.2 & 0.0 & 0.0 & 9.9 & 50.0 & 13.2 & $\ldots$ & 87.5 & 31.4 & 5.3 & 45.5 \\
\hline Switzerland & & $\ldots$ & . & & $\ldots$ & $\ldots$ & $\ldots$ & $\ldots$ & $\ldots$ & $\ldots$ & $\ldots$ \\
\hline Turkey & 3.1 & $\ldots$ & 2.2 & 5.9 & $\ldots$ & 6.6 & $\ldots$ & $\ldots$ & 76.9 & $\ldots$ & 8.4 \\
\hline Ukraine & & $\ldots$ & & $\ldots$ & $\ldots$ & $\ldots$ & $\ldots$ & $\ldots$ & $\ldots$ & $\ldots$ & $\ldots$ \\
\hline UK: England \& Wales & 1.0 & $\ldots$ & 3.8 & 72.7 & $\ldots$ & 0.0 & $\ldots$ & $\ldots$ & 18.4 & ... & 8.9 \\
\hline $\begin{array}{l}\text { UK: Northern Ireland } \\
\text { UK: Scotland }\end{array}$ & $\cdots$ & $\begin{array}{l}\ldots \\
\ldots\end{array}$ & $\begin{array}{l}\ldots \\
\ldots\end{array}$ & $\begin{array}{l}\ldots \\
\ldots\end{array}$ & $\begin{array}{l}\ldots \\
\ldots\end{array}$ & $\begin{array}{l}\ldots \\
\ldots \\
\ldots\end{array}$ & $\begin{array}{l}\cdots \\
\ldots\end{array}$ & $\begin{array}{l}\ldots \\
\ldots\end{array}$ & $\begin{array}{l}\ldots \\
\ldots\end{array}$ & $\begin{array}{l}\ldots \\
\ldots\end{array}$ & $\begin{array}{l}\ldots \\
\ldots\end{array}$ \\
\hline Mean & 0.9 & 8.3 & 1.3 & 33.2 & 57.6 & 42.4 & 60.6 & 44.0 & 25.2 & 30.9 & 8.2 \\
\hline Median & 0.6 & 1.3 & 0.0 & 30.1 & 65.3 & 34.7 & 80.0 & 44.3 & 18.4 & 28.5 & 2.6 \\
\hline Minimum & 0.0 & 0.0 & 0.0 & 0.0 & 0.0 & 0.0 & 0.0 & 0.0 & 0.0 & 0.0 & 0.0 \\
\hline Maximum & 3.1 & 37.5 & 7.7 & 100.0 & 100.0 & 100.0 & 100.0 & 87.5 & 76.9 & 66.7 & 45.5 \\
\hline
\end{tabular}


Table 3.2.4.8 Minors receiving sanctions/measures in 2015 - Rape

\begin{tabular}{|c|c|c|c|c|c|c|c|c|c|c|c|}
\hline & \multirow[b]{2}{*}{ 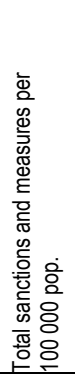 } & \multirow[b]{2}{*}{ 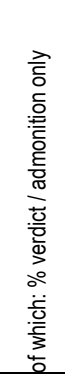 } & \multirow[b]{2}{*}{ 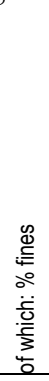 } & \multicolumn{2}{|c|}{$\begin{array}{l}\text { of which: \% } \\
\text { non-custodial } \\
\text { sanctions and } \\
\text { measures }\end{array}$} & \multicolumn{3}{|c|}{$\begin{array}{l}\text { of which: \% suspended } \\
\text { custodial sanctions and } \\
\text { measures }\end{array}$} & \multicolumn{2}{|c|}{$\begin{array}{l}\text { of which: \% un- } \\
\text { suspended cus- } \\
\text { todial sanctions } \\
\text { and measures }\end{array}$} & \multirow[b]{2}{*}{ 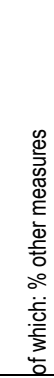 } \\
\hline & & & & 判 & 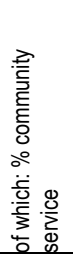 & 要 & 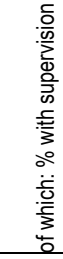 & 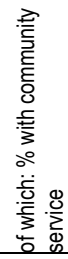 & 受 & 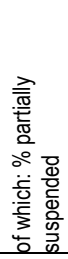 & \\
\hline Albania & & $\ldots$ & $\ldots$ & $\ldots$ & $\ldots$ & $\ldots$ & $\ldots$ & $\ldots$ & $\ldots$ & $\ldots$ & $\ldots$ \\
\hline Armenia & 0.0 & $\ldots$ & $\ldots$ & $\ldots$ & $\ldots$ & $\ldots$ & $\ldots$ & $\ldots$ & $\ldots$ & $\ldots$ & $\ldots$ \\
\hline Austria & 0.1 & $\ldots$ & 0.0 & $\ldots$ & $\ldots$ & 33.3 & $\ldots$ & $\ldots$ & 58.3 & 85.7 & 8.3 \\
\hline Azerbaijan & $\ldots$ & $\ldots$ & $\ldots$ & $\ldots$ & $\ldots$ & $\ldots$ & $\ldots$ & $\ldots$ & $\ldots$ & $\ldots$ & $\ldots$ \\
\hline Belgium & 0.0 & $\ldots$ & 0.0 & 0.0 & $\ldots$ & 100.0 & 0.0 & $\ldots$ & 0.0 & $\ldots$ & 0.0 \\
\hline Bosnia-Herzegovina & $\ldots$ & $\ldots$ & $\ldots$ & $\ldots$ & $\ldots$ & $\ldots$ & $\ldots$ & $\ldots$ & $\ldots$ & $\ldots$ & $\ldots$ \\
\hline Bulgaria & 0.2 & $\ldots$ & 0.0 & 25.0 & $\ldots$ & $\ldots$ & $\ldots$ & $\ldots$ & 75.0 & $\ldots$ & 0.0 \\
\hline Croatia & 0.2 & 28.6 & $\ldots$ & 0.0 & $\ldots$ & 42.9 & 100.0 & $\ldots$ & 28.6 & $\ldots$ & $\ldots$ \\
\hline Cyprus & $\ldots$ & $\ldots$ & $\ldots$ & $\ldots$ & $\ldots$ & $\ldots$ & $\ldots$ & $\ldots$ & $\ldots$ & $\ldots$ & $\ldots$ \\
\hline Czech Republic & 0.1 & 0.0 & 0.0 & 0.0 & $\ldots$ & 57.1 & 25.0 & $\ldots$ & 14.3 & $\ldots$ & 14.3 \\
\hline Denmark & $\ldots$ & $\ldots$ & $\ldots$ & $\ldots$ & $\ldots$ & $\ldots$ & $\ldots$ & $\ldots$ & $\ldots$ & $\ldots$ & $\ldots$ \\
\hline Estonia & $\ldots$ & $\ldots$ & $\ldots$ & $\ldots$ & $\ldots$ & $\ldots$ & $\ldots$ & $\ldots$ & $\ldots$ & ... & $\ldots$ \\
\hline Finland & 0.2 & 0.0 & 0.0 & 0.0 & $\ldots$ & 91.7 & 54.5 & 27.3 & 8.3 & $\ldots$ & 0.0 \\
\hline France & 0.5 & 0.0 & 0.0 & 11.5 & $\ldots$ & 42.4 & 0.0 & $\ldots$ & 46.1 & 57.4 & $\ldots$ \\
\hline Georgia & 0.0 & $\ldots$ & $\ldots$ & $\ldots$ & $\ldots$ & $\ldots$ & $\ldots$ & $\ldots$ & 100.0 & $\ldots$ & $\ldots$ \\
\hline Germany & 0.1 & 4.8 & $\ldots$ & 15.2 & $\ldots$ & 46.7 & 100.0 & $\ldots$ & 33.3 & $\ldots$ & $\ldots$ \\
\hline Hungary & 0.3 & 0.0 & 0.0 & 7.4 & 0.0 & 25.9 & 85.7 & 0.0 & 66.7 & 0.0 & 0.0 \\
\hline Iceland & $\ldots$ & $\ldots$ & $\ldots$ & $\ldots$ & $\ldots$ & $\ldots$ & $\ldots$ & $\ldots$ & $\ldots$ & $\ldots$ & $\ldots$ \\
\hline $\begin{array}{l}\text { Italy } \\
\text { Kosovo (UN }\end{array}$ & $\ldots$ & $\cdots$ & $\ldots$ & $\ldots$ & $\ldots$ & $\cdots$ & $\ldots$ & $\ldots$ & $\cdots$ & $\cdots$ & $\ldots$ \\
\hline $\mathrm{R} / 1244 / 99)$ & $\ldots$ & $\cdots$ & $\ldots$ & $\ldots$ & $\cdots$ & $\cdots$ & $\cdots$ & $\ldots$ & $\ldots$ & $\cdots$ & ... \\
\hline Latvia & $\ldots$ & $\ldots$ & $\ldots$ & $\ldots$ & $\ldots$ & $\ldots$ & $\ldots$ & $\ldots$ & ... & ... & $\ldots$ \\
\hline Lithuania & 1.1 & $\ldots$ & $\ldots$ & $\ldots$ & $\ldots$ & $\ldots$ & $\ldots$ & $\ldots$ & $\ldots$ & ... & $\ldots$ \\
\hline Luxembourg & $\ldots$ & $\ldots$ & $\ldots$ & $\ldots$ & $\cdots$ & $\cdots$ & $\ldots$ & $\ldots$ & $\ldots$ & $\cdots$ & $\ldots$ \\
\hline Moldova & $\ldots$ & $\ldots$ & $\ldots$ & $\ldots$ & $\ldots$ & $\cdots$ & $\cdots$ & $\ldots$ & $\ldots$ & $\cdots$ & $\ldots$ \\
\hline Montenegro & & $\ldots$ & $\ldots$ & $\ldots$ & $\ldots$ & $\ldots$ & $\ldots$ & $\ldots$ & $\ldots$ & $\cdots$ & $\cdots$ \\
\hline Netherlands & 0.0 & $\ldots$ & 0.0 & 0.0 & $\ldots$ & 45.5 & $\ldots$ & 100.0 & 45.5 & 100.0 & $\ldots$ \\
\hline North Macedonia & 0.1 & $\ldots$ & $\ldots$ & $\ldots$ & $\ldots$ & $\ldots$ & $\ldots$ & $\ldots$ & $\ldots$ & $\ldots$ & $\ldots$ \\
\hline Norway & $\ldots$ & $\ldots$ & $\ldots$ & $\ldots$ & $\ldots$ & $\ldots$ & $\ldots$ & $\ldots$ & $\ldots$ & $\ldots$ & $\ldots$ \\
\hline Poland & 0.1 & $\ldots$ & $\ldots$ & 65.4 & $\ldots$ & 7.7 & $\ldots$ & $\ldots$ & 26.9 & $\ldots$ & $\ldots$ \\
\hline Portugal & 0.0 & $\ldots$ & $\ldots$ & $\ldots$ & $\ldots$ & $\ldots$ & $\ldots$ & $\ldots$ & $\ldots$ & ... & $\ldots$ \\
\hline Romania & $\ldots$ & $\ldots$ & $\ldots$ & $\ldots$ & $\ldots$ & $\ldots$ & $\ldots$ & $\ldots$ & $\ldots$ & $\ldots$ & ... \\
\hline Russian Federation & $\ldots$ & $\ldots$ & $\ldots$ & $\ldots$ & $\ldots$ & $\ldots$ & ... & $\ldots$ & $\ldots$ & ... & $\ldots$ \\
\hline Serbia & 0.1 & $\ldots$ & $\ldots$ & 100.0 & $\ldots$ & $\ldots$ & $\ldots$ & $\ldots$ & 0.0 & $\ldots$ & $\ldots$ \\
\hline Slovak Republic & $\ldots$ & $\ldots$ & $\ldots$ & $\ldots$ & $\ldots$ & $\cdots$ & $\ldots$ & $\ldots$ & $\ldots$ & $\cdots$ & $\ldots$ \\
\hline Slovenia & $\ldots$ & $\ldots$ & $\ldots$ & $\ldots$ & $\ldots$ & $\ldots$ & ... & $\ldots$ & $\cdots$ & $\cdots$ & $\ldots$ \\
\hline Spain & $\ldots$ & $\ldots$ & $\ldots$ & $\ldots$ & $\ldots$ & $\ldots$ & $\ldots$ & $\ldots$ & $\ldots$ & $\ldots$ & $\cdots$ \\
\hline Sweden & 0.7 & 0.0 & 0.0 & 5.6 & 50.0 & 4.2 & $\ldots$ & 100.0 & 50.7 & 5.6 & 39.4 \\
\hline Switzerland & $\ldots$ & $\ldots$ & $\ldots$ & $\ldots$ & $\ldots$ & $\ldots$ & $\ldots$ & $\ldots$ & $\ldots$ & $\ldots$ & $\ldots$ \\
\hline Turkey & $\ldots$ & $\ldots$ & $\ldots$ & $\ldots$ & $\ldots$ & $\ldots$ & $\ldots$ & $\ldots$ & $\ldots$ & $\ldots$ & $\ldots$ \\
\hline Ukraine & 0.0 & $\ldots$ & $\ldots$ & 20.0 & 0.0 & $\ldots$ & $\ldots$ & $\ldots$ & 80.0 & $\ldots$ & $\ldots$ \\
\hline UK: England \& Wales & 0.2 & $\ldots$ & 0.0 & 53.0 & $\ldots$ & 0.0 & $\ldots$ & $\ldots$ & 40.9 & $\ldots$ & 6.1 \\
\hline $\begin{array}{l}\text { UK: Northern Ireland } \\
\text { UK: Scotland }\end{array}$ & $\begin{array}{l}\ldots \\
\ldots\end{array}$ & $\begin{array}{l}\ldots \\
\ldots\end{array}$ & $\begin{array}{l}\ldots \\
\ldots\end{array}$ & $\begin{array}{l}\ldots \\
\ldots\end{array}$ & $\begin{array}{l}\ldots \\
\ldots\end{array}$ & $\begin{array}{l}\ldots \\
\ldots\end{array}$ & $\begin{array}{l}\ldots \\
\ldots\end{array}$ & $\begin{array}{l}\ldots \\
\ldots\end{array}$ & $\begin{array}{l}\ldots \\
\ldots\end{array}$ & $\begin{array}{l}\ldots \\
\ldots\end{array}$ & $\cdots$ \\
\hline Mean & 0.2 & 4.8 & 0.0 & 21.7 & 16.7 & 41.4 & 52.2 & 56.8 & 42.2 & 49.7 & 8.5 \\
\hline Median & 0.1 & 0.0 & 0.0 & 9.5 & 0.0 & 42.6 & 54.5 & 63.6 & 43.2 & 57.4 & 3.0 \\
\hline Minimum & 0.0 & 0.0 & 0.0 & 0.0 & 0.0 & 0.0 & 0.0 & 0.0 & 0.0 & 0.0 & 0.0 \\
\hline Maximum & 1.1 & 28.6 & 0.0 & 100.0 & 50.0 & 100.0 & 100.0 & 100.0 & 100.0 & 100.0 & 39.4 \\
\hline
\end{tabular}


Table 3.2.4.9 Minors receiving sanctions/measures in 2015 - Sexual abuse of a child

\begin{tabular}{|c|c|c|c|c|c|c|c|c|c|c|c|}
\hline & \multirow[b]{2}{*}{ 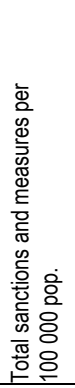 } & \multirow[b]{2}{*}{ 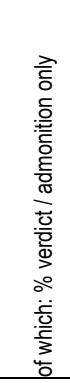 } & \multirow[b]{2}{*}{ 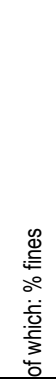 } & \multicolumn{2}{|c|}{$\begin{array}{l}\text { of which: \% } \\
\text { non-custodial } \\
\text { sanctions and } \\
\text { measures }\end{array}$} & \multicolumn{3}{|c|}{$\begin{array}{l}\text { of which: \% suspended } \\
\text { custodial sanctions and } \\
\text { measures }\end{array}$} & \multicolumn{2}{|c|}{$\begin{array}{l}\text { of which: \% un- } \\
\text { suspended custo- } \\
\text { dial sanctions } \\
\text { and measures }\end{array}$} & \multirow[b]{2}{*}{ 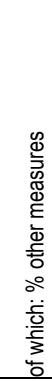 } \\
\hline & & & & 핑 & 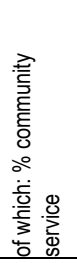 & 푱 & 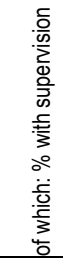 & 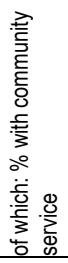 & 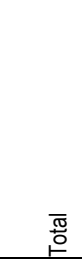 & 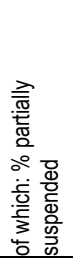 & \\
\hline Albania & $\ldots$ & $\ldots$ & $\ldots$ & $\ldots$ & $\ldots$ & $\ldots$ & $\ldots$ & $\ldots$ & $\ldots$ & $\ldots$ & $\ldots$ \\
\hline Armenia & $\ldots$ & $\ldots$ & $\ldots$ & $\ldots$ & $\ldots$ & $\ldots$ & $\ldots$ & $\ldots$ & $\ldots$ & $\ldots$ & $\ldots$ \\
\hline Austria & 0.2 & $\ldots$ & 0.0 & $\ldots$ & $\ldots$ & 82.4 & $\ldots$ & $\ldots$ & 11.8 & 0.0 & 5.9 \\
\hline Azerbaijan & $\ldots$ & $\ldots$ & $\ldots$ & $\ldots$ & $\ldots$ & $\ldots$ & $\ldots$ & $\ldots$ & $\ldots$ & $\ldots$ & $\ldots$ \\
\hline Belgium & 0.0 & $\ldots$ & $\ldots$ & $\ldots$ & $\ldots$ & $\ldots$ & $\ldots$ & $\ldots$ & $\ldots$ & $\ldots$ & $\ldots$ \\
\hline Bosnia-Herzegovina & $\ldots$ & $\ldots$ & $\ldots$ & $\ldots$ & $\ldots$ & $\ldots$ & $\ldots$ & $\ldots$ & $\ldots$ & $\ldots$ & $\ldots$ \\
\hline Bulgaria & $\ldots$ & $\ldots$ & $\ldots$ & $\ldots$ & $\ldots$ & $\ldots$ & $\ldots$ & $\ldots$ & $\ldots$ & $\ldots$ & $\ldots$ \\
\hline Croatia & 0.0 & 100.0 & $\ldots$ & 0.0 & $\ldots$ & 0.0 & $\ldots$ & $\ldots$ & 0.0 & $\ldots$ & $\ldots$ \\
\hline Cyprus & $\ldots$ & $\ldots$ & $\ldots$ & $\ldots$ & $\ldots$ & $\ldots$ & $\ldots$ & $\ldots$ & $\ldots$ & $\ldots$ & $\ldots$ \\
\hline Czech Republic & 1.1 & 13.5 & 0.0 & 0.0 & $\cdots$ & 82.0 & 8.8 & $\cdots$ & 3.6 & $\begin{array}{l}\cdots \\
\ldots\end{array}$ & 0.0 \\
\hline Denmark & $\ldots$ & $\ldots$ & $\ldots$ & $\ldots$ & $\ldots$ & $\ldots$ & $\ldots$ & $\ldots$ & $\ldots$ & $\ldots$ & $\ldots$ \\
\hline Estonia & $\ldots$ & $\ldots$ & $\ldots$ & $\ldots$ & $\ldots$ & $\ldots$ & $\ldots$ & $\ldots$ & $\ldots$ & $\ldots$ & $\ldots$ \\
\hline Finland & 0.4 & 0.0 & 12.5 & 0.0 & $\ldots$ & 66.7 & 37.5 & 25.0 & 16.7 & $\ldots$ & 4.2 \\
\hline France & 1.4 & 1.4 & 0.0 & 39.4 & $\ldots$ & 47.6 & $\ldots$ & $\ldots$ & 11.6 & 70.3 & $\ldots$ \\
\hline Georgia & $\ldots$ & $\ldots$ & $\ldots$ & $\ldots$ & $\ldots$ & $\ldots$ & $\ldots$ & $\ldots$ & $\ldots$ & $\ldots$ & $\ldots$ \\
\hline Germany & 0.5 & 8.8 & $\ldots$ & 62.7 & $\ldots$ & 22.9 & 100.0 & $\ldots$ & 5.6 & $\ldots$ & $\ldots$ \\
\hline Hungary & 0.1 & 0.0 & 0.0 & 88.9 & 0.0 & 11.1 & 100.0 & 0.0 & 0.0 & $\ldots$ & 0.0 \\
\hline Iceland & $\ldots$ & $\ldots$ & $\ldots$ & $\ldots$ & $\ldots$ & $\ldots$ & $\ldots$ & $\ldots$ & $\ldots$ & $\ldots$ & $\ldots$ \\
\hline $\begin{array}{l}\text { Italy } \\
\text { Kosovo (UN }\end{array}$ & $\ldots$ & $\ldots$ & $\ldots$ & $\ldots$ & $\ldots$ & $\cdots$ & $\ldots$ & $\ldots$ & $\ldots$ & $\ldots$ & $\ldots$ \\
\hline $\mathrm{R} / 1244 / 99)$ & $\ldots$ & $\ldots$ & $\ldots$ & $\ldots$ & $\ldots$ & $\ldots$ & $\ldots$ & $\ldots$ & $\ldots$ & $\ldots$ & $\ldots$ \\
\hline Latvia & $\ldots$ & $\ldots$ & $\ldots$ & $\ldots$ & $\ldots$ & $\ldots$ & $\ldots$ & $\ldots$ & $\ldots$ & $\ldots$ & $\ldots$ \\
\hline Lithuania & 0.1 & $\ldots$ & $\ldots$ & $\ldots$ & $\cdots$ & $\ldots$ & $\ldots$ & $\cdots$ & $\ldots$ & $\ldots$ & $\cdots$ \\
\hline Luxembourg & $\ldots$ & $\ldots$ & $\ldots$ & $\ldots$ & $\ldots$ & $\ldots$ & $\ldots$ & $\ldots$ & $\ldots$ & $\ldots$ & $\ldots$ \\
\hline Moldova & $\ldots$ & $\ldots$ & $\ldots$ & $\ldots$ & $\ldots$ & $\ldots$ & $\ldots$ & $\ldots$ & $\ldots$ & $\ldots$ & $\ldots$ \\
\hline Montenegro & $\ldots$ & $\ldots$ & $\ldots$ & $\ldots$ & $\ldots$ & $\ldots$ & $\ldots$ & $\ldots$ & $\ldots$ & $\ldots$ & $\ldots$ \\
\hline Netherlands & 0.0 & $\ldots$ & $\ldots$ & $\ldots$ & $\ldots$ & $\ldots$ & $\ldots$ & $\ldots$ & $\ldots$ & $\ldots$ & $\ldots$ \\
\hline North Macedonia & 0.0 & $\ldots$ & $\ldots$ & $\ldots$ & $\ldots$ & $\ldots$ & $\ldots$ & $\ldots$ & $\ldots$ & $\ldots$ & $\ldots$ \\
\hline Norway & & $\ldots$ & $\ldots$ & $\ldots$ & $\ldots$ & $\ldots$ & $\ldots$ & $\ldots$ & $\ldots$ & $\ldots$ & $\ldots$ \\
\hline Poland & 0.4 & $\ldots$ & $\ldots$ & 91.4 & $\ldots$ & 2.6 & $\ldots$ & $\ldots$ & 6.0 & $\ldots$ & $\ldots$ \\
\hline Portugal & 0.1 & $\ldots$ & $\ldots$ & $\ldots$ & $\ldots$ & 90.9 & 100.0 & $\ldots$ & $\ldots$ & $\ldots$ & $\ldots$ \\
\hline Romania & $\ldots$ & $\ldots$ & $\ldots$ & $\ldots$ & $\ldots$ & $\ldots$ & $\ldots$ & $\ldots$ & $\ldots$ & $\ldots$ & $\ldots$ \\
\hline Russian Federation & $\ldots$ & $\ldots$ & $\ldots$ & $\ldots$ & $\ldots$ & $\ldots$ & ... & $\ldots$ & $\ldots$ & $\ldots$ & $\ldots$ \\
\hline Serbia & 0.0 & $\ldots$ & $\ldots$ & 100.0 & $\ldots$ & $\ldots$ & $\ldots$ & $\ldots$ & 0.0 & $\ldots$ & $\ldots$ \\
\hline Slovak Republic & $\ldots$ & $\ldots$ & $\ldots$ & $\ldots$ & $\ldots$ & $\ldots$ & ... & $\ldots$ & $\ldots$ & $\ldots$ & ... \\
\hline Slovenia & $\ldots$ & $\ldots$ & $\ldots$ & $\ldots$ & $\ldots$ & $\ldots$ & $\ldots$ & $\ldots$ & $\ldots$ & $\ldots$ & $\ldots$ \\
\hline Spain & & . & $\ldots$ & $\ldots$ & $\ldots$ & $\ldots$ & $\ldots$ & $\ldots$ & $\ldots$ & $\ldots$ & $\ldots$ \\
\hline Sweden & 0.5 & 0.0 & 0.0 & 17.4 & 50.0 & 26.1 & $\ldots$ & 83.3 & 2.2 & 0.0 & 54.3 \\
\hline Switzerland & $\ldots$ & $\ldots$ & $\ldots$ & $\ldots$ & $\ldots$ & $\ldots$ & $\ldots$ & $\ldots$ & $\ldots$ & $\ldots$ & $\ldots$ \\
\hline Turkey & $\ldots$ & $\ldots$ & $\ldots$ & $\ldots$ & $\ldots$ & $\ldots$ & $\ldots$ & $\ldots$ & $\ldots$ & $\ldots$ & $\ldots$ \\
\hline Ukraine & & $\ldots$ & $\ldots$ & $\ldots$ & $\ldots$ & $\ldots$ & $\ldots$ & $\ldots$ & $\ldots$ & $\ldots$ & $\ldots$ \\
\hline UK: England \& Wales & 0.4 & $\ldots$ & 0.0 & 100.0 & $\ldots$ & 0.0 & $\ldots$ & $\ldots$ & 0.0 & $\ldots$ & 0.0 \\
\hline UK: Northern Ireland & $\ldots$ & $\ldots$ & $\ldots$ & $\ldots$ & $\ldots$ & $\ldots$ & $\ldots$ & $\ldots$ & $\ldots$ & $\ldots$ & $\ldots$ \\
\hline UK: Scotland & $\ldots$ & $\ldots$ & $\ldots$ & $\ldots$ & $\ldots$ & $\ldots$ & $\ldots$ & $\ldots$ & $\ldots$ & $\ldots$ & $\ldots$ \\
\hline Mean & 0.3 & 17.7 & 1.8 & 50.0 & 25.0 & 39.3 & 69.3 & 36.1 & 5.2 & 23.4 & 10.7 \\
\hline Median & 0.2 & 1.4 & 0.0 & 51.0 & 25.0 & 26.1 & 100.0 & 25.0 & 3.6 & 0.0 & 2.1 \\
\hline Minimum & 0.0 & 0.0 & 0.0 & 0.0 & 0.0 & 0.0 & 8.8 & 0.0 & 0.0 & 0.0 & 0.0 \\
\hline Maximum & 1.4 & 100.0 & 12.5 & 100.0 & 50.0 & 90.9 & 100.0 & 83.3 & 16.7 & 70.3 & 54.3 \\
\hline
\end{tabular}


Table 3.2.4.10 Minors receiving sanctions/measures in 2015 - Robbery

\begin{tabular}{|c|c|c|c|c|c|c|c|c|c|c|c|}
\hline & \multirow[b]{2}{*}{ 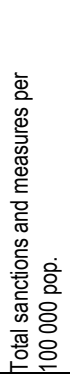 } & \multirow{2}{*}{ 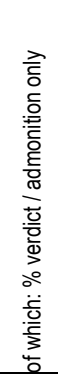 } & \multirow[b]{2}{*}{ 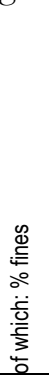 } & \multicolumn{2}{|c|}{$\begin{array}{l}\text { of which: \% } \\
\text { non-custodial } \\
\text { sanctions and } \\
\text { measures }\end{array}$} & \multicolumn{3}{|c|}{$\begin{array}{l}\text { of which: } \% \text { suspended } \\
\text { custodial sanctions and } \\
\text { measures }\end{array}$} & \multicolumn{2}{|c|}{$\begin{array}{l}\text { of which: } \% \text { un- } \\
\text { suspended custo- } \\
\text { dial sanctions } \\
\text { and measures }\end{array}$} & \multirow[b]{2}{*}{ 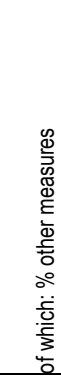 } \\
\hline & & & & 苞 & 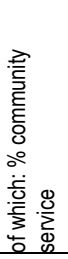 & 兼 & 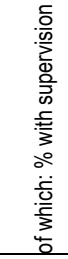 & 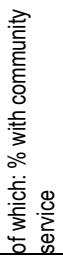 & 判 & 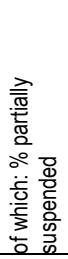 & \\
\hline Albania & & $\ldots$ & $\ldots$ & & $\ldots$ & & $\ldots$ & $\ldots$ & $\ldots$ & $\ldots$ & \\
\hline Armenia & 0.1 & $\ldots$ & 0.0 & 0.0 & $\ldots$ & 0.0 & $\ldots$ & $\ldots$ & 0.0 & $\ldots$ & 100.0 \\
\hline Austria & 2.9 & $\ldots$ & 1.2 & $\ldots$ & $\ldots$ & 52.8 & $\ldots$ & $\ldots$ & 40.8 & 59.8 & 5.2 \\
\hline Azerbaijan & & $\ldots$ & $\ldots$ & $\ldots$ & $\ldots$ & $\ldots$ & $\ldots$ & $\ldots$ & $\ldots$ & $\ldots$ & $\ldots$ \\
\hline Belgium & 0.0 & $\ldots$ & 0.0 & 0.0 & $\ldots$ & 0.0 & $\ldots$ & $\ldots$ & 100.0 & $\ldots$ & 0.0 \\
\hline Bosnia-Herzegovina & & $\ldots$ & $\ldots$ & $\ldots$ & $\ldots$ & $\ldots$ & $\ldots$ & $\ldots$ & $\ldots$ & $\ldots$ & $\ldots$ \\
\hline Bulgaria & 1.5 & $\ldots$ & $\ldots$ & 29.9 & $\ldots$ & $\ldots$ & $\ldots$ & $\ldots$ & 54.2 & $\ldots$ & 15.9 \\
\hline Croatia & 0.9 & 10.8 & $\ldots$ & 24.3 & $\ldots$ & 27.0 & 50.0 & $\ldots$ & 37.8 & $\ldots$ & $\ldots$ \\
\hline Cyprus & & & $\ldots$ & & $\ldots$ & & & $\ldots$ & & $\ldots$ & \\
\hline Czech Republic & 1.3 & 1.5 & 0.0 & 0.0 & $\ldots$ & 78.7 & 26.2 & $\ldots$ & 18.4 & $\ldots$ & 1.5 \\
\hline Denmark & $\ldots$ & $\ldots$ & $\ldots$ & $\ldots$ & $\ldots$ & $\ldots$ & $\ldots$ & $\ldots$ & $\ldots$ & $\ldots$ & $\ldots$ \\
\hline Estonia & $\ldots$ & $\ldots$ & $\ldots$ & $\ldots$ & $\ldots$ & $\ldots$ & $\ldots$ & $\ldots$ & $\ldots$ & $\ldots$ & $\ldots$ \\
\hline Finland & 2.1 & 0.0 & 0.0 & 0.9 & 100.0 & 85.2 & 67.3 & 7.1 & 12.2 & $\ldots$ & 1.7 \\
\hline France & 1.6 & $\ldots$ & $\ldots$ & $\ldots$ & $\ldots$ & $\ldots$ & $\ldots$ & $\ldots$ & $\ldots$ & $\ldots$ & $\ldots$ \\
\hline Georgia & 1.2 & $\ldots$ & $\ldots$ & $\ldots$ & $\ldots$ & $\ldots$ & $\ldots$ & $\ldots$ & 32.6 & $\ldots$ & $\ldots$ \\
\hline Germany & 4.3 & 7.1 & $\ldots$ & 37.1 & $\ldots$ & 30.8 & 100.0 & $\ldots$ & 24.9 & $\ldots$ & $\ldots$ \\
\hline Hungary & 3.6 & 0.0 & 0.0 & 3.1 & 27.3 & 35.9 & 86.5 & 0.0 & 61.0 & 0.0 & 0.0 \\
\hline Iceland & $\ldots$ & $\ldots$ & $\ldots$ & $\ldots$ & $\ldots$ & $\ldots$ & $\ldots$ & $\ldots$ & $\ldots$ & $\ldots$ & $\ldots$ \\
\hline Italy & $\ldots$ & $\ldots$ & $\ldots$ & $\ldots$ & $\ldots$ & $\ldots$ & $\ldots$ & $\ldots$ & $\ldots$ & $\ldots$ & $\ldots$ \\
\hline Kosovo (UN & & & & & & & & & & & \\
\hline R/1244/99) & $\ldots$ & $\ldots$ & $\ldots$ & $\ldots$ & $\ldots$ & $\ldots$ & $\ldots$ & $\ldots$ & $\ldots$ & $\ldots$ & $\ldots$ \\
\hline Latvia & $\ldots$ & $\ldots$ & $\ldots$ & $\ldots$ & $\ldots$ & $\ldots$ & $\ldots$ & $\ldots$ & $\ldots$ & $\ldots$ & $\ldots$ \\
\hline Lithuania & 7.9 & $\ldots$ & $\ldots$ & $\ldots$ & $\ldots$ & $\ldots$ & $\ldots$ & $\ldots$ & $\ldots$ & $\ldots$ & $\ldots$ \\
\hline Luxembourg & $\ldots$ & $\ldots$ & $\ldots$ & $\ldots$ & $\ldots$ & $\ldots$ & $\ldots$ & $\ldots$ & $\ldots$ & $\ldots$ & $\ldots$ \\
\hline Moldova & $\ldots$ & $\ldots$ & $\ldots$ & $\ldots$ & $\ldots$ & $\ldots$ & $\ldots$ & $\ldots$ & $\ldots$ & $\ldots$ & $\ldots$ \\
\hline Montenegro & $\ldots$ & $\ldots$ & $\ldots$ & $\ldots$ & $\ldots$ & $\ldots$ & $\ldots$ & $\ldots$ & $\ldots$ & $\ldots$ & $\ldots$ \\
\hline Netherlands & $\ldots$ & $\ldots$ & 0.0 & 38.7 & 94.2 & 14.7 & $\ldots$ & 82.4 & 46.5 & 74.7 & $\ldots$ \\
\hline North Macedonia & 3.4 & $\ldots$ & $\ldots$ & $\ldots$ & $\ldots$ & $\ldots$ & $\ldots$ & $\ldots$ & $\ldots$ & $\ldots$ & $\ldots$ \\
\hline Norway & $\ldots$ & $\ldots$ & $\ldots$ & $\ldots$ & $\ldots$ & $\ldots$ & $\ldots$ & $\ldots$ & $\ldots$ & $\ldots$ & $\ldots$ \\
\hline Poland & 1.2 & $\ldots$ & $\ldots$ & 64.6 & $\ldots$ & 11.1 & $\ldots$ & $\ldots$ & 24.2 & $\ldots$ & $\ldots$ \\
\hline Portugal & 3.2 & $\ldots$ & 6.0 & 8.4 & 96.4 & 69.3 & 91.3 & $\ldots$ & 15.1 & $\ldots$ & 1.2 \\
\hline Romania & $\ldots$ & $\ldots$ & $\ldots$ & $\ldots$ & $\ldots$ & $\ldots$ & $\ldots$ & $\ldots$ & $\ldots$ & $\ldots$ & $\ldots$ \\
\hline Russian Federation & & $\ldots$ & $\ldots$ & $\ldots$ & $\ldots$ & $\ldots$ & $\ldots$ & $\ldots$ & $\ldots$ & $\ldots$ & $\ldots$ \\
\hline Serbia & 2.3 & $\ldots$ & $\ldots$ & 99.4 & $\ldots$ & $\ldots$ & $\ldots$ & $\ldots$ & 0.6 & $\ldots$ & $\ldots$ \\
\hline Slovak Republic & $\ldots$ & $\ldots$ & $\ldots$ & $\ldots$ & $\ldots$ & $\ldots$ & $\ldots$ & $\ldots$ & $\ldots$ & $\ldots$ & $\ldots$ \\
\hline Slovenia & $\ldots$ & $\ldots$ & $\ldots$ & $\ldots$ & $\ldots$ & $\ldots$ & $\ldots$ & $\ldots$ & $\ldots$ & $\ldots$ & $\ldots$ \\
\hline Spain & & $\ldots$ & $\ldots$ & $\ldots$ & $\ldots$ & $\ldots$ & $\ldots$ & $\ldots$ & $\ldots$ & $\ldots$ & $\ldots$ \\
\hline Sweden & 3.3 & 0.0 & 0.0 & 11.7 & 44.7 & 3.1 & $\ldots$ & 80.0 & 38.2 & 19.4 & 47.1 \\
\hline Switzerland & & $\ldots$ & $\ldots$ & $\ldots$ & $\ldots$ & $\ldots$ & $\ldots$ & $\ldots$ & $\ldots$ & $\ldots$ & $\ldots$ \\
\hline Turkey & 4.6 & $\ldots$ & 2.2 & 3.7 & $\ldots$ & 18.7 & $\ldots$ & $\ldots$ & 62.0 & $\ldots$ & 13.4 \\
\hline Ukraine & 1.1 & $\ldots$ & 5.6 & $\ldots$ & $\ldots$ & $\ldots$ & $\ldots$ & $\ldots$ & 17.6 & $\ldots$ & $\ldots$ \\
\hline UK: England \& Wales & 7.1 & $\ldots$ & 0.5 & 71.3 & $\ldots$ & 0.0 & $\ldots$ & $\ldots$ & 26.4 & $\ldots$ & 2.3 \\
\hline $\begin{array}{l}\text { UK: Northern Ireland } \\
\text { UK: Scotland }\end{array}$ & $\cdots$ & $\begin{array}{l}\cdots \\
\ldots\end{array}$ & $\begin{array}{l}\ldots \\
\ldots\end{array}$ & $\begin{array}{l}\cdots \\
\ldots\end{array}$ & $\begin{array}{l}\ldots \\
\ldots\end{array}$ & $\begin{array}{l}\cdots \\
\ldots\end{array}$ & $\begin{array}{l}\cdots \\
\ldots\end{array}$ & $\begin{array}{l}\cdots \\
\ldots\end{array}$ & $\begin{array}{l}\ldots \\
\ldots\end{array}$ & $\begin{array}{l}\ldots \\
\ldots\end{array}$ & $\begin{array}{l}\cdots \\
\ldots\end{array}$ \\
\hline Mean & 2.7 & 3.2 & 1.3 & 26.2 & 72.5 & 30.5 & 70.2 & 42.4 & 34.0 & 38.5 & 17.1 \\
\hline Median & 2.2 & 0.7 & 0.0 & 11.7 & 94.2 & 22.9 & 76.9 & 43.6 & 29.5 & 39.6 & 2.3 \\
\hline Minimum & 0.0 & 0.0 & 0.0 & 0.0 & 27.3 & 0.0 & 26.2 & 0.0 & 0.0 & 0.0 & 0.0 \\
\hline Maximum & 7.9 & 10.8 & 6.0 & 99.4 & 100.0 & 85.2 & 100.0 & 82.4 & 100.0 & 74.7 & 100.0 \\
\hline
\end{tabular}


Table 3.2.4.11 Minors receiving sanctions/measures in 2015 - Theft

\begin{tabular}{|c|c|c|c|c|c|c|c|c|c|c|c|}
\hline & \multirow[b]{2}{*}{ 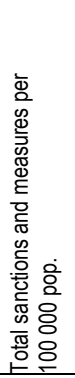 } & \multirow{2}{*}{ 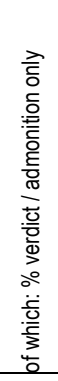 } & \multirow[b]{2}{*}{ 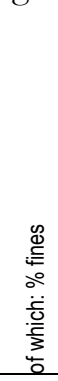 } & \multicolumn{2}{|c|}{$\begin{array}{l}\text { of which: \% } \\
\text { non-custodial } \\
\text { sanctions and } \\
\text { measures }\end{array}$} & \multicolumn{3}{|c|}{$\begin{array}{l}\text { of which: \% suspended } \\
\text { custodial sanctions and } \\
\text { measures }\end{array}$} & \multicolumn{2}{|c|}{$\begin{array}{l}\text { of which: \% un- } \\
\text { suspended custo- } \\
\text { dial sanctions and } \\
\text { measures }\end{array}$} & \multirow[b]{2}{*}{ 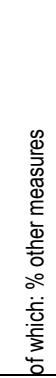 } \\
\hline & & & & 푬 & 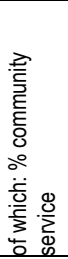 & 氶 & 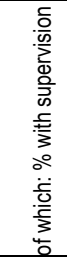 & 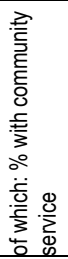 & 要 & 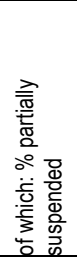 & \\
\hline Albania & & $\ldots$ & & & $\ldots$ & & & & & & \\
\hline Armenia & 1.5 & $\ldots$ & 0.0 & 0.0 & $\ldots$ & 73.9 & 0.0 & 0.0 & 8.7 & 0.0 & 17.4 \\
\hline Austria & 6.0 & $\ldots$ & 17.0 & $\ldots$ & $\ldots$ & 56.4 & $\ldots$ & $\ldots$ & 23.8 & 66.4 & 2.7 \\
\hline Azerbaijan & $\ldots$ & $\ldots$ & $\ldots$ & $\ldots$ & $\ldots$ & $\ldots$ & $\ldots$ & $\ldots$ & $\ldots$ & $\ldots$ & $\ldots$ \\
\hline Belgium & 0.1 & $\ldots$ & 0.0 & 0.0 & $\ldots$ & 60.0 & 0.0 & $\ldots$ & 40.0 & $\ldots$ & 0.0 \\
\hline Bosnia-Herzegovina & $\ldots$ & $\ldots$ & $\ldots$ & $\ldots$ & $\ldots$ & $\ldots$ & $\ldots$ & $\ldots$ & $\ldots$ & $\ldots$ & $\ldots$ \\
\hline Bulgaria & 10.5 & $\ldots$ & 0.0 & 39.2 & $\ldots$ & & $\ldots$ & $\ldots$ & 39.8 & $\ldots$ & 21.0 \\
\hline Croatia & 5.0 & 36.5 & $\ldots$ & 41.7 & $\ldots$ & 5.7 & 33.3 & $\ldots$ & 16.1 & $\ldots$ & 0.0 \\
\hline Cyprus & $\ldots$ & $\ldots$ & $\ldots$ & $\ldots$ & $\ldots$ & $\ldots$ & $\ldots$ & $\ldots$ & $\ldots$ & $\ldots$ & $\ldots$ \\
\hline Czech Republic & 5.0 & 14.1 & 0.0 & 24.1 & 100.0 & 55.3 & 14.9 & $\ldots$ & 6.3 & $\ldots$ & 0.4 \\
\hline Denmark & $\ldots$ & $\ldots$ & $\ldots$ & $\ldots$ & $\ldots$ & $\ldots$ & $\ldots$ & $\ldots$ & $\ldots$ & $\ldots$ & $\ldots$ \\
\hline Estonia & $\ldots$ & $\ldots$ & $\ldots$ & $\ldots$ & $\ldots$ & $\ldots$ & $\ldots$ & $\ldots$ & $\ldots$ & $\ldots$ & $\ldots$ \\
\hline Finland & 39.3 & 0.0 & 96.0 & 0.0 & 100.0 & 3.3 & 52.1 & 5.6 & 0.1 & $\ldots$ & 0.5 \\
\hline France & 29.9 & 2.4 & 2.4 & 56.1 & $\ldots$ & 27.3 & $\ldots$ & $\ldots$ & 11.9 & 26.6 & $\ldots$ \\
\hline Georgia & 3.8 & $\ldots$ & $\ldots$ & & $\ldots$ & & $\ldots$ & $\ldots$ & 26.1 & $\ldots$ & $\ldots$ \\
\hline Germany & 20.3 & 2.8 & $\ldots$ & 81.9 & $\ldots$ & 8.6 & 100.0 & $\ldots$ & 6.6 & $\ldots$ & $\ldots$ \\
\hline Hungary & 22.5 & 1.4 & 1.0 & 68.1 & 37.1 & 18.3 & 86.5 & 0.0 & 11.1 & 0.0 & 0.0 \\
\hline Iceland & $\ldots$ & $\ldots$ & $\ldots$ & $\ldots$ & $\ldots$ & $\ldots$ & $\ldots$ & $\ldots$ & $\ldots$ & $\ldots$ & $\ldots$ \\
\hline $\begin{array}{l}\text { Italy } \\
\text { Kosovo (UN }\end{array}$ & $\ldots$ & $\ldots$ & $\ldots$ & $\ldots$ & $\cdots$ & $\ldots$ & $\ldots$ & $\ldots$ & $\ldots$ & $\ldots$ & $\ldots$ \\
\hline $\mathrm{R} / 1244 / 99)$ & $\ldots$ & $\ldots$ & $\ldots$ & $\ldots$ & $\ldots$ & $\ldots$ & $\ldots$ & $\ldots$ & $\ldots$ & $\ldots$ & $\ldots$ \\
\hline Latvia & $\ldots$ & $\ldots$ & $\ldots$ & $\ldots$ & $\ldots$ & $\begin{array}{l}\cdots \\
\ldots\end{array}$ & $\ldots$ & $\ldots$ & $\ldots$ & $\ldots$ & $\ldots$ \\
\hline Lithuania & 20.8 & $\ldots$ & $\ldots$ & $\ldots$ & $\ldots$ & $\ldots$ & $\ldots$ & $\ldots$ & $\ldots$ & $\ldots$ & $\ldots$ \\
\hline Luxembourg & $\ldots$ & $\ldots$ & $\ldots$ & $\ldots$ & $\ldots$ & $\ldots$ & $\ldots$ & $\ldots$ & $\ldots$ & $\ldots$ & $\ldots$ \\
\hline Moldova & $\ldots$ & $\ldots$ & $\ldots$ & $\ldots$ & $\ldots$ & $\ldots$ & $\ldots$ & $\ldots$ & $\ldots$ & $\ldots$ & $\ldots$ \\
\hline Montenegro & $\ldots$ & $\ldots$ & $\ldots$ & $\ldots$ & $\ldots$ & $\ldots$ & $\ldots$ & $\ldots$ & $\ldots$ & $\ldots$ & $\ldots$ \\
\hline Netherlands & $\ldots$ & $\ldots$ & 1.6 & 77.4 & 98.4 & 8.9 & $\ldots$ & 65.4 & 12.1 & 50.3 & $\ldots$ \\
\hline North Macedonia & 7.1 & $\ldots$ & $\ldots$ & $\ldots$ & $\ldots$ & $\ldots$ & $\ldots$ & $\ldots$ & $\ldots$ & $\ldots$ & $\ldots$ \\
\hline Norway & 9.5 & $\ldots$ & $\ldots$ & $\ldots$ & $\ldots$ & $\ldots$ & $\ldots$ & $\ldots$ & $\ldots$ & $\ldots$ & $\ldots$ \\
\hline Poland & 4.8 & $\ldots$ & $\ldots$ & 84.1 & $\ldots$ & 1.7 & $\ldots$ & $\ldots$ & 14.2 & $\ldots$ & $\ldots$ \\
\hline Portugal & 2.6 & 1.5 & 43.1 & 9.9 & 92.6 & 38.3 & 71.4 & $\ldots$ & 5.5 & $\ldots$ & 1.8 \\
\hline Romania & $\ldots$ & $\ldots$ & $\ldots$ & $\ldots$ & $\ldots$ & $\ldots$ & $\ldots$ & $\ldots$ & $\ldots$ & $\ldots$ & $\ldots$ \\
\hline Russian Federation & $\ldots$ & $\ldots$ & $\ldots$ & $\ldots$ & ... & $\ldots$ & $\ldots$ & $\ldots$ & $\ldots$ & $\ldots$ & $\ldots$ \\
\hline Serbia & 12.3 & $\ldots$ & ... & 99.5 & ... & $\ldots$ & $\ldots$ & $\ldots$ & 0.5 & $\ldots$ & $\ldots$ \\
\hline Slovak Republic & $\ldots$ & $\ldots$ & ... & $\ldots$ & ... & $\ldots$ & $\ldots$ & $\ldots$ & $\ldots$ & $\ldots$ & $\ldots$ \\
\hline Slovenia & $\cdots$ & $\cdots$ & $\cdots$ & $\cdots$ & $\cdots$ & $\ldots$ & $\cdots$ & $\cdots$ & $\ldots$ & $\cdots$ & $\ldots$ \\
\hline Spain & & & $\ldots$ & $\ldots$ & $\ldots$ & $\ldots$ & $\ldots$ & $\ldots$ & $\ldots$ & $\ldots$ & $\ldots$ \\
\hline Sweden & 49.6 & 0.0 & 22.9 & 4.1 & 5.6 & 9.4 & $\ldots$ & 2.6 & 2.8 & 2.2 & 60.8 \\
\hline Switzerland & & $\ldots$ & $\ldots$ & $\ldots$ & $\ldots$ & $\ldots$ & $\ldots$ & $\ldots$ & $\ldots$ & $\ldots$ & \\
\hline Turkey & 48.3 & $\ldots$ & 32.7 & 2.6 & $\ldots$ & 11.9 & $\ldots$ & $\ldots$ & 40.5 & $\ldots$ & 12.3 \\
\hline Ukraine & 6.7 & $\ldots$ & 8.5 & $\ldots$ & $\ldots$ & $\ldots$ & $\ldots$ & $\ldots$ & 10.1 & $\ldots$ & $\ldots$ \\
\hline UK: England \& Wales & 39.1 & $\ldots$ & 3.3 & 77.5 & $\ldots$ & 0.0 & $\ldots$ & $\ldots$ & 7.4 & $\ldots$ & 15.0 \\
\hline UK: Northern Ireland & $\ldots$ & $\ldots$ & $\ldots$ & $\ldots$ & ... & $\ldots$ & $\ldots$ & $\ldots$ & $\ldots$ & $\ldots$ & $\ldots$ \\
\hline UK: Scotland & $\ldots$ & $\ldots$ & $\ldots$ & $\ldots$ & $\ldots$ & $\ldots$ & $\ldots$ & $\ldots$ & $\ldots$ & $\ldots$ & $\ldots$ \\
\hline Mean & 16.4 & 7.3 & 16.3 & 41.6 & 72.3 & 25.3 & 44.8 & 14.7 & 14.9 & 24.3 & 11.0 \\
\hline Median & 9.5 & 1.9 & 2.8 & 40.4 & 95.5 & 11.9 & 42.7 & 2.6 & 11.1 & 14.4 & 2.3 \\
\hline Minimum & 0.1 & 0.0 & 0.0 & 0.0 & 5.6 & 0.0 & 0.0 & 0.0 & 0.1 & 0.0 & 0.0 \\
\hline Maximum & 49.6 & 36.5 & 96.0 & 99.5 & 100.0 & 73.9 & 100.0 & 65.4 & 40.5 & 66.4 & 60.8 \\
\hline
\end{tabular}


Table 3.2.4.12 Minors receiving sanctions/measures in 2015 - Aggravated theft

\begin{tabular}{|c|c|c|c|c|c|c|c|c|c|c|c|}
\hline & \multirow{2}{*}{ 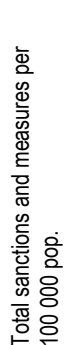 } & \multirow{2}{*}{ 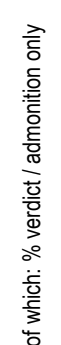 } & \multirow{2}{*}{ 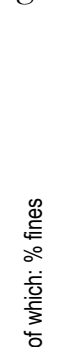 } & \multicolumn{2}{|c|}{$\begin{array}{l}\text { of which: \% } \\
\text { non-custodial } \\
\text { sanctions and } \\
\text { measures }\end{array}$} & \multicolumn{3}{|c|}{$\begin{array}{l}\text { of which: \% suspended } \\
\text { custodial sanctions and } \\
\text { measures }\end{array}$} & \multicolumn{2}{|c|}{$\begin{array}{l}\text { of which: \% un- } \\
\text { suspended custo- } \\
\text { dial sanctions and } \\
\text { measures }\end{array}$} & \multirow[b]{2}{*}{ 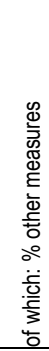 } \\
\hline & & & & 愛 & 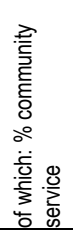 & 言 & 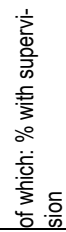 & 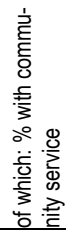 & 営 & 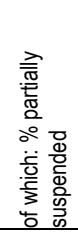 & \\
\hline Austria & 4.4 & & 8.4 & & $\ldots$ & 59.8 & & $\ldots$ & 29.9 & 71.1 & 1.8 \\
\hline Belgium & 0.1 & & 0.0 & 0.0 & $\ldots$ & 62.5 & 0.0 & $\ldots$ & 37.5 & & 0.0 \\
\hline Croatia & 3.8 & 38.4 & & 39.6 & $\ldots$ & 6.3 & 40.0 & & 15.7 & $\ldots$ & 0.0 \\
\hline Finland & 0.5 & 0.0 & 3.4 & 0.0 & $\ldots$ & 89.7 & 38.5 & 15.4 & 6.9 & $\ldots$ & 0.0 \\
\hline Germany & 6.3 & 5.1 & & 64.5 & $\cdots$ & 17.1 & 100.0 & & 13.2 & & \\
\hline Hungary & 22.5 & 1.4 & 1.0 & 68.1 & 37.1 & 18.3 & 86.5 & 0.0 & 11.1 & 0.0 & 0.0 \\
\hline Netherlands & 5.2 & $\ldots$ & 1.0 & 73.9 & 98.0 & 10.0 & $\ldots$ & 65.9 & 15.1 & 50.8 & $\ldots$ \\
\hline Poland & 2.0 & $\cdots$ & & 80.6 & & 2.7 & & $\ldots$ & 16.8 & $\ldots$ & \\
\hline $\begin{array}{l}\text { Portugal } \\
\text { Serbia }\end{array}$ & $\begin{array}{l}1.9 \\
81\end{array}$ & & 25.3 & $\begin{array}{l}12.9 \\
99.3\end{array}$ & 92.0 & 52.6 & 71.6 & $\ldots$ & $\begin{array}{l}6.7 \\
0.7\end{array}$ & $\ldots$ & 2.1 \\
\hline $\begin{array}{l}\text { Mean } \\
\text { Mean }\end{array}$ & 5.5 & 11.2 & 6.5 & 48.8 & 75.7 & 35.4 & 56.1 & 27.1 & 0.1 & 40.6 & 0.6 \\
\hline Median & 4.1 & 3.3 & 2.2 & 64.5 & 92.0 & 18.3 & 55.8 & 15.4 & 14.1 & 50.8 & 0.0 \\
\hline Minimum & 0.1 & 0.0 & 0.0 & 0.0 & 37.1 & 2.7 & 0.0 & 0.0 & 0.7 & 0.0 & 0.0 \\
\hline Maximum & 22.5 & 38.4 & 25.3 & 99.3 & 98.0 & 89.7 & 100.0 & 65.9 & 37.5 & 71.1 & 2.1 \\
\hline
\end{tabular}

Table 3.2.4.13 Minors receiving sanctions/measures in 2015 - Theft of a motor vehicle

\begin{tabular}{lrrrrrrrrrrr}
\hline Bulgaria & 0.6 & $\ldots$ & 0.0 & 34.1 & $\ldots$ & $\ldots .$. & $\ldots$ & $\ldots$. & 53.7 & $\ldots$ & 12.2 \\
Finland & 1.0 & 0.0 & 87.5 & 0.0 & $\ldots$. & 10.7 & 50.0 & 0.0 & 0.0 & $\ldots$. & 1.8 \\
Hungary & 0.7 & 0.0 & 3.0 & 56.7 & 47.4 & 31.3 & 90.5 & 0.0 & 9.0 & 0.0 & 0.0 \\
Portugal & 0.1 & $\ldots$ & 66.7 & 20.0 & $\ldots$ & $\ldots$ & $\ldots$ & $\ldots$ & $\ldots$ & $\ldots$ & $\ldots$ \\
Serbia & 0.5 & $\ldots$ & $\ldots$. & 100.0 & $\ldots$ & $\ldots$ & $\ldots$ & $\ldots$ & 0.0 & $\ldots$ & $\ldots$ \\
Sweden & 1.7 & 0.0 & 3.7 & 12.3 & 0.0 & 11.0 & $\ldots$ & 11.1 & 0.6 & 0.0 & 72.4 \\
Ukraine & 1.2 & $\ldots$ & 1.8 & $\ldots$. & $\ldots$ & $\ldots$ & $\ldots$ & $\ldots$ & 17.8 & $\ldots$ & $\ldots$ \\
UK: England \& Wales & 1.4 & $\ldots$ & 9.2 & 82.8 & $\ldots$ & 0.0 & $\ldots$ & $\ldots$ & 4.8 & $\ldots$ & 12.4 \\
\hline
\end{tabular}

Table 3.2.4.14 Minors receiving sanctions/measures in 2015 - Theft by means of burglary

\begin{tabular}{lrrrrrrrrrrr}
\hline Austria & 2.1 & $\ldots$ & 12.6 & $\ldots$ & $\ldots$ & 65.6 & $\ldots$ & $\ldots$ & 19.7 & 66.7 & 2.2 \\
Croatia & 3.5 & 39.9 & $\ldots$ & 39.2 & $\ldots$ & 5.4 & 25.0 & $\ldots$ & 15.5 & $\ldots$ & $\ldots$ \\
Germany & 4.0 & 5.5 & $\ldots$ & 64.1 & $\ldots$ & 16.9 & 100.0 & $\ldots$ & 13.5 & $\ldots$ & $\ldots$ \\
Hungary & 6.5 & 0.9 & 0.5 & 63.6 & 44.0 & 20.9 & 90.3 & 0.0 & 14.1 & 0.0 & 0.0 \\
Poland & 2.0 & $\ldots$ & $\ldots$ & 80.6 & $\ldots$ & 2.7 & $\ldots$ & $\ldots$ & 16.8 & $\ldots$ & $\ldots$ \\
Portugal & 0.2 & $\ldots$ & 22.2 & 16.7 & $\ldots$ & 50.0 & 55.6 & $\ldots$ & $\ldots$ & $\ldots$ & $\ldots$ \\
UK: England \& Wales & 2.9 & $\ldots$ & 0.3 & 79.4 & $\ldots$ & 0.0 & $\ldots$ & $\ldots$ & 13.7 & $\ldots$ & 6.9 \\
\hline
\end{tabular}

Table 3.2.4.15 Minors receiving sanctions/measures in 2015 - Theft by means of domestic burglary

\begin{tabular}{lrrrrrrrrrrr}
\hline Germany & 0.9 & 6.3 & $\ldots$ & 54.0 & $\ldots$ & 22.2 & 100.0 & $\ldots$ & 17.6 & $\ldots$ & $\ldots$ \\
Hungary & 0.5 & 1.9 & 0.0 & 75.9 & 39.0 & 9.3 & 100.0 & 0.0 & 13.0 & 0.0 & 0.0 \\
Portugal & 0.1 & $\ldots$ & $\ldots$ & $\ldots$ & $\ldots$ & 50.0 & 60.0 & $\ldots$ & $\ldots$ & $\ldots$ & $\ldots$ \\
UK: England \& Wales & 1.7 & $\ldots$ & 0.2 & 76.4 & $\ldots$ & 0.0 & $\ldots$ & $\ldots$ & 18.5 & $\ldots$ & $\ldots$ \\
\hline
\end{tabular}


Table 3.2.4.16 Minors receiving sanctions/measures in 2015 - Fraud

\begin{tabular}{|c|c|c|c|c|c|c|c|c|c|c|c|}
\hline & \multirow[b]{2}{*}{ 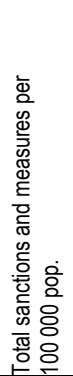 } & \multirow[b]{2}{*}{ 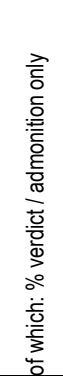 } & \multirow[b]{2}{*}{ 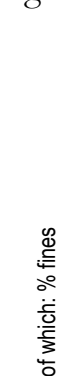 } & \multicolumn{2}{|c|}{$\begin{array}{l}\text { of which: \% } \\
\text { non-custodial } \\
\text { sanctions and } \\
\text { measures }\end{array}$} & \multicolumn{3}{|c|}{$\begin{array}{l}\text { of which: \% suspended } \\
\text { custodial sanctions and } \\
\text { measures }\end{array}$} & \multicolumn{2}{|c|}{$\begin{array}{l}\text { of which: } \% \text { un- } \\
\text { suspended custo- } \\
\text { dial sanctions } \\
\text { and measures }\end{array}$} & \multirow[b]{2}{*}{ 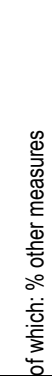 } \\
\hline & & & & 兽 & 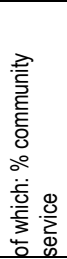 & $\begin{array}{l}\text { 丞 } \\
\end{array}$ & 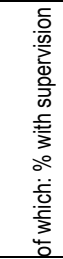 & 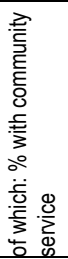 & 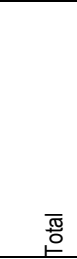 & 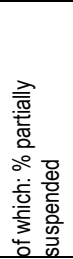 & \\
\hline Albania & & $\ldots$ & & & $\ldots$ & & & 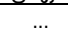 & & $\ldots$ & $\ldots$ \\
\hline Armenia & 0.0 & $\ldots$ & 0.0 & 0.0 & $\ldots$ & 100.0 & 0.0 & 0.0 & 0.0 & $\ldots$ & 0.0 \\
\hline Austria & 0.5 & $\ldots$ & 44.4 & $\ldots$ & $\begin{array}{l}\cdots \\
\cdots\end{array}$ & 40.0 & $\ldots$ & $\ldots$ & 11.1 & 60.0 & 4.4 \\
\hline Azerbaijan & $\ldots$ & $\ldots$ & $\ldots$ & $\ldots$ & $\ldots$ & $\ldots$ & $\ldots$ & $\ldots$ & $\ldots$ & $\ldots$ & $\ldots$ \\
\hline Belgium & 0.0 & $\ldots$ & $\ldots$ & $\ldots$ & $\ldots$ & $\ldots$ & $\ldots$ & $\ldots$ & $\ldots$ & $\ldots$ & $\ldots$ \\
\hline Bosnia-Herzegovina & & $\ldots$ & $\ldots$ & $\ldots$ & $\ldots$ & $\ldots$ & $\ldots$ & $\ldots$ & $\ldots$ & $\ldots$ & $\ldots$ \\
\hline Bulgaria & 0.1 & & 0.0 & 20.0 & $\ldots$ & $\ldots$ & $\ldots$ & $\ldots$ & 80.0 & $\ldots$ & 0.0 \\
\hline Croatia & 0.1 & 0.0 & $\ldots$ & 66.7 & $\ldots$ & 33.3 & 0.0 & $\ldots$ & 0.0 & $\ldots$ & $\ldots$ \\
\hline Cyprus & & & & $\ldots$ & $\ldots$ & & & $\ldots$ & & $\ldots$ & $\ldots$ \\
\hline Czech Republic & 0.2 & 26.1 & 0.0 & 0.0 & $\ldots$ & 56.5 & 7.7 & $\ldots$ & 4.3 & $\ldots$ & 13.0 \\
\hline Denmark & $\ldots$ & $\ldots$ & $\ldots$ & $\ldots$ & $\ldots$ & $\ldots$ & $\ldots$ & $\ldots$ & $\ldots$ & $\ldots$ & $\ldots$ \\
\hline Estonia & $\ldots$ & $\ldots$ & $\ldots$ & $\ldots$ & $\ldots$ & $\ldots$ & $\ldots$ & $\ldots$ & $\ldots$ & $\ldots$ & $\ldots$ \\
\hline Finland & 1.9 & 0.0 & 88.6 & 0.0 & $\ldots$ & 9.5 & 50.0 & 0.0 & 0.0 & $\ldots$ & 1.9 \\
\hline France & 0.4 & 2.3 & 3.1 & 67.0 & $\ldots$ & 20.7 & 0.0 & $\ldots$ & 6.9 & 5.6 & $\ldots$ \\
\hline Georgia & 0.2 & $\ldots$ & $\ldots$ & $\ldots$ & $\ldots$ & $\ldots$ & $\ldots$ & $\ldots$ & 33.3 & $\ldots$ & $\ldots$ \\
\hline Germany & 3.8 & 4.1 & $\ldots$ & 80.3 & $\ldots$ & 10.3 & 100.0 & $\ldots$ & 5.3 & $\ldots$ & $\ldots$ \\
\hline Hungary & 0.8 & 1.2 & 6.2 & 58.0 & 25.5 & 23.5 & 89.5 & 0.0 & 11.1 & 0.0 & 0.0 \\
\hline Iceland & $\ldots$ & $\ldots$ & $\ldots$ & $\ldots$ & $\ldots$ & $\ldots$ & $\ldots$ & $\ldots$ & $\ldots$ & $\ldots$ & $\ldots$ \\
\hline $\begin{array}{l}\text { Italy } \\
\text { Kosovo (UN }\end{array}$ & $\ldots$ & $\ldots$ & $\ldots$ & $\ldots$ & $\ldots$ & $\ldots$ & $\ldots$ & $\ldots$ & $\ldots$ & $\ldots$ & $\ldots$ \\
\hline $\mathrm{R} / 1244 / 99)$ & $\ldots$ & $\ldots$ & $\ldots$ & $\ldots$ & $\ldots$ & $\ldots$ & $\ldots$ & $\ldots$ & $\ldots$ & $\ldots$ & $\ldots$ \\
\hline Latvia & $\ldots$ & $\ldots$ & $\ldots$ & $\ldots$ & $\ldots$ & $\ldots$ & $\ldots$ & $\ldots$ & $\ldots$ & $\ldots$ & $\ldots$ \\
\hline Lithuania & 1.6 & $\ldots$ & $\ldots$ & $\ldots$ & $\ldots$ & $\ldots$ & $\ldots$ & $\ldots$ & $\ldots$ & $\ldots$ & $\ldots$ \\
\hline Luxembourg & $\ldots$ & $\ldots$ & $\ldots$ & $\ldots$ & $\ldots$ & $\ldots$ & $\ldots$ & $\ldots$ & $\ldots$ & $\ldots$ & $\ldots$ \\
\hline Moldova & $\ldots$ & $\ldots$ & $\ldots$ & $\ldots$ & $\ldots$ & $\ldots$ & $\ldots$ & $\ldots$ & $\ldots$ & $\ldots$ & $\ldots$ \\
\hline Montenegro & $\ldots$ & $\ldots$ & $\ldots$ & $\ldots$ & $\ldots$ & $\ldots$ & ... & $\ldots$ & $\ldots$ & $\ldots$ & $\ldots$ \\
\hline Netherlands & $\ldots$ & $\ldots$ & 0.0 & 80.0 & 93.8 & 0.0 & $\ldots$ & $\ldots$ & 0.0 & $\ldots$ & $\ldots$ \\
\hline North Macedonia & 0.1 & $\ldots$ & $\ldots$ & $\ldots$ & $\ldots$ & $\ldots$ & $\ldots$ & $\ldots$ & $\ldots$ & $\ldots$ & $\ldots$ \\
\hline Norway & $\ldots$ & $\ldots$ & $\ldots$ & $\ldots$ & $\ldots$ & $\ldots$ & $\ldots$ & $\ldots$ & $\ldots$ & $\ldots$ & $\ldots$ \\
\hline Poland & 0.2 & $\ldots$ & $\ldots$ & 90.4 & $\ldots$ & 2.4 & ... & $\ldots$ & 7.2 & $\ldots$ & $\ldots$ \\
\hline Portugal & 0.1 & $\ldots$ & 100.0 & $\ldots$ & $\ldots$ & $\ldots$ & $\ldots$ & $\ldots$ & $\ldots$ & $\ldots$ & ... \\
\hline Romania & $\ldots$ & $\ldots$ & $\ldots$ & $\ldots$ & $\ldots$ & $\ldots$ & $\ldots$ & $\ldots$ & $\ldots$ & $\ldots$ & $\ldots$ \\
\hline Russian Federation & & $\ldots$ & $\ldots$ & $\ldots$ & $\ldots$ & $\ldots$ & $\ldots$ & $\ldots$ & $\ldots$ & $\ldots$ & $\ldots$ \\
\hline Serbia & 0.2 & $\ldots$ & $\ldots$ & 100.0 & $\ldots$ & $\ldots$ & ... & $\ldots$ & 0.0 & $\ldots$ & $\ldots$ \\
\hline Slovak Republic & $\ldots$ & $\ldots$ & $\ldots$ & $\ldots$ & $\ldots$ & $\ldots$ & $\ldots$ & $\ldots$ & $\ldots$ & $\ldots$ & $\ldots$ \\
\hline Slovenia & $\ldots$ & $\ldots$ & $\ldots$ & $\ldots$ & $\ldots$ & $\ldots$ & ... & $\ldots$ & $\ldots$ & $\ldots$ & ... \\
\hline Spain & $\ldots$ & $\ldots$ & $\ldots$ & $\ldots$ & $\ldots$ & $\ldots$ & $\ldots$ & $\ldots$ & $\ldots$ & $\ldots$ & $\ldots$ \\
\hline Sweden & 1.7 & 0.0 & 14.1 & 14.7 & 12.5 & 20.2 & $\ldots$ & 15.2 & 4.9 & 25.0 & 46.0 \\
\hline Switzerland & & $\ldots$ & & $\ldots$ & $\ldots$ & $\ldots$ & $\ldots$ & $\ldots$ & $\ldots$ & $\ldots$ & $\ldots$ \\
\hline Turkey & 0.5 & $\ldots$ & 51.5 & 2.2 & $\ldots$ & 10.1 & $\ldots$ & $\ldots$ & 19.5 & $\ldots$ & 16.7 \\
\hline Ukraine & $\ldots$ & $\ldots$ & $\ldots$ & $\ldots$ & $\ldots$ & $\ldots$ & $\ldots$ & $\ldots$ & $\ldots$ & $\ldots$ & $\ldots$ \\
\hline UK: England \& Wales & 0.7 & $\ldots$ & 3.7 & 81.5 & $\ldots$ & 0.0 & $\ldots$ & $\ldots$ & 3.5 & $\ldots$ & 15.1 \\
\hline $\begin{array}{l}\text { UK: Northern Ireland } \\
\text { UK: Scotland }\end{array}$ & $\ldots$ & $\ldots$ & $\ldots$ & $\begin{array}{l}\ldots \\
\ldots\end{array}$ & $\begin{array}{l}\ldots \\
\ldots\end{array}$ & $\begin{array}{l}\ldots \\
\ldots\end{array}$ & $\begin{array}{l}\ldots \\
\ldots\end{array}$ & $\begin{array}{l}\ldots \\
\ldots\end{array}$ & $\begin{array}{l}\ldots \\
\ldots\end{array}$ & $\begin{array}{l}\ldots \\
\ldots\end{array}$ & $\begin{array}{l}\ldots \\
\ldots\end{array}$ \\
\hline Mean & 0.7 & 4.8 & 26.0 & 47.2 & 43.9 & 25.1 & 35.3 & 3.8 & 11.7 & 22.6 & 10.8 \\
\hline Median & 0.2 & 1.2 & 4.9 & 62.3 & 25.5 & 20.2 & 7.7 & 0.0 & 5.1 & 15.3 & 4.4 \\
\hline Minimum & 0.0 & 0.0 & 0.0 & 0.0 & 12.5 & 0.0 & 0.0 & 0.0 & 0.0 & 0.0 & 0.0 \\
\hline Maximum & 3.8 & 26.1 & 100.0 & 100.0 & 93.8 & 100.0 & 100.0 & 15.2 & 80.0 & 60.0 & 46.0 \\
\hline
\end{tabular}


Table 3.2.4.17 Minors receiving sanctions/measures in 2015 - Cyber fraud

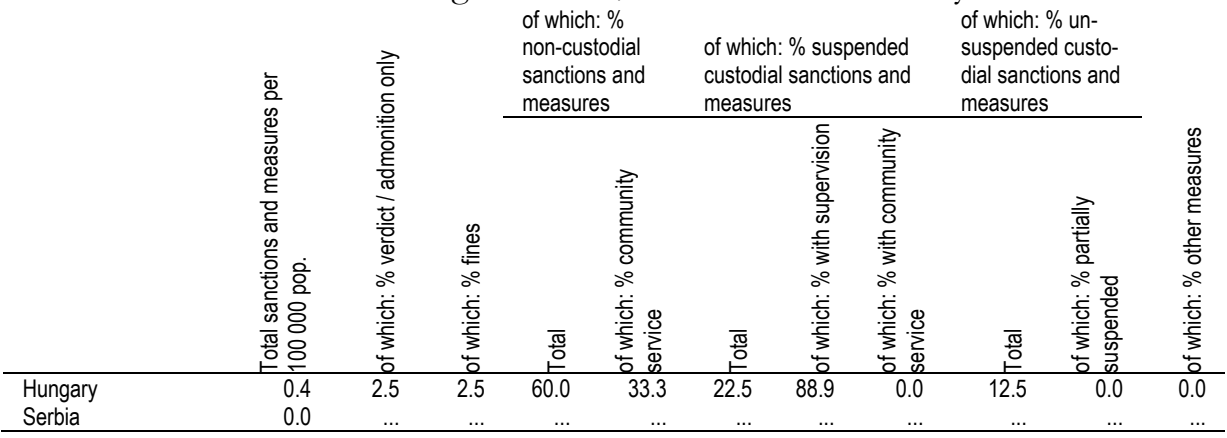

Table 3.2.4.19 Minors receiving sanctions/measures in 2015 - Money laundering

\begin{tabular}{|c|c|c|c|c|c|c|c|c|c|c|c|}
\hline Finland & 0.0 & 0.0 & 100.0 & 0.0 & ... & 0.0 & & 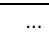 & 0.0 & ... & 0.0 \\
\hline Germany & 0.0 & 8.7 & $\ldots$ & 69.6 & $\ldots$ & 17.4 & 100.0 & $\ldots$ & 4.3 & $\ldots$ & $\ldots$ \\
\hline Hungary & 0.0 & $\ldots$ & $\ldots$ & $\ldots$ & $\ldots$ & $\ldots$ & $\ldots$ & $\ldots$ & $\ldots$ & $\ldots$ & $\ldots$ \\
\hline Latvia & 15.4 & 62.1 & 15.0 & 0.3 & $\ldots$ & $\ldots$ & $\ldots$ & $\ldots$ & $\ldots$ & $\ldots$ & $\ldots$ \\
\hline Netherlands & 0.0 & 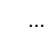 & 0.0 & 100.0 & 100.0 & 0.0 & $\ldots$ & $\ldots$ & 0.0 & 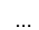 & $\ldots$ \\
\hline Sweden & 0.2 & 0.0 & 4.5 & 22.7 & 0.0 & 31.8 & $\ldots$ & 28.6 & 4.5 & 0.0 & 36.4 \\
\hline UK: England \& Wales & 0.1 & $\ldots$ & 3.2 & 64.5 & $\ldots$ & 0.0 & $\ldots$ & $\ldots$ & 16.1 & $\ldots$ & 19.4 \\
\hline
\end{tabular}

Table 3.2.4.20 Minors receiving sanctions/measures in 2015-Corruption in the public sector

\begin{tabular}{lrrrrrrrrrrr}
\hline Austria & 0.0 & $\ldots$ & 100.0 & $\ldots$ & $\ldots$ & 0.0 & $\ldots$ & $\ldots$ & 0.0 & $\ldots$ & 0.0 \\
France & 0.0 & 0.0 & 3.7 & 55.6 & $\ldots$ & 18.5 & $\ldots$ & $\ldots$ & 7.4 & 50.0 & $\ldots$ \\
Germany & 0.0 & 0.0 & $\ldots$ & 100.0 & $\ldots$ & 0.0 & $\ldots$ & $\ldots$ & 0.0 & $\ldots$ & $\ldots$ \\
Hungary & 0.0 & $\ldots$ & $\ldots$ & $\ldots$ & $\ldots$ & $\ldots$ & $\ldots$ & $\ldots$ & $\ldots$ & $\ldots$ & $\ldots$ \\
Lithuania & 0.1 & $\ldots$ & $\ldots$ & $\ldots$ & $\ldots$ & $\ldots$ & $\ldots$ & $\ldots$ & $\ldots$ & $\ldots$ & $\ldots$ \\
Poland & 0.0 & $\ldots$ & $\ldots$ & 100.0 & $\ldots$ & 0.0 & $\ldots$ & $\ldots$ & 0.0 & $\ldots$ & $\ldots$ \\
Turkey & 0.0 & $\ldots$ & 40.0 & 20.0 & $\ldots$ & 20.0 & $\ldots$ & $\ldots$ & 20.0 & $\ldots$ & 0.0 \\
\hline
\end{tabular}


Table 3.2.4.18 Minors receiving sanctions/measures in 2015 - Forgery of documents

\begin{tabular}{|c|c|c|c|c|c|c|c|c|c|c|c|}
\hline & \multirow[b]{2}{*}{ 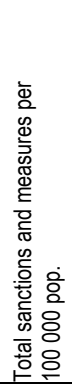 } & \multirow[b]{2}{*}{ 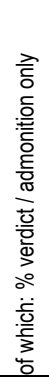 } & \multirow[b]{2}{*}{ 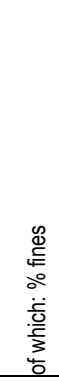 } & \multicolumn{2}{|c|}{$\begin{array}{l}\text { of which: \% } \\
\text { non-custodial } \\
\text { sanctions and } \\
\text { measures }\end{array}$} & \multicolumn{3}{|c|}{$\begin{array}{l}\text { of which: } \% \text { suspended } \\
\text { custodial sanctions and } \\
\text { measures }\end{array}$} & \multicolumn{2}{|c|}{$\begin{array}{l}\text { of which: } \% \text { un- } \\
\text { suspended cus- } \\
\text { todial sanctions } \\
\text { and measures }\end{array}$} & \multirow[b]{2}{*}{ 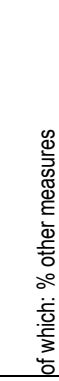 } \\
\hline & & & & 氶 & 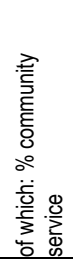 & $\begin{array}{l}\overline{\widetilde{\pi}} \\
\stackrel{0}{0}\end{array}$ & 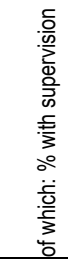 & 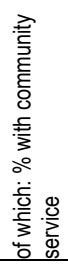 & 氶 & 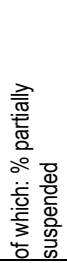 & \\
\hline Albania & $\ldots$ & $\ldots$ & $\ldots$ & $\ldots$ & $\ldots$ & $\ldots$ & $\ldots$ & $\ldots$ & $\ldots$ & $\ldots$ & $\ldots$ \\
\hline Armenia & $\ldots$ & $\ldots$ & $\ldots$ & $\ldots$ & $\ldots$ & $\ldots$ & $\ldots$ & $\ldots$ & $\ldots$ & $\ldots$ & $\ldots$ \\
\hline Austria & $\ldots$ & $\ldots$ & $\ldots$ & $\ldots$ & $\ldots$ & $\ldots$ & $\ldots$ & $\ldots$ & $\ldots$ & $\ldots$ & $\ldots$ \\
\hline Azerbaijan & $\ldots$ & $\ldots$ & $\ldots$ & $\ldots$ & $\ldots$ & $\ldots$ & $\ldots$ & $\ldots$ & $\ldots$ & $\ldots$ & $\ldots$ \\
\hline Belgium & 0.0 & $\ldots$ & 0.0 & 0.0 & $\ldots$ & 100.0 & 0.0 & $\ldots$ & 0.0 & $\ldots$ & 0.0 \\
\hline Bosnia-Herzegovina & $\ldots$ & $\ldots$ & $\ldots$ & $\ldots$ & $\ldots$ & $\ldots$ & $\ldots$ & $\ldots$ & $\ldots$ & $\ldots$ & $\ldots$ \\
\hline Bulgaria & & & $\ldots$ & $\ldots$ & $\ldots$ & $\ldots$ & $\ldots$ & $\ldots$ & $\ldots$ & $\ldots$ & $\ldots$ \\
\hline Croatia & 0.0 & 0.0 & $\ldots$ & 100.0 & 0.0 & 0.0 & $\ldots$ & $\ldots$ & 0.0 & $\ldots$ & $\ldots$ \\
\hline Cyprus & $\ldots$ & & $\ldots$ & $\ldots$ & $\ldots$ & $\ldots$ & $\ldots$ & $\ldots$ & $\ldots$ & $\ldots$ & $\ldots$ \\
\hline Czech Republic & 0.0 & 0.0 & 0.0 & 0.0 & $\ldots$ & 0.0 & $\ldots$ & $\ldots$ & 0.0 & $\ldots$ & 100.0 \\
\hline Denmark & $\ldots$ & $\ldots$ & $\ldots$ & $\ldots$ & $\ldots$ & $\ldots$ & $\ldots$ & $\ldots$ & $\ldots$ & $\ldots$ & $\ldots$ \\
\hline Estonia & $\ldots$ & $\ldots$ & $\ldots$ & $\ldots$ & $\ldots$ & $\ldots$ & $\ldots$ & $\ldots$ & $\ldots$ & $\ldots$ & $\ldots$ \\
\hline Finland & 1.8 & 0.0 & 94.9 & 0.0 & $\ldots$ & 2.0 & 50.0 & 0.0 & 0.0 & $\ldots$ & 3.1 \\
\hline France & 0.0 & 5.6 & 5.6 & 83.3 & $\ldots$ & 5.6 & $\ldots$ & $\ldots$ & 0.0 & $\ldots$ & $\ldots$ \\
\hline Georgia & $\ldots$ & $\ldots$ & $\ldots$ & $\ldots$ & $\ldots$ & $\ldots$ & $\ldots$ & $\ldots$ & $\ldots$ & $\ldots$ & $\ldots$ \\
\hline Germany & 1.0 & 3.2 & $\ldots$ & 80.4 & $\ldots$ & 10.8 & 100.0 & $\ldots$ & 5.5 & $\ldots$ & $\ldots$ \\
\hline Hungary & 1.1 & 2.8 & 6.4 & 65.1 & 35.2 & 12.8 & 78.6 & 0.0 & 12.8 & 0.0 & 0.0 \\
\hline Iceland & $\ldots$ & $\ldots$ & $\ldots$ & $\ldots$ & $\ldots$ & $\ldots$ & $\ldots$ & $\ldots$ & $\ldots$ & $\ldots$ & $\ldots$ \\
\hline $\begin{array}{l}\text { Italy } \\
\text { Kosovo (UN }\end{array}$ & $\ldots$ & $\ldots$ & $\ldots$ & $\ldots$ & $\ldots$ & ... & $\ldots$ & $\ldots$ & $\ldots$ & $\cdots$ & $\ldots$ \\
\hline R/1244/99) & $\ldots$ & $\ldots$ & $\ldots$ & $\ldots$ & $\ldots$ & $\ldots$ & $\ldots$ & $\ldots$ & $\ldots$ & & $\ldots$ \\
\hline Latvia & $\ldots$ & $\ldots$ & $\ldots$ & $\ldots$ & $\ldots$ & $\ldots$ & $\ldots$ & $\ldots$ & $\ldots$ & 159.3 & $\ldots$ \\
\hline Lithuania & 0.6 & $\ldots$ & $\ldots$ & $\ldots$ & $\ldots$ & $\ldots$ & $\ldots$ & $\ldots$ & $\ldots$ & $\ldots$ & $\ldots$ \\
\hline Luxembourg & $\ldots$ & $\ldots$ & $\ldots$ & $\ldots$ & $\ldots$ & $\ldots$ & $\ldots$ & $\ldots$ & $\ldots$ & $\ldots$ & $\ldots$ \\
\hline Moldova & $\ldots$ & $\ldots$ & $\ldots$ & $\ldots$ & $\ldots$ & $\ldots$ & $\ldots$ & $\ldots$ & $\ldots$ & $\ldots$ & $\ldots$ \\
\hline Montenegro & $\ldots$ & $\ldots$ & $\ldots$ & $\ldots$ & $\ldots$ & $\ldots$ & $\ldots$ & $\ldots$ & $\ldots$ & $\ldots$ & $\ldots$ \\
\hline Netherlands & 0.2 & $\ldots$ & 0.0 & 0.0 & $\ldots$ & 0.0 & $\ldots$ & $\ldots$ & 0.0 & $\ldots$ & $\ldots$ \\
\hline North Macedonia & 0.0 & $\ldots$ & $\ldots$ & $\ldots$ & $\ldots$ & $\ldots$ & $\ldots$ & $\ldots$ & $\ldots$ & $\ldots$ & $\ldots$ \\
\hline Norway & $\ldots$ & $\ldots$ & $\ldots$ & $\ldots$ & $\ldots$ & $\ldots$ & $\ldots$ & $\ldots$ & $\ldots$ & $\ldots$ & $\ldots$ \\
\hline Poland & 0.3 & $\ldots$ & $\ldots$ & 95.2 & $\ldots$ & 0.0 & $\ldots$ & $\ldots$ & 4.8 & ... & $\ldots$ \\
\hline Portugal & 0.1 & $\ldots$ & 71.4 & $\ldots$ & $\ldots$ & $\ldots$ & $\ldots$ & $\ldots$ & $\ldots$ & $\ldots$ & $\cdots$ \\
\hline Romania & $\ldots$ & $\ldots$ & $\ldots$ & $\ldots$ & $\cdots$ & $\ldots$ & $\cdots$ & $\ldots$ & $\cdots$ & $\cdots$ & $\ldots$ \\
\hline Russian Federation & $\ldots$ & $\ldots$ & $\ldots$ & $\ldots$ & $\ldots$ & $\ldots$ & $\ldots$ & $\ldots$ & $\ldots$ & $\ldots$ & $\ldots$ \\
\hline Serbia & 0.1 & $\ldots$ & $\ldots$ & 100.0 & $\ldots$ & $\ldots$ & $\ldots$ & $\ldots$ & 0.0 & $\ldots$ & $\ldots$ \\
\hline Slovak Republic & $\ldots$ & $\ldots$ & $\ldots$ & $\ldots$ & $\ldots$ & $\ldots$ & $\ldots$ & $\ldots$ & $\ldots$ & $\ldots$ & $\ldots$ \\
\hline Slovenia & $\ldots$ & $\ldots$ & $\ldots$ & $\ldots$ & $\ldots$ & $\ldots$ & $\ldots$ & $\ldots$ & $\ldots$ & $\ldots$ & $\ldots$ \\
\hline Spain & & & $\ldots$ & $\ldots$ & $\ldots$ & $\ldots$ & $\ldots$ & $\ldots$ & $\ldots$ & $\ldots$ & $\ldots$ \\
\hline Sweden & 0.8 & 0.0 & 27.6 & 3.9 & 0.0 & 34.2 & $\ldots$ & 3.8 & 7.9 & 0.0 & 26.3 \\
\hline Switzerland & $\ldots$ & $\ldots$ & $\ldots$ & $\ldots$ & $\ldots$ & $\ldots$ & $\ldots$ & $\ldots$ & $\ldots$ & $\ldots$ & $\ldots$ \\
\hline Turkey & 0.1 & $\ldots$ & 28.2 & 7.7 & $\ldots$ & 11.5 & $\ldots$ & $\ldots$ & 41.0 & $\ldots$ & 11.5 \\
\hline Ukraine & $\ldots$ & $\ldots$ & $\ldots$ & $\ldots$ & $\ldots$ & $\ldots$ & $\ldots$ & $\ldots$ & $\ldots$ & $\ldots$ & $\ldots$ \\
\hline UK: England \& Wales & 0.0 & $\ldots$ & 0.0 & 90.0 & $\ldots$ & 0.0 & $\ldots$ & $\ldots$ & 0.0 & $\ldots$ & 10.0 \\
\hline $\begin{array}{l}\text { UK: Northern Ireland } \\
\text { UK: Scotland }\end{array}$ & $\ldots$ & $\begin{array}{l}\ldots \\
\ldots\end{array}$ & $\begin{array}{l}\ldots \\
\ldots \\
\end{array}$ & $\begin{array}{l}\ldots \\
\ldots\end{array}$ & $\begin{array}{l}\ldots \\
\ldots\end{array}$ & $\begin{array}{l}\ldots \\
\ldots\end{array}$ & $\begin{array}{l}\ldots \\
\ldots\end{array}$ & $\begin{array}{l}\ldots \\
\ldots\end{array}$ & $\begin{array}{l}\ldots \\
\ldots\end{array}$ & $\begin{array}{l}\ldots \\
\ldots\end{array}$ & $\cdots$ \\
\hline Mean & 0.4 & 1.6 & 23.4 & 48.1 & 11.7 & 14.8 & 57.1 & 1.3 & 5.5 & 53.1 & 21.6 \\
\hline Median & 0.1 & 0.0 & 6.0 & 65.1 & 0.0 & 3.8 & 64.3 & 0.0 & 0.0 & 0.0 & 10.0 \\
\hline Minimum & 0.0 & 0.0 & 0.0 & 0.0 & 0.0 & 0.0 & 0.0 & 0.0 & 0.0 & 0.0 & 0.0 \\
\hline Maximum & 1.8 & 5.6 & 94.9 & 100.0 & 35.2 & 100.0 & 100.0 & 3.8 & 41.0 & 159.3 & 100.0 \\
\hline
\end{tabular}


Table 3.2.4.21 Minors receiving sanctions/measures in 2015 - Drug offences: Total

\begin{tabular}{|c|c|c|c|c|c|c|c|c|c|c|c|}
\hline & \multirow[b]{2}{*}{ 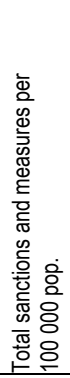 } & \multirow[b]{2}{*}{ 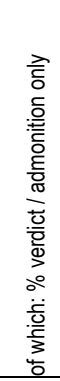 } & \multirow[b]{2}{*}{ 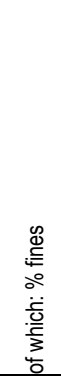 } & \multicolumn{2}{|c|}{$\begin{array}{l}\text { of which: \% } \\
\text { non-custodial } \\
\text { sanctions and } \\
\text { measures }\end{array}$} & \multicolumn{3}{|c|}{$\begin{array}{l}\text { of which: \% suspended } \\
\text { custodial sanctions and } \\
\text { measures }\end{array}$} & \multicolumn{2}{|c|}{$\begin{array}{l}\text { of which: } \% \text { un- } \\
\text { suspended cus- } \\
\text { todial sanctions } \\
\text { and measures }\end{array}$} & \multirow[b]{2}{*}{ 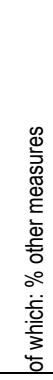 } \\
\hline & & & & 要 & 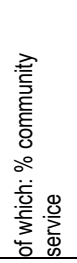 & 要 & 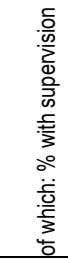 & 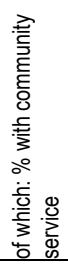 & 丞 & 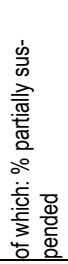 & \\
\hline Albania & & & & & $\ldots$ & & $\ldots$ & & & $\ldots$ & $\ldots$ \\
\hline Armenia & 0.1 & 0.0 & 0.0 & 0.0 & $\ldots$ & 100.0 & 0.0 & 0.0 & 0.0 & $\ldots$ & $\ldots$ \\
\hline Austria & 3.1 & $\ldots$ & 30.7 & $\ldots$ & $\ldots$ & 49.6 & $\ldots$ & $\ldots$ & 17.4 & 50.0 & 2.3 \\
\hline Azerbaijan & $\ldots$ & $\ldots$ & $\ldots$ & $\ldots$ & $\ldots$ & $\ldots$ & $\ldots$ & $\ldots$ & $\ldots$ & $\ldots$ & $\ldots$ \\
\hline Belgium & 0.0 & $\ldots$ & 0.0 & 0.0 & $\ldots$ & 66.7 & 0.0 & $\ldots$ & 33.3 & $\ldots$ & 0.0 \\
\hline Bosnia-Herzegovina & $\ldots$ & $\ldots$ & $\ldots$ & $\ldots$ & $\ldots$ & $\ldots$ & $\ldots$ & $\ldots$ & $\ldots$ & $\ldots$ & $\ldots$ \\
\hline Bulgaria & 0.8 & $\ldots$ & 0.0 & 48.2 & $\ldots$ & $\ldots$ & $\ldots$ & $\ldots$ & 37.5 & $\ldots$ & 14.3 \\
\hline Croatia & 1.0 & 34.1 & $\ldots$ & 39.0 & 0.0 & 22.0 & 55.6 & $\ldots$ & 4.9 & $\ldots$ & $\ldots$ \\
\hline Cyprus & $\ldots$ & $\ldots$ & $\ldots$ & $\ldots$ & $\ldots$ & $\ldots$ & $\ldots$ & $\ldots$ & $\ldots$ & $\ldots$ & $\ldots$ \\
\hline Czech Republic & 0.8 & 17.1 & 0.0 & 11.0 & 11.1 & 64.6 & 7.5 & $\ldots$ & 3.7 & $\ldots$ & 13.4 \\
\hline Denmark & $\ldots$ & $\ldots$ & $\ldots$ & $\ldots$ & $\ldots$ & $\ldots$ & $\ldots$ & $\ldots$ & $\ldots$ & $\ldots$ & $\ldots$ \\
\hline Estonia & & & & & $\ldots$ & & $\ldots$ & $\ldots$ & & $\ldots$ & \\
\hline Finland & 5.6 & 0.0 & 90.0 & 0.0 & $\ldots$ & 4.5 & 64.3 & 0.0 & 0.0 & $\ldots$ & 5.5 \\
\hline France & 7.7 & 2.3 & 5.3 & 51.4 & $\ldots$ & 30.8 & $\ldots$ & $\ldots$ & 10.2 & 35.8 & $\ldots$ \\
\hline Georgia & 0.5 & $\ldots$ & $\ldots$ & $\ldots$ & $\ldots$ & $\ldots$ & $\ldots$ & $\ldots$ & 16.7 & $\ldots$ & $\ldots$ \\
\hline Germany & 10.8 & 3.5 & $\ldots$ & 84.1 & $\ldots$ & 8.7 & 100.0 & $\ldots$ & 3.7 & $\ldots$ & $\ldots$ \\
\hline Hungary & 0.7 & 6.8 & 1.4 & 76.7 & 48.2 & 12.3 & 77.8 & 0.0 & 2.7 & 0.0 & 0.0 \\
\hline Iceland & $\ldots$ & $\ldots$ & $\ldots$ & $\ldots$ & $\ldots$ & $\ldots$ & $\ldots$ & $\ldots$ & $\ldots$ & $\ldots$ & $\ldots$ \\
\hline $\begin{array}{l}\text { Italy } \\
\text { Kosovo (UN }\end{array}$ & $\ldots$ & $\ldots$ & $\ldots$ & $\ldots$ & $\ldots$ & $\ldots$ & $\ldots$ & $\ldots$ & $\cdots$ & $\cdots$ & $\ldots$ \\
\hline $\mathrm{R} / 1244 / 99)$ & $\ldots$ & $\ldots$ & $\ldots$ & $\ldots$ & $\ldots$ & $\ldots$ & $\ldots$ & $\ldots$ & $\ldots$ & $\ldots$ & $\ldots$ \\
\hline Latvia & $\ldots$ & $\ldots$ & $\ldots$ & $\ldots$ & $\ldots$ & $\ldots$ & $\ldots$ & $\ldots$ & $\ldots$ & $\ldots$ & $\ldots$ \\
\hline Lithuania & 2.3 & $\ldots$ & $\ldots$ & $\ldots$ & $\ldots$ & $\ldots$ & $\ldots$ & $\ldots$ & $\ldots$ & ... & ... \\
\hline Luxembourg & $\ldots$ & $\ldots$ & $\ldots$ & $\ldots$ & $\ldots$ & $\ldots$ & $\ldots$ & $\ldots$ & ... & $\ldots$ & ... \\
\hline Moldova & $\ldots$ & $\ldots$ & $\ldots$ & $\cdots$ & $\ldots$ & $\ldots$ & $\ldots$ & $\ldots$ & $\ldots$ & $\cdots$ & $\cdots$ \\
\hline Montenegro & $\ldots$ & $\ldots$ & $\ldots$ & $\ldots$ & $\ldots$ & $\ldots$ & $\cdots$ & $\ldots$ & $\ldots$ & $\ldots$ & $\ldots$ \\
\hline Netherlands & $\ldots$ & $\ldots$ & 0.0 & 76.8 & 100.0 & 10.4 & $\ldots$ & 84.6 & 12.0 & 53.3 & $\ldots$ \\
\hline North Macedonia & 0.7 & $\ldots$ & $\ldots$ & $\ldots$ & $\ldots$ & $\ldots$ & ... & $\ldots$ & $\ldots$ & $\ldots$ & $\ldots$ \\
\hline Norway & 15.6 & $\ldots$ & $\ldots$ & $\ldots$ & $\ldots$ & $\ldots$ & $\ldots$ & $\ldots$ & $\ldots$ & $\ldots$ & $\ldots$ \\
\hline Poland & 3.5 & $\ldots$ & $\ldots$ & 94.6 & $\ldots$ & 0.5 & $\ldots$ & $\ldots$ & 4.9 & $\ldots$ & $\ldots$ \\
\hline Portugal & 0.8 & $\ldots$ & 31.0 & 10.3 & 100.0 & 50.6 & 86.4 & $\ldots$ & 4.6 & ... & $\ldots$ \\
\hline Romania & $\ldots$ & $\ldots$ & $\ldots$ & $\ldots$ & $\ldots$ & $\ldots$ & $\ldots$ & $\ldots$ & $\ldots$ & $\ldots$ & $\ldots$ \\
\hline Russian Federation & $\ldots$ & $\ldots$ & $\ldots$ & $\ldots$ & $\ldots$ & $\ldots$ & $\ldots$ & $\ldots$ & $\ldots$ & $\ldots$ & $\ldots$ \\
\hline Serbia & 2.2 & $\ldots$ & $\ldots$ & 100.0 & $\ldots$ & $\ldots$ & $\ldots$ & $\ldots$ & 0.0 & $\ldots$ & $\ldots$ \\
\hline Slovak Republic & $\ldots$ & $\ldots$ & $\ldots$ & $\ldots$ & $\ldots$ & $\ldots$ & $\ldots$ & $\ldots$ & $\ldots$ & $\ldots$ & ... \\
\hline Slovenia & $\ldots$ & $\ldots$ & $\ldots$ & $\ldots$ & $\ldots$ & $\ldots$ & ... & $\ldots$ & $\ldots$ & $\cdots$ & ... \\
\hline Spain & & & & & & & $\ldots$ & $\ldots$ & & $\ldots$ & $\cdots$ \\
\hline Sweden & 54.6 & 0.0 & 65.2 & 1.5 & 16.0 & 0.9 & $\ldots$ & 41.3 & 0.8 & 4.4 & 31.6 \\
\hline Switzerland & $\ldots$ & $\ldots$ & & & $\ldots$ & $\ldots$ & $\ldots$ & $\ldots$ & $\ldots$ & $\ldots$ & $\ldots$ \\
\hline Turkey & 8.5 & $\ldots$ & 47.8 & 2.6 & $\ldots$ & 6.2 & $\ldots$ & $\ldots$ & 21.8 & $\ldots$ & 21.6 \\
\hline Ukraine & 0.4 & $\ldots$ & 30.5 & $\ldots$ & $\ldots$ & $\ldots$ & $\ldots$ & $\ldots$ & 4.3 & $\ldots$ & $\ldots$ \\
\hline UK: England \& Wales & 9.1 & $\ldots$ & 19.3 & 53.3 & $\ldots$ & 0.0 & $\ldots$ & $\ldots$ & 4.1 & $\ldots$ & 42.2 \\
\hline UK: Northern Ireland & $\ldots$ & $\ldots$ & $\ldots$ & $\ldots$ & $\ldots$ & $\ldots$ & $\ldots$ & $\ldots$ & $\ldots$ & $\ldots$ & $\ldots$ \\
\hline UK: Scotland & $\ldots$ & $\ldots$ & $\ldots$ & $\ldots$ & $\ldots$ & $\ldots$ & $\ldots$ & $\ldots$ & $\ldots$ & $\ldots$ & $\ldots$ \\
\hline Mean & 6.1 & 8.0 & 22.9 & 40.6 & 45.9 & 28.5 & 48.9 & 25.2 & 9.6 & 28.7 & 14.5 \\
\hline Median & 2.2 & 2.9 & 12.3 & 43.6 & 32.1 & 12.3 & 59.9 & 0.0 & 4.6 & 35.8 & 13.4 \\
\hline Minimum & 0.0 & 0.0 & 0.0 & 0.0 & 0.0 & 0.0 & 0.0 & 0.0 & 0.0 & 0.0 & 0.0 \\
\hline Maximum & 54.6 & 34.1 & 90.0 & 100.0 & 100.0 & 100.0 & 100.0 & 84.6 & 37.5 & 53.3 & 42.2 \\
\hline
\end{tabular}


Table 3.2.4.22 Minors receiving sanctions/measures in 2015 - Drug trafficking

\begin{tabular}{|c|c|c|c|c|c|c|c|c|c|c|c|}
\hline & \multirow[b]{2}{*}{ 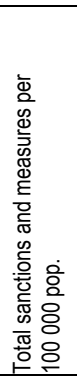 } & \multirow[b]{2}{*}{ 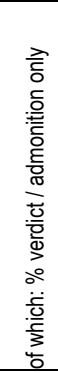 } & \multirow[b]{2}{*}{ 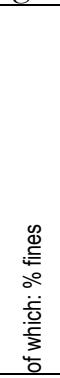 } & \multicolumn{2}{|c|}{$\begin{array}{l}\text { of which: \% } \\
\text { non-custodial } \\
\text { sanctions and } \\
\text { measures } \\
\end{array}$} & \multicolumn{3}{|c|}{$\begin{array}{l}\text { of which: \% suspended } \\
\text { custodial sanctions and } \\
\text { measures }\end{array}$} & \multicolumn{2}{|c|}{$\begin{array}{l}\text { of which: \% un- } \\
\text { suspended custo- } \\
\text { dial sanctions } \\
\text { and measures }\end{array}$} & \multirow[b]{2}{*}{ 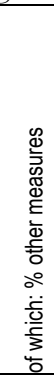 } \\
\hline & & & & $\begin{array}{l}\overline{\widetilde{\pi}} \\
\text { 음 }\end{array}$ & 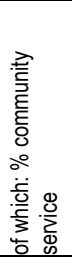 & $\begin{array}{l}\overline{\underline{\pi}} \\
\text { 으 }\end{array}$ & 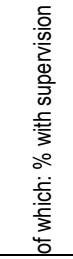 & 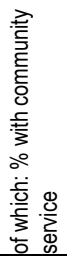 & 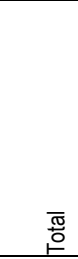 & 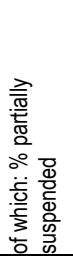 & \\
\hline Albania & & $\ldots$ & $\ldots$ & $\ldots$ & $\ldots$ & $\ldots$ & $\ldots$ & $\ldots$ & $\ldots$ & $\ldots$ & $\ldots$ \\
\hline Armenia & 0.1 & $\ldots$ & 0.0 & 0.0 & $\ldots$ & 100.0 & 0.0 & 0.0 & 0.0 & $\ldots$ & $\ldots$ \\
\hline Austria & $\ldots$ & $\ldots$ & $\ldots$ & $\ldots$ & $\ldots$ & $\ldots$ & $\ldots$ & $\ldots$ & $\ldots$ & $\ldots$ & $\ldots$ \\
\hline Azerbaijan & $\ldots$ & $\ldots$ & $\ldots$ & $\ldots$ & $\ldots$ & $\ldots$ & $\ldots$ & $\ldots$ & $\ldots$ & $\ldots$ & $\ldots$ \\
\hline Belgium & $\ldots$ & $\ldots$ & $\ldots$ & $\ldots$ & $\ldots$ & $\ldots$ & $\ldots$ & $\ldots$ & $\ldots$ & $\ldots$ & $\ldots$ \\
\hline Bosnia-Herzegovina & $\ldots$ & $\ldots$ & $\ldots$ & $\ldots$ & $\ldots$ & $\ldots$ & $\ldots$ & $\ldots$ & $\ldots$ & $\ldots$ & $\ldots$ \\
\hline Bulgaria & $\ldots$ & $\ldots$ & $\ldots$ & $\ldots$ & $\ldots$ & $\ldots$ & $\ldots$ & $\ldots$ & $\ldots$ & $\ldots$ & $\ldots$ \\
\hline Croatia & 1.0 & 34.1 & $\ldots$ & 39.0 & $\cdots$ & 22.0 & 55.6 & $\cdots$ & 4.9 & $\cdots$ & $\cdots$ \\
\hline Cyprus & & $\ldots$ & $\ldots$ & & $\ldots$ & & $\ldots$ & $\ldots$ & $\ldots$ & $\ldots$ & $\ldots$ \\
\hline Czech Republic & 0.7 & 16.7 & 0.0 & 12.5 & 100.0 & 66.7 & 8.3 & $\ldots$ & 4.2 & $\ldots$ & 0.0 \\
\hline Denmark & $\ldots$ & $\ldots$ & $\ldots$ & $\ldots$ & $\ldots$ & $\ldots$ & $\ldots$ & $\ldots$ & $\ldots$ & $\ldots$ & $\ldots$ \\
\hline Estonia & & $\ldots$ & $\ldots$ & $\ldots$ & $\ldots$ & $\ldots$ & $\ldots$ & $\ldots$ & $\ldots$ & $\ldots$ & $\ldots$ \\
\hline Finland & 1.9 & 0.0 & 84.8 & 0.0 & $\ldots$ & 13.3 & 64.3 & 0.0 & 0.0 & $\ldots$ & 1.9 \\
\hline France & 5.6 & 1.6 & 4.8 & 40.4 & $\ldots$ & 39.9 & 0.0 & $\ldots$ & 13.3 & 37.6 & $\ldots$ \\
\hline Georgia & & $\ldots$ & $\ldots$ & & $\ldots$ & $\ldots$ & $\ldots$ & $\ldots$ & $\ldots$ & $\ldots$ & $\ldots$ \\
\hline Germany & 0.9 & 9.0 & $\ldots$ & 36.7 & $\ldots$ & 41.1 & 100.0 & $\ldots$ & 13.1 & $\ldots$ & $\ldots$ \\
\hline Hungary & 0.1 & 0.0 & 0.0 & 77.8 & 57.1 & 22.2 & 100.0 & 0.0 & 0.0 & $\ldots$ & 0.0 \\
\hline Iceland & $\ldots$ & $\ldots$ & $\ldots$ & $\ldots$ & $\ldots$ & $\ldots$ & $\ldots$ & $\ldots$ & $\ldots$ & $\ldots$ & $\ldots$ \\
\hline $\begin{array}{l}\text { Italy } \\
\text { Kosovo (UN }\end{array}$ & $\ldots$ & $\ldots$ & $\ldots$ & $\ldots$ & ... & $\ldots$ & $\ldots$ & $\ldots$ & $\cdots$ & $\ldots$ & ... \\
\hline $\mathrm{R} / 1244 / 99)$ & $\ldots$ & $\ldots$ & $\ldots$ & $\ldots$ & $\ldots$ & $\ldots$ & $\ldots$ & $\ldots$ & $\ldots$ & $\ldots$ & $\ldots$ \\
\hline Latvia & & $\ldots$ & $\ldots$ & $\ldots$ & ... & $\ldots$ & $\ldots$ & $\ldots$ & ... & $\ldots$ & $\ldots$ \\
\hline Lithuania & 1.0 & $\ldots$ & $\ldots$ & $\ldots$ & $\ldots$ & $\ldots$ & $\ldots$ & $\ldots$ & $\ldots$ & $\ldots$ & $\ldots$ \\
\hline Luxembourg & $\ldots$ & $\ldots$ & $\ldots$ & $\ldots$ & $\ldots$ & $\ldots$ & $\ldots$ & $\ldots$ & $\ldots$ & $\ldots$ & $\ldots$ \\
\hline Moldova & $\ldots$ & $\ldots$ & $\ldots$ & $\ldots$ & $\ldots$ & $\ldots$ & $\ldots$ & $\ldots$ & $\ldots$ & $\ldots$ & $\ldots$ \\
\hline Montenegro & $\ldots$ & $\ldots$ & $\ldots$ & $\ldots$ & $\ldots$ & $\ldots$ & $\ldots$ & $\ldots$ & $\ldots$ & $\ldots$ & $\ldots$ \\
\hline Netherlands & $\ldots$ & $\ldots$ & $\ldots$ & $\ldots$ & $\ldots$ & $\ldots$ & $\ldots$ & $\ldots$ & $\ldots$ & $\ldots$ & $\ldots$ \\
\hline North Macedonia & $\ldots$ & $\ldots$ & $\ldots$ & $\ldots$ & $\ldots$ & $\ldots$ & $\ldots$ & $\ldots$ & $\ldots$ & $\ldots$ & $\ldots$ \\
\hline Norway & $\ldots$ & $\ldots$ & $\ldots$ & $\ldots$ & $\ldots$ & $\ldots$ & $\ldots$ & $\ldots$ & $\ldots$ & $\ldots$ & $\ldots$ \\
\hline Poland & 0.1 & $\ldots$ & $\ldots$ & 94.3 & $\ldots$ & 0.0 & $\ldots$ & $\ldots$ & 5.7 & $\ldots$ & $\ldots$ \\
\hline Portugal & 0.6 & $\ldots$ & 12.3 & 12.3 & 100.0 & 64.6 & 85.7 & $\ldots$ & 9.2 & $\ldots$ & $\ldots$ \\
\hline Romania & $\ldots$ & $\ldots$ & $\ldots$ & $\ldots$ & $\ldots$ & $\ldots$ & $\ldots$ & $\ldots$ & $\ldots$ & $\ldots$ & $\ldots$ \\
\hline Russian Federation & & $\ldots$ & $\ldots$ & $\ldots$ & $\ldots$ & $\ldots$ & $\ldots$ & $\ldots$ & $\ldots$ & $\ldots$ & $\ldots$ \\
\hline Serbia & 0.7 & $\ldots$ & $\ldots$ & 100.0 & $\ldots$ & $\ldots$ & $\ldots$ & $\ldots$ & 0.0 & $\ldots$ & $\ldots$ \\
\hline Slovak Republic & $\ldots$ & $\ldots$ & $\ldots$ & $\ldots$ & ... & $\ldots$ & $\ldots$ & $\ldots$ & $\ldots$ & $\ldots$ & $\ldots$ \\
\hline Slovenia & $\ldots$ & $\ldots$ & $\ldots$ & $\ldots$ & $\ldots$ & $\ldots$ & $\ldots$ & $\ldots$ & ... & $\ldots$ & $\ldots$ \\
\hline Spain & & $\ldots$ & $\ldots$ & $\ldots$ & $\ldots$ & $\ldots$ & $\ldots$ & $\ldots$ & $\ldots$ & $\ldots$ & $\ldots$ \\
\hline Sweden & 3.0 & 0.0 & 42.4 & 13.5 & 23.1 & 8.3 & $\ldots$ & 45.8 & 9.7 & 7.1 & 26.0 \\
\hline Switzerland & & $\ldots$ & $\ldots$ & $\ldots$ & $\ldots$ & $\ldots$ & $\ldots$ & $\ldots$ & $\ldots$ & $\ldots$ & $\ldots$ \\
\hline Turkey & 3.6 & $\ldots$ & 41.6 & 4.7 & $\ldots$ & 6.4 & $\ldots$ & $\ldots$ & 38.6 & $\ldots$ & 8.7 \\
\hline Ukraine & & $\ldots$ & $\ldots$ & $\ldots$ & $\ldots$ & $\ldots$ & $\ldots$ & $\ldots$ & $\ldots$ & $\ldots$ & $\ldots$ \\
\hline UK: England \& Wales & 0.0 & $\ldots$ & $\ldots$ & $\ldots$ & $\ldots$ & $\ldots$ & $\ldots$ & $\ldots$ & $\ldots$ & $\ldots$ & ... \\
\hline UK: Northern Ireland & $\ldots$ & $\ldots$ & $\ldots$ & $\ldots$ & $\ldots$ & $\ldots$ & $\ldots$ & $\ldots$ & $\ldots$ & $\ldots$ & $\ldots$ \\
\hline UK: Scotland & $\ldots$ & $\ldots$ & $\ldots$ & $\ldots$ & $\ldots$ & $\ldots$ & $\ldots$ & $\ldots$ & $\ldots$ & $\ldots$ & $\ldots$ \\
\hline Mean & 1.4 & 8.8 & 23.2 & 35.9 & 70.1 & 35.0 & 51.7 & 11.5 & 8.2 & 22.4 & 7.3 \\
\hline Median & 0.8 & 1.6 & 8.6 & 25.1 & 78.6 & 22.2 & 59.9 & 0.0 & 5.3 & 22.4 & 1.9 \\
\hline Minimum & 0.0 & 0.0 & 0.0 & 0.0 & 23.1 & 0.0 & 0.0 & 0.0 & 0.0 & 7.1 & 0.0 \\
\hline Maximum & 5.6 & 34.1 & 84.8 & 100.0 & 100.0 & 100.0 & 100.0 & 45.8 & 38.6 & 37.6 & 26.0 \\
\hline
\end{tabular}


Notes on tables 3.2.3.1 to 3.2.4.22

\begin{tabular}{|c|c|}
\hline Austria & $\begin{array}{l}\text { "A conviction accompanied only by a simple warning without any further sanction." only applies } \\
\text { for minors. }\end{array}$ \\
\hline Belgium & $\begin{array}{l}\text { Prison sentences for which the execution is partially suspended are only counted under "sus- } \\
\text { pended custodial sanctions and measures", not under "unsuspended custodial sanctions and } \\
\text { measures. }\end{array}$ \\
\hline \multirow[t]{3}{*}{ Bulgaria } & $\begin{array}{l}\text { Custodial sanctions include imprisonment, life imprisonment and life imprisonment without pa- } \\
\text { role. }\end{array}$ \\
\hline & $\begin{array}{l}\text { Other sanctions include confiscation of property, revocation of the right to occupy certain state } \\
\text { or public position, revocation of the right to practice a certain profession or activity, revocation } \\
\text { of the right to received orders, honorary titles and insignia of honour, revocation of military } \\
\text { rank, and public reprimand. }\end{array}$ \\
\hline & $\begin{array}{l}\text { Custodial sanctions imposed on minors include both the suspended and unsuspended custo- } \\
\text { dial sanctions. }\end{array}$ \\
\hline Czech Republic & $\begin{array}{l}\text { Category other sanctions includes house confinement, confiscation of a thing or other asset } \\
\text { value, prohibition of activity, prohibition of stay, prohibition of entering sport, cultural and other } \\
\text { social events, loss of honorary titles or decorations, loss of military rank and banishment }\end{array}$ \\
\hline Iceland & $\begin{array}{l}\text { In the "suspended custodial sanctions and measures column the term "of which under super- } \\
\text { vision" does not apply to the Icelandic legal system. }\end{array}$ \\
\hline Lithuania & Other measures - Coercive medical treatment \\
\hline \multirow[t]{3}{*}{ Serbia } & The data in tables 3.2.3. refer to adults only \\
\hline & $\begin{array}{l}\text { Non-custodial sentences include only two criminal sanctions: community services and revoca- } \\
\text { tion of driver's license, which could be pronounced both as principal and as secondary sanc- } \\
\text { tions. }\end{array}$ \\
\hline & $\begin{array}{l}\text { Other measures include a number of persons found guilty but released from the punishment } \\
\text { and education measures imposed on adults }(18-21) \text {. }\end{array}$ \\
\hline Sweden & $\begin{array}{l}\text { Other measures include forensic psychiatric care, court-imposed care order, care of young } \\
\text { persons, youth service, care under the Care of Abusers Act, abstention from prosecution } \\
\text { (waivers of prosecution) and appointments. }\end{array}$ \\
\hline Switzerland & The data in tables 3.2.3. refer to adults only \\
\hline UK: Northern Ireland & $\begin{array}{l}\text { Data is only available on principal offence level. It is not possible to provide a further break- } \\
\text { down of the data. }\end{array}$ \\
\hline
\end{tabular}


3.2.5 Persons convicted by length of unsuspended custodial sanctions and measures imposed in 2015

Table 3.2.5.1 Persons convicted by length of unsuspended custodial sanctions and measures imposed in 2015 - Criminal offences: Total

\begin{tabular}{|c|c|c|c|c|c|c|c|c|c|c|}
\hline & 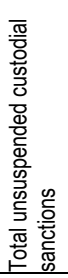 & 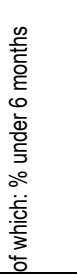 & 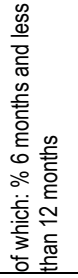 & 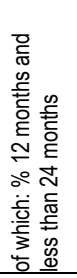 & 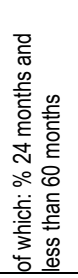 & 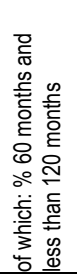 & 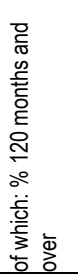 & 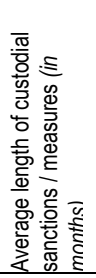 & 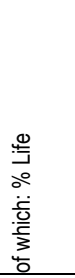 & 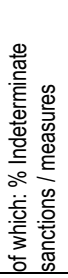 \\
\hline Albania & $\ldots$ & $\ldots$ & $\ldots$ & & $\ldots$ & $\ldots$ & $\ldots$ & $\ldots$ & & $\ldots$ \\
\hline Armenia & 51 & $\ldots$ & 31.8 & 15.0 & 43.1 & 8.7 & 1.4 & $\ldots$ & 0.0 & $\ldots$ \\
\hline Austria & 109 & 14.5 & 8.7 & 19.1 & 4.1 & 2.7 & $\ldots$ & $\ldots$ & 0.1 & $\ldots$ \\
\hline Azerbaijan & 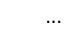 & $\ldots$ & $\ldots$ & & $\ldots$ & $\ldots$ & $\ldots$ & $\ldots$ & $\ldots$ & $\ldots$ \\
\hline Belgium & 121 & 29.4 & 28.3 & 24.1 & 14.1 & 3.0 & 1.0 & 0.1 & 0.1 & $\ldots$ \\
\hline Bosnia-Herzegovina & $\ldots$ & $\ldots$ & $\ldots$ & $\ldots$ & $\ldots$ & $\ldots$ & $\ldots$ & $\ldots$ & $\ldots$ & $\ldots$ \\
\hline Bulgaria & 261 & 52.9 & 25.4 & 18.2 & 2.0 & 1.1 & 0.5 & $\ldots$ & 0.0 & $\ldots$ \\
\hline Croatia & 67 & 12.5 & 42.6 & 29.9 & 10.9 & 1.3 & 0.6 & $\ldots$ & $\ldots$ & 2.3 \\
\hline Cyprus & & & & & & & & & & \\
\hline Czech Republic & 90 & 0.0 & 59.9 & 34.5 & 0.0 & 5.1 & 0.5 & 0.2 & 0.0 & 0.0 \\
\hline Denmark & $\ldots$ & $\ldots$ & $\ldots$ & $\ldots$ & $\ldots$ & $\ldots$ & $\ldots$ & $\ldots$ & $\ldots$ & $\ldots$ \\
\hline Estonia & $\ldots$ & $\ldots$ & $\ldots$ & $\ldots$ & $\ldots$ & $\ldots$ & $\ldots$ & $\ldots$ & $\ldots$ & $\ldots$ \\
\hline Finland & 93 & 60.2 & 10.2 & 13.7 & 12.2 & 2.7 & 0.7 & 0.2 & 0.3 & $\ldots$ \\
\hline France & 190 & 54.6 & 24.0 & 16.5 & 3.0 & 1.7 & 0.1 & 0.0 & $\ldots$ & $\ldots$ \\
\hline Georgia & 122 & $\ldots$ & 27.2 & 22.2 & 43.0 & 16.8 & 10.6 & $\ldots$ & 0.0 & $\ldots$ \\
\hline Germany & 44 & 22.7 & 29.4 & 19.1 & 24.3 & 4.0 & 0.2 & $\ldots$ & 0.3 & $\ldots$ \\
\hline Hungary & 91 & 2.1 & 16.3 & 35.8 & 32.3 & 10.8 & 2.3 & 0.3 & 0.4 & 0.0 \\
\hline Iceland & $\ldots$ & $\ldots$ & $\ldots$ & $\ldots$ & $\ldots$ & $\ldots$ & $\ldots$ & $\ldots$ & $\ldots$ & $\ldots$ \\
\hline Italy & $\ldots$ & $\ldots$ & $\ldots$ & $\ldots$ & $\ldots$ & $\ldots$ & $\ldots$ & $\ldots$ & $\ldots$ & $\ldots$ \\
\hline Kosovo (UN R/1244/99) & $\ldots$ & $\ldots$ & $\ldots$ & $\ldots$ & $\ldots$ & $\ldots$ & $\ldots$ & $\ldots$ & $\ldots$ & $\ldots$ \\
\hline Latvia & 172 & 21.9 & 34.9 & 27.3 & 9.0 & 5.6 & 1.3 & $\ldots$ & 0.0 & $\ldots$ \\
\hline Lithuania & 181 & $\ldots$ & $\ldots$ & $\ldots$ & $\ldots$ & $\ldots$ & $\ldots$ & $\ldots$ & $\ldots$ & $\ldots$ \\
\hline Luxembourg & $\ldots$ & $\ldots$ & $\cdots$ & $\cdots$ & $\ldots$ & $\ldots$ & $\cdots$ & $\cdots$ & $\cdots$ & $\cdots$ \\
\hline Moldova & $\ldots$ & $\ldots$ & $\ldots$ & $\ldots$ & $\ldots$ & $\ldots$ & $\ldots$ & $\ldots$ & $\ldots$ & $\ldots$ \\
\hline Montenegro & $\ldots$ & & $\ldots$ & $\ldots$ & $\ldots$ & $\ldots$ & $\ldots$ & $\ldots$ & $\ldots$ & $\ldots$ \\
\hline Netherlands & 150 & 84.4 & 7.3 & 5.4 & 3.4 & 0.8 & 0.3 & 0.0 & 0.0 & $\ldots$ \\
\hline North Macedonia & $\ldots$ & $\ldots$ & $\ldots$ & $\ldots$ & $\ldots$ & $\ldots$ & $\ldots$ & $\ldots$ & $\ldots$ & $\ldots$ \\
\hline Norway & 210 & 74.8 & 12.0 & 9.7 & 1.9 & 1.4 & 0.3 & $\ldots$ & $\ldots$ & $\ldots$ \\
\hline Poland & 90 & 20.4 & 32.4 & 33.9 & 10.7 & 1.8 & 0.7 & 0.0 & 0.2 & $\ldots$ \\
\hline Portugal & $\ldots$ & $\ldots$ & $\ldots$ & $\ldots$ & $\ldots$ & $\ldots$ & $\ldots$ & $\ldots$ & $\ldots$ & $\ldots$ \\
\hline Romania & $\ldots$ & $\ldots$ & $\ldots$ & $\ldots$ & $\ldots$ & $\ldots$ & $\ldots$ & $\ldots$ & $\ldots$ & $\ldots$ \\
\hline Russian Federation & $\ldots$ & $\ldots$ & $\ldots$ & $\ldots$ & $\ldots$ & $\ldots$ & $\ldots$ & $\ldots$ & $\cdots$ & $\ldots$ \\
\hline Serbia & 124 & 37.5 & 27.5 & 16.3 & 16.2 & 1.9 & 0.6 & $\ldots$ & $\ldots$ & $\ldots$ \\
\hline Slovak Republic & $\ldots$ & $\ldots$ & $\ldots$ & $\ldots$ & $\ldots$ & $\ldots$ & $\ldots$ & $\ldots$ & $\ldots$ & $\cdots$ \\
\hline Slovenia & $\ldots$ & $\ldots$ & $\ldots$ & $\ldots$ & $\ldots$ & $\ldots$ & $\cdots$ & $\cdots$ & $\cdots$ & $\cdots$ \\
\hline Spain & & $\ldots$ & $\ldots$ & $\ldots$ & $\ldots$ & $\ldots$ & $\ldots$ & $\ldots$ & $\ldots$ & $\ldots$ \\
\hline Sweden & 112 & 64.2 & 14.2 & 13.2 & 5.3 & 2.2 & 0.3 & 0.1 & 0.2 & 2.7 \\
\hline Switzerland & 119 & 77.3 & 8.6 & 6.1 & 6.4 & 1.3 & 0.3 & 0.1 & 0.0 & $\ldots$ \\
\hline Turkey & 555 & $\ldots$ & $\ldots$ & $\ldots$ & $\ldots$ & $\ldots$ & $\ldots$ & $\ldots$ & $\ldots$ & $\ldots$ \\
\hline Ukraine & 46 & $\ldots$ & 8.1 & 16.4 & 59.3 & 14.3 & 1.6 & $\ldots$ & 0.2 & $\ldots$ \\
\hline UK: England \& Wales & 66 & 14.7 & 16.1 & 35.5 & 34.1 & 10.1 & 2.9 & 0.0 & 1.0 & 0.0 \\
\hline UK: Northern Ireland & 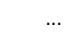 & & $\ldots$ & & & $\ldots$ & $\ldots$ & $\ldots$ & $\ldots$ & $\ldots$ \\
\hline UK: Scotland & 255 & 65.0 & 16.4 & 10.8 & 4.7 & 3.0 & 0.0 & 0.1 & 0.2 & 0.0 \\
\hline Mean & 144 & 39.4 & 22.9 & 20.1 & 16.2 & 4.8 & 1.3 & 0.1 & 0.2 & 0.8 \\
\hline Median & 119 & 33.4 & 24.0 & 18.2 & 10.7 & 2.7 & 0.6 & 0.1 & 0.1 & 0.0 \\
\hline Minimum & 44 & 0.0 & 7.3 & 5.4 & 0.0 & 0.8 & 0.0 & 0.0 & 0.0 & 0.0 \\
\hline Maximum & 555 & 84.4 & 59.9 & 35.8 & 59.3 & 16.8 & 10.6 & 0.3 & 1.0 & 2.7 \\
\hline
\end{tabular}


Table 3.2.5.2 Persons convicted by length of unsuspended custodial sanctions and measures imposed in 2015 - Criminal offences: Major road traffic offences

\begin{tabular}{|c|c|c|c|c|c|c|c|c|c|c|}
\hline & 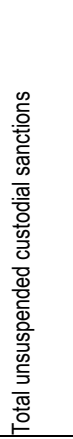 & 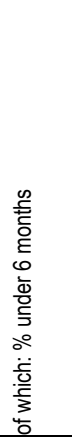 & 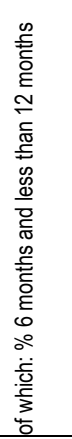 & 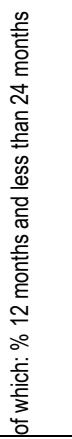 & 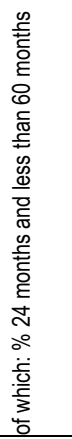 & 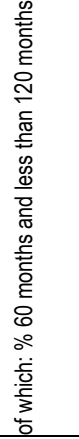 & 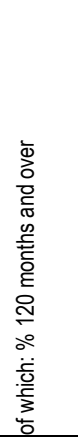 & 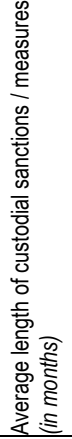 & 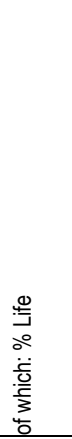 & 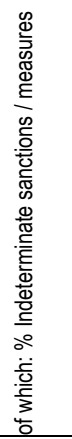 \\
\hline $\begin{array}{l}\text { Albania } \\
\text { Armenia }\end{array}$ & 50 & $\cdots$ & 286 & 558 & 130 & & & $\ldots$ & & $\ldots$ \\
\hline $\begin{array}{l}\text { Armenia } \\
\text { Austria }\end{array}$ & $\begin{array}{r}5.0 \\
\ldots\end{array}$ & $\begin{array}{l}\cdots \\
\ldots\end{array}$ & $\begin{array}{r}28.6 \\
\ldots\end{array}$ & $\begin{array}{r}55.8 \\
\ldots\end{array}$ & $\begin{array}{r}13.0 \\
\ldots\end{array}$ & $\begin{array}{r}2.6 \\
\ldots\end{array}$ & 0.0 & $\cdots$ & 0.0 & $\cdots$ \\
\hline Azerbaijan & $\ldots$ & $\ldots$ & $\ldots$ & $\ldots$ & $\ldots$ & $\ldots$ & $\ldots$ & $\cdots$ & $\cdots$ & $\ldots$ \\
\hline Belgium & $\ldots$ & $\ldots$ & $\ldots$ & $\ldots$ & $\ldots$ & $\ldots$ & $\ldots$ & $\ldots$ & $\ldots$ & $\ldots$ \\
\hline Bosnia-Herzegovina & & & & & & & & $\cdots$ & & $\ldots$ \\
\hline Bulgaria & 20.0 & 74.3 & 17.9 & 6.9 & 0.7 & 0.2 & 0.0 & $\ldots$ & 0.0 & $\ldots$ \\
\hline Croatia & 3.6 & 7.8 & 44.7 & 30.1 & 17.5 & 0.0 & 0.0 & $\ldots$ & $\ldots$ & 0.0 \\
\hline Cyprus & & & & & $\ldots$ & & & & & \\
\hline Czech Republic & 10.9 & $\ldots$ & 76.2 & 22.6 & $\ldots$ & 1.2 & 0.1 & 1.2 & 0.0 & 0.0 \\
\hline $\begin{array}{l}\text { Denmark } \\
\text { Fstonia }\end{array}$ & ... & $\ldots$ & ... & $\ldots$ & ... & $\ldots$ & $\ldots$ & $\cdots$ & $\ldots$ & $\ldots$ \\
\hline Finland & 25.5 & 91.1 & 5.9 & 2.9 & 0.2 & 0.0 & 0.0 & 0.2 & 0.0 & $\cdots$ \\
\hline France & 17.7 & 77.8 & 19.1 & 3.1 & 0.0 & 0.0 & 0.0 & 0.0 & $\ldots$ & $\ldots$ \\
\hline Georgia & 1.6 & & 20.3 & 47.3 & 29.7 & 2.7 & & & & $\ldots$ \\
\hline Germany & 5.4 & 44.6 & 44.7 & 6.8 & 3.7 & 0.2 & 0.0 & 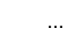 & 0.0 & $\ldots$ \\
\hline Hungary & 3.7 & 3.6 & 29.1 & 35.1 & 27.3 & 3.6 & 1.2 & 6.5 & 0.0 & 0.0 \\
\hline Iceland & $\ldots$ & $\ldots$ & $\ldots$ & $\ldots$ & $\ldots$ & $\ldots$ & $\ldots$ & $\ldots$ & $\ldots$ & $\ldots$ \\
\hline Italy & $\ldots$ & $\ldots$ & $\ldots$ & $\ldots$ & $\ldots$ & $\ldots$ & $\ldots$ & $\ldots$ & $\ldots$ & $\ldots$ \\
\hline Kosovo (UN R/1244/99) & $\ldots$ & $\ldots$ & $\ldots$ & $\ldots$ & $\ldots$ & $\ldots$ & $\ldots$ & $\ldots$ & $\ldots$ & $\ldots$ \\
\hline Latvia & $\ldots$ & $\ldots$ & $\ldots$ & $\ldots$ & $\ldots$ & $\ldots$ & $\ldots$ & $\ldots$ & $\ldots$ & $\ldots$ \\
\hline Lithuania & $\ldots$ & $\ldots$ & $\ldots$ & $\ldots$ & $\ldots$ & $\ldots$ & $\ldots$ & $\ldots$ & $\ldots$ & $\ldots$ \\
\hline Luxembourg & $\ldots$ & $\ldots$ & $\ldots$ & $\ldots$ & $\ldots$ & $\ldots$ & $\ldots$ & $\ldots$ & $\ldots$ & $\ldots$ \\
\hline Moldova & $\ldots$ & $\ldots$ & $\ldots$ & $\ldots$ & $\ldots$ & $\ldots$ & $\ldots$ & $\ldots$ & $\ldots$ & $\ldots$ \\
\hline Montenegro & & & & & $\ldots$ & & & $\ldots$ & $\ldots$ & $\ldots$ \\
\hline Netherlands & 7.0 & 98.1 & 1.2 & 0.3 & 0.3 & 0.0 & 0.0 & 0.0 & 0.0 & $\ldots$ \\
\hline North Macedonia & & & & & & & & $\ldots$ & $\ldots$ & ... \\
\hline Norway & 0.2 & 99.5 & 0.5 & 0.0 & 0.0 & 0.0 & 0.0 & & & $\ldots$ \\
\hline Poland & 14.6 & 25.8 & 44.1 & 25.4 & 3.3 & 1.3 & 0.1 & 0.2 & 0.0 & $\ldots$ \\
\hline Portugal & $\ldots$ & $\ldots$ & $\ldots$ & $\ldots$ & $\ldots$ & $\ldots$ & $\ldots$ & $\ldots$ & $\ldots$ & $\ldots$ \\
\hline Romania & $\ldots$ & $\ldots$ & $\ldots$ & $\ldots$ & $\ldots$ & $\ldots$ & $\ldots$ & $\ldots$ & $\ldots$ & $\ldots$ \\
\hline Russian Federation & & & & & & & & & & $\ldots$ \\
\hline Serbia & 3.7 & 41.2 & 32.3 & 13.1 & 12.5 & 0.9 & 0.0 & $\ldots$ & $\ldots$ & $\ldots$ \\
\hline Slovak Republic & $\ldots$ & $\ldots$ & $\ldots$ & $\ldots$ & $\ldots$ & $\ldots$ & $\ldots$ & & $\ldots$ & $\ldots$ \\
\hline Slovenia & $\ldots$ & $\ldots$ & $\ldots$ & $\ldots$ & $\ldots$ & $\ldots$ & $\ldots$ & $\ldots$ & $\ldots$ & $\ldots$ \\
\hline Spain & & & & & & & & $\ldots$ & & $\ldots$ \\
\hline Sweden & 25.9 & 98.9 & 1.1 & 0.1 & 0.0 & 0.0 & 0.0 & 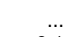 & 0.0 & 0.1 \\
\hline Switzerland & 1.8 & 81.0 & 13.8 & 5.2 & 0.0 & 0.0 & 0.0 & 2.1 & 0.0 & $\ldots$ \\
\hline Turkey & 1.6 & $\ldots$ & & & & & & $\ldots$ & & $\ldots$ \\
\hline Ukraine & 5.8 & $\ldots$ & 0.5 & 2.1 & 73.9 & 23.3 & 0.2 & $\ldots$ & 0.0 & $\ldots$ \\
\hline UK: England \& Wales & $\ldots$ & $\ldots$ & $\ldots$ & $\ldots$ & $\ldots$ & $\ldots$ & $\ldots$ & $\cdots$ & $\ldots$ & $\cdots$ \\
\hline UK: Northern Ireland & & & & & & & 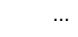 & 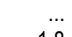 & & $\ldots$ \\
\hline UK: Scotland & 3.2 & 56.3 & 34.6 & 7.1 & 1.8 & 0.2 & $\ldots$ & 1.8 & 0.0 & 0.0 \\
\hline Mean & 8.7 & 61.5 & 24.4 & 15.5 & 11.5 & 2.1 & 0.1 & 1.5 & 0.0 & 0.0 \\
\hline Median & 5.2 & 74.3 & 20.3 & 6.9 & 2.5 & 0.2 & 0.0 & 0.7 & 0.0 & 0.0 \\
\hline Minimum & 0.2 & 3.6 & 0.5 & 0.0 & 0.0 & 0.0 & 0.0 & 0.0 & 0.0 & 0.0 \\
\hline Maximum & 25.9 & 99.5 & 76.2 & 55.8 & 73.9 & 23.3 & 1.2 & 6.5 & 0.0 & 0.1 \\
\hline
\end{tabular}


Table 3.2.5.3 Persons convicted by length of unsuspended custodial sanctions and measures imposed in 2015 - Intentional homicide: Total

\begin{tabular}{|c|c|c|c|c|c|c|c|c|c|c|}
\hline & 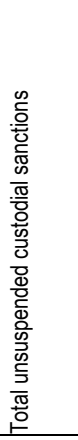 & 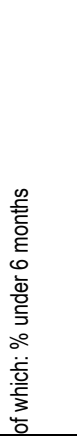 & 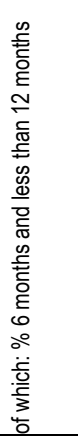 & 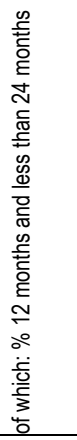 & 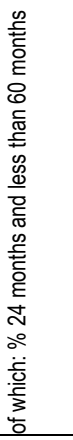 & 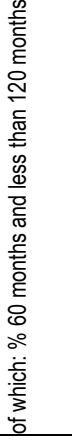 & 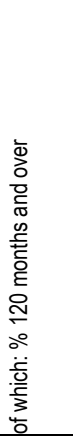 & 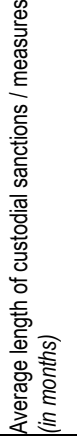 & 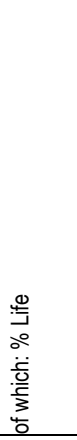 & 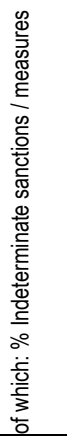 \\
\hline Albania & & $\ldots$ & & & & & & $\ldots$ & & $\ldots$ \\
\hline Armenia & 1.5 & $\ldots$ & 13.0 & 8.7 & 8.7 & 39.1 & 30.4 & $\ldots$ & 0.0 & $\ldots$ \\
\hline Austria & 0.4 & $\ldots$ & $\ldots$ & 2.6 & 7.9 & 71.1 & $\ldots$ & $\ldots$ & 18.4 & $\ldots$ \\
\hline Azerbaijan & & $\ldots$ & & & $\ldots$ & & & $\ldots$ & 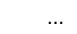 & $\ldots$ \\
\hline Belgium & 1.3 & 0.0 & 0.6 & 2.3 & 12.1 & 30.6 & 48.0 & 93.3 & 6.4 & $\ldots$ \\
\hline Bosnia-Herzegovina & & $\ldots$ & & $\ldots$ & $\ldots$ & & $\ldots$ & $\ldots$ & $\ldots$ & $\ldots$ \\
\hline Bulgaria & 0.7 & 0.0 & 0.8 & 9.2 & 8.5 & 35.4 & 46.2 & $\ldots$ & 1.5 & $\ldots$ \\
\hline Croatia & 2.6 & 0.0 & 0.0 & 30.1 & 32.9 & 16.4 & 20.5 & 0.0 & $\ldots$ & 0.0 \\
\hline Cyprus & $\ldots$ & $\ldots$ & $\ldots$ & $\ldots$ & $\ldots$ & $\ldots$ & $\ldots$ & $\ldots$ & $\ldots$ & $\ldots$ \\
\hline Czech Republic & 1.2 & $\ldots$ & 1.8 & 8.1 & $\ldots$ & 44.1 & 45.9 & 145.2 & 1.8 & 0.0 \\
\hline Denmark & $\ldots$ & $\ldots$ & $\ldots$ & $\ldots$ & $\ldots$ & $\ldots$ & $\ldots$ & $\ldots$ & $\ldots$ & $\ldots$ \\
\hline Estonia & $\ldots$ & $\ldots$ & $\ldots$ & $\ldots$ & $\ldots$ & $\ldots$ & $\ldots$ & $\ldots$ & $\ldots$ & $\ldots$ \\
\hline Finland & 2.5 & 0.0 & 0.8 & 0.0 & 56.3 & 20.3 & 12.5 & 52.9 & 10.2 & $\ldots$ \\
\hline France & 0.1 & 0.0 & 2.2 & 10.9 & 5.4 & 60.9 & 13.0 & 84.6 & $\ldots$ & $\ldots$ \\
\hline Georgia & 2.8 & $\ldots$ & 0.8 & 3.2 & 16.0 & 40.8 & 39.2 & $\ldots$ & $\ldots$ & $\ldots$ \\
\hline Germany & 1.5 & 0.0 & 0.0 & 0.0 & 25.9 & 50.1 & 7.9 & $\ldots$ & 16.2 & $\ldots$ \\
\hline Hungary & 2.0 & 0.0 & 0.0 & 1.7 & 7.3 & 34.3 & 37.6 & 55.1 & 18.5 & 0.6 \\
\hline Iceland & $\cdots$ & $\ldots$ & $\ldots$ & $\ldots$ & $\ldots$ & $\ldots$ & $\cdots$ & $\cdots$ & $\ldots$ & $\cdots$ \\
\hline Italy & $\ldots$ & $\ldots$ & $\ldots$ & $\ldots$ & $\ldots$ & $\ldots$ & $\ldots$ & $\ldots$ & $\ldots$ & $\ldots$ \\
\hline Kosovo (UN R/1244/99) & $\ldots$ & $\ldots$ & $\ldots$ & $\ldots$ & $\ldots$ & $\ldots$ & $\ldots$ & $\ldots$ & $\ldots$ & $\ldots$ \\
\hline Latvia & $\ldots$ & $\ldots$ & $\ldots$ & $\ldots$ & $\ldots$ & $\ldots$ & $\ldots$ & $\cdots$ & $\cdots$ & $\ldots$ \\
\hline Lithuania & $\ldots$ & $\ldots$ & $\ldots$ & $\ldots$ & $\ldots$ & $\ldots$ & $\ldots$ & $\ldots$ & $\ldots$ & $\ldots$ \\
\hline Luxembourg & $\ldots$ & $\ldots$ & $\ldots$ & $\ldots$ & $\ldots$ & $\ldots$ & $\ldots$ & $\ldots$ & $\ldots$ & $\ldots$ \\
\hline Moldova & $\ldots$ & $\ldots$ & $\ldots$ & $\ldots$ & $\ldots$ & $\cdots$ & $\ldots$ & $\ldots$ & $\ldots$ & ... \\
\hline Montenegro & $\ldots$ & $\ldots$ & $\ldots$ & $\ldots$ & $\ldots$ & $\ldots$ & $\ldots$ & $\ldots$ & $\ldots$ & $\ldots$ \\
\hline Netherlands & 2.0 & 20.4 & 14.8 & 16.3 & 22.6 & 14.6 & 11.3 & 9.1 & 1.0 & $\ldots$ \\
\hline North Macedonia & $\ldots$ & $\ldots$ & $\ldots$ & $\ldots$ & $\ldots$ & $\ldots$ & $\ldots$ & $\ldots$ & $\ldots$ & ... \\
\hline Norway & & $\ldots$ & & & $\ldots$ & $\ldots$ & $\ldots$ & $\ldots$ & $\ldots$ & $\ldots$ \\
\hline Poland & 1.6 & 0.0 & 0.7 & 2.0 & 20.3 & 33.9 & 41.9 & 22.1 & 1.1 & $\ldots$ \\
\hline Portugal & $\ldots$ & $\ldots$ & $\ldots$ & $\ldots$ & $\ldots$ & $\ldots$ & $\ldots$ & $\ldots$ & $\ldots$ & ... \\
\hline Romania & $\ldots$ & $\ldots$ & $\ldots$ & $\ldots$ & $\ldots$ & $\ldots$ & $\ldots$ & $\ldots$ & $\ldots$ & $\ldots$ \\
\hline Russian Federation & $\ldots$ & $\ldots$ & $\ldots$ & $\ldots$ & $\ldots$ & $\ldots$ & $\ldots$ & $\ldots$ & $\ldots$ & $\ldots$ \\
\hline Serbia & 1.3 & 0.8 & 0.8 & 3.4 & 30.5 & 28.0 & 36.4 & $\ldots$ & $\ldots$ & $\ldots$ \\
\hline Slovak Republic & $\ldots$ & $\ldots$ & $\ldots$ & $\ldots$ & $\ldots$ & $\ldots$ & $\ldots$ & $\ldots$ & $\ldots$ & ... \\
\hline Slovenia & $\ldots$ & $\ldots$ & $\ldots$ & $\ldots$ & $\ldots$ & $\ldots$ & $\ldots$ & $\ldots$ & $\ldots$ & $\ldots$ \\
\hline Spain & $\ldots$ & $\ldots$ & $\ldots$ & $\ldots$ & $\ldots$ & $\ldots$ & $\ldots$ & $\ldots$ & $\ldots$ & $\ldots$ \\
\hline Sweden & 1.4 & 0.0 & 0.0 & 1.9 & 7.1 & 34.6 & 21.8 & $\ldots$ & 10.3 & 19.2 \\
\hline Switzerland & 0.2 & 0.0 & 0.0 & 0.0 & 26.3 & 52.6 & 21.1 & 507.2 & 0.0 & $\ldots$ \\
\hline Turkey & 1.8 & $\ldots$ & $\ldots$ & $\ldots$ & $\ldots$ & $\ldots$ & $\ldots$ & $\ldots$ & $\ldots$ & $\ldots$ \\
\hline Ukraine & 4.0 & $\ldots$ & 0.4 & 2.2 & 3.9 & 52.9 & 34.9 & $\ldots$ & 5.7 & $\ldots$ \\
\hline UK: England \& Wales & $\ldots$ & $\ldots$ & $\ldots$ & $\ldots$ & $\ldots$ & $\ldots$ & $\ldots$ & $\ldots$ & $\ldots$ & $\ldots$ \\
\hline UK: Northern Ireland & $\ldots$ & $\ldots$ & $\ldots$ & $\ldots$ & $\ldots$ & $\ldots$ & $\ldots$ & $\ldots$ & $\ldots$ & $\ldots$ \\
\hline UK: Scotland & $\ldots$ & $\ldots$ & $\ldots$ & $\ldots$ & $\ldots$ & $\ldots$ & $\ldots$ & $\ldots$ & $\ldots$ & $\ldots$ \\
\hline Mean & 1.6 & 1.8 & 2.3 & 6.0 & 18.2 & 38.8 & 29.3 & 107.7 & 7.0 & 4.9 \\
\hline Median & 1.5 & 0.0 & 0.8 & 2.6 & 14.1 & 35.4 & 32.6 & 55.1 & 5.7 & 0.3 \\
\hline Minimum & 0.1 & 0.0 & 0.0 & 0.0 & 3.9 & 14.6 & 7.9 & 0.0 & 0.0 & 0.0 \\
\hline Maximum & 4.0 & 20.4 & 14.8 & 30.1 & 56.3 & 71.1 & 48.0 & 507.2 & 18.5 & 19.2 \\
\hline
\end{tabular}


Table 3.2.5.4 Persons convicted by length of unsuspended custodial sanctions and measures imposed in 2015 - Intentional homicide: Completed

\begin{tabular}{|c|c|c|c|c|c|c|c|c|c|c|}
\hline & 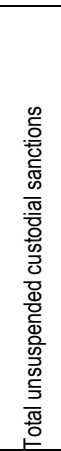 & 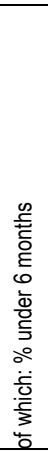 & 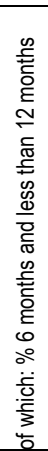 & 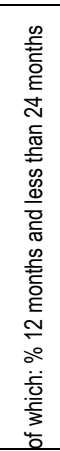 & 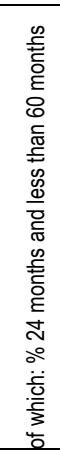 & 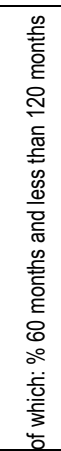 & 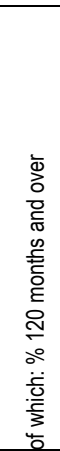 & 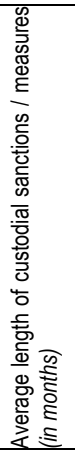 & 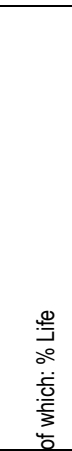 & 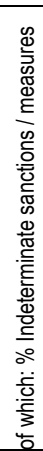 \\
\hline Austria & 50.0 & & 0.0 & 5.3 & & 63.2 & & $\ldots$ & 31.6 & $\ldots$ \\
\hline Bulgaria & 73.8 & 0.0 & 0.0 & 7.3 & 7.3 & 28.1 & 57.3 & $\ldots$ & 2.1 & \\
\hline Croatia & 42.5 & 0.0 & 0.0 & 12.9 & 19.4 & 29.0 & 38.7 & & $\ldots$ & 0.0 \\
\hline France & 31.5 & 0.0 & 3.4 & 13.8 & 3.4 & 75.9 & 3.4 & 254.1 & $\ldots$ & $\ldots$ \\
\hline Hungary & 51.7 & 0.0 & 0.0 & 0.0 & 1.1 & 14.1 & 55.4 & 121.6 & 28.3 & 1.1 \\
\hline Switzerland & 63.2 & 0.0 & 0.0 & 0.0 & 0.0 & 66.7 & 33.3 & 946.3 & 0.0 & \\
\hline UK: England \& Wales & $\ldots$ & 0.0 & 0.0 & 0.0 & 0.0 & 0.0 & 0.0 & & 100.0 & 0.0 \\
\hline UK: Scotland & & 1.6 & 1.6 & 6.6 & 6.6 & 39.3 & & 104.9 & 44.3 & 0.0 \\
\hline
\end{tabular}


Table 3.2.5.5 Persons convicted by length of unsuspended custodial sanctions and measures imposed in 2015 - Bodily injury

\begin{tabular}{|c|c|c|c|c|c|c|c|c|c|c|}
\hline & 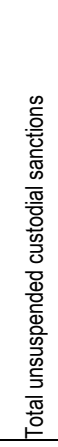 & 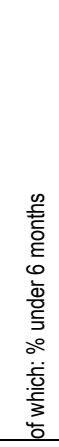 & 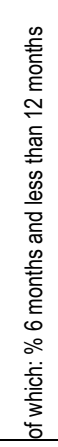 & 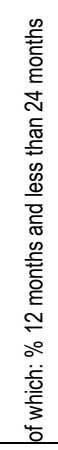 & 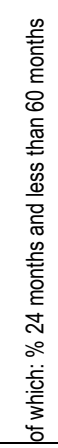 & 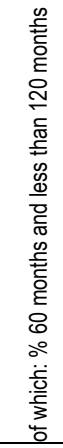 & 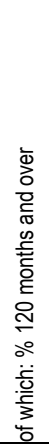 & 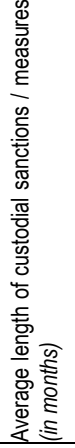 & 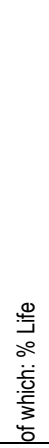 & 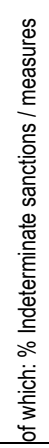 \\
\hline Albania & & $\ldots$ & & & & & & $\ldots$ & & $\ldots$ \\
\hline Armenia & 6.3 & $\ldots$ & 10.3 & 5.2 & 73.2 & 11.3 & 0.0 & $\ldots$ & 0.0 & $\ldots$ \\
\hline Austria & 6.1 & 71.9 & 13.7 & 12.8 & 1.4 & 0.2 & $\ldots$ & $\ldots$ & 0.0 & $\ldots$ \\
\hline Azerbaijan & $\ldots$ & $\ldots$ & $\ldots$ & $\ldots$ & $\ldots$ & $\ldots$ & $\ldots$ & $\ldots$ & $\ldots$ & $\ldots$ \\
\hline Belgium & $\ldots$ & $\ldots$ & $\ldots$ & $\ldots$ & $\ldots$ & $\ldots$ & $\ldots$ & $\ldots$ & $\ldots$ & $\ldots$ \\
\hline Bosnia-Herzegovina & $\ldots$ & $\ldots$ & $\ldots$ & $\ldots$ & $\ldots$ & $\ldots$ & $\ldots$ & $\ldots$ & $\ldots$ & $\ldots$ \\
\hline Bulgaria & 2.1 & 38.7 & 36.9 & 20.9 & 2.2 & 0.5 & 0.7 & $\ldots$ & 0.0 & $\ldots$ \\
\hline Croatia & 4.0 & 19.3 & 50.0 & 21.1 & 7.9 & 0.0 & 0.0 & 0.0 & $\ldots$ & 1.8 \\
\hline Cyprus & $\ldots$ & $\ldots$ & $\ldots$ & $\ldots$ & $\ldots$ & $\ldots$ & $\ldots$ & $\ldots$ & $\ldots$ & $\ldots$ \\
\hline Czech Republic & 3.5 & $\ldots$ & 18.1 & 65.9 & $\ldots$ & 15.4 & 0.6 & 11.6 & 0.0 & 0.0 \\
\hline Denmark & $\ldots$ & $\ldots$ & $\ldots$ & $\ldots$ & $\ldots$ & $\ldots$ & $\ldots$ & $\ldots$ & $\ldots$ & $\ldots$ \\
\hline Estonia & $\ldots$ & $\ldots$ & $\ldots$ & $\ldots$ & $\ldots$ & $\ldots$ & $\ldots$ & $\ldots$ & $\ldots$ & $\ldots$ \\
\hline Finland & 14.6 & 49.8 & 11.7 & 23.9 & 13.2 & 1.3 & 0.0 & 1.6 & 0.0 & $\ldots$ \\
\hline France & 14.4 & 44.9 & 30.8 & 20.4 & 2.6 & 1.1 & 0.0 & 0.2 & $\ldots$ & $\ldots$ \\
\hline Georgia & 3.7 & $\ldots$ & 4.7 & 40.6 & 20.6 & 17.6 & 5.9 & $\ldots$ & $\ldots$ & $\ldots$ \\
\hline Germany & 12.3 & 11.4 & 39.1 & 25.6 & 22.6 & 1.3 & 0.0 & $\ldots$ & 0.0 & $\ldots$ \\
\hline Hungary & 14.0 & 0.9 & 9.7 & 35.7 & 35.4 & 14.7 & 3.2 & 2.8 & 0.5 & 0.0 \\
\hline Iceland & $\ldots$ & $\ldots$ & $\ldots$ & $\ldots$ & $\ldots$ & $\ldots$ & $\ldots$ & $\ldots$ & $\ldots$ & $\ldots$ \\
\hline Italy & $\ldots$ & $\ldots$ & $\ldots$ & $\ldots$ & $\ldots$ & $\cdots$ & $\ldots$ & $\ldots$ & $\ldots$ & $\ldots$ \\
\hline Kosovo (UN R/1244/99) & $\ldots$ & $\ldots$ & $\ldots$ & $\ldots$ & $\ldots$ & $\ldots$ & $\ldots$ & $\ldots$ & $\ldots$ & $\ldots$ \\
\hline Latvia & $\cdots$ & $\ldots$ & $\cdots$ & $\ldots$ & $\ldots$ & $\cdots$ & $\cdots$ & $\cdots$ & $\cdots$ & $\cdots$ \\
\hline Lithuania & $\ldots$ & $\ldots$ & $\ldots$ & $\ldots$ & $\ldots$ & $\ldots$ & $\ldots$ & $\cdots$ & $\cdots$ & $\cdots$ \\
\hline Luxembourg & $\ldots$ & $\ldots$ & $\cdots$ & $\ldots$ & $\ldots$ & $\ldots$ & $\cdots$ & $\cdots$ & $\cdots$ & $\ldots$ \\
\hline Moldova & $\cdots$ & $\cdots$ & $\ldots$ & $\ldots$ & $\cdots$ & $\ldots$ & $\ldots$ & $\ldots$ & $\cdots$ & $\cdots$ \\
\hline Montenegro & $\ldots$ & $\ldots$ & $\ldots$ & $\ldots$ & $\ldots$ & $\ldots$ & $\ldots$ & $\ldots$ & $\ldots$ & $\cdots$ \\
\hline Netherlands & 7.1 & 88.5 & 8.6 & 2.1 & 0.7 & 0.0 & 0.0 & 0.1 & 0.0 & $\ldots$ \\
\hline North Macedonia & $\ldots$ & $\ldots$ & $\ldots$ & $\ldots$ & $\ldots$ & $\ldots$ & $\ldots$ & $\ldots$ & $\ldots$ & $\ldots$ \\
\hline Norway & $\ldots$ & $\ldots$ & $\ldots$ & $\ldots$ & $\ldots$ & $\ldots$ & $\ldots$ & $\ldots$ & $\ldots$ & $\ldots$ \\
\hline Poland & 9.3 & 13.6 & 41.2 & 37.8 & 6.2 & 1.1 & 0.0 & 0.5 & 0.0 & $\ldots$ \\
\hline Portugal & $\ldots$ & $\ldots$ & $\ldots$ & $\ldots$ & $\ldots$ & $\ldots$ & $\ldots$ & $\ldots$ & $\ldots$ & $\ldots$ \\
\hline Romania & $\ldots$ & $\ldots$ & $\ldots$ & $\ldots$ & $\ldots$ & $\ldots$ & $\ldots$ & $\ldots$ & $\ldots$ & $\ldots$ \\
\hline Russian Federation & $\ldots$ & $\ldots$ & $\ldots$ & $\ldots$ & $\ldots$ & $\ldots$ & $\ldots$ & $\ldots$ & $\ldots$ & $\ldots$ \\
\hline Serbia & 3.7 & 50.9 & 32.5 & 8.0 & 7.4 & 1.2 & 0.0 & $\ldots$ & $\ldots$ & $\ldots$ \\
\hline Slovak Republic & $\ldots$ & $\ldots$ & $\ldots$ & $\ldots$ & $\ldots$ & $\ldots$ & $\ldots$ & $\ldots$ & $\ldots$ & $\cdots$ \\
\hline Slovenia & $\ldots$ & $\ldots$ & $\ldots$ & $\ldots$ & $\ldots$ & $\ldots$ & $\ldots$ & $\ldots$ & $\cdots$ & $\ldots$ \\
\hline Spain & $\ldots$ & & & & $\ldots$ & & $\ldots$ & $\ldots$ & & \\
\hline Sweden & 11.9 & 48.8 & 15.3 & 22.7 & 5.5 & 0.9 & 0.0 & $\ldots$ & 0.0 & 6.7 \\
\hline Switzerland & 0.6 & 62.7 & 13.6 & 11.9 & 11.9 & 0.0 & 0.0 & 17.0 & 0.0 & $\ldots$ \\
\hline Turkey & 11.0 & $\ldots$ & $\ldots$ & $\ldots$ & $\ldots$ & $\ldots$ & $\ldots$ & $\ldots$ & $\ldots$ & $\ldots$ \\
\hline Ukraine & $\ldots$ & $\ldots$ & $\ldots$ & $\ldots$ & $\ldots$ & $\ldots$ & $\ldots$ & $\ldots$ & $\ldots$ & $\ldots$ \\
\hline $\begin{array}{l}\text { UK: England \& Wales } \\
\text { UK: Northern Ireland }\end{array}$ & 31.3 & 33.5 & 18.6 & 21.9 & 14.6 & 6.4 & $\begin{array}{r}2.2 \\
\ldots\end{array}$ & $\begin{array}{r}0.2 \\
\ldots\end{array}$ & $\begin{array}{r}2.7 \\
\ldots\end{array}$ & 0.0 \\
\hline UK: Scotland & 21.1 & 43.8 & 21.5 & 18.2 & 9.7 & 5.8 & $\ldots$ & 0.3 & 0.9 & 0.0 \\
\hline Mean & 9.8 & 41.3 & 22.1 & 23.2 & 14.7 & 4.6 & 0.8 & 3.4 & 0.3 & 1.4 \\
\hline Median & 8.2 & 44.3 & 18.1 & 21.1 & 8.8 & 1.2 & 0.0 & 0.4 & 0.0 & 0.0 \\
\hline Minimum & 0.6 & 0.9 & 4.7 & 2.1 & 0.7 & 0.0 & 0.0 & 0.0 & 0.0 & 0.0 \\
\hline Maximum & 31.3 & 88.5 & 50.0 & 65.9 & 73.2 & 17.6 & 5.9 & 17.0 & 2.7 & 6.7 \\
\hline
\end{tabular}


Table 3.2.5.6 Persons convicted by length of unsuspended custodial sanctions and measures imposed in 2015 - Aggravated bodily injury

\begin{tabular}{|c|c|c|c|c|c|c|c|c|c|c|}
\hline & 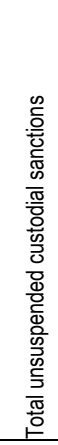 & 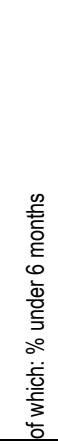 & 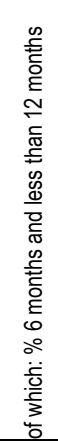 & 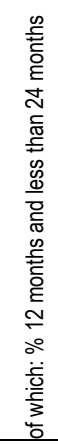 & 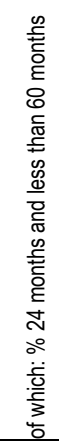 & 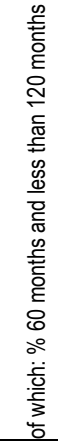 & 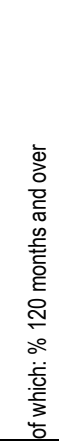 & 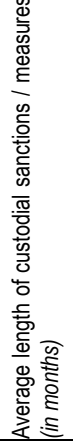 & 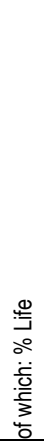 & 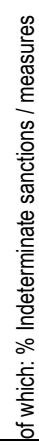 \\
\hline Albania & & $\ldots$ & & & & & & $\ldots$ & & $\ldots$ \\
\hline Armenia & 85.6 & $\ldots$ & 1.2 & 2.4 & 84.3 & 12.0 & 0.0 & $\ldots$ & 0.0 & $\ldots$ \\
\hline Austria & 31.6 & 23.9 & 30.6 & 40.6 & 4.4 & 0.6 & $\ldots$ & $\ldots$ & 0.0 & $\ldots$ \\
\hline Azerbaijan & $\ldots$ & $\ldots$ & $\ldots$ & $\ldots$ & $\ldots$ & $\ldots$ & $\ldots$ & $\ldots$ & $\ldots$ & $\ldots$ \\
\hline Belgium & $\ldots$ & $\ldots$ & $\ldots$ & $\ldots$ & $\ldots$ & $\ldots$ & $\ldots$ & $\ldots$ & $\ldots$ & $\ldots$ \\
\hline Bosnia-Herzegovina & $\ldots$ & $\ldots$ & $\ldots$ & $\ldots$ & $\ldots$ & $\ldots$ & $\ldots$ & $\ldots$ & $\ldots$ & $\ldots$ \\
\hline Bulgaria & $\ldots$ & $\ldots$ & $\ldots$ & $\ldots$ & $\ldots$ & $\ldots$ & $\ldots$ & $\ldots$ & $\ldots$ & $\ldots$ \\
\hline Croatia & 76.3 & 14.9 & 50.6 & 23.0 & 9.2 & 0.0 & 0.0 & $\ldots$ & $\ldots$ & 2.3 \\
\hline Cyprus & $\ldots$ & $\ldots$ & $\ldots$ & & $\ldots$ & $\ldots$ & $\ldots$ & $\ldots$ & $\ldots$ & $\ldots$ \\
\hline Czech Republic & 44.2 & $\ldots$ & 0.7 & 69.8 & $\ldots$ & 28.2 & 1.3 & 39.1 & 0.0 & 0.0 \\
\hline Denmark & $\ldots$ & $\ldots$ & $\ldots$ & $\ldots$ & $\ldots$ & $\ldots$ & $\ldots$ & $\ldots$ & $\ldots$ & $\ldots$ \\
\hline Estonia & $\ldots$ & $\ldots$ & $\ldots$ & $\ldots$ & $\ldots$ & $\ldots$ & $\ldots$ & $\ldots$ & $\ldots$ & $\ldots$ \\
\hline Finland & 36.3 & 3.7 & 4.5 & 51.7 & 36.4 & 3.7 & 0.0 & 9.4 & 0.0 & $\ldots$ \\
\hline France & 20.7 & 22.3 & 28.6 & 35.4 & 8.1 & 4.6 & 0.1 & 2.2 & $\ldots$ & $\ldots$ \\
\hline Georgia & 54.7 & $\ldots$ & $\ldots$ & 19.4 & 37.6 & 32.3 & 10.8 & $\ldots$ & $\ldots$ & $\ldots$ \\
\hline Germany & 50.5 & 2.5 & 29.0 & 31.4 & 34.9 & 2.3 & 0.0 & $\ldots$ & 0.0 & $\ldots$ \\
\hline Hungary & 72.6 & 0.5 & 6.6 & 33.4 & 36.3 & 18.4 & 4.1 & 4.4 & 0.7 & 0.0 \\
\hline Iceland & $\ldots$ & $\ldots$ & $\ldots$ & $\ldots$ & $\ldots$ & $\ldots$ & $\ldots$ & $\ldots$ & $\ldots$ & $\ldots$ \\
\hline Italy & $\ldots$ & $\ldots$ & $\ldots$ & $\ldots$ & $\ldots$ & $\ldots$ & $\ldots$ & $\ldots$ & $\ldots$ & $\ldots$ \\
\hline Kosovo (UN R/1244/99) & $\ldots$ & $\ldots$ & $\ldots$ & $\ldots$ & $\ldots$ & $\ldots$ & $\ldots$ & $\ldots$ & $\ldots$ & $\ldots$ \\
\hline Latvia & $\ldots$ & $\ldots$ & $\ldots$ & $\ldots$ & $\ldots$ & $\ldots$ & $\ldots$ & $\ldots$ & $\ldots$ & $\ldots$ \\
\hline Lithuania & $\ldots$ & $\ldots$ & $\ldots$ & $\ldots$ & $\ldots$ & $\ldots$ & $\ldots$ & $\ldots$ & $\ldots$ & $\ldots$ \\
\hline Luxembourg & $\ldots$ & $\ldots$ & $\ldots$ & $\ldots$ & $\cdots$ & $\ldots$ & $\ldots$ & $\cdots$ & $\cdots$ & $\ldots$ \\
\hline Moldova & $\ldots$ & $\ldots$ & $\ldots$ & $\ldots$ & $\ldots$ & $\ldots$ & $\ldots$ & $\ldots$ & $\ldots$ & $\ldots$ \\
\hline Montenegro & $\ldots$ & $\ldots$ & $\ldots$ & $\ldots$ & $\ldots$ & $\ldots$ & $\ldots$ & $\ldots$ & $\ldots$ & $\ldots$ \\
\hline Netherlands & 29.0 & 70.2 & 22.1 & 5.2 & 2.3 & 0.0 & 0.0 & 0.9 & 0.0 & $\ldots$ \\
\hline North Macedonia & $\ldots$ & $\ldots$ & $\ldots$ & $\ldots$ & $\ldots$ & $\ldots$ & $\ldots$ & $\ldots$ & $\ldots$ & $\ldots$ \\
\hline Norway & & & & & & & & & & $\ldots$ \\
\hline Poland & 9.7 & 4.6 & 15.7 & 36.4 & 32.8 & 10.2 & 0.3 & 10.3 & 0.0 & $\ldots$ \\
\hline Portugal & $\ldots$ & $\ldots$ & $\ldots$ & $\ldots$ & $\ldots$ & $\ldots$ & $\ldots$ & $\ldots$ & $\ldots$ & $\ldots$ \\
\hline Romania & $\ldots$ & $\ldots$ & $\ldots$ & $\ldots$ & $\ldots$ & $\ldots$ & $\ldots$ & $\ldots$ & $\ldots$ & $\ldots$ \\
\hline Russian Federation & $\ldots$ & $\ldots$ & $\ldots$ & $\ldots$ & $\ldots$ & $\ldots$ & $\ldots$ & $\ldots$ & $\ldots$ & $\ldots$ \\
\hline Serbia & 56.7 & 43.8 & 35.1 & 10.8 & 8.1 & 2.2 & 0.0 & $\ldots$ & $\ldots$ & $\ldots$ \\
\hline Slovak Republic & $\ldots$ & $\ldots$ & $\ldots$ & $\ldots$ & $\ldots$ & $\ldots$ & $\ldots$ & $\ldots$ & $\ldots$ & $\ldots$ \\
\hline Slovenia & $\ldots$ & $\ldots$ & $\ldots$ & $\ldots$ & $\ldots$ & $\ldots$ & $\ldots$ & $\ldots$ & $\ldots$ & $\ldots$ \\
\hline Spain & $\ldots$ & $\ldots$ & $\ldots$ & $\ldots$ & $\ldots$ & $\ldots$ & $\ldots$ & $\ldots$ & $\ldots$ & $\ldots$ \\
\hline Sweden & 35.4 & 4.6 & 8.9 & 61.3 & 15.7 & 2.6 & 0.0 & $\ldots$ & 0.0 & 6.3 \\
\hline Switzerland & 27.1 & 37.5 & 12.5 & 12.5 & 37.5 & 0.0 & 0.0 & 140.6 & 0.0 & $\ldots$ \\
\hline Turkey & 1.4 & $\ldots$ & & $\ldots$ & $\ldots$ & $\ldots$ & $\ldots$ & $\ldots$ & $\ldots$ & $\ldots$ \\
\hline Ukraine & $\ldots$ & $\ldots$ & 0.2 & 1.5 & 36.6 & 61.6 & 0.1 & $\ldots$ & 0.0 & $\ldots$ \\
\hline UK: England \& Wales & $\ldots$ & $\ldots$ & $\ldots$ & $\ldots$ & $\ldots$ & $\ldots$ & $\ldots$ & $\ldots$ & $\ldots$ & $\ldots$ \\
\hline UK: Northern Ireland & & & & $\ldots$ & $\ldots$ & $\ldots$ & $\ldots$ & $\ldots$ & $\ldots$ & \\
\hline UK: Scotland & 35.1 & 5.2 & 15.1 & 37.3 & 23.5 & 16.2 & $\ldots$ & 3.0 & 2.7 & 0.0 \\
\hline Mean & 41.7 & 19.5 & 17.4 & 29.5 & 27.2 & 12.2 & 1.2 & 26.2 & 0.3 & 1.7 \\
\hline Median & 35.9 & 10.1 & 15.1 & 32.4 & 32.8 & 4.2 & 0.0 & 6.9 & 0.0 & 0.0 \\
\hline Minimum & 1.4 & 0.5 & 0.2 & 1.5 & 2.3 & 0.0 & 0.0 & 0.9 & 0.0 & 0.0 \\
\hline Maximum & 85.6 & 70.2 & 50.6 & 69.8 & 84.3 & 61.6 & 10.8 & 140.6 & 2.7 & 6.3 \\
\hline
\end{tabular}


Table 3.2.5.7 Persons convicted by length of unsuspended custodial sanctions and measures imposed in 2015 - Sexual assault

\begin{tabular}{|c|c|c|c|c|c|c|c|c|c|c|}
\hline & 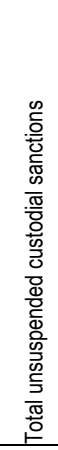 & 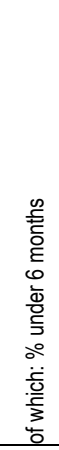 & 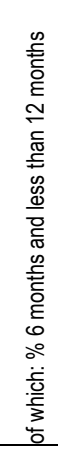 & 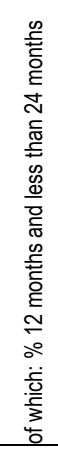 & 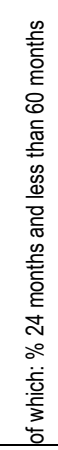 & 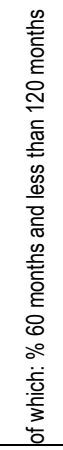 & 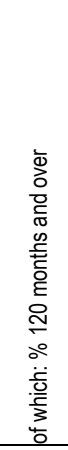 & 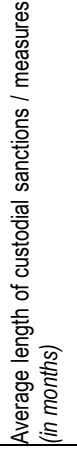 & 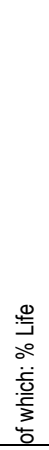 & 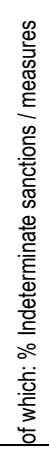 \\
\hline Albania & $\ldots$ & $\ldots$ & $\ldots$ & $\ldots$ & $\ldots$ & $\ldots$ & $\ldots$ & $\ldots$ & $\ldots$ & $\ldots$ \\
\hline Armenia & $\ldots$ & $\ldots$ & $\ldots$ & $\ldots$ & $\ldots$ & $\ldots$ & $\ldots$ & $\ldots$ & $\ldots$ & $\ldots$ \\
\hline Austria & 1.2 & 5.1 & 0.9 & 48.7 & 14.5 & 30.8 & $\ldots$ & $\ldots$ & 0.0 & $\ldots$ \\
\hline Azerbaijan & $\ldots$ & $\ldots$ & $\ldots$ & $\ldots$ & $\ldots$ & $\ldots$ & $\ldots$ & $\ldots$ & $\ldots$ & $\ldots$ \\
\hline Belgium & 4.8 & 0.5 & 1.1 & 5.9 & 10.4 & 9.9 & 2.0 & 8.1 & 0.3 & $\ldots$ \\
\hline Bosnia-Herzegovina & $\ldots$ & $\ldots$ & $\ldots$ & $\ldots$ & $\ldots$ & $\ldots$ & $\ldots$ & $\ldots$ & $\ldots$ & $\ldots$ \\
\hline Bulgaria & 0.6 & 2.5 & 11.7 & 54.2 & 19.2 & 10.8 & 1.7 & $\ldots$ & 0.0 & $\ldots$ \\
\hline Croatia & 3.2 & 1.1 & 34.1 & 24.2 & 30.8 & 4.4 & 2.2 & $\ldots$ & $\ldots$ & 3.3 \\
\hline Cyprus & $\ldots$ & $\ldots$ & $\ldots$ & $\ldots$ & $\ldots$ & $\ldots$ & $\ldots$ & $\ldots$ & $\ldots$ & $\ldots$ \\
\hline Czech Republic & 1.2 & $\ldots$ & 5.5 & 61.8 & $\ldots$ & 30.9 & 1.8 & 52.7 & 0.0 & 0.0 \\
\hline Denmark & $\ldots$ & $\ldots$ & $\ldots$ & $\ldots$ & $\ldots$ & $\ldots$ & $\ldots$ & $\ldots$ & $\ldots$ & $\ldots$ \\
\hline Estonia & $\ldots$ & $\ldots$ & $\ldots$ & $\ldots$ & $\ldots$ & $\ldots$ & $\ldots$ & $\ldots$ & $\ldots$ & $\ldots$ \\
\hline Finland & 3.2 & 5.0 & 4.3 & 30.4 & 47.2 & 11.8 & 1.2 & 21.4 & 0.0 & $\ldots$ \\
\hline France & 2.6 & 12.7 & 15.3 & 35.2 & 12.4 & 9.7 & 0.5 & 1.4 & $\ldots$ & $\ldots$ \\
\hline Georgia & 0.7 & $\ldots$ & 14.7 & 50.0 & $\ldots$ & $\ldots$ & $\ldots$ & $\ldots$ & $\ldots$ & $\ldots$ \\
\hline Germany & 2.6 & 0.0 & 2.2 & 9.5 & 63.9 & 23.4 & 1.1 & $\ldots$ & 0.0 & $\ldots$ \\
\hline Hungary & 2.6 & 0.4 & 0.9 & 5.6 & 32.5 & 45.7 & 15.0 & 30.6 & 0.0 & 0.0 \\
\hline Iceland & $\ldots$ & $\ldots$ & $\ldots$ & $\ldots$ & $\ldots$ & $\ldots$ & $\ldots$ & $\ldots$ & $\ldots$ & $\ldots$ \\
\hline Italy & $\ldots$ & $\ldots$ & $\ldots$ & $\ldots$ & $\ldots$ & $\ldots$ & $\ldots$ & $\ldots$ & $\ldots$ & $\ldots$ \\
\hline Kosovo (UN R/1244/99) & $\ldots$ & $\ldots$ & $\ldots$ & $\ldots$ & $\ldots$ & $\ldots$ & $\ldots$ & $\ldots$ & $\ldots$ & $\ldots$ \\
\hline Latvia & $\ldots$ & $\ldots$ & $\ldots$ & $\ldots$ & $\ldots$ & $\ldots$ & $\ldots$ & $\ldots$ & $\ldots$ & $\ldots$ \\
\hline Lithuania & $\ldots$ & $\ldots$ & $\cdots$ & $\ldots$ & $\ldots$ & $\ldots$ & $\ldots$ & $\ldots$ & $\cdots$ & $\ldots$ \\
\hline Luxembourg & $\ldots$ & $\ldots$ & $\ldots$ & $\ldots$ & $\ldots$ & $\ldots$ & $\ldots$ & $\ldots$ & $\ldots$ & $\ldots$ \\
\hline Moldova & $\ldots$ & $\ldots$ & $\ldots$ & $\ldots$ & $\ldots$ & $\ldots$ & $\ldots$ & $\cdots$ & $\cdots$ & $\ldots$ \\
\hline Montenegro & $\ldots$ & $\ldots$ & $\ldots$ & $\ldots$ & $\ldots$ & $\ldots$ & $\ldots$ & $\ldots$ & $\ldots$ & $\ldots$ \\
\hline Netherlands & 2.6 & 47.5 & 17.3 & 15.2 & 17.3 & 2.6 & 0.0 & 1.7 & 0.0 & $\ldots$ \\
\hline North Macedonia & $\ldots$ & $\ldots$ & $\ldots$ & $\ldots$ & $\ldots$ & $\ldots$ & $\ldots$ & $\ldots$ & $\ldots$ & $\ldots$ \\
\hline Norway & 0.1 & 42.8 & 12.7 & 18.2 & 14.7 & 11.6 & 0.0 & $\ldots$ & $\ldots$ & $\ldots$ \\
\hline Poland & 1.8 & 0.6 & 1.4 & 31.3 & 48.6 & 15.4 & 2.7 & $\ldots$ & 0.0 & $\ldots$ \\
\hline Portugal & $\ldots$ & $\ldots$ & $\ldots$ & $\ldots$ & $\ldots$ & $\ldots$ & $\ldots$ & $\ldots$ & $\ldots$ & $\ldots$ \\
\hline Romania & $\ldots$ & $\ldots$ & $\ldots$ & $\ldots$ & $\ldots$ & $\ldots$ & $\ldots$ & $\ldots$ & $\ldots$ & $\ldots$ \\
\hline Russian Federation & $\ldots$ & $\ldots$ & $\ldots$ & $\ldots$ & $\ldots$ & $\ldots$ & $\ldots$ & $\ldots$ & $\ldots$ & $\ldots$ \\
\hline Serbia & 1.1 & 14.6 & 10.4 & 10.4 & 43.8 & 17.7 & 3.1 & $\ldots$ & $\ldots$ & $\ldots$ \\
\hline Slovak Republic & $\ldots$ & $\ldots$ & $\ldots$ & $\ldots$ & $\ldots$ & $\ldots$ & $\ldots$ & $\cdots$ & $\ldots$ & $\ldots$ \\
\hline Slovenia & $\ldots$ & $\ldots$ & $\ldots$ & $\ldots$ & $\ldots$ & $\ldots$ & $\ldots$ & $\ldots$ & $\ldots$ & $\ldots$ \\
\hline Spain & $\ldots$ & $\ldots$ & $\ldots$ & $\ldots$ & $\ldots$ & $\ldots$ & $\ldots$ & $\ldots$ & $\ldots$ & $\ldots$ \\
\hline Sweden & 2.5 & 2.9 & 10.4 & 34.5 & 31.7 & 11.2 & 0.4 & $\ldots$ & 0.0 & 5.0 \\
\hline Switzerland & 0.3 & 0.0 & 10.3 & 27.6 & 41.4 & 20.7 & 0.0 & 140.8 & 0.0 & $\ldots$ \\
\hline Turkey & 2.4 & $\ldots$ & $\ldots$ & $\ldots$ & $\ldots$ & $\ldots$ & $\ldots$ & $\ldots$ & $\ldots$ & $\ldots$ \\
\hline Ukraine & 0.7 & $\ldots$ & 1.4 & 4.9 & 34.3 & 47.6 & 11.9 & $\ldots$ & 0.0 & $\ldots$ \\
\hline UK: England \& Wales & 11.0 & 9.3 & 6.9 & 13.8 & 32.5 & 22.8 & 12.4 & 1.5 & 0.9 & 0.0 \\
\hline UK: Northern Ireland & $\ldots$ & $\ldots$ & $\ldots$ & $\ldots$ & $\ldots$ & $\ldots$ & $\ldots$ & $\ldots$ & $\ldots$ & $\ldots$ \\
\hline UK: Scotland & 1.6 & 4.2 & 8.3 & 16.2 & 15.3 & 56.0 & $\ldots$ & 31.0 & 0.0 & 0.0 \\
\hline Mean & 2.3 & 9.3 & 8.9 & 26.2 & 30.0 & 21.3 & 3.5 & 32.1 & 0.1 & 1.4 \\
\hline Median & 2.1 & 3.5 & 8.3 & 24.2 & 31.7 & 16.5 & 1.7 & 21.4 & 0.0 & 0.0 \\
\hline Minimum & 0.1 & 0.0 & 0.9 & 4.9 & 10.4 & 2.6 & 0.0 & 1.4 & 0.0 & 0.0 \\
\hline Maximum & 11.0 & 47.5 & 34.1 & 61.8 & 63.9 & 56.0 & 15.0 & 140.8 & 0.9 & 5.0 \\
\hline
\end{tabular}


Table 3.2.5.8 Persons convicted by length of unsuspended custodial sanctions and measures imposed in 2015 - Rape

\begin{tabular}{|c|c|c|c|c|c|c|c|c|c|c|}
\hline & 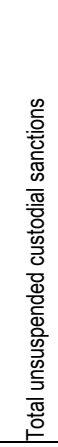 & 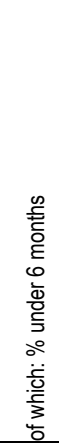 & 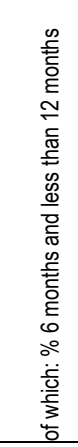 & 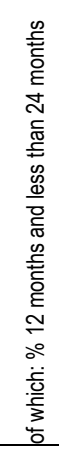 & 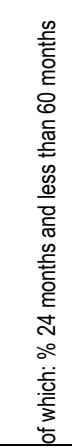 & 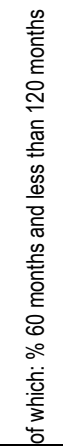 & 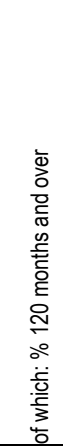 & 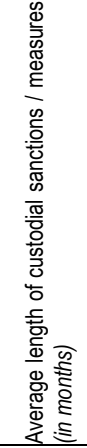 & 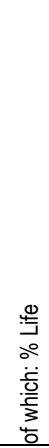 & 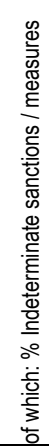 \\
\hline Albania & $\ldots$ & $\ldots$ & & & & & & & & $\ldots$ \\
\hline Armenia & $\ldots$ & $\ldots$ & 100.0 & 0.0 & 0.0 & 0.0 & 0.0 & 0.0 & 0.0 & $\ldots$ \\
\hline Austria & 56.4 & 0.0 & 0.0 & 57.6 & 9.1 & 33.3 & $\ldots$ & $\ldots$ & 0.0 & $\ldots$ \\
\hline Azerbaijan & $\ldots$ & $\ldots$ & $\ldots$ & $\ldots$ & $\ldots$ & $\ldots$ & $\ldots$ & $\ldots$ & $\ldots$ & $\ldots$ \\
\hline Belgium & 20.1 & 0.8 & 0.8 & 9.1 & 35.6 & 43.2 & 9.1 & 49.7 & 1.5 & $\ldots$ \\
\hline Bosnia-Herzegovina & $\ldots$ & $\ldots$ & $\ldots$ & $\ldots$ & $\ldots$ & $\ldots$ & $\ldots$ & $\ldots$ & $\ldots$ & $\ldots$ \\
\hline Bulgaria & 57.5 & 0.0 & 7.2 & 53.6 & 23.2 & 13.0 & 2.9 & $\ldots$ & 0.0 & $\ldots$ \\
\hline Croatia & 74.7 & 0.0 & 23.5 & 22.1 & 41.2 & 5.9 & 2.9 & 0.0 & $\ldots$ & 4.4 \\
\hline Cyprus & $\ldots$ & $\ldots$ & & & $\ldots$ & $\ldots$ & $\ldots$ & $\ldots$ & $\ldots$ & $\ldots$ \\
\hline Czech Republic & 71.8 & $\ldots$ & 3.8 & 55.7 & $\ldots$ & 30.4 & 2.5 & 75.8 & 0.0 & 0.0 \\
\hline Denmark & $\ldots$ & $\ldots$ & $\ldots$ & $\ldots$ & $\ldots$ & $\ldots$ & $\ldots$ & $\ldots$ & $\ldots$ & $\ldots$ \\
\hline Estonia & $\ldots$ & $\ldots$ & $\ldots$ & $\ldots$ & $\ldots$ & $\ldots$ & $\ldots$ & $\ldots$ & $\ldots$ & $\ldots$ \\
\hline Finland & 37.9 & 0.0 & 3.3 & 42.6 & 34.4 & 16.4 & 3.3 & 63.6 & 0.0 & $\ldots$ \\
\hline France & 18.3 & 0.0 & 2.9 & 13.4 & 7.6 & 47.0 & 3.6 & 6.3 & $\ldots$ & $\ldots$ \\
\hline Georgia & 32.4 & $\ldots$ & $\ldots$ & $\ldots$ & 45.5 & 36.4 & 18.2 & $\ldots$ & $\ldots$ & $\ldots$ \\
\hline Germany & 36.3 & 0.0 & 0.6 & 5.4 & 59.3 & 32.9 & 1.8 & $\ldots$ & 0.0 & $\ldots$ \\
\hline Hungary & 62.0 & 0.0 & 0.0 & 0.0 & 29.7 & 50.3 & 20.0 & 55.9 & 0.0 & 0.0 \\
\hline Iceland & $\ldots$ & $\ldots$ & $\ldots$ & $\ldots$ & $\ldots$ & $\ldots$ & $\ldots$ & $\ldots$ & $\ldots$ & $\ldots$ \\
\hline Italy & $\ldots$ & $\ldots$ & $\ldots$ & $\ldots$ & $\ldots$ & $\ldots$ & $\ldots$ & $\ldots$ & $\ldots$ & $\ldots$ \\
\hline Kosovo (UN R/1244/99) & $\ldots$ & $\ldots$ & $\ldots$ & $\ldots$ & $\ldots$ & $\ldots$ & $\ldots$ & $\ldots$ & $\ldots$ & $\ldots$ \\
\hline Latvia & $\ldots$ & $\ldots$ & $\ldots$ & $\ldots$ & $\ldots$ & $\ldots$ & $\ldots$ & $\cdots$ & $\ldots$ & $\ldots$ \\
\hline Lithuania & $\ldots$ & $\ldots$ & $\ldots$ & $\ldots$ & $\ldots$ & $\ldots$ & $\ldots$ & $\ldots$ & $\ldots$ & $\ldots$ \\
\hline Luxembourg & $\ldots$ & $\ldots$ & $\ldots$ & $\ldots$ & $\ldots$ & $\ldots$ & $\ldots$ & $\ldots$ & $\ldots$ & $\ldots$ \\
\hline Moldova & $\ldots$ & $\ldots$ & $\ldots$ & $\ldots$ & $\ldots$ & $\ldots$ & $\ldots$ & $\ldots$ & $\cdots$ & $\ldots$ \\
\hline Montenegro & $\ldots$ & $\ldots$ & $\ldots$ & $\ldots$ & $\ldots$ & $\ldots$ & $\ldots$ & $\ldots$ & $\ldots$ & $\ldots$ \\
\hline Netherlands & 13.7 & 17.6 & 8.8 & 24.2 & 42.9 & 6.6 & 0.0 & 24.7 & 0.0 & $\ldots$ \\
\hline North Macedonia & $\ldots$ & $\ldots$ & $\ldots$ & $\ldots$ & $\ldots$ & $\ldots$ & $\ldots$ & $\ldots$ & $\ldots$ & $\ldots$ \\
\hline Norway & & & & & & & & & & $\ldots$ \\
\hline Poland & 65.1 & 0.2 & 1.2 & 27.3 & 48.3 & 19.2 & 3.7 & 11.8 & 0.0 & $\ldots$ \\
\hline Portugal & $\ldots$ & $\ldots$ & $\ldots$ & $\ldots$ & $\ldots$ & $\ldots$ & $\ldots$ & $\ldots$ & $\ldots$ & $\ldots$ \\
\hline Romania & $\ldots$ & $\ldots$ & $\ldots$ & $\ldots$ & $\ldots$ & $\ldots$ & $\ldots$ & $\ldots$ & $\ldots$ & $\ldots$ \\
\hline Russian Federation & $\ldots$ & $\ldots$ & $\ldots$ & $\ldots$ & $\ldots$ & $\ldots$ & $\ldots$ & $\ldots$ & $\ldots$ & $\ldots$ \\
\hline Serbia & 49.0 & 2.1 & 4.3 & 6.4 & 51.1 & 31.9 & 4.3 & $\ldots$ & $\ldots$ & $\ldots$ \\
\hline Slovak Republic & $\ldots$ & $\ldots$ & $\ldots$ & $\ldots$ & $\ldots$ & $\ldots$ & $\ldots$ & $\ldots$ & $\ldots$ & $\ldots$ \\
\hline Slovenia & $\ldots$ & $\ldots$ & $\ldots$ & $\ldots$ & $\ldots$ & $\ldots$ & $\ldots$ & $\ldots$ & $\ldots$ & $\ldots$ \\
\hline Spain & $\ldots$ & $\ldots$ & $\ldots$ & $\ldots$ & $\ldots$ & $\ldots$ & $\ldots$ & $\ldots$ & $\ldots$ & $\ldots$ \\
\hline Sweden & 88.1 & 0.8 & 4.1 & 36.7 & 35.9 & 12.2 & 0.4 & $\ldots$ & 0.0 & 5.3 \\
\hline Switzerland & 3.4 & 0.0 & 0.0 & 0.0 & 100.0 & 0.0 & 0.0 & 5401.0 & 0.0 & $\ldots$ \\
\hline Turkey & $\ldots$ & $\ldots$ & $\ldots$ & $\ldots$ & & $\ldots$ & $\ldots$ & $\ldots$ & $\ldots$ & $\ldots$ \\
\hline Ukraine & 49.7 & $\ldots$ & 0.0 & 2.8 & 26.8 & 57.7 & 12.7 & $\ldots$ & 0.0 & $\ldots$ \\
\hline UK: England \& Wales & $\ldots$ & $\ldots$ & $\ldots$ & $\ldots$ & $\ldots$ & $\ldots$ & $\ldots$ & $\ldots$ & $\ldots$ & $\ldots$ \\
\hline UK: Northern Ireland & $\ldots$ & $\ldots$ & $\ldots$ & $\ldots$ & $\ldots$ & $\ldots$ & $\ldots$ & $\ldots$ & $\ldots$ & $\ldots$ \\
\hline UK: Scotland & 44.0 & 0.0 & 0.0 & 1.1 & 3.2 & 95.8 & $\ldots$ & 89.5 & 0.0 & 0.0 \\
\hline Mean & 45.9 & 1.5 & 9.4 & 21.1 & 34.9 & 29.6 & 5.3 & 525.3 & 0.1 & 1.9 \\
\hline Median & 49.0 & 0.0 & 2.9 & 13.4 & 35.6 & 31.1 & 3.1 & 49.7 & 0.0 & 0.0 \\
\hline Minimum & 3.4 & 0.0 & 0.0 & 0.0 & 0.0 & 0.0 & 0.0 & 0.0 & 0.0 & 0.0 \\
\hline Maximum & 88.1 & 17.6 & 100.0 & 57.6 & 100.0 & 95.8 & 20.0 & 5.401 .0 & 1.5 & 5.3 \\
\hline
\end{tabular}


Table 3.2.5.9 Persons convicted by length of unsuspended custodial sanctions and measures imposed in 2015 - Sexual abuse of a child

\begin{tabular}{|c|c|c|c|c|c|c|c|c|c|c|}
\hline & 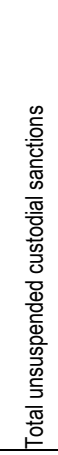 & 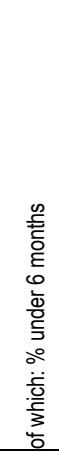 & 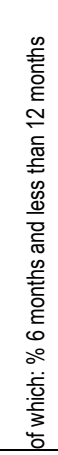 & 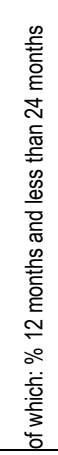 & 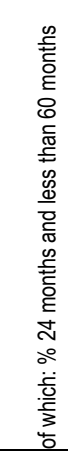 & 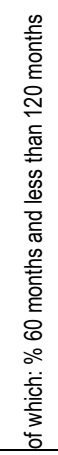 & 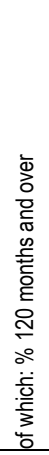 & 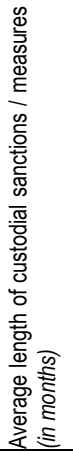 & 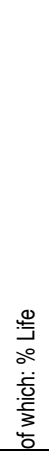 & 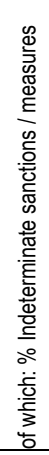 \\
\hline Albania & $\ldots$ & $\ldots$ & $\ldots$ & $\ldots$ & $\ldots$ & $\ldots$ & $\ldots$ & $\ldots$ & $\ldots$ & $\ldots$ \\
\hline Armenia & $\ldots$ & $\ldots$ & $\ldots$ & $\ldots$ & $\ldots$ & $\ldots$ & $\ldots$ & $\ldots$ & $\ldots$ & $\ldots$ \\
\hline Austria & 38.5 & 2.2 & 0.0 & 42.2 & 24.4 & 31.1 & $\ldots$ & $\ldots$ & 0.0 & $\ldots$ \\
\hline Azerbaijan & $\ldots$ & $\ldots$ & $\ldots$ & $\ldots$ & $\ldots$ & $\ldots$ & $\ldots$ & $\ldots$ & $\ldots$ & $\ldots$ \\
\hline Belgium & 14.5 & 2.1 & 2.1 & 20.0 & 32.6 & 35.8 & 6.3 & 56.0 & 1.1 & $\ldots$ \\
\hline Bosnia-Herzegovina & $\cdots$ & $\cdots$ & $\cdots$ & $\ldots$ & $\cdots$ & $\ldots$ & $\ldots$ & $\cdots$ & $\cdots$ & $\ldots$ \\
\hline Bulgaria & $\ldots$ & $\ldots$ & $\ldots$ & $\ldots$ & $\ldots$ & $\ldots$ & $\ldots$ & $\ldots$ & $\ldots$ & $\ldots$ \\
\hline Croatia & 8.8 & 0.0 & 12.5 & 87.5 & 0.0 & 0.0 & 0.0 & $\ldots$ & $\ldots$ & 0.0 \\
\hline Cyprus & $\ldots$ & $\ldots$ & $\ldots$ & $\ldots$ & $\ldots$ & $\ldots$ & $\ldots$ & $\ldots$ & $\ldots$ & $\ldots$ \\
\hline Czech Republic & 32.7 & $\ldots$ & 8.3 & 63.9 & ... & 27.8 & 0.0 & 143.6 & 0.0 & 0.0 \\
\hline Denmark & $\ldots$ & $\ldots$ & $\ldots$ & $\ldots$ & ... & $\ldots$ & $\ldots$ & $\ldots$ & $\ldots$ & $\ldots$ \\
\hline Estonia & $\ldots$ & $\ldots$ & $\ldots$ & $\ldots$ & $\ldots$ & & $\ldots$ & $\ldots$ & $\ldots$ & $\ldots$ \\
\hline Finland & 57.8 & 5.4 & 4.3 & 23.7 & 57.0 & 9.7 & 0.0 & 35.3 & 0.0 & $\ldots$ \\
\hline France & 35.1 & 4.2 & 13.8 & 43.6 & 15.3 & 13.3 & 1.1 & 8.6 & $\ldots$ & $\ldots$ \\
\hline Georgia & $\ldots$ & $\ldots$ & $\ldots$ & $\ldots$ & $\ldots$ & $\ldots$ & $\ldots$ & $\ldots$ & $\ldots$ & $\ldots$ \\
\hline Germany & 47.9 & 0.0 & 1.8 & 6.4 & 67.0 & 23.9 & 0.9 & $\ldots$ & 0.0 & $\ldots$ \\
\hline Hungary & 19.7 & 0.0 & 4.3 & 23.9 & 28.3 & 37.0 & 6.5 & 116.5 & 0.0 & 0.0 \\
\hline Iceland & $\cdots$ & $\ldots$ & $\ldots$ & $\ldots$ & $\ldots$ & $\ldots$ & $\ldots$ & $\ldots$ & $\ldots$ & $\ldots$ \\
\hline Italy & $\ldots$ & $\ldots$ & $\ldots$ & $\ldots$ & $\ldots$ & $\cdots$ & $\ldots$ & $\ldots$ & $\ldots$ & $\ldots$ \\
\hline Kosovo (UN R/1244/99) & $\ldots$ & $\ldots$ & $\ldots$ & $\ldots$ & $\ldots$ & $\ldots$ & $\ldots$ & $\ldots$ & $\ldots$ & $\ldots$ \\
\hline Latvia & $\ldots$ & $\ldots$ & $\ldots$ & $\ldots$ & $\cdots$ & $\cdots$ & $\cdots$ & $\cdots$ & $\cdots$ & $\cdots$ \\
\hline Lithuania & $\cdots$ & $\cdots$ & $\cdots$ & $\ldots$ & $\cdots$ & $\ldots$ & $\cdots$ & $\cdots$ & $\cdots$ & $\cdots$ \\
\hline Luxembourg & $\cdots$ & $\cdots$ & $\ldots$ & $\cdots$ & $\cdots$ & $\cdots$ & $\cdots$ & $\cdots$ & $\cdots$ & $\cdots$ \\
\hline Moldova & $\ldots$ & $\cdots$ & $\cdots$ & $\ldots$ & $\cdots$ & $\ldots$ & $\cdots$ & $\cdots$ & $\cdots$ & $\cdots$ \\
\hline Montenegro & $\ldots$ & $\ldots$ & $\ldots$ & $\ldots$ & $\ldots$ & $\ldots$ & $\ldots$ & ‥ & $\ldots$ & $\cdots$ \\
\hline Netherlands & 6.5 & 86.0 & 11.6 & 0.0 & 0.0 & 0.0 & 0.0 & 3.7 & 0.0 & $\cdots$ \\
\hline North Macedonia & $\ldots$ & $\ldots$ & $\ldots$ & $\ldots$ & $\ldots$ & $\ldots$ & $\ldots$ & $\ldots$ & $\cdots$ & $\cdots$ \\
\hline Norway & $\ldots$ & $\ldots$ & $\ldots$ & $\ldots$ & $\ldots$ & $\ldots$ & $\ldots$ & 16.7 & 0.0 & $\cdots$ \\
\hline Poland & 34.9 & 1.4 & 1.8 & 38.5 & 49.1 & 8.3 & 0.9 & 16.7 & 0.0 & $\cdots$ \\
\hline Portugal & $\cdots$ & $\cdots$ & $\cdots$ & $\ldots$ & $\cdots$ & $\ldots$ & $\ldots$ & $\cdots$ & $\cdots$ & $\cdots$ \\
\hline Romania & $\cdots$ & $\ldots$ & $\ldots$ & $\ldots$ & $\ldots$ & $\ldots$ & $\ldots$ & $\ldots$ & $\cdots$ & $\cdots$ \\
\hline Russian Federation & $\ldots$ & $\ldots$ & $\ldots$ & $\ldots$ & $\ldots$ & $\ldots$ & $\ldots$ & $\cdots$ & $\cdots$ & $\cdots$ \\
\hline $\begin{array}{l}\text { Serbia } \\
\text { Sonublic }\end{array}$ & 17.7 & 0.0 & 11.8 & 11.8 & 58.8 & 11.8 & 5.9 & $\ldots$ & $\cdots$ & $\cdots$ \\
\hline Slovak Republic & $\cdots$ & $\cdots$ & $\cdots$ & $\cdots$ & $\cdots$ & $\cdots$ & $\cdots$ & $\cdots$ & $\begin{array}{l}\cdots \\
\ldots\end{array}$ & $\cdots$ \\
\hline $\begin{array}{l}\text { Slovenia } \\
\text { Spain }\end{array}$ & $\begin{array}{l}\cdots \\
\ldots\end{array}$ & $\begin{array}{l}\cdots \\
\ldots\end{array}$ & $\begin{array}{l}\cdots \\
\ldots\end{array}$ & $\begin{array}{l}\cdots \\
\ldots\end{array}$ & $\begin{array}{l}\cdots \\
\ldots\end{array}$ & $\begin{array}{l}\cdots \\
\ldots\end{array}$ & $\begin{array}{l}\cdots \\
\ldots\end{array}$ & $\begin{array}{l}\cdots \\
\ldots\end{array}$ & $\begin{array}{l}\cdots \\
\ldots\end{array}$ & $\begin{array}{l}\cdots \\
\ldots\end{array}$ \\
\hline Sweden & 10.4 & 13.8 & 62.1 & 20.7 & 0.0 & 0.0 & 0.0 & $\ldots$ & 0.0 & 3.4 \\
\hline Switzerland & 17.2 & 0.0 & 60.0 & 40.0 & 0.0 & 0.0 & 0.0 & 202.0 & 0.0 & $\ldots$ \\
\hline Turkey & $\ldots$ & $\ldots$ & $\ldots$ & $\ldots$ & $\ldots$ & $\ldots$ & $\ldots$ & $\ldots$ & $\ldots$ & $\ldots$ \\
\hline Ukraine & 2.1 & $\ldots$ & 0.0 & 0.0 & 100.0 & 0.0 & 0.0 & $\ldots$ & 0.0 & $\ldots$ \\
\hline UK: England \& Wales & $\ldots$ & $\ldots$ & $\ldots$ & $\ldots$ & $\ldots$ & $\ldots$ & $\ldots$ & $\ldots$ & $\ldots$ & $\ldots$ \\
\hline UK: Northern Ireland & $\ldots$ & $\ldots$ & $\ldots$ & $\ldots$ & $\ldots$ & $\ldots$ & $\ldots$ & $\ldots$ & $\ldots$ & $\ldots$ \\
\hline UK: Scotland & $\ldots$ & $\ldots$ & $\ldots$ & $\ldots$ & $\ldots$ & $\ldots$ & $\ldots$ & $\ldots$ & $\ldots$ & $\ldots$ \\
\hline Mean & 24.6 & 9.6 & 13.9 & 30.2 & 33.3 & 14.2 & 1.7 & 72.8 & 0.1 & 0.9 \\
\hline Median & 18.7 & 1.7 & 6.3 & 23.8 & 28.3 & 10.7 & 0.0 & 45.6 & 0.0 & 0.0 \\
\hline Minimum & 2.1 & 0.0 & 0.0 & 0.0 & 0.0 & 0.0 & 0.0 & 3.7 & 0.0 & 0.0 \\
\hline Maximum & 57.8 & 86.0 & 62.1 & 87.5 & 100.0 & 37.0 & 6.5 & 202.0 & 1.1 & 3.4 \\
\hline
\end{tabular}


Table 3.2.5.10 Persons convicted by length of unsuspended custodial sanctions and measures imposed in 2015 - Robbery

\begin{tabular}{|c|c|c|c|c|c|c|c|c|c|c|}
\hline & 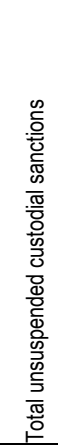 & 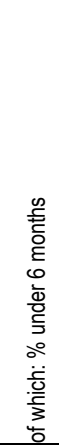 & 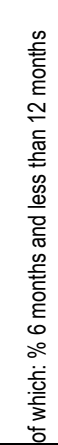 & 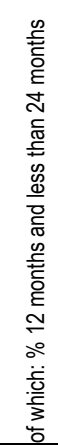 & 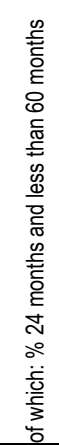 & 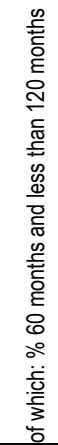 & 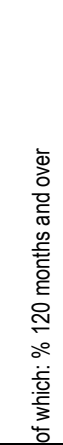 & 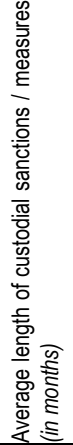 & 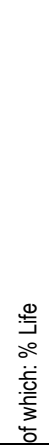 & 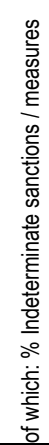 \\
\hline Albania & & $\ldots$ & & & & & & $\ldots$ & & \\
\hline Armenia & 4.7 & $\ldots$ & 5.5 & 9.6 & 32.9 & 4.1 & 0.0 & $\ldots$ & 0.0 & 0.0 \\
\hline Austria & 3.9 & 2.2 & 3.0 & 37.6 & 21.4 & 35.7 & $\ldots$ & $\ldots$ & 0.0 & $\ldots$ \\
\hline Azerbaijan & $\ldots$ & $\ldots$ & $\ldots$ & & $\ldots$ & & $\ldots$ & $\ldots$ & $\ldots$ & $\ldots$ \\
\hline Belgium & 6.5 & 1.6 & 13.8 & 39.0 & 31.0 & 11.0 & 3.1 & 3.7 & 0.3 & $\ldots$ \\
\hline Bosnia-Herzegovina & $\ldots$ & $\ldots$ & & & & & $\ldots$ & $\ldots$ & & $\ldots$ \\
\hline Bulgaria & 3.5 & 11.3 & 20.1 & 38.8 & 16.7 & 10.0 & 3.0 & $\ldots$ & 0.0 & $\ldots$ \\
\hline Croatia & 7.9 & 0.9 & 29.6 & 28.3 & 27.9 & 6.6 & 0.0 & $\ldots$ & $\ldots$ & 6.6 \\
\hline Cyprus & $\ldots$ & $\ldots$ & $\ldots$ & $\ldots$ & $\ldots$ & $\ldots$ & $\ldots$ & $\ldots$ & $\ldots$ & $\ldots$ \\
\hline Czech Republic & 5.2 & $\ldots$ & 1.6 & 76.1 & $\ldots$ & 21.5 & 0.8 & 10.3 & 0.0 & 0.0 \\
\hline Denmark & $\ldots$ & $\ldots$ & $\ldots$ & $\ldots$ & $\ldots$ & $\ldots$ & $\ldots$ & $\ldots$ & $\ldots$ & $\ldots$ \\
\hline Estonia & $\ldots$ & $\ldots$ & $\ldots$ & $\ldots$ & $\ldots$ & $\ldots$ & $\ldots$ & $\ldots$ & $\ldots$ & $\ldots$ \\
\hline Finland & 6.7 & 15.2 & 17.6 & 31.4 & 35.2 & 0.6 & 0.0 & 5.7 & 0.0 & $\ldots$ \\
\hline France & 1.5 & 30.1 & 26.4 & 31.3 & 8.9 & 3.3 & 0.1 & $\ldots$ & $\ldots$ & $\ldots$ \\
\hline Georgia & 6.2 & $\ldots$ & $\ldots$ & 17.1 & 22.9 & 35.0 & 27.9 & $\ldots$ & $\ldots$ & $\ldots$ \\
\hline Germany & 8.2 & 0.2 & 8.8 & 27.1 & 52.4 & 11.0 & 0.5 & $\ldots$ & 0.0 & $\ldots$ \\
\hline Hungary & 11.7 & 0.1 & 0.1 & 6.4 & 44.0 & 42.0 & 6.7 & 5.8 & 0.8 & 0.0 \\
\hline Iceland & $\ldots$ & $\ldots$ & $\ldots$ & $\ldots$ & $\ldots$ & $\ldots$ & $\ldots$ & $\ldots$ & $\ldots$ & $\ldots$ \\
\hline Italy & $\ldots$ & $\ldots$ & $\ldots$ & $\ldots$ & $\ldots$ & $\ldots$ & $\ldots$ & $\ldots$ & $\ldots$ & $\ldots$ \\
\hline Kosovo (UN R/1244/99) & $\ldots$ & $\ldots$ & $\ldots$ & $\ldots$ & $\ldots$ & $\ldots$ & $\ldots$ & $\ldots$ & $\ldots$ & $\ldots$ \\
\hline Latvia & $\ldots$ & $\ldots$ & $\ldots$ & $\ldots$ & $\ldots$ & $\ldots$ & $\ldots$ & $\ldots$ & $\ldots$ & $\ldots$ \\
\hline Lithuania & $\ldots$ & $\ldots$ & $\ldots$ & $\ldots$ & $\ldots$ & $\ldots$ & $\ldots$ & $\ldots$ & $\ldots$ & $\ldots$ \\
\hline Luxembourg & $\ldots$ & $\ldots$ & $\ldots$ & $\ldots$ & $\ldots$ & $\ldots$ & $\ldots$ & $\ldots$ & $\ldots$ & $\ldots$ \\
\hline Moldova & $\ldots$ & $\ldots$ & $\ldots$ & $\ldots$ & $\ldots$ & $\ldots$ & $\ldots$ & $\ldots$ & $\ldots$ & $\ldots$ \\
\hline Montenegro & $\ldots$ & $\ldots$ & $\ldots$ & $\ldots$ & $\ldots$ & $\ldots$ & $\ldots$ & $\ldots$ & $\ldots$ & $\ldots$ \\
\hline Netherlands & 6.0 & 57.9 & 15.3 & 10.2 & 12.8 & 3.6 & 0.3 & 0.7 & 0.0 & $\ldots$ \\
\hline North Macedonia & $\ldots$ & $\ldots$ & $\ldots$ & $\ldots$ & $\ldots$ & $\ldots$ & $\ldots$ & $\ldots$ & $\ldots$ & $\ldots$ \\
\hline Norway & $\ldots$ & $\ldots$ & 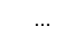 & . & $\ldots$ & $\ldots$ & $\ldots$ & $\ldots$ & $\ldots$ & $\ldots$ \\
\hline Poland & 7.8 & 1.6 & 3.7 & 36.5 & 54.1 & 4.1 & 0.0 & 1.3 & 0.0 & $\ldots$ \\
\hline Portugal & $\ldots$ & $\ldots$ & $\ldots$ & $\ldots$ & $\ldots$ & $\ldots$ & $\ldots$ & $\ldots$ & $\ldots$ & $\ldots$ \\
\hline Romania & $\ldots$ & $\ldots$ & $\ldots$ & $\ldots$ & $\ldots$ & $\ldots$ & $\ldots$ & $\ldots$ & $\ldots$ & $\ldots$ \\
\hline Russian Federation & $\ldots$ & $\ldots$ & $\ldots$ & $\ldots$ & $\ldots$ & $\ldots$ & $\ldots$ & $\ldots$ & $\ldots$ & $\ldots$ \\
\hline Serbia & 6.2 & 10.6 & 19.9 & 26.8 & 37.8 & 4.7 & 0.2 & $\ldots$ & $\ldots$ & $\ldots$ \\
\hline Slovak Republic & $\ldots$ & $\ldots$ & $\ldots$ & $\ldots$ & $\ldots$ & $\ldots$ & $\ldots$ & $\ldots$ & ... & $\ldots$ \\
\hline Slovenia & $\ldots$ & $\ldots$ & $\ldots$ & $\ldots$ & $\ldots$ & $\ldots$ & $\ldots$ & $\ldots$ & $\ldots$ & $\ldots$ \\
\hline Spain & $\ldots$ & $\ldots$ & $\ldots$ & $\ldots$ & $\ldots$ & $\ldots$ & $\ldots$ & $\ldots$ & $\ldots$ & $\ldots$ \\
\hline Sweden & 3.6 & 10.5 & 9.7 & 50.4 & 18.2 & 4.1 & 0.5 & $\ldots$ & 0.0 & 2.3 \\
\hline Switzerland & 0.3 & 17.2 & 17.2 & 17.2 & 31.0 & 17.2 & 0.0 & 117.8 & 0.0 & $\ldots$ \\
\hline Turkey & 2.5 & $\ldots$ & $\ldots$ & $\ldots$ & $\ldots$ & $\ldots$ & $\ldots$ & $\ldots$ & $\ldots$ & $\ldots$ \\
\hline Ukraine & 11.1 & $\ldots$ & 1.9 & 5.3 & 87.9 & 5.0 & 0.0 & $\ldots$ & 0.0 & $\ldots$ \\
\hline UK: England \& Wales & 8.6 & 2.5 & 9.4 & 21.5 & 45.3 & 17.6 & 2.2 & 1.3 & 0.3 & 0.0 \\
\hline UK: Northern Ireland & & & & & & & $\ldots$ & & & \\
\hline UK: Scotland & 2.2 & 9.1 & 18.5 & 39.1 & 26.9 & 13.1 & $\ldots$ & 8.4 & 0.0 & 0.0 \\
\hline Mean & 5.7 & 11.4 & 12.3 & 28.9 & 33.7 & 13.2 & 2.7 & 17.2 & 0.1 & 1.3 \\
\hline Median & 6.1 & 9.1 & 11.8 & 28.3 & 31.0 & 10.0 & 0.3 & 5.7 & 0.0 & 0.0 \\
\hline Minimum & 0.3 & 0.1 & 0.1 & 5.3 & 8.9 & 0.6 & 0.0 & 0.7 & 0.0 & 0.0 \\
\hline Maximum & 11.7 & 57.9 & 29.6 & 76.1 & 87.9 & 42.0 & 27.9 & 117.8 & 0.8 & 6.6 \\
\hline
\end{tabular}


Table 3.2.5.11 Persons convicted by length of unsuspended custodial sanctions and measures imposed in 2015 - Theft

\begin{tabular}{|c|c|c|c|c|c|c|c|c|c|c|}
\hline & 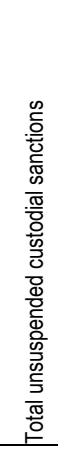 & 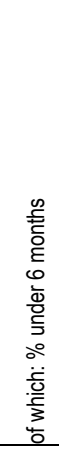 & 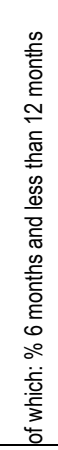 & 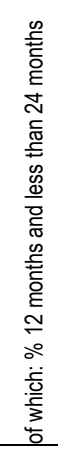 & 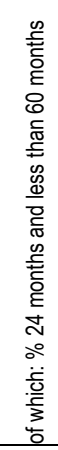 & 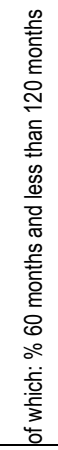 & 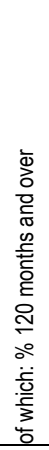 & 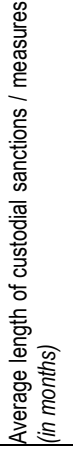 & 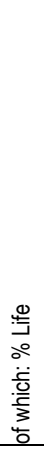 & 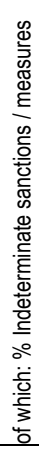 \\
\hline Albania & & $\ldots$ & & & & & & $\ldots$ & & $\ldots$ \\
\hline Armenia & 18.0 & $\ldots$ & 1.4 & 17.2 & 68.5 & 12.9 & 0.0 & $\ldots$ & 0.0 & $\ldots$ \\
\hline Austria & 20.9 & 25.5 & 17.9 & 47.4 & 8.0 & 1.2 & $\ldots$ & $\ldots$ & 0.0 & $\ldots$ \\
\hline Azerbaijan & $\ldots$ & $\ldots$ & $\ldots$ & $\ldots$ & $\ldots$ & $\ldots$ & $\ldots$ & $\ldots$ & $\ldots$ & $\ldots$ \\
\hline Belgium & 31.0 & 18.3 & 29.9 & 34.0 & 15.2 & 2.1 & 0.4 & 0.4 & 0.0 & $\ldots$ \\
\hline Bosnia-Herzegovina & $\ldots$ & $\ldots$ & $\ldots$ & $\ldots$ & $\ldots$ & $\ldots$ & $\ldots$ & $\ldots$ & $\ldots$ & $\ldots$ \\
\hline Bulgaria & 26.0 & 39.1 & 34.2 & 24.6 & 1.7 & 0.2 & 0.1 & $\ldots$ & 0.0 & $\ldots$ \\
\hline Croatia & 28.8 & 12.9 & 47.5 & 29.4 & 5.6 & 0.1 & 0.0 & 0.0 & $\ldots$ & 4.4 \\
\hline Cyprus & $\ldots$ & $\ldots$ & $\ldots$ & $\ldots$ & $\ldots$ & $\ldots$ & $\ldots$ & $\ldots$ & $\ldots$ & $\ldots$ \\
\hline Czech Republic & 42.8 & $\ldots$ & 63.4 & 35.5 & $\ldots$ & 1.1 & 0.1 & 0.6 & 0.0 & 0.0 \\
\hline Denmark & $\ldots$ & $\ldots$ & $\ldots$ & $\ldots$ & $\ldots$ & $\ldots$ & $\ldots$ & $\ldots$ & $\ldots$ & $\ldots$ \\
\hline Estonia & $\ldots$ & $\ldots$ & $\ldots$ & $\ldots$ & $\ldots$ & $\ldots$ & $\ldots$ & $\ldots$ & $\ldots$ & $\ldots$ \\
\hline Finland & 14.5 & 74.0 & 12.0 & 10.4 & 3.7 & 0.0 & 0.0 & 0.8 & 0.0 & $\ldots$ \\
\hline France & 28.1 & 53.7 & 25.3 & 17.1 & 2.9 & 1.1 & 0.0 & 0.0 & $\ldots$ & $\ldots$ \\
\hline Georgia & 24.6 & 0.0 & 1.8 & 35.4 & 45.7 & 17.0 & $\ldots$ & $\ldots$ & $\ldots$ & $\ldots$ \\
\hline Germany & 33.4 & 29.6 & 36.9 & 20.3 & 12.6 & 0.7 & 0.0 & $\ldots$ & 0.0 & $\ldots$ \\
\hline Hungary & 48.6 & 13.6 & 18.2 & 39.8 & 24.7 & 3.3 & 0.4 & 0.5 & 0.1 & 0.0 \\
\hline Iceland & $\cdots$ & $\ldots$ & $\ldots$ & $\ldots$ & $\ldots$ & $\cdots$ & $\ldots$ & $\cdots$ & $\ldots$ & $\ldots$ \\
\hline Italy & $\ldots$ & $\ldots$ & $\ldots$ & $\ldots$ & $\ldots$ & $\cdots$ & $\ldots$ & $\ldots$ & $\ldots$ & $\ldots$ \\
\hline Kosovo (UN R/1244/99) & $\ldots$ & $\ldots$ & $\ldots$ & $\ldots$ & $\ldots$ & $\ldots$ & $\ldots$ & $\ldots$ & $\ldots$ & $\ldots$ \\
\hline Latvia & $\cdots$ & $\cdots$ & $\ldots$ & $\ldots$ & $\ldots$ & $\ldots$ & $\ldots$ & $\ldots$ & $\ldots$ & $\cdots$ \\
\hline Lithuania & $\cdots$ & $\cdots$ & $\cdots$ & $\ldots$ & $\ldots$ & $\ldots$ & $\cdots$ & $\cdots$ & $\cdots$ & ... \\
\hline Luxembourg & $\cdots$ & $\cdots$ & $\cdots$ & $\ldots$ & $\ldots$ & $\cdots$ & $\cdots$ & $\cdots$ & $\cdots$ & ... \\
\hline Moldova & $\cdots$ & $\cdots$ & $\ldots$ & $\ldots$ & $\cdots$ & $\ldots$ & $\cdots$ & $\cdots$ & $\cdots$ & $\cdots$ \\
\hline Montenegro & $\ldots$ & $\ldots$ & $\ldots$ & $\ldots$ & $\ldots$ & $\ldots$ & $\ldots$ & $\ldots$ & $\ldots$ & $\cdots$ \\
\hline Netherlands & 43.7 & 94.7 & 3.4 & 1.2 & 0.6 & 0.0 & 0.0 & 0.0 & 0.0 & $\cdots$ \\
\hline North Macedonia & $\ldots$ & $\ldots$ & $\ldots$ & $\ldots$ & $\ldots$ & $\ldots$ & $\ldots$ & $\ldots$ & $\ldots$ & ... \\
\hline Norway & 0.4 & 36.8 & 26.4 & 23.8 & 1.5 & 0.2 & 0.0 & & & $\ldots$ \\
\hline Poland & 25.1 & 17.4 & 27.9 & 49.6 & 4.8 & 0.2 & 0.0 & 0.2 & 0.0 & $\ldots$ \\
\hline Portugal & $\ldots$ & $\cdots$ & $\ldots$ & $\ldots$ & $\ldots$ & $\cdots$ & $\cdots$ & $\ldots$ & $\ldots$ & ... \\
\hline Romania & $\ldots$ & $\ldots$ & $\ldots$ & $\ldots$ & $\ldots$ & $\cdots$ & $\ldots$ & $\ldots$ & $\ldots$ & $\ldots$ \\
\hline Russian Federation & $\ldots$ & $\ldots$ & $\ldots$ & $\ldots$ & $\ldots$ & $\ldots$ & $\ldots$ & $\cdots$ & $\ldots$ & $\ldots$ \\
\hline Serbia & 37.9 & 35.1 & 33.0 & 25.3 & 6.3 & 0.3 & 0.0 & $\ldots$ & $\ldots$ & $\ldots$ \\
\hline Slovak Republic & $\ldots$ & $\ldots$ & $\ldots$ & $\ldots$ & $\ldots$ & $\ldots$ & $\ldots$ & $\ldots$ & $\ldots$ & $\ldots$ \\
\hline Slovenia & $\cdots$ & $\cdots$ & $\cdots$ & $\cdots$ & $\cdots$ & $\ldots$ & $\ldots$ & $\cdots$ & $\ldots$ & $\cdots$ \\
\hline Spain & & & $\cdots$ & $\ldots$ & $\ldots$ & & $\ldots$ & $\ldots$ & $\ldots$ & \\
\hline Sweden & 18.9 & 68.8 & 21.1 & 7.0 & 1.7 & 0.3 & 0.0 & $\ldots$ & 0.0 & 1.0 \\
\hline Switzerland & 6.7 & 88.4 & 10.0 & 1.2 & 0.3 & 0.0 & 0.0 & 0.4 & 0.0 & $\ldots$ \\
\hline Turkey & 17.9 & $\ldots$ & $\ldots$ & $\ldots$ & $\ldots$ & $\ldots$ & $\ldots$ & $\ldots$ & $\ldots$ & $\ldots$ \\
\hline Ukraine & 46.0 & $\ldots$ & 11.1 & 21.3 & 65.7 & 1.9 & 0.0 & $\ldots$ & 0.0 & $\ldots$ \\
\hline UK: England \& Wales & 72.0 & 72.2 & 7.8 & 8.2 & 11.2 & 0.6 & 0.2 & 0.0 & 0.0 & 0.0 \\
\hline UK: Northern Ireland & & & $\ldots$ & $\ldots$ & $\ldots$ & $\ldots$ & $\ldots$ & $\ldots$ & $\ldots$ & . \\
\hline UK: Scotland & 27.0 & 74.9 & 14.4 & 7.9 & 2.4 & 0.3 & $\ldots$ & 0.2 & 0.0 & 0.0 \\
\hline Mean & 29.2 & 44.4 & 22.2 & 22.8 & 14.9 & 2.2 & 0.1 & 0.3 & 0.0 & 0.9 \\
\hline Median & 27.0 & 36.8 & 19.6 & 22.6 & 5.6 & 0.4 & 0.0 & 0.2 & 0.0 & 0.0 \\
\hline Minimum & 0.4 & 0.0 & 1.4 & 1.2 & 0.3 & 0.0 & 0.0 & 0.0 & 0.0 & 0.0 \\
\hline Maximum & 72.0 & 94.7 & 63.4 & 49.6 & 68.5 & 17.0 & 0.4 & 0.8 & 0.1 & 4.4 \\
\hline
\end{tabular}


Table 3.2.5.12 Persons convicted by length of unsuspended custodial sanctions and measures imposed in 2015 - Aggravated theft

\begin{tabular}{|c|c|c|c|c|c|c|c|c|c|c|}
\hline & 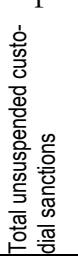 & 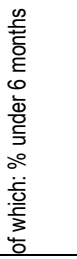 & 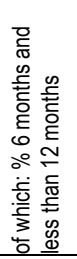 & 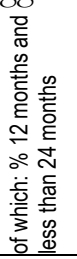 & 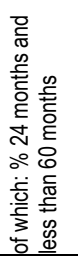 & 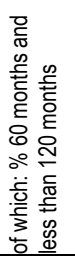 & 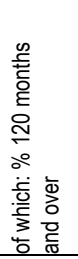 & 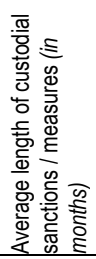 & 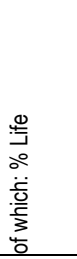 & 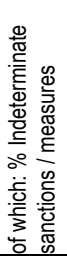 \\
\hline Austria & 76.6 & 5.3 & 22.5 & 60.6 & 10.0 & $\overline{1.5}$ & $\ldots$ & $\ldots$ & 0.0 & $\ldots$ \\
\hline Belgium & 44.5 & 5.0 & 22.9 & 42.7 & 24.9 & 3.6 & 0.8 & 1.1 & 0.1 & $\ldots$ \\
\hline Croatia & 62.3 & 7.1 & 46.1 & 34.5 & 7.1 & 0.2 & 0.0 & $\ldots$ & $\ldots$ & 5.1 \\
\hline Germany & 51.6 & 6.5 & 37.8 & 31.9 & 22.5 & 1.3 & 0.0 & $\ldots$ & 0.0 & \\
\hline Hungary & 100.0 & 13.6 & 18.2 & 39.8 & 24.7 & 3.3 & 0.4 & 0.5 & 0.1 & 0.0 \\
\hline Netherlands & 45.5 & 89.6 & 6.4 & 2.5 & 1.4 & 0.1 & 0.0 & 0.1 & 0.0 & $\ldots$ \\
\hline Poland & 45.8 & 3.0 & 4.8 & 82.1 & 9.7 & 0.4 & 0.0 & 0.5 & 0.0 & $\ldots$ \\
\hline Serbia & 64.7 & 16.8 & 38.3 & 36.1 & 8.4 & 0.5 & 0.0 & $\ldots$ & $\ldots$ & $\ldots$ \\
\hline Switzerland & 7.5 & 30.6 & 59.2 & 6.1 & 4.1 & 0.0 & 0.0 & 17.3 & 0.0 & \\
\hline Mean & 52.7 & 19.7 & 28.5 & 37.4 & 12.5 & 1.2 & 0.2 & 3.9 & 0.0 & 2.5 \\
\hline Median & 48.7 & 7.1 & 22.9 & 36.1 & 9.7 & 0.5 & 0.0 & 0.5 & 0.0 & 2.5 \\
\hline Minimum & 7.5 & 3.0 & 4.8 & 2.5 & 1.4 & 0.0 & 0.0 & 0.1 & 0.0 & 0.0 \\
\hline Maximum & 100.0 & 89.6 & 59.2 & 82.1 & 24.9 & 3.6 & 0.8 & 17.3 & 0.1 & 5.1 \\
\hline
\end{tabular}

Table 3.2.5.13 Persons convicted by length of unsuspended custodial sanctions and measures imposed in 2015 - Theft of a motor vehicle

\begin{tabular}{|c|c|c|c|c|c|c|c|c|c|c|}
\hline Armenia & $\ldots$ & $\ldots$ & 50.0 & 0.0 & 0.0 & 50.0 & 0.0 & $\ldots$ & 0.0 & $\ldots$ \\
\hline Bulgaria & $\ldots$ & 36.4 & 44.4 & 17.3 & 1.9 & 0.0 & 0.0 & $\ldots$ & 0.0 & $\ldots$ \\
\hline Finland & 32.4 & 92.6 & 4.4 & 2.9 & 0.0 & 0.0 & 0.0 & 3.8 & 0.0 & $\ldots$ \\
\hline Hungary & 2.3 & 1.0 & 8.0 & 33.0 & 51.0 & 5.0 & 2.0 & 29.7 & 0.0 & 0.0 \\
\hline Serbia & 3.6 & 50.0 & 30.8 & 14.1 & 5.1 & 0.0 & 0.0 & $\ldots$ & $\ldots$ & \\
\hline Sweden & $\ldots$ & 89.6 & 6.3 & 2.1 & 0.0 & 0.0 & 0.0 & $\ldots$ & 0.0 & 2.1 \\
\hline Ukraine & $\ldots$ & $\ldots$ & 0.5 & 1.6 & 71.8 & 26.0 & 0.1 & $\ldots$ & 0.0 & $\ldots$ \\
\hline UK: Scotland & $\ldots$ & 64.2 & 25.3 & 9.5 & 1.1 & 0.0 & $\ldots$ & 7.4 & 0.0 & 0.0 \\
\hline
\end{tabular}

Table 3.2.5.14 Persons convicted by length of unsuspended custodial sanctions and measures imposed in 2015 - Theft by means of burglary

\begin{tabular}{|c|c|c|c|c|c|c|c|c|c|c|}
\hline Austria & 18.9 & 12.3 & 32.7 & 53.9 & 1.1 & 0.0 & $\ldots$ & $\ldots$ & 0.0 & \\
\hline Croatia & 94.9 & 7.2 & 46.5 & 33.7 & 7.4 & 0.2 & $\ldots$ & $\ldots$ & $\ldots$ & 5.0 \\
\hline Germany & 51.1 & 4.5 & 34.7 & 35.3 & 24.6 & 0.8 & 0.0 & $\ldots$ & 0.0 & \\
\hline Hungary & 22.4 & 14.3 & 20.8 & 36.5 & 25.3 & 3.0 & 0.0 & 2.2 & 0.2 & 0.0 \\
\hline Poland & 100.0 & 3.0 & 4.8 & 82.1 & 9.7 & 0.4 & 0.0 & 0.5 & 0.0 & $\ldots$ \\
\hline Ukraine & $\ldots$ & $\ldots$ & 1.3 & 2.4 & 94.1 & 2.2 & 0.0 & $\ldots$ & 0.0 & $\ldots$ \\
\hline UK: Scotland & $\ldots$ & 26.6 & 27.2 & 34.2 & 11.7 & 0.4 & $\ldots$ & 2.6 & 0.0 & 0.0 \\
\hline
\end{tabular}

Table 3.2.5.15 Persons convicted by length of unsuspended custodial sanctions and measures imposed in 2015 - Theft by means of domestic burglary

\begin{tabular}{|c|c|c|c|c|c|c|c|c|c|c|}
\hline Germany & 15.1 & 1.3 & 23.9 & 39.0 & 34.3 & 1.5 & 0.0 & $50 ?$ & 0.0 & \\
\hline Hungary & 0.9 & 19.5 & 34.1 & 24.4 & 17.1 & 4.9 & 0.0 & 50.2 & 0.0 & 0.0 \\
\hline
\end{tabular}


Table 3.2.5.16 Persons convicted by length of unsuspended custodial sanctions and measures imposed in 2015 - Fraud

\begin{tabular}{|c|c|c|c|c|c|c|c|c|c|c|}
\hline & 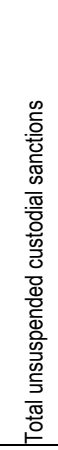 & 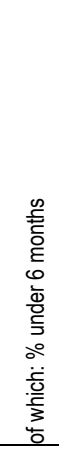 & 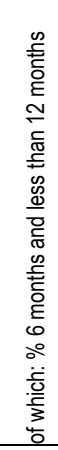 & 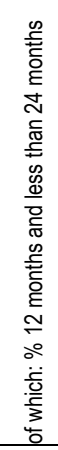 & 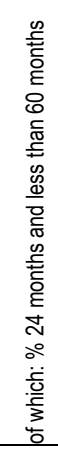 & 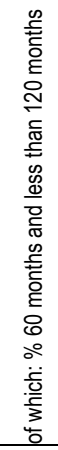 & 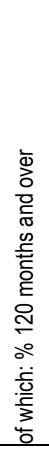 & 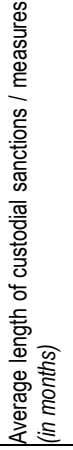 & 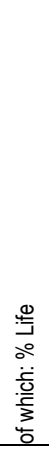 & 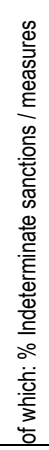 \\
\hline Albania & & $\ldots$ & & & & & & $\ldots$ & & $\ldots$ \\
\hline Armenia & 3.2 & $\ldots$ & 6.0 & 8.0 & 64.0 & 20.0 & 2.0 & $\ldots$ & 0.0 & $\ldots$ \\
\hline Austria & 4.4 & 32.1 & 19.3 & 37.2 & 9.4 & 1.9 & $\ldots$ & $\ldots$ & 0.0 & $\ldots$ \\
\hline Azerbaijan & $\ldots$ & $\ldots$ & $\ldots$ & $\ldots$ & $\ldots$ & $\ldots$ & $\ldots$ & $\ldots$ & $\ldots$ & $\ldots$ \\
\hline Belgium & 6.9 & 12.4 & 30.4 & 33.5 & 19.9 & 3.2 & 0.5 & 1.8 & 0.0 & $\ldots$ \\
\hline Bosnia-Herzegovina & $\ldots$ & $\ldots$ & $\ldots$ & $\ldots$ & $\ldots$ & $\ldots$ & $\ldots$ & $\ldots$ & $\ldots$ & $\ldots$ \\
\hline Bulgaria & 2.6 & 21.5 & 33.0 & 41.6 & 2.6 & 1.2 & 0.0 & $\ldots$ & 0.0 & $\ldots$ \\
\hline Croatia & 7.7 & 11.0 & 41.3 & 39.0 & 8.7 & 0.0 & 0.0 & $\ldots$ & $\ldots$ & 0.0 \\
\hline Cyprus & $\ldots$ & $\ldots$ & $\ldots$ & $\ldots$ & $\ldots$ & $\ldots$ & $\ldots$ & $\ldots$ & $\ldots$ & $\ldots$ \\
\hline Czech Republic & 4.0 & $\ldots$ & 18.7 & 66.2 & $\ldots$ & 15.0 & 0.0 & 12.1 & 0.0 & 0.0 \\
\hline Denmark & $\ldots$ & $\ldots$ & $\ldots$ & $\ldots$ & $\ldots$ & $\ldots$ & $\ldots$ & $\ldots$ & $\ldots$ & $\ldots$ \\
\hline Estonia & $\ldots$ & $\ldots$ & $\ldots$ & $\ldots$ & $\ldots$ & $\ldots$ & $\ldots$ & $\ldots$ & $\ldots$ & $\ldots$ \\
\hline Finland & 7.2 & 65.2 & 18.6 & 13.2 & 3.0 & 0.0 & 0.0 & 1.8 & 0.0 & $\ldots$ \\
\hline France & 2.1 & 38.7 & 28.5 & 27.4 & 4.6 & 0.7 & 0.0 & 0.4 & $\ldots$ & $\ldots$ \\
\hline Georgia & 4.6 & $\ldots$ & 13.9 & 35.4 & 7.2 & 30.1 & $\ldots$ & $\ldots$ & $\ldots$ & $\ldots$ \\
\hline Germany & 8.0 & 16.9 & 30.2 & 23.5 & 28.0 & 1.4 & 0.0 & $\ldots$ & 0.0 & $\ldots$ \\
\hline Hungary & 9.0 & 3.1 & 10.9 & 34.4 & 44.5 & 6.6 & 0.4 & 3.6 & 0.1 & 0.0 \\
\hline Iceland & $\cdots$ & $\ldots$ & $\ldots$ & $\ldots$ & $\cdots$ & $\cdots$ & $\ldots$ & $\cdots$ & $\ldots$ & $\ldots$ \\
\hline Italy & $\ldots$ & $\ldots$ & $\ldots$ & $\ldots$ & $\ldots$ & $\ldots$ & $\ldots$ & $\ldots$ & $\ldots$ & $\ldots$ \\
\hline Kosovo (UN R/1244/99) & $\ldots$ & $\ldots$ & $\ldots$ & $\ldots$ & $\ldots$ & $\ldots$ & $\ldots$ & $\ldots$ & $\ldots$ & $\ldots$ \\
\hline Latvia & $\ldots$ & $\ldots$ & $\ldots$ & $\ldots$ & $\cdots$ & $\cdots$ & $\cdots$ & $\cdots$ & $\cdots$ & $\cdots$ \\
\hline Lithuania & $\cdots$ & $\cdots$ & $\cdots$ & $\ldots$ & $\ldots$ & $\ldots$ & $\cdots$ & $\cdots$ & $\cdots$ & $\cdots$ \\
\hline Luxembourg & $\ldots$ & $\cdots$ & $\cdots$ & $\cdots$ & $\ldots$ & ... & $\cdots$ & $\cdots$ & $\cdots$ & $\ldots$ \\
\hline Moldova & $\ldots$ & $\ldots$ & $\ldots$ & $\ldots$ & $\cdots$ & $\ldots$ & $\cdots$ & $\ldots$ & $\cdots$ & $\cdots$ \\
\hline Montenegro & $\ldots$ & $\ldots$ & $\ldots$ & $\ldots$ & $\ldots$ & $\ldots$ & $\ldots$ & $\ldots$ & $\ldots$ & $\ldots$ \\
\hline Netherlands & 1.1 & 80.9 & 9.9 & 6.0 & 2.8 & 0.0 & 0.0 & 1.3 & 0.0 & $\cdots$ \\
\hline North Macedonia & $\ldots$ & $\ldots$ & $\ldots$ & $\ldots$ & $\ldots$ & $\ldots$ & $\ldots$ & $\ldots$ & $\cdots$ & $\ldots$ \\
\hline Norway & $\ldots$ & $\ldots$ & $\ldots$ & $\ldots$ & $\ldots$ & $\ldots$ & $\ldots$ & $\ldots$ & $\ldots$ & $\ldots$ \\
\hline Poland & 10.4 & 4.4 & 52.6 & 35.8 & 6.6 & 0.6 & 0.0 & 0.4 & 0.0 & $\ldots$ \\
\hline Portugal & $\ldots$ & $\ldots$ & $\ldots$ & $\ldots$ & $\ldots$ & $\ldots$ & $\ldots$ & $\ldots$ & $\ldots$ & $\cdots$ \\
\hline Romania & $\ldots$ & $\ldots$ & $\ldots$ & $\ldots$ & $\ldots$ & $\ldots$ & $\ldots$ & $\ldots$ & $\ldots$ & $\ldots$ \\
\hline Russian Federation & $\ldots$ & $\ldots$ & $\ldots$ & $\ldots$ & $\ldots$ & $\ldots$ & $\ldots$ & $\cdots$ & $\ldots$ & $\ldots$ \\
\hline Serbia & 2.4 & 38.3 & 32.2 & 16.4 & 12.6 & 0.5 & 0.0 & $\ldots$ & $\ldots$ & $\ldots$ \\
\hline Slovak Republic & $\ldots$ & $\ldots$ & $\ldots$ & $\ldots$ & $\ldots$ & $\ldots$ & $\ldots$ & $\ldots$ & $\ldots$ & $\ldots$ \\
\hline Slovenia & $\ldots$ & $\ldots$ & $\ldots$ & $\ldots$ & $\ldots$ & $\ldots$ & $\ldots$ & $\cdots$ & $\ldots$ & $\cdots$ \\
\hline Spain & & $\ldots$ & $\cdots$ & $\ldots$ & $\ldots$ & & . & $\ldots$ & $\ldots$ & $\ldots$ \\
\hline Sweden & 2.5 & 30.6 & 21.0 & 31.7 & 13.7 & 0.7 & 0.0 & $\ldots$ & 0.0 & 1.5 \\
\hline Switzerland & 0.7 & 72.3 & 13.8 & 4.6 & 9.2 & 0.0 & 0.0 & 11.9 & 0.0 & $\ldots$ \\
\hline Turkey & 4.5 & $\ldots$ & $\ldots$ & $\ldots$ & $\ldots$ & $\ldots$ & $\ldots$ & $\ldots$ & $\ldots$ & $\ldots$ \\
\hline Ukraine & 2.2 & $\ldots$ & 21.2 & 40.0 & 31.3 & 7.3 & 0.0 & $\ldots$ & 0.0 & $\ldots$ \\
\hline UK: England \& Wales & 6.0 & 34.1 & 21.3 & 22.5 & 21.6 & 0.4 & 0.0 & 0.8 & 0.0 & 0.0 \\
\hline UK: Northern Ireland & $\ldots$ & $\ldots$ & & & $\ldots$ & $\ldots$ & $\ldots$ & $\ldots$ & $\ldots$ & $\ldots$ \\
\hline UK: Scotland & 1.2 & 50.9 & 27.9 & 11.5 & 7.9 & 1.8 & $\ldots$ & 6.7 & 0.0 & 0.0 \\
\hline Mean & 4.5 & 34.2 & 23.7 & 27.8 & 16.5 & 4.8 & 0.2 & 4.1 & 0.0 & 0.2 \\
\hline Median & 4.2 & 32.1 & 21.2 & 31.7 & 9.3 & 1.2 & 0.0 & 1.8 & 0.0 & 0.0 \\
\hline Minimum & 0.7 & 3.1 & 6.0 & 4.6 & 2.6 & 0.0 & 0.0 & 0.4 & 0.0 & 0.0 \\
\hline Maximum & 10.4 & 80.9 & 52.6 & 66.2 & 64.0 & 30.1 & 2.0 & 12.1 & 0.1 & 1.5 \\
\hline
\end{tabular}


Table 3.2.5.18 Persons convicted by length of unsuspended custodial sanctions and measures imposed in 2015 - Forgery of documents

\begin{tabular}{|c|c|c|c|c|c|c|c|c|c|c|}
\hline & 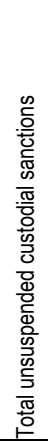 & 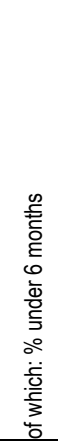 & 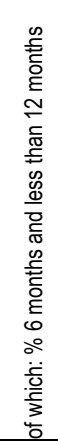 & 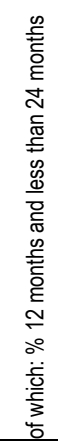 & 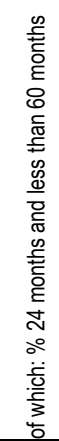 & 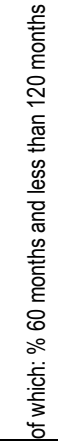 & 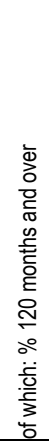 & 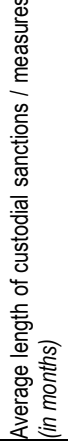 & 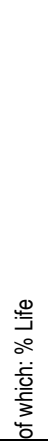 & 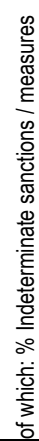 \\
\hline Albania & $\ldots$ & $\ldots$ & $\ldots$ & $\ldots$ & $\ldots$ & $\ldots$ & $\ldots$ & $\ldots$ & $\ldots$ & $\ldots$ \\
\hline Armenia & $\ldots$ & $\ldots$ & $\ldots$ & $\ldots$ & $\ldots$ & $\ldots$ & $\ldots$ & $\ldots$ & $\ldots$ & $\ldots$ \\
\hline Austria & 0.4 & 82.9 & 17.1 & 0.0 & 0.0 & 0.0 & $\ldots$ & $\ldots$ & 0.0 & $\ldots$ \\
\hline Azerbaijan & $\ldots$ & $\ldots$ & $\ldots$ & $\ldots$ & & & $\ldots$ & $\ldots$ & $\ldots$ & $\ldots$ \\
\hline Belgium & 4.3 & 14.0 & 28.4 & 29.6 & 23.9 & 3.8 & 0.3 & 3.1 & 0.0 & $\ldots$ \\
\hline Bosnia-Herzegovina & $\ldots$ & $\ldots$ & $\ldots$ & $\ldots$ & $\ldots$ & $\ldots$ & $\ldots$ & $\ldots$ & $\ldots$ & $\ldots$ \\
\hline Bulgaria & $\ldots$ & $\ldots$ & $\ldots$ & $\ldots$ & $\ldots$ & $\ldots$ & $\ldots$ & $\ldots$ & $\ldots$ & $\ldots$ \\
\hline Croatia & 2.7 & 30.8 & 51.3 & 15.4 & 2.6 & 0.0 & 0.0 & $\ldots$ & $\ldots$ & 0.0 \\
\hline Cyprus & $\ldots$ & $\ldots$ & $\ldots$ & $\ldots$ & $\ldots$ & $\ldots$ & $\ldots$ & $\ldots$ & $\ldots$ & $\ldots$ \\
\hline Czech Republic & 0.5 & $\ldots$ & 43.2 & 43.2 & $\ldots$ & 13.6 & 0.0 & 78.4 & 0.0 & 0.0 \\
\hline Denmark & $\ldots$ & $\ldots$ & $\ldots$ & $\ldots$ & $\ldots$ & $\ldots$ & $\ldots$ & $\cdots$ & $\ldots$ & $\ldots$ \\
\hline Estonia & $\ldots$ & $\ldots$ & $\ldots$ & $\ldots$ & $\ldots$ & $\ldots$ & $\ldots$ & $\ldots$ & $\ldots$ & $\ldots$ \\
\hline Finland & 1.3 & 89.6 & 7.5 & 3.0 & 0.0 & 0.0 & 0.0 & 4.9 & 0.0 & $\ldots$ \\
\hline France & 0.6 & 62.9 & 24.9 & 11.6 & 0.5 & 0.1 & 0.0 & 0.7 & $\ldots$ & $\ldots$ \\
\hline Georgia & $\ldots$ & $\ldots$ & $\ldots$ & $\ldots$ & $\ldots$ & $\ldots$ & $\ldots$ & $\ldots$ & $\ldots$ & $\ldots$ \\
\hline Germany & 1.8 & 15.5 & 48.2 & 23.3 & 12.2 & 0.8 & 0.0 & $\ldots$ & 0.0 & $\ldots$ \\
\hline Hungary & 6.0 & 1.5 & 10.6 & 35.8 & 42.5 & 9.0 & 0.4 & 5.5 & 0.2 & 0.0 \\
\hline Iceland & $\ldots$ & $\ldots$ & $\ldots$ & $\ldots$ & $\ldots$ & $\ldots$ & $\ldots$ & $\ldots$ & $\ldots$ & $\ldots$ \\
\hline Italy & $\ldots$ & $\ldots$ & $\ldots$ & $\ldots$ & $\ldots$ & $\ldots$ & $\ldots$ & $\ldots$ & $\ldots$ & $\ldots$ \\
\hline Kosovo (UN R/1244/99) & $\ldots$ & $\ldots$ & $\ldots$ & $\ldots$ & $\ldots$ & $\ldots$ & $\ldots$ & $\ldots$ & $\ldots$ & $\ldots$ \\
\hline Latvia & $\ldots$ & $\ldots$ & $\ldots$ & $\ldots$ & $\ldots$ & $\ldots$ & $\ldots$ & $\ldots$ & $\ldots$ & $\ldots$ \\
\hline Lithuania & $\ldots$ & $\ldots$ & $\ldots$ & $\ldots$ & $\ldots$ & $\ldots$ & $\ldots$ & $\ldots$ & $\ldots$ & $\ldots$ \\
\hline Luxembourg & $\ldots$ & $\ldots$ & $\ldots$ & $\ldots$ & $\ldots$ & $\ldots$ & $\ldots$ & $\ldots$ & $\ldots$ & $\ldots$ \\
\hline Moldova & $\ldots$ & $\ldots$ & $\ldots$ & $\ldots$ & $\ldots$ & $\ldots$ & $\ldots$ & $\ldots$ & $\ldots$ & $\ldots$ \\
\hline Montenegro & $\ldots$ & $\ldots$ & $\ldots$ & $\ldots$ & $\ldots$ & $\ldots$ & $\ldots$ & $\ldots$ & $\ldots$ & $\ldots$ \\
\hline Netherlands & 3.0 & 85.4 & 7.5 & 3.9 & 3.2 & 0.0 & 0.0 & 0.5 & 0.0 & $\ldots$ \\
\hline North Macedonia & $\ldots$ & $\ldots$ & $\ldots$ & $\ldots$ & $\ldots$ & $\ldots$ & $\ldots$ & $\ldots$ & $\ldots$ & $\ldots$ \\
\hline Norway & ( & & & & $\ldots$ & $\cdots$ & $\ldots$ & $\ldots$ & $\ldots$ & $\ldots$ \\
\hline Poland & 0.6 & 47.7 & 42.6 & 8.3 & 1.4 & 0.0 & 0.0 & 3.2 & 0.0 & $\ldots$ \\
\hline Portugal & $\ldots$ & $\ldots$ & $\ldots$ & $\ldots$ & $\ldots$ & $\ldots$ & $\ldots$ & $\ldots$ & $\ldots$ & $\ldots$ \\
\hline Romania & $\ldots$ & $\ldots$ & $\ldots$ & $\ldots$ & $\ldots$ & $\ldots$ & $\ldots$ & $\ldots$ & $\ldots$ & $\ldots$ \\
\hline Russian Federation & $\ldots$ & $\ldots$ & $\ldots$ & $\ldots$ & $\ldots$ & $\ldots$ & $\ldots$ & $\ldots$ & $\ldots$ & $\ldots$ \\
\hline Serbia & 2.0 & 66.1 & 20.9 & 7.9 & 4.5 & 0.6 & 0.0 & $\ldots$ & $\ldots$ & $\ldots$ \\
\hline Slovak Republic & $\ldots$ & $\ldots$ & $\ldots$ & $\ldots$ & $\ldots$ & $\ldots$ & $\ldots$ & $\ldots$ & $\ldots$ & $\ldots$ \\
\hline Slovenia & $\ldots$ & $\ldots$ & $\ldots$ & $\ldots$ & $\ldots$ & $\ldots$ & $\ldots$ & $\ldots$ & $\ldots$ & $\ldots$ \\
\hline Spain & $\ldots$ & $\ldots$ & $\ldots$ & $\ldots$ & $\ldots$ & $\ldots$ & $\ldots$ & $\ldots$ & $\ldots$ & $\ldots$ \\
\hline Sweden & 1.2 & 63.5 & 12.7 & 19.0 & 4.8 & 0.0 & 0.0 & $\ldots$ & 0.0 & 0.0 \\
\hline Switzerland & 0.2 & 90.9 & 9.1 & 0.0 & 0.0 & 0.0 & 0.0 & 9.4 & 0.0 & $\ldots$ \\
\hline Turkey & 2.8 & $\ldots$ & $\ldots$ & $\ldots$ & $\ldots$ & $\ldots$ & $\ldots$ & $\ldots$ & $\ldots$ & $\ldots$ \\
\hline Ukraine & 0.1 & $\ldots$ & 0.0 & 0.0 & 90.0 & 10.0 & 0.0 & $\ldots$ & 0.0 & $\ldots$ \\
\hline UK: England \& Wales & $\ldots$ & $\ldots$ & $\ldots$ & $\ldots$ & $\ldots$ & $\ldots$ & $\ldots$ & $\ldots$ & $\ldots$ & $\ldots$ \\
\hline UK: Northern Ireland & $\ldots$ & $\ldots$ & $\ldots$ & $\ldots$ & $\ldots$ & $\ldots$ & $\ldots$ & $\ldots$ & $\ldots$ & $\ldots$ \\
\hline UK: Scotland & $\ldots$ & $\ldots$ & $\ldots$ & $\ldots$ & $\ldots$ & $\ldots$ & $\ldots$ & $\ldots$ & $\ldots$ & $\ldots$ \\
\hline Mean & 1.8 & 54.2 & 23.1 & 14.4 & 14.3 & 2.7 & 0.1 & 13.2 & 0.0 & 0.0 \\
\hline Median & 1.3 & 63.2 & 19.0 & 9.9 & 3.2 & 0.1 & 0.0 & 4.1 & 0.0 & 0.0 \\
\hline Minimum & 0.1 & 1.5 & 0.0 & 0.0 & 0.0 & 0.0 & 0.0 & 0.5 & 0.0 & 0.0 \\
\hline Maximum & 6.0 & 90.9 & 51.3 & 43.2 & 90.0 & 13.6 & 0.4 & 78.4 & 0.2 & 0.0 \\
\hline
\end{tabular}


Table 3.2.5.17 Persons convicted by length of unsuspended custodial sanctions and measures imposed in 2015 - Cyber fraud

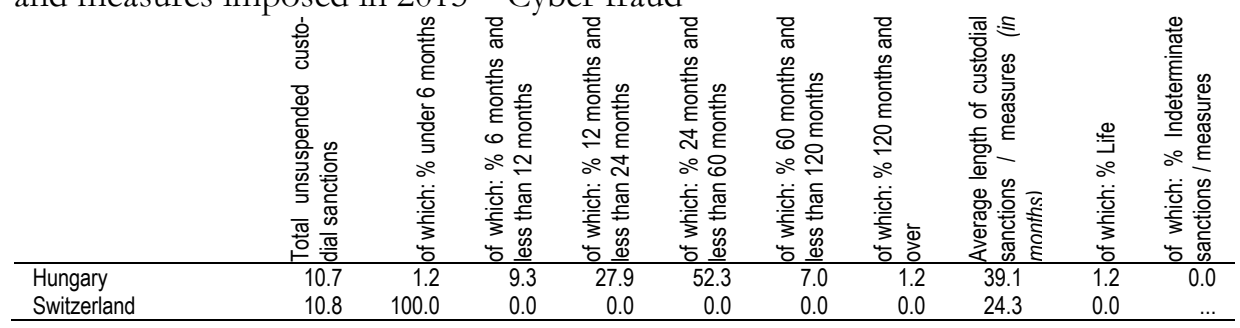

Table 3.2.5.19 Persons convicted by length of unsuspended custodial sanctions and measures imposed in 2015 - Money laundering

\begin{tabular}{lrrrrrrrrrr}
\hline Austria & 0.0 & 50.0 & 0.0 & 25.0 & 0.0 & 25.0 & $\ldots$ & $\ldots$ & 0.0 & $\ldots$ \\
Belgium & 1.5 & 7.4 & 17.2 & 36.8 & 30.9 & 6.9 & 1.0 & 11.4 & 0.0 & $\ldots$ \\
Croatia & 0.0 & 0.0 & 0.0 & 100.0 & 0.0 & 0.0 & 0.0 & $\ldots$ & $\ldots$ & 0.0 \\
Czech Republic & 0.1 & $\ldots$ & 9.1 & 72.7 & $\ldots$ & 45.5 & 0.0 & 387.3 & 0.0 & 0.0 \\
Germany & 0.0 & 0.0 & 50.0 & 25.0 & 25.0 & 0.0 & 0.0 & $\ldots$ & 0.0 & $\ldots$ \\
Hungary & 0.0 & 100.0 & 0.0 & 0.0 & 0.0 & 0.0 & 0.0 & 400.0 & 0.0 & 0.0 \\
Netherlands & 0.6 & 42.0 & 22.2 & 19.8 & 13.6 & 3.1 & 0.0 & 7.2 & 0.0 & $\ldots$ \\
Poland & 0.0 & 0.0 & 0.0 & 92.3 & 7.7 & 0.0 & 0.0 & 152.3 & 0.0 & $\ldots$ \\
Sweden & 0.4 & 29.3 & 22.0 & 29.3 & 17.1 & 0.0 & 0.0 & $\ldots$ & 0.0 & 0.0 \\
Switzerland & 0.0 & 50.0 & 50.0 & 0.0 & 0.0 & 0.0 & 0.0 & 225.0 & 0.0 & $\ldots$ \\
Ukraine & 0.0 & $\ldots$ & 0.0 & 0.0 & 0.0 & 100.0 & 0.0 & $\ldots$ & 0.0 & $\ldots$ \\
\hline Mean & 0.2 & 31.0 & 15.5 & 36.4 & 9.4 & 16.4 & 0.1 & 197.2 & 0.0 & 0.0 \\
Median & 0.0 & 29.3 & 9.1 & 25.0 & 3.8 & 0.0 & 0.0 & 188.7 & 0.0 & 0.0 \\
Minimum & 0.0 & 0.0 & 0.0 & 0.0 & 0.0 & 0.0 & 0.0 & 7.2 & 0.0 & 0.0 \\
Maximum & 1.5 & 100.0 & 50.0 & 100.0 & 30.9 & 100.0 & 1.0 & 400.0 & 0.0 & 0.0 \\
\hline
\end{tabular}

Table 3.2.5.20 Persons convicted by length of unsuspended custodial sanctions and measures imposed in 2015 - Corruption

\begin{tabular}{lrrrrrrrrrr}
\hline Austria & 0.0 & 33.3 & 0.0 & 66.7 & 0.0 & 0.0 & $\ldots$ & $\ldots$ & 0.0 & $\ldots$ \\
Belgium & 0.0 & 0.0 & 20.0 & 0.0 & 60.0 & 20.0 & 0.0 & 654.0 & 0.0 & $\ldots$ \\
Bulgaria & 0.3 & 44.1 & 18.6 & 37.3 & 0.0 & 0.0 & 0.0 & $\ldots$ & 0.0 & $\ldots$ \\
Croatia & 3.0 & 32.1 & 38.1 & 25.0 & 4.8 & 0.0 & 0.0 & 0.0 & $\ldots$ & 0.0 \\
Czech Republic & 0.1 & $\ldots$ & 8.3 & 41.7 & $\ldots$ & 50.0 & 0.0 & 566.7 & 0.0 & 0.0 \\
France & 0.1 & 43.1 & 26.4 & 25.0 & 5.6 & 0.0 & 0.0 & 12.9 & $\ldots$ & $\ldots$ \\
Georgia & 1.5 & 0.0 & 5.8 & 73.9 & 21.7 & $\ldots$ & $\ldots$ & $\ldots$ & $\ldots$ & $\ldots$ \\
Germany & 0.0 & 14.3 & 14.3 & 14.3 & 57.1 & 0.0 & 0.0 & $\ldots$ & 0.0 & $\ldots$ \\
Hungary & 0.3 & 3.6 & 3.6 & 14.3 & 67.9 & 7.1 & 3.6 & 129.3 & 0.0 & 0.0 \\
Poland & 0.3 & 1.0 & 5.9 & 84.3 & 7.8 & 1.0 & 0.0 & 19.5 & 0.0 & $\ldots$ \\
Serbia & 0.3 & 18.5 & 40.7 & 25.9 & 14.8 & 0.0 & 0.0 & $\ldots$ & $\ldots$ & $\ldots$ \\
Turkey & 0.1 & $\ldots$ & $\ldots$ & $\ldots$ & $\ldots$ & $\ldots$ & $\ldots$ & $\ldots$ & $\ldots$ & $\ldots$ \\
Ukraine & 0.3 & $\ldots$ & 1.7 & 5.1 & 71.2 & 22.0 & 0.0 & $\ldots$ & 0.0 & $\ldots$ \\
\hline Mean & 0.4 & 19.0 & 15.3 & 34.5 & 28.3 & 9.1 & 0.4 & 230.4 & 0.0 & 0.0 \\
Median & 0.1 & 16.4 & 11.3 & 25.5 & 14.8 & 0.0 & 0.0 & 74.4 & 0.0 & 0.0 \\
Minimum & 0.0 & 0.0 & 0.0 & 0.0 & 0.0 & 0.0 & 0.0 & 0.0 & 0.0 & 0.0 \\
Maximum & 3.0 & 44.1 & 40.7 & 84.3 & 71.2 & 50.0 & 3.6 & 654.0 & 0.0 & 0.0 \\
\hline
\end{tabular}


Table 3.2.5.21 Persons convicted by length of unsuspended custodial sanctions and measures imposed in 2015 - Drug offences: Total

\begin{tabular}{|c|c|c|c|c|c|c|c|c|c|c|}
\hline & 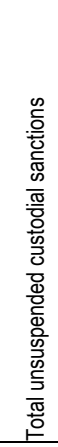 & 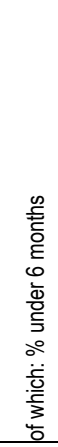 & 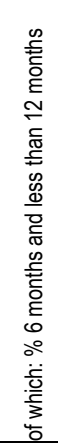 & 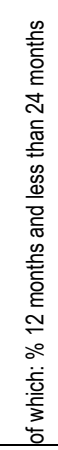 & 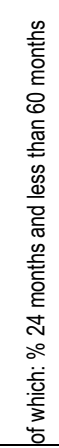 & 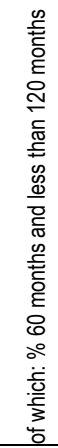 & 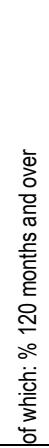 & 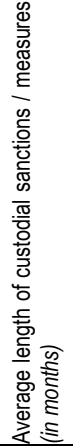 & 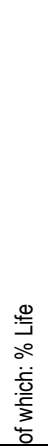 & 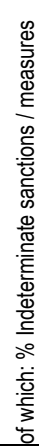 \\
\hline Albania & $\ldots$ & $\ldots$ & $\ldots$ & $\ldots$ & $\ldots$ & $\ldots$ & $\ldots$ & $\ldots$ & $\ldots$ & $\ldots$ \\
\hline Armenia & $\ldots$ & $\ldots$ & $\ldots$ & $\ldots$ & $\ldots$ & $\ldots$ & $\ldots$ & $\ldots$ & $\ldots$ & $\ldots$ \\
\hline Austria & 11.6 & 24.0 & 26.5 & 40.1 & 7.3 & 2.1 & $\ldots$ & $\ldots$ & 0.0 & $\ldots$ \\
\hline Azerbaijan & $\ldots$ & $\ldots$ & $\ldots$ & $\ldots$ & $\ldots$ & $\ldots$ & $\ldots$ & $\ldots$ & $\ldots$ & $\ldots$ \\
\hline Belgium & 14.6 & 12.6 & 18.7 & 28.5 & 36.1 & 4.0 & 0.2 & 1.1 & 0.0 & $\ldots$ \\
\hline Bosnia-Herzegovina & $\ldots$ & $\ldots$ & & $\ldots$ & 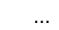 & $\ldots$ & $\ldots$ & $\ldots$ & $\ldots$ & $\ldots$ \\
\hline Bulgaria & 6.7 & 29.4 & 33.7 & 33.7 & 2.5 & 0.6 & 0.1 & $\ldots$ & 0.0 & $\ldots$ \\
\hline Croatia & 11.9 & 5.3 & 40.1 & 35.0 & 18.1 & 0.9 & 0.0 & 0.0 & $\ldots$ & 0.6 \\
\hline Cyprus & $\ldots$ & $\ldots$ & 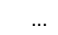 & & $\ldots$ & $\ldots$ & $\ldots$ & $\ldots$ & $\ldots$ & $\ldots$ \\
\hline Czech Republic & 7.1 & $\ldots$ & 11.9 & 70.9 & $\ldots$ & 17.1 & 0.0 & 8.1 & 0.0 & 0.0 \\
\hline Denmark & $\ldots$ & $\ldots$ & $\ldots$ & $\ldots$ & $\ldots$ & $\ldots$ & $\ldots$ & $\ldots$ & $\ldots$ & $\ldots$ \\
\hline Estonia & $\ldots$ & $\ldots$ & $\ldots$ & $\ldots$ & $\ldots$ & $\ldots$ & $\ldots$ & $\ldots$ & $\ldots$ & $\ldots$ \\
\hline Finland & 12.3 & 31.7 & 9.6 & 19.4 & 24.0 & 12.7 & 2.6 & 4.5 & 0.0 & $\ldots$ \\
\hline France & 12.9 & 42.1 & 26.5 & 24.8 & 4.9 & 1.6 & 0.1 & 0.1 & $\ldots$ & $\ldots$ \\
\hline Georgia & 20.8 & 0.0 & 16.4 & 32.8 & 41.3 & 9.5 & $\ldots$ & $\ldots$ & $\ldots$ & $\ldots$ \\
\hline Germany & 12.9 & 14.8 & 12.6 & 17.0 & 48.0 & 7.5 & 0.1 & $\ldots$ & 0.0 & $\ldots$ \\
\hline Hungary & 3.5 & 2.2 & 7.6 & 17.0 & 45.1 & 26.2 & 1.6 & 13.5 & 0.3 & 0.0 \\
\hline Iceland & $\ldots$ & $\ldots$ & $\ldots$ & $\ldots$ & $\ldots$ & $\ldots$ & $\ldots$ & $\ldots$ & $\ldots$ & $\ldots$ \\
\hline Italy & $\ldots$ & $\ldots$ & $\ldots$ & $\ldots$ & $\ldots$ & $\ldots$ & $\ldots$ & $\ldots$ & $\ldots$ & $\ldots$ \\
\hline Kosovo (UN R/1244/99) & $\ldots$ & $\ldots$ & $\ldots$ & $\ldots$ & $\ldots$ & $\ldots$ & $\ldots$ & $\ldots$ & $\ldots$ & $\ldots$ \\
\hline Latvia & $\ldots$ & $\ldots$ & $\ldots$ & $\ldots$ & $\ldots$ & $\ldots$ & $\ldots$ & $\ldots$ & $\ldots$ & $\ldots$ \\
\hline Lithuania & $\ldots$ & $\ldots$ & $\ldots$ & $\ldots$ & $\ldots$ & $\ldots$ & $\ldots$ & $\ldots$ & $\ldots$ & $\ldots$ \\
\hline Luxembourg & $\ldots$ & $\ldots$ & $\ldots$ & $\ldots$ & $\ldots$ & $\ldots$ & $\ldots$ & $\ldots$ & $\ldots$ & $\ldots$ \\
\hline Moldova & $\ldots$ & $\ldots$ & $\ldots$ & $\ldots$ & $\ldots$ & $\ldots$ & $\ldots$ & $\ldots$ & $\ldots$ & $\ldots$ \\
\hline Montenegro & $\ldots$ & $\ldots$ & $\ldots$ & $\ldots$ & $\ldots$ & $\ldots$ & $\ldots$ & $\ldots$ & $\ldots$ & $\ldots$ \\
\hline Netherlands & 9.2 & 60.5 & 19.6 & 9.8 & 8.8 & 1.4 & 0.0 & 0.3 & 0.0 & $\ldots$ \\
\hline North Macedonia & $\ldots$ & $\ldots$ & $\ldots$ & $\ldots$ & $\ldots$ & $\ldots$ & $\ldots$ & $\ldots$ & $\ldots$ & $\ldots$ \\
\hline Norway & 1.4 & 83.1 & 5.0 & 8.0 & 1.8 & 1.8 & 0.3 & . & $\ldots$ & $\ldots$ \\
\hline Poland & 5.3 & 15.3 & 10.4 & 42.3 & 28.4 & 3.5 & 0.1 & 1.3 & 0.0 & $\ldots$ \\
\hline Portugal & $\ldots$ & $\ldots$ & $\ldots$ & $\ldots$ & $\ldots$ & $\ldots$ & $\ldots$ & $\ldots$ & $\ldots$ & $\ldots$ \\
\hline Romania & $\ldots$ & $\ldots$ & $\ldots$ & $\ldots$ & ... & $\ldots$ & $\ldots$ & $\ldots$ & $\ldots$ & $\ldots$ \\
\hline Russian Federation & $\ldots$ & $\ldots$ & $\ldots$ & $\ldots$ & $\ldots$ & $\ldots$ & $\ldots$ & $\ldots$ & $\ldots$ & $\ldots$ \\
\hline Serbia & 12.8 & 27.6 & 13.6 & 4.5 & 48.9 & 4.8 & 0.5 & $\ldots$ & $\ldots$ & $\ldots$ \\
\hline Slovak Republic & $\ldots$ & $\ldots$ & $\ldots$ & $\ldots$ & $\ldots$ & $\ldots$ & $\ldots$ & $\ldots$ & $\ldots$ & $\ldots$ \\
\hline Slovenia & $\ldots$ & $\ldots$ & $\ldots$ & $\ldots$ & $\ldots$ & $\ldots$ & $\ldots$ & $\ldots$ & $\ldots$ & $\ldots$ \\
\hline Spain & $\ldots$ & $\ldots$ & $\ldots$ & $\ldots$ & $\ldots$ & $\ldots$ & $\ldots$ & $\ldots$ & $\ldots$ & $\ldots$ \\
\hline Sweden & 13.2 & 48.4 & 18.7 & 14.4 & 11.4 & 6.7 & 0.1 & $\ldots$ & 0.0 & 0.2 \\
\hline Switzerland & 5.3 & 68.9 & 7.9 & 7.7 & 12.7 & 2.9 & 0.0 & 2.1 & 0.0 & $\ldots$ \\
\hline Turkey & 6.0 & $\ldots$ & $\ldots$ & $\ldots$ & $\ldots$ & $\ldots$ & $\ldots$ & $\ldots$ & $\ldots$ & $\ldots$ \\
\hline Ukraine & 11.6 & $\ldots$ & 8.7 & 25.4 & 41.5 & 24.3 & 0.1 & 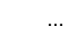 & 0.0 & $\ldots$ \\
\hline UK: England \& Wales & 18.8 & 18.7 & 14.8 & 20.6 & 35.5 & 7.5 & 2.9 & 0.5 & 0.0 & 0.0 \\
\hline UK: Northern Ireland & $\ldots$ & & & & & $\ldots$ & $\ldots$ & $\ldots$ & $\ldots$ & $\ldots$ \\
\hline UK: Scotland & 7.4 & 39.7 & 18.7 & 22.2 & 13.5 & 5.9 & $\ldots$ & 1.8 & 0.0 & 0.0 \\
\hline Mean & 10.3 & 30.9 & 16.9 & 24.9 & 23.9 & 7.4 & 0.5 & 3.0 & 0.0 & 0.1 \\
\hline Median & 11.6 & 27.6 & 14.8 & 22.2 & 21.1 & 4.8 & 0.1 & 1.3 & 0.0 & 0.0 \\
\hline Minimum & 1.4 & 0.0 & 5.0 & 4.5 & 1.8 & 0.6 & 0.0 & 0.0 & 0.0 & 0.0 \\
\hline Maximum & 20.8 & 83.1 & 40.1 & 70.9 & 48.9 & 26.2 & 2.9 & 13.5 & 0.3 & 0.6 \\
\hline
\end{tabular}


Table 3.2.5.22 Persons convicted by length of unsuspended custodial sanctions and measures imposed in 2015 - Drug trafficking

\begin{tabular}{|c|c|c|c|c|c|c|c|c|c|c|}
\hline & 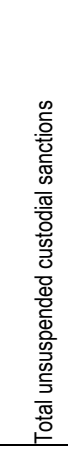 & 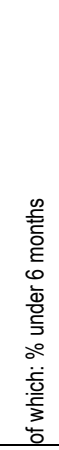 & 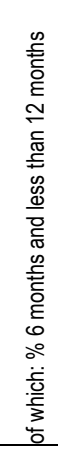 & 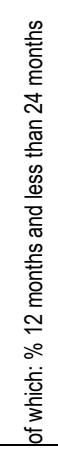 & 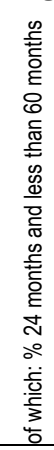 & 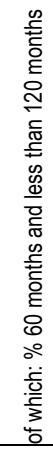 & 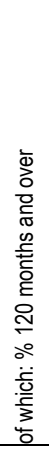 & 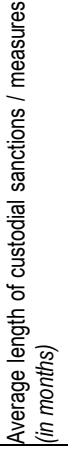 & 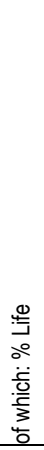 & 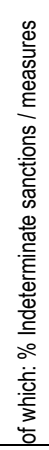 \\
\hline Albania & $\ldots$ & $\ldots$ & & & & & & $\ldots$ & & $\ldots$ \\
\hline Armenia & $\ldots$ & $\ldots$ & 2.5 & 47.5 & 22.5 & 17.5 & 0.0 & $\ldots$ & 0.0 & $\ldots$ \\
\hline Austria & $\ldots$ & $\ldots$ & $\ldots$ & $\ldots$ & $\ldots$ & $\ldots$ & $\ldots$ & $\ldots$ & $\ldots$ & $\ldots$ \\
\hline Azerbaijan & $\ldots$ & $\ldots$ & $\ldots$ & $\ldots$ & $\ldots$ & $\ldots$ & $\ldots$ & $\ldots$ & $\ldots$ & $\ldots$ \\
\hline Belgium & $\ldots$ & $\ldots$ & $\ldots$ & $\ldots$ & $\ldots$ & $\ldots$ & $\ldots$ & $\ldots$ & $\ldots$ & $\ldots$ \\
\hline Bosnia-Herzegovina & $\ldots$ & $\ldots$ & $\ldots$ & $\ldots$ & $\ldots$ & $\ldots$ & $\ldots$ & $\ldots$ & $\ldots$ & $\ldots$ \\
\hline Bulgaria & $\ldots$ & $\ldots$ & $\ldots$ & $\ldots$ & $\ldots$ & $\ldots$ & $\ldots$ & $\ldots$ & $\ldots$ & $\ldots$ \\
\hline Croatia & 100.0 & 5.3 & 40.1 & 35.0 & 18.1 & 0.9 & 0.0 & $\ldots$ & $\ldots$ & 0.6 \\
\hline Cyprus & $\ldots$ & $\ldots$ & $\ldots$ & $\ldots$ & $\ldots$ & $\ldots$ & $\ldots$ & $\ldots$ & $\ldots$ & $\ldots$ \\
\hline Czech Republic & 86.1 & $\ldots$ & 7.4 & 73.1 & $\ldots$ & 19.5 & 0.0 & 9.7 & 0.0 & 0.0 \\
\hline Denmark & $\ldots$ & $\ldots$ & $\ldots$ & $\ldots$ & $\ldots$ & $\ldots$ & $\ldots$ & $\ldots$ & $\ldots$ & $\ldots$ \\
\hline Estonia & $\ldots$ & $\ldots$ & $\ldots$ & $\ldots$ & $\ldots$ & $\ldots$ & $\ldots$ & $\ldots$ & $\ldots$ & $\ldots$ \\
\hline Finland & 100.0 & 31.7 & 9.6 & 19.4 & 24.0 & 12.7 & 2.6 & 4.5 & 0.0 & $\ldots$ \\
\hline France & 89.1 & 36.1 & 29.0 & 27.6 & 5.5 & 1.8 & 0.1 & 0.1 & $\ldots$ & $\ldots$ \\
\hline Georgia & 6.3 & $\ldots$ & $\ldots$ & 41.7 & 25.0 & 33.3 & $\ldots$ & $\ldots$ & $\ldots$ & $\ldots$ \\
\hline Germany & 64.7 & 0.1 & 3.0 & 16.5 & 69.1 & 11.2 & 0.1 & $\ldots$ & 0.0 & $\ldots$ \\
\hline Hungary & 60.6 & 1.0 & 2.1 & 10.9 & 49.0 & 34.4 & 2.1 & 26.1 & 0.5 & 0.0 \\
\hline Iceland & $\ldots$ & $\ldots$ & $\ldots$ & $\ldots$ & $\ldots$ & $\ldots$ & $\ldots$ & $\ldots$ & $\ldots$ & $\ldots$ \\
\hline Italy & $\ldots$ & $\ldots$ & $\ldots$ & $\ldots$ & $\ldots$ & $\ldots$ & $\ldots$ & $\ldots$ & $\ldots$ & $\ldots$ \\
\hline Kosovo (UN R/1244/99) & $\ldots$ & $\ldots$ & $\ldots$ & $\ldots$ & ... & $\ldots$ & $\ldots$ & $\ldots$ & $\ldots$ & $\ldots$ \\
\hline Latvia & $\ldots$ & $\ldots$ & $\cdots$ & $\ldots$ & $\ldots$ & $\cdots$ & $\cdots$ & $\cdots$ & $\cdots$ & $\cdots$ \\
\hline Lithuania & $\ldots$ & $\ldots$ & $\ldots$ & $\ldots$ & $\ldots$ & $\ldots$ & $\ldots$ & $\ldots$ & $\cdots$ & $\cdots$ \\
\hline Luxembourg & $\ldots$ & $\ldots$ & $\cdots$ & $\ldots$ & $\ldots$ & $\ldots$ & $\ldots$ & $\cdots$ & $\cdots$ & $\cdots$ \\
\hline Moldova & $\ldots$ & $\ldots$ & $\ldots$ & $\ldots$ & $\cdots$ & $\cdots$ & $\cdots$ & $\cdots$ & $\ldots$ & $\ldots$ \\
\hline Montenegro & $\ldots$ & $\ldots$ & $\ldots$ & $\ldots$ & ... & $\ldots$ & $\ldots$ & ... & $\cdots$ & $\cdots$ \\
\hline Netherlands & $\ldots$ & $\ldots$ & $\ldots$ & $\ldots$ & $\cdots$ & $\ldots$ & $\ldots$ & $\cdots$ & $\ldots$ & $\ldots$ \\
\hline North Macedonia & $\ldots$ & $\ldots$ & $\ldots$ & $\ldots$ & $\ldots$ & $\ldots$ & $\ldots$ & $\ldots$ & $\ldots$ & $\ldots$ \\
\hline Norway & & $\ldots$ & $\ldots$ & & $\ldots$ & $\ldots$ & $\ldots$ & $\ldots$ & $\ldots$ & $\ldots$ \\
\hline Poland & 36.6 & 0.6 & 3.0 & 35.7 & 52.8 & 7.8 & 0.1 & 5.4 & 0.0 & $\ldots$ \\
\hline Portugal & $\ldots$ & $\ldots$ & $\ldots$ & $\ldots$ & $\ldots$ & $\ldots$ & $\ldots$ & $\ldots$ & $\ldots$ & $\ldots$ \\
\hline Romania & $\ldots$ & $\ldots$ & $\ldots$ & $\ldots$ & $\ldots$ & $\ldots$ & $\ldots$ & $\ldots$ & $\ldots$ & $\ldots$ \\
\hline Russian Federation & $\ldots$ & $\ldots$ & $\ldots$ & $\ldots$ & $\ldots$ & $\ldots$ & $\ldots$ & $\ldots$ & $\ldots$ & $\ldots$ \\
\hline Serbia & 61.5 & 2.4 & 9.8 & 3.9 & 75.2 & 7.8 & 0.9 & $\ldots$ & $\ldots$ & $\ldots$ \\
\hline Slovak Republic & $\ldots$ & $\ldots$ & $\ldots$ & $\ldots$ & $\ldots$ & $\ldots$ & $\ldots$ & $\ldots$ & $\ldots$ & $\ldots$ \\
\hline Slovenia & $\ldots$ & $\ldots$ & $\ldots$ & $\ldots$ & ... & ... & $\ldots$ & $\ldots$ & $\ldots$ & $\ldots$ \\
\hline Spain & & & $\ldots$ & $\ldots$ & $\ldots$ & $\ldots$ & $\ldots$ & $\ldots$ & $\ldots$ & $\ldots$ \\
\hline Sweden & 56.7 & 33.5 & 18.4 & 19.3 & 16.8 & 11.4 & 0.1 & $\ldots$ & 0.0 & 0.4 \\
\hline Switzerland & 57.4 & 63.9 & 7.7 & 7.4 & 17.7 & 3.3 & 0.0 & 4.4 & 0.0 & $\ldots$ \\
\hline Turkey & 68.8 & $\ldots$ & $\ldots$ & $\ldots$ & $\ldots$ & $\ldots$ & $\ldots$ & $\ldots$ & $\ldots$ & $\ldots$ \\
\hline Ukraine & 41.4 & $\ldots$ & 0.7 & 4.4 & 40.0 & 54.6 & 0.2 & $\ldots$ & 0.0 & $\ldots$ \\
\hline UK: England \& Wales & $\ldots$ & $\ldots$ & $\ldots$ & $\ldots$ & $\ldots$ & $\ldots$ & $\ldots$ & $\ldots$ & $\ldots$ & $\ldots$ \\
\hline UK: Northern Ireland & $\ldots$ & $\ldots$ & $\ldots$ & $\ldots$ & $\ldots$ & $\ldots$ & $\ldots$ & $\ldots$ & $\ldots$ & $\ldots$ \\
\hline UK: Scotland & $\ldots$ & $\ldots$ & $\ldots$ & $\ldots$ & $\ldots$ & $\ldots$ & $\ldots$ & $\ldots$ & $\ldots$ & $\ldots$ \\
\hline Mean & 63.8 & 19.4 & 11.1 & 26.3 & 34.6 & 16.6 & 0.5 & 8.4 & 0.1 & 0.2 \\
\hline Median & 61.5 & 5.3 & 7.5 & 19.4 & 24.5 & 11.4 & 0.1 & 4.9 & 0.0 & 0.2 \\
\hline Minimum & 6.3 & 0.1 & 0.7 & 3.9 & 5.5 & 0.9 & 0.0 & 0.1 & 0.0 & 0.0 \\
\hline Maximum & 100.0 & 63.9 & 40.1 & 73.1 & 75.2 & 54.6 & 2.6 & 26.1 & 0.5 & 0.6 \\
\hline
\end{tabular}


Notes on tables 3.2.5.1 to 3.2.5.22

\begin{tabular}{|c|c|}
\hline Bulgaria & $\begin{array}{l}\text { Bulgaria: Custodial sanctions include both the suspended and unsuspended custodial sanctions. Sep- } \\
\text { arate statistics on the length of suspended custodial sanctions are not available. } \\
\text { Statistics in the category ' } 12 \text { months and less than } 24 \text { months' include statistics on custodial sanctions } \\
\text { of } 12 \text { months and less than } 36 \text { months. Statistics in the category ' } 24 \text { months and less than } 60 \text { months' } \\
\text { include statistics on custodial sanctions of } 36 \text { months and less than } 60 \text { months. }\end{array}$ \\
\hline Finland & $\begin{array}{l}\text { Finland: In this table, some crime categories include more offence types due to different grouping in } \\
\text { data sources. }\end{array}$ \\
\hline France & $\begin{array}{l}\text { France: Only for Robbery statistics in the category ' } 12 \text { months and less than } 24 \text { months' include sta- } \\
\text { tistics on custodial sanctions of } 12 \text { months and less than } 36 \text { months, statistics in the category ' } 24 \\
\text { months and less than } 60 \text { months' include statistics on custodial sanctions of } 36 \text { months and less than } \\
60 \text { months. }\end{array}$ \\
\hline Poland & Poland: In category "12 months and less 24 months" Polish data refers to 12-24 months (Incl.). \\
\hline Serbia & $\begin{array}{l}\text { Serbia: Data refer only to the length of the prison sentence imposed to adult offenders by an irrevo- } \\
\text { cable court verdict. The data do not include the length of the juvenile prison and institutional educa- } \\
\text { tional measures for minors. }\end{array}$ \\
\hline Switzerland & Switzerland: Data refer to adults only. \\
\hline
\end{tabular}

3.2.6 Persons held in pre-trial detention (at least temporarily) among persons convicted in 2015

Table 3.2.6 Persons held in pre-trial detention (at least temporarily) among persons convicted in 2015 - Criminal offences: Total

\begin{tabular}{lrr} 
& Total of persons convicted & \multicolumn{2}{c}{$\begin{array}{l}\text { of which: \% held in pre-trial detention } \\
\text { (at least temporarily) }\end{array}$} \\
\hline Czech Republic & 622 & 5.1 \\
Finland & 3321 & 1.2 \\
France & 864 & 5.6 \\
Georgia & 256 & 10.6 \\
Germany & 1137 & 2.9 \\
Poland & 737 & 2.1 \\
Serbia & 465 & 12.2 \\
Switzerland & 1505 & 22.0 \\
UK: England \& Wales & 2158 & 0.9 \\
\hline
\end{tabular}


3.2.7 Judges in criminal courts per 100000 population - 2015

Table 3.2.7.1 Judges in criminal courts per 100000 population - 2015

\begin{tabular}{|c|c|c|c|c|c|c|}
\hline & \multicolumn{3}{|c|}{ Continental law countries } & \multicolumn{3}{|c|}{ Common law countries } \\
\hline & $\begin{array}{l}\text { Number of } \\
\text { professional } \\
\text { judges: Total } \\
\text { per } 100000 \\
\text { pop }\end{array}$ & $\begin{array}{l}\text { of which: \% } \\
\text { of criminal } \\
\text { court judges }\end{array}$ & $\begin{array}{l}\text { Number of } \\
\text { lay judges (in } \\
\text { criminal } \\
\text { courts) per } \\
100000 \text { pop }\end{array}$ & $\begin{array}{l}\text { Number of } \\
\text { professional } \\
\text { judges: Total } \\
\text { per } 100000 \\
\text { pop }\end{array}$ & $\begin{array}{l}\text { Number of } \\
\text { Magistrates } \\
\text { per } 100000 \\
\text { pop }\end{array}$ & $\begin{array}{l}\text { Number of } \\
\text { Clerks per } \\
100000 \text { pop }\end{array}$ \\
\hline Albania & & $\ldots$ & $\ldots$ & $\ldots$ & $\ldots$ & $\ldots$ \\
\hline Armenia & 7.7 & $\ldots$ & $\ldots$ & $\ldots$ & $\ldots$ & $\ldots$ \\
\hline Austria & $\ldots$ & $\ldots$ & $\ldots$ & $\ldots$ & $\ldots$ & $\ldots$ \\
\hline Azerbaijan & 5.3 & $\ldots$ & $\ldots$ & $\ldots$ & $\ldots$ & $\ldots$ \\
\hline Belgium & $\ldots$ & $\ldots$ & $\ldots$ & $\ldots$ & $\ldots$ & $\ldots$ \\
\hline Bosnia-Herzegovina & $\ldots$ & $\ldots$ & $\ldots$ & $\ldots$ & $\ldots$ & $\ldots$ \\
\hline Bulgaria & 33.7 & 15.1 & $\ldots$ & $\ldots$ & $\ldots$ & $\ldots$ \\
\hline Croatia & 44.5 & $\ldots$ & $\cdots$ & $\cdots$ & $\ldots$ & $\cdots$ \\
\hline Cyprus & & $\ldots$ & $\ldots$ & $\ldots$ & $\ldots$ & $\ldots$ \\
\hline Czech Republic & 28.7 & 25.2 & $\ldots$ & $\ldots$ & $\cdots$ & $\ldots$ \\
\hline Denmark & & $\ldots$ & $\ldots$ & $\ldots$ & $\ldots$ & $\ldots$ \\
\hline Estonia & 17.5 & $\ldots$ & $\ldots$ & $\ldots$ & $\ldots$ & $\ldots$ \\
\hline Finland & $\ldots$ & $\ldots$ & $\ldots$ & $\ldots$ & $\ldots$ & $\ldots$ \\
\hline France & 11.1 & $\ldots$ & $\ldots$ & $\ldots$ & $\ldots$ & $\ldots$ \\
\hline Georgia & 10.2 & 35.5 & $\ldots$ & $\ldots$ & $\ldots$ & $\ldots$ \\
\hline Germany & 25.0 & 20.6 & 47.3 & $\ldots$ & $\ldots$ & $\ldots$ \\
\hline Hungary & 29.4 & 35.8 & $\ldots$ & $\ldots$ & $\ldots$ & $\ldots$ \\
\hline Iceland & $\ldots$ & $\ldots$ & $\ldots$ & $\ldots$ & $\ldots$ & $\ldots$ \\
\hline Italy & $\ldots$ & $\ldots$ & $\ldots$ & $\ldots$ & $\ldots$ & $\ldots$ \\
\hline Kosovo (UN R/1244/99) & $\ldots$ & $\ldots$ & $\ldots$ & $\ldots$ & $\ldots$ & $\ldots$ \\
\hline Latvia & 21.9 & $\ldots$ & $\ldots$ & $\ldots$ & $\ldots$ & $\ldots$ \\
\hline Lithuania & 26.1 & $\ldots$ & $\ldots$ & $\ldots$ & $\ldots$ & $\ldots$ \\
\hline Luxembourg & $\ldots$ & $\ldots$ & $\ldots$ & $\ldots$ & $\ldots$ & $\ldots$ \\
\hline Moldova & 12.2 & $\ldots$ & $\ldots$ & $\ldots$ & $\ldots$ & $\ldots$ \\
\hline Montenegro & $\ldots$ & $\ldots$ & $\ldots$ & $\ldots$ & $\ldots$ & $\ldots$ \\
\hline Netherlands & 13.8 & $\ldots$ & $\ldots$ & $\ldots$ & $\ldots$ & $\ldots$ \\
\hline North Macedonia & $\ldots$ & $\ldots$ & $\ldots$ & $\ldots$ & $\ldots$ & $\ldots$ \\
\hline Norway & 16.9 & $\ldots$ & $\ldots$ & $\ldots$ & $\ldots$ & $\ldots$ \\
\hline Poland & 25.4 & 38.0 & $\ldots$ & $\ldots$ & $\ldots$ & $\ldots$ \\
\hline Portugal & 13.1 & $\ldots$ & $\ldots$ & $\ldots$ & $\ldots$ & $\ldots$ \\
\hline Romania & $\ldots$ & $\ldots$ & $\ldots$ & $\ldots$ & $\ldots$ & $\ldots$ \\
\hline Russian Federation & $\ldots$ & $\ldots$ & $\ldots$ & $\ldots$ & $\ldots$ & $\ldots$ \\
\hline Serbia & 38.7 & $\ldots$ & $\ldots$ & $\ldots$ & $\ldots$ & $\ldots$ \\
\hline Slovak Republic & $\ldots$ & $\ldots$ & $\ldots$ & $\ldots$ & $\ldots$ & $\ldots$ \\
\hline Slovenia & $\ldots$ & $\ldots$ & $\ldots$ & $\ldots$ & $\ldots$ & $\ldots$ \\
\hline Spain & 11.5 & 6.8 & & $\ldots$ & $\ldots$ & $\ldots$ \\
\hline Sweden & 11.7 & 69.7 & 4.7 & $\ldots$ & $\ldots$ & $\ldots$ \\
\hline Switzerland & $\ldots$ & $\ldots$ & $\ldots$ & $\ldots$ & $\ldots$ & $\ldots$ \\
\hline Turkey & 9.9 & $\ldots$ & $\ldots$ & $\ldots$ & $\ldots$ & $\ldots$ \\
\hline Ukraine & 18.7 & $\ldots$ & $\ldots$ & $\ldots$ & $\ldots$ & $\ldots$ \\
\hline UK: England \& Wales & $\ldots$ & $\ldots$ & $\ldots$ & 5.6 & 33.9 & $\ldots$ \\
\hline UK: Northern Ireland & $\ldots$ & $\ldots$ & $\ldots$ & 3.2 & 7.2 & 21.2 \\
\hline UK: Scotland & $\ldots$ & $\ldots$ & $\ldots$ & 4.9 & $\ldots$ & $\ldots$ \\
\hline Mean & 19.7 & 30.8 & 26.0 & 4.6 & 20.6 & 21.2 \\
\hline Median & 17.2 & 30.4 & 26.0 & 4.9 & 20.6 & 21.2 \\
\hline Minimum & 5.3 & 6.8 & 4.7 & 3.2 & 7.2 & 21.2 \\
\hline Maximum & 44.5 & 69.7 & 47.3 & 5.6 & 33.9 & 21.2 \\
\hline
\end{tabular}

Notes on tables 3.2.6 and 3.2.7

Netherlands The number of judges refers to 2016.

Portugal Includes judges in first instance common courts only. 


\subsection{Technical information}

\subsubsection{Technical comments}

\section{What is recorded?}

Next to court convictions, the conviction statistics in this chapter include sanctions imposed by the prosecutor (or by the court, but on application of the prosecutor and without a formal court hearing) that lead to a formal verdict and count as a conviction (e.g., penal order, Strafbefebl) in 11 countries: Austria, Denmark, Finland, France, Germany, Italy, Lithuania, Romania, Sweden, Switzerland, and UK: Scotland. All countries except France and UK: England \& Wales exclude sanctions imposed by the prosecutor that do not lead to a formal verdict and do not count as a conviction (e.g., conditional disposals).

Only Denmark includes sanctions/measures imposed by the police as convictions. Both the principal offence and the principal sanction rule are applied in most countries. Recording is based on the main conviction.

Most countries have written rules regarding the way they record sanctions and measures, except Belgium, Cyprus, Denmark, Italy, Latvia, Montenegro, and Slovenia.

\section{Differences between Chapters 1 and 3 with regard to offence definitions}

The offence definitions used in Chapter 1 reflect the definitions that are used in the national police statistics. They are usually based on concepts that are close to everyday life experience, e.g., theft by means of burglary, armed robbery, and car theft.

On the other hand, the definitions used for convictions reflect different legal traditions and criminal codes. For this reason, in some countries there are no separate conviction statistics for some offences, such as car theft, drug trafficking, theft by means of burglary, robbery, and sexual abuse of minors.

\section{Differences in convictions and sanctions/measures}

Countries have different rules for counting sanctions and measures and non-custodial sanctions.

The sentence length of unsuspended custodial sanctions and measures imposed upon adults or minors in many countries differs from the standard used in this publication. In addition, the time of publication of the statistics varies among countries. Romania provided figures for 2016 instead of 2015. 


\subsubsection{Minors in conviction statistics}

Age brackets used in the Tables

All countries count minors as persons who are under 18 years. The exception is Poland where only those under 17 years are included.

The lower limit varies widely among countries as far as criminal responsibility is concerned. Persons below the age of criminal responsibility will not be convicted and therefore not counted in convictions statistics (regardless of the 'civil' or administrative treatment or sanction they will actually receive). This was not necessarily the case for police statistics where persons below the age of criminal responsibility were sometimes included (for details see Table 1.3.3).

For the offences considered here, the following age limits were indicated. For the countries not in this table, the same minimum age is used as in chapter 1.

Table 3.3.1 Minimum age for consideration in conviction statistics 2015 Minimum age

\begin{tabular}{lr}
\hline Armenia & 14 \\
Azerbaijan & 14 \\
Belgium & 16 \\
Cyprus & 14 \\
Czech Republic & 15 \\
Denmark & 15 \\
Finland & 15 \\
Georgia & 14 \\
Germany & 14 \\
Hungary & 12 \\
Netherlands & 12 \\
Poland & 15 \\
Slovenia & 14 \\
\hline
\end{tabular}

The transition from the status of minor to adult raises difficult legal and statistical questions as to how a person is treated who, having committed an offence as a minor, is dealt with in court once they have reached the age of adulthood. Some countries apply rules for minors, and count them as such, whereas others treat and count them as adults. For example, in Germany young adults aged 18-20 years are often sanctioned according to juvenile law so that this age group is partially included in the sentencing tables for minors and partially in adults. 


\subsection{Sources}

\begin{tabular}{|c|c|}
\hline Austria & $\begin{array}{l}\text { Statistics Austria- STATCUBE: http://www.statistik.at/web_de/services/statcube/index.html } \\
\text { Service Public Fédéral Justice - Direction générale, }\end{array}$ \\
\hline \multirow[t]{2}{*}{ Belgium } & $\begin{array}{l}\text { Législation, Libertés et Droits fondamentaux - Direction Droit pénal - Service de la Politique criminelle : } \\
\text { Casier judiciaire central, données non publiées. } \\
\text { Source: National Statistical Institute: Crimes, Accused and Persons Convicted 2011-2016, available } \\
\text { only in Bulgarian at: } \\
\text { https://infostat.nsi.bg/infostat/pages/module.jsf?x_2=56 }\end{array}$ \\
\hline & $\begin{array}{l}\text { National Statistical Institute, Crimes and Persons Convicted 2015, available at: } \\
\text { http://www.nsi.bg/sites/default/files/files/publications/CRIMES2015.pdf }\end{array}$ \\
\hline Bulgaria & $\begin{array}{l}\text { Source related to the figures concerning "aggravated bodily injury", "sexual abuse of a child", "aggra- } \\
\text { vated theft" and "money laundering": Supreme Judicial Council, Activities of the Courts: Annual Sum- } \\
\text { marised Statistical Tables 2011-2016, available only in Bulgarian at: http://www.vss.jus- } \\
\text { tice.bg/page/view/1082 }\end{array}$ \\
\hline Cyprus & $\begin{array}{l}\text { Ministry of Finance, Statistical Service, available online: } \\
\text { https://www.mof.gov.cy/mof/cystat/statistics.nsf/populationcondition_27main_n/ } \\
\text { populationcondition_27main_en?OpenForm\&sub=7\&sel=2 }\end{array}$ \\
\hline \multirow{2}{*}{ Czech Republic } & Central Information System for Statistical Lists and Reporting of the Ministry of Justice \\
\hline & Statistical sheet, overview No. 2, counting unit a person \\
\hline Denmark & Tables bought by the Ministry of justice at Statistics Denmark \\
\hline Finland & $\begin{array}{l}\text { Statistics Finland, Syytetyt, tuomitut ja rangaistukset } 7.8 .2018 \\
\text { http://pxnet2.stat.fi/PXWeb/pxweb/fi/StatFin/StatFin_oik_syyttr/ } \\
\text { Report of Supreme Court of Georgia 201-2016 }\end{array}$ \\
\hline Georgia & $\begin{array}{l}\text { The judiciary in Georgia - statistical data for the year 2015, "Dynamic of quantity of convicted minors } \\
\text { according to the types of crimes- } \\
\text { National Office for the Judiciary - Database of juvenile and adult convicts, acquitted or other accused }\end{array}$ \\
\hline Hungary & $\begin{array}{l}\text { persons with definitive sentences } \\
\text { Hungarian Prison Service Headquarters, Department of Central Transfer and Registry }\end{array}$ \\
\hline Iceland & Annual reports for the years 2009-2016 from the Prison and Probation Administration \\
\hline Italy & Italian Institute of statistics - http://www.istat.it - Ministry of Justice. Department of Statistics \\
\hline Latvia & The Court Administration \\
\hline Lithuania & $\begin{array}{l}\text { Data provided by National Courts Administration upon request. Statistics were collected from two pro- } \\
\text { duced reports: 1) Report on the Criminal Proceedings. Types of sanctions and amnesty application (I } \\
\text { Instance Courts), and 2) Report on the Criminal Proceedings. Persons (I Instance Courts). Data is not } \\
\text { accessible publicly. }\end{array}$ \\
\hline Netherlands & Ministry of Justice / WODC \\
\hline Poland & Ministry of Justice, Department of Statistics. \\
\hline Portugal & $\begin{array}{l}\text { Directorate-General for Justice Policy - Ministry of Justice } \\
\text { Superior Council of Magistracy (www.csm1909.ro }) \text { - Human Resources and Organization Office, Statis- }\end{array}$ \\
\hline Romania & $\begin{array}{l}\text { tics Bureau (Directia Resurse Umane si Organizare - Serviciul de Formare Profesionala si Statistica } \\
\text { Judiciara) }\end{array}$ \\
\hline Serbia & Statistical Office of The Republic of Serbia / SORS \\
\hline Spain & National Institute of Statistics (INE) \\
\hline North Macedonia & State Statistical Office \\
\hline Turkey & $\begin{array}{l}\text { Ministry of Justice, General Directorate for Judicial Records and Statistics. } \\
\text { Judicial Statistics Archive http://www.adlisicil.adalet.gov.tr/en/statarchive2.html } \\
\text { http://www.justice.gov.uk/statistics/criminal-justice/criminal-justice-statistics }\end{array}$ \\
\hline UK: England \& Wales & $\begin{array}{l}\text { The data have been obtained by using pivot table analysis from the tool available on this web site. } \\
\text { Addition of Tables A3.4 and A3.6 from annual published statistical bulletin. } \\
\text { The Scottish Government Justice Statistics Unit Criminal proceedings in Scottish courts to be found at } \\
\text { https://beta.gov.scot/publications/criminal-proceedings-scotland-2015-16/pages/11/ }\end{array}$ \\
\hline & The Scottish Government Justice Analytical Services Criminal proceedings in Scottis \\
\hline
\end{tabular}





\section{Prison Statistics}

\subsection{General Comments}

\subsubsection{Introduction}

This chapter provides indicators of the use of imprisonment across Europe. These include the annual number of entries into penal institutions (prisons or any other detention facility) and the annual number of releases from them during the years 2011 to 2016 (known respectively as the flow of entries and the flow of releases), as well as the number of persons actually held in these institutions on $1^{\text {st }}$ September of each of these years (stock of inmates) and the staff working in them on $1^{\text {st }}$ September 2016. Inmates include pre-trial detainees and sentenced prisoners, and the latter are also presented according to the offence for which they were convicted. Further information on the use of imprisonment can be found in the Council of Europe Annual Penal Statistics (SPACE) available online at www.unil.ch/space.

Prisons are placed near the end of the criminal justice process, but pre-trial detention can take place near the beginning of it, which implies that the relationship between prison population rates (number of inmates per 100,000 population) and crime rates is indirect and complex. This relationship exists because, in a democratic society, only suspects or persons prosecuted or convicted for a crime can be deprived of freedom; however, the actual number of inmates is primarily influenced by the efficiency of a criminal justice system (the percentage of cases solved or 
clearance rate, the length of the procedures, etc.) and its punitiveness, which can be measured by the length of the sentences imposed and actually served. Research suggests that high prison population rates (number of inmates per 100,000 population) tend to be correlated with long lengths of imprisonment and high homicide rates, but not necessarily with large numbers of entries ${ }^{30}$.

In addition, cross-national comparisons of prison populations are not as straightforward as they may seem because there are differences across countries regarding the categories of persons included under the total number of persons held in penal institutions. For example, some countries include minors and others do not include them, and the same is true for mentally ill offenders held in psychiatric institutions or persons held as fine defaulters. Basic information on such differences is presented under the heading Technical information (4.3).

Some countries have more than one Prison Administration. That is the case the United Kingdom, whose data is presented separately for (a) England and Wales, (b) Northern Ireland, and (c) Scotland. Spain has two prison administrations (The State Administration and Catalonia), but both are presented together in the Tables of this chapter. Bosnia and Herzegovina has three prison administrations, but the few data available are presented together; the metadata, on the contrary, corresponds to the rules applied in the Republika Srpska.

\section{The 'stock' and 'flow' perspectives}

Generally speaking, data on prison populations can be described from two perspectives, which generate different but equally important results. The first perspective refers to 'how many persons are held in penal institutions on a given day' (stock). The second perspective refers to 'how many persons have been admitted into penal institutions during the course of the year' (flow of entries) and to 'how many people have left penal institutions during the course of the year' (flow of exits). Both perspectives are also interrelated, in such a way that the stock of inmates on $1^{\text {st }}$ September of a given year is influenced by the flows of entries and releases during that year, but also by the number of persons that entered into penal institutions during the previous years and are still deprived of freedom. For example, an inmate that serves ten years of imprisonment will be counted as an entry during the first year, but will appear in the stock of inmates every year during the next decade. This is a major difference with most of the data presented in the first three chapters of the Sourcebook, which usually correspond to a flow perspective (for example, the annual number of offences recorded by the police, of cases treated by the prosecution services, or of persons convicted).

\footnotetext{
30 Aebi, M.F., Linde, A. \& Delgrande, N. (2015). Is There a Relationship Between Imprisonment and Crime in Western Europe? European Journal on Criminal Policy and Research, 21(3): 425-446.
} 
Regarding prison populations, the following data were requested:

- Number of persons held in penal institutions on 1 September 2011 to 2016: stock of inmates (including pre-trial detainees and sentenced prisoners) and its breakdown in the following categories: pre-trial detainees, women, minors, foreigners, and the subcategory of foreigners who are EU citizens (see Tables 4.2.1).

- Convicted prison population on 1 September 2015: stock of sentenced prisoners (i.e., excluding pre-trial detainees) and its breakdown by the type of offence for which the prisoner was convicted: major road traffic offences; intentional homicide (including attempts); bodily injury and its subcategory aggravated bodily injury; sexual assault and its subcategories rape and sexual abuse of a child; robbery; theft; and drug offences (see Tables 4.2.2.1 and 4.2.2.2).

- The convicted prison population on $1^{\text {st }}$ September 2015 for each of the offences listed above is also broken down into the following sub-categories: pre-trial detainees, women, minors, foreigners, and the subcategory of foreigners who are EU citizens (see Tables 4.2.2.3-4.2.2.14).

- Annual number of entries into penal institutions during the years 2011 to 2016: flow of entries (including entries of pre-trial detainees and entries of sentenced prisoners) and its breakdown in the following categories: entries of pre-trial detainees, of women, of minors, of foreigners, and the subcategory of EU citizens among foreigners (see Tables 4.2.3). The counting unit is the person entering a penal institution but, as the same person can be counted multiple times if (s)he is admitted in institutions more than once during the same year, this indicator is referred to as the flow of entries (instead of the flow of persons entering penal institutions).

- Annual number of exits from penal institutions during the years 2011 to 2016: flow of exits (including exits of pre-trial detainees and exits of sentenced prisoners) and its breakdown in two main categories: releases and deaths. For the deaths, it was also required to indicate those that were due to suicides as well as the subcategory of suicides in pretrial detention. Regarding releases, it was required to provide their breakdown in the following categories: releases of pre-trial detainees, releases of sentenced prisoners, transfers to another country and its subcategory of transfers to an EU country (see Tables 4.2.4). As in the case of entries, the counting unit is the person released from a penal institution but, as the same person can be counted multiple times if (s)he is released more than once during the same year, this indicator is referred to as the flow of releases and, consequently, the overarching category is referred to as the flow of exits.

- Prison staff including a distinction among those employed by the prison administration and those not employed by it. The latter category has gained in importance since the 1980s as some tasks that were traditionally performed by persons employed by the prison administrations (perimeter 
guards, cleaning personnel, persons responsible for workshops or vocational training) are currently performed by private companies in some countries, and also by the rise of private prisons, mainly in the United Kingdom, and prisons working in public private partnership.

\subsubsection{Quality of the data}

Most of the prison data included in this edition of the European Sourcebook come from the Council of Europe Annual Penal Statistics (SPACE) ${ }^{31}$. The data validation procedure did not reveal inconsistencies, which can partly be due to the fact that the SPACE data for the period 2005 to 2015 had been consolidated in the framework of a project funded by the European Union and the Council of Europe ${ }^{32}$. In that context, it was also decided to change the date of reference for stock indicators from 1 September to 31 January in order to allow faster publication of the SPACE annual reports. A collateral effect of that change is that flow data for the year 2016 were not collected. As a consequence, whenever such data are included in the following Tables, they have been estimated using linear interpolation from the data for the years 2015 and 2017, and they are presented in grey coloured cells.

\subsubsection{Results}

\section{Cross-sectional analysis}

On $1^{\text {st }}$ September 2016, the average European prison population rate was 139 inmates per 100,000 population, but there are considerable differences across countries. In particular, the rates range from 37 inmates per 100000 population in Iceland to 444 in the Russian Federation. In general, the lowest prison population rates (less than 75 inmates per 100,000 inhabitants) are distributed across the Scandinavian countries, the Netherlands, Slovenia, and Croatia, while the highest (more than 225 inmates per 100,000 inhabitants) are found in Azerbaijan, Lithuania, Turkey, Georgia, and the Russian Federation.

Roughly $20 \%$ of the inmates are not serving a final sentence and can thus be considered as pre-trial detainees, who are also known as detainees on remand. Although intuitively one may hypothesize that a large percentage of pre-trial detainees may contribute to increase artificially the prison population rate, data show that this is not necessarily the case. The Nordic countries have very low prison population rates, but roughly one fourth of their inmates are pre-trial detainees, and the

\footnotetext{
31 See www.unil.ch/space.

32 Aebi, M.F., Berger-Kolopp, L., Burkhardt, C. \& Tiago, M.M. (2019). Prisons in Europe: 2005-2015.

Volume 1: Country Profiles. Strasbourg: Council of Europe Publishing (Vol. 1: Country profiles; Vol. 2: Sourcebook of Prison Statistics); Aebi, M.F., Berger-Kolopp, L., Burkhardt, C., Chopin, J., Hashimoto, Y.Z. \& Tiago, M.M. (2019). Foreign offenders in prison and on probation in Europe: Trends from 2005 to 2015 (inmates) and situation in 2015 (inmates and probationers). Strasbourg: Council of Europe Publishing. Available in open access at www.unil.ch/space.
} 
Netherlands have the second lowest prison population of the continent, but one third of its inmates are pre-trial detainees.

The percentage of women in penal institutions remains very low (5\% on average), as it has been the case from the beginning of the Sourcebook series in 1990. In 2016, the highest percentages are found in Latvia (8.4\%), Malta (8.3\%) and Cyprus $(8,1 \%)$, while the lowest were in Albania (1.9\%), Georgia, $(2.8 \%)$ and North Macedonia (3\%).

The percentage of foreigners in penal institutions differs considerably across regions of the continent. In some Western and Mediterranean countries, it represents more than $25 \%$ of the prison population, while in Central and Eastern Europe it remains under $5 \%$ of it. These differences reflect diverse factors such as geographical location, economic development, and immigration policies. The highest percentages were found in Switzerland (72\%), Greece (55\%) and Austria (54\%), while the lowest (around 1\% or less) were in Georgia, Poland, Romania, and Moldova. Roughly one third of the foreigners held in European prisons come from member states of the European Union (EU). The highest percentages are found in other EU countries. For example, approximately three quarters of the foreign inmates held in Iceland, Ireland and Northern Ireland are EU citizens.

Minors (i.e., persons under the age of 18) do not usually enter the prison system and sometimes are not included in the total prison population (see the Technical information in chapter 4.3). When they are included, on average they account for about $1 \%$ of the prison populations.

\section{Trend analysis}

The period 2011 to 2016 is characterized by a decrease of prison population rates in the vast majority of European countries. This decrease takes place during the financial crisis that started in 2008, refuting thus the already classical hypothesis proposed by Rusche \& Kirchheimer - of a negative correlation between imprisonment and the state of the labour market. The state of the latter got worst across the continent but, instead of leading to an increase of prison population rates, that led to a decrease of imprisonment throughout the continent. As can be seen in Table 4.A, in 28 out of the 46 prison administrations that provided the necessary data, the 2016 prison population rate (stock) was more than $5 \%$ lower than in 2011 . In nine prison administrations the rates were comparable (the 2016 was up to $5 \%$ lower or higher than that of 2011), and only in nine prison administrations, the 2016 rate was more than $5 \%$ higher than that of 2011.

Similarly, in 28 out of the 35 prison administrations that provided the necessary data, the 2016 rate of entries (flow of entries) was more than 5\% lower than in 2011. In three prison administrations the rates were comparable (the 2016 flow of entries was up to $5 \%$ lower or higher than that of 2011), and only in four prison administrations, the 2016 flow of entries was more than 5\% higher than that of 2011. 
The decrease also concerned the rate of releases (flow of releases). In 20 out of the 30 prison administrations that provided the necessary data, the 2016 flow of releases was more than 5\% lower than in 2011. In three prison administrations the rates were comparable (the 2016 flow of releases was up to $5 \%$ lower or higher than that of 2011), and in seven prison administrations, the 2016 flow of entries was more than 5\% higher than that of 2011.

In times of decreasing prison population rates, the interpretation of changes in the percentages of specific categories of inmates is particularly hazardous. For example, if the number of foreign inmates decreases at a slower pace than that of national inmates, the percentage of the former will increase even if their absolute number is decreasing. Several examples of that pattern were found in an analysis of prison and probation rates in Europe from 2005 to 2015 (Aebi et al., 2019; quoted in the previous footnote). For that reason, the slight variations in the percentages of women (4.9\% in 2011 and 5.2\% in 2016) and foreign inmates $(16.4 \%$ in 2011 and $16.7 \%$ in 2016) should be considered as reflecting a relative stability in the composition of prison populations. 
Table 4.A Percentage change (2016 compared to 2011) for three key indicators of imprisonment

\begin{tabular}{|c|c|c|c|}
\hline & Stock (PPR) & Flow of entries & Flow of releases \\
\hline Albania & 28 & 114 & 51 \\
\hline Armenia & -6 & $\ldots$ & -34 \\
\hline Austria & -3 & -6 & -10 \\
\hline Azerbaijan & -7 & -4 & 37 \\
\hline Belgium & -4 & $\ldots$ & $\ldots$ \\
\hline Bosnia-Herzegovina & 13 & $\ldots$ & $\ldots$ \\
\hline Bulgaria & -13 & -22 & $\ldots$ \\
\hline Croatia & -37 & -36 & -34 \\
\hline Cyprus & -27 & -38 & -40 \\
\hline Czech Republic & -4 & -32 & -30 \\
\hline Denmark & -16 & -19 & -18 \\
\hline Estonia & -20 & -33 & -22 \\
\hline Finland & -7 & -13 & -14 \\
\hline France & -8 & 4 & 11 \\
\hline Georgia & -53 & -53 & 2 \\
\hline Germany & -12 & -16 & $\ldots$ \\
\hline Greece & -20 & $\ldots$ & $\ldots$ \\
\hline Hungary & 6 & -9 & 29 \\
\hline Iceland & -20 & -39 & -19 \\
\hline Ireland & -16 & -26 & -26 \\
\hline Italy & -20 & -40 & -39 \\
\hline Kosovo (UN R/1244/99) & 16 & $\ldots$ & $\ldots$ \\
\hline Latvia & -33 & $\ldots$ & $\ldots$ \\
\hline Lithuania & -22 & -17 & $\ldots$ \\
\hline Luxembourg & 0 & -20 & -13 \\
\hline Malta & -14 & 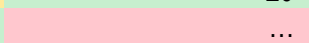 & \\
\hline Moldova & 21 & -49 & 145 \\
\hline Montenegro & -19 & 8 & -25 \\
\hline Netherlands & -26 & -14 & -16 \\
\hline Norway & 3 & -22 & -24 \\
\hline Poland & -13 & -12 & -12 \\
\hline Portugal & 11 & -13 & 13 \\
\hline Romania & -5 & -14 & 23 \\
\hline Russia & -18 & $\ldots$ & $\ldots$ \\
\hline Serbia & 0 & -21 & -24 \\
\hline Slovakia & -6 & 15 & -1 \\
\hline Slovenia & 2 & -32 & -35 \\
\hline Spain & -15 & -25 & -23 \\
\hline Sweden & -18 & $\ldots$ & $\ldots$ \\
\hline Switzerland & 8 & -5 & $\ldots$ \\
\hline North Macedonia & 32 & -6 & 1 \\
\hline Turkey & 46 & 119 & $\ldots$ \\
\hline Ukraine & -55 & $\ldots$ & $\ldots$ \\
\hline UK: England and Wales & -4 & 1 & $\ldots$ \\
\hline UK: Northern Ireland & -14 & -38 & -33 \\
\hline UK: Scotland & -9 & $\ldots$ & .. \\
\hline
\end{tabular}




\subsubsection{Recidivism}

As in previous editions, data on recidivism were not collected. The reason is that the European Sourcebook aims to provide data as comparable as possible for the largest possible number of countries, but that goal cannot be reached for recidivism studies yet, because the methodology applied to measure recidivism differs considerably from one country to another. Some countries simply count the number of inmates that had been previously incarcerated, which provides a weak measure of the concept. Some countries conduct a follow up of the inmates released from prisons, which provide a robust measure of recidivism. However, some Western European countries have a relatively large number of foreign inmates who, upon release, are expelled from the country, something that affects the validity of the recidivism measure. For that reason, there are countries that do not include foreigners when measuring recidivism, but that also affects the validity of the measure of recidivism. Furthermore, there are countries that conduct cohort studies in which they collect data on the imprisonment of all persons born in the country in a given year throughout their life. Similarly, a few countries have built up large databases of offender histories, which enable reconviction rates and criminal careers to be studied on a regular basis. At the same time, it must be mentioned that some countries measure recidivism through reincarceration while others measure it through reconviction, and that several countries do not make a distinction between specific recidivism (the new offence is the same or similar to the previous one) and general recidivism (reconviction or reincarceration for any kind of offence).

For all these reasons, only a brief account of some of the main methodological issues and some common features in the results from available reconviction studies are presented here.

In general, results depend heavily on the size of the sample under study, the characteristics of the offenders (are all offenders chosen or only special subgroups according to gender, age, prior conviction, type of offence, type of sanction, etc.?), the length of the follow-up period, and the definition of recidivism (reconviction or reincarceration? all offences or only specific offences?).

In fact, by choosing different offender characteristics, follow-up periods, or recidivism definitions, it is possible to increase or decrease artificially the recidivism rates. This means that readers must be particularly cautious when interpreting such rates, even within a single country, and even more so when comparing recidivism rates across countries. It is also important to keep in mind that recidivism rates are in fact "rates of recapture", which means that they depend on the efficiency of each criminal justice systems.

Although the magnitude of reconviction rates varies considerably between countries, there are some common features in the results, namely:

- Past criminal history is the most important predictor of recidivism. The highest recidivism rates are found among the offenders with the longest criminal history. 
- Reconviction rates are higher for men than for women. This is mostly explained by differences in criminal history, with men being convicted for violent offence much more often than women

- Younger persons tend to have higher recidivism rates than older persons.

- Recidivism rates are highest during the first year after release.

- There is no simple relationship between the seriousness of the offence and reconviction.

- There is no simple relationship between the first conviction and the subsequent offences.

- There is no simple relationship between the type of sentence and the recidivism rate

The SPACE website includes a page dedicated to recidivism studies: http://www3.unil.ch/wpmu/space/publications/recidivism-studies/ 


\subsection{Tables}

\subsubsection{Prison population: Stock of inmates on 1 September}

Table 4.2.1.1 Prison population rate per 100000 population (stock of inmates)

\begin{tabular}{|c|c|c|c|c|c|c|c|}
\hline & 2011 & 2012 & 2013 & 2014 & 2015 & 2016 & $\begin{array}{c}\% \text { change } \\
2011-2016\end{array}$ \\
\hline Albania & 160 & 168 & 172 & 188 & 207 & 206 & 28 \\
\hline Armenia & 138 & 144 & 162 & 137 & 129 & 130 & -6 \\
\hline Austria & 105 & 104 & 104 & 104 & 105 & 101 & -3 \\
\hline Azerbaijan & 255 & 228 & 217 & 238 & 252 & 236 & -7 \\
\hline Belgium & 107 & 111 & 114 & 118 & 114 & 103 & -4 \\
\hline Bosnia-Herzegovina & 72 & 75 & 80 & 78 & 83 & 81 & 13 \\
\hline Bulgaria & 134 & 130 & 121 & 109 & 105 & 117 & -13 \\
\hline Croatia & 119 & 111 & 102 & 89 & 79 & 74 & -37 \\
\hline Cyprus & 108 & 108 & 94 & 79 & 77 & 79 & -27 \\
\hline Czech Republic & 221 & 216 & 155 & 177 & 198 & 213 & -4 \\
\hline Denmark & 71 & 69 & 73 & 64 & 57 & 60 & -16 \\
\hline Estonia & 255 & 258 & 247 & 225 & 211 & 203 & -20 \\
\hline Finland & 61 & 59 & 58 & 57 & 55 & 57 & -7 \\
\hline France & 111 & 117 & 119 & 117 & 114 & 103 & -8 \\
\hline Georgia & 541 & 516 & 219 & 228 & 275 & 256 & -53 \\
\hline Germany & 89 & 84 & 80 & 81 & 78 & 78 & -12 \\
\hline Greece & 112 & 113 & 120 & 110 & 89 & 89 & -20 \\
\hline Hungary & 174 & 166 & 185 & 185 & 180 & 185 & 6 \\
\hline Iceland & 47 & 48 & 47 & 47 & 44 & 37 & -20 \\
\hline Ireland & 93 & 94 & 88 & 83 & 80 & 78 & -16 \\
\hline Italy & 113 & 111 & 105 & 88 & 86 & 90 & -20 \\
\hline Kosovo (UN R/1244/99) & 80 & 96 & 97 & 102 & 82 & 93 & 16 \\
\hline Latvia & 316 & 303 & 257 & 240 & 221 & 213 & -33 \\
\hline Lithuania & 311 & 334 & 324 & 305 & 275 & 244 & -22 \\
\hline Luxembourg & 126 & 126 & 134 & 119 & 118 & 126 & 0 \\
\hline Malta & 144 & 149 & 137 & 133 & 130 & 123 & -14 \\
\hline Moldova & 178 & 186 & 187 & 201 & 220 & 216 & 21 \\
\hline Montenegro & 214 & 198 & 184 & 170 & 177 & 174 & -19 \\
\hline Netherlands & 70 & 68 & 63 & 59 & 53 & 51 & -26 \\
\hline Norway & 72 & 71 & 72 & 73 & 71 & 74 & 3 \\
\hline Poland & 214 & 221 & 220 & 205 & 192 & 187 & -13 \\
\hline Portugal & 120 & 129 & 136 & 134 & 137 & 133 & 11 \\
\hline Romania & 148 & 159 & 165 & 159 & 144 & 141 & -5 \\
\hline Russian Federation & 542 & 498 & 474 & 467 & 446 & 444 & -18 \\
\hline Serbia & 151 & 153 & 140 & 144 & 141 & 151 & 0 \\
\hline Slovakia & 195 & 201 & 180 & 185 & 183 & 184 & -6 \\
\hline Slovenia & 62 & 67 & 66 & 74 & 68 & 63 & 2 \\
\hline Spain & 154 & 149 & 146 & 142 & 138 & 131 & -15 \\
\hline Sweden & 72 & 68 & 61 & 61 & 58 & 58 & -18 \\
\hline Switzerland & 77 & 83 & 88 & 85 & 84 & 83 & 8 \\
\hline North Macedonia & 122 & 123 & 138 & 151 & 169 & 162 & 32 \\
\hline Turkey & 174 & 183 & 191 & 208 & 229 & 255 & 46 \\
\hline Ukraine & 348 & 332 & 324 & 204 & 172 & 157 & -55 \\
\hline UK: England \& Wales & 152 & 152 & 147 & 149 & 149 & 146 & -4 \\
\hline UK: Northern Ireland & 94 & 98 & 100 & 101 & 91 & 81 & -14 \\
\hline UK: Scotland & 156 & 153 & 149 & 147 & 144 & 142 & -9 \\
\hline Mean & 160 & 159 & 149 & 144 & 142 & 139 & \\
\hline Median & 130 & 129 & 136 & 134 & 130 & 128 & \\
\hline Minimum & 47 & 48 & 47 & 47 & 44 & 37 & \\
\hline Maximum & 542 & 516 & 474 & 467 & 446 & 444 & \\
\hline
\end{tabular}

Note: Ukraine: Since 2014, figures do not include inmates held in Crimea and Sebastopol and in areas of Donetsk and Luhansk (areas that held more than one third of the prisons of the country) that are not under the control of the Ukrainian authorities. 
Table 4.2.1.2 Percentage of pre-trial detainees in the prison population

\begin{tabular}{|c|c|c|c|c|c|c|c|}
\hline & 2011 & 2012 & 2013 & 2014 & 2015 & 2016 & $\begin{array}{c}\% \text { change } \\
2011-2016\end{array}$ \\
\hline Albania & 40 & 41 & 40 & 33 & 31 & 50 & 27 \\
\hline Armenia & 27 & 25 & 36 & 28 & 27 & 32 & 20 \\
\hline Austria & 20 & 21 & 21 & 21 & 23 & 20 & 2 \\
\hline Azerbaijan & 73 & 14 & 18 & 17 & 18 & & \\
\hline Belgium & 23 & 22 & 21 & 20 & 21 & 23 & 0 \\
\hline Bosnia-Herzegovina & 15 & 12 & 12 & 13 & 15 & 16 & 8 \\
\hline Bulgaria & 24 & 16 & 9 & 9 & 9 & 11 & -55 \\
\hline Croatia & 18 & 16 & 22 & 22 & 22 & 25 & 41 \\
\hline Cyprus & 38 & 40 & 42 & 15 & 17 & 17 & -56 \\
\hline Czech Republic & 11 & 10 & 14 & 12 & 9 & 8 & -23 \\
\hline Denmark & 28 & 29 & 30 & 30 & 29 & 27 & -2 \\
\hline Estonia & 23 & 24 & 24 & 20 & 22 & 23 & -1 \\
\hline Finland & 20 & 20 & 19 & 21 & 20 & 18 & -11 \\
\hline France & 23 & 22 & 21 & 22 & 24 & 26 & 15 \\
\hline Georgia & 7 & 5 & 14 & 16 & 14 & 15 & 121 \\
\hline Germany & 15 & 17 & 17 & 17 & 18 & 18 & 16 \\
\hline Greece & 34 & 34 & 23 & 22 & 24 & 24 & -28 \\
\hline Hungary & 28 & 30 & 29 & 28 & 24 & 22 & -20 \\
\hline Iceland & 4 & 13 & 6 & 5 & 10 & 12 & 200 \\
\hline Ireland & 14 & 12 & 14 & 15 & 16 & 16 & 10 \\
\hline Italy & 20 & 19 & 18 & 18 & 16 & 17 & -16 \\
\hline Kosovo (UN R/1244/99) & 43 & 44 & 32 & 31 & 25 & 25 & -41 \\
\hline Latvia & 27 & 27 & 24 & 25 & 25 & 9 & -65 \\
\hline Lithuania & 12 & 12 & 11 & 10 & 8 & 9 & -22 \\
\hline Luxembourg & 38 & 39 & 45 & 43 & 43 & 47 & 25 \\
\hline Malta & 30 & 29 & 23 & 30 & 30 & 24 & -21 \\
\hline Moldova & 21 & 21 & 23 & 21 & 20 & 21 & 2 \\
\hline Montenegro & 20 & 23 & 22 & 30 & 30 & 31 & 51 \\
\hline Netherlands & 49 & 48 & 46 & 43 & 43 & 33 & -32 \\
\hline Norway & 25 & 27 & 29 & 27 & 27 & 26 & 4 \\
\hline Poland & 11 & 9 & 8 & 9 & 6 & 7 & -30 \\
\hline Portugal & 15 & 14 & 13 & 11 & 12 & 12 & -15 \\
\hline Romania & 12 & 11 & 11 & 8 & 8 & 8 & -31 \\
\hline Russian Federation & 15 & 16 & 17 & 17 & 18 & 17 & 16 \\
\hline Serbia & 27 & 25 & 19 & 91 & 15 & 16 & -40 \\
\hline Slovakia & 13 & 12 & 12 & 13 & 14 & 14 & 8 \\
\hline Slovenia & 25 & 24 & 19 & 18 & 17 & 16 & -39 \\
\hline Spain & 17 & 16 & 15 & 13 & 13 & 13 & -20 \\
\hline Sweden & 24 & 25 & 25 & 26 & 25 & 26 & 8 \\
\hline Switzerland & 28 & 31 & 30 & 27 & 27 & 25 & -10 \\
\hline North Macedonia & 4 & 3 & 4 & 7 & 7 & 7 & 65 \\
\hline Turkey & 28 & 23 & 20 & 14 & 15 & 36 & 30 \\
\hline Ukraine & 24 & 21 & & 20 & $\ldots$ & & \\
\hline UK: England \& Wales & 15 & 13 & 13 & 14 & 14 & 10 & -33 \\
\hline UK: Northern Ireland & 38 & 37 & 32 & 30 & 29 & 29 & -23 \\
\hline UK: Scotland & 19 & 19 & 19 & 21 & 21 & 18 & -9 \\
\hline Mean & 24 & 22 & 21 & 22 & 20 & 20 & \\
\hline Median & 23 & 21 & 20 & 20 & 20 & 18 & \\
\hline Minimum & 4 & 3 & 4 & 5 & 6 & 7 & \\
\hline Maximum & 73 & 48 & 46 & 91 & 43 & 50 & \\
\hline
\end{tabular}


4 Prison Statistics

Table 4.2.1.3 Percentage of women in the prison population

\begin{tabular}{|c|c|c|c|c|c|c|c|}
\hline & 2011 & 2012 & 2013 & 2014 & 2015 & 2016 & $\begin{array}{c}\% \text { change } \\
2011-2016\end{array}$ \\
\hline Albania & 1.8 & 1.8 & 1.8 & 1.6 & 2.0 & 1.9 & 7 \\
\hline Armenia & 4.3 & 4.3 & 4.5 & 4.8 & 4.4 & 4.0 & -5 \\
\hline Austria & 6.5 & 6.6 & 6.3 & 6.1 & 5.9 & 5.5 & -16 \\
\hline Azerbaijan & 2.9 & 2.4 & 2.7 & 2.8 & 2.9 & 3.1 & 10 \\
\hline Belgium & 4.2 & 4.6 & 4.2 & 4.6 & 5.0 & 4.3 & 4 \\
\hline Bosnia-Herzegovina & 2.4 & 2.3 & 2.3 & & & & 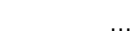 \\
\hline Bulgaria & 3.3 & 3.2 & 3.0 & 3.3 & 3.2 & 3.1 & -7 \\
\hline Croatia & 4.9 & 4.4 & 4.5 & 5.0 & 4.9 & 4.0 & -20 \\
\hline Cyprus & 5.7 & 5.7 & 5.5 & 6.2 & 6.1 & 8.1 & 41 \\
\hline Czech Republic & 6.4 & 6.4 & 5.6 & 6.3 & 6.9 & 7.3 & 13 \\
\hline Denmark & 4.2 & 3.9 & 4.6 & 4.0 & 3.7 & 4.4 & 5 \\
\hline Estonia & 5.4 & 5.2 & 5.0 & 5.3 & 5.2 & 5.5 & 2 \\
\hline Finland & 7.5 & 7.2 & 7.3 & 8.0 & 7.6 & 7.5 & 0 \\
\hline France & 3.5 & 3.5 & 3.5 & 3.7 & 2.8 & 3.3 & -5 \\
\hline Georgia & 5.0 & 5.1 & 3.3 & 2.2 & 3.1 & 2.8 & -44 \\
\hline Germany & 5.5 & 5.7 & 5.6 & 5.7 & 5.9 & 5.9 & 6 \\
\hline Greece & 4.5 & 4.5 & 5.2 & 4.8 & 5.4 & 5.3 & 18 \\
\hline Hungary & 7.0 & 7.6 & 7.6 & 7.7 & 7.4 & 7.4 & 5 \\
\hline Iceland & 5.4 & 8.6 & 3.3 & 1.9 & 4.1 & 6.5 & 20 \\
\hline Ireland & 3.3 & 3.7 & 4.0 & 3.8 & 3.4 & 3.9 & 18 \\
\hline Italy & 4.2 & 4.3 & 4.3 & 4.3 & 4.0 & 4.2 & 0 \\
\hline Kosovo (UN R/1244/99) & & & & & & & \\
\hline Latvia & 6.5 & 6.8 & 6.7 & 7.0 & 7.7 & 8.4 & 28 \\
\hline Lithuania & 4.3 & 4.6 & 4.6 & 4.3 & & 4.6 & 7 \\
\hline Luxembourg & 5.6 & 4.4 & 4.6 & 4.0 & 5.8 & 5.0 & -11 \\
\hline Malta & 6.5 & 6.4 & 7.3 & 6.1 & 0.0 & 8.3 & 27 \\
\hline Moldova & 6.2 & 6.2 & 6.3 & 6.2 & & 6.2 & -1 \\
\hline Montenegro & 2.8 & 3.0 & 2.3 & 1.8 & 3.4 & 3.1 & 13 \\
\hline Netherlands & 6.0 & 5.4 & 5.4 & 5.3 & 5.4 & 5.3 & -12 \\
\hline Norway & 6.3 & 5.3 & 5.1 & 5.1 & 13.2 & 5.8 & -7 \\
\hline Poland & 3.2 & 3.2 & 3.4 & 3.4 & 3.5 & 3.5 & 10 \\
\hline Portugal & 5.6 & 5.6 & 6.0 & 6.0 & 6.1 & 6.3 & 12 \\
\hline Romania & 4.5 & 4.6 & 4.5 & 5.0 & 3.0 & 5.0 & 11 \\
\hline Russian Federation & 8.2 & 8.2 & 8.2 & 8.1 & 8.1 & 7.9 & -3 \\
\hline Serbia & 3.5 & 3.9 & 4.1 & 3.2 & 3.6 & 3.8 & 7 \\
\hline Slovakia & 6.0 & 6.3 & 6.4 & 6.8 & 6.5 & 6.9 & 15 \\
\hline Slovenia & 4.5 & 5.1 & 4.7 & 5.8 & 5.8 & 8.0 & 78 \\
\hline Spain & 7.6 & 7.6 & 7.6 & 7.6 & 7.7 & 7.6 & 1 \\
\hline Sweden & 5.9 & 6.0 & 5.8 & 5.7 & 5.7 & 6.0 & 2 \\
\hline Switzerland & 5.3 & 4.9 & 5.2 & 4.7 & 5.4 & 5.6 & 4 \\
\hline North Macedonia & 2.6 & 2.4 & 3.0 & 3.3 & 3.2 & 3.0 & 16 \\
\hline Turkey & 3.5 & 3.3 & 3.4 & 3.4 & 3.5 & 3.9 & 11 \\
\hline Ukraine & 4.5 & 6.3 & 5.4 & 5.4 & 3.7 & & \\
\hline UK: England \& Wales & 4.9 & 4.8 & 4.6 & 4.6 & 4.5 & 4.5 & -7 \\
\hline UK: Northern Ireland & 3.2 & 3.3 & 3.5 & 3.3 & 3.1 & 3.6 & 14 \\
\hline UK: Scotland & 5.6 & 5.8 & 5.8 & 5.4 & 5.3 & 5.2 & -9 \\
\hline Mean & 4.9 & 5.0 & 4.9 & 4.9 & 5.1 & 5.2 & \\
\hline Median & 4.9 & 4.9 & 4.6 & 4.9 & 5.1 & 5.2 & \\
\hline Minimum & 1.8 & 1.8 & 1.8 & 1.6 & 2.0 & 1.9 & \\
\hline Maximum & 8.2 & 8.6 & 8.2 & 8.1 & 13.2 & 8.4 & \\
\hline
\end{tabular}


Table 4.2.1.4 Percentage of minors in the prison population

\begin{tabular}{|c|c|c|c|c|c|c|c|}
\hline & 2011 & 2012 & 2013 & 2014 & 2015 & 2016 & $\begin{array}{l}\% \text { change } \\
2011-2016\end{array}$ \\
\hline Albania & 2.6 & 2.8 & 2.1 & 1.7 & 1.5 & 1.1 & -58 \\
\hline Armenia & 0.5 & 0.3 & 0.4 & 0.4 & 0.2 & 0.2 & -56 \\
\hline Austria & 1.6 & 1.6 & 1.2 & 1.1 & 1.4 & 1.7 & 6 \\
\hline Azerbaijan & 0.1 & 0.1 & 0.1 & 0.3 & 0.3 & 0.3 & 268 \\
\hline Belgium & 0.4 & 0.4 & 0.4 & 0.4 & & & \\
\hline Bosnia-Herzegovina & 0.5 & 0.4 & 0.2 & 1.0 & 0.7 & 0.4 & -21 \\
\hline Bulgaria & 0.6 & 0.7 & 0.2 & 0.4 & 0.5 & 0.1 & -80 \\
\hline Croatia & 1.1 & 1.4 & 0.8 & 1.1 & 0.7 & 0.7 & -35 \\
\hline Cyprus & 0.4 & 0.4 & 0.6 & 0.4 & 1.4 & 0.3 & -32 \\
\hline \multirow{2}{*}{\multicolumn{8}{|c|}{ Denmark }} \\
\hline & & & & & & & \\
\hline Estonia & 1.1 & 1.6 & 1.2 & 0.5 & 0.9 & 0.7 & -38 \\
\hline Finland & & & & & 0.3 & & \\
\hline France & 0.3 & 0.3 & 0.3 & 0.3 & 1.0 & 1.0 & 254 \\
\hline Georgia & 0.9 & 1.0 & 0.2 & 0.8 & 0.5 & 0.2 & -80 \\
\hline Germany & 1.4 & 1.4 & 1.3 & 1.3 & 1.2 & 1.3 & -10 \\
\hline Greece & 0.3 & 0.3 & 3.8 & 3.3 & 2.8 & 0.1 & -60 \\
\hline Hungary & $\ldots$ & $\ldots$ & $\ldots$ & $\ldots$ & $\ldots$ & 4.5 & $\ldots$ \\
\hline \multicolumn{8}{|l|}{ Iceland } \\
\hline Ireland & 1.5 & 1.1 & 1.2 & 1.3 & 1.5 & 0.2 & -84 \\
\hline Italy & 0.7 & 0.7 & 0.6 & 0.7 & 0.8 & 0.8 & 14 \\
\hline Kosovo (UN R/1244/99) & 3.0 & 3.2 & 2.3 & 2.2 & 2.8 & 3.6 & 20 \\
\hline Latvia & 0.8 & 0.5 & 0.7 & 0.5 & 0.7 & 0.7 & -12 \\
\hline Lithuania & 2.0 & 1.2 & 0.9 & 0.9 & 1.1 & 1.0 & -52 \\
\hline Luxembourg & & 0.2 & 0.1 & 0.8 & 0.1 & 0.3 & \\
\hline Malta & 0.7 & 0.6 & 0.7 & 1.9 & & 0.4 & -46 \\
\hline Moldova & 0.2 & 0.3 & 0.3 & 0.3 & 0.8 & 0.2 & 0 \\
\hline \multicolumn{8}{|l|}{ Montenegro } \\
\hline Netherlands & 4.8 & 4.9 & 4.5 & 4.7 & 4.6 & 4.8 & 0 \\
\hline Norway & 0.3 & 0.5 & 0.2 & 0.1 & 0.1 & 0.1 & -72 \\
\hline \multicolumn{8}{|l|}{ Poland } \\
\hline Portugal & 0.2 & 0.7 & 0.1 & 0.1 & 0.0 & 0.0 & -81 \\
\hline Romania & 0.8 & 0.7 & 0.7 & 0.6 & 0.5 & 0.6 & -22 \\
\hline Russian Federation & 0.6 & 0.5 & 0.5 & 0.4 & 0.4 & 0.4 & -31 \\
\hline Serbia & 2.3 & 2.0 & 2.4 & 2.4 & 2.1 & 2.9 & 26 \\
\hline Slovakia & 0.9 & 1.0 & 0.7 & 0.5 & 0.6 & 0.5 & -47 \\
\hline Slovenia & 0.0 & 0.0 & 0.1 & 0.0 & 0.0 & 0.0 & $\ldots$ \\
\hline Spain & $\ldots$ & $\ldots$ & $\ldots$ & $\ldots$ & $\ldots$ & $\ldots$ & $\ldots$ \\
\hline \multicolumn{8}{|l|}{ Sweden } \\
\hline Switzerland & 0.5 & 0.8 & 0.0 & 0.0 & 2.6 & 2.5 & 420 \\
\hline North Macedonia & 1.0 & 0.7 & 0.0 & 0.7 & 0.6 & 0.0 & -97 \\
\hline Turkey & 1.6 & 0.5 & 1.2 & 1.1 & 1.4 & 0.5 & -67 \\
\hline \multicolumn{8}{|l|}{ Ukraine } \\
\hline UK: England \& Wales & 1.9 & 1.5 & 1.0 & 0.9 & 0.8 & 0.7 & -60 \\
\hline UK: Northern Ireland & 0.8 & 2.1 & 1.5 & 2.0 & 1.4 & 1.5 & 78 \\
\hline UK: Scotland & 1.5 & 1.2 & 0.9 & 0.8 & 1.0 & 0.9 & -37 \\
\hline Mean & 1.1 & 1.0 & 0.9 & 1.0 & 1.0 & 1.0 & \\
\hline Median & 0.8 & 0.7 & 0.7 & 0.7 & 0.8 & 0.5 & \\
\hline Minimum & 0.0 & 0.0 & 0.0 & 0.0 & 0.0 & 0.0 & \\
\hline Maximum & 4.8 & 4.9 & 4.5 & 4.7 & 4.6 & 4.8 & \\
\hline
\end{tabular}


4 Prison Statistics

Table 4.2.1.5 Percentage of foreigners in the prison population

\begin{tabular}{|c|c|c|c|c|c|c|c|}
\hline & 2011 & 2012 & 2013 & 2014 & 2015 & 2016 & $\begin{array}{c}\% \text { change } \\
2011-2016\end{array}$ \\
\hline Albania & 1.5 & 1.8 & 1.7 & 1.8 & 1.5 & 1.5 & 2 \\
\hline Armenia & 3.7 & 2.7 & 3.1 & 3.3 & 3.2 & 3.9 & 8 \\
\hline Austria & 45.9 & 46.7 & 48.2 & 50.1 & 53.3 & 53.9 & 17 \\
\hline Azerbaijan & 3.2 & 3.0 & 3.0 & 2.7 & 2.5 & 2.3 & -29 \\
\hline Belgium & 42.0 & 42.3 & 42.8 & 40.6 & 40.1 & 40.7 & -3 \\
\hline Bosnia-Herzegovina & 2.4 & 3.8 & 2.8 & 1.7 & 2.0 & 1.8 & -27 \\
\hline Bulgaria & 2.3 & 1.9 & 2.9 & 2.9 & 3.1 & 3.2 & 38 \\
\hline Croatia & 5.7 & 5.8 & 6.3 & 6.1 & 3.2 & 6.1 & 8 \\
\hline Cyprus & 40.9 & 39.5 & 38.8 & 37.7 & 38.2 & 41.8 & 2 \\
\hline Czech Republic & 7.5 & 7.5 & 8.8 & 8.3 & 8.0 & 8.0 & 8 \\
\hline Denmark & 21.2 & 24.6 & 26.0 & 28.0 & 27.0 & 28.0 & 32 \\
\hline Estonia & 7.6 & 7.0 & 7.0 & 7.6 & 7.5 & 7.6 & 1 \\
\hline Finland & 14.3 & 14.8 & 14.5 & 16.0 & 15.1 & 17.5 & 22 \\
\hline France & 17.2 & 17.9 & 18.1 & 18.9 & 19.3 & 21.5 & 25 \\
\hline Georgia & 1.5 & 1.3 & 1.8 & 2.4 & 3.0 & 0.3 & -76 \\
\hline Germany & 27.0 & 28.5 & 30.0 & 29.8 & 31.3 & 35.6 & 32 \\
\hline Greece & 63.2 & 63.2 & 60.4 & 59.3 & 54.5 & 55.2 & -13 \\
\hline Hungary & 3.6 & 3.9 & 3.5 & 3.5 & 4.6 & 5.0 & 37 \\
\hline Iceland & 18.8 & 24.3 & 15.1 & 14.3 & 20.5 & 16.9 & -10 \\
\hline Ireland & 12.3 & 12.9 & 13.8 & 13.3 & 12.4 & 12.7 & 4 \\
\hline Italy & 36.1 & 35.8 & 34.9 & 32.6 & 33.2 & 34.1 & -6 \\
\hline Kosovo (UN R/1244/99) & 4.2 & 5.5 & 7.0 & 6.9 & 6.0 & 5.5 & 29 \\
\hline Latvia & 1.3 & 1.2 & 1.3 & 1.7 & 3.5 & 3.9 & 198 \\
\hline Lithuania & 1.2 & 1.5 & 1.8 & 1.7 & 1.6 & 1.5 & 22 \\
\hline Luxembourg & 68.6 & 68.9 & 72.2 & 72.7 & 73.6 & 38.4 & -44 \\
\hline Malta & 34.7 & 33.4 & 38.5 & 42.2 & 38.9 & 41.7 & 20 \\
\hline Moldova & 1.6 & 1.4 & 0.9 & 1.3 & 1.1 & 1.1 & -31 \\
\hline Montenegro & 11.4 & 14.4 & 14.9 & 18.0 & 15.5 & 18.8 & 65 \\
\hline Netherlands & 20.8 & 19.5 & 20.3 & 18.5 & 19.1 & 18.2 & -12 \\
\hline Norway & 30.5 & 32.0 & 32.9 & 33.6 & 33.4 & 33.9 & 11 \\
\hline Poland & 0.7 & 0.7 & 0.7 & 0.7 & 0.7 & 0.9 & 24 \\
\hline Portugal & 20.1 & 19.1 & 18.5 & 17.6 & 17.5 & 16.7 & -17 \\
\hline Romania & 0.7 & 0.6 & 0.5 & 0.8 & 0.9 & 1.1 & 52 \\
\hline Russian Federation & 3.4 & 3.7 & 4.0 & 4.2 & 4.3 & 4.6 & 35 \\
\hline Serbia & 2.2 & 2.0 & 3.5 & 2.9 & 3.5 & 3.4 & 56 \\
\hline Slovakia & 1.8 & 1.9 & 1.9 & 1.8 & 1.9 & 2.1 & 15 \\
\hline Slovenia & 10.4 & 11.5 & 10.7 & 10.7 & 9.4 & 9.0 & -14 \\
\hline Spain & 35.4 & 33.6 & 32.0 & 30.5 & 29.2 & 28.5 & -19 \\
\hline Sweden & 21.0 & 23.0 & 23.6 & 22.6 & 23.3 & 21.3 & 1 \\
\hline Switzerland & 71.4 & 74.2 & 74.5 & 73.0 & 71.0 & 72.0 & 1 \\
\hline North Macedonia & 6.0 & 2.7 & 3.1 & 3.8 & 5.7 & 5.4 & -10 \\
\hline Turkey & 1.7 & 1.6 & 1.7 & 1.8 & 2.0 & 2.2 & 26 \\
\hline Ukraine & 1.7 & 1.7 & & 2.0 & & & \\
\hline UK: England \& Wales & 12.6 & 12.6 & 12.9 & 12.7 & 12.2 & 11.6 & -8 \\
\hline UK: Northern Ireland & 8.5 & 7.1 & 7.1 & 6.7 & 8.1 & 9.1 & 7 \\
\hline UK: Scotland & 3.4 & 3.6 & 3.7 & 3.7 & 3.8 & 3.9 & 15 \\
\hline Mean & 16.4 & 16.7 & 17.2 & 16.8 & 17.1 & 16.7 & \\
\hline Median & 8.0 & 7.3 & 8.8 & 8.0 & 8.1 & 9.0 & \\
\hline Minimum & 0.7 & 0.6 & 0.5 & 0.7 & 0.7 & 0.3 & \\
\hline Maximum & 71.4 & 74.2 & 74.5 & 73.0 & 73.6 & 72.0 & \\
\hline
\end{tabular}


Table 4.2.1.6 Percentage of EU citizens among foreigners in the prison population

\begin{tabular}{|c|c|c|c|c|c|c|c|}
\hline & 2011 & 2012 & 2013 & 2014 & 2015 & 2016 & $\begin{array}{c}\% \text { change } \\
2011-2016\end{array}$ \\
\hline Albania & $\ldots$ & 26 & 60 & 35 & 31 & 9 & $\ldots$ \\
\hline Armenia & $\ldots$ & $\ldots$ & 4 & 4 & 10 & 10 & $\ldots$ \\
\hline Austria & 12 & 40 & 42 & 44 & 42 & 39 & 211 \\
\hline Azerbaijan & 0.4 & 0 & 0.5 & 1 & 1 & 1 & 43 \\
\hline Belgium & 28 & 30 & 29 & 31 & $\ldots$ & $\ldots$ & $\ldots$ \\
\hline Bosnia-Herzegovina & 6 & 1 & 9 & $\ldots$ & $\ldots$ & $\ldots$ & $\ldots$ \\
\hline Bulgaria & & & & $\ldots$ & 20 & & \\
\hline Croatia & 6 & 16 & 16 & 14 & 29 & 16 & 193 \\
\hline Cyprus & 35 & 39 & 48 & 43 & 49 & 44 & 26 \\
\hline Czech Republic & 48 & 47 & 44 & 51 & 47 & 48 & 1 \\
\hline Denmark & 33 & 33 & 31 & 30 & 32 & 26 & -23 \\
\hline Estonia & 16 & 21 & 17 & 8 & 16 & 5 & -67 \\
\hline Finland & 55 & 56 & 56 & 52 & 50 & 49 & -10 \\
\hline France & 24 & 24 & 26 & 26 & $\ldots$ & & \\
\hline Georgia & 3 & & & 2 & 3 & 24 & 613 \\
\hline Germany & 33 & 34 & 38 & $\ldots$ & $\ldots$ & $\ldots$ & $\ldots$ \\
\hline Greece & 20 & 20 & 13 & $\ldots$ & $\ldots$ & 17 & -11 \\
\hline Hungary & & $\ldots$ & $\ldots$ & $\ldots$ & $\ldots$ & $\ldots$ & $\ldots$ \\
\hline Iceland & 71 & 46 & 78 & 73 & 57 & 76 & 7 \\
\hline Ireland & 66 & 62 & 63 & 63 & 74 & 76 & 16 \\
\hline Italy & 38 & 40 & 42 & 42 & 42 & 38 & 0 \\
\hline Kosovo (UN R/1244/99) & & $\ldots$ & $\ldots$ & $\ldots$ & $\ldots$ & & $\ldots$ \\
\hline Latvia & 26 & 15 & 41 & 15 & 17 & 22 & -17 \\
\hline Lithuania & 18 & 55 & 15 & 29 & 25 & 26 & 47 \\
\hline Luxembourg & 57 & 56 & 21 & 58 & 57 & & $\ldots$ \\
\hline Malta & $\ldots$ & $\ldots$ & 41 & 43 & $\ldots$ & 174 & $\ldots$ \\
\hline Moldova & $\ldots$ & $\ldots$ & 22 & $\ldots$ & 21 & 34 & \\
\hline Montenegro & 3 & 6 & 5 & 0 & 2 & 3 & 30 \\
\hline Netherlands & 38 & 41 & 44 & 43 & 42 & 41 & 9 \\
\hline Norway & 47 & 49 & 51 & 40 & 41 & 49 & 5 \\
\hline Poland & & $\ldots$ & . & $\ldots$ & $\ldots$ & 33 & $\ldots$ \\
\hline Portugal & 22 & 23 & 22 & 22 & 26 & 19 & -12 \\
\hline Romania & 31 & 34 & 34 & 27 & 34 & 34 & 8 \\
\hline Russian Federation & & & $\ldots$ & $\ldots$ & $\ldots$ & $\ldots$ & $\ldots$ \\
\hline Serbia & 29 & 25 & 19 & 13 & 14 & 31 & 6 \\
\hline Slovakia & 42 & 48 & 56 & 44 & 48 & 60 & 44 \\
\hline Slovenia & 23 & 26 & 24 & 21 & 9 & 18 & -21 \\
\hline Spain & 19 & 21 & 22 & 23 & 24 & 24 & 28 \\
\hline Sweden & 38 & 35 & 36 & 34 & 36 & 35 & -6 \\
\hline Switzerland & & & & & $\ldots$ & $\ldots$ & \\
\hline North Macedonia & 2 & 0 & 20 & 24 & 4 & 1 & -72 \\
\hline Turkey & 10 & 15 & 13 & 11 & 10 & $\ldots$ & $\ldots$ \\
\hline Ukraine & 3 & 3 & & 2 & 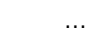 & & \\
\hline UK: England \& Wales & 6 & 35 & 37 & 39 & 39 & 43 & 610 \\
\hline UK: Northern Ireland & 35 & 57 & 53 & 60 & 66 & 72 & 108 \\
\hline UK: Scotland & 39 & 45 & 51 & 55 & 56 & 58 & 50 \\
\hline Mean & 27 & 31 & 33 & 31 & 32 & 37 & \\
\hline Median & 27 & 34 & 33 & 30 & 32 & 33 & \\
\hline Minimum & 0 & 0 & 0 & 0 & 1 & 1 & \\
\hline Maximum & 71 & 62 & 78 & 73 & 74 & 174 & \\
\hline
\end{tabular}




\subsubsection{Convicted prison population by type of offence on 1 September 2015}

4.2.2.1 Convicted prison population in 2015 by type of offence, in percentages of which \%:

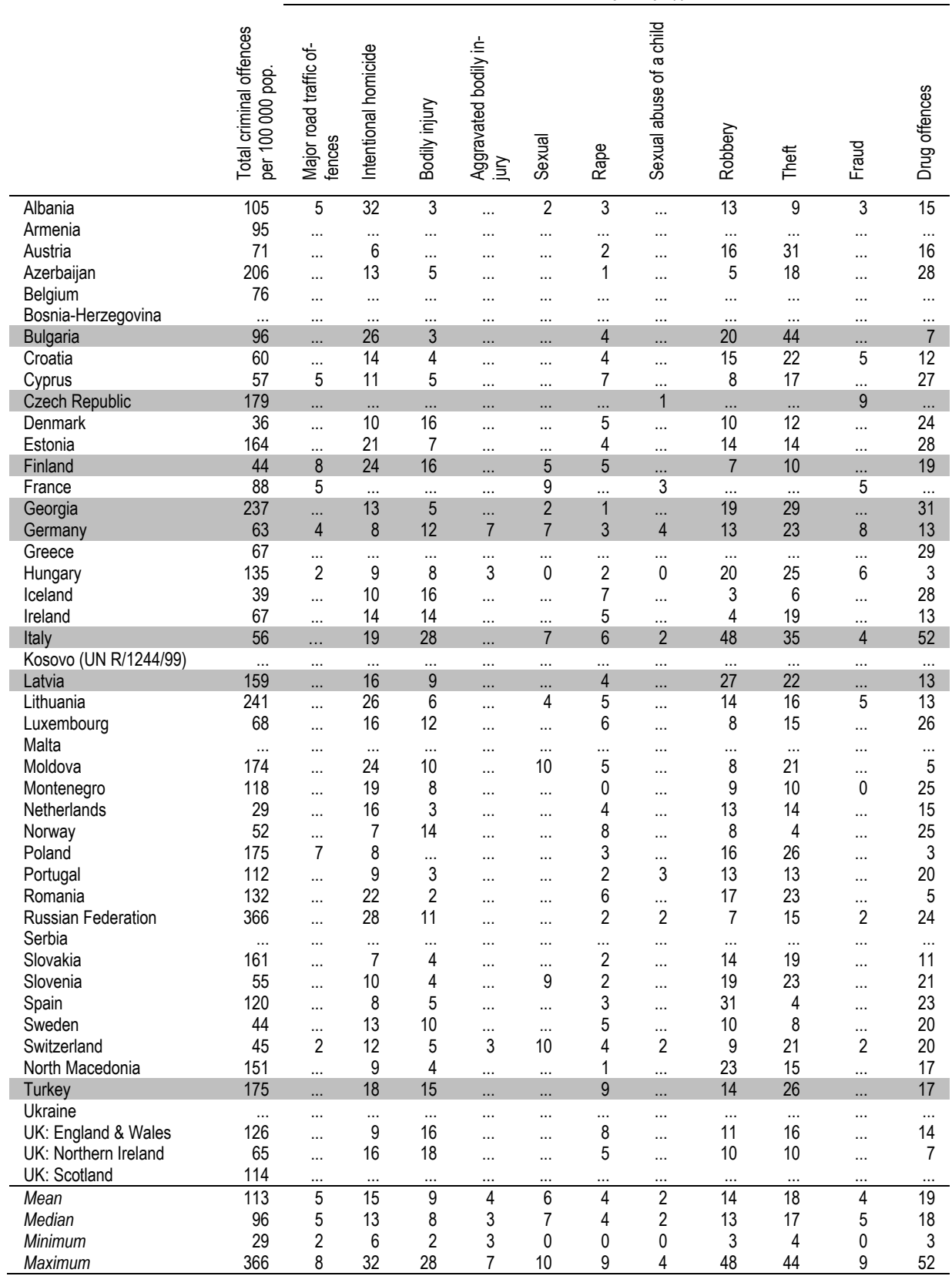

Note: Grey coloured cells correspond to countries that do not apply the principal offence rule. 
4.2.2.2 Convicted prison population in 2015 by type of offence, in rates per 100,000 population

Rates per 100000 population

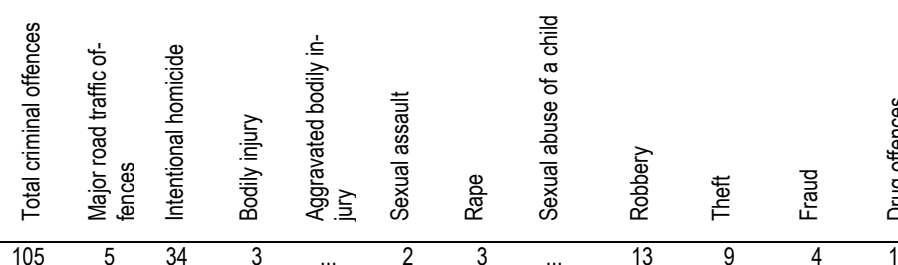

\begin{tabular}{|c|c|c|c|c|c|c|c|c|c|c|c|c|}
\hline Albania & 105 & 5 & 34 & 3 & $\ldots$ & 2 & 3 & $\ldots$ & 13 & 9 & 4 & 15 \\
\hline Armenia & 95 & $\ldots$ & $\ldots$ & $\ldots$ & $\ldots$ & $\ldots$ & $\ldots$ & $\ldots$ & $\ldots$ & $\ldots$ & $\ldots$ & $\ldots$ \\
\hline Austria & 71 & $\ldots$ & 4 & $\ldots$ & $\ldots$ & $\ldots$ & 2 & $\ldots$ & 11 & 22 & $\ldots$ & 11 \\
\hline Azerbaijan & 206 & $\ldots$ & 26 & 10 & $\ldots$ & ... & 2 & $\ldots$ & 11 & 38 & $\ldots$ & 58 \\
\hline Belgium & 76 & $\ldots$ & $\ldots$ & $\ldots$ & ... & ... & ... & $\ldots$ & $\ldots$ & $\ldots$ & $\ldots$ & $\ldots$ \\
\hline Bosnia-Herzegovina & $\ldots$ & ... & $\ldots$ & $\ldots$ & ... & ... & ... & ... & $\ldots$ & $\ldots$ & ... & $\ldots$ \\
\hline Bulgaria & 96 & $\ldots$ & 25 & 3 & $\ldots$ & $\ldots$ & 4 & $\ldots$ & 19 & 43 & $\ldots$ & 7 \\
\hline Croatia & 60 & $\ldots$ & 8 & 2 & $\ldots$ & $\ldots$ & 2 & $\ldots$ & 9 & 13 & 3 & 7 \\
\hline Cyprus & 57 & 3 & 6 & 3 & $\ldots$ & $\ldots$ & 4 & $\ldots$ & 5 & 10 & $\ldots$ & 16 \\
\hline Czech Republic & 179 & $\ldots$ & $\ldots$ & $\ldots$ & $\ldots$ & $\ldots$ & $\ldots$ & 2 & & $\ldots$ & 15 & \\
\hline Denmark & 36 & $\ldots$ & 3 & 6 & $\ldots$ & $\ldots$ & 2 & $\ldots$ & 4 & 4 & $\ldots$ & 9 \\
\hline Estonia & 164 & $\ldots$ & 34 & 11 & $\ldots$ & $\ldots$ & 7 & $\ldots$ & 22 & 24 & $\ldots$ & 46 \\
\hline Finland & 44 & 4 & 11 & 7 & $\ldots$ & 2 & 2 & $\ldots$ & 3 & 4 & $\ldots$ & 8 \\
\hline France & 88 & 4 & $\ldots$ & $\ldots$ & $\ldots$ & 8 & $\ldots$ & 3 & $\ldots$ & $\ldots$ & 4 & $\ldots$ \\
\hline Georgia & 237 & $\ldots$ & 31 & 12 & $\ldots$ & 5 & 3 & $\ldots$ & 45 & 68 & $\ldots$ & 73 \\
\hline Germany & 63 & 2 & 5 & 8 & 5 & 4 & 2 & 2 & 8 & 14 & 5 & 8 \\
\hline Greece & 67 & $\ldots$ & $\ldots$ & $\ldots$ & $\ldots$ & $\ldots$ & $\ldots$ & $\ldots$ & $\ldots$ & $\ldots$ & $\ldots$ & 20 \\
\hline Hungary & 135 & 2 & 13 & 11 & 3 & 0.02 & 3 & 0.3 & 28 & 33 & 8 & 4 \\
\hline Iceland & 39 & $\ldots$ & 4 & 6 & $\ldots$ & $\ldots$ & 3 & $\ldots$ & 1 & 2 & ... & 11 \\
\hline Ireland & 67 & $\ldots$ & 9 & 9 & $\ldots$ & $\ldots$ & 3 & $\ldots$ & 3 & 13 & $\ldots$ & 9 \\
\hline Italy & 56 & $\ldots$ & 11 & 16 & $\ldots$ & 4 & 3 & 1 & 27 & 19 & 2 & 29 \\
\hline Kosovo (UN R/1244/99) & $\ldots$ & $\ldots$ & $\ldots$ & $\ldots$ & $\ldots$ & $\ldots$ & $\ldots$ & $\ldots$ & $\ldots$ & $\ldots$ & $\ldots$ & $\ldots$ \\
\hline Latvia & 159 & $\ldots$ & 25 & 14 & $\ldots$ & $\ldots$ & 7 & $\ldots$ & 43 & 35 & $\ldots$ & 21 \\
\hline Lithuania & 241 & $\ldots$ & 64 & 14 & $\ldots$ & 11 & 12 & $\ldots$ & 35 & 40 & 13 & 31 \\
\hline Luxembourg & 68 & $\ldots$ & 11 & 8 & $\ldots$ & $\ldots$ & 4 & $\ldots$ & 5 & 10 & $\ldots$ & 18 \\
\hline Malta & $\ldots$ & $\ldots$ & $\ldots$ & $\ldots$ & $\ldots$ & $\ldots$ & $\ldots$ & $\ldots$ & $\ldots$ & $\ldots$ & 0 & $\ldots$ \\
\hline Moldova & 174 & $\ldots$ & 42 & 17 & $\ldots$ & 18 & 9 & $\ldots$ & 14 & 36 & $\ldots$ & 9 \\
\hline Montenegro & 118 & $\ldots$ & 22 & 10 & $\ldots$ & $\ldots$ & 0.5 & $\ldots$ & 10 & 12 & 0 & 30 \\
\hline Netherlands & 29 & $\ldots$ & 5 & 1 & $\ldots$ & $\ldots$ & 1 & $\ldots$ & 4 & 4 & $\ldots$ & 4 \\
\hline Norway & 52 & $\ldots$ & 4 & 7 & $\ldots$ & $\ldots$ & 4 & $\ldots$ & 4 & 2 & $\ldots$ & 13 \\
\hline Poland & 175 & 12 & 14 & $\ldots$ & $\ldots$ & $\ldots$ & 5 & $\ldots$ & 28 & 45 & $\ldots$ & 6 \\
\hline Portugal & 112 & $\ldots$ & 10 & 4 & ... & ... & 2 & 3 & 14 & 14 & $\ldots$ & 22 \\
\hline Romania & 132 & ... & 29 & 2 & $\ldots$ & $\ldots$ & 9 & $\ldots$ & 23 & 30 & $\ldots$ & 6 \\
\hline Russian Federation & 366 & $\ldots$ & 103 & 41 & $\ldots$ & $\ldots$ & 8 & 6 & 24 & 55 & 6 & 89 \\
\hline Serbia & $\ldots$ & 2 & 10 & 2 & $\ldots$ & 4 & 3 & 1 & 16 & 26 & 2 & 24 \\
\hline Slovakia & 161 & $\ldots$ & 11 & 7 & $\ldots$ & $\ldots$ & 2 & $\ldots$ & 22 & 30 & $\ldots$ & 18 \\
\hline Slovenia & 55 & $\ldots$ & 6 & 2 & $\ldots$ & 5 & 1 & $\ldots$ & 11 & 12 & $\ldots$ & 11 \\
\hline Spain & 120 & $\ldots$ & 9 & 6 & $\ldots$ & $\ldots$ & 4 & $\ldots$ & 37 & 4 & $\ldots$ & 27 \\
\hline Sweden & 44 & $\ldots$ & 6 & 5 & $\ldots$ & $\ldots$ & 2 & $\ldots$ & 4 & 4 & $\ldots$ & 9 \\
\hline Switzerland & 45 & 1 & 5 & 2 & 1 & 4 & 2 & 1 & 4 & 9 & 1 & 9 \\
\hline North Macedonia & 151 & $\ldots$ & 14 & 6 & $\ldots$ & $\ldots$ & 2 & $\ldots$ & 35 & 23 & $\ldots$ & 26 \\
\hline Turkey & 175 & $\ldots$ & 32 & 26 & $\ldots$ & $\ldots$ & 16 & $\ldots$ & 25 & 46 & $\ldots$ & 30 \\
\hline Ukraine & , & $\ldots$ & $\ldots$ & $\ldots$ & $\ldots$ & $\ldots$ & $\ldots$ & $\ldots$ & $\ldots$ & $\ldots$ & $\ldots$ & $\cdots$ \\
\hline UK: England \& Wales & 126 & $\ldots$ & 12 & 20 & $\ldots$ & $\ldots$ & 11 & $\ldots$ & 14 & 20 & $\ldots$ & 18 \\
\hline UK: Northern Ireland & 65 & $\ldots$ & 10 & 12 & $\ldots$ & $\ldots$ & 3 & $\ldots$ & 7 & 6 & $\ldots$ & 5 \\
\hline UK: Scotland & 114 & $\ldots$ & $\ldots$ & $\ldots$ & $\ldots$ & $\ldots$ & $\ldots$ & $\ldots$ & $\ldots$ & $\ldots$ & $\ldots$ & $\ldots$ \\
\hline Mean & 113 & 4 & 19 & 9 & 3 & 6 & 4 & 2 & 16 & 22 & 5 & 21 \\
\hline Median & 96 & 3 & 11 & 7 & 3 & 4 & 3 & 2 & 14 & 17 & 4 & 15 \\
\hline Minimum & 29 & 1 & 3 & 1 & 1 & 0.02 & 0.5 & 0.3 & 1 & 2 & 0 & 4 \\
\hline Maximum & 366 & 12 & 103 & 41 & 5 & 18 & 16 & 6 & 45 & 68 & 15 & 89 \\
\hline
\end{tabular}

Note: Grey coloured cells correspond to countries that do not apply the principal offence rule. 
Table 4.2.2.3 Convicted prison population in 2015 - Total Criminal offences

\begin{tabular}{|c|c|c|c|c|c|}
\hline & $\begin{array}{c}\text { Rate per } \\
100000 \text { pop. }\end{array}$ & $\begin{array}{l}\text { of which } \% \\
\text { of women }\end{array}$ & $\begin{array}{l}\text { of which \% } \\
\text { of minors }\end{array}$ & $\begin{array}{l}\text { of which \% } \\
\text { of foreigners }\end{array}$ & $\begin{array}{c}\% \text { of EU } \\
\text { citizens amongst } \\
\text { foreigners }\end{array}$ \\
\hline Albania & 105 & 3.8 & 0.4 & 1.4 & $\ldots$ \\
\hline Armenia & 95 & 6.0 & 0.2 & 4.4 & 10 \\
\hline Austria & 71 & $\ldots$ & $\ldots$ & $\ldots$ & $\ldots$ \\
\hline Azerbaijan & 206 & 3.5 & 0.4 & 3.1 & 1 \\
\hline Belgium & 76 & $\ldots$ & $\ldots$ & $\ldots$ & ... \\
\hline Bosnia-Herzegovina & $\ldots$ & $\ldots$ & $\ldots$ & $\ldots$ & ... \\
\hline Bulgaria & 96 & 3.5 & 1.2 & 3.4 & 20 \\
\hline Croatia & 60 & 6.4 & 1.9 & 4.2 & 29 \\
\hline Cyprus & 57 & 8.3 & 2.4 & 51.7 & 49 \\
\hline Czech Republic & 179 & 7.6 & 0.5 & 8.8 & 47 \\
\hline Denmark & 36 & $\ldots$ & $\ldots$ & $\ldots$ & ... \\
\hline Estonia & 164 & $\ldots$ & $\ldots$ & $\ldots$ & ... \\
\hline Finland & 44 & 9.5 & 0.4 & 19.0 & 50 \\
\hline France & 88 & 3.6 & 1.3 & 2.0 & 23 \\
\hline Georgia & 237 & 3.6 & 0.6 & 3.5 & 3 \\
\hline Germany & 63 & 6.1 & 0.9 & 26.1 & 36 \\
\hline Greece & 67 & $\ldots$ & $\ldots$ & & $\ldots$ \\
\hline Hungary & 135 & 7.2 & 2.0 & 2.2 & ... \\
\hline Iceland & 39 & $\ldots$ & $\ldots$ & $\ldots$ & ... \\
\hline Ireland & 67 & $\ldots$ & $\ldots$ & $\ldots$ & $\ldots$ \\
\hline Italy & 56 & 6.2 & 1.3 & 51.1 & 42 \\
\hline Kosovo (UN R/1244/99) & $\ldots$ & $\ldots$ & $\ldots$ & $\ldots$ & $\ldots$ \\
\hline Latvia & 159 & 10.8 & 1.2 & 4.9 & 17 \\
\hline Lithuania & 241 & 3.8 & 0.8 & 1.1 & 29 \\
\hline Luxembourg & 68 & 10.5 & 0.5 & 135.1 & $\ldots$ \\
\hline Malta & & & & & $\ldots$ \\
\hline Moldova & 174 & 7.8 & 1.1 & 1.4 & 21 \\
\hline Montenegro & 118 & 2.9 & 0.5 & 12.7 & 0 \\
\hline Netherlands & 29 & $\ldots$ & $\ldots$ & & ... \\
\hline Norway & 52 & 18.0 & 0.1 & 45.6 & 41 \\
\hline Poland & 175 & 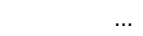 & $\ldots$ & & $\ldots$ \\
\hline Portugal & 112 & 5.6 & 0.1 & 15.7 & ... \\
\hline Romania & 132 & 3.3 & 2.7 & 1.0 & 34 \\
\hline Russian Federation & 366 & 8.3 & 0.3 & 5.4 & $\ldots$ \\
\hline Serbia & $\ldots$ & $\ldots$ & $\ldots$ & $\ldots$ & 14 \\
\hline Slovakia & 161 & $\ldots$ & $\ldots$ & $\ldots$ & $\ldots$ \\
\hline Slovenia & 55 & 7.1 & 1.6 & 11.5 & 9 \\
\hline Spain & 120 & $\ldots$ & $\ldots$ & 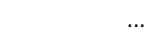 & ... \\
\hline Sweden & 44 & 5.3 & $\ldots$ & 30.9 & 36 \\
\hline Switzerland & 45 & 4.8 & $\ldots$ & 64.1 & $\ldots$ \\
\hline North Macedonia & 151 & $\ldots$ & $\ldots$ & $\ldots$ & $\cdots$ \\
\hline Turkey & 175 & $\ldots$ & $\ldots$ & $\ldots$ & $\ldots$ \\
\hline Ukraine & $\ldots$ & $\ldots$ & $\ldots$ & $\ldots$ & $\ldots$ \\
\hline UK: England \& Wales & 126 & 5.4 & 1.0 & 14.5 & 39 \\
\hline UK: Northern Ireland & 65 & 4.4 & 1.9 & 11.5 & 66 \\
\hline UK: Scotland & 114 & 6.6 & 8.5 & 4.8 & 56 \\
\hline Mean & 113 & 6 & 1 & 19 & \\
\hline Median & 96 & 6 & 1 & 7 & \\
\hline Minimum & 29 & 3 & 0 & 1 & \\
\hline Maximum & 366 & 18 & 8 & 135 & \\
\hline
\end{tabular}


Table 4.2.2.4 Convicted prison population in 2015 - Major road traffic offences

\begin{tabular}{lrrrrr} 
& $\begin{array}{c}\text { Rate per } \\
100000 \text { pop. }\end{array}$ & $\begin{array}{c}\text { of which \% } \\
\text { of women }\end{array}$ & $\begin{array}{c}\text { of which \% } \\
\text { of minors }\end{array}$ & $\begin{array}{c}\text { of which \% } \\
\text { of foreigners }\end{array}$ & $\begin{array}{c}\text { citizens amongst } \\
\text { foreigners }\end{array}$ \\
\hline Albania & 5 & 0 & 0 & 0 & $\ldots$ \\
Cyprus & 3 & 8.3 & $\ldots$ & $\ldots$ & $\ldots$ \\
Finland & 4 & 5.1 & 0 & 2.0 & 100 \\
France & 4 & 1.3 & 0.1 & 9.8 & 22 \\
Germany & 2 & 1.8 & 0.0 & 18.0 & 45 \\
Hungary & 2 & 0.9 & 0.4 & 3.5 & $\ldots$ \\
Serbia & 2 & 0.7 & 0 & 0 & NAP \\
Switzerland & 1 & 1.2 & $\ldots$ & 55.3 & $\ldots$ \\
\hline
\end{tabular}

Table 4.2.2.5 Convicted prison population in 2015 - Intentional homicide

\begin{tabular}{lrrrrr} 
& $\begin{array}{c}\text { Rate per } \\
100000 \text { pop. }\end{array}$ & $\begin{array}{c}\text { of which \% } \\
\text { of women }\end{array}$ & $\begin{array}{c}\text { of which \% } \\
\text { of minors }\end{array}$ & $\begin{array}{c}\text { of which \% } \\
\text { of foreigners }\end{array}$ & $\begin{array}{c}\text { \% of EU } \\
\text { citizens amongst } \\
\text { foreigners }\end{array}$ \\
\hline Albania & 34 & 1.9 & 0.1 & 0.2 & $\ldots$ \\
Finland & 11 & 10.3 & $\ldots$ & 5.7 & 27.3 \\
Germany & 5 & 6.5 & 0.2 & $\ldots$ & $\ldots$ \\
Hungary & 13 & 9.5 & 1.5 & 2.6 & $\ldots$ \\
Italy & 11 & 3.8 & 0.8 & $\ldots$ & $\ldots$ \\
Moldova & 42 & $\ldots$ & 0.9 & $\ldots$ & $\ldots$ \\
Montenegro & 22 & 0.7 & $\ldots$ & 8.0 & $\ldots$ \\
Russian Federation & 103 & 7.7 & 0.2 & 2.4 & NAP \\
Serbia & 10 & 5.8 & 4.5 & 0.0 & $\ldots$ \\
Switzerland & 5 & 8.1 & $\ldots$ & 48.8 & \\
\hline
\end{tabular}

Table 4.2.2.6 Convicted prison population in 2015 - Bodily injury

\begin{tabular}{|c|c|c|c|c|c|}
\hline & $\begin{array}{c}\text { Rate per } \\
100000 \text { pop. }\end{array}$ & $\begin{array}{l}\text { of which } \% \\
\text { of women }\end{array}$ & $\begin{array}{l}\text { of which } \% \\
\text { of minors }\end{array}$ & $\begin{array}{l}\text { of which } \% \\
\text { of foreigners }\end{array}$ & $\begin{array}{l}\text { citizens amongst } \\
\text { Foreigners }\end{array}$ \\
\hline Albania & 3 & 1.1 & 0 & 0 & NAP \\
\hline Finland & 7 & 7.9 & 0 & 4.1 & 44 \\
\hline Georgia & 12 & & $\ldots$ & $\ldots$ & ... \\
\hline Germany & 8 & 3.3 & 1.1 & $\ldots$ & $\ldots$ \\
\hline Hungary & 11 & 3.6 & 1.5 & 1.1 & \\
\hline Italy & 16 & 2.4 & 1.9 & 0 & NAP \\
\hline Lithuania & 14 & 2.2 & 0.2 & 0.7 & $\ldots$ \\
\hline Montenegro & 10 & 1.6 & $\ldots$ & 1.6 & $\ldots$ \\
\hline Portugal & 4 & 3.4 & $\ldots$ & 11.6 & $\ldots$ \\
\hline Russian Federation & 41 & $\ldots$ & 0.3 & $\ldots$ & $\ldots$ \\
\hline Serbia & 2 & 2.2 & 1.4 & 0.7 & $\ldots$ \\
\hline Switzerland & 2 & 2.8 & $\ldots$ & 52.2 & $\ldots$ \\
\hline
\end{tabular}


Table 4.2.2.7 Convicted prison population in 2015 - Aggravated bodily injury

\begin{tabular}{lrrrrr} 
& $\begin{array}{c}\text { Rate per } \\
100000 \text { pop. }\end{array}$ & $\begin{array}{c}\text { of which } \% \\
\text { of women }\end{array}$ & $\begin{array}{c}\text { of which \% } \\
\text { of minors }\end{array}$ & $\begin{array}{c}\text { of which \% } \\
\text { of foreigners }\end{array}$ & $\begin{array}{c}\% \text { of EU } \\
\text { citzens amongst } \\
\text { foreigners }\end{array}$ \\
\hline Germany & 5 & 3.3 & 1.2 & $\ldots$ & $\ldots$ \\
Hungary & 3 & 2.6 & 3.5 & 0.3 & $\ldots$ \\
Switzerland & 1 & 0.9 & $\ldots$ & 48.6 & $\ldots$ \\
\hline
\end{tabular}

Table 4.2.2.8 Convicted prison population in 2015 - Sexual assault

\begin{tabular}{lrrrrr} 
& $\begin{array}{c}\text { Rate per } \\
100000 \text { pop. }\end{array}$ & $\begin{array}{c}\text { of which } \% \\
\text { of women }\end{array}$ & $\begin{array}{c}\text { of which } \% \\
\text { of minors }\end{array}$ & $\begin{array}{c}\text { of which \% } \\
\text { of foreigners }\end{array}$ & $\begin{array}{c}\text { citizens amongst } \\
\text { foreigners }\end{array}$ \\
\hline Albania & 2 & $\ldots$ & 0 & 1.5 & $\ldots$ \\
Finland & 2 & 0.8 & 0 & 16.8 & 20.0 \\
France & 8 & 1.1 & 0 & 12.9 & 21.4 \\
Germany & 4 & 0.6 & 0.6 & $\ldots$ & $\ldots$ \\
Hungary & 0.02 & 0 & 0 & 0 & NAP \\
Italy & 4 & 3.2 & $\ldots$ & $\ldots$ & $\ldots$ \\
Lithuania & 11 & 0 & 0.3 & 0.3 & $\ldots$ \\
Malta & $\ldots$ & $\ldots$ & $\ldots$ & $\ldots$ & 102.7 \\
Moldova & 18 & $\ldots$ & 1.4 & $\ldots$ & $\ldots$ \\
Serbia & 4 & 1.0 & 1.3 & 2.9 & $\ldots$ \\
Switzerland & 4 & 1.4 & $\ldots$ & 38.6 & $\ldots$ \\
\hline
\end{tabular}

Table 4.2.2.9 Convicted prison population in 2015 - Rape

\begin{tabular}{lrrrrr} 
& $\begin{array}{c}\text { Rate per } \\
100000 \text { pop. }\end{array}$ & $\begin{array}{c}\text { of which \% } \\
\text { of women }\end{array}$ & $\begin{array}{c}\text { of which \% } \\
\text { of minors }\end{array}$ & $\begin{array}{c}\text { \% of EU } \\
\text { of foreigners } \%\end{array}$ & $\begin{array}{c}\text { citizens amongst } \\
\text { foreigners }\end{array}$ \\
\hline Albania & 3 & $\ldots$ & 0 & $\ldots$ & $\ldots$ \\
Croatia & 2 & 0 & $\ldots$ & $\ldots$ & $\ldots$ \\
Germany & 2 & 0.6 & 1.1 & $\ldots$ & $\ldots$ \\
Hungary & 3 & 1.0 & 1.7 & 3.4 & $\ldots$ \\
Italy & 3 & 3.0 & $\ldots$ & $\ldots$ & $\ldots$ \\
Montenegro & 0 & $\ldots$ & $\ldots$ & 66.7 & $\ldots$ \\
Portugal & 2 & $\ldots$ & $\ldots$ & 18.1 & $\ldots$ \\
Russian Federation & 2 & 0.4 & 0.4 & $\ldots$ & $\ldots$ \\
Serbia & 3 & 0 & 0.5 & 3.8 & $\ldots$ \\
Switzerland & 2 & 0 & $\ldots$ & 53.3 & $\ldots$ \\
\hline
\end{tabular}


Table 4.2.2.10 Convicted prison population in 2015 - Sexual abuse of a child

\begin{tabular}{lrrrrr}
$\begin{array}{c}\text { Rate per } \\
10000 \text { pop. }\end{array}$ & $\begin{array}{c}\text { of which \% of } \\
\text { women }\end{array}$ & $\begin{array}{c}\text { of which \% of } \\
\text { minors }\end{array}$ & $\begin{array}{c}\text { of which \% of } \\
\text { foreigners }\end{array}$ & $\begin{array}{c}\text { colizens amongst } \\
\text { coreigners }\end{array}$ \\
\hline Czech Republic & 2 & 3.5 & $\ldots$ & $\ldots$ & $\ldots$ \\
France & 3 & 1.1 & 0.2 & 7.9 & 30 \\
Germany & 2 & 0.7 & 0.2 & $\ldots$ & $\ldots$ \\
Hungary & 0.3 & 3.2 & 6.5 & 3.2 & $\ldots$ \\
Italy & 1 & 3.0 & $\ldots$ & $\ldots$ & $\ldots$ \\
Portugal & 3 & $\ldots$ & $\ldots$ & 15.1 & $\ldots$ \\
Russian Federation & 6 & 0.6 & 2.4 & $\ldots$ & $\ldots$ \\
Serbia & 1 & 0 & 0 & 2.4 & $\ldots$ \\
Switzerland & 1 & 1.4 & $\ldots$ & 40.3 & $\ldots$ \\
\hline
\end{tabular}

Table 4.2.2.11 Convicted prison population in 2015 - Robbery

\begin{tabular}{lrrrrr} 
& $\begin{array}{c}\text { Rate per } \\
100000 \text { pop. }\end{array}$ & $\begin{array}{c}\text { of which \% of } \\
\text { women }\end{array}$ & $\begin{array}{c}\text { of which \% of } \\
\text { minors }\end{array}$ & $\begin{array}{c}\text { co which \% of } \\
\text { foreigners }\end{array}$ & $\begin{array}{c}\text { \% of EU } \\
\text { citizens amongst } \\
\text { foreigners }\end{array}$ \\
\hline Albania & 13 & 0.3 & 0 & 0.3 & $\ldots$ \\
Finland & 3 & 3.8 & 1.3 & 9.4 & 33 \\
Germany & 8 & 3.0 & 2.8 & 29.2 & 28 \\
Hungary & 28 & 7.7 & 4.3 & 2.0 & $\ldots$ \\
Italy & 27 & 2.9 & 3.4 & $\ldots$ & $\ldots$ \\
Lithuania & 35 & 1.4 & 2.6 & 0.7 & $\ldots$ \\
Moldova & 14 & $\ldots$ & 2.0 & $\ldots$ & NAP \\
Portugal & 14 & 4.6 & 0.3 & 15.9 & $\ldots$ \\
Russian Federation & 24 & 3.8 & 0.7 & 5.8 & $\ldots$ \\
Serbia & 16 & 2.3 & 3.7 & 1.4 & $\ldots$ \\
Switzerland & 16 & 3.8 & $\ldots$ & 63.8 & $\ldots$ \\
\hline
\end{tabular}

Table 4.2.2.12 Convicted prison population in 2015 - Theft

\begin{tabular}{lrrrrr} 
& $\begin{array}{c}\text { Rate per } \\
100000 \text { pop. }\end{array}$ & $\begin{array}{c}\text { of which \% of } \\
\text { women }\end{array}$ & $\begin{array}{c}\text { of which \% of } \\
\text { minors }\end{array}$ & $\begin{array}{c}\text { of which \% of } \\
\text { foreigners }\end{array}$ & $\begin{array}{c}\text { \% of EU } \\
\text { citizens amongst } \\
\text { foreigners }\end{array}$ \\
\hline Albania & 9 & $\ldots .5$ & 3.5 & 3.5 & 100 \\
Finland & 4 & 6.2 & 0 & 11.1 & 70 \\
Georgia & 68 & $\ldots$ & $\ldots$ & $\ldots$. & $\ldots$ \\
Germany & 14 & 7.3 & 1.0 & 30.3 & 48 \\
Hungary & 33 & 6.3 & 2.3 & 8.6 & $\ldots$ \\
Italy & 19 & 4.5 & 4.6 & $\ldots$ & $\ldots$ \\
Lithuania & 40 & 3.1 & 2.1 & 0.4 & $\ldots$ \\
Moldova & 36 & $\ldots$ & 0.6 & $\ldots$ & $\ldots$ \\
Montenegro & 12 & 1.3 & $\ldots$ & 18.7 & $\ldots$ \\
Portugal & 14 & 4.7 & $\ldots$ & 7.2 & $\ldots$ \\
Russian Federation & 55 & 7.2 & 0.3 & 2.8 & $\ldots$ \\
Serbia & 26 & 3.6 & 3.7 & 0.9 & $\ldots$ \\
Switzerland & 9 & 3.9 & $\ldots$ & 79.9 & \\
\hline
\end{tabular}


Table 4.2.2.13 Convicted prison population in 2015 - Fraud

\begin{tabular}{lrrrrr} 
& $\begin{array}{c}\text { Rate per } \\
100000 \text { pop. }\end{array}$ & $\begin{array}{l}\text { of which \% } \\
\text { of women }\end{array}$ & \multicolumn{1}{c}{$\begin{array}{c}\text { of which \% } \\
\text { of minors }\end{array}$} & $\begin{array}{c}\text { \% of EU } \\
\text { of foreigners }\end{array}$ & $\begin{array}{c}\text { citizens amongst } \\
\text { foreigners }\end{array}$ \\
\hline Albania & 4 & 1.9 & 0 & $\ldots$ & $\ldots$ \\
Croatia & 3 & 11.5 & $\ldots$ & $\ldots$ & $\ldots$ \\
Czech Republic & 15 & 10.5 & $\ldots$ & $\ldots$ & $\ldots$ \\
France & 4 & 4.2 & 0.6 & 20.2 & 31 \\
Germany & 5 & 13.4 & 0.2 & $\ldots$ & $\ldots$ \\
Hungary & 8 & 12.5 & 0 & 1.0 & $\ldots$ \\
Italy & 2 & 7.1 & $\ldots$ & $\ldots$ & $\ldots$ \\
Lithuania & 13 & 6.8 & 0 & 1.1 & $\ldots$ \\
Russian Federation & 6 & 19.9 & 0 & 3.8 & $\ldots$ \\
Serbia & 2 & 7.6 & 0.8 & 2.3 & $\ldots$ \\
Switzerland & 1 & 15.0 & $\ldots$ & 48.3 & $\ldots$ \\
\hline
\end{tabular}

Table 4.2.2.14 Convicted prison population in 2015 - Drug offences

\begin{tabular}{lrrrrr} 
& $\begin{array}{c}\text { Rate per } \\
100000 \text { pop. }\end{array}$ & $\begin{array}{c}\text { cof which \% } \\
\text { of women }\end{array}$ & $\begin{array}{c}\text { of which \% } \\
\text { of minors }\end{array}$ & $\begin{array}{c}\text { of which \% } \\
\text { of foreigners }\end{array}$ & $\begin{array}{c}\text { \% of EU } \\
\text { citizens amongst } \\
\text { foreigners }\end{array}$ \\
\hline Albania & 15 & 1.3 & 0 & 5.2 & $\ldots$ \\
Finland & 8 & 5.5 & 0 & 27.4 & 50 \\
Germany & 8 & 6.1 & 0.1 & 34.0 & 31 \\
Hungary & 4 & 5.9 & 0 & 18.5 & $\ldots$ \\
Italy & 29 & 3.9 & 0.8 & 35.4 & $\ldots$ \\
Lithuania & 31 & 7.1 & 0 & 3.1 & $\ldots$ \\
Montenegro & 30 & 1.6 & $\ldots$ & 1.6 & $\ldots$ \\
Portugal & 22 & 11.2 & $\ldots$ & 27.0 & $\ldots$ \\
Russian Federation & 89 & 13.0 & 0.1 & 8.3 & $\ldots$ \\
Serbia & 24 & 3.7 & 0.2 & 4.1 & $\ldots$ \\
Switzerland & 9 & 3.6 & $\ldots$ & 81.9 & $\ldots$ \\
\hline
\end{tabular}


Notes on Tables 4.2.1 (4.2.1.1 to 4.2.1.6) and 4.2.2 (4.2.2.1 to 4.2.4.14)

Also see the notes under 4.4.1 regarding the reference date (different from 1 st September), the standard definition for inmates, minors, foreigners, and offences

Bulgaria

The number of the convicted but not yet sentenced detainees includes those who have appealed or who are within the statutory limit for doing so. The number of sentenced detainees who have appealed or who are within the statutory limit for doing so is not registered as a separate item in the source of data that has been used.

Germany Table 4.2.1: Data refer to $31^{\text {st }}$ March of the respective year. Data on minors serving a prison sentence after conviction stems from a different source than the rest. The data on minors included in SPACE I refers to persons in youth prisons, which are usually are young adults, not minors. This has been amended in the data included in this chapter of the Sourcebook.

Netherlands In order to be consistent with SPACE, total numbers exclude juveniles and persons in psychiatric institutions. Where figures are given for these, they must not be seen as "of which ..."

Poland

Minors, convicted according to Penal Code, are included in the tables as convicts. Minors, convicted according to Act of Juvenile Treatment, are not included in the tables. Data as of 31 August (Table 4.2.1) except the numbers of aliens, data as of 31 December. Number of total prison population consists of: pre-trial detainees, sentenced persons and persons sentenced according to Code of misdemeanours (Table 4.2.1, 4.2.3).

Switzerland

The number of detainees who have not received a final sentence yet, but who have started serving a prison sentence in advance includes untried detainees, convicted but not yet sentenced detainees, and sentenced detainees who have appealed or who are within the statutory limit for doing so.

Turkey

Tables 4.2.1: Stock data for 2016 refers to 1 st November 2016 instead of 1st September 2016. Data on foreigners comes from the UNCTS database.

Tables 4.2.2.: The data on minors provided for SPACE included inconsistencies that have been amended in the data included here. However, the new data refer to $31^{\text {st }}$ December from 2011 to 2015, and to 1 st November in 2016 instead of 1 st September. Tables 4.2.3.: The data provided for SPACE included inconsistencies that have been amended in the data included here.

Tables 4.2.4 The data provided for SPACE included inconsistencies that have been amended here. The new data provided allows a breakdown by gender, age, and citizenship. However, it does not include pre-trial detainees.

UK: England and Wales The date used for the information in table 4.2.1 is the same of the Offender Management Statistics quarterly publication and refers to $30^{\text {th }}$ June. 


\subsubsection{Prison population: Flow of entries into penal institutions}

Table 4.2.3.1 Flow of entries into penal institutions per 100000 population

\begin{tabular}{|c|c|c|c|c|c|c|c|}
\hline & 2011 & 2012 & 2013 & 2014 & 2015 & 2016 & $\begin{array}{l}\% \text { change } \\
2011-2016\end{array}$ \\
\hline Albania & 121 & 141 & 157 & 223 & 216 & 260 & 114 \\
\hline Armenia & & & & & & & \\
\hline Austria & 141 & 137 & 141 & 135 & 133 & 132 & -6 \\
\hline Azerbaijan & 91 & 93 & 95 & 104 & 99 & 87 & -4 \\
\hline Belgium & 172 & 165 & 167 & 173 & 166 & $\ldots$ & $\ldots$ \\
\hline Bosnia-Herzegovina & 99 & 110 & & & & & $\ldots$ \\
\hline Bulgaria & 102 & 84 & 98 & 74 & 70 & 80 & -22 \\
\hline Croatia & 294 & 273 & 259 & 216 & 185 & 187 & -36 \\
\hline Cyprus & 337 & 366 & 312 & 265 & 228 & 209 & -38 \\
\hline Czech Republic & 158 & 136 & 87 & 101 & 110 & 108 & -32 \\
\hline Denmark & 251 & 249 & 257 & 223 & 211 & 204 & -19 \\
\hline Estonia & 210 & 200 & 163 & 134 & 143 & 141 & -33 \\
\hline Finland & 120 & 112 & 107 & 105 & 104 & 104 & -13 \\
\hline France & 136 & 139 & 136 & 138 & 140 & 142 & 4 \\
\hline Georgia & 541 & 516 & 219 & 228 & 275 & 256 & -53 \\
\hline Germany & 140 & 126 & 119 & 117 & 115 & 118 & -16 \\
\hline Greece & & & 123 & 110 & 118 & 104 & $\ldots$ \\
\hline Hungary & 253 & 243 & 324 & 311 & 220 & 231 & -9 \\
\hline Iceland & 105 & 101 & 95 & 85 & 86 & 64 & -39 \\
\hline Ireland & 383 & 376 & 345 & 354 & 368 & 283 & -26 \\
\hline Italy & 130 & 106 & 100 & 83 & 75 & 78 & -40 \\
\hline Kosovo (UN R/1244/99) & & & & $\ldots$ & $\ldots$ & $\ldots$ & $\ldots$ \\
\hline Latvia & 741 & 738 & 606 & 626 & 645 & & \\
\hline Lithuania & 322 & 309 & 297 & 288 & 263 & 268 & -17 \\
\hline Luxembourg & 213 & 159 & 147 & 173 & 169 & 170 & -20 \\
\hline Malta & 175 & 164 & 159 & 140 & 120 & $\ldots$ & $\ldots$ \\
\hline Moldova & 413 & 434 & 277 & 238 & 308 & 209 & -49 \\
\hline Montenegro & 392 & 506 & 411 & 384 & 364 & 424 & 8 \\
\hline Netherlands & 241 & 233 & 237 & 254 & 228 & 207 & -14 \\
\hline Norway & 218 & 207 & 198 & 175 & 176 & 169 & -22 \\
\hline Poland & 235 & 251 & 234 & 223 & 207 & 207 & -12 \\
\hline Portugal & 59 & 63 & 59 & 52 & 54 & 52 & -13 \\
\hline Romania & 74 & 76 & 79 & 63 & 64 & 63 & -14 \\
\hline Russian Federation & & & 214 & 222 & 222 & 218 & $\ldots$ \\
\hline Serbia & 370 & 378 & 361 & 325 & 313 & 293 & -21 \\
\hline Slovakia & 138 & 167 & 148 & 166 & 156 & 159 & 15 \\
\hline Slovenia & 167 & 186 & 189 & 159 & 166 & 113 & -32 \\
\hline Spain & 98 & 112 & 93 & 98 & 75 & 73 & -25 \\
\hline Sweden & 414 & 411 & 392 & 401 & 423 & $\ldots$ & $\ldots$ \\
\hline Switzerland & 673 & 725 & 670 & 645 & 646 & 637 & -5 \\
\hline North Macedonia & 109 & 115 & 114 & 153 & 118 & 102 & -6 \\
\hline Turkey & 109 & 155 & 214 & 223 & 217 & 238 & 119 \\
\hline Ukraine & 108 & & & & & & \\
\hline UK: England \& Wales & 215 & 199 & 188 & 211 & 197 & 218 & 1 \\
\hline UK: Northern Ireland & 349 & 349 & 239 & 219 & 207 & 215 & -38 \\
\hline UK: Scotland & 700 & 658 & 627 & 605 & 583 & & \\
\hline Mean & 246 & 250 & 225 & 220 & 214 & 184 & \\
\hline Median & 193 & 186 & 189 & 193 & 180 & 170 & \\
\hline Minimum & 59 & 63 & 59 & 52 & 54 & 52 & \\
\hline Maximum & 741 & 738 & 670 & 645 & 646 & 637 & \\
\hline
\end{tabular}

Note: Grey coloured cells are interpolations. 
Table 4.2.3.2 Percentage of pre-trial detainees in the flow of entries

\begin{tabular}{|c|c|c|c|c|c|c|c|}
\hline & 2011 & 2012 & 2013 & 2014 & 2015 & 2016 & $\begin{array}{l}\% \text { change } \\
2011-2016\end{array}$ \\
\hline Albania & 79 & 89 & 89 & 79 & 82 & $\ldots$ & $\ldots$ \\
\hline Armenia & & & $\ldots$ & $\ldots$ & $\ldots$ & & \\
\hline Austria & 71 & 73 & 72 & 73 & 74 & 73 & 2 \\
\hline Azerbaijan & 94 & 90 & 90 & 99 & 99 & 99 & 5 \\
\hline Belgium & 65 & 63 & 63 & 61 & 59 & $\ldots$ & $\ldots$ \\
\hline Bosnia-Herzegovina & 35 & 30 & $\ldots$ & $\ldots$ & $\ldots$ & $\ldots$ & $\ldots$ \\
\hline Bulgaria & 41 & 36 & 31 & 35 & 35 & 31 & -26 \\
\hline Croatia & & 26 & 31 & 33 & 38 & 41 & \\
\hline Cyprus & 50 & 53 & 50 & 49 & 51 & 57 & 13 \\
\hline Czech Republic & 37 & 38 & 58 & 46 & 38 & 38 & 2 \\
\hline Denmark & & & $\ldots$ & $\ldots$ & $\ldots$ & & \\
\hline Estonia & 65 & 74 & 74 & 62 & 60 & 61 & -6 \\
\hline Finland & 32 & 36 & 34 & 34 & 36 & 34 & 6 \\
\hline France & 54 & 51 & 53 & 54 & 55 & 56 & 5 \\
\hline Georgia & 7 & 4 & 8 & 11 & 14 & 11 & 58 \\
\hline Germany & 47 & 46 & 12 & & & & 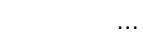 \\
\hline Greece & & $\ldots$ & $\ldots$ & 36 & 33 & 35 & $\ldots$ \\
\hline Hungary & 48 & 47 & 39 & 31 & 33 & 29 & -40 \\
\hline Iceland & 34 & 38 & 44 & 42 & 48 & 63 & 84 \\
\hline Ireland & 27 & 22 & 21 & 22 & 19 & 26 & -5 \\
\hline Italy & 88 & 85 & 85 & 84 & 80 & 78 & -11 \\
\hline Kosovo (UN R/1244/99) & $\ldots$ & $\ldots$ & $\ldots$ & $\ldots$ & $\ldots$ & $\ldots$ & $\ldots$ \\
\hline Latvia & 67 & 67 & 65 & 64 & 66 & & $\ldots$ \\
\hline Lithuania & 65 & 65 & 67 & 65 & 66 & 64 & 0 \\
\hline Luxembourg & 63 & 85 & 81 & 71 & 68 & 67 & 6 \\
\hline Malta & & 60 & 56 & 59 & 61 & & \\
\hline Moldova & 17 & 26 & 38 & 50 & 40 & 37 & 114 \\
\hline Montenegro & 26 & 24 & 26 & 27 & 33 & 30 & 15 \\
\hline Netherlands & 45 & 44 & 40 & 33 & 36 & 39 & -14 \\
\hline Norway & 34 & 38 & 40 & 41 & 40 & 39 & 16 \\
\hline Poland & 24 & 19 & 18 & 19 & 15 & 16 & -34 \\
\hline Portugal & 43 & 43 & 41 & 43 & 44 & 43 & 0 \\
\hline Romania & 10 & 32 & 10 & 10 & $\ldots$ & $\ldots$ & $\ldots$ \\
\hline Russian Federation & & & 64 & 64 & 64 & 61 & \\
\hline Serbia & 32 & 32 & 32 & 29 & 35 & 41 & 28 \\
\hline Slovakia & 40 & 32 & 36 & 36 & 35 & 37 & -7 \\
\hline Slovenia & 29 & 23 & 22 & 26 & 20 & 37 & 25 \\
\hline Spain & 55 & 64 & 66 & $\ldots$ & $\ldots$ & $\ldots$ & $\ldots$ \\
\hline Sweden & 76 & 76 & 76 & 77 & 79 & . & $\ldots$ \\
\hline Switzerland & 27 & 28 & 28 & 26 & 26 & 26 & -3 \\
\hline North Macedonia & 4 & 5 & 15 & 3 & 4 & 5 & 40 \\
\hline Turkey & $\ldots$ & 50 & 36 & 31 & 32 & $\ldots$ & $\ldots$ \\
\hline Ukraine & & & & & & & \\
\hline UK: England \& Wales & 78 & 53 & 77 & 45 & 46 & 42 & -46 \\
\hline UK: Northern Ireland & $\ldots$ & $\ldots$ & $\ldots$ & 74 & 71 & 69 & $\ldots$ \\
\hline UK: Scotland & & & & & 57 & & $\ldots$ \\
\hline Mean & 46 & 46 & 47 & 46 & 47 & 45 & \\
\hline Median & 43 & 43 & 41 & 43 & 42 & 39 & \\
\hline Minimum & 4 & 4 & 8 & 3 & 4 & 5 & \\
\hline Maximum & 94 & 90 & 90 & 99 & 99 & 99 & \\
\hline
\end{tabular}

Note: Grey coloured cells are interpolations. 
Table 4.2.3.3 Percentage of women in the flow of entries

\begin{tabular}{lrrrrrrr} 
& \multicolumn{2}{c}{2011} & \multicolumn{2}{c}{2012} & \multicolumn{2}{c}{2013} & \multicolumn{2}{c}{2014} & \multicolumn{2}{c}{2015} & 2016 & $\begin{array}{c}\% \text { change } \\
2011-2016\end{array}$ \\
\hline Croatia & $\ldots .$. & 5.0 & 5.3 & 5.5 & 5.7 & 5.7 & $\ldots$ \\
Cyprus & 5.3 & 4.9 & 4.8 & 5.9 & 6.3 & 6.0 & 15 \\
Czech Republic & 9.0 & 10.2 & 10.5 & 11.0 & 12.3 & 14.5 & 61 \\
Finland & 8.4 & 8.0 & 9.5 & 8.7 & 9.7 & 10.6 & 26 \\
France & 4.8 & 5.0 & 4.9 & $\ldots$ & 4.9 & 5.0 & 5 \\
Georgia & 5.0 & 5.1 & $\ldots$ & 2.5 & 3.1 & 2.8 & -44 \\
Hungary & 10.0 & 9.5 & 10.2 & 10.1 & 8.6 & 9.1 & -8 \\
Italy & 7.7 & 7.8 & 7.6 & 7.4 & 7.3 & 7.2 & -7 \\
Moldova & $\ldots .$. & $\ldots$. & $\ldots$. & $\ldots$. & 4.2 & $\ldots$. & $\ldots$ \\
Portugal & 6.9 & 7.1 & 7.8 & 7.3 & 7.8 & 7.6 & 9 \\
Serbia & 1.5 & 4.0 & 4.2 & 3.8 & 3.9 & 3.7 & 152 \\
Turkey & 4.2 & 3.4 & 3.4 & 3.7 & 3.7 & 3.8 & -8 \\
\hline
\end{tabular}

Table 4.2.3.4 Percentage of minors in the flow of entries

\begin{tabular}{|c|c|c|c|c|c|c|c|}
\hline & 2011 & 2012 & 2013 & 2014 & 2015 & 2016 & $\begin{array}{c}\% \text { change } \\
2011-2016\end{array}$ \\
\hline Croatia & & & & & 0.3 & $\ldots$ & ... \\
\hline Cyprus & 0.1 & 0.2 & 0.3 & 0.7 & 0.2 & 0.1 & 6 \\
\hline Czech Republic & 1.2 & 1.2 & 1.2 & 1.0 & 0.8 & 0.7 & -30 \\
\hline Finland & 0.6 & 0.4 & 0.4 & 0.5 & 0.7 & 0.6 & 15 \\
\hline France & 3.5 & 3.5 & 3.5 & & 3.3 & 3.5 & -2 \\
\hline Georgia & 0.9 & 0.6 & $\ldots$ & 0.8 & 0.5 & 0.2 & -76 \\
\hline Italy & 1.6 & 2.0 & 2.0 & 2.0 & 2.3 & 2.4 & 49 \\
\hline Moldova & $\ldots$ & $\ldots$ & $\ldots$ & $\ldots$ & 0.5 & $\ldots$ & .. \\
\hline Montenegro & $\ldots$ & $\ldots$ & - & 0.3 & 0.4 & 0.8 & .. \\
\hline Netherlands & 4.6 & 4.8 & 3.7 & 3.2 & 3.7 & 4.1 & -10 \\
\hline Portugal & 0.9 & 1.1 & 0.8 & 0.8 & 0.7 & 0.7 & -24 \\
\hline Serbia & 0.4 & 0.3 & 0.4 & 0.4 & 0.3 & 0.5 & 15 \\
\hline Turkey & 2.1 & 2.7 & 3.8 & 4.4 & 5.3 & 4.9 & 136 \\
\hline
\end{tabular}

Table 4.2.3.5 Percentage of foreigners in the flow of entries

\begin{tabular}{|c|c|c|c|c|c|c|c|}
\hline & 2011 & 2012 & 2013 & 2014 & 2015 & 2016 & $\begin{array}{c}\% \text { change } \\
2011-2016\end{array}$ \\
\hline Czech Republic & 10.4 & 12.0 & 10.5 & 11.0 & 12.3 & 14.5 & 39 \\
\hline Finland & 14.1 & 16.0 & 15.8 & 16.7 & 15.7 & 17.0 & 21 \\
\hline France & 20.1 & 21.0 & 22.1 & $\ldots$ & 20.5 & 21.6 & 8 \\
\hline Georgia & 1.5 & & & 2.4 & 3.0 & 3.5 & 139 \\
\hline Italy & 43.3 & 42.9 & 43.5 & 45.3 & 44.8 & 44.6 & 3 \\
\hline Montenegro & & & 27.9 & 26.9 & 24.0 & 23.0 & $\ldots$ \\
\hline Portugal & 19.2 & 18.8 & 16.9 & 16.7 & 17.7 & 16.0 & -17 \\
\hline Serbia & 19.3 & 18.6 & 16.4 & 13.4 & 10.1 & 6.6 & -66 \\
\hline Turkey & 0.3 & 0.4 & 0.3 & 0.4 & 0.6 & 0.5 & 49 \\
\hline
\end{tabular}


Table 4.2.3.6 Percentage of foreigners with EU citizenship in the flow of entries

\begin{tabular}{lrrrrrrr} 
& \multicolumn{2}{c}{2011} & \multicolumn{1}{c}{2012} & \multicolumn{1}{c}{2013} & \multicolumn{2}{c}{2014} & \multicolumn{2}{c}{2015} & \multicolumn{2}{c}{2016} & $\begin{array}{r}\% \text { change } \\
2011-2016\end{array}$ \\
\hline Czech Republic & 47.6 & 46.4 & 69.2 & 60.0 & 54.2 & 52.5 & 10 \\
Finland & 58.8 & 59.5 & 58.0 & 55.1 & 55.8 & 52.2 & -11 \\
France & 27.6 & 27.7 & 28.8 & 28.4 & 27.0 & 24.8 & -10 \\
Georgia & $\ldots$. & $\ldots$ & $\ldots$ & 2.4 & 2.9 & 2.4 & $\ldots$ \\
Serbia & 6.7 & 4.9 & 6.9 & 10.0 & 14.9 & 19.1 & 187 \\
\hline
\end{tabular}




\subsubsection{Prison population: Flow of exits from penal institutions}

Table 4.2.4.1 Flow of exits from penal institutions per 100000 population*

\begin{tabular}{|c|c|c|c|c|c|c|c|}
\hline & 2011 & 2012 & 2013 & 2014 & 2015 & 2016 & $\begin{array}{l}\% \text { change } \\
2011-2016\end{array}$ \\
\hline Albania & 110 & 142 & 124 & 155 & 193 & 166 & 51 \\
\hline Armenia & 84 & 54 & 88 & 52 & 50 & & \\
\hline Austria & 141 & 139 & 140 & 137 & 133 & 127 & -10 \\
\hline Azerbaijan & 56 & 65 & 80 & 64 & 76 & 75 & 35 \\
\hline Belgium & 164 & 155 & 166 & 179 & 164 & $\ldots$ & $\ldots$ \\
\hline Bosnia-Herzegovina & 106 & 111 & $\ldots$ & $\ldots$ & $\ldots$ & $\ldots$ & $\ldots$ \\
\hline Bulgaria & 94 & 92 & 93 & 86 & 75 & $\ldots$ & $\ldots$ \\
\hline Croatia & 275 & 265 & 256 & 214 & 183 & 182 & -34 \\
\hline Cyprus & 256 & 268 & 242 & 197 & 163 & 154 & -40 \\
\hline Czech Republic & 146 & 141 & 146 & 80 & 89 & 102 & -30 \\
\hline Denmark & 152 & 157 & 160 & 145 & 138 & 125 & -18 \\
\hline Estonia & 198 & 202 & 178 & 159 & 158 & 154 & -22 \\
\hline Finland & 120 & 114 & 110 & 106 & 103 & 103 & -14 \\
\hline France & 125 & 135 & 135 & 136 & 138 & 139 & 11 \\
\hline Georgia & 201 & 246 & 384 & 171 & 275 & 206 & 2 \\
\hline Germany & $\ldots$ & $\ldots$ & $\ldots$ & & $\ldots$ & $\ldots$ & $\ldots$ \\
\hline Greece & $\ldots$ & $\ldots$ & 82 & 86 & 106 & 93 & $\ldots$ \\
\hline Hungary & 172 & 177 & 316 & 241 & 215 & 222 & 29 \\
\hline Iceland & 104 & 105 & 107 & 90 & 90 & 84 & -19 \\
\hline Ireland & 386 & 379 & 366 & 365 & 373 & 285 & -26 \\
\hline Italy & 141 & 124 & 116 & 108 & 88 & 86 & -39 \\
\hline Kosovo (UN R/1244/99) & $\ldots$ & $\ldots$ & $\ldots$ & $\ldots$ & $\ldots$ & $\ldots$ & $\ldots$ \\
\hline Latvia & 164 & 184 & 186 & 178 & 185 & $\ldots$ & $\ldots$ \\
\hline Lithuania & & & & & & 163 & \\
\hline Luxembourg & 202 & 225 & 147 & 167 & 155 & 175 & -13 \\
\hline Malta & 163 & 157 & 153 & $\ldots$ & 120 & $\ldots$ & $\ldots$ \\
\hline Moldova & 40 & 85 & 68 & 110 & 79 & 95 & 139 \\
\hline Montenegro & 543 & 487 & 460 & 360 & 329 & 407 & -25 \\
\hline Netherlands & 245 & 236 & 242 & 258 & 230 & 206 & -16 \\
\hline Norway & 215 & 209 & 196 & 175 & $\ldots$ & $\ldots$ & $\ldots$ \\
\hline Poland & 234 & 243 & 248 & 228 & 225 & 205 & -12 \\
\hline Portugal & 50 & 54 & 53 & 55 & 52 & 56 & 13 \\
\hline Romania & 61 & 69 & 71 & 79 & 72 & 75 & 23 \\
\hline Russian Federation & & 178 & 201 & 195 & $\ldots$ & $\ldots$ & $\ldots$ \\
\hline Serbia & 371 & 390 & 365 & 322 & 314 & 283 & -24 \\
\hline Slovakia & 128 & 129 & 138 & 127 & 128 & 128 & 0 \\
\hline Slovenia & 181 & 187 & 156 & 163 & 130 & 117 & -35 \\
\hline Spain & 101 & 115 & 98 & 89 & 83 & 78 & -23 \\
\hline Sweden & $\ldots$ & $\ldots$ & $\ldots$ & $\ldots$ & $\ldots$ & $\ldots$ & $\ldots$ \\
\hline Switzerland & & & $\ldots$ & $\ldots$ & $\ldots$ & & $\ldots$ \\
\hline North Macedonia & 102 & 147 & 124 & 154 & 119 & 103 & 1 \\
\hline Turkey & $\ldots$ & 161 & 335 & 220 & 213 & $\ldots$ & $\ldots$ \\
\hline Ukraine & 124 & 125 & 118 & $\ldots$ & $\ldots$ & $\ldots$ & $\ldots$ \\
\hline UK: England \& Wales & & & $\ldots$ & & & & \\
\hline $\begin{array}{l}\text { UK: Northern Ireland } \\
\text { UK: Scotland }\end{array}$ & 330 & 350 & 234 & 225 & $\begin{array}{l}220 \\
311\end{array}$ & 222 & -33 \\
\hline Mean & 175 & 179 & 181 & 163 & 160 & 154 & \\
\hline Median & 149 & 156 & 150 & 157 & 138 & 133 & \\
\hline Minimum & 40 & 54 & 53 & 52 & 50 & 56 & \\
\hline Maximum & 543 & 487 & 460 & 365 & 373 & 407 & \\
\hline
\end{tabular}

Note: The flow of exits is estimated by adding the flows of releases and deaths. 
Table 4.2.4.2 Flow of releases from penal institutions per 100000 population*

\begin{tabular}{|c|c|c|c|c|c|c|c|}
\hline & 2011 & 2012 & 2013 & 2014 & 2015 & 2016 & $\begin{array}{c}\% \text { change } \\
2011-2016\end{array}$ \\
\hline Albania & 109 & 142 & 123 & 155 & 193 & 165 & 51 \\
\hline Armenia & 83 & 54 & 87 & 50 & 49 & 55 & -34 \\
\hline Austria & 141 & 138 & 140 & 136 & 133 & 127 & -10 \\
\hline Azerbaijan & 54 & 63 & 79 & 63 & 74 & 74 & 37 \\
\hline Belgium & 164 & 155 & 165 & 179 & 164 & $\ldots$ & $\ldots$ \\
\hline Bosnia-Herzegovina & 106 & 111 & $\ldots$ & $\ldots$ & $\ldots$ & $\ldots$ & $\ldots$ \\
\hline Bulgaria & 94 & 92 & 92 & 86 & 75 & $\ldots$ & \\
\hline Croatia & 275 & 264 & 256 & 214 & 183 & 181 & -34 \\
\hline Cyprus & 256 & 268 & 242 & 197 & 163 & 154 & -40 \\
\hline Czech Republic & 146 & 140 & 146 & 80 & 88 & 102 & -30 \\
\hline Denmark & & & $\ldots$ & & 138 & 125 & \\
\hline Estonia & 197 & 202 & 178 & 158 & 158 & 153 & -22 \\
\hline Finland & 120 & 114 & 109 & 106 & 103 & 102 & -14 \\
\hline France & 125 & 135 & 134 & 136 & 137 & 139 & 11 \\
\hline Georgia & $\ldots$ & $\ldots$ & $\ldots$ & $\ldots$ & $\ldots$ & $\ldots$ & $\ldots$ \\
\hline Germany & $\ldots$ & $\ldots$ & $\ldots$ & $\ldots$ & $\ldots$ & $\ldots$ & $\ldots$ \\
\hline Greece & & $\ldots$ & $\ldots$ & 86 & 106 & 92 & \\
\hline Hungary & 167 & 172 & 309 & 236 & 207 & 215 & 29 \\
\hline Iceland & 104 & 105 & 106 & 90 & 90 & 84 & -19 \\
\hline Ireland & 386 & 379 & 366 & 365 & 372 & 285 & -26 \\
\hline Italy & 141 & 123 & 116 & 108 & 88 & 86 & -39 \\
\hline Kosovo (UN R/1244/99) & & $\ldots$ & $\ldots$ & $\ldots$ & $\ldots$ & $\ldots$ & $\ldots$ \\
\hline Latvia & 162 & 182 & 185 & 176 & 184 & $\ldots$ & $\ldots$ \\
\hline Lithuania & & & $\ldots$ & & $\ldots$ & 161 & \\
\hline Luxembourg & 202 & 224 & 147 & 167 & 155 & 175 & -13 \\
\hline Malta & 162 & 156 & 152 & ... & 119 & ... & $\ldots$ \\
\hline Moldova & 38 & 84 & 67 & 108 & 78 & 93 & 145 \\
\hline Montenegro & 542 & 487 & 459 & 359 & 328 & 406 & -25 \\
\hline Netherlands & 245 & 236 & 242 & 258 & 230 & 206 & -16 \\
\hline Norway & 215 & 209 & 196 & 175 & 175 & 163 & -24 \\
\hline Poland & 234 & 243 & 248 & 227 & 225 & 205 & -12 \\
\hline Portugal & 49 & 54 & 52 & 55 & 52 & 56 & 13 \\
\hline Romania & 60 & 69 & 70 & 79 & 72 & 74 & 23 \\
\hline Russian Federation & $\ldots$ & 175 & 198 & 192 & $\ldots$ & $\ldots$ & $\ldots$ \\
\hline Serbia & 370 & 389 & 364 & 322 & 313 & 282 & -24 \\
\hline Slovakia & 128 & 129 & 138 & 127 & 128 & 127 & -1 \\
\hline Slovenia & 181 & 187 & 156 & 163 & 130 & 117 & -35 \\
\hline Spain & 100 & 114 & 97 & 89 & 82 & 77 & -23 \\
\hline Sweden & $\ldots$ & $\ldots$ & $\ldots$ & $\ldots$ & $\ldots$ & $\ldots$ & $\ldots$ \\
\hline Switzerland & & & 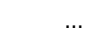 & & & & \\
\hline North Macedonia & 101 & 146 & 123 & 153 & 118 & 103 & 1 \\
\hline Turkey & $\ldots$ & 161 & 335 & 220 & 212 & 234 & $\ldots$ \\
\hline Ukraine & 122 & 122 & 116 & $\ldots$ & $\ldots$ & $\ldots$ & $\cdots$ \\
\hline UK: England \& Wales & & & & & & & \\
\hline $\begin{array}{l}\text { UK: Northern Ireland } \\
\text { UK: Scotland }\end{array}$ & 330 & 349 & 234 & 225 & $\begin{array}{l}220 \\
310\end{array}$ & 222 & -33 \\
\hline Mean & 174 & 177 & 178 & 163 & 157 & 151 & \\
\hline Median & 143 & 151 & 147 & 156 & 138 & 133 & \\
\hline Minimum & 38 & 54 & 52 & 50 & 49 & 55 & \\
\hline Maximum & 542 & 487 & 459 & 365 & 372 & 406 & \\
\hline
\end{tabular}


Table 4.2.4.3 Percentage of pre-trial detainees in the flow of releases

\begin{tabular}{|c|c|c|c|c|c|c|c|}
\hline & 2011 & 2012 & 2013 & 2014 & 2015 & 2016 & $\begin{array}{l}\% \text { change } \\
2011-2016\end{array}$ \\
\hline Albania & 58 & 55 & 64 & 67 & 76 & $\ldots$ & $\ldots$ \\
\hline Armenia & 27 & 24 & 22 & 33 & 35 & 34 & 26 \\
\hline Austria & 28 & 22 & 27 & 27 & 30 & 31 & 10 \\
\hline Azerbaijan & $\ldots$ & 11 & 12 & 18 & 16 & 21 & $\ldots$ \\
\hline Belgium & 44 & 43 & 40 & 38 & 43 & $\ldots$ & $\ldots$ \\
\hline Bosnia-Herzegovina & 31 & 27 & $\ldots$ & $\ldots$ & $\ldots$ & $\ldots$ & $\ldots$ \\
\hline Bulgaria & 15 & 10 & 10 & 10 & $\ldots$ & $\ldots$ & $\ldots$ \\
\hline Croatia & 37 & 28 & 30 & 35 & 38 & 41 & 10 \\
\hline Cyprus & $\ldots$ & $\ldots$ & $\ldots$ & $\ldots$ & $\ldots$ & $\ldots$ & $\ldots$ \\
\hline Czech Republic & 13 & 13 & 12 & 16 & 15 & 16 & 24 \\
\hline Denmark & & $\ldots$ & $\ldots$ & $\ldots$ & $\ldots$ & $\ldots$ & $\ldots$ \\
\hline Estonia & 10 & 20 & 19 & 15 & 15 & 15 & 44 \\
\hline Finland & 18 & 20 & 19 & 19 & 20 & 19 & 8 \\
\hline France & 13 & 12 & 14 & $\ldots$ & $\ldots$ & 22 & 65 \\
\hline Georgia & $\ldots$ & $\ldots$ & $\ldots$ & $\ldots$ & $\ldots$ & $\ldots$ & $\ldots$ \\
\hline Germany & $\ldots$ & $\ldots$ & $\ldots$ & $\ldots$ & $\ldots$ & $\ldots$ & $\ldots$ \\
\hline Greece & $\ldots$ & $\ldots$ & $\ldots$ & 28 & 16 & 19 & $\ldots$ \\
\hline Hungary & 27 & 25 & 18 & 18 & 19 & 17 & -39 \\
\hline Iceland & 20 & 23 & 21 & 22 & 20 & 25 & 28 \\
\hline Ireland & 29 & 25 & 22 & 22 & 21 & 28 & -1 \\
\hline Italy & 50 & 41 & 41 & 41 & 37 & 37 & -28 \\
\hline Kosovo (UN R/1244/99) & $\ldots$ & $\ldots$ & $\ldots$ & $\ldots$ & $\ldots$ & $\ldots$ & $\ldots$ \\
\hline Latvia & 34 & 32 & 34 & 37 & 35 & $\ldots$ & $\ldots$ \\
\hline Lithuania & & & $\ldots$ & & $\ldots$ & $\ldots$ & $\ldots$ \\
\hline Luxembourg & 31 & 35 & 48 & 55 & 47 & 43 & 36 \\
\hline Malta & 28 & 47 & 31 & $\ldots$ & 47 & $\ldots$ & $\ldots$ \\
\hline Moldova & 33 & 53 & 39 & 33 & 54 & 54 & 65 \\
\hline Montenegro & 28 & 16 & 23 & 27 & 33 & 30 & 7 \\
\hline Netherlands & 27 & 26 & 25 & 21 & 22 & 24 & -11 \\
\hline Norway & 18 & 20 & 19 & 18 & 22 & 22 & 19 \\
\hline Poland & 18 & 16 & 14 & 15 & 13 & 10 & -43 \\
\hline Portugal & & 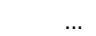 & $\ldots$ & 21 & 21 & 19 & $\ldots$ \\
\hline Romania & 13 & 10 & 10 & 9 & 19 & 13 & 0 \\
\hline Russian Federation & . & 28 & 3 & 19 & $\ldots$ & $\ldots$ & $\ldots$ \\
\hline Serbia & 33 & 33 & 34 & 30 & 35 & 41 & 27 \\
\hline Slovakia & 17 & 16 & 17 & 17 & 17 & 18 & 6 \\
\hline Slovenia & 22 & 23 & 27 & 25 & 34 & 27 & 19 \\
\hline Spain & 53 & 31 & 35 & $\ldots$ & 22 & $\ldots$ & $\ldots$ \\
\hline Sweden & $\ldots$ & $\ldots$ & $\ldots$ & $\ldots$ & $\ldots$ & $\ldots$ & $\ldots$ \\
\hline Switzerland & & & $\ldots$ & & $\ldots$ & $\ldots$ & $\ldots$ \\
\hline North Macedonia & 19 & 27 & 37 & 25 & 20 & 16 & -16 \\
\hline Turkey & & $\ldots$ & $\ldots$ & 28 & $\ldots$ & $\ldots$ & $\ldots$ \\
\hline Ukraine & 26 & 26 & 17 & $\ldots$ & $\ldots$ & $\ldots$ & $\ldots$ \\
\hline UK: England \& Wales & & & $\ldots$ & & $\ldots$ & $\ldots$ & $\ldots$ \\
\hline UK: Northern Ireland & 40 & 37 & 49 & 49 & $\begin{array}{l}48 \\
43\end{array}$ & 49 & 25 \\
\hline $\begin{array}{l}\text { UK: Scotland } \\
\text { Mean }\end{array}$ & $\ldots$ & $\ldots$ & $\ldots$ & $\ldots$ & $\frac{43}{30}$ & $\ldots$ & \\
\hline Median & 27 & 25 & 22 & 25 & 22 & 23 & \\
\hline Minimum & 10 & 10 & 3 & 9 & 13 & 10 & \\
\hline Maximum & 58 & 55 & 64 & 67 & 76 & 54 & \\
\hline
\end{tabular}


Table 4.2.4.4 Percentage of sentenced prisoners in the flow of releases

\begin{tabular}{|c|c|c|c|c|c|c|c|}
\hline & 2011 & 2012 & 2013 & 2014 & 2015 & 2016 & $\begin{array}{c}\% \text { change } \\
2011-2016\end{array}$ \\
\hline Albania & 41 & 45 & 36 & 33 & 22 & & \\
\hline Armenia & 73 & 75 & 77 & 64 & 61 & 63 & -13 \\
\hline Austria & 63 & 63 & 64 & 69 & 70 & 69 & 9 \\
\hline Azerbaijan & 99 & 91 & 88 & 80 & 83 & 73 & -26 \\
\hline Belgium & 47 & 50 & 53 & 54 & 49 & $\ldots$ & $\ldots$ \\
\hline Bosnia-Herzegovina & 65 & 69 & $\ldots$ & . & $\ldots$ & $\ldots$ & $\ldots$ \\
\hline Bulgaria & 85 & 90 & 90 & 91 & 92 & $\ldots$ & $\ldots$ \\
\hline Croatia & 26 & 29 & 28 & 29 & 30 & 44 & 73 \\
\hline Cyprus & 55 & 47 & 53 & 49 & 45 & 41 & -26 \\
\hline Czech Republic & 82 & 10 & 79 & 76 & 77 & 77 & -6 \\
\hline Denmark & & & $\ldots$ & & 100 & 100 & \\
\hline Estonia & 90 & 327 & 81 & 85 & 85 & 86 & -5 \\
\hline Finland & 81 & 78 & 79 & 79 & 79 & 79 & -2 \\
\hline France & 87 & 88 & 86 & $\ldots$ & $\ldots$ & 78 & -11 \\
\hline Georgia & $\ldots$ & $\ldots$ & $\ldots$ & $\ldots$ & $\ldots$ & $\ldots$ & $\ldots$ \\
\hline Germany & $\ldots$ & $\ldots$ & $\ldots$ & $\ldots$ & $\ldots$ & $\ldots$ & $\ldots$ \\
\hline Greece & $\ldots$ & $\ldots$ & $\ldots$ & 72 & 82 & 80 & $\ldots$ \\
\hline Hungary & 71 & 74 & 81 & 81 & 80 & 82 & 15 \\
\hline Iceland & 79 & 76 & 78 & 78 & 79 & 75 & -6 \\
\hline Ireland & 71 & 75 & 78 & 78 & 79 & 72 & 0 \\
\hline Italy & 49 & 57 & 59 & 58 & 62 & 63 & 29 \\
\hline Kosovo (UN R/1244/99) & & . & $\ldots$ & & $\ldots$ & $\ldots$ & $\ldots$ \\
\hline Latvia & 66 & 68 & 66 & 64 & 65 & $\ldots$ & $\ldots$ \\
\hline Lithuania & $\ldots$ & $\ldots$ & $\ldots$ & $\ldots$ & $\ldots$ & 100 & $\ldots$ \\
\hline Luxembourg & 40 & 52 & 48 & 41 & 49 & 53 & 31 \\
\hline Malta & 72 & 44 & 69 & & 50 & $\ldots$ & $\ldots$ \\
\hline Moldova & 71 & 48 & 63 & 68 & 48 & 46 & -34 \\
\hline Montenegro & 72 & 84 & 77 & 73 & 66 & 69 & -3 \\
\hline Netherlands & 70 & 72 & 73 & 76 & 74 & 72 & 3 \\
\hline Norway & 68 & 70 & 71 & 75 & 66 & 66 & -2 \\
\hline Poland & 70 & 71 & 69 & 60 & 59 & 60 & -15 \\
\hline Portugal & $\ldots$ & $\ldots$ & $\ldots$ & $\ldots$ & 79 & 81 & $\ldots$ \\
\hline Romania & 87 & 91 & 91 & 91 & 81 & 87 & -1 \\
\hline Russian Federation & & 62 & 97 & 81 & $\ldots$ & & $\ldots$ \\
\hline Serbia & 67 & 67 & 66 & 70 & 65 & 59 & -13 \\
\hline Slovakia & 82 & 84 & 83 & 83 & 83 & 82 & 0 \\
\hline Slovenia & 25 & 27 & 34 & 31 & 66 & 63 & 147 \\
\hline Spain & 47 & 69 & 79 & $\ldots$ & 78 & $\ldots$ & $\ldots$ \\
\hline Sweden & $\ldots$ & $\ldots$ & $\ldots$ & $\ldots$ & $\ldots$ & $\ldots$ & $\ldots$ \\
\hline Switzerland & & & $\ldots$ & & $\ldots$ & $\ldots$ & $\ldots$ \\
\hline North Macedonia & 81 & 72 & 63 & 75 & 78 & 82 & 1 \\
\hline Turkey & & 91 & 62 & 81 & 84 & 108 & $\ldots$ \\
\hline Ukraine & 74 & 74 & 83 & $\ldots$ & $\ldots$ & $\ldots$ & $\ldots$ \\
\hline UK: England \& Wales & & & $\ldots$ & $\ldots$ & $\ldots$ & $\ldots$ & $\ldots$ \\
\hline $\begin{array}{l}\text { UK: Northern Ireland } \\
\text { UK: Scotland }\end{array}$ & 60 & 62 & $\begin{array}{c}\ldots \\
48 \\
\ldots\end{array}$ & 48 & $\begin{array}{l}\dddot{39} \\
58\end{array}$ & 49 & -19 \\
\hline Mean & 67 & 73 & 69 & 67 & 68 & 72 & \\
\hline Median & 71 & 70 & 72 & 73 & 70 & 73 & \\
\hline Minimum & 25 & 10 & 28 & 29 & 22 & 41 & \\
\hline Maximum & 99 & 327 & 97 & 91 & 100 & 108 & \\
\hline
\end{tabular}


Table 4.2.4.5 Percentage of inmates transferred to another country in the flow of releases (2015-2016)

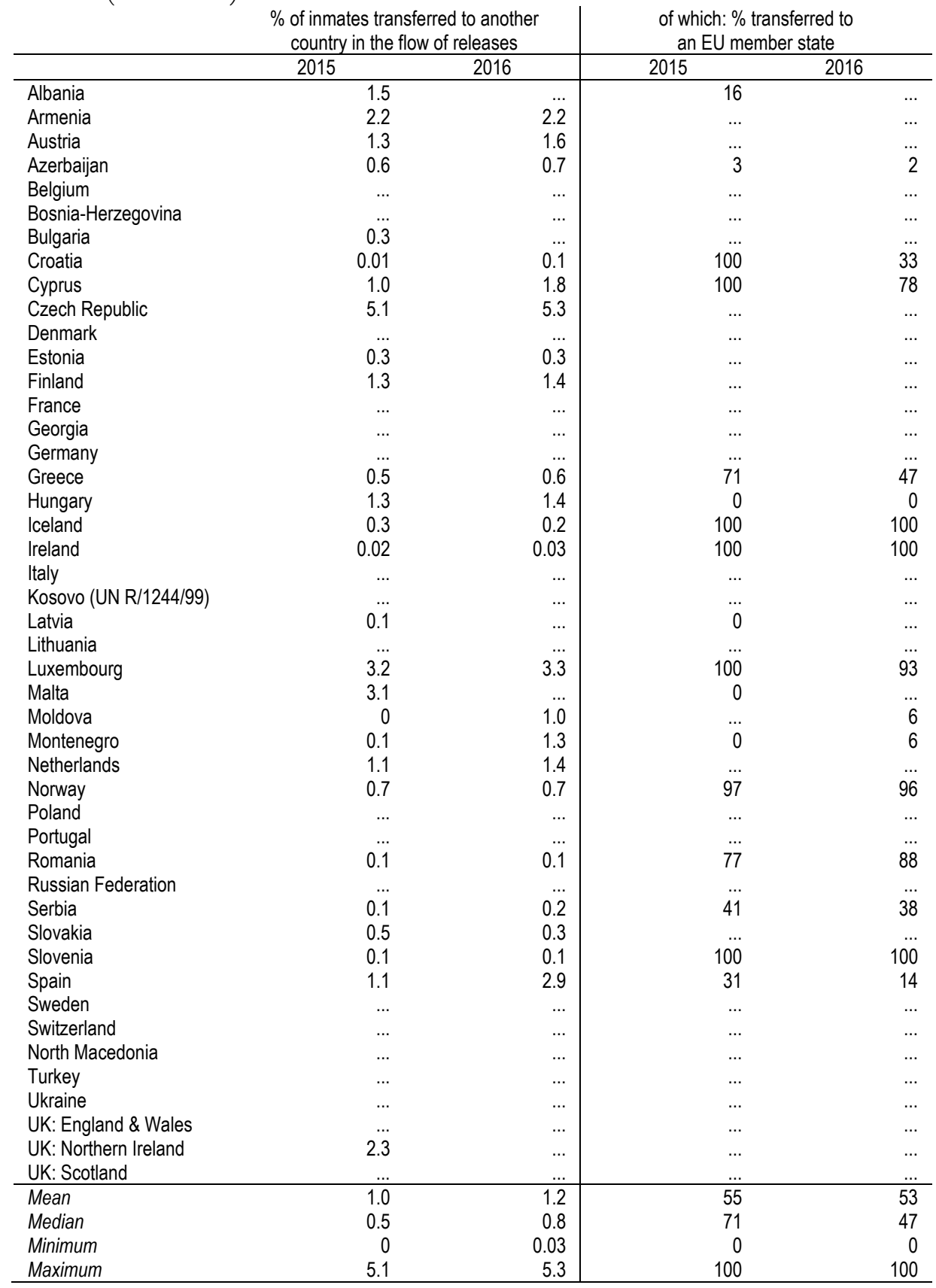


Table 4.2.4.6 Percentage of "other" releases in the flow of releases

\begin{tabular}{|c|c|c|c|c|c|c|c|}
\hline & 2011 & 2012 & 2013 & 2014 & 2015 & 2016 & $\begin{array}{l}\% \text { change } \\
2011-2016\end{array}$ \\
\hline Albania & 0 & 0 & 0 & 0 & 0 & $\ldots$ & $\ldots$ \\
\hline Armenia & 25 & 2 & 1 & 3 & $\ldots$ & $\ldots$ & $\ldots$ \\
\hline Austria & 9 & 15 & 9 & 4 & $\ldots$ & $\ldots$ & \\
\hline Azerbaijan & 4 & $\ldots$ & 2 & 4 & 2 & 6 & 60 \\
\hline Belgium & 9 & 8 & 7 & 8 & 8 & $\ldots$ & $\ldots$ \\
\hline Bosnia-Herzegovina & 4 & 4 & $\ldots$ & $\ldots$ & $\ldots$ & $\ldots$ & $\ldots$ \\
\hline Bulgaria & 1 & 1 & $\ldots$ & $\ldots$ & 9 & $\ldots$ & $\ldots$ \\
\hline Croatia & 37 & 44 & 42 & 37 & 32 & $\ldots$ & \\
\hline Cyprus & 1 & 0 & 0 & 0 & 0 & 0 & -93 \\
\hline Czech Republic & 5 & 7 & 8 & 8 & 1 & 1 & -74 \\
\hline Denmark & $\ldots$ & $\ldots$ & $\ldots$ & & 0 & $\ldots$ & $\ldots$ \\
\hline Estonia & 0 & 0 & 0 & 0 & 0 & 0 & $\ldots$ \\
\hline Finland & 1 & 1 & 2 & 2 & 0 & 0 & -91 \\
\hline France & 0 & 0 & 0 & 0 & $\ldots$ & $\ldots$ & $\ldots$ \\
\hline Georgia & $\ldots$ & $\ldots$ & $\ldots$ & $\ldots$ & $\ldots$ & $\ldots$ & $\ldots$ \\
\hline Germany & $\ldots$ & $\ldots$ & $\ldots$ & $\ldots$ & $\ldots$ & $\ldots$ & $\ldots$ \\
\hline Greece & $\ldots$ & $\ldots$ & $\ldots$ & $\ldots$ & 1 & 1 & $\ldots$ \\
\hline Hungary & 3 & 2 & 2 & 2 & 3 & 3 & 7 \\
\hline Iceland & 1 & 1 & 1 & 0 & 0 & 0 & -100 \\
\hline Ireland & $\ldots$ & $\ldots$ & $\ldots$ & $\ldots$ & 0 & $\ldots$ & $\ldots$ \\
\hline Italy & 1 & 1 & 1 & 1 & 1 & 1 & -19 \\
\hline Kosovo (UN R/1244/99) & $\ldots$ & $\ldots$ & $\ldots$ & $\ldots$ & $\ldots$ & $\ldots$ & $\ldots$ \\
\hline Latvia & 1 & 1 & 1 & 0 & 1 & $\ldots$ & $\ldots$ \\
\hline Lithuania & $\ldots$ & $\ldots$ & $\ldots$ & $\ldots$ & $\ldots$ & 1 & $\ldots$ \\
\hline Luxembourg & 28 & 14 & 4 & 3 & 2 & 3 & -89 \\
\hline Malta & 0 & 9 & 0 & $\ldots$ & 0 & $\ldots$ & $\ldots$ \\
\hline Moldova & 0 & 0 & 0 & $\ldots$ & 0 & 0 & $\ldots$ \\
\hline Montenegro & 0 & 0 & 0 & 0 & 0 & 0 & $\ldots$ \\
\hline Netherlands & 3 & 2 & 2 & 3 & 3 & 3 & 19 \\
\hline Norway & 14 & 10 & 10 & 7 & 11 & 11 & -17 \\
\hline Poland & 8 & 0 & $\ldots$ & $\ldots$ & $\ldots$ & $\ldots$ & $\ldots$ \\
\hline Portugal & 26 & 29 & 30 & 0 & 0 & 7 & -74 \\
\hline Romania & 8 & 0 & 1 & 1 & 1 & $\ldots$ & $\ldots$ \\
\hline Russian Federation & $\ldots$ & $\ldots$ & $\ldots$ & $\ldots$ & $\ldots$ & $\ldots$ & $\ldots$ \\
\hline Serbia & 0 & 0 & 0 & 0 & 0 & 0 & 11 \\
\hline Slovakia & 1 & 0 & 0 & 0 & 0 & 0 & -100 \\
\hline Slovenia & 52 & 49 & 39 & 44 & 0 & 2 & -96 \\
\hline Spain & $\ldots$ & $\ldots$ & $\ldots$ & $\ldots$ & $\ldots$ & $\ldots$ & $\ldots$ \\
\hline Sweden & $\ldots$ & $\ldots$ & $\ldots$ & $\ldots$ & $\ldots$ & $\ldots$ & $\ldots$ \\
\hline Switzerland & $\ldots$ & $\ldots$ & $\ldots$ & $\ldots$ & $\ldots$ & $\ldots$ & \\
\hline North Macedonia & 0 & 0 & 0 & 0 & 1 & 1 & 391 \\
\hline Turkey & $\ldots$ & $\ldots$ & 0 & $\ldots$ & $\ldots$ & $\ldots$ & $\ldots$ \\
\hline Ukraine & $\ldots$ & $\ldots$ & $\ldots$ & $\ldots$ & $\ldots$ & $\ldots$ & $\ldots$ \\
\hline UK: England \& Wales & $\ldots$ & $\ldots$ & $\ldots$ & $\ldots$ & $\ldots$ & $\ldots$ & $\ldots$ \\
\hline $\begin{array}{l}\text { UK: Northern Ireland } \\
\text { UK: Scotland }\end{array}$ & 0 & $\begin{array}{c}2 \\
\ldots\end{array}$ & $\begin{array}{c}3 \\
\ldots\end{array}$ & $\begin{array}{l}3 \\
\ldots\end{array}$ & $\begin{array}{l}1 \\
\ldots\end{array}$ & $\begin{array}{l}\ldots \\
\ldots\end{array}$ & $\begin{array}{l}\ldots \\
\ldots\end{array}$ \\
\hline Mean & 8 & 7 & 6 & 5 & 3 & 2 & \\
\hline Median & 1 & 1 & 1 & 1 & 1 & 1 & \\
\hline Minimum & 0 & 0 & 0 & 0 & 0 & 0 & \\
\hline Maximum & 52 & 49 & 42 & 44 & 32 & 11 & \\
\hline
\end{tabular}


4 Prison Statistics

Table 4.2.4.7 Rate of deaths in prison per 10000 inmates

\begin{tabular}{|c|c|c|c|c|c|c|c|}
\hline & 2011 & 2012 & 2013 & 2014 & 2015 & 2016 & $\begin{array}{c}\text { Average } \\
2011-2016\end{array}$ \\
\hline Albania & 19 & 17 & 26 & 26 & 26 & 36 & 25 \\
\hline Armenia & 71 & 62 & 42 & 84 & 62 & $\ldots$ & 64 \\
\hline Austria & 42 & 38 & 43 & 24 & 39 & 38 & 37 \\
\hline Azerbaijan & 63 & 57 & 44 & 53 & 59 & 53 & 55 \\
\hline Belgium & 44 & 44 & 55 & 50 & 37 & $\ldots$ & 46 \\
\hline Bosnia-Herzegovina & 22 & 40 & & $\ldots$ & $\ldots$ & $\ldots$ & 31 \\
\hline Bulgaria & 53 & 32 & 32 & 29 & 44 & 40 & 38 \\
\hline Croatia & 26 & 26 & 31 & 31 & 22 & 22 & 26 \\
\hline Cyprus & 0 & 0 & 22 & 33 & 22 & 22 & 17 \\
\hline Czech Republic & 16 & 21 & 11 & 13 & 19 & 19 & 16 \\
\hline Denmark & 33 & 13 & 20 & 10 & 10 & 16 & 17 \\
\hline Estonia & 35 & 15 & 15 & 24 & 12 & 12 & 19 \\
\hline Finland & 28 & 12 & 15 & 28 & 9 & 28 & 20 \\
\hline France & 23 & 23 & 21 & 18 & 32 & 27 & 24 \\
\hline Georgia & 60 & $\ldots$ & 10 & 11 & 5 & 5 & 18 \\
\hline Germany & 18 & 17 & 17 & 21 & 21 & 23 & 19 \\
\hline Greece & 50 & 21 & 66 & 23 & 32 & 22 & 36 \\
\hline Hungary & 24 & 32 & 37 & 42 & 35 & 37 & 34 \\
\hline Iceland & 0 & 67 & 134 & 0 & 0 & 0 & 34 \\
\hline Ireland & 14 & 12 & 21 & 19 & 33 & 27 & 21 \\
\hline Italy & 25 & 23 & 23 & 14 & 16 & 17 & 20 \\
\hline Kosovo (UN R/1244/99) & $\ldots$ & $\ldots$ & & $\ldots$ & & $\ldots$ & $\ldots$ \\
\hline Latvia & 41 & 47 & 23 & 43 & 26 & 22 & 34 \\
\hline Lithuania & $\ldots$ & $\ldots$ & $\ldots$ & $\ldots$ & $\ldots$ & 40 & 40 \\
\hline Luxembourg & 31 & 47 & 16 & 16 & 16 & 31 & 26 \\
\hline Malta & 33 & 17 & 83 & $\ldots$ & 33 & $\ldots$ & 42 \\
\hline Moldova & 77 & 49 & 43 & 71 & 77 & 72 & 65 \\
\hline Montenegro & 38 & 30 & 38 & 53 & 45 & 34 & 40 \\
\hline Netherlands & 35 & 22 & 12 & 22 & 28 & 22 & 23 \\
\hline Norway & 17 & 17 & 34 & 17 & & $\ldots$ & 21 \\
\hline Poland & 16 & 13 & 13 & 13 & 13 & 15 & 14 \\
\hline Portugal & 50 & 52 & 49 & 58 & 53 & 54 & 53 \\
\hline Romania & 30 & 39 & 34 & 41 & 38 & 32 & 35 \\
\hline Russian Federation & & 53 & 54 & 53 & & $\ldots$ & 53 \\
\hline Serbia & 58 & 82 & 63 & 34 & 56 & 44 & 56 \\
\hline Slovakia & 14 & 22 & 11 & 17 & 17 & 22 & 17 \\
\hline Slovenia & 31 & 47 & 31 & 47 & 39 & 24 & 37 \\
\hline Spain & 28 & 27 & 23 & 22 & 29 & 23 & 25 \\
\hline Sweden & 21 & 24 & 19 & 24 & 12 & 9 & 18 \\
\hline Switzerland & 16 & 48 & 16 & 25 & 40 & 28 & 29 \\
\hline North Macedonia & 48 & 32 & 52 & 40 & 52 & 58 & 47 \\
\hline Turkey & 21 & 27 & 24 & 30 & 33 & $\ldots$ & 27 \\
\hline Ukraine & 64 & 64 & 50 & $\ldots$ & & $\ldots$ & 59 \\
\hline UK: England \& Wales & 22 & 22 & 25 & 28 & 30 & 32 & 27 \\
\hline UK: Northern Ireland & 23 & 41 & 18 & 6 & 12 & 18 & 20 \\
\hline UK: Scotland & 29 & 22 & 29 & 29 & 29 & 32 & 28 \\
\hline Mean & 33 & 33 & 34 & 30 & 30 & 28 & 32 \\
\hline Median & 29 & 27 & 26 & 26 & 30 & 27 & 28 \\
\hline Minimum & 0 & 0 & 10 & 0 & 0 & 0 & 14 \\
\hline Maximum & 77 & 82 & 134 & 84 & 77 & 72 & 65 \\
\hline
\end{tabular}


Table 4.2.4.8 Percentage of suicides among inmates who died in prison

\begin{tabular}{|c|c|c|c|c|c|c|c|}
\hline & 2011 & 2012 & 2013 & 2014 & 2015 & 2016 & $\begin{array}{c}\text { Average } \\
2011-2016\end{array}$ \\
\hline Albania & 22 & 0 & 33 & 25 & 8 & 6 & 16 \\
\hline Armenia & 19 & 11 & 11 & 11 & 11 & $\ldots$ & 12 \\
\hline Austria & 35 & 36 & 16 & 38 & 18 & 25 & 28 \\
\hline Azerbaijan & 8 & 3 & 2 & 2 & 5 & 8 & 5 \\
\hline Belgium & 23 & 25 & 22 & 31 & 36 & $\ldots$ & 27 \\
\hline Bosnia-Herzegovina & 17 & 9 & $\ldots$ & $\ldots$ & $\ldots$ & $\ldots$ & 13 \\
\hline Bulgaria & 12 & 13 & 13 & 0 & 16 & 11 & 11 \\
\hline Croatia & 15 & 0 & 0 & 0 & 9 & 0 & 4 \\
\hline Cyprus & NAP & NAP & 100 & 100 & 0 & 0 & 63 \\
\hline Czech Republic & 24 & 33 & 27 & 41 & 30 & 33 & 31 \\
\hline Denmark & 38 & 80 & 38 & 50 & 50 & 46 & 50 \\
\hline Estonia & 25 & 0 & 40 & 13 & 0 & 13 & 15 \\
\hline Finland & 78 & 50 & 40 & 22 & 67 & 22 & 46 \\
\hline France & 59 & 58 & 63 & 58 & 43 & 49 & 55 \\
\hline Georgia & 4 & $\ldots$ & 24 & 26 & 17 & 67 & 27 \\
\hline Germany & 41 & 48 & 41 & 39 & 45 & 47 & 44 \\
\hline Greece & $\ldots$ & & 5 & 21 & 13 & 9 & 12 \\
\hline Hungary & 22 & 14 & 11 & 8 & 8 & 14 & 13 \\
\hline Iceland & NAP & 0 & 50 & NAP & NAP & NAP & 25 \\
\hline Ireland & 0 & 20 & 22 & 25 & 7 & & 15 \\
\hline Italy & 38 & 37 & 27 & 47 & 36 & 37 & 37 \\
\hline Kosovo (UN R/1244/99) & $\ldots$ & & $\ldots$ & & $\ldots$ & $\ldots$ & $\ldots$ \\
\hline Latvia & 26 & 23 & 20 & 18 & 18 & 21 & 21 \\
\hline Lithuania & $\ldots$ & & $\ldots$ & $\ldots$ & $\ldots$ & 37 & 37 \\
\hline Luxembourg & 100 & 67 & 100 & 0 & 0 & 0 & 44 \\
\hline Malta & 50 & 0 & 20 & & 0 & $\ldots$ & 18 \\
\hline Moldova & 14 & 16 & $\ldots$ & 18 & 10 & 9 & 13 \\
\hline Montenegro & 60 & 25 & 0 & 0 & 17 & 11 & 19 \\
\hline Netherlands & 38 & 40 & 29 & 56 & 34 & 42 & 40 \\
\hline Norway & 67 & 67 & 92 & 100 & $\ldots$ & $\ldots$ & 81 \\
\hline Poland & 17 & 17 & 17 & 24 & 22 & 20 & 20 \\
\hline Portugal & 13 & 24 & 21 & 30 & 16 & 13 & 20 \\
\hline Romania & 10 & 19 & 19 & 11 & 10 & 11 & 13 \\
\hline Russian Federation & $\ldots$ & & 11 & 10 & $\ldots$ & & 10 \\
\hline Serbia & 6 & 8 & 9 & 5 & 16 & 17 & 10 \\
\hline Slovakia & 47 & 26 & 33 & 33 & 28 & 32 & 33 \\
\hline Slovenia & 25 & 33 & 75 & 0 & 0 & 0 & 22 \\
\hline Spain & 8 & 16 & 24 & 20 & 14 & 20 & 17 \\
\hline Sweden & 50 & 44 & 46 & 44 & 38 & 33 & 42 \\
\hline Switzerland & 60 & 31 & 20 & 60 & 42 & 29 & 40 \\
\hline North Macedonia & 17 & 0 & 8 & 0 & 8 & 10 & 7 \\
\hline Turkey & 11 & 11 & 14 & 14 & 10 & $\ldots$ & 12 \\
\hline Ukraine & 5 & 5 & 8 & & 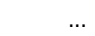 & & 6 \\
\hline UK: England \& Wales & 30 & 31 & 35 & 37 & 35 & 29 & 33 \\
\hline UK: Northern Ireland & 50 & 0 & 0 & & $\ldots$ & $\ldots$ & 17 \\
\hline UK: Scotland & $\ldots$ & 6 & 21 & 13 & 8 & 9 & 11 \\
\hline Mean & 30 & 24 & 30 & 27 & 20 & 21 & 25 \\
\hline Median & 24 & 20 & 21 & 22 & 16 & 18 & 20 \\
\hline Minimum & 0 & 0 & 0 & 0 & 0 & 0 & 4 \\
\hline Maximum & 100 & 80 & 100 & 100 & 67 & 67 & 81 \\
\hline
\end{tabular}

Note: NAP = Not applicable because there were no deaths among inmates in prison (see Table 4.2.4.7) 
Table 4.2.4.9 Percentage of suicides in pre-trial detention among inmates who committed suicide in prison

\begin{tabular}{|c|c|c|c|c|c|c|c|}
\hline & 2011 & 2012 & 2013 & 2014 & 2015 & 2016 & $\begin{array}{c}\text { Average } \\
2011-2016\end{array}$ \\
\hline Albania & $\ldots$ & NAP & 25 & 67 & $\ldots$ & $\ldots$ & 46 \\
\hline Armenia & $\ldots$ & $\ldots$ & 0 & 0 & $\ldots$ & $\ldots$ & 0 \\
\hline Austria & $\ldots$ & $\ldots$ & 50 & 88 & 100 & 82 & 80 \\
\hline Azerbaijan & $\ldots$ & $\ldots$ & 100 & 0 & 57 & 42 & 50 \\
\hline Belgium & $\ldots$ & $\ldots$ & 71 & $\ldots$ & $\ldots$ & $\ldots$ & 71 \\
\hline Bosnia-Herzegovina & $\ldots$ & $\ldots$ & $\ldots$ & $\ldots$ & $\ldots$ & $\ldots$ & $\ldots$ \\
\hline Bulgaria & $\ldots$ & $\ldots$ & 50 & NAP & 29 & 44 & 41 \\
\hline Croatia & $\ldots$ & $\ldots$ & NAP & NAP & 0 & NAP & 0 \\
\hline Cyprus & $\ldots$ & $\ldots$ & $\ldots$ & 0 & NAP & NAP & 0 \\
\hline Czech Republic & $\ldots$ & $\ldots$ & 43 & 50 & 62 & 29 & 46 \\
\hline Denmark & $\ldots$ & $\ldots$ & 67 & 100 & 100 & 100 & 92 \\
\hline Estonia & $\ldots$ & $\ldots$ & 100 & 100 & NAP & 100 & 100 \\
\hline Finland & 86 & 100 & 50 & 100 & 0 & 50 & 64 \\
\hline France & $\ldots$ & $\ldots$ & 34 & 0 & 47 & 47 & 32 \\
\hline Georgia & $\ldots$ & $\ldots$ & $\ldots$ & $\ldots$ & $\ldots$ & $\ldots$ & $\ldots$ \\
\hline Germany & 57 & 47 & 48 & 42 & 55 & 49 & 49 \\
\hline Greece & $\ldots$ & $\ldots$ & $\ldots$ & $\ldots$ & 20 & 20 & 20 \\
\hline Hungary & 44 & 25 & 29 & 50 & 40 & 33 & 37 \\
\hline Iceland & $\ldots$ & $\ldots$ & 0 & NAP & NAP & NAP & 0 \\
\hline Ireland & $\ldots$ & $\ldots$ & 0 & 0 & 0 & $\ldots$ & 0 \\
\hline Italy & $\ldots$ & $\ldots$ & 62 & 49 & 49 & 55 & 54 \\
\hline Kosovo (UN R/1244/99) & $\ldots$ & $\ldots$ & $\ldots$ & $\ldots$ & $\ldots$ & $\ldots$ & $\ldots$ \\
\hline Latvia & $\ldots$ & $\ldots$ & 67 & 20 & 100 & 83 & 68 \\
\hline Lithuania & $\ldots$ & $\ldots$ & 25 & 9 & 25 & 14 & 18 \\
\hline Luxembourg & $\ldots$ & $\ldots$ & 100 & NAP & NAP & NAP & 100 \\
\hline Malta & $\ldots$ & $\ldots$ & 0 & $\ldots$ & NAP & $\ldots$ & 0 \\
\hline Moldova & $\ldots$ & $\ldots$ & $\ldots$ & 0 & $\ldots$ & $\ldots$ & 0 \\
\hline Montenegro & $\ldots$ & $\ldots$ & NAP & NAP & 0 & 0 & 0 \\
\hline Netherlands & $\ldots$ & $\ldots$ & 50 & 50 & 55 & 71 & 56 \\
\hline Norway & $\ldots$ & $\ldots$ & 100 & 0 & $\ldots$ & $\ldots$ & 50 \\
\hline Poland & $\ldots$ & $\ldots$ & $\ldots$ & $\ldots$ & $\ldots$ & $\ldots$ & $\ldots$ \\
\hline Portugal & $\ldots$ & $\ldots$ & $\ldots$ & $\ldots$ & $\ldots$ & $\ldots$ & $\ldots$ \\
\hline Romania & $\ldots$ & $\ldots$ & 16 & 0 & 18 & 30 & 16 \\
\hline Russian Federation & $\ldots$ & $\ldots$ & $\ldots$ & $\ldots$ & $\ldots$ & $\ldots$ & $\ldots$ \\
\hline Serbia & $\ldots$ & $\ldots$ & $\ldots$ & $\ldots$ & $\ldots$ & $\ldots$ & $\ldots$ \\
\hline Slovakia & $\ldots$ & $\ldots$ & 50 & 17 & 40 & 60 & 42 \\
\hline Slovenia & $\ldots$ & $\ldots$ & 0 & NAP & NAP & NAP & 0 \\
\hline Spain & $\ldots$ & $\ldots$ & 28 & 19 & 17 & 15 & 20 \\
\hline Sweden & $\ldots$ & $\ldots$ & 67 & 57 & 33 & 50 & 52 \\
\hline Switzerland & 33 & 33 & 0 & 44 & 90 & 40 & 40 \\
\hline North Macedonia & $\ldots$ & $\ldots$ & $\ldots$ & $\ldots$ & $\ldots$ & $\ldots$ & $\ldots$ \\
\hline Turkey & $\ldots$ & $\ldots$ & 39 & 0 & $\ldots$ & $\ldots$ & 19 \\
\hline Ukraine & $\ldots$ & $\ldots$ & $\ldots$ & $\ldots$ & $\ldots$ & $\ldots$ & $\ldots$ \\
\hline UK: England \& Wales & $\ldots$ & $\ldots$ & $\ldots$ & $\ldots$ & $\ldots$ & $\ldots$ & $\ldots$ \\
\hline UK: Northern Ireland & $\ldots$ & $\ldots$ & NAP & $\ldots$ & $\ldots$ & $\ldots$ & $\ldots$ \\
\hline UK: Scotland & $\ldots$ & $\ldots$ & 20 & 33 & 100 & $\ldots$ & 51 \\
\hline Mean & 55 & 51 & 43 & 34 & 45 & 48 & 38 \\
\hline Median & 51 & 40 & 45 & 27 & 40 & 47 & 41 \\
\hline Minimum & 33 & 25 & 0 & 0 & 0 & 0 & 0 \\
\hline Maximum & 86 & 100 & 100 & 100 & 100 & 100 & 100 \\
\hline
\end{tabular}

Note: NAP = Not applicable because there were no deaths among inmates in prison (see Table 4.2.4.7) 
Notes on Tables 4.2.3 (4.2.3.1 to 4.2.3.6) and 4.2.4 (4.2.4.1 to 4.2.4.9)

Also see the notes under 4.4 .1 regarding the standard definition for entries (4.2.3), the standard definition for exits (4.2.4), minors and foreigners.

France Tables 4.2.3. and 4.2.4: These are entries and exits from prison (not only from detention, i.e., work releases and electronic bracelets are included).

Lithuania According to the Prisons Department, there was a mistake in the data provided for the flow of entries in SPACE, which has been amended in the figures published here.

Serbia Comment to Table 4.2.3 (women): Until 2012, only entries of convicted women were recorded (i.e., the figures did not include entries of women in pre-trial detention nor women detained for misdemeanours). In 2011, the total number of entries of convicted women was 396, in 2012: 318; in 2013: 295; in 2014: 256; in 2015: 230; and in 2016: 227. Since 2012, the numbers included in the Tables of the Sourcebook include all women imprisoned (pre-trial detainees, convicted and incarcerated for misdemeanours).

Switzerland

Table 4.2.2. Entry following a transfer from one penal institution to another in the same country includes entry following the detainee's removal from the institution in order to appear before a judicial authority and entry following a prison leave or a period of absence by permission.

Turkey Table 4.2.4: only Data for Deaths in available.

UK: Scotland The flow data provided in this chapter allows a breakdown by gender, age, and citizenship. However, it does not include pre-trial detainees. The SPACE data, on the contrary, includes pre-trial detainees, but does not allow that breakdown. Flow of entries is measured using prison receptions which are not equivalent to persons received. If a person enters prison on remand or having been sentenced by one court, this is counted as one reception. Where a person subsequently receives a custodial sentence after a period on remand or while serving another custodial sentence, this constitutes a further reception. If several custodial sentences are imposed on the same person by two or more courts in one day, this counts as several receptions. Individuals may enter the prison system more than once on different types of custody (remand or sentenced) and charged with different crimes, so receptions are the main unit of analysis as this allows highly disaggregated analyses by type of custody and crime type. 


\subsubsection{Prison staff}

Table 4.2.5.1 Prison staff employed and not employed by the prison administration in 2016

\begin{tabular}{|c|c|c|c|c|}
\hline & $\begin{array}{c}\text { Total prison staff per } \\
100000 \text { pop. }\end{array}$ & $\begin{array}{c}\text { Ratio of inmates per } \\
\text { one member of } \\
\text { prison staff }\end{array}$ & $\begin{array}{l}\% \text { of staff employed } \\
\text { by the prison admin. }\end{array}$ & $\begin{array}{l}\% \text { of staff not em- } \\
\text { ployed by the prison } \\
\text { admin. }\end{array}$ \\
\hline Albania & 145 & & 100 & $\ldots$ \\
\hline Armenia & 73 & 1.8 & 100 & 0 \\
\hline Austria & 46 & 2.2 & 94 & 6 \\
\hline Azerbaijan & $\ldots$ & $\ldots$ & $\ldots$ & $\ldots$ \\
\hline Belgium & $\ldots$ & $\ldots$ & $\ldots$ & $\ldots$ \\
\hline Bosnia-Herzegovina & $\ldots$ & $\ldots$ & $\ldots$ & $\ldots$ \\
\hline Bulgaria & 48 & 2.4 & 100 & $\ldots$ \\
\hline Croatia & 63 & 1.2 & 100 & $\ldots$ \\
\hline Cyprus & 48 & 1.7 & 95 & 5 \\
\hline Czech Republic & 104 & 2.0 & 100 & 0 \\
\hline Denmark & 78 & 0.8 & 100 & $\ldots$ \\
\hline Estonia & 100 & 2.0 & 94 & 6 \\
\hline Finland & 42 & 1.3 & 100 & $\ldots$ \\
\hline France & 57 & 1.8 & 96 & 4 \\
\hline Georgia & 101 & 2.5 & 100 & 0 \\
\hline Germany & 46 & 1.7 & 100 & $\ldots$ \\
\hline Greece & 42 & 2.1 & 100 & 0 \\
\hline Hungary & 86 & 2.2 & 100 & $\ldots$ \\
\hline Iceland & 35 & 1.1 & 100 & $\ldots$ \\
\hline Ireland & 69 & 1.1 & 100 & $\ldots$ \\
\hline Italy & 73 & 1.2 & 100 & 0 \\
\hline Kosovo (UN R/1244/99) & $\ldots$ & $\ldots$ & $\ldots$ & $\ldots$ \\
\hline Latvia & 146 & 1.5 & 92 & 8 \\
\hline Lithuania & 134 & 1.8 & 88 & 12 \\
\hline Luxembourg & 76 & 1.6 & 100 & $\ldots$ \\
\hline Malta & 58 & 2.1 & 99 & 1 \\
\hline Moldova & 73 & 2.9 & 100 & 0 \\
\hline Montenegro & 75 & 2.3 & 100 & 0 \\
\hline Netherlands & 59 & 0.9 & 100 & 0 \\
\hline Norway & 81 & 0.9 & 91 & 9 \\
\hline Poland & 77 & 2.4 & 100 & $\ldots$ \\
\hline Portugal & 61 & 2.2 & 100 & $\begin{array}{l}\cdots \\
\ldots\end{array}$ \\
\hline Romania & 62 & 2.3 & 100 & $\ldots$ \\
\hline Russian Federation & 205 & 2.2 & 100 & $\ldots$ \\
\hline Serbia & 57 & 2.6 & 98 & 2 \\
\hline Slovakia & 101 & 1.8 & 100 & $\ldots$ \\
\hline Slovenia & 40 & 1.6 & 100 & 0 \\
\hline Spain & 52 & 2.5 & 100 & $\ldots$ \\
\hline Sweden & 74 & 0.8 & 100 & $\ldots$ \\
\hline Switzerland & 52 & 1.6 & 95 & 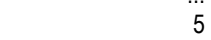 \\
\hline North Macedonia & 41 & 3.9 & 100 & $\ldots$ \\
\hline Turkey & 73 & 3.5 & 100 & $\ldots$ \\
\hline Ukraine & $\ldots$ & $\ldots$ & $\ldots$ & $\cdots$ \\
\hline UK: England \& Wales & $\ldots$ & $\ldots$ & $\ldots$ & NA \\
\hline UK: Northern Ireland & 84 & 1.0 & 100 & $\ldots$ \\
\hline UK: Scotland & 127 & 1.1 & 82 & 18 \\
\hline Mean & 77 & 1.9 & 98 & 4 \\
\hline Median & 73 & 1.8 & 100 & 2 \\
\hline Minimum & 35 & 0.8 & 82 & 0 \\
\hline Maximum & 205 & 3.9 & 100 & 18 \\
\hline
\end{tabular}

Note: UK: England and Wales: The number of members of the prison staff not employed by the prison administration (i.e., the staff working in private prisons) is unavailable. 
Table 4.2.5.2 Distribution of the staff employed and not employed by the prison administration

\begin{tabular}{|c|c|c|c|c|c|c|}
\hline & \multirow[b]{2}{*}{$\begin{array}{l}\text { Staff em- } \\
\text { ployed by the } \\
\text { prison admin. } \\
\text { per } 100000 \\
\text { pop. }\end{array}$} & \multicolumn{2}{|c|}{ Of which: } & \multirow[b]{2}{*}{$\begin{array}{l}\text { Staff not em- } \\
\text { ployed by the } \\
\text { prison admin. } \\
\text { per } 100000 \\
\text { pop. }\end{array}$} & \multicolumn{2}{|c|}{ Of which: } \\
\hline & & $\begin{array}{c}\text { Percentage } \\
\text { working out- } \\
\text { side penal } \\
\text { institutions }\end{array}$ & $\begin{array}{l}\text { Percentage } \\
\text { working in- } \\
\text { side penal } \\
\text { institutions }\end{array}$ & & $\begin{array}{l}\text { Percentage } \\
\text { working out- } \\
\text { side penal } \\
\text { institutions }\end{array}$ & $\begin{array}{l}\text { Percentage } \\
\text { working in- } \\
\text { side penal } \\
\text { institutions }\end{array}$ \\
\hline Albania & 145 & 16 & 84 & $\ldots$ & $\ldots$ & $\ldots$ \\
\hline Armenia & 73 & 8 & 92 & $\ldots$ & $\ldots$ & $\ldots$ \\
\hline Austria & 43 & 1 & $\ldots$ & 3 & 0 & $\ldots$ \\
\hline Azerbaijan & $\ldots$ & $\ldots$ & $\ldots$ & $\ldots$ & $\ldots$ & ... \\
\hline Belgium & $\ldots$ & $\ldots$ & $\ldots$ & $\ldots$ & $\ldots$ & $\ldots$ \\
\hline Bosnia-Herzegovina & $\ldots$ & $\ldots$ & $\ldots$ & $\ldots$ & $\ldots$ & $\ldots$ \\
\hline Bulgaria & 48 & $\ldots$ & 100 & $\ldots$ & $\ldots$ & $\ldots$ \\
\hline Croatia & 63 & $\ldots$ & 98 & $\ldots$ & $\ldots$ & $\ldots$ \\
\hline Cyprus & 45 & 0 & 100 & 2 & 0 & 100 \\
\hline Czech Republic & 104 & 11 & 89 & 0.05 & 100 & 0 \\
\hline Denmark & 78 & 28 & 72 & $\ldots$ & $\ldots$ & $\ldots$ \\
\hline Estonia & 94 & $\ldots$ & 100 & 6 & 32 & 68 \\
\hline Finland & 42 & 10 & 90 & $\ldots$ & $\ldots$ & $\ldots$ \\
\hline France & 55 & 18 & 82 & 2 & 38 & 62 \\
\hline Georgia & 101 & 17 & 95 & $\ldots$ & $\ldots$ & $\ldots$ \\
\hline Germany & 46 & 1 & 95 & $\ldots$ & $\ldots$ & $\ldots$ \\
\hline Greece & 42 & 1 & 99 & $\ldots$ & $\ldots$ & $\ldots$ \\
\hline Hungary & 86 & 5 & 95 & $\ldots$ & $\ldots$ & $\ldots$ \\
\hline Iceland & 35 & 19 & 81 & $\ldots$ & $\ldots$ & $\ldots$ \\
\hline Ireland & 69 & 9 & 91 & $\ldots$ & $\ldots$ & $\ldots$ \\
\hline Italy & 73 & 6 & 88 & 0.03 & 0 & 100 \\
\hline Kosovo (UN R/1244/99) & & & & $\ldots$ & $\ldots$ & \\
\hline Latvia & 133 & 7 & 93 & 12 & 0 & 100 \\
\hline Lithuania & 118 & 12 & 88 & 16 & $\ldots$ & 100 \\
\hline Luxembourg & 76 & 1 & 99 & $\ldots$ & $\ldots$ & $\ldots$ \\
\hline Malta & 58 & 2 & 98 & 1 & 0 & 100 \\
\hline Moldova & 73 & 10 & 85 & $\ldots$ & $\ldots$ & $\ldots$ \\
\hline Montenegro & 75 & 6 & 94 & $\ldots$ & $\ldots$ & $\ldots$ \\
\hline Netherlands & 59 & 18 & 82 & $\ldots$ & $\ldots$ & $\ldots$ \\
\hline Norway & 74 & 6 & 94 & 7 & 0 & 100 \\
\hline Poland & 77 & 4 & 96 & $\ldots$ & $\ldots$ & $\ldots$ \\
\hline Portugal & 61 & $\ldots$ & 79 & $\ldots$ & $\ldots$ & $\ldots$ \\
\hline Romania & 62 & 5 & 95 & $\ldots$ & $\ldots$ & $\ldots$ \\
\hline Russian Federation & 205 & 12 & 88 & $\ldots$ & $\ldots$ & $\ldots$ \\
\hline Serbia & 56 & 2 & 98 & 1 & 0 & 100 \\
\hline Slovakia & 101 & 10 & 90 & $\ldots$ & $\ldots$ & $\ldots$ \\
\hline Slovenia & 40 & 7 & 93 & $\ldots$ & $\ldots$ & $\ldots$ \\
\hline Spain & 52 & 3 & 120 & $\ldots$ & $\ldots$ & $\ldots$ \\
\hline Sweden & 74 & 17 & 83 & $\ldots$ & $\ldots$ & $\ldots$ \\
\hline Switzerland & 50 & $\ldots$ & 10 & 2 & $\ldots$ & $\ldots$ \\
\hline North Macedonia & 41 & 3 & 97 & $\ldots$ & $\ldots$ & ... \\
\hline Turkey & 73 & 1 & 92 & $\ldots$ & $\ldots$ & $\ldots$ \\
\hline Ukraine & $\ldots$ & $\ldots$ & $\ldots$ & $\ldots$ & $\ldots$ & $\ldots$ \\
\hline UK: England \& Wales & 74 & 28 & 72 & $\ldots$ & $\ldots$ & $\ldots$ \\
\hline UK: Northern Ireland & 84 & 7 & 93 & $\ldots$ & $\ldots$ & $\ldots$ \\
\hline UK: Scotland & 104 & 78 & 71 & 23 & 1 & 99 \\
\hline Mean & 75 & 11 & 89 & 6 & 16 & 84 \\
\hline Median & 73 & 7 & 92 & 2 & 0 & 100 \\
\hline Minimum & 35 & 0 & 10 & 0 & 0 & 0 \\
\hline Maximum & 205 & 78 & 120 & 23 & 100 & 100 \\
\hline
\end{tabular}


Table 4.2.5.3 Ratio of inmates per one member of staff employed by the prison administration on $1^{\text {st }}$ September 2016, according to different categories of staff

\begin{tabular}{|c|c|c|c|c|c|c|}
\hline & $\begin{array}{l}\text { Custodial } \\
\text { staff dedi- } \\
\text { cated solely } \\
\text { to the cus- } \\
\text { tody of in- } \\
\text { mates }\end{array}$ & $\begin{array}{l}\text { Custodial } \\
\text { staff not ded- } \\
\text { icated solely } \\
\text { to the cus- } \\
\text { tody of in- } \\
\text { mates }\end{array}$ & $\begin{array}{c}\text { Medical and } \\
\text { paramedical } \\
\text { staff }\end{array}$ & $\begin{array}{l}\text { Staff respon- } \\
\text { sible for as- } \\
\text { sessment } \\
\text { and psy- } \\
\text { chologists }\end{array}$ & $\begin{array}{c}\text { Staff respon- } \\
\text { sible for edu- } \\
\text { cational ac- } \\
\text { tivities }\end{array}$ & $\begin{array}{l}\text { Other staff } \\
\text { responsible } \\
\text { for work- } \\
\text { shops or vo- } \\
\text { cational } \\
\text { training }\end{array}$ \\
\hline Albania & 2.8 & 6.0 & 23 & 739 & 42 & $\ldots$ \\
\hline Armenia & 2.9 & 6.0 & 24 & 80 & 103 & $\ldots$ \\
\hline Austria & 2.9 & $\ldots$ & 102 & 150 & 4412 & $\ldots$ \\
\hline Azerbaijan & $\ldots$ & $\ldots$ & $\ldots$ & $\ldots$ & $\ldots$ & $\ldots$ \\
\hline Belgium & $\ldots$ & $\ldots$ & $\ldots$ & $\ldots$ & $\ldots$ & $\ldots$ \\
\hline Bosnia-Herzegovina & $\ldots$ & $\ldots$ & $\ldots$ & $\ldots$ & $\ldots$ & $\ldots$ \\
\hline Bulgaria & 3.5 & 25.8 & 73 & 278 & 58 & 334 \\
\hline Croatia & 2.0 & $\ldots$ & 25 & 345 & 15 & 14 \\
\hline Cyprus & 1.8 & $\ldots$ & $\ldots$ & $\ldots$ & $\ldots$ & $\ldots$ \\
\hline Czech Republic & 3.9 & 144.1 & 53 & 17 & $\ldots$ & 201 \\
\hline Denmark & 1.6 & $\ldots$ & 31 & $\ldots$ & 24 & 11 \\
\hline Estonia & 5.5 & 28.4 & 33 & 128 & 381 & $\ldots$ \\
\hline Finland & 2.3 & $\ldots$ & $\ldots$ & $\ldots$ & 15 & 17 \\
\hline France & 2.5 & $\ldots$ & $\ldots$ & $\ldots$ & 20 & 1215 \\
\hline Georgia & 3.3 & $\ldots$ & 18 & 59 & $\ldots$ & $\ldots$ \\
\hline Germany & & 4.2 & 43 & 86 & 176 & 18 \\
\hline Greece & 2.5 & $\ldots$ & 108 & 370 & 137 & $\ldots$ \\
\hline Hungary & 5.3 & 4.1 & 39 & 45 & 649 & 37 \\
\hline Iceland & 1.6 & $\ldots$ & $\ldots$ & 54 & 62 & 12 \\
\hline Ireland & 1.7 & 25.8 & 29 & 169 & $\ldots$ & 10 \\
\hline Italy & 1.5 & $\ldots$ & 667 & 1952 & 63 & $\ldots$ \\
\hline Kosovo (UN R/1244/99) & & $\ldots$ & $\ldots$ & $\ldots$ & & $\ldots$ \\
\hline Latvia & 2.4 & $\ldots$ & 34 & 22 & 127 & 523 \\
\hline Lithuania & 3.7 & $\ldots$ & 25 & 176 & 34 & 641 \\
\hline Luxembourg & 2.3 & $\ldots$ & 724 & 138 & 39 & 24 \\
\hline Malta & 2.4 & $\ldots$ & $\ldots$ & 185 & 556 & 70 \\
\hline Moldova & 10.1 & $\ldots$ & 32 & 268 & 65 & 124 \\
\hline Montenegro & 8.6 & 3.5 & 68 & 360 & 57 & 27 \\
\hline Netherlands & 4.4 & 2.7 & 35 & 106 & 45 & 14 \\
\hline Norway & 1.4 & 7.3 & $\ldots$ & $\ldots$ & $\ldots$ & $\ldots$ \\
\hline Poland & 5.0 & 44.8 & 44 & 26 & 336 & $\ldots$ \\
\hline Portugal & 3.5 & 90.1 & $\ldots$ & $\ldots$ & 51 & $\ldots$ \\
\hline Romania & 13.0 & 14.0 & 43 & 335 & 60 & $\ldots$ \\
\hline Russian Federation & 3.4 & $\ldots$ & 22 & 211 & 103 & 41 \\
\hline Serbia & 4.6 & $\ldots$ & 40 & 36 & & 24 \\
\hline Slovakia & 3.3 & $\ldots$ & 34 & 169 & 384 & $\ldots$ \\
\hline Slovenia & 2.6 & $\ldots$ & 101 & 187 & 19 & 15 \\
\hline Spain & 3.3 & $\ldots$ & 48 & 75 & 32 & 74 \\
\hline Sweden & 1.3 & $\ldots$ & 56 & 180 & 25 & 18 \\
\hline Switzerland & 3.3 & $\ldots$ & 26 & 11 & $\ldots$ & $\ldots$ \\
\hline North Macedonia & 21.1 & 8.7 & 186 & 99 & 84 & 223 \\
\hline Turkey & 7.4 & 21.2 & 289 & 297 & 151 & 30 \\
\hline Ukraine & $\ldots$ & $\ldots$ & $\ldots$ & $\ldots$ & $\ldots$ & $\ldots$ \\
\hline UK: Eng. \& Wales & 4.8 & 18.2 & $\ldots$ & 162 & 70 & $\ldots$ \\
\hline UK: Northern Ireland & 1.2 & $\ldots$ & 2778 & 76 & 84 & $\ldots$ \\
\hline UK: Scotland & 78.9 & 2.4 & & $\ldots$ & 139 & \\
\hline Mean & 6 & 25 & 183 & 223 & 253 & 155 \\
\hline Median & 3 & 11 & 42 & 156 & 64 & 29 \\
\hline Minimum & 1 & 2 & 18 & 11 & 15 & 10 \\
\hline Maximum & 79 & 144 & 2778 & 1952 & 4412 & 1215 \\
\hline
\end{tabular}


Table 4.2.5.4 Distribution of the staff not employed by the prison administration on 1 st September 2016, according to different categories of staff, in percentage Inmates per one staff member working as...

\begin{tabular}{lrrrrrr}
\hline & $\begin{array}{c}\text { Custodial } \\
\text { staff dedi- } \\
\text { cated } \\
\text { solely to } \\
\text { the custody } \\
\text { of inmates }\end{array}$ & $\begin{array}{c}\text { Custodial } \\
\text { staff not } \\
\text { dedicated } \\
\text { solely to } \\
\text { the custody } \\
\text { of inmates }\end{array}$ & $\begin{array}{c}\text { Medical } \\
\text { and para- } \\
\text { medical } \\
\text { staff }\end{array}$ & $\begin{array}{c}\text { Staff re- } \\
\text { sponsible } \\
\text { for assess- } \\
\text { ment and } \\
\text { psycholo- } \\
\text { gists }\end{array}$ & $\begin{array}{c}\text { Staff re- } \\
\text { sponsible } \\
\text { for educa- } \\
\text { tional activ- } \\
\text { ities }\end{array}$ & $\begin{array}{c}\text { Other staff } \\
\text { responsible } \\
\text { for work- } \\
\text { shops or } \\
\text { vocational } \\
\text { training }(\end{array}$ \\
\hline Austria & 0 & 0 & 41 & 15 & 17 & $\ldots$ \\
Cyprus & 0 & 0 & 0 & 16 & 53 & 11 \\
Czech Republic & 0 & 0 & 0 & 0 & $\ldots$ & 0 \\
Estonia & $\ldots$ & $\ldots$ & $\ldots$ & $\ldots$ & 24 & 8 \\
Italy & 0 & 0 & 0 & 0 & 0 & 0 \\
Latvia & 0 & 0 & 0 & 0 & 100 & 0 \\
Lithuania & $\ldots$ & $\ldots$ & 0 & $\ldots$ & 56 & 31 \\
Malta & 0 & 0 & 43 & 0 & 57 & 0 \\
Norway & 0 & 0 & 33 & 0 & 67 & 0 \\
Serbia & 0 & 0 & 67 & 0 & 0 & 15 \\
UK: Scotland & $\ldots$ & $\ldots$ & 55 & $\ldots$ & 25 & $\ldots$ \\
\hline
\end{tabular}

Notes on Tables 4.2.5 (4.2.5.1 to 4.2.5.6)

See the notes under 4.4.1 regarding the standard definition for staff (Tables 4.2.5). 


\subsection{Technical information}

The information concerning what is and is not counted refer primarily to data collected by SPACE I in 2015. To provide a complete picture, information from other editions of SPACE I have also been used. Categories are considered as included when the prison administrations which have provided the relevant data reported including these categories, and as excluded either when the prison administrations reported excluding these categories, or that the category is not applicable (does not exist) in their penal system.

\subsubsection{Stock}

The standard definition of stock used in SPACE refers to the total number of inmates (including pre-trial detainees), which corresponds to the total number of persons effectively deprived of freedom in any kind of penal institution. Compliance with that definition was distributed as follows:

- Most prison administrations (39 out of 45) exclude persons held in police stations or other similar types of investigative institutions before trial. Exceptions: Bulgaria, Cyprus, Georgia, Montenegro, Switzerland, and Turkey.

- Most prison administrations (30 out of 45) include persons held in custodial institutions/units for juvenile offenders. Exceptions: Belgium, Denmark, Finland, Hungary, Iceland, Italy, Montenegro, Netherlands, Norway, Poland, Serbia, Spain, Sweden, and Turkey.

- Most prison administrations (39 out of 45) exclude persons placed in educational institutions/units for juvenile offenders. Exceptions: Bulgaria, Romania, Serbia, Slovenia, Switzerland, and Turkey.

- Most prison administrations (41 out of 44) exclude persons held in institutions for drug-addicted offenders outside penal institutions. Exceptions: Malta and Spain.

- Most prison administrations (38 out of 44) exclude persons with psychiatric disorders in psychiatric institutions or hospitals outside penal institutions. Exceptions: Austria, Belgium, Ireland, Italy, Malta, and Portugal.

- Most prison administrations (38 out of 45) exclude asylum seekers or illegal aliens held for administrative reasons. Exceptions: Belgium, Germany, Ireland, Switzerland, UK: England \& Wales, UK: Northern Ireland and UK: Scotland.

- Most prison administrations (42 out of 45) exclude persons held in private facilities. Exceptions: Finland, Germany, and UK: England \& Wales.

- Most prison administrations (33 out of 45) prison administrations exclude persons under electronic surveillance/electronic monitoring. Exceptions: Austria, Belgium, Bulgaria, Cyprus, Estonia, Finland, Hungary, Ireland, Netherlands, Poland, and Spain. 
- Most prison administrations (25 out of 30) include fine defaulters among sentenced prisoners in the prison population. Exceptions: Czech Republic, Estonia, Italy, Romania, and Slovak Republic.

- Most prison administrations (17 out of 21) include persons detained because of the revocation, suspension or annulment of the conditional release or probation in the prison population. Exceptions: Czech Republic, Estonia, Italy, and Romania.

The standard definition of pre-trial detainees used in SPACE refers to the total number of inmates who have not received a final sentence yet. These include untried detainees, detainees found guilty but who have not yet received a sentence yet (in the countries where such concept exists), sentenced prisoners who have appealed or who are within the statutory limit for doing so, and detainees who have not received a final sentence yet, but who started serving a prison sentence in advance (in the countries where such concept exists). Compliance with that definition was distributed as follows:

- All prison administrations (40 out of 40) include untried detainees in the total number of pre-trial detainees.

- The concept of detainees found guilty but who have not yet received a sentence yet in the prison population does not exist in 19 countries. The others include them in their total number of pre-trial detainees.

- Most prison administrations (24 out of 33) include sentenced prisoners who have appealed or who are within the statutory limit for doing so in the total number of pre-trial detainees. Exceptions: Austria, Croatia, Cyprus, Estonia, Germany, Greece, Ireland, and Spain.

- The concept of detainees who have not received a final sentence yet, but who started serving a prison sentence in advance does not exist in 22 countries. The others include them in the total number of pre-trial detainees.

\subsubsection{Flow of entries}

The standard definition of entries used in SPACE refers to all entries of inmates into penal institutions that are not related to an ongoing detention. The counting unit is the number of admissions.

It should include: (1) admissions of detainees not serving a final sentence (pretrial detainees), (2) admissions of inmates who have been found guilty but who are not yet sentenced, and (3) admissions of inmates who have been sentenced, even if they have lodged an appeal or are within the statutory limit to do so.

It should exclude: (1) admissions following a transfer from one penal institution to another, (2) admissions of inmates following their removal from the institution in order to appear before a judicial authority (investigating judge, court, etc.), (3) admissions of inmates following their removal from the institution in order to be 
treated in a hospital, (4) admissions of inmates following a prison leave or a period of absence by permission, and (5) admissions of inmates re-arrested after an escape/abscond.

Most prison administrations (28 out of 36) comply with the standard definition of entries. Exceptions: Hungary, Latvia, Netherlands, Russian Federation, Slovenia, Sweden, Switzerland, and UK: Scotland.

\subsubsection{Flow of exists}

The standard definition of exits used in SPACE refers to releases from penal institutions, inmates who died inside penal institutions and escapes from penal institutions.

It should include: (1) Exits of inmates who have been released from the penal institutions; (2) exits of inmates who died inside penal institutions, and (3) exits due to an escape/abscond from a penal institution.

It should exclude: (1) Transfer from one penal institution to another, (2) exits in order to appear before a judicial authority (investigative magistrate, court, etc.), (3) exits in order to be treated in a hospital, (4) placement in another penal institution that do not lead to the change of the status of the detainee/prisoner, and (5) exits corresponding to a prison leave or a period of absence with permission.

Most prison administrations (30 out of 39) comply with the standard definition of exits. Exceptions: Bulgaria, Cyprus, Latvia, Lithuania, Russian Federation, Slovenia, Sweden, UK: England \& Wales and UK: Scotland.

\subsubsection{Staff}

The standard definition of staff used in SPACE refers to the total number of fulltime and part-time staff. Part-time staff should be counted on the basis of "fulltime equivalents" (FTE). 


\subsection{Technical information}

\subsubsection{Notes}

Reference date (different from 1 September)

- Croatia: The reference date is 31 December.

- Czech Republic: The reference date is 31 December.

- Georgia: The reference date is 31 August.

- Germany: The reference date is 31 March.

- Ireland: The reference date is 31 August.

- Poland: The reference date is 31 December.

- Portugal: The reference date is 31 December.

- Sweden: The reference date is 1 October.

- Switzerland: The reference date is 7 September.

- UK: England \& Wales: The reference date is 30 June.

Standard definition of inmates

Inmates: persons effectively deprived of freedom in any kind of penal institution.

- Netherlands: Data only include adult inmates.

- Russian Federation: The total number of inmates include all inmates held in temporary detention centres of (1) the penitentiary system, (2) the internal affairs bodies of Russian Federation, (3) the border guards of the Federal Security Service of Russian Federation, and (4) guardhouses, as well as suspects and defendants, in respect of whom detention has been chosen as a preventive measure, and those who are placed in medical organizations for medical assistance.

- Spain: Juvenile offenders are excluded in the total prison population.

Standard definition of entries (Tables 4.2.3)

- Cyprus: Only entries in penal institutions are included. Entries in police stations are excluded.

- Hungary: Only the fact of entry is recorded. The circumstantial details are not stated, e.g.: where the inmate came from.

- Latvia: The counting unit is the person, not the event.

- Netherlands: Only entries in penal institutions are included. Entries in custodial clinics, institutions for juveniles and institutions for aliens are $e x-$ cluded. In the total number of entries are included entries from free society and those from police stations into penal institutions. Entries following an escape/abscond are included. 
- Russian Federation: The total number of persons newly arrested who entered the pre-trial detention centres and facilities operating as pre-trial detention centres includes: (1) persons in respect of whom the court chose a preventive measure in the form of pre-trial detention, (2) defendants in respect of whom the court changed the preventive measure for taking into custody at the judicial stage of the examination of the - case on the merits prior to the decision of the sentence; (3) persons with respect to whom at the pretrial stage detention in custody was not used as a preventive measure, but the sentence determined the measure of punishment associated with the deprivation of liberty, and they were detained upon pronouncement of the sentence; (4) persons conditionally convicted or sentenced to punishments not related to deprivation of liberty, in respect of which the court has replaced the sentence with real deprivation of liberty; (5) wanted persons and detainees on the basis of a court decision on detention; (6) persons sentenced to imprisonment who were not arrested before the sentence entered into legal force; and (7) persons taken into custody pursuant according to the Article 466 of the Code of Criminal Procedure of the Russian Federation.

- Slovenia: In the total number of entries are included transfers from one penal institution to another.

- Sweden: Admissions of detainees not serving a final sentence (pre-trial detainees) are not available, and thus excluded in the total number of admissions. Admissions of persons who have been sentenced and have lodged an appeal or are within the statutory time limit to do so are excluded in the total number of entries because figures are not available.

- Switzerland: All admissions (entries) are included. No distinction can be made concerning the different type of entries. It is not possible to distinguish all type of entries from $1^{\text {st }}$ time entries (incarcerations).

- UK: England \& Wales: The total number of entries corresponds to the sum of first receptions and the number of offenders recalled and returned to custody.

- UK: Scotland: Prisoner origin is not available in the management information collected by SPS. Recording practise is somewhat inconsistent, therefore, the total number of admissions may therefore include situations that should be excluded according to the standard definition. 
Standard definition of exits (Tables 4.2.4)

- Bulgaria: The total number of exits excludes data on exits of remand centres.

- Cyprus: The total number of exits excludes inmates who died inside penal institutions. Releases from police stations are excluded.

- Iceland: Exits includes the total number of releases from prisons, half-way houses, alcoholic treatment and from electronic monitoring.

- Latvia: The counting unit for exits is the person, not the event. Inmates who died also includes inmates who died or committed suicide in community hospitals and inmates who died during short prison leaves.

- Lithuania: Inmates who died includes persons who died in public hospitals.

- Netherlands: Releases only include releases from penal institutions. Releases from custodial clinics, institutions for juveniles and institutions for aliens are excluded.

- Russian Federation: The definition of total number of exits does not exist in the Russian legal system. The figure indicated corresponds, therefore, to the sum of the number of releases on sentenced prisoners and non-sentenced inmates, the number of inmates who died inside penal institutions and the number of inmates who escaped from penal institutions.

- Slovenia: Releases includes transfers from one penal institution to another one.

- Sweden: Exits following an escape/abscond are excluded; data concerning exits of inmates not serving a final sentence is not available; Exits only include releases.

- UK: England \& Wales: Deaths in prison custody figures include all deaths of prisoners arising from incidents during prison custody. They include deaths of prisoners while released on temporary license (ROTL) for medical reasons but exclude other types of ROTL where the state has less direct responsibility. In recent years, approximately one half of natural cause deaths in prison custody actually occur in hospitals or hospices.

- UK: Scotland: The total number of exits excludes escapes/absconds. 
Standard definition of staff (Tables 4.2.5)

- Bulgaria: The total staff include all the staff of the system, including administrative staff, staff working inside prison institutions, staff working inside remand centres and staff working on probation service.

- Cyprus: All figures concern only the Prison institution without police stations.

- Czech Republic: The total number of staff includes female uniformed staff on maternity leave and staff members on long-term sickness leave. Total number of staff excludes members of uniformed staff as reserve (not permanently at work), civilians on maternity/family leaves, and other staff members not permanently at work for other reasons.

- Denmark: Probation officials are included in the total number of staff. The staff that is provisionally not fulfilling their tasks foreseen for them (maternity, education, compulsory military service in the Defence Forces, temporary assignment to another service, etc.) is excluded in the total number of staff.

- Lithuania: No distinction is made between part-time and full-time staff.

- Luxembourg: Total number of staff includes persons hired under the status of "state employees".

- Portugal: Total number of staff includes personnel assigned to the Prison Administration as well as those working in the Probation and Insertion Service.

- Russian Federation: The employees of the penal system of the Russian Federation (herein after referred to as the "UIS") include persons with special ranks of the UIS (employees), the federal state civil servants who occupy the posts of the federal state civil service, the workers and employees of penal institutions, the federal state unitary enterprises, the federal body of the UIS and of its territorial bodies, as well as the pre-trial detention facilities, enterprises, research, design, medical, educational and other organizations of the UIS. The employees of penal correctional institutions, which are in the staff of penal institutions and pre-trial detention facilities that are part of penal correctional systems, are personnel of penal institutions.

- Spain (Catalonia): Part-time staff has been counted as one full-time staff.

- Turkey: Prison staff working in prisons in General Directorate of Prisons and Detention Houses are included. Within the framework of the provisions of the Protocol on the Regulation of Health Services in Penal Institutions between the Ministry of Justice and the Ministry of Health, the number of staff assigned by the Ministry of Health is excluded.

- UK: England \& Wales: Data refers to public sector prisons in England and Wales only and exclude privately run prisons. 


\section{Minors}

- Albania: Minors includes offenders between 14 years old to less than 18 years old.

- Austria: There is a single penal institution specialised in juvenile offenders, however it includes offenders over 18 years old up to 21 years old. Specialised departments have also been established for juvenile offenders in other Austrian penal institutions.

- Cyprus: Offenders are considered juvenile offenders until 21 years old.

- Estonia: Minors includes offenders between 14 and 20 years old (included). However, some inmates over the age of 21 may be found in juvenile units.

- Hungary: The age of criminal responsibility can be 12 years of age in special cases. For persons who are older than 12 years of age but have not reached 14 years of age, the most severe sanction can be 1-4 years in special educative institutions. As a basic rule, the age of criminal majority is 18 , although in special cases it can be 21 .

- Netherlands: Juvenile offenders (which may include offenders aged 18 years and older) held in specialised facilities are excluded in the total number of inmates. However, the data for Netherlands only includes adult inmates.

- Norway: There are no juvenile courts in Norway, nor is there special legislation for young offenders over the age of 15. The General Penal Code however prescribes some special provisions for persons between 15 and 18 years of age.

- Portugal: Persons aged from 16 to less than 21 years are young adults and are tried under a special law which is specific to them.

- Serbia: A person who, at the time of committing the offence, has reached the age of 14 and has not reached the age of 18, is considered a juvenile offender.

- Spain: The Prison Administration has no competence concerning juvenile offenders, this matter is managed by autonomous communities. Therefore, juvenile offenders are excluded in the total prison population.

- UK: England \& Wales: Minors includes offenders between 15 and 17 years old. 


\section{Foreigners}

- Foreigners include inmates with unknown nationality and other statuses in Croatia, Denmark, Finland, France, Germany, Greece, Hungary, Iceland, Lithuania, Luxembourg, Moldova, Netherlands, Norway, Romania, Serbia, Switzerland, and Turkey.

- Foreigners exclude stateless inmates and inmates with unknown nationality in Azerbaijan, Belgium, Czech Republic, and Poland.

- Foreigners only include inmates with a foreign citizenship (not nationality) in Estonia and Latvia.

- Foreigners exclude inmates with the specific status of "non-citizen of Latvia" in Latvia.

- Foreigners include inmates with dual citizenship in Armenia and Austria.

- National inmates include British and Irish citizens in UK: Northern Ireland

\section{Offences}

- The following countries do not apply the principal offence rule: Bulgaria, Czech Republic, Finland (for fine defaulters), Georgia, Germany, Italy, Latvia, and Turkey.

- Rape and other types of sexual offences are not counted separately in the following countries: Finland, Germany, and Netherlands. 


\subsubsection{Tables}

Table 4.4.1 Compliance with the standard definitions for inmates, entries, exits, and staff

\begin{tabular}{|c|c|c|c|c|c|}
\hline & $\begin{array}{l}\text { Compliance with } \\
\text { the standard defi- } \\
\text { nition of inmates? }\end{array}$ & $\begin{array}{c}\text { Compliance with } \\
\text { the standard defi- } \\
\text { nition of entries? }\end{array}$ & $\begin{array}{l}\text { Compliance with } \\
\text { the standard defi- } \\
\text { nition of exits? }\end{array}$ & $\begin{array}{l}\text { Compliance with } \\
\text { the standard defi- } \\
\text { nition of staff? }\end{array}$ & $\begin{array}{l}\text { Does the total } \\
\text { number of staff in- } \\
\text { clude the staff not } \\
\text { employed by the } \\
\text { prison administra- } \\
\text { tion? }\end{array}$ \\
\hline Albania & Yes & Yes & Yes & Yes & No \\
\hline Armenia & Yes & Yes & Yes & Yes & No \\
\hline Austria & Yes & Yes & Yes & & No \\
\hline Azerbaijan & Yes & Yes & Yes & & \\
\hline \multicolumn{6}{|l|}{ Belgium } \\
\hline Bulgaria & Yes & Yes & No & Yes & No \\
\hline Croatia & Yes & & Yes & Yes & No \\
\hline Cyprus & Yes & Yes & No & Yes & No \\
\hline Czech Rep. & Yes & Yes & Yes & Yes & No \\
\hline Denmark & Yes & Yes & Yes & Yes & No \\
\hline Estonia & & Yes & Yes & Yes & Yes \\
\hline Finland & Yes & Yes & Yes & Yes & No \\
\hline \multicolumn{5}{|l|}{ Georgia } & No \\
\hline Germany & Yes & Yes & Yes & Yes & Yes \\
\hline Greece & Yes & Yes & Yes & Yes & Yes \\
\hline Hungary & Yes & No & Yes & Yes & No \\
\hline Iceland & Yes & Yes & Yes & Yes & No \\
\hline Ireland & Yes & Yes & Yes & Yes & Yes \\
\hline Italy & Yes & Yes & Yes & Yes & Yes \\
\hline Latvia & Yes & No & No & Yes & No \\
\hline Lithuania & Yes & Yes & No & No & No \\
\hline \multirow{2}{*}{\multicolumn{6}{|c|}{ Malta }} \\
\hline & & & & & \\
\hline Moldova & Yes & Yes & Yes & Yes & No \\
\hline Montenegro & Yes & & Yes & Yes & No \\
\hline Netherlands & No & No & Yes & Yes & No \\
\hline North Macedonia & Yes & Yes & Yes & Yes & Yes \\
\hline Norway & Yes & Yes & Yes & Yes & No \\
\hline Poland & Yes & & Yes & Yes & No \\
\hline Portugal & & & Yes & Yes & No \\
\hline Romania & Yes & Yes & Yes & Yes & No \\
\hline Russian Fed. & No & No & No & No & No \\
\hline Serbia & Yes & Yes & Yes & Yes & Yes \\
\hline Slovak Rep. & Yes & Yes & Yes & Yes & No \\
\hline Slovenia & Yes & No & No & Yes & No \\
\hline Spain & No & Yes & Yes & $\begin{array}{c}\text { No (Catalonia) } \\
\text { Yes (State Adm.) }\end{array}$ & Yes \\
\hline Sweden & Yes & No & No & Yes & No \\
\hline Switzerland & Yes & No & & Yes & No \\
\hline Turkey & & & & No & No \\
\hline \multicolumn{6}{|l|}{ Ukraine } \\
\hline UK: Engl. \& Wales & Yes & No & No & Yes & No \\
\hline UK: North. Ireland & Yes & Yes & Yes & Yes & No \\
\hline UK: Scotland & Yes & No & No & Yes & No \\
\hline
\end{tabular}


Table 4.4.2 Categories of inmates included in the total prison population

\begin{tabular}{|c|c|c|c|c|c|c|c|c|}
\hline & $(1)$ & $(2)$ & (3) & (4) & (5) & $(6)$ & (7) & (8) \\
\hline & \multicolumn{8}{|c|}{ Included? } \\
\hline Armenia & No & Yes & NAP & NAP & No & NAP & No & NAP \\
\hline Azerbaijan & No & Yes & No & NAP & No & No & NAP & NAP \\
\hline Belgium & No & No & No & No & Yes & Yes & No & Yes \\
\hline Croatia & No & Yes & No & No & No & NAP & NAP & NAP \\
\hline Cyprus & Yes & Yes & NAP & NAP & NAP & NAP & NAP & Yes \\
\hline Czech Rep. & NAP & Yes & NAP & NAP & NAP & NAP & NAP & NAP \\
\hline Denmark & No & No & NAP & NAP & No & No & NAP & No \\
\hline Estonia & No & Yes & NAP & NAP & NAP & No & NAP & Yes \\
\hline Greece & No & Yes & NAP & NAP & NAP & No & No & No \\
\hline Hungary & No & No & No & No & No & No & No & Yes \\
\hline Iceland & No & NAP & NAP & No & No & No & No & No \\
\hline Ireland & NAP & Yes & NAP & NAP & Yes & Yes & NAP & Yes \\
\hline Italy & No & No & NAP & NAP & Yes & NAP & NAP & No \\
\hline Latvia & No & Yes & No & No & No & NAP & NAP & NAP \\
\hline Lithuania & No & Yes & No & No & No & No & NAP & NAP \\
\hline Luxembourg & No & Yes & No & No & No & No & No & No \\
\hline Malta & NAP & Yes & NAP & Yes & Yes & NAP & No & No \\
\hline Moldova & No & Yes & No & No & No & No & No & No \\
\hline Montenegro & Yes & No & No & No & No & No & No & No \\
\hline Serbia & No & No & Yes & No & No & No & NAP & No \\
\hline Slovak Rep. & No & Yes & No & No & No & No & No & No \\
\hline Slovenia & No & Yes & Yes & No & No & No & No & No \\
\hline Spain & No & No & No & Yes & No & No & NAP & Yes \\
\hline Sweden & No & No & No & No & No & No & No & No \\
\hline Switzerland & Yes & Yes & Yes & No & No & Yes & No & No \\
\hline Turkey & Yes & NAP & Yes & No & No & NAP & NAP & No \\
\hline Ukraine & & & & & & & & \\
\hline UK: Engl. \& Wales & No & Yes & NAP & NAP & No & Yes & Yes & No \\
\hline UK: North. Ireland & No & Yes & No & No & No & Yes & No & No \\
\hline UK: Scotland & No & Yes & No & No & No & Yes & No & No \\
\hline
\end{tabular}

(1) Persons held in police stations or other similar types of investigative institutions before trial

(2) Persons held in custodial institutions/units for juvenile offenders

(3) Persons placed in educational institutions/units for juvenile offenders

(4) Persons held in institutions for drug-addicted offenders outside penal institutions

(5) Persons with psychiatric disorders in psychiatric institutions or hospitals outside penal institutions (e.g., persons considered as non-criminally liable by the court, persons under security measures, etc.)

(6) Asylum seekers or illegal aliens held for administrative reasons

(7) Persons held in private facilities (e.g., private prisons, detention centres, centres for the application of certain penal measures [e.g., centres for the treatment of psychiatric disorders, centres for the treatment of addictions etc.])

(8) Persons under electronic surveillance/electronic monitoring 
Table 4.4.3 Age and criminal responsibility

\begin{tabular}{|c|c|c|c|}
\hline & $\begin{array}{l}\text { Age of criminal } \\
\text { responsibility }\end{array}$ & $\begin{array}{l}\text { Minimal age for the appli- } \\
\text { cation of custodial sanc- } \\
\text { tions and measures }\end{array}$ & Age of criminal majority \\
\hline Albania & 14 & 14 & 18 \\
\hline Armenia & 14 & 14 & 18 \\
\hline Austria & 14 & 14 & 18 \\
\hline Azerbaijan & 14 & 14 & 18 \\
\hline Belgium & NAP & 14 & 18 \\
\hline Bosnia-Herzegovina & 14 & 14 & 18 \\
\hline Bulgaria & 14 & 14 & 18 \\
\hline Croatia & 14 & 14 & $18 / 21$ \\
\hline Cyprus & 14 & 14 & 16 \\
\hline Czech Rep. & 15 & 15 & 18 \\
\hline Denmark & 15 & 15 & 18 \\
\hline Estonia & 14 & 14 & 18 \\
\hline Finland & 15 & 15 & $18 / 21$ \\
\hline France & 13 & 16 & 18 \\
\hline Georgia & 14 & 14 & 18 \\
\hline Germany & 14 & 14 & 21 \\
\hline Greece & 15 & 15 & 18 \\
\hline Hungary & 14 & 14 & $18 / 21$ \\
\hline Iceland & 15 & 15 & 18 \\
\hline Ireland & 12 & 12 & 18 \\
\hline Italy & 14 & 14 & 18 \\
\hline Latvia & 14 & 14 & 18 \\
\hline Lithuania & 14 & 14 & 18 \\
\hline Luxembourg & 16 & 16 & 18 \\
\hline Malta & 14 & 14 & 18 \\
\hline Moldova & 14 & 14 & 18 \\
\hline Montenegro & 14 & 16 & 18 \\
\hline Netherlands & 12 & 12 & 18 \\
\hline North Macedonia & 14 & 16 & 18 \\
\hline Norway & 15 & 15 & 18 \\
\hline Poland & 13 & 15 & 17 \\
\hline Portugal & 16 & NAP & 21 \\
\hline Romania & 16 & 14 & 18 \\
\hline Russian Fed. & 14 & 14 & 18 \\
\hline Serbia & 14 & 14 & 18 \\
\hline Slovak Rep. & 14 & 14 & 18 \\
\hline Slovenia & 14 & 16 & $18 / 21$ \\
\hline Spain & 14 & 14 & 18 \\
\hline Sweden & 15 & 18 & 18 \\
\hline Switzerland & 10 & 15 & 18 \\
\hline Turkey & 12 & 12 & 18 \\
\hline Ukraine & 14 & 16 & 18 \\
\hline UK: Engl. \& Wales & 10 & 15 & 18 \\
\hline UK: North. Ireland & 10 & 10 & 18 \\
\hline UK: Scotland & $8 / 12$ & 16 & $18 / 21$ \\
\hline
\end{tabular}


Table 4.4.4 Legal status of prison population

\begin{tabular}{|c|c|c|c|c|c|c|}
\hline \multirow{2}{*}{ 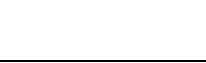 } & \multirow{2}{*}{ (1) } & \multirow{2}{*}{ (2) } & \multirow{2}{*}{ (3) } & \multirow{2}{*}{ (4) } & \multicolumn{2}{|c|}{ (5) } \\
\hline & & & & & (5.1) & $(5.2)$ \\
\hline & \multicolumn{6}{|c|}{ Included? } \\
\hline Albania & Yes & Yes & Yes & Yes & Yes & Yes \\
\hline Armenia & & & & NAP & & \\
\hline Austria & Yes & NAP & NAP & NAP & & \\
\hline Azerbaijan & Yes & NAP & & NAP & & \\
\hline Belgium & Yes & NAP & Yes & NAP & Yes & \\
\hline BH: Rep. Srpska & Yes & Yes & Yes & Yes & Yes & Yes \\
\hline Bulgaria & Yes & Yes & & & & \\
\hline Croatia & & NAP & NAP & & & \\
\hline Cyprus & Yes & NAP & NAP & NAP & Yes & Yes \\
\hline Czech Rep. & Yes & Yes & Yes & NAP & NAP & NAP \\
\hline Denmark & Yes & Yes & Yes & NAP & Yes & Yes \\
\hline Estonia & Yes & NAP & NAP & NAP & NAP & NAP \\
\hline Finland & & & & & Yes & \\
\hline France & Yes & & Yes & & & \\
\hline Georgia & Yes & NAP & & NAP & & Yes \\
\hline Germany & Yes & NAP & NAP & NAP & Yes & \\
\hline Greece & Yes & NAP & NAP & NAP & Yes & \\
\hline Hungary & Yes & NAP & Yes & NAP & Yes & Yes \\
\hline Iceland & Yes & NAP & Yes & Yes & Yes & Yes \\
\hline Ireland & Yes & NAP & NAP & NAP & Yes & \\
\hline Italy & Yes & NAP & Yes & NAP & NAP & NAP \\
\hline Latvia & Yes & Yes & Yes & Yes & Yes & \\
\hline Lithuania & Yes & Yes & Yes & & & \\
\hline Luxembourg & Yes & NAP & & NAP & Yes & Yes \\
\hline \multicolumn{7}{|l|}{ Maltaa } \\
\hline Moldova & Yes & Yes & Yes & Yes & Yes & Yes \\
\hline Montenegro & Yes & Yes & Yes & Yes & Yes & Yes \\
\hline Netherlands & Yes & Yes & Yes & NAP & Yes & \\
\hline North Macedonia & Yes & Yes & Yes & Yes & Yes & Yes \\
\hline Norway & Yes & Yes & Yes & Yes & Yes & \\
\hline Poland & Yes & Yes & Yes & Yes & Yes & \\
\hline Portugal & Yes & NAP & Yes & NAP & & \\
\hline Romania & Yes & Yes & Yes & & NAP & NAP \\
\hline Russian Fed. & Yes & NAP & & NAP & & \\
\hline Serbia & Yes & Yes & Yes & Yes & & \\
\hline Slovak Rep. & Yes & & & NAP & NAP & Yes \\
\hline Slovenia & Yes & Yes & Yes & Yes & & \\
\hline Spain & Yes & NAP & NAP & NAP & Yes & NAP \\
\hline Sweden & Yes & & & & & \\
\hline Switzerland & Yes & & & Yes & Yes & Yes \\
\hline Turkey & & NAP & Yes & & & \\
\hline \multicolumn{7}{|l|}{ Ukraine } \\
\hline UK: Engl. \& Wales & Yes & Yes & & NAP & Yes & Yes \\
\hline UK: North. Ireland & Yes & NAP & Yes & Yes & Yes & Yes \\
\hline UK: Scotland & Yes & Yes & Yes & NAP & Yes & \\
\hline
\end{tabular}

Pre-trial detainees: Categories included/excluded:

(1) Untried detainees (no court decision has been reached yet);

(2) Detainees found guilty but who have not yet received a sentence yet;

(3) Sentenced prisoners who have appealed or who are within the statutory limit for doing so;

(4) Detainees who have not received a final sentence yet, but who started serving a prison sentence in advance;

(5) Sentenced prisoners (5): Categories included/excluded (apart from those with final sentence)

(5.1): Persons detained for fine conversion reasons (fine defaulters);

(5.2): Persons detained because of the revocation, suspension or annulment of the conditional release or probation. 


\subsection{Sources}

\begin{tabular}{|c|c|}
\hline Albania & $\begin{array}{l}\text { The General Directory of Prisons, Ministry of Justice and SPACE I, The Council of Europe } \\
\text { Annual Penal Statistics (www.unil.ch/space). }\end{array}$ \\
\hline Armenia & SPACE I, The Council of Europe Annual Penal Statistics (www.unil.ch/space). \\
\hline Austria & SPACE I, The Council of Europe Annual Penal Statistics (www.unil.ch/space). \\
\hline Azerbaijan & SPACE I, The Council of Europe Annual Penal Statistics (www.unil.ch/space). \\
\hline Belgium & SPACE I, The Council of Europe Annual Penal Statistics (www.unil.ch/space). \\
\hline Bosnia-Herzegovina & $\begin{array}{l}\text { United Nations Surveys on Crime Trends and the Operations of Criminal Justice Systems } \\
\text { (UNCTS) and SPACE I, The Council of Europe Annual Penal Statistics } \\
\text { (www.unil.ch/space). }\end{array}$ \\
\hline Bulgaria & $\begin{array}{l}\text { National Statistical Institute: Statistical Yearbook 2016, Chapter "Criminality and Jus- } \\
\text { tice", available at: http://www.nsi.bg/sites/default/files/files/publications/God2016.pdf }\end{array}$ \\
\hline Croatia & Report from the Ministry of Justice- Prison department. \\
\hline Cyprus & $\begin{array}{l}\text { Ministry of Finance, Statistical Service, https://www.mof.gov.cy/mof/cystat/statis- } \\
\text { tics.nsf/populationcondition_27main_en/populationcondition_27main_en?Open- } \\
\text { Form\&sub=7\&sel=2. }\end{array}$ \\
\hline Czech Republic & Central Registry of Imprisoned Persons, Prison Service of the Czech Republic \\
\hline Denmark & SPACE I, The Council of Europe Annual Penal Statistics (www.unil.ch/space). \\
\hline Estonia & Ministry of Justice - Unpublished. \\
\hline Finland & $\begin{array}{l}\text { Tables 4.2.1., 4.2.3. and 4.2.4.: Criminal Sanctions Agency, personal communication Au- } \\
\text { gust 2018. }\end{array}$ \\
\hline France & $\begin{array}{l}\text { Table 4.2.1. : Statistique mensuelle des personnes détenues et écrouées en France au } \\
\text { 1er septembre } 2015 \text { (collecte auprès des établissements); } \\
\text { Tables 4.2.3. and 4.2.3. : Infocentre pénitentiaire (données issues des logiciels de ges- } \\
\text { tion). }\end{array}$ \\
\hline Georgia & SPACE I, The Council of Europe Annual Penal Statistics (www.unil.ch/space). \\
\hline Germany & $\begin{array}{l}\text { Table 4.2.1: Statistisches Bundesamt (Ed.), Bestand der Gefangenen und Verwahrten in } \\
\text { den deutschen Justizvollzugsanstalten nach ihrer Unterbringung auf Haftplätze des ge- } \\
\text { schlossenen und offenen Vollzuges jeweils zu den Stichtagen 31. März, 31. August und } \\
\text { 30. November eines Jahres, Wiesbaden 2012...017; Statistisches Bundesamt (Ed.), Straf- } \\
\text { vollzug - Demographische und kriminologische Merkmale der Gefangenen am } \\
\text { 31.03.2011...016, Wiesbaden 2012...017. } \\
\text { Table 4.2.3: No published data available. } \\
\text { Table 4.2.4: Bundestags-Drucksache 19/2872, } 15 \text { June 2018. }\end{array}$ \\
\hline Greece & SPACE I, The Council of Europe Annual Penal Statistics (www.unil.ch/space). \\
\hline Hungary & SPACE I, The Council of Europe Annual Penal Statistics (www.unil.ch/space). \\
\hline Iceland & SPACE I, The Council of Europe Annual Penal Statistics (www.unil.ch/space). \\
\hline Ireland & SPACE I, The Council of Europe Annual Penal Statistics (www.unil.ch/space). \\
\hline Italy & Italian Institute of statistics - http://wwwistatit - Ministry of Justice Department of Statistics \\
\hline Latvia & SPACE I, The Council of Europe Annual Penal Statistics (www.unil.ch/space). \\
\hline Lithuania & $\begin{array}{l}\text { Prison Department under the Ministry of Justice of the Republic of Lithuania - General } \\
\text { Unit. }\end{array}$ \\
\hline Luxembourg & SPACE I, The Council of Europe Annual Penal Statistics (www.unil.ch/space). \\
\hline Malta & SPACE I, The Council of Europe Annual Penal Statistics (www.unil.ch/space). \\
\hline Moldova & Data provided by the Ministry of Justice, National Penitentiary Institution. \\
\hline Montenegro & ZIKS-unpublished statistical data. \\
\hline
\end{tabular}


Table 4.5 Sources (2/2)

\begin{tabular}{|c|c|}
\hline Netherlands & $\begin{array}{l}\text { Ministry of Justice / WODC and SPACE I, The Council of Europe Annual Penal Statistics } \\
\text { (www.unil.ch/space). }\end{array}$ \\
\hline North Macedonia & $\begin{array}{l}\text { Table 4.2.1 - Foreigners total - from UNODC database and SPACE I, The Council of } \\
\text { Europe Annual Penal Statistics (www.unil.ch/space). }\end{array}$ \\
\hline Norway & $\begin{array}{l}\text { https://www.ssb.no/en/sosiale-forhold-og-kriminalitet/statistikker/fengsling and SPACE I, } \\
\text { The Council of Europe Annual Penal Statistics (www.unil.ch/space). }\end{array}$ \\
\hline Poland & Central Prison Authority, Department of Statistics. \\
\hline Portugal & $\begin{array}{l}\text { Directorate-General for Probation and Prison Services, Ministry of Justice and SPACE I, } \\
\text { The Council of Europe Annual Penal Statistics (www.unil.ch/space). }\end{array}$ \\
\hline Romania & $\begin{array}{l}\text { Romanian National Administration of Penitentiaries (www.anp.gov.ro) - Social Reintegra- } \\
\text { tion Office }\end{array}$ \\
\hline Russian Federation & SPACE I, The Council of Europe Annual Penal Statistics (www.unil.ch/space). \\
\hline Serbia & \\
\hline Slovak & I, The Council of Europe Annual Penal Statistics (www.unil.ch/space). \\
\hline Slovenia & SPACE I, The Council of Europe Annual Penal Statistics (www.unil.ch/space). \\
\hline Spain & EI, The Council of Europe Annual Penal Statistics (www.unil.ch/space). \\
\hline Sweden & $\begin{array}{l}\text { Swedish prison and probation service - Statistical section: Prison and probation service } \\
\text { register (KVR and KLAS), unpublished. } \\
\text { Some of the statistics are available at http://statistik.kriminalvarden.se/SASPor- } \\
\text { tal/main.do (the website is in Swedish). }\end{array}$ \\
\hline Switzerland & $\begin{array}{l}\text { Source: Federal Statistical Office - Detention Statistic } 2018 \text { https://www.bfs.ad- } \\
\text { min.ch/bfs/en/home/statistics/crime-criminal-justice/execution-penal-sentences-jus- } \\
\text { tice/persones-placement-detainee.html }\end{array}$ \\
\hline Turkey & $\begin{array}{l}\text { Table 4.2.1 - Foreigners total - from UNODC database. } \\
\text { The source for "stock of minors" row in Table 4.2.1 is Ministry of Justice General Direc- } \\
\text { torate of Prisons and Detention Houses website. Link: http://www.cte.adalet.gov.tr. } \\
\text { All other stock data provided in above tables is from is Ministry of Justice General Direc- } \\
\text { torate of Prisons and Detention Houses website. Link: http://www.cte.adalet.gov.tr. } \\
\text { All flow data is from Turkish Statistical Institute, Justice Statistics http://www.tuik.gov.tr/ } \\
\text { VeriBilgi.do?alt_id=1070 }\end{array}$ \\
\hline & SPACE I, The Council of Europe Annual Penal Statistics (www.unil.ch/space). \\
\hline & $\begin{array}{l}\text { Remand data on young offenders include everyone in prisons under the responsibility of } \\
\text { NOMS and exclude those in secured training centres and children home run by Youth } \\
\text { Justice Boards. Source: Based on data taken from 'Offender Management Statistics quar- } \\
\text { terly' Annual Tables http://www.justice.gov.uk/statistics/prisons-and-probation/oms-quar- } \\
\text { terly }\end{array}$ \\
\hline $\begin{array}{l}\text { UK: Northern Ireland } \\
\text { UK: Scotland }\end{array}$ & $\begin{array}{l}\text { SPACE I, The Council of Europe Annual Penal Statistics (www.unil.ch/space). } \\
\text { Scottish Government Justice Analytical Services prison statistics. }\end{array}$ \\
\hline
\end{tabular}




\section{Probation Statistics}

\subsection{General comments}

\subsubsection{Introduction}

This chapter provides information on the number and the characteristics of probationers, that is to say persons placed under the supervision of probation agencies, as well as on the staff and work of these agencies. The Council of Europe's Recommendation $\mathrm{CM} / \operatorname{Rec}(2014) 4$ defines a probation agency as "a body responsible for the execution in the community of sanctions and measures defined by law and imposed on an offender. Its tasks include a range of activities and interventions, which involve supervision, guidance and assistance aiming at the social inclusion of offenders, as well as at contributing to community safety. It may also, depending on the national legal system, implement one or more of the following functions: providing information and advice to judicial and other deciding authorities to help them reach informed and just decisions; providing guidance and support to offenders while in custody in order to prepare their release and resettlement; monitoring and assistance to persons subject to early release; restorative justice interventions; and offering assistance to victims of crime. A probation agency may also be, depending on the national legal system, the 'agency responsible for supervising persons under electronic monitoring"'. In that context, the Council of Europe's Recommendation $\mathrm{CM} / \operatorname{Rec}(2017) 3$ states that "the expression 'community sanctions 
and measures' means sanctions and measures which maintain suspects or offenders in the community and involve some restrictions on their liberty through the imposition of conditions and/or obligations. The term designates any sanction imposed by a judicial or administrative authority, and any measure taken before or instead of a decision on a sanction, as well as ways of enforcing a sentence of imprisonment outside a prison establishment".

The definitions of the Council of Europe reflect the wide variety of the sanctions and measures placed under the generic term of community sanctions and measures in Europe, which in turn explains the broad range of functions fulfilled by the European probation agencies. In particular, probation is used as a generic term that includes both the cases in which a person found guilty by a court is released by that court without imprisonment, but subject to conditions that will be supervised by a probation agency (a procedure known as probation in its strict sense) as well as the cases in which an inmate is conditionally released from imprisonment (a procedure known in many countries as parole), as long as he or she is placed under supervision of a probation agency. The extent of that supervision, however, differs considerably from one country to another.

Some countries have a specific Probation Agency and others a Prison and Probation Administration. Independently of that within the same country there may be more than one agency or administration. The latter are the same that were listed in Chapter 4 of the European Sourcebook (Prison Statistics): Bosnia and Herzegovina, Spain, and the United Kingdom.

The indicators presented in this chapter include the annual number of entries on probation and the annual number of releases from it during the years 2011 to 2016 (known respectively as the flow of entries and the flow of exits), as well as the number of persons effectively placed under the supervision of probation agencies on 31st December of each of these years (stock of probationers), the staff working in these agencies on 31 December 2015 by type of staff, and the number of written reports produced by them during the year 2015. The stock on 31 December 2015 and the flow of entries during 2015 are also broken down by type of supervision, while the flow of exits during that same year is a breakdown by type of exits.

Probation is placed at the end of the criminal justice process and has only a remote and indirect relationship with crime rates; instead, it is dependent on the penal policy of each country, which may or may not promote the use of community sanctions and measures. Furthermore, the interpretation of probation rates is not straightforward. In fact, "there is no 'magic formula' to estimate a rate of probationers that would be appropriate for a country. The reason is that probationers are serving community sanctions and measures, which are frequently referred to as alternatives to imprisonment because they aim at the social inclusion of the offender by keeping him/her in the community. Consequently, the probation rate cannot be interpreted without comparing it to the prison population rate" (Aebi, Hashimoto 
\& Tiago, 2020: 15) ${ }^{33}$. Research based on comparisons of trends in probation rates, prison population rates and crime rates suggest that, at least in some countries, community sanctions and measures are not really being used as alternatives to imprisonment, but rather as supplementary sanctions, hence 'widening the net' of European criminal justice systems ${ }^{34}$.

Finally, and similarly to what happens with all the figures based on criminal justice statistics presented in the European Sourcebook, there are also differences across countries that do not reflect substantial dissimilarities but are merely due to the statistical counting rules applied to collect them (particularly relevant in that perspective is the counting unit used in probation statistics), or to other legal, statistical, or criminal policy factors. Basic information on such differences is presented under the heading Technical information (5.3), while further information on the use of probation can be found in the Council of Europe Annual Penal Statistics (SPACE II) available online at www.unil.ch/space.

\section{The 'stock' and 'flow' perspectives}

As it was the case with prison statistics (see Chapter 4 of the European Sourcebook), data on probation populations can be described from two perspectives, which generate different but equally important results. The first perspective refers to how many probationers are under the supervision of probation agencies on a given day' (stock). The second perspective refers to 'how many persons were placed under the supervision of probation agencies during the course of the year' (flow of entries) and to 'how many probation services ceased to be under the supervision of probation agencies during the course of the year' (flow of exits). Both perspectives are also interrelated, in such a way that the stock of probationers on 31st December of a given year is influenced by the flows of entries and exits during that year, but also by the number of persons placed under the supervision of probation agencies during the previous years who are still under that supervision. The situation is hence identical to the one described when introducing prison statistics, which means that the stock data cannot easily be compared to the data presented in the first three chapters of the European Sourcebook, which usually uses a flow perspective (for example, the annual number of offences recorded by the police, of cases treated by the prosecution services, or of persons convicted).

Regarding probation populations, the following data were requested:

- Number of persons under the supervision of probation agencies on 31 December 2011 to 2016: stock of probationers (Table 5.2.1.1)

- Distribution of the probationers placed under the supervision of probation agencies on 31 December 2015 by

\footnotetext{
33 Aebi, M. F., Hashimoto, Y. Z. \& Tiago, M. M. (2020). Probation and Prisons in Europe 2019: Key Findings of the SPACE reports. Strasbourg: Council of Europe.

34 Aebi, M.F., Delgrande, N. \& Marguet, Y. (2015). Have community sanctions and measures widened the net of the European criminal justice systems? Punishment \& Society, 17(5): 575-597.
} 
- sociodemographic characteristics: women, minors, and foreigners (Table 5.2.1.2);

○ type of supervision: Supervision before a final sentence, Fully suspended custodial sanctions with probation, Partially suspended custodial sentences with probation, Conditional pardon or conditional discharge (with probation), Community service, Electronic monitoring, Home arrest (curfew orders), Semi-liberty, Treatment, Mixed orders, Supervision after conditional release from prison, and the residual category "other" (Table 5.2.1.3).

- Annual number of entries on probation during the years 2011 to 2016: flow of entries. The counting unit is the person entering probation but, as the same person can be counted multiple times if she is placed under the supervision of a probation agency more than once during the same year, this indicator is referred to as the flow of entries, instead of the flow of persons entering probation (Table 5.2.2.1).

- Distribution of the persons who entered probation during the year 2015 by

o sociodemographic characteristics: women, minors, and foreigners (Table 5.2.2.2);

○ type of supervision: Supervision before a final sentence, fully suspended custodial sanctions with probation, Partially suspended custodial sentences with probation, Conditional pardon or conditional discharge (with probation), Community service, Electronic monitoring, Home arrest (curfew orders), Semi-liberty, Treatment, Mixed orders, Supervision after conditional release from prison, and the residual category "other" (Table 5.2.2.3).

- Annual number of exits from probation during the year 2015 (flow of exits) and its distribution by type of exit: completion, revocation, imprisonment, absconders, death, and the residual category "other". The counting unit is the person that ceases to be under the supervision of a probation agency but, as the same person can be counted multiple times if (s)he exits probation more than once during the same year, this indicator is referred to as the flow of exits, instead of the flow of persons that ceased to be on probation (Table 5.2.3).

- Probation staff: rate of staff per 100 probationers and distribution of the staff in the following categories: Top-level executives at the national probation administrations, Top-level executives at the regional probation administrations, Senior Probation officers (chiefs of units), Probation officers (qualified Probation staff), Probation agency officers (unqualified Probation staff), Paid external staff, Volunteers, and the residual category "other staff' (Table 5.2.4).

- Number of written reports produced per one staff member during 2015 and their distribution by the following types of report: Pre-sentence 
reports, Advisory reports with respect to conditional release, and the residual category "other reports" (Table 5.2.5).

\subsubsection{Quality of the data}

Most of the probation data included in this edition of the European Sourcebook come from the Council of Europe Annual Penal Statistics (SPACE. II) ${ }^{35}$. The data validation procedure did not reveal major inconsistencies.

Up to 37 countries provided data on the stock of probationers for at least one year of the series, although a comparison between 2011 and 2016 is possible for only 29 of them

Twenty-nine countries provided data on the percentage of females among their probationers in 2015. Most of the countries (23) in which minors are included in the probation population provided data on them. However, only 18 countries provided data on the flow on the percentage of foreigners

Few countries provided data on the distribution of probationers by type of supervision on 31 December 2015.

Up to 37 countries provided data on the flow of probationers for at least one year of the series, although a comparison between 2011 and 2016 is possible for only 33 of them. The percentages of countries that provided data on the number of females, minors, and foreigners in the flow of entries during 2015 are similar to the ones observed for stock data. Likewise, only few countries provided data on the distribution of the flow of probationers during 2015 by type of supervision.

Thirty-three countries provided data on their probation staff, but only 14 were able to do so for the number of written reports produced by that staff.

\subsubsection{Results}

There were considerable differences between the countries as regards the total number of persons under the supervision of probation agencies in 2015. The rates per 100000 population ranged from 3 (Serbia) to 866 (Georgia). Such differences reflect the recent development of supervision by probation agencies in many countries as well as - to a larger extent - the different definitions of the concept. In particular, the extent of what precisely means being under the supervision of an agency varies widely across countries. For example, when one compares the low number of probation staff to the high number of probationers observed in some countries, it seems clear that the level of the supervision cannot be the same as the one provided in countries where the ratio staff/probationers is lower. In particular, it would seem that, in some countries, inmates conditionally released are formally placed under the supervision of probation agencies, but that placement does not imply a personal follow up by probation staff. This corroborates that, as we mentioned in the

\footnotetext{
35 See www.unil.ch/space.
} 
introduction, cross-national comparisons of the rates of persons under the supervision of probation agencies are misleading.

The ratio of probation staff per 100 probationers varies from less than one member of staff per 100 probationers (in Greece) to 10 or 12 per 100 in some Nordic countries. The average number of reports produced by that staff during 2015 differs considerably from one country to the other, ranging from one to 86, which corroborates that figures are not comparable because the tasks of probation agencies are not equivalent as far as the production of reports is concerned.

The average percentage of women under the supervision of probation agencies is $10 \%$. This is a low percentage, but it represents the double of the percentage observed in the prison population (see Chapter 4). In general, the percentage of women on probation corroborates the differential implication of men and women in delinquency. In particular, the difference between the percentage of women on probation and in prison corroborates that the difference comes mainly from the lesser involvement of women in violent offences, which are overrepresented among the prison population.

The average percentage of foreigners on probation is $11 \%$, which corroborates that it is much more difficult for them than for nationals to be placed on probation. The main reason is that quite often foreigners do not have a stable residence in the country where they were sentenced. This interpretation is corroborated through a comparison with the higher percentage of foreigners among inmates (roughly $16 \%$ on average, according to the information provided in Chapter 4). It must be mentioned, however, that the majority of probation agencies (28 out of 46) were unable to provide information on the nationality of their probationers.

The percentage of minors on probation is slightly higher than that of minors in prison, but that can be explained by the fact that, in most countries, minors are not included in the prison population. At the level of probation, there are also several agencies that do not include minors and, among those that include them, the differences are sometimes striking.

From 2011 to 2016, the rate of probationers per 100,000 population increased in a majority of countries. As can be seen in Table 5.2.1.1, in 17 out of the 29 probation agencies that provided the necessary data, the 2016 probation population rate (stock) was more than 5\% higher than in 2011; in 11 the 2016 rate was more than $5 \%$ higher than that of 2011; while in Austria both rates were comparable.

Similarly, in 19 out of the 33 probation agencies that provided the necessary data, the 2016 rate of entries (flow of entries) was more than $5 \%$ higher than in 2011. In three prison administrations, the rates were comparable (the 2016 flow of entries was up to $5 \%$ lower or higher than that of 2011), and in 11 prison administrations, the 2016 flow of entries was more than 5\% higher than that of 2011. 
Notes on Tables 5.2.4 and 5.2.5

\begin{tabular}{|c|c|}
\hline \multicolumn{2}{|r|}{ Notes on Table 5.2 .4} \\
\hline Czech Republic & $\begin{array}{l}\text { The counting rule of the FTE (full-time equivalent) is not respected. Every employee } \\
\text { is counted as one employee independently of their percentage of working hours. } \\
\text { However, there are only } 2 \text { or } 3 \text { employees working part time. }\end{array}$ \\
\hline Lithuania & The counting rule of the FTE (full-time equivalent) is not respected. \\
\hline UK: Northern Ireland & $\begin{array}{l}\text { The Information provided is based on actual numbers of people rather than 'Work } \\
\text { time Equivalent'. For example, on } 31 \text { December } 2010 \text { PBNI staff totalled } 441 \text { people } \\
\text { working the equivalent of } 405.97 \text { full-time members of staff. } \\
\text { Administrative Staff includes all corporate staff, administrative support within field } \\
\text { teams and also cleaning staff. } \\
\text { Other Probation Workers include Probation Service Officers, Community Service and } \\
\text { Psychology Staff. }\end{array}$ \\
\hline \multicolumn{2}{|r|}{ Notes on Table 5.2 .5} \\
\hline Albania & No information available. \\
\hline Hungary & $\begin{array}{l}\text { There are two main categories of advisory reports in Hungary: probation advisory re- } \\
\text { ports and social inquiry reports. Most of the probation advisory reports are pre-sen- } \\
\text { tence reports made at the request of the prosecutor or the judge. Social inquiry re- } \\
\text { ports are prepared in every juvenile case at the request of the police. Probation offic- } \\
\text { ers make social inquiry also reports during reprieve proceedings, and for the prepara- } \\
\text { tion of the decision about the cancellation of the payment of costs of the criminal pro- } \\
\text { cedure or court fine }\end{array}$ \\
\hline Ireland & Other reports include generic reports and Revocation Report \\
\hline Slovak Republic & $\begin{array}{l}\text { Other reports correspond to the Report and review prepared by the centres of social } \\
\text { work on the request of the courts. }\end{array}$ \\
\hline Slovenia & Other reports include 83 reports on the help to the family during the process. \\
\hline \multirow[t]{4}{*}{ UK: England \& Wales } & $\begin{array}{l}\text { Pre-Sentence- Reports include both Pre-Sentence Reports and Shortened Pre-Sen- } \\
\text { tence Reports. }\end{array}$ \\
\hline & $\begin{array}{l}\text { Reports concerning supervision during the execution of community sanctions in- } \\
\text { cludes Breach Reports }\end{array}$ \\
\hline & Reports after a conditional release include Recall Reports \\
\hline & $\begin{array}{l}\text { Other reports not detailed in the table but included in the total figures include Adden- } \\
\text { dum Report, Home Circumstances Report, Report for The Life Sentence Commis- } \\
\text { sioners Progress Report To The Life Sentence Unit, Parole Report, Probation Offic- } \\
\text { ers Report. }\end{array}$ \\
\hline
\end{tabular}




\subsection{Tables}

\subsubsection{Probation population: Stock of probationers}

Table 5.2.1.1 Probation population rate per 100000 population (stock of probationers) on 31 December

\begin{tabular}{|c|c|c|c|c|c|c|c|}
\hline & 2011 & 2012 & 2013 & 2014 & 2015 & 2016 & $\begin{array}{l}\% \text { change } \\
2011-2016\end{array}$ \\
\hline Albania & 161 & 250 & 323 & 462 & 669 & 865 & 439 \\
\hline Armenia & 103 & 83 & 113 & 77 & 112 & 149 & 45 \\
\hline Austria & 176 & 178 & 155 & 183 & 182 & 174 & -1 \\
\hline Azerbaijan & 90 & 104 & 62 & 90 & 109 & $\ldots$ & $\ldots$ \\
\hline Belgium & 369 & 352 & 354 & 364 & 382 & 392 & 6 \\
\hline Bosnia-Herzegovina & & & & $\ldots$ & & & $\ldots$ \\
\hline Bulgaria & 164 & 162 & 145 & $\ldots$ & 144 & 108 & -34 \\
\hline Croatia & 24 & 70 & 68 & 71 & 77 & 84 & 248 \\
\hline Cyprus & 188 & 144 & 131 & 141 & 126 & 97 & -48 \\
\hline Czech Republic & $\ldots$ & 321 & 213 & 262 & 236 & 252 & $\ldots$ \\
\hline Denmark & 172 & 173 & 176 & 176 & 168 & 151 & -12 \\
\hline Estonia & 544 & 529 & 485 & 431 & 369 & 321 & -41 \\
\hline Finland & 46 & 44 & 46 & 46 & 40 & 54 & 17 \\
\hline France & 284 & 287 & $\ldots$ & 278 & 257 & 262 & -8 \\
\hline Georgia & 866 & 736 & 283 & 342 & 516 & 577 & -33 \\
\hline Germany & 195 & 195 & 194 & 194 & 193 & $\ldots$ & $\ldots$ \\
\hline Greece & 65 & $\ldots$ & 107 & 105 & 188 & 183 & 183 \\
\hline Hungary & $\ldots$ & $\ldots$ & 385 & 443 & 434 & 422 & $\ldots$ \\
\hline Iceland & 60 & 63 & 58 & 57 & 55 & 74 & 22 \\
\hline Ireland & 136 & 142 & 143 & 145 & 131 & 121 & -11 \\
\hline Italy & 72 & 49 & 56 & 72 & 87 & 98 & 35 \\
\hline Kosovo (UN R/1244/99) & $\ldots$ & $\ldots$ & $\ldots$ & $\ldots$ & $\ldots$ & $\ldots$ & $\ldots$ \\
\hline Latvia & $\ldots$ & $\ldots$ & 859 & 303 & 5 & 316 & $\ldots$ \\
\hline Lithuania & 234 & 266 & 279 & 269 & 272 & 271 & 16 \\
\hline Luxembourg & 286 & 199 & & 205 & 198 & 156 & -45 \\
\hline Malta & 212 & 205 & 229 & 233 & 251 & 248 & 17 \\
\hline Moldova & 232 & 257 & 280 & 262 & 298 & 292 & 26 \\
\hline Montenegro & $\ldots$ & $\ldots$ & $\ldots$ & 52 & $\ldots$ & $\ldots$ & $\ldots$ \\
\hline Netherlands & 220 & 210 & 256 & 267 & $\ldots$ & 250 & 14 \\
\hline North Macedonia & . & & & $\ldots$ & $\ldots$ & $\ldots$ & $\ldots$ \\
\hline Norway & 38 & 36 & 38 & 37 & 36 & 42 & 9 \\
\hline Poland & 641 & 531 & 547 & $\ldots$ & $\ldots$ & $\ldots$ & $\ldots$ \\
\hline Portugal & 187 & 226 & 252 & 248 & 283 & 284 & 52 \\
\hline Romania & 64 & 75 & 93 & 126 & 203 & 263 & 314 \\
\hline Russia & 332 & 326 & 316 & 302 & 213 & 293 & -12 \\
\hline Serbia & 3 & 5 & 10 & 16 & 17 & 20 & 525 \\
\hline Slovak Republic & 299 & 2090 & 113 & 148 & 247 & $\ldots$ & $\ldots$ \\
\hline Slovenia & $\ldots$ & $\ldots$ & $\ldots$ & 2 & 2 & 3 & $\ldots$ \\
\hline Spain & $\ldots$ & $\ldots$ & $\ldots$ & $\ldots$ & $\ldots$ & $\ldots$ & $\ldots$ \\
\hline Sweden & 146 & 153 & 137 & 125 & 119 & 109 & -25 \\
\hline Switzerland & 101 & 95 & 87 & 93 & 51 & 48 & -52 \\
\hline Turkey & $\ldots$ & $\ldots$ & $\ldots$ & $\ldots$ & $\ldots$ & 371 & $\ldots$ \\
\hline Ukraine & & & 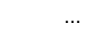 & . & & & \\
\hline UK: England \& Wales & 290 & 275 & 264 & 258 & 287 & 326 & 13 \\
\hline UK: Northern Ireland & 236 & 237 & 245 & 234 & 235 & $\ldots$ & $\ldots$ \\
\hline UK: Scotland & $\ldots$ & $\ldots$ & 322 & 389 & 406 & 407 & $\ldots$ \\
\hline Mean & 213 & 267 & 217 & 198 & 205 & 231 & \\
\hline Median & 181 & 197 & 185 & 188 & 193 & 248 & \\
\hline Minimum & 3 & 5 & 10 & 2 & 2 & 3 & \\
\hline Maximum & 866 & 2090 & 859 & 462 & 669 & 865 & \\
\hline
\end{tabular}


Table 5.2.1.2 Percentage of women, minors, and foreigners in the probation population on 31 December 2015

\begin{tabular}{|c|c|c|c|c|}
\hline & $\begin{array}{l}\text { Total offenders } \\
\text { per } 100000 \text { pop. }\end{array}$ & $\begin{array}{l}\text { of which } \% \\
\text { of women }\end{array}$ & $\begin{array}{l}\text { of which } \% \\
\text { of minors }\end{array}$ & $\begin{array}{l}\text { of which } \% \\
\text { of foreigners }\end{array}$ \\
\hline Albania & 669 & 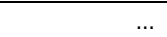 & $\ldots$ & 0.0 \\
\hline Armenia & 112 & 10.6 & 2.1 & 0.7 \\
\hline Austria & 182 & 15.4 & 20.0 & 25.7 \\
\hline Azerbaijan & 109 & $\ldots$ & & \\
\hline Belgium & 382 & 12.0 & 0.2 & 11.0 \\
\hline Bosnia-Herzegovina & & & & $\ldots$ \\
\hline Bulgaria & 144 & 6.2 & 3.0 & \\
\hline Croatia & 77 & 8.6 & $\ldots$ & 1.0 \\
\hline Cyprus & 126 & 1.8 & 32.8 & 6.0 \\
\hline Czech Republic & 236 & 12.4 & 7.2 & \\
\hline Denmark & 168 & 13.3 & 0.6 & 8.3 \\
\hline Estonia & 369 & 8.8 & 3.8 & 24.2 \\
\hline Finland & 40 & 11.4 & 0.1 & 6.6 \\
\hline France & 257 & 6.8 & 0.0 & ... \\
\hline Georgia & 516 & 5.6 & 1.2 & 0.4 \\
\hline Germany & 193 & & $\ldots$ & \\
\hline Greece & 188 & 3.0 & 0.2 & 5.2 \\
\hline Hungary & 434 & 12.3 & $\ldots$ & \\
\hline Iceland & 55 & 8.3 & 5.0 & 3.3 \\
\hline Ireland & 131 & 13.3 & 3.4 & $\ldots$ \\
\hline Italy & 87 & 9.9 & $\ldots$ & 14.6 \\
\hline Kosovo (UN R/1244/99) & & $\ldots$ & $\ldots$ & $\ldots$ \\
\hline Latvia & 5 & $\ldots$ & $\ldots$ & $\ldots$ \\
\hline Lithuania & 272 & 11.1 & 6.1 & \\
\hline Luxembourg & 198 & 13.5 & $\ldots$ & 39.7 \\
\hline Malta & 251 & & $\ldots$ & ... \\
\hline Moldova & 298 & 0.1 & 1.4 & ... \\
\hline Montenegro & $\ldots$ & $\ldots$ & $\ldots$ & $\ldots$ \\
\hline Netherlands & $\ldots$ & $\ldots$ & $\ldots$ & $\ldots$ \\
\hline North Macedonia & $\ldots$ & $\ldots$ & $\ldots$ & $\ldots$ \\
\hline Norway & 36 & $\ldots$ & $\ldots$ & $\ldots$ \\
\hline Poland & & & $\ldots$ & \\
\hline Portugal & 283 & 10.2 & 0.5 & 7.6 \\
\hline Romania & 203 & 9.0 & 1.3 & $\ldots$ \\
\hline Russia & 213 & 15.8 & 1.9 & \\
\hline Serbia & 17 & 7.9 & $\ldots$ & 0.2 \\
\hline Slovak Republic & 247 & $\ldots$ & $\ldots$ & ... \\
\hline Slovenia & 2 & $\ldots$ & $\ldots$ & ... \\
\hline Spain & & $\ldots$ & $\ldots$ & $\ldots$ \\
\hline Sweden & 119 & 13.0 & 0.1 & 14.0 \\
\hline Switzerland & 51 & 11.4 & $\ldots$ & 36.3 \\
\hline Turkey & $\ldots$ & $\ldots$ & $\ldots$ & $\ldots$ \\
\hline Ukraine & & & $\ldots$ & $\ldots$ \\
\hline UK: England \& Wales & 287 & 12.3 & $\ldots$ & $\ldots$ \\
\hline UK: Northern Ireland & 235 & 9.4 & 0.9 & ... \\
\hline UK: Scotland & 406 & 14.2 & 1.8 & \\
\hline Mean & 205 & 9.9 & 4.3 & 11.4 \\
\hline Median & 193 & 10.6 & 1.6 & 7.1 \\
\hline Minimum & 2 & 0.1 & 0.0 & 0.0 \\
\hline Maximum & 669 & 15.8 & 32.8 & 39.7 \\
\hline
\end{tabular}


Table 5.2.1.3 Distribution of the probationers under the supervision of probation agencies on $31^{\text {st }}$ December 2015 by type of supervision $(1 / 2)$

of which \%

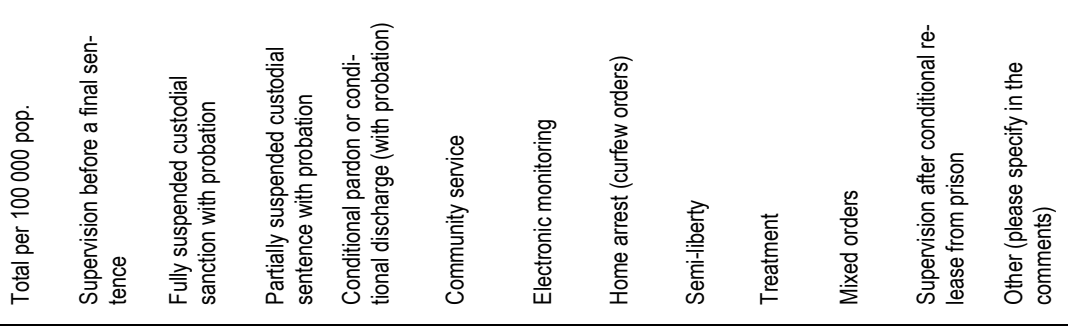

\begin{tabular}{|c|c|c|c|c|c|c|c|c|c|c|c|c|c|}
\hline Albania & $\ldots$ & $\ldots$ & $\ldots$ & $\ldots$ & $\ldots$ & $\ldots$ & $\ldots$ & $\ldots$ & $\ldots$ & $\ldots$ & $\ldots$ & $\ldots$ & $\ldots$ \\
\hline Armenia & $\ldots$ & $\ldots$ & $\ldots$ & $\ldots$ & $\ldots$ & $\ldots$ & $\ldots$ & $\ldots$ & $\ldots$ & $\ldots$ & $\ldots$ & $\ldots$ & $\ldots$ \\
\hline Austria & $\ldots$ & $\ldots$ & $\ldots$ & $\ldots$ & $\ldots$ & $\ldots$ & $\ldots$ & $\ldots$ & $\ldots$ & $\ldots$ & $\ldots$ & $\ldots$ & $\ldots$ \\
\hline Azerbaijan & 109 & $\ldots$ & 1.0 & $\ldots$ & $\ldots$ & $\ldots$ & $\ldots$ & $\ldots$ & $\ldots$ & $\ldots$ & $\ldots$ & 27.8 & 70.6 \\
\hline Belgium & $\ldots$ & $\ldots$ & $\ldots$ & $\ldots$ & $\ldots$ & $\ldots$ & $\ldots$ & $\ldots$ & $\ldots$ & $\ldots$ & $\ldots$ & $\ldots$ & $\ldots$ \\
\hline Bosnia- & & $\ldots$ & $\ldots$ & $\ldots$ & & ... & $\ldots$ & $\ldots$ & $\ldots$ & $\ldots$ & $\ldots$ & $\ldots$ & $\ldots$ \\
\hline $\begin{array}{l}\text { Herze- } \\
\text { govina }\end{array}$ & $\ldots$ & & & & $\ldots$ & & & & & & & & \\
\hline Bulgaria & 144 & $\ldots$ & $\ldots$ & $\ldots$ & $\ldots$ & 72.1 & 1.8 & $\ldots$ & $\ldots$ & $\ldots$ & 20.0 & 6.1 & $\ldots$ \\
\hline Croatia & 77 & 0.5 & 8.4 & 0.4 & 0.0 & 70.7 & 0.0 & 0.0 & 0.0 & 0.0 & 0.0 & 17.0 & 3.0 \\
\hline Cyprus & 126 & 18.0 & $\ldots$ & $\ldots$ & $\ldots$ & 81.3 & $\ldots$ & $\ldots$ & $\ldots$ & $\ldots$ & $\ldots$ & 0.7 & $\ldots$ \\
\hline $\begin{array}{l}\text { Czech } \\
\text { Republic }\end{array}$ & $\cdots$ & $\ldots$ & ... & $\ldots$ & $\ldots$ & $\ldots$ & $\ldots$ & $\ldots$ & $\ldots$ & $\ldots$ & $\ldots$ & $\ldots$ & $\ldots$ \\
\hline Denmark & $\ldots$ & $\ldots$ & $\ldots$ & $\ldots$ & $\ldots$ & $\ldots$ & $\ldots$ & $\ldots$ & $\ldots$ & $\ldots$ & $\ldots$ & $\ldots$ & $\ldots$ \\
\hline Estonia & $\ldots$ & $\ldots$ & $\ldots$ & $\ldots$ & $\ldots$ & $\ldots$ & $\ldots$ & $\ldots$ & $\ldots$ & $\ldots$ & $\ldots$ & $\ldots$ & $\ldots$ \\
\hline Finland & 40 & $\ldots$ & $\ldots$ & $\ldots$ & $\ldots$ & 47.0 & 2.3 & $\ldots$ & $\ldots$ & $\ldots$ & 4.4 & 46.2 & $\ldots$ \\
\hline France & 258 & 3.2 & 72.3 & 0.0 & $\ldots$ & 22.4 & 5.5 & $\ldots$ & $\ldots$ & $\ldots$ & $\ldots$ & 3.7 & $\ldots$ \\
\hline Georgia & 516 & $\ldots$ & 82.5 & 15.5 & 0.9 & 1.0 & $\ldots$ & $\ldots$ & 0.1 & $\ldots$ & $\ldots$ & 0.9 & 0.2 \\
\hline Germany & $\ldots$ & $\ldots$ & $\ldots$ & $\ldots$ & $\ldots$ & $\ldots$ & $\ldots$ & $\ldots$ & $\ldots$ & $\ldots$ & $\ldots$ & $\ldots$ & $\ldots$ \\
\hline Greece & $\ldots$ & $\ldots$ & $\ldots$ & $\ldots$ & $\ldots$ & $\ldots$ & $\ldots$ & $\ldots$ & $\ldots$ & $\ldots$ & $\ldots$ & $\ldots$ & $\ldots$ \\
\hline Hungary & 455 & 12.0 & 13.7 & $\ldots$ & 2.9 & 64.4 & 0.3 & $\ldots$ & $\ldots$ & $\ldots$ & $\ldots$ & 6.7 & $\ldots$ \\
\hline Iceland & $\ldots$ & $\ldots$ & $\ldots$ & $\ldots$ & $\ldots$ & $\ldots$ & $\ldots$ & $\ldots$ & $\ldots$ & $\ldots$ & $\ldots$ & $\ldots$ & $\ldots$ \\
\hline Ireland & $\ldots$ & $\ldots$ & $\ldots$ & $\ldots$ & $\ldots$ & $\ldots$ & $\ldots$ & $\ldots$ & $\ldots$ & $\ldots$ & $\ldots$ & $\ldots$ & $\ldots$ \\
\hline Italy & 87 & 30.2 & 11.6 & $\begin{array}{l}\cdots \\
\ldots\end{array}$ & $\cdots$ & 11.2 & $\begin{array}{l}\cdots \\
\cdots\end{array}$ & 17.9 & 1.3 & 5.8 & 7.3 & 4.8 & 9.9 \\
\hline $\begin{array}{l}\text { Kosovo } \\
\text { (UN } \\
\text { R/1244/99) }\end{array}$ & $\ldots$ & $\ldots$ & $\ldots$ & $\ldots$ & & $\ldots$ & ... & $\ldots$ & $\ldots$ & $\ldots$ & $\ldots$ & $\ldots$ & $\ldots$ \\
\hline Latvia & 5 & 100.0 & 3113.8 & $\ldots$ & 163.8 & 2870.2 & 28.7 & $\ldots$ & $\ldots$ & $\ldots$ & $\ldots$ & 460.6 & 124.5 \\
\hline Lithuania & $\ldots$ & $\ldots$ & $\ldots$ & $\ldots$ & $\ldots$ & $\ldots$ & $\ldots$ & $\ldots$ & $\ldots$ & $\ldots$ & $\ldots$ & $\ldots$ & $\ldots$ \\
\hline $\begin{array}{l}\text { Luxem- } \\
\text { bourg }\end{array}$ & 198 & 1.9 & 31.3 & 10.9 & & 37.7 & 2.2 & $\ldots$ & 1.3 & $\ldots$ & $\ldots$ & 14.3 & 0.4 \\
\hline Malta & 251 & 7.2 & 10.3 & $\ldots$ & 62.5 & 3.4 & $\ldots$ & $\ldots$ & $\ldots$ & 3.2 & 3.3 & 2.3 & $\ldots$ \\
\hline Moldova & 295 & 0.6 & 38.4 & $\ldots$ & 49.1 & 9.1 & 0.0 & $\ldots$ & $\ldots$ & $\ldots$ & 14.1 & 3.0 & 39.3 \\
\hline $\begin{array}{l}\text { Monte- } \\
\text { negro }\end{array}$ & $\ldots$ & $\ldots$ & $\ldots$ & ... & $\ldots$ & $\ldots$ & $\ldots$ & $\ldots$ & ... & $\ldots$ & $\ldots$ & $\ldots$ & $\ldots$ \\
\hline $\begin{array}{l}\text { Nether- } \\
\text { lands }\end{array}$ & $\ldots$ & $\ldots$ & $\ldots$ & $\ldots$ & $\ldots$ & $\cdots$ & $\cdots$ & $\cdots$ & $\cdots$ & $\ldots$ & $\ldots$ & $\ldots$ & $\cdots$ \\
\hline $\begin{array}{l}\text { North Mac- } \\
\text { edonia }\end{array}$ & $\ldots$ & $\cdots$ & $\ldots$ & $\ldots$ & $\ldots$ & $\ldots$ & $\ldots$ & $\ldots$ & $\ldots$ & $\ldots$ & $\ldots$ & $\ldots$ & $\ldots$ \\
\hline Norway & 44 & $\ldots$ & 24.1 & $\ldots$ & $\ldots$ & 47.4 & 11.9 & 0.8 & $\ldots$ & $\ldots$ & 0.0 & 15.4 & 0.4 \\
\hline Poland & 909 & 1.9 & 39.1 & $\ldots$ & 0.9 & 26.1 & 1.0 & $\ldots$ & $\ldots$ & 6.1 & 0.1 & 9.0 & 12.4 \\
\hline Portugal & & $\ldots$ & & $\ldots$ & $\ldots$ & $\ldots$ & $\ldots$ & $\ldots$ & $\ldots$ & $\ldots$ & & & $\ldots$ \\
\hline Romania & 203 & $\ldots$ & 75.9 & $\ldots$ & $\ldots$ & $\ldots$ & $\ldots$ & $\ldots$ & $\ldots$ & $\ldots$ & 4.7 & 0.2 & 19.3 \\
\hline Russia & 187 & $\ldots$ & $\ldots$ & $\ldots$ & $\ldots$ & 3.7 & $\ldots$ & 1.4 & $\ldots$ & 0.0 & $\ldots$ & $\ldots$ & 94.8 \\
\hline Serbia & 17 & 23.7 & $\ldots$ & $\ldots$ & $\ldots$ & 12.9 & 33.0 & 28.0 & $\ldots$ & $\ldots$ & $\ldots$ & 0.1 & 2.3 \\
\hline $\begin{array}{l}\text { Slovak } \\
\text { Republic }\end{array}$ & $\ldots$ & $\cdots$ & $\ldots$ & $\ldots$ & . & $\ldots$ & $\ldots$ & $\ldots$ & $\ldots$ & $\ldots$ & $\ldots$ & $\ldots$ & $\ldots$ \\
\hline Slovenia & 3 & $\ldots$ & $\ldots$ & $\ldots$ & $\ldots$ & $\ldots$ & $\ldots$ & 5.9 & 94.1 & $\ldots$ & $\ldots$ & $\ldots$ & $\ldots$ \\
\hline
\end{tabular}


Table 5.2.1.3 Distribution of the probationers under the supervision of probation agencies on $31^{\text {st }}$ December 2015 by type of supervision $(2 / 2)$ of which \%:

\begin{tabular}{|c|c|c|c|c|c|c|c|c|c|c|c|c|}
\hline 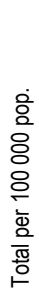 & 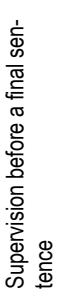 & 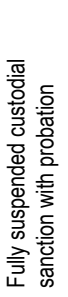 & 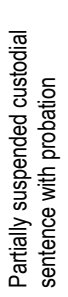 & 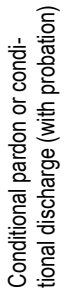 & 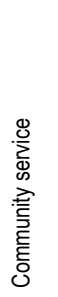 & 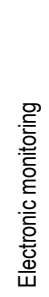 & 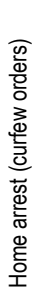 & 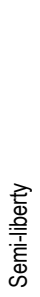 & 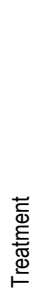 & 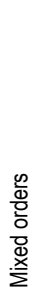 & 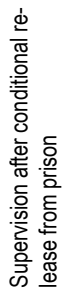 & 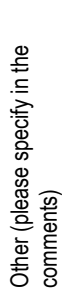 \\
\hline 119 & $\begin{array}{l}\ldots \\
\ldots \\
\ldots\end{array}$ & $\begin{array}{r}\ldots \\
\ldots \\
19.4\end{array}$ & $\begin{array}{c}\ldots \\
\ldots \\
7.3\end{array}$ & 0.0 & $\begin{array}{l}18.5 \\
26.1\end{array}$ & $\begin{array}{l}2.2 \\
2.4\end{array}$ & $\begin{array}{l}\cdots \\
\cdots \\
\ldots\end{array}$ & $\begin{array}{r}\cdots \\
\ldots \\
8.0\end{array}$ & $\begin{array}{l}8.0 \\
5.6\end{array}$ & $\begin{array}{c}\ldots \\
\ldots \\
0.0\end{array}$ & $\begin{array}{l}30.7 \\
27.5\end{array}$ & $\begin{array}{l}40.8 \\
36.8\end{array}$ \\
\hline 292 & $\begin{array}{l}\ldots \\
\ldots \\
\ldots\end{array}$ & $\begin{array}{r}\ldots \\
\ldots \\
25.4\end{array}$ & $\begin{array}{l}\ldots \\
\ldots \\
\ldots\end{array}$ & $\begin{array}{l}\ldots \\
\ldots\end{array}$ & $\begin{array}{r}0.0 \\
\ldots \\
8.2\end{array}$ & $\begin{array}{r}44.6 \\
\ldots \\
0.3\end{array}$ & $\begin{array}{l}\ldots \\
\ldots \\
\ldots\end{array}$ & $\begin{array}{l}\ldots \\
\ldots \\
\ldots\end{array}$ & $\begin{array}{c}\ldots \\
\ldots \\
8.6\end{array}$ & $\begin{array}{r}\ldots \\
\ldots \\
17.3\end{array}$ & 34.7 & $\begin{array}{r}\ldots \\
\ldots \\
8.0\end{array}$ \\
\hline 235 & $\cdots$ & $\ldots$ & $\ldots$ & & 17.6 & 2.7 & $\ldots$ & $\ldots$ & 6.9 & 39.9 & 13.6 & 11.4 \\
\hline $\begin{array}{r}212 \\
187 \\
3 \\
909\end{array}$ & $\begin{array}{r}18 \\
7 \\
1 \\
100\end{array}$ & $\begin{array}{r}238 \\
25 \\
1 \\
3114\end{array}$ & $\begin{array}{r}7 \\
7 \\
0 \\
16\end{array}$ & $\begin{array}{r}35 \\
2 \\
0 \\
164\end{array}$ & $\begin{array}{r}158 \\
24 \\
0 \\
2870\end{array}$ & $\begin{array}{r}8 \\
2 \\
0 \\
45\end{array}$ & $\begin{array}{r}9 \\
4 \\
0 \\
28\end{array}$ & $\begin{array}{r}17 \\
1 \\
0 \\
94\end{array}$ & $\begin{array}{l}5 \\
6 \\
0 \\
9\end{array}$ & $\begin{array}{r}12 \\
5 \\
0 \\
40\end{array}$ & $\begin{array}{r}33 \\
10 \\
0 \\
461\end{array}$ & $\begin{array}{r}30 \\
12 \\
0 \\
125\end{array}$ \\
\hline
\end{tabular}




\subsubsection{Probation population: Flow of entries in probation}

Table 5.2.2.1 Flow of entries on probation per 100000 population

\begin{tabular}{|c|c|c|c|c|c|c|c|}
\hline & 2011 & 2012 & 2013 & 2014 & 2015 & 2016 & $\begin{array}{l}\% \text { change } \\
2011-2016\end{array}$ \\
\hline Albania & 73 & 90 & 72 & 138 & 206 & 194 & 166 \\
\hline Armenia & 43 & 48 & 54 & 42 & 61 & 69 & 61 \\
\hline Austria & 209 & 221 & 222 & 223 & 216 & 207 & -1 \\
\hline Azerbaijan & 161 & 190 & 183 & 145 & 173 & 198 & 23 \\
\hline Belgium & 292 & 282 & 308 & 325 & 350 & 336 & 15 \\
\hline Bosnia-Herzegovina & $\ldots$ & $\ldots$ & $\ldots$ & $\ldots$ & $\ldots$ & $\ldots$ & $\ldots$ \\
\hline Bulgaria & 404 & 395 & 176 & $\ldots$ & 104 & 77 & -81 \\
\hline Croatia & 35 & 90 & 150 & 155 & 167 & 177 & 412 \\
\hline Cyprus & 202 & 118 & 117 & 268 & 260 & 268 & 33 \\
\hline Czech Republic & 203 & 145 & 173 & 203 & 199 & 191 & -6 \\
\hline Denmark & 208 & 210 & 210 & 222 & 223 & 201 & -4 \\
\hline Estonia & 468 & 435 & 389 & 355 & 309 & 318 & -32 \\
\hline Finland & 63 & 65 & 61 & 57 & 57 & 69 & 9 \\
\hline France & 203 & 215 & $\ldots$ & 224 & $\ldots$ & 142 & -30 \\
\hline Georgia & 384 & 291 & 326 & 287 & 319 & 298 & -22 \\
\hline Germany & $\ldots$ & $\ldots$ & $\ldots$ & $\ldots$ & $\ldots$ & $\ldots$ & $\ldots$ \\
\hline Greece & 78 & $\ldots$ & 109 & 139 & 165 & 149 & 91 \\
\hline Hungary & $\ldots$ & $\ldots$ & 276 & 262 & 245 & 261 & $\ldots$ \\
\hline Iceland & 89 & 94 & 103 & 98 & 97 & 123 & 39 \\
\hline Ireland & 141 & 134 & 136 & 135 & 121 & 125 & -11 \\
\hline Italy & 108 & 79 & 89 & 107 & 133 & 144 & 33 \\
\hline Kosovo (UN R/1244/99) & $\ldots$ & $\ldots$ & $\ldots$ & $\ldots$ & $\ldots$ & $\ldots$ & $\ldots$ \\
\hline Latvia & 912 & 920 & $\ldots$ & 877 & 514 & 529 & -42 \\
\hline Lithuania & 260 & 373 & 397 & 393 & 413 & 420 & 61 \\
\hline Luxembourg & 106 & 126 & $\ldots$ & 78 & 86 & 87 & -18 \\
\hline Malta & 117 & 105 & 154 & 149 & 172 & 185 & 58 \\
\hline Moldova & 204 & 207 & 224 & 219 & 257 & 231 & 13 \\
\hline Montenegro & $\ldots$ & $\ldots$ & $\ldots$ & 38 & $\ldots$ & 34 & $\ldots$ \\
\hline Netherlands & 270 & 260 & 307 & 311 & $\ldots$ & 292 & 8 \\
\hline North Macedonia & $\ldots$ & $\ldots$ & $\ldots$ & $\ldots$ & $\ldots$ & $\ldots$ & $\ldots$ \\
\hline Norway & 105 & 107 & 111 & 125 & 127 & 126 & 19 \\
\hline Poland & 963 & 920 & 857 & $\ldots$ & $\ldots$ & $\ldots$ & $\ldots$ \\
\hline Portugal & 235 & 293 & 335 & 304 & 351 & 352 & 50 \\
\hline Romania & 28 & 14 & 35 & 55 & 104 & 111 & 292 \\
\hline Russia & 699 & 668 & 660 & 645 & 592 & 604 & -14 \\
\hline Serbia & 6 & 19 & 24 & 48 & 42 & 45 & 659 \\
\hline Slovak Republic & 189 & 168 & 174 & 151 & 150 & $\ldots$ & $\ldots$ \\
\hline Slovenia & 29 & 31 & 116 & 23 & 102 & 119 & 306 \\
\hline Spain & $\ldots$ & $\ldots$ & $\ldots$ & $\ldots$ & $\ldots$ & $\ldots$ & $\ldots$ \\
\hline Sweden & 207 & 203 & 191 & 174 & 168 & 155 & -25 \\
\hline Switzerland & 91 & 79 & 80 & 83 & 65 & 65 & -29 \\
\hline Turkey & 120 & 196 & 311 & 375 & 398 & 456 & 281 \\
\hline Ukraine & $\ldots$ & $\ldots$ & $\ldots$ & $\ldots$ & $\ldots$ & $\ldots$ & $\ldots$ \\
\hline UK: England \& Wales & 334 & 314 & 302 & 293 & $\ldots$ & 319 & -4 \\
\hline UK: Northern Ireland & 200 & 198 & 196 & 159 & $\ldots$ & $\ldots$ & $\ldots$ \\
\hline UK: Scotland & 419 & 425 & 420 & 436 & 435 & 442 & 5 \\
\hline Mean & 233 & 236 & 224 & 219 & 217 & 219 & \\
\hline Median & 201 & 196 & 179 & 166 & 172 & 191 & \\
\hline Minimum & 6 & 14 & 24 & 23 & 42 & 34 & \\
\hline Maximum & 963 & 920 & 857 & 877 & 592 & 604 & \\
\hline
\end{tabular}


Table 5.2.2.2 Percentage of women, minors, and foreigners in the flow of entries in probation during 2015

\begin{tabular}{|c|c|c|c|c|}
\hline & $\begin{array}{l}\text { Total offenders } \\
\text { per } 100000 \text { pop. }\end{array}$ & $\begin{array}{l}\text { of which \% } \\
\text { of women }\end{array}$ & $\begin{array}{l}\text { of which } \% \\
\text { of minors }\end{array}$ & $\begin{array}{l}\text { of which } \% \\
\text { of foreigners }\end{array}$ \\
\hline Albania & 206 & & 7.0 & 0.0 \\
\hline Armenia & 61 & 11.6 & 2.8 & 0.7 \\
\hline Austria & 216 & 18.0 & 16.6 & 26.0 \\
\hline Azerbaijan & 173 & & & \\
\hline Belgium & 350 & 10.6 & 0.7 & 12.6 \\
\hline Bosnia-Herzegovina & $\ldots$ & & $\ldots$ & $\ldots$ \\
\hline Bulgaria & 104 & 6.9 & $\ldots$ & $\ldots$ \\
\hline Croatia & 167 & 8.2 & $\ldots$ & 0.9 \\
\hline Cyprus & 260 & 4.8 & 23.1 & 21.4 \\
\hline Czech Republic & 199 & 13.5 & 9.5 & \\
\hline Denmark & 223 & 8.9 & 1.5 & 7.2 \\
\hline Estonia & 309 & 9.9 & 6.4 & 23.9 \\
\hline Finland & 57 & 10.2 & 0.3 & 4.7 \\
\hline France & $\ldots$ & & $\ldots$ & $\ldots$ \\
\hline Georgia & 319 & 6.0 & 1.4 & $\ldots$ \\
\hline Germany & $\ldots$ & $\ldots$ & $\ldots$ & $\ldots$ \\
\hline Greece & 165 & 1.1 & 0.2 & 2.3 \\
\hline Hungary & 245 & 16.4 & $\ldots$ & $\ldots$ \\
\hline Iceland & 97 & & & $\ldots$ \\
\hline Ireland & 121 & 14.1 & 5.8 & \\
\hline Italy & 133 & 10.3 & $\ldots$ & 15.5 \\
\hline Kosovo (UN R/1244/99) & & $\ldots$ & $\ldots$ & ... \\
\hline Latvia & 514 & $\ldots$ & $\ldots$ & $\ldots$ \\
\hline Lithuania & 413 & 10.4 & 10.3 & $\ldots$ \\
\hline Luxembourg & 86 & 11.2 & $\ldots$ & 44.7 \\
\hline Malta & 172 & 1.5 & 8.1 & $\ldots$ \\
\hline Moldova & 257 & 0.2 & 2.6 & $\ldots$ \\
\hline Montenegro & $\ldots$ & $\ldots$ & $\ldots$ & $\ldots$ \\
\hline Netherlands & $\ldots$ & $\ldots$ & $\ldots$ & $\ldots$ \\
\hline North Macedonia & $\ldots$ & $\ldots$ & $\ldots$ & $\ldots$ \\
\hline Norway & 127 & 14.9 & 0.8 & 8.9 \\
\hline Poland & $\ldots$ & & $\ldots$ & \\
\hline Portugal & 351 & 11.4 & 2.2 & 7.8 \\
\hline Romania & 104 & 8.0 & 0.5 & \\
\hline Russia & 592 & 12.8 & 2.3 & 0.4 \\
\hline Serbia & 42 & 8.4 & $\ldots$ & 0.2 \\
\hline Slovak Republic & 150 & 10.7 & 1.8 & $\ldots$ \\
\hline Slovenia & 102 & $\ldots$ & $\ldots$ & $\ldots$ \\
\hline Spain & $\ldots$ & $\ldots$ & $\ldots$ & $\ldots$ \\
\hline Sweden & 168 & 11.8 & 0.2 & 14.7 \\
\hline Switzerland & 65 & 17.8 & $\ldots$ & 39.0 \\
\hline Turkey & 398 & 5.0 & 7.2 & 1.3 \\
\hline Ukraine & $\ldots$ & $\ldots$ & $\ldots$ & $\ldots$ \\
\hline UK: England \& Wales & $\ldots$ & $\ldots$ & $\ldots$ & $\ldots$ \\
\hline UK: Northern Ireland & $\ldots$ & & $\ldots$ & $\ldots$ \\
\hline UK: Scotland & 435 & 15.4 & 3.0 & \\
\hline Mean & 217 & 10.0 & 5.0 & 12.2 \\
\hline Median & 172 & 10.4 & 2.6 & 7.8 \\
\hline Minimum & 42 & 0.2 & 0.2 & 0.0 \\
\hline Maximum & 592 & 18.0 & 23.1 & 44.7 \\
\hline
\end{tabular}


Table 5.2.2.3 Distribution of the probationers placed under the supervision of probation agencies during 2015 (flow of entries) by type of supervision (1/2) of which \%:

\begin{tabular}{|c|c|c|c|c|c|c|c|c|c|c|c|c|c|}
\hline & 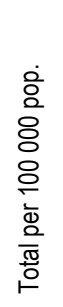 & 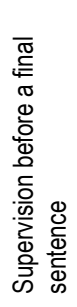 & 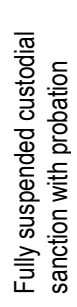 & 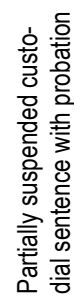 & 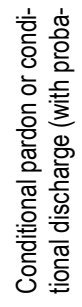 & 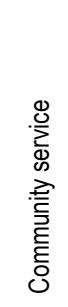 & 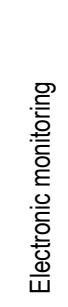 & 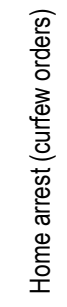 & 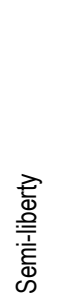 & 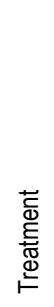 & 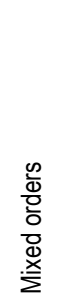 & 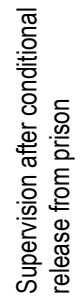 & 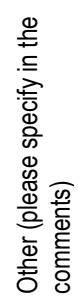 \\
\hline Albania & 206 & $\ldots$ & 80.6 & $\ldots$ & 1.4 & 16.4 & 0.7 & 1.5 & 0.1 & 0.1 & $\ldots$ & 0.0 & 0.0 \\
\hline Armenia & $\ldots$ & $\ldots$ & $\ldots$ & $\ldots$ & $\ldots$ & $\ldots$ & $\ldots$ & $\ldots$ & $\ldots$ & $\ldots$ & $\ldots$ & $\ldots$ & $\ldots$ \\
\hline Austria & $\ldots$ & $\ldots$ & $\ldots$ & $\ldots$ & $\ldots$ & $\ldots$ & $\ldots$ & $\ldots$ & $\ldots$ & $\ldots$ & $\ldots$ & $\ldots$ & $\ldots$ \\
\hline Azerbaijan & 173 & $\ldots$ & 0.7 & $\ldots$ & $\ldots$ & $\ldots$ & $\ldots$ & $\ldots$ & $\ldots$ & $\ldots$ & $\ldots$ & 35.2 & 63.1 \\
\hline Belgium & $\ldots$ & $\ldots$ & $\ldots$ & $\ldots$ & $\ldots$ & $\ldots$ & $\ldots$ & $\ldots$ & $\ldots$ & $\ldots$ & $\ldots$ & $\ldots$ & $\ldots$ \\
\hline $\begin{array}{l}\text { Bosnia- } \\
\text { Herze- } \\
\text { govina }\end{array}$ & $\ldots$ & $\ldots$ & $\ldots$ & $\ldots$ & $\ldots$ & $\ldots$ & $\ldots$ & $\ldots$ & $\ldots$ & $\ldots$ & $\ldots$ & $\ldots$ & $\ldots$ \\
\hline Bulgaria & 104 & $\ldots$ & 1.6 & 1.8 & $\ldots$ & 31.4 & 1.5 & $\ldots$ & $\ldots$ & 8.7 & 46.6 & 8.5 & $\ldots$ \\
\hline Croatia & 167 & 1.0 & 5.0 & 0.2 & 0.0 & 55.0 & 0.0 & 0.0 & 0.0 & 0.0 & $\ldots$ & 15.3 & 18.1 \\
\hline Cyprus & 260 & 39.8 & $\ldots$ & $\ldots$ & $\ldots$ & 60.1 & $\ldots$ & $\ldots$ & $\ldots$ & $\ldots$ & $\ldots$ & $\ldots$ & $\ldots$ \\
\hline $\begin{array}{l}\text { Czech } \\
\text { Republic }\end{array}$ & $\ldots$ & $\ldots$ & $\ldots$ & $\ldots$ & $\ldots$ & $\ldots$ & $\ldots$ & $\ldots$ & $\ldots$ & $\ldots$ & $\ldots$ & $\ldots$ & $\ldots$ \\
\hline Denmark & $\ldots$ & $\ldots$ & $\ldots$ & $\ldots$ & $\ldots$ & $\ldots$ & $\ldots$ & $\cdots$ & $\ldots$ & $\ldots$ & $\ldots$ & $\ldots$ & $\ldots$ \\
\hline Estonia & $\ldots$ & $\ldots$ & $\ldots$ & $\ldots$ & $\ldots$ & $\ldots$ & $\ldots$ & $\ldots$ & $\ldots$ & $\ldots$ & $\ldots$ & $\ldots$ & $\ldots$ \\
\hline Finland & 57 & $\ldots$ & $\ldots$ & $\ldots$ & $\ldots$ & 58.7 & 8.4 & $\ldots$ & $\ldots$ & $\ldots$ & 9.5 & 23.4 & $\ldots$ \\
\hline France & 0 & $\ldots$ & $\ldots$ & $\ldots$ & $\ldots$ & $\ldots$ & $\ldots$ & $\ldots$ & $\ldots$ & $\ldots$ & $\ldots$ & $\ldots$ & $\ldots$ \\
\hline Georgia & 319 & $\ldots$ & $\ldots$ & 21.3 & $\ldots$ & $\ldots$ & $\ldots$ & $\ldots$ & 0.0 & $\ldots$ & $\ldots$ & $\ldots$ & 0.3 \\
\hline Germany & $\ldots$ & $\ldots$ & $\ldots$ & $\ldots$ & $\ldots$ & $\ldots$ & $\ldots$ & $\ldots$ & $\ldots$ & $\ldots$ & $\ldots$ & $\ldots$ & $\ldots$ \\
\hline Greece & $\ldots$ & $\ldots$ & $\ldots$ & $\ldots$ & $\ldots$ & $\ldots$ & $\ldots$ & $\ldots$ & $\ldots$ & $\ldots$ & $\ldots$ & $\ldots$ & $\ldots$ \\
\hline Hungary & 278 & 28.9 & 8.9 & $\ldots$ & 3.1 & 47.2 & 0.8 & $\ldots$ & $\ldots$ & $\ldots$ & $\ldots$ & 11.1 & $\ldots$ \\
\hline $\begin{array}{l}\text { Iceland } \\
\text { Ireland }\end{array}$ & $\cdots$ & $\cdots$ & $\cdots$ & $\cdots$ & $\cdots$ & $\cdots$ & $\ldots$ & $\ldots$ & $\cdots$ & $\cdots$ & $\ldots$ & $\ldots$ & $\cdots$ \\
\hline $\begin{array}{l}\text { Ireland } \\
\text { Italy }\end{array}$ & $\begin{array}{r}\ldots \\
133\end{array}$ & $\begin{array}{r}\ldots \\
335\end{array}$ & $\begin{array}{c}\cdots \\
87\end{array}$ & $\cdots$ & $\cdots$ & 116 & $\cdots$ & 18 & $\ldots$ & 37 & 27 & 30 & $\begin{array}{r}\ldots \\
174\end{array}$ \\
\hline $\begin{array}{l}\text { Kosovo } \\
\text { (UN } \\
\text { R/1244/99) }\end{array}$ & $\ldots$ & 00.0 & $\begin{array}{r}0.1 \\
\ldots\end{array}$ & $\begin{array}{l}\cdots \\
\cdots\end{array}$ & $\begin{array}{l}\cdots \\
\cdots\end{array}$ & $\ldots$ & $\begin{array}{l}\cdots \\
\cdots\end{array}$ & $\begin{array}{r}10.0 \\
\ldots\end{array}$ & $\begin{array}{r}0.0 \\
\ldots\end{array}$ & $\begin{array}{r}0.1 \\
\ldots\end{array}$ & $\begin{array}{r}2.1 \\
\ldots\end{array}$ & $\begin{array}{r}3.0 \\
\ldots\end{array}$ & $\begin{array}{r}17.4 \\
\ldots\end{array}$ \\
\hline Latvia & 514 & 10.7 & 16.5 & $\ldots$ & 3.3 & 59.4 & 0.3 & $\ldots$ & $\ldots$ & $\ldots$ & 4.2 & 4.6 & 1.0 \\
\hline Lithuania & $\ldots$ & $\ldots$ & $\ldots$ & $\ldots$ & $\ldots$ & $\ldots$ & $\ldots$ & $\ldots$ & $\ldots$ & $\ldots$ & $\ldots$ & $\ldots$ & $\ldots$ \\
\hline $\begin{array}{l}\text { Luxem- } \\
\text { bourg }\end{array}$ & 86 & 1.7 & 19.9 & 3.1 & $\ldots$ & 39.1 & 10.8 & $\ldots$ & 5.8 & $\ldots$ & $\ldots$ & 15.9 & 3.7 \\
\hline Malta & 172 & 8.3 & 7.5 & $\ldots$ & 35.9 & 5.0 & $\ldots$ & $\ldots$ & $\ldots$ & 5.4 & 1.1 & 3.0 & 1.1 \\
\hline Moldova & 257 & 0.2 & 34.8 & $\ldots$ & 42.5 & 11.1 & 0.0 & $\ldots$ & $\ldots$ & $\ldots$ & 13.2 & 3.4 & 27.5 \\
\hline $\begin{array}{l}\text { Monte- } \\
\text { negro }\end{array}$ & $\ldots$ & $\ldots$ & $\ldots$ & $\ldots$ & $\ldots$ & $\ldots$ & $\ldots$ & $\ldots$ & $\ldots$ & $\ldots$ & $\ldots$ & $\ldots$ & $\ldots$ \\
\hline $\begin{array}{l}\text { Nether- } \\
\text { lands }\end{array}$ & $\ldots$ & $\ldots$ & $\ldots$ & $\ldots$ & $\ldots$ & $\cdots$ & $\ldots$ & $\ldots$ & $\cdots$ & $\ldots$ & $\ldots$ & $\ldots$ & $\cdots$ \\
\hline $\begin{array}{l}\text { North } \\
\text { Macedonia }\end{array}$ & $\ldots$ & $\cdots$ & $\ldots$ & $\ldots$ & $\ldots$ & $\ldots$ & $\ldots$ & $\ldots$ & $\cdots$ & $\cdots$ & $\ldots$ & $\ldots$ & $\cdots$ \\
\hline Norway & 127 & $\ldots$ & 9.0 & $\ldots$ & $\ldots$ & 29.2 & 48.7 & 1.0 & $\ldots$ & $\ldots$ & 0.0 & 11.6 & 0.5 \\
\hline $\begin{array}{l}\text { Poland } \\
\text { Portugal }\end{array}$ & $\begin{array}{l}\ldots \\
\ldots \\
\end{array}$ & $\begin{array}{l}\ldots \\
\ldots \\
\ldots\end{array}$ & $\begin{array}{l}\ldots \\
\ldots \\
\end{array}$ & $\begin{array}{l}\ldots \\
\ldots \\
\ldots\end{array}$ & $\begin{array}{l}\ldots \\
\ldots \\
\ldots\end{array}$ & $\begin{array}{l}\ldots \\
\ldots \\
\end{array}$ & $\begin{array}{l}\ldots \\
\ldots \\
\end{array}$ & $\begin{array}{l}\ldots \\
\ldots \\
\end{array}$ & $\begin{array}{l}\ldots \\
\ldots \\
\ldots\end{array}$ & $\begin{array}{l}\ldots \\
\ldots\end{array}$ & $\begin{array}{l}\ldots \\
\ldots \\
\end{array}$ & $\begin{array}{l}\ldots \\
\ldots \\
\end{array}$ & $\begin{array}{l}\ldots \\
\ldots \\
\end{array}$ \\
\hline
\end{tabular}


Table 5.2.2.3 Distribution of the probationers placed under the supervision of probation agencies during 2015 (flow of entries) by type of supervision (2/2) of which \%:

\begin{tabular}{|c|c|c|c|c|c|c|c|c|c|c|c|c|c|}
\hline & $\begin{array}{l}\text { 응 } \\
8 \\
8 \\
8 \\
8 \\
\frac{0}{\Phi} \\
\frac{0}{\mathbb{0}} \\
\frac{\pi}{0}\end{array}$ & 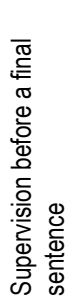 & 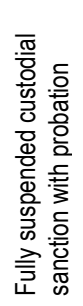 & 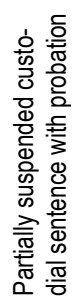 & 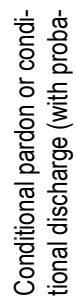 & 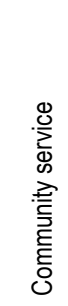 & 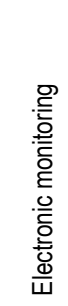 & 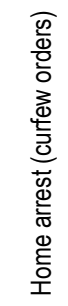 & 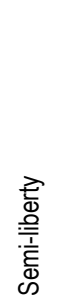 & 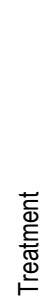 & 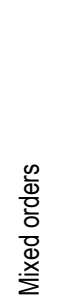 & 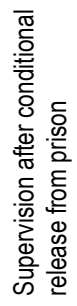 & 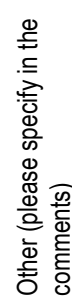 \\
\hline Romania & 104 & $\ldots$ & 60.6 & $\ldots$ & $\ldots$ & $\ldots$ & $\ldots$ & $\ldots$ & $\ldots$ & $\ldots$ & 8.0 & 0.3 & 31.1 \\
\hline Russia & 211 & $\ldots$ & $\ldots$ & $\ldots$ & $\ldots$ & 15.0 & $\ldots$ & 2.5 & $\ldots$ & 0.0 & $\ldots$ & $\ldots$ & 82.5 \\
\hline Serbia & 43 & 18.1 & $\ldots$ & $\ldots$ & $\ldots$ & 16.6 & 42.2 & 22.1 & $\ldots$ & $\ldots$ & $\ldots$ & 0.1 & 0.8 \\
\hline $\begin{array}{l}\text { Slovak } \\
\text { Republic }\end{array}$ & $\ldots$ & & $\ldots$ & $\ldots$ & $\ldots$ & $\ldots$ & $\ldots$ & $\ldots$ & $\ldots$ & $\ldots$ & $\ldots$ & $\ldots$ & $\ldots$ \\
\hline Slovenia & 102 & 77.9 & 8.6 & $\ldots$ & $\ldots$ & 4.1 & $\ldots$ & 1.1 & 3.4 & $\ldots$ & $\ldots$ & 1.5 & 3.4 \\
\hline Spain & $\ldots$ & $\ldots$ & $\ldots$ & $\ldots$ & $\ldots$ & $\ldots$ & $\ldots$ & $\ldots$ & $\ldots$ & $\ldots$ & $\ldots$ & $\ldots$ & $\ldots$ \\
\hline Sweden & 168 & $\ldots$ & $\ldots$ & $\ldots$ & $\ldots$ & 29.9 & 11.2 & $\ldots$ & $\ldots$ & 4.6 & $\ldots$ & 24.3 & 30.1 \\
\hline $\begin{array}{l}\text { Switzer- } \\
\text { land }\end{array}$ & 71 & $\ldots$ & 4.0 & 1.6 & $\ldots$ & 65.1 & 4.4 & $\ldots$ & 5.1 & 1.3 & 0.0 & 13.0 & 6.5 \\
\hline Turkey & $\ldots$ & $\ldots$ & $\ldots$ & $\ldots$ & $\ldots$ & $\ldots$ & $\ldots$ & $\ldots$ & $\ldots$ & $\ldots$ & $\ldots$ & $\ldots$ & $\ldots$ \\
\hline Ukraine & $\ldots$ & $\ldots$ & $\ldots$ & $\ldots$ & $\ldots$ & $\ldots$ & $\ldots$ & $\ldots$ & $\ldots$ & $\ldots$ & $\ldots$ & $\ldots$ & $\ldots$ \\
\hline $\begin{array}{l}\text { UK: } \\
\text { England \& }\end{array}$ & $\ldots$ & & $\ldots$ & $\ldots$ & $\ldots$ & $\ldots$ & $\ldots$ & $\ldots$ & $\ldots$ & $\ldots$ & $\ldots$ & $\ldots$ & $\ldots$ \\
\hline $\begin{array}{l}\text { Wales } \\
\text { UK: North- } \\
\text { ern Ireland }\end{array}$ & $\ldots$ & $\ldots$ & $\cdots$ & $\ldots$ & $\ldots$ & $\cdots$ & $\ldots$ & $\cdots$ & $\ldots$ & $\cdots$ & $\cdots$ & $\ldots$ & $\cdots$ \\
\hline $\begin{array}{l}\text { UK: } \\
\text { Scotland }\end{array}$ & 435 & 1.7 & $\ldots$ & $\ldots$ & $\ldots$ & 41.1 & 7.7 & $\ldots$ & $\ldots$ & 4.7 & 27.4 & 4.6 & 12.7 \\
\hline Mean & 181 & 20 & 19 & 6 & 14 & 33 & 11 & 7 & 2 & 3 & 11 & 10 & 18 \\
\hline Median & 168 & 11 & 9 & 2 & 3 & 31 & 4 & 2 & 1 & 4 & 6 & 7 & 7 \\
\hline Minimum & 0 & 0 & 1 & 0 & 0 & 4 & 0 & 0 & 0 & 0 & 0 & 0 & 0 \\
\hline Maximum & 514 & 78 & 81 & 21 & 43 & 65 & 49 & 22 & 6 & 9 & 47 & 35 & 83 \\
\hline
\end{tabular}




\subsubsection{Probation population: Flow of exits from probation}

Table 5.2.3 Number of persons that ceased to be under the supervision of probation agencies (flow of exits from probation) during the year 2015, by type of exit

\begin{tabular}{|c|c|c|c|c|c|c|c|}
\hline & Total per 100000 pop. & $\begin{array}{l}\text { Comple- } \\
\text { tion }\end{array}$ & $\begin{array}{l}\text { Revoca- } \\
\text { tion }\end{array}$ & $\begin{array}{l}\text { Imprison- } \\
\text { ment }\end{array}$ & $\begin{array}{c}A b- \\
\text { sconder }\end{array}$ & Death & Other \\
\hline Albania & 62.4 & 99.3 & 1.8 & 1.3 & $\ldots$ & 0.7 & 4.5 \\
\hline Armenia & 32.6 & 97.7 & 1.1 & 1.4 & $\ldots$ & 2.1 & 3.9 \\
\hline Austria & 211.9 & 68.5 & 16.4 & 0.6 & $\ldots$ & 0.5 & 14.0 \\
\hline Azerbaijan & 64.7 & 90.2 & 1.3 & 0.5 & 1.6 & 0.5 & 5.8 \\
\hline Belgium & 337.0 & 65.2 & 18.8 & $\ldots$ & $\ldots$ & 0.5 & 15.5 \\
\hline Bosnia-Herzegovina & $\ldots$ & $\ldots$ & $\ldots$ & $\ldots$ & $\ldots$ & $\ldots$ & $\ldots$ \\
\hline Bulgaria & 169.9 & 96.0 & 1.6 & 1.9 & 0.5 & $\ldots$ & $\ldots$ \\
\hline Croatia & 88.9 & 92.6 & 0.4 & 4.8 & 0.0 & 0.6 & 1.7 \\
\hline Cyprus & 53.7 & $\ldots$ & $\ldots$ & $\ldots$ & $\ldots$ & 0.2 & $\ldots$ \\
\hline Czech Republic & 150.0 & 31.6 & 17.4 & $\ldots$ & $\ldots$ & 0.7 & 62.3 \\
\hline Denmark & $\ldots$ & $\ldots$ & $\ldots$ & $\ldots$ & $\ldots$ & $\ldots$ & $\ldots$ \\
\hline Estonia & 342.8 & 79.8 & 10.5 & 8.3 & $\ldots$ & 1.3 & 0.0 \\
\hline Finland & 54.7 & 90.8 & 7.2 & 0.7 & 0.0 & 1.4 & 0.0 \\
\hline France & $\ldots$ & $\ldots$ & $\ldots$ & $\ldots$ & $\ldots$ & $\ldots$ & $\ldots$ \\
\hline Georgia & 185.4 & 90.5 & 1.4 & 6.6 & 0.5 & 0.9 & 0.1 \\
\hline Germany & 75.3 & 67.1 & 25.8 & $\ldots$ & $\ldots$ & $\ldots$ & 7.1 \\
\hline Greece & 27.1 & 85.9 & 11.0 & 1.1 & 0.3 & 0.6 & 1.1 \\
\hline Hungary & 249.8 & 70.2 & 13.3 & 0.2 & 0.1 & 1.1 & $\ldots$ \\
\hline Iceland & 52.3 & 80.8 & 4.1 & 15.1 & 0.0 & 0.0 & $\ldots$ \\
\hline Ireland & 97.6 & 87.7 & 7.1 & 4.5 & 2.7 & 1.0 & 0.4 \\
\hline Italy & 88.5 & 82.7 & 5.8 & $\ldots$ & 0.8 & 0.6 & 10.1 \\
\hline Kosovo (UN R/1244/99) & $\ldots$ & $\ldots$ & $\ldots$ & $\ldots$ & $\ldots$ & $\ldots$ & $\ldots$ \\
\hline Latvia & $\ldots$ & $\ldots$ & $\ldots$ & $\ldots$ & $\ldots$ & $\ldots$ & $\ldots$ \\
\hline Lithuania & 411.4 & 68.6 & 8.3 & 2.7 & $\ldots$ & 0.8 & 19.5 \\
\hline Luxembourg & 112.8 & 85.4 & 10.6 & 3.6 & $\ldots$ & 0.5 & 0.0 \\
\hline Malta & $\ldots$ & $\ldots$ & $\ldots$ & $\ldots$ & $\ldots$ & $\ldots$ & $\ldots$ \\
\hline Moldova & 212.3 & 77.5 & 3.6 & 3.8 & 1.8 & 1.1 & 14.1 \\
\hline Montenegro & $\ldots$ & $\ldots$ & $\ldots$ & $\ldots$ & $\ldots$ & $\ldots$ & $\ldots$ \\
\hline Netherlands & $\ldots$ & $\ldots$ & $\ldots$ & $\ldots$ & $\ldots$ & $\ldots$ & $\ldots$ \\
\hline North Macedonia & $\ldots$ & $\ldots$ & $\ldots$ & $\ldots$ & $\ldots$ & $\ldots$ & $\ldots$ \\
\hline Norway & 128.2 & 91.9 & 9.2 & $\ldots$ & $\ldots$ & 0.4 & $\ldots$ \\
\hline Poland & & $\ldots$ & $\ldots$ & $\ldots$ & $\ldots$ & $\ldots$ & $\ldots$ \\
\hline Portugal & 284.7 & 90.7 & 2.7 & $\ldots$ & $\ldots$ & 0.5 & 6.2 \\
\hline Romania & 21.1 & 69.2 & 4.2 & $\ldots$ & $\ldots$ & 3.2 & 23.4 \\
\hline Russia & 325.0 & 36.0 & $\ldots$ & 8.1 & $\ldots$ & $\ldots$ & 55.9 \\
\hline Serbia & 27.2 & 93.1 & 0.5 & 1.7 & 4.0 & 0.3 & 0.4 \\
\hline Slovak Republic & 50.6 & $\ldots$ & $\ldots$ & $\ldots$ & $\ldots$ & $\ldots$ & $\ldots$ \\
\hline Slovenia & & $\ldots$ & $\ldots$ & $\ldots$ & $\ldots$ & $\ldots$ & $\ldots$ \\
\hline Spain & 241.8 & 96.8 & 1.3 & 0.1 & $\ldots$ & 0.3 & $\ldots$ \\
\hline Sweden & 150.1 & $\ldots$ & $\ldots$ & $\ldots$ & $\ldots$ & $\ldots$ & $\ldots$ \\
\hline Switzerland & $\ldots$ & $\ldots$ & $\ldots$ & $\ldots$ & $\ldots$ & $\ldots$ & $\ldots$ \\
\hline Turkey & 419.0 & 56.2 & 27.6 & 1.0 & $\ldots$ & $\ldots$ & $\ldots$ \\
\hline Ukraine & $\ldots$ & $\ldots$ & $\ldots$ & $\ldots$ & $\ldots$ & $\ldots$ & $\ldots$ \\
\hline UK: England \& Wales & 288.0 & 68.7 & 7.0 & 10.0 & 1.2 & 0.6 & 12.5 \\
\hline UK: Northern Ireland & $\ldots$ & $\ldots$ & $\ldots$ & $\ldots$ & $\ldots$ & $\ldots$ & $\ldots$ \\
\hline UK: Scotland & 373.7 & 69.6 & 11.5 & 12.5 & $\ldots$ & 0.9 & 5.5 \\
\hline Mean & 168.5 & 78.62 & 8.27 & 4.11 & 1.05 & 0.83 & 11.47 \\
\hline Median & 139.1 & 82.67 & 7.05 & 2.27 & 0.54 & 0.83 & 11.78 \\
\hline Minimum & 21.1 & 31.58 & 0.40 & 0.07 & 0.00 & 0.78 & 12.12 \\
\hline Maximum & 419.0 & 99.28 & 27.60 & 15.12 & 4.03 & 0.79 & 12.04 \\
\hline
\end{tabular}




\subsubsection{Staff of probation agencies}

Table 5.2.4 Staff of probation agencies on 31st December 2015, by type of staff

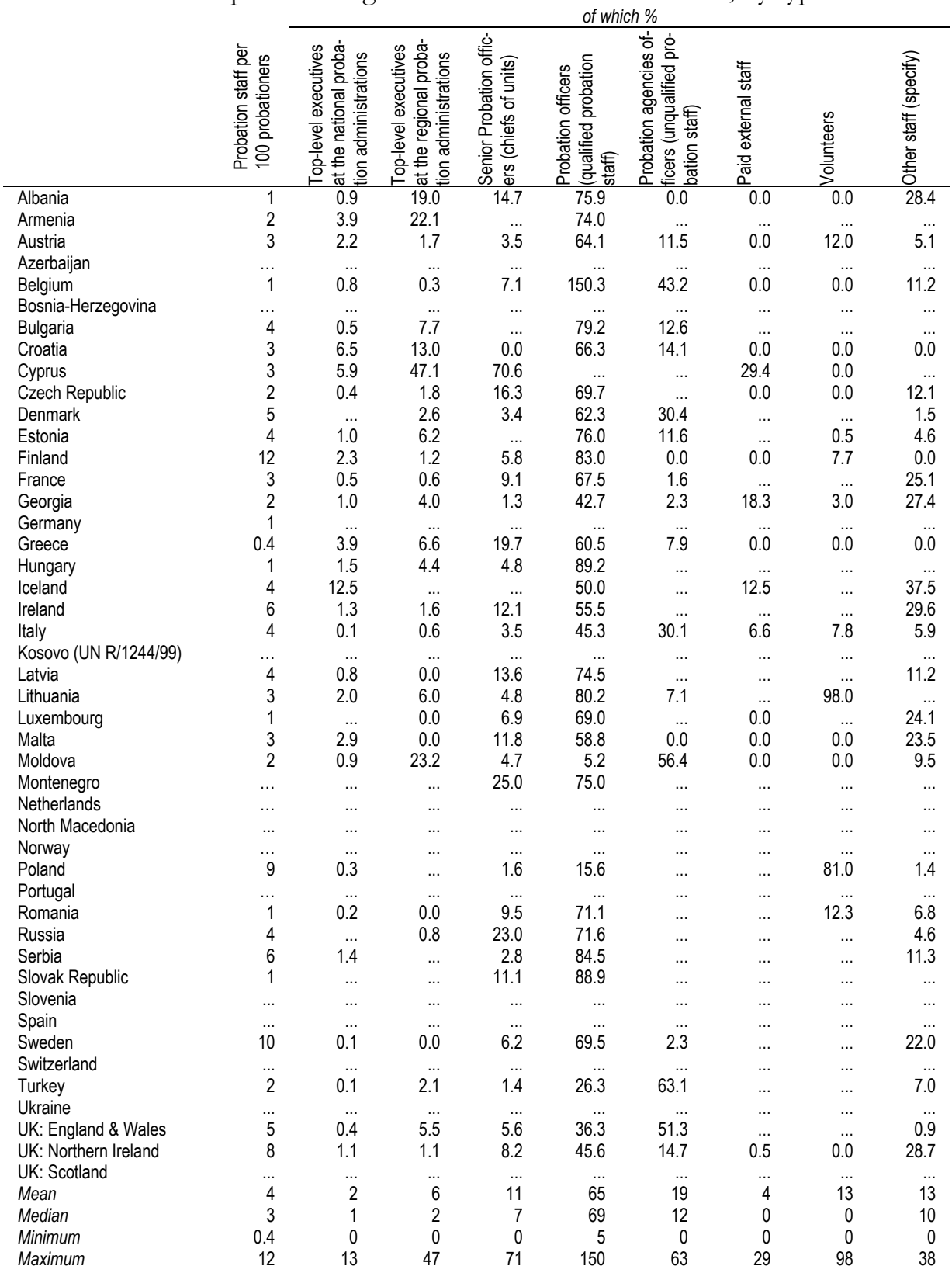




\subsubsection{Reports produced by probation agencies}

Table 5.2.5 Number of written reports produced probation agencies during 2015, by type of report

\begin{tabular}{|c|c|c|c|c|}
\hline & \multirow[b]{2}{*}{$\begin{array}{l}\text { Number of reports per } \\
1 \text { staff member }\end{array}$} & \multicolumn{3}{|c|}{ of which \% } \\
\hline & & $\begin{array}{l}\text { Number of pre-sen- } \\
\text { tence reports }\end{array}$ & $\begin{array}{l}\text { Number of advisory re- } \\
\text { ports with respect to } \\
\text { conditional release }\end{array}$ & $\begin{array}{l}\text { Other reports } \\
\text { (please specify) }\end{array}$ \\
\hline Albania & $\ldots$ & $\ldots$ & $\ldots$ & $\ldots$ \\
\hline Armenia & $\ldots$ & $\ldots$ & $\ldots$ & $\ldots$ \\
\hline Austria & $\cdots$ & $\ldots$ & $\ldots$ & $\ldots$ \\
\hline Azerbaijan & $\ldots$ & $\ldots$ & $\ldots$ & $\ldots$ \\
\hline Belgium & $\cdots$ & $\begin{array}{l}\cdots \\
\ldots\end{array}$ & $\begin{array}{l}\cdots \\
\ldots\end{array}$ & $\begin{array}{l}\cdots \\
\ldots\end{array}$ \\
\hline Bosnia-Herzegovina & $\ldots$ & $\ldots$ & $\ldots$ & $\ldots$ \\
\hline Bulgaria & 86.0 & 0.1 & 1.4 & 98.6 \\
\hline Croatia & 12.6 & 1.0 & 99.0 & 100.0 \\
\hline Cyprus & $\ldots$ & $\ldots$ & $\ldots$ & $\ldots$ \\
\hline Czech Republic & $\ldots$ & $\ldots$ & $\ldots$ & $\ldots$ \\
\hline Denmark & $\ldots$ & $\ldots$ & $\ldots$ & $\ldots$ \\
\hline Estonia & $\ldots$ & $\ldots$ & $\ldots$ & $\ldots$ \\
\hline Finland & 19.2 & 76.1 & $\ldots$ & 23.9 \\
\hline France & $\ldots$ & $\ldots$ & $\ldots$ & $\ldots$ \\
\hline Georgia & $\ldots$ & $\ldots$ & $\ldots$ & $\ldots$ \\
\hline Germany & $\ldots$ & $\ldots$ & $\ldots$ & $\ldots$ \\
\hline Greece & $\ldots$ & $\ldots$ & $\ldots$ & $\ldots$ \\
\hline Hungary & 26.7 & 16.7 & 0.3 & 83.0 \\
\hline Iceland & $\ldots$ & $\ldots$ & $\ldots$ & $\ldots$ \\
\hline Ireland & $\ldots$ & $\ldots$ & $\ldots$ & $\ldots$ \\
\hline Italy & 6.8 & 88.9 & $\ldots$ & 11.1 \\
\hline Kosovo (UN & $\ldots$ & $\ldots$ & $\ldots$ & $\ldots$ \\
\hline$R / 1244 / 99)$ & & & & \\
\hline Latvia & 3.4 & 31.9 & 68.1 & $\ldots$ \\
\hline Lithuania & $\ldots$ & $\ldots$ & $\ldots$ & $\ldots$ \\
\hline Luxembourg & 0.9 & 100.0 & $\ldots$ & $\ldots$ \\
\hline Malta & 8.7 & 24.7 & 35.1 & 40.2 \\
\hline Moldova & 5.1 & 79.4 & 20.6 & 0.0 \\
\hline Montenegro & $\ldots$ & $\ldots$ & $\ldots$ & $\ldots$ \\
\hline Netherlands & $\ldots$ & $\ldots$ & $\ldots$ & $\ldots$ \\
\hline North Macedonia & $\ldots$ & $\ldots$ & $\ldots$ & $\ldots$ \\
\hline Norway & $\ldots$ & 100.0 & $\ldots$ & $\ldots$ \\
\hline Poland & 22.4 & 39.1 & 46.3 & 14.6 \\
\hline Portugal & $\ldots$ & $\ldots$ & $\ldots$ & $\ldots$ \\
\hline Romania & 15.1 & 78.8 & 13.5 & 7.7 \\
\hline Russia & & $\ldots$ & $\ldots$ & 100.0 \\
\hline Serbia & 22.7 & $\ldots$ & 62.2 & 37.8 \\
\hline Slovak Republic & $\ldots$ & $\ldots$ & $\ldots$ & $\ldots$ \\
\hline Slovenia & $\ldots$ & $\ldots$ & 88.2 & 11.8 \\
\hline Spain & $\ldots$ & $\ldots$ & $\ldots$ & $\ldots$ \\
\hline Sweden & $\ldots$ & $\ldots$ & $\ldots$ & $\ldots$ \\
\hline Switzerland & $\ldots$ & $\ldots$ & $\ldots$ & $\ldots$ \\
\hline Turkey & $\ldots$ & $\ldots$ & $\ldots$ & $\ldots$ \\
\hline Ukraine & $\ldots$ & $\ldots$ & $\ldots$ & $\ldots$ \\
\hline UK: England \& Wales & 17.9 & 100.0 & $\ldots$ & $\ldots$ \\
\hline UK: Northern Ireland & 23.1 & 62.1 & 0.1 & 37.7 \\
\hline UK: Scotland & $\ldots$ & 87.6 & 12.4 & $\ldots$ \\
\hline Mean & 19 & 59 & 37 & 44 \\
\hline Median & 16 & 76 & 28 & 38 \\
\hline Minimum & 1 & 0 & 0 & 0 \\
\hline Maximum & 86 & 100 & 99 & 100 \\
\hline
\end{tabular}


Notes on Tables 5.2.4 and 5.2.5

Notes on Table 5.2.4

Czech Republic The counting rule of the FTE (full-time equivalent) is not respected. Every employee is counted as one employee independently of their percentage of working hours. However, there are only 2 or 3 employees working part time.

Lithuania The counting rule of the FTE (full-time equivalent) is not respected.

UK: Northern Ireland The Information provided is based on actual numbers of people rather than 'Work time Equivalent'. For example, on 31 December 2010 PBNI staff totalled 441 people working the equivalent of 405.97 full-time members of staff.

Administrative Staff includes all corporate staff, administrative support within field teams and also cleaning staff.

Other Probation Workers include Probation Service Officers, Community Service and Psychology Staff.

\begin{tabular}{ll}
\hline & \multicolumn{1}{c}{ Notes on Table 5.2.5 } \\
\hline Albania & No information available. \\
Hungary & There are two main categories of advisory reports in Hungary: probation advisory reports \\
& and social inquiry reports. Most of the probation advisory reports are pre-sentence reports \\
& made at the request of the prosecutor or the judge. Social inquiry reports are prepared in \\
& every juvenile case at the request of the police. Probation officers make social inquiry also \\
& reports during reprieve proceedings, and for the preparation of the decision about the can- \\
& cellation of the payment of costs of the criminal procedure or court fine \\
Ireland & Other reports include generic reports and Revocation Report \\
Slovak Republic & Other reports correspond to the Report and review prepared by the centres of social work \\
& on the request of the courts. \\
Slovenia & Other reports include 83 reports on the help to the family during the process. \\
UK: England \& Wales & Pre-Sentence- Reports include both Pre-Sentence Reports and Shortened Pre-Sentence \\
& Reports. \\
& Reports concerning supervision during the execution of community sanctions includes \\
& Breach Reports \\
& Reports after a conditional release include Recall Reports \\
& Other reports not detailed in the table but included in the total figures include Addendum \\
& Report, Home Circumstances Report, Report For The Life Sentence Commissioners Pro- \\
& gress Report To The Life Sentence Unit, Parole Report, Probation Officers Report. \\
\hline
\end{tabular}




\subsection{Technical information}

This section provides information on the organisation of probation agencies in each country. It is based on a section created in collaboration with the Confederation of European Probation (CEP) for the fifth edition of the European Sourcebook ${ }^{36}$. The section has been updated with the information collected for this sixth edition of the Sourcebook and with data from the SPACE II Council of Europe Penal Statistics.

\subsubsection{The structure and organisation of Probation Agencies}

All countries have a probation agency or an institution that fulfils the typical tasks of a probation agency, but under a different name (see the comments to Table 5.3.1.1). In 25 countries, that agency is independent from the prison agency, in 14 countries there is only one prison and probation administration, and in Switzerland their status differs across cantons. The types and competencies of probation agencies are described in Table 5.3.1.1 and the notes to it.

\footnotetext{
36 The following experts of the CEP contributed to Section 5.3.1 of the previous edition (2014) of the European Sourcebook: Bernd Glaeser (NEUSTART, Wien, Austria), Jana Spero (Ministry of Justice, Zagreb, Croatia), Michal Karban (Probation and Mediation Service, Prague, Czech Republic), Andri Ahven ( Ministry of Justice, Tallinn, Estonia), Roberta Palmisano (Office for Studies Research Legislation and International Relations, Rome, Italy), Mariella Camilleri (Department of Probation and Parole, Valetta, Malta), Valeriu Melinte and Alisa Simicevscaia (Oficul Central de Probațiune, Chişinău, Moldova), Martine Wiekeraad, Reclassering Nederland, Utrecht, Netherlands), Evelina Obersterescu (Ministry of Justice, Bucharest, Romania), Ján Evin (Ministry of Justice, Bratislava, Slovak Republic), Mats Johansson (Swedish Prison and Probation Service, Norrköping (Sweden), and Francesca Emmett (National Offenders Management Service, Warrington, UK: England \& Wales).
} 
Table 5.3.1.1 Type and competency of the probation agencies (or equivalent bodies)

\begin{tabular}{|c|c|c|c|c|c|c|c|}
\hline & \multicolumn{3}{|c|}{ Type } & \multicolumn{4}{|c|}{ Competency } \\
\hline & Public & $\begin{array}{l}\text { Non-profit/ } \\
\text { state subsi- } \\
\text { dised }\end{array}$ & $\begin{array}{l}\text { Private en- } \\
\text { terprise }\end{array}$ & Minors & Adults & $\begin{array}{l}\text { Pre-sen- } \\
\text { tence stage }\end{array}$ & $\begin{array}{l}\text { Execution } \\
\text { stage }\end{array}$ \\
\hline Albania & $\mathrm{X}$ & & & $\mathrm{X}$ & $\mathrm{X}$ & $X$ & $\mathrm{X}$ \\
\hline Armenia & $x$ & & & $x$ & $x$ & $x$ & $x$ \\
\hline Austria & & $\mathrm{X}$ & & $\mathrm{x}$ & $\mathrm{X}$ & $\mathrm{x}$ & $x$ \\
\hline Belgium & $\mathrm{x}$ & $x$ & & $x$ & $x$ & $\ldots$ & $\ldots$ \\
\hline Bulgaria & $\mathrm{x}$ & & & $\mathrm{x}$ & $\mathrm{x}$ & $\mathrm{x}$ & $\mathrm{x}$ \\
\hline Croatia & $\mathrm{x}$ & & & & $\mathrm{x}$ & $x$ & $\mathrm{x}$ \\
\hline Cyprus & $\mathrm{x}$ & & & $x$ & $x$ & $x$ & $x$ \\
\hline Czech Republic & $\mathrm{x}$ & & & $x$ & $\mathrm{x}$ & $\mathrm{x}$ & $\mathrm{x}$ \\
\hline Denmark & $\mathrm{x}$ & & & $x$ & $\mathrm{x}$ & $\mathrm{x}$ & $\mathrm{x}$ \\
\hline Estonia & $x$ & & & $\mathrm{x}$ & $\mathrm{x}$ & $\mathrm{x}$ & $\mathrm{x}$ \\
\hline Finland & $\mathrm{x}$ & $\mathrm{x}$ & & $\mathrm{x}$ & $\mathrm{x}$ & $\mathrm{x}$ & $x$ \\
\hline France & $\mathrm{x}$ & & & & $x$ & $x$ & $x$ \\
\hline Georgia & $x$ & & & $\mathrm{x}$ & $\mathrm{X}$ & $\mathrm{x}$ & \\
\hline Germany & $\mathrm{x}$ & $x$ & & $\mathrm{x}$ & $\mathrm{x}$ & $\mathrm{x}$ & $x$ \\
\hline Hungary & $x$ & & & $x$ & $x$ & $x$ & $x$ \\
\hline Iceland & $\mathrm{x}$ & & & $\mathrm{x}$ & $x$ & $x$ & $x$ \\
\hline Italy & $\mathrm{x}$ & & & $x$ & $\mathrm{x}$ & & $\mathrm{x}$ \\
\hline $\begin{array}{l}\text { Kosovo (UN } \\
\text { R/1244/99) (UNR) }\end{array}$ & $\mathrm{x}$ & $x$ & & $\mathrm{x}$ & $x$ & $x$ & $x$ \\
\hline $\begin{array}{l}\text { R/1244/Yy) (U/NR) } \\
\text { Latvia }\end{array}$ & $\mathrm{x}$ & & & $\mathrm{X}$ & $\mathrm{x}$ & $x$ & $x$ \\
\hline Lithuania & $\hat{x}$ & & & $\hat{x}$ & $x$ & & $\hat{x}$ \\
\hline Malta & $\mathrm{x}$ & & & $\mathrm{x}$ & $\mathrm{x}$ & $\mathrm{x}$ & $\mathrm{x}$ \\
\hline Moldova & $x$ & & & $x$ & $x$ & $\mathrm{x}$ & $\mathrm{x}$ \\
\hline Netherlands & & $x$ & & $x$ & $x$ & $\mathrm{x}$ & $x$ \\
\hline North Macedonia & & & & & & & \\
\hline Norway & $\mathrm{x}$ & & & $x$ & $x$ & $x$ & $\mathrm{x}$ \\
\hline Poland & $x$ & & & $x$ & $\mathrm{x}$ & $\mathrm{x}$ & $x$ \\
\hline Portugal & $\mathrm{x}$ & & & $\mathrm{x}$ & $x$ & $\mathrm{x}$ & $\mathrm{x}$ \\
\hline Romania & $\mathrm{x}$ & & & $x$ & $x$ & $x$ & $x$ \\
\hline Russian Fed. & $\mathrm{x}$ & & & $\mathrm{x}$ & $\mathrm{x}$ & $\mathrm{x}$ & $\mathrm{x}$ \\
\hline Serbia & $\mathrm{x}$ & & & $x$ & $x$ & $x$ & $x$ \\
\hline Slovak Republic & $\mathrm{x}$ & & & $x$ & $x$ & $x$ & $x$ \\
\hline Slovenia & $\mathrm{x}$ & & & & $\mathrm{x}$ & & $\mathrm{x}$ \\
\hline Spain & $\mathrm{x}$ & & & $\mathrm{x}$ & $\mathrm{x}$ & & $\mathrm{x}$ \\
\hline Sweden & $x$ & $\mathrm{X}$ & & $\mathrm{x}$ & $\mathrm{X}$ & $\mathrm{x}$ & $\mathrm{x}$ \\
\hline Switzerland & $\mathrm{x}$ & & & & $x$ & & $\mathrm{x}$ \\
\hline Turkey & $\mathrm{x}$ & & & $\mathrm{x}$ & $x$ & $x$ & $x$ \\
\hline UK: Eng. \& Wales & $\mathrm{x}$ & $x$ & $\mathrm{x}$ & $\mathrm{X}$ & $\mathrm{x}$ & $\mathrm{x}$ & $\mathrm{x}$ \\
\hline UK: N. Ireland & $\mathrm{x}$ & & & $x$ & $x$ & $x$ & $x$ \\
\hline UK: Scotland & $\mathrm{x}$ & & & & $x$ & $\mathrm{x}$ & $x$ \\
\hline
\end{tabular}


Comments to Table 5.3.1.1 (1/3)

Albania The Probation Service, created in 2008, is the institution which deals with offenders convicted with alternative sanctions in the criminal justice system in Albania. The Probation Service Institute prepares for the prosecutor an assessment report for the accused / person under investigation and implements the Execution Order issued by the Prosecution. It prepares an assessment report on the request of the Court for defendants sentenced to imprisonment.

Austria The probation service in Austria is run by NEUSTART, a private non-profit organisation almost fully funded by the Ministry of Justice. Within the Ministry of Justice, the Prison administration is responsible for NEUSTART, which nevertheless is a separated independent body.

NEUSTART offers various social work services to victims and offenders all over the country. The probation service in the narrow sense of a supervision order is carried out either by professional social workers or volunteers trained and guided by professionals.

Besides probation, victim-offender mediation (VOM), unpaid work as a diversion measure, unpaid work as an alternative to custody for fine defaulters and electronic monitoring are the main activities.

Belgium In the context of the 6th state reform, the probation services have been transferred from the Ministry of Justice to the following three federal entities: (a) the Flemish community, (b) the German-speaking community, (c) The French community.

Bulgaria General Directorate "Execution of Sentences" (GDES) is a specialised administrative structure, legal entity under the Minister of Justice with headquarters in Sofia. The Directorate exercises direct supervision and control over the places of deprivation of liberty and probation, and the remand measure of detention in places of deprivation of liberty.

Croatia Probation offices started opening in 2011 (12 local offices and a head office in the Ministry of Justice).

Cyprus The Police and the "Conditional Release - Parole Board" (PB) are under the authority of the Ministry of Justice and Public Order. Probation officers are also employed by the Social Welfare Services (SWS) of the Ministry of Labour, Welfare and Social Insurance. The Police and the SWS are not considered probation agencies, however these two government agencies employ probation officers who handle probation cases (among other responsibilities that they have).

Czech Rep. Probation and Mediation Service - Czech Republic (PMS) is an organisational unit of the Ministry of Justice of the Czech Republic. Supervision of the activities carried out by the Ministry of Justice. The legislation of PMS is contained in Act No. 257/2000 Coll. Probation and Mediation Service.

Estonia There are probation supervision departments of prisons. There are no separate agencies.

Germany There is no uniformed federal system for probation. The systems differ across states (Länder). As a consequence, there are no national statistics on probation and data are no longer available since 2016, as it can be seen in the SPACE II Council of Europe Annual Penal Statistics (www.unil.ch/space)

Iceland The Prison system in Iceland is run by the Prison and Probation Administration (PPA), a governmental institution controlled by the Ministry of Justice. According to the Execution of Sentences Act (ESA) no. $15 / 2016$ the PPA's role is to supervise the execution of sentences and other functions in accordance with the provision of the Act and the regulations issued thereunder and to supervise the running of the prisons.

Italy The Ministry of Justice, Department of Penitentiary Administration manages probation in Italy, through the Offices for the Execution of Sentences in the Community (UEPE) Those Offices are staffed mainly with social workers of justice (probation officers) At the central level, at the Department Headquarters there is the Directorate General for the Execution of Sentences in the Community (DGEPE), providing coordination, directions, and guidance to local Offices.

Lithuania Until 2012 there were correction inspections with territorial subdivisions. After a change in legislation, these were renamed as probation agencies, which have further tasks.

Malta The current probation agency was set up in 2012 as a department of the Ministry of Home Affairs and National Security. It replaced the former Probation Service (before 2012, the prisons and the Probation Service were part of the Department for Correctional Services).

Netherlands In the Netherlands there are three probation agencies (independent private bodies). These agencies are almost fully financed by the Ministry of Justice. 
Comments to Table 5.3.1.1 (2/3) $\begin{array}{ll}\text { Norway } & \text { The Correctional Service of Norway consists of the Directorate, five regional offices and prisons and pro- } \\ \text { bation offices. At the central and regional level, both prison and probation are managed while prisons and } \\ \text { probation offices as local units are managed separately. A number of pilots are currently being carried out } \\ \text { where prison and probation are under the same local management as well. }\end{array}$

Portugal The Probation Agency, in the Ministry of Justice, is called the Directorate-General for Reintegration and Prison Services (DGRSP)

Romania There is a central department in the Ministry of Justice and 42 probation services (one in each county).

Serbia The probation agency was created in 2011.

Slovak Rep. According to national legislation, the Criminal Law Department of the Ministry of Justice governs and guides conceptually and methodically the administration of probation. However, such an activity should not be considered probation administration as such.

Probation is performed by probation and mediation officers, who are public servants employed by the eight (8) regional courts, but physically based at the district courts. The president of each regional court is considered their chief of staff.

Slovenia Probation tasks are performed by social work centres, which are under the jurisdiction of the Ministry of Labour, Family, and Social Affairs.

Spain In the General state Administration, probation agencies are placed under the authority of the Ministry of Interior. In Catalonia, the only autonomous community with the prison competences transferred, probation agencies are placed under the authority of the Regional Justice Administration.

Switzerland There is no uniformed federal system for probation. The systems differ across cantons.

Ukraine In 2018 the Statutes of the Probation Service and Prison Service were changed. The Probation and Prison Departments in the structure of the Ministry of Justice were replaced by the following legal entities (without the independent body status): The Public Institution "Centre of Probation" and the Prison Administration. Their activities are directed and coordinated by the Ministry of Justice of Ukraine.

UK: England \& The Probation Service for England and Wales is a statutory Criminal Justice Service for the supervision of Wales offenders in the community and the provision of reports to the criminal courts to assist them in their sentencing duties. The Service works with the Police, Prison Service, and other organisations under the Multi Agency Public Protection Arrangement (MAPPA). The Service also fulfils a role in assisting victims of crime. The service is part of the National Offender Management Service (NOMS) which itself is part of the Ministry of Justice. It comprises 42 probation areas which are coterminous with police force area boundaries and served by 35 probation trusts. Trusts are funded by NOMS and employ all staff except the Chief Probation Officer and are accountable to local boards and NOMS. The work of Trusts is scrutinised both by NOMS and Her Majesty's Inspector of Probation. Starting from 2014 the structure of the service was changed so that more serious offenders were dealt with by the National Probation Service and the less serious by around 20 Community Rehabilitation Companies whose legal status gradually moved from being owned by the government to private companies.

The Probation Service have a statutory requirement to assist the criminal courts by the provision of reports and to supervise offenders in the community. They work with other agencies to provide a multi-agency approach to deal with offenders.

UK: Northern The Northern Ireland Assembly is the devolved legislature for Northern Ireland. It is responsible for making Ireland laws on transferred matters in Northern Ireland and for scrutinising the work of Ministers and Government Departments. The Probation Board for Northern Ireland is a Non-Departmental Public Body, sponsored by the Department of Justice.

UK: Scotland Probation services in Scotland are funded through the Scottish Government equivalent of the Ministry of Justice (Directorate General of Education, Communities and Justice). The funding is then distributed by geographically based local authorities who manage the operation of criminal justice social work through their social work departments. Some services are also provided by the voluntary sector.

This means that here is no central Probation Agency in Scotland. Community orders involving supervision and/or unpaid work are imposed by courts. It is then the responsibility of Scottish local authority social work departments to arrange the appropriate supervision / work placements for offenders. There are 32 Scottish local authority social work departments. 


\subsubsection{Description of data recording methods for Tables on probation}

\section{Stock data}

The reference date for stock data is $31^{\text {st }}$ December, but in Scotland is $31^{\text {st }}$ March, in Sweden $1^{\text {st }}$ October, while in France, Latvia, and the Russian Federation is the following day (1 ${ }^{\text {st }}$ January of the following year)

\section{Minors}

Minors are included in the figures provided by the majority of countries. The details are presented in the following Table.

\begin{tabular}{|l|l|l|}
\hline Minors are included & Minors are NOT included & $\begin{array}{l}\text { Minors are PARTIALLY in- } \\
\text { cluded }\end{array}$ \\
\hline 30 countries: & 10 countries: & 3 countries: \\
Albania, Armenia, Austria, Azerbaijan, Belgium, & $\begin{array}{l}\text { Croatia, Czech Republic, Italy, } \\
\text { Bulgaria, Cyprus, Denmark, Estonia, Finland, } \\
\text { Leorgia, Germany, Greece, Hungary, Iceland, } \\
\text { Kosovo (UN R/1244/99) (UNR), Ireland, Latvia, } \\
\text { Foland, Slovenia, Spain, Switzer- } \\
\begin{array}{l}\text { Lithuania, Malta, Moldova, Norway, Portugal, } \\
\text { Romania, Serbia, Slovak Rep., Sweden, Tur- } \\
\text { key, Ukraine, UK: Northern Ireland. }\end{array}\end{array}$ & \\
\hline
\end{tabular}

\section{Counting unit}

In most countries, the counting unit used in probation statistics is the person. The details are presented in the following Table. The counting unit is:

\begin{tabular}{|c|c|c|c|}
\hline & the person & partially the person* & other* \\
\hline $\begin{array}{l}\text { Stock } \\
\text { indica- } \\
\text { tors }\end{array}$ & $\begin{array}{l}25 \text { countries: } \\
\text { Armenia, Austria, Azerbaijan, Bulgaria, } \\
\text { Croatia, Cyprus, Estonia, Finland, Geor- } \\
\text { gia, Greece, Iceland, Italy, Latvia, Lithu- } \\
\text { ania, Moldova, Monaco, Montenegro, } \\
\text { Netherlands, North Macedonia, Norway, } \\
\text { Poland, Switzerland, Turkey, UK: Eng- } \\
\text { land \& Wales, UK: Northern Ireland. }\end{array}$ & $\begin{array}{l}9 \text { countries: } \\
\text { Czech Republic, France, Ire- } \\
\text { land, Portugal, Romania, Ser- } \\
\text { bia, Spain, Sweden, UK: Scot- } \\
\text { land }\end{array}$ & $\begin{array}{l}7 \text { countries: } \\
\text { Belgium, Denmark, Lux- } \\
\text { embourg, Malta, Slovak } \\
\text { Republic, Slovenia, } \\
\text { Ukraine }\end{array}$ \\
\hline $\begin{array}{l}\text { Flow in- } \\
\text { dicators }\end{array}$ & $\begin{array}{l}21 \text { countries: } \\
\text { Armenia, Austria, Azerbaijan, Bulgaria, } \\
\text { Croatia, Cyprus, Estonia, Finland, Geor- } \\
\text { gia, Greece, Iceland, Lithuania, Moldova, } \\
\text { Monaco, Montenegro, Netherlands, } \\
\text { North Macedonia, Poland, Turkey, UK: } \\
\text { England \& Wales, UK: Northern Ireland. }\end{array}$ & $\begin{array}{l}10 \text { countries: } \\
\text { Czech Republic, France, Ire- } \\
\text { land, Latvia, Portugal, Romania, } \\
\text { Serbia, Spain, Sweden, Switzer- } \\
\text { land, UK: Scotland }\end{array}$ & $\begin{array}{l}8 \text { countries: } \\
\text { Belgium, Denmark, It- } \\
\text { aly, Luxembourg, Malta, } \\
\text { Norway, Slovak Repub- } \\
\text { lic, Slovenia, Ukraine }\end{array}$ \\
\hline
\end{tabular}


Notes on the counting unit

\begin{tabular}{ll}
\hline Belgium & The counting unit is the number of files and not the number of persons. \\
Czech Republic & The counting unit is the sanction or measure (i.e., both for stock and flow, one person can \\
be registered with more than one sanction or measure). \\
The counting unit is the number of cases. \\
Senmark & Sometimes the counting unit is persons, sometimes it is measures. In fact, some persons \\
may be concerned by several measures, so when details according to the type of monitoring \\
are asked, it is about measures and no longer about persons.
\end{tabular}




\subsubsection{Electronic monitoring}

Implementation of electronic monitoring (EM) across Europe by technique and type of EM

\begin{tabular}{|c|c|c|c|c|c|}
\hline \multicolumn{3}{|c|}{ Technique } & \multicolumn{3}{|c|}{ Type } \\
\hline Electronic tag & $\begin{array}{l}\text { Telephone } \\
\text { calls }\end{array}$ & $\begin{array}{c}\text { Other electronic } \\
\text { system }\end{array}$ & Electronic curfew & $\begin{array}{l}\text { Tracking of } \\
\text { movement }\end{array}$ & Other \\
\hline $\begin{array}{l}23 \text { countries: Al- } \\
\text { bania, Austria, } \\
\text { Belgium, Bul- } \\
\text { garia, Denmark, } \\
\text { Estonia, Finland, } \\
\text { France, Italy, } \\
\text { Lithuania, Neth- } \\
\text { erlands, North } \\
\text { Macedonia, Nor- } \\
\text { way, Poland, } \\
\text { Portugal, Serbia, } \\
\text { Spain, Sweden, } \\
\text { Switzerland, Tur- } \\
\text { key, UK: Eng- } \\
\text { land \& Wales, } \\
\text { UK: Northern Ire- } \\
\text { land, UK: Scot- } \\
\text { land. }\end{array}$ & $\begin{array}{l}9 \text { countries: Al- } \\
\text { bania, Finland, } \\
\text { Hungary, Lithu- } \\
\text { ania, Moldova, } \\
\text { North Macedo- } \\
\text { nia, Poland, } \\
\text { Spain, UK: } \\
\text { England \& } \\
\text { Wales. }\end{array}$ & $\begin{array}{l}7 \text { countries: Bul- } \\
\text { garia, France, } \\
\text { Moldova, Nether- } \\
\text { lands, Russian } \\
\text { Fed., Sweden, } \\
\text { Turkey }\end{array}$ & $\begin{array}{l}19 \text { countries: Al- } \\
\text { bania, Austria, } \\
\text { Belgium, Bul- } \\
\text { garia, Estonia, } \\
\text { France, Italy, } \\
\text { Lithuania, Neth- } \\
\text { erlands, Norway, } \\
\text { Poland, Portugal, } \\
\text { Spain, Sweden, } \\
\text { Switzerland, Tur- } \\
\text { key, UK: Eng- } \\
\text { land \& Wales, } \\
\text { UK: Northern Ire- } \\
\text { land, UK: Scot- } \\
\text { land. }\end{array}$ & $\begin{array}{l}14 \text { countries: Al- } \\
\text { bania, Bulgaria, } \\
\text { Estonia, Finland, } \\
\text { Hungary, Italy, } \\
\text { Lithuania, Neth- } \\
\text { erlands, Poland, } \\
\text { Portugal, Rus- } \\
\text { sian Fed., Spain, } \\
\text { Sweden, Turkey. }\end{array}$ & $\begin{array}{l}6 \text { countries: } \\
\text { Bulgaria, } \\
\text { Finland, } \\
\text { France, Mol- } \\
\text { dova, Rus- } \\
\text { sian Fed., } \\
\text { Turkey }\end{array}$ \\
\hline
\end{tabular}




\begin{tabular}{|c|c|}
\hline Albania & $\begin{array}{l}\text { Electronic tagging is implemented in Albania by placing a bracelet on the foot of the con- } \\
\text { victed person, which enables his/her localisation at all times, as well as tracks his/her move- } \\
\text { ments. The convicted person is contacted through phone calls for possible violations or } \\
\text { bracelet malfunction. }\end{array}$ \\
\hline Armenia & No EM implemented in Armenia. \\
\hline Bulgaria & $\begin{array}{l}\text { As to "technique", radio-frequency monitoring may be applied. As to "type", voice identifica- } \\
\text { tion may be applied (Article } 262 \text { of the Execution of Punishments and Detention Act). }\end{array}$ \\
\hline Czech Republic & $\begin{array}{l}\text { Electronic monitoring was integrated into the Czech law system in } 2009 \text {, but bracelets or } \\
\text { other type of technique of EM were not available in } 2015 \text {. The EM system was started in } \\
\text { September } 2018 \text {. }\end{array}$ \\
\hline Denmark & $\begin{array}{l}\text { Electronic monitoring is in all cases an alternative way of serving a full (short) prison sen- } \\
\text { tence. The decision is made by the Prison Service. }\end{array}$ \\
\hline Estonia & $\begin{array}{l}\text { The majority of persons are monitored by use of a base station at the offender's home. } \\
\text { Tracking movement means use of GPS equipment. }\end{array}$ \\
\hline Finland & $\begin{array}{l}\text { The person is confined to their home outside of their daily schedule which may include going } \\
\text { to work/school or running errands. They have an electronical ankle bracelet and in addition, } \\
\text { they are visited by a team of probation officers at random times to make sure they are fol- } \\
\text { lowing the rules and remain sober. Source of data: } \\
\text { http://www.rikosseuraamus.fi/material/attachments/rise/esitteet/697aJhOOE/VALRA_si- } \\
\text { dosryhmille.pdf }\end{array}$ \\
\hline Netherlands & $\begin{array}{l}\text { Electronic monitoring in the Netherlands is not a sanction in its own right, but it is a condition } \\
\text { attached to: pre-trial supervision by probation agencies, fully or partially suspended custo- } \\
\text { dial sentence with probation, home arrest, or conditional release with probation. There are } \\
\text { two types of EM executed: Radio Frequency-Identification (RFId) and Global Positioning } \\
\text { System (GPS). }\end{array}$ \\
\hline Norway & $\begin{array}{l}\text { Since electronic monitoring is a way of executing unconditional imprisonment granted by } \\
\text { the Correctional Services, breach of conditions results in transfer to prison, and this is done } \\
\text { without further intervention by the judicial authorities. The curfew implies that the offender } \\
\text { will have to be at home during certain hours and has to be out and active (work, school, } \\
\text { program, other - decided by the Correctional Services) during the rest of the time. His or her } \\
\text { presence during out-time is checked through contact persons and random visits. }\end{array}$ \\
\hline Portugal & Tracking of movement is used only in domestic violence restraint orders. \\
\hline Russian Federation & $\begin{array}{l}\text { For electronic monitoring are used: Stationary control device is paired with an electronic } \\
\text { bracelet on his ankle to control the mode of the presence on the premises or on the desig- } \\
\text { nated territory. The mobile control device is paired with an electronic ankle bracelet to track } \\
\text { the location of a person controlled by the signals of global navigation satellite system } \\
\text { GLONASS/GPS. }\end{array}$ \\
\hline Slovenia & No EM implemented in Slovenia. \\
\hline Spain & $\begin{array}{l}\text { Electronic monitoring is not an autonomous alternative sanction. However, alternatives to } \\
\text { imprisonment are only applied to prisoners during the execution of the imprisonment sanc- } \\
\text { tion. Data for adults are recorded as an input. Electronic monitoring is not provided by the } \\
\text { juvenile criminal law. }\end{array}$ \\
\hline Sweden & $\begin{array}{l}\text { Some of the electronic tags are combined with GPS (global positioning system). This is to } \\
\text { ensure that the person is in an approved place at every point in time. Besides electronic } \\
\text { curfew at home as a way to carry out a prison sentence, electronic monitoring is also partly } \\
\text { applied for granted prison leaves. It is also applied inside some of the prison institutions, } \\
\text { namely the institutions with the lowest level of safety regulations, which is where the inmates } \\
\text { with the lowest risk of breaching the conditions are serving their sentences. }\end{array}$ \\
\hline Turkey & Other techniques include GPS tracking and Alcohol use monitoring. \\
\hline
\end{tabular}




\subsection{Sources}

The vast majority of data on stock and flow from 2011 to 2016 are taken from the SPACE II Council of Europe Annual Penal Statistics ${ }^{37}$, available at www.unil.ch/ space. Additional sources include

\begin{tabular}{|c|c|}
\hline Albania & $\begin{array}{l}\text { Data drawn from analysing statistical reports gathered by the General Department of Proba- } \\
\text { tion from local Probation Offices. }\end{array}$ \\
\hline Austria & EUSTART - Bewährungshilfe, Konfliktregelung, Soziale Arbeit www.neustart.at. \\
\hline Belgium & atabase of the Houses of Justice. \\
\hline Bulgaria & $\begin{array}{l}\text { Ministry of Justice - General Directorate Execution of Penalties: Statistics on Execution of } \\
\text { Penalties, not published. }\end{array}$ \\
\hline Czech Republic & AIS PMS - administrative and statistical file system 2015. \\
\hline Estonia & Ministry of Justice, unpublished. \\
\hline France & $\begin{array}{l}\text { Ministry of Justice. Penitentiary Administration. Stock data come from the informatics program } \\
\text { SPIP: APPI. }\end{array}$ \\
\hline Hungary & $\begin{array}{l}\text { The Hungarian Prison Service Headquarters and the Hungarian Probation Service national } \\
\text { registry system (unpublished) }\end{array}$ \\
\hline Iceland & Prison and probation Administration. \\
\hline Italy & $\begin{array}{l}\text { Italian Institute of statistics - http://wwwistatit - Ministry of Justice, and Department of Statistics } \\
\text { Directorate General for the Execution of Sentences in the Community (DGEPE) -Observatory }\end{array}$ \\
\hline & $\begin{array}{l}\text { on Community Sanctions and Measures. Published on the Internet website } \\
\text { www.giustizia/statistiche. }\end{array}$ \\
\hline Lithuania & $\begin{array}{l}\text { Prison Department under the Ministry of Justice of the Republic of Lithuania - Planning and } \\
\text { Project Management Division, unpublished. }\end{array}$ \\
\hline Malta & Department of Probation and Parole. \\
\hline Moldova & Ministry of Justice - Central Probation Office. \\
\hline North Macedonia & $\begin{array}{l}\text { Annual reports of the Department for the treatment and enforcement of non-custodial sanc- } \\
\text { tions and measures in the Administration for Enforcement of Penal Sanctions. }\end{array}$ \\
\hline Norway & Registration system of the Correctional Services of Norway. \\
\hline Poland & Ministr \\
\hline Portugal & al for Reintegratior \\
\hline Romania & $\begin{array}{l}\text { Data are gathered by the Probation Department and they partially published on the Ministry } \\
\text { of Justice website. }\end{array}$ \\
\hline Serbia & $\begin{array}{l}\text { Annual reports of the Department for the treatment and enforcement of non-custodial sanc- } \\
\text { tions and measures in the Administration for Enforcement of Penal Sanctions. } \\
\text { www.uiks.mpravde.gov.rs. }\end{array}$ \\
\hline Slovak Republic & $\begin{array}{l}\text { Ministry of Justice of the Slovak Republic, Department of Informatics and Project Manage- } \\
\text { ment, Department of Sectoral Statistics and Reporting, unpublished. }\end{array}$ \\
\hline Slovenia & Social data database and several additional sources. \\
\hline Spain & stitute of Snain (INF). httn.//wow ine es \\
\hline \multirow[t]{2}{*}{ Sweden } & $\begin{array}{l}\text { Swedish prison and probation service - Statistical section: Prison and probation service reg- } \\
\text { ister (KVR), unpublished. }\end{array}$ \\
\hline & $\begin{array}{l}\text { Some of the statistics are available (in Swedish) at } \\
\text { http://statistik.kriminalvarden.se/SASPortal/main.do. }\end{array}$ \\
\hline Switzerland & Swiss Federal Office of Statistics \\
\hline Turkey & $\begin{array}{l}\text { Ministry of Justice, General Directorate for Probation website, Statistics http://www.cte- } \\
\text { ds.adalet.gov.tr/menusayfalari/bilgibankasi//istatistik/\%20istatistik/istatistik.htm }\end{array}$ \\
\hline UK: England \& & Source: Ministry of Justice - Justice Statistics Analytical Services - Prison Probations and \\
\hline Wales & \\
\hline UK: Nort & PBNI's Case Management System, Probation Information Management System (PIMS). \\
\hline UK: Scotland & Criminal Justice Social Work Statistics bulletin published by the Scottish Government. \\
\hline
\end{tabular}

${ }^{37}$ See, e.g., Aebi, M. F., \& Chopin, J. (2017). SPACE II - 2016 - Council of Europe Annual Penal Statistics: Persons under the supervision of probation agencies. Strasbourg: Council of Europe 


\section{National Victimisation Surveys}

\subsection{General comments}

\subsubsection{Introduction}

Victimisation surveys started in the 1970s to give another estimate of crime experienced in a country to enhance the figures of crime recorded by the police. However, since then they have developed extensively to give estimates of many other aspects of how the population of a country interacts with social conditions and with the criminal justice system. Originally directed at households only, they have also developed to research prevalence of crime and use of crime prevention measures in business and government agencies. They have proved particularly useful in looking at the experience of new types of crime such as cybercrime and computer fraud. A discussion of the wide range of other issues covered by recent victimisation surveys in European countries can be found in section 6.4.

This chapter provides information on the national victimisation surveys carried out in countries participating in the European Sourcebook. To improve comparability with other types of crime data included in the different editions of the 
European Sourcebook, data from national victimisation surveys were collected for six different years: 1990, 1995, 2000, 2005, 2010 and $2015^{38}$.

Readers should keep in mind that the results of national victimisation surveys conducted in different countries cannot be directly compared because of the differences in methodology. Indeed, even in the same country, methodologies and sample sizes do not remain the same since many countries are developing their victimisation surveys in an attempt to measure new types of crime, cover new types of victim and measure new aspects of their criminal justice systems. Such developments are often hampered by shortages in resources. To appreciate the extent to which comparisons are able to be made, the original documents for each country should be consulted. In this chapter web references are given throughout but especially in Tables 6.1.4 and 6.4.

This chapter has been expanded from previous editions which concentrated on households, to include some other types of surveys: e.g., section 6.1.6.1. mentions the national business surveys that are conducted and section 6.2.11 considers cybercrime against businesses. The police crime data in chapter 1 includes all crimes reported to the police, whether from individuals, businesses, or government organisations.

This chapter also does not include data from local or regional surveys in individual countries. Neither does it cover cross-national victimisation surveys that have been carried by groups of countries or international bodies from time to time: examples are:

The International Crime Victim Survey that was carried out from 1989 to 2005 in many European countries ${ }^{39}$.

The EU-ICS (European Union Crime and Safety Survey) a one-time survey carried out in 2005.40

In the past, some countries used the ICVS as an alternative to a national survey. Thus, we include Table 6.1.1.to show 23 European countries that participated in different sweeps of the ICVS. Others have used ICVS methodology or questions as a basis for their own surveys.

\footnotetext{
${ }^{38}$ For a review of the victimisation surveys carried out in the EU countries since their first developments in the 1960s until 2008 see Aebi M.F. \& Linde A. (2010). A review of victimisation surveys in Europe from 1970 to 2010 in Van Dijk, J., Mayhew, P, Van Kesteren, J., Aebi, M.F. \& Linde, A. (Eds) Final Report on the study of crime victimisation (pp.D1-D76) Tilburg: Intervict/PrismaPrint Tilburg.: available online at http://www3.unil.ch/wpmu/icvs/key-publications.

$39 \mathrm{~A}$ full list of ICVS publications and all details of the survey can be found at http://www.unil.ch/icvs.

${ }^{40}$ For full details see http://www.worldsocialscience.org/documents/european-crime-safety-surveyeu-ics.pdf.
} 
Table 6.1.1. European countries participating in the different sweeps of the ICVS with national samples

\begin{tabular}{|c|c|c|c|c|c|}
\hline & 1989 & 1992 & 1996 & 2000 & $2004 / 5$ \\
\hline Austria & & & * & & \\
\hline Belgium & * & * & & * & * \\
\hline Bulgaria & & & & & * \\
\hline Denmark & & & & * & * \\
\hline Estonia & & * & * & * & * \\
\hline Finland & * & * & * & * & * \\
\hline France & * & & * & * & * \\
\hline Germany & * & & & & * \\
\hline Greece & & & & & * \\
\hline Hungary & & & & & * \\
\hline Iceland & & & & & * \\
\hline Ireland & & & & & * \\
\hline Italy & & * & * & & * \\
\hline Luxembourg & & & & & * \\
\hline Netherlands & * & * & * & * & * \\
\hline Norway & * & & & & * \\
\hline Poland & & * & * & * & * \\
\hline Portugal & & & & * & * \\
\hline Spain & * & & & & * \\
\hline Switzerland & * & & * & * & * \\
\hline UK: England \& Wales & * & * & * & * & * \\
\hline UK: Northern Ireland & * & & * & * & * \\
\hline UK: Scotland & * & & * & * & * \\
\hline
\end{tabular}

6.1.2 Data collected on Victimisation Surveys for the European Sourcebook

The following data on national victimisation surveys was requested from all countries contributing to the Sourcebook:

a) Availability and periodicity of national victimisation surveys. This data is summarised at Table 6.1.2.

b) Wording of the questions for the following offences:

i. Bodily injury/assault

ii. Sexual assault

iii. Robbery

iv. Theft of personal property

v. Theft of a motor vehicle

vi. Theft by means of domestic burglary

vii. Corruption

A summary of definitions is at Table 6.1 .5 and separate more detailed tables by offence can be found in Tables 6.2.1.3 to 6.2.9.2

a) Wording on the questions on trust in the police and feelings of safety.

These are summarised at Table 6.1.5, 6.2.8.2 and 6.2.9.2.

b) Methodology of the national victimisation surveys: e.g.: 
i. $\quad$ Sample size (see Table 6.3.1)

ii. Sample design (see Table 6.3.2)

iii. $\quad$ Sample representativeness (see Table 6.3.3)

iv. Response rate Table 6.3.4)

v. Age range of those interviewed (see Table 6.3.5)

vi. Survey mode (see Table 6.3.6)

c) Main results of national victimisation surveys for the following indicators:

i. Prevalence and incidence of victimisation for the last 12 months and

ii. Percentages of victims reporting to the police

For the following offences: (see Tables 6.2.1.1. to 6.2.7.1)

i. Bodily injury/assault

ii. Sexual assault

iii. Robbery

iv. Theft of personal property

v. Theft of as motor vehicle

vi. Theft by means of domestic burglary

vii. Corruption

d) Incidence is not included in this Chapter as the results are not at all comparable between countries.

e) The data received from countries can be found in the raw data available on the web site (http://www.unil.ch/europeansourcebook)

f) Any errors in this chapter or incompatibilities with the raw data should be reported to the ESB team at the University of Lausanne (marcelo.aebi@unil.ch)

Not all countries answered the questionnaire about national victimisation surveys and those that answered did not always reply for each sweep of the ESB. Of the 38 countries who replied five (Greece, Kosovo, Malta, Russian Federation and Slovak Republic) had never conducted a national victimisation survey. Fourteen others conduct a periodical national victimisation survey: see table 6.1.2.1 for a list of countries and survey frequency. Another 19 countries do not conduct a periodical survey but have conducted one or more national or regional victimisation surveys: see Table 6.1.2.2 for a list of countries. More details and comments are given in Table 6.1.2.3. 
Table 6.1.2.1 Countries with periodical national victimisation surveys and frequency of such surveys

\begin{tabular}{|c|c|}
\hline Belgium & $\begin{array}{l}\text { Belgium has resumed conducting victimisation surveys on a regular ba- } \\
\text { sis, starting with } 2018 \text { data, although the gap between surveys has not } \\
\text { yet been finalised. The previous survey was in 2008/9. Prior to that sur- } \\
\text { veys were conducted normally every } 2 \text { years. }\end{array}$ \\
\hline Denmark & Annual surveys have been carried out since 2005 \\
\hline Finland & Annual surveys have been conducted annually since 2012 . \\
\hline France & Annual since 2007 \\
\hline Germany & $\begin{array}{l}\text { Surveys were conducted in } 2012 \text { and } 2017 \text {. There are plans to conduct } \\
\text { surveys every two years starting in } 2020 \text {. }\end{array}$ \\
\hline Iceland & Annually for the whole country since 2011 \\
\hline Italy & About every 5 years \\
\hline Netherlands & Annual \\
\hline Norway & Surveys were conducted in 2004, 2007, 2012, 2015 and 2018 \\
\hline Sweden & Annual \\
\hline Turkey & Annual \\
\hline UK: England \& Wales & Continuous (with annual results) \\
\hline UK: Northern Ireland & Continuous (with annual results) \\
\hline UK: Scotland & Every two years \\
\hline
\end{tabular}


Table 6.1.2.2 Countries with occasional national victimisation surveys and characteristics of such surveys

\begin{tabular}{|c|c|}
\hline Albania & $\begin{array}{l}\text { Participated in } 2010 \text { International Crime Business Survey, the } 2006 \mathrm{Na}- \\
\text { tional Survey on Children Violence, and the } 2008 \text { National Survey on Do- } \\
\text { mestic Violence }\end{array}$ \\
\hline Armenia & 2010 \\
\hline Austria & $\begin{array}{l}\text { Austria conducted a } 2016 \text { nationwide survey on domestic violence (in- } \\
\text { cluding attacks on sexual integrity) }\end{array}$ \\
\hline Bulgaria & $\begin{array}{l}\text { Annual surveys were carried out up to } 2010 \text {. None have been carried out } \\
\text { since then or are planned for the future. }\end{array}$ \\
\hline Croatia & $1997,2000,2009$ \\
\hline Cyprus & $\begin{array}{l}\text { A Victimisation Survey was conducted in 2009, by Ministry of Finance, } \\
\text { Statistical Service }\end{array}$ \\
\hline Czech Republic & $\begin{array}{l}\text { 2006, } 2013 \text { and } 2017 \text { Victimisation surveys } \\
2013 \text { Domestic violence survey } \\
\text { 2016-2019 Violence against elderly survey }\end{array}$ \\
\hline Estonia & $\begin{array}{l}\text { There have been annual small surveys since } 2010 \text { (similar to the ICVS, } \\
\text { sample c. } 1000 \text { respondents). The general victimisation level is not com- } \\
\text { parable to the earlier surveys due to much shorter questionnaire, but the } \\
\text { wording of some questions was the same as was in the previous surveys }\end{array}$ \\
\hline Finland & $\begin{array}{l}\text { Before } 2012 \text { surveys were conducted in } 1980,1988,1993,1997,2003,2006 \\
\text { and } 2009 \text {. }\end{array}$ \\
\hline Georgia & Surveys were carried out in 2009, 2010, 2011 and 2013. \\
\hline Ireland & $\begin{array}{l}\text { Surveys were conducted in 1998, 2003, } 2008 \text { and 2010. From } 2015 \text { some } \\
\text { questions on victims were included in the quarterly household survey }\end{array}$ \\
\hline Lithuania & $\begin{array}{l}\text { Surveys were conducted in } 2003,2005,2006,2007,2008 \text { and } 2011 . \\
\text { There have also been surveys of victims such as young people or women }\end{array}$ \\
\hline Poland & $\begin{array}{l}\text { Surveys were conducted in 1991, 1995, 1999, 2004, 2006, 2007, } 2008 \\
\text { and } 2014\end{array}$ \\
\hline Portugal & $\begin{array}{l}\text { A partial survey was conducted in } 1990 \text { in and around Lisbon. Wider sur- } \\
\text { veys were conducted in } 1992 \text { and } 1994 .\end{array}$ \\
\hline Serbia & $\begin{array}{l}\text { Serbia was recently included in the survey on violence against women, } \\
\text { which also used victimisation survey methodology (Research in the EU } \\
\text { countries conducted by Fundamental Rights) }\end{array}$ \\
\hline Slovenia & A survey on ICVS lines was conducted in 2001 \\
\hline Spain & $\begin{array}{l}\text { Surveys were conducted in } 1978,1980,1991,1995 \text { by the Centre of Soci- } \\
\text { ological Research but data are no longer available. }\end{array}$ \\
\hline Switzerland & $\begin{array}{l}\text { Surveys - on ICVS lines- were conducted in } 1984 / 7,1989,1996,2000 \\
\text { and } 2005 \text { by the University of Lausanne and in } 2011 \text { by Zurich University }\end{array}$ \\
\hline Ukraine & Regional victimisation surveys have been carried by different institutions. \\
\hline
\end{tabular}


Table 6.1.2.3 National victimisation surveys: general comments and references

Albania

Details of some past surveys can be found at:

http://www.unicef.org/albania/Violence_against_children_in_Albania.pdf

http://www.undp.org/content/albania/en/home/library/poverty/domestic-violence-in-albanianational-survey/

Hysi, V. (2000) The ICVS in Albania, in UNICRI publication No 62, Rome

Hysi, V. (2001) The ICVS Albania (National Report), Tirana.

Armenia

The 2010 survey was conducted with the support of the OSCE office in Yerenan

Austria

Data from the 2016 survey on domestic violence can be found at https://rm.coe.int/16806ee8b2

Croatia

A 1997 Survey was conducted - for Zagreb only - by the Institute for Criminal law, criminology, and victimisation at the Zagreb Law School. A 2000 survey was conducted by Gallup and the 2009 survey by UNDP Croatia.

Czech Republic The 2006 and 2013 victimisation surveys were based on the ICVS.

Surveys conducted by the Institute of Criminology \& Social Prevention

Finland

Since 2012 the Finnish National Research Institute of Legal Policy (from 2015 onwards Institute of Criminology and Legal Policy, University of Helsinki) has conducted an annual victimisation survey. Data is collected by mail and online questionnaire. In 2015 the sample size was 14000 and 15-74 years-old persons were picked by random sampling from the Finnish Population register. Response rate was $47.6 \%$. The results of this survey are comparable with those of 2012 to 2014 but not with the surveys conducted before 2012 .

In 2013, a survey on the experiences of violence and abuse by children and adolescents was conducted. A nationally representative sample $(\mathrm{N}=11,364)$ of Finnish 6 th and 9th graders, 12 and 15 years old respectively, answered the questionnaire, which asked about the respondents' experiences of general criminal violence, sibling and peer victimisation, parental corporal punishment, sexual abuse, violence, and harassment connected to online activity and mobile phones, and witnessing domestic violence. In 2018, the University of Helsinki will perform the second national survey of crime against businesses. The national business crime survey analyses crime against companies and their employees, and the harm caused by such crime. The 2018 survey will focus on crime targeted at the retail and hotel and restaurant sectors. The survey will cover around 3,000 workplaces across the whole of Finland.

France In 1996 CESDIP-CRNS conducted the first national victimisation survey. INSEE included a victimisation section in its permanent survey on living standards in households (EPCVM) from 1996 to 2006 . From 2007 INSEE replaced this by a reference section on living standards and security. All national surveys in France have a reference period of 24 months.

Georgia

Lithuania Surveys were supported by the EU. Each wave contained 3,000 respondents.

Methodology depends on the institution conducting the survey. Three specific institutions were the Ministry of the Interior, the Police Department, and the Law Institute of Lithuania.

Norway The Survey of Living Conditions EU-SILC is carried out annually. From 2011 onwards the survey consists of a set of core questions and a theme sections with rotating topics. The topics are repeated in a cycle of three years. In 2011 and 2014, the topics were outdoor activities, organizational activity, political participation, and social networks. In 2012, 2015 and 2018 the topics were housing conditions and offences and fear of crime.

Slovenia Data for the 2001 survey are held in the Social Sciences Data Archive. See https://www.fdv.uni-lj.si/en/research/journals/social-science-data-archive

UK: England \& Wales The Crime Survey for England and Wales (CSEW) is a continuous victimisation survey which asks respondents about their experiences of crime during the previous 12 months. Publications giving details of the methodology and the results can be accessed through: https://www.ons.gov.uk/releases/crimeinenglandandwalesyearendingmarch2019

UK: Northern Ireland The Northern Ireland Crime Survey (NICS) asks those over 16 their experiences of crime in the previous 12 months. Details of methodology and results can be found at https://www.justice-ni.gov.uk/articles/northern-ireland-crime-survey

UK: Scotland The Scottish Crime and Justice Survey (SCJS) asks people about experiences and perceptions of crime. It is completed face to face in the homes of respondents. The survey in its current format was carried out on an annual basis in the 2008/09, 2009/10 and 2010/11 survey years. From $2011 / 12$ to $2016 / 7$ the survey interviewed 12,000 households every two years. From 2016/7 the survey interviews just under 6,000 households every year. More details of methodology and results are at https://www.gov.scot/publications/scottish-crimejustice-survey-2017-18-main-findings/ 


\subsubsection{Standard wording of the questions included in national victimisation surveys}

Table 6.1.3.1 shows the wording of the questions for the different offences included in the surveys, as well as for trust in the police and feelings of safety. The table provides the standard wording inspired by the ICVS questionnaire, specifying the countries that applied a similar wording, those that did not include the question in their survey, and those that used a different wording. For the latter, the tables included in section 6.2 provide the wording used in their questionnaire

Table 6.1.3.1 Wording of the questions included in national victimisation surveys $(1 / 2)$

\begin{tabular}{|c|c|c|c|c|}
\hline $\begin{array}{c}\text { Offencel } \\
\text { Topic }\end{array}$ & Standard wording & Similar wording & Different wording & Question not included \\
\hline : & $\begin{array}{l}\text { Have you been per- } \\
\text { sonally attacked (e.g. } \\
\text { someone hit you with } \\
\text { his/her fists, kicked } \\
\text { you, or used force or } \\
\text { violence in any way?) }\end{array}$ & $\begin{array}{l}12 \text { countries; Belgium, } \\
\text { Croatia, Estonia, } \\
\text { Georgia, Germany, } \\
\text { Ireland, Italy, Nether- } \\
\text { lands, Poland, Swe- } \\
\text { den, UK: Northern Ire- } \\
\text { land, UK: Scotland }\end{array}$ & $\begin{array}{l}10 \text { countries: } \\
\text { Bulgaria, Czech Re- } \\
\text { public, Denmark Fin- } \\
\text { land, France, Iceland, } \\
\text { Lithuania, Norway, } \\
\text { Turkey, UK: England } \\
\text { \& Wales. }\end{array}$ & 1 country: Portugal \\
\hline 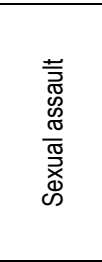 & $\begin{array}{l}\text { Has anyone grabbed } \\
\text { you, touched you or } \\
\text { assaulted you for sex- } \\
\text { ual reasons in a really } \\
\text { offensive way? }\end{array}$ & $\begin{array}{l}6 \text { countries: Belgium, } \\
\text { Estonia, Georgia, It- } \\
\text { aly, Netherlands, } \\
\text { Sweden }\end{array}$ & $\begin{array}{l}12 \text { countries: Bulgaria, } \\
\text { Croatia, Czech Re- } \\
\text { public, Denmark, Fin- } \\
\text { land, France, Iceland, } \\
\text { Lithuania, Portugal, } \\
\text { Turkey, UK: England } \\
\& \text { Wales, UK: Scot- } \\
\text { land }\end{array}$ & $\begin{array}{l}5 \text { countries: Germany, } \\
\text { Ireland, Norway, Po- } \\
\text { land, UK: Northern } \\
\text { Ireland }\end{array}$ \\
\hline $\begin{array}{l}\text { ते } \\
\text { ه্ㅇ } \\
\text { ه }\end{array}$ & $\begin{array}{l}\text { Has anyone stolen } \\
\text { from you by using } \\
\text { force or threatening } \\
\text { you? }\end{array}$ & $\begin{array}{l}11 \text { countries: Belgium, } \\
\text { Bulgaria, Croatia, } \\
\text { Denmark, Estonia, } \\
\text { Georgia, Germany, } \\
\text { Ireland, Italy, Poland, } \\
\text { Sweden }\end{array}$ & $\begin{array}{l}10 \text { countries: Czech } \\
\text { Republic, Finland, } \\
\text { France, Lithuania, } \\
\text { Netherlands, Portugal, } \\
\text { Turkey, UK: England } \\
\text { \& Wales, UK: North- } \\
\text { ern Ireland, UK: Scot- } \\
\text { land }\end{array}$ & $\begin{array}{l}2 \text { countries: Iceland, } \\
\text { Norway }\end{array}$ \\
\hline 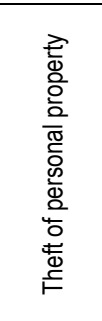 & $\begin{array}{l}\text { Have you personally } \\
\text { been the victim of a } \\
\text { theft of personal prop- } \\
\text { erty such as pickpock- } \\
\text { eting or theft of a } \\
\text { purse, wallet, clothing, } \\
\text { jewellery, sports } \\
\text { equipment, etc.? }\end{array}$ & $\begin{array}{l}7 \text { countries: Bulgaria, } \\
\text { Croatia, Estonia, } \\
\text { Georgia, Germany, It- } \\
\text { aly, Poland }\end{array}$ & $\begin{array}{l}15 \text { countries: Belgium, } \\
\text { Czech Republic, Den- } \\
\text { mark, Finland, France, } \\
\text { Iceland, Ireland, Lithu- } \\
\text { ania, Netherlands, } \\
\text { Norway, Portugal, } \\
\text { Sweden, UK: England } \\
\text { \& Wales, UK: North- } \\
\text { ern Ireland, UK: Scot- } \\
\text { land }\end{array}$ & 0 countries \\
\hline 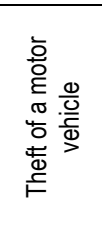 & $\begin{array}{l}\text { Have you or other } \\
\text { members of your } \\
\text { household had any of } \\
\text { their cars, vans or } \\
\text { trucks, stolen? }\end{array}$ & $\begin{array}{l}11 \text { countries: Bulgaria, } \\
\text { Estonia, Georgia, Ger- } \\
\text { many, Ireland, Italy, } \\
\text { Netherlands, Portugal, } \\
\text { Sweden, UK: Scot- } \\
\text { land, UK: Northern } \\
\text { Ireland }\end{array}$ & $\begin{array}{l}8 \text { countries: Belgium, } \\
\text { Croatia, Czech Re- } \\
\text { public, Finland, } \\
\text { France, Poland, Tur- } \\
\text { key, UK: England \& } \\
\text { Wales, }\end{array}$ & $\begin{array}{l}4 \text { countries: Denmark, } \\
\text { Iceland, } \\
\text { Lithuania } \\
\text { Norway }\end{array}$ \\
\hline
\end{tabular}


Table 6.1.3.1 Wording of the questions included in national victimisation surveys (2/2)

\begin{tabular}{|c|c|c|c|c|}
\hline $\begin{array}{l}\text { Offence/ } \\
\text { Topic }\end{array}$ & Standard wording & Similar wording & Different wording & Question not included \\
\hline 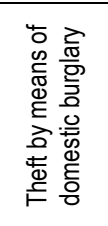 & $\begin{array}{l}\text { Has anyone actually } \\
\text { got into your house or } \\
\text { flat without permis- } \\
\text { sion and stolen or } \\
\text { tried to steal some- } \\
\text { thing? }\end{array}$ & $\begin{array}{l}12 \text { countries: Bul- } \\
\text { garia, Croatia, Esto- } \\
\text { nia, Georgia, Ger- } \\
\text { many, Ireland, Italy, } \\
\text { Poland, Sweden, UK: } \\
\text { England \& Wales, } \\
\text { UK: Northern Ireland }\end{array}$ & $\begin{array}{l}7 \text { countries: Czech } \\
\text { Republic, Denmark, } \\
\text { Finland, France, Ice- } \\
\text { land, Portugal, Tur- } \\
\text { key, UK: Scotland }\end{array}$ & $\begin{array}{l}3 \text { countries: Lithuania, } \\
\text { Netherlands, } \\
\text { Norway }\end{array}$ \\
\hline 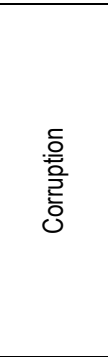 & $\begin{array}{l}\text { Has any government } \\
\text { official, for example a } \\
\text { customs officer, a po- } \\
\text { lice officer, or inspec- } \\
\text { tor in your country } \\
\text { asked you or ex- } \\
\text { pected you to pay a } \\
\text { bribe for his or her } \\
\text { services? }\end{array}$ & $\begin{array}{l}2 \text { countries: Estonia, } \\
\text { Georgia }\end{array}$ & $\begin{array}{l}3 \text { countries: Lithuania, } \\
\text { Portugal, Sweden }\end{array}$ & $\begin{array}{l}17 \text { countries: Bul- } \\
\text { garia, Croatia, Czech } \\
\text { Republic, Denmark, } \\
\text { Finland, France, Ger- } \\
\text { many, Ireland, Ice- } \\
\text { land, Italy, Nether- } \\
\text { lands, Norway, Po- } \\
\text { land, Turkey, UK: } \\
\text { England \& Wales, } \\
\text { UK: Northern Ireland, } \\
\text { UK: Scotland }\end{array}$ \\
\hline 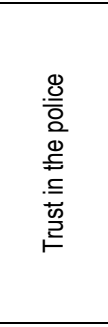 & $\begin{array}{l}\text { Taking everything into } \\
\text { account how good a } \\
\text { job do you think the } \\
\text { police do in your area } \\
\text { in controlling crime? } \\
\text { Do you think they do } \\
\text { a very good job, a } \\
\text { fairly good job, a poor } \\
\text { job or a very poor } \\
\text { job? }\end{array}$ & $\begin{array}{l}9 \text { countries: Bulgaria, } \\
\text { Croatia, Estonia, } \\
\text { Georgia, Germany, } \\
\text { Iceland, Ireland, Italy, } \\
\text { Poland }\end{array}$ & $\begin{array}{l}10 \text { countries: Czech } \\
\text { Republic, France, } \\
\text { Lithuania, Nether- } \\
\text { lands, Portugal, Swe- } \\
\text { den, Turkey, UK: } \\
\text { England \& Wales UK: } \\
\text { Northern Ireland, UK: } \\
\text { Scotland }\end{array}$ & $\begin{array}{l}3 \text { countries: Denmark, } \\
\text { Finland, Norway }\end{array}$ \\
\hline 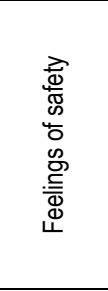 & $\begin{array}{l}\text { How safe do you feel } \\
\text { walking alone in your } \\
\text { area after dark? Do } \\
\text { you feel very safe, } \\
\text { fairly safe, a bit un- } \\
\text { safe or very unsafe? }\end{array}$ & $\begin{array}{l}13 \text { countries: Bul- } \\
\text { garia, Croatia, Esto- } \\
\text { nia, Georgia, Ger- } \\
\text { many, Iceland, Ire- } \\
\text { land, Italy, Poland, } \\
\text { Sweden. UK: England } \\
\text { \& Wales, UK: North- } \\
\text { ern Ireland, UK: Scot- } \\
\text { land. }\end{array}$ & $\begin{array}{l}8 \text { countries: Belgium, } \\
\text { Finland, France, Lith- } \\
\text { uania, Netherlands, } \\
\text { Norway, Portugal, } \\
\text { Turkey }\end{array}$ & $\begin{array}{l}2 \text { countries: Czech } \\
\text { Republic, Denmark }\end{array}$ \\
\hline
\end{tabular}


Table 6.1.3.2 Comments on the wording of the questions included in national victimisation surveys

\begin{tabular}{|c|c|}
\hline Bulgaria & $\begin{array}{l}\text { No questions on corruption were included. However, a separate, much more elaborate, } \\
\text { annual, national survey on corruption is conducted. Sometimes it coincides with the victim- } \\
\text { isation survey (the same sample, the questions are added to the victimisation question- } \\
\text { naire), but usually it does not. }\end{array}$ \\
\hline Croatia & $\begin{array}{l}\text { The wording of the questions asked in } 2000 \text { only differed from those in } 2009 \text { with regard to } \\
\text { sexual assaults. The definition of sexual assault in the Croatian survey in } 2009 \text { was nar- } \\
\text { rower in the sense that only rape and attempted rape were included, while other forms of } \\
\text { sexual assaults were excluded. The } 2000 \text { survey included a broader question that in addi- } \\
\text { tion to rape and attempted rape also covered other offensive sexual behaviour. As far as } \\
\text { robbery is concerned, the question is sufficiently similar to be considered as matching the } \\
\text { one provided here. The question on theft of a motor vehicle in the Croatian } 2009 \text { survey } \\
\text { was narrower than the one provided here since it referred only to personal automobiles and } \\
\text { did not include other members of the same household. }\end{array}$ \\
\hline Czech Republic & $\begin{array}{l}\text { For the most recent survey, a new model was used with both core and specific variable } \\
\text { modules. The core module is basic battery of questions that creates the space for long- } \\
\text { term regularly repeated monitoring. The survey also focuses on previously neglected or } \\
\text { new issues and phenomena such as psychological aspects of victimisation (e.g., victim's } \\
\text { motivation for reporting the incident, impacts of victimisation). The survey explored a 3- } \\
\text { year period. In most incidents victims were further questioned whether the incident had } \\
\text { occurred in the last year, and how many times. The specific variable module is a change- } \\
\text { able battery of questions that focus on specific topics (they might not be repeated in each } \\
\text { round). Its content is flexible and partly dependent on available finance. One module fo- } \\
\text { cuses on mapping the effectiveness of legislation and the level of care for victims. }\end{array}$ \\
\hline Denmark & $\begin{array}{l}\text { The question of theft is followed by a question regarding the place and type of the theft. } \\
\text { The safety question is: How often do you think of the risk of being a victim of crime, i.e., } \\
\text { assault, theft, vandalism, etc. }\end{array}$ \\
\hline Estonia & $\begin{array}{l}\text { Bodily injury (assault): according to the given definition verbal assaults are excluded and } \\
\text { therefore the reporting rate is not known (it is known for all assaults only). }\end{array}$ \\
\hline France & $\begin{array}{l}\text { For detailed information on the French victimisation survey see Ministere de L'Interieur } \\
\text { 'Rapport enquete - cadres de vie et securite 2016' }\end{array}$ \\
\hline Germany & $\begin{array}{l}\text { The following question was included about cybercrime from 2012: "Viktimisierung bei In- } \\
\text { ternetnutzung: Bitte denken Sie an Ihre Nutzung des Internets zu privaten Zwecken, Waren } \\
\text { Sie in der Zeit seit Anfang [2012] von den folgenden Sicherheitsproblemen selbst betrof- } \\
\text { fen?": }\end{array}$ \\
\hline Lithuania & $\begin{array}{l}\text { Not all results of the } 2011 \text { survey have been published. The methodology of victimisation } \\
\text { surveys was different: respondents were asked to list which offences they had been a vic- } \\
\text { tim of, or were asked whether they had become a victim of crime. See report at Justickis, } \\
\text { Viktoras, Uscila, Rokas and Kiškis, Alfredas (2012) "Two-Rays Approach in the Integration } \\
\text { of Victimological and Recorded Data on Criminality". Jurisprudence, } 19 \text { (12), p. 803-820 } \\
\text { (http://www3.mruni.eu/ akiskis/Alfredo-str2012-2.pdf) }\end{array}$ \\
\hline Netherlands & Not all questions are available for each of the required years \\
\hline Norway & $\begin{array}{l}\text { No specific questions on Robbery, Domestic Burglary or Theft of a motor vehicle but such } \\
\text { offences are probably included in the question about theft. Threats are also collected. }\end{array}$ \\
\hline Poland & $\begin{array}{l}\text { There were no changes in methodology of survey between 2001-2016. There were } \\
\text { changes in the way of calculating presented data - it was not directly calculated from the } \\
\text { survey database but from the published report. }\end{array}$ \\
\hline UK: England \& Wales & $\begin{array}{l}\text { Full details of the most recent surveys can be found using the ONS gateway: } \\
\text { https://www.ons.gov.uk/releases/crimeinenglandandwalesyearendingmarch2017 }\end{array}$ \\
\hline UK: Scotland & $\begin{array}{l}\text { More detail can be found at https://wwwgov.scot/Topics/Statistics/Browse/Crime-Jus- } \\
\text { tice/crime-and-justi2.ce-survey }\end{array}$ \\
\hline
\end{tabular}




\subsubsection{Completeness and quality of the data}

Up to 23 countries answered the questions on the wording of the different questions and the methodology of the surveys.

Regarding the completeness of the surveys:

a) Bodily injury is the offence with the highest number of countries reporting data (23 on its prevalence, 10 on its incidence and 17 on its reporting to the police.)

b) Theft by means of domestic burglary $(22,11$ and 17 countries)

c) Theft of a motor vehicle (18,10 and 16 countries)

d) Sexual assault (15, 9 and 10 countries)

e) Corruption (4,1 and 1 country)

The indicator most commonly used by countries was the prevalence of victimisation: e.g., the percentage of households/individuals victimised) followed by the percentage of victims that reported the offence to the police, while the incidence of victimisation was reported less frequently. Seventeen countries provided data on the answers to the questions on trust in the police and the quality of the job of the police and 21 provided data on feelings of safety.

No results from national victimisation surveys can be exact because of the sampling errors associated with carrying out surveys on a finite sample of the population. This contrasts with figures in other chapters of the sourcebook that are a complete record of events or persons recorded by the criminal justice system. Sample sizes are shown in Table 6.3.1. and many countries give ranges associated with their survey results. Such ranges should be taken into account when interpreting national results.

\subsubsection{Main Results}

Among the offences included in this section, theft of personal property showed the highest prevalence in Europe in 2015 and sexual assault the lowest one. The percentage of respondents feeling unsafe or very unsafe on the street after dark varies widely across countries; but, with only a couple of exceptions, it was lower than $50 \%$. Also, with a couple of exceptions, the percentage of respondents thinking that the police were doing a good or very good job in controlling crime in the local area was higher than $50 \%$. However, data showed no direct correlation between confidence in the police and unsafety in the streets after dark.

\subsubsection{Other victimisation surveys carried out by European countries.}

Data and metadata contained in Chapter 6 are those associated with national household victimisation surveys. However, crime data included in Chapter 1 is the total of crimes recorded by the police and this will include crimes other than against those 
living in households. Readers may be interested in the following comments and sources:

\section{Business and commercial surveys}

Many crimes recorded by the police are committed against businesses and other commercial organisations. Measuring such crimes is problematic and a good discussion of difficulties and attempts to overcome them can be found in Killias et al. (2011) ${ }^{41}$. Business surveys have been carried out from time to time by only a small number of countries in Europe. Most other countries are content to join crossnational attempts to measure crime against business (see section 6.1.6.2). The first cross-national business crime survey - using a methodology similar to the ICVS was conducted in 1994 in the Czech Republic, Germany, Hungary, Netherlands, Switzerland, and the UK. National surveys have included:

a) In 1989, a business crime survey was carried out among Dutch businesses $^{42}$.

b) UK: England and Wales has carried out commercial victimisation surveys since 1994. Years covered are 1994, 2002 and annually since 2012. More details are given at https://www.gov.uk/government/statistics/crimeagainst-businesses-findings-from-the-2017-commercial-victimisation-survey

c) UK- Scotland. Results from the first Scottish Business Crime Survey were published in 2001: https://link.springer.com/article/10.1057/palgrave.sj.8340089 Since then further commercial surveys have been carried out by the industry itself: e.g. the Scottish Grocers Federation carried a further survey in 2017 see: https://www.scottishshop.org.uk/images/ SGF-Crime-Report-Guidance-2017.pdf

d) The first Italian Business crime survey was carried out by Transcrime in 2008 and collected data from 11.500 companies about their experience of crime: see http://www.transcrime.it/wp-content/uploads/2014/02/Executive-summary-Report-16.pdf. This was a pilot for the cross-national European business survey described in 6.1.5.2 (f).

\section{Cross-national surveys of different types of victim}

Another related group of surveys not covered by this chapter are those on specific types of victims, either on a national or cross-national basis: examples are:

\footnotetext{
41 Killias et al. (2011) A survey of Business crime in Switzerland: on the difficulties of field research, see: https://www.zora.uzh.ch/id/eprint/58433/.

42 Directie Criminaliteitspreventie (1990). Bedrijfsleven en Criminaliteit, Kerngetallen uit de eerste Nederlandse slachtofferenquet onder bedrijven, Ministerie van Justitie, Den Haag.
} 
a) The EU minorities and discrimination survey (EU-MIDIS) conducted in 200943.

b) The Violence against women in the EU survey conducted in $2014^{44}$.

c) Surveys of victims of cybercrime 45

d) The 4th biennial Global Economic Crime Survey is based on interviews with executives responsible for detecting economic fraud in 5428 companies in 40 countries. ${ }^{46}$ It is conducted by PWC, a commercial accounting organisation. Results are also published for individual European countries: e.g., the Russian results for 2018 are published at https://www.pwc.ru/en/publications/recs-2018.html

e) The Global White Collar crime survey: Anti-Bribery and Corruption was based upon 250 companies and carried out by the University of Manchester, UK in 2018.: see https://www.research.manchester.ac.uk/portal/ files/78276482/Lord_et_al_2018_Global_White_Collar_Crime_Survey_spreads.pdf

f) A pilot Study of a EU-wide survey of Business crime was carried out in 201247: see https://ec.europa.eu/home-affairs/sites/homeaffairs/files/elibrary/docs/1eu_bcs_final_report_galluptranscrime_executive_summary_en.pdf

\footnotetext{
${ }^{43}$ See http://fra.europa.eu/en/project/2011/eu-midis-european-union-minorities-and-discrimination-survey.

${ }^{44}$ See http:// fra.europa.eu/en/publication/2014/vaw-survey-main-results.

${ }^{45}$ See Can, M., Reep-van be Burgh, M. \& Junger, M. (2018). Victims of Cybercrime in Europe. A review of victim surveys https://link.springer.com/article/10.1186/s40163-018-0079-3.

46 The 4th biennial Global Economic Crime Survey is available for download at pwc.com/crimesurvey.

${ }^{47}$ For a brief description see Del Frate, A.A. (2012) The International Crime Business Survey: Findings from Nine Central-Eastern European Cities. European Journal on Criminal Policy and Research, September 2004, Volume 10, Issue 2-3, pp 137-161
} 


\subsection{Tables from household victimisation surveys}

\subsubsection{Bodily injury}

Table 6.2.1.1 Prevalence of bodily injury (assault) victimisation during the last 12 months according to national victimisation surveys

\begin{tabular}{|c|c|c|c|c|c|c|}
\hline & 1990 & 1995 & 2000 & 2005 & 2010 & 2015 \\
\hline Belgium & .. & 1.2 & 2.3 & 2.1 & 2.8 & .. \\
\hline Bulgaria & .. & .. & (1.1) & $(0.3)$ & $(0.5)$ & .. \\
\hline Croatia & .. & .. & 0.9 & .. & 7 & .. \\
\hline Czech Republic & .. & .. & .. & .. & .. & 1.5 \\
\hline Denmark & .. & 1.7 & 3.2 & 1.8 & 1.4 & 1.3 \\
\hline Estonia & 2.2 & 1.7 & 2.3 & 1.4 & 2.4 & 2.3 \\
\hline Finland & 5.7 & 5.6 & 6.1 & 5.8 & 6.1 & 7.3 \\
\hline France & 0.9 & 1.5 & 1.4 & 1.3 & 1.5 & 1.5 \\
\hline Georgia & .. & .. & .. & .. & 0.4 & .. \\
\hline Germany & .. & .. & .. & .. & 2.8 & 3.0 \\
\hline Iceland & .. & & .. & .. & 3.4 & 2.1 \\
\hline Ireland & .. & 1 & 1 & 1 & 1 & .. \\
\hline Italy & .. & $(0.5)$ & $(0.8)$ & .. & $(0.6)$ & 1.2 \\
\hline Lithuania & .. & & 8.2 & 11.5 & 4 & .. \\
\hline Netherlands & .. & 1.8 & 1.3 & 1.5 & 1 & 0.7 \\
\hline Norway & .. & .. & 5.1 & 5.5 & 4.3 & 3.5 \\
\hline Poland & .. & & .. & .. & 1.1 & 0.8 \\
\hline Portugal & .. & 0.8 & .. & .. & .. & .. \\
\hline Sweden & .. & .. & .. & 2.7 & 2.4 & 2.0 \\
\hline Turkey & .. & .. & .. & (1.1) & (2.4) & (1.6) \\
\hline UK: England \& Wales & 2.2 & 3.2 & 2.2 & 2 & 1.6 & 0.9 \\
\hline UK: Northern Ireland & .. & .. & (2.1) & (2.1) & (1.6) & $(0.7)$ \\
\hline UK: Scotland & .. &.. & .. & .. & 2.8 & 2.8 \\
\hline Mean & 3 & 2 & 3 & 3 & 2.4 & 2.1 \\
\hline Median & 2 & 2 & 2 & 2 & 2.0 & 2.0 \\
\hline Minimum & 1 & 1 & 1 & 0 & 0.4 & 0.7 \\
\hline Maximum & 6 & 6 & 8 & 12 & 7.0 & 7.3 \\
\hline
\end{tabular}

Figures in brackets see table 6.2.1.3. and notes on tables 6.2.1.1. to 6.2.9.2. 
Table 6.2.1.2 Bodily injury (assault) victimisation: Percentage of victims reporting to the police

\begin{tabular}{lrrrrrr} 
& 1990 & 1995 & 2000 & 2005 & 2010 & 2015 \\
\hline Belgium &.. & 39 & 29.6 & 33.9 & 32.7 &.. \\
Croatia &.. &.. & 26.6 &.. & 39 &.. \\
Denmark &.. & 35 & 39 & 43 & 47 & 38 \\
Finland & 8.2 & 17.4 & 14.9 & 22.6 & 15 &.. \\
France & 54.4 & 38.2 & 45.6 & 36.6 & 30.6 & 42.0 \\
Georgia &.. &.. &.. &.. & 42 &.. \\
Germany &.. &.. &.. &.. & 31.6 & 36.6 \\
Iceland &.. &.. &.. &.. & 45.8 & 38.7 \\
Ireland &.. & 62 & 51 & 53 & 55 &.. \\
Italy &.. &.. & 21.8 &.. & 19 & 20 \\
Lithuania &.. &.. & 53.8 & $(42.6)$ &.. &.. \\
Netherlands &.. & 48.2 & 40.5 & 52.8 & 41.3 & 34.9 \\
Poland &.. &.. &.. &.. & 52.8 &.. \\
Sweden &.. &.. &.. & 32 & 37 & 27 \\
UK: England \& Wales & $(47.7)$ & $(39.7)$ & $(55.9)$ & $(58.2)$ & $(64.9)$ &.. \\
UK: Northern Ireland &.. &.. & 54 & 30 & 36 & 48 \\
UK: Scotland &.. &.. &.. &.. & 52 & 43 \\
\hline Mean & 37 & 40 & 349 & 40 & 40.1 & 36.6 \\
Median & 48 & 39 & 41 & 40 & 41 & 39 \\
Minimum & 8 & 17 & 15 & 23 & 15 & 20 \\
Maximum & 54 & 62 & 56 & 58 & $(64.9)$ & 48 \\
\hline Figures in backets & &. & &
\end{tabular}

Figures in brackets see table 6.2.1.3. and notes on tables 6.2.1.1. to 6.2.9.2. 
Table 6.2.1.3 Bodily injury (assault) victimisation: Deviations from the ICVS standard wording of the question

\begin{tabular}{|c|c|}
\hline ESB standard wording & $\begin{array}{l}\text {...have you been personally attacked (e.g. did someone hit you with } \\
\text { his /her fists, kicked you, or used force or violence on you in any } \\
\text { way)? }\end{array}$ \\
\hline Bulgaria & $\begin{array}{l}\text { Has someone attacked you or threatened you so that you experi- } \\
\text { enced intense fear, indoors or outside - in a bar, on the street, at } \\
\text { school, on public transport, at the beach or at your workplace? Other } \\
\text { questions in the survey ask if it was just a threat or an actual attack } \\
\text { and whether the respondent was injured or not }\end{array}$ \\
\hline Czech Republic & $\begin{array}{l}\text { a) In the last } 3 \text { years has someone personally (who is not a member } \\
\text { of your household) physically attacked you, and not because of trying } \\
\text { to steal from you? b) Has this happened during the last } 12 \text { months? }\end{array}$ \\
\hline Denmark & Have you been a victim of violence during the last 12 months? \\
\hline Finland & $\begin{array}{l}\text { During the last } 12 \text { months, has any known or unknown person be- } \\
\text { haved in any of the following ways toward you: (1) slapped you; (2) } \\
\text { pulled your hair; (3) hit you with a fist; (4) hit you with a hard object; } \\
\text { (5) kicked or strangled you; (6) used a weapon? }\end{array}$ \\
\hline France & $\begin{array}{l}\text { (In year } n-1 \text { or } n-2 \text { ), have you personally been a victim of physical } \\
\text { violence from a person not currently living in the same dwelling as } \\
\text { you (including from a former spouse or a spouse who currently does } \\
\text { not live with you)? }\end{array}$ \\
\hline Iceland & $\begin{array}{l}\text { Were you a victim of a violent crime in } 2015 \text { ? Violent crimes include } \\
\text { assault, for example being beaten with a fist or a weapon. }\end{array}$ \\
\hline Lithuania & $\begin{array}{l}\text { Have you been beaten or has physical pain or health impairment } \\
\text { been caused to you by the use of other types of violence during } 2015 \text { ? }\end{array}$ \\
\hline Norway & $\begin{array}{l}\text { We ask the respondents whether during the last } 12 \text { months they have } \\
\text { been exposed to violence with or without visible marks or injury. }\end{array}$ \\
\hline Turkey & $\begin{array}{l}\text { Have you personally been a victim of one of the events below in } \\
\text { (year): ...other (injury, sexual harassment, robbery)? }\end{array}$ \\
\hline UK: England \& Wales & $\begin{array}{l}\text { And again, since ... has anyone, including people you know well, de- } \\
\text { liberately hit you with their fists or with a weapon of any sort or kicked } \\
\text { you or used force or violence in any other way? }\end{array}$ \\
\hline
\end{tabular}
Similar definition: Belgium, Croatia, Estonia, Finland, Georgia, Germany, Ireland, Italy, Netherlands, Poland, Sweden, UK: Northern Ireland, UK: Scotland. 


\subsubsection{Sexual assault}

Table 6.2.2.1 Prevalence of sexual assault victimisation during the last 12 months according to national victimisation surveys

\begin{tabular}{lrrrrrr} 
& 1990 & 1995 & 2000 & 2005 & 2010 & 2015 \\
\hline Belgium &.. &.. & 1.2 & 0.9 & 1.2 &.. \\
Bulgaria &.. &.. & $(0.2)$ & $(0.1)$ & $(0.3)$ &.. \\
Croatia &.. &.. & 2.7 &.. & 0.3 &.. \\
Czech Republic &.. &.. &.. & 2 &.. & 0.5 \\
Denmark &.. &.. &.. &.. & 0.1 & 0.4 \\
Estonia & $(2.5)$ & $(1.3)$ & $(3.6)$ & $(1.4)$ & $(2)$ &.. \\
Finland &.. &.. &.. &.. &.. & 1.1 \\
France &.. &.. &.. &.. &.. & 1.0 \\
Georgia &.. &.. &.. &.. & 0.1 &.. \\
Iceland &.. &.. &.. &.. & 0.5 & 2.0 \\
Lithuania &.. &.. &. & 0.7 & 0.3 &.. \\
Netherlands &.. & 1.1 & 1 & 0.9 & 0.7 & 0.1 \\
Sweden &.. &.. &.. & 0.9 & 0.7 & 1.7 \\
Turkey &.. &.. &.. & $(0.5)$ &.. &.. \\
UK: England \& Wales &.. &.. &.. & 1.5 &.. &.. \\
\hline Mean & 3 & 1 & 1 & 1 & 0.6 & 1.1 \\
Median & 3 & 1 & 1 & 1 & 0.7 & 1.0 \\
Minimum & 3 & 0 & 0 & 0 & 0.1 & 0.1 \\
Maximum & 3 & 1 & 4 & 2 & $(2)$ & 2.0 \\
\hline
\end{tabular}

Figures in brackets see table 6.2.2.3. and notes on tables 6.2.1.1. to 6.2.9.2.

Table 6.2.2.2. Sexual assault: Percentage of victims reporting to the police

\begin{tabular}{lrrrrrr} 
& 1990 & 1995 & 2000 & 2005 & 2010 & 2015 \\
\hline Belgium &.. &.. & 3.8 & 4.8 & 7.2 &.. \\
Croatia &.. &.. & 15.5 &.. & 16 &.. \\
Denmark &.. &.. &.. &.. & 24 & 39 \\
Estonia &.. &. & 10 & 25 &.. &.. \\
France & & & & & & 8 \\
Georgia &.. &.. &.. &.. & $(100)$ &.. \\
Iceland &.. &.. &.. &.. & 18.2 & 10.3 \\
Lithuania &.. &.. & 0 & $(40)$ &.. &.. \\
Netherlands &.. & 15 & 6.8 & 11.3 & 7.3 & 12.4 \\
Sweden &.. &.. &.. & 11 & 23 & 9 \\
\hline Mean &.. & 12 & 7 & 18 & 17 & 16 \\
Median &.. & 12 & 7 & 11 & 18 & 10 \\
Minimum & 0 & 8 & 0 & 5 & 7 & 8 \\
Maximum & 0 & 15 & 16 & 40 & $(100)$ & 39 \\
\hline
\end{tabular}

Figures in brackets see table 6.2.2.3. and notes on tables 6.2.1.1. to 6.2.9.2. 
Table 6.2.2.3 Sexual assault: Deviations from the ICVS standard wording of the question

\begin{tabular}{|c|c|}
\hline ESB Standard wording & $\begin{array}{l}\text {... has anyone grabbed you, touched you or assaulted you for sexual reasons } \\
\text { in a really offensive way? }\end{array}$ \\
\hline Bulgaria & $\begin{array}{l}\text { Let me ask you a very personal question. Sometimes a person can be touched } \\
\text { or attacked in a very offensive way, for sexual reasons. This can happen in- } \\
\text { doors or outside, for example in a bar, on the street, at school, on public } \\
\text { transport, at the cinema, on the beach or at the workplace. Has someone } \\
\text { touched you or attacked you for sexual reasons and against your will? }\end{array}$ \\
\hline Croatia & Has someone raped you or tried to rape you? \\
\hline Czech Republic & $\begin{array}{l}\text { has anyone grabbed you, touched you or assaulted you for sexual reasons in } \\
\text { a really offensive way? It can happen at home or elsewhere, such as on the } \\
\text { street, in a restaurant }\end{array}$ \\
\hline Denmark & $\begin{array}{l}\text { Has a man during the last } 5 \text { years by use of force or threats tried to force you } \\
\text { or actually forced you to have intercourse with him? This also includes boy- } \\
\text { friends, a husband and other sexual partner. There is also a question of prev- } \\
\text { alence during the last } 12 \text { months. Only women are asked. The question was } \\
\text { not included until } 2008 \text {. The same goes for the question on robbery. }\end{array}$ \\
\hline Finland & $\begin{array}{l}\text { During the last } 12 \text { months, has any known or unknown person behaved in any } \\
\text { of the following ways toward you: (1) forced you into sexual intercourse or other } \\
\text { sexual interaction against your will; ( } 2 \text { ) tried to force you into sexual intercourse } \\
\text { or other sexual interaction against your will? }\end{array}$ \\
\hline France & $\begin{array}{l}\text { There are three questions in the CVS: (in year n-1 or n-2 year), (apart from the } \\
\text { people who are currently living with you) Did someone engage in a sexual ex- } \\
\text { hibition, for example a man that stripped in front of you against your will? (In } \\
\text { year n-1 or n-2 year), (apart from the people who are currently living with you). } \\
\text { Did someone try to kiss you against your will, to fondle or do other inappropriate } \\
\text { gestures? (In year n-1 or n-2 year), (apart from the people who are currently } \\
\text { living with you) Did someone require you to undergo sexual touching or to have } \\
\text { sex against your will, or try to do it? Sexual assault was not included in the } \\
\text { surveys from } 1996 \text { to } 2006 \text {. It was in the investigation of } 1986 \text {, but in a different } \\
\text { form. The figure for } 2015 \text { is an average for } 2011-2015\end{array}$ \\
\hline Iceland & $\begin{array}{l}\text { Were you a victim of a sexual crime in } 2015 \text {, including rape or an individual } \\
\text { showing their genitals to others (flashing), incest and abuse? The questions on } \\
\text { sexual assault have changed from time to time and data are not comparable. }\end{array}$ \\
\hline Lithuania & $\begin{array}{l}\text { Did anyone satisfy their sexual passion by physical contact with you against } \\
\text { your will by using physical violence or threatening to use it immediately, or oth- } \\
\text { erwise denying the possibility of resistance as well as taking advantage of your } \\
\text { helpless condition, dependence, or made you do that during } 2015 ?\end{array}$ \\
\hline Portugal & $\begin{array}{l}\text { During the last year, were you victim of a sexual crime in which you were at- } \\
\text { tacked, grabbed or groped? (If yes, how many times?) }\end{array}$ \\
\hline Turkey & $\begin{array}{l}\text { Have you personally been a victim of one of the events below in (year): ...other } \\
\text { (injury, sexual harassment, robbery) }\end{array}$ \\
\hline UK: England \& Wales & $\begin{array}{l}\text { During the last } 12 \text { months, have you been sexually interfered with, assaulted } \\
\text { or attacked, either by someone you knew or by a stranger? }\end{array}$ \\
\hline UK: Scotland & $\begin{array}{l}\text { Separate response categories for: Sexually threatened you and touched you } \\
\text { sexually when you did not want it (groping, touching of breasts, bottom or gen- } \\
\text { itals, unwanted kissing). }\end{array}$ \\
\hline
\end{tabular}

Similar definition: Belgium, Estonia, Georgia, Italy, Netherlands, Sweden. Question not included: Germany, Ireland, Poland, UK: Northern Ireland. 


\subsubsection{Robbery}

Table 6.2.3.1 Prevalence of robbery victimisation during the last 12 months according to national victimisation surveys

\begin{tabular}{|c|c|c|c|c|c|c|}
\hline & 1990 & 1995 & 2000 & 2005 & 2010 & 2015 \\
\hline Belgium & .. & 0.7 & 1 & 0.7 & 0.4 & .. \\
\hline Bulgaria & .. & .. & $(0.7)$ & $(0.6)$ & $(0.3)$ & .. \\
\hline Croatia & .. & .. & 0.7 & .. & 3 & .. \\
\hline Czech Republic & .. & .. & .. & 1.4 & .. & 1.1 \\
\hline Denmark & .. & .. & .. & .. & 1.1 & .. \\
\hline Estonia & 2.9 & 3.4 & 2.9 & 1.8 & 2.1 & 1.4 \\
\hline France & .. & .. & .. & 0.4 & 0.5 & 0.5 \\
\hline Georgia & .. & .. & .. & .. & 0.6 & .. \\
\hline Germany & .. & .. & .. & .. & 0.7 & 1.0 \\
\hline Ireland & .. & 1 & 1 & 1 & 1 & .. \\
\hline Italy & .. & 0.3 & 0.4 & .. & 0.3 & 0.5 \\
\hline Lithuania & .. & .. & 5.7 & 8.5 & 2.2 & .. \\
\hline Netherlands & .. & .. & .. & 0.3 & 0.1 & 0.1 \\
\hline Poland & .. & .. & .. & .. & 1.9 & 1.5 \\
\hline Portugal & .. & 0.5 & .. & .. & .. & .. \\
\hline Sweden & .. & .. & .. & 1 & 1 & 0.9 \\
\hline Turkey & .. & .. & .. & (2) & 1.1 & .. \\
\hline UK: England \& Wales & 0.4 & 0.7 & 0.6 & 0.5 & 0.5 & 0.3 \\
\hline UK: Northern Ireland & .. & .. & $(0.3)$ & $(0.2)$ & $(0.2)$ & $(0.2)$ \\
\hline UK: Scotland & .. & .. & .. & .. & $(0.2)$ & $(0.2)$ \\
\hline Mean & 2 & 1 & 1 & 2 & 1.0 & 0.7 \\
\hline Median & 2 & 1 & 1 & 1 & 1.0 & 0.5 \\
\hline Minimum & 0 & 0 & 0 & 0 & 0.1 & 0.1 \\
\hline Maximum & 3 & 3 & 6 & 9 & 3.0 & 1.5 \\
\hline
\end{tabular}

Figures in brackets see table 6.2.3.3. and notes on tables 6.2.1.1. to 6.2.9.2. 
Table 6.2.3.2 Robbery: Percentage of victims reporting to the police

\begin{tabular}{lrrrrrr} 
& 1990 & 1995 & 2000 & 2005 & 2010 & 2015 \\
\hline Belgium &.. & 43.9 & 50.2 & 50 & 59.4 &.. \\
Bulgaria &.. &.. & $(36)$ & $(30)$ & $(76)$ &.. \\
Croatia &.. &.. & 55 &.. & 62 &.. \\
Denmark &.. &.. &.. &.. & 77 &.. \\
Estonia &.. & 35 & 39 & 38 &.. &.. \\
France &.. &.. &.. & 57.4 & 40 & 43 \\
Georgia &.. &.. &.. &.. & 44.5 &.. \\
Germany &.. &.. &.. &.. & 30 & 32 \\
Italy &.. &.. & 49.6 &.. & 75.6 & 87.9 \\
Lithuania &.. &.. & 77.8 & $(45.7)$ &.. &.. \\
Netherlands &.. &.. &.. & 92.1 &.. &.. \\
Poland &.. &.. &.. &.. & 56.6 &.. \\
Sweden &.. &.. &.. & 33 & 57 & 44 \\
UK: England \& Wales & 47.2 & 55.1 & 44.5 & 47.4 & 55.3 &.. \\
UK: Northern Ireland &.. &.. & 62 & 58 & 73 &.. \\
UK: Scotland &.. &.. &.. &.. & 31 &.. \\
\hline Mean & 47 & 45 & 52 & 50 & 57 & 52 \\
Median & 47 & 44 & 50 & 47 & 58 & 43.5 \\
Minimum & 47 & 35 & 36 & 30 & 30 & 32 \\
Maximum & 47 & 55 & 79 & 92 & 77 & 88 \\
\hline
\end{tabular}

Figures in brackets see table 6.2.3.3. and notes on tables 6.2.1.1. to 6.2.9.2. 
Table 6.2.3.3 Robbery: Deviations from the standard ICVS wording of the question

\begin{tabular}{|c|c|}
\hline $\begin{array}{l}\text { ESB Standard word- } \\
\text { ing }\end{array}$ & $\begin{array}{l}\text { Has anyone stolen something from you by using force or threatening } \\
\text { you? }\end{array}$ \\
\hline Czech Republic & $\begin{array}{l}\text { a) In the last } 3 \text { years have anyone stolen something from you person- } \\
\text { ally by using violence or threatening of violence or has anyone tried it? } \\
\text { b) Has this happened during the last } 12 \text { months? }\end{array}$ \\
\hline Finland & $\begin{array}{l}\text { Has any of the following happened to you during the last } 12 \text { months: } \\
\text { (1) theft of personal property, such as wallet, purse, credit card or mo- } \\
\text { bile phone, taking place outside your home? }\end{array}$ \\
\hline France & $\begin{array}{l}\text { Have you personally been a victim of theft/attempted theft with physical } \\
\text { violence or threat (theft with grievous bodily harm, hand-held or mobile } \\
\text { phone bag snatching, theft with verbal threats or using a weapon, rack- } \\
\text { eteering/ extortion)? }\end{array}$ \\
\hline Iceland & $\begin{array}{l}\text { No specific question regarding robbery but it is probably included by } \\
\text { most in the question of theft and burglary. }\end{array}$ \\
\hline Lithuania & $\begin{array}{l}\text { Was your property robbed by using physical violence (threatening to } \\
\text { use it immediately), or was there an attempt to do so during 2011? }\end{array}$ \\
\hline Portugal & $\begin{array}{l}\text { There were } 2 \text { questions: - Did someone take or try to take from you } \\
\text { any values or objects using force or threats? (If yes, how many times) } \\
\text { - During the year 1994, did someone take or try to take your purse or } \\
\text { any other object used or carried with you through the process of } \\
\text { snatching? (If yes, how many times?) }\end{array}$ \\
\hline Turkey & $\begin{array}{l}\text { Have you personally been a victim of one of the events below in (year): } \\
\text {...purse snatching, pickpocketing, theft ... other (injury, sexual harass- } \\
\text { ment, robbery? }\end{array}$ \\
\hline $\begin{array}{l}\text { UK: England \& } \\
\text { Wales }\end{array}$ & $\begin{array}{l}\text { Apart from anything you have already mentioned], during that time has } \\
\text { anyone tried to steal something you were carrying out of your hands or } \\
\text { from your pockets or from a bag or case? }\end{array}$ \\
\hline UK: Northern Ireland & $\begin{array}{l}\text { A combination of questions asked which equate to mugging which in- } \\
\text { cludes robbery and snatch theft }\end{array}$ \\
\hline UK: Scotland & $\begin{array}{l}\text { Separate questions on using force and theft are asked in the incident } \\
\text { form. }\end{array}$ \\
\hline
\end{tabular}

Similar definition: Belgium, Bulgaria, Croatia, Estonia, Georgia, Germany, Ireland, Italy, Netherlands, Poland, Sweden Question not included: Finland 


\subsubsection{Theft of personal property}

Table 6.2.4.1 Prevalence of theft of personal property victimisation during the last 12 months according to national victimisation surveys

\begin{tabular}{lrrrrrr} 
& 1990 & 1995 & 2000 & 2005 & 2010 & 2015 \\
\hline Bulgaria &.. &.. & $(5.8)$ & $(2.8)$ & $(3)$ &.. \\
Croatia &.. &.. & $(1.3)$ &.. & $(4)$ &.. \\
Czech Republic &.. &.. &.. & 17.5 &.. & 6.7 \\
Denmark &.. & 16 & 17 & 13 & 12 & 10 \\
Estonia &. & 5.5 & 5.5 & 6.3 & 3.6 & 3.8 \\
Finland &.. & 2.8 & 2.6 & 2.3 & 2.3 & 2.7 \\
France & 2.7 & 3.5 & $(2.4)$ & 2 & 1.8 & 1.5 \\
Georgia &.. &.. &.. &.. & 8.5 &.. \\
Germany &.. &.. &.. &.. & 3.1 & 3.1 \\
Iceland &.. &.. &.. &.. & $(9.9)$ & $(8.5)$ \\
Italy &.. & 2.1 & 2.1 &.. & 2.2 & 1.5 \\
Lithuania &.. &.. & 6.7 & $(5.8)$ & $(16)$ &.. \\
Poland &.. &.. &.. &.. & 2.3 & 1.7 \\
Portugal &.. & 1.2 &.. &.. &.. &.. \\
Turkey &.. &.. &.. & $(7.1)$ & $(4.2)$ & $(2.7)$ \\
UK: England \& Wales & $(3.3)$ & $(4.1)$ & $(2.8)$ & $(2.2)$ & $(2.1)$ & $(2.5)$ \\
UK: Northern Ireland &.. &.. &.. &.. &.. & $(1.5)$ \\
UK: Scotland &.. &.. &.. &.. & 2.5 & 2.2 \\
\hline Mean & 5 & 5 & 5 & 7 & 5.2 & 3.7 \\
Median & 3 & 4 & 3 & 6 & 3 & 1.7 \\
\hline
\end{tabular}

Figures in brackets see table 6.2.1.3. and notes on tables 6.2.1.1. to 6.2.9.2. 
Table 6.2.4.2. Theft of personal property: Percentage of victims reporting to the police

\begin{tabular}{lrrrrrr} 
& 1990 & 1995 & 2000 & 2005 & 2010 & 2015 \\
\hline Bulgaria &.. &.. & $(17)$ & $(35)$ & $(48)$ &.. \\
Croatia &.. &.. & 50.1 &.. & 51 &.. \\
Denmark &.. &.. & 67 & 67 & 65 & 60 \\
Estonia &.. & 28 & 29 & 29 & 26 &.. \\
Finland &.. & 34 & 38 & 35 &.. &.. \\
France & 67.6 & 54.6 & $(53.1)$ & 41.8 & 33.2 & 42 \\
Georgia &.. &.. &.. &.. & 40 &.. \\
Germany &.. &.. &.. &.. & 37.6 & 42.3 \\
Iceland &.. &.. &.. &.. & 59.5 & 33.0 \\
Ireland &.. &.. &.. &.. &.. &.. \\
Italy &.. &.. & 26.8 &.. & 29.3 & 35.1 \\
Lithuania &.. &.. & 74.5 & $(46.9)$ &.. &.. \\
Netherlands &.. &.. &.. &.. &.. &.. \\
Poland &.. &.. &.. &.. & 43.6 &.. \\
UK: England \& Wales & 38 & 28.8 & 32 & 33.4 & 34.6 &.. \\
UK: Scotland &.. &.. &.. &.. & 30 & 27 \\
\hline Mean & 53 & 36 & 43 & 41 & 39 & 40 \\
Median & 53 & 31 & 38 & 35 & 35 & 38 \\
Minimum & 38 & 28 & 17 & 29 & 26 & 27 \\
Maximum & 68 & 55 & 75 & 67 & 65 & 60 \\
\hline
\end{tabular}

Figures in brackets see table 6.2.4.3. and notes on tables 6.2.1.1. to 6.2.9.2. 
Table 6.2.4.3 Theft of personal property: Deviations from the standard ICVS wording of the question $(1 / 2)$

ESB Standard wording $\quad \ldots$ have you personally been the victim of a theft of personal property, such as pick-pocketing or theft of a purse, wallet, clothing, jewellery, sports equipment?

Belgium

In the last 12 months have you been the victim of a theft out of your home?

(1) when you were not there (2) when you were there, but without violence or threat.

Czech Republic $\quad$ a) Has anyone stolen from you personally without using the violence or threats in the past 3 years - e.g. pocket theft or theft of some of your things e.g. at work, school, transport, street, etc.? (Do not include any thefts of things in your car and theft of personal belongings when breaking into dwellings or cottages / chalets) b) Has this happened during the last 12 months?

Denmark Has anyone stolen or tried to steal money or things belonging to you during the last 12 months?

Finland

France

Has any of the following happened to you during the last 12 months: theft of personal property, such as wallet, purse, credit card or mobile phone, taking place outside your home?

(In year n-1 or n-2 year), have you personally been a victim of theft or attempted theft without physical violence or threats (pickpocket theft, theft of a portfolio, a bag, a coat, a mobile phone or any other property in a public place - restaurant, dressing room or at your place of work or study?) This victimisation has been featured in all surveys, although the wording of the question may vary.

Iceland Were you a victim of a burglary or theft in 2011? Burglary includes someone entering your home, vehicle, summer cottage or other dwellings with the purpose of stealing, and theft includes stealing a wallet, bicycle or other valuables.

Ireland 3 distinct questions as follows: Theft of mobile phone, Theft with violence, Theft without violence.

Lithuania Was your property of a value over $130 \mathrm{LTL}$ stolen or was there an attempt to steal it from you personally during 2011 ?

Netherlands It is specified in more categories: a. bicycle theft; $b$. car theft; $c$. theft out of car; d. pickpocketing; e. other theft. Data for prevalence could not be provided.

Norway We ask the respondents whether during the last 12 months they have been exposed to theft or criminal damage.

Portugal There were 2 questions: - During the year was your wallet, purse or other valuables you carried taken from you by pickpocketing? (If yes, how many times) - Not counting the three situations that we have just spoken of (theft by pickpocketing and other thefts), during the year did someone take personal items from you in other circumstances? I shall ask you to disregard the theft of personal objects from your house or car. I am referring to clothes, wallet, purse, camera or any other personal items that you may have left anywhere - for instance, at the place you work or study, at a restaurant, coffee shop or cinema, at a transportation station or at the beach.

Sweden Different wording not provided.

Turkey Have you personally been a victim of one of the events below in (year): ...purse snatching, pickpocketing, theft? 
Table 6.2.4.3 Theft of personal property: Deviations from the standard ICVS wording of the question $(1 / 2)$

UK: England \& Wales Since the first of [^DATE ${ }^{\wedge}$, [apart from anything you may have already mentioned], was anything you were carrying stolen out of your hands or from your pockets or from a bag or case? AND Apart from anything you have already mentioned], in that time has anyone TRIED to STEAL something you were carrying out of your hands or from your pockets or from a bag or case?

UK: Northern Ireland Several questions are asked in relation to personal theft including; .... was anything you were carrying stolen - out of your hands or from your pockets or from a bag or case? ....And (apart from anything you have already mentioned), in that time has anything (else) of yours been stolen, from a cloakroom, an office, a car or anywhere else you left it? and ...Can I just check, were you/was he/she holding, carrying or wearing (any of) what was stolen, including items in pockets of clothes being worn at the time?

UK: Scotland Victim form asks what was taken? from either the respondent or members of their household and includes a variety of response categories detailing what was stolen, these include: "purse/wallet" and "briefcase/handbag/shopping bag", "jewellery" etc.

Similar definition: Bulgaria, Croatia, Czech Republic, Estonia, Finland, Georgia, Germany, Italy, Poland. 


\subsubsection{Theft of a motor vehicle}

Table 6.2.5.1 Prevalence of theft of a motor vehicle victimisation during the last 12 months according to national victimisation surveys

\begin{tabular}{|c|c|c|c|c|c|c|}
\hline & 1990 & 1995 & 2000 & 2005 & 2010 & 2015 \\
\hline Belgium & .. & 1.1 & 1.2 & 0.6 & 0.4 & .. \\
\hline Bulgaria & .. & .. & $(0.9)$ & $(0.5)$ & $(0.3)$ & .. \\
\hline Croatia & .. & .. & 0.8 & .. & 1 & .. \\
\hline Czech Republic & .. & .. & .. & 2.8 & .. & 0.52 \\
\hline Estonia & 0.7 & 1.6 & 0.9 & 0.7 & 0.4 & .. \\
\hline Finland & .. & 0.4 & 0.8 & 0.4 & 0.4 & 1.1 \\
\hline France & .. & .. & .. & 2.6 & 1.2 & 0.8 \\
\hline Georgia & .. & .. & .. & .. & 5.5 & .. \\
\hline Germany & .. & .. & .. & .. & 0.1 & 0.1 \\
\hline Ireland & .. & 1 & 1 & 1 & 1 & .. \\
\hline Italy & .. & 8 & 6.3 & .. & 6.3 & 3 \\
\hline Netherlands & 0.5 & 0.3 & 0.3 & 0.4 & 0.3 & 0.2 \\
\hline Poland & .. & .. & .. & .. & 0.3 & 0.3 \\
\hline Sweden & .. & .. & .. & 0.9 & 0.6 & 0.5 \\
\hline Turkey &.. & .. & .. & & $(0.1)$ & $(0.3)$ \\
\hline UK: England \& Wales & 2.4 & 2.1 & 1.3 & 0.7 & 0.4 & 0.3 \\
\hline UK: Northern Ireland & .. & .. & 1.8 & 0.5 & 0.4 & 0.1 \\
\hline UK: Scotland & .. & .. & .. & .. & 0.2 & 0.1 \\
\hline Mean & 1 & 2 & 2 & 1 & 1.1 & 0.6 \\
\hline Median & 1 & 1 & 1 & 1 & 0.3 & 0.4 \\
\hline Minimum & 1 & 0 & 0 & 0 & 0.1 & 0.1 \\
\hline Maximum & 2 & 8 & 6 & 3 & 6.3 & 3 \\
\hline
\end{tabular}

Figures in brackets see table 6.2.5.3. and notes on tables 6.2.1.1. to 6.2.9.2. 
Table 6.2.5.2 Theft of a motor vehicle: Percentage of victims reporting to the police

\begin{tabular}{lrrrrrr} 
& 1990 & 1995 & 2000 & 2005 & 2010 & 2015 \\
\hline Belgium &.. & 84.8 & 87.8 & 84.1 & 79.4 &.. \\
Bulgaria &.. &.. & $(100)$ & $(100)$ & $(100)$ &.. \\
Croatia &.. &.. & 92.8 &.. & 88 &.. \\
Estonia &.. & 86 & 86 & $(58)$ & 88 &.. \\
France &.. &.. &.. & 44.6 & 46.3 & 51 \\
Georgia &.. &.. &.. &.. & 47.2 &.. \\
Germany &.. &.. &.. &.. & 99.1 & 100 \\
Ireland &.. & 95 &.. &.. &.. &.. \\
Italy &.. &.. & 93.4 &.. & 88.6 & 96 \\
Lithuania &.. &.. &.. &.. &.. &.. \\
Netherlands &.. & 93.2 & 94.6 & 92.7 &.. & 55 \\
Poland &.. &.. &.. &.. & 90.2 &.. \\
Sweden &.. &.. &.. & 94 &.. &.. \\
UK: England \& Wales & 98.6 & 97.7 & 93.5 & 93.4 & 93.6 &.. \\
UK: Northern Ireland &.. &.. & 63 & 52 & 35 & 44 \\
UK: Scotland &.. &.. &.. &.. & 92 &.. \\
\hline Mean & 99 & 91 & 89 & 77 & 79 & 69 \\
Median & 99 & 93 & 93 & 86 & 88 & 55 \\
Minimum & 99 & 85 & 63 & 45 & 35 & 44 \\
Maximum & 99 & 98 & 100 & 100 & 100 & 100 \\
\hline
\end{tabular}

Figures in brackets see table 6.2.5.3. and notes on tables 6.2.1.1. to 6.2.9.2. 
Table 6.2.5.3 Theft of a motor vehicle: Deviations from the standard ICVS wording of the question

\begin{tabular}{|c|c|c|}
\hline $\begin{array}{l}\text { ESB Standard wor } \\
\text { ing }\end{array}$ & & $\begin{array}{l}\text {... have you or other members of your household had any of their cars, } \\
\text { vans or trucks stolen? }\end{array}$ \\
\hline Belgium & & Different wording not provided \\
\hline Croatia & & $\begin{array}{l}\text { Did the following happen to you in the past twelve months? ...stolen } \\
\text { personal automobile }\end{array}$ \\
\hline Czech Republic & & $\begin{array}{l}\text { a) have you or other members of your household had any of their cars } \\
\text { stolen in last } 3 \text { years? } \\
\text { b) Has this happened during the last } 12 \text { months? }\end{array}$ \\
\hline Finland & & $\begin{array}{l}\text { During the last } 12 \text { months, have you, or a member of your household, } \\
\text { experienced any of the following acts: (1) a car was stolen? }\end{array}$ \\
\hline France & & $\begin{array}{l}\text { Has your household experienced a theft or attempted theft of your car? } \\
\text { In surveys from } 1996 \text { to } 2004 \text {, there was no distinction between car } \\
\text { theft and theft in or from the car. Percentages are based on households } \\
\text { not populations. }\end{array}$ \\
\hline Iceland & & $\begin{array}{l}\text { No such question but many might include such an experience in their } \\
\text { answer to the question regarding burglary and theft. }\end{array}$ \\
\hline Poland & & ...has someone broken into your car and stolen it? \\
\hline Turkey & & $\begin{array}{l}\text { Has your household been a victim of one the events below in (year): } \\
\text {...theft of a car, motorcycle or similar. }\end{array}$ \\
\hline $\begin{array}{l}\text { UK: England } \\
\text { Wales }\end{array}$ & \& & $\begin{array}{l}\text { During the last } 12 \text { months, that is [since }{ }^{\wedge} \mathrm{DATE}^{\wedge} \text {,] have [you/ you or } \\
\text { anyone else now in your household] had [your/their] car, van, motorcy- } \\
\text { cle or other motor vehicle stolen or driven away without permission? }\end{array}$ \\
\hline
\end{tabular}




\subsubsection{Theft by means of domestic burglary}

Table 6.2.6.1 Prevalence of theft by means of domestic burglary victimisation during the last 12 months according to national victimisation surveys

\begin{tabular}{|c|c|c|c|c|c|c|}
\hline & 1990 & 1995 & 2000 & 2005 & 2010 & 2015 \\
\hline Belgium & .. & 5.1 & 9.0 & 6.9 & 6.1 & .. \\
\hline Bulgaria & .. & .. & (3.1) & (2.3) & $(2,1)$ & .. \\
\hline Croatia & .. & .. & 2.0 & & 5.0 & .. \\
\hline Czech Republic & .. & .. & .. & 3.9 & .. & 2.2 \\
\hline Denmark & .. & .. & .. & .. & .. & 3 \\
\hline Estonia & 5.7 & 4.2 & 3.7 & 3.1 & 3.0 & 2.7 \\
\hline Finland & .. & 0.3 & 0.5 & 0.5 & 0.5 & 1.7 \\
\hline France & 2.3 & 1.8 & 1.3 & 1.1 & 1.5 & 0.8 \\
\hline Georgia & .. & .. & .. & .. & 2.7 & .. \\
\hline Germany & .. & .. & .. & .. & 0.4 & 0.5 \\
\hline Iceland & .. & .. & .. & .. & .. & 7.2 \\
\hline Ireland & .. & 3 & 3 & 3 & 3 & .. \\
\hline Italy & .. & 2.8 & 1.8 & .. & 1.4 & 1.8 \\
\hline Lithuania & .. & .. & 2 & 1.7 & & .. \\
\hline Netherlands & 2.5 & 2.8 & 1.8 & 3 & 2.7 & 2.7 \\
\hline Poland & .. & .. & .. & .. & 3 & 2.5 \\
\hline Portugal & .. & 2.4 & .. & .. & .. & .. \\
\hline Sweden & .. & .. & .. & 1 & 1 & 1.0 \\
\hline Turkey & .. & .. & .. & .. & 2 & 2.5 \\
\hline UK: England \& Wales & 5.3 & 6.4 & 3.4 & 2.5 & 2.4 & 2.3 \\
\hline UK: Northern Ireland & .. & .. & 2 & 1.8 & 2.2 & 1.4 \\
\hline UK: Scotland & .. & .. & .. & .. & 1.1 & 0.9 \\
\hline Mean & 4 & 3 & 3 & 3 & 2.4 & 2.2 \\
\hline Median & 4 & 3 & 2 & 2 & 2.0 & 2.1 \\
\hline Minimum & 2 & 0 & 1 & 1 & 0.4 & 0.5 \\
\hline Maximum & 6 & 6 & 9 & 7 & 6.1 & 7.2 \\
\hline
\end{tabular}

Figures in brackets see table 6.2.6.3. and notes on tables 6.2.1.1. to 6.2.9.2. 
Table 6.2.6.2 Theft by means of domestic burglary: Percentage of victims reporting to the police

\begin{tabular}{|c|c|c|c|c|c|c|}
\hline & 1990 & 1995 & 2000 & 2005 & 2010 & 2015 \\
\hline Bulgaria & & .. & (54) & (70) & (66) & .. \\
\hline Croatia & .. & .. & $(64.4)$ & .. & 73 & .. \\
\hline Denmark & .. & & & & & 81 \\
\hline Estonia & & 55 & 62 & 51 & 38 & .. \\
\hline France & 75.2 & 81.9 & 79.8 & 67.1 & 54.9 & 59 \\
\hline Georgia & .. & ... & .. & .. & 47.5 & \\
\hline Germany & .. & .. & .. & .. & 87.5 & 72.5 \\
\hline Iceland & .. & & & & & 39.1 \\
\hline Ireland & .. & 77 & 69 & 70 & 75 & .. \\
\hline Italy & .. & .. & 66.6 & & 74.2 & 80.9 \\
\hline Lithuania & .. & .. & 81.8 & (62.2) & & .. \\
\hline Netherlands & .. & 89 & 90.7 & 71.7 & 86.9 & 49 \\
\hline Poland & & .. & & & 49.9 & .. \\
\hline Sweden & & & & 74 & 86 & 74 \\
\hline UK: England \& Wales & 73 & 65.7 & 61.3 & 65.9 & 66.8 & \\
\hline UK: Northern Ireland & 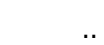 & .. & 65 & 57 & 67 & 67 \\
\hline UK: Scotland & & & & & 62 & 50 \\
\hline Mean & 74 & 74 & 69 & 65 & 67 & 56 \\
\hline Median & 74 & 77 & 66 & 67 & 67 & 67 \\
\hline Minimum & 73 & 55 & 54 & 51 & 38 & 39 \\
\hline Maximum & 75 & 89 & 91 & 72 & 88 & 81 \\
\hline
\end{tabular}

Figures in brackets see table 6.2.6.3. and notes on tables 6.2.1.1. to 6.2.9.2. 
Table 6.2.6.3 Theft by means of domestic burglary: Deviations from the standard ICVS wording of the question

\begin{tabular}{ll}
\hline ESB Standard wording & ... has anyone actually got into your house or flat without permission \\
and stolen or tried to steal something? \\
Czech Republic & a) Has someone broke into your dwelling during the last 3 years? \\
& Take into account burglaries in the basement and other buildings \\
& you have at your dwelling (e.g. garage, shed). Do not include bur- \\
& glaries in the chat / cottage and the objects belonging to them. b) \\
& Has this happened during the last 12 months? \\
& Has anyone - to your knowledge - broken into or tried to break into \\
your home within the past 12 months? Home includes the rooms \\
Denmark
\end{tabular}

Similar wording: Bulgaria, Croatia, Czech Republic, Estonia, Finland, Georgia, Germany, Ireland, Italy, Netherlands, Poland, Sweden, UK: England \& Wales, UK: Northern Ireland.

Question not included: Denmark, Lithuania. 


\subsubsection{Corruption}

Table 6.2.7.1 Prevalence of corruption victimisation during the last 12 months according to national victimisation surveys

\begin{tabular}{lrrrrrr} 
& 1990 & 1995 & 2000 & 2005 & 2010 & 2015 \\
\hline Czech Republic &.. &.. &.. & .9 .6 &.. &.. \\
Estonia & 4.5 & 3.6 & 5.2 & 3.3 & 0.5 &.. \\
Georgia &.. &.. &.. &.. & 0.5 &.. \\
Lithuania &.. &.. &.. &.. & 7.1 &.. \\
\hline
\end{tabular}

Table 6.2.7.2 Corruption: Percentage of victims reporting to the police

\begin{tabular}{lrrrrrrr} 
& 1990 & 1995 & 2000 & 2005 & 2010 & 2015 \\
\hline Czech Republic &.. &.. &.. & 5 &.. &.. \\
Georgia &.. &.. &.. &.. & $(100)$ &.. \\
\hline
\end{tabular}

Table 6.2.7.3 Corruption: Deviations from the standard wording of the question

\begin{tabular}{ll}
\hline ESB Standard & $\ldots$ has any government official, for instance a customs officer, a police \\
wording & officer or inspector in your country asked you, or expected you to pay \\
& a bribe for his or her services? \\
Lithuania & Did any public officer or an equivalent person demand a bribe from \\
& you, or provoke you to give a bribe for performance or non-perfor- \\
& mance of their obligations during 2011?
\end{tabular}

Similar wording: Czech Republic, Estonia, Georgia.

Question not included: Bulgaria, Croatia, Denmark, Finland, France, Germany, Iceland, Ireland, Italy, Netherlands, Poland, Turkey, UK: England \& Wales, UK: Northern Ireland, UK: Scotland. 


\subsubsection{Trust in the police}

Table 6.2.8.1 Trust in the police: Percentage of the public who believe the police are doing a good job or a very good job in controlling crime in the local area.

\begin{tabular}{lrrrrrr} 
& 1990 & 1995 & 2000 & 2005 & 2010 & 2015 \\
\hline Belgium &.. &.. & 77.8 & 86.4 & 69.2 &.. \\
Bulgaria &.. &.. & $(43)$ & $(46)$ &.. &.. \\
Croatia &.. &.. & 48 &.. & 61 &.. \\
Czech Republic &.. &.. &.. & 54.5 &.. &.. \\
Estonia &.. &.. &.. & 47 & 63 &.. \\
Georgia &.. &.. &.. &.. & 53 &.. \\
Germany &.. &.. &.. &.. & 87 & 83.3 \\
Iceland &.. &.. &.. &.. &.. & 87 \\
Ireland &.. & 63 & 56 & 51 & 67 & 75 \\
Italy &.. & 57.8 & 63.8 &.. & 61.6 &.. \\
Netherlands &.. &.. & 55.8 & 42.9 & 41.5 & 41.7 \\
Poland &.. &.. &.. &.. & 71.7 & 78.1 \\
Sweden &.. &.. &.. & 55 & 65 & 61 \\
Turkey &.. &.. &.. & 69.3 & 78 & 75.1 \\
UK: England \& Wales &.. & .1 & 75 & 51 & 62 & 62 \\
UK: Northern Ireland &.. &.. &.. &.. & 43 & 51 \\
UK: Scotland &.. &.. &.. &.. &.. & 56 \\
\hline Mean & 81 & 64 & 60 & 56 & 63 & 67 \\
Median & 81 & 60 & 56 & 51 & 65 & 62 \\
Minimum & 81 & 56 & 43 & 43 & 42 & 42 \\
Maximum & 81 & 81 & 78 & 86 & 87 & 87 \\
\hline Figures in backets see tabl & .2. &. & & \\
\hline
\end{tabular}

Figures in brackets see table 6.2.8.2 and notes on tables 6.2.1.1. to 6.2.9.2. 
Table 6.2.8.2 Trust in the police: Deviations from standard ICVS wording of the question

\begin{tabular}{|c|c|}
\hline ESB Standard wording & $\begin{array}{l}\text { Taking everything into account, how good a job do you think the } \\
\text { police do in your area in controlling crime? Do you think they do a } \\
\text { very good job, a fairly good job, a poor job or a very poor job? }\end{array}$ \\
\hline Czech Republic & $\begin{array}{l}\text { Were you satisfied with the police work during the investigation? Do } \\
\text { the following statements about police work apply? }\end{array}$ \\
\hline Finland & $\begin{array}{l}\text { This kind of question is asked in later national surveys but it is not } \\
\text { reported. }\end{array}$ \\
\hline France & $\begin{array}{l}\text { Regarding the action of the police or the gendarmerie in the fight } \\
\text { against crime in your neighbourhood (or your village), would you } \\
\text { say that it is very effective, effective, ineffective, not effective at all, } \\
\text { don't know? This question is from the } 2007 \text { survey. }\end{array}$ \\
\hline Lithuania & $\begin{array}{l}\text { How would you evaluate the work of the following institutions?: po- } \\
\text { lice). }\end{array}$ \\
\hline Portugal & $\begin{array}{l}\text { What does the person who reported the crime think of the way } \\
\text { he/she was treated by the authorities? very satisfied; satisfied; not } \\
\text { very satisfied; not satisfied at all? }\end{array}$ \\
\hline Sweden & $\begin{array}{l}\text { How much confidence do you have in the way the police conduct } \\
\text { their work? A great deal, Quite a lot, Neither a lot nor little, Not very } \\
\text { much, Very little, No opinion/ Don't know? }\end{array}$ \\
\hline Turkey & $\begin{array}{l}\text { How satisfied are you with public security services? (Not satisfied at } \\
\text { all, not satisfied, Medium, Satisfied, Very satisfied). }\end{array}$ \\
\hline UK: Northern Ireland & $\begin{array}{l}\text { Taking everything into account, how good a job do you think the } \\
\text { police in this area are doing? Excellent, Good, Fair, Poor and Very } \\
\text { poor. }\end{array}$ \\
\hline UK: Scotland & $\begin{array}{l}\text { There is no single question looking at confidence in the police. In- } \\
\text { stead, a battery of questions is used to look at different aspects of } \\
\text { police performance: Investigating incidents after they occur, dealing } \\
\text { with incidents as they occur, solving crimes, responding quickly to } \\
\text { appropriate calls and information from the public, Catching crimi- } \\
\text { nals, and Preventing crime. }\end{array}$ \\
\hline
\end{tabular}

Similar wording: Bulgaria, Croatia, Czech Republic, Estonia, Georgia, Germany, Iceland, Ireland, Italy, Netherlands, Poland. Question not included: Denmark 


\subsubsection{Feelings of safety}

Table 6.2.9.1 Feelings of safety: Percentage of the respondents feeling unsafe or very unsafe on the street after dark

\begin{tabular}{lrrrrrr} 
& 1990 & 1995 & 2000 & 2005 & 2010 & 2015 \\
\hline Belgium &.. & 20 & 20 & 18 & 16 &.. \\
Bulgaria &.. &.. & $(55)$ & $(48)$ & $(45)$ &.. \\
Croatia &.. &.. & 27.6 &.. & 10 &.. \\
Czech Republic &.. &.. &.. & 48.7 &.. &.. \\
Estonia & 49 & 43 & 41 & 32 & 28 & 16.9 \\
Finland & 19 & 23 & 27 & 33 & 22 & 38.2 \\
France & & & & & 11 & 11 \\
Georgia &.. &.. &.. &.. & 5 &.. \\
Germany &.. &.. &.. &.. & 17.1 & 21.5 \\
Iceland &.. &.. &.. &.. & 9.5 & 9.2 \\
Ireland &.. & 26 & 25 & 26 & 25 &.. \\
Italy &.. &.. & 27.6 &.. & 28.9 &.. \\
Lithuania &.. &.. & 42.5 & 72 & 52.9 &.. \\
Netherlands &.. &.. &.. &.. & 4.4 & 3.5 \\
Norway &.. &.. & 7.9 & 6.7 & 7.5 & 5.6 \\
Poland &.. &.. &.. &.. & 20.4 & 20.3 \\
Sweden &.. &.. &.. & 21 & 16 & 19 \\
Turkey &.. &.. &.. & 39.4 & 25.8 & 25 \\
UK: England \& Wales &.. &.. &.. &.. & $(24)$ &.. \\
UK: Northern Ireland &.. &.. & 32 & 33 & 28 &.. \\
UK: Scotland &.. &.. &.. &.. & 31 & 23 \\
\hline Mean & 34 & 27 & 33 & 36 & 22 & 17.5 \\
Median & 34 & 25 & 28 & 33 & 22 & 18.0 \\
Minimum & 19 & 20 & 20 & 18 & 4.4 & 3.5 \\
Maximum & 49 & 43 & 55 & 72 & 52.9 & 38.2 \\
\hline Figures in brackets &. &. & .5 &
\end{tabular}

Figures in brackets see table 6.2.9.2. and notes on tables 6.2.1.1. to 6.2.9.2. 
Table 6.2.9.2 Feelings of security: Deviations from the ICVS standard wording of the question

\begin{tabular}{|c|c|}
\hline $\begin{array}{l}\text { ESB Standard word- } \\
\text { ing }\end{array}$ & $\begin{array}{l}\text { How safe do you feel walking alone in your area after dark? Do you } \\
\text { feel very safe, fairly safe, a bit unsafe, or very unsafe? }\end{array}$ \\
\hline Belgium & Do you ever avoid leaving your home when it is dark? \\
\hline Finland & $\begin{array}{l}\text { During the last } 12 \text { months, have you been afraid of becoming a victim } \\
\text { of violence when going out in the evening? }\end{array}$ \\
\hline France & $\begin{array}{l}\text { The question does not specifically target the night situation: Do you } \\
\text { ever personally feel insecure in your neighbourhood or in your village? } \\
\text { Often, occasionally, rarely, never, do not know? From the } 2007 \text { survey, } \\
\text { there is also a question: in everyday life, do you ever refrain from going } \\
\text { out for safety reasons? yes often, yes sometimes, yes but very rarely, } \\
\text { never, never goes out? If affirmative: in the vicinity of your home, are } \\
\text { there in particular groups of people that you are concerned about to } \\
\text { the point of refraining from going out? often, yes sometimes, yes but } \\
\text { very rarely, no. Percentage includes the population } 14 \text { years old or } \\
\text { more }\end{array}$ \\
\hline Lithuania & $\begin{array}{l}\text { Do you feel safe from different offences in Lithuania? (survey con- } \\
\text { ducted by Centre for Crime Prevention). Do you feel safe in your local } \\
\text { area? (survey conducted by the Police Department under the Ministry } \\
\text { of the Interior) Do you feel safe in Lithuania? / In your local area (city/ } \\
\text { district)? / In your inner environment (street/ village) (survey conducted } \\
\text { by the Ministry of the Interior) }\end{array}$ \\
\hline Norway & $\begin{array}{l}\text { The respondents are asked whether they recently have feared expo- } \\
\text { sure to violence or threats of violence when walking alone in their } \\
\text { neighbourhood. }\end{array}$ \\
\hline Portugal & $\begin{array}{l}\text { When you have to walk on foot, alone, at night in your neighbourhood, } \\
\text { how do you feel? Very safe, Reasonably safe, Somewhat unsafe, Very } \\
\text { unsafe, You don't go out at night, Doesn't know / Doesn't answer. }\end{array}$ \\
\hline Sweden & $\begin{array}{l}\text { If you go out alone late in the evening in the area where you live, do } \\
\text { you feel very safe, quite safe, quite unsafe, very unsafe or do you never } \\
\text { go out alone late in the evening? }\end{array}$ \\
\hline Turkey & $\begin{array}{l}\text { How safe do you feel walking around your neighbourhood at night? Not } \\
\text { safe at all, Not safe, Medium, Safe, Very safe. }\end{array}$ \\
\hline
\end{tabular}


Notes on Tables 6.2.1.1 to 6.2.9.2

Armenia
Bulgaria
Croatia

Czech Republic

Estonia

France

Finland

Iceland

Italy

Norway

Turkey

UK: England \& Wales

UK: Northern Ireland

UK: Scotland
The questions in the 2010 survey refer to victimisation in the previous 3 years.

Data include the answers "don't know" or "refused to answer".

In 2009 the percentage of victims of theft of a motor vehicle was $1 \%$. Note that this $\%$ was calculated in relation to the number of all the persons interviewed (although $15 \%$ did not own a motor vehicle). In 2000 the $\%$ of victims of theft of a motor vehicle was calculated taking into account only car owners. In 2000 , the $\%$ of victims reporting the crime of burglary to the police refers only to completed burglaries. Attempted burglary was much less frequently reported to the police - only in $30.5 \%$ of the cases.

Bodily injury: Data are available only for the five-year period (2002-2006), and not for any particular year. Percentage of victims reporting to police: with the exception of corruption, data are available only for the five-year period 20022006. Incidence has not been studied.

Sexual assault: From 1992 to 2003 this includes both verbal and physical harassment; in 2008 it includes physical harassment only (the question was not comparable to the previous surveys, conclusions on trends cannot be made).

Data on sexual assault in 2010 is calculated only for persons aged 18-75 years.

Wording of the Trust in police question differs: How much do you trust in police? Responses: very much $42.4 \%$ quite much $49.2 \%=92 \%$

Number for theft of a personal property might include robbery, and theft of a motor vehicle.

Bodily injury (assault) includes sexual assault.

Bodily injury is likely to include sexual assault

Bodily injury: In 2005 this included being beaten or injured. In 2010 it included threats, injuries, \& sexual harassment. Sexual assault is defined as sexual harassment. Theft includes purse snatching and pickpocketing. Motor vehicle includes theft of motorcycle.

Reporting rates for bodily injury refer to the offence of more serious assaults with injury. Sexual assault questions are based on an additional CASI module on interpersonal violence asked of people aged 16-59. Theft of personal property data are from 'Other theft of personal property' and exclude pickpocketing and theft of items on the victim's person. Trust in police: breaks in the series in 2001 and 2010.

1) No data available for 1990 or 1995. 2) The NICS common assault definition includes minor injuries. 3) Trust in the police - this question was only included in the NICS from 2007/08 onwards, and therefore no data are available for 1995, 2001, 2005. 4) In all NICS publications victimisation rates for robbery are not published separately. However, they are categorised with snatch theft as mugging.

Since 2011/12, the SCJS has been delivered on a biennial basis with no data collection in that financial year. The SCJS in its current form started in 2008/09, and therefore comparable data does not exist for years 2005 and before. Please note that the survey fieldwork is based on financial years (April-March) 
6 National Victimisation Surveys

Table 6.9.2.3 Years of reference

\begin{tabular}{lcccccc} 
& 1990 & 1995 & 2000 & 2005 & 2010 & 2015 \\
\hline Belgium &.. & 1998 & 2000 & 2004 & 2010 &.. \\
Bulgaria &.. &.. & 2001 & 2006 & 2010 & 2015 \\
Croatia &.. &.. & 2000 &.. & 2009 &.. \\
Czech Republic &.. &.. &.. & 2008 &.. & 2017 \\
Estonia & 1992 & 1994 & 1999 & 2003 & 2008 & 2015 \\
Finland & 1988 & 1997 & 2003 & 2006 & 2009 & 2015 \\
France & 1985 & 1995 & 2000 & 2005 & 2010 & 2015 \\
Georgia &.. &.. &.. &.. & 2010 &.. \\
Germany &.. &.. &.. &.. & 2012 & 2017 \\
Iceland &.. &.. &.. &.. & 2010 & 2015 \\
Ireland &.. & 1996 & 2003 & 2006 & 2010 & 2015 \\
Italy &.. & 1997 & 2002 &.. & 2008 & 2015 \\
Lithuania &.. &.. & 2004 & 2005 & 2007 & 2015 \\
Netherlands & 1990 & 1995 & 2000 & 2005 & 2010 & 2015 \\
Norway &.. &.. & 2004 & 2007 & 2012 & 2015 \\
Poland &.. &.. &.. &.. & 2008 & 2014 \\
Portugal &.. & 1994 &.. &.. &.. & 2015 \\
Sweden &.. &.. &.. & 2005 & 2010 & 2015 \\
Turkey &.. &.. &.. &.. & 2010 & 2014 \\
UK: England \& Wales & 1991 & 1995 & 2000 & 2005 & 2010 & Apr 15- \\
& & & & & & Mar 16 \\
UK: Northern Ireland &.. &.. & 2001 & 2005 & 2010 & 2015 \\
UK: Scotland & & & & & & 2016 \\
\hline
\end{tabular}




\subsubsection{Computer/cybercrime against individuals}

This section includes information on estimates of computer or cybercrime against victims, as measured by household surveys. Many commentators believe that computer crime in various forms, measured as reported in household surveys, is of the same order of magnitude as 'traditional' crime discussed throughout the Sourcebook. Some surveys confirm this.

This section is not comprehensive as collection of this data was not an integral part of the Sourcebook process. Only a few countries supplied details. Neither were standards or definitions set by Sourcebook editors for the collection of cybercrime numbers. Details vary considerably from one country to another, as can be seen from Table 6.2.10.1. A selection of cybercrime data available is given Table 6.2.10.2, for the most recent year. Differences are likely to be accounted for by differences in definitions and scope of the questions, although there is good comparability between the British and the Dutch sources for different types of cybercrime. 
Table 6.2.10.1 Cybercrime against households as measured by surveys Country Cybercrime types and definitions used

Sources/dates

2020 onwards

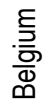

Has any of the following happened to you:

Given personal information to others (phishing)

Debit/credit card misused on the internet (fraud)

Identity been stolen and misused (Identity Theft)

Your device has been infected by Malware (Malware)

Your e-mail/social media account hacked (Hacking)

든 Received sexually harassing messages (Sexual Har-

assment)

Received other harassing messages (General Harass-

ment)

Sensitive information been circulated about you.

False information circulated about you (Defamation)

You have been threatened with violence on the inter-

net

ID fraud: skimming; phishing and pharming

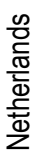

Buying and selling fraud: buying; selling.

Hacking: computer; email account; website; other

Cyberbullying: Slander; Blackmail; stalking; Threat;

Other

Fraud: Bank and credit acct fraud; consumer/retail

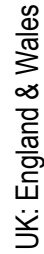
fraud; advance fee fraud; other Computer misuse: computer virus; unauthorised access to personal information, including hacking

Personal details were stolen online

Device infected by malicious software

Someone accessed social media, email or other

online account without your consent for fraudulent purposes

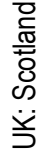

Locked out of device and asked to make a payment to have it unlocked

Card or bank account details were stolen online

Received a scam email and provided bank details or

made a payment

Received a phone call from someone claiming there

was a problem with your device: you let them access

your device and/or paid them a fee, but it was a scam

Victim of online dating fraud
2018 Finnish National Crime survey. Ages 15-74. Survey of households

Dutch Safety Monitor conducted

by Statistics Netherlands: annual cross-sectional household survey using representative sampling methods Data available for 2012 17, and 2019.

(https://www.cbs.nl/en-gb). (Household) Crime Survey of England and Wales (CSEW) Financial years from April 2016March 2017 onwards. https://www.ons.gov.uk/peoplepopulationandcommunity/crimeandjustice/datasets/crimeinenglandandwalesexperimentaltables (Household) Scottish Crime and Justice Survey 2018-2019: supplementary tables on cybercrime: https://www.gov.scot/publications/scottish-crime-justice-survey-2018-19-datasets/ 
Table 6.2.10.2 Cybercrime against households: types of crime and prevalence

\begin{tabular}{|c|c|c|c|c|}
\hline \multirow[t]{2}{*}{ Country } & \multirow[t]{2}{*}{ Year } & \multirow[t]{2}{*}{ Type of Cybercrime } & \multicolumn{2}{|c|}{$\begin{array}{l}\text { Prevalence of cyber } \\
\text { victimisation (\%) }\end{array}$} \\
\hline & & & Ever & $\begin{array}{l}\text { Last } 12 \\
\text { months }\end{array}$ \\
\hline \multirow[t]{10}{*}{ Finland } & \multirow[t]{10}{*}{2018} & Malware & 42.4 & 12.5 \\
\hline & & General Harassment & 16.3 & 9.1 \\
\hline & & Sexual Harassment & 14.2 & 8.4 \\
\hline & & Hacking & 8.8 & 3.1 \\
\hline & & Fraud & 6.2 & 2.2 \\
\hline & & Defamation & 4.3 & 1.2 \\
\hline & & Threat of violence & 3.5 & 1.2 \\
\hline & & Phishing & 2.2 & 0.7 \\
\hline & & Violation of personal privacy & 1.7 & 0.6 \\
\hline & & Identity theft & 1.4 & 0.5 \\
\hline \multirow[t]{17}{*}{ The Netherlands } & \multirow[t]{17}{*}{2019} & ID fraud: & .. & 0.5 \\
\hline & & skimming; & .. & 0.4 \\
\hline & & phishing and pharming & .. & 0.1 \\
\hline & & Buying and selling fraud: & .. & 5.7 \\
\hline & & buying; & .. & 5.2 \\
\hline & & selling; & .. & 0.4 \\
\hline & & Hacking: & .. & 8.2 \\
\hline & & computer; & .. & 0.8 \\
\hline & & email account; & .. & 2.6 \\
\hline & & website; & .. & 3.2 \\
\hline & & other & .. & 2.2 \\
\hline & & Cyberbullying: & .. & 7.9 \\
\hline & & Slander; & .. & 2.0 \\
\hline & & Blackmail; & .. & 1.7 \\
\hline & & stalking; & .. & 1.7 \\
\hline & & Threat; & .. & 1.1 \\
\hline & & Other & .. & 2.5 \\
\hline \multirow{11}{*}{$\begin{array}{l}\text { UK (England \& } \\
\text { Wales) } \\
\text { UK (Scotland) }\end{array}$} & \multirow{11}{*}{$\begin{array}{l}\text { April } 19- \\
\text { March } 20 \\
\text { April 18- } \\
\text { March } 19\end{array}$} & Fraud & .. & 7.0 \\
\hline & & Computer misuse (including hacking) & .. & 3.0 \\
\hline & & Personal details were stolen online &. & 0.7 \\
\hline & & $\begin{array}{l}\text { Device infected by malicious software } \\
\text { Someone accessed social media, email } \\
\text { or other online account without your }\end{array}$ & $\ddot{. .}$ & 8.0 \\
\hline & & consent for fraudulent purposes & .. & 4.8 \\
\hline & & $\begin{array}{l}\text { Locked out of device and asked to } \\
\text { make a payment to have it unlocked }\end{array}$ & 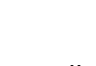 & 08 \\
\hline & & $\begin{array}{l}\text { Card or bank account details stolen } \\
\text { online }\end{array}$ &. & 4.5 \\
\hline & & $\begin{array}{l}\text { Received a scam email and provided } \\
\text { bank details or made a payment } \\
\text { Received a phone call from someone }\end{array}$ & .. & 4.5 \\
\hline & & $\begin{array}{l}\text { claiming there was a problem with your } \\
\text { device: you let them access your device }\end{array}$ & .. & 4.1 \\
\hline & & $\begin{array}{l}\text { and/or paid them a fee, but it was a } \\
\text { scam }\end{array}$ & .. & 0.2 \\
\hline & & Victim of online dating fraud & & \\
\hline
\end{tabular}




\subsubsection{Computer/cybercrime against companies and charities}

A separate issue is the incidence of computer/cybercrime against companies, charities, and other organisations, which is acknowledged by law enforcement authorities and governments as a growing problem. Some countries have set up cyber security breach surveys. The purpose of such surveys is not only to gain an understanding of the amount of such cybercrime against companies, charities, NGOs, etc. but to discover the crime prevention methods, training of staff and investment that companies have found necessary to cope with this new phenomenon, as well as the success of such measures. They tend to be both qualitative and quantitative, based on a large questionnaire and interviews. Up to 5,000 companies, charities, and NGOs, etc. can take part and often the surveys are carried out annually.

It is not within the remit of this chapter to collect such information, which would be a considerable task, but it is mentioned here for completeness. Table 6.2.11.1 gives an indication of the extent of such surveys for Germany and for the UK. Overall results are similar and show significant differences by size of company and by type of organisation. 
Table 6.2.11 Cybercrime against companies, charities, and other organisations

\begin{tabular}{|c|c|c|c|}
\hline Country & Year & Content of survey & Title and source of survey data \\
\hline 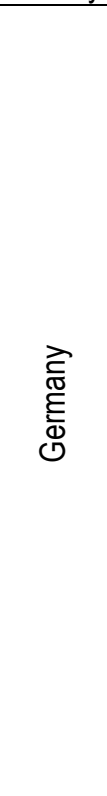 & 2019 & $\begin{array}{l}\text { A nationwide survey of } 5,000 \\
\text { companies with } 10+\text { employ- } \\
\text { ees on the subject of cyber- } \\
\text { attacks was conducted be- } \\
\text { tween August } 2018 \text { and Janu- } \\
\text { ary } 2019 \text {. This focused on the } \\
\text { prevalence of different types } \\
\text { of cyber-attacks, conse- } \\
\text { quences for the companies } \\
\text { affected and factors that } \\
\text { could increase or reduce the } \\
\text { risk of being affected by such } \\
\text { cyber-attacks. }\end{array}$ & $\begin{array}{l}\text { Cyber-attacks against companies } \\
\text { in Germany: results of a repre- } \\
\text { sentative company survey } 2018-19 \\
\text { KFN Research Report } 158 . \\
41 \% \text { of the companies surveyed } \\
\text { have experienced at least one } \\
\text { cyber-attack in the previous twelve } \\
\text { months that required a response, } \\
\text { attacks that were thwarted auto- } \\
\text { matically are not included. With an } \\
\text { annual prevalence rate of } \\
58 \% \text {, large companies (500+ em- } \\
\text { ployees) are significantly more fre- } \\
\text { quently affected than } \\
\text { medium-sized (46-47 \%) or small } \\
\text { companies (10-49 employees: } \\
39 \% \text { ). } \\
\text { https:/len.kfn.de/blog/2020/03/new- } \\
\text { research-report-cyber-attacks- } \\
\text { against-companies-in-germany/ }\end{array}$ \\
\hline 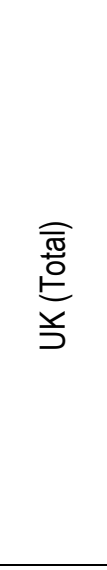 & $\begin{array}{l}2020 \\
\text { (an- } \\
\text { nual) }\end{array}$ & $\begin{array}{l}\text { The UK conducts an annual } \\
\text { survey of cyber breaches di- } \\
\text { rected at commercial compa- } \\
\text { nies. Results are mostly } \\
\text { about policies and compa- } \\
\text { nies' reactions to cybercrime } \\
\text { more than the crimes them- } \\
\text { selves. Published chapters in- } \\
\text { clude awareness and atti- } \\
\text { tudes: } \\
\text { approaches to cyber security } \\
\text { incidents and impact of } \\
\text { breaches: } \\
\text { dealing with breaches: }\end{array}$ & $\begin{array}{l}\text { Cyber Breaches Survey, UK } 2020 \\
\text { Almost half of businesses ( } 46 \%) \\
\text { and a quarter of charities ( } 26 \%) \text { re- } \\
\text { port having cyber security } \\
\text { breaches or attacks in the last } 12 \\
\text { months. Like previous years, this is } \\
\text { higher among medium businesses } \\
(68 \%) \text {, large businesses (75\%) and } \\
\text { high-income charities ( } 57 \%) \text {. } \\
\text { https://www.gov.uk/govern- } \\
\text { ment/publications/cyber-security- } \\
\text { breaches-survey-2020/cyber-secu- } \\
\text { rity-breaches-survey-2020 }\end{array}$ \\
\hline
\end{tabular}




\subsection{Technical information on household surveys}

The following tables include information on the methodology applied in the different countries for their victimisation surveys.

Table 6.3.1 shows the size of the samples used in each survey. It can be seen that they have been gradually increasing during the 20 years under observation. By 2010,10 countries out of 20 used samples of more than 10,000 households.

Table 6.3.2 specifies the kind of sample design used in the national surveys. In general, the most common design is multistage probability sample.

Table 6.3.3 shows the level of representativeness of the national samples used in the surveys.

Table 6.3.4 shows the response rate of the surveys. It can be seen that such rate has been generally decreasing since 2000 . The reliability of response rates reported reaching $100 \%$ seems doubtful.

Table 6.3 .5 shows the age range of people interviewed. The minimum age is usually 15-16 years old. Most countries do not fix a maximum age.

Table 6.3.6 shows the survey modes that have been used for each year of reference. CATI and CAPI are the most frequent modes of survey.

Table 6.3.1 Sample size of the national victimisation surveys

\begin{tabular}{|c|c|c|c|c|c|c|}
\hline Year & 1990 & 1995 & 2000 & 2005 & 2010 & 2015 \\
\hline Albania & .. & 1200 & 1500 & 1500 & 2590 & .. \\
\hline Armenia & .. & & & & 5337 & .. \\
\hline Belgium & .. & $(6000)$ & $(6000)$ & (12000) & $(12000)$ & .. \\
\hline Bulgaria & .. & .. & 1615 & 2500 & 2557 & .. \\
\hline Croatia & .. & .. & 1532 & & 4500 & .. \\
\hline Czech Republic & .. & .. & & 3082 & & 3328 \\
\hline Denmark & 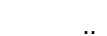 & 12000 & $(1000)$ & 11668 & 11585 & 11492 \\
\hline Estonia & 1000 & 1173 & 1700 & 1687 & 4181 & 1000 \\
\hline Finland & 9598 & 13762 & 8163 & 7715 & 7193 & 14000 \\
\hline France & 11156 & 5786 & 5594 & 13263 & 16958 & $\begin{array}{r}22,800 \\
\text { units }\end{array}$ \\
\hline Georgia & .. & .. & 3000 & 3000 & 3000 & .. \\
\hline Germany & .. & .. & .. & .. & 35503 & 31192 \\
\hline Iceland & .. & .. & .. & .. & 4000 & 4000 \\
\hline Ireland & .. & 2690 & 2994 & 3243 & 11391 & .. \\
\hline Italy & .. & 50001 & 60001 & .. & 60001 & 50350 \\
\hline Lithuania & & & 1003 & 1001 & 1001 & \\
\hline Netherlands & 4513 & 5936 & 8756 & 5242 & 39220 & 111252 \\
\hline Norway & .. & .. & 3340 & 3212 & 6186 & 6393 \\
\hline Poland & .. & .. & .. & & 17000 & 17000 \\
\hline Sweden & .. & .. & .. & 10000 & 20000 & 20000 \\
\hline Turkey & & & .. & 2880 & 3440 & 3904 \\
\hline UK: England \& Wales & 10059 & 16348 & 32824 & 47023 & 46031 & 35000 \\
\hline UK: Northern Ireland & . & 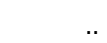 & 3010 & 3692 & 4081 & c. 3000 \\
\hline UK: Scotland & & .. &.. & & 10010 & 5570 \\
\hline
\end{tabular}

Figures in brackets see notes on tables 6.3.1. to 6.3.6 
Table 6.3.2 Sample design of national victimisation surveys

\begin{tabular}{|c|c|c|c|c|c|c|}
\hline & 1990 & 1995 & 2000 & 2005 & 2010 & 2015 \\
\hline $\begin{array}{l}\text { Simple ran- } \\
\text { dom sam- } \\
\text { pling }\end{array}$ & $\begin{array}{l}2 \text { coun- } \\
\text { tries: Fin- } \\
\text { land, } \\
\text { France }\end{array}$ & $\begin{array}{l}3 \text { coun- } \\
\text { tries Den- } \\
\text { mark, Fin- } \\
\text { land, } \\
\text { France }\end{array}$ & $\begin{array}{l}3 \text { coun- } \\
\text { tries Fin- } \\
\text { land, } \\
\text { France, } \\
\text { Norway }\end{array}$ & $\begin{array}{l}4 \text { coun- } \\
\text { tries Den- } \\
\text { mark, Fin- } \\
\text { land } \\
\text { France, } \\
\text { Norway }\end{array}$ & $\begin{array}{l}4 \text { coun- } \\
\text { tries Den- } \\
\text { mark, Fin- } \\
\text { land, } \\
\text { France, } \\
\text { Norway }\end{array}$ & $\begin{array}{l}4 \text { coun- } \\
\text { tries } \\
\text { Denmark, } \\
\text { Finland, } \\
\text { France, } \\
\text { Norway, } \\
\text { UK: } \\
\text { Northern } \\
\text { Ireland }\end{array}$ \\
\hline $\begin{array}{l}\text { Stratified } \\
\text { random } \\
\text { sampling }\end{array}$ & & $\begin{array}{l}1 \text { country } \\
\text { Italy }\end{array}$ & $\begin{array}{l}1 \text { country } \\
\text { Italy }\end{array}$ & $\begin{array}{l}1 \text { country } \\
\text { Italy }\end{array}$ & $\begin{array}{l}2 \text { coun- } \\
\text { tries, Ice- } \\
\text { land, Italy }\end{array}$ & $\begin{array}{l}4 \text { coun- } \\
\text { tries Ice- } \\
\text { land, It- } \\
\text { aly, Swe- } \\
\text { den. UK: } \\
\text { Scotland }\end{array}$ \\
\hline $\begin{array}{l}\text { Stratified } \\
\text { two stage } \\
\text { cluster } \\
\text { sampling }\end{array}$ & & & $\begin{array}{l}1 \text { country } \\
\text { Bulgaria }\end{array}$ & $\begin{array}{l}2 \text { coun- } \\
\text { tries Bul- } \\
\text { garia, } \\
\text { Turkey }\end{array}$ & $\begin{array}{l}2 \text { coun- } \\
\text { tries Bul- } \\
\text { garia, } \\
\text { Turkey }\end{array}$ & $\begin{array}{l}1 \text { country } \\
\text { Turkey }\end{array}$ \\
\hline $\begin{array}{l}\text { Multistage } \\
\text { probability } \\
\text { sampling }\end{array}$ & $\begin{array}{l}2 \text { coun- } \\
\text { tries: Es- } \\
\text { tonia, UK: } \\
\text { England } \\
\& \text { Wales }\end{array}$ & $\begin{array}{l}3 \text { coun- } \\
\text { tries Esto- } \\
\text { nia, Ire- } \\
\text { land, UK: } \\
\text { England } \\
\& \text { Wales }\end{array}$ & $\begin{array}{l}5 \text { coun- } \\
\text { tries Esto- } \\
\text { nia, Ire- } \\
\text { land, Lith- } \\
\text { uania, } \\
\text { UK: Eng- } \\
\text { land \& } \\
\text { Wales, } \\
\text { UK: Scot- } \\
\text { land }\end{array}$ & $\begin{array}{l}5 \text { coun- } \\
\text { tries Esto- } \\
\text { nia, Ire- } \\
\text { land, Lith- } \\
\text { uania, } \\
\text { UK: Eng- } \\
\text { land \& } \\
\text { Wales, } \\
\text { UK: Scot- } \\
\text { land }\end{array}$ & $\begin{array}{l}7 \text { coun- } \\
\text { tries Esto- } \\
\text { nia, Geor- } \\
\text { gia, Ger- } \\
\text { many, Ire- } \\
\text { land, Lith- } \\
\text { uania, } \\
\text { UK: Eng- } \\
\text { land \& } \\
\text { Wales, } \\
\text { UK: Scot- } \\
\text { land }\end{array}$ & $\begin{array}{l}6 \text { coun- } \\
\text { tries } \\
\text { Estonia, } \\
\text { Georgia, } \\
\text { Germany, } \\
\text { Ireland, } \\
\text { Nether- } \\
\text { lands, } \\
\text { UK: Eng- } \\
\text { land \& } \\
\text { Wales, }\end{array}$ \\
\hline $\begin{array}{l}\text { Other } \\
\text { quota sam- } \\
\text { pling }\end{array}$ & & & & $\begin{array}{l}1 \text { country } \\
\text { Czech } \\
\text { Republic }\end{array}$ & & $\begin{array}{l}1 \text { country } \\
\text { Czech } \\
\text { Republic }\end{array}$ \\
\hline $\begin{array}{l}\text { Random } \\
\text { Route sam- } \\
\text { pling }\end{array}$ & & & & & & $\begin{array}{l}1 \text { country } \\
\text { Poland }\end{array}$ \\
\hline
\end{tabular}


Table 6.3.3. Sample representativeness of national victimisation surveys

\begin{tabular}{|c|c|c|c|c|c|c|}
\hline & 1990 & 1995 & 2000 & 2005 & 2010 & 2015 \\
\hline $\begin{array}{l}\text { National } \\
\text { level }\end{array}$ & $\begin{array}{l}2 \text { coun- } \\
\text { tries } \\
\text { Estonia } \\
\text { France }\end{array}$ & $\begin{array}{l}3 \text { coun- } \\
\text { tries Esto- } \\
\text { nia, } \\
\text { France, } \\
\text { UK: Eng- } \\
\text { land \& } \\
\text { Wales }\end{array}$ & $\begin{array}{l}5 \text { coun- } \\
\text { tries Cro- } \\
\text { atia, Es- } \\
\text { tonia, } \\
\text { France, } \\
\text { Lithuania, } \\
\text { UK: Eng- } \\
\text { land \& } \\
\text { Wales }\end{array}$ & $\begin{array}{l}4 \text { coun- } \\
\text { tries Croa- } \\
\text { tia, } \\
\text { France, } \\
\text { Lithuania, } \\
\text { UK: Eng- } \\
\text { land \& } \\
\text { Wales }\end{array}$ & $\begin{array}{l}4 \text { countries } \\
\text { Croatia, } \\
\text { France, Lithua- } \\
\text { nia, UK: Eng- } \\
\text { land \& Wales }\end{array}$ & $\begin{array}{l}7 \text { countries } \\
\text { Czech Re- } \\
\text { public, Esto- } \\
\text { nia, Finland, } \\
\text { France, Tur- } \\
\text { key, UK: } \\
\text { Northern Ire- } \\
\text { land, UK: } \\
\text { Scotland }\end{array}$ \\
\hline $\begin{array}{l}\text { National } \\
\text { level and } \\
\text { first re- } \\
\text { gional level }\end{array}$ & $\begin{array}{l}1 \text { coun- } \\
\text { try Fin- } \\
\text { land }\end{array}$ & $\begin{array}{l}3 \text { coun- } \\
\text { tries Den- } \\
\text { mark, Fin- } \\
\text { land, Italy }\end{array}$ & $\begin{array}{l}4 \text { coun- } \\
\text { tries Bul- } \\
\text { garia, } \\
\text { Finland, } \\
\text { Italy, Nor- } \\
\text { way }\end{array}$ & $\begin{array}{l}5 \text { coun- } \\
\text { tries Bul- } \\
\text { garia, } \\
\text { Czech Re- } \\
\text { public, } \\
\text { Denmark, } \\
\text { Finland, } \\
\text { Norway }\end{array}$ & $\begin{array}{l}9 \text { countries } \\
\text { Bulgaria, } \\
\text { Croatia, } \\
\text { Denmark, } \\
\text { Estonia, } \\
\text { Germany, } \\
\text { Finland, } \\
\text { Iceland, } \\
\text { Italy, } \\
\text { Norway }\end{array}$ & $\begin{array}{l}8 \text { countries } \\
\text { Denmark, } \\
\text { Germany, } \\
\text { Iceland, Italy, } \\
\text { Netherlands, } \\
\text { Norway, Po- } \\
\text { land, Swe- } \\
\text { den, UK: Eng- } \\
\text { land \& Wales }\end{array}$ \\
\hline $\begin{array}{l}\text { National } \\
\text { level, first } \\
\text { regional } \\
\text { level and } \\
\text { second re- } \\
\text { gional level }\end{array}$ & & $\begin{array}{l}1 \text { country } \\
\text { Belgium }\end{array}$ & $\begin{array}{l}1 \text { country } \\
\text { Belgium }\end{array}$ & $\begin{array}{l}1 \text { country } \\
\text { Belgium }\end{array}$ & $\begin{array}{l}1 \text { country Bel- } \\
\text { gium, }\end{array}$ & \\
\hline $\begin{array}{l}\text { National } \\
\text { level and } \\
\text { urban-rural } \\
\text { breakdown }\end{array}$ & & & & $\begin{array}{l}1 \text { country } \\
\text { Turkey }\end{array}$ & $\begin{array}{l}1 \text { country Tur- } \\
\text { key }\end{array}$ & \\
\hline $\begin{array}{l}\text { Blocks then } \\
\text { household }\end{array}$ & & $\begin{array}{l}1 \text { country } \\
\text { Ireland }\end{array}$ & $\begin{array}{l}1 \text { country } \\
\text { Ireland }\end{array}$ & $\begin{array}{l}1 \text { country } \\
\text { Ireland }\end{array}$ & $\begin{array}{l}1 \text { country Ire- } \\
\text { land }\end{array}$ & $\begin{array}{l}1 \text { country Ire- } \\
\text { land }\end{array}$ \\
\hline
\end{tabular}


Table 6.3.4 Response rate of national victimisation surveys

\begin{tabular}{lrrrrrr} 
& 1990 & 1995 & 2000 & 2005 & 2010 & 2015 \\
\hline Belgium &.. & 72 & 59 & 66 & 63 &.. \\
Denmark &.. & 64 & & 64 & 63 & 61 \\
Estonia &.. &.. &.. &.. & 58 &.. \\
Finland & 87 & 82 & 81 & 76 & 75 & 48 \\
France & & & & & & 68.8 \\
Georgia &.. &.. &.. &.. & 40 &.. \\
Germany &.. &.. &.. &.. & 21 & 15 \\
Iceland &.. &.. &.. &.. & 55.3 & 63.6 \\
Italy &.. & $(100)$ & $(100)$ &.. & $(100)$ & $(100)$ \\
Ireland &.. &.. &.. &.. &.. & 62 \\
Netherlands &.. & 55 & 59 & 70 & 70 & $(37)$ \\
Poland &.. &.. &.. &.. & 65 &.. \\
Sweden &.. &.. &.. & 70 & 70 & 60 \\
Turkey &.. &.. &.. &.. &.. & 86 \\
UK: England \& Wales & 77 & 83 & 73 & 75 & $(67 / 75)$ & $(67 / 75)$ \\
UK: Northern Ireland &.. &.. & 70 & 64 & 68 & 67 \\
UK: Scotland &.. &.. &.. &.. & 62 & 63 \\
\hline Note: The methon
\end{tabular}

Note: The methodology applied for computing the response rate varies from country to country. Rates reaching $100 \%$ must be interpreted cautiously and are therefore presented in brackets 
Table 6.3.5 Age range of respondents in national victimisation surveys

\begin{tabular}{|c|c|c|c|c|c|c|}
\hline Age range & 1990 & 1995 & 2000 & 2005 & 2010 & 2015 \\
\hline $\begin{array}{l}\text { Countries } \\
\text { setting a } \\
\text { minimum } \\
\text { age for the } \\
\text { persons in- } \\
\text { terviewed }\end{array}$ & $\begin{array}{l}3 \text { countries } \\
\text { Estonia (18), } \\
\text { Finland (15), } \\
\text { France (14) }\end{array}$ & $\begin{array}{l}8 \text { Countries } \\
\text { Belgium } \\
\text { (15), Estonia } \\
\text { (16), Finland } \\
\text { (15), } \\
\text { France (14) } \\
\text { Ireland (18), } \\
\text { Italy (14), } \\
\text { Netherlands } \\
\text { (15), Portu- } \\
\text { gal (16) }\end{array}$ & $\begin{array}{l}12 \text { countries } \\
\text { Belgium } \\
\text { (15), Bul- } \\
\text { garia (16), } \\
\text { Croatia (16), } \\
\text { Estonia (16), } \\
\text { Finland (15), } \\
\text { France (14), } \\
\text { Georgia } \\
\text { (16), Ireland } \\
(18), \\
\text { Italy (14), } \\
\text { Netherlands } \\
\text { (15) } \\
\text { Norway (16), } \\
\text { Portugal (16) }\end{array}$ & $\begin{array}{l}12 \text { countries } \\
\text { Belgium } \\
\text { (15), Bul- } \\
\text { garia (16), } \\
\text { Czech Re- } \\
\text { public (15), } \\
\text { Denmark } \\
\text { (16), Estonia } \\
\text { (16), Finland } \\
\text { (15), France } \\
\text { (14) } \\
\text { Georgia } \\
\text { (16), Ireland } \\
\text { (18), Lithua- } \\
\text { nia (15), } \\
\text { Netherlands } \\
\text { (15), Norway } \\
\text { (16) }\end{array}$ & $\begin{array}{l}16 \text { countries } \\
\text { Belgium } \\
\text { (15), Bul- } \\
\text { garia (16), } \\
\text { Croatia (18), } \\
\text { Denmark } \\
\text { (16), } \\
\text { Estonia (16), } \\
\text { Finland (15), } \\
\text { France (14), } \\
\text { Georgia } \\
\text { (16), } \\
\text { Germany } \\
\text { (16) } \\
\text { Iceland (18), } \\
\text { Ireland (18), } \\
\text { Italy (14), } \\
\text { Lithuania } \\
\text { (15), Nether- } \\
\text { lands (15), } \\
\text { Norway (16), } \\
\text { Portugal (16) }\end{array}$ & $\begin{array}{l}17 \text { countries } \\
\text { Czech Re- } \\
\text { public (15), } \\
\text { Denmark } \\
\text { (16), } \\
\text { Estonia (15) } \\
\text { Finland (15), } \\
\text { France (14) } \\
\text { Germany } \\
\text { (16) } \\
\text { Iceland (18), } \\
\text { Ireland (18), } \\
\text { Italy (14), } \\
\text { Netherlands } \\
\text { (15), } \\
\text { Norway (16), } \\
\text { Poland (15), } \\
\text { Sweden } \\
\text { (16), } \\
\text { Turkey (18), } \\
\text { UK: England } \\
\& \text { Wales } \\
\text { (16), UK: } \\
\text { Northern Ire- } \\
\text { land (16), } \\
\text { UK: Scot- } \\
\text { land (16) }\end{array}$ \\
\hline $\begin{array}{l}\text { Countries } \\
\text { setting a } \\
\text { maximum } \\
\text { age for per- } \\
\text { sons inter- } \\
\text { viewed }\end{array}$ & $\begin{array}{l}2 \text { countries } \\
\text { Estonia (74), } \\
\text { France (74) }\end{array}$ & $\begin{array}{l}2 \text { countries } \\
\text { Estonia (74), } \\
\text { France (74) }\end{array}$ & $\begin{array}{l}3 \text { countries } \\
\text { Estonia }(74), \\
\text { Finland (74), } \\
\text { France }(74)\end{array}$ & $\begin{array}{l}5 \text { countries } \\
\text { Czech Re- } \\
\text { public (79), } \\
\text { Denmark } \\
\text { (74), Estonia } \\
\text { (74), Finland } \\
\text { (74), France } \\
\text { (74) }\end{array}$ & $\begin{array}{l}6 \text { countries } \\
\text { Denmark } \\
\text { (74), } \\
\text { Estonia (74), } \\
\text { Georgia } \\
\text { (65), Iceland } \\
\text { (75), Lithua- } \\
\text { nia (74), } \\
\text { France (74) }\end{array}$ & $\begin{array}{l}5 \text { countries } \\
\text { Denmark } \\
\text { (74), } \\
\text { Finland (74), } \\
\text { France (74) } \\
\text { Sweden } \\
\text { (79), } \\
\text { Turkey (99) }\end{array}$ \\
\hline $\begin{array}{l}\text { Countries } \\
\text { having a } \\
\text { separate } \\
\text { survey for } \\
\text { children }\end{array}$ & & & & & & $\begin{array}{l}1 \text { Country } \\
\text { UK: England } \\
\text { \& Wales (10- } \\
\text { 15) }\end{array}$ \\
\hline
\end{tabular}


Table 6.3.6 Survey mode of national victimisation surveys

\begin{tabular}{|c|c|c|c|c|c|c|}
\hline Survey Mode & 1990 & 1995 & 2000 & 2005 & 2010 & 2015 \\
\hline CATI & & $\begin{array}{l}2 \text { countries } \\
\text { Denmark, } \\
\text { Italy }\end{array}$ & $\begin{array}{l}4 \text { countries } \\
\text { Belgium, } \\
\text { Croatia, } \\
\text { Finland, It- } \\
\text { aly }\end{array}$ & $\begin{array}{l}3 \text { coun- } \\
\text { tries Bel- } \\
\text { gium, } \\
\text { Denmark, } \\
\text { Finland }\end{array}$ & $\begin{array}{l}5 \text { countries } \\
\text { Belgium. } \\
\text { Finland, } \\
\text { Germany, } \\
\text { Iceland, Italy }\end{array}$ & $\begin{array}{l}2 \text { countries } \\
\text { Germany, } \\
\text { Sweden }\end{array}$ \\
\hline CATI + PAPI & & $\begin{array}{l}1 \text { country } \\
\text { Belgium }\end{array}$ & & $\begin{array}{l}1 \text { country } \\
\text { Czech } \\
\text { Republic }\end{array}$ & $\begin{array}{l}1 \text { country } \\
\text { Croatia }\end{array}$ & $\begin{array}{l}2 \text { countries } \\
\text { Czech Re- } \\
\text { public, } \\
\text { Italy }\end{array}$ \\
\hline CATI/CASI & & & & & 1 country & 2 countries \\
\hline +CAWI & & & & & Denmark & $\begin{array}{l}\text { Denmark, } \\
\text { Finland }\end{array}$ \\
\hline $\begin{array}{l}\text { CATI + Face to } \\
\text { face }\end{array}$ & $\begin{array}{l}1 \text { country } \\
\text { Finland }\end{array}$ & $\begin{array}{l}1 \text { country } \\
\text { Finland }\end{array}$ & & & & \\
\hline CAPI & & $\begin{array}{l}1 \text { country } \\
\text { Ireland }\end{array}$ & $\begin{array}{l}2 \text { countries } \\
\text { Estonia, } \\
\text { Ireland }\end{array}$ & $\begin{array}{l}6 \text { coun- } \\
\text { tries Esto- } \\
\text { nia, } \\
\text { France, } \\
\text { Ireland, } \\
\text { Norway, } \\
\text { Turkey, } \\
\text { UK: Scot- } \\
\text { land }\end{array}$ & $\begin{array}{l}7 \text { countries } \\
\text { Estonia, } \\
\text { France, } \\
\text { Georgia, } \\
\text { Ireland, } \\
\text { Norway, } \\
\text { Turkey, } \\
\text { UK: Scot- } \\
\text { land }\end{array}$ & $\begin{array}{l}7 \text { countries } \\
\text { Estonia, } \\
\text { France, } \\
\text { Ireland, } \\
\text { Norway, } \\
\text { Poland, } \\
\text { Turkey, } \\
\text { UK: Scot- } \\
\text { land }\end{array}$ \\
\hline CAWI & & & & & & $\begin{array}{l}1 \text { country } \\
\text { Iceland }\end{array}$ \\
\hline CAPI + CASI & & $\begin{array}{l}1 \text { country } \\
\text { UK: Eng- } \\
\text { land \& } \\
\text { Wales }\end{array}$ & $\begin{array}{l}1 \text { country } \\
\text { UK: Eng- } \\
\text { land \& } \\
\text { Wales }\end{array}$ & $\begin{array}{l}1 \text { country } \\
\text { UK: Eng- } \\
\text { land \& } \\
\text { Wales }\end{array}$ & $\begin{array}{l}2 \text { countries } \\
\text { France, UK: } \\
\text { England \& } \\
\text { Wales }\end{array}$ & $\begin{array}{l}1 \text { country } \\
\text { UK: Eng- } \\
\text { land \& } \\
\text { Wales }\end{array}$ \\
\hline PAPI & $\begin{array}{l}3 \text { coun- } \\
\text { tries Es- } \\
\text { tonia, } \\
\text { France, } \\
\text { UK: Eng- } \\
\text { land \& } \\
\text { Wales }\end{array}$ & $\begin{array}{l}2 \text { countries } \\
\text { Estonia, } \\
\text { France }\end{array}$ & $\begin{array}{l}4 \text { countries } \\
\text { Bulgaria, } \\
\text { France, } \\
\text { Lithuania, } \\
\text { UK: Scot- } \\
\text { land }\end{array}$ & $\begin{array}{l}2 \text { coun- } \\
\text { tries Bul- } \\
\text { garia, } \\
\text { Lithuania }\end{array}$ & $\begin{array}{l}2 \text { countries } \\
\text { Bulgaria, } \\
\text { Lithuania }\end{array}$ & \\
\hline $\begin{array}{l}\text { CAWI, PAPI, } \\
\text { CATI, CAPI } \\
\text { OTHER - One } \\
\text { person inter- } \\
\text { viewed at ran- } \\
\text { dom from each } \\
\text { household } \\
\text { sampled }\end{array}$ & & & & & & $\begin{array}{l}1 \text { country } \\
\text { Netherlands } \\
1 \text { country } \\
\text { UK: North- } \\
\text { ern Ireland }\end{array}$ \\
\hline
\end{tabular}


Notes on Tables 6.3.1-6.3.6

\begin{tabular}{|c|c|}
\hline Belgium & $\begin{array}{l}\text { The figures for the sample size are weighted. In } 2010 \text { the non-weighted sample } \\
\text { was } 37,000 \text {. }\end{array}$ \\
\hline Croatia & The counting unit in the 2000 and the 2009 surveys was the person. \\
\hline Czech Republic & $\begin{array}{l}2006 \text { means data collected November 2005-November 2006. In } 2015 \text { the sam- } \\
\text { ple design was quota sampling based on age, sex, education, size of place of } \\
\text { residence and region. Main differences from previous research can be caused } \\
\text { by asking first on } 3 \text { years period and then last } 12 \text { months. }\end{array}$ \\
\hline Denmark & $\begin{array}{l}\text { Data corresponds to the year in which surveys were carried out. There are no } \\
\text { exact data for the sample size in } 2000 \text {, but it was much smaller than the others. }\end{array}$ \\
\hline Estonia & $\begin{array}{l}\text { The most recent survey was carried out from November } 2008 \text { to May } 2009 \text {. The } \\
\text { period of reference was } 12 \text { months prior to the interview. Accordingly, for most } \\
\text { of the respondents the major reference period was } 2008 \text {, but it could include } \\
\text { also victimisations suffered from November } 2007 \text { to May } 2009 \text {. }\end{array}$ \\
\hline Finland & $\begin{array}{l}\text { Since 2012, the Finnish National Research Institute of Legal Policy has started } \\
\text { an annual victimisation survey. The counting unit is an individual not a house- } \\
\text { hold. }\end{array}$ \\
\hline France & $\begin{array}{l}\text { In } 2016 \text { the sample consisted of } 22,800 \text { units (approximately } 15,500 \text { respondent } \\
\text { households) as well as an extension for priority areas. }\end{array}$ \\
\hline Georgia & $\begin{array}{l}\text { The respondents represented the whole country, with the exception of the } \\
\text { breakaway territories (South Ossetia and Abkhazia). }\end{array}$ \\
\hline Germany & $\begin{array}{l}\text { In } 2012 \text { and } 2017 \text { the sampling was at the National level and first regional level } \\
\text { (but the latter only for five Federal States, for which the sample size was in- } \\
\text { creased) }\end{array}$ \\
\hline Iceland & $\begin{array}{l}\text { Data from the ICVS for } 2005 \text { is available but it is not comparable to the data } \\
\text { from } 2010 \text {. }\end{array}$ \\
\hline Lithuania & $\begin{array}{l}\text { The methodology and results presented here correspond to the surveys con- } \\
\text { ducted by the Centre for Crime Prevention in } 2005,2006 \text { and } 2008 \text {. For the rest } \\
\text { of the surveys mentioned in Table } 6.1 .3 \text { there were no such detailed analyses } \\
\text { of offences or the surveys covered a five-year period of reference. }\end{array}$ \\
\hline Netherlands & The sample size and response rate are given for persons, not households \\
\hline Netherlands & $\begin{array}{l}\text { The SLC on victimisation is based on the general surveys of living conditions, } \\
\text { which had questions regarding victimisation for the first time in } 1983 \text {. The SLC } \\
\text { in } 1983,1987,1991,1995,1997,2001,2004,2007 \text { and } 2012 \text { included, in var- } \\
\text { ious degrees, questions regarding victimisation and fear of crime. The content } \\
\text { of the surveys has been nearly identical from } 1997 \text {. }\end{array}$ \\
\hline Turkey & $\begin{array}{l}\text { Although detailed information is not available, it appears that more than one } \\
\text { person was surveyed in each household, as the total number of interviews was } \\
6983 \text { for } 2005 \text {, and } 7027 \text { for } 2010 \text {. The survey was conducted for the first time } \\
\text { in } 2003 \text {, hence there are no data before that. From } 2015 \text { onwards data are not } \\
\text { generally available but can be purchased from the statistical office. As a result, } \\
2014 \text { data have been used. }\end{array}$ \\
\hline UK: England \& Wales & $\begin{array}{l}\text { The response rates given are } 67 \% \text { for those aged } 10-15 \text { and } 75 \% \text { for those } \\
\text { aged } 16+\text { For } 2015 \text { data for injury, sexual assault (harassment) and robbery are } \\
\text { aggregated. }\end{array}$ \\
\hline UK: Northern Ireland & $\begin{array}{l}\text { A good deal of the variation between years in the results is due to the fact that } \\
\text { the amount of crime in many offences, particularly the serious ones, is quite low } \\
\text { in Northern Ireland, because of the small size of the population. For indications } \\
\text { of the sampling errors associated with the estimates the reader should refer to } \\
\text { the NI statistical bulletins. }\end{array}$ \\
\hline
\end{tabular}




\subsection{Sources of national metadata and results}

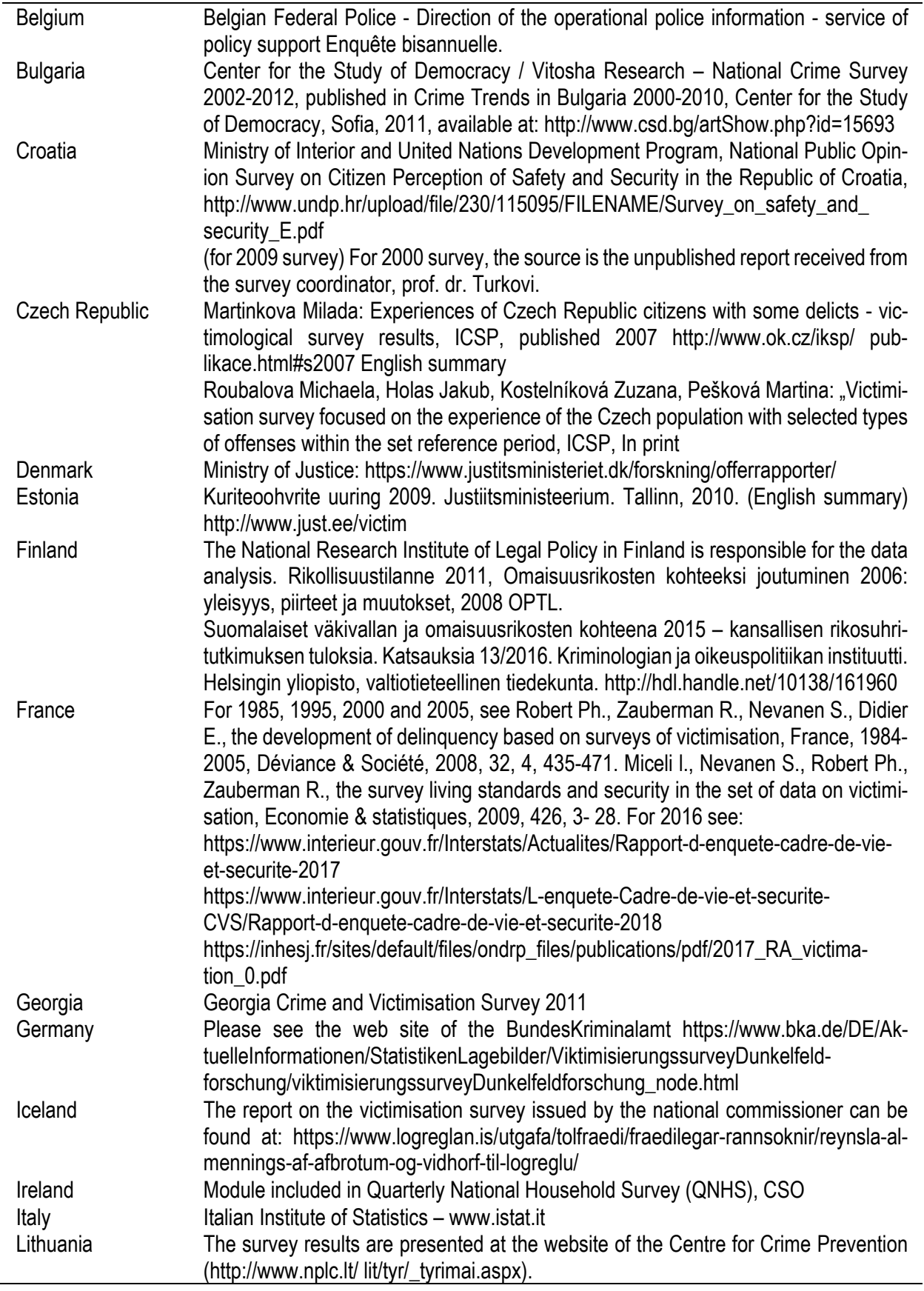


Netherlands Incidence of victimisation over the last 12 months are provisional figures. Theft of personal property is split up according to categories provided in Table on availability of questions in the survey.

Norway The report on the survey for 2015 can be found at: https://www.ssb.no/sosiale-forhold-og-kriminalitet/artikler-og-pub-

likasjoner/levekarsundersokelsen-eu-silc-2015-tema-boforhold-utsatthet-og-uro-forlovbrudd.

Poland An analytical tool is available online to allow the reader to access more detailed data.

Portugal Data base of the Polish Crime Survey.

Slovenia

Sweden

Turkey

Based on data from Inquérito de vitimação 1992, ISBN 972-8030-02-9; and Inquérito de Vitimação 1994, ISBN 972-8030-05-3.

Pečar (1982) - first victimisation study in Ljubljana; Pavlović (1992) - ICVS in Ljubljana; Pavlović (1997) - ICVS in Slovenia; Pavlovič (2001) - ICVS in Slovenia; Dekleva (1995) - bullying in primary and secondary schools; Cvek \& Pšunder (2013) - peer violence and victimisation in primary schools; Dolinar, Jere, Meško, Podbregar in Eman (2010) - mobbing; Selič \& Jakopin (2010) - mobbing among trainee doctors; Mičović (2011) - exposure of preschool children to food additives; Eman (2011) environmental crime; Pavšič Mrevlje (2014) - victimisation of elderly in Ljubljana; Meško \& Bernik (2011) - cybercrime and victimisation; Dimc \& Dobovšek (2013) cybercrime; Završnik (2015) - cybercrime; Umek \& Meško (1999) - effects of crime on victims; Gorenak (2003) - satisfaction of victims of property crime with the police proceedings; Dvoršek, Maver \& Meško (2006) - satisfaction of victims of property crime with the police proceedings; Meško \& Pavlović (1998) - fear of crime; Meško \& Umek (1999) - fear of crime; Meško, Šifrer \& Vošnjak (2012) - comparison of fear of crime in urban and rural environments; Vošnjak (2011) - correlations between victimisation and the fear of crime; Hacin \& Eman (2014) - fear of crime in the municipality of Trbovlje using crime mapping tools.

Project Feelings of Safety and the Role of Police in Ensuring Safety in Local Communities (2010...012) - local safety and security (feelings of safety)

Project Legitimacy and Legality of Policing, Criminal Justice and Execution of Penal Sanctions (2013...016) - victims of crime

Programme Safety and Security in Local Communities (2015...018) - local safety and security (feelings of safety.

Sweden National Council for Crime Prevention, Sweden, www.bra.se.

Turkish Statistical Institute, Life Satisfaction Survey online statistical tables: http://www.tuik.gov.tr/PreTabloArama.do

Turkish Statistical Institute, Life Satisfaction Survey 2014, https://biruni.tuik.gov.tr/yayin/views/visitorPages/index.zul

UK: England \& The User Guide to Crime Statistics in England and Wales Wales http://www.ons.gov.uk/ons/guide-method/method-quality/specific/crime-statisticsmethodology/index.html and BCS 2010/11 User Guide http://www.esds.ac.uk/findingData/snDescription.asp?sn=6937

UK: Northern $\quad$ The Northern Ireland crime survey is closely based on the Crime Survey for England Ireland and Wales. More details can be found in the web site below https://www.justice-ni.gov.uk/sites/default/files/publications/justice/experience-ofcrime-findings...015-16-ni-crime-survey-feb-17.pdf

UK: Scotland $\quad$ http://www.scotland.gov.uk/Publications/2011/10/28142346/19 2010/11 Scottish Crime and Justice Survey: Main Findings. 


\subsection{Other topics covered by national victimisation surveys in Europe}

Chapter 6 has concentrated on prevalence and incidence of crime and respondents' views about the work of the police and safety issues. However, as countries have become more experienced with their use of victimisation surveys, they have realised that many other topics can be covered successfully. This section considers the most recent questionnaires used in Denmark, Germany, Sweden, and UK: England \& Wales as examples of how wide the possibilities have become.

\section{Denmark}

As well as the questions already covered in this chapter, Table 6.5 .1 presents additional topics covered in the Danish victimisation surveys over time.

Table 6.5.1 Additional topics covered in the Danish Victimisation Survey

\begin{tabular}{|c|c|}
\hline Number & Topic \\
\hline 1 & Vandalism (since 2005) \\
\hline 2 & Hate crimes (since 2008) \\
\hline 3 & Concerns about crime in society in general (since 2015) \\
\hline 4 & Different types of cybercrime (since 2018) \\
\hline 5 & Other sexual crimes than rape (since 2018) \\
\hline 6 & Hateful speech online (since 2020) \\
\hline 7 & Sextortion (since 2020)" \\
\hline
\end{tabular}




\section{Germany}

As well as the questions already covered in this chapter, the 2017 German Victimisation Survey questionnaire covers the topics in Table 6.5.2. The questionnaire is available in three languages, German, Turkish and Russian to cope with the minority populations living in Germany. More detail can be found in the publication Victimisation Surveys in Germany - English Summaries by Leitgöb-Guzy, Birkel and Mischkowitz (Eds.) ${ }^{48}$.

Table 6.5.2 Additional topics covered in the German Victimisation Survey

\begin{tabular}{|c|c|}
\hline Number & Topic \\
\hline 1 & Sexual violence and domestic violence \\
\hline 2 & $\begin{array}{l}\text { Sexual and physical abuse of children } \\
\text { (including in the domestic environment) }\end{array}$ \\
\hline 3 & Hate crime \\
\hline 4 & Cybercrime \\
\hline 5 & Violence against the elderly \\
\hline
\end{tabular}

\section{Sweden}

As well as the questions already covered in this chapter, the 2017 German Victimisation Survey questionnaire covers the topics in Table 6.5.3. More details are available at: https://www.bra.se/bra-in-english/home/crime-and-statistics/swedishcrime-survey.html

Table 6.5.3 Additional topics covered in the Swedish Victimisation Survey Number

\begin{tabular}{ll}
\hline 1 & Experiences of the police \\
2 & Harassment (including online) \\
3 & Credit card fraud \\
4 & Sales fraud \\
5 & Pickpocketing \\
6 & Threats \\
\hline
\end{tabular}

\footnotetext{
${ }^{48}$ See the publication by the Bundeskriminalamt at: https://www.bka.de/SharedDocs/Downloads/DE/Publikationen/Publikationsreihen/PolizeiUndForschung/1_47_3_VictimisationSurveysInGermany_Volume3.pdf?_blob=publicationFile\&v $=3$.
} 


\section{$U K:$ England and Wales}

As well as the questions already covered in this chapter, the 2017 CSEW questionnaire covers the topics in Table 6.5.4. More detail can be found at: https://www.ons.gov.uk/file?uri=/peoplepopulationandcommunity/crimeandjustice/methodologies/crimeandjusticemethodology/201718csewquestionnaire.pdf

Moreover, the demographic information collected on the respondents has also increased so that victims can be identified by characteristics such as their age, education, employment, and health.

Table 6.5.4 Additional topics covered in the 2017 Crime Survey of England and Wales

Number

\begin{tabular}{ll}
\hline 1 & Performance of the criminal justice system \\
2 & Experience of the criminal justice system \\
3 & Mobile phone crime \\
4 & Experiences of the police \\
5 & Attitudes to the criminal justice system \\
6 & Crime prevention and security \\
7 & Financial loss and fraud \\
8 & Anti-social behaviour \\
9 & Drug use and drinking \\
10 & Gangs and personal security \\
11 & Domestic abuse, sexual victimisation and stalking \\
12 & Online fraud \\
\hline
\end{tabular}

Topic covered 



\section{Appendix I: Definitions}

\section{Offences}

The offence definitions given hereafter are operational, not legal definitions ("standard" definitions). They were devised to allow national correspondents to provide the necessary data for their countries and to specify the scope of the statistical (and legal) definitions underlying their (police and conviction) statistics. Standard definitions were chosen in a way to maximize the number of countries that could meet them without reservation. Standard definitions are listed for police-recorded offences and for convictions, with the possibility to state for both levels, using an include / exclude checklist, whether national definitions deviate from the standard definition.

The following Tables 1 and 2 show which countries were able to meet the standard definitions in all respects (marked "YES"), which countries provided data, but did not fully meet the standard definition (marked "NO') and which countries did not provide any figures in chapters 1 and / or 3 for certain offences (marked “...”). In a small number of cases, country responses were ambiguous or incomplete, thus making it unclear whether a certain definition had been fully met or not; the respective definitions are marked " $Y / N$ " for these countries in the tables.

Table 1 refers to the police level, Table 2 to convictions. At the bottom of each table is indicated how many countries were able to meet the standard definitions. A high rate of deviation from the standard definition stands for substantial variation 
in definitions across Europe, while a low rate of deviation suggests rather uniform offence definitions across the continent. ${ }^{49}$ Consistency in definitions is rather high with respect to, for example, the definitions of robbery, domestic burglary, and sexual assault.

For those countries that were unable to meet the standard definition, the following text (after Table 2) shows the way in which their offence definitions deviated from the standard. If a deviation refers to only one level (police or convictions), this level is indicated in brackets..$^{50}$ Otherwise, deviations refer to both levels.

Deviations are relatively frequent with respect to offences that are rather vague and hard to distinguish from related offences, such as bodily injury. As the detailed indications in the following sections will illustrate, the deviations are often related to problems in statistical recording of cases on the fringes to other offences, like assault leading to death. Such problems increase for offence groups between mere administrative and truly criminal offences, like major road traffic offences: Offences that are not defined as criminal in one country can and should typically not be $i n$ cluded, while it is also difficult to exclude from a given offence group in another country offences that are considered criminal.

In order to ensure that the data correspond to changing legal and statistical situations and in general to improve comparability, some definitions have been changed in this edition. For three offences, the change was so significant that figures can only be compared very cautiously with earlier editions. This applies for major road traffic offences, which no longer require the committing of a severe road crime but instead it is sufficient if the offence is prosecuted in criminal proceedings (i.e.: not merely administrative ones). In addition, the definitions for the sexual offences of rape and sexual abuse of minors have been substantially modified. The definition of rape has been extended and, in line with legal developments, the focus on consent and the ability to validly give it was strengthened. This, accordingly, leads to a corresponding restriction of the offence definition of sexual abuse of minors. The offences of aggravated theft, cyber fraud and forgery of documents have been introduced to the Sourcebook for the first time in this edition.

How important are deviations in quantitative respect, and how much do they affect comparability? As a general rule, one may say that the inclusion or exclusion of "minor" offences (e.g., minor theft) has a greater impact on overall rates than deviations on serious but relatively rare offences, such as "assault leading to death".

\footnotetext{
${ }^{49}$ Compliance with standard definitions was analysed in more detail for the 5th edition of the Sourcebook in Harrendorf, S. (2018): Prospects, Problems, and Pitfalls in Comparative Analyses of Criminal Justice Data, Crime and Justice: A Review of Research 47, 159-207, and for the 4th edition in Harrendorf, S. (2012): Offence Definitions in the European Sourcebook of Crime and Criminal Justice Statistics and Their Influence on Data Quality and Comparability, European Journal on Criminal Policy and Research 18(1), 23-53.

${ }^{50}$ This does not necessarily mean that the rule was followed on the other level: It is also possible that data were not available, or the reply of the country was rather ambiguous or incomplete (also cf. Tables 1 and 2).
} 
Table 1.Standard definitions followed in all respects on police level (part 1)

\begin{tabular}{|c|c|c|c|c|c|c|c|c|}
\hline & $\begin{array}{c}\text { Total } \\
\text { criminal } \\
\text { offences } \\
\end{array}$ & $\begin{array}{c}\text { Major road } \\
\text { traffic } \\
\text { offences } \\
\end{array}$ & $\begin{array}{l}\text { Intentional } \\
\text { homicide }\end{array}$ & $\begin{array}{l}\text { Bodily } \\
\text { Injury }\end{array}$ & $\begin{array}{c}\text { Aggrav. } \\
\text { bodily } \\
\text { injury }\end{array}$ & $\begin{array}{l}\text { Sexual } \\
\text { assault }\end{array}$ & Rape & $\begin{array}{c}\text { Sexual } \\
\text { abuse of } \\
\text { a child }\end{array}$ \\
\hline Albania & $Y / N$ & NO & NO & NO & NO & NO & NO & NO \\
\hline Armenia & NO & NO & NO & NO & NO & YES & NO & \\
\hline Austria & YES & NO & YES & YES & YES & YES & NO & YES \\
\hline Azerbaijan & NO & NO & NO & & NO & & YES & \\
\hline Belgium & YES & YES & NO & NO & $\ldots$ & YES & NO & NO \\
\hline Bosnia-Herzegovina & Y/N & & Y/N & Y/N & & & Y/N & \\
\hline Bulgaria & NO & NO & NO & YES & NO & NO & NO & NO \\
\hline Croatia & YES & YES & YES & YES & YES & YES & YES & YES \\
\hline Cyprus & NO & NO & YES & YES & YES & YES & YES & YIN \\
\hline Czech Republic & YES & NO & NO & NO & & YES & YES & NO \\
\hline Denmark & NO & NO & YES & NO & YES & YES & NO & NO \\
\hline Estonia & NO & Y/N & NO & YES & YES & YES & NO & YES \\
\hline Finland & NO & YES & YES & NO & NO & NO & YES & YES \\
\hline France & NO & & NO & NO & & NO & YES & NO \\
\hline Georgia & YES & NO & YES & YES & YES & YES & NO & \\
\hline Germany & NO & & YES & YES & NO & YES & YES & NO \\
\hline Greece & NO & YES & $\mathrm{Y} / \mathrm{N}$ & NO & & YES & YES & \\
\hline Hungary & YES & NO & NO & NO & NO & NO & NO & NO \\
\hline Iceland & NO & NO & YES & NO & NO & Y/N & YES & NO \\
\hline Ireland & & Y/N & Y/N & & & Y/N & Y/N & Y/N \\
\hline Italy & NO & NO & Y/N & YES & YES & YES & YES & YES \\
\hline Kosovo (UN R/1244/99) & & & Y/N & $\mathrm{Y} / \mathrm{N}$ & & & $\mathrm{Y} / \mathrm{N}$ & $\ldots$ \\
\hline Latvia & NO & YES & NO & NO & NO & YES & NO & \\
\hline Lithuania & NO & NO & YES & YES & NO & YES & YES & YES \\
\hline Luxembourg & Y/N & & $\mathrm{Y} / \mathrm{N}$ & & Y/N & $\mathrm{Y} / \mathrm{N}$ & $\mathrm{Y} / \mathrm{N}$ & \\
\hline Malta & Y/N & Y/N & Y/N & Y/N & Y/N & Y/N & $\mathrm{Y} / \mathrm{N}$ & Y/N \\
\hline Moldova & YES & NO & NO & NO & Y/N & NO & NO & NO \\
\hline Montenegro & NO & YES & NO & NO & NO & YES & NO & NO \\
\hline Netherlands & Y/N & YES & NO & NO & & NO & NO & \\
\hline North Macedonia & NO & NO & NO & YES & YES & YES & YES & YES \\
\hline Norway & Y/N & Y/N & Y/N & NO & NO & Y/N & $\mathrm{Y} / \mathrm{N}$ & NO \\
\hline Poland & NO & NO & YES & NO & YES & YES & YES & NO \\
\hline Portugal & YES & NO & NO & NO & NO & NO & NO & \\
\hline Romania & YES & NO & NO & NO & YES & YES & YES & YES \\
\hline Russian Federation & Y/N & & & Y/N & & & & \\
\hline Serbia & NO & NO & NO & NO & YES & YES & NO & YES \\
\hline Slovak Republic & Y/N & $\ldots$ & Y/N & Y/N & & & $\mathrm{Y} / \mathrm{N}$ & \\
\hline Slovenia & NO & & NO & NO & NO & YES & YES & YES \\
\hline Spain & NO & NO & NO & NO & & NO & NO & NO \\
\hline Sweden & NO & YES & YES & NO & Y/N & NO & YES & NO \\
\hline Switzerland & NO & $\ldots$ & NO & NO & NO & YES & NO & NO \\
\hline Turkey & Y/N & & Y/N & Y/N & & $\mathrm{Y} / \mathrm{N}$ & & Y/N \\
\hline Ukraine & NO & NO & NO & NO & NO & NO & NO & NO \\
\hline UK: England \& Wales & NO & NO & NO & YES & NO & YES & NO & YIN \\
\hline UK: Northern Ireland & Y/N & NO & Y/N & YES & & YES & YES & $\mathrm{Y} / \mathrm{N}$ \\
\hline UK: Scotland & Y/N & & NO & NO & NO & YES & YES & \\
\hline Total "YES" & $\begin{array}{cl}9 \\
\end{array}$ & 8 & $\begin{array}{ll}11 \\
\end{array}$ & $\begin{array}{ll}12 \\
\end{array}$ & $\begin{array}{ll}11 \\
\end{array}$ & $\begin{array}{ll}24 \\
\end{array}$ & $\begin{array}{cc}18 \\
\end{array}$ & 10 \\
\hline Total "NO" & 24 & 23 & 23 & 25 & 18 & 11 & 19 & 17 \\
\hline Total "Y/N" & 11 & 4 & 11 & 6 & 4 & 6 & 7 & 6 \\
\hline Total "..." & 2 & 11 & 1 & 3 & 13 & 5 & 2 & 13 \\
\hline \% "YES" & $20 \%$ & $17 \%$ & $24 \%$ & $26 \%$ & $24 \%$ & $52 \%$ & $39 \%$ & $22 \%$ \\
\hline \% “NO” & $52 \%$ & $50 \%$ & $50 \%$ & $54 \%$ & $39 \%$ & $24 \%$ & $41 \%$ & $37 \%$ \\
\hline \% "Y/N" & $24 \%$ & $9 \%$ & $24 \%$ & $13 \%$ & $9 \%$ & $13 \%$ & $15 \%$ & $13 \%$ \\
\hline$\% "$ "..." & $4 \%$ & $24 \%$ & $2 \%$ & $7 \%$ & $28 \%$ & $11 \%$ & $4 \%$ & $28 \%$ \\
\hline
\end{tabular}


Table 1. Standard definitions followed in all respects on police level (part 2)

\begin{tabular}{|c|c|c|c|c|c|c|c|c|}
\hline & Robbery & Theft & $\begin{array}{c}\text { Aggra- } \\
\text { vated theft }\end{array}$ & $\begin{array}{c}\text { Theft of a } \\
\text { motor } \\
\text { vehicle }\end{array}$ & $\begin{array}{l}\text { Theft by } \\
\text { means of } \\
\text { burglary }\end{array}$ & $\begin{array}{l}\text { Theft bmo } \\
\text { domestic } \\
\text { burglary }\end{array}$ & Fraud & $\begin{array}{l}\text { Cyber } \\
\text { fraud }\end{array}$ \\
\hline Albania & NO & $\mathrm{Y} / \mathrm{N}$ & NO & NO & NO & $\mathrm{Y} / \mathrm{N}$ & NO & NO \\
\hline Armenia & YES & NO & NO & Y/N & NO & YES & NO & $\ldots$ \\
\hline Austria & YES & Y/N & Y/N & NO & NO & YES & NO & $\ldots$ \\
\hline Azerbaijan & NO & NO & $\ldots$ & & & & NO & \\
\hline Belgium & NO & Y/N & $\ldots$ & NO & NO & YES & YES & YES \\
\hline Bosnia-Herzegovina & Y/N & Y/N & & Y/N & Y/N & $\mathrm{Y} / \mathrm{N}$ & & \\
\hline Bulgaria & YES & YES & NO & NO & NO & NO & YES & YES \\
\hline Croatia & YES & YES & YES & & NO & & YES & $\ldots$ \\
\hline Cyprus & NO & NO & $\ldots$ & YES & YES & YES & NO & \\
\hline Czech Republic & NO & NO & & NO & NO & YES & NO & NO \\
\hline Denmark & YES & YES & NO & YES & YES & YES & YES & YES \\
\hline Estonia & YES & NO & & NO & & YES & YES & $\ldots$ \\
\hline Finland & YES & YES & YES & YES & YES & NO & YES & $\ldots$ \\
\hline France & YES & YES & $\ldots$ & NO & NO & NO & NO & $\ldots$ \\
\hline Georgia & YES & YES & & YES & NO & NO & NO & \\
\hline Germany & YES & YES & YES & YES & YES & YES & YES & NO \\
\hline Greece & YES & NO & NO & NO & NO & $\ldots$ & NO & \\
\hline Hungary & YES & YES & $\ldots$ & YES & & $\ldots$ & NO & NO \\
\hline Iceland & YES & YES & $\ldots$ & Y/N & NO & $\ldots$ & NO & $\ldots$ \\
\hline Ireland & Y/N & Y/N & $\ldots$ & Y/N & $\ldots$ & $\ldots$ & Y/N & $\ldots$ \\
\hline Italy & YES & NO & $\ldots$ & Y/N & & YES & YES & $\ldots$ \\
\hline Kosovo (UN R/1244/99) & Y/N & $\mathrm{Y} / \mathrm{N}$ & & Y/N & Y/N & Y/N & & $\ldots$ \\
\hline Latvia & YES & YES & $\ldots$ & & & YES & & $\ldots$ \\
\hline Lithuania & NO & YES & $\ldots$ & YES & NO & YES & YES & $\ldots$ \\
\hline Luxembourg & Y/N & Y/N & & Y/N & Y/N & & & $\ldots$ \\
\hline Malta & Y/N & Y/N & & Y/N & Y/N & Y/N & $\mathrm{Y} / \mathrm{N}$ & $\ldots$ \\
\hline Moldova & NO & NO & NO & NO & NO & Y/N & NO & YIN \\
\hline Montenegro & NO & NO & NO & NO & & & NO & NO \\
\hline Netherlands & YES & YES & & NO & YES & YES & YES & \\
\hline North Macedonia & YES & YES & YES & YES & & NO & YES & YES \\
\hline Norway & Y/N & NO & NO & Y/N & Y/N & Y/N & Y/N & $\ldots$ \\
\hline Poland & NO & NO & NO & NO & NO & NO & NO & \\
\hline Portugal & YES & YES & NO & NO & YES & YES & Y/N & NO \\
\hline Romania & YES & NO & $\ldots$ & NO & & YES & NO & NO \\
\hline Russian Federation & Y/N & Y/N & & Y/N & Y/N & & & \\
\hline Serbia & YES & NO & YES & YES & NO & NO & YES & YES \\
\hline Slovak Republic & Y/N & Y/N & & Y/N & Y/N & Y/N & & \\
\hline Slovenia & NO & YES & NO & NO & NO & YES & YES & NO \\
\hline Spain & YES & NO & & NO & NO & NO & NO & Y/N \\
\hline Sweden & NO & YES & YES & NO & NO & YES & NO & NO \\
\hline Switzerland & YES & NO & $\ldots$ & YES & YES & YES & NO & YES \\
\hline Turkey & Y/N & Y/N & $\ldots$ & NO & Y/N & Y/N & Y/N & Y/N \\
\hline Ukraine & NO & NO & $\ldots$ & NO & & YES & NO & $\ldots$ \\
\hline UK: England \& Wales & Y/N & NO & $\ldots$ & Y/N & Y/N & YES & NO & $\ldots$ \\
\hline UK: Northern Ireland & Y/N & NO & $\ldots$ & NO & Y/N & YES & NO & $\ldots$ \\
\hline UK: Scotland & NO & NO & . & NO & NO & YES & NO & $\ldots$ \\
\hline Total "YES" & $2 \quad 22$ & $\begin{array}{ll}16 \\
\end{array}$ & 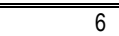 & $\begin{array}{ll}10 \\
\end{array}$ & 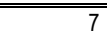 & $\begin{array}{ll}21 \\
\end{array}$ & $\begin{array}{ll}13 \\
\end{array}$ & $\overline{\overline{6}}$ \\
\hline Total "NO" & 13 & 19 & 11 & 21 & 19 & 8 & 22 & 9 \\
\hline Total "Y/N" & 11 & 11 & 1 & 12 & 10 & 8 & 5 & 3 \\
\hline Total "..." & 0 & 0 & 28 & 3 & 10 & 9 & 6 & 28 \\
\hline \% "YES" & $48 \%$ & $35 \%$ & $13 \%$ & $22 \%$ & $15 \%$ & $46 \%$ & $28 \%$ & $13 \%$ \\
\hline \% "NO" & $28 \%$ & $41 \%$ & $24 \%$ & $46 \%$ & $41 \%$ & $17 \%$ & $48 \%$ & $20 \%$ \\
\hline \% "Y/N" & $24 \%$ & $24 \%$ & $2 \%$ & $26 \%$ & $22 \%$ & $17 \%$ & $11 \%$ & $7 \%$ \\
\hline \% "..." & $0 \%$ & $0 \%$ & $61 \%$ & $7 \%$ & $22 \%$ & $20 \%$ & $13 \%$ & $61 \%$ \\
\hline
\end{tabular}


Table 1.Standard definitions followed in all respects on police level (part 3)

\begin{tabular}{|c|c|c|c|c|c|c|}
\hline & $\begin{array}{l}\text { Forgery of } \\
\text { documents }\end{array}$ & $\begin{array}{l}\text { Money } \\
\text { laundering }\end{array}$ & $\begin{array}{l}\text { Corruption in } \\
\text { the public sector }\end{array}$ & $\begin{array}{c}\text { Drug } \\
\text { offences total }\end{array}$ & Drug trafficking & Firearm \\
\hline Albania & NO & NO & NO & NO & $\mathrm{NO}$ & NO \\
\hline Armenia & & & YES & NO & NO & NO \\
\hline Austria & NO & YES & YES & NO & $\ldots$ & NO \\
\hline Azerbaijan & & & NO & NO & & \\
\hline Belgium & YES & NO & YES & NO & NO & NO \\
\hline $\begin{array}{l}\text { Bosnia-Herze- } \\
\text { govina }\end{array}$ & $\ldots$ & & $\ldots$ & $\ldots$ & $Y / N$ & $Y / N$ \\
\hline Bulgaria & $\cdots$ & YES & NO & NO & & NO \\
\hline Croatia & NO & YES & YES & NO & NO & \\
\hline Cyprus & NO & NO & YES & NO & NO & NO \\
\hline Czech Republic & NO & YES & NO & NO & NO & $\ldots$ \\
\hline Denmark & YES & & NO & NO & YES & $\ldots$ \\
\hline Estonia & NO & YES & NO & NO & YES & YIN \\
\hline Finland & YES & YES & NO & YES & YES & \\
\hline France & & $\ldots$ & & YES & NO & NO \\
\hline Georgia & YES & & NO & NO & YES & YES \\
\hline Germany & YES & YES & YES & NO & YES & YES \\
\hline Greece & NO & & NO & NO & & \\
\hline Hungary & NO & NO & NO & NO & NO & NO \\
\hline Iceland & YES & $\ldots$ & $\ldots$ & NO & NO & Y/N \\
\hline Ireland & $\ldots$ & & $\ldots$ & Y/N & Y/N & $\ldots$ \\
\hline Italy & $\ldots$ & YES & $\ldots$ & NO & $\ldots$ & $\ldots$ \\
\hline Kosovo & & & $\ldots$ & $\ldots$ & & \\
\hline $\mathrm{R} / 1244 / 99)$ & $\ldots$ & $\ldots$ & & & Y/N & $\ldots$ \\
\hline Latvia & & & & NO & YES & \\
\hline Lithuania & NO & YES & NO & NO & YES & NO \\
\hline Luxembourg & & $\ldots$ & Y/N & Y/N & Y/N & Y/N \\
\hline Malta & Y/N & & & Y/N & Y/N & Y/N \\
\hline Moldova & NO & NO & NO & NO & NO & Y/N \\
\hline Montenegro & NO & NO & NO & NO & NO & NO \\
\hline Netherlands & YES & YES & $\ldots$ & NO & & \\
\hline North Macedonia & YES & YES & & YES & YES & YES \\
\hline Norway & Y/N & YIN & NO & $\mathrm{Y} / \mathrm{N}$ & & Y/N \\
\hline Poland & YES & YIN & YES & NO & NO & NO \\
\hline Portugal & NO & YES & NO & NO & NO & Y/N \\
\hline Romania & Y/N & YES & YES & NO & $\ldots$ & Y/N \\
\hline Russian Federation & & & & & & \\
\hline Serbia & YES & YES & YES & YES & Y/N & NO \\
\hline Slovak Republic & & & & & Y/N & Y/N \\
\hline $\begin{array}{l}\text { Slovenia } \\
\text { Sumb }\end{array}$ & YES & YES & Y/N & NO & NO & NO \\
\hline Spain & NO & YES & NO & YES & & NO \\
\hline Sweden & NO & NO & NO & YES & NO & NO \\
\hline Switzerland & YES & NO & YES & YES & YES & YES \\
\hline Turkey & NO & & & & & Y/N \\
\hline Ukraine & YES & YES & YES & NO & NO & Y/N \\
\hline UK: England \& & & & $\ldots$ & Y/N & & \\
\hline Wales & $\ldots$ & $\ldots$ & & & NO & Y/N \\
\hline UK: Northern Ire- & & & $\ldots$ & YES & & \\
\hline land & $\ldots$ & $\ldots$ & & & YES & NO \\
\hline UK: Scotland & $\ldots$ & $\ldots$ & $\ldots$ & NO & 10 & 年 \\
\hline Total "YES" & 13 & $\overline{18}$ & 11 & 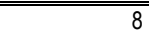 & 10 & 4 \\
\hline Total "NO" & 15 & 8 & 17 & 28 & 17 & 16 \\
\hline Total "Y/N" & 3 & 2 & 2 & 5 & 7 & 13 \\
\hline Total "..." & 15 & 18 & 16 & 5 & 12 & 13 \\
\hline$\%$ "YES" & $28 \%$ & $39 \%$ & $24 \%$ & $17 \%$ & $22 \%$ & $9 \%$ \\
\hline \%"NO" & $33 \%$ & $17 \%$ & $37 \%$ & $61 \%$ & $37 \%$ & $35 \%$ \\
\hline \% "Y/N" & $7 \%$ & $4 \%$ & $4 \%$ & $11 \%$ & $15 \%$ & $28 \%$ \\
\hline$\% " \ldots "$ & $33 \%$ & $39 \%$ & $35 \%$ & $11 \%$ & $26 \%$ & $28 \%$ \\
\hline
\end{tabular}


Table 2. Standard definitions followed in all respects on convictions level (part 1)

\begin{tabular}{|c|c|c|c|c|c|c|c|c|}
\hline & $\begin{array}{c}\text { Total } \\
\text { criminal of- } \\
\text { fences } \\
\end{array}$ & $\begin{array}{c}\text { Major road } \\
\text { traffic } \\
\text { offences } \\
\end{array}$ & $\begin{array}{l}\text { Intentional } \\
\text { homicide }\end{array}$ & $\begin{array}{l}\text { Bodily } \\
\text { Injury }\end{array}$ & $\begin{array}{c}\text { Aggrav. } \\
\text { bodily } \\
\text { injury }\end{array}$ & $\begin{array}{l}\text { Sexual } \\
\text { assault }\end{array}$ & Rape & $\begin{array}{c}\text { Sexual } \\
\text { abuse of } \\
\text { a child }\end{array}$ \\
\hline Albania & Y/N & YES & NO & NO & NO & NO & & $\ldots$ \\
\hline Armenia & $\mathrm{Y} / \mathrm{N}$ & NO & NO & NO & NO & YES & NO & \\
\hline Austria & YES & & YES & YES & YES & YES & NO & YES \\
\hline Azerbaijan & NO & NO & NO & & NO & & YES & \\
\hline Belgium & NO & YES & NO & NO & NO & YES & NO & NO \\
\hline Bosnia-Herzegovina & Y/N & & & & & & & \\
\hline Bulgaria & NO & NO & NO & YES & NO & NO & NO & NO \\
\hline Croatia & YES & YES & YES & YES & YES & YES & YES & YES \\
\hline Cyprus & NO & NO & & & & & & \\
\hline Czech Republic & NO & NO & NO & NO & NO & YES & YES & NO \\
\hline Denmark & YES & NO & YES & NO & YES & YES & NO & NO \\
\hline Estonia & NO & Y/N & NO & YES & YES & YES & NO & YES \\
\hline Finland & NO & YES & YES & NO & NO & NO & YES & YES \\
\hline France & YES & NO & NO & NO & NO & NO & YES & NO \\
\hline Georgia & YES & NO & NO & YES & YES & YES & NO & \\
\hline Germany & YES & NO & YES & YES & NO & YES & NO & NO \\
\hline Greece & & & & & & & & \\
\hline Hungary & YES & NO & NO & NO & NO & NO & NO & NO \\
\hline Iceland & $\cdots$ & $\ldots$ & $\ldots$ & $\ldots$ & $\ldots$ & $\ldots$ & $\ldots$ & $\ldots$ \\
\hline $\begin{array}{l}\text { Iteland } \\
\text { Italy }\end{array}$ & NO & YES & Y/N & YES & YES & YES & YES & YES \\
\hline Kosovo (UN R/1244/99) & Y/N & & & & & $\ldots$ & & $\ldots$ \\
\hline Latvia & NO & YES & NO & NO & NO & & NO & \\
\hline Lithuania & NO & NO & YES & YES & NO & YES & YES & YES \\
\hline Luxembourg & Y/N & $\ldots$ & Y/N & $\mathrm{Y} / \mathrm{N}$ & $\ldots$ & Y/N & Y/N & $\ldots$ \\
\hline Malta & $\ldots$ & & & & $\ldots$ & & & $\ldots$ \\
\hline Moldova & $\ldots$ & NO & NO & NO & $\ldots$ & NO & NO & \\
\hline Montenegro & & & & & Y/N & & Y/N & Y/N \\
\hline Netherlands & Y/N & YES & NO & NO & NO & No & NO & NO \\
\hline North Macedonia & NO & & YES & YES & YES & YES & YES & $\ldots$ \\
\hline Norway & Y/N & Y/N & & & & Y/N & & \\
\hline Poland & NO & NO & YES & NO & YES & YES & YES & NO \\
\hline Portugal & YES & YES & NO & NO & NO & NO & NO & NO \\
\hline Romania & YES & NO & NO & NO & YES & YES & YES & YES \\
\hline Russian Federation & YIN & & & & & & & \\
\hline Serbia & NO & YES & YES & NO & YES & YES & YES & YES \\
\hline Slovak Republic & Y/N & & & & & & & \\
\hline Slovenia & NO & NO & NO & Y/N & $\mathrm{Y} / \mathrm{N}$ & Y/N & NO & $\mathrm{Y} / \mathrm{N}$ \\
\hline Spain & Y/N & & & & & & & \\
\hline Sweden & NO & YES & YES & NO & YES & NO & YES & NO \\
\hline Switzerland & Y/N & NO & NO & NO & NO & YES & NO & NO \\
\hline Turkey & NO & NO & NO & NO & NO & NO & & \\
\hline Ukraine & NO & NO & NO & NO & NO & NO & NO & NO \\
\hline UK: England \& Wales & NO & NO & NO & NO & Y/N & NO & YES & NO \\
\hline UK: Northern Ireland & NO & $\ldots$ & $\ldots$ & YES & & YES & & $\ldots$ \\
\hline UK: Scotland & Y/N & 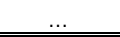 & $\ldots$ & NO & NO & YES & YES & $\ldots$ \\
\hline $\begin{array}{l}\text { Total "YES" } \\
\end{array}$ & 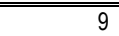 & $\begin{array}{l}10 \\
\end{array}$ & $\begin{array}{c}10 \\
\end{array}$ & $\begin{array}{ll}10 \\
\end{array}$ & $\begin{array}{ll}11 \\
\end{array}$ & $\begin{array}{ll}18 \\
\end{array}$ & $\begin{array}{ll}14 \\
\end{array}$ & 8 \\
\hline Total "NO" & 19 & 19 & 20 & 21 & 18 & 12 & 16 & 14 \\
\hline Total "Y/N" & 12 & 2 & 2 & 2 & 3 & 3 & 2 & 2 \\
\hline Total "..." & 6 & 15 & 14 & 13 & 14 & 13 & 14 & 22 \\
\hline \% "YES" & $20 \%$ & $22 \%$ & $22 \%$ & $22 \%$ & $24 \%$ & $39 \%$ & $30 \%$ & $17 \%$ \\
\hline \% “NO” & $41 \%$ & $41 \%$ & $43 \%$ & $46 \%$ & $39 \%$ & $26 \%$ & $35 \%$ & $30 \%$ \\
\hline \% "Y/N" & $26 \%$ & $4 \%$ & $4 \%$ & $4 \%$ & $7 \%$ & $7 \%$ & $4 \%$ & $4 \%$ \\
\hline \% "..." & $13 \%$ & $33 \%$ & $30 \%$ & $28 \%$ & $30 \%$ & $28 \%$ & $30 \%$ & $48 \%$ \\
\hline
\end{tabular}


Table 2.Standard definitions followed in all respects on convictions level (part 2)

\begin{tabular}{|c|c|c|c|c|c|c|c|c|}
\hline & Robbery & Theft & $\begin{array}{c}\text { Aggra- } \\
\text { vated theft }\end{array}$ & $\begin{array}{c}\text { Theft of a } \\
\text { motor } \\
\text { vehicle }\end{array}$ & $\begin{array}{l}\text { Theft by } \\
\text { means of } \\
\text { burglary }\end{array}$ & $\begin{array}{l}\text { Theft bmo } \\
\text { domestic } \\
\text { burglary }\end{array}$ & Fraud & $\begin{array}{l}\text { Cyber } \\
\text { fraud }\end{array}$ \\
\hline Albania & NO & $\mathrm{Y} / \mathrm{N}$ & NO & & $\ldots$ & $\ldots$ & NO & $\ldots$ \\
\hline Armenia & YES & NO & $\ldots$ & $\mathrm{Y} / \mathrm{N}$ & $\ldots$ & $\ldots$ & NO & $\ldots$ \\
\hline Austria & YES & Y/N & $\mathrm{Y} / \mathrm{N}$ & $\ldots$ & NO & $\ldots$ & NO & $\ldots$ \\
\hline Azerbaijan & NO & NO & $\ldots$ & $\ldots$ & $\ldots$ & $\ldots$ & NO & $\ldots$ \\
\hline Belgium & YES & YES & NO & $\ldots$ & $\ldots$ & $\ldots$ & YES & $\ldots$ \\
\hline Bosnia-Herzegovina & & $\ldots$ & & $\ldots$ & $\ldots$ & $\ldots$ & & $\ldots$ \\
\hline Bulgaria & YES & YES & NO & NO & $\ldots$ & $\ldots$ & YES & $\ldots$ \\
\hline Croatia & YES & YES & YES & $\ldots$ & NO & $\ldots$ & YES & $\ldots$ \\
\hline Cyprus & $\ldots$ & $\ldots$ & $\ldots$ & $\ldots$ & $\ldots$ & $\ldots$ & $\ldots$ & $\ldots$ \\
\hline Czech Republic & NO & NO & $\ldots$ & $\ldots$ & $\ldots$ & $\ldots$ & NO & $\ldots$ \\
\hline Denmark & YES & YES & NO & YES & YES & YES & YES & YES \\
\hline Estonia & YES & NO & $\ldots$ & $\ldots$ & $\ldots$ & $\ldots$ & YES & $\ldots$ \\
\hline Finland & YES & YES & YES & YES & $\ldots$ & $\ldots$ & YES & $\ldots$ \\
\hline France & YES & NO & $\ldots$ & $\ldots$ & $\ldots$ & $\ldots$ & YES & $\ldots$ \\
\hline Georgia & YES & NO & & $\ldots$ & $\ldots$ & $\ldots$ & NO & $\ldots$ \\
\hline Germany & YES & YES & YES & $\ldots$ & NO & NO & NO & $\ldots$ \\
\hline Greece & & & & & & & & \\
\hline Hungary & YES & YES & NO & YES & NO & NO & NO & NO \\
\hline Iceland & $\ldots$ & $\ldots$ & $\ldots$ & $\ldots$ & $\ldots$ & $\ldots$ & $\ldots$ & $\ldots$ \\
\hline Ireland & & $\ldots$ & $\ldots$ & $\ldots$ & $\ldots$ & $\ldots$ & $\ldots$ & $\ldots$ \\
\hline Italy & YES & NO & $\ldots$ & $\ldots$ & $\ldots$ & $\ldots$ & YES & $\ldots$ \\
\hline Kosovo (UN R/1244/99) & & $\ldots$ & $\ldots$ & $\ldots$ & $\ldots$ & $\ldots$ & $\ldots$ & $\ldots$ \\
\hline Latvia & YES & YES & $\ldots$ & $\ldots$ & $\ldots$ & $\ldots$ & $\ldots$ & $\ldots$ \\
\hline Lithuania & NO & YES & $\ldots$ & $\ldots$ & $\ldots$ & $\ldots$ & YES & $\ldots$ \\
\hline Luxembourg & $\mathrm{Y} / \mathrm{N}$ & Y/N & $\ldots$ & $\ldots$ & $\ldots$ & $\ldots$ & $\mathrm{Y} / \mathrm{N}$ & $\mathrm{Y} / \mathrm{N}$ \\
\hline Malta & & $\ldots$ & $\ldots$ & $\ldots$ & $\ldots$ & $\ldots$ & $\ldots$ & $\ldots$ \\
\hline Moldova & NO & NO & NO & $\ldots$ & $\ldots$ & $\ldots$ & NO & $\ldots$ \\
\hline Montenegro & & $\ldots$ & $\mathrm{Y} / \mathrm{N}$ & $\ldots$ & $\ldots$ & $\ldots$ & $\ldots$ & $\mathrm{Y} / \mathrm{N}$ \\
\hline Netherlands & YES & YES & NO & $\ldots$ & $\ldots$ & $\ldots$ & YES & $\ldots$ \\
\hline North Macedonia & YES & YES & YES & YES & $\ldots$ & $\ldots$ & YES & YES \\
\hline Norway & $\ldots$ & $\mathrm{Y} / \mathrm{N}$ & $\ldots$ & $\ldots$ & $\ldots$ & $\ldots$ & $\ldots$ & $\ldots$ \\
\hline Poland & NO & NO & NO & $\ldots$ & NO & $\ldots$ & NO & $\ldots$ \\
\hline Portugal & YES & YES & NO & YES & YES & YES & YES & NO \\
\hline Romania & YES & NO & NO & $\ldots$ & $\ldots$ & $\ldots$ & NO & NO \\
\hline Russian Federation & & $\ldots$ & $\ldots$ & $\ldots$ & $\ldots$ & $\ldots$ & $\ldots$ & $\ldots$ \\
\hline Serbia & YES & NO & YES & NO & $\ldots$ & $\ldots$ & YES & YES \\
\hline Slovak Republic & $\ldots$ & $\ldots$ & $\ldots$ & $\ldots$ & $\ldots$ & $\ldots$ & $\ldots$ & $\ldots$ \\
\hline Slovenia & NO & NO & $\ldots$ & $\ldots$ & $\mathrm{Y} / \mathrm{N}$ & $\ldots$ & NO & $\ldots$ \\
\hline Spain & & $\ldots$ & $\cdots$ & $\ldots$ & $\ldots$ & $\cdots$ & $\ldots$ & $\cdots$ \\
\hline Sweden & NO & YES & & NO & $\ldots$ & $\ldots$ & NO & . \\
\hline Switzerland & YES & NO & YES & $\ldots$ & $\ldots$ & $\ldots$ & NO & YES \\
\hline Turkey & YES & YES & $\ldots$ & $\ldots$ & $\ldots$ & $\ldots$ & NO & $\ldots$ \\
\hline Ukraine & NO & NO & $\ldots$ & NO & NO & $\ldots$ & NO & $\ldots$ \\
\hline UK: England \& Wales & NO & NO & $\ldots$ & $\mathrm{Y} / \mathrm{N}$ & $\mathrm{Y} / \mathrm{N}$ & YES & NO & $\ldots$ \\
\hline UK: Northern Ireland & $\mathrm{Y} / \mathrm{N}$ & NO & $\ldots$ & $\ldots$ & $\mathrm{Y} / \mathrm{N}$ & $\ldots$ & NO & $\ldots$ \\
\hline UK: Scotland & $\mathrm{Y} / \mathrm{N}$ & NO & $\ldots$ & NO & NO & $\ldots$ & NO & $\ldots$ \\
\hline Total "YES" & 21 & 14 & 6 & $\overline{5}$ & $\overline{2}$ & 3 & 13 & $\overline{74}$ \\
\hline Total "NO" & 10 & 17 & 10 & 5 & 7 & 2 & 19 & 3 \\
\hline Total "Y/N" & 3 & 4 & 2 & 2 & 3 & 0 & 1 & 2 \\
\hline Total "..." & 12 & 11 & 28 & 34 & 34 & 41 & 13 & 37 \\
\hline \% "YES" & $46 \%$ & $30 \%$ & $13 \%$ & $11 \%$ & $4 \%$ & $7 \%$ & $28 \%$ & $9 \%$ \\
\hline \% "NO” & $22 \%$ & $37 \%$ & $22 \%$ & $11 \%$ & $15 \%$ & $4 \%$ & $41 \%$ & $7 \%$ \\
\hline \% "Y/N" & $7 \%$ & $9 \%$ & $4 \%$ & $4 \%$ & $7 \%$ & $0 \%$ & $2 \%$ & $4 \%$ \\
\hline \% "..." & $26 \%$ & $24 \%$ & $61 \%$ & $74 \%$ & $74 \%$ & $89 \%$ & $28 \%$ & $80 \%$ \\
\hline
\end{tabular}


Table 2. Standard definitions followed in all respects on convictions level (part 3)

\begin{tabular}{|c|c|c|c|c|c|}
\hline & $\begin{array}{l}\text { Forgery of } \\
\text { documents }\end{array}$ & Money laundering & $\begin{array}{l}\text { Corruption in the } \\
\text { public sector }\end{array}$ & Drug offences total & Drug trafficking \\
\hline Albania & NO & NO & NO & NO & NO \\
\hline Armenia & & YES & YES & NO & NO \\
\hline Austria & NO & YES & YES & NO & $\mathrm{Y} / \mathrm{N}$ \\
\hline Azerbaijan & & & NO & NO & $\ldots$ \\
\hline Belgium & YES & YES & YES & NO & $\ldots$ \\
\hline Bosnia-Herzegovina & $\ldots$ & & & & $\ldots$ \\
\hline Bulgaria & $\cdots$ & YES & NO & NO & $\cdots$ \\
\hline Croatia & NO & YES & YES & NO & NO \\
\hline Cyprus & & & & & \\
\hline Czech Republic & NO & YES & NO & NO & NO \\
\hline Denmark & YES & & NO & NO & YES \\
\hline Estonia & NO & YES & NO & NO & YES \\
\hline Finland & YES & YES & NO & YES & YES \\
\hline France & NO & $\ldots$ & YES & YES & NO \\
\hline Georgia & YES & & NO & NO & YES \\
\hline Germany & YES & YES & YES & NO & YES \\
\hline Greece & & & & & \\
\hline Hungary & NO & NO & NO & NO & NO \\
\hline Iceland & $\ldots$ & $\ldots$ & $\ldots$ & $\ldots$ & $\ldots$ \\
\hline Ireland & & & $\ldots$ & & $\ldots$ \\
\hline Italy & Y/N & YES & $\ldots$ & NO & $\ldots$ \\
\hline Kosovo (UN R/1244/99) & $\ldots$ & $\ldots$ & $\ldots$ & & $\ldots$ \\
\hline Latvia & & & & NO & \\
\hline Lithuania & NO & YES & NO & NO & YES \\
\hline Luxembourg & $\ldots$ & $\ldots$ & $\ldots$ & Y/N & $\mathrm{Y} / \mathrm{N}$ \\
\hline Malta & $\ldots$ & & & & $\ldots$ \\
\hline Moldova & $\ldots$ & NO & NO & NO & $\cdots$ \\
\hline Montenegro & Y/N & $\mathrm{Y} / \mathrm{N}$ & & & $\ldots$ \\
\hline Netherlands & YES & YES & YES & NO & $\ldots$ \\
\hline North Macedonia & YES & YES & $\ldots$ & & $\ldots$ \\
\hline Norway & & & & Y/N & \\
\hline Poland & YES & Y/N & YES & NO & NO \\
\hline Portugal & NO & YES & NO & NO & NO \\
\hline Romania & Y/N & YES & YES & YES & NO \\
\hline Russian Federation & & & & & \\
\hline Serbia & YES & YES & YES & YES & Y/N \\
\hline Slovak Republic & $\ldots$ & & & & 单 \\
\hline Slovenia & $\ldots$ & NO & NO & NO & YIN \\
\hline $\begin{array}{l}\text { Spain } \\
\text { Sweden }\end{array}$ & NO & YES & NO & YES & YES \\
\hline Switzerland & YES & NO & YES & YES & YES \\
\hline Turkey & NO & NO & NO & NO & NO \\
\hline Ukraine & YES & YES & YES & NO & NO \\
\hline UK: England \& Wales & Y/N & $\mathrm{Y} / \mathrm{N}$ & $\ldots$ & $\mathrm{Y} / \mathrm{N}$ & Y/N \\
\hline UK: Northern Ireland & $\ldots$ & & & YES & $\ldots$ \\
\hline UK: Scotland & & NO & YES & NO & \\
\hline "Total "YES" & 11 & 19 & 13 & $\overline{c 7}$ & 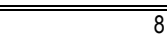 \\
\hline Total "NO" & 11 & 7 & 15 & 24 & 11 \\
\hline Total "Y/N" & 4 & 3 & 0 & 3 & 5 \\
\hline Total "..." & 20 & 17 & 18 & 12 & 22 \\
\hline \% "YES" & $24 \%$ & $41 \%$ & $28 \%$ & $15 \%$ & $17 \%$ \\
\hline \% "NO" & $24 \%$ & $15 \%$ & $33 \%$ & $52 \%$ & $24 \%$ \\
\hline \% "Y/N" & $9 \%$ & $7 \%$ & $0 \%$ & $7 \%$ & $11 \%$ \\
\hline$\% " \ldots "$ & $43 \%$ & $37 \%$ & $39 \%$ & $26 \%$ & $48 \%$ \\
\hline
\end{tabular}




\subsection{Total criminal offences}

In principle, all offences subject to criminal proceedings should be included. This rule is, however, not trivial: There are some countries which follow a minor offence concept either excluding such offences from the criminal code (for example the 'wykroczenia' in Poland in cases of minor thefts etc.) or making them subject to special proceedings (for example most 'contraventions' in France which are handled by the police only) outside the criminal justice system. Sometimes they are recorded in police statistics, sometimes not.

Where possible, the figures include:

- Minor theft and other minor property offences

- Minor assault and other minor violent offences

- Criminal offences committed by minors

- Crimes according to a military penal code

- Major road traffic offences

- All other criminal offences subject to criminal proceedings

They exclude:

- All traffic offences subject to proceedings outside the criminal justice system

- All traffic offences sanctioned by fines issued automatically by a technical system

- Administrative offences subject to proceedings outside the criminal justice system

- Minor offences subject to proceedings outside the criminal justice system This means that the providers of the data (= national correspondents) were requested to ensure that "their" figures included, where available from their national statistics, "minor theft", "minor assault", etc.

\subsubsection{Countries deviating from include rules:}

The following countries exclude minor theft and other minor property offences from their data:

- Azerbaijan

- Cyprus (police level)

- Czech Republic (police level)

- Estonia

- Lithuania

- Poland

- Ukraine 
Regarding minor assault and other minor violent offences, the following countries exclude this offence category from the total:

- Azerbaijan

- Cyprus (police level)

- Czech Republic (conviction level)

- Montenegro (police level)

- Poland

- Spain (police level)

- Ukraine

Criminal offences committed by minors are excluded in:

- Belgium (conviction level)

- Lithuania

- Poland (conviction level, except for most serious offences)

Crimes according to a military penal code are excluded in:

- Bulgaria

- Cyprus

- Czech Republic (conviction level)

- Estonia

- Greece (police level)

- Iceland (police level)

- Italy

- Lithuania

- Montenegro (police level)

- North Macedonia

- Poland

- Serbia

- Slovenia (conviction level)

- Spain (police level)

- Sweden

- Switzerland (police level)

- Ukraine 
Major road traffic offences are only excluded in:

- Denmark (police level)

- France (police level)

- Germany (police level)

- Slovenia (police level)

- Switzerland (police level)

Regarding all other criminal offences subject to criminal proceedings, these are - in general (except for Germany and Slovenia on police level) - included in the police and conviction statistics of all countries. There are - however - some specific offence categories which are excluded sometimes.

For example, in Bulgaria police statistics exclude all crimes against the Republic of Bulgaria (treason, espionage, etc.), crimes against the country's defence capacity, military crimes, crimes against peace and humanity, and crimes committed abroad. In Germany, tax, and customs offences as well as offences against the security of the state (like treason, terrorism, etc.) and international crimes are excluded. Such exceptions will exist in many countries.

\subsubsection{Countries deviating from exclude rules:}

All traffic offences subject to proceedings outside the criminal justice system are included in:

- Spain (police level)

- Turkey (conviction level)

- UK: England \& Wales (conviction level)

- UK: Northern Ireland (conviction level)

In the following countries, traffic offences sanctioned by fines issued automatically by a technical system are included:

- Iceland (police level)

- Latvia

- Spain (police level)

- UK: England \& Wales

- UK: Northern Ireland (conviction level)

Administrative offences subject to proceedings outside the criminal justice system are included in:

- Finland

- Latvia

- Spain (police level) 
Other minor offences subject to proceedings outside the criminal justice system are included in:

- Armenia (police level)

- Finland

- Latvia

1.2 Major road traffic offences

The definition of major road traffic offences has been revised for the $6^{\text {th }}$ edition. Whereas previously only severe road traffic offences were included, it is now sufficient that the respective offences are prosecuted as criminal offences. The data for major road traffic offences in the $6^{\text {th }}$ edition will therefore not be comparable with data provided in the $5^{\text {th }}$ edition.

According to the standard definition, major road traffic offences mean road traffic offences subject to criminal proceedings. Where possible, the figures include:

- Negligent homicide and negligent injury in road traffic

- Dangerous / reckless driving

- (i.e.: driving in a way that falls far below what would be expected of a competent and careful driver and is obviously endangering life or health of another person or leads to the danger of serious damage to property)

- Seriously endangering road traffic in other ways

- (e.g., removing traffic signs, building obstacles, throwing objects onto the motorway)

- Driving under the influence of drugs or alcohol

- All other traffic offences subject to criminal proceedings

They exclude:

- Offences committed outside road traffic (e.g., involving trains, airplanes, ships, or boats)

- All traffic offences subject to proceedings outside the criminal justice system 


\subsubsection{Countries deviating from include rules:}

The following countries exclude negligent homicide and negligent injury in road traffic:

- Cyprus

- France (conviction level)

- Romania

- Spain (police level)

- Turkey (conviction level)

- UK: England \& Wales (conviction level)

Dangerous or reckless driving is excluded in:

- Albania (police level)

- Armenia

- Austria (police level)

- Czech Republic

- Denmark

- Georgia

- Hungary (conviction level)

- Italy (police level)

- Lithuania

- Ukraine

In these countries seriously endangering road traffic in other ways is excluded:

- Armenia

- Austria (police level)

- Czech Republic

- Denmark

- Italy (police level)

- Moldova

- Poland

- Portugal (police level)

- Slovenia (conviction level)

- UK: England \& Wales (conviction level)

- UK: Northern Ireland (police level) 
Driving under the influence of drugs or alcohol is excluded in:

- Armenia

- Austria (police level)

- Denmark (police level)

- Italy (police level)

- Slovenia (conviction level)

- Ukraine

- UK: England \& Wales

- UK: Northern Ireland (police level)

The following countries exclude all other traffic offences subject to criminal proceedings:

- Denmark (police level)

- France (conviction level)

- Iceland (police level)

- Italy (police level)

- Portugal (police level)

1.2.2 Countries deviating from exclude rules:

Offences committed outside road traffic are included in:

- Azerbaijan

- Bulgaria

- Germany (conviction level)

- Hungary (police level)

- Moldova (conviction level)

- North Macedonia (police level)

- Serbia (police level)

- Switzerland (conviction level)

- Turkey (conviction level)

- Ukraine

The following countries include all traffic offences subject to proceedings outside the criminal justice system in their data:

- Germany (conviction level)

- UK: England \& Wales (conviction level) 


\subsection{Intentional homicide}

According to the standard definition, intentional homicide means intentional killing of a person. Where possible, the figures include:

- Assault leading to death

- Euthanasia

- Infanticide

- Attempts

They exclude:

- Assistance with suicide

- Abortion

- Negligent killing

- War crimes, genocide, crimes against humanity

\subsubsection{Countries deviating from include rules:}

The following countries exclude assault leading to death: 51

- Armenia

- Azerbaijan

- Belgium (police level)

- Bulgaria

- Czech Republic

- France (conviction level)

- Hungary

- Latvia

- Netherlands

- Portugal (conviction level)

- Romania

- Slovenia

- Spain (police level)

- Turkey (conviction level)

- Ukraine

${ }^{51}$ As could be expected, many of these countries on the other hand include assault leading to death in bodily injury data. 
These countries exclude cases of euthanasia:

- Azerbaijan

- Belgium

- Moldova (police level)

- Montenegro (police level)

- North Macedonia (police level)

- Romania

- Serbia (police level)

- Switzerland

- UK: England \& Wales

Infanticide is excluded in:

- Azerbaijan

- Moldova

- Romania

- Slovenia

Finally, attempts are excluded in:

- Estonia

- Georgia

- Moldova

- Portugal (police level)

- Slovenia (conviction level)

- UK: England \& Wales (police level)

\subsubsection{Countries deviating from exclude rules:}

Assistance with suicide is included only in:

- Estonia

- Hungary

- Montenegro (police level)

- Switzerland (police level)

- UK: England \& Wales (police level)

- UK: Scotland (police level)

Only four countries include abortion:

- Estonia

- Hungary (conviction level)

- Montenegro (police level)

- Netherlands 
Some countries even include negligent killings:

- Estonia

- Montenegro (police level)

- UK: England \& Wales

- UK: Scotland (police level)

A number of countries include war crimes, genocide, and crimes against bumanity:

- Albania

- Estonia (police level)

- France

- Slovenia (conviction level)

- UK: England \& Wales (police level)

- UK: Scotland (police level)

1.4 Bodily injury

According to the standard definition, bodily injury means inflicting bodily injury on another person with intent. Where possible, the figures include:

- Minor bodily injury

- Aggravated bodily injury

- Bodily injury of a public servant/official

- Bodily injury in a domestic dispute

- Attempts

They exclude:

- Assault leading to death

- Threats

- Assault only causing pain (e.g., slapping)

- Sexual assault

- Negligent bodily injury

\subsubsection{Countries deviating from include rules:}

The following countries exclude minor bodily injury:

- Czech Republic

- France (police level)

- Moldova

- Poland

- Switzerland (conviction level)

- Turkey (conviction level) 
- Ukraine

Only Turkey on conviction level could not include aggravated bodily injury.

Bodily injury of a public servant is excluded in:

- Albania

- Armenia

- Hungary (police level)

- Montenegro (police level)

- Portugal

- Romania

- Serbia (police level)

- Spain (police level)

- Sweden (conviction level)

- Turkey (conviction level)

- Ukraine

Bodily injury in a domestic dispute is excluded in:

- Moldova (conviction level)

- Romania

- Serbia

- Turkey (conviction level)

Attempts are excluded in:

- Moldova

- Montenegro (police level)

- Norway (police level)

- Turkey (conviction level)

1.4.2 Countries deviating from exclude rules:

Assault leading to death is included in the following countries: ${ }^{52}$

- Armenia

- Belgium

- Czech Republic

- France (conviction level)

- Greece (police level)

52 As could be expected, many of these countries on the other hand exclude assault leading to death from homicide data. 
- Hungary

- Iceland (police level)

- Latvia

- Netherlands

- Portugal (conviction level)

- Slovenia (police level)

- Switzerland

- Turkey (conviction level)

- Ukraine

Threats are only included in:

- Georgia (police level)

- Norway (police level)

- UK: England \& Wales (conviction level)

Assault only causing pain is included in these countries:

- Albania

- Belgium

- Denmark

- Finland

- Greece (police level)

- Netherlands

- Portugal

- Romania

- Sweden

- Switzerland

- Turkey (conviction level)

- UK: Scotland

Sexual assault is only included in Greece and Norway (both on police level).

The following countries even include negligent bodily injury:

- Hungary (conviction level)

- UK: Scotland 


\subsection{Aggravated bodily injury}

According to the standard definition, aggravated bodily injury means inflicting serious (e.g., life-threatening or disabling) bodily injury to another person with intent, or under aggravated circumstances (use of weapons, or on a vulnerable victim). Cases of aggravated bodily are counted under the total of bodily injury as well. Where possible, the figures include:

- $\quad$ Serious and lasting (i.e., disabling) bodily injury

- Life-threatening bodily injury

- Use of weapons (dangerous objects)

- Particularly vulnerable victims

- Attempts

They exclude:

- Assault leading to death

- Mere threats

- Sexual assault

- $\quad$ Negligent bodily injury

\subsubsection{Countries deviating from include rules:}

All countries are able to include serious and lasting bodily injury and life-threatening bodily injury.

Use of weapons (dangerous objects) is excluded only in:

- Albania

- Lithuania

- Switzerland

- Turkey (conviction level)

- Ukraine

- UK: England \& Wales (police level)

Particularly vulnerable victims are excluded in the statistics of:

- Finland

- Germany

- Lithuania

- Switzerland

- Turkey (conviction level)

- Ukraine

- UK: England \& Wales (police level) 
Attempts are only excluded in:

- Montenegro (police level)

- Norway (police level)

- Portugal (police level)

- UK: England \& Wales (police level)

- UK: Scotland

1.5.2 Countries deviating from exclude rules:

Assault leading to death is included in the data for the following countries:

- Albania

- Armenia

- $\quad$ Czech Republic (conviction level)

- $\quad$ France (conviction level)

- Hungary

- $\quad$ Iceland (police level)

- Latvia

- Netherlands (conviction level)

- Norway (police level)

- $\quad$ Portugal (conviction level)

- Slovenia (police level)

- Switzerland

- Turkey (conviction level)

- Ukraine

All countries are able to exclude mere threats and sexual assault except from Norway on police level.

The following countries even include negligent bodily injury:

- Bulgaria

- Norway (police level)

- Portugal (police level)

1.6 Sexual assault

The new standard definition for sexual assault is physical sexual contact with a person against her/ his will or with a person who cannot validly consent to sexual acts. Where possible, the figures include:

- Any sexual acts committed with violence or threat of violence

- Any sexual acts committed with abuse of authority or undue pressure

- Any sexual acts committed against a helpless person 
- Any sexual acts committed against a marital partner against her/his will

- Acts considered as rape

- Acts considered as physical sexual abuse of a child

- Attempts

They exclude:

- Any verbal or any other form of non-physical molestation

- Pornography

- Pimping

- Buying / offering paid sex

- Exhibitionism

\subsubsection{Countries deviating from include rules:}

Acts considered as rape are excluded in UK: England \& Wales on conviction level.

Acts considered as physical sexual abuse of a child are excluded in Moldova on police level.

Moldova also excludes attempts.

Otherwise, all reporting countries could fully meet the include rules.

1.6.2 Countries deviating from exclude rules:

Some countries actually report data based on a wider concept and thus include verbal or any other form of non-physical molestation:

- Albania (police level)

- France (police level)

- Netherlands

- Portugal

- Sweden

- Turkey (conviction level)

- Ukraine

Pornography is only included in:

- Albania

- Hungary (conviction level)

- Spain (police level)

- Turkey (conviction level) 
The following countries include pimping:

- Bulgaria

- Finland

- France (conviction level)

- Hungary

- Spain (police level)

- Turkey (conviction level)

The list of countries which include buying / offering paid sex is shorter, but somewhat identical:

- Finland

- Spain (police level)

- Turkey (conviction level)

Exhibitionism is also only included in countries which seem to follow a very wide concept of sexual assault:

- France (conviction level)

- Hungary

- Portugal

- Turkey (conviction level)

\subsection{Rape}

The definition of rape has been significantly extended compared to the $5^{\text {th }}$ edition, in line with ongoing trends towards a legal model of rape centring around consent and the ability to give it. From this edition on, seemingly 'consensual' sexual acts are considered as rape if they are committed on/with persons unable to give their consent (like minors, severely intoxicated persons, etc.). Only for sexual acts between minors, some exceptions have been made from this general rule. Hence, rape data in the $6^{\text {th }}$ edition will not be comparable to the data of the $5^{\text {th }}$ edition.

According to the standard definition, rape means sexual intercourse with a person against her/his will (per vaginam or other). Where possible, the figures include:

- Penetration other than vaginal (e.g., buggery)

- Violent intra-marital sexual intercourse

- Sexual intercourse without force with a helpless person

- Sexual intercourse of an adult with a child or any other person who cannot validly consent

- Attempts 
They exclude:

- Sexual intercourse between children, if factually consented by both partners

- Sexual intercourse between a child and a juvenile, if factually consented by both partners and the age difference is not larger than three years

1.7.1 Countries deviating from include rules:

Penetration other than vaginal is excluded from statistics on rape in:

- Moldova

- Switzerland

- Ukraine

Violent intra-marital intercourse is included by all countries.

Sexual intercourse without force with a helpless person is excluded in the following countries:

- Netherlands

- Serbia (police level)

- Slovenia (conviction level)

- Spain (police level)

- Switzerland

Sexual intercourse of an adult with a child or any other person who cannot validly consent is excluded in:

- Austria

- Estonia

- Germany (conviction level)

- Netherlands

- Portugal

- Serbia (police level)

Just two countries exclude attempts:

- Moldova

- Portugal (police level)

- Serbia (police level)

\subsubsection{Countries deviating from exclude rules:}

Sexual intercourse between children, if factually consented by both partners is included in:

- Albania (police level)

- Armenia 
- Denmark

- Latvia

- Montenegro (police level)

- Spain (police level)

- UK: England \& Wales (police level)

Sexual intercourse between a child and a juvenile (age difference max. 3 years) is included in the rape statistics of:

- Albania (police level)

- Belgium

- Bulgaria

- Denmark

- Georgia

- Hungary

- Latvia

- Montenegro (police level)

- Spain (police level)

\subsection{Sexual abuse of a child}

As a consequence of the extension of the definition of rape, sexual intercourse with a child is now always considered rape (see above) and was accordingly excluded here. The exceptions for certain sexual activities between minors are similar to the ones for rape. The data will not be comparable with the previous editions.

According to the standard definition, any form of physical sexual contact of a person above the age of sexual consent with a person below the age of sexual consent, except of sexual intercourse (because the latter falls under the category of rape). Where possible, the figures include:

- Any form of physical sexual contact not amounting to (statutory) rape

- Attempts

They exclude:

- Verbal or any other form of non-physical molestation

- Child pornography

- Acts considered as rape

- Sexual intercourse between children, if factually consented by both partners

- Sexual intercourse between a child and a juvenile, if factually consented by both partners and the age difference is not larger than three years 


\subsubsection{Age of consent}

Table 3. Age of consent for sexual abuse of a child by country ${ }^{53}$.

\begin{tabular}{lllll}
\multicolumn{1}{c}{14} & \multicolumn{1}{c}{16} & \multicolumn{1}{c}{17} & 18 \\
\hline Albania54 & Czech Republic & Armenia & Cyprus & France \\
Austria & Denmark & Belgium & Ireland & Turkey \\
Croatia 55 & Greece & Finland & & \\
Estonia & Iceland & Lithuania & & \\
Germany & Poland & Netherlands & & \\
Hungary & Slovak Republic & North Macedonia & \\
Italy56 & Slovenia & Norway & \\
Portugal & Sweden & Switzerland & \\
Serbia & & UK: England \& Wales & \\
Slovenia & & UK: Northern Ireland & \\
Ukraine & & UK: Scotland & \\
\hline
\end{tabular}

Table 3 above shows the age of consent, i.e., the age under which a minor cannot validly consent to have sexual contacts, for the responding countries.

Romania reported a differentiated approach, in which for some offences the age of consent is 13 , but for other 15 or even 18 years.

\subsubsection{Countries deviating from include rules:}

All countries are able to include any form of sexual contact not amounting to (statutory) rape in their data.

Attempts are only excluded in Montenegro, Moldova, and Norway (police level).

\subsubsection{Countries deviating from exclude rules:}

Verbal or any other form of non-physical molestation of persons under the age of consent is included in the following countries:

- Albania (police level)

- Moldova (police level)

- Montenegro (police level)

- Poland

- Sweden

- Switzerland

- Ukraine

\footnotetext{
${ }^{53}$ Ireland, Poland, Russian Federation, Slovak Republic, and Sweden didn't update the age of consent. Age is taken from the previous edition.

${ }^{54}$ For women minors the age of consent varies depending on when they reach sexual maturity.

55 The age of consent is 14 if the partner is not more than three years older.

56 The age of consent in Italy is 13 if the partner is not more than three years older.
} 
Child pornography is included only in:

- Albania (police level)

- Iceland (police level)

- Montenegro (police level)

- Switzerland

Acts considered as rape are included in:

- Bulgaria

- France

- Germany (conviction level)

- Iceland (police level)

- Moldova (police level)

- Montenegro (police level)

- Portugal (conviction level)

- Spain (police level)

- Switzerland

- UK: England \& Wales (conviction level)

Sexual intercourse between children, if factually consented by both partners is included in:

- Czech Republic (police level)

- Denmark

- France (police level)

- Germany (police level)

- Montenegro (police level)

- Netherlands (conviction level)

Sexual intercourse between a child and a juvenile (age difference max. 3 years) is included in the rape statistics of:

- Belgium

- Bulgaria

- Czech Republic

- Denmark

- Germany

- Hungary

- Montenegro (police level)

- Netherlands (conviction level)

- Portugal (conviction level)

- Ukraine 


\subsection{Robbery}

According to the standard definition, robbery means stealing from a person with force or threat of force. Where possible, the figures include:

- Muggings (bag-snatchings)

- Theft immediately followed by force or threat of force used to keep hold of the stolen goods

- Attempts

They exclude:

- Pick-pocketing

- Extortion

- Blackmailing

- Theft with force against property only

\subsubsection{Countries deviating from include rules:}

Countries excluding muggings are:

- Lithuania

- Poland

- Slovenia

- Sweden

Only two countries exclude theft immediately followed by force or threat of force used to keep bold of the stolen goods:

- Czech Republic

- UK: Scotland (police level)

Attempts are only excluded in Moldova and Montenegro (police level).

1.9.2 Countries deviating from exclude rules:

Pickpocketing is only included in:

- Albania (police level)

- Cyprus (conviction level)

- UK: England \& Wales (conviction level)

Extortion is only included in:

- Belgium (police level)

- Cyprus (police level)

- UK: England \& Wales (conviction level) 
Blackmailing is included in:

- Albania (conviction statistics)

- Cyprus (police statistics)

- UK: England \& Montenegro (conviction statistics)

Theft with force against property only is included in:

- Albania

- Azerbaijan

- Cyprus (police level)

- Montenegro (police level)

- Ukraine

\subsection{Theft}

According to the standard definition, theft means depriving a person or organization of property with the intent to keep it. Where possible, the figures include:

- Minor (e.g., small value) theft

- Theft committed by means of burglary (i.e., by breaking and entering)

- Theft of motor vehicles

- Theft by employees

- Attempts

They exclude:

- Robbery

- Fraud

- Receiving/handling stolen goods

1.10.1 Countries deviating from include rules:

Minor (e.g., small value) theft is excluded in:

- Azerbaijan

- Cyprus (police level; threshold value: $1000 €$ )

- Estonia (only excluded for the first and second offence of an offender; threshold value: $64 €$ before 2014)

- Georgia (conviction level; threshold value: $20 €$ )

- Montenegro (police level; threshold value: $150 €$ )

- Poland (threshold value: $100 €$ )

- Serbia (no threshold provided)

- Switzerland (conviction level; no threshold provided)

- Ukraine (threshold value: $6 €$ ) 
Only Armenia, Montenegro, and Norway (each on police level) exclude theft committed by means of burglary.

Theft of motor vehicles is excluded in:

- Moldova (conviction level)

- Slovenia (conviction level)

- Ukraine

Apart from that, Estonia excludes joyriding with respect to the total of theft, while it is included in the subcategory theft of a motor vehicle.

Theft by employees is excluded in:

- Montenegro (police level)

- Norway (police level)

- Romania

- Slovenia (conviction level)

- Switzerland

Attempts are excluded in:

- Armenia

- Estonia

- Greece (police level)

- Italy

- Moldova

- Montenegro (police level)

- Norway (police level)

- Slovenia (conviction level)

- Spain (police level)

- UK: Northern Ireland

- UK: Scotland

1.10.2 Countries deviating from exclude rules:

Robbery is excluded in every country.

Fraud is included in UK: Northern Ireland (conviction level) and UK: Scotland.

Only France (conviction level) and UK: England \& Wales includes receiving/handling stolen goods. 


\subsection{Aggravated theft}

According to the standard definition, aggravated theft means theft under aggravating circumstances concerning the modus operandi or the kind of victim/property stolen. Where possible, the figures include:

- $\quad$ theft committed by means of burglary (i.e., by breaking and entering)

- all other cases of theft with force against property (e.g., breaking of a safe)

- theft using false or skeleton keys

- theft of motor vehicles

- theft against vulnerable persons

- theft of weapons

- theft of items of increased cultural or religious value

- attempts

They exclude:

- Robbery

- Fraud

- Receiving/handling stolen goods

1.11.1 Countries deviating from include rules:

The following countries exclude theft committed by means of burglary:

- Albania

- Hungary (conviction level)

- Norway (police level)

All other cases of theft with force against property is excluded in:

- Albania

- Denmark

- Hungary (conviction level)

Theft using false or skeleton keys is excluded in:

- Albania

- Armenia (police level)

- Denmark

- Hungary (conviction level)

Theft of motor vehicles is excluded in the statistics of:

- Albania

- Armenia (police level)

- Greece (police level) 
- Hungary (conviction level)

- Moldova

- Netherlands (conviction level)

- Romania (conviction level)

- Spain (police level)

The following countries exclude theft against vulnerable persons:

- Albania

- Armenia (police level)

- Bulgaria

- Denmark

- Greece (police level)

- Hungary (conviction level)

- Moldova

- Montenegro (police level)

- Netherlands (conviction level)

- Poland

- Portugal

- Romania (conviction level)

Theft of weapons is excluded in:

- Albania

- Armenia (police level)

- Greece (police level)

- Hungary (conviction level)

- Moldova

- Netherlands (conviction level)

- Poland

- Portugal (police level)

- Romania (conviction level)

Theft of items of increased cultural or religious value is excluded in:

- Albania

- Bulgaria

- Denmark

- Hungary (conviction level)

- Netherlands (conviction level)

- Poland 
Attempts are only excluded in:

- Albania

- Hungary (conviction level)

- Moldova

- Montenegro (police level)

1.11.2 Countries deviating from exclude rules:

Robbery, fraud, and receiving/ handling stolen goods are only included in:

- Belgium (conviction level)

- Slovenia (police level)

1.12 Theft of a motor vehicle

According to the standard definition, theft of a motor vehicle means depriving a person or organization of a motor vehicle with the intent to keep it or to use it. Where possible, the figures include:

- Joyriding

- Theft of trucks / lorries

- Theft of motorcycles

- Theft of motorboats

- Theft of a motor vehicle using force against the vehicle or other property

- Attempts

They exclude:

- Theft of motor vehicle parts

- Robbery of a motor vehicle

- Receiving/handling a stolen vehicle

1.12.1 Countries deviating from include rules:

The following countries exclude joyriding:

- Albania (police level)

- Czech Republic (police level)

- Greece (police level)

- Moldova (police level)

- Montenegro (police level)

- Netherlands (police level)

- Romania (police level)

- Serbia (conviction level)

- Slovenia (police level) 
- Spain (police level)

- Turkey (police level)

- Ukraine

Theft of trucks / lorries is only excluded in Poland on police level and in Serbia on conviction level and theft of motorycles additionally in Moldova (police level).

Theft of motorboats is excluded in these countries:

- Austria (police level)

- Belgium (police level)

- Bulgaria

- Estonia (police level)

- Netherlands (police level)

- Poland (police level)

- Portugal (police level)

- Serbia (conviction level)

- UK: Northern Ireland (police level)

- UK: Scotland

Only two countries exclude theft of a motor vehicle using force against the vehicle or other property:

- Montenegro (police level)

- Serbia (conviction level)

Attempts are excluded in:

- Montenegro (police level)

- Portugal (police level)

- Serbia (conviction level)

- UK: Northern Ireland (police level)

1.12.2 Countries deviating from exclude rules:

Theft of motor vehicle parts is included in:

- France (police level)

- Montenegro (police level)

- Spain (police level)

- Sweden

Robbery is only included in the following countries: 
- Belgium (police level)

- Bulgaria

- France (police level)

Receiving and handling a stolen vehicle is included in France (police level).

\subsection{Theft by means of burglary}

According to the standard definition, burglary means theft from a closed part of a building or other premises after gaining access to it against the owners' will (e.g., by use of force against an object). Where possible, the figures include:

- Domestic burglary

- Theft from a factory, shop, office, etc.

- Theft from a military establishment

- Theft by using false keys

- Attempts

They exclude:

- Theft from a motor vehicle

- Theft from a container

- Theft from a vending machine

- Theft from a parking meter

- Theft from a fenced meadow/compound

\subsubsection{Countries deviating from include rules:}

Theft by means of domestic burglary was only excluded in Serbia (police level).

All countries are able to include theft from a factory, shop, office, etc.

Only three countries exclude theft from a military establishment:

- Albania (police level)

- Armenia (police level)

- Belgium (police level)

- Georgia (police level)

Theft by using false keys is excluded in:

- Armenia (police level)

- Bulgaria (police level)

- France (police level)

- UK: Scotland 
Attempts are excluded in Armenia and Moldova on police level.

\subsubsection{Countries deviating from exclude rules:}

Theft from a motor vehicle is included in:

- Austria

- Croatia

- Czech Republic (police level)

- Germany (conviction level)

- Greece (police level)

- Hungary (conviction level)

- Iceland (police level)

- Poland

- Slovenia (police level)

The following countries include theft from a container.

- Austria

- Croatia

- Czech Republic (police level)

- Greece (police level)

- Hungary (conviction level)

- Iceland (police level)

- Poland

- Slovenia (police level)

- Spain (police level)

- Sweden (police level)

- Ukraine (conviction level)

The group of countries including theft from a vending machine is almost identical:

- Austria

- Croatia

- Czech Republic (police level)

- Greece (police level)

- Hungary (conviction level)

- Poland

- Slovenia (police level)

- Sweden (police level) 
Again, almost the same group of countries includes theft from a parking meter:

- Austria

- Croatia

- Czech Republic (police level)

- Greece (police level)

- Hungary (conviction level)

- Poland

- Slovenia (police level)

- Sweden (police level)

Finally, theft from a fenced meadow / compound is included in the statistics of:

- Austria

- Croatia

- Czech Republic (police level)

- Greece (police level)

- Hungary (conviction level)

- Iceland (police level)

- Lithuania (police level)

- Poland

- Sweden (police level)

- Ukraine (conviction level)

1.14 Theft by means of domestic burglary

According to the standard definition, domestic burglary means theft from closed private premises after gaining access to them against the owner's will (e.g., by use of force against an object). Where possible, the figures include:

- Theft from an attic or basement in a multi-dwelling building

- Theft from a secondary residence (even if unoccupied)

- Attempts

They exclude:

- Theft from a factory, shop, office, etc.

- Theft from a detached garage, shed, barn or stable

- Theft from a fenced meadow/compound 
1.14.1 Countries deviating from include rules:

Theft from an attic or basement in a multi-dwelling building is excluded in:

- Finland (police level)

- France (police level)

- Germany (conviction level)

Theft from a secondary residence (even if unoccupied) and attempts are included everywhere.

1.14.2 Countries deviating from exclude rules:

These countries include theft from a factory, shop, office, etc.:

- Bulgaria (police level)

- Hungary (conviction level)

- Poland (police level)

Theft from a detached shed, barn or stable is included for the following countries:

- Bulgaria (police level)

- Georgia (police level)

- Hungary (conviction level)

- North Macedonia (police level)

- Poland (police level)

- Serbia (police level)

- Spain (police level)

Theft from a fenced meadow / compound is included in the statistics of:

- Hungary (conviction level)

- Poland (police level)

\subsection{Fraud}

According to the standard definition, fraud means deceiving someone or taking advantage of someone's error with the intent to unlawfully gain financial benefits, thereby causing the deceived person to enter any operation that will be damaging to his or a third person's financial interests. Where possible, the figures include:

- Cyber fraud (i.e., fraud committed by means of computer-mediated communication, e.g., via the internet)

- Attempts

They exclude:

- Receiving / handling stolen property

- Forgery of documents, passports etc. 
- Tax and customs offences

- Subsidy fraud

- Fraud involving welfare payments

- Money laundering

- Forgery of money / payment instruments

- Consuming goods or services

- Breaching of trust / embezzlement

1.15.1 Countries deviating from include rules:

Cyber fraud is excluded in:

- Georgia

- Hungary

- Moldova (conviction level)

- Montenegro (police level)

- Romania

Attempts are excluded in:

- Azerbaijan

- Georgia

- Moldova

- Montenegro (police level)

- Slovenia (conviction level)

- Sweden

1.15.2 Countries deviating from exclude rules:

Azerbaijan, Montenegro (police level) and Turkey (conviction level) are the only countries to include receiving / handling stolen goods.

Forgery of documents, passports etc. is included in:

- Turkey (conviction level)

- UK: England \& Wales (conviction level)

- UK: Northern Ireland (police level)

The following countries include tax and customs offences:

- Azerbaijan

- Turkey (conviction level)

- UK: Northern Ireland 
A considerably large number of countries include subsidy fraud:

- Albania

- Armenia

- Azerbaijan

- Cyprus (police level)

- France (police level)

- Greece (police level)

- Iceland (police level)

- Poland

- Switzerland (police level)

- Turkey (conviction level)

- Ukraine

- UK: England \& Wales

- UK: Northern Ireland

- UK: Scotland

Even more countries include fraud involving welfare payments:

- Albania

- Armenia

- Austria

- Azerbaijan

- Cyprus (police level)

- France (police level)

- Greece (police level)

- Iceland (police level)

- Montenegro (police level)

- Switzerland

- Turkey (conviction level)

- Ukraine

- UK: England \& Wales

- UK: Northern Ireland (conviction level)

- UK: Scotland

Money laundering is only included in:

- Turkey (conviction level)

Forgery of money / payment instruments is included in the statistics of:

- Switzerland

- Turkey (conviction level) 
- UK: England \& Wales (conviction level)

- UK: Northern Ireland (police level)

The following countries follow a rather broad concept of deception, thus including consumption of goods and services in their fraud data:

- Czech Republic

- France (police level)

- Iceland (police level)

- Poland

- Spain (police level)

- Turkey (conviction level)

- UK: Scotland

Breaching of trust / embezzlement is included in:

- Albania

- Azerbaijan

- France (police level)

- Georgia

- Poland

- Spain (police level)

- Turkey (conviction level)

\subsection{Cyber fraud}

According to the standard definition, cyber fraud means fraud committed by means of computer-mediated communication, e.g., via the internet. Where possible, the figures include:

- online banking fraud (e.g., by phishing)

- online shopping fraud (e.g., by phishing, by selling goods without the intent of delivery, or by buying goods without the intent to pay for them)

- fraud by unauthorized online use of payment instruments (e.g., credit card or debit card data, PayPal or other payment accounts, Bitcoin)

- other forms of fraud committed via the internet

- fraud committed in other data networks (e.g., on an intranet or peer-topeer network)

- $\quad$ attempts

They exclude:

- other cybercrimes

- fraud by unauthorized use of credit or debit cards at automated teller machines (ATM) 
- fraud by unauthorized use of credit or debit cards at point of sale (POS) terminals (i.e.: electronic payment at retail locations)

- fraud by unauthorized offline use of payment instruments

\subsubsection{Countries deviating from include rules:}

Online banking fraud is included everywhere.

Online shopping fraud is only excluded in:

- Hungary (police level)

- Montenegro (police level)

Only three countries exclude frand by unauthorized online use of payment.

- Hungary (conviction level)

- Portugal

- Romania

Other forms of fraud committed via the internet are only excluded in Portugal.

Germany (police statistics) is the only country to exclude frand committed in other data networks.

Attempts are excluded in Sweden (police level) only.

\subsubsection{Countries deviating from exclude rules:}

Other cybercrimes are included in:

- $\quad$ Czech Republic (police level)

- Hungary (conviction level)

- Slovenia (police level)

- $\quad$ Sweden (police level)

Albania and Slovenia (police level) are the only countries to include frand by unauthorizes use of credit or debit cards at automated teller machines and frand by unauthorized use of credit or debit cards at point-of-sale terminals.

Only two countries include fraud by unauthorized offline use of payment instruments:

- Slovenia (police level)

- Sweden (police level) 


\subsection{Forgery of documents}

According to the standard definition, forger of documents means creation or use of a false ${ }^{57}$ document or tampering of a genuine document with the intent to deceive. Where possible, the figures include:

- forgery or use of passports and identity cards

- forgery or use of certificates

- forgery or use of contracts

- forgery or use of physical documents with the aid of a computer system

- attempts

They exclude:

- forgery or use of money or payment instruments

- forgery or use of electronic (i.e.: virtual, non-physical) documents

- preparatory offences to forgery (e.g., purchase of a computer program or copier in order to use it for forgery)

- mere written lies (untrue information in an original document)

- fraud

\subsubsection{Countries deviating from include rules:}

Cyprus (police level) is the only country to exclude forgery or use of passports and identity cards and forgery or use of certificates.

Two countries exclude forgery or use of contracts:

- Cyprus (police level)

- Czech Republic

Again, Cyprus (police level) is the only country to exclude forgery or use of physical documents with the aid of a computer system.

Attempts are excluded in the statistics of:

- Cyprus (police level)

- Moldova (police level)

- Montenegro (police level)

- Sweden (police level)

\footnotetext{
${ }^{57}$ For the purpose of this definition, a document is only to be considered "false" if it seems to stem from a person or institution that actually has not created it and has also not authorized the contents. As an example, take a certificate that looks as if it was issued by a school, yet it was created by the student him- or herself to create the impression of better grades than actually achieved.
} 


\subsubsection{Countries deviating from exclude rules:}

Forgery or use of money or payment instruments is included in:

- Spain (police level)

- Turkey (conviction level)

The following countries include forgery or use of electronic documents:

- Austria

- Croatia

- Czech Republic

- Estonia

- France (conviction level)

- Greece (police level)

- Moldova (police level)

- Montenegro (police level)

- Portugal

- Spain (police level)

- Sweden

- Turkey (conviction level)

Preparatory offences to forgery are included in:

- Hungary

- Montenegro (police level)

- Spain (police level)

- Sweden

- Turkey (conviction level)

Mere written lies are included in:

- Albania

- Croatia

- France (conviction level)

- Hungary (police level)

- Lithuania

- Moldova (police level)

- Spain (police level)

- Sweden

- Turkey (conviction level)

Only one country includes fraud:

- Turkey 


\subsection{Money laundering}

According to the standard definition, money laundering means specific financial transactions to conceal the identity, source, and/ or destination of money or non-monetary property deriving from criminal activities. Where possible, the figures include:

- Receiving and handling illegally obtained (but not stolen) non-monetary property

- Attempts

They exclude:

- Receiving / handling stolen property

- Violations of the 'know-your-customer' rule (i.e., negligence in identification of customer's identity or origin of funds)

1.18.1 Countries deviating from include rules:

Receiving and handling illegally obtained (but not stolen) non-monetary property is only excluded in:

- Switzerland

Only two countries exclude attempts:

- Cyprus (police level)

- Slovenia (conviction statistics)

- UK: Scotland (conviction level)

1.18.2 Countries deviating from exclude rules:

Receiving / handling stolen property is included in:

- Albania

- Belgium

- Cyprus (police level)

- Moldova

- Montenegro (police level)

- Turkey (conviction level)

Four countries include violations of the 'know-your-customer' rule:

- Cyprus (police level)

- Hungary

- Sweden (police level)

- Turkey (conviction level) 
1.19 Corruption in the public sector

According to the standard definition, corruption means offering or accepting financial or any other advantage in exchange of favourable treatment by public officials. Where possible, the figures include:

- Active and passive corruption

- Instigation to corruption

- Complicity

- Corruption of domestic officials

- Corruption of foreign officials

- Extortion by public officials

- Offering officials advantages without immediate interest

- (i.e.: in order to get them hooked on receiving gifts)

- Attempts

They exclude:

- Corruption in the private sector

- Extortion (except by public officials)

- Bribery of the electorate

1.19.1 Countries deviating from include rules:

All countries include both active and passive corruption in their data.

Instigation to corruption is excluded in:

- Albania

- Azerbaijan

- Portugal

- Slovenia (conviction level)

These countries exclude complicity:

- Portugal

- Slovenia (conviction level)

Corruption of domestic officials is included everywhere.

Almost all countries are also able to include corruption of foreign officials. This kind of behaviour is only excluded in:

- Greece (police level)

- Portugal 
Extortion by public officials is excluded in the following countries:

- Albania

- Czech Republic

- Denmark

- Finland

- Sweden

Offering officials advantages without immediate interest is excluded in:

- Albania

- Bulgaria

- Greece (police level)

Attempts are excluded in:

- Albania

- Moldova

- Montenegro (police level)

- Slovenia (conviction level)

1.19.2 Countries deviating from exclude rules:

Corruption data for the following countries include corruption in the private sector:

- Azerbaijan

- Estonia

- Georgia

- Hungary

- Lithuania

- Montenegro (police level)

- Norway (police level)

- Spain (police level)

- Sweden

- Turkey (conviction level)

Extortion (except by public officials) is excluded everywhere.

Bribery of the electorate is included only for Montenegro (police statistics) 


\subsection{Drug offences}

According to the standard definition, drug offences mean all illicit intentional acts in connection with narcotic drugs and psychotropic substances as defined in the international drug control conventions. ${ }^{58}$ Where possible, the figures include:

- Cultivation

- Production and manufacture

- Extraction and preparation

- Offering and offering for sale

- Distribution

- Purchase

- Sale

- Delivery on any terms whatsoever

- Brokerage

- Dispatch and dispatch in transit

- Transport

- Importation

- Exportation

- Financing of drug operations

- Possession not in connection with personal use

- Possession for personal use (i.e.: possession of small quantities)

- Consumption

- Attempts

They exclude:

- Offences with respect to precursor substances

1.20.1 Countries deviating from include rules:

Almost all countries are able to include cultivation, production and manufacture, extraction and preparation, distribution, purchase, and delivery on any terms whatsoever in their data. Only Slovenia excludes purchase and delivery on conviction level.

Offering and offering for sale and sale is excluded in Moldova (conviction level only).

Brokerage is excluded for:

- Albania

- Moldova

\footnotetext{
${ }^{58}$ Single Convention on Narcotic Drugs, 1961, as amended by the 1972 protocol, Convention on Psychotropic Substances, 1971, and Convention against Illicit Traffic in Narcotic Drugs and Psychotropic Substances, 1988.
} 
- Ukraine

- UK: Scotland

Dispatch, dispatch in transit, transport, importation, and exportation are again included for all countries.

Few countries exclude the financing of drug operations:

- Austria

- Belgium

- Czech Republic

- Germany (conviction level)

- Montenegro (police level)

- Slovenia (conviction level)

Possession not in connection with personal use is only excluded in Germany (conviction level) and Georgia.

Possession for personal use / possession of small quantities is excluded in:

- Albania

- Croatia

- Czech Republic

- Estonia

- Georgia

- Germany (conviction level)

- Italy

- Netherlands

- Slovenia (police level) 
Table 4. Upper limits for possession for personal use

\begin{tabular}{|c|c|c|c|c|c|c|}
\hline & Cannabis & Heroin & Cocaine & Ecstasy & $\begin{array}{l}\text { Ampheta- } \\
\text { mines }\end{array}$ & $\begin{array}{l}\text { Other syn- } \\
\text { thetic drugs }\end{array}$ \\
\hline Armenia & $0.5 \mathrm{~g}$ & $0.03 g$ & $0.005 \mathrm{~g}$ & $0.05 g$ & $0.025 \mathrm{~g}$ & - \\
\hline Azerbaijan & $0.5 \mathrm{~g}$ & $0.15 \mathrm{~g}$ & $0.02 \mathrm{~g}$ & $0.03 \mathrm{~g}$ & $0.15 \mathrm{~g}$ & - different \\
\hline Czech Republic & $10 \mathrm{~g}$ & $1.5 \mathrm{~g}$ & $1 \mathrm{~g}$ & $\begin{array}{l}4 \text { tablets or } \\
0.4 \mathrm{~g}\end{array}$ & $2 g$ & $\begin{array}{l}\text { amounts for } \\
\text { different sub- } \\
\text { stances }\end{array}$ \\
\hline Georgia & $\begin{array}{l}250 \mathrm{~g} \\
\text { at least } 6 \mathrm{~g} \text { (in }\end{array}$ & - & - & - & - & - \\
\hline Germany & $\begin{array}{l}\text { some Federal } \\
\text { States, the } \\
\text { limit is higher) }\end{array}$ & $\begin{array}{l}\text { prosecutorial } \\
\text { discretion }\end{array}$ & $\begin{array}{l}\text { prosecutorial } \\
\text { discretion }\end{array}$ & $\begin{array}{l}\text { prosecutorial } \\
\text { discretion }\end{array}$ & $\begin{array}{l}\text { prosecutorial } \\
\text { discretion }\end{array}$ & $\begin{array}{l}\text { prosecutorial } \\
\text { discretion }\end{array}$ \\
\hline Iceland & all included & all included & all included & all included & all included & all included \\
\hline Italy & $0.5 \mathrm{~g}$ & $0.15 \mathrm{~g}$ & $0.75 \mathrm{~g}$ & $0.75 \mathrm{~g}$ & $0.5 \mathrm{~g}$ & - \\
\hline Lithuania & $5 g$ & $0.02 \mathrm{~g}$ & $0.2 \mathrm{~g}$ & $0.2 \mathrm{~g}$ & $0.2 \mathrm{~g}$ & - \\
\hline Netherlands & $5 g$ & - & - & - & - & - \\
\hline Portugal & $\begin{array}{l}\text { personal use } \\
\text { not restricted } \\
\text { by the quan- } \\
\text { tity }\end{array}$ & $\begin{array}{l}\text { personal use } \\
\text { not restricted } \\
\text { by the quan- } \\
\text { tity }\end{array}$ & $\begin{array}{l}\text { personal use } \\
\text { not restricted } \\
\text { by the quan- } \\
\text { tity }\end{array}$ & $\begin{array}{l}\text { personal use } \\
\text { not restricted } \\
\text { by the quan- } \\
\text { tity }\end{array}$ & $\begin{array}{l}\text { personal use } \\
\text { not restricted } \\
\text { by the quan- } \\
\text { tity }\end{array}$ & $\begin{array}{l}\text { personal use } \\
\text { not restricted } \\
\text { by the quan- } \\
\text { tity }\end{array}$ \\
\hline Ukraine & $5 \mathrm{~g}$ (grams) & $0.005 \mathrm{~g}$ & $0.02 \mathrm{~g}$ & $0.15 \mathrm{~g}$ & $0.15 \mathrm{~g}$ & - \\
\hline
\end{tabular}

Table 4 shows the upper limits of the "small quantity" for the countries that stated that possession for personal use is excluded. Typically, possession for personal use is pragmatically defined via a maximum quantity that may be possessed. However, as the example of Portugal shows, this is not necessarily always the case. In Germany no clear limits for the small quantities exist for heroin, cocaine, ecstasy, and amphetamines. For cannabis, on the other hand, a more definite limit has been fixed, which is, however, only set down in prosecutorial guidelines that differ between Federal States. The Netherlands also has a fixed upper limit for the small quantity of cannabis. Others have such a limit for all common drugs (e.g., Armenia, Czech Republic). The amounts that make up a "small" quantity differ significantly between countries, e.g., for heroin between $0.03 \mathrm{~g}$ (Armenia) and 1.5g (Czech Republic), which is factor 50, for cannabis even between $0.5 \mathrm{~g}$ (Armenia, Azerbaijan, and Italy) and $250 \mathrm{~g}$ (Georgia) factor 500 .

The following countries exclude consumption from their data:

- Albania

- Austria

- Bulgaria

- Croatia

- Czech Republic

- Denmark

- Estonia

- Georgia 
- Germany

- Lithuania

- Moldova (conviction level)

- Poland

- Portugal

- Slovenia (police level)

- Ukraine

- UK: Scotland

In many of these countries, consumption will not constitute an offence at all.

Attempts are only excluded in Georgia, Moldova, and UK: Scotland.

1.20.2 Countries deviating from exclude rules:

The following countries include offences with respect to precursor substances:

- Albania

- Armenia

- Austria

- Azerbaijan

- Belgium (police level)

- Bulgaria

- Croatia

- Cyprus (police level)

- Czech Republic

- Greece (police level)

- Hungary

- Iceland (police level)

- Latvia

- Moldova (police level)

- Montenegro (police level)

- Poland (police level)

- Portugal

- Romania (police level)

- Slovenia (police level)

- Turkey (conviction level)

- Ukraine 


\subsection{Drug trafficking}

According to the standard definition, drug trafficking means drug offences which are not in connection with personal use. Where possible, the figures include:

- Cultivation

- Production and manufacture

- Extraction and preparation

- Offering and offering for sale

- Distribution

- Purchase

- Sale

- Delivery on any terms whatsoever

- Brokerage

- Dispatch and dispatch in transit

- Transport

- Importation

- Exportation

- Financing of drug operations

- Possession

- Attempts

They exclude:

- Offences with respect to precursor substances

- Possession for personal use (i.e.: possession of small quantities)

- Consumption

\subsubsection{Countries deviating from include rules:}

Only Albania, France (conviction level) and Hungary (police level) exclude cultivation, production, manufacture, extraction, and preparation.

All countries include offering, offering for sale.

Distribution is excluded in Albania.

Purchase is again excluded in Albania, France, Hungary (police level) and Turkey (conviction level).

Sale is excluded in Turkey (conviction level). 
Delivery on any terms whatsoever is excluded by:

- Albania

- Poland

- Turkey (conviction level)

Brokerage is excluded by Albania, Moldova (police level) and Ukraine.

Dispatch and dispatch in transit is excluded in Albania.

Transport, importation, and exportation are included everywhere.

Financing of drug operations is excluded in:

- Albania

- Belgium (police level)

- Czech Republic

- Montenegro (police level)

The following countries exclude possession:

- Albania

- Belgium (police level)

- Hungary (police level)

- Poland

- Sweden (police level)

- Turkey (conviction level)

- UK: England \& Wales (police level)

Attempts are only excluded in Moldova (police level).

1.21.2 Countries deviating from exclude rules:

Offences with respect to precursor substances are included in:

- Armenia

- Belgium (police level)

- Croatia

- Cyprus (police level)

- Czech Republic

- Hungary (conviction level)

- Montenegro (police level)

- Poland

- Portugal 
- Romania (conviction level)

- Slovenia (police level)

- Turkey (conviction level)

- Ukraine

The following countries include possession for personal use / possession of small quantities in drug trafficking data, which makes it dubious for these countries whether the data reported actually refer to trafficking:

- Armenia

- Cyprus (police level)

- Iceland (police level)

- Montenegro (police level)

- Romania (conviction level)

Finally, there are even countries which state to include consumption:

- Croatia

- Cyprus (police level)

- Hungary (conviction level)

- Iceland (police level)

- Montenegro (police level)

- Portugal (conviction level)

\subsection{Firearm involved}

According to the standard definition firearm involved means that a firearm has been involved in committing the crime, regardless of whether it has been shot, used as a blunt weapon or threat, or just been carried or in any other way been ready to hand. This definition is used as a subcategory for homicide (completed and total) and robbery. Data were collected on police level only. Where possible, the figures include:

- Firearm shot

- Firearm used as a blunt weapon

- Firearm used as a threat

- Firearm carried

- Firearm ready to hand, even if not carried

- (e.g.: lying readily available on a table directly at the crime scene)

They exclude:

- Offences involving weapons not considered as firearms

- Offences involving other dangerous objects 
There is a separate standard definition used for the firearm itself, which is defined as a weapon that launches a bullet or otherprojectile (or several at a time), making use of an explosive charge as a propellant, and that can be carried and used by a single person. Where possible, figures on the involvement of firearm include:

- Pistols, revolvers

- Rifles, shotguns

- Sub-machine guns, light, and medium machine guns

- Improvised and special firearms (e.g., pen guns)

- Unloaded firearms carried with ammunition at hand

- Legally owned firearms

They exclude:

- Heavy machine guns

- Hand grenades, Molotov cocktails

- Air guns, gas pistols, paintball rifles

- Crossbows, bows and arrows

- Replica firearms and other fakes

- Unloaded firearms carried without ammunition at hand

\subsubsection{Deviations from the firearm definition}

1.22.1.1 Countries deviating from include rules:

Pistols, revolvers, rifles, and shotguns are included everywhere.

Unloaded firearms carried with ammunition and legally owned firearms are excluded in France.

Sub-machine guns, light and medium machine are excluded in:

- Spain

The following countries exclude manportable grenade launchers:

- Hungary

- Montenegro

- Sweden

Improvised and special firearms are excluded in:

- France

- Lithuania

- Montenegro 
1.22.1.2 Countries deviating from exclude rules:

Heavy machine guns are - at least theoretically - included in:

- Austria

- Belgium

- Bulgaria

- Cyprus

- France

- Poland

- Serbia

- Slovenia

- Spain

- Sweden

- UK: Northern Ireland

The following countries include hand grenades:

- Armenia

- Austria

- France

- Montenegro

- Serbia

- Slovenia

- Spain

- UK: Northern Ireland

Air guns, gas pistols and/or paintball rifles are included in:

- Armenia

- Austria

- Cyprus

- France

- Germany (for robbery offences only) ${ }^{59}$

- Montenegro

- Spain

- Sweden

- UK: Northern Ireland

Crossbows, bows, and arrows are - probably only theoretically - included in Armenia, France, Spain, and Sweden.

59 This means: Excluded for homicide offences and homicide and robbery suspects. 
The following countries include replica firearms and other fakes:

- Armenia

- Germany (for robbery offences only) ${ }^{60}$

- Spain

- Sweden

- UK: Northern Ireland

Unloaded firearms carried without ammunition at hand are included in:

- Armenia

- Austria

- Belgium

- Cyprus

- France

- Germany (for robbery offences only) ${ }^{61}$

- Hungary

- Lithuania

- Poland

- Slovenia

- Spain

- Sweden

- UK: Northern Ireland

\subsubsection{Deviations from the definition of involvement}

1.22.2.1 Countries deviating from include rules:

Firearm shot is excluded in Montenegro.

Firearm used as a blunt weapon is excluded in:

- Germany (for homicide offences only) ${ }^{62}$

- Lithuania

- Montenegro

Firearm used as a threat is excluded in Montenegro only.

${ }^{60}$ This means: Excluded for homicide offences and homicide and robbery suspects.

${ }^{61}$ This means: Excluded for homicide offences and homicide and robbery suspects.

${ }^{62}$ This means: Included for robbery offences and homicide and robbery suspects. 
The following countries exclude firearm carried:

- Germany (for offences only) ${ }^{63}$

- Hungary

- Lithuania

- Poland

Firearm ready to hand, even if not carried, is excluded from the statistics of:

- Albania

- Armenia

- Germany (for offences only) ${ }^{64}$

- Hungary

- Lithuania

- Montenegro

- Poland

1.22.1.2 Countries deviating from exclude rules:

Offences involving weapons not considered as firearms are included in:

- Armenia

- Montenegro

- UK: Northern Ireland

Offences involving other dangerous objects are included in Armenia and UK: Northern Ireland.

\section{Young offenders and state reactions to their offending}

The following definitions refer to young offenders and the reactions of the state on offences committed by them. Young offenders are minors (persons who have not yet reached the age of adulthood) on the one hand and young adults on the other. The definitions assembled here have an impact on the recording of data on minors and young adults in all sections of this book. In addition, chapters 1 to 4 also feature specific information on minors. This information refers to the inclusion of minors in the reported data and on the relevant age brackets applied. The special metadata provided there should always be read against the backdrop of the overarching results presented here.

\footnotetext{
63 This means: Included for homicide and robbery suspects.

64 This means: Included for homicide and robbery suspects.
} 


\subsection{Age of criminal responsibility}

Table 5. Age of criminal responsibility

\begin{tabular}{|c|c|c|c|c|c|c|}
\hline 10 & 11 & 12 & 13 & 14 & 15 & 16 \\
\hline Switzerland & - & Ireland & France & Albania & $\begin{array}{l}\text { Czech Repub- } \\
\text { lic }\end{array}$ & Armenia 65 \\
\hline \multirow{26}{*}{$\begin{array}{l}\text { UK: England \& } \\
\text { Wales } \\
\text { UK: Northern } \\
\text { Ireland }\end{array}$} & & Netherlands & Greece & Austria & Denmark & Luxembourg \\
\hline & & Turkey & & Azerbaijan & Finland & Portugal \\
\hline & & UK: Scotland & & $\begin{array}{l}\text { Bosnia-Herze- } \\
\text { govina }\end{array}$ & Iceland & Ukraine 66 \\
\hline & & & & Bulgaria & Norway & \\
\hline & & & & Croatia & Poland & \\
\hline & & & & Cyprus & Sweden & \\
\hline & & & & Estonia & & \\
\hline & & & & Georgia & & \\
\hline & & & & Germany & & \\
\hline & & & & Hungary 67 & & \\
\hline & & & & Italy & & \\
\hline & & & & Latvia & & \\
\hline & & & & Lithuania & & \\
\hline & & & & Malta & & \\
\hline & & & & Moldova & & \\
\hline & & & & Montenegro & & \\
\hline & & & & North Mace- & & \\
\hline & & & & donia & & \\
\hline & & & & Romania & & \\
\hline & & & & Russian Fed- & & \\
\hline & & & & eration & & \\
\hline & & & & Serbia & & \\
\hline & & & & Slovak Repub- & & \\
\hline & & & & lic & & \\
\hline & & & & Slovenia & & \\
\hline & & & & Spain & & \\
\hline
\end{tabular}

Table 5 shows the age of criminal responsibility for minors in the different countries. While there are some countries which apply an early age of criminal responsibility of ten years (Switzerland, UK: England \& Wales, UK: Northern Ireland) and there are also a few countries which use a late age of criminal responsibility (16 in Armenia, Luxembourg, Portugal, and Ukraine), in the vast majority of countries minors reach criminal responsibility at the age of 14 .

6514 for specific offences, including homicide, theft, robbery, joyriding, bodily injury, and rape.

6614 for specific offences, including murder, bodily injury of at least medium severity, rape, robbery, and theft.

6712 for specific offences, including homicide, voluntary manslaughter, terrorism, robbery, lifethreatening bodily injury and plundering, if the perpetrator had the capacity to understand nature/consequences of the act. 


\subsection{Age of adulthood in penal law}

In almost all countries, persons are no longer considered as minors, but as adults when they reach the age of 18 . The penal law in some countries, however, uses a lower or a higher age:

- Cyprus: 16

- Poland: 17

- Portugal: 21

- UK: Scotland: 21

\subsection{Treatment of young adults}

In some countries, it is possible to apply juvenile criminal law on persons which have already reached adulthood before they committed their offences. Where this possibility is available, it is always restricted to young adults. Typically, the conditions for young adults are not identical to those for minors. One common possibility for this group of offenders is that juvenile criminal law competes against adult criminal law and the court has to decide which law to apply depending on the special characteristics of the offence and the offender. Another possibility is that the criminal law applied for young adults is a kind of intermediate criminal law that is milder than the criminal law for older adults, but also differs from the criminal law applicable for minors.

In the following countries, such specific rules for the treatment of young adults exist. The maximum age below which these rules can be applied is indicated:

- Albania: 21 (only specific rules regarding probation service and prison)

- Austria: 21

- Finland: 21

- Germany: 21

- Greece: 21

- Italy: 2168

- Lithuania: 21

- Netherlands: 21

- North Macedonia: 21

- Poland: $18^{69}$

- Portugal: 22

- Serbia: 21

- Slovenia: $188^{70}$

\footnotetext{
68 Although it was not indicated whether or not juvenile criminal law is applied, an age was given.

${ }^{69}$ Note that the age of adulthood in criminal law for Poland is 17.

${ }^{70}$ Although it wasn't indicated whether or not juvenile criminal law is applied, an age was given.
} 
The following countries stated in the questionnaire that juvenile criminal law is applied but didn't provide an age:

- Croatia

- Georgia

- Moldova

- Netherlands

2.4 State reactions to criminal acts of minors

In this edition of the ESB the state reactions to criminal acts of minors were not examined. An overview is, however, provided on pp. 404-407 of the $5^{\text {th }}$ edition. 

Appendix II: Population 
Table 1. Population by country from 2011 to 2016 (in thousands)

\begin{tabular}{|c|c|c|c|c|c|c|}
\hline & 2011 & 2012 & 2013 & 2014 & 2015 & 2016 \\
\hline Albania & 2907.4 & 2903.0 & 2897.8 & 2892.4 & 2885.8 & 2875.6 \\
\hline Armenia & 3262.7 & 3274.3 & 2894.0 & $2906.0^{*}$ & 3010.6 & 2998.6 \\
\hline Austria & 8375.2 & 8408.1 & 8451.9 & 8507.8 & 8584.9 & 8700.5 \\
\hline Azerbaijan & 9111.1 & 9235.1 & 9356.5 & 9477.1 & 9593.0 & 9705.6 \\
\hline Belgium & 11000.6 & 11075.9 & 11138.0 & 11180.8 & 11237.3 & 11311.1 \\
\hline Bosnia-Herzegovina & 3843.2 & 3839.3 & $3542.6^{*}$ & $3482.1^{*}$ & $3429.4^{*}$ & $3386.3^{*}$ \\
\hline Bulgaria & 7369.4 & 7327.2 & 7284.6 & 7245.7 & 7202.2 & 7153.8 \\
\hline Croatia & 4289.9 & 4276.0 & 4262.1 & 4246.8 & 4225.3 & 4190.7 \\
\hline Cyprus & 839.8 & 862.0 & 865.9 & 858.0 & 847.0 & 848.3 \\
\hline Czech Republic & 10486.7 & 10505.4 & 10516.1 & 10512.4 & 10538.3 & 10553.8 \\
\hline Denmark & 5560.6 & 5580.5 & 5602.6 & 5627.2 & 5659.7 & 5707.3 \\
\hline Estonia & 1329.7 & 1325.2 & 1320.2 & 1315.8 & 1314.9 & 1315.9 \\
\hline Finland & 5375.3 & 5401.3 & 5426.7 & 5451.3 & 5471.8 & 5487.3 \\
\hline France & 64978.7 & 65277.0 & 65600.4 & 66166.0 & 66458.2 & 66638.4 \\
\hline Georgia & 4469.3 & 4497.6 & 4046.0 & 4490.5 & 3729.5 & 3720.4 \\
\hline Germany & 80222.1 & 80327.9 & 80523.7 & 80767.5 & 81197.5 & 82175.7 \\
\hline Greece & 11123.4 & 11086.4 & 11003.6 & 10926.8 & 10858.0 & 10783.7 \\
\hline Hungary & 9985.7 & 9931.9 & 9908.8 & 9877.4 & 9855.6 & 9830.5 \\
\hline Iceland & 318.5 & 319.6 & 321.9 & 325.7 & 329.1 & 332.5 \\
\hline Ireland & 4570.9 & 4589.3 & 4609.8 & 4637.9 & 4677.6 & 4726.3 \\
\hline Italy & 59364.7 & 59394.2 & 59685.2 & 60782.7 & 60795.6 & 60665.6 \\
\hline Kosovo & 1794.2 & $1805.0^{\star *}$ & $1824.0^{\star *}$ & $1822.0^{* \star}$ & $1802.0^{\star *}$ & 1771.6 \\
\hline Latvia & 2074.6 & 2044.8 & 2023.8 & 2001.5 & 1986.1 & 1969.0 \\
\hline Lithuania & 3052.6 & 3003.6 & 2971.9 & 2943.5 & 2921.3 & 2888.6 \\
\hline Luxembourg & 511.8 & 524.9 & 537.0 & 549.7 & 563.0 & 576.2 \\
\hline Malta & 415.0 & 417.5 & 422.5 & 429.4 & 439.7 & 450.4 \\
\hline Moldova & 3560.4 & 3559.5 & 3559.5 & 3557.6 & 3555.2 & 3728.0 \\
\hline Montenegro & 619.9 & 620.3 & 620.9 & 621.5 & 622.1 & 622.2 \\
\hline Netherlands & 16655.8 & 16730.3 & 16779.6 & 16829.3 & 16900.7 & 16979.1 \\
\hline North Macedonia & 2057.3 & 2059.8 & 2062.3 & 2065.8 & 2069.2 & 2071.3 \\
\hline Norway & 4920.3 & 4985.9 & 5051.3 & 5108.0 & 5166.5 & 5210.7 \\
\hline Poland & 38062.7 & 38063.8 & 38062.5 & 38017.9 & 38005.6 & 37967.2 \\
\hline Portugal ${ }^{* \star *}$ & 10542.4 & 10487.29 & 10427.3 & 10374.82 & 10341.33 & 10309.57 \\
\hline Romania & 20199.1 & 20096.0 & 20020.1 & 19947.3 & 19870.6 & 19760.6 \\
\hline Russia & 142856.5 & 143056.4 & $143500.0^{*}$ & $143666.9^{*}$ & $144100.0^{*}$ & $144300.0^{*}$ \\
\hline Serbia & 7251.5 & 7216.6 & 7181.5 & 7146.8 & 7114.4 & 7076.4 \\
\hline Slovakia & 5392.4 & 5404.3 & 5410.8 & 5415.9 & 5421.3 & 5426.3 \\
\hline Slovenia & 2050.2 & 2055.5 & 2058.8 & 2061.1 & 2062.9 & 2064.2 \\
\hline Spain & 46667.2 & 46818.2 & 46727.9 & 46512.2 & 46449.6 & 46440.1 \\
\hline Sweden & 9415.6 & 9482.9 & 9555.9 & 9644.9 & 9747.4 & 9851.0 \\
\hline Switzerland & 7870.1 & 7954.7 & 8039.1 & 8139.6 & 8237.7 & 8327.1 \\
\hline Turkey & 73723.0 & 74724.3 & 75627.4 & 76667.9 & 77695.9 & 78741.1 \\
\hline Ukraine & 45598.2 & 45453.3 & 45372.7 & 45245.9 & 42759.7 & 42590.9 \\
\hline UK: England and Wales & 56170.9 & 56567.8 & 56948.2 & 57408.7 & 57885.4 & 58381.2 \\
\hline UK: Northern Ireland & 1814.3 & 1823.6 & 1829.7 & 1840.5 & 1851.6 & 1862.1 \\
\hline UK: Scotland & 5299.9 & 5313.6 & 5327.7 & 5347.6 & 5373.0 & 5404.7 \\
\hline
\end{tabular}

Source: Eurostat Database, retrieved on 24 February 2020

*UN Population Statistics

**World Bank Data

${ }^{* * *}$ Data provided by national correspondent. 

T his is the sixth edition of a data collection initiative that started in 1993 under the umbrella of the Council of Europe and has been continued since 2000 by an international group of experts. These experts also act as regional coordinators of a network of national correspondents whose contribution has been decisive in collecting and validating data on a variety of subjects from 42 countries. The Sourcebook is composed of six chapters. The first five cover the current main types of national crime and criminal justice statistics - police, prosecution, conviction, prison, and probation statistics - for the years 2011 to 2016, providing detailed analysis for 2015 . The sixth chapter covers national victimization surveys, providing rates for the main indicators every five years from 1990 to 2015. As with every new edition of the Sourcebook, the group has tried to improve data quality as well as comparability and, where appropriate, increase the scope of data collection. This new edition will continue to promote comparative research throughout Europe and make European experiences and data available worldwide.

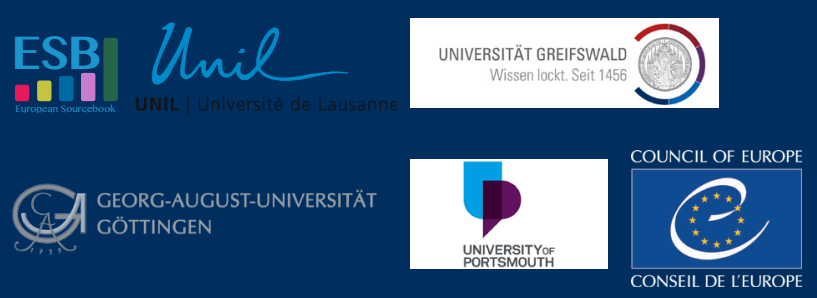

